\title{
Domesticación en el Continente Americano Volumen 2. Investigación para el manejo sustentable de recursos genéticos en...
}

Book · May 2017

CITATION

1

3 authors, including:

\section{Alejandro Casas}

Universidad Nacional Autónoma de México

226 PUBLICATIONS 3,511 CITATIONS

SEE PROFILE

\section{READS}

859

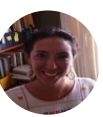

Fabiola Parra

Universidad Nacional Agraria La Molina 37 PUBLICATIONS 313 CITATIONS

SEE PROFILE

Some of the authors of this publication are also working on these related projects:

Project Phylogeography of perennial plants domestication View project

Diversidad, flujo génico de cultivos andinos y seguridad alimentaria: contrarrestando procesos de 


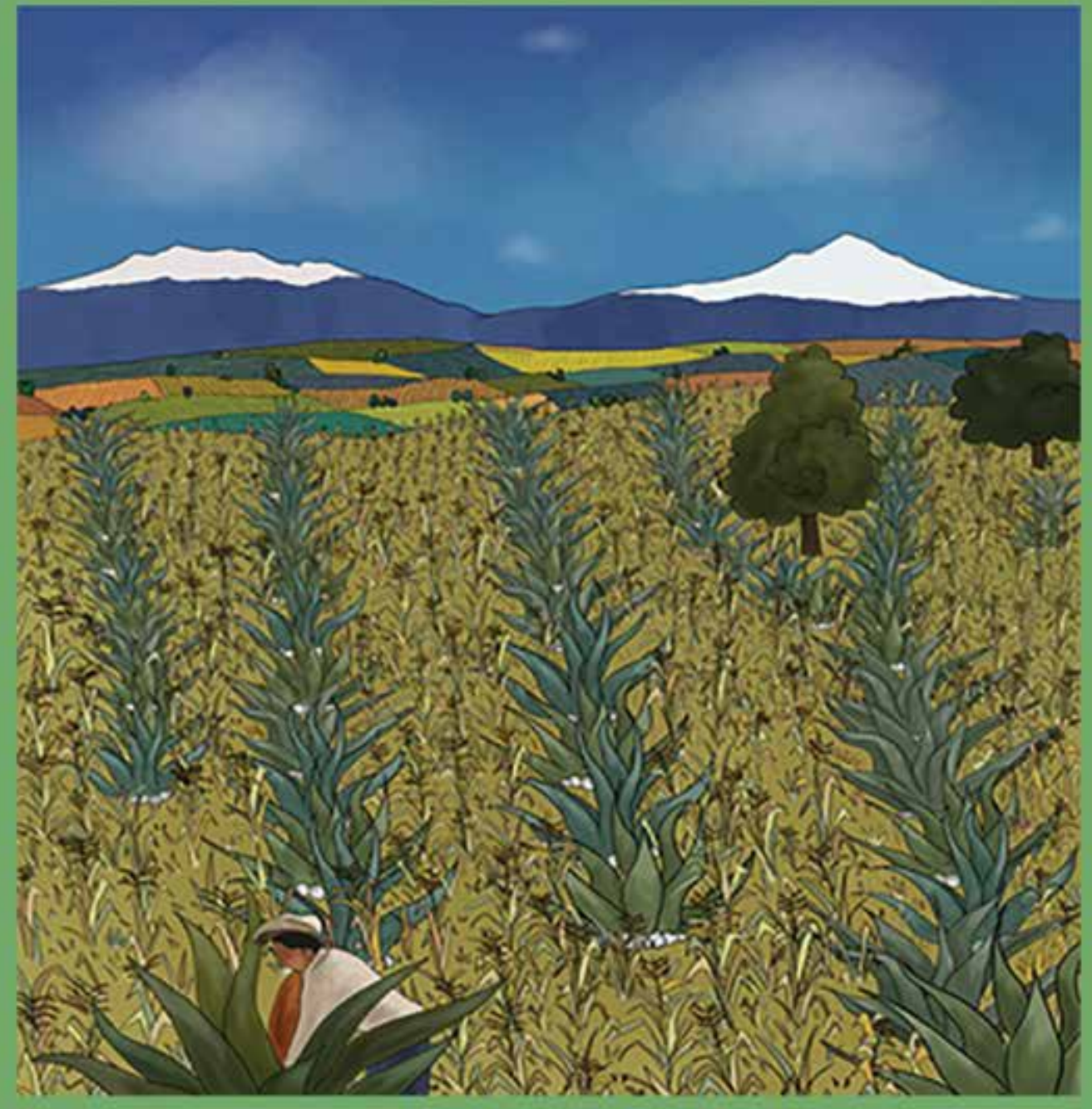

\section{Domesticación en el continente americano}

Volumen 2

Investigación para el manejo sustentable de recursos genéticos en el Nuevo Mundo

Alejandro Casas, Juan Torres-Guevara y Fabiola Parra

EIXIORES

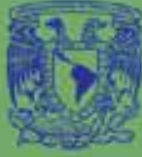



enfasis los procesos evolutivos asociados al manejo, tanto los asociados a la domesticación de plantas, animales y microorganismos, como aquelios que determinan cambios estructurales y funcionales en los ecosistemas y paisajes.
Este úitimo enfoque es crucial para contribuir al entendimiento de los procesos que generan agrobiodiversidad y, por lo tanto, su conservación in situ y su mantenirmiento a largo plazo; es decir, el manejo sustentable de recursos genéticos:

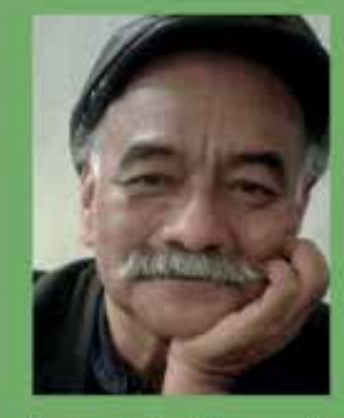

Juan Torres Guevara es biólogo de la Universidad Nacional Agrana La Molina (UNALM). Orienta sus estudios a la ecologia y a la cuitura de los desiertos y las montanas, en especial las interacoiones entre sociedades y naturaleza Ha puesto énfasis en el estudio de los conocimientes Iradicionales ancestrales y los conocimientos cientificos contemporáneos. Su princpal preocupación es contribuir a identificar y tender puentes o pasarelas entre estos grandes epistemes Sus principales temas de investigación han sido la ecologia de desiertos y dentro de elios las lomas y los bosques tropicales secos de la costa, asicomo la conservación in situ de la agrobiodiversidad nativa que manejan las cuituras ancestrales en espacios como las microcuencas andinas del Penu.

\section{Domesticación en el continente americano}

Volumen 2

Investigación para el manejo sustentable de recursos genéticos en el Nuevo Mundo

Alejandro Casas, Juan Torres-Guevara y Fabiola Parra-Rondinel

Editores

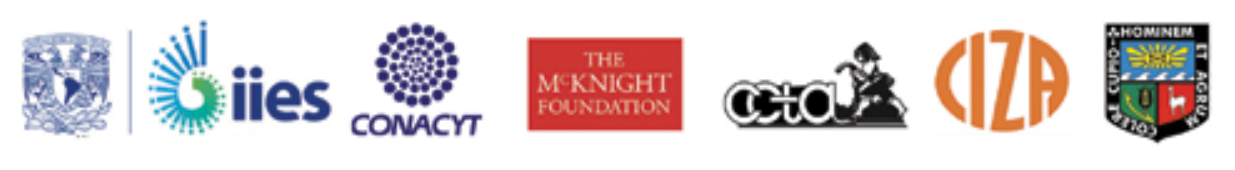




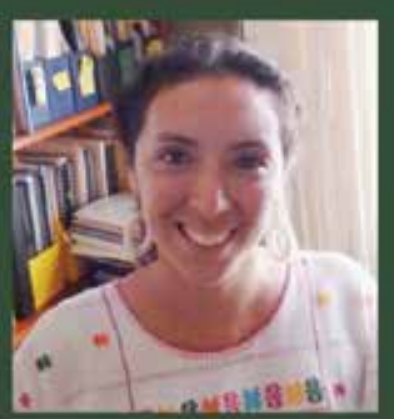

Fabiola Parra es bióloga de la Universidad Nacional Agraria La Molina, con investigaciones en temas de manejo local de recursos genéticos y ecosistemas, con especial éntasis en los agroecosistemas tradicionales. Ha estudiado procesos de evolución de plantas bajo domesticación, integrando disciplinas como la ecologia, la genética y la etnobiología, en la búsqueda de la comprensión de los origenes de la agricultura y del manejo local de recursos genéticos, para contribuir al reconocimiento del papel de los conocmientos tradicionales en el manejo sostenible de recursos y ecosistemas. Actualmente participa en la coordinación y como parte del equipo de proyectos de investigación y desarrollo relacionados con comunidades rurales establecidas en ecosistemas de zonas aridas y montañas 
Se reúnen en este volumen textos de autores argentinos, brasileños, bolivianos, colombianos, estadounidenses, ingleses, mexicanos y peruanos que realizan investigaciones sobre procesos de domesticación y manejo de recursos genéticos en el continente americano. Es un caleidoscopio de información, reflexiones y teorias sobre los procesos de domesticación y manejo de recursos genéticos en distintas regiones del continente, principalmente Latinoamérica. El contexto del que derivan los manuscritos fue el simposio "Domesticación y Manejo in situ de Recursos Genéticos en el Continente Americano", llevado a cabo en 2015 en Lima, Perú, organizado por la Universidad Nacional Autónoma de México (UNAM) y la Universidad Nacional Agraria La Molina (UNALM).

La diversidad biocultural del continente americano es de las más altas del mundo y se ha ido conformando en más de diez mil años de historia que continúa adquiriendo sus matices en un lento y continuo proceso que persiste en la actualidad. La base del manejo sustentable de los recursos genéticos parte de comprender que la tecnología actual permite considerar como diversidad genética aprovechable a la diversidad biológica en su conjunto. Por ello, es ahora preciso incluir en la agenda de investigación y toma de decisiones la biodiversidad y la agrobiodiversidad: una surgida en millones de años de historia natural, otra construida en miles de años de historia humana. Desde cualquier perspectiva, es hoy inminente que la conservación de recursos genéticos implica el mantenimiento a largo plazo de la diversidad biológica y los ecosistemas, naturales y/o construidos por humanos. Implica visualizar los procesos generatrices de tal diversidad y dirigir los esfuerzos al mantenimiento de los procesos más que de elementos en particular. Existe una historia de conservación ex situ e in situ de la diversidad genética, no solo de agrobiodiversidad, sino también de la diversidad biológica de los grandes biomas del planeta. Estos esfuerzos ya son parte de estrategias mundiales que merecen tener un adecuado seguimiento y una mayor integración para procurar su adecuado aprovechamiento con bases sustentables que garanticen su conservación y su recuperación. Los retos intelectuales desde la academia, la visión de largo plazo en los usuarios de los recursos y tomadores de decisiones, requieren asimismo un mayor entrelazamiento y coordinación de acciones para mantener vivos los procesos --naturales y humanos-- que generan, mantienen y recuperan la diversidad biológica y la agrobiodiversidad. Abordamos en este intercambio nuestras visiones y experiencias a escala continental, pero con la certeza de que nuestras conclusiones regionales tienen una extensión a escala global. La flora, la fauna y la microbiota son severamente afectadas por las actividades humanas, particularmente aquellas encaminadas a fortalecer los procesos industriales y la inaudita ceguera escondida en los rincones que aspiran a abultar los grandes capitales y el desarrollo visto desde la perspectiva del crecimiento económico. Esta visión se ha agudizado a escala global en los últimos ochenta años y coincide con la mayor destrucción de los ecosistemas planetarios. Son a todas luces insostenibles. Paralelamente se construyen teorias alternativas para el buen vivir y el desarrollo sin la obsesiva visión de crecimiento. $Y$ paralelamente se construyen a diario formas de vida fuera de esta órbita destructiva. Entender su experiencia, su filosofia y su técnica es la base para la construcción de un mundo alternativo capaz de preservar el patrimonio biocultural y la conservación global de los ecosistemas. Es este libro un intercambio de visiones desde culturas y territorios que conforman el fascinante mosaico biocultural del continente americano, pero que ve más allá, extendiendo su mirada a los fenómenos de la casa global que inciden en el continente, a los ajustes que requiere con urgencia la sociedad global para sostener los ecosistemas del planeta. Sin ecosistemas sanos no hay posibilidades de mantener la diversidad biológica: recursos genéticos fundamentales. Sin estos es imposible mantener o recuperar los ecosistemas.
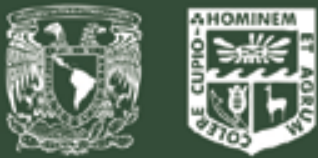
"Mientras haya sobre la tierra miseria, los libros de la naturaleza del presente podrán no ser inútiles".

Hauteville House, 1 de enero de 1862

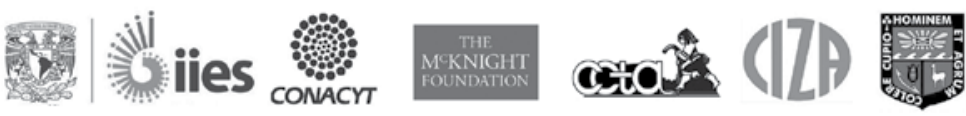

Domesticación en el continente americano. Volumen 2

Investigación para el manejo sustentable de recursos genéticos en el Nuevo Mundo

Primera edición, 2017

"El contenido de los textos de cada capítulo ha sido sometido a un riguroso arbitraje por pares académicos"

A aquellos que con sus anhelos y su lucha cotidiana establecen los cimientos de un futuro posible y

la construcción de la historia de un mundo

en el que los sueños son realizables;

proyectando seres renovados

que sepultan a la nada

D.R. ๑ (2017) UNIVERSIDAD NACIONAL AUTÓNOMA DE MÉXICO

Av. Universidad 3000

Col. Universidad Nacional Autónoma de México

C.P. 04510, México.

UNIVERSIDAD NACIONAL AGRARIA LA MOLINA (UNALM) DEL PERÚ

Camilo Carrillo 300-A, Lima 11

República del Perú

Alejandro Casas, Juan Torres-Guevara y Fabiola Parra-Rondinel-Rondinel [Coordinadores]

Cuidado de la edición, diseño y formación: Carlos Villaseñor Zamorano

Corrección de textos: Thalía Servín Chávez

Impresión: Editorial Morevalladolid, Morelia, México

ISBN

HECHO EN MÉXICO / IMPRESO EN MÉXICO 


\section{Agradecimientos}

Los editores y autores de este libro agradecemos el apoyo de la Escuela de Posgrado y la Maestría en Ecología Aplicada de la Universidad Nacional Agraria La Molina (UNALM) del Perú, así como el Posgrado en Ciencias Biológicas de la Universidad Nacional Autónoma de México (UNAM); así como a la Coordinadora de Ciencia y Tecnologia en los Andes CCTA, Perú instituciones que hicieron posible la realización del Simposio Internacional Domesticación y Manejo de Recursos Genéticos en el Nuevo Mundo. Las ponencias de este simposio constituyen el presente volumen.

Al CONCYTEC del Perú y al CONACYT de México agradecemos el apoyo financiero que nos permitió resolver múltiples aspectos de la logística del Simposio. Un agradecimiento especial lo extendemos a la Fundacion McKnight por su extraordinario apoyo financiero que hizo posible la realización del Simposio. El CONICET de Argentina brindó apoyo para la participación de nuestras queridas colegas María Lelia Pochettino, Ana Ladio y Verónica Lema en el Simposio. Asimismo, ha brindado apoyo financiero a estudiantes argentinos que han podido asistir regularmente al curso Domesticación y Manejo de Recursos Genéticos y a la Dra. Verónica Lema quien, con apoyo de esta institución, hoy forma parte del grupo de profesores responsable de curso. Agradecemos al CONACYT de México, en especial al proyecto CB-2013-01-221800, que ha apoyado directamente la interacción académica de mexicanos con nuestros colegas latinoamericanos, la realización del simposio, así como la elaboración y publicación del primer y segundo volumen de los libros que ahora presentamos. También agradecemos al Programa de Apoyo Académico a los Proyectos de Investigación e Innovación Tecnológica (PAPIIT, DGAPA, UNAM, IN205111-3, IN209214 y IN2062017), los cuales han dado soporte fundamental a los estudios mesoamericanos y ahora han tenido la visión de apoyar la organización del simposio y los proyectos de investigación en las zonas andina y amazónica.
La minuciosa revisión de contenidos, formato y el mejoramiento de algunas figuras, se lle vó a cabo por un extraordinario equipo de apasionados estudiosos de la domesticación y e manejo de los recursos genéticos, formado por las doctoras Dánae Cabrera Toledo, Mariana Vallejo, Ana Isabel Moreno Calles, Selene Rangel Landa, Carmen Julia Figueredo y Fabiola Parra-Rondinel, así como por los doctores Ignacio Torres-García, José Juan Blancas y Alejandro Casas. La corrección ortotipográfica y de estilo estuvo a cargo de Thalía Servín Chávez y el trabajo de diseño se llevó a cabo por el Lic. Carlos Villaseñor Zamorano.

Los editores agradecemos a Mariana Zarazúa el texto "Baile de maíz" en cuyas líneas nos regala el manejo delicado de las letras, del imaginario y de la cultura: poesía viva surgida de la vida diaria mesoamericana y andina. Agradecemos, también, el diseño de la portada realizado por María Casas Castillo, quien en la imagen de este volumen 2 plasmó una perspectiva de los sistemas agroforestales denominados metepantles en la zona del Altiplano Central de México. Estos sistemas combinan el cultivo de agaves y maíz y constituyen una muestra representativa del paisaje de la región central mesoamericana en altitudes cercanas a los $2500 \mathrm{~m}$. Los agaves tienen múltiples usos, pero los que se ilustran son el de la formación de bordos de terrazas y el de proveedores de la savia dulce denominada aguamiel, que al fermentarse produce la bebida conocida como pulque: sello imprescindible de las culturas mesoamericanas, al igual que el maíz que acompaña a estos magueyes en el sistema de metepantle. Al fondo, dos de los volcanes icónicos de México: el Iztaccíhuatl (en náhuatl 'mujer blanca') y el Popocatépetl (en náhuatl 'cerro que humea'), titanes de la franja volcánica que atraviesa a México en su parte media y que son parte fundamental de la historia y cosmovisión mesoamericana. 


\section{Baile de maíz}

Cuidada eres, también quien cría. En el calor un refresco y para el frío una cobija. Sustento en complicidad de manos, cal, fuego, hormigas.

Quizá la maraña del monte te inspira. Abrazas con timidez al enredo y le das guía. A quien se enrolla en la duda, ¿qué consejo le darías?

Seduces quieta a la presa, ¿disfrutas la cacería?

El surco encuentras al vuelo, ¿tu tiempo esperas dormida?, ¿te escabulles de la tierra a lomo de ratón o ardilla?

Silencio. Escucha tus hojas al soplo del viento.

De la mazorca rojo carmín se asoma brillante un punto amarillo; desde la que es azul con morado saluda un blanco diente muy tímido. "Es que bailaron" dirán por allí o "es porque al loro le gustan asi".

Si pudieras elegir, ¿de qué color crecerías?

Mariana Zarazúa, 25 de diciembre de 2016 


\section{Contenido volumen 2}

13 La perspectiva sustentable del manejo de recursos genéticos y los desafíos de la investigación científica

Alejandro Casas

CAPÍTULO 1

27 Panorama de los recursos genéticos de Brasil,

con énfasis en la Amazonia

Charles R. Clement

CAPÍTULO 2

43 Los recursos genéticos en Argentina:

caminos para su conocimiento, atajos para su acceso

y avatares de su gestión

María LeliaPochettino, Verónica Lema, Norma Hilgert y Ana H. Ladio

CAPÍTULO 3

69 Manejo y domesticación de plantas en Mesoamérica.

Una estrategia de investigación

y estado del conocimiento sobre los recursos genéticos en México

Alejandro Casas, Fabiola Parra-Rondinel, Selene Rangel-Landa, José Blancas, Mariana Vallejo

Ana Isabel Moreno-Calles, Susana Guillén, Ignacio Torres-García, América Delgado-Lemus,

Edgar Pérez-Negrón, Carmen Julia Figueredo, Jeniffer M. Cruse-Sanders,

Berenice Farfan-Heredia, Leonor Solis, Xitlali Aguirre-Dugua,

Adriana Otero-Arnaiz, Hernán Alvarado-Sizzo, Andrés Camou-Guerrero

CAPÍTULO 4

103 Panorama de los recursos genéticos en Perú

Juan Torres-Guevara, Fabiola Parra-Rondinel y Alejandro Casas

CAPÍTULO 5

135 Domesticaciones americanas:

la recursividad humana y la ayuda botánica

contra el impuesto geográfico y la migración origina

Daniel Debouck

CAPÍTULO 6

$151 \mathrm{Al}$ toro ¿por las astas?

Reflexiones sobre aproximaciones teóricas

y metodológicas de la temática de domesticación

en el área andina meridional

Verónica S. Lema

CAPÍTULO 7

177 Ajíes or chile peppers (Capsicum spp.): history and biology Barbara Pickersgill 
CAPÍTULO 8

193 Evolución y domesticación de los camélidos sudamericanos

Jane C. Wheeler

CAPÍTULO 9

217 La quimera de la domesticación de la vicuña

y la falacia de la crianza en semicautiverio

Julio B. Sumar

CAPÍTULO 10

231 Factores e indicios de conservación in situ

y evolución bajo la domesticación del maíz en México en el último siglo

Rafael Ortega Paczka y Baruch Xocoyotzin Chamorro Cobaxin

CAPÍTULO 11

273 Los agaves y las prácticas mesoamericanas

de aprovechamiento, manejo y domesticación

Patricia Colunga-GarcíaMarín, Ignacio Torres-García, Alejandro Casas, Carmen J. Figueredo,

Selene Rangel-Landa; América Delgado; Ofelia Vargas, Dánae Cabrera-Toledo;

Xitlali Aguirre-Dugua, Luis Eguiarte, Daniel Zizumbo-Villarreal, Guadalupe Carrillo-Galván

CAPÍTULO 12

311 Uso, manejo y domesticación de cactáceas en Brasi

Reinaldo Farias Paiva de Lucena, Camilla Marques de Lucena, Marcos Vinicius Meiado,

Denise Dias da Cruz, Maristela Oliveira de Andrade, Alejandro Casas

CAPÍTULO 13

327 El manejo de plantas silvestres alimenticias

en escenarios de deforestación,

ilustrado por una comunidad mestiza de la Amazonía Peruana

Gisella S. Cruz-García y Lore Vael

CAPÍTULO 14

345 Las plantas aromáticas en los Andes peruanos

Milka Tello Villavicenci

CAPÍTULO 15

375 El sistema agroalimentario mesoamericano precolombino:

origen, diversificación y difusión de sus recursos fitogenéticos

Daniel Zizumbo-Villarreal y Patricia Colunga-GarcíaMarín

CAPÍTULO 16

391 Etnoconservacionismo y prácticas locales en La Patagonia: avances y perspectivas

Ana Haydeé Ladio y Soledad Molares

CAPÍTULO 17

413 Huertos comerciales del periurbano de La Plata (Buenos Aires, Argentina): Reservorio de diversidad biocultura

María Lelia Pochettino, María Margarita Bonicatto y Julio A. Hurrell
CAPÍTULO 18

431 Domesticación de plantas medicinales aromáticas Guadalupe Carrillo, Robert A. Bye y Luis Eguiart

CAPÍTULO 19

451 Impactos evolutivos de las actividades humanas sobre las plantas: manejo, domesticación y conservación in situ y ex situ Jennifer M. Cruse-Sanders Alejandro Casas

CAPÍTULO 20

475 Avances en el estudio de la fauna

de los traspatios familiares en el sureste de México Ramón Mariaca Méndez

CAPITULO 21

509 Contemporary domestication practices

by indigenous peoples and the industry Paulina R. Lezama-Núñez y Dídac Santos-Fita

CAPÍTULO 22

523 Bioseguridad en el Perú:

Moratoria a los organismos vivos modificados (OVM)

a mitad de camino de una decisión importante en un centro de origen Santiago Pastor-Soplín

CAPÍTULO 23

537 Patrones continentales de domesticación

Perspectivas para el estudio y manejo de recursos genéticos Alejandro Casas, Fabiola Parra-Rondinel, Ignacio Torres-García Selene Rangel-Landa, Mariana Zarazúa y Juan Torres-Guevara

571 Lista de autores 
UNA INTRODUCCIÓN

\section{La perspectiva sustentable del manejo de recursos genéticos y los desafíos de la investigación científica}

Alejandro Casas

\section{Resumen}

El presente volumen muestra un conjunto de experiencias de grupos de investigación sobre procesos de manejo de recursos genéticos en el continente americano, algunos ligados a proyectos de manejo y conservación in situ y ex situ. Se parte de una definición amplia de lo que son los recursos genéticos -diversidad genética actual o potencialmente aprovechable en procesos biotecnológicos-, bajo tal definición, los autores coincidimos en la necesidad de incluir el concepto de biodiversidad, ya que las técnicas de manejo de diversidad genética disponibles en la actualidad conllevan a ese amplio universo. Desde tal premisa, se discuten las distintas estrategias que a escala de genes particulares, individuos, poblaciones y comunidades bióticas requieren formas de manejo que garanticen su permanencia a largo plazo. Se reconocen cuatro grandes estrategias que aportan experiencias en el aprovechamiento, recuperación, conservación y generación de diversidad genética: 1) el manejo tradicional campesino, que por miles de años ha sido el motor principal de la domesticación de miles de especies en todo el mundo y que ha moldeado la agrobiodiversidad, así como la diversidad de animales y microorganismos que las culturas diseminadas en el planeta han utilizado por miles de años. Este proceso aprovecha la diversidad genética surgida mediante procesos naturales y la moldea para generar, mediante selección artificial, diversidad biológica humanizada; 2) el manejo moderno de mejoramiento (fitomejoramiento y zootécnia, entre otros) que ha permitido manejar sistemáticamente los procesos generatrices de diversidad y planear las estrategias de selección, logrando un proceso, relativamente más acelerado, de diversificación biológica humanizada; 3) la biotecnología contemporánea basada en la ingeniería genética y el manejo de ADN recombinante, entre otras técnicas que permiten el manejo de genes puntuales entre organismos filogenéticamente distantes y 4) la genética de la conservación, rama de la ciencia que permite integrar el análisis de la diversidad, estructura genética y flujo génico para diseñar estrategias para mantener en ecosistemas naturales o en reservorios artificiales de organismos un buen estado de salud de la diversidad genética. Ante estos escenarios y estrategias, el volumen discute las particularidades que en cada escala -y bajo cada tipo de manejo- se requieren en los mecanismos de manejo para asegurar su permanencia a largo plazo. 
Se parte de considerar la importancia de inventariar los recursos genéticos y la experiencia de manejo resultante de la experiencia humana en distintos países, es el caso de Brasil, Colombia, Bolivia y Perú, principalmente en la Amazonía; México, particularmente en la región mesoamericana, Argentina y el Perú en sus regiones costa, sierra y selva. Enseguida se analizan estudios de caso sobre los procesos de manejo y domesticación y sus consecuencias en la generación de divergencias evolutivas. Se incluye una reflexión metodológica sobre los estudios arqueológicos, sus alcances y limitaciones. También se incluyen capítulos sobre ajíes o chiles, agaves, maíz, plantas aromáticas y medicinales, y camélidos. Otro bloque de capítulos analiza la domesticación en el contexto de paisajes rurales y urbanos (especialmente los traspatios) y plantea los espacios manejados como áreas con potencial de conservación de recursos genéticos tanto vegetales como animales. Finalmente, se cierra este volumen poniendo en perspectiva una agenda de temas de investigación que resultan prioritarias, así como estrategias de colaboración internacional en la región latinoamericana con el fin de potenciar el conocimiento, aprovechamiento sustentable y conservación de los recursos y de los procesos que generan diversificación de recursos genéticos.

Palabras clave: biodiversidad, biotecnología, diversidad biocultural, diversidad genética, domesticación, recursos genéticos, manejo sustentable.

\section{Introducción}

En el primer volumen de esta obra definimos a los recursos genéticos como diversidad genética aprovechable en procesos biotecnológicos y concluimos que esta definición involucra desde genes particulares existentes en los individuos, hasta aquellos conjuntos que se encuentran en poblaciones y comunidades bióticas (Casas et al., 2016a, 2016b). En última instancia, esta definición conlleva a considerar como recursos genéticos a la biodiversidad en su conjunto. $Y$ por ello, el manejo sustentable de la diversidad biológica a distintas escalas de organización debe conformar, de manera integral, la estrategia para el manejo sustentable de los recursos genéticos (Casas et al., 2014, 2016b). La intención de este segundo volumen es mostrar algunos estudios de caso y análisis de distintas perspectivas del aprovechamiento, recuperación y conservación de recursos genéticos y, con base en ellos, discutir los grandes temas para una agenda de investigación y acciones que, conjuntamente, diversos grupos de trabajo que confluimos en escenarios latinoamericanos podamos compartir, unificar y sintonizar para la evaluación de su estado, los retos para su aprovechamiento y su conservación a largo plazo.

En el Volumen 1 definimos también las grandes aproximaciones de manejo de recursos genéticos (Casas et al., 2016b), las cuales incluyen: 1) el manejo tradicional campesino, basado en el aprovechamiento de la variación genética surgida mediante procesos naturales en los oganismos que aprovecha (mutación, recombinación, intercambio de genes a través de la reproducción sexual). La apreciación de la diversidad fenotípica, su valoración, uso y manejo diferencial que establecen la pauta de mecanismos evolutivos como la selección artificial y otros procesos evolutivos guiadas por los seres humanos, principalmente el flujo génico y e manejo de sistemas reproductivos, todos estos ifluidos en última instancia por los contextos ambientales, tecnológicos, culturales, económicos y sociales en los que se aprovechan tales recursos; 2) las acciones relacionadas con las ciencias y técnicas del "mejoramiento" (fitomejoramiento, zootécnia) surgidas a partir del manejo dirigido y sistemático de los mecanismos reproductivos de plantas y animales, de los procesos generatrices de diversidad (inducción de mutaciones y manejo de la reproducción), así como procesos planificados e intensivamente dirigidos de selección artificial, todo lo cual determina procesos de domesticación más rápidos que los descritos bajo las técnicas campesinas tradicionales; 3) la ingeniería genética y otras biotecnologías contemporáneas que en las últimas décadas permiten intervenciones directas para la transferencia de genes entre genomas muy distantes entre sí desde el punto de vista filogenético, así como el manejo de diversas técnicas que permiten el manejo de genes y genomas y 4) la genética de la conservación, que involucra estrategias de manejos de individuos, poblaciones y comunidades bióticas dirigidas a mantener y recuperar diversidad genética a esas escalas, asegurar mecanismos de flujo génico que llegan a interrumpirse por actividades humanas, dirigir manejo reproductivo para abatir los niveles de endogamia, entre múltiples estrategias (Casas et al., 2015, 2016b; Casas y Parra, 2016).

Tales expresiones del manejo de recursos genéticos constituyen ejes principales que plantean desafíos específicos para la recuperación y conservación de la diversidad genética a largo plazo: metas fundamentales del manejo sustentable de los recursos genéticos. En el caso de manejo campesino tradicional, diversos autores han identificado como básica la permanencia de mecanismos naturales y artificiales que influyen en la generación de diversidad genética; como lo es el mantenimiento de las poblaciones de organismos, silvestres y domésticos, la heterogeneidad de ecosistemas en los que se distribuyen, y los mecanismos reproductivos que determinan el flujo génico entre las poblaciones y comunidades bióticas (Casas et al., 2016a, 2016b; Casas y Parra, 2007, 2016). Desde la perspectiva humana, mecanismos como la selección artificial, el manejo del flujo génico y de los sistemas reproductivos, los cuales son dirigidos por la cultura, resultan cruciales. Y es la cultura, con objetivos multipropósito, el principal motor que procura el mantenimiento de la diversidad. En los sistemas manejados por seres humanos coexisten elementos silvestres y domesticados, y la diversidad de especies, la que hay dentro de cada una de ellas permite satisfacer necesidades particulares planteadas por las culturas. De esta manera, el mantenimiento de los procesos de diversificación cultura es, al mismo tiempo, el motor fundamental del mantenimiento y desarrollo de la diversificación de recursos genéticos. En otras palabras, la integración de ambos procesos, ecológicos y culturales, mantiene vivos los procesos de generación de diversidad, por ello, estos son considerados expresiones directas de la diversidad biocultural (Casas et al., 2014).

El manejo moderno de recursos genéticos se basa en la generación de información clave sobre los atributos diversificados de los recursos en cuestión. Razón por la cual un gran esfuerzo se ha basado en la caracterización de descriptores de plantas y animales domesticados y, en algunos casos, sus parientes silvestres. Se basa en el mantenimiento in situ de muestras de la diversidad de material biológico y en la experimentación y manejo de mecanismos para poner en contacto reproductivo los linajes de especies o categorías intra-específicas de interés. Las limitaciones de la conservación ex situ discutidas en el volumen 1 de esta obra han permitido el impulso de las estrategias de mejoramiento en campos experimentales, pero también han contribuido a fortalecer programas de manejo in situ en aquellas áreas en las que las varieda- 
des tradicionales se han perdido y se encuentran disponibles en los bancos de germoplasma (Casas et al., 2016b; Casas, 2016; Torres-Guevara et al., 2016). Bajo esta perspectiva, los recursos genéticos mantenidos ex situ e in situ han logrado un entrelazamiento funcional a través de estrategias conocidas como 'fitomejoramiento participativo'. Se trata de impulsar, fortalecer y potenciar los procesos tradicionales de manejo de recursos genéticos integrando procesos de manejo moderno, es decir, integrar las herramientas modernas para dirigir los procesos de diversificación asociados a las culturas locales a los intereses campesinos. La investigación detallada de los sistemas de reproducción sexual y vegetativa en microorganismos y plantas ha constituido una rama de trabajo crucial para ecólogos, microbiólogos, biotecnólogos, botánicos y zoólogos. Esta información es esencialmente relevante en los programas de fitomejoramiento participativo, sobre todo en el caso de las plantas, entre las que la diversidad de mecanismos reproductivos es particularmente alta (sistemas hermafroditas, monoicos, dioicos o trioicos; sistemas autocompatibles, parcialmente autocompatibles y autoincompatibles; sistemas especializados, dependientes de gremios específicos de visitantes florales, o bien sistemas generalistas que pueden reproducirse con la participación de gremios de visitantes florales de amplio espectro) (Casas y Parra, 2016; Casas, 2016).

La biotecnología basada en el ADN recombinante ha sido motivo de una amplia controversia. Por una parte, debido a la incertidumbre en el control de la inserción de genes entre organismos filogenéticamente distantes y las variables interacciones génicas que resultan de dicha incertidumbre. La síntesis de proteínas y reacciones alergénicas son motivo de discusión hoy en día en temas de salud humana. Por otra, las consecuencias ambientales de transferencia de transgenes a poblaciones arvenses o silvestres de plantas han motivado precauciones que no pueden subestimarse. Y finalmente, la mayor crítica a la incorporación masiva de estas herramientas biotecnológicas la ha motivado la presión abierta que ejercen, para su beneficio, las grandes compañías y consorcios industriales que comercializan las semillas y los paquetes de agroquímicos íntimamente asociados a tales semillas. Es el caso de los herbicidas derivados de glifosfatos, para cuya resistencia los organismos genéticamente modificados han sido diseñados con el fin de controlar las plantas arvenses de los cultivos que poseen los transgenes de resistencia a tal herbicida. En este caso, el mayor problema es la ventaja que significa para las empresas vender ambos productos y la alta toxicidad de los compuestos del glifosfato. De manera similar, la otra avenida de organismos genéticamente modificados es la de la incorporación de resistencia otorgada por los genes Bt. En este caso, la dependencia que generan las compañías en los productores se asocia a la progresiva ineficacia de la tecnología, debido a la rápida evolución de resistencia de los herbívoros a las moléculas Bt. En efecto, esta tecnología, como en el caso de los pesticidas, es rápidamente falible debido a la alta tasa evolutiva de los insectos cuya elevada fecundidad y variabilidad, así como los ciclos de vida cortos, permiten respuestas relativamente rápidas al control de una determinada forma de Bt. Ello genera una progresiva necesidad de incorporar nuevas modalidades de genes en las semillas de nueva generación (Casas et al., 2016b; Casas, 2016; Casas y Parra, 2016; Pastor-Soplín et al., 2016).

Las escalas de organización biológica en las que se pueden visualizar los recursos genéticos y las distintas estrategias que pueden vislumbrarse, plantean retos de investigación y acciones diferentes. La agenda de investigación, en todos los contextos, implica conocer y reconoce las especies y variedades silvestres y arvenses emparentadas con los organismos domésti- cos. Reconocer su distribución natural, diagnosticar su abundancia y estado de diversidad genética, y poner en práctica acciones que permitan proteger la salud de sus poblaciones con base en el mantenmiento de niveles altos de diversidad genética. Además, restablecer los puentes de flujo génico de aquellos casos en los que las actividades humanas los han interrumpido. Los parientes silvestres son los reservorios más amplios de diversidad genética de los organismos que constituyen prioridades para la producción de alimentos y materias primas en el mundo contemporáneo (Casas, 2016). Por ello requieren una protección especial. Una de las grandes prioridades a nivel mundial es, sin duda, demarcar las áreas de distribución y proteger las poblaciones de estos. Hasta ahora, la creación de áreas naturales protegidas ha tenido como criterio primordial la existencia de buenas condiciones de conservación y altos niveles de diversidad de especies. Este es un criterio que contribuye a la conservación genera de los recursos genéticos. Sin embargo, es necesario inventariar las especies que han estado dentro de la órbita de las culturas humanas, que han sido aprovechadas de distintas maneras y más aún, aquellas que han recibido formas de manejo. Estos recursos, como se analizó en el volumen I de esta obra, son de una alta prioridad -por su capacidad probada como recursos- a lo largo de la historia humana. Pues bien, la identificación de los parientes silvestres y el diseño de estrategias específicas de conservación de tales especies resultan tan importantes como las estrategias que prevalecen hoy en día en la definición de áreas naurales protegidas. Muchas de estas especies tienen tras de sí una historia de interacciones humanas, incluyendo formas de manejo, por lo que sensu stricto, estas áreas deben reconocerse como áreas de protección biocultural La documentación de los procesos bioculturales, la identificación de las especies y de las áreas clave, son retos de mayor importancia en la construcción de nuevas visiones para definir criterios de prioridades para la conservación. En México, por ejemplo, las áreas remanentes de distribución de los teocintles ameritan políticas específicas de conservación, pero no existen, a excepción de la Reserva de la Biósfera de Manantlán que se decretó como tal a raíz del descubrimiento de Zea diploperennis y explícitamente dirigida a generar un contexto de protección prioritariamente a dicha especie. En el Perú, y en general en la región andina, las especies de Solanum de la serie Petota ameritan políticas específicas de conservación y protección. Las hay para la protección de las variedades nativas, destacando en ello el parque nacional de la papa, pero tampoco existen lineamientos con la orientación de proteger a los parientes silvestres (Casas, 2016, Torres-Guevara et al., 2016).

La protección de las poblaciones y comunidades de parientes silvestres involucra el mantenimiento de estas sin perturbación alguna, así como aquellos estados en los que las poblaciones mantienen interacciones genéticas naturales. Las transformaciones de hábitats naturales, así como el efecto de contaminantes industriales son amenazas primarias de los recursos genéticos y hacia estos factores deben dirigirse políticas específicas. Una amenaza que se ha acentuado en las últimas décadas es el flujo génico con organismos genéticamente modificados. Existen pocos estudios que evalúen la magnitud del flujo génico y menos aún aquellos que hayan medido el efecto de los transgenes en la adecuación de los organismos silvestres o arvenses emparentados. Sin embargo, los pocos trabajos dispnibles sugieren que las posibilidades son reales y las consecuencias sobre los ecosistemas tienen un alto nivel de incertidumbre que ameritan precauciones definidas en diversos protocolos de bioseguridad. Este principio debe conducir a limitar la liberación de organismos genéticamente modificados en las 
áreas que son centros de origen y aun en aquellas áreas en donde existen taxa silvestres que pueden intercambiar genes con los organismos genéticamente modificados.

La erosión genética es una realidad en numerosas áreas del planeta, debida, en parte, a las presiones de las corporaciones e instituciones de los distintos países por promover paquetes tecnológicos (en el pasado las variedades híbridas asociadas a los paquetes tecnológicos de la Revolución Verde, en el presente estos procesos continúan y se acentúan a partir de las presiones de corporaciones productoras de semillas transgénicas adecuadas a su propio paquete tecnológico). Los mecanismos de desplazamiento son, en principio, ocasionados por la adopción de variedades modernas o transgénicas, un proceso que involucra variables sociales, económicas y culturales (Casas y Velásquez-Milla, 2016; Velásquez-Milla et al., 2011, 2016). Estas variables deben entenderse con mayor profundidad, pues se trata de procesos sumamente complejos. Los bloqueos económicos al mercado de productos genéticamente modificados y su prohibición en países del primer mundo han motivado políticas agresivas de comercialización de germoplasma en los países en desarrollo. Ello ha implicado presiones de las corporaciones a los gobiernos, a las instituciones de investigación y a los productores, quienes -en última instancia- padecen las relaciones sociales en sus condiciones de producción, en específico, los costos de producción que motivan fenómenos de migración temporales o definitivos altamente conflictivos. Entre otros conflictos, deben mencionarse las relaciones de dependencia que la adopción de paquetes tecnológicos comerciales genera en las sociedades que han vivido por miles de años de la selección de sus propias semillas.

La cultura es el principal motor de la diversificación de los recursos genéticos en el proceso de domesticación. La pérdida de costumbres asociada a procesos de cambio cultural frecuen temente involucra la pérdida de interés por mantener una determinada varedad o conjunto de variedades. Los procesos migratorios y los efectos de los medios masivos de comunicación como la televisión, la radio, la prensa y desafortunadamente los programas educativos escolares, contribuyen de manera significativa en el desprestigio de los alimentos nativos y e aumento de prestigio de otros de menor valor nutricional (Casas et al., 2016a, 2016b). Todos estos fenómenos de transculturación tienen un efecto negativo sobre la preservación de la diversidad de recursos genéticos y deben ser contrarrestados mediante políticas públicas que lleguen a los foros y contextos que los ocasionan. Nuevamente, son los monopolios -las corporaciones que controlan la producción de alimentos- los principales agentes promotores de cambios culturales. Ante estos, la sociedad civil, las organizaciones sociales, las ONG, entre otros sectores de la sociedad, han tomado iniciativas para contrarrestarlas, pero, sin duda, los esfuerzos requieren la magnitud de políticas de estado y políticas públicas para contrarrestar los efectos nocivos de la propaganda que favorece su promoción.

La protección y recuperación de recursos genéticos requiere, en resumen, conocimiento de estos: su distribución, abundancia, la ecología de sus interacciones y relaciones ecosistémicas (Casas et al., 2016a). Requiere también la documentación de las técnicas tradicionales, modernas y contemporáneas que pueden contribuir a estas metas y ponerlas en concierto (Casas et al., 2016b). Y requiere que el motor cultural que guía los procesos de conservación, recuperación mantiene viva la diversificación pueda mantenerse vigoroso con base en políticas públicas que alcancen los medios masivos de comunicación; sobre todo, los procesos educativos institucio- nales, que justo han sido utilizados en contra. Los trabajos que se presentan en esta obra constituyen un caleidoscopio de experiencias que muestran contextos, avances y limitaciones de las investigaciones realizadas en diferentes países de la región latinoamericana y aun en zonas de los Estados Unidos, reconocidas todas ellas como regiones bioculturales diversas y principales centros de origen de la domesticación, la agricultura y las civilizaciones del Nuevo Mundo.

\section{El libro}

Como se considera de gran importancia documentar el estado de los recursos genéticos de la región, los primeros cuatro capítulos ilustran los esfuerzos que en algunos países se llevan a cabo para inventariar y documentar el estado de los recursos genéticos. En el capítulo 1 Charles Clement (Clement, 2017) muestra un panorama de los recursos vegetales de Brasil, justamente la región del mundo con mayor diversidad en especies vegetales y una de las áreas del mundo con mayor diversidad cultural. Clement pone énfasis en la región amazónica, sin duda, la región más extensa del planeta en términos de diversidad biocultural. En el capítulo 2, Pochettino et al. (2017) muestran un balance del estado de conocimiento de los recursos fitogenéticos de Argentina y hacen una importante reflexión de las rutas para potenciar el diagnóstico de uno de los países más extensos del continente americano, así como un análisis de las políticas necesarias para regular su acceso y manejo con una perspectiva de sustentabilidad. En el capítulo 3, Casas et al. (2017) presentan su estrategia grupal para diagnosticar e estado de los recursos y las experiencias de manejo de estos entre los pueblos mesoamericanos. Muestran, además, el recuento de lo que se conoce sobre la etnoflora de Mesoamérica una de las más antiguas, más vastas y dinámicas del continente. En esa región hay esfuerzos institucionales muy importantes impulsados por la Universidad Nacional Autónoma de México (UNAM) y la Comisión Nacional para el Conocimiento y Uso de la Biodiversdad (CONABIO) que han permitido sistematizar en gigantescos bancos de datos la información documentada por miles de científicos mexicanos y de otros países en el área. Analizan los alcances de estos esfuerzos, así como los riesgos y nuevas metas para continuar en el camino. En el capítulo 4 Torres-Guevara et al. (2017) resumen el proceso histórico de investigación sobre recursos genéticos en el Perú y el estado de conocimientos alcanzados. Este diagnóstico es sumamente importante, pues nos pone frente a una de las áreas más vastas, heterogéneas y antiguas de la civilización del Nuevo Mundo: la región andina. El diagnóstico incluye las áreas geográficas primordiales del Perú: la costa, la sierra y la selva, áreas representativas de la región andina intertropical. Es una de las regiones reconocidas como principal centro de origen de la domesticación de plantas y animales, independiente de la región mesoamericana. Los panoramas peruano, mesoamericano y amazónico tienen un importante complemento con el capítulo 5 , en el que Daniel Debouck (Debouck, 2017) aborda una reflexión general sobre las domesticaciones americanas (así, en plural) y analiza el papel de la diversidad de culturas en su migración original y el puente que ha permitido la botánica contra lo que el autor denomina el impuesto geográfico. El análisis de Debouck tiene interesantes alcances cuando se analizan otros grupos de organismos domesticados: los hongos, los animales vertebrados, los insectos y los frecuentemente olvidados microorganismos (bacterias, levaduras y protozoarios) asociados a los innumerables fermentos diseminados por el continente. 
El caleidoscopio continúa girando y alcanza un momento apasionante y trascendente en el capítulo 6, en el que Verónica Soledad Lema (Lema, 2017) toma al toro ¿por las astas? y aunque no sabemos si es por las astas, los cuernos u otras partes, su irónico título es tomado como punto de partida para mostrarnos profundas e interesantes reflexiones sobre las aproximaciones teóricas y metodológicas en el estudio de la domesticación en el área andina meridional, su región de estudio. Sin embargo, su disertación tiene alcances mucho más lejanos del ámbito territorial para el que se analizan y se proyectan a ambos hemisferios en el norte y sur planetarios.

El capítulo 7, que inaugura una sección del libro, es dedicado a analizar el estado de conocimiento, preguntas e hipótesis por contestar alrededor de grupos particulares de organismos. Esta sección nos conduce a la reflexión de la diversidad y unidad metodológica que se requiere en e estudio de los procesos bioculturales que involucra la domesticación. En el capítulo 7, Barbara Pickersgill (Pickersgill, 2017) resume su monumental experiencia en el estadio de los ajíes o chiles del género Capsicum. Nos cuenta una fascinante historia sobre el aprovechamiento, la domesticación y la biología de este extraordinario e interesante grupo de plantas. Barbara Pickersgill es, hoy por hoy, una de las grandes estudiosas de la domesticación. Su visión y aproximaciones metodológicas incluyeron puentes entre el pasado y el presente; la arqueología representa los estudios del pasado, mientras que la etnobotánica y la sistemática molecular son estudios del presente.

En el capítulo 8, la Dra. Jane C. Wheeler (Wheeler, 2017) nos presenta un interesante panorama acerca del origen y evolución de los camélidos y profundiza en los linajes sudamericanos. Es este, indudablemente, un tratamiento filogenético, etnozoológico y arqueológico de gran valor para entender la evolución natural y artificial de este grupo de animales que marca la gran diferencia entre los patrones de domesticación en el hemisferio norte y en el hemisferio sur de continente americano. El aporte de la Dra. Wheeler ha constituido un parteaguas en el tratamiento del estudio de la domesticación en el curso Domesticación y Manejo in situ de Recursos Genéticos de la UNAM y la UNALM. Su escuela, su grupo de investigación y ahora su contribución escrita han permitido, de manera progresiva, abrir el abordaje de la domesticación de animales, tema que durante los primeros años del curso estuvo prácticamente ausente. En el capítulo 9, Sumar (2017) discute de manera detallada y con una perspectiva muy interesante el tema de la crianza en semicautiverio de la vicuña y cuestiona que estos procesos, eventualmente, condujeron a la domesticación y origen de la alpaca. Ya en el capítulo 10 del volumen 1, Zarazúa (2016) ilustró un gradiente de interacciones entre humanos y animales, y entre ellos identifica la crianza de animales silvestres como una fase altamente significativa en algunos grupos. El análisis de Sumar sobre la vicuña ofrece una perspectiva de gran valor, aportando hipótesis de gran utilidad a investigaciones futuras para aclarar incógnitas que surgen ante la diversidad de los grupos de animales y la complejidad de los problemas que ofrece la realidad lentendimiento humano. Ni todos los grupos de plantas ni todos los grupos de animales han sido factibles de domesticarse, entender no solo los atributos que lo han permitido, sino también aquellos que lo han impedido resulta igualmente interesante.

En el capítulo 10, Rafael Ortega Paczka (Paczka, 2017) nos deleita con un panorama de la diversificación del maíz en Mesoamérica. Analiza, de forma particular, los factores e indicios de conservación in situ y la evolución del maíz bajo domesticación en México, Rafael Ortega Paczka es uno de los grandes conocedores del maíz en México, explorador de campo incansable, digno representante de una escuela etnobotánica y sistemática del maíz iniciada por Efraim Hernández Xolocotzi, uno de los grandes estudiosos de las interacciones entre sociedades humanas y plantas y, desde luego, de los procesos de domesticación. La generosidad del $\mathrm{Dr}$. Paczka permite presentar en este libro una iconografía panorámica de la diversidad de maíces mexicanos y junto con el análisis de los procesos actuales de domesticación del maíz, el lector podrá deleitar su pupila con la mirada de los logros de la diversificación, llevada a cabo en miles de años por los domesticadores mesoamericanos del maíz. El lector podrá coincidir con la ya popular expresión mexicana "sin maíz no hay país".

El capítulo 11 está dedicado al estudio panorámico de otro importante ícono de la domesticación en Mesoamérica: los agaves. Colunga-GarcíaMarín et al. (2017) reúnen en "Los agaves y las prácticas mesoamericanas de aprovechamiento, manejo y domesticación” información sobre el estado de conocimiento de tan importante grupo de plantas domesticadas cuya influencia puede apreciarse en la región andina. Los agaves son de los principales y más antiguos grupos de plantas que brindaron alimentos a los pueblos mesoamericanos, más tarde fueron, a partir de fermentos, y en los últimos siglos han sido bebidas alcohólicas que gozan de un amplio prestigio mundial. El capítulo 12 sigue una línea similar, pues Reinaldo Farias Paiva de Lucena y colaboradores (Lucena et al. 2017), analizan las cactáceas del nordeste brasileño como fuente de recursos para diversos propósitos de la población local, destacando su uso forrajero y como alimento humano. Destaca de entre estas especies la Cereus jamacaru o "mandacaru", especie en la cual los autores han explorado procesos incipientes de domesticación mediante análisis comparativos, morfológicos, reproductivos y genéticos entre poblaciones silvestres y manejadas.

Los capítulos 13 y 14 abordan temas contrastantes de las interacciones de pueblos peruanos con plantas. En el capítulo 13, Gisella S. Cruz-García y Lore Vael (Cruz-García y Vael, 2017) analizan el manejo de plantas comestibles silvestres en una comunidad amazónica, mientras que en el capítulo 14 Milka Tello (Tello, 2017) nos muestra un interesante espectro de percepciones sobre la diversidad de plantas aromáticas usadas por los pueblos andinos. Tello (2017) identifica una percepción de plantas "macho" y "hembra" en la muña (Minthostachys mollis) y en otras especies de plantas, con criterios y patrones similares a los ya identificados en diversas especies mesoamericanas (Casas et al., 1997, 2007, Blancas et al., 2013) y que se traducen en uso diferencial, procesos de selección artificial y domesticación incipiente. Ambos estudios de caso permiten visualizar la diversidad y unidad de formas de interacción entre seres humanos y plantas que nutren teorías e hipótesis del manejo y domesticación de plantas y sus consecuencias en distintas regiones del continente bajo diferentes contextos ambientales y culturales. El forma en la que Tello aborda el tema (2017) encuentra un complemento muy pertinente en el capítulo 18, en donde Carrillo et al. (2017) presentan una revisión del estado del arte sobre la domesticación de plantas medicinales aromáticas. Este grupo de plantas es muy amplio y el manejo y domesticación han sido muy antiguos, pero la mayor atención en los estudios de domesticación la han tenido las plantas comestibles, por ello, este conjunto de trabajos permite abrir la puerta a la comprensión de un grupo muy importante de recursos genéticos.

En el capítulo 15, Daniel Zizumbo y Patricia Colunga (Zizumbo-Villarreal y Coluga-GarcíaMarín, 2017) analizan el sistema agroalimentario mesoamericano precolombino, reconstruyendo aspectos de su origen y diversificación en relación con la difusión de sus recursos fitogené- 
ticos. Ambos son autores pioneros en México en el campo del estudio de la domesticación, ligando la etnobotánica y los estudios morfométricos y genéticos. Su aporte encuentra una valiosa síntesis en el estudio de los patrones precolombinos de alimentación.

En el capítulo 16 Ana Haydeé Ladio y Soledad Molares (Ladio y Molares 2017) presentan un panorama de etnoconservacionismo con base en prácticas locales en la Patagonia. Analizan s universo de estudio desde una perspectiva paisajística, como una construcción cultural de poblaciones rurales mestizas y mapuches que viven de la ganadería, horticultura y recolección. Documentan conocimientos y prácticas de uso del ambiente que brindan soluciones a diversos temas de conservación, con particular énfasis en prácticas in situ y ex situ que incluyen componentes y mecanismos que generan redundancia, diversidad y autosuficiencia. Analizan normas sociales que aseguran el aprovisionamiento de plantas útiles y un uso eficiente y solidario que evita su sobreexplotación. Ponen un énfasis especial en que estos procesos pueden construir importantes perspectivas para el aprovechamiento y conservación de los componentes y los paisajes.

En contextos contrastantes, pero con lineamientos conceptuales similares a los de Molares y Ladio (2017), en el capítulo 17 Pochettino et al. (2017) analizan en paisajes periurbanos de Buenos Aires, Argentina, los huertos comerciales como reservorios de diversidad biocultural capaces de satisfacer las necesidades de los habitantes, al mismo tiempo que permiten mantener recursos genéticos locales y otros servicios ambientales ligados al mantenimiento de los huertos. Para seguir con esta línea de conservación ex situ, en el capítulo 19 Cruse-Sanders y Casas (2017) analizan el papel de huertos tradicionales, lo mismo que jardínes botánicos en la conservación y domesticación de biodiversidad. Los huertos son reservorios de una elevada diversidad de especies de plantas, pero también de animales. $Y$ en este contexto, en el capítulo 20, el trabajo de Ramón Mariaca (Mariaca, 2017) nos muestra un panorama de sus estudios faunísticos en los traspatios familiares del sureste de México.

Los capítulos que componen este volumen culminan con tres reflexiones fundamentales: en el capítulo 21, Paulina Lezama-Núñez y Dídac Santos-Fida (Lezama-Núñez y Santos-Fida, 2017) hacen un análisis comparativo de los criterios de selección humana en animales entre las comunidades tradicionales y los productores industriales. Nos ilustran que después de 500 años de colonización europea, los animales introducidos al continente americano han continuado procesos evolutivos en contextos culturales y ecológicos distintos. Lo mismo en contextos tradicionales indígenas en zonas calientes y frías, así como en contextos de producción intensiva para la producción masiva dirigida a la industria. En el capítulo 22, Santiago Pasto (Pastor-Soplín et al.,2017) analiza el marco legislativo peruano que norma el aprovechamiento de recursos genéticos, su fragilidad y vilnerabilidad ante los embates de las grandes corporaciones y la debilidad $u$ oportunismo de las instituciones gubernamentales. Ponen sobre la mesa las premisas fundamentales para regular la protección de los recursos genéticos como parte del patrimonio biocultural de los pueblos. Finalmente, el conjunto de textos de este volumen da pauta para, en el capítulo 23, analizar (Casas et al., 2017) algunos patrones continentales de manejo y domesticación de recursos genéticos. Además, propone lineamientos generales de la agenda de investigación y acciones e interacciones que permitirían potenciar las actividades capaces de satisfacer la diversidad de requerimientos humanos, al mismo tiempo que preservar la diversidad del patrimonio biocultural.

\section{Bibliografía}

Blancas, J., A. Casas, S. Rangel-Landa, I. Torres, E. Pérez- Casas, A., A. I. Moreno-Calles, M. Vallejo, F. Parra, 2016b. Negrón, L. Solís, A. I. Moreno, A. Delgado, F. Parra, Y. Arellanes, J. Caballero, L. Cortés, R. Lira y P. Dávila, 2010. Plant management in the Tehuacán-Cuicatlán

Blancas, J., A. Casas, D. Pérez-Salicrup, J. Caballero y E. Vega, 2013. Ecological and sociocultural factors of the Tehuacán Valley, Mexico. Journal of Ethnobiology and Ethnomedicine 9: 39.

Carrillo, G., R. A. Bye y L. Eguiarte, 2017. Capítulo 18 A. J. En: Casas, A., J. Torres-Guevara y F. Parra (Eds.). Domesticación en el continente americano. Volumen 2 . Investigación para el manejo sustentable de recursos genéticos en el Nuevo Mundo. Universidad Naciona Autónoma de México, Universidad Nacional Agraria México. Ediagraria, Lima, Perú.

Casas, A., 2016. Capítulo 12. Manejo in situ y ex situ de recursos genéticos En: Casas, A., J. Torres-Guevara y Volumen 1. Manejo de biodiveridad y evolución dirigida por las culturas del Nuevo Mundo. Universidad Naciona Autónoma de México /Universidad Nacional Agraria L Molina, Peru/ Consejo Nacional de Ciencia y Tecnología, México. Ediagraria, Lima, Perú, pp. 347-359.

Casas, A., J. Caballero, C. Mapes y S. Zárate, 1997. Manejo de la vegetación, domesticaciónde plantas y origen de la agricultura en Mesoamérica. Boletín de la Sociedad

Casas, A., A. Otero-Arnaiz, E. Pérez-Negrón, y A. ValienteBanuet, 2007. In situ management and domestication
of plants in Mesoamerica. Annals of Botany 100(5): of plants in

Casas, A., A. Camou, S. Rangel-Landa, L. Solís, I. Torres, A. Gelgado-Lemus, A. I. Moreno Calles, M. Vallejo, Farfán-Heredia, Y. Arellanes y E. Pérez-Negrón, 2014 Manejo tradicional de biodiversidad y ecosistema en Mesoamérica: El Valle de Tehuacán. Investigación Ambiental, Ciencia y Política Pública 6(2): 23-44.

Casas A., F. Parra, S. Rangel, S. Guillén, J. Blancas y C. J. Figueredo, 2015. Evolutionary ecology and ethnobiology. En: Albuquerque, U. P., P. Medeiros y A. Casas (Eds.) Evolutionary ethnobiology. Springer. Utrecht, Holanda,
pp. $37-57$.

Casas A., R. Lira, I. Torres, A. Delgado-Lemus, A. I. MorenoCalles, S. Rangel-Landa, J. Blancas, L. Solís, E y Y. Arellanes, 2016a. Ethnobotany for sustainable ecosystem management: A regional perspective in the Tehuacán Valley. En: Lira, R., A. Casas y J. Blancas (Eds.). Ethnobotany of Mexico. Interactions of peoples and plants in Mesoamerica. Capitulo 8. Springer, Utrecht, Holanda, pp. 179-206. genéticos. En: Casas, A., J. Torres-Guevara y F. Parra por las culturas del de biodiveridad y evolución dirigid Autónoma de México /Universidad Nacional Agraria La México. Ediagraria, Lima, Perú, pp. 51-74.

Casas, A. y F. Parra, 2007. Agrobiodiversidad, parientes Silvestres
23(2): $5-8$.

Casas, A. y Parra, F. 2016. Capítulo 1. El manejo de recursos naturales y ecosistemas: la sustentabilidad en el manejo de recursos genéticos. En: Casas, A. J. Torres-Guevara y F. Parra (Eds.). Domesticación biodiversidad y evolución dirigida por las culturas de México Universidad Nacional Agraria La Molina Consejo Nacional de Ciencia y Tecnología, Mexico. Ediagraria, Lima, Perú., pp. 25-50.

Casas, A. y D. Velásquez-Milla, 2016. Capítulo 3. Erosión En: Casas, A., J. Torres Guevara y F. Parra Eds.). Domesticación en el continente americano. Volumen 1. Manejo de biodiveridad y evolución dirigida por las culturas del Nuevo Mundo. Universidad Naciona Autónoma de México /Universidad Nacional Agraria México. Ediagraria, Lima, Perú, pp. 75-95.

asas A., F. Parra, S. Rangel-Landa, J. Blancas, M. Vallejo, A. I. Moreno-Calles, S. Guillén,I. TorresFircia, A. Delgado-Lemus, E. Pérez-Negrón, C. $X$. Aguirre-Dugua, A O Otero-Arnaiz, H. AlvaradoSizzo, A. Camou-Guerrero, 2017. Capítulo 3. Manejo y domesticación de plantas en Mesoamérica. Una estrategia de investigación y estado del conocimiento sobre los recursos geneticos en Mexico. En: Casas, en el continente americano. Volumen 2. Investigación para el manejo sustentable de recursos genéticos en el Nuevo Mundo. Universidad Nacional Autónom de México, Universidad Nacional Agraria La Molina, Consejo Nacional de Ciencia y Tecnología, México. Ediagraria, Lima, Perú.

Casas, A., F. Parra y J. Torres-Guevara, 2017. Capítulo 23. Estudios y patrones continentales de domesticación manejo de recursos genéticos: Perspectivas. En: Casas, A., J. Tons-Gevara y F. Par (Eds.). Domesticación para el manejo sustentable de recursos genéticos en el Nuevo Mundo. Universidad Nacional Autónoma de México, Universidad Nacional Agraria La Molina, Consejo Nacional de Ciencia y Tecnología, México. Ediagraria Lima, Perú. (Eds.). Domesticación en el continente americano. Molina, Perú/ Consejo Nacional de Ciencia y Tecnología, en el continente americano. Volumen 1. Manejo de 
Clement, C. R., 2017. Capítulo 1. Panorama de los Recursos Lucena, Re. F. P., C. Marques de Lucena, M. V. Meiado, D. Genéticos de Brasil, con énfasis en la Amazonia. En: Casas, A., J. Torres-Gevara y F. Parra (Eds.).
Domesticación en el continente americano. Volumen 2. Investigación para el manejo sustentable de recursos genéticos en el Nuevo Mundo. Universidad Naciona Aa Molina Consejo Nacional de Ciencia y Tecnologí México. Ediagraria, Lima, Perú.

Colunga-GarcíaMarín, P., A. Casas, I. Torres, C. J. Figueredo, S. Rangel-Landa, A. Delgado-Lemus, O. Vargas, D. Cabrera-Toledo, X. Aguirre-Dugua, L. E. Eguiarte, G 11. Los agaves $\mathrm{y}$ las prácticas mesoamericanas $d$ aprovechamiento, manejo y domesticación. En: Casas A., J. Torres-Gevara y F. Parra (Eds.). Domesticación para el manejo sustentable de recursos genéticos para el manejo sustentable de recursos genéticos en México, Universidad Nacional Agraria La Molina, Consejo Nacional de Ciencia y Tecnología, México. Lima, Perú.

Cruse-Sanders, J. M. y A. Casas, 2017. Capítulo 19. Impacto evolutivo de actividades humanas sobre plantas:
Domesticación y conservation ex-situ. En: Casas, A. J. Torres-Gevara y F. Parra (Eds.). Domesticación en el Continente Americano. Volumen 2. Investigación para el manejo sustentable de recursos genéticos en el Nuevo Mundo. Universidad Nacional Autónoma de Nacional de Ciencia y Tecnología, México. Ediagraria, Lima, Perú.

Cruz-García G. S. y L. Vael, 2017. Capítulo 13. El manejo de plantas silvestres alimenticias en escenarios de deforestación, ilustrado por una comunidad mestiza de la Amazonía Peruana. En: Casas, A., J. Torres-Gevara y F. Parra (Eds.). Domesticación en el continente americano.
Volumen 2. Investigación para el manejo sustentable de recursos genéticos en el Nuevo Mundo. Universidad Agraria La Molina, Consejo Nacional de Ciencia Tecnología, México. Ediagraria, Lima, Perú

Debouck, D. 2017. Capítulo 5. Domesticaciones americanas: la recursividad humana y la ayuda botánica contra A., J. Torres-Gevara y F. Parra (Eds.). Domesticación
impuration en el continente americano. Volumen 2. Investigación el Nuevo Mundo. Universidad Nacional Autónoma de Mexico, Universidad Nacional Agraria La Molina, Consejo Lima, Perú. Lema, V. S., 2017. Capítulo 6. Al toro ¿por las astas? Reflexiones sobre aproximaciones teóricas y
metodológicas a la temática de la domesticación en el área andina meridional. En: Casas, A., J. TorresGuevara y F. Parra (Eds.). Domesticación en el continente americano. Volumen 2. Investigación para el manejo
sustentable de recursos genéticos en el Nuevo Mundo. sustentable de recursos genéticos en el Nuevo Mundo.
Universidad Nacional Autónoma de México, Universidad Universidad Nacional Autonoma de México, Universidad y Tecnología, México. Ediagraria, Lima, Perú.
Dias da Cruz, M. Oliveira de Andrade y A. Casas, 2017. en Brasil. En: Casas, A., J. Torres-Guevara y F. Parra (Eds.). Domesticación en el continente americano der. Nacional Autónoma de México, Universidad Naciona Agraria La Molina, Consejo Nacional de Ciencia y Tecnología, México. Ediagraria, Lima, Perú.

ariaca Méndez, R., 2017. Capítulo 20. Avances en el estudio de la fauna de los traspatios familiares en el sureste de México. En: Casas, A., J. Torres-Guevara y F. Parra (Eds.). Domesticación en el continente americano. Volumen 2 . Investigación para el manejo sustentable de recursos genéticos en el Nuevo Mundo. Universidad Naciona

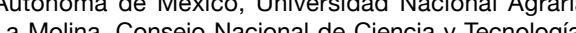
México. Ediagraria, Lima, Perú.

Monroe, J., 2017. Capítulo 21. En: Casas, A., J. TorresGuevaray F. Parra (Eds) Domesticación en el continente americano. Volumen 2. Investigación para el manejo sustentable de recursos genéticos en el Nuevo Mundo. Universidad Nacional Autónoma de México, Universidad Nacional Agraria La Molina, Consejo Nacional de Ciencia y Tecnología, México. Ediagraria, Lima, Peru. Etnoconservacionismo y prácticas locales en Patagonia: avances y perspectivas. En. Casas, A., J. Torres-Guevara y F. Parra (Eds.). Do E Sticación Jún el continente sustentable de recursos genéticos en el Nuevo Mundo. Universidad Nacional Autónoma de México, Universidad Nacional Agraria La Molina, Consejo Nacional de Ciencia y Tecnología, México. Ediagraria, Lima, Perú.

ortega Paczka, R., 2017. Capítulo 10. Factores e indicios de conservación in situ y evolucion bajo domesticación de maíz en México en el último siglo. En: Casas, A., J. Torres-Guevara y F. Parra (Eds.). Domesticación en ef continente americano. Volumen 2. Investigación para manejo sustentable de recursos genéticos en el Nuevo Universidad Nacional Agraria La Molina, Consejo Ciencia y Tecnología, México. Ediagraria Lima, Perú.

astor-Soplín S., E. Yglesias-Gálvez y E. RivasSeoane, 2016. Apuntes y reflexiones sobre algunas herramientas biotecnológicas para la conservación de la agrobiodiversidad y mejoramiento de la agricultura familiar en el Peru. En: Casas, A., J. Torres-Guevara y Parra (Eds.). Domesticación en el continente americano. por les culturas del Nuevo Mundo. Universidad dirigicia Autónoma de México /Universidad Nacional Agraria La Molina, Perú, Consejo Nacional de Ciencia y
México. Ediagraria, Lima, Perú, pp. 387-412.

kersgill, B., 2017. Capítulo 7. Ajíes o chiles (Capsicum spp.): historia y biología. En: Casas, A., J. Torres-
Guevaray F. Parra (Eds.). Domesticación en el continente americano. Volumen 2. Investigación para el manejo Capítulo 12. Uso, manejo y domesticació de cactáceas

Molares S. y A. H. Ladio., 2017. Capítulo 16 sustentable de recursos genéticos en el Nuevo Mundo. Universidad Nacional Autonoma de México, Universida Teriona y Tecnología, Méxicc

Pochettino, M. L., Lema, Verónica, Hilgert, N. y Ladio A. H., 2017. Capítulo 2. Los recursos genéticos en Argentina: Caminos para su conocimiento, atajos para su acceso, avatares de su gestión. En: Casas en el continente americano. Volumen 2 . Investigación para el manejo sustentable de recursos genéticos en el Nuevo Mundo. Universidad Nacional Autónoma de México, Universidad Nacional Agraria La Molina, Perú, Consejo Nacional de Ciencia y Tecnología, México. Ediagraria, Lima, Perú.

Pochettino, M. L., M. M. Bonicatto y J. A. Hurrell., 2017 Capitulo 17. Huertos comerciales del periurbano de Plata (Buenos Aires, Argentina): Reservorio de diversidad (Eds). Domesticasión en el continente americano. Volumen 2. Investigación para el manejo sustentable de recursos genéticos en el Nuevo Mundo. Universida Nacional Autónoma de México, Universidad Naciona Agraria La Molina, Perú, Consejo Nacional de Ciencia Tecnología, México. Ediagraria, Lima, Perú.

Sumar, J., 2017. Capítulo 9. La Quimera de la Domesticación de la Vicuña y la falacia de la crianza en semicautiverio.
En: Casas, A., J. Torres-Gevara y F. Parra (Eds). En: Casas, A., J. Torres-Gevara y F. Parra (Eds.).
Domesticación en el continente americano. Volumen 2. Domesticación en el continente americano. Volumen 2.
Investigación para el manejo sustentable de recursos Investigación para el manejo sustentable de recursos Autónoma de México, Universidad Nacional Agraria La Molina, Perú, Consejo Nacional de Ciencia y Tecnología, México. Ediagraria, Lima, Perú.

Tello-Villavicencio, M., 2017. Capítulo 14. Las plantas aromáticas en los Andes peruanos. En: Casas, A., J. Torres-Guevara y F. Parra (Eds.). Domesticación en el continente americano. Volumen 2. Investigación para el manejo sustentable de recursos genéticos en el Nuevo Mnido. Universidad Nacional Autonnoma de Mexico, Nacional de Ciencia y Tecnología México. Ediagrajia, Lima, Perú.

Torres Guevara, J., A. Cruz-Soriano y F. Parra, 2016. La conservacín in situ en el Perí Una experiencia dentro del proyecto "Conservación in situ de cultivos nativos y sus parientes silvestres en el Perú" En: Casas, A. J. Torres-Guevara y F. Parra (Eds.). Domesticación en el continente americano. Volumen 1. Manejo de biodiveridad y evolución dirigida por las culturas del Nuevo Mundo. Universidad Nacional Autónoma de . Ediagraria, Lima, Perú, pp. 361-386.

es-Guevara J. y F. Parra, 2017. Capítulo 4. Panoram de los recursos genéticos en Perú. En: Casas, A., Ton el Gontinante americano. Volumen 2 . Investigción para el manejo sustentable de recursos genéticos en el Nuevo Mundo. Universidad Nacional Autónoma de México, Universidad Nacional Agraria La Molina Perú, Consejo Nacional de Ciencia y Tecnología, México. Ediagraria, Lima, Perú

squez-Milia, D., A. Casas, J. Torres-Guevara y A. Cruz, 2011. Ecological and socio-cultural factors influencing in situ conservation of crop diversity by tradition Andean households in Peru. Journal of Ethnobiology

ásquez-Milla, D., A. Casas, J. Torres-Guevara, A. Cruz-Soriano, 2016. Capítulo 4.Erosión Genética ecológicos y socio-culturales que influyen en a pérdid y conservación de agrobiodiversidad. En: Casas, A J. Torres-Guevara y F. Parra (Eds.). Domesticación $y$ en el continente americano. Volumen 1. Manejo de biodiveridad y evolución dirigida por las culturas del Núxo Mundo. Universidad Nacional Autonoma de México /Universidad Nacional Agraria La Molina, Ediagraria, Lima, Perú, pp. 97-131.

heeler, J. C., 2017. Capítulo 8. Evolución y domesticación de los camélidos sudamericanos. En: Casas, A., J Torres-Guevara y F. Parra (Eds.). Domesticación en el continente americano. Volumen 2. Investigación para el manejo sustentable de recursos geneticos en el Nuevo Mundo. Universidad Nacional Autónoma de México, Universidad Nacional Agraria La Molina, Perú, Consejo Lima, Perú.

Zizumbo-Villarreal, D. y P. Colunga-GarcíaMarín, 2017 Capitulo 15. El sistema agroalimentario mesoamerican precolonbito: ónen, divericicación y difusión de sus y F. Parra (Eds.). Domesticación en el continente americano. Volumen 2. Investigación para el manejo sustentable de recursos genéticos en el Nuevo Mundo. Universidad Nacional Autónoma de Mexico, Universidad Nacional Agraria La Molina, Perú, Consejo Nacional. 


\section{Panorama de los recursos genéticos en Brasil con énfasis en la Amazonia}

Charles R. Clement

\section{Resumen}

Junto con Mesoamérica y los Andes, la Amazonia es uno de los principales centros de domesticación de cultivos neotropicales, con al menos 83 especies de plantas nativas en algún grado de domesticación. La conquista de Brasil inició en 1500, y durante la colonización otras especies fueron introducidas y sometidas a procesos locales de domesticación. El uso sustentable de recursos genéticos (diversidad genética aprovechable actual o potencialmente) es la utilización de componentes de la diversidad biológica, de manera y en un ritmo tal que no conduzcan, a largo plazo, a una disminución de la diversidad biológica, manteniendo así su potencial para atender las necesidades y aspiraciones de las generaciones presentes y futuras. La agrobiodiversidad es un concepto relacionado -término relativamente nuevo- que engloba a los recursos genéticos, pero incluye también al agroecosistema, pues los recursos genéticos requieren ayuda de los seres humanos y otros organismos para producir. Aproximadamente veinticinco millones de personas viven actualmente en la Amazonia, veinte millones en la Amazonia brasileña. El sur y el sureste de la Amazonia son importantes productores de alimentos y madera, pero la mayor parte de la producción se basa en cultivos exóticos, mientras que casi toda la madera proviene de especies nativas explotadas de forma extractiva. La biodiversidad es inmensa, aproximadamente el $15 \%$ del total mundial, y supuestamente se encuentra protegida por esfuerzos internacionales. La Amazonia es considerada una las doce regiones más importantes de la domesticación de plantas cultivadas antes de la conquista europea de planeta, pero no fue considerada así por Vavilov, por no considerar que las tierras bajas del trópico húmedo mundial tuvieran algo que ofrecer a la agricultura soviética. La mayoría de las 83 especies nativas con poblaciones domesticadas son arbóreas, lo que no sorprende siendo la Amazonia un bioma eminentemente forestal, pero este rasgo la hace diferente a la mayoría de los centros de domesticación. Los primeros pueblos llegaron a la región hace unos 15 000 años y fueron cazadores-recolectores. Aproximadamente hace 12000 años domesticaban Cucurbita ecuadorensis y las plantas nativas de la Amazonia aparecen entre 8000 y 6000 años A.P. en sitios arqueológicos a lo largo del litoral de Perú. La primera planta nativa de la Amazonia fue la mandioca y apareció en la parte peruana de la región, lo que sugiere que su domesticación comenzó por lo menos 9000 años A.P. Hacia el final del Holoceno medio, entre 4000 y 3000 años A.P., las poblaciones humanas comenzaron a depender de la producción 
de alimentos, y sus tamaños poblacionales comenzaron a expandirse a ritmos acelerados. No obstante, la mayor expansión poblacional no ocurrió en la periferia de la Amazonia, sino a lo largo de los grandes ríos de agua blanca en la región central de las cuencas de los ríos Amazonas, Solimões, Madeira y Ucayali. La conquista europea devastó los pueblos americanos. Entre 1500 y 1750 d.C., la población indígena descendió en un 95\% y además de la pérdida de vidas, se perdieron también conocimientos y recursos genéticos acumulados a lo largo de milenios. Una estimación razonable es que la pérdida de recursos genéticos fue similar a la pérdida de la población humana. Durante la colonia, la economía amazónica se concentró en el extractivismo de productos forestales no maderables, las llamadas drogas del desierto, y la producción agropecuaria, incluyendo la introducción de cultivos tropicales, predominantemente de Asia y África. La introducción de cultivos asiáticos y africanos involucró la sustitución de recursos genéticos. Muchos de los cultivos tropicales que fueron introducidos en la Amazonia se volvieron más importantes. La era moderna de investigación y desarrollo en los recursos genéticos nativos de la Amazonia tuvo inicio con la creación del Instituto Agronómico del Norte (IAN) en Belém, en 1939. El IAN fue incluido en el Servicio Nacional de Pesquisas Agronómicas, en 1943, y pasó a ser el núcleo de una red de institutos menores de los principales centros de la Amazonia. En 1946, Adolfo Ducke publicó lo que puede considerarse el primer levantamiento de recursos genéticos indígenas. El IAN pasó a ser denominado Instituto de Investigación y Experimentación Agropecuaria del Norte en 1962. Después de la creación del Embrapa en 1973, el IPEAN pasó a ser denominado Centro de Investigación Agropecuaria del Trópico Húmedo. Entre 1975 y 1990 asociaciones como el CENARGEN, las unidades de Embrapa y otras instituciones amazónicas e internacionales recolectaron recursos genéticos de mandioca, cacao, piña, caucho, la palma aceitera "caiaué" (Elaeis oleifera), la palma "pupuña" (Bactris gasipaes), "babaçu" (Attalea speciosa), "açaí-do-pará" (Euterpe oleracea), "patauá" (Oenocarpus bataua) y la "vacaba" (O. bacaba, O. distichus, O. mapora, O. minor), y diversos chiles o ajíes (Capsicum spp.). En tiempos recientes, las instituciones brasileñas de la Amazonia, como sus pares en Brasil y en América Latina, no han sido apoyadas para desarrollar nuevos recursos genéticos nativos y nuevos productos para crear nuevos nichos en los mercados locales y nacionales. Como consecuencia, han tenido dificultades para mantener sus colecciones, y la mayoría de estas ha sufrido erosión genética en algún grado, llegando incluso a la extinción de colecciones. El uso actual de los recursos genéticos de la agrobiodiversidad amazónica no es sustentable y la situación no es diferente en el resto de Brasil. Esta afirmación se basa en el actual modelo de desarrollo que está siendo practicado en la Amazonia, en Brasil y en el mundo. Un mundo distinto es posible, pero lograrlo requiere un modelo diferente de desarrollo que priorice a las personas, a las comunidades y a la naturaleza más que al capital.

Palabras clave: Amazonia, Brasil, cultivos neotropicales, domesticación, recursos forestales no maderables, recursos genéticos.

\section{Introducción}

La Amazonia es uno de los principales centros de domesticación de cultivos neotropicales, unto con Mesoamérica y los Andes (Clement, 1999a, 1999b; Clement et al., 2010). Por lo menos 83 especies nativas de la Amazonia poseen poblaciones con algún grado de domesticación. En el Cerrado, la Mata Atlántica y en la Caatinga otras especies también fueron domesticadas (Clement, 2001), aunque en menor medida que en la Amazonia. La conquista de Brasil comenzó en 1500, y durante la colonización otras especies de distintas partes de mundo fueron introducidas, determinando así que numerosas regiones de Brasil sean consideradas centros secundarios de diversidad genética sensu Vavilov (1992b). Estos cultivos -tanto los nativos como los exóticos que han evolucionado regionalmente por cerca de quinientos años- conforman en conjunto la agrobiodiversidad de Brasil y, como en el resto de mundo, vale la pena evaluar su historia y el actual estado del arte de su uso y conservación. En este capítulo, comenzaré definiendo algunos conceptos, abordaré un poco de la historia sobre su origen, domesticación y dispersión de especies como cultivos, principalmente de aquellos domesticados en la Amazonia, para después examinar los problemas de erosión genética y su estado actual.

\section{Conceptos de uso sustentable, recursos genéticos y agrobiodiversidad}

La sustentabilidad es una preocupación reciente, nacida con el sello de la comunidad académica, cuando se constata el impacto de la actividad humana sobre la biodiversidad de planeta. La sustentabilidad se encuentra íntimamente asociada al desarrollo, de forma que su primera definición fue sobre el binomio: "desarrollo sustentable" el cual ha sido entendido como las acciones que "[...] deben atender las necesidades de la generación actual sin comprometer la habilidad de las generaciones futuras para atender sus necesidades" (Brundtland, 1987). Consecuentemente, el uso sustentable es la utilización de componentes de la diversidad biológica de manera y en un ritmo tal que no conduzcan, a largo plazo, a una diminución de la diversidad biológica, manteniendo así su potencial para atender las necesidades y aspiraciones de las generaciones presentes y futuras (ONU, 1992). Recursos genéticos es un término con más historia, habiendo aparecido por primera vez durante las primeras décadas del siglo pasado. En la primera época, el término reconoció el trabajo implícito en transformar un componente de la biodiversidad en algo útil para los seres humanos; es decir, la selección y propagación efectuada por los humanos crean nuevos recursos genéticos, lo que explica por qué están íntimamente asociados estos recursos a la agricultura. Sin embargo, una definición más reciente, también en un documento de la ONU, plantea que los recursos genéticos adquirieron un nuevo sentido: ·material genético de valor actual o potencial" (ONU, 1992). La palabra 'potencial' es definida en el Diccionario de Aurélio como "un carácter que puede ser producido, o producirse, aunque aún no exista" 
Con esta definición, los ideólogos de la Convención sobre la Diversidad Biológica (CDB) transformaron toda la biodiversidad en recursos genéticos, con la esperanza de estimular la conservación; un propósito no exitoso, pues se sabe que las extinciones no disminuyeron y probablemente se expandieron (Rockström et al., 2009). Agrobiodiversidad igualmente es un término nuevo que engloba a los recursos genéticos, pero este incluye al agroecosistema, pues los recursos genéticos requieren ayuda de los seres humanos y otros organismos para producir. Nuevamente, un documento de la ONU la define como: "La variedad y variabilidad de animales, plantas y microorganismos usados directa o indirectamente como alimentos y en la agricultura, incluyendo los cultivos, los componentes pecuarios, los bosques y los recursos pesqueros" (Pimbert et al., 1999).

¿Por qué tantas definiciones extraídas de tratados legales y documentos oficiales? Porque estos temas no son ya del ámbito exclusivo de biólogos, ingenieros agrónomos y forestales, zootecnistas y mejoradores. Lo son también de abogados, diplomáticos, políticos, empresarios y hasta de la policía; todo ello, debido a un esfuerzo mundial que busca garantizar contribuciones para un desarrollo sustentable, lo que también exige una repartición equitativa y justa de los beneficios de tal desarrollo.

¿Y qué tienen que ver estos asuntos con la Amazonia? Aproximadamente veinticinco millones de personas viven actualmente en la Amazonia, veinte millones de los cuales tan solo en la Amazonia brasileña. El sur y el sureste de la Amazonia son importantes productores de alimentos y madera, y la mayor parte de la producción agrícola se basa en cultivos exóticos, mientras que la -casi- totalidad de madera proviene de especies nativas explotadas de forma extractivista. Es la biodiversidad el principal tema que estimula la imaginación de las personas cuando se escucha de la Amazonia, ya que tal biodiversidad en la región es inmensa: constituye aproximadamente el $15 \%$ del total mundial, y supuestamente es protegida internacionalmente. Sin embargo, la biodiversidad amazónica contribuye con apenas $0.6 \%$ del producto interno bruto de Brasil (Clement, 2007), lo que constituye un elemento que ayuda a entender por qué está tan amenazada. Si la biodiversidad amazónica tuviera un cierto valor sería conservada; este es al menos uno de los supuestos de la CDB. Y de ser así, también sería lógico que consecuentemente fuera protegida por los brasileños, no solamente por los extranjeros. A continuación planteo una interrogante, de cierta forma ingenua, pero pertinente: si es tan valiosa la biodiversidad, ¿por qué estamos derribando los bosques para plantar pastos y soya? Es evidente, aún para los legos, que estas acciones no constituyen en forma alguna un uso sustentable de la biodiversidad.

¿Será que la situación de la agrobiodiversidad es diferente? En este análisis pretendo tratar tan solo una fracción de la agrobiodiversidad amazónica, aquella parte que se refiere a los supuestos y premisas de la definición original de recursos genéticos, o sea, la de las plantas domesticadas en algún grado por los primeros pueblos nativos. No trataré los recursos animales porque los primeros pueblos domesticaron tan solo una especie de pato (Kerr y Clement, 1980). En cambio, mencionaré algunos esfuerzos modernos para usar el mejoramiento genético con el fin de generar nuevos recursos genéticos. Se verá que los recursos genéticos de la agrobiodiversidad nativa fueron usados de forma sustentable en el pasado y se discutirá una comparación con las formas presentes.

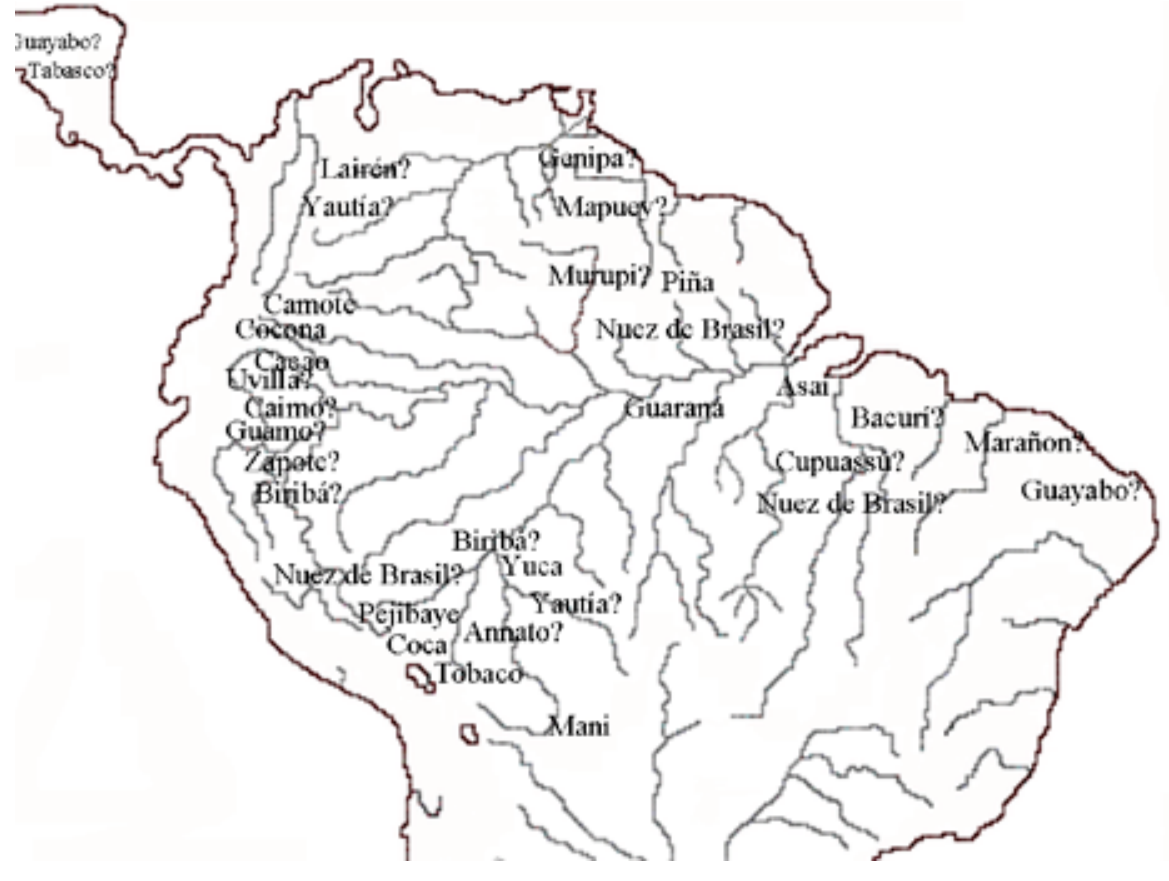

Figura 1.1. Las regiones en las que algunas plantas cultivadas comenzaron a ser domesticadas son conocidas, y otras son apenas hipotéticas (nombres con signo de interrogación) (Clement et al., 2010). Obsérvese que muchas de las especies amazónicas familiares para todos los amazónicos no están en el mapa, simplemente porque no tenemos idea de dónde podría haber iniciado su domesticación.

\section{El origen de los cultivos de Amazonia. periferia más que centro}

La Amazonia es actualmente considerada como una de las doce regiones más importantes de domesticación de plantas cultivadas antes de la conquista europea del planeta (Meyer et al., 2012); pero ello no se concluyó como tal por Vavilov (1992b), quien identificó apenas ocho regiones, por no considerar que las regiones de las tierras bajas del trópico húmedo mundial tuvieran algo que ofrecer a la agricultura soviética. Entre los cultivos más importantes del mundo, la mandioca (Manihot esculenta), la piña (Ananas comosus) y el cacao (Theobroma cacao) se originaron en la Amazonia y se dispersaron a los neotrópicos antes de la conquista europea. Por lo menos 83 especies nativas de la Amazonia presentan poblaciones con evidencias de domesticación en algún grado, desde domesticación incipiente hasta domesticación completa; estas especies representan la agrobiodiversidad nativa, y la lista completa se puede consultar en el trabajo de Clement (1999a). De los cultivos nativos sobre los que se tiene alguna información, la mayoría se originó en la periferia de la región (Clement et al., 2010), no en el área central de la Amazonia (Figura 1.1). Los cultivos que se originaron en los bosques abiertos al sur de la Amazonia con- 
cuerdan con las expectativas de Piperno y Pearsall (1998); sin embargo, los que se originaron en los bosques menos abiertos en las inmediaciones de los Andes no concuerdan con tales predicciones. Para dichas áreas no se sabe lo suficiente sobre la arqueología de las tierras bajas adyacentes a los Andes como para plantear hipótesis capaces de explicar las aparentes anomalías en distribución y abundancia de especies domesticadas y silvestres.

Además de los cultivos domesticados en la Amazonia, los pueblos nativos cultivaban un alto número de especies exóticas, provenientes de Mesoamérica y de otras regiones del norte de América del Sur, del Nordeste brasileño y tal vez de la Mata Atlántica y del Cerrado (Tabla 20.1). La mayoría de las 83 especies nativas con poblaciones domesticadas son arbóreas, hecho que no resulta sorprendente por tratarse de un bioma forestal, pero este rasgo hace de la Amazonia diferente a la mayoría de los centros de domesticación. Entre los cultivos antiguos y actuales, se encuentran restos de una especie de origen africano, la Lagenaria siceraria, el calabazo, que llegó de Asia con los primeros inmigrantes del continente americano.

\section{Los centros de diversidad de recursos genéticos en la época de la conquista}

Los primeros pueblos en llegar a la Amazonia, aproximadamente 15000 años antes del presente (años A.P.) fueron cazadores-recolectores, aunque ya estaban predispuestos a cultivar cualquier especie útil. Hace unos 12000 años A.P. estaban domesticando una calabaza nativa de Ecuador, la Cucurbita ecuadorensis (Piperno y Stothert, 2003). Esta observación ayuda a entender por qué las plantas nativas de la Amazonia aparecen entre 8000 y 6000 años A.P. en sitios arqueológicos a lo largo del litoral de Perú (Pearsall, 1992). La primera planta nativa de la Amazonia que aparece en esta región de Perú fue la mandioca, lo que sugiere que su domesticación comenzó por lo menos 9000 años A.P. pues un cazador recolector no perdería su tiempo llevando plantas silvestres para otro lado de los Andes. Schaal et al. (2006) usaron varios marcadores moleculares para localizar el origen de la domesticación de mandioca en el área que hoy es Rondônia y áreas adyacentes de Acre, Bolivia y Mato Grosso.

Tabla 1.1. Número de especies nativas y exóticas en diferentes grados de domesticación que estaban presentes en la Amazonia en la época de la conquista (Clement,

$$
\text { 1999a). }
$$

\begin{tabular}{lcccccc} 
& \multicolumn{2}{c}{ Incipiente Domesticada } & \multicolumn{2}{c}{ Semidomesticada } & \multicolumn{2}{c}{ Domesticada } \\
& Nativas & Exóticas & Nativas & Exóticas & Nativas & Exóticas \\
\hline Familias & 17 & 6 & 21 & 11 & 13 & 19 \\
\hline Géneros & 27 & 9 & 22 & 13 & 16 & 26 \\
\hline Especies & 36 & 9 & 28 & 13 & 19 & 33 \\
\hline Especies & 45 & & 41 & & & 52
\end{tabular}

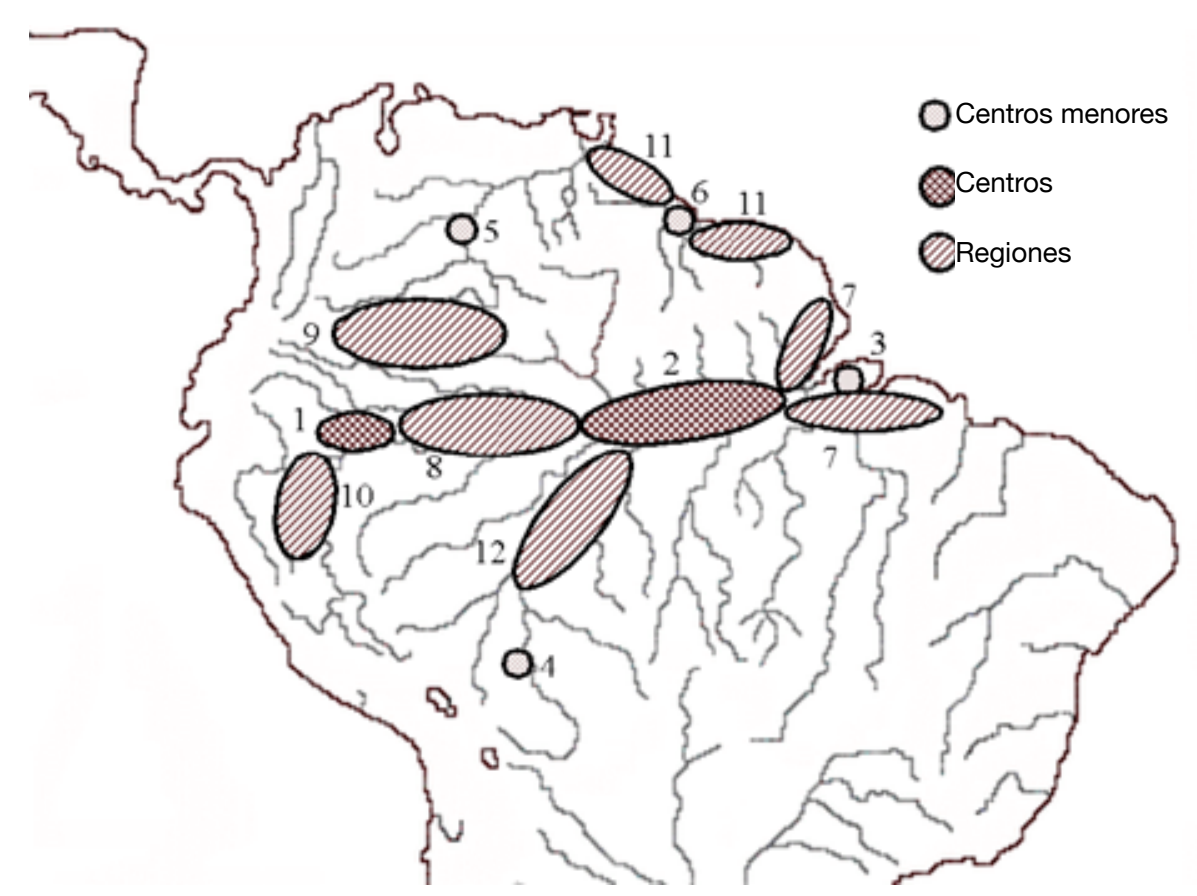

Figura 1.2. Biogeografia de la Amazonia y áreas adyacentes en $1500 \mathrm{~d}$. C. (Clement y Junqueira, 2008). Centros de Diversidad con grandes concentraciones de plantas cultivadas: 1. Noroeste de la Amazonia; 2. Amazonia central. Centros menores de diversidad con grandes concentraciones en pequeñas áreas; 3 . Isla de Marajó; 4. Llanos de Mojos; 5. Medio Orinoco; 6. Guiana. Regiones de diversidad con razonables concentraciones de plantas cultivadas; 7. Estuario del río Amazonas; 8. Río Solimões; 9. Alto Río Negro; 10. Alto Amazonas; 11. Litoral de las Guianas y 12. Río Madeira.

A lo largo del Holoceno, los cazadores-recolectores gradualmente domesticaron la lista de las especies referidas arriba y aquellas a las que se hace referencia en el Tabla 1.1, ya sea a través del intercambio de plantas con personas que iban y venían de otras partes del continente americano. Como consecuencia, los centros de acumulación de recursos genéticos, o los centros de diversidad en la terminología de Vavilov (1992b), también aparecieron en la región central de la cuenca (Figura 1.2). Además de estos centros, existieron áreas de diversidad en ecosistemas de agua prieta, como en el alto río Negro, y en las cabeceras de algunos ríos de la periferia del sur, como los altos ríos Madeira y Xingu (Heckenberger et al., 2007). En los Llanos de Mojos (Erickson, 2008) y del Orinoco, en donde se asentaron sociedades complejas, construyeron casas de piedra por encima del nivel de las inundaciones de las sabanas, como también ocurrió en la Isla de Marajó (Schaan, 2010). Recientemente, los campos de asentamientos fueron descritos a lo largo del litoral de las Guianas (Rostain, 2012). Estas fueron las sociedades complejas y numerosas que fueron encontradas y descritas por los primeros conquistadores; sin embargo, desaparecieron antes de la llegada de los primeros historiadores naturales de finales del siglo XVIII. 


\section{El primer ciclo de erosión genética}

La conquista europea devastó los pueblos americanos en todas las regiones, pues estos carecían de resistencia inmunológica a las enfermedades europeas -cuyos efectos se amplificaron debido a las guerras, la esclavitud y el misionerismo- incentivadas por los propios europeos (Denevan, 1992). Entre 1500 y 1750 d. C., la población indígena descendió en un $95 \%$ o más debido a estas causas. Junto con la pérdida de vidas, se perdieron también conocimientos acumulados a lo largo de milenios, así como recursos genéticos creados en el mismo período (Clement, 1999a). Evidentemente es imposible saber cuántos recursos genéticos se perdieron, pero una estimación razonable es que fue similar a la pérdida de la población humana, pues cada aldea de cada sociedad, simple o compleja, tenía recursos genéticos propios, en la mayoría de los casos, las mismas especies de sus vecinos. Por ejemplo, los pueblos de los principales centros de diversidad de recursos genéticos plantaron mucho maíz (Zea mays) en las llanuras inundables y en las tierras prietas, ciertamente con decenas de razas adaptadas a tales condiciones en diferentes partes de la región, pero prácticamente todo se perdió, quedando apenas algunas razas de maíz en las sociedades más simples que habitaban la periferia de la Amazonia (Goodman, 1976)

Las especies que sobrevivieron (Tabla 1.1) pueden representar un artefacto de tal colap so poblacional, pues a priori se esperaba encontrar muchas más especies con poblaciones bajo domesticación incipiente que de especies con poblaciones plenamente domesticadas. También, el elevado número de especies arbóreas puede ser un artefacto, pues estas tienen mayor probabilidad de sobrevivir sin sus poblaciones humanas en comparación con lo que ocurre con las especies herbáceas anuales (Clement, 1999a).

\section{Las drogas del desierto y el ciclo de la goma del caucho}

Concomitantemente con el colapso demográfico indígena, la expansión portuguesa se consolidó con la fundación de Belém en 1616. Durante la colonia, la economía amazónica se concentró en dos sectores: el extractivismo de productos forestales no maderables, las llamadas drogas del desierto, y la producción agropecuaria, incluyendo la introducción de cultivos tropicales, predominantemente de Asia y secundariamente de África, así como de animales domésticos (Homma, 2003). Aunque el extractivismo llame más la atención, la mayoría de sus productos y recursos biológicos no pasaron por la criba de la selección humana y propagación que desarrollan nuevos recursos genéticos. En contraste, la introducción de cultivos asiáticos y africanos involucraron la incorporación de recursos genéticos, y expandieron las posibilidades económicas de la región, como bien analiza Homma (2003). Muchos de los cultivos tropicales que fueron introducidos en la Amazonia se volvieron más importantes en otras regiones del país. La lista completa la reportan Homma (2003) y Pio Corrêa (1926-1975). Fue también durante la primera fase de la economía basada en las drogas del desierto que comenzó la salida de los principales cultivos de la Amazonia: en 1746 el cacao fue llevado hacia Bahía (Homma, 2003). En 1822 (1823 en Amazonia), el Brasil declaró su independencia de Portugal.
La economía basada en las drogas del desierto perdió su auge con el ciclo de la goma del caucho que comenzó en 1827 y se aceleró después de la invención de la vulcanización en 1837. En 1876, el inglés Henry Wickham fue autorizado por el gobierno de Grão Pará para llevar semillas de caucho (Hevea brasiliense) a Inglaterra, de donde fueron remitidas a Asia, lo que resultó en el colapso del ciclo de caucho cuarenta años más tarde (Gonçalves y Fontes, 2009; Homma, 2003). Desafortunadamente, poca de la riqueza generada durante el ciclo de la goma del caucho fue invertida para apoyar el desarrollo del sector primario de la región. Estas inversiones solo comenzaron después del colapso.

\section{La era moderna y sus instituciones}

La Asociación Filomática (Amigos de la Ciencia) se fundó en 1866 con el liderazgo de Domingos Soares Ferreira Penna, y más tarde, en 1936, dio origen al actual Museo Paraense Emílio Goeldi, la primera de las instituciones de investigación establecidas en la Amazonia (Homma 2003). Diversos investigadores del Museo trabajaban en la catalogación de los recursos genéticos nativos y exóticos.

No obstante, la era moderna de investigación y desarrollo (Pesquisa y Desenvolvimento P\&D), con los recursos genéticos nativos de la Amazonia, tuvo inicio con la creación del Instituto Agronómico del Norte (IAN), también en Belém, en 1939. EI IAN fue incluido en el Servicio Nacional de Pesquisas Agronómicas, en 1943, y pasó a ser el núcleo de una red de institutos menores de los principales centros de la Amazonia (Homma, 2003). En 1946, Adolfo Ducke publicó su clásico estudio sobre las plantas de cultura precolombina, que puede ser considerado el primer inventario de recursos genéticos indígenas. Como la mayoría de las instituciones brasileñas, el IAN tuvo una historia tortuosa, la cual se reflejó en sus colecciones de recursos genéticos y en sus proyectos de mejoramiento. El IAN pasó a ser denominado Instituto de Investigación y Experimentación Agropecuaria del Norte (IPEAN por sus siglas en portugués) en 1962. En 1969, el centro IPEAN en Manaos ganó el estatus de instituto independiente, denominado IPEAAOc. Después de la creación del Embrapa en 1973, el IPEAN y el IPEAAOc fueron incorporados al nuevo sistema nacional de P\&D agropecuaria. En 1975, el IPEAN pasó a ser denominado Centro de Investigación Agropecuária del Trópico Húmedo.

En 1952, el Instituto Nacional de Pesquisas de Amazonia fue creado por decreto y se implementó en 1954. En 1975, el INPA creó una División de Ciencias Agronómicas para estudiar especies nativas que no estaban recibiendo la atención del sistema Embrapa. El INPA concentró sus actividades en la Amazonia Occidental, donde la Embrapa tenía una Unidad de Experimentación y Pesquisa de Ámbito Estatal, UEPAE, y un Centro Nacional de seringueira (caucho) y dendê (palma aceitera), y decidió trabajar principalmente con frutales y hortalizas nativas.

Es importante reflexionar sobre las razones del INPA en ese momento, porque ayuda a entender nuestra pregunta sobre el uso sustentable de los recursos genéticos de la agrobiodiversidad nativa. La UEPAE de Manaos, como las otras instituciones de la Amazonia estaba concentrando su P\&D en los cultivos fundamentales para la región y para el país. La mayoría de estos cultivos son exóticos, como también lo son todos los animales criados en 
Brasil. Se sabe ahora que tal concentración de atención en los cultivos de fundamental importancia tuvo sus aciertos, y actualmente Brasil es uno de los principales exportadores de productos agrícolas del mundo. Ello se debe justamente a que el sistema Embrapa generó, y continúa generando, los recursos genéticos y las tecnologías agrícolas necesarias para dicho propósito. Sin embargo, tal concentración de atención también tuvo implicaciones negativas, la más significativa de ellas es que los cultivos nativos son menos importantes que los exóticos comerciales, y, por lo tanto, no reciben la misma atención. Además de esto la concentración de la atención en los principales productos implica también centrar la atención en los sistemas de producción de monocultivos, lo que, a su vez, afecta severamente la agricultura tradicional, justamente en donde la mayoría de los recursos genéticos nativos se utilizan. Esta política de Embrapa fue evidente en 1975 y continúa hasta el presente, con implicaciones importantes para el uso sustentable de los recursos genéticos y de la agrobiodiversidad nativa de Brasil.

En 1957, la Comisión Ejecutiva de Planificacón de la Labor Cacaotera, CEPLAC, se creó en Bahía y su Centro de Pesquisas de Cacao se implementó en 1964. Durante el primer año, la CEPLAC celebró una conjunción con el IPEAN y abrió una unidad de investigación en Pará, y enseguida una más en Amazonas (Homma, 2003). Actualmente la CEPLAC tiene importantes unidades de investigación en Belém y Manaos, así como en otros estados de la región.

Entre la creación del Museo Paraense Emilio Goeldi y el presente, numerosas universidades federales y estatales se impulsaron en la Amazonia, así como otros institutos involucrados en diferentes áreas de las ciencias y las tecnologías (C\&T). Asimismo, con la creación de esas instituciones, el total de recursos federales destinados a apoyar C\&T y P\&D en la Amazonia es aproximadamente $4 \%$ de los gastos nacionales, mientras que la Amazonia genera alrededor de $8 \%$ del PIB nacional, lo que caracteriza una situación de colonia (Clement 2007). En términos de recursos genéticos y de agrobiodiversidad, el sistema Embrapa, el INPA y la CEPLAC son las instituciones más importantes, y han sufrido discontinuidades de recursos humanos y financieros, de la misma forma que lo han sufrido otras regiones de la colonia.

\section{La expansión de las colecciones ex situ}

Desde que Brasil entró en la era de P\&D agrícola al inicio del siglo passado, todas las instituciones involucradas formaron colecciones de recursos genéticos nativos y exóticos para apoyar sus programas de mejoramento o para fomentar su plantación local mediante la estrategia de asegurar la disponibilidade de semillas y plântulas a los productores. Pero fue solamente a partir de la fundación del Centro Nacional de Recursos Genéticos - CENARGEN, por la Embrapa en 1974, cuando la colección y conservación de recursos genéticos agrícolas pasaron a ser prioridades nacionales y entonces recibieron apoyo de agencias de fomento del exterior. Ya entonces la comunidad académica estaba preocupada por la erosión genética, particularmente de los recursos genéticos de cultivos tradicionales en todo el mundo, associada a impulso de la Revolución Verde. Aunque la Revolución Verde original no había llegado a Brasil, la propia Embrapa generó los recursos genéticos y tecnologías agrícolas que hcieron que la expansión de los agronegocios del país se conformara en una Revolución Verde Brasileña. Las implicaciones de la versión brasileña de la Revolución Verde son similares a las de la versión original, teniendo como foco central de atención los productos modernos associados a los monocultivos y menor atención a los cultivos nativos de la agricultura tradicional.

A lo largo del período entre 1975 y 1990, diversas asociaciones entre ellas el CENARGEN, las unidades de Embrapa y otras instituciones amazónicas, la CEPLAC, así como instituciones internacionales colectarom recursos genéticos de mandioca, cacao, piña, caucho, la palma aceitera caiaué (Elaeis oleifera), la palma pupuña (Bactris gasipaes), babaçu (Attalea speciosa), açaí-do-pará (Euterpe oleracea), patauá (Oenocarpus bataua) y la bacaba $(O$. bacaba, O. distichus, O. mapora, O. minor), y diversos chiles o ajíes (Capsicum spp.). Tanto el INPA como el CPATU formaron colecciones grandes de especies nativas, entre otras las citadas por Clement et al. (1982). Varias de las colecciones usaron métodos experimentales para tratar de maximizar la representatividad de la colecta en cada sitio. A priori, esas colecciones sugieren que una parte de la agrobiodiversidad nativa está razonablemente bien representada en las colecciones ex situ. Sin embargo, es pertinente cuestionarse si estas coleciones son sustentables.

\section{El ciclo de erosión genética institucional}

La respuesta simple a una pregunta sorpresiva es no. Varias de estas colecciones sufrieron erosión genética en las siguientes dos décadas. La primera en sufrir fuerte erosión genética fue la colección de caucho, ocasionada por el mal de las hojas (Microcyclus ulei). Las colecciones de frutales del INPA sufrieron con los planes económicos de los gobiernos del período de 1985 a 1994. Todas las instituciones brasileñas, en especial las asentadas en la Amazonia, sufrieron de discontinuidades financeras en la década que antecedió al Plan Real, el cual afectó la manutención de las colecciones y la permanencia de investigadores. Además de esto, muchas de las especies fueron plantadas en agroecosistemas no apropiados para su mantenimiento a largo plazo, o que contribuyeron a la senescencia acelerada de plantas sin adaptación a las nuevas condiciones. Ejemplos claros son los frutales domesticados de la región, como la pupuñaa, la biribá (Rollinia mucosa) y el abiu (Pouteria caimito), especies que fueron domesticadas em las huertas y parcelas de sistema de roza indígenas. En las huertas, los niveles de nutrientes disponibles son altos, pues la tierra quemada producida por las familias forman tierra prieta (WinklerPrins, 2009). En las parcelas de roza indígenas, otras práticas de manejo formaban tierra mulata (Denevan, 2009). En los plantíos nuevos em las instituciones, los suelos geralmente son bien drenados, pero no reciben incrementos anuales de condicionadores de suelo (carbón vegetal y otros restos orgánicos parcialmente carbonizados) que mantienen o aumentan la capacidad de intercambio de cationes y ayudan a hacer disponibles los nutrientes (Sombroek et al., 2009); en las colecciones, las plantas reciben un poco de NPK durante todo el año - si tienen suerte. Tal falta de combinación correcta entre genotipos y agroecosistemas va a ser cada vez más importante conforme se acentúan los estreses associados a los cambios climáticos. Tal vez más importante, los proyetos que trataron de incentivar la producción no encontraron respaldo en el mercado, o sea, las tentativas de expandir o abrir nichos de mercado no tuvieron éxito, como consecuencia de que los proyetos llevados a cabo no con- 
siguieron desarrollar cultivares competitivos durante la vigencia de los proyetos de corto plazo (editado con base en información de CNPq, Finep, Embrapa), o también, debido al hecho de que los consumidores no se entusiasmaron por más oferta. Esto fue especialmente importante para los cultivos de menor expresión.

La erosión dentro de las colecciones normalmente es escondida para evitar evidencia que demuestra incompetencia institucional, pero los factores mencionados arriba como determinantes de la erosión están generalmente fuera de control de los investigadores responsables y frecuentemente también fuera del control de las instituciones. Uno de los pocos casos analizados fue el de las colecciones de INPA, sin incluir el Banco Activo de Germoplasma de Pupuña mantenido por el INPA en colaboración con Embrapa, y la colección de cupuasú, manejada como colección aparte de la colección general de frutales. Las pérdidas entre el auge en 1982 y el inicio del Plan Real, cuando se planteó retomar un manejo adequado, fueron de $63 \%$ de las muestras (Figura 1.3), pero entre 20 y $80 \%$ de las plantas dentro de las muestras, para determinar una pérdida neta de entre 70 y $93 \%$ de la diversidad genética de la colección. La mayor parte de esas pérdidas se debió a las discontinuidades institucionales causadas por los planes económicos del gobierno federal durante el período referido.

Posteriormente, se expandió el análisis a los proyectos de pupuña, esta vez a nivel latinoamericano, pues numerosas instituciones tuvieron objetivos y colecciones similares de recursos genéticos (Clement et al., 2004). De esos proyectos, los que se centraban en el desarrollo de cultivo para producir palmito tuvieron un éxito razonable, y en Brasil, en Costa Rica y en Ecuador existen agronegocios en expansión (Clement et al., 2009; Kalil Filho et al., 2010). Los proyectos que se enfocaban al desarrollo del cultivo de frutos no tuvieron éxito. Una parte se explica porque los investigadores estaban interesados en usos para los cuales ya había productos afianzados en el mercado desde hace varios siglos. Es el caso de los trabajos que vislumbraron la harina de pupuña como alternativa para las panificadoras, o como bebida fermentada (la caissuma consumida por los indígenas), aceite vegetal y forraje para el ganado. En el caso de la industria panificadora, la harina de pupuña tuvo que enfrentar competidores como las harinas de trigo y de maíz, productos con tecnologías de producción y procesamiento bastante avanzadas e imbatibles en términos de precio, comparadas con la harina de pupuña. Lo mismo sucedió cuando el foco de atención eran los fermentos de pupuña; en este caso, la cerveza era una competidora imbatible, o con el aceite vegetal (compitiendo con el aceite de palma) y como forraje (compitiendo con maíz, sorgo, y salvado de arroz). Paradójicamente, los investigadores no evaluaron adecuadamente la demanda de los consumidores para el fruto cocido, el principal uso de pupuña en América Latina hoy en día (Clement et al., 2004). Las colecciones de pupuña en América Latina tienen muchas muestras para atender todos estos objetivos, pero apenas una fracción relativamente pequeña para atender lo que los consumidores modernos quieren en Belém y en Manaos: frutos con cáscara roja, cuyo peso sea de 30 a $50 \mathrm{~g}$, con moderadas cantidades de aceite, buen sabor, y fáciles de descascarar (Clement y Santos, 2002; Clement et al., 2009). En todos los países que tuvieron o tienen proyectos con pupuña, las colecciones ex situ contienen enormes cantidades de muestras sin uso, o con usos de reducida relación costo-beneficio, lo que ayuda a explicar por qué son tan difíciles de justificar. No sorprende, por lo tanto, que diversas colecciones se hayan perdido (Clement et al., 2004).

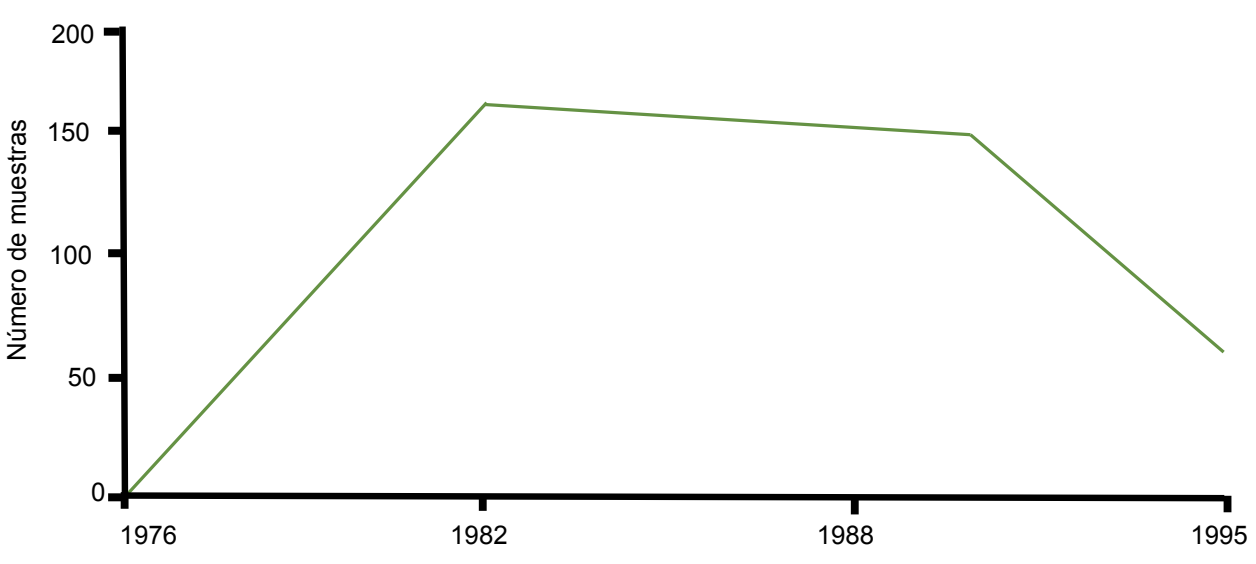

Figura 1.3. Acumulación de recursos genéticos y la erosión genética en la colección eneral de frutales del INPA entre su creación en 1976 y la retomada en su manejo 995 después de las discontinuidades económicas de la década 1985-1994.

Posteriormente, el análisis se amplió nuevamente, esta vez hacia las palmeras colectadas durante el período de auge del entusiasmo, en la década de 1975 a 1985. Otra vez se encontró que los proyectos no habían conseguido desarrollar cultivares que atendiesen las expectativas de los productores y que ofrecieran productos que desearan los consumidores (Van Leeuwen et al., 2005; Clement et al., 2005). Una vez más, las colecciones no fueron usadas y resultó difícil justificar su mantenimiento y, nuevamente, algunas variedades se perdieron. Las excepciones de estos estudios fueron los Bancos Activos de Germoplasma de Caiaué de Embrapa en la Amazonia occidental y el de Açaí de Embrapa en la Amazonia oriental. En el primer caso, entre su creación en la década de 1970 y el inicio de la fiebre del biodiesel, el BAG Caiaué fue bien estudiado y contribuyó mucho al desarrollo de híbridos interespecíficos como el dendê (E. guineenses), pero no estaba en la lista de prioridades de la sede y sobrevivió precariamente. Con la creación del Embrapa Agroenergía y los nuevos proyectos de biodiesel, el BAG Caiaué comenzó a ser revitalizado y está contribuyendo a la expansión de este agronegocio (Cunha et al., 2009). En el caso del açaí, entre su creación en la década de 1970 y el inicio de la fiebre para la bebida de açaí, el BAG Açaí vivió una situación similar. Sin embargo, con la conquista de nuevos mercados para el açaí y el aumento de consumo de la bebida de açaí en los grandes centros urbanos de la Amazonia, Brasil y el mundo, el banco fue revitalizado y está siendo debidamente caracterizado, evaluado y expandido para apoyar los agronegocios de esa fruta, que actualmente es la fruta nativa de la Amazonia de mayor consumo (Oliveira et al., 2009).

En resumen, las instituciones brasileñas de la Amazonia, como sus pares en todo Brasil y en la América Latina en general, no han sido adecuadamente apoyadas para desarrollar nuevos recursos genéticos nativos y nuevos productos para crear nuevos nichos en los mercados locales y nacionales. Como consecuencia, han tenido dificultades para mantener sus colecciones, y la mayoría ha sufrido erosión genética en algún grado, hasta el grado máximo de extinción de colecciones completas. En otras publicaciones he examinado otros aspec- 
tos de la tarea compleja de desarrollar nichos y conservar recursos genéticos, así como propuestas para el futuro, entre estas se pueden consultar Clement (1997, 2001); Clement et al. $(2004,2007)$.

\section{La era moderna y la agrobiodiversidad}

Estamos construyendo una sociedad global en la que muchos de nosotros no queremos vivir. Vimos esto claramente con el reciente fracaso de la conferencia de la ONU denominada Río+20. Vimos esto claramente en las actuales discusiones sobre el Código Forestal, cuando tanto la Cámara de Diputados como el Senado de Brasil simplemente ignoraron las sugerencias de las comunidades de C\&T y P\&D para hacer compatible la producción agropecuaria con la conservación de la naturaleza brasileña.

"Las poblaciones urbanas no piensan en la Naturaleza" (José Aldemir de Oliveira, Rector de la Universidad Estatal de Amazonas, 2009). Podemos también decir que las poblaciones urbanas consideran que la comida viene de los supermercados. Vale la pena recordar que la población de Amazonia ya es entre 70 y $80 \%$ urbana. Estas frases aparentemente inconexas tienen mucho que ver con el uso sustentable de los recursos genéticos de la agrobiodiversidad de la Amazonia. Las poblaciones urbanas quieren comodidad y precios bajos, lo que frecuentemente no es intrínseco a las características de la agrobiodiversidad nativa porque la mayoría de sus especies no recibieron el P\&D necesario o no cuentan con emprendedores para crear los productos que van a atender las necesidades de los consumidores urbanos.

En la Amazonia moderna, y no solo en su futuro próximo, los agronegocios están y estarán en expansión, pues la población brasileña y el mercado mundial están demandando sus productos. La primera implicación de este descubrimiento es que la agricultura tradicional, que heredó los recursos genéticos indígenas y está manteniendo y desarrollando nuevos recursos, está perdiendo espacio físico en la región. Esto aunado a las dificultades de los gobiernos municipales, estatales y federal para incluir a las comunidades tradicionales en los programas sociales, debido a su distribución propagada y dispersas en el interior, lo que alimenta el éxodo rural. Como consecuencia, lógicamente el proceso está determinando erosión genética que es imposible de cuantificar. Ya se ha visto que las instituciones han tenido éxito irregular en el apoyo a los emprendedores que crean nuevos nichos, lo que también significa que el espacio en los mercados locales y regionales para los productos de la agrobiodiversidad nativa se está contrayendo. Basta mirar en cualquier puesto de frutas en los mercados de Belém o en Manaos para apreciar la invasión de los frutos exóticos.

En conclusión, el uso actual de los recursos genéticos de la agrobiodiversidad amazónica no es sustentable y la situación no es diferente en el resto de Brasil. Esta afirmación se basa en el actual modelo de desarrollo que está siendo practicado en la Amazonia, en Brasil y en el mundo. Un mundo distinto es posible; sin embargo, lograrlo requiere un modelo diferente de desarrollo que priorice a las personas, a las comunidades y a la naturaleza más que al capital.

\section{Bibliografía}

Brundtland, G. H., 1987. Report of the World Commission on Environment and Development: Our Common Future.

Clement, C. R., 1997. Environmental impacts of, and biological and socio-economic limitations on new crop development in Brazilian Amazonia. En: Smartt, J., N. Haq (Eds.). Domestication, production and utilization Southampton.

Clement C R 1999 1492 and the loss of Amazoning cop genetic resources. I. The relation between domestication and human population decline. Economic Botany 53(2): $188-202$

Clement, C. R., 1999b. 1492 and the loss of Amazonian crop genetic resources. II. Crop biog
Economic Botany 53(2):203-216.

Clement, C. R., 2001. Melhoramento de espécies nativas. En: Nass, LL.; A. C. C Valois, I. S. Melo, M. C. Valadares-Inglis (Eds.). Recursos genéticos e melhoramento: plantas. Fundação MT, Rondonópolis.

Clement, C. R., 2007. Um pote de ouro no fim do arco-íris? O valor da biodiversidade e do conhecimento tradicional associado, e as mazelas da lei de acesso: uma visâa e proposta a partir da Amazonia. Amazônia: Ciência

Clement, C. R., M. de Cristo-Araújo, G. C. d'Eeckenbrugge, A. Alves Pereira, and D. Picanço-Rodrigues. 2010. Origin 2(1):72-106.

Clement, C. R. y A. B. Junqueira, 2008. Plantas domesticadas, uma historia fascinante. En: Furtado, R. O. (Ed.) Origens. São Paulo: Duetto Editorial.

Clement, C. R., A. N. Kalil Filho, V. A. Modolo, K. Yuyama, D. Picanco Rodrigues, J van Leouwen, J. T. Farias Neto, M. Cristo Araújo y W. B. Chávez Flores, 2009. Domesticação e melhoramento de pupunha. En: Borém, A., M. T. Lopes y C. Clement (Eds.). Domesticação e melhoramento: espécies

Clement, C. R., E. Lleras Pérez y J. Van Leeuwen, 2005. $O$ potencial das palmeiras tropicais no Brasil: acerto e fracassos das últimas décadas. Agrociencia 9(1-
2): $67-71$.

Clement, C. R., C. H. Muller y W. Chávez Flores, 1982 Recursos geneticos de especies frutiferas nativas
Amazonia brasileira. Acta Amazonica 12(4):677-695.

Clement, C. R., S. F. Rocha, D. M. Cole, and J. L. Vivan. 2007. Gońtiça on tarm. En. Nass, LL. (Ed.). Rétirsos Biotecnologia.

Y. A. Santos, 2002 . Pupunha no meado de Manaus: preferências de consumidores e subs de Manaus: preferências de consumidores e suas
implicações. Revista Brasileira de Fruticultura 24:778779 .
Clement, C. R., J. C. Weber, J. van Leeuwen, C. Astorga Domian, D. M. Cole, L. A. Arévalo Lopez y H. Argüello, 2004. Why extensive research and development did not promote use of peach palm fruit in Latin Americ

unha, R. N. V., R. Lopes, R. N. C. Rocha, W. A. A. Lima, P. C. Teixeira, E. Barcelos y M. D. R. L. Rodrigues, 2009 M. T. G. Lopes y C. R. Clement (Eds.). Domesticacão melhoramento: espécies amazônicas. Viçosa: Editora da Univ. Fed. Viçosa.

Denevan, W. M., 1992. Native American populations in 1492 recent research and a revised hemispheric estimate. En: W. M. Denevan (Ed.). The native population of the
Americas in 1492. Madison, Wl: Univ. of Wisconsin Press. Amazônia. En: Texeira, W. G., D. C. Kern, B. E. Madari, H. N. Lima y W. I. Woods (Eds.). As Terras Preta de Indio da Amazônia: sua caracterização e uso deste conhecimento na criação de novas arreas. Manaus: Embrapa Amazôn

ucke, A., 1946. Plantas de cultura precolombiana na espontâneas que supostamente lhes terian formas origem. Boletim Técnico do Instituto Agronômico do Norte 8:1-24.

Frickson, C. L., 2008. Amazonia: the historical ecology of a domesticated landscape. En: Silverman, H. y W. Isbell
(Eds.). Handbook of South American Archaeology. New York: Springer.

onçalves, P. D. S. y J. R. A. Fontes, 2009. Domesticacãão melhoramento de seringueira. En: Bórem, A., M. T. G. Lopes espécies amazônicas. Viçosa: Editora da Univ. Fed. Viçosa.

Maize, Zea mays (GraminaeMaydeae). En: Simmonds, N. W. (Ed.). Evolution of crop plants. London: Longman

Heckenberger, M. J., J. C. Russell, J. R. Toney y M. J. Schmidt, 2007. The legacy of cultural landscapes in the Brazilian Amazon: implications for biodiversity. Philosophica Transactions of the Royal Society B-Biological Sciences
362(1478):197-208. omma, A. K. O., 2003. História da agricultura na Amazônia: da era pré-colombiana ao terceiro $m$

Kalil Filho, A. N., C. R. Clement, M. D. V. d. Resende, J. T D. Farias Neto, C. L. Bergo, G. K.-I. Yokomizo, P. E. de melhoramento genético de pupunha na Embrapa, IAC e INPA. En: Embrapa Florestas Documentos. Colombo, Paraná: Embrapa Florestas.

Kerr, W. E. y C. R. Clement, 1980. Práticas agrícolas de consequuencias genéticas que possibilitaram aos índios da Amazônia uma melhor adaptação as condições regionais. Acta Amazonica 10(2):251-261. 
Meyer, R. S., A. E. DuVal y H. R. Jensen, 2012. Patterns and Schaal, B. A., K. M. Olsen y L. J. C. B. Carvalho, 2006. processes in crop domestication: an historical review Evolution, domestication, and agrobiodiversity in the and quantitative analysis of 203 global food crops. New tropical crop cassava. En: Motley, T. J., N. Zerega and H. Cross (Eds.). Darwin's harvest: New approaches to Oliveira, M. D. S. P., S. Mochiutti y J. T. Farias Neto, 2009. The origins, evolution, and conservation of crops. New Domesticação e melhoramento do açaizeiro. En: Bórem, A., M. T. G. Lopes y C. R. Clement (Eds.). Domesticação e melhoramento: especi.
da Univ. Fed. Viçosa. Marajó Island landscapes, Am
2(2):182-206.

Pearsall, D. M., 1992. The origins of plant cultivation in South Sombroek, W., D. C. Kern, T. E. Rodrigues, M. S. Cravo, T Amigins of. Aoriculture: An I P. J. Watson (Eds.). The J. F. Cunha, W. I. Woods y B. Glaser, 2009. Terra preta

an Institution Press.

Pimbert, M., L. Collette, M. Duwayri y W. g. o. B. D. f. F. a. Agriculture, 1999. Agricultural biodiversity. En: Conference on the Multifunctional Char
Agriculture and Land. The Netherlands: FAO.

Pio Corrêa, M. 1926-1975. Diccionário das plantas úteis do Brasil e das exóticas cultivadas. 6 vols. Rio de Janeiro: Imprensa Nacional.

Piperno, D. R. y D. M. Pearsall, 1998. The origins of agriculture in the lowland Neotropics. San Diego: Academic Press.

Piperno, D. R. y K. E. Stothert, 2003. Phytolith evidence for early Holocene Cucurbita domestica

Rockström, J. W. Steffen, K. Noone, A. Persson, F. S. Chapin E. F. Lambin, T. M. Lenton, M. Scheffer, C. Folke y H. J. Schellnhuber, 2009. A safe operating space for humanity. Nature 461(7263):472-475.

Rostain, S., 2012. Islands in the rainforest: landscape management in pre-Columbian Amazonia. En: Balee, W. y C. Walnut e terra mulata: suas potencialidades agrícolas, sua G., D. C. Kern, B. E. Madari, H. N. Lima y W. I. Woods (Eds.). As Terras Pretas de Indio da Amazônia: sua caracterização e uso deste conhecimento na criação de novas áreas. Manaus. Embrapa Amaz N, 1992. The convention of biological diversity. New York: United Nations.

an Leeuwen, J., E. Lleras Pérez y C. R. Clement, 2005. Field genebanks may impede instead of promote crop development: lessons of failed genebanks of "promising"

avilov, N. I., 1992a. Origin and geography of cultivated phan Thand by Love. Cambridge University Press.

avilov, N. I. 1992b. The phyto-geographical basis for plan breeding. En: Origin and geography of cultivated plants. N. I.Vavi Ev New York: Cam

WinklerPrins, A. M. y G. A., 2009. Sweep and char and the creation of Amazonian Dark Earths in homegardens. En:
Woods, W. I., W. G. Teixeira, J. Lehmann, C. Steiner. A. M. G. A. WinklerPrins y L Rebellato (Eds). Amzzonien Dark Earths: Wim Sombroek's vision. Dordrect: Springer.

\section{Los recursos genéticos en Argentina:}

caminos para su conocimiento, atajos para su acceso, avatares de su gestión

María Lelia Pochettino, Verónica S. Lema, Norma I. Hilgert y Ana H. Ladio

\section{Resumen}

Es frecuente que Argentina sea caracterizada como "el granero del mundo" debido a las amplias superficies destinadas a la agricultura. Este sistema productivo se desarrolla a gran escala -industrial- preponderantemente en la zona pampeana; la agricultura familiar queda así, relegada como una actividad prácticamente marginal. Sin embargo, la historia agrícola de nuestro territorio es muy distinta, con importantes áreas de selección y domesticación de variedades de plantas americanas de valor económico. A lo largo de la constitución del país, primero como colonia, luego como nación, esta agricultura regional fue incorporando cultivos exóticos, algunos de ellos apropiados y devenidos en patrimonio de las zonas donde se cultivan, para luego ser desplazados por especies de mayor valor comercial y/o para exportación. Dado el significativo ingreso que estos cultivos industriales representan para el país, desde el sector oficial se promueve el incremento del área cultivada aunque, al mismo tiempo, se origina legislación tendiente a proteger e incentivar la agricultura familiar y la conservación de bosques nativos. La investigación y gestión de estos recursos se generan desde universidades públicas y organismos oficiales. No obstante, las acciones de estos sectores públicos pueden contraponerse entre sí difiriendo, por ejemplo, en cuanto a la viabilidad, incumbencias y términos referidos a los desarrollos tecnológicos a partir de estos recursos. En esta contribución discutimos brevemente, y a través de casos clave, el origen, destino y actores vinculados a los recursos genéticos en nuestro país, así como los espacios que requieren una revisión en la legislación vigente.

Palabras clave: Argentina, agricultura sustentable, gestión de recursos, manejo sustentable, recursos forestales no maderables, recursos genéticos, resiliencia, sustentabilidad. 


\section{Breve historia agrícola de nuestro territorio}

\section{La agricultura prehispánica}

Al momento de la entrada de los primeros conquistadores españoles al actual territorio argentino, las sociedades cuyos modos de subsistencia estaban basados en la agricultura o incluían aportes de la recolección y producción de alimentos, se situaban en la parte norte de nuestro país y en las zonas cordilleranas de las regiones central y nor-patagónica, conviviendo con grupos cazadores recolectores en algunas zonas de esta última región y del Noreste. Tanto en el centro del país como en la Patagonia (área pampa- Patagonia extra cordillerana y Tierra de Fuego), los grupos humanos siempre fueron cazadores recolectores y/o sociedades con algún tipo de agricultura incipiente. La caza de guanacos (Lama guanicoe) y choiques (Pterocnemia pennata), a lo largo de ese territorio y la marisquería en la zona atlántica, fueron los ejes de origen animal de la alimentación de los pueblos del sur del país (Figura 2.1).
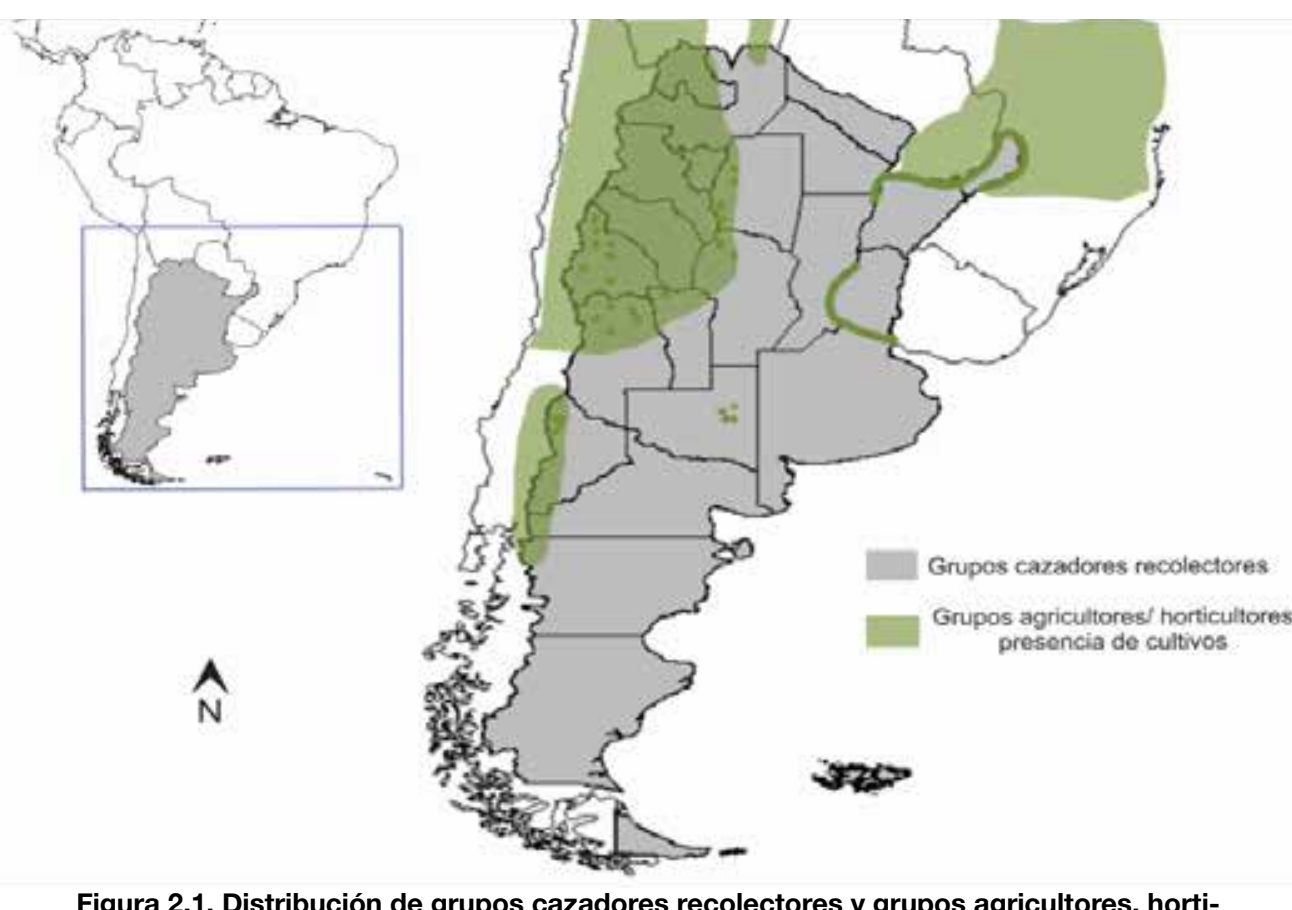

Figura 2.1. Distribución de grupos cazadores recolectores y grupos agricultores, horticultores o con empleo de algún cultivo al momento de la conquista española.

En lo que refiere a los grupos agricultores se pueden considerar diversos casos. La agricultura del Noroeste de Argentina (NOA) fue sostenida por grupos que tenían una economía agrícola pastoril de alto desarrollo desde ca. 2000 años A.P., en vinculación con el Área Andina Meridional; vinculación de la que hay numerosos registros que confirman la presencia de redes de intercambio desde el Pacífico a las tierras bajas orientales junto al uso complementario de los distintos ambientes presentes a lo largo del gradiente altitudinal (Aschero, 1984; Albeck 2000; García-Moritan y Ventura, 2007). Como consecuencia, la agricultura local albergó especies que, en su mayoría, no forman parte del elenco actual de cultivos industriales, e incluso muchas de ellas se comercializan ocasionalmente en los mercados locales, como es el caso del yacón (Smallanthus sonchifolius), sobre el que se discutirá más adelante. Estas características bioculturales diversas hicieron del Noroeste un área de importancia en la domesticación de variedades de cultivos andinos importantes como maíces, ajíes, porotos, zapallos, e incluso se postula la posible domesticación de cultivos poliploides como maní (Arachis hypogaea) (Seijo et al., 2007) y tabaco (Nicotiana tabacum) (Brücher, 1989) en las laderas orientales de los Andes de Bolivia y NOA. En esta área la agricultura se caracterizó por mantener escalas comunitarias y domésticas de manejo hasta tiempos tardíos (Korstanje et al., 2015), y formas malezoides e híbridas entre los cultivos y sus antecesores silvestres (Lema, 2014a). Este patrón se dio sin abandonar la recolección de productos silvestres, destacándose el "algarrobo" (Prosopis spp.), el cual aportó significativamente a la dieta de las comunidades, inclusive durante los momentos de ocupación incaica y colonial del Noroeste (Capparelli y Lema, 2011).

Dentro de lo que, geopolíticamente, hoy es el NOA, en la zona de Yungas se han registrado diferentes ocupaciones a lo largo del territorio, que demuestran la presencia de importantes asentamientos, tanto en el ecotono entre el monte y el pastizal de neblina, como entre el bosque nublado y el piedemonte desde momentos prehispánicos (García Moritán y Ventura, 2007). En ese contexto, las poblaciones que estuvieron asentadas en este bioma cumplieron, desde la antigüedad, un importante rol en la red de intercambios de bienes y productos, y de contacto e integración entre las sociedades asentadas en las zonas de valles y puna, y las de las llanuras orientales (Aschero, 1984; Núñez-Regueiro y Tartusi, 1990; Reboratti, 1996). Intercambios que, en líneas generales, aportaban sal y materias primas líticas a las tierras bajas, y maderas, miel, plantas medicinales y papa semilla a las tierras altas, y que antes de la llegada de los incas habrían sido individuales y sin intermediarios y que luego habrían pasado a ser regulados desde la Quebrada de Humahuaca (Albeck, 1994). En cuanto al desarrollo agrícola, hay evidencias, en las tierras más altas, donde se registran cultivos andinos en complejos sistemas de terrazas y cría de camélidos (Márquez-Miranda, 1941), así como en los pastizales de los valles húmedos (Raffino et al., 1986), a lo que se sumaría un patrón de caza-pesca-recolección y horticultura en la cuenca del río San Francisco (Ortiz et al., 2015). Hacia finales del período prehispánico, la región fue ocupada por los incas que se trasladaron desde el sur de Bolivia con fines agrícolas y de defensa del asedio y asaltos de los grupos chiriguanos que ocupaban las tierras bajas (Sánchez y Sica, 1994).

Por una parte, en el área chaqueña y noreste -incluyendo las cuencas del Paraná y el Uruguay, hasta el norte de provincia de Buenos Aires-, la estrategia de producción de alimentos vegetales también fue a escala hortícola. Hubo cultivo de zapallos, porotos y maíz en terrenos sobre elevados (Bonomo et al., 2011) o claros en la selva en el extremo nordeste (provincia de Misiones), con cultivos típicos de tierras bajas como mandioca (Manihot esculenta) y batata (Ipomea batatas). Por otra parte, los bosques productores de piñones comestibles de Araucaria angustifolia y su especie asociada llex paraguariensis (yerba mate, usada como infusión tradicional) parecen haber contribuido a la dieta local de manera preponderante en 
esta época. Es de destacar que investigaciones en zonas lindantes de Brasil estarían mostrando un manejo de paisaje favorecido y promovido por parte de los pobladores locales prehispánicos para estas dos especies (Reis et al., 2014). En esta región de Argentina no hubo manejo de animales domésticos, ya que estuvieron restringidos al área cordillerana del noroeste y centro-este del país.

En el área centro-oeste y Patagonia Norte, en su sector cordillerano, la estrategia de subsistencia fue mixta, con grupos cazadores recolectores que incorporaron cultivos -desde momentos muy tempranos hasta épocas tardías- en una zona buffer vinculada al límite de la frontera agrícola prehispánica (Gil, 2005). La dieta prehispánica, según el registro arqueológico y a través de información de viajeros y naturalistas en la Patagonia, muestra el rol significativo de los piñones de Araucaria araucana, no solo de las poblaciones que habitaban dichos bosques, sino por intercambio con sociedades de otras regiones de la Patagonia (Nacuzzi y Pérez de Micou, 1985). Además, se cuenta con evidencia de que dichas sociedades también habrían incorporado el consumo de zapallo, maíz, porotos y quinoa a lo largo del tiempo, pero sin que estos cultivos resultaran en un aporte significativo a la dieta (Llano, 2011).

\section{La agricultura colonial}

La consolidación de las economías coloniales se dio sobre un proceso de explotación de las poblaciones nativas bajo la forma de encomiendas, fundamentalmente en el área del Noroeste a la que rápidamente sobrevino una crisis por la drástica disminución de esas poblaciones. A causa de la lejana posición geográfica de los puertos desde donde salían las exportaciones americanas, gran parte de lo que hoy es territorio argentino, se mantuvo ajeno a las exportaciones hacia la metrópoli europea. Este hecho, sumado a la falta de mano de obra, llevó, en un principio, al establecimiento de agricultura de subsistencia y autoconsumo en numerosos enclaves (Fradkin, 2000; Barsky y Gelman, 2001).

A mediados del siglo XVI, en el altiplano del Alto Perú (actual Bolivia), se dio la mayor explosión demográfica de la época a partir de la explotación de las minas de plata de Potosí. Para abastecer a este nuevo centro, se reforzaron antiguas redes de comunicación y comercio. En ese contexto, al igual que en buena parte del Perú y del Alto Perú, en lo que hoy es nuestro país, tuvo lugar un proceso de especialización económica con miras a dicho abastecimiento. Uno de los ejemplos de reconversión más frecuentemente mencionados fue el de la zona de Córdoba, cuya industria textil artesanal se vio seriamente afectada por la disminución de la mano de obra, y cambió a la cría de mulas en sus valles (Fradkin, 2000; Barsky y Gelman, 2001).

En líneas generales, desde el punto de vista productivo, podrían reconocerse cinco zonas relativamente autónomas (Figura 2.2):

1. Noroeste: formado por las actuales provincias de Salta, Jujuy, Santiago del Estero, Catamarca y Tucumán. Esta fue la región con más desarrollo agrícola durante el período colonia, en parte como continuación del desarrollo en época prehispánica, por el temprano ingreso de simientes no americanas junto a la fundación de ciudades, por el sojuzgamiento temprano y estratégico de poblaciones nativas, por la diversidad de explotaciones

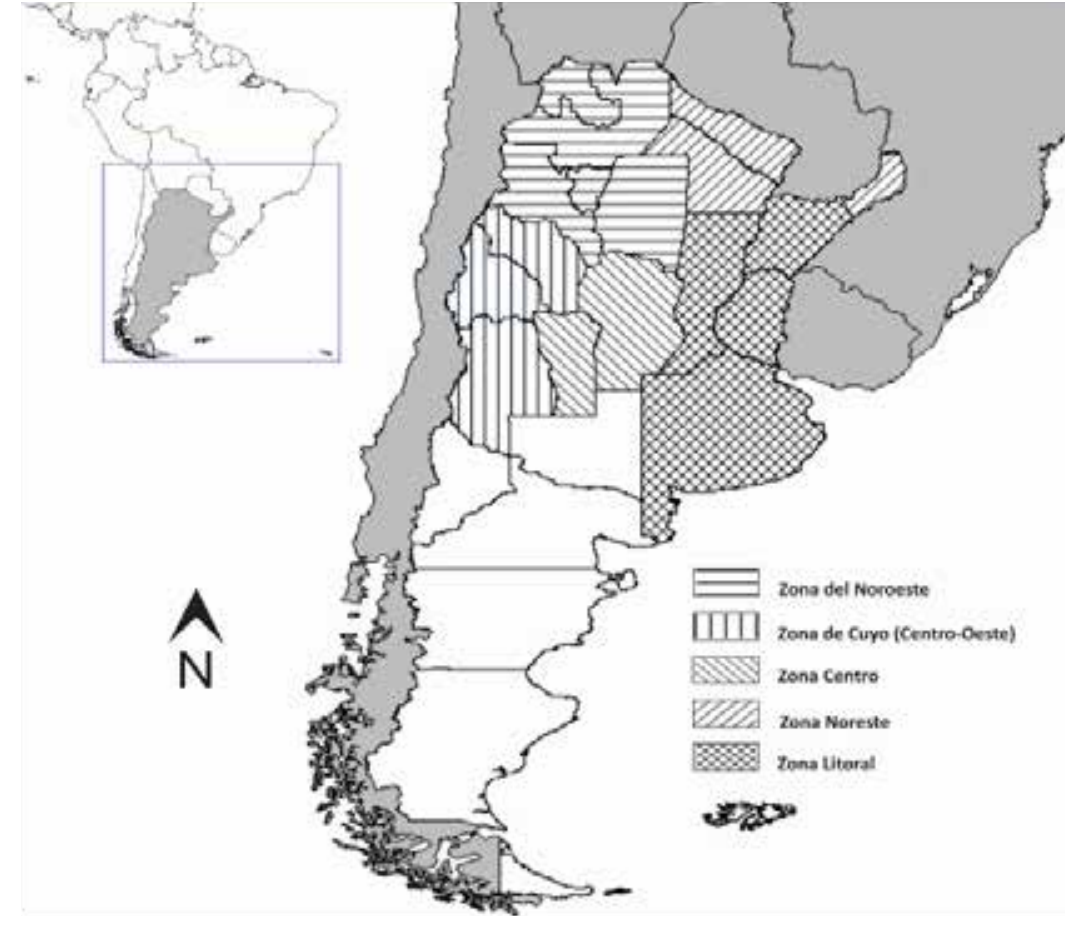

Figura 2.2. Ubicación de las áreas con economía agrícola en época colonial (siglos XVI al XVIII). Las divisiones corresponden a las empleadas en el texto.

posibles y además por su posición privilegiada con respecto al Alto Perú. Es así que dentro de este territorio se dieron, a su vez, especializaciones; por ejemplo, el algodón en el actual territorio de Catamarca (unido a la producción textil). En valles y quebradas de altura desde muy temprano, el trigo fue una producción de importancia junto al maíz (Capparell et al., 2005; Giovanneti y Lema, 2005; Bugallo et al., 2014), acompañado por la cebada y los frutales (principalmente duraznos, pero también manzanas, peras y vid) de introducción temprana (Mendonça et al., 2003; Capparelli et al., 2005; Lambaré, 2015). También las habas fueron de importancia y, con el tiempo, reemplazaron a los porotos en algunas regiones como las zonas prepuneñas de la provincia de Jujuy. En toda la región, el cultivo de alfalfa (Medicago sativa) fue de gran relevancia, vinculado al paso de mulas en el comercio entre las minas del Alto Perú y el puerto de Buenos Aires (Quesada y Lema, 2012). En pisos ecológicos más bajos, los Jesuitas introdujeron, a principios del siglo XVII, el cultivo de la caña de azúcar, que se expandió hacia fines del siglo XIX con nuevo germoplasma y sobre la base de una explotación diferente: el latifundio con mano de obra ocasional.

2. Cuyo (Centro-Oeste): abarca las actuales provincias de Mendoza, San Juan y La Rioja. En esta zona se establece como principal actividad agropecuaria, el cultivo de vid, olivos y frutales euroasiáticos, tradición agrícola que, en la actualidad, caracteriza a la zona, habiendo registros para la ciudad de Mendoza de trigo, olivo, durazno, cebada, vid y avena en momentos tan tempranos como los de contacto hispano-indígena (Mafferra, 2009). 
Estos primeros cultivos se introdujeron desde Chile, en algunos casos como contrabando por las prohibiciones de la Corona, estableciéndose rápidamente como productos típicos. Incluso se generaron variedades locales, como, por ejemplo, las aceitunas de la variedad Arauco, oriundas de La Rioja (Pochettino, 2015). A fines del siglo XVI, Mendoza ya enviaba vinos a Tucumán, y más tarde lo haría al Litoral y Buenos Aires. San Juan, por su parte, se especializaba en la producción de aguardiente (Barsky y Gelman, 2001).

3. Centro: compuesto por las actuales provincias de Córdoba y San Luis. Como se dijo, durante la colonia, la actividad más importante de la región era la cría de animales de carga para el Alto Perú, y se registraba una agricultura doméstica de autoconsumo.

4. Noreste: esta región integrada por las actuales provincias de Misiones, Chaco y Formosa estaba, en parte, integrada a Paraguay, pero durante el siglo XVII y buena parte del XVIII se integraron al sistema productor y exportador de las misiones jesuíticas a través del cultivo de la yerba mate que llegaba a todos los rincones del Virreinato del Perú y luego del Río de la Plata. Esta especie nativa comenzó a utilizarse a partir de poblaciones del monte, pero los jesuitas promovieron diversas estrategias de cultivo, con el establecimiento de plantaciones que llegan hasta nuestros días. También se producía algo de tabaco, ganadería textiles, pero sin la importancia del mate para otras regiones (Garavaglia, 1983; Mayo, 1994; Barsky y Gelman, 2001).

5. Litoral: integrada por Buenos Aires, Entre Ríos, Santa Fe y Corrientes. Esta fue la región menos poblada y menos desarrollada; si bien alrededor del puerto de Buenos Aires se formó un pequeño núcleo comercial, su crecimiento estaba obstaculizado por el monopolio comercial y su situación marginal con respecto a la producción en las zonas antes mencionadas. En el interior de la región, la principal actividad fue la ganadería bovina de haciendas cimarronas que podían ser capturadas libremente y que se aprovechaban íntegramente (carne, cueros, grasa.). Hacia mediados del siglo XVII comenzaron a otorgarse licencias, lo que llevó al establecimiento de las vaquerías con mano de obra temporal: el gaucho. Asociado a esto existía una pequeña agricultura de autoconsumo (Mandrini, 1987; Barsky y Gelman, 2001).

\section{El nacimiento de una nación y la consolidación del granero del mundo}

Hacia fines del período colonial se mantenían, a grandes rasgos, las características productivas reseñadas y otros hechos sociales vinculados: distribución desigual de población y riqueza, con un fuerte peso de la región centro-noroeste, y un Litoral escasamente poblado, pero en franco crecimiento a partir de la explotación y exportación pecuaria. Además de las especializaciones mencionadas, y debido a los altos costos de transporte, cada región también produjo los recursos necesarios para su subsistencia (carne, trigo, maíz). Las guerras por la independencia supusieron situaciones desiguales para las distintas regiones: en el Noroeste, escenario de combates, se rompieron redes de producción y comercio, mientras que en otras zonas como el Litoral se encontraron oportunidades de desarrollo. La Patagonia, en cambio, estuvo ajena a esas vicisitudes por la presencia continua de poblaciones nativas, lo cual cam-

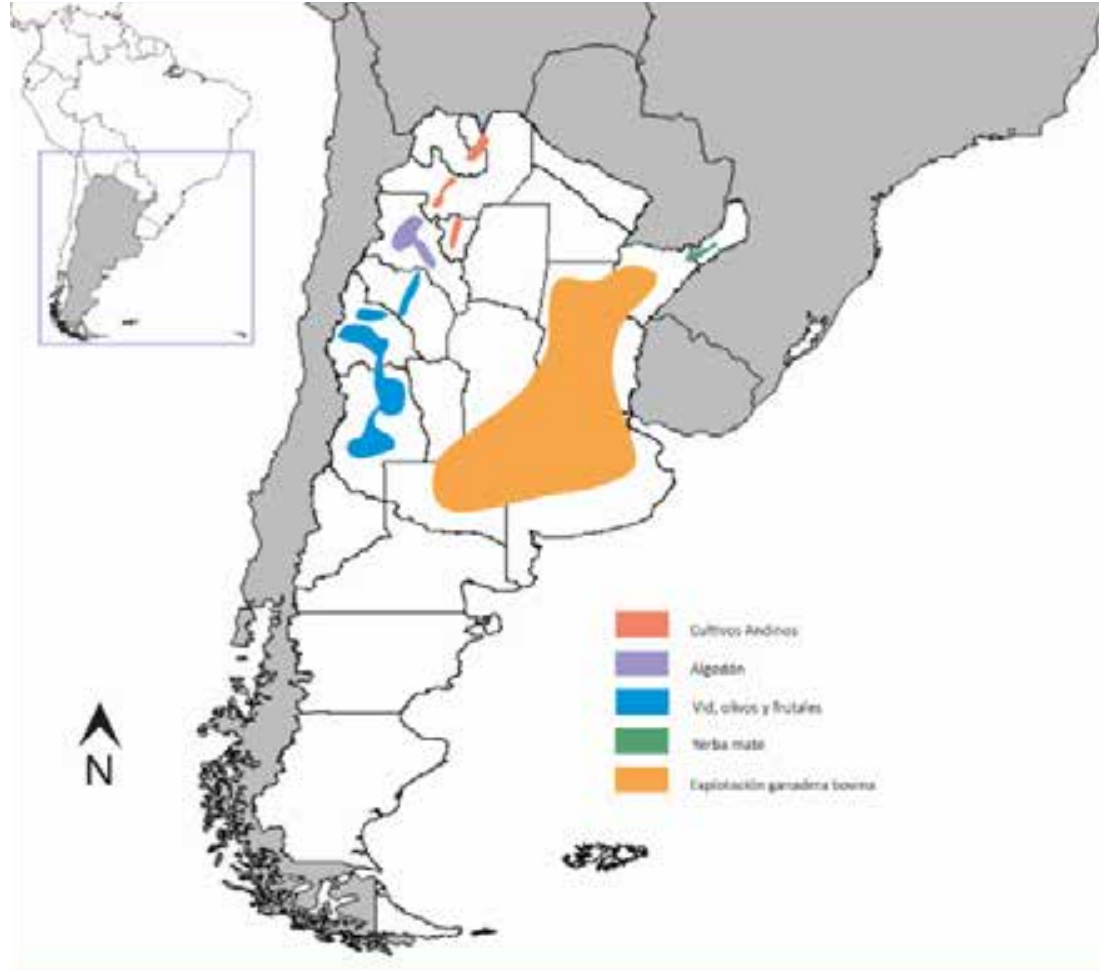

Figura 2.3. Consolidación de las economías regionales a fines del período colonial y durante la organización nacional (siglo XIX).

biaría a partir de las campañas militares gestadas para el exterminio de poblaciones y anexión de sus territorios a los nacionales (Barsky y Gelman, 2001).

Todo el período de organización nacional, hasta bien entrada la segunda mitad del siglo XIX (Figura 2.3), se caracterizó por la intensificación en la explotación ganadera en la región pampeana, el establecimiento de los saladeros de cueros para exportación, el avance de la frontera ganadera hacia la Patagonia con cría de ovinos, y la consecuente pérdida de importancia de las economías regionales como base de una economía nacional.

La Pampa húmeda de Argentina ocupa más de 50000000 ha y se caracteriza por la alta fertilidad de suelos modernos, no consolidados, con vegetación natural de pradera de gramíneas y clima templado húmedo. Este territorio se incorporó tardíamente a la producción agrícola con la llegada, desde 1856, de inmigrantes europeos contratados para la colonización de estas áreas, y como contención de los pueblos originarios. Desde ese momento y hasta 1970, la zona pampeana se consolida como una región agropecuaria, de explotación mixta poco común y característica de la zona. Se incorporan cultivos anuales, cereales y oleaginosas, a través de un sistema de rotación de cultivos y alternancia con pasturas para el ganado, tanto para 
carne y cuero como para leche. La explotación, muchas veces basada en ensayo y error hasta dar con los recursos más adecuados, se va tecnificando paulatinamente, lo que acrecienta en forma notoria, el potencial productivo de la región. Desde el punto de vista económico, se dieron grandes vaivenes con alzas y caídas bruscas del precio de la producción agropecuaria, pero la diversificación se mantuvo unos cien años (Barsky y Gelman, 2001).

Un cambio significativo en la producción se dio a partir de 1970-1980 (Figura 2.4). Sobre la base de una política de desregulación, las exportaciones agropecuarias carecieron de aranceles y alcanzaron precios inusitados, sobre todo los granos y oleaginosas. Junto con esto comenzó una nueva forma de explotación sobre la base de importantes cambios tecnoló gicos, que conllevaron a la disminución de mano de obra rural e intensificación en el uso de agroquímicos (siembra directa), lo que hace que tierras de uso tradicionalmente ganadero se trasladaran a la agricultura. Desde el punto de vista de los recursos vegetales involucrados, la escena está dominada por la introducción de semillas genéticamente modificadas de trigo, maíz, sorgo granífero y girasol y la difusión masiva de la soja (Fig. 5). Este proceso interrumpe el ciclo tradicional de selección, guarda y reproducción de semillas propias, que, no obstante, se mantiene en la agricultura familiar (Bonicatto et al., 2015).

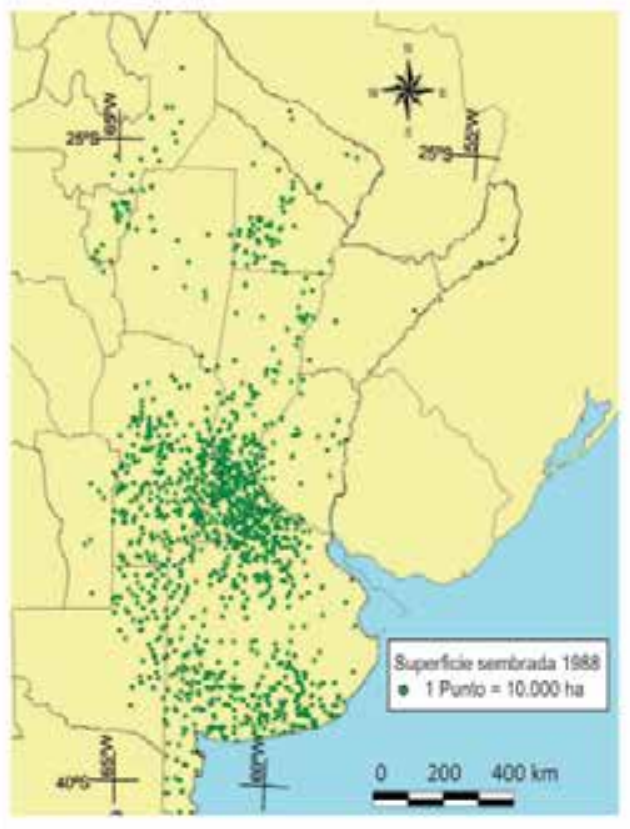

Distribución de la superficie sembrada en Argentina. Campaña 1988/1989

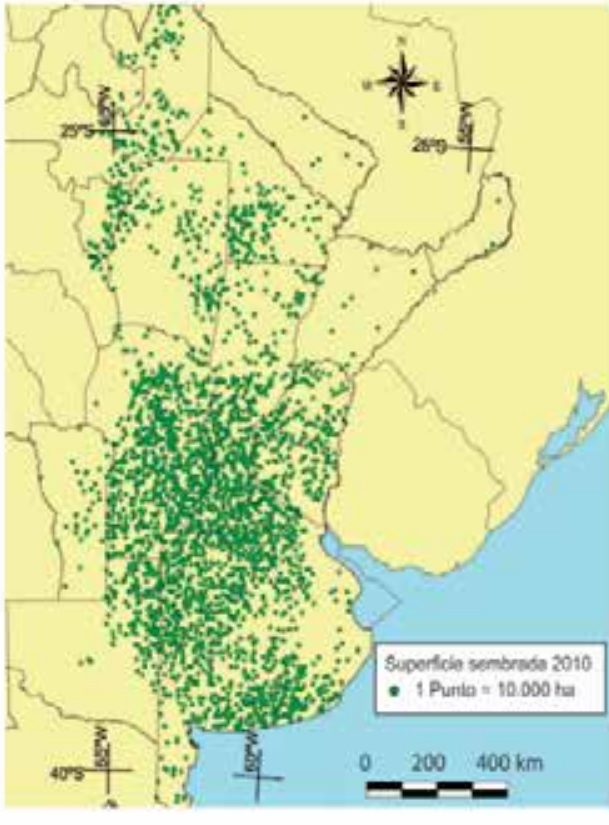

Distribución de la superficie sembrad en Argentina. Campaña 2010/2011
Figura 2.4. Expansión de la agricultura industrial (fines del siglo XX y principios del siglo XXI). Tomado de Cruzate y Casas (2012).

\section{La agricultura familiar: el espacio de la experimentación}

La agricultura familiar en Argentina adquiere diversas formas, tanto para el autoconsumo como para la comercialización, en ámbitos netamente rurales como otros periurbanos. La modalidad social de agricultor familiar se caracteriza como aquella donde las unidades doméstica y productiva se hallan físicamente integradas (Prividera y López-Castro, 2010). Asimismo, la fuerza de trabajo utilizada en la producción corresponde en su mayor parte al aporte de la familia, la producción es diversificada, se dirige tanto al autoconsumo como al mercado y, en general, se registra pluriactividad de los miembros de las familias que desarrollan alternativas productivas y laborales dentro o fuera de su predio. En la actualidad, los agricultores familiares también son uno de los principales proveedores de alimentos frescos para las economías locales tanto urbanas como suburbanas (Muzi, 2013). Sin embargo, en todos los casos constituye una instancia de resistencia al modelo agroexportador descrito y se basa en la selección y conservación de la diversidad biocultural.

A modo de ejemplo, tomamos cuatro enclaves caracterizados por esta actividad, desarrollamos su historia productiva desde la conquista hasta su situación actual, enfatizando la situación de la agricultura familiar en cada uno.

\section{Breve historia productiva en La Patagonia}

En La Patagonia, las poblaciones locales entraron en contacto con los núcleos hispánicos que llegaron a la región, pero mantuvieron su autonomía, y por ende, aislamiento, hasta fines del siglo XIX. Hasta esa fecha, los registros arqueológicos y prehispánicos dan cuenta de una gran diversidad de vegetales silvestres comestibles y de plantas cultivadas que formaron parte de la dieta de los pueblos del sur de Argentina y Chile. Se han descrito en la región patagónica, sistemas irrigados de cultivo de maíz (Zea mays), papa (Solanum tuberosum), porotos (Phaseolus sp.), quinoa (Chenopodium quinoa), zapallos (Cucurbita sp.) y ajíes (Capsicum sp.), así como también del cereal llamado mango (Bromus mango, Poaceae) y la oleaginosa denominada madi (Madia sativa, Asteraceae), estos dos últimos abandonados por completo luego de la conquista. La lógica del uso del paisaje era de apropiación colectiva con normas vinculadas a intercambio y la reciprocidad (Ladio, 2011).

A fines del siglo XIX, a partir de la mal llamada Campaña del Desierto (Wingka Malón en lengua Mapuche) -una fuerte embestida militar al mando del General Roca que generó el genocidio de las comunidades originarias de la región o su desarraigo- fue cuando las tierras patagónicas entraron al sistema nacional. A partir de esa fecha, las tierras comenzaron a recibir inmigrantes o colonos, y fueron utilizadas aplicando las lógicas de producción de alimentos propias del modelo europeo de áreas templadas. La usurpación de las tierras se sustentaba con la ley del Hogar de 1889, dándoles a los colonos tierras para producción ganadera y de granos (principalmente trigo y cebada) destinados a la exportación. En todo este período se produjo un afianzamiento de la partición del espacio con base en la noción de propiedad privada y del acorralamiento o abandono de las lógicas de uso de la tierra que 
poseían los pueblos originarios (Ladio y Molares, 2014). Finalizada la Campaña del Desierto, la del Nahuel Huapi y los Andes $(1879,1881$ y 1885), los establecimientos de los colonos ocuparon las mejores tierras de calidad forrajera y ganadera, desencadenando el desplazamiento de los pequeños y medianos productores caprinos hacia el este de la cordillera de los Andes, las zonas más secas de la región. A fines del siglo XIX y principios del XX, se produjo un gran auge en la zona de la producción lanera desencadenando un proceso conocido como "merinización" (ovejas de raza merino) y convirtiendo a la Patagonia argentina en la principal zona con stock ovino hasta el día de hoy (SENASA, 2012) y visibilizándose solo en grandes establecimientos agropecuarios.

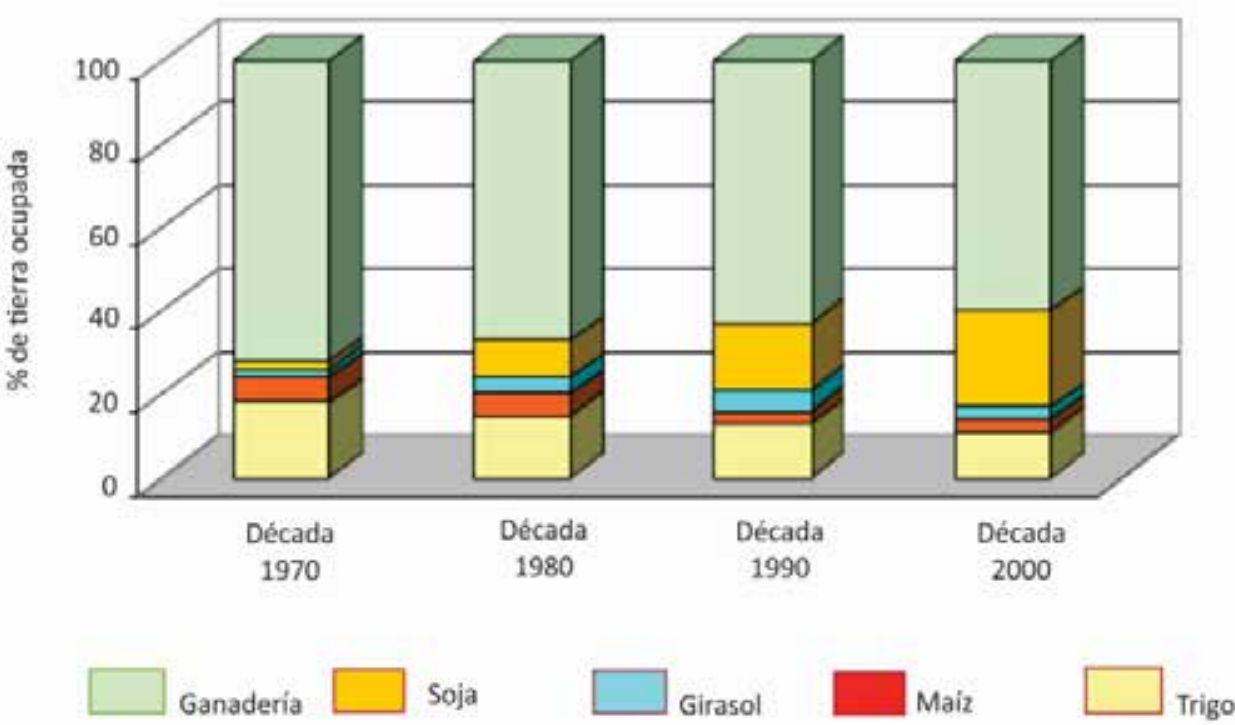

Figura 2.5. Cambios históricos en la configuración del uso de la tierra y su impacto sobre el margen bruto por hectárea (Tomado de Viglizzo, 2004).

Adicionalmente, en la región se ha dado el desarrollo paulatino de otras economías regionales de nivel industrial, tal es el cultivo de frutas de pepita como manzanas (Malus domestica) $(23000 \mathrm{~kg} / \mathrm{ha})$ y peras $(10000 \mathrm{~kg} / \mathrm{ha}$ ) en el Alto Valle rionegrino, y posteriormente la fruta fina en la comarca andina de Río Negro, Chubut, entre otras, que dan cuenta de una marcada orientación y visibilización de la región como un lugar que ha orientado su producción a la exportación de variedades y especies comerciales de origen exótico. Gran parte de la producción se exporta a Brasil, Países Bajos, Alemania y Suecia. Otros frutales cultivados en esta amplia y diversa región son el durazno (Prunus persica), membrillo (Cydonia oblonga), cereza (Prunus avium), tomate (Solanum lycopersicum), vid (Vitis vinifera) y el lúpulo (Humulus lupulus), principalmente en el valle del Río Negro (Río Negro) destinados mayoritariamente al consumo interno. Más a sur, en los valles del Río Chubut o del Río Sengerr (Chubut), hay cierta especialización hacia el cultivo de forrajes como la alfalfa. En la zona de los Antiguos (Santa Cruz) se destaca el cultivo de cerezas. La forestación con pinos del hemisferio norte (Pinus ponderosa, Pseudotsuga menziesii, Pinus contorta), ha sido, desde hace 35 años, una de las principales actividades impulsadas por diversos estados provinciales de la Patagonia (Raffaele et al., 2014).

\section{Agricultura familiar en Nor-Patagonia}

Poca atención se le ha dado a los sistemas que integran los pequeños productores que viven en la Patagonia, muchos de ellos descendientes de los pueblos originarios que se sustentan por medio de economías de subsistencia, y que ascienden en la región a más de 12000 familias. Dichos pequeños productores se concentran principalmente en el Norte de la Patagonia en las provincias de Neuquén, Río Negro y Chubut (Muzi, 2013).

Estas unidades familiares se caracterizan por tener como lógica la complementariedad de múltiples estrategias de producción donde coexiste diversidad de recursos genéticos animales y vegetales que, manipulados por los productores, aportan a la economía predial familiar, ya sea para el autoconsumo o para la transformación de tales productos en mercancías para su venta en mercados informales (verduras, hilados, trabajos en cuero, venta de huevos y animales de granja) (Eyssartier et al., 2011a; Ladio et al., 2013). Estos sistemas constituyen modos de vida y producción específicos que se han construido in situ y que se orientan hacia la disminución de los riesgos más que al incremento de la productividad, lógicas que son muy diferentes a las del mercado (Richeri et al., 2013). También se caracterizan por la poca inversión de dinero $y$ de la dependencia de la mano de obra familiar (Eyssartier et al., 2013). Las actividades de cuidado del ganado están principalmente basadas en la fuerza de trabajo de los varones de la casa, mientras que las desarrolladas en las cercanías del hogar están a cargo de las mujeres, como el cultivo y cuidado de especies vegetales en la huerta familiar, el suministro de plantas silvestres y la crianza de aves domésticas (Eyssartier et al., 2011b). En este sentido, la práctica de la trashumancia ganadera llevada a cabo por los pequeños productores que subsistieron en la región -como una estrategia resignificada de la caza del guanaco que implica el traslado de las familias hacia las pasturas cordilleranas en verano y el regreso a las tierras bajas en el invierno- ha sido para varias zonas de la Patagonia una solución frente a la rigurosidad ambiental, pero que también ha tenido implicancias en la diversidad de recursos vegetales alimentarios consumidos (Ladio y Lozada, 2009). Los estudios indican que esta práctica está en grave retroceso, y esto genera una disminución en la riqueza y variedad de especies comestibles silvestres que son utilizadas por los pobladores (Ladio y Lozada, 2004).

En los relevamientos actuales encontramos que se cultivan aproximadamente unas 120 140 especies por comunidad, siendo entre el $80-90 \%$ especies exóticas de preponderancia mundial como la lechuga (Lactuca sativa), cebolla (Allium cepa), ajo (Allium sativum), haba (Vicia faba) zanahorias (Daucus carota var. sativa), arvejas (Pisum sativum), papas (Solanum tuberosum) y repollo (Brassica oleraceae var. capitata) (Eyssartier et al., 2013). Sin embargo, las plantas nativas comestibles y/o medicinales no están ausentes en este escenario, manejadas esencialmente en los ambientes silvestres, y totalizando cerca de 200 especies diferentes (Ladio, 2011; Eyssartier et al., 2011b; Molares y Ladio, 2012). Estos números nos dan una idea acabada acerca de que la riqueza de recursos genéticos de la Patagonia está principalmente 
en manos de los campesinos, y ellos son los que están custodiando estos reservorios locales mediante su utilización y cuidado. Los espacios de cultivo son principalmente huertos y jardines (ubicados en los alrededores del hogar) en donde también los frutales están presentes. En algunos lugares existe la chacra, siempre de mayor tamaño y con frutales en su perímetro. La horticultura familiar ha sufrido grandes cambios en los últimos años, en particular debido a la intervención de agencias de desarrollo como el INTA (Instituto Nacional de Tecnología Agropecuaria). Entre las mayores intervenciones se encuentra la introducción de invernaderos y microtúneles desde hace veinte años aproximadamente. El cultivo en invernaderos ha permitido proteger a los cultivos de los fuertes vientos, de las heladas y las temperaturas extremas de la estepa. También ha ayudado a incorporar especies poco conocidas por los pobladores locales y ampliar el período de siembra y cosecha (Eyssartier et al., 2011a). Además, la introducción de invernaderos trajo aparejada una nueva fuente de suministro periódico de semillas de origen externo. Según lo mencionado por varios pobladores patagónicos locales, antiguamente prevalecía la cosecha de semillas de la propia producción y el intercambio de las mismas. Desde entonces, muchas semillas empezaron a ser compradas y otras repartidas por los técnicos agropecuarios, perdiéndose dicha tradición en la zona. Sin embargo, algunas experiencias más recientes muestran un cambio de visión entre los extensionistas y productores, donde el intercambio de semillas locales comienza a ser estimulado así como la conformación de Ferias Francas Regionales. Como ejemplo de lo anterior pouede mencionarse el caso de la Feria Franca del Nahuel Huapi que desde 2009 comercializa hortalizas, frutas y plantas ornamentales, así como también semillas locales y algunas plantas silvestres obtenidas por productores minifundistas de los alrededores de S.C. de Bariloche (Ladio et al., 2013).

\section{Breve historia productiva en el Noroeste-Quebrada y Puna de Jujuy}

A lo largo del período colonial y hasta comienzos del siglo XX, las áreas del NOA aquí tratadas, la Quebrada de Humahuaca y la Puna, constituían zonas caracterizadas por una economía de autosubsistencia, si bien mantenían distinto grado de articulación con mercados locales y regionales como resultado de su inclusión en el Marquesado de Tojo, uno de los pocos mayorazgos que estableció la Corona Española en territorio argentino. Esta unidad productiva que abarcaba el Norte de Jujuy, Noroeste de Salta y sur de Bolivia (Tarija) se consolidó en 1708 y su unidad se prolongó más allá de la muerte del último marqués en 1820 (Barsky y Gelman, 2001). En esta vasta propiedad se encontraban diversos pisos ecológicos y se observaba cierta especialización en cada uno de ellos: ganadería en la Puna, vitivinicultura en Tarija, mientras que la Quebrada de Humahuaca tenía una economía agrícola-ganadera, vinculada al tránsito de animales hacia el Alto Perú (Conti, 1989; Reboratti et al., 2003; Teruel, 2005).

El panorama productivo descrito podía observarse aún a principios del siglo XX. A partir de su introducción en el siglo XVI, varios cultivos europeos tales como alfafa, trigo y habas prosperaban en territorio jujeño con distintos fines. La alfalfa, forraje de primera calidad, y el trigo entraban en los circuitos de intercambio, mientras que las habas pasaron a ser un alimento central en la dieta de los pobladores locales. Junto con esto, las familias continuaban cultivando especies nativas, como distintas variedades de papa, maíz y oca (Oxalis tuberosa); papa lisa (Ullucus tuberosus) y quinoa; junto con frutales como duraznos, manzanas y peras y, en menor medida, algunas hortalizas y legumbres de introducción más tardía como cebolla, repollo, acelga (Beta vulgaris var. cicla) y tomate (Arzeno, 1999 en Bugallo et al., 2014; Reboratti et al., 2003).

En estos momentos la distribución de la población también cambió. La Puna, que había llegado a albergar entre el 50 y $60 \%$ de la población de la actual provincia de Jujuy a fines del siglo XVIII, perdió importancia frente al crecimiento de la Quebrada y valles subtropicales, "partícipes del nuevo eje económico que integraría la producción jujeña al mercado nacional" (Teruel, 2005). Un elemento central en esta situación fue la llegada del ferrocarril hacia 1905 Aunque no tuvo un efecto inmediato, con el tiempo fue un elemento importante en la modificación de la estructura productiva de la zona. Por una parte, desaparecieron los grandes alfalfares, ya que supuso un cambio en los medios de transporte, y, por otra, también se perdió el cultivo de cereales por el transporte de productos en gran escala de y hacia otras zonas (Bugallo et al., 2014). La producción entonces se orientó hacia la fruticultura, incorporando, a partir de la década de 1950, distintas hortalizas (Karasik, 1994; Arzeno y Castro, 1998; Reboratti et al., 2003). Como ejemplo de uno de los nuevos cultivos introducidos con destino a mercado puede citarse la incorporación del tomate (Arzeno et al., 1999 en Bugallo et al., 2014) Las nuevas orientaciones económicas llevaron a que la producción agrícola y ganadera para autoconsumo también sufriera cambios. Desde la segunda mitad del siglo XX, y como consecuencia de una incipiente modernización tecnológica -junto con la introducción de nuevos productos y la expansión de los mercados urbanos-, con el consecuente incremento de la demanda de productos hortícolas, la producción agrícola mercantil en la Quebrada tomó un fuerte impulso, sobre todo en las últimas décadas (Reboratti et al., 2003). Durante la década de 1990, la actividad agrícola presentó un nuevo cambio: la producción frutihortícola de la década de 1940 se transformó en, casi exclusivamente, una producción de hortalizas y flores. Según datos del INDEC de 1988, aproximadamente el 61\% de las 1300 ha se destinaba a la horticultura, el $20 \%$ a las forrajeras, el $7 \%$ a granos, fundamentalmente maíz, y el $6 \%$ a frutales (INDEC 2002; Bugallo et al., 2014).

\section{La agricultura familiar en Quebrada y Puna}

El censo agropecuario en 2002 (INDEC, 2002) muestra una distribución similar a la de fines de la década de los noventa en cuanto a los cultivos, pero con un gran incremento de hortalizas $(+6 \%$,$) y legumbres (+38 \%)$. En el presente, los agricultores familiares cultivan tanto especies locales como introducidas. En zonas cercanas a la Puna, donde el pastoreo de camélidos, ovinos y/o caprinos es preponderante, se ha relevado el cultivo en pequeñas parcelas de habas, arvejas, trigo, variedades de papa, oca, quinoa blanca y rosada, cebada y alfalfa en huertos a cielo abierto (Lema, 2006; Fabron, 2014). Con la introducción de viveros en la puna, se logra el cultivo de lechuga, tomate, zanahoria, acelga, cebolla, perejil (Petroselinum crispum), ajenjo (Artemisia absinthium), menta (Mentha spp.), aloe (Aloe spp.) y maíz -aunque este último llega a crecer tanto que rompe los plásticos del invernadero y el espacio se convierte en un huerto a cielo abierto- entre otras (Lema, 2006). Las zonas de cultivo están constituidas por rastrojos de alfalfa, sembraderos para consumo de la familia próximos o alejados de la casa y jardines o quintas anexas a las mismas (Lema, 2014b). En la Quebrada, articulada con la Puna mediante 
circuitos de intercambio y redes familiares en un sistema socioeconómico agropastoril, se registra un rango de especies que incluye algunas de las ya mencionadas, junto a variedades de maíz, papa "abajeña", duraznos, manzanas, peras (Pyrus communis), vid, zanahorias, acelga, ají, zapallos (Cucurbita spp.) y flores (Fabron, 2014; Lambaré, 2015), siendo excepcional el cultivo de yacón, situado en una o dos localidades. También se observan huertos destinados exclusivamente al comercio, donde se cultivan unas 20-30 especies, entre las que destacan por la extensión cultivada choclos, lechuga, ajo, acelga, haba y zanahoria (INDEC, 2002). A diferencia de lo planteado para Patagonia, quizá como consecuencia de una larga tradición agrícola, son muy pocas las especies silvestres usadas como comestibles, con excepción de frutos de algarrobo (Prosopis spp.) y varias cactáceas, aunque es elevado el número de aquellas empleadas como condimenticias y medicinales, alcanzando una cifra similar de 200 especies (Scarpa y Arenas, 1996; Martínez et al., 2000). El intercambio de semillas entre familias y en ferias de intercambio locales sigue vigente, tanto a través de prácticas tradicionales como impulsado desde organismos oficiales de promoción, organismos que también se hacen presentes en las comunidades quebradeñas para aportar semillas -muchas de ellas "curadas" con "remedio"- e infraestructura. En los últimos años, los llamados "cultivos andinos" (tales como oca, papa lisa, yacón, quinoa, variedades de maíz) han aumentado su salida comercia para una gastronomía local orientada al turismo y una de exportación dentro del mercado interno para restaurantes gourmet (Arzeno y Troncoso, 2012). Esta demanda ha sido, en parte, respondida desde los agricultores familiares locales a través de su participación en cooperativas. Actualmente, el uso de agroquímicos en el sector central de la Quebrada -para abastecer la demanda del mercado versus la manutención de sistemas tradicionales a nivel familiar (como forma de aportar valor agregado a los productos de comercialización)- es una de las principales pujas que se dan en la región.

\section{Breve historia productiva en el Noroeste-Yungas}

Con la llegada de los españoles, en el siglo XVI, se repartieron las tierras de las Yungas en grandes encomiendas (Rutledge, 1987), y hacia finales del siglo se establecieron sistemas reduccionales, primero Jesuitas y luego Franciscanos (Tommasini, 1933). Hacia comienzos del siglo XVII, las tierras se dividieron en mercedes, lo que dio origen al sistema de haciendas -grandes latifundios conocidos como fincas en la región- (Vergara, 1934), donde los pobladores locales pasaron a ser arrendatarios u "ocupantes" con pocos derechos sobre el uso del espacio. En este período se incorporaron nuevos productos agrícolas tales como trigo, habas, arvejas, cebada, y frutales como cítricos, naranja y lima especialmente, durazno, ciruelos, manzanas y peras, y se incorporó la cría de ovejas, vacas y burros (Compañía de Jesús 1690-1614, Reboratti, 1996). Con la llegada de los españoles se modificaron las redes de intercambio prehispánicas y la economía de los pueblos pasó a ser mayoritariamente responsabilidad del grupo doméstico, a diferencia del anterior sistema comunitario (Custred, 1977; Karasik, 1984; Hilgert, 2007a).

A comienzos del siglo XX, la llegada del ferrocarril, a La Quiaca en 1906 y a Orán en 1916 generó una redistribución de las vías de comunicación y contribuyó a una nueva modificación de las redes de intercambio vigentes (García Moritán y Ventura, 2007). En esa época se acentuó la transformación de las tierras bajas (piedemonte) con el objetivo de ampliar las plantaciones de caña de azúcar, actividad iniciada en el siglo anterior. Lo anterior significó la transformación de más del $90 \%$ de ese ambiente y la redistribución de las poblaciones locales, del campo hacia centros urbanos; así, las áreas naturales quedaron reducidas a la explotación forestal selectiva, la ganadería de trashumancia y la permanencia de pequeños poblados rurales (Reboratti, 1995; Brown et al., 2001; Hilgert y Gil, 2005). Otro cultivo de importancia en el piedemonte y en el valle es el tabaco (Nicotiana tabacum y más raramente $N$. sylvestris), de larga historia en la zona, sobre todo para cubrir las necesidades familiares y con un alto valor simbólico, ritual y medicinal (Serrano, 1934; Hilgert, 1998). Sin embargo, a partir de la segunda mitad del siglo XIX, comienza en la provincia de Salta un crecimiento ininterrumpido del área cultivada. Las dos guerras mundiales constituyen un fuerte impulso para la exportación de tabaco, y hacia 1950 se consolida también su producción en la provincia de Jujuy (Rodríguez-Faraldo y Zilocchi, 2012).

\section{Agricultura familiar en Yungas}

En los poblados rurales de las yungas, que se distribuyen de modo heterogéneo desde la ceja de monte en el pastizal de neblina, pasando por los valles húmedos y llegando al piedemonte, se mantiene gran parte de la variabilidad ancestral de cultivares nativos y criollos, que recientemente se enriquecieron con numerosas hortalizas, entre ellas acelga, repollo y lechuga (Hilgert, 1999). No obstante, los cultivos más importantes en estos parajes siguen siendo la papa, los zapallos y el maíz. A modo de ejemplo, de los 25 etnotaxa de maíces criollos cultivados en distintos enclaves de yungas, se han identificado como factores que modelan el mantenimiento de estos cultivos, la preservación del uso diversificado del ambiente -que se refuerza con el mantenimiento de algún grado de trashumancia- (Hilgert y Gil, 2005; Ramos et al., 2013), el mantenimiento de la identidad cultural y la religiosidad local (Hilgert et al., 2013). Asimismo, se ha constatado que este sistema productivo se nutre de nuevos cultivares procedentes de intercambios entre agricultores de diferentes regiones (en parte bolivianos) y que aún en la actualidad es un proceso dinámico (Ramos et al. 2013). Además, se ha demostrado que la trashumancia entre los agricultores fomenta una mayor diversidad de cultivos y/o del uso de recursos silvestres alimenticios, aquellos propios de cada piso altitudinal y de otros más versátiles, así como la conservación de técnicas de manejo adecuadas a las características de cada sitio y del grupo cultural (Hilgert, 2007b).

Sin embargo, los estudios también muestran que el abandono de dicha actividad trashumante, la disminución de la actividad agrícola en distintos pisos altitudinales y la incorporación de productos alimenticios foráneos contribuyen a la disminución de tal riqueza. Dentro de los casos estudiados, en la provincia de Salta, se ha observado que el elenco de cultivares está relacionado con el piso altitudinal y con la distancia a la casa del espacio donde se cultiva. En los sitios próximos al hogar se encuentra todo aquello destinado al uso cotidiano -especies que se consumen en estadios madurativos incompletos, como choclos, condimentos, verduras, etcétera- $\mathrm{y}$ en el resto de los sitios se cultiva aquello que se cosechará maduro y se almacenará para consumo propio o venta (Hilgert, 1998; 1999; 2007a; Hilgert y Gil, 2005). Estos espacios son huertos y jardines (ubicados en los alrededores del hogar), con dos variantes ubicadas en sitios un poco más alejados, pero con un rol similar: los huertos vegetales (ubicados en los 
puestos del cerro, dentro de los corrales donde pernoctan las ovejas, en un espacio separado por cercos transitorios), los huertos frutales (comunes en el valle y monte, donde predomina e cultivo de frutales, pero además se producen otros elementos propios de estos ambientes) y los espacios de agricultura migratoria (roza, tumba y quema) (Hilgert y Gil, 2005).

\section{Breve historia productiva del Noreste -Bosque Atlántico-}

Ierritorio del bosque atlántico ha estado habitado por pueblos guaraníes desde hace unos 6000 años (Martínez Sarasola, 1992). En esta región, la población aumentó considerablemente durante el período colonial, con los jesuitas, y a mediados del siglo XVII fue la región más densamente poblada de Argentina (Belastegui, 2004). Población que, luego de la expulsión de la orden Jesuita y de las guerras locales, decae hasta la promulgación de la Ley de Avellaneda en 1876, momento en que se inicia un programa de colonización de la región con el fin de poblar el territorio e incrementar la producción agrícola (Slutzky, 2011). Dicha colonización se fue expandiendo desde el sur hacia el norte del territorio; inicialmente en tierras fiscales $y$ luego privadas -por la costa del río Paraná- (Belastegui, 2004). Más tarde, en la década de los ochenta del siglo XX hubo una nueva ola de colonización siguiendo la costa del río Uruguay (Bartolomé, 1982, 2000; Schiavoni 1995).

En la segunda mitad del siglo XX, entre 1960 y 1980, se destaca un proceso de ocupación espontánea de tierras fiscales, protagonizado por familias de agricultores autoorganizados originarios de otras zonas de Misiones y de los estados vecinos de Brasil (Schiavoni, 1995).

A partir de 1940 se impulsa la producción de tung (Vernicia fordii), período que es recordado por los pobladores locales como la época de mayor crecimiento y auge económico en la región. Durante las décadas de los años sesenta y setenta comienza la promoción de la actividad forestal en la provincia. Si bien las primeras plantaciones forestales de Araucaria angustifolia con fines comerciales fueron en los años cincuenta, a partir de los años sesenta las reforestaciones pasan a ser monocultivos de pino resinoso, quintuplicándose la superficie implantada de esta especie. Luego, en los años noventa se estimula la reforestación con pino resinoso con base en incentivos fiscales que se ampliaron a partir de la ley 25.080 y que se mantiene en la actualidad. Este panorama convierte a Misiones en la última frontera agropecuaria de Argentina, es decir, con grandes latifundios tierras fiscales disponibles, donde se combina el uso de recursos forestales con el desarrollo de la agricultura de autoconsumo Galindo-Leal y Gusmão Câmara, 2003; Ferrero, 2005; Izquierdo et al., 2010; Mastrángelo y Trpin, 2011; Cariola et al., 2013).

Como resultado, la mitad de la superficie boscosa del territorio provincial ha sido convertida en plantaciones forestales con agricultura de subsistencia (predominan tabaco, maíz y mandioca) (Izquierdo et al., 2008). La agricultura industrial actual está dominada principalmente por cultivos perennes de yerba mate y té (Manzi, 2000), y cultivos anuales, principalmente tabaco, plantaciones forestales de Pinus, Eucalyptus y, en menor medida, Araucaria. Asimismo, hay un desarrollo ganadero incipiente en el sur de la provincia en pasturas naturales implantadas $y$ en áreas forestales con manejo agrosilvícola (Izquierdo et al., 2010).

\section{La agricultura familiar en el Bosque Atlántico}

En el presente, entre los pobladores guaraníes, las actividades de subsistencia de mayor importancia como fuente de alimento están constituidas por la horticultura de roza y quema, donde se observa diversidad de cultivos nativos tradicionales, así como introducidos en épocas más o menos recientes (Cadogan, 1960; Martínez-Crovetto, 1968; Bartolomé, 1978; Martínez et al. 2003; Pochettino, 2007). Tradicionalmente desarrollaban un complejo sistema de agricultura migratoria -en el que se definen ciclos de rotaciones, asociaciones particulares de cultivos y control de plagas, junto con una fuerte vinculación entre la actividad y la religiosidad local (Martínez-Crovetto, 1968)-, el cual se mantiene en la medida en que lo permite la sedentarización a la que se han visto forzadas estas comunidades por la aparición de la propiedad privada.

Sus principales predios de cultivo -chacras- se caracterizan por combinar plantas erguidas -como avachĩ o maíz, manji'o o mandioca, kuaray rova o girasol (Helianthus annuus), kumanda yvyra'i (Cajanus flavus),- con rastreras que protegen el suelo -como 12 variedades de cucurbitas, kuarapepe o zapallo, andai o calabaza dulce, mandui o maní (Arachis hypogaea), jety o batata (Ipomoea batatas), chanjáu o sandía (Citrullus lanatus), merõ o melón (Cucumis melo)-combinadas con trepadoras -como especies de Vigna (kumanda cha'i, kumanda rope puku, etc.) y Phaseolus lunatus (choperĩ) - las que se siembran en la base de plantas adultas de maíz, aprovechando el vástago como soporte. En bordes de selva se cultivan pakova o banana (Musa x paradisiaca), avakachĩ o ananás (Ananas comosus) takuare'ẽ o caña de azúcar -Saccharum officinarum como Sorghum vulgare var. saccharatum- y el kapi'i yvate o pasto elefante -este último, para alimentar cerdos y bueyes-. También se observan árboles frutales, excepcionalmente el cultivo de arroz y tabaco (Pochettino, 2007: Keller, 2008). Es frecuente observar el cultivo de hortalizas -repollo, lechuga, tomates- provenientes de intercambios o de planes nacionales y/o provinciales de promoción hortícola en un espacio diferente a la chacra, ubicado junto a la vivienda y denominado quinta (Pochettino, 2007).

Hacia la década de los setenta del siglo pasado, se registraba una disminución en las prácticas agrícolas de este grupo cultural, la que se fundamenta en el deterioro del ambiente, la disminución de la superficie de las tierras que utilizan y la participación temporal en la cosecha de yerba mate y tabaco de las unidades productivas de los colonos (Chase-Sardi, 1971; Crivos et al., 2004; Pochettino, 2007). En ese contexto, la diversidad de cultivares actual ha sufrido cambios, entre ellos los más relevantes son: a) la desaparición de especies como e mangara (Xanthosoma sp); b) la pérdida de variedades de algunos cultivos tradicionales, entre ellas la batata, especie de la que se observaron siete variedades locales y una de reciente incorporación. Esta última es la que se cultiva en mayor proporción, junto a dos de las locales -en menor volumen-, y c) el abandono o disminución del cultivo de legumbres y maíz por la provista de estos elementos desde programas estatales. La agricultura se complementa con actividad pecuaria de cría de larvas comestibles de curculiónidos aramandái (Rhynchosporum palmarum) y otros coleópteros, producto del apeo y manejo adecuado de palmeras, árboles y cañas locales, así como la cría de aves de corral, cerdos y, más recientemente, ganado vacuno (Keller, 2008) 
La colonización de esta región desde fines del siglo XIX, basada en los distintos tipos de explotación económica mencionados, ha ido reduciendo y modificando las características de este ambiente y, consecuentemente, el territorio y la horticultura de las poblaciones aborígenes. Estos emprendimientos fueron fomentados por políticas migratorias a nivel nacional, las que otorgaban tierras a los inmigrantes europeos, llamados colonos, que se establecieron a través del sistema de concesiones en gran parte de los territorios habitados por los mbyá (Martínez et al., 2003). La actividad agrícola de los colonos -en principio para el autoconsumo, luego se orientó al mercado- estuvo alentada en algunos momentos de su historia por excelentes posibilidades económicas; por ejemplo, el tung en la década de 1940, la yerba mate y el té (Chiffarelli, 2010 a y b). Sin embargo, los vaivenes en las políticas de promoción de distintos cultivos generaron incertidumbre en los colonos y sus hijos, convirtiéndolos en personas escépticas con relación a su futuro como productores agropecuarios (Crivos, et al., 2005). E tabaco, en el centro y noreste del territorio misionero, constituye la principal producción de los grupos domésticos (suele ser el único producto que genera excedentes en efectivo) (Freaza, 2000; Ferrero, 2005). Por esta razón, en el caso de los productos de la chacra y la huerta, ya sean frescos o procesados -y los derivados de la cría de ganado y aves de corral- en la actualidad los destinan tanto al consumo doméstico como a la comercialización. Entran en el mercado a pequeña escala a través de la venta en las ferias francas (pioneras en este emprendimiento, hoy de alcance nacional) y en ferias regionales en ocasión de fiestas comunales y/o a través de la venta domiciliaria (Martínez et al., 2003). Con respecto a las especies utilizadas, el número es muy elevado, se calculan unas 400 entre silvestres y cultivadas. Esto se debe tanto a la diversidad biológica local, como a su característica pluricultural, con inmigrantes centroeuropeos, españoles y japoneses, y actualmente una zona de tránsito de pobladores de países vecinos, Brasil y Paraguay (Furlan et al., 2013).

\section{Reglamentando al granero del mundo}

En la actualidad, dado el significativo ingreso que los cultivos industriales representan para el país, desde el sector oficial se promueve el incremento del área cultivada aunque, al mismo tiempo, se origina legislación tendiente a proteger e incentivar la agricultura familiar y la conservación de bosques nativos. La investigación y gestión de estos recursos se generan desde universidades públicas y organismos oficiales. Sin embargo, las acciones de estos sectores públicos pueden contraponerse entre sí, difiriendo, por ejemplo, en cuanto a la viabilidad, incumbencias y términos referidos a los desarrollos tecnológicos a partir de estos recursos.

Como ejemplo de las investigaciones promovidas puede mencionarse el programa "Argentina Innovadora 2020". A través de este plan nacional que establece los lineamientos para los próximos años en materia de ciencia, tecnología e innovación productiva, se han identificado 34 núcleos socioproductivos estratégicos ubicados en todo el país. Uno de ellos es el yacón, especie originaria de la región andina del sur de Perú, Bolivia y noroeste de Argentina. Este cultivo andino prehispánico es objeto actual de investigaciones, puesto que se espera lograr una producción a escala industrial (MINCYT, 2013). Un extracto del discurso de la entonces presidente, Cristina Fernández de Kirchner, es demostrativo de las tensiones entre la agricul- tura familiar e industrial en nuestro país y qué lugar se le reserva al desarrollo tecnológico: "En nuestro país esta producción es de escala familiar, pero tenemos fuertes posibilidades en las provincias de Jujuy, Salta y Tucumán, precisamente de producirla a escala. Se llama Proyecto Yacón, está trabajando un importante laboratorio argentino (...) Hoy el amaranto, hoy la quinoa hoy el yacón son cosas que están demandadas por los grandes países desarrollados para industria farmacéutica, para industria alimentaria y sobre este proyecto estamos trabajando" (Casa Rosada, 2013) (ver Post Scriptum).

Con relación al acceso a los recursos genéticos, la legislación actual tiende a poner controles estrictos a los agricultores, limitando prácticas como el intercambio de semillas (las semillas deben adquirirse -y por ende obtenerse- en el mercado y tener un comprobante legal de respaldo), su circulación por fuera de los predios de producción y la expansión de áreas bajo cultivo a partir de semilla propia. Reglas que se contraponen con otros planes de desarrollo, tal como el Programa Nacional de Ferias Francas, donde la venta de mano del productor y e intercambio de semillas es altamente promovida.

En la República Argentina, el marco legal que regula la protección de variedades vegetales es la Ley № 24.376 de Adhesión al Convenio Internacional para la Protección de las Obtenciones Vegetales - UPOV; Acta de 1978-y la Ley № 20.247, de Semillas y Creaciones Fitogenéticas promulgada en 1973 y reglamentada en el año 1991 por los Decretos $N^{\circ} 2183 / 91$ y 2817/91, ambos ratificados por la ley $\mathrm{N}^{\circ} 25.84$.

La ley de Semillas en Argentina tiene como principal objetivo resguardar y asegurar los derechos de los obtentores de variedades vegetales, y regular su siembra, circulación y comercialización. En dicha ley se define al obtentor como "toda persona que crea o descubre desarrolla una variedad", no parece estar en el espíritu de la norma que eso incluya variedades desarrolladas localmente por agricultores campesinos o indígenas, basta ver los requisitos que una variedad debe cumplir para poder ser registrada como tal. En lo que respecta a los pequeños productores o agricultores familiares, si bien no de manera explícita, los mismos estarían contemplados en el artículo 27 de la ley de semillas, y en los decretos que la regulan del año 1991-cabe aclarar que en ese año se dio el fomento de pruebas de campo para soja transgénica, y que la misma se liberó para consumo en 1996, año en que se crea el Instituto Nacional de Semillas (INASE)-, estableciendo que el agricultor puede hacer uso de semillas siempre y cuando estas provengan de su cosecha previa y las venda como materia prima o alimento (no como semilla); además, la semilla de la variedad protegida (semilla originaria), de la que derivó su grano, debe haber sido adquirida legalmente en el mercado (Gianni, 2010).

Dadas las contradicciones en la ley vigente, hay un anteproyecto de reforma, el que en su versión provisoria -de mayo de 2014- con relación al acceso de la semilla, contempla exceptuar del pago de cánones de Derechos del Obtentor a aquellos agricultores que soliciten ser exceptuados (por incluirse en un régimen especial para pequeños productores y comunidades tradicionales y locales). Para ello, estos productores deberán estar inscritos en el Registro Nacional de Agricultura Familiar, siendo atribución del INASE otorgar la categoría de Agricultor Exceptuado, pudiendo asesorar al respecto la Comisión Nacional de la Semilla, CONASE. Es decir, el INASE resolverá sobre la inclusión, eliminación, y/o continuidad de cada agricultor en la categoría de exceptuado, tomando en consideración parámetros de análisis como volumen 
de cosecha, especies y/o variedades que cultiva, multiplicación de la semilla propia. Algunos de los aspectos llamativos son, por ejemplo, que la CONASE está conformada por seis representantes del sector público y seis del sector privado, y no cuenta con representante del sector de agricultura familiar. Otras de las atribuciones asignadas al INASE en este anteproyecto son regular la producción y el comercio de semillas de las especies nativas y criollas, y promover las acciones necesarias con el fin de fomentar e incentivar la conservación, manejo, uso sustentable, producción y comercio de las mismas. Asimismo, este instituto es el encargado de regular la fiscalización de las actividades que se llevan a cabo en el país con Organismos Vegetales Genéticamente Modificados no autorizados, incluyendo los procedimientos para su importación o exportación.

En un contexto similar, y en parte contradictorio, en enero de 2015 es promulgada la ley 27.118 denominada "Ley de Reparación histórica de la agricultura familiar para la construcción de una nueva ruralidad en la Argentina”. Esta ley -además de reivindicar el valor de este tipo de agricultura relegada por la legislación argentina y asegurar un régimen de tierras, agua de riego, caminos, infraestructura, vivienda y sanidad agropecuaria para la mismabusca promocionar marcas comerciales y denominaciones de origen y otros mecanismos de certificación como estrategia de valorización de los productos de la Agricultura Familiar difundir la producción natural orgánica y ecológica; promover el desarrollo productivo integral para el buen vivir, en armonía con la naturaleza y preservando la diversidad genética, respetando los usos y costumbres. De modo similar al anteproyecto de Ley de Semilla arriba analizado, para ser beneficiario de la ley, será necesario registrarse en el Registro Nacional de Agricultura Familiar.

En síntesis, la ley de agricultura familiar y la propuesta de modificaciones a la ley de semillas generan más controles, registros y acciones que quedan en manos del Estado y de ciertos sectores privados (asociaciones que nuclean a los grandes colectivos agropecuarios y excluyen a los representantes de asociaciones o cooperativas indígenas o campesinas). Como dice Perelmuter (en Prieto, 2014): "Todo lo que no está registrado es ilegal. Y eso ilegaliza gran parte de as semillas que forman parte de nuestra diversidad agrícola. $Y$ también ilegaliza a gran parte de nuestros productores, sobre todo campesinos e indígenas".

Finalmente, Argentina está avanzando en la legislación nacional en relación con el acceso a recursos genéticos, conocimientos tradicionales asociados a su uso y la distribución de beneficios derivados de su utilización ("ABS" de access and benefit-sharing), producto de la implementación del Convenio sobre la Diversidad Biológica (CDB), del cual Argentina es parte y del Protocolo de Nagoya (PN), del cual es signatario y pronto será parte. Ambos instrumentos promueven que el acceso a los recursos genéticos se produzca solo cuando medie el consentimiento fundamentado previo del país proveedor (Artículo 15.5 CDB y 6.1 PN,) y una distribución justa y equitativa de beneficios con este (Artículo 15.4 CDB y 5.1 PN), la cual se materializa mediante un acuerdo. Asimismo, disponen que el acceso al conocimiento tradicional asociado a la utilización de recursos genéticos que se encuentra en posesión de comunidades indígenas y/o locales se realice con la aprobación de estas y con su participación en los beneficios que pudieran derivarse (Artículo 8 j CDB y 5.5 y 7 PN). Argentina aún no concreta estos lineamientos (Silvestri, 2015)

\section{Conclusiones}

Argentina se autoproclama como el gran reservorio de alimentos para el mundo durante los próximos años a través de la agricultura industrial en las amplias llanuras centrales. Sin embargo, esta agricultura, de carácter industrial y a gran escala, está hoy destinada a la exportación en muchos casos, con fines diferentes a la alimentación humana. Por el contrario, los huertos chacras de las distintas regiones del país forman parte de uno de los eslabones principales de la vida de las comunidades locales, brindándoles autosuficiencia alimentaria a pesar de que ocupan una situación marginal desde lo económico, y periférica desde lo geográfico. La agricultura familiar se destaca por superar condiciones muy exigentes de cultivo debido a las condiciones extremas en términos climáticos de algunas regiones como la Patagonia, la Puna y otras regiones periféricas a la Pampa. Se destaca por el predominio del trabajo manual sobre e trabajo mecanizado, la preponderancia del policultivo (incluyendo variedades subespecíficas) sobre el monocultivo, y la menor o nula utilización de plaguicidas y herbicidas comerciales. En consideración de esta importancia de la agricultura familiar, desde diversos sectores públicos se promueve y protege dicha actividad con investigaciones interesadas en su caracterización y leyes tendientes a garantizar su viabilidad y asegurar beneficios a los productores familiares, mediante registro y regularización de su quehacer. El mismo fin tendría la regulación del intercambio de recursos genéticos con el exterior y el establecimiento de diversos proyectos de investigación referidos a cultivos típicos de distintas zonas del país. A pesar de lo dicho, y como consecuencia del significado económico que tiene la agricultura industrial para la economía del país, se promueve una ley de semillas que garantiza máximas ganancias a los obtentores de nuevas variedades a escala de laboratorio y a través de manipulación genética.

Desde nuestra perspectiva interdisciplinaria, consideramos indispensable reflexionar en torno a estas contradicciones con el fin de encontrar soluciones propias de cada región ancladas en el desarrollo sustentable, es decir, económicamente viable, ambientalmente compatible y social y culturalmente aceptable. Por ejemplo, tanto para Patagonia como para las Yungas, hay evidencias que apoyan que la conservación de la trashumancia fomenta mayor diversidad de cultivos y/o del uso de recursos silvestres alimenticios para sus poblaciones locales, hecho que pone en consideración la importancia de preservar aquellas prácticas locales de uso del ambiente que propician una mayor autosuficiencia y diversidad alimentaria. Por otra parte, la incentivación de la práctica de conservación de semillas para el cultivo en el próximo año constituye un eje fundamental para la conservación in situ de las variedades locales. De cualquier forma, es necesario realizar mayores estudios en cada una de las regiones con investigaciones que incluyan la participación de los agricultores familiares de modo de poner en perspectiva cómo son los caminos y avatares de la gran diversidad de recursos alimentarios producidos en nuestro país, y lograr una mayor visibilización del papel crucial de los mismos en la gestión de la agrodiversidad.

\section{Post Scriptum}

Este trabajo fue escrito en el año 2015, hoy, a inicios del 2017 la situación a nivel nacional ha cambiado tras las últimas elecciones presidenciales. Este cambio implicó una renovación 
completa del gabinete y cartera de ministros a nivel presidencial con una sola excepción: el ministro de Ciencia, Técnica e Innovación productiva. Esta continuidad en la gestión del ministro Lino Barañao llevó a considerar que era posible una plena factibilidad del plan Argentina Innovadora 2020 a pesar del cambio de gobierno. Sin embargo, al día de hoy, el ministro ya ha incumplido aspectos claves del plan. A lo anterior se suma el hecho de que el actual presidente Mauricio Macri posee una declarada política abierta a las exportaciones y a favorecer impositivamente a los sectores que nuclean a los grandes productores agropecuarios, a lo cual se suma el achicamiento en personal e infraestructura de la Secretaría de Agricultura Familiar dependiente del ex Ministerio de Agricultura, Ganadería y Pesca, hoy denominado Ministerio de Agroindustria. El panorama actual es, a lo sumo, incierto en muchos aspectos vinculados a la investigación en Argentina, y ciertamente poco favorable para los productores familiares.

\section{Bibliografía}

Albeck, M. A., 1994. Taller de Costa a Selva. Producción e Bartolomé, L. J., 1982. Colonias y colonizadores en Misiones Intercambio entre los pueblos agroalfareros de los Andes Instituto de Investigación de la Facultad de Humanidades Tilcara. Jujuy. Argentina.

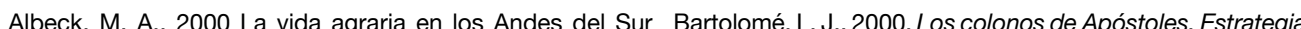
Ek, M. A., 2000 La vida agraria en los Andes del Sur Bartolomé, L. J., 2000. Los colonos de Apóstoles. Estrategias En: Tarragó, M. (Ed.). Nueva Historia Argentina T. 1 Los
pueblos originarios y la conquista. Ed. Sudamericana, Buenos Aires: pp. 187-228.

Arzeno, M. y H. Castro, 1998. Agricultura y modernización en la Quebrada de Humanuaca. Jornadas de Estudios Agrarios "Horacio Giberti", Instituto de Geografía-Grupo Agrarios
de Estudic
UBA.

Arzeno, M. y C. A. Troncoso. 2012. Alimentos tradicionales andinos, turismo y lugar: definiendo la nueva geografia de la Quebrada de Humahuaca (Argentina). Revista Geográfica Norte Grande, 52: 71-90 (en línea, disponible en: http://dx

Aschero, C., 1984. El sitio ICC-4: un asentamiento preceramico en la Quebrada de Inca Cueva (Jujuy,

Barsky, O. y J. Gelman. 2001. Historia del agro argentino. Mondadori. Buenos Aires.

Bartolomé, M. A, 1978 La situación de los Guaraní (Mby'a de Misiones (Argentina). En: Roa Bastos, A. (Ed.).
Culturas Condenadas. Siglo XXI, México: 86-112.
Belasteguí, H. M. 2004. Los colonos de Misiones. Universidad Nacional de Misiones, Posadas.

Bonicatto, M. M., M. E. Marasas, S. Sarandon y M. L. Pochettino, 2015. Seed Conservation by Family Farmers Argentina: The Dynamics of an Ancient Practice. Agroecology and Sustainable Food Systems, 39: 6 , 65.2015.1020405)

onomo, M., F. J. Aceituno, G. G. Politis y M. L. Pochettino, 2011. Pre-Hispanic horticulture in the Paraná Delta (Argentina): archaeological and historical evidence. World

rown, A. D.; H. R. Grau, L. R. Malizia y A. Grau, 2001. Los Bosques Nublados de Argentina En: Kappelle, M. Y A. D. Brown (Eds.). Bosques nublados de / neotrópico. Editori

Brücher, H. 1989. Useful plants of Neotropical origin: and their wild relatives. Springer, Berlin.

Bugallo, L., L. Mamani y L. Paredes, 2014. Moliendas y producción de harinas para autoconsumo en las 625-646 (en linea, disponible en DOI: 10.1080/21683 economías domésticas quebraderas durante el Cruzate, G. A. y R. R Casas, 2012. Extracción y balance siglo XX. En: Sánchez Patsy, R. y L. Cometta (Eds.). Investigaciones del Instituto Interdisciplinario Tilcara. Colección Saberes. Facultad de Filosofia y Letras, Universidad de Buenos Aires, Buenos Aires.

Cadogan, L., 1960. En torno a la aculturación de los MbyaGuaraní del Guairá. América Indígena, 22 (2): 133-150. Capparelli, A., V. Lema, M. Giovannetti y R. Raffino, 2005.
Introduction of European crops (wheat, barley and peach) in Andean Argentina during the 16th century: archaeobotanical and ethnohistorical evidence.

Capparelli, A. y V. Lema, 2011. Recognition of post-harvest processing of algarrobo (Prosopis spp.) as food from two experimental approach for desiccated macroremains. Journal of Anthropological and Archaeological Sciences 3 (1):71-92.

Cariola, L., A. E. Izquierdo y N. I. Hilgert. 2013. Efectos de las plantaciones forestales en los sistemas productivos familiares: evaluación de la configuración del paisaje productivo y de la concepción local de bienestar a escala
de paisaje y de predio. Actas extendidas IV Congreso de paisaje y de predio. Actas extendidas IV Congreso
Forestal Argentino y Latinoamericano. Puerto Iguazú, Misiones.

Casa Rosada, Presidencia de la Nación, 2013. Acto de lanzamiento del plan Argentina Innovadora 2020. (en linea, disponible en http://Www.casarosada.gob.ar/ del-plan-argentina-innovadora-2020-palabras-dela-presidenta-de-la-nacion).Compañía de Jesús. 1609-1614. Cartas Anuas de la provincia de Paraguay, Chile y Tucumán, de la Companía de Jesús. Instituto de Investigaciones Históricas (Facultad de Filosofía y Letras, UBA): Documentos p

Chase Sardi, M., 1971. La situación actual de los indígenas

de Pa

Chifarelli, D., 2010a. Acumulación, éxodo y expansión Misinalsis sobre la agricullura familar yr

Chifarelli, D., 2010b. El modelo de monocultivos de coníferas a gran escala. Análisis de sustentabilidad en el Alto Paran y Ambiente. Miradas y conflictos. Flacso, Buenos Aires.

Conti, V., 1989. Una periferia del espacio mercantil andino: norte argentino en el siglo XIX Avances de Investigación: Antropología e Historia, UNSa, Salta.

Crivos, M., M. R. Martínez, M. L. Pochettino, C. Remorini, C. Saenz y A. Sy, 2004. Nature and domestic life in the Valle del Cuñapirú (Misiones, Argentina): Reflections on Mbyá-Guaraní ethnoecology. Agriculture and Human Values, 21: 111-125.

Crivos, M., M. R. Martínez y M. L. Pochettino, 2005. La narrativa acerca del paisaje y del cambio ambiental entre los pobladores del área rural del municipio de Aristobulo del Valle (Misiones, Argentina). Actas Congreso Argentino International Plant Nutrition Institute, 6: 7-14.

ustred, G., 1977. Los Punas de los Andes Centrales. En de Estudios Peruanos -I.E.P.- Lima: 55- 85.

. horticultural knowledge change in a rural population of the Patagonian steppe. Journal of Arid Environments, 75: 78-86.

Eyssartier, C., A. H. Ladio y M. Lozada, 2011b. Horticultura ind gathering practices complement each other: a case Ecology of Food and Nutrition, 50: 429-451.

Eyssartier, C., A. H. Ladio y M. Lozada, 2013. Traditiona horticultural and gathering practices in two semi-rura populations of Northwestern Patagonia: resilience an 18-25.

Fabron, G., 2014. Producción agrícola tradicional en las nacientes de la quebrada de Humahuaca (Dpto. de Humahuaca, Jujuy, Argentina). Zaranda ideas, 11: 29-46 (en línea, disponible en <http://www.scielo.

rero, B. G., 2005. Estudio de la gestión territorial y de los recursos naturales, de la población rural del - Argentina-. Buscando alternativas pera un desaborrollo local sustentable en torno a una Reserva de Biosfera. Programa de Postgrado en Antropología Social, Facultad de Humanidades y Ciencias Sociales, Universidad

Fradkin, R. O., 2000. El mundo rural colonial. En: Tandeter, E. (Ed.). Nueva Historia Argentina. La sociedad colonial.
Tomo 2. Ed. Sudamericana, Buenos Aires: pp. $241-284$. . Economia de Misiones. Editoria Universitaria, Universidad Nacional de Misiones,

Furlan, V., N. I. Hilgert y M. L. Pochettino., 2013. Caracterización de las unidades productivas en Puerto Iguazú, Misiones Argentina. Espacios productivos, manejo y etnoespecies ulinadas. GT 77. Etnoecologí interdisciplinares de las antropologicas y perspectivas ambiente. CD de trabajos de la X RAM Córdoba.

Galindo-Leal, C. y I. Gusmão Câmara (Eds.), 2003. The Atlantic Forest of South America: biodiversity status, threats and outlook. Island Press, Washington.

Garavaglia, J. C. 1983. Mercado interno y economía colonial. Grijalbo, México.

García Moritán, M. y B. Ventura, 2007. Caracterización sociohistórica. En: Brown, A., M. García Moritán, B. Ventura, N.I. Hilgert y L. Malizia (Ed.). Finca San Andrés pp. 67-82. Flores Ochoa, J. (Ed.). Pastores de Puna; Uywamichie org. ar/scielo.php?script=sci_arttext\&pid=S1853 Nacional de Misiones. Posadas. Alto Bermejo. Ediciones del Subtrópico, Tucumán 
Gianni, C. 2010. La excepción del agricultor en el Derecho Karasik, G., 1984. Intercambio tradicional en la Puna Jujeña. Argentino En: Distintas facetas de las variedades vegetales. Propiedad intelectual, biotecnología agropecuaria, recursos genéticos, comercio de semillas. Tomo I: La propiedad intelectual de las variedades vegetales. El derecho de obtentor. Ed Ministerio de
Agricultura, Ganadería y Pesca de la Nación; INASE.
Buenos Aires.

Gil, A. 2005. Arqueología de La Payunia (Mendoza, Argentina) El poblamiento humano en los márgenes de la agricultura. BAR International Series.

Giovannetti, M y V Lema, 2005 Los cultivos europeos y la vida aborigen bajo dominio español: apropiación y consumo de trigo en La Rioja de fines del siglo XVI.
Actas del VI Congreso internacional de Etnohistoria. Simposio: Sociedad, población y economía. CD Room.

Hilgert, N. I., 1998. Las plantas vinculadas con el ámbito doméstico y la subsistencia de los campesinos de cuenca del río Zenta, Dpto. Orán, Prov. Salta. Tesis Doctoral. Facultad de Ciencias Físicas, Exactas y

Hilgert, N. I., 1999. Las plantas comestibles en una zona de las Yungas meridionales (Argentina). Anales del Jardín

Hilgert, N. I., 2007a. La vinculación del hombre actual con los recursos naturales y el uso de la tierra En: Brown, A., M Finca San Andrés. Un espacio de cambios ambiental. y sociales en el Alto Bermejo. Ediciones del Subtrópico, Tucumán: pp. 159-186.

Hilgert, N. l., 2007b. Plantas silvestres, ámbito doméstico y subsistencia. En: Brown, A., M. García Moritán; B.
Ventura, N. I. Hilgert y L. Malizia (Eds.). Finca San Andrés. Un espacio de cambios ambientales y sociales en el Alto Bermejo. Ediciones del Subtrópico, Tucumán: pp. $187-228$

Hilgert, N. I. y G. E. Gil, 2005. Traditional Andean agriculture and changing processes in the Zenta river basin, Salta,
Northwestern Argentine. Darwiniana, 43 (1-4): 30-43.

Hilgert N. I., F. Zamudio, V. Furlan y L. Cariola, 2013. The key role of cultural preservation in maize diversity conservation in the Argentine Yungas. Evidence-Based ID 732760 (en línea, disponible en: http://dx.doi. org/10.1155/2013/732760).

INDEC, 2002. Censo Nacional Agropecuario. (en línea, disponible en: http://www.minagri.gob.ar/site/ agricultura/analisis_economico/02-CNA_2002).

Izquierdo, A. E., C. D. De Angelo y T. M. Aide, 2008. Thirty years of human demography and land-use change in the Allantic Forest of Misiones, Argentina: an evaluation o
the forest transition model. Ecology and Society, 13(2): 3 . (En línea, disponible en: http://www.ecologyandsociety. org/vol13/iss2/art3/)

Izquierdo, A. E., H. R. Grau y T. M. Aide, 2010. Implication of rural-urban migration for conservation of the Atlantic Forest and urban growh in $M$. Runa, 14: $51-91$.

asik, G., 1994. Pequeños productores agropecuarios de Tilcara y desarrollo local. Proyecto SECTER/D 15.2 Facultad de Humanidades y Ciencias Sociales, Univ. Nac. de Jujuy, San Salvador de Jujuy.

Keller, H. A., 2008. Etnobotánica de comunidades guaranies de misiones, argentina; valoración de la vegetación como fuente de recursos. Tesis presentada para optar al grado de Doctor de la Universidad Nacional del Nordeste.

Korstanje, A., M. Quesada, V. Franco Salvi, V. Lema y M.
Maloverti, 2015. Gente, tierra, agua y cultivos: Ios Maloverti, 2015. Gente, tierra, agua y cultivos: los En: Korstanje, A., M. Lazzari, M. Basile, F. Bugliani, Lema, L. Pereyra Domingorena y M. Quesada (Eds.) Crónicas materiales precolombinas. Arqueologia de los primeros poblados del Noroeste Argentino, Sociedad Argentina de Antropología, Buenos Aires, Argentina pp. $721-749$

Ladio, A. H., 2011. Underexploited wild plant foods of NorthWestern Patagonia. En: Filip, R. (Ed.). Multidisciplinary Approaches on Food Science and Nutrition for the XX dio, A. H., 2013. Mapuche resilience and human adaptation to arid Uplands in NW Patagonia, Argentina (Chapter Cultural Adaptation to Mountain Environments, Studies in Human Ecology and Adaptation. Springer Science. New York: pp. 259-273.

Ladio, A. H. y M. Lozada, 2004. Summer cattle transhumance and edible wild plant gathering in a Mapuche community
of NW Patagonia. Human Ecology, 32 (2): 225-240.

Ladio, A. H. y M. Lozada, 2009. Human ecology, ethnobotany and traditional practices in a rural population of the Monte region, Argentina: resilience and ecological knowledge. Journal of Arid Environments, 73 (2): 222-227.

alio, A. H. y S. Molares, 2014. El paisaje patagónico y su gente. Capitulo 9. En. Raffaele, E., M de Torres Curth,
C. Morales y T. Kistzberger (Eds.). Ecología e Historia
Natural de la Patagonia. Vázquez-Mazzini. Argentina: Natural de la
pp. 205-223.

Ladio, A. H., S. Molares, J. Ochoa y B. Cardoso, 2013 tnobotánica aplicada en Patagonia: Ia comercialización de malezas de uso comestible y medicinal en un Argentina). Boletín Latinoamericano y del Caribe de Plant Medicinales y Aromáticas, 12 (1): 24-37.

ambaré, D. A., 2015. Procesos locales de selección cultural en poblaciones frutales de la familia Rosaceae originarias del Viejo Mundo utilizados por comunidades rurales de Naturales y Museo, Tesis Doctoral Inédita.

Lema, V., 2006. Huertos de altura: el manejo humano de especies vegetales en la puna argentina. Revista de
Antropología, XII: 173-186. Universidad Nacional de Antropo
Rosario.
Lema, V., 2014a Boceto para un esquema: domesticación y agricultura temprana en el Noroeste argentino. Revista

Lema, V., 2014b. Criar y ser criados por las plantas y sus espacios en los Andes Septentrionales de Argentina, En: Benedetti, A. y J. Tomasi. (Comps.) Espacialidades
altoandinas. Nuevos aportes desde la Argentina. Tomo I: Miradas hacia lo local, lo comunitario y lo doméstico. de Buenos Aires. Buenos Aires. Pp: 301-338.

Llano, C., 2011. Aprovechamiento de recursos vegetales entre las sociedades cazadoras recolectoras del su Comahue, San Carlos de Bariloche.

Mafferra, L., 2009. Interpretaciones del registro arqueobotánico en arqueología histórica. En: Ramos, M., A. Tapia, F.
Bognanni, M. Fernández, V. Helfer, C. Landa, M. Lanza, E. Montanari, E. Néspolo y V. Pineau (Eds.). Temas y problemas de la Arqueología Histórica. Programa de Arqueologia Histórica y Estudios Pluridisciplinario (PRiversided . Departamento de Clencias Sociales.

Mandrini, R. J., 1987. La agricultura indígena en la región pampeana y sus adyacencias (siglos XVIII- XIX). Anuario
parion pampeana y sus adyacencise
del IEHS Tandil, 1: $11-43$.

Manzi, G. A. 2000. Industrial development missions. A critical perspective to the discussion with a view to territoria

Márquez Miranda, F., 1941. La arqueología del este de la Quebrada de Humahuaca (frontera argentino-boliviana) del 27 Congreso Internacional de Arqueología, 1939, 1:211- 237. Lima.

Martínez Crovetto, R., 1968. Notas sobre la agricultura de los indios guaraníes de Misiones (República Argentina). Actas y Memorias 37 Con
Americanistas, Buenos Aires.

Martínez, M. R., M. L. Pochettino y A. R. Cortella, 2000. Unidad doméstica y medicina: recursos vegetales empleados en la terapia de diferentes enfermedades por los pobladores de Molinos (Salta, Noroeste de Argentina). En: Guerci, A. (Ed.). Etnofarmacolc

Martinez, M. R., M. L. Pochettino y P. M. Arenas. 2003. La horticultura: estrategia de subsistencia en contextos pluriculturales,

Martínez Sarasola, C., 1992. Nuestros paisanos los indios. Emecé, Buenos Aires.

Mastrángelo A. y V. Trpin (Comp.), 2011. Entre chacras y que Argentina exporta. CICCUS, Buenos Aires.

Mayo, C. (Comp.)., 1994. La historia agraria del interior Haciendas jesuíticas de Córdoba y el Noroeste. Centro Editor de América Latina, Buenos Aires.

Mendonça, O., M. Bordach y M. Grosso, 2003. Ocupación Estudio comparado de dos cementerios: $\mathrm{RCH} 21$
(Catamarca) y SJ TIL 43 (Jujuy). Cuadernos FHYCSUNJu 20: 221-237.

(en línea, gob.ar).

ares, S. y A. H. Ladio, 2012. Mapuche perceptions and conservation of Andean Nothofagus forests and their medicinal plants: A case study from a rural communit in Patagonia, Argentina. Blodiversity and Conservation 21 (4): 1079-1093 (en línea, disponible en: DOl: 10.1007/

zi, E., 2013. Atlas Población y Agricultura familiar en la Region Pa A acuzzi, L. R., y C. B. Pérez de Micou, 1985. Los recursos vegetales de los cazadores de la cuenca del Río Chubut. Cuadernos

ñez Regueiro, V. A. y M. R. A. Tartusi, 1990. Aproximación estudio del área Pedemontana de Sudamérica. $125-160$

Ortiz, G., C. Heit, L. Nieva, F. Zamora, N. Batallanos y F. Chapur, 2015: Pensando al Formativo desde la región pedemontana de las yungas de Jujuy. En: Korstanje, Pereyra Domingorena y M. Quesada (Eds.). Crónicas materiales precolombinas. Arqueología de los primeros poblados del Noroeste Argentino, Sociedad Argentin co07. La dinámica en la horticultura comunidades mbya-guaraní, Misiones, Argentina.
contino, M. L., 2007. La dinámica en la horticultura en Etnobiología, 5: 36-50.

Pochettino, M. L., 2015. Botánica económica. Las plantas interpretadas según tiempo, espacio y cultura. Corrientes, Sociedad Argentina de Botánica.

Prieto, F., 2014. Argentina, Venezuela, Monsanto y la soberanía alimentaria (III). Notas periodismo popular. argentina-venezuela-monsanto-soberania-alimentariaii/.)

Prividera, G. y N. López Castro (Comps.), 2010. Repensar la agricultura familiar. Aportes para desentrañar la Quesada, M. y C. Lema. 2012. Lo potreros de Antofagasta. Trabajo indígena y propiedad (Finales del siglo XVIII y comienzos del XIX). Andes. Antropología e Historia, 22: 247-273.

Raffaele, E., M. de Torres Curth, C. Morales y T. Kistzberger, 2014. Ecología e historia natur

Raffino, R., R. Alvis, D. Olivera y J. Palma, 1986. La instalación Inka en la Sección Andina Meridional de Bolivia y extrem boreal de Argentina. Comechingonia, 4: 63-131.

Ramos, R. S., N. I. Hilgert y D. A. Lambaré. 2013. Agricultura Tradicional y Riqueza de maices (Zea mays L.). Estudio de Caso en Caspalá, provincia de Jujuy, Argentina. $607-621$. 
Reboratti, C., 1995. Apropiación y uso de la tierra en las Seijo, G., G. I. Lavia, A. Fernández, A. Krapovickas, D.A. Yungas del Alto Bermejo. En: Brown, A. D. y H. R. Grau Ducasse, D. Bertioli y E. A. Moscone, 2007. Genomic (Eds.). Investigación, conservación y desarrollo en las relationships between the cultivated peanut (Arachis Selvas Subtropicales de Montaña. LIEY/GTZ, Tucumán:
pp. 199-204.

Reboratti, C., 1996. Sociedad, ambiente y desarrollo regional de la Alta Cuenca del Río Bermejo. Instituto de Geografía, Facultad de Filosofía y Letras, Universidad de Buenos
Aires, Buenos Aires.

Reboratti. C., M. Arzeno y H. Castro, 2003. Desarrollo sustentable y estructura agraria en la Quebrada

Reis, M. S. A. H. Lalio N N. Perci, 2014. Landscapesw Araucaria in South America: Evidence for a Cultural
Drat Araucaria in South America: Evidence for a Cultura
Dimension. Ecology and Society, 19 (2):43. (En línea, disponible en: http://www.ecologyandsociety.org/vol19/ iss2/art43/).

by double GISH. American Journal of Botany, 94 (12):

ENASA, 2012. Base de datos stock ovino nacional. Servicio Nacional de Sanidady Calidad Agroalimentaria. Sistema Gestión y Programas Especiales, Buenos Aires.

Serrano, A., 1934. El uso del tabaco y vegetales narcotizantes entre los indígenas de América. Revista Geografí
Americana, 74.2 (15): 415-430.

Sivestri, L. C., 2015. La conservación de la diversidad genética argentina: tres desafíos para implementar el régimen de
acceso a los recursos genéticos y la distribución de los beneficios. Ecología Austral, 25:273-278.

Richeri, M., M.B. Cardoso y A.H. Ladio. 2013. Soluciones Slutzky, D., 2011. Estructura social agraria y agroindustrial $\begin{array}{ll}\text { locales y flexibilidad en el conocimiento ecológico del nordeste de la argentina: desde la incorporación a la } \\ \text { tradicional frente a procesos de cambio ambiental: } & \text { economía nacional al actual subdesarrollo concentrador }\end{array}$ estudios de caso en Patagonia. Ecología Austral, 23:184-193 y excluyente. Instituto Argentino para el Desarrollo Económico, Buenos Aires.

Rodríguez Faraldo, M. y H. O. Zilocchi, 2012. Historia del Teruel, A., 2005. Estructuras agrarias comparadas: la Puna cultivo del tabaco en Salta. Ministerio de Agricultura, argentina y el sur boliviano a comienzos del siglo XX
Ganadería y Pesca, Buenos Aires.

Rutledge, l., 1987. Cambio Agrario e Integración. El desarrollo del Capitalismo en Jujuy: 1550-1960. ECIRA-CICSO-

Sánchez, S. y G. Sica, 1994. Entre la Quebrada y los Valles. Intercambio y Producción, siglos XVI y XVIII. En: Albeck, M.A. (Ed.). Taller de Costa a Selva. Producción Centro Sur. Instituto Interdisciplinario Tilcara, Tilcara, Jujuy, pp. 133-151. www.mundoagrario.unlp.edu.arn.

Tommasini, G., 1933. Los indios Ocloyas y sus doctrineros en el siglo XVII. Imprenta de la Universidad, Publicación

rerara, M. A., 1934. Orígenes de Jujuy, 1535-1600. Librerí del Colegio, Buenos Aires.

Zardini, E. M. y M. L. Pochettino, 1983. Resutados de rpa, G. F. y P. Arenas, 1996. Especias y colorantes en $483-514$.

Schiavoni, G., 1995. Colonos y ocupantes: parentesco, reciprocidad y diferenciación social en la frontera viaje etnobónicico al Norte de Salta (Argentina). IDIA. viaje etnobotánico al Norte 1 S
Argentina, 417-420: 108-121.

\section{Manejo y domesticación de plantas en Mesoamérica}

Una estrategia de investigación y estado del conocimiento sobre los recursos genéticos

Alejandro Casas, Fabiola Parra-Rondinel, Xitlali Aguirre-Dugua, Selene Rangel-Landa, José Blancas, Mariana Vallejo, Ana Isabel Moreno-Calles, Susana Guillén, Ignacio Torres-García, América Delgado-Lemus, Edgar Pérez-Negrón,

Carmen Julia Figueredo, Jeniffer M. Cruse-Sanders, Berenice Farfán-Heredia, Leonor Solís, Adriana Otero-Arnaiz, Hernán Alvarado-Sizzo, Andrés Camou-Guerre-

\section{Resumen}

Mesoamérica es una región de alta diversidad biocultural y una de las áreas reconocidas como centro de origen de la domesticación y la agricultura. Aunque ha sido una zona cultural que ha cambiado a lo largo del tiempo, en general, se reconoce que su territorio cubrió la mitad meridional de México y hasta el noroeste de Costa Rica. Los contactos e intercambios de elementos materiales y culturales -incluyendo tanto plantas silvestres, como animales domesticados entre las grandes regiones del Nuevo Mundo-se han demostrado a través de diversos estudios arqueológicos. Ello anima a considerar que las fronteras territoriales de las áreas culturales de Nuevo Mundo fueron sumamente porosas, y que una visión dinámica de intercambios entre regiones es más adecuada para visualizar las influencias mutuas entre las grandes culturas del continente en tiempos preclásicos y clásicos, y aun entre las comunidades aldeanas desde tiempos precerámicos. La presencia temprana del maíz en la región Andina, así como la presencia del cacao, la mandioca, el cacahuate y otros cultivos sudamericanos en Mesoamérica sugieren una antigua interacción entre regiones. Parece más pertinente visualizar el territorio continental como una compleja red de interacciones culturales y ecológicas marcadamente influenciadas por interrelaciones sociales. Tal apertura en el pensamiento arqueológico e histórico permitirá entender de manera dinámica los procesos de domesticación, origen y difusión de la agricultura, así como la construcción de las civilizaciones del continente americano que hoy en día nos maravillan. Nuestro grupo de investigación ha vuelto a estudiar regiones de México, con diferentes grupos culturales originarios y mestizos sobre: 1) los grupos de plantas preferentemente incorporados por las culturas regionales a sus formas de subsistencia; 2) los factores que impulsan a las sociedades humanas a practicar el manejo; 3) la diversidad de prácticas de manejo que se llevan a cabo y aquellas que involucran procesos de domesticación; 4) por qué se motiva la domesticación; 5) las tendencias generales y particulares morfofisiológicas, 
reproductivas y genéticas que pueden expresar los procesos de domesticación; 6) los procesos de domesticación de ecosistemas y paisajes, y su influencia sobre la domesticación de especies en particular, y 7) cómo influyen las diferentes fuerzas evolutivas (selección, deriva génica, flujo génico, endogamia) en la domesticación, y qué tanto estas fuerzas son dirigidas intencionalmente o por procesos naturales. Para estudiar el manejo articulamos tres grandes dimensiones de investigación, una de ellas incluye estudios de la sociedad, la cultura y la economía de los grupos humanos que practican el manejo analizado, incluyendo la etnoecología los estudios de gobernanza y la economía ecológica. Desde la ecología se analizan procesos a diferentes escalas: la distribución, abundancia y diversidad de los recursos. También las interacciones en las comunidades bióticas, principalmente la polinización, la dispersión de semillas, la facilitación mediante plantas nodrizas y la competencia. Se analizan la composición y el funcionamiento de los ecosistemas naturales y artificiales, entre otros aspectos. Se examina cómo todas estas características influyen sobre las decisiones que toman los seres humanos para detonar procesos de manejo y cómo determinan criterios para llevarlos a cabo. La tercera dimensión de investigación son los procesos evolutivos asociados a la domesticación. El manejo determina ajustes en las formas, las funciones y comportamientos de los organismos de acuerdo con las necesidades humanas primarias, valores, costumbres, gustos y preferencias moldeadas por la cultura. Estos ajustes-en las poblaciones manejadas comúnmente determinan características divergentes con respecto a los individuos que componen las poblaciones silvestres o sin manejo. Ambos procesos son expresiones de la domesticación. A nivel de especie, la morfometría, la genética, la fisiología y la biología reproductiva comparada entre poblaciones silvestres y cultivadas permiten entender los procesos que guían la domesticación sus consecuencias y tendencias evolutivas. La reunión de estudios sobre la estructura filogeográfica de algunas especies domesticadas, particularmente aquellas que tienen distribución a escala continental, podrá arrojar mayor luz sobre la porosidad de las regiones culturales, los intercambios materiales y culturales, y la difusión de la experiencia de manejar y domesticar recursos en el continente americano.

Se estima la existencia de entre 10000 y 12000 especies con algún tipo de uso, y alrededor de 4000 especies bajo alguna forma de manejo. Se ha analizado el riesgo y otros factores culturales como detonadores de manejo. Uno de los efectos más importantes del manejo es la domesticación. En este proceso los seres humanos modifican las formas y funciones de los organismos para satisfacer sus necesidades principalmente mediante selección artificial. Además de la selección directa, influyen otras fuerzas evolutivas como el flujo génico, la deriva génica y la endogamia. Los mecanismos y criterios con los que opera la domesticación están profundamente ligados a la cultura, por eso la domesticación es un problema de investigación eminentemente biocultural. Se han estudiado los procesos de domesticación en hierbas comestibles, árboles como los "guajes" (Leucaena esculenta), y Sideroxylon palmeri, y Ceiba aesculifolia. El sistema que se ha estudiado con mayor detalle es el de cactáceas columnares, que permite visualizar un gradiente de intensidad de manejo en función del tipo de propagación, selección artificial y velocidad de crecimiento. Las diferencias en la biología de estas especies y en las distintas prácticas permiten visualizar gradientes de intensidad de manejo las que están sometidas y permiten comprender el efecto variable de la domesticación en tal contexto variable del manejo. Se ha hipotetizado que a mayor intensidad de manejo los proce- sos de domesticación y divergencia son más notorios. Lo anterior permite analizar el grado de selección artificial con base en diferentes atributos, la diversificación morfológica, los montos de la diversidad genética de las poblaciones silvestres y manejadas, así como los cambios en los sistemas de reproducción y germinación. Hemos impulsado métodos de estudio para documentar procesos de domesticación en el presente para descifrar lo que ocurrió en el pasado. Las investigaciones del presente no solo contribuirán a mejores interpretaciones de los hallazgos arqueológicos, sino a entender los procesos activos del manejo y la domesticación que operan en el presente. Su aporte teórico es tan relevante, así como su aporte práctico, al desarrollo de estrategias de manejo sustentable de recursos genéticos.

Palabras clave: domesticación, ethnobotany, evolutionary ecology, manejo de recursos genéticos, Mesoamérica, Mexico

\section{Introducción}

Mesoamérica es una región de alta diversidad biocultural (Maffi, 2005; Toledo y Barrera-Bassols, 2008; Boege, 2008) que se expresa de manera relevante en los sistemas de manejo y domesticación de paisajes, plantas, animales y microorganismos. Los estudiosos de la domesticación de plantas consistentemente han reconocido que Mesoamérica es una de las áreas más antiguas y dinámicas en el manejo y domesticación de plantas, y en la diversificación de sistemas agrícolas del continente americano (Vavilov, 1992; Harlan, 1975; Hawkes, 1983; Smith, 2006) Mesoamérica originalmente fue definida por Paul Kirchoff (Kirchoff, 1943) como una región cultural con aspectos peculiares. De acuerdo con Kirchoff (1943), Matos-Moctezuma (1994) y otros autores, en Mesoamérica es posible identificar rasgos culturales distintivos de asentamientos, alimentación y cultura con respecto a las regiones áridas y montañosas del norte de México y sur de Estados Unidos de América, denominadas Aridoamérica, así como con respecto a las regiones amazónica y andina en Sudamérica. Kirchoff (Kirchoff, 1943) propuso más de cuarenta elementos culturales que distinguen Mesoamérica de otras regiones, entre ellos destacan, por ejemplo, el consumo de tortillas de maíz como eje principal de la alimentación, elaboradas a partir del proceso de nixtamalización, que involucra la cocción de maíz con cal, la elaboración de masa a partir de la molienda del grano cocido en metates o molinos de piedra y su cocción fina en planchas de barro denominadas comales. También son considerados como propios de $\mathrm{Me}-$ soamérica el pulque -bebida alcohólica elaborada a partir de la savia fermentada de agaves- $y$ el juego de pelota, que con frecuencia ha sido encontrado en las construcciones precolombinas de Mesoamérica del que, ciertamente, no hay una versión similar en otras regiones del Nuevo Mundo. Igualmente se incluyen otros diversos instrumentos y alimentos. Con el tiempo, algunos de los elementos planteados por Kirchoff (Kirchoff, 1943) se han confirmado y otros han sido refutados, pues investigaciones arqueológicas y antropológicas posteriores a su trabajo las han identificado arraigadas desde la antigüedad en otras regiones del continente.

Matos-Moctezuma (1994) planteó que la región mesoamericana comprendió aproximadamente desde la mitad meridional de México hasta la porción noroccidental del actual territorio de Costa Rica. Sin embargo, reconoce que fue una región bastante dinámica, cuyas fronteras variaron en el curso de la historia. Los contactos e intercambios de elementos materiales y cul- 
turales -incluyendo plantas y animales, tanto silvestres como domesticados entre las grandes regiones del Nuevo Mundo- se han demostrado con diversos estudios arqueológicos (MacNeish, 1992; Piperno y Pearsall, 1993). Ello anima a considerar que las fronteras territoriales de las áreas culturales del Nuevo Mundo fueron sumamente porosas y que una visión dinámica de intercambios entre regiones es, quizá, más adecuada para visualizar no solo las influencias mutuas entre las grandes culturas del continente en tiempos preclásicos y clásicos (1500 a C - 900 d. C), sino aun entre las comunidades aldeanas desde tiempos precerámicos (López Austin y López Luján, 2002). La presencia temprana del maíz en la región Andina (Piperno y Pearsall, 1993), así como la presencia del cacao, la mandioca, el cacahuate y otros cultivos sudamericanos en Mesoamérica sugieren una antigua interacción entre regiones. Parece más pertinente visualizar el territorio continental como una compleja red de interacciones culturales y ecológicas marcadamente influenciadas por interrelaciones sociales. La arqueología, las fuentes históricas, la antropología, la ecología, la biogeografía y la filogeografía han ido esclareciendo parte de esta historia biocultural y seguirán contribuyendo a comprenderla; desde que inició con las primeras acciones de manejo de recursos biológicos hasta su estado actual, conforme avancen sus investigaciones.

La apertura en el pensamiento arqueológico e histórico permitirá entender de manera dinámica los procesos de domesticación, origen y difusión de la agricultura, así como las construcciones de las civilizaciones del continente americano que hoy en día nos maravillan. Con tal consideración en mente, se pasará a examinar los procesos de manejo y domesticación de plantas que se han documentado en el pasado y que ocurren en el presente en la región mesoamericana.

Las culturas de Mesoamérica desarrollaron técnicas de manejo de recursos bióticos y de ecosistemas que condujeron a la domesticación de plantas y a la agricultura hace aproximadamente 9000 y 10000 años (MacNeish, 1967, 1992; Benz, 2006). Diversas prácticas como la recolección, el intercambio o el manejo pueden reconstruirse con base en información arqueológica. Afortunadamente, muchas de estas prácticas siguen vigentes, por lo que sus detalles pueden documentarse con otros enfoques, principalmente de la etnobiología, la economía ecológica, la ecología evolutiva, la filogeografía, entre los más importantes. No obstante es preciso reconocer que los contextos y motivaciones actuales son muy distintos a los del pasado, y aunque es posible estudiarlos y usarlos como bases empíricas para entender las motivaciones que en el pasado pudieron impulsar el surgimiento de la agricultura, la diferencia de contextos es de gran relevancia en la interpretación (Blancas et al., 2009).

Actualmente se reconoce que las experiencias de domesticación y agricultura de Mesoamérica son de las más antiguas que se han registrado en el continente americano (MacNeish 1967, 1992). Aunque las prácticas tradicionales de manejo forestal y agrícola hoy en día están influenciadas por casi quinientos años de cultura y técnicas de manejo introducidas desde el Viejo Mundo, así como por más de medio siglo de tecnologías de agricultura moderna, aún existe una alta diversidad de conocimientos y técnicas tradicionales de manejo desarrollados por los pueblos indígenas del país (Moreno-Calles et al. 2013, 2016a, 2016b; Vallejo-Ramos et al., 2105, 2016). Nuestro grupo de investigación ha realizado estudios en varias regiones de México, con diferentes grupos culturales originarios y mestizos, analizando diversos grupos de plantas. El propósito de tales investigaciones multidimensionales es identificar patrones generales sobre: 1) los grupos de plantas preferentemente incorporados por las culturas regionales a sus formas de subsistencia; 2 ) los factores que impulsan a las sociedades humanas practicar el manejo; 3) la diversidad de prácticas de manejo que se llevan a cabo y aquellas que involucran procesos de domesticación; 4) por qué se motiva la domesticación; 5) las tendencias generales y particulares morfofisiológicas, reproductivas y genéticas que pueden expresar los procesos de domesticación; 6) los procesos de domesticación de ecosistemas y paisajes, y su influencia sobre la domesticación de especies en particular, y 7) cómo influyen las diferentes fuerzas evolutivas (selección, deriva génica, flujo génico, endogamia) en la domesticación y qué tanto estas fuerzas son dirigidas intencionalmente o por procesos naturales.

Para abordar estas preguntas, nuestro grupo ha combinado enfoques de investigación etnobiológicos, ecológicos y evolutivos. Tratamos de documentar la diversidad de formas de manejo y de los procesos de domesticación de plantas. Entender qué factores socioecológicos influyen en la motivación de manejar recursos -la inventiva, la innovación, la transmisión de experiencias y la adopción de las técnicas desarrolladas- entre individuos y entre grupos humanos. Especialmente, nos interesa entender por qué y cómo operan estos mecanismos. Asimismo, las investigaciones tienen como finalidad entender las consecuencias sociales, ecológicas y evolutivas de las prácticas de manejo. Se considera que estas preguntas son relevantes para analizar cómo y por qué se originó la agricultura. Pero al mismo tiempo su estudio aporta información útil para entender y apoyar los procesos activos de innovación tecnológica y su difusión. Esta última es una meta que, en términos prácticos, aspira a contribuir al desarrollo de estrategias de manejo sustentable de recursos genéticos con base en la experiencia local y que puede complementar la investigación científica.

Durante el siglo XX, numerosas investigaciones arqueológicas, etnográficas, biogeográficas, genéticas, ecológicas y evolutivas -en gran medida articuladas por marcos conceptuales etnobiológicos- generaron información clave para contestar preguntas acerca de dónde, cuándo cómo y por qué se originó la agricultura. Para dilucidar el dónde, fueron de particular trascendencia los estudios de De Candolle (1882) y de Vavilov (1992) quienes, desde perspectivas botánicas, antropológicas, lingüísticas, ecológicas y genéticas, sugirieron las regiones del mundo de las que podrían haber provenido los principales cultivos que sustentan la alimentación, y otras materias primas del mundo moderno. Las regiones propuestas por estos autores conformaron valiosas hipótesis que condujeron a grupos de arqueólogos a buscar evidencias que permitieran confirmar las áreas del mundo donde la agricultura y el pastoralismo se desarrollaron más tempranamente. Sin embargo, el descubrimiento de más sitios arqueológicos y el mejoramiento de las técnicas de fechamiento basadas en isótopos radiactivos continuaron su desarrollo durante el siglo XX, motivando una intensa discusión sobre dónde y cuándo iniciaron los procesos en cuestión. A la propuesta de centros de origen de Vavilov siguieron las de Harlan (1975) y las de Bruce Smith (Smith, 2006), entre las más sobresalientes. No obstante, las respuestas al cómo y sobre todo, al porqué del surgimiento de la domesticación y la agricultura siguen siendo altamente controvertidas, pues la evidencia es escasa. Entre las principales propuestas destaca la de Gordon Childe (Childe, 1956), quien propuso la idea de Revolución Neolítica, un salto tecnológico en un tiempo relativamente corto, en principio asociado a cambios ambientales. Posteriormente, Flannery (1986), Harris y Hillman (1989) (1996) propusieron modelos más complejos que involucraron una combinación de cambios ecológicos, crecimiento demográfico e innovación tecnoló- 
gica para determinar un cambio progresivo en la tecnología de producir recursos.

Nuestro grupo de investigación parte de considerar que, puesto que los procesos de manejo y domesticación son vigentes, su estudio y comprensión en el contexto actual, a partir de diversas herramientas metodológicas pueden aportar elementos más detallados sobre los procesos causales que permiten entender lo que ocurrió en el pasado. Algunas técnicas moleculares, por ejemplo, están aportando valiosa información acerca del dónde y cuándo se originaron y difundieron las especies domesticadas, complementando significativamente los estudios arqueológicos y los fechamientos con isótopos radiactivos. El estudio sobre el origen y la difusión de estos recursos ha encontrado en la filogeografía una herramienta de gran valor. Esta disciplina permite analizar las relaciones de parentesco y la distribución espacial de linajes de genes, lo que lleva a corroborar aquellas áreas en donde se iniciaron y difundieron las experiencias de manejar y domesticar los recursos. En particular, este enfoque plantea nuevas preguntas e hipótesis más detalladas sobre las ideas de los "centros" y los "no centros" propuestos por Vavilov (1992) y por Harlan (1975), respectivamente, acerca del origen de los taxa y de su domesticación. Ha sido de alta relevancia la articulación de enfoques etnobiológicos, ecológicos y evolutivos, pues aportan valiosa información para analizar respuestas a cómo y por qué operan en el presente los procesos de manejo y domesticación. Con esta información es posible apoyar explicaciones más robustas sobre los procesos que pudieron ocurrir en el pasado.

La búsqueda de respuestas a estas preguntas posee un alto valor teórico para entender cómo y por qué se originó la agricultura, así como los contextos que moldearon el surgimiento del modelo civilizatorio mesoamericano. De manera notoria, el entendimiento de estos procesos permite ampliar nuestro conocimiento sobre la experiencia técnica, y la conformación del legado biocultural de las culturas originarias para entender y apoyar los procesos activos de innovación tecnológica, así como su difusión. Esta última es una meta que, en términos prácticos, aspira a contribuir al desarrollo de estrategias de manejo sustentable de recursos bióticos y ecosistemas o paisajes, con base en la experiencia local y el complemento de la investigación científica, cuyos alcances hoy en día son valiosos no solo para México, sino para todo el mundo.

El grupo de investigación que conformamos ha realizado estudios en más de cuarenta comunidades campesinas mixtecas, nahuas, mazatecas, cuicatecas, popolocas, ixcatecas, purhépechas, mazahuas, mayas, teenek, rarámuri y mestizas en distintas regiones de México (Figura 3.1, véase Casas et al., 1994; 2001, 2007, 2014; Farfán et al., 2007; Pérez-Negrón y Casas, 2007; Camou et al., 2008; Lira et al., 2009; Blancas et al., 2010, 2013). Estos estudios han desarrollado diversas estrategias y métodos de investigación que buscan caracterizar patrones de las culturas mesoamericanas para manejar y domesticar plantas. Estos patrones poseen rasgos particulares y generales, y, eventualmente, permitirán analizar los patrones que se comparten con otras regiones del continente americano. De manera particular, hemos impulsado colaboraciones siguiendo estrategias metodológicas similares con colegas que estudian el manejo de recursos genéticos en la región andina (Velásquez-Milla et al., 2011). Con ellos se han realizado cerca de treinta proyectos de investigación asociados al curso "Domesticación y Manejo in situ de Recursos Genéticos" que se ha llevado a cabo por diez años conjuntamente por la Universidad Nacional Autónoma de México y la Universidad Nacional Agraria La Molina de Perú. También se han iniciado colaboraciones y publicaciones conjuntas con colegas del

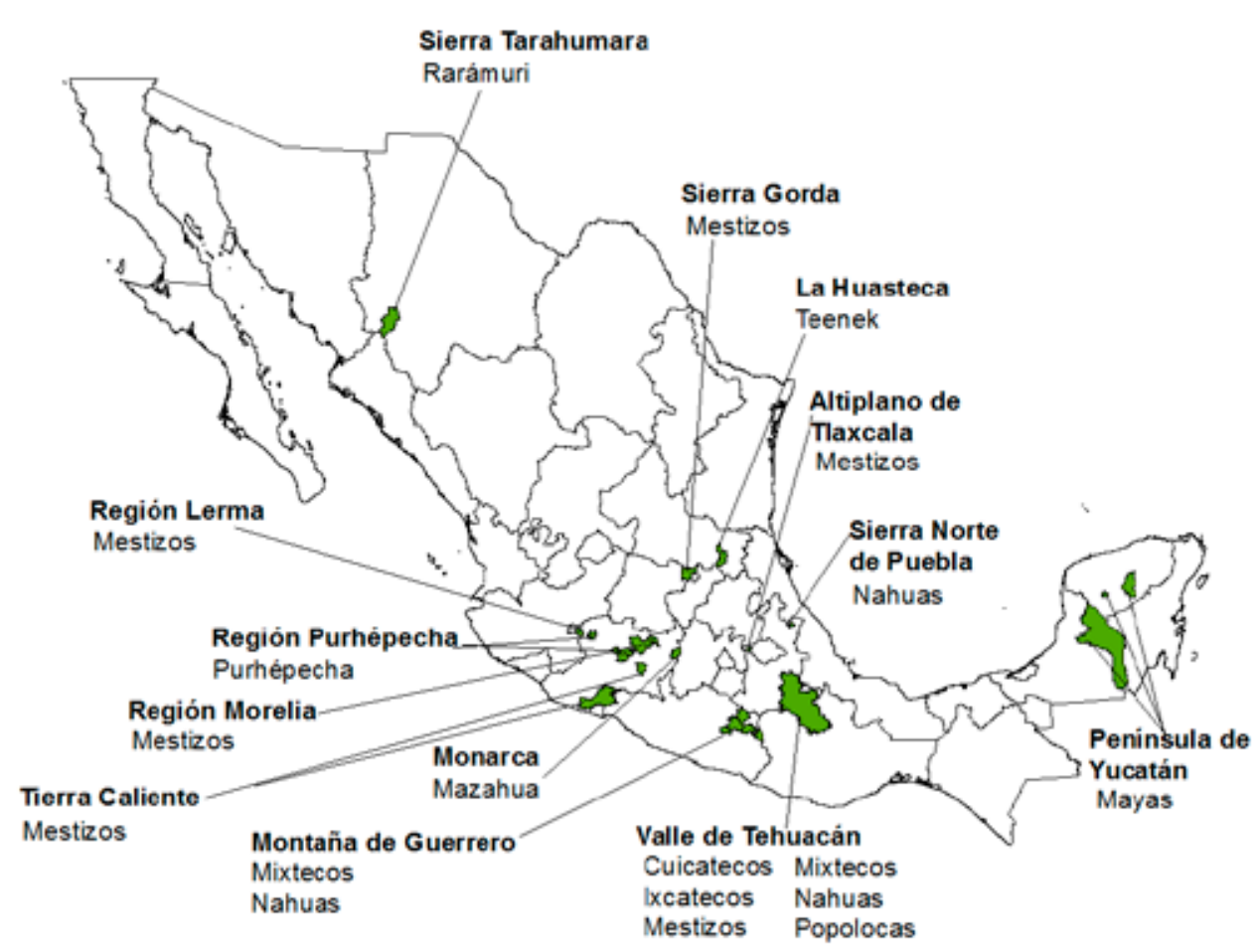

Figura 3.1. Regiones en donde se encuentran las cerca de cuarenta comunidades rurales estudiadas por nuestro grupo de investigación. Se han anotado los grupos étnicos a los que pertenecen las comunidades.

nordeste brasileño, principalmente de las universidades de Pernambuco (Albuquerque et al 2008, 2015; Lins-Neto et al., 2014) y Paraíba (Lucena et al., 2014). Próximamente se iniciarán colaboraciones con investigadores peruanos y brasileños que trabajan sobre el manejo de recursos vegetales amazónicos. Asimismo, se tiene proyectado establecer colaboraciones con investigadores que estudian el manejo de plantas en el noreste de Estados Unidos de América el noroeste de Perú y suroeste de Ecuador, regiones que han sido propuestas por diversos autores como áreas activas de domesticación e innovación agrícola temprana.

\section{Estrategia de investigación}

El tema central de nuestras investigaciones es el manejo, pues este es una expresión crucia de las interacciones entre las sociedades y la naturaleza. A través del manejo, las sociedades obtienen sus satisfactores materiales, y al hacerlo generan consecuencias sobre los ecosistemas, sus componentes y procesos. Por ello, el estudio del manejo ofrece la oportunidad de entender, de una manera profunda y dinámica, las interrelaciones entre sistemas sociales naturales. Se entiende por manejo las intervenciones intencionales (que obedecen a propósi- 
tos determinados) sobre los sistemas naturales y artificiales, sobre sus elementos (los recursos naturales) o, inclusive, sobre procesos que ocurren en los sistemas (algunos procesos o funciones de los ecosistemas son reconocidos como servicios ecosistémicos). Cabe mencionar que hay cambios accidentales o circunstanciales que determinan cambios en los sistemas sin mediar un propósito, pero estos no deben considerarse propiamente como manejo, sino como consecuencias incidentales de este. El manejo puede involucrar aprovechamiento (apropiación y uso), conservación (mantenimiento) o restauración (recuperación) de recursos, procesos y/o sistemas (Casas et al., 2007, 2014; Blancas et al., 2010, 2013).

Para estudiar el manejo se articulan tres grandes dimensiones de investigación; una de ellas incluye estudios de la sociedad, la cultura y la economía de los grupos humanos que practican el manejo analizado. La etnoecología (Toledo, 2002; Toledo y Barrera-Bassols, 2008) permite analizar de forma integral la articulación de los saberes y visiones del mundo que poseen los grupos sociales con sus prácticas de manejo (Figura 3.2). Por su parte, los estudios de gobernanza permiten analizar cómo se construyen las instituciones, los acuerdos colectivos y las regulaciones de acceso a los recursos (Ostrom, 1990). La existencia de regulaciones frecuentemente permite identificar los recursos que los grupos sociales consideran prioritarios $y$ al mismo tiempo, expresan estrategias y planes que por sí mismos deben considerarse aspectos del manejo. La economía ecológica es una herramienta teórico-metodológica que permite analizar los patrones de subsistencia, el papel del intercambio de los recursos - en particular, contribuye a identificar la jerarquía de valores sobre los recursos- (Martínez-Alier, 2005), y reconocer cómo el valor y el intercambio incentivan el desarrollo de estrategias diferenciales para manejar los recursos y los ecosistemas de los que forman parte.

Una segunda dimensión de nuestras investigaciones es la ecología, analizando procesos ecológicos a diferentes escalas. Estudiamos la distribución, la abundancia y la diversidad de los recursos a través de muestreos de vegetación a distintas escalas espaciales. También se estudian las interacciones en las comunidades bióticas, principalmente la polinización, la dispersión de semillas, la facilitación mediante plantas nodrizas y la competencia. Se analizan la composición y el funcionamiento de los ecosistemas naturales y artificiales (principalmente sistemas agroforestales), entre otros aspectos. Nos interesa especialmente examinar cómo todas estas características influyen sobre las decisiones que toman los seres humanos para detonar procesos de manejo y cómo determinan criterios para llevarlos a cabo. De la lectura del párrafo anterior puede entenderse que estos aspectos ecológicos son relevantes en relación con los aspectos sociales, económicos y culturales referidos. A su vez, nos interesa e análisis de las consecuencias del manejo sobre la sobrevivencia y reproducción de los individuos manejados, sobre la estructura y dinámica de sus poblaciones, sobre la composición e interacciones en comunidades bióticas, y sobre las funciones ecosistémicas (Figura 3.2).

Se busca, entonces, entender cómo influyen los procesos ecológicos en las formas de manejar los recursos, y viceversa (Blancas et al., 2013). Mediante estos estudios se trata de probar la hipótesis de que la disponibilidad espacial de los recursos de mayor valor cultural es una motivación principal (mas no la única) del manejo. Su escasez y/o la incertidumbre en su disponibilidad son aspectos relevantes. Desde esta perspectiva, son importantes indicadores de la motivación del manejo aspectos biológicos de los recursos, tales como la forma de vida

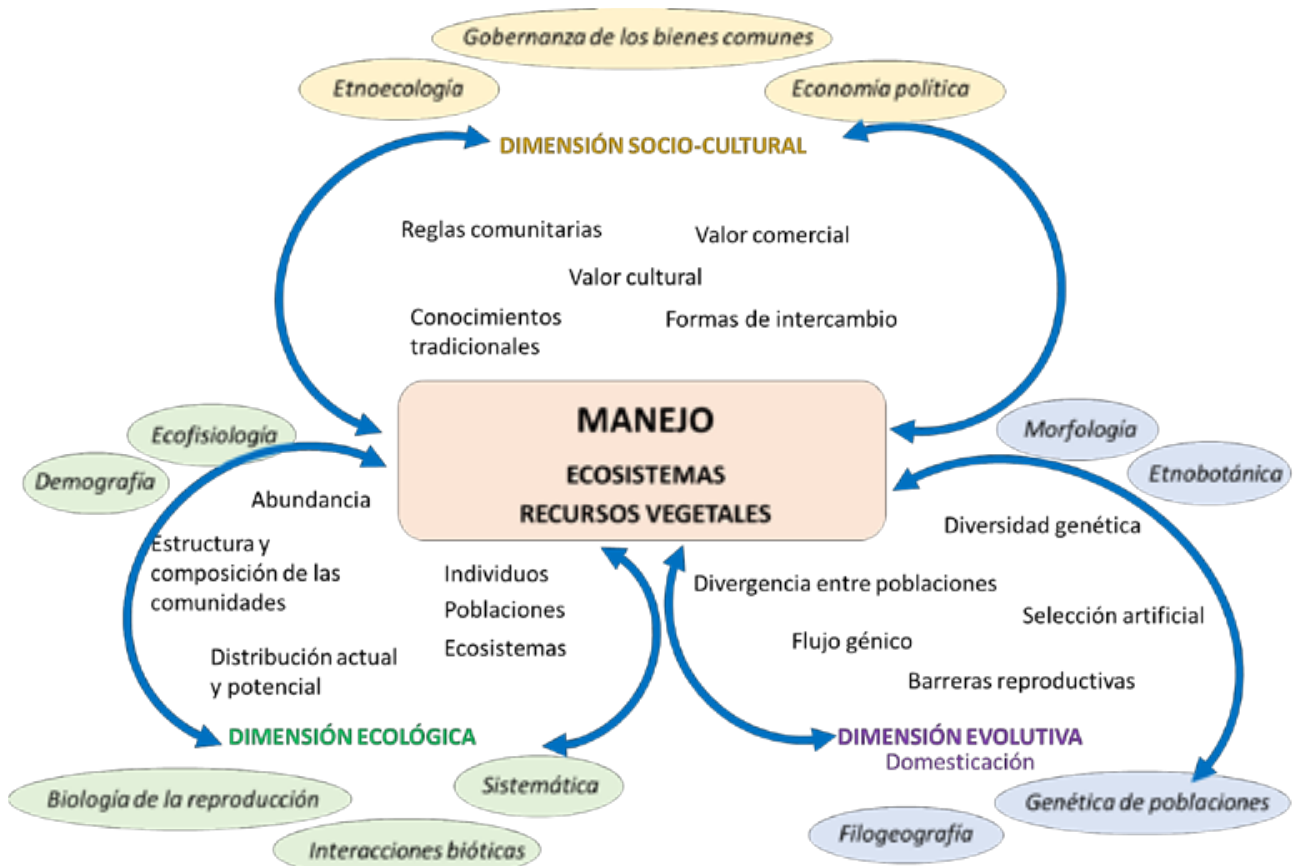

Figura 3.2. Estrategia general de la investigación que lleva a cabo nuestro grupo de trabajo. EI objetivo general es entender los procesos que influyen y son influidos por el manejo de recursos vegetales y de ecosistemas, utilizando marcos conceptuales y herramientas provenientes de distintas disciplinas, según las distintas dimensiones analizadas: sociocultural, ecológica y evolutiva. Desde la perspectiva social, se examina el papel de la cultura, la organización social y procesos económicos en las estrategias de manejo. Desde la perspectiva ecológica, se busca entender los factores ecológicos que detonan respuestas de manejo y, asimismo, establecer bases para el manejo sustentable de recursos y ecosistemas. Desde la perspectiva evolutiva, se trata de entender cómo el manejo determina procesos de domesticación a escala poblacional y cómo se articulan estos con los que ocurren a escala de paisajes.

y la duración de su ciclo de vida, la parte aprovechada y la capacidad de los individuos para reponerse de la cosecha, el sistema de reproducción y la forma en que la afecta el manejo, entre otros. Asimismo, es relevante determinar el balance entre la escasez de un recurso y la intensidad de su aprovechamiento por un grupo humano. Este balance depende de la distribución y abundancia del recurso, así como del valor de uso y de cambio que posee, de la factibilidad de almacenarlo o de sustituirlo por otro recurso, entre otros factores. El análisis de estos procesos también es útil para establecer las bases para el aprovechamiento sustentable tanto de recursos como de ecosistemas. De esta forma, un problema teórico contribuye a construir una perspectiva aplicada de los estudios. Entender cómo los procesos ecológicos incentivan y han incentivado los procesos de innovación tecnológica está aportando importantes respuestas para afrontar problemas de pérdida de recursos y degradación de ecosistemas. Constituye una estrategia para documentar las técnicas de manejo que ya existen para atender un problema, así como el proceso para impulsar su innovación.

La tercera dimensión de investigación que aborda nuestro grupo son los procesos evo- 
lutivos asociados al manejo: la domesticación. El manejo determina ajustes en las formas, las funciones y comportamientos de los organismos de acuerdo con las necesidades humanas primarias, valores, costumbres, gustos y preferencias moldeadas por la cultura. Estos ajustes en las poblaciones manejadas comúnmente determinan características divergentes con respecto a los individuos que componen las poblaciones silvestres o sin manejo. De manera similar, el manejo determina ajustes en la composición, fisonomía y funciones de los sistemas y transforma los ecosistemas naturales en artificiales. Ambos procesos, a nive de especie y de ecosistema, son expresiones de la domesticación. A nivel de especie, la morfometría, la genética, la fisiología y la biología reproductiva comparada entre poblaciones silvestres y cultivadas nos permiten entender los procesos que guían la domesticación sus consecuencias y tendencias evolutivas en la escala de las poblaciones. Entre estas consecuencias está la reunión de distintos linajes en las poblaciones y su dispersión artificial entre poblaciones, modificando la estructura filogeográfica natural de las especies bajo domesticación. La reunión de estudios de caso sobre la estructura filogeográfica de algunas especies domesticadas - particularmente aquellas que tienen distribución a escala continental- podrá, por lo tanto, arrojar mayor luz sobre la porosidad de las regiones culturales, los intercambios materiales y culturales, y la difusión de la experiencia de manejar y domesticar recursos en el continente americano.

A nivel de ecosistema, nos hemos enfocado en analizar cómo se moldean la composición disposición espacial y regulación de funciones sistémicas a distintas escalas (desde la parcela hasta el paisaje) con base en la presencia e interacción de componentes tanto bióticos como abióticos. El marco conceptual de esta aproximación es el manejo de ecosistemas (Grumbine, 1994, 1997), que permite apreciar de manera holística no solo recursos en particular, sino estos y su contexto integral. Nuestro grupo tiene particular interés en entender cómo se llevan a cabo los procesos de domesticación a escala de ecosistemas, paisajes y territorios (Casas et al., 1997; Terrell et al., 2003; Parra et al., 2012), y, con especial énfasis, cómo se articulan los procesos de domesticación a escala poblacional con los que ocurren a escala de paisaje y viceversa.

\section{La diversidad biocultural de Mesoamérica}

México posee una diversidad biocultural excepcional. En sus dos millones de $\mathrm{km}^{2}$ de extensió existe una alta variedad de ecosistemas naturales que representan prácticamente todos los diferentes tipos de biomas registrados en el planeta (Toledo y Ordóñez, 1993; Rzedowski, 1993). Asimismo, existe una extraordinaria riqueza de paisajes modelados por miles de años de manejo por las sociedades que han habitado el territorio (Moreno Calles et al., 2010; Blancas et al., 2010, 2013; Larios et al., 2013; Vallejo et al., 2014). Aloja, además, una elevada diversidad biológica que comprende más de 25000 especies vegetales (Toledo y Ordóñez, 1993; Villaseñor, 2003), 1150 especies de aves (Navarro-Sigüenza et al.,2014) y más de 500 especies de mamíferos (Ceballos et al., 2002). Por si fuera poco, el territorio mexicano cuenta con una alta diversidad cultural: existen 58 grupos étnicos indígenas hablantes de cerca de 290 lenguas (Toledo et al., 2001, De Ávila, 2008, Lewis et al., 2015). La interacción de las sociedades tradicionales y la diversidad biológica de sus territorios (Casas et al., 2007; Blancas et al., 2010,
Tabla 3.1. Total de especies de plantas registradas en la flora de distintas regiones de México, así como el total y proporción que de tales floras son especies registradas con algún uso por los pueblos regionales.

\begin{tabular}{crrr} 
Región & Total spp. & Spp. últiles & $\%$ \\
Valle de Tehuacán & 2621 & 1608 & 61.2 \\
\hline Sierra de Manantlán & 2774 & 650 & 23.4 \\
\hline Selva Lacandona & 1660 & 415 & 24.9 \\
\hline Los Tuxtlas & 814 & 274 & 33.7 \\
\hline Tuxtepec & 737 & 296 & 40.2 \\
\hline Uxpanapa & 800 & 336 & 40.6 \\
\hline Península de Yucatán & 2900 & 1000 & 23.4 \\
\hline Sian Ka'an & 558 & 316 & 56.6 \\
\hline Montaña de Guerrero & 800 & 430 & 53.8 \\
\hline Sierra Huichola & 1652 & 532 & 32.2 \\
\hline MÉXICO & $\mathbf{3 0 ~ 0 0 0}$ & $\mathbf{1 1 7 0 0}$ & $\mathbf{3 9 . 0}$ \\
\hline & $\mathbf{2 5 0 0 0}$ & &
\end{tabular}

2013) han conformado por más de 10000 años de historia de presencia humana (MacNeish, 1992), un importante patrimonio biocultural (Boege, 2008)

En un recuento sobre la flora útil de México, Caballero et al. (1998) estimaron que en el país existen entre 5000 y 7000 especies de plantas que son utilizadas por las diversas culturas. Sin embargo, en los últimos años se han publicado inventarios etnobiológicos que permiten proponer que esa cifra es subestimada. Por ejemplo, tan solo en el Valle de Tehuacán-Cuicatlán Casas et al. (2001) y Lira et al. (2009) registraron un inventario de más de 1600 especies aprovechadas actualmente por las culturas regionales, constituyendo cerca del $54 \%$ de la flora regional. Un ejercicio similar en otras regiones permite calcular que, en promedio, $39 \%$ de las especies de las floras regionales registran algún uso (Tabla 3.1), lo que significa que de un total de 25000 (Villaseñor, 2003) a 30000 (Toledo y Ordóñez, 1993) especies de plantas vasculares existentes en el país, debería esperarse la existencia de entre 10000 y 12000 especies con algún tipo de uso.

Un análisis similar puede realizarse para estimar el inventario de especies manejadas y de formas de manejo de plantas. Estudios detallados en el Valle de Tehuacán indican que alrededor de 600 especies (cerca de $40 \%$ de las especies utilizadas) reciben alguna forma de manejo (Blancas et al., 2010). Desafortunadamente este es, por el momento, el único estudio disponible sobre la proporción de plantas utilizadas que son manejadas en territorios específicos. Llevada a escala nacional, esta cifra permitiría esperar alrededor de 4000 especies bajo alguna forma de manejo pero el cálculo es aún prematuro. Por ahora, el inventario más completo de plantas utilizadas y manejadas registradas en México, es la base de datos del Jardín Botánico de la UNAM. Caballero et al. (1998) identifican cerca de 1000 especies, Ashworth et al. (2009) identificaron más de 400 especies de plantas cultivadas comestibles; y si se considera el amplio inventario de plantas ornamentales y medicinales cultivadas, el universo puede ser significativamente más alto. Con base en esta información y en un inventario de plantas cultivadas a nivel nacional reelaborado por nuestro grupo de investigación, se calcula que hay en México al menos 500 especies de plantas cultivadas y domesticadas, de las cuales alrededor de 200 son especies nativas. Otras estimaciones basadas en el muestreo de BADEPLAM apoyadas con datos recientes, principalmente aquellos documentados en el Valle de Tehuacán-Cuicatlán, permiten las estimaciones que 


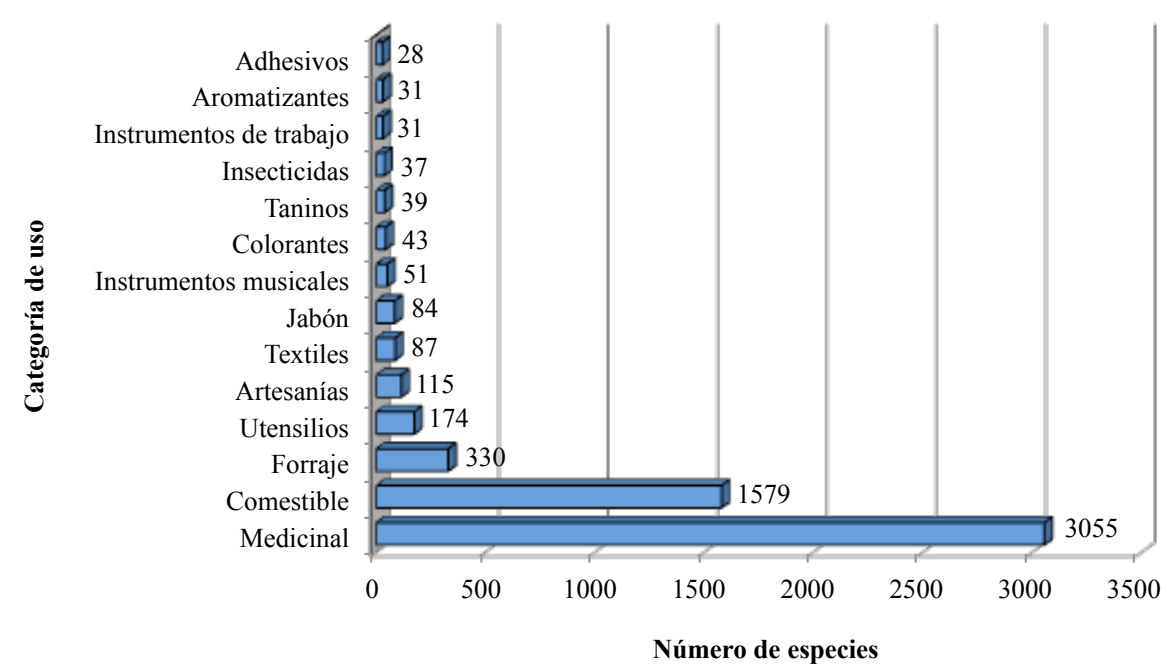

Figura 3.3. Número de especies de plantas utilizadas por las distintas culturas de México, con base en estimaciones realizadas por Caballero et al. (1998), la cual incluye información de la Base de Datos Etnobotánicos de México BADEPLAM del Jardín Botánico, Instituto de Ecología, UNAM. Esta información se actualizó con base en Casas et al. (2014) y con base en ambas fuentes se efectuaron los cálculos que se presentan. Aproximadamente el $70 \%$ de la información tiene ya un respaldo de ejemplares y registros en bases de datos.

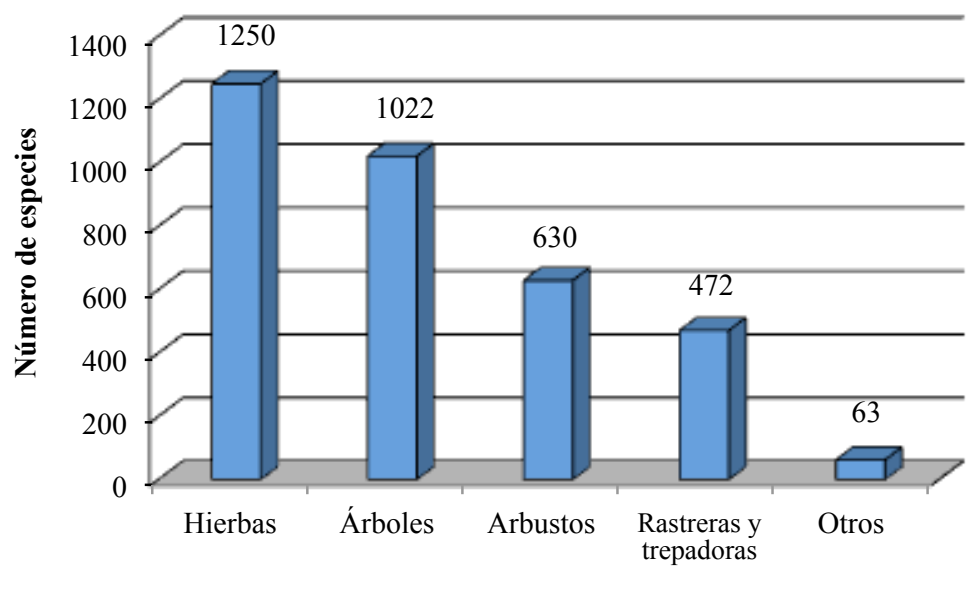

Forma de vida

Figura 3.4. Formas de vida de las especies de plantas utilizadas por las distintas culturas de México. La información se basa en estimaciones realizadas por Caballero et al. (1998) con una muestra de información de la Base de Datos Etnobotánicos de México BADEPLAM del Jardín Botánico, Instituto de Ecología UNAM. Esta información se actualizó con base en Casas et al, 2014 y con base en ambas fuentes se efectuaro accálcú paldo de ejemplares y registros en bases de datos.

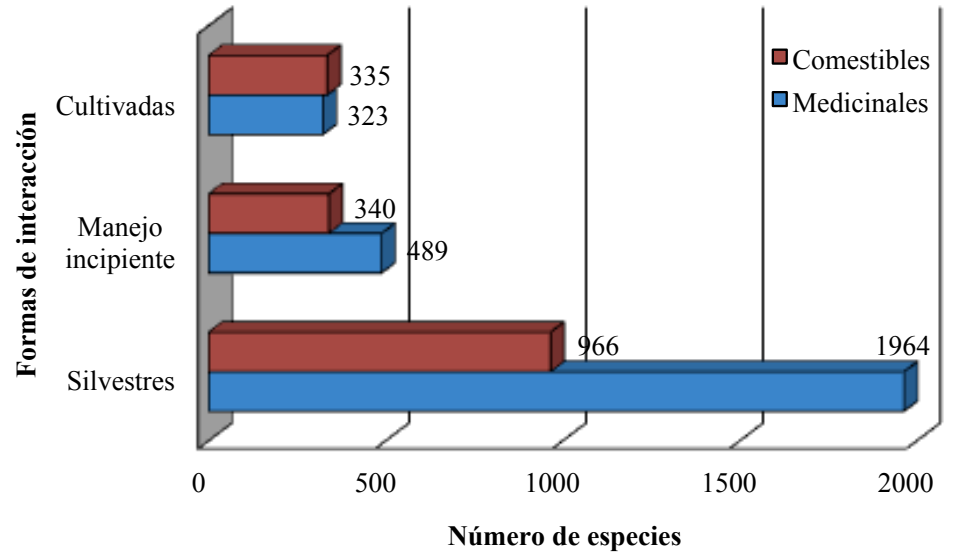

Figura 3.5. Número de especies medicinales y comestibles recolectadas de poblaciones silvestres, manejadas in silu o cultivadas. La información se basa en estimaciones reaizadas por Caballero et al. (1998) con una muestra de información de la Base de Datos Etnobotánicos de México BADEPLAM del Jardín Botánico, Instituto de Ecología, UNAM. Esta información se actualizo con base en Casas et al. (2014), y con base en ambas fuentes se efectuaron los cálculos que se presentan. Aproximadamente el $70 \%$ de la información tiene ya un respaldo de ejemplares y registros en bases de datos.

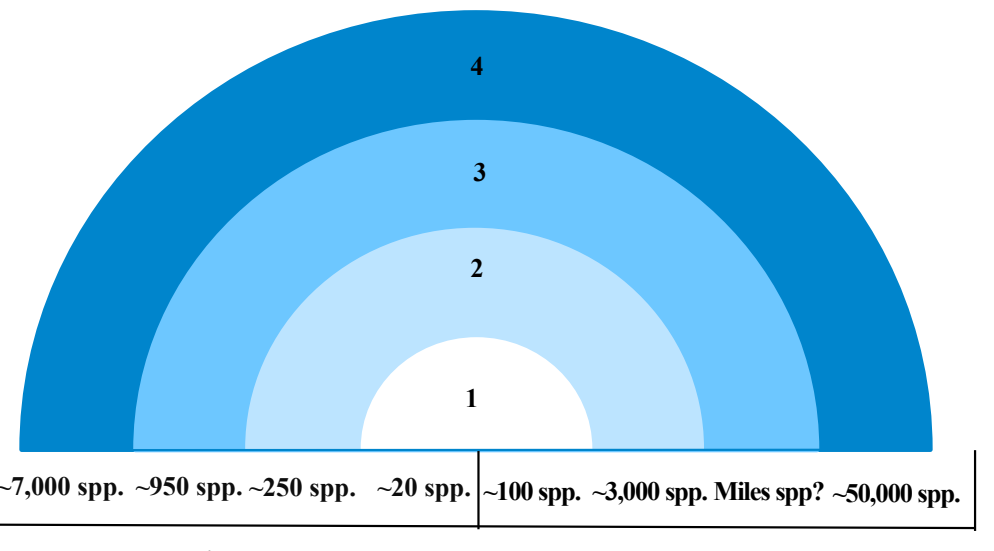

México

El mundo

Figura 3.6. Número de especies utilizadas por las culturas mexicanas, comparadas con aquellas que se han registrado a nivel mundial. Los círculos muestran una escala de importancia económica y cultural, así como aspectos de manejo. El círculo más pequeño, identificado con el número 1, representa el núcleo de especies domesticadas y cultivadas de mayor importancia económica en México (a la izquierda) y en el mundo (a la derecha). El círculo con el número 2 indica un conjunto de especies de plantas domesticadas que tienen importancia reiona 2 círculo con el número 3 indica aquellas plantas que presentan mane y domesticación incipiente, miestra que se obion presenta información actualizada que se basa en las publicadas por Casas y Parra (2007). 
se muestran en las figuras 3.3, 3.4 y 3.5, las cuales brindan un panorama de los grupos de recursos más importantes, sus formas de vida y la información registrada acerca de su manejo y a la cual se referirá adelante. La Figura 3.6 permite dimensionar el universo de recursos vegetales de México en distintos niveles de importancia económica y cultural, a diferentes escalas territoriales y compararlas con información con que se cuenta a nivel mundial.

El manejo tradicional de ecosistemas es la base fundamental para construir cualquier estrategia de conservación de la biodiversidad, entenderlo es, por lo tanto, altamente prioritario en cualquier agenda de conservación de la biodiversidad. Los sistemas de manejo tradiciona continuamente se renuevan, así que deben verse como procesos dinámicos y la investigación debe verse como un medio que puede brindar elementos para potenciar tal proceso.

\section{Diversidad de riesgos}

dentificar cuáles son los recursos de mayor importancia para los pobladores en distintas regiones -su consumo anual, la frecuencia de uso, las cantidades utilizadas y las preferencias, cuáles son consideradas sustituibles y cuáles no- es información clave para dimensionar e riesgo y el interés humano por asegurar su disponibilidad. Lo mismo aplica para plantas comestibles que para medicinales usadas en la atención de enfermedades específicas, así como para plantas forrajeras, ornamentales, y para aquellas con otros usos. Algunos ejemplos que

Tabla 3.2. Ejemplos de evaluaciones sobre las cantidades totales, frecuencia de consumo y preferencia de algunas especies de quelites, frutos comestibles y leña consumidas por unidades familiares de la comunidad mestiza de origen cuicateco y mazateco de Quiotepec, Oaxaca (para mayores detalles véase Pérez-Negrón y Casas, 2007), la comunidad cuicateca de San Lorenzo Pápalo, Oaxaca (mayores detalles en Solís-Rojas, 2006) y la comunidad tarahumara o raramuri de Cuiteco, Chihuahua (mayores de en Camou et al., 2008).

\begin{tabular}{cccc} 
Especies & $\begin{array}{c}\text { Consumo promedio anual } \\
\text { por familia (kg) }\end{array}$ & $\begin{array}{c}\text { Frecuencia de uso } \\
\text { (veces / temporada) }\end{array}$ & $\begin{array}{c}\text { índice de } \\
\text { mencióna }\end{array}$ \\
Santiago Quiotepec (mestizos) & & & \\
\hline Quelites & & 8.1 & 92.9 \\
\hline Quintonil Amaranthus hybridus & 3.0 & 5.3 & 89.3 \\
\hline Verdolaga Portulaca oleracea & 3.0 & 3.2 & 78.4 \\
\hline Quelite Chenopodium berlandieri & 2.3 & 2.4 & 63.4 \\
\hline Chipile Crotolaria pumila & 1.0 & 2.3 & 46.3 \\
\hline Yerba mora Solanum nigrum & 1.0 & & \\
\hline Frutos & & 12.3 & 93.5 \\
\hline Chonosle (Escontria chiotilla) & 2.1 & 13.1 & 90.5 \\
\hline Pitaya (Stenocereus pruinosus) & 2.0 & 11.7 & 90.1 \\
\hline Cardón (Pachycereus weberi) & 2.0 & & \\
\hline $\begin{array}{c}\text { San Lorenzo Pápalo, Oaxaca } \\
\text { (cuicatecos) }\end{array}$ & & & \\
\hline Quelites & & 13 & 93.3 \\
\hline Yerba mora Solanum nigrescens & 8.2 & 13 & 93.3 \\
\hline Quintonil Amaranthus hybridus & 10.8 & 14 & 90 \\
\hline Berro Roripa nastruntium.officinale & 16.96 & & \\
\hline & &
\end{tabular}

\begin{tabular}{|c|c|c|c|}
\hline $\begin{array}{r}\text { Papaloquelite Porophyllum ruderale } \\
\text { subsp macrocephallum }\end{array}$ & 2.74 & 31 & 73.3 \\
\hline Pepicha Porophyllum tagetoides & 0.41 & 2 & 63.3 \\
\hline Verdolaga Portulaca oleracea & 1.84 & 5 & 43.3 \\
\hline Quelite Chenopodium berlandieri & 2.3 & 3.2 & 78.4 \\
\hline \multicolumn{4}{|l|}{$\begin{array}{ll} & \text { Frutos }\end{array}$} \\
\hline Pitaya Stenocereus pruinosus & 65.5 & 8 & 87 \\
\hline \multicolumn{4}{|l|}{ Leña } \\
\hline Encino cucharo Quercus conzatii & 4436 & & 100 \\
\hline Encino blanco Quercus magnolifolia & 2594 & & 100 \\
\hline \multicolumn{4}{|l|}{ Cuiteco, Chihuahua (rarámuri) } \\
\hline \multicolumn{4}{|l|}{$\begin{array}{ll}\text { Quelites } \\
\end{array}$} \\
\hline Quelite mostaza Brassica campestris & 51.8 & 34.5 & 94.8 \\
\hline Wasorí Amaranthus hybridus & 31.0 & 41.3 & 79.3 \\
\hline Verdolaga Portulaca oleracea & 32.9 & 50.3 & 53.4 \\
\hline Chuyaca Chenopodium berlandieri & 11.5 & 15.0 & 27.6 \\
\hline \multicolumn{4}{|l|}{ Medicinales } \\
\hline Hierba de la víbora Zornia reticulata & 0.95 & 3.0 & $75.9^{\mathrm{b}}$ \\
\hline Chuchupate Ligusticum porteri & 3.78 & 3.3 & $22.4^{\mathrm{c}}$ \\
\hline Babiza Cosmos pringlei & 2.87 & 3.3 & $27.6^{\mathrm{d}}$ \\
\hline \multicolumn{4}{|l|}{ Leña $a^{e}$} \\
\hline U'turi Quercus crassifolia & 1207.0 & - & 30.3 \\
\hline Achíchuri Quercus viminea & 1402.0 & - & 24.2 \\
\hline Amawi Quercus coccolobifolia & 1023.0 & - & 15.2 \\
\hline Mapake Quercus arizonica & 597.8 & - & 15.2 \\
\hline Especies & $\begin{array}{l}\text { Consumo promedio anual } \\
\text { por familia (kg) }\end{array}$ & $\begin{array}{l}\text { Frecuencia de uso } \\
\text { (veces / temporada) }\end{array}$ & $\begin{array}{l}\text { Índice de } \\
\text { mención }{ }^{a}(\%)\end{array}$ \\
\hline
\end{tabular}

se han documentado en distintas regiones se muestran en la Tabla 3.2. Los estudios efectuados arrojan importante información sobre las especies bajo mayor presión humana, y tales indicadores junto con información ecológica brindan información útil para evaluar su vulnerabilidad natural y la asociada a actividades humanas.

La información sobre su escasez, distribución, tasas de recuperación ante el disturbio y las tasas de extracción, permite identificar qué recursos se encuentran en mayor riesgo de desaparecer en asociación con su aprovechamiento. Ejemplos de estos estudios pueden apreciarse en trabajos como los de Casas et al. (2008), Pérez-Negrón y Casas (2007), Farfán et al. (2007), Camou et al. (2008), Arellanes et al. (2013), Blancas et al. (2010, 2013) y Delgado-Lemus et al. (2014a), entre otros. En una muestra de once comunidades campesinas estudiadas en diferentes puntos de México (Valle de Tehuacán, Reserva de la Biosfera Mariposa Monarca, Montaña de Guerrero y Sierra Tarahumara), se encontró que en promedio $15 \% \pm 4$ de las especies registradas como utilizadas tiene un alto valor cultural y económico, por lo que sobresalen significativamente en comparación con el resto de las especies y están sujetas a las mayores tasas de extracción. En estos casos, las especies de ciclo de vida largo, las que se extraen por 
completo, las de distribución restringida y las escasas son las más vulnerables. En tales especies es de esperarse que los esfuerzos de manejo estén especialmente dirigidos a las especies más vulnerables y, en caso contrario, esas especies pueden llegar a extinguirse localmente.

Para analizar qué tanto la magnitud de la extracción de un recurso pone en riesgo su permanencia futura, es necesario analizar también la estructura y dinámica de sus poblaciones, as etapas del ciclo de vida que son críticos para su permanencia, qué interacciones con otras plantas y animales también lo son, qué partes de la planta se colectan y cuál es su efecto sobre la permanencia de las poblaciones. Se pueden identificar categorías de riesgo con base en indicadores de estas variables. Así, por ejemplo, una especie escasa y con extracción intensa está en mayor riesgo que especies con alta disponibilidad y baja extracción. Pero en los ecosistemas hay recursos bajo una gran variedad de condiciones de riesgo influenciadas por distintos factores naturales y sociales que afectan su adecuación. Por ejemplo, el riesgo es más alto si se extrae todo un individuo que si se extrae solo parte de este; es mayor el riesgo si los recursos son escasos que si son muy abundantes, si son de distribución restringida o amplia, respectivamente. Los sistemas de polinización especializados pueden determinar que los organismos que los presentan sean más vulnerables que los generalistas, la combinación de reproducción asexual y sexual puede amortiguar la vulnerabilidad que puede implicar la exclusividad de un tipo de reproducción, entre otros aspectos (Delgado-Lemus et al., 2014b). Factores sociales y culturales como el aprecio especial por un recurso o su alta demanda en el mercado, pueden aumentar el riesgo de un recurso (Arellanes et al., 2013; Blancas et al., 2013), pues incentivan la intensidad de su extracción. Por el contrario, los procesos organizativos de las comunidades para abatir los riesgos, la existencia de reglas de uso, la organización productiva, la práctica de técnicas de almacenamiento y conservas, o el impulso de estrategias y planes de manejo, entre otros aspectos, pueden contribuir a disminuir el riesgo. Finalmente, el riesgo neto de un recurso será un balance de todos estos procesos, y los propósitos últimos (no exclusivos, como se analizará más adelante) del manejo son abatir los riesgos. Eso es así, pues el riesgo de un recurso determina incertidumbre en su disponibilidad. La intención del manejo es disminuir dicha incertidumbre o, en otras palabras, asegurar la disponibilidad de los recursos.

\section{Diversidad de formas de manejo}

Diferentes autores han propuesto que la agricultura y el pastoralismo surgieron como estrategias para disminuir la incertidumbre en la disponibilidad de recursos (Flannery, 1986; Harris, 1996; Hillman, 1996). Sin embargo, durante milenios, y hasta el presente, las comunidades rurales siguieron practicando la recolección y la extracción de recursos forestales, así como la cacería y la pesca junto a la agricultura y el pastoreo. Estas prácticas normalmente se incluyen en una categoría general de aprovechamiento de los recursos denominado "forrajeo". Autores como González-Insuasti y Caballero (2007) distinguen una categoría de recolección simple de otras formas de recolección. En efecto, la recolección de productos naturales, vegetales, animales u hongos puede implicar la cosecha de elementos útiles, pero esta práctica puede ser eventual o sistemática, circunstancial o planificada, aleatoria o siguiendo una estrategia, manual o involucrando herramientas, generalizada o selectiva. $Y$ cada forma de recolección o de

forrajeo es clave para entender los factores que pueden llegar a detonar el manejo. De hecho, las estrategias para sistematizar o planificar la recolección deben considerarse propiamente como prácticas de manejo.

Actualmente, numerosos recursos vegetales se encuentran bajo formas de manejo que no son ni recolección ni agricultura, y que se han denominado por diversos autores como forma de manejo incipiente por ser relativamente menos complejas que el manejo agrícola (Casas et al., 1996, 1997, 2007). Entre ellas deben incluirse las estrategias planificadas y selectivas de recolección descritas en el párrafo anterior. Junto a estas, destaca también la tolerancia (Figura 3.7), la cual implica dejar en pie algunos elementos de la vegetación cuando se practican perturbaciones en los bosques. Ocurre, por ejemplo, cuando la gente abre un terreno de cultivo y mantiene en pie algunos árboles o arbustos, o bien, cuando la gente realiza desyerbes en la milpa y deja en pie plantas arvenses útiles (como los quelites, varias especies de tomates como Physalis, varias especies de Solanum, chiles y cucurbitáceas como Melothria pendula o Cucurbita foetidissima). Otra forma de manejo es la inducción, que implica propagar algunas

Categorías de manejo

Manejo in situ

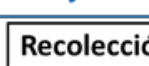

Protección

Tolerancia

Promoción

Manejo ex situ

Siembra

Trasplante

Trasplante
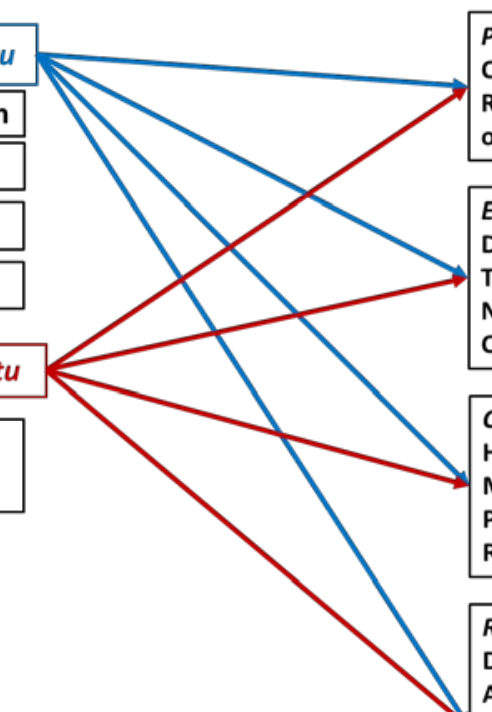

A

Abundancia

Ciclo de vida

Capacidad de recuperación ante el disturbio Viabilidad de manejo

Figura 3.7. Espectro de formas de manejo que se pueden identificar en distintas regiones de México. Las formas de manejo o interacciones in situ y ex situ son categorías generales de clasificación de los tipos de manejo. Estos pueden variar en la intensidad de acuerdo con aspectos ecológicos de recurso manejado, el valor cultural o económico que este tenga, la viabilidad de manejarse, la fuerza de trabajo invertido en su aprovechamiento,

la productividad y la práctica de selección artificial. Modificado de Blancas et al. (2010).

Intensidad de manejo del recurso Relación entre energía invertida y productos

Distancia recorrida

Númo y esfuerzo por persona

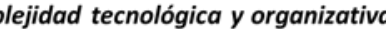

Herramientas

Maquinaria

de aprovechamiento

aprovechamiento 
plantas a través de sus semillas o partes vegetativas con el fin de aumentar su disponibilidad. Ejemplos de este manejo pueden apreciarse en especies de quelites y tomates como los descritos anteriormente, así como la dispersión intencional de semillas, propágulos vegetativos o plántulas de arbustos, árboles, cactáceas columnares, tunas o nopales, entre otras especies. Algunas plantas reciben formas de protección especial, por ejemplo, la remoción de sus competidores, la protección de herbívoros o parásitos, de la sombra o de la radiación solar excesiva. Todas estas son interacciones in situ, es decir, ocurren en el lugar donde se encuentran originalmente los organismos.

Hay formas de manejo que ocurren fuera de su ámbito natural (manejo ex situ) en lugares artificiales como los huertos y campos de cultivo. La gente lleva a estos sitios numerosos ejemplares de plantas silvestres y bajo otras formas de manejo, por ejemplo, suelen llevar orquídeas, cactáceas, agaves o magueyes, entre otras, y las manejan. En la Figura $3.7 \mathrm{se}$ puede apreciar que estas categorías de manejo están sujetas a distintos grados de intensidad. Influyen en la intensidad de manejo características biológicas y ecológicas de las especies, así como aspectos culturales, sociales y tecnológicos que marcan los ritmos de la interacción. Tomando en cuenta la intensidad, las formas de manejo pueden expresarse en una amplia gama de condiciones que merecen caracterizarse con tipologías detalladas, las cuales no solo son de valor teórico, sino que permiten establecer una base metodológica para caracterizar y diseñar estrategias de manejo en diversas áreas del país.

En estudios en el Valle de Tehuacán (Blancas et al., 2013; Larios et al., 2013) se analiza a detalle el espectro de formas de manejo de plantas comestibles en comunidades rurales nahuas. De un total de 122 especies de plantas comestibles, cerca de $30 \%$ son domesticadas introducidas y $42 \%$ se obtienen mediante recolección simple, mientras que el resto (33 especies) son plantas nativas bajo alguna forma de manejo. El estudio destaca el amplio espectro de condiciones de riesgo ocasionado por múltiples factores ecológicos y sociales. De igual modo, destaca la alta relación entre las condiciones de riesgo y las respuestas de intensidad de manejo (Figura 3.8).

\section{Diversidad de procesos de domesticación}

Uno de los efectos más importantes del manejo es la domesticación. En este proceso, los seres humanos modifican las formas y funciones de los organismos para satisfacer sus necesidades -sobre todo alimentarias, por ejemplo por medio de frutos más grandes y más dulces, pero también necesidades estéticas, utilitarias y medicinales- principalmente mediante selección artificial de los individuos más atractivos. Además de la selección directa, el manejo de la variabilidad fenotípica y genética presente en las poblaciones conduce la acción (deliberada o no) de otras fuerzas evolutivas como el flujo génico, la deriva génica y la endogamia, pues la domesticación se acompaña comúnmente de cambios en el tamaño efectivo de las poblaciones, su biología reproductiva y sus capacidades de dispersión. Los mecanismos y criterios con los que opera la domesticación están profundamente ligados a la cultura, por eso la domesticación es un problema de investigación eminentemente biocultural. Es importante documentar la diversidad de formas de vida de los organismos que se domestican, la diversi-
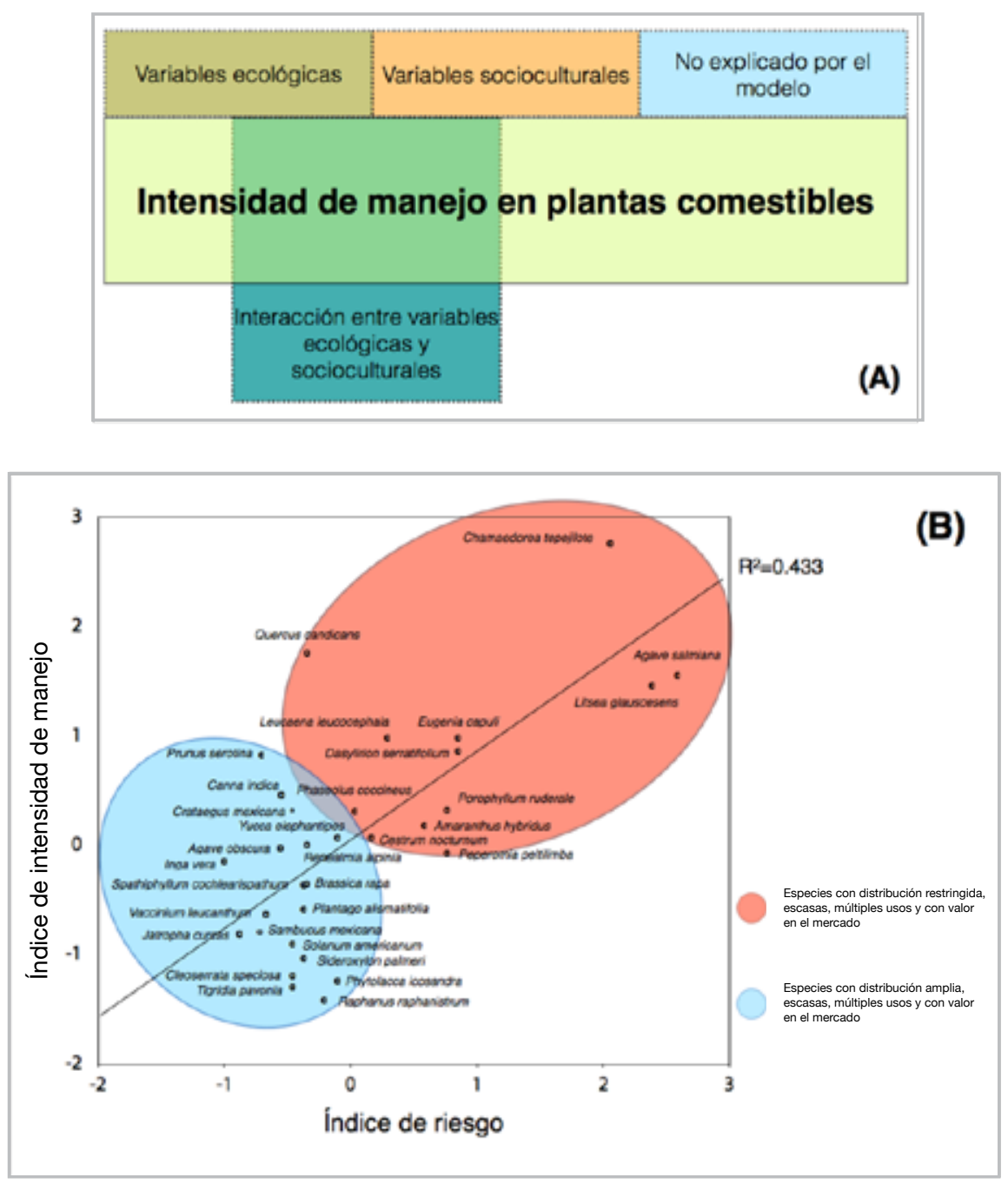

Figura 3.8. (A) Relación entre el riesgo -evaluado a través de la escasez, la distribución restringida o amplia, la parte de la planta aprovechada, la demanda en el mercado y su valor cultural-y la intensidad de manejo -evaluada a través de la complejidad de prácticas de manipulación, la existencia o no de prácticas de selección artificial, la cantidad de productos obtenidos por unidad de área y el tipo de herramientas utilizadas-, modelo que explica cómo la intensidad de manejo está relacionada con variables ecológicas y socioculturales, pero sobre todo es la interacción entre ellas la que explica esta intensidad en plantas comestibles por comunidades nahuas de Coyomeapan, Puebla (con base en Blancas et al., 2013). (B) Relación entre el índice de riesgo y el índice de intensidad de manejo, calculados ambos con base en los scores del primer componente principal de análisis multivariados de factores ecológicos, culturales, económicos y tecnológicos para 33 especies nativas de Coyomeapan, Puebla (Con base en Blancas et al., 2013). 
dad de atributos que la gente distingue y valora, la diversidad de mecanismos a través de los cuales favorece o desfavorece la abundancia de determinados fenotipos, así como la manera deliberada de favorecer artificialmente otros mecanismos evolutivos.

La domesticación es un proceso evolutivo que involucra diversificación. Darwin (1859) usó como modelo el proceso de domesticación para fundamentar su teoría sobre el origen de las especies por medio de selección natural. Mediante la domesticación la gente mantiene diversidad, genera continuamente nuevas variedades, y, además, incorpora al sistema diversidad que proviene de otros sitios. Es un proceso continuo y, por lo tanto, vigente y observable en la actualidad. Entenderlo es muy importante desde el punto de vista teórico, pero también lo es para desarrollar criterios en la toma de decisiones acerca del manejo sustentable de recursos genéticos. Así, más importante que conservar una u otra variedad interesante, es crucial mantener el proceso cultural, ecológico y biológico que hace posible la continua generación de variantes.

Hemos estudiado procesos de domesticación de recursos bajo distintas intensidades de manejo. Son los casos de hierbas comestibles o quelites, como los "alaches" (Anoda cristata) y "chipiles" (Crotalaria pumila) y algunos árboles como los "guajes" (Leucaena esculenta). Los detalles de los estudios de estas especies pueden consultarse en Casas et al. (1997, 2007), Casas y Caballero (1996) y Zárate et al. (2005). Otro árbol que se estudió es el Sideroxylon palmeri, cuyos frutos son ampliamente comercializados en Tehuacán y en Oaxaca (González-Soberanis y Casas, 2004). También se ha estudiado la Ceiba aesculifolia, que se encuentra en los registros arqueológicos tempranos de Tehuacán y que hoy en día es un recurso de alto valor económico y cultural (Avendaño et al., 2006, 2009; Arellanes et al., 2013). Sus semillas y raíces son comestibles y su algodón es una fibra muy importante aún en el presente; sus semillas comestibles se comercializan con una alta demanda y precio en el mercado regional. Al analizar aspectos de distribución y abundancia, así como niveles de extracción y comercialización, Arellanes et al. (2013) identificaron que esta es una de las especies más vulnerables en el Valle de Tehuacán, por lo que analizar el efecto de la recolección de semillas en poblaciones naturales, y el desarrollo de modelos de aprovechamiento sustentable es prioritario.

El sistema que hemos estudiado con mayor detalle es el de las cactáceas columnares, recursos de alta importancia cultural y económica en distintas regiones de México. Este sistema permite visualizar un gradiente de intensidad de manejo en función del tipo de propagación, selección artificial y velocidad de crecimiento. Especies como la Escontria chiotilla son de lento crecimiento y difíciles de cultivar. Otras especies como la Neobuxbaumia tetetzo producen frutos muy valorados por la gente, pero su crecimiento es aún más lento que el de E. chiotilla. Estas especies se manejan en sistemas agroforestales, en los que la gente deja en pie, protege o trasplanta individuos de un sitio a otro. Otras especies como la Stenocereus pruinosus y la S. stellatus se cultivan intensivamente, tienen propagación vegetativa, su rápido crecimiento facilita su cultivo y la selección artificial es más intensa que en especies de lento crecimiento (Casas et al., 2007). Las diferencias en la biología de estas especies y en las distintas prácticas permiten visualizar gradientes de intensidad de manejo a las que están sometidas, y permiten comprender el efecto variable de la domesticación en tal contexto variable del manejo.

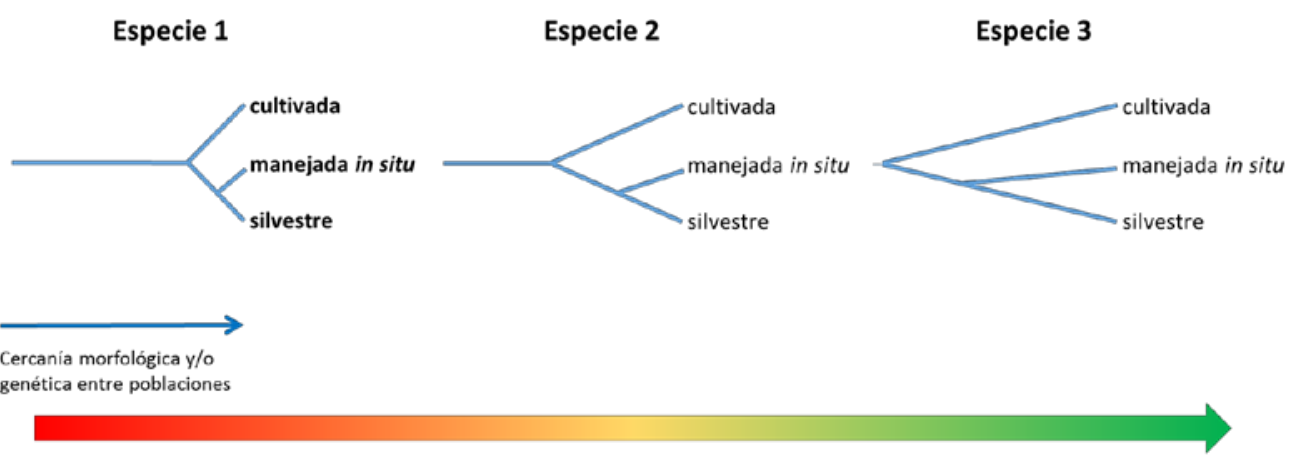

Intensidad de manejo

Figura 3.9. Patrones de divergencia entre poblaciones en relación con la intensidad de manejo. De acuerdo con esta hipótesis, una mayor intensidad de manejo determina manejo. De acuerdo con esta hipótesis, una mayor intensidad de manejo determina in situ y las cultivadas. Dicha divergencia es considerada evidencia de domesticación.

Hemos hipotetizado que a mayor intensidad de manejo, los procesos de domesticación y divergencia son más notorios. Así, las poblaciones bajo manejo silvícola in situ se parecen más a las silvestres que a las cultivadas, pues dichas poblaciones derivan directamente de poblaciones silvestres. Pero si la selección artificial opera más intensamente, la divergencia (tanto morfológica como fisiológica y genética) puede ser más pronunciada (Figura 3.9). Lo anterior permite analizar el grado de selección artificial con base en diferentes atributos: la diversificación morfológica, los montos de la diversidad genética de las poblaciones silvestres y manejadas, así como los cambios en los sistemas de reproducción y germinación.

Para documentar las motivaciones y mecanismos mediante los cuales opera la selección artificial es fundamental reunir información etnobotánica. Una condición fundamental de cualquier proceso de selección es que haya variabilidad; en el caso de la selección artificial es preciso documentar tal variabilidad y cómo la percibe la gente. Así, por ejemplo, la gente clasifica variedades de especies de cactáceas con base en atributos como el tamaño de fruto, el color de la pulpa y de la cáscara, sabor, textura y grosor de la cáscara. Los estudios morfométricos permiten documentar cómo varían estos atributos y qué patrones resultan del proceso selectivo.

Se han diseñado índices multivariados de diversidad y diferenciación morfológica entre las poblaciones silvestres y las manejadas, análogos a los que se usan con marcadores genéticos. Se esperaría mayor diferenciación entre poblaciones silvestres y las cultivadas que entre las silvestres y las que están bajo manejo silvícola, pues las poblaciones cultivadas son más intensamente manejadas. Los resultados hasta el presente parecen indicar que efectivamente existe un gradiente de divergencia en relación con la intensidad del manejo (Blancas et al., 2009; Parra et al., 2012). La Tabla 3 muestra algunos datos al respecto. La información es aún escasa, pero es posible apreciar un patrón congruente con la hipótesis planteada. 
Tabla 3.3. Diferenciación morfológica y genética entre poblaciones silvestres y bajo manejo silvícola, y entre poblaciones silvestres y cultivadas de especies de cactáceas columnares en el Valle de Tehuacán-Cuicatlán. Los índices se encuentran en escalas de valores entre 0 (ninguna diferencia) y 1 (total diferencia). Las especies se escalas de valores entre (ninguna diforian ordenadas de menor a mayor intensidad de manejo en las filas superiores e inferiores
de cada tabla.

\begin{tabular}{ccc} 
Especie & $\begin{array}{c}\text { Diferenciación } \\
\text { entre poblaciones } \\
\text { silvestres y silvícolas }\end{array}$ & $\begin{array}{c}\text { entre poblaciones } \\
\text { silvestres y cultivadas }\end{array}$ \\
\hline Polaskia chende & 0.009 & - \\
\hline Escontria chiotilla & 0.011 & - \\
\hline Myrtillocactus schenkii & 0.069 & 0.110 \\
\hline Polaskia chichipe & 0.193 & 0.353 \\
\hline Stenocereus stellatus & 0.251 & 0.379 \\
\hline Stenocereus pruinosus & $?$ & $?$ \\
\hline
\end{tabular}

Diferenciación genética

\begin{tabular}{ccc} 
ESPECIE & $\begin{array}{c}\text { Diferenciación genética } \\
\text { entre poblaciones } \\
\text { silvestres y silvícolas }\end{array}$ & $\begin{array}{c}\text { entre poblaciones } \\
\text { silvestres y cultivadas }\end{array}$ \\
\hline Polaskia chende & 0.023 & - \\
\hline Escoria chiotilla & 0.031 & - \\
\hline Myrtillocactus schenkii & $?$ & $?$ \\
\hline Polaskia chichipe & 0.041 & 0.045 \\
\hline Pachycereus hollianus & $?$ & $?$ \\
\hline Stenocereus stellatus & 0.050 & 0.059 \\
\hline Stenocereus pruinosus & 0.069 & 0.075 \\
\hline
\end{tabular}

En cuanto al efecto de la selección sobre la diversidad genética, las poblaciones cultivadas generalmente tienen menor diversidad genética que las silvestres y al comparar varias especies, se puede apreciar que algunas presentan ese patrón, pero otras no. Las excepciones son justamente las especies más intensamente manejadas, en las que las poblaciones cultivadas pueden tener mayor diversidad genética que las poblaciones silvestres. Ello puede deberse a que la gente transporta continuamente materiales silvestres a sus solares, que se mantienen en contacto reproductivo con sus parientes silvestres y continúan recibiendo genes de estos. Asimismo, la gente recambia continuamente las plantas de su solar, y algunos campesinos incluso llevan a sus solares materiales vegetales desde otros pueblos. Es decir, en los sistemas manejados se mueven propágulos de muy diverso origen. Para comprender este fenómeno se ha explorado la proveniencia de los materiales mediante entrevistas con la gente y marcado- res moleculares (Parra et al., 2010, 2012; Cruse-Sanders et al., 2013), lo cual permite analiza procesos de flujo génico entre lo silvestre y lo cultivado y los patrones de difusión regional e interregional. Estos datos ilustran la gran capacidad que tienen los pueblos tradicionales de mantener e incorporar nueva diversidad, y el papel fundamental que desempeñan en la conservación de los recursos genéticos y la biodiversidad.

De manera similar, se esperaría que a mayor intensidad de manejo haya mayor divergencia en los patrones de germinación y en los patrones de reproducción. Parcialmente, hemos encontrado resultados consistentes con esta suposición, sin embargo, las especies que se han estudiado tienen una historia natural más compleja que lo que plantea la hipótesis del trabajo. Está documentado que en la historia de la domesticación de diversas especies, la selección artificial ha favorecido una mayor frecuencia de plantas con autopolinización, pues esto permite una producción de frutos aun en ausencia de polinizadores. Sin embargo, las especies de cactáceas que se han estudiado son predominantemente autoincompatibles. En Polaskia chichipe la autopolinización es posible en condiciones naturales, logrando producir frutos independientemente de que haya o no polinizadores y, efectivamente, en las poblaciones cultivadas de especies de los géneros Polaskia y Myrtillocactus se encuentra que hay un porcentaje mayor de autocompatibilidad que en las poblaciones silvestres. En contraste, hay especies como las del género Stenocereus en las que no se ha logrado registrar autocompatibilidad ni en poblaciones silvestres ni en poblaciones cultivadas. En cambio, lo que se encontró fue que las poblaciones silvestres de Stenocereus son visitadas principalmente por una especie de murciélago, mientras que las poblaciones cultivadas son visitadas por otra especie. Así pues, el cambio generado por la intervención humana se presenta no en e sistema reproductivo en sí, sino en el tipo de polinizador que visita a cada tipo de población lo que representa otro tipo de barrera reproductiva. Otro ejemplo similar es el del Myrtillocactus schenckii, un garambullo (Ortiz et al., 2010); las flores de esta especie son visitadas por abejas del género Plebeia, tábanos y una abeja carpintera (Xylocopa mexicanorum), siendo esta última especie el polinizador más efectivo. Lo notorio es que las Plebeia visitan más a las poblaciones silvestres, y la abeja carpintera visita más a las cultivadas. Es posible que estas diferencias en los tipos de polinizadores se deban a la abundancia diferencial de recursos (generalmente mayor en poblaciones cultivadas), diferente tolerancia a la perturbación, así como capacidades competitivas distintas entre especies.

Los estudios expuestos permiten visualizar la diversidad de temas ecológicos, biológicos y culturales que se requieren abordar al estudiar procesos bioculturales como lo es la domesticación. Es posible imaginar que la extinción de alguna de las variedades o especies como las mencionadas, así como la pérdida de cultura de uso y manejo de los recursos referidos pueden colapsar todo el sistema. Es, por lo tanto, necesario considerar que todos estos elementos y procesos tienen riesgos de desaparecer. Por ejemplo, en el caso de los murciélagos ha habido campañas para erradicar vampiros, e invariablemente han afectado a los murciélagos en general. En Tehuacán hay 36 especies de murciélagos, pero solo una es hematófaga, mientras que las demás son insectívoras, nectarívoras, frugívoras, con importantes roles en el mantenimiento de los ecosistemas. La disminución de las poblaciones de murciélagos afecta la producción de fruta de especies como Stenocereus pruinosus y $S$. 
stellatus. Lo mismo podría comentarse sobre las poblaciones de abejas carpinteras (Xylocopa mexicanorum), abejorros (Bombus spp.) y meliponinas (Plebeia spp., Mellipona spp.), las cuales polinizan a las flores de Polaskia, Escontria y Myrtillocactus, y cuyas poblaciones se ven afectadas por el uso de insecticidas. Implicaciones similares puede tener la pérdida de alguna de las variedades que se han mencionado anteriormente, o la pérdida del interés por cultivar y seguir practicando la selección artificial. Los procesos mencionados se encuentran integrados y debe hacerse un esfuerzo por entenderlos de manera holística.

\section{Origen y difusión de la domesticación}

En el capítulo 6 del volumen 1 se profundizó en los planteamientos teóricos que permiten a la filogeografía contribuciones relevantes para analizar el origen y difusión de la domesticación de especies en particular. Este enfoque se basa en el análisis de la distribución espacial de linajes de genes, sobre todo aquellos que caracterizan a los materiales domesticados. El grupo ha iniciado estos análisis con el Stenocereus pruinosus (Parra et al., 2010, 2014), cactácea columnar domesticada principalmente en función de la calidad de sus frutos. Esta especie tiene un activo manejo y diversificación asociada a selección artificial en el Valle de Tehuacán-Cuicatlán, sin embargo, tiene una distribución amplia en el territorio mexicano. Los estudios iniciales permiten diferenciar al menos tres grupos genéticos significativos: uno localizado en la región central de México, incluyendo el Valle de Tehuacán y el Istmo de Tehuantepec, que parecen tener la mayor afinidad filogenética entre sí, aunque las poblaciones del Istmo son principalmente silvestres, mientras que en Tehuacán coexisten las silvestres y domesticadas. Otro grupo genético se encuentra en la región noreste de México (especie con frecuencia identificada por algunos investigadores como Stenocereus griseus) y otro más localizado en la región sur del estado de Chiapas (identificada por algunos investigadores como Stenocereus laevigatus). Los taxa son morfológicamente muy similares, pero los marcadores moleculares empleados hasta el momento (microsatélites nucleares) permiten diferenciar los tres grupos que forman el complejo. Actualmente se llevan a cabo estudios con marcadores de cloroplasto, incluyendo materiales sudamericanos en donde se describió la especie Stenocereus griseus. El reto de este estudio es identificar la naturaleza del complejo de taxa (reconocido por los taxónomos como complejo Stenocereus griseus) analizando la influencia -posiblemente dirigida por el hombre sobre un escenario biogeográfico natural- de los materiales sudamericanos en México y viceversa.

Una aproximación similar se llevó a cabo con especies de Crescentia que se distribuyen en México (Crescentia cujete y C. alata), ambas especies empleadas por su fruto con pericarpio resistente y que ha sido utilizado como recipiente desde tiempos antiguos. Aguirre-Dugua et al. $(2012,2013)$ y Aguirre-Dugua (2015) encontraron signos claros de divergencias morfológicas y genéticas entre los materiales silvestres y cultivados (Figura 3.10). Particularmente interesante es el caso de C. cujete en la península de Yucatán, en donde los haplotipos cultivados pertenecen a linajes distintos a los de las poblaciones silvestres. Nuestro grupo ha hipotetizado la posibilidad de que los materiales cultivados que predominan en los huertos mayas de la península de Yucatán, y de otras regiones de México, provengan de algunas
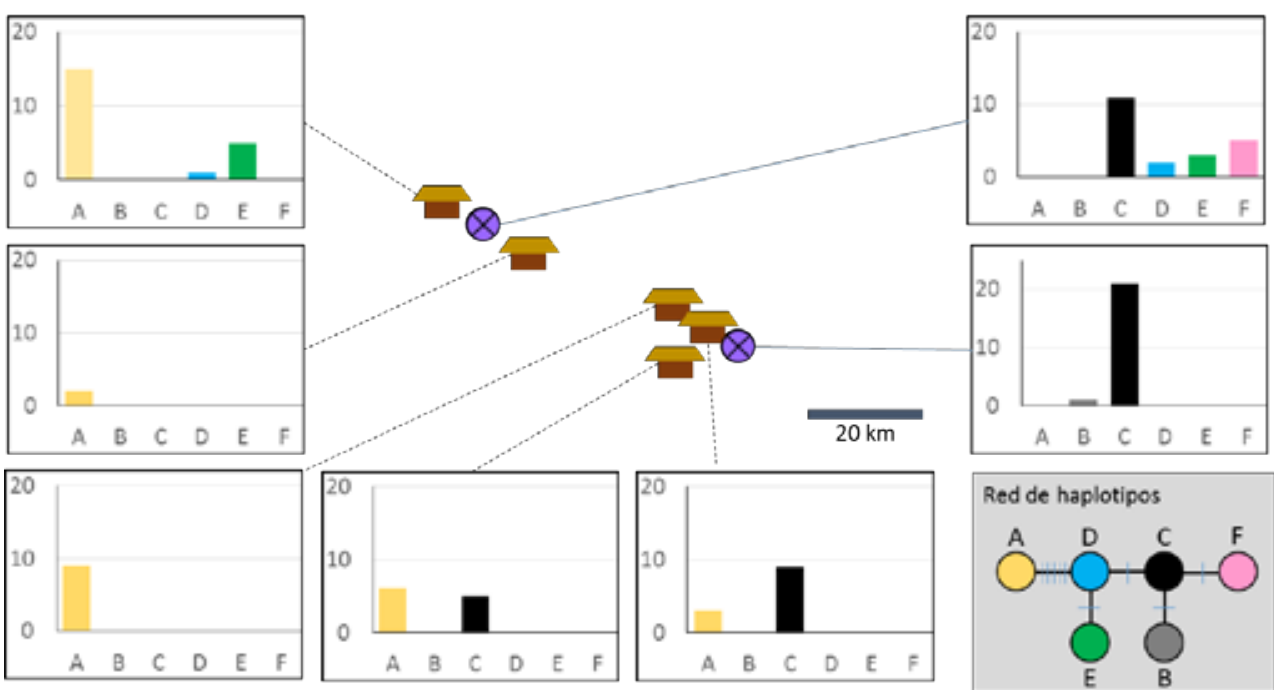

Figura 3.10. Composición genética de los árboles de Crescentia cujete presentes en los huertos (izquierda) y en las poblaciones silvestres (derecha) en la zona este del estado de Campeche, en la península de Yucatán (México). Con base en microsatelites de cloroplasto se identicaron en la región seis haplotipos, uno muy abundante en los individuos de huertos (haplotipo A) y cinco caracteristicos de las poblaciones silvestres (haplotipos B-F. Los haplotipos silvestres se encontraron en baja frecuencia en algunos huertos, senalando flujo genico de las poblaciones silvestres aledanas hacia las comunidades. Como se observa en la red de haplotipos, en la parte inferior izquierda de la figura, los haplotipos silvestres se encuentran cercanamente emparentados entre sí, mientras que el haplotipo A cultivado es muy distante genéticamente y no se encontró en las poblaciones silvestres locales, por lo que es probable que haya sido introducido desde otra región. Elaborada con base en datos de Aguirre-Dugua et al. (2012).

regiones más al sur del territorio mexicano. Están en proceso investigaciones para poner a prueba esta hipótesis.

Estas aproximaciones se suman a los estudios llevados a cabo con Spondias purpurea por Miller y Schaal (2006), Chrysophyllum cainito por Parker et al. (2010) y Petersen et al. (2014), Manihot esculenta por Olsen y Schaal (2007), y con Euphorbia pulcherrima por Trejo et al. (2012, 2015). La sistematización de estudios de caso en distintas áreas del continente americano permitiría una aproximación más clara acerca de los intercambios de materiales y experiencias de domesticación entre regiones del continente americano. Además, se podría evaluar con mayor precisión el sentido de los "centros" de origen. Es más factible que las investigaciones encuentren una constelación de centros de origen para las diferentes especies domesticadas, más que áreas discretas de las que partieron conjuntos amplios de estas. Pero, por lo pronto, esta es una hipótesis posible que requiere mayor esfuerzo de investigación. 

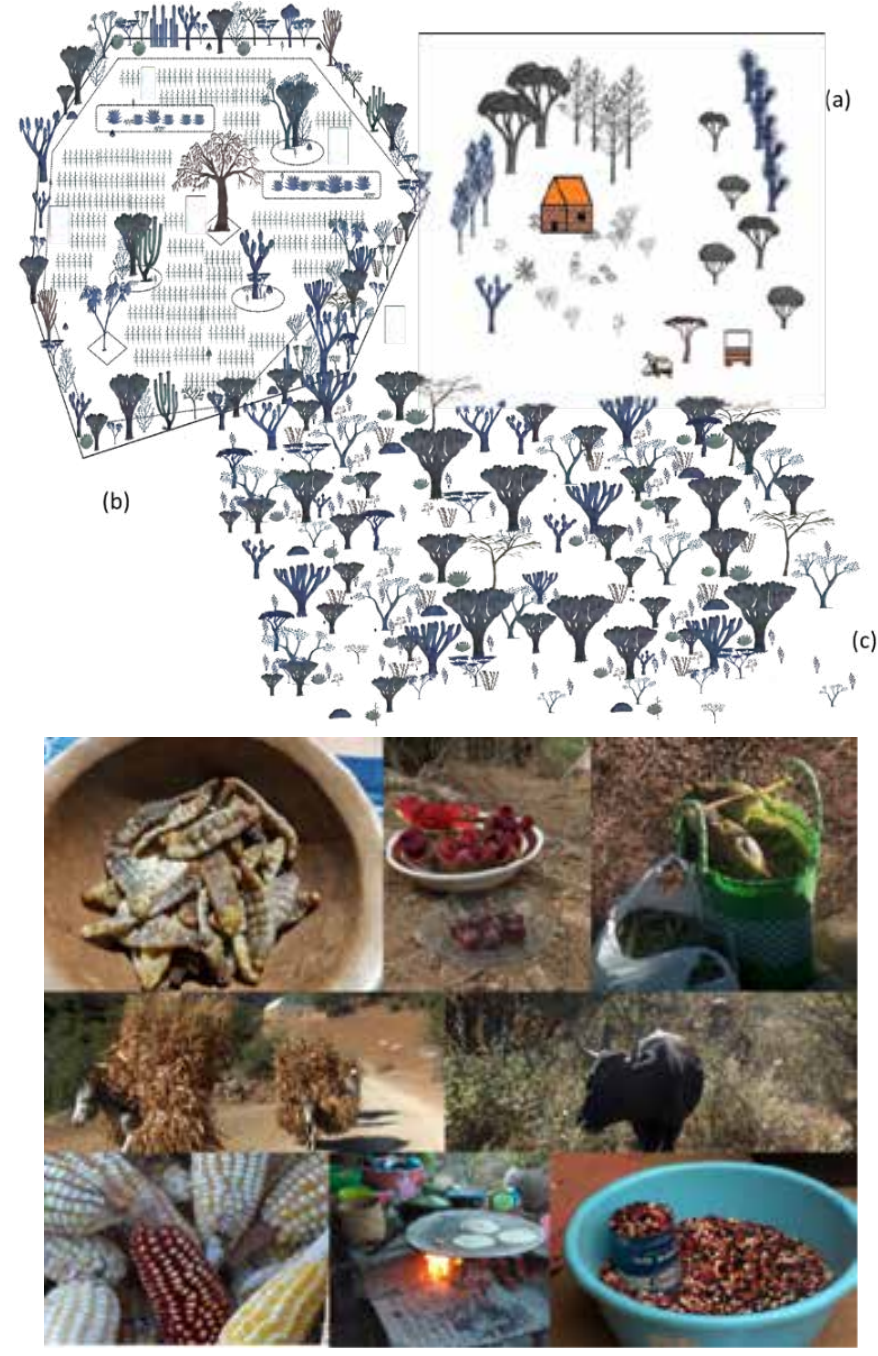
Figura 3.11. Recursos del sistema agroforestal de milpa-chichipera en el Valle de Tehuacan. En la imagen se presenta la diversidad de recursos alimentarios, forrajeros y combustibles (por nombrar algunos de los más importantes) a los que pueden acceder los comunidad de San Luis Atolottlán en Puebla, México. Este sistema involucra el manejo de más de 100 especies de plantas, varios animales e insectos silvestres bajo manejo in situ y ex situ, as como una gran diversidad de plantas cultivadas y animales domésticos como es el caso de los maíces criollos, los frijoles enredadores, las calabazas, cabras, burros, caballos y bueyes en la misma unidad de terreno, esta unidad comúnmente no supera las dos hectáreas. En el esquema se muestran tres espacios que suelen estar en constante interacción: a) el huerto, espacio junto a la casa donde se mantienen plantas y animales porque representan algún uso o valor para la familia campesina; b) la parcela agrícola, que mantiene prácticas agroforestales ya que brinda diversos beneficios ecosistémicos, productivos, económicos y culturales; c) el bosque (chichipera por la dominancia de la especie Polaskia chichipe), de donde la familia campesina también obtiene parte de sus recursos, además de ser el espacio que provee de plantas y animales a los sistemas aroforestales tanto huertos como parcelas; d) ale plantas y animas a los sistemas agroforestales tanto huertos como parcels, d) algun pistemas agerions', larvas de lepidope dólares americanos); frutos de cactán Stenocereus stellatus, S. pruinosus y Myrtillocactus schenckii, en el area estudiada); ejotes (frutos tiernos de frijol, elotes y huitlacoche, un hongo comestible que infesta al maíz); rastrojo de maíz, uno de los subproductos de mayor precio en el mercado local; forraje para el ganado, principalmente plantas herbáceas y arbustivas colonizadoras en las áreas abiertas de los SAF, y maíz y frijol, que forman parte de la dieta básica de los campesinos de la región estudiada.

\section{Manejo de sistemas de diversidad}

En México existe una gran variedad de sistemas agroforestales (Moreno-Calles et al., 2013), y en ellos se ha encontrado una alta diversidad de especies manejadas (Blancas et al., 2010). Entre los estudios más detallados están los sistemas de milpa realizados en zonas áridas (Moreno-Calles et al., 2010, 2012; Hoogesteger, 2012), bosque tropical seco, bosques templados, valles aluviales y huertos (Larios et al., 2013; Vallejo et al., 2014; 2015 Figura 3.11).

En estos estudios se muestrearon los sistemas agroforestales y los bosques en áreas comparables, analizando el número de especies que están en el bosque y que también se encuentran en el sistema agroforestal. Se encontró que en los sistemas de zonas áridas, en promedio, $56 \%$ de las especies de plantas que se encuentran en los muestreos del bosque están también en los sistemas agroforestales. En los bosques templados se encontró que alrededor del $43 \%$ de las especies de los bosques locales se encontraban en dichos sistemas (Vallejo et al., 2014); en los valles aluviales cerca del 50\% (Vallejo et al., 2014) y en los huertos del 16\% a 35\% (Larios et al., 2013). Hay un mayor número de especies o una mayor proporción de especies útiles en los sistemas agroforestales que en la vegetación silvestre; es decir, el manejo favorece la abundancia de especies utilizadas. En estos procesos a escala de paisaje la gente deja y quita elementos de distintas especies que componen el paisaje, moldeándolo o domesticándolo (Terrell et al., 2003); o quizá, más adecuadamente, por tratarse de unidades espaciales de significancia cultural, deberíamos hablar de procesos de domesticación de territorios. Se ha escrito relativamente poco en la conceptualización de estos procesos como expresiones de domesticación (Terrell et al., 2003). Sin embargo, es posible visualizar que los procesos de domesticación a escala de individuos y poblaciones influyen significativamente sobre los que ocurren a escala de paisaje y viceversa; por ello, consideramos de particular relevancia abordar de manera integral los procesos de domesticación en las diferentes escalas.

Los sistemas agroforestales son fundamentales en cualquier política de conservación de biodiversidad. No solamente en términos de la composición que pueden albergar, sino también de las interacciones que establecen los componentes de estos sistemas con los bosques naturales. Estas interacciones pueden ser reproductivas, pues el polen y/o las semillas se mueven de una población a otras (estos procesos involucran lo que los ecólogos denominan 
flujo de genes entre poblaciones). Otras interacciones como la frugivoría, la herbivoría o el nodricismo también son interacciones relevantes. Generalmente, en los estudios de genética de poblaciones que hemos realizado, se han encontrado valores de flujo génico entre poblaciones cultivadas y silvestres mucho mayores que 1. Esto significa que ambos tipos de poblaciones tienen una interacción reproductiva y genética muy alta y que estos sistemas artificiales son importantes en términos del mantenimiento general de la diversidad genética de las poblaciones tanto cultivadas como manejadas in situ y silvestres. Los sistemas agroforestales son reservorios de recursos, áreas de domesticación, y áreas de interacciones entre los componentes de los sistemas silvestres y domesticados.

Pese a sus bondades, estos sistemas enfrentan una problemática que pone en entredicho su mantenimiento futuro: la cobertura vegetal disminuye o incluso se pierde en la medida que se intensifica la agricultura. Este proceso, en parte, está ligado a la fragmentación de la propiedad de las parcelas. Los ejidatarios que cuentan con una parcela se la dejan a sus hijos que forman nuevas familias, cada una de las cuales hace uso de una parte de la parcela original, lo que los obliga a intensificar la agricultura y a eliminar los remanentes de vegetación. Pero además, programas gubernamentales como "Procampo", que, sin entender la importancia del componente forestal de estos sistemas, desincentivan su mantenimiento, pues a su juicio tales fragmentos forestales restan superficie agrícola a las parcelas (Moreno-Calles et al., 2012). Es necesario identificar y entender las causas de estos problemas para diseñar estrategias y abordarlas.

\section{La investigación como apoyo a las experiencias locales de manejo}

El conocimiento local tiene muchas virtudes, pero también limitaciones. Las técnicas locales están en continua construcción, son dinámicas, y frecuentemente los ritmos que se requieren para atender un problema son rebasados. Reconocer las limitaciones de los procesos tradicionales conlleva a visualizar el papel activo que puede desempeñar la investigación como soporte a las estrategias que día a día construyen las personas y las comunidades que aprovechan y manejan los recursos biológicos. Si se logra aportar respuestas acorde con las presiones, la gente y los recursos contarán con un camino constructivo hacia el futuro, pero si no, hay un riesgo de que estos sistemas colapsen. Un ejemplo de estos procesos lo ilustra el maguey mezcalero Agave potatorum; este maguey en la zona zapoteca de los Valles Centrales e Istmo de Tehuantepec se conoce como "tobalá" y con él se produce uno de los mezcales más exquisitos, sin embargo su extracción mermó sensiblemente las poblaciones de agave de esa región y determinó extinciones en áreas relativamente extensas. Este maguey se encuentra también en Tehuacán, donde quizá están los remanentes más importantes de poblaciones de dicha especie. Actuar para su conservación en esta región es crucial.

Delgado-Lemus et al. (2014a), caracterizaron cómo es el proceso de producción de mezcal, la extracción del maguey y el proceso de elaboración. Hicieron una investigación ecológica para saber cuánto maguey hay disponible en el territorio de la comunidad y un estudio de las tasas anuales de extracción. Los datos indican que en el territorio estudiado hay cerca de 10 000 individuos adultos por año. Para elaborar mezcal se cancela el único evento reproductivo de esta especie, pues se utilizan los individuos adultos justo antes de que produzcan su inflorescencia y cosecha; el impacto de la extracción es muy severo.

Anualmente la gente utiliza alrededor de 12000 magueyes. De su territorio extraen cerca de 6000 y el resto lo compran a otras comunidades. Aproximadamente el $60 \%$ de los individuos reproductivos de ese territorio es cosechado para elaborar mezcal. Pero hay parajes en los que la gente prefiere ir a cosecharlos y en algunas áreas se puede extraer el $100 \%$ de individuos adultos. Hay áreas que la gente identifica como sitios que en el pasado (10 a 20 años) eran zonas en las que se encontraba el maguey y hoy en día ha desaparecido.

Torres et al. (2013) hicieron un estudio demográfico para calcular la tasa de crecimiento finito poblacional (lambda) de algunas poblaciones; cuando este parámetro es igual a 1 indica que la población es estable, mientras que si es menor o mayor, la población está decreciendo o creciendo, respectivamente. Nuestro grupo de investigación emprendió acciones conjuntas con e Grupo de Estudios Ambientales (GEA, A.C.), una organización civil que colabora con comunidades campesinas. Una de las vertientes principales de su trabajo es el desarrollo de estrategias de producción sustentable de otra especie de maguey con uso mezcalero Agave cupreata en la región Centro-Montaña del estado de Guerrero en los municipios de Chilapa y Ahuacuotzingo, se efectuó un taller en el que los campesinos de Tehuacán intercambiaron sus experiencias con los de Chilapa. Si bien nuestro trabajo en el Valle de Teuacán-Cuicatlán tenía el fin de explorar modelos de extracción sustentable, no encontramos una propuesta clara. En Tehuacán, donde los sitios estudiados son de los más conservados, desafortunadamente la lambda está por debajo de 1; es decir, también están ya en riesgo. Algunas comunidades, sintiéndose presionadas por las autoridades de la Reserva de la Biósfera en su asamblea comunitaria, optaron por declara vedas en algunas áreas y hacer trabajo de recuperación de las poblaciones.

Las semillas del Agave potatorum son dispersadas por el viento y polinizadas por murciélagos. Estrella-Ruíz (2008) estudió la polinización y encontró que en sitios donde hay escasos individuos reproductivos los murciélagos acuden muy poco a visitar las flores. Es decir, en los sitios ya diezmados, la producción de semillas por individuo va a ser más baja que en otros sitios menos perturbados. Otro tema importante lo abordaron Rangel-Landa et al. (2015) y Torres et al. (2013), quienes estudiaron cómo germinan y cómo se establecen los agaves. Encontraron que en el campo solamente entre el 7 y $8 \%$ de las semillas que caen en sitios seguros logran germinar y de las plántulas que resultan sobreviven unas cuantas. En cambio, si se germinan las semillas en laboratorio se obtiene hasta $90 \%$ de germinación. Por lo tanto, en términos de un esfuerzo por recuperar las poblaciones, vale la pena hacer propagación ex situ. Los campesinos en la comunidad lo hicieron en sus propios viveros. Pero e trasplante al campo fue llevado a cabo sin ningún plan, y a los dos años murió el $66 \%$ de las plantas en espacios abiertos en comparación con el 16\% de mortalidad en los agaves trasplantados bajo el dosel arbustos. Nuestro diagnóstico concluyó que estos agaves necesitan plantas "nodrizas", ya no pueden crecer en los sitios abiertos. Esto resultó de un estudio ecológico que permitió identificar especies de plantas nodrizas específicas que brindan microambientes particularmente favorables a estas plantas. Finalmente, este rompecabezas ha ayudado a diseñar una propuesta de cómo manejar el recurso del maguey tobalá con base en diversos criterios ecológicos. 
A lo largo de esta y otras experiencias, el equipo ha observado que es de particular relevancia construir y aportar a las comunidades estrategias de monitoreo participativo de las acciones emprendidas. La gente está ensayando técnicas de manejo continuamente, poniendo en práctica sus iniciativas de proteger, de conservar, de recuperar recursos, y lo más importante es agilizar el aprendizaje de las lecciones que dejan esas prácticas. El equipo colaboró con el proyecto que ellos impulsaron. La investigación y experimentación en campo y laboratorio, el estudio de las interacciones con polinizadores y nodrizas y, sobre todo, los métodos para sisematizar la experiencia son, quizá, de las aportaciones más valiosas. Todo ello contribuye, de lguna forma, a acortar caminos, a reducir los tiempos en los que se construyen innovaciones técnicas para el aprovechamiento sustentable.

\section{Perspectivas y conclusiones}

Nuestro grupo de investigación ha impulsado métodos de estudio, para documentar procesos de domesticación en el presente, que pueden ser útiles para descifrar lo que ocurrió en el pasado. Se abre una avenida muy amplia al documentar que el manejo y la domesticación pueden estar asociados a estrategias de manipulación que no son propiamente manejo agrícola. Las diferentes formas de manejo documentadas y las diferentes intensidades de manejo pueden representar diferentes condiciones bajo las cuales pueden operar los procesos de domesticación. Entender esta amplia gama de procesos permite interpretaciones más adecuadas para explicar el origen de la domesticación y de la agricultura.

La colaboración de investigación bajo principios metodológicos comunes en diferentes regiones del continente permitirá identificar con mayor claridad patrones particulares y generales en distintas áreas. Una perspectiva abierta acerca de los intercambios materiales y culturales, así como experiencias de manejo resulta altamente conveniente para una interpretación adecuada de los procesos.

Las investigaciones del presente no solo contribuirán a mejores interpretaciones de los hallazgos arqueológicos, sino a entender los procesos activos del manejo y la domesticación que operan en el presente. Su aporte teórico es relevante al igual que su aporte práctico, a desarrollo de estrategias de manejo sustentable.

\section{Agradecimientos}

Los autores agradecemos al PAPIIT, DGAPA, UNAM (proyectos IN205111-3 y IN209214), as como al CONACYT (proyecto CB-2008-01-103551) su apoyo financiero. En especial, agradecemos la calidez humana de la gente de las comunidades campesinas en las que hemos trabajado, quienes han compartido su sabiduría y han sido muy generosos durante nuestra estancia en sus territorios. Agradecemos a GEA y CONTEC, organizaciones civiles con las que aspiramos a consolidar alianzas de trabajo conjunto.

\section{Bibliografía}

Aguirre-Dugua, X., 2015. Filogeografía y procesos de Blancas, J., A. Casas, D. Pérez-Salicrup, J. Caballero y domesticación de Crescentia alata y C. cujete (Bignoniaceae) en México. Tesis de Doctorado. Posgrado

Aguirre-Dugua, X., A. González, L. Eguiarte y A. Casas, 2012. Round and large: Morphological and genetic consequences of artificial selection on the gourd
tree Crescentia cujete by the Maya from the Yucatán
Peninsula, Mexico. Annals of Botany 109: 1307-1316.

Aguirre-Dugua, X., A. Casas y E. Pérez-Negrón, 2013. Phenotypic differentiation between wild and
domesticated varieties of Crescentia cujete and culturally relevant uses of fruits as bowls in the Yucatan Peninsula, Mexico. Journal of Ethnobiology
and Ethnomedicine 9: 76 (en línea, disponible en: and Ethnomedicine 9: 76 (en línea, disponible en: http://www.ethmobiomed.com/content/9/1/76).

Albuquerque, U. P. y M. Alves (Eds.), 2008. Current topics in Ethnobotany. Research Signpost, Kerala.

Albuquerque, U. P., P. M. Medeiros y A. Casas (Eds.), 2015. Evolutionary ethnobiology. Springer, Switzerland

Ashworth, L., M. Quesada, A. Casas, R. Aguilar y K. Oyama 2009. Pollinator- dependent food production in Mexico. Biological Conservation 142: 1050-1057.

Arellanes, Y., A. Casas, A. Arellanes, E. Vega, J. Blancas, M. Vallejo, I. Torres, S. Rangel-Landa, A. I. MorenoCalles, L. Solís y E. Pérez-Negrón, 2013. Influence of traditional markets on plant management in the Tehuacan Valley. Journal of Ethnobiology and http://www.ethnobiomed.com/content/9/1/38)

Avendaño, A., A. Casas, P. Dávila y R. Lira, 2006. Traditional use, management and commercialization of "pochote" parvifolia (Rose) P. E. Gibbs \& Semir (Bombacaceae) in the Tehuacán Valley, Central Mexico. Journal of Arid Environments 67: 15-35.

Avendaño, A., A. Casas, P. Dávila y R. Lira, 2009. In situ management and patterns of morphological variation of Ceiba aesculifolia subsp. parvifolia in the Tehuacán Valley. Economic Botany 63(2): 138-151.

Benz, B. F., 2006. Maize in the Americas. Maize in the Americas. En: Staller J., R. Tykot y B. F. Benz (Eds.). Histories of maize: Multi-disciplinary approaches to the prehistory, linguistics, biogeography and evolution

Blancas, J., A. Casas, R. Lira y J. Caballero, 2009 Traditional Management and Morphological patterns Valley, Central Mexico1. Economic Botany 63(4): 375387.

Blancas, J., A. Casas, S. Rangel-Landa, A. Moreno-Calles, I. Torres, E. Pérez-Negrón, L. Solís, A. Delgado-Lemus, F. Parra, Y. Arellanes, J. Caballero, L. Cortés, R. Lira P. Dávila, 2010. Plant Management in the Tehuacán-
Cuicatlán Valley, Mexico. Economic Botany 64: 287-302. influencing plant management in Nahuatl communities of the Tehuacan Valley, Mexico. Journal of Ethnobiology (en línea, disponible en:http://

oege, E., 2008. El patrimonio biocultural de los pueblos indigenas de México. Instituto Nacional de Antropolog Pueblos Indígenas, México.

Pallero J A Casas, L Cortés y C. Mapes, 1998. Patrones en el conocimiento, uso y manejo de plantas en puanes indígenas de México. Estudios Atacameños 16: 181-196.

Casas, A., J. L. Viveros y J. Caballero, 1994. Etnobotánica mixteca: sociedad, cultura y recursos naturales en la
Montaña de Guerrero. Instituto Nacional Indigenista CONACULTA, México.

Casas, A. y J. Caballero, 1996. Traditional management and morphological variation in Leucaena esculenta (Moc. et Mexico. Economic Botany 50(2): 167-181.

Casas, A., M. C. Vázquez, J. L. Viveros y J. Caballero, 1996. Plant management among the Nahua and the Mixtec of the Balsas river basin: an ethnobotanical approach to the study of plant domestication. Human Ecology

Casa, A., J. Caballero, C. Mapes y S. Zárate, 1997. Manejo de la vegetación, domesticación de plantas y origen do Botánica de México 61: 31-47.

Casas, A., A. Valiente-Banuet, J. L. Viveros, J. Caballero, L. Cortés, P. Dávila, R. Lira y I. Rodríguez, 2001. Plant resources of the Tehuacin
Botany 55(1): 129-166.

Casas, A., A. Otero-Arnaiz, E. Peréz-Negrón y A. ValienteBanuet, 2007. In situ management and domestication
of plants in Mesoamerica. Annals of Botany 100: 1101-1115.

Casas, A. y F. Parra, 2007. Agrobiodiversidad, parientes silvestres y
23(2): $5-8$.

Casas, A., S. Rangel-Landa, I. Torres, E. Peréz-Negrón, L. Solís, F. Parra, J. Blancas, B. Farfán-Heredia y A I. Moreno-Calles, 2008. In situ management and Cuicatlán Valley, Mexico: an ethnobotanical an Ramos (Eds). Current topics in Ethnobotany. Research Signpost, Kerala, India, pp 1-25.

Casas, A. A. Camou, A. Otero-Arnaiz S. Rangel-Land

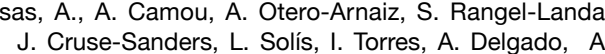
I. Moreno-Calles, M. Vallejo, S. Guillén, J. Blancas, F. Parra, B. Farfán-Heredia, X. Aguirre-Dugua y $Y$ Arellanes, 2014. Manejo tradicional de biodiversidad conservation of plant resources in the Tehuacán- 
Investigación ambiental Ciencia y politica pública 6:23-44 (en linea, disponible en: http://www.revista.inecc.gob. mx/article/view/225/246\#.VjGj3bcvflU).

Camou-Guerrero, A., V. Reyes-García, M. Martinez-Ramos, A. Casas, 2008. Knowledge and use value of plant species Ecology 36: 259-272.

Ceballos, G., J. Arroyo-Cabrales y R. Medellín, 2002. Mamiferos de México. En: Ceballos, G. y J. A. Simonett (Eds.). 2002. Diversidad y Conservación de los Mamiferos ilde, V. G., 1956. Society and Knowledge. Harper and Childe, V. G., 1956. So

Cruse-Sanders, J. M., E. A. Friar, K. C. Parker, D. I. Huang, S. Mashayekhi, L. M. Prince, A. Otero-Arnaiz y A. Casas, in 1 . Managing diversity. domestication and gene flow Evolution 3(5): 1340-1355.

Darwin, C. 1859. On the origin of species by means of natural selection, or the preservation of favored races in the
struggle for life. John Murray, Londres.

De Ávila A 2008. La diversidad lingǘstica y el conocimiento etnobiológico. En: Sarukhán Kermez, J. (Coordinador generall), Soberón, J., G. Halffter y J. Llorente-Bousquets (compiladores). Capital natural de México. Volumen I: Conocimiento actual de la biodiversidad. Capitulo 16 CONABIO, Mexico, D.F., pp. 497-556.

De Candolle, A., 1882. Darwin considéré au point de vue des causes de son succès et de l'importance de ses travaux. Geneva, Switzerland.

Delgado-Lemus, A., A. Casas y O. Téllez-Valdés, 2014a. Distribution, abundance and traditiona management of Agave potatorum in the Tehuacán Valley, Mexico: Perspectives for its sustainable Ethnomedicine 10:63 (en línea, disponible en http://www.ethnobiomed.com/content/10/1/63).

Delgado-Lemus, A., I. Torres, J. Blancas y A. Casas, 2014b. Vulnerability and risk management of Agave species in and Ethnomedicine 10:53 (en línea, disponible en: http://www.ethnobiomed.com/content/10/1/53).

Estrella-Ruíz, P., 2008. Efecto de la explotación humana en a biologia de la polinización de Agave salmiana y Agave potatorum en el Valle de Tehuacán-Cuicatlán. Tesis de Maestría. Posgrado en Ciencias Biológicas, UNAM

Farfán, B., A. Casas, G. Ibarra y E. Pérez Negrón, 2007. Mazahua ethnobotany and people subsistence in the Monarch Butterfly Biosp

Flannery, K. (Ed.), 1986. Guilá Naquitz. Academic Press. New York.

González-Insuasti, M.S. y J. Caballero, 2007. Managing plant resources: How intensive can it be? Human Ecology

González-Soberanis, C. y A. Casas, 2004. Traditiona management and domestication of tempesquistle,
Sideroxylon palmeri (Sapotaceae) in the TehuacánCuicatlán Valley, Central Mexico. Journal of Arid Environments 59(2): 245-258.

at is ecosystem management? Conservation Biology 8: 27-38.

Gumbine, R. E., 1997. Reflections on 'What is Ecosystem Management? Conservation Biology 11: 41-47.

an, J., 1975. Crops and man. American Society of Agronomy and Crop
Madison, Wisconsin

ris, D. R. (Ed.), 1996. The Origins and Spread of Agriculture and Pastoralism in Eurasia. UCL Press, Londres.

arris, D. R. y G. C. Hillman (Eds.), 1989. Foraging and Folution of Plant Exploitation. Routledge, Abingdon y New York.

Unes, J. G., 1983. The diversity of crop plants. Harvard University Press. Cambridge, Massachusetts, USA.

man, G. C., 1996. Late Pleistocene changes in wild plantfoods available to hunters-gathers of the northern Fertile Crescent: possible preludes to cereal cultivation. En: Hand D. R. (Ed.). The Origins and Spread of Agriculture and Pasto $159-203$.

oogesteger, V. M., 2012. Tajos de la Sierra Gorda guanajuatense: agroecosistemas de importancia ecologica, economica y cultural. Tesis de Licenciatura.

Kirchhoff, P., 1943. Mesoamérica: Sus límites geográficos, composición étnica y caracteres culturales. Acta Americana 1: 92-107, Washington D.C.

Larios, C., A. Casas, M. Vallejo, A. I. Moreno-Calles y J. Blancas, 2013. Plant management and biodiversity Valley, Mexico. Journal of Ethnbiology and Ethnomedicin 9: 74 (en línea, disponible en: http://www.ethnobiomed. com/content/9/1/74).

is, M. P, G. F. Simons y C. D. Fennig (Eds.), 2015. Ethnologue: Languages of the World. Décimo octava Edicion, Dallas, Texas: SIL International disponible en. hthp./WwW.ethologue.com).

Lins Neto, E. M. F., N. Peroni, A. Casas, F. Parra, X. Aguirre, S. Guilien y U. P. Albuquerque, 2014. Brazilian and Mexican experiences in the study of incipient domestication linea, disponible en: http//www.ethnobiomed.com/ content/10/1/33).

ira, R., A. Casas, R. Rosas-López, M. Paredes-Flores, S. Rangel-Landa, L. Solís, I. Torres y P. Dávila, 2009 Traditional knowledge and useful plant richness in the
Tehuacán Cuicatlán, México. Economic Botany 63 : 271-287.

Lez-Austin, A. y L. López-Lujān, 2002. La periodización de la historia

Lucena, C. M., T. K. N. Carvalho, E. A. Marín, J. G. Melo, A. Casas y R. F. P. Lucena, 2014. Potencial medicinal de
cactáceas de nordeste semiárido brasileño. Gaia Scientia
Volume Especial Populações Tridicionais: 36-50.

MacNeish, R. S., 1967. A summary of subsistence. En Byers, D.S. (Ed.). The prehistory of the Tehuacán Valley: Press, Austin, Texas, pp 290-309.

s of agriculture and settled life. Oklahoma University Press.

Maffi, L., 2005. Linguistic, cultural, and biological diversity. Annual Review of Anthropology 34: 599-617.

Martínez-Alier, J., 2005.Social metabolism and ecological Ecological Economics. Massey University, Palmersto North.

Matos-Moctezuma, E., 1994. Mesoamérica. En: Manzanilla L. y L. Lopez Lujan, (Eds.). Historia Antigua de México: EI México Antiguo, sus Areas Culturales, los Orígenes y el Horizonte Preclásico, Vol. I: 49-74, Instituto Naciona

Miller, A. y B. Schaal, 2006. Domestication and the distribution of genetic variation in wild and cultivated population (Anacardiaceae). Molecular Ecology 15: 1467-1480.

Moreno-Calles, A. I., A. Casas, J. Blancas, I. Torres, O Masera, J. Caballero, L. García-Barrios, E. Pérez-Negró y S. Rangel-Landa, 2010. Agroforestry systems and Tehuacan Valley, Central Mexico. Agroforestry Systems 80: 315-331.

Moreno-Calles, A. I., A. Casas, E. García-Frapolli y I. Torres, 2012. Traditional agroforestry systems of multi-crop "milpa" and "chichipera" cactus forest in the arid Tehuacan Valley Mexico: Their management and role
in people's subsistence. Agroforestry Systems 84 : in people's

Moreno-Calles, A., V. Toledo y A. Casas, 2013. Los sistemas agroforestales tradicionales de México: Un 398.

Moreno-Calles A. I., A. Casas, A. D. Rivero-Romero, Y. A. Bautista-Romero, D. Garrido Rojas, R. A. Fisher, D. Santos Fita, 2016 (a). Ethnoagroforestry: Integration of biocultural diversity for food sovereignty in Mexico. Journal of Ethnobiology and Ethnomedicine 12:54.

Moreno Calles, A. I., A. Casas, M. Vallejo y V. M. Toledo (Ed.).),2016

Navarro-Sigüenza, A. G., M. F. Rebón-Gallardo, A. GordilloMartínez, A. Townsend Peterson, H. Berlanga-García y L. A. Sánchez-González. 2014. Biodiversidad de aves en México. Revist

Olsen, K. y B. Schaal, 2007. Insights on the evolution of a vegetatively propagated crop species. Molecular Ecology

Ortiz, F., K. E. Stoner, E. Pérez-Negrón y A. Casas, 2010. Pollination biology of Myrtillocactus schenckil
(Cactaceae) in wild and managed populations of the
Tehuacán Valley, Mexico. Journal of Arid Environments 74: 897-904.

strom, E., 1990. Governing the commons: The evolution of institutions for collective action. Cambridge University Press. Estados Unidos de América.

ker, I., I. Lopez, J. Petersen, L. Anaya, L. Cubilla-Rios D. Potter, 2010. Domestication syndrome in Caimito (Chrysophyllum cainito L.). fruit and seed characteristics. Economic Botany 64: 161-175.

a, F., A. Casas, J. Peñaloza-Ramírez, A. C. CortésPalomec, V. Rocha-Ramírez y A. González-Rodríguez, 2010. Evolution under domestication: Ongoing artificia selection and divergence of wild and managed Tehuacán Valley, Mexico. Annals of Botany 106: 483-496.

Parra, F., J. Blancas y A. Casas, (2012). Landscape management and domestication of Stenocereus guided selection and gene flow. Journal of Ethnobiology and Ethnomedicine 8(1): 1-17.

Parra, F., A. Casas, V. Rocha, A. González-Rodríguez, S. Arias-Montes, H. Rodríguez-Correa y J. Tovar, 2014 Spatial distribution of genetic variation of Stenocereus pruinosus (Otto) Buxb. in Mexico: analysing evidence on the origins of its domestication. Genetic Resources an Crop Evolution 62(6): 893-912.

Perez-Negrón, E. y A. Casas, 2007. Use, extraction rates and spatial availability of plant resources in the Quiotepec, Oaxaca. Journal of Arid Environments 70(2): 356-379.

Petersen, J., I. Parker y D. Potte, 2014. Domestication of the neotropical tree Chrysophyllum cainito from a
geographically limited yet genetically diverse gene poo

erno, D. y D. Pearsall, 1993. Phytoliths in the Reproductive Structures of Maize and Teosinte: Implications for the Study of Maize Evolution
Science 20: 337-362.

Rangel-Landa, S., P. Dávila y A. Casas, 2015. Facilitation of Agave potatorum: An ecological approach for assisted population recovery. Forest Ecology and Management

Rzedowski, J., 1993. Diversity and origins of the phanerogamic flora of Mexico. En: Ramamoorthy, T., R., A. Bye, A. Lo y J. Fa (Eds.). Biological diversity of Mexico, origins pp. 129-144.

mith, B.D., 2006. Eastern North America as an independent center of plant domestication. Proceedings of the America 103:12223-12228.

Solís Rojas, L., 2006. Etnoecología cuicateca en San Lorenzo Pápalo, Oaxaca. Tesis de Maestría. Posgrado en Ciencias Morelia, Michoacán.

Terrell, J.E., J. P. Hart, S. Barut, N. Cellinese, A. Curet, T Denham, C. M. Kusimba, K. Latinis, R. Oka, J. Palka, 
E. D. Pohl, K. O. Pope, P. R. Williams, H. Haines y J. E. Staller, 2003. Domesticated landscapes: The subsistence ecology of plant and animal domestication. Journal
Archaeological Method and Theory 10(4): 323-368.

Toledo, V. M. y M. J. Ordóñez, 1993. The biodiversity scenario of México: A review of terrestrial habitats. En: T. P. Ramamoorthy, R. Bye, A. Lot y J. Fa (Eds.) Biological diversity of Mexico: origins and distribution. Oxford

Toledo, V. M., 2002. Ethnoecology: a conceptual framework for the study of indigenous knowledge of nature. Ethnobiology and biocultural diversity. Zager (Eds.) Society of Ethnobiology, Georgia: pp. 511-552.

Toledo, V. M. y N. Barrera-Bassols, 2008. La memoria biocultural. Icaria, España.

Toledo, V. M., P. Alarcón-Chaires, P. Moguel, M. Olivo, A. Cabrera, E. Leyequien y A. Rodríguez-Aldabe, 2001. El Atlas Etnoecológico de México y Centroamérica: Fundamentos, Métodos y Resultados. Etnoecológica $6(8): 7-41$.

Torres, I., A. Casas, A. Delgado-Lemus y S. Rangel-Landa, 2013. Aprovechamiento, demografia y establecimiento de Agave potatorum en el Valle de Tehuacán, México: Aportes etnobiológicos y ecológicos para su manejo

Trejo, L., T. P. Feria Arroyo, K. M. Olsen, L. E. Eguiarte, B. Arroyo, J. A. Gruhn y M. E. Olson, 2012. Poinsettia's wild ancestorin Ghe Mexican dry tropics: Historical, genetic, 99: $1146-1157$.

Trejo-Hernández, L., M. E.Olson-Zúnica y R. A. Bye-Boettler, notos
Federal, México. Revista Mexicana de Biodiversidad 86: 478-485

allejo, M. A. Casas, J. Blancas, Ana I. Moreno-Calles, L. Solís, S. Rangel-Landa, P. Dávila y O. Téllez, 2014. Agroforestry systems in the highlands of the Tehuacan Valley, Mexico: Indigenous culture and biodiversity consewation. Agroforesty Systems 88(1): 125-140.

Vallejo, M., A. Casas, E. Pérez-Negrón, A. I. Moreno-Calles, P. Dávila, O. Téllez y O. Hernández-Ordoñez, 2015. Agroforestry systems of the lowland alluvial valleys of of their biocultural cappheity. Reserve. An evaluation and Ethnomedicine 11: 8 Vavilov, N. I. 1992. Origin and geography of cultivated plants. Cambridge: Cambridge Geography of cullivar

Vallejo, Mariana, A. Casas y A. I. Moreno-Calles, 2016. TEK and biodiversity managementin agroforestry systems of different socioecological contexts of the Tehuacán Valley, . Journal of Elmnobiology and Ethnomedicin 12: 31

elásquez-Milla, D., A. Casas, J. Torres-Guevara y A. Cruz-Soriano, 2011. Ecological and socio-cultura factors influencing in situ conservation of crop Jornal of Ethnobiolog and Ethnomedicine $7: 40$ : linea, disponible en: http://www.ethnobiomed.com/ content/7/1/40).

señor J L L 2003 . Diversidad y distribución de las Magnoliophyta de México. Interciencia 28(3): 160-167. Zárate, S., N. Pérez-Nasser y A. Casas, 2005. Genetics of wild and managed populations of Leucaena esculenta subsp. Guerrero, Mexico. Genetic Resources and Crop Evolution 52: 941-957.

\section{Capítulo 4}

Panorama de los recursos genéticos en Perú

\author{
Juan Torres Guevara, Fabiola Parra-Rondinel y Alejandro Casas
}

\section{Resumen}

La zona andina es uno de los principales centros de origen de domesticación de plantas animales en el mundo. Es uno de los denominados "centros vavilovianos" de origen de la agricultura, y posee un alto potencial de diversidad genética aprovechable en múltiples propósitos presentes y futuros. Para el Perú, se han registrado cerca de 4400 especies vegetales nativas con usos conocidos, 1700 especies cultivadas o manejadas y 182 especies de plantas son cultivadas intensivamente y presentan signos avanzados de domesticación. De este panorama surge la necesidad de desarrollar alternativas de uso sostenible de los recursos genéticos, de ampliar nuestras miradas hacia nuevas formas de aprovechamiento e incluir en estas otros recursos biológicos más allá de los convencionales, los cuales son aprovechables y así lo han sido por milenios. En ello radica la clave para ampliar la base de recursos alimentarios y de otras materias primas para la industria, y amortiguar la sobreexplotación de unos cuantos recursos. Los conocimientos de las diversas culturas locales -principalmente las andinas y amazónicas, pero también las de las zonas áridas- contribuyen significativamente a la seguridad alimentaria con estrategias de producción y modelos tecnológicos poco reconocidos por los modelos modernos. Estos modelos son potencialmente de gran eficacia bajo esquemas de manejo capaces de incorporar tal potencial natural y bajo nuevas visiones de la seguridad y de la soberanía alimentaria.

Se presenta en este capítulo una revisión histórica de las tendencias conceptuales y de los cambios institucionales que acompañaron al tema del manejo y conservación de los recursos genéticos, específicamente los recursos fitogenéticos, su relación con los ecosistemas y la biodiversidad en general, así como con la diversidad cultural del Perú, una diversidad biocultural de las más sobresalientes del planeta. Enseguida se examinan los nuevos componentes que sobre este tema han surgido en las últimas décadas, desde el punto de vista técnico como cultural, económico y legal. De manera enfática se analiza el contexto cultural como motor generatriz de diversidad de recursos genéticos, así como los conceptos que conducen a definir a los recursos genéticos como servicios de provisión de los ecosistemas, y las condiciones para su mantenimiento a largo plazo. En este análisis se incluyen nuevos conceptos que son ahora parte del discurso científico contemporáneo y que localmente en el Perú comienzan ser usados recurrentemente en los discursos políticos y legales. Son los casos de la resiliencia, el manejo adaptativo, las "rutas de adaptación iterativas". Todos ellos son elementos que plan- 
tean la necesidad de una institucionalidad acorde con los tiempos en el contexto actual y una cada vez más necesaria, alianza con otros epistemes relacionados con los recursos genéticos y las políticas institucionales.

Es particularmente relevante el caso de los conocimientos tradicionales, ancestrales indíge nas, y sus relaciones interculturales con las sociedades urbanas y rurales. Los derechos de propiedad de los recursos y los derechos de propiedad intelectual asociados al conocimiento de sus propiedades, preparaciones y técnicas culinarias, técnicas de manejo y de conservas y almacenamiento, entre otros aspectos, generalmente son desventajosas para la población rural indígena, y con frecuencia toman mayor ventaja de ellas las corporaciones industriales privadas. Se discute la perspectiva de la investigación y el posible entrelazamiento de acciones entre las ONG, las instituciones gubernamentales, las organizaciones sociales rurales y urbanas y el sector académico para potenciar el aprovechamiento justo y sustentable y la protección de derechos de propiedad y propiedad intelectual de tan importante patrimonio biocultural del Perú.

Palabras clave: Aymaras, Amazonia, Cordillera de los Andes, centros de origen, cultura andina, diversidad genética, domesticación, origen de la agricultura, Perú, quechuas, recursos genéticos.

\section{Introducción}

Los conceptos, al igual que las semillas, cambian, viajan, y con ellos las instituciones y los discursos de las personas que laboran en ellas. Los que hoy son considerados recursos -y antes no lo eran-y aquellos que seguramente mañana lo serán de acuerdo con nuevas capacidadestécnicas que se desarrollen, y asimismo, algunos recursos importantes en el presente podrán ser obsoletos en el futuro. Los recursos son elementos aprovechables por los individuos y las sociedades a distintas escalas de organización (Casas et al., 2016a, 2016b). Algunos en e pasado fueron muy importantes, por ejemplo, los casos del caucho en Brasil (Dean, 1986), la grana cochinilla en México (Chávez-Moreno et al., 2009), o el sisal y el henequén (Carstensen, 1986; Carey, 2010), también en México, entre otros, que representaron el soporte de la economía de algunos países y sin embargo que hoy ya no lo son en la misma magnitud o incluso su mercado se desplomó hace décadas. Y otros que hoy se consideran recursos "potenciales" serán centrales en los mercados y requerimientos del mañana.

El presente capítulo, muestra una visión panorámica de los recursos genéticos del Perú, un país de historia y cultura profunda en la América Latina, de vieja tradición en las interacciones entre las sociedades y los recursos naturales. En esta región se originó la agricultura, aparentemente de forma independiente a otras áreas del mundo y del propio continente americano (Vavilov, 1992; MacNeish 1967, 1992; Harlan, 2005). Se desarrollaron sistemas de manejo sumamente elaborados, técnicamente con base en numerosas especies de plantas que producen tubérculos, pero también con otras que producen semillas, tallos y hojas aprovechables. La región andina es reconocida como el principal escenario del continente americano que mayor- mente aportó a la domesticación de animales (Zeder, 2006a, 2006b). Y, junto con Mesoamérica, fue una de las áreas con organización social más compleja y con un gran desarrollo de técnicas de construcción urbana, así como de sistemas agrícolas con tecnologías sumamente refinadas de manejo de suelos y agua (Rostorowski, 2009, 2011, 2014).

Es ampliamente conocida la leyenda fundacional de las sociedades locales previas a la conquista española. Los Hermanos Ayar tienen entre uno de sus hermanos al llamado Ayar Uchu, el "hermano aji". Y como ellos, un conjunto de personajes, desde los Apus, las montañas, hasta los animales más pequeños que insospechadamente forman parte de la cosmovisión andina (Rostorowski, 2007; 2016), y que hoy en día requieren entenderse para plantear políticas adecuadas de protección de los ecosistemas y de sus componentes. Somos conscientes de lo pretencioso que resulta, aun a nivel de ensayo, abordar el tema de la cosmovisión andina y su relación con el manejo de los recursos y los ecosistemas de los que forman parte. Pero es indispensable llamar la atención sobre la importancia que este hecho tiene. Por ello, en este capítulo se combinará una aproximación que incluye la visión de los manejadores fundamentales de los recursos genéticos regionales, con un carácter aproximativo, de visión panorámica, y su importancia en la elaboración del diseño de políticas apropiadas para su protección y aprovechamiento sustentable.

La historia de la cultura y de la interacción entre sociedades humanas y el entorno andino es larga. Hoy en día se sabe que la ocupación de los territorios andinos por cazadores y recolectores es milenaria, probablemente cerca de 15000 años (Clement, 2017) y que como resultado de esa historia hace aproximadamente 10000 años se iniciaron prácticas agrícolas en la región (MacNeish, 1992; Brack, 2003; Clement et al., 2016). Las culturas andinas desarrollaron una extraordinaria diversidad biocultural, una de las más sobresalientes del denominado Nuevo Mundo. Tal diversidad biocultural tiene expresiones concretas en la gran variedad de especies de plantas, animales y microorganismos aprovechados, la gran diversidad de variedades de cada una de esas especies (tan solo de papas el proyecto in situ registró cerca de 9000 varie dades distintas; véase Torres et al., 2016; Velásquez-Milla et al., 2016), una alta diversidad de sistemas de cultivo combinando elementos silvícolas y domesticados con sofisticados sistemas de manejo de agua y suelos (Figura 4.1). La cultura andina incluyó técnicas y herramientas como las ruedas, las poleas y otros instrumentos, así como una extraordinaria diversidad de técnicas de manejo hidráulico, de las más sobresalientes entre las culturas del mundo (Rostorowski, 2009, 2011, 2014). Y, como se ha mencionado, el arte y la ciencia de la domesticación de plantas, animales y aun microorganismos asociados a los diversos fermentos-ampliamente difundidos y del dominio popular en el Perú contemporáneo- como las chichas, los tocosh, el chocolate, entre una gran variedad de alimentos en los que los microorganismos son los actores cruciales. Cada tocosh y chicha, en diferentes regiones, actuando bajo distintos sustratos (variedades de papas, de maíz y otras gramíneas) son diversidad biológica moldeada con base en procesos que a su vez generaron durante los últimos milenios una elevada diversidad de recursos genéticos.

Las estrategias de generar variedades biológicas constituyeron verdaderas culturas biotecnológicas precolombinas, pero estas son vigentes y continúan desarrollándose y, sin duda, documentar ese conocimiento y técnicas es una de las grandes prioridades de la investiga- 


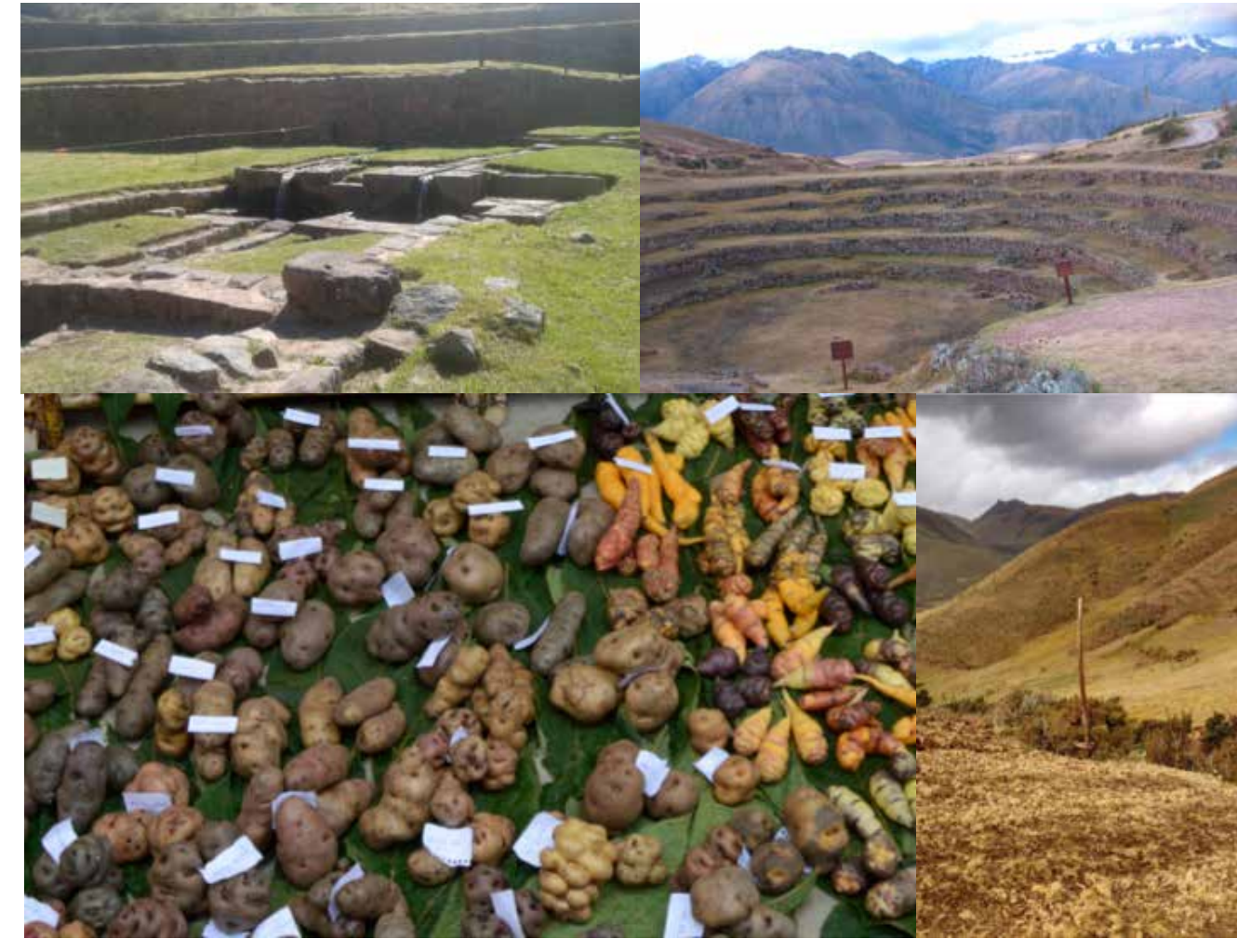

Figura 4.1. Sistemas prehispánicos de manejo de cultivos, agua y suelos: a) sistema de irrigación del período incaico en Tipón, Cusco; b) sistema de andenes concéntricos, Moray, Cusco; c) diversidad de papas, ocas y mashuas presentadas por una familia en la Feria de Semillas o Muru Raymi de Kichki, Huánuco, Perú y d) chaquitaclla amilia en la Fer de Semulacitacla, arado tradicional utilizado para la preparación de la til

ción científica en el Perú. La historia económica del Perú es la historia de interacciones de sus grupos humanos y sus sociedades con los recursos naturales del entorno. Se incluyen los minerales, como el oro y otros metales, la sal, tan importante en todas las épocas, desde luego el agua y el barro. Pero también los recursos bióticos que incluyen el aprovechamiento y manejo del guano, la quinina, el caucho, la anchoveta, la coca y una gran diversidad de cultivos y especies de plantas semicultivadas (Brack, 2003; Brack y Bravo, 2006; Brack et al., 2008). Todos estos recursos marcaron épocas de auge económico, de beneficios sociales y bienestar humano, así como episodios de violencia entre las propias poblaciones indígenas, $y$, desde luego conflictos armados con los conquistadores europeos y hasta con otros países de la región, aun después de la independencia con respecto al imperio español.

El presente capítulo se centra en los recursos genéticos vegetales, otros capítulos de esta obra abordan la domesticación de animales, principalmente los camélidos sudamericanos.
Quedará para el futuro un tratamiento específico sobre la diversidad de comunidades de bacterias y levaduras asociadas a los fermentos utilizados históricamente, y hasta el presente, por las culturas del Perú. El enfoque de este trabajo es principalmente conceptual, y procura analizar sobre todo la perspectiva histórica de las ideas y de las instituciones peruanas que han trabajado sobre la gestión de recursos bióticos y, de forma explícita, de los recursos genéticos. Los conceptos han cambiado de manera continua con el desarrollo de la ciencia y la técnica; el proceso ha sido acelerado desde el siglo XVIII, pero particularmente se ha incrementado durante los siglos XX y XXI. Con los cambios conceptuales las instituciones adecúan sus visiones del mundo o se convierten en entidades obsoletas que desaparecen más temprano que tarde. Desde luego, cuando se trata de instituciones que toman decisiones, sus referentes y criterios en las políticas que llevan a cabo son tales cambios conceptuales, y este es el caso de las instituciones que regulan las interacciones entre sociedades y naturaleza.

Como se discute arriba, el discurso científico contemporáneo sobre un tema particular cambia continuamente, así como la ciencia y sus conceptos tienen una historicidad. $Y$ tal historicidad permea la visión de la sociedad sobre el mundo; los temas principales de esta obra, los recursos genéticos y su domesticación, no fueron la excepción. Es hasta las primeras décadas del siglo XX cuando en el mundo comenzó a hablarse de recursos genéticos, aún antes de entender la naturaleza de los mecanismos de la herencia. Recordemos, los experimentos de Mendel de mediados del siglo XIX fueron descubiertos y relanzados a la visión científica moderna en 1909 por Hugo de Vries (véase Casas y Parra, 2016), pero la identificación del ADN como molécula asociada a estos procesos es de un par de décadas posteriores, mientras que la estructura del ADN fue dilucidada por Watson y Crick en 1953 (Watson y Crick, 1953) y la ingeniería genética dio sus primeros pasos durante la segunda mitad de la década de los setenta (Herrrera-Estrella et al., 1983a, 1983b). De la misma forma, las instituciones que actualmente tienen como tema principal la conservación y el manejo de los recursos genéticos no existieron (en Europa) sino hasta finales del siglo XIX, cuando se comprendió la importancia de emplear mediante el entrecruzamiento de organismos con características deseables, la posibilidad de mejorar la calidad de los recursos aprovechables. El desarrollo de las técnicas y políticas a nivel mundial influyeron la conformación de las instituciones y las políticas educativas y de investigación. Es este, por ejemplo, el caso de la Revolución Verde y el establecimiento de Centro Internacional de la Papa (CIP) (Brush, 1992, 2005; Conway, 1998; Delgado y Zwarteveen, 2008; Zimmerer, 1991)

El Perú, y en particular la región andina, se encuentran ubicados en un área donde los seres humanos tienen una vieja relación con la naturaleza. Así lo demuestran numerosas evidencias materiales, principalmente la extraordinaria riqueza de restos arqueológicos que se aloja en los museos regionales y aquellos que están aún por descubrirse. Se incluye la enorme diversidad de elementos de cerámica, orfebrería, gráfica mural y textil. Toda esta riqueza arqueológica incluye la representación de una gran diversidad de elementos fitomórficos y zoomórficos que muestran el peculiar simbolismo que para las culturas precolombinas significaron las plantas y animales tanto silvestres como domesticados. $Y$ desde luego, los importantes yacimientos de restos arqueológicos humanos, de plantas y de animales son evidencia directa que ha permitido una reconstrucción de la historia del manejo, de la evo- 
lución bajo procesos de domesticación, una de las historias más completas que se han logrado reconstruir en el continente americano (MacNeish, 1992). Lo mismo puede decirse de los grupos humanos que habitaron el área alto-andina, como también de aquellos que ocuparon las zonas áridas y las del trópico húmedo de la región amazónica del Perú. La cultura de estos pueblos no es solamente historia, es vigente y en continua renovación y ajuste de acuerdo con los tiempos actuales. El objetivo de este análisis es mostrar de una forma panorámica, y como una primera aproximación, un recorrido de la historia de las culturas andinas y su legado material y simbólico. Posteriormente analizaremos los cambios conceptuales de las instituciones y de los discursos que de estas surgieron. La primera aproximación comprende períodos de miles de años, la segunda se centrará en los últimos 65 a 70 años de la historia del Perú, período en el que ocurrieron las grandes transformaciones en la política agraria (entre otras la Reforma Agraria) y el proceso de inserción del Perú en el proyecto de Revolución Verde (Zimmerer, 1991; Eguren, 2006; Delgado y Zwarteveen, 2008). Asimismo, los grandes cambios tecnológicos, desarrollo institucional y políticas públicas que involucraron el manejo de recursos genéticos en relación directa con ese proyecto.

\section{Reseña histórica del concepto de recursos genéticos}

En el largo camino de aprovechamiento, conservación y recuperación de los recursos vegetales andinos, debe considerarse el papel pionero de los cronistas de la conquista y del período colonial. Los protomédicos, los geógrafos y naturalistas que documentaron el estado de conocimientos y condiciones del Perú, justo al momento de la conquista, permiten visualizar lo que ocurría en la región antes del contacto con los europeos. Después, fueron particularmente destacados los trabajos de los naturalistas botánicos, zoólogos y geólogos que entre los siglos XVII y XVIII viajaron de Europa para continuar y profundizar el inventario de las posesiones de imperio, dejando un valioso legado de información de gran utilidad para la ciencia contemporánea. Así, todos los textos referidos en esta sección tenían como propósito principal efectuar prospecciones de los recursos naturales del actual territorio andino, amazónico y árido de Perú, con el fin de inventariar la riqueza del imperio español. Desde finales del siglo XV y principios del siglo XVI fue el mismo proceder en Cuba y las islas del Caribe (Colón, 1998), el siglo XVI en México, el Perú (De las Casas, 1875, 1964; Díaz del Castillo, 1982; Sahagún, 1992) y las zonas ocupadas por los colonizadores. Pero más allá de la naturaleza de sus fines colonialistas, las descripciones de los naturalistas y protomédicos son documentos altamente valiosos para las distintas ciencias naturales y sociales.

En el último siglo (XX y XXI) ha sido de gran importancia el aporte de los intelectuales peruanos: botánicos, agrónomos, biotecnólogos y científicos sociales (principalmente historiadores y antropólogos) que han contribuido sustancialmente a la reconstrucción de tan fascinante historia con enfoques y motivaciones distintas, pero todas ellas buscando construir una visión propia, la visión peruana de nación. Un trabajo excepcional para complementar la visión panorámica que aquí se muestra, es el trabajo de Mario Tapia (Tapia, 1999), en cuyo libro Agrobiodiversidad en los Andes destaca los grandes momentos históricos del conocimiento de los recursos naturales andinos. Cada uno de los momentos reseñados por Tapia está asociado a un campo de las ciencias naturales, por ejemplo, las primeras observaciones de la época de la conquista y la colonia (siglo XVI - XVII) están asociadas al trabajo de los cronistas, el siglo XVIII está relacionado con e trabajo de los geógrafos y los primeros botánicos y etnobotánicos tienen gran presencia en el siglo XIX. A continuación una reseña de los cuatro momentos resaltados por Tapia (1999).

\section{Las observaciones de los cronistas} de la Conquista y la Colonia

Entre las principales contribuciones que hoy en día son invaluables fuentes históricas se pueden mencionar las obras monumentales de Garcilaso de la Vega (De la Vega, 1991) y las de Guamán Poma de Ayala (Poma de Ayala, 1991), pero también las contribuciones parciales de numerosos cronistas, entre ellos destacando los escritos de Pedro Cieza de León (Cieza de León, 1913, 1922, 2002), Agustín de Zárate (Zárate, 1991), Calancha (Porras-Barrenechea, 1962) y los del padre Jesuita Bernabé Cobo (Cobo, 2017), quienes hicieron referencias a la gran variedad de cultivos y plantas útiles de distintas regiones del Perú. De particular valor es el trabajo de Bernabé Cobo, quien documentó las denominaciones que los indígenas quechuas utilizaban para clasificar los grandes ecosistemas, las cuales se siguen utilizando en la actualidad; estas son las zonas de Yunga, Quechua y Puna que hacen referencia a los pisos altitudinales. También hace referencia a las especies vegetales y variedades de cultivos que eran y son propios en cada una de dichas zonas. En el Perú estas unidades ambientales son significativas como pisos altitudinales, a escala continenta son visibles en un plano latitudinal.

\section{Los antropólogos e historiadores}

Son de gran trascendencia las investigaciones antropológicas, arqueológicas e históricas de un amplio espectro de investigadores peruanos y extranjeros que analizaron la conformación de las civilizaciones antiguas en relación con el desarrollo del manejo de recursos genéticos en sistemas agro-silvo pastoriles. Las investigaciones de Duccio Bonavia (Bonavia, 1991, 1993 2014) y las de Grobman et al. (2012) contribuyeron con grandes aportaciones a los estudios sobre la diversidad de maíces y la cultura que esta mueve y promueve. Son también de gran relevancia los estudios arqueológicos de la prehistoria de Frederic Engel (Engel, 1967, 1987) Bernardino Ojeda (Sandweiss et al., 1998; Quilter et al., 1991; Benfer et al., 2010), entre otros que siguieron los pasos clásicos de las investigaciones iniciadas en los años sesenta por Richard S. MacNeish (1992), Eric O. Callen, Kent B. Flannery, Barbara Pickersgill, entre otros grandes de este campo de la investigación. John Murra $(1984,1985,2002)$, aportó grandemente con sus análisis acerca del manejo vertical del espacio de las montañas andinas por las culturas del área. John Earls (1971, 1986, 1989, 1996, 2009), Enrique Mayer (2002, 2004), Stephen Brush (2008), Ángel Mujica (Mujica et al., 1996, 2006) y Zimmerer (1993), entre otros investigadores, han efectuado contribuciones significativas desde perspectivas culturales, geográficas e históricas a la comprensión del modelaje de la agrobiodiversidad asociada a los procesos de domesticación en el Perú. 


\section{La visión de los geógrafos y de los primeros botánicos}

En el siglo XVIII se realizaron expediciones naturalistas que incluyen en sus descripciones la documentación de la flora y fauna, aspectos geográficos y valiosas anotaciones antropológicas con fines científicos, que hoy en día son cruciales para analizar los cambios paisajísticos ocurridos en los últimos siglos. Naturalistas españoles como Hipólito Ruiz y José Pavón quienes realizaron una extraordinaria expedición naturalista en Perú, Ecuador y Chile (Muñoz-Garmendía, 2004). Tadeo Haenke, quien llevó a cabo la importante expedición de 1789 a 1794 en Perú y Bolivia (Ibáñez, 1989), y Joseph Dombey (naturalista francés descubridor de la quinina), fueron de los primeros en hacer importantes aportaciones al conocimiento botánico andino. Reconocieron la excepcionalmente valiosa riqueza de la flora del Perú, y trabajaron con particular detalle los componentes de la flora de la región andina. Sus colecciones y descripciones botánicas son hoy en día de gran importancia para todo aquel que incursiona en el entendimiento de cualquier grupo de organismos en la región.

A principios del siglo XIX, en 1802, Alexander von Humboldt y Aimé Bonpland (Humboldt 1991, 1995) recorrieron el sur de Ecuador y el norte del Perú, dejaron un importante legado de descripciones e iconografía de inmenso valor. Quizá el mayor viraje en el enfoque de investigación lo imprimió Giovanni Antonio Raimondi Dell'Acqua, quien en 1859 recorrió todo el país, logrando recolectar un amplio herbario (Raimondi, 2005). Publicó varias obras, pero entre estas son de particular importancia sus libros Elementos de Botánica aplicada a la Medicina y a la Industria y El Perú (Raimondi, 2005). Las plantas, la botánica, la etnobotánica e incluso la ecología vegetal encuentran en estas obras los fundamentos de la ciencia moderna del Perú.

\section{Los botánicos: la etnobotánica y el conocimiento local de las plantas útiles}

Entre 1922 y 1933 Fortunato Herrera (Herrera, 1930) realizó importantes colecciones botánicas en la región sur del Perú, las cuales le sirvieron de base para publicar el trabajo El mundo vegetal de los antiguos peruanos (1941). César Vargas, un botánico cusqueño, continuó estos importantes trabajos durante la década de los años cuarenta. Es también durante ese período en el que se gestaron numerosas publicaciones sobre la flora en general y la flora utilizada por los pueblos tradicionales del Perú. Así, en 1945 apareció El mundo vegetal de los Andes peruanos, por Augusto Weberbauer (Weberbauer, 1945), botánico alemán que trabajó por largos años estudiando la flora peruana, y quien estableció las bases metodológicas y de sistematización de información para un conocimiento botánico científico y ordenado de la vegetación de los Andes (Figuras 4.2a y 4. 2b). También se debe mencionar al padre Jaroslav Soukup, quien a inicios del siglo XX llevó a cabo numerosas colecciones botánicas, recogiendo los nombres tradicionales de las especies de importancia económica y medicinal (Soukup, 1970).

En las últimas décadas han hecho grandes aportes las consideradas tres escuelas botánicas más importantes del Perú: las de la Universidad Nacional de San Marcos, la Universi- dad Nacional San Antonio de Abad del Cusco y la Universidad Nacional de la Libertad-Trujillo. Estas instituciones han llevado a cabo los principales inventarios florísticos del país y establecido los herbarios de mayor envergadura para respaldar los inventarios nacionales de flora del Perú. Son de particular relevancia las investigaciones florísticas de investigadores de la Universidad Nacional de San Antonio Abad, entre ellos destacan los trabajos de Washington Galiano (Phillips et al., 2003a, 2003b; Ccana-Ccapatinta et al., 2014) y Rosa Urrunaga (Senatore et al., 1998; De Feo et al., 1998; Huamantupa et al., 2011). Por un lado, estos esfuerzos y las numerosas investigaciones que se están trabajando en zonas andinas, áridas y en la amazonía han permitido identificar al Perú como un país megadiverso. Por otro lado, en la Universidad Nacional de la Libertad-Trujillo destaca la labor científica del profesor Abundio Sagástegui, el cual aportó al conocimiento de la flora peruana con decenas de publicaciones en revistas nacionales y extranjeras (Rodríguez y León, 2012) y fue en esta misma universidad donde surgió el gran botánico Isidoro Sánchez, conocido como "el padre de las Jalca" por promover el estudio, descubrimientos botánicos y conservación de este singular ecosistema del nororiente peruano, también fue investigador en la Universidad Nacional de Cajamarca, en la Nacional de Piura e investigador asociado del Field Museum of Natural History en Chicago y de la Ohio State University Herbarium (Funk, 2016).

La Universidad Nacional Mayor de San Marcos es una de las instituciones académicas con mayor trayectoria en investigaciones etnobotánicas, lo cual inicia formalmente con la apertura del curso de Etnobotánica en el año 1950 (La Torre-Cuadros y Alban, 2006), por parte de la Dra. Emma Cerrate (Cerrate de Ferreyra, 1979) y la formación de una importante cantidad de etnobotánicos como Joaquina Albán $(1998,2008)$, entre otros.

\section{Los agrónomos}

Paralelamente, es de destacarse el trabajo sobresaliente del agrónomo Carlos Ochoa Nieves, quien realizó importantes y minuciosos estudios sobre las papas del Perú, incluyendo la enorme diversidad de papas cultivadas y los parientes silvestres de estas. Ochoa nació en Cusco en 1920 y realizó un profundo trabajo botánico, genético y taxonómico entre 1950 y 1995. Su trabajo de cerca de cuatro décadas alcanza la cúspide con la publicación de su obra Las Papas de Sudamérica: Perú (Parte I) (Ochoa, 1999), y poco después la que se refiere a las papas de Bolivia. En estas obras, Ochoa hace contribuciones fundamentales al estudio y clasificación de más de 12000 muestras de papas nativas cultivadas, agrupándolas en 11 especies y en 3600 morfotipos diferentes caracterizados con base en rasgos morfológicos, muchos de los cuales fueron retomados en los descriptores de papas del Centro Internacional de la Papa (CIP) que se utiliza en la actualidad. Asimismo, colectó y revisó cerca de 4000 ejemplares herborizados del género Solanum, que incluían cerca de 2000 muestras de sus propias colectas botánicas y, el resto, especímenes voucher de distintos herbarios de mundo. Su análisis permitió identificar, de acuerdo con su criterio, a 140 especies del género Solanum considerados parientes silvestres de las papas cultivadas. Así que el gran legado del conocimiento de las papas sudamericanas tienen en Carlos Ochoa uno de los principales referentes (Figura $4.2 \mathrm{c}$ ). 


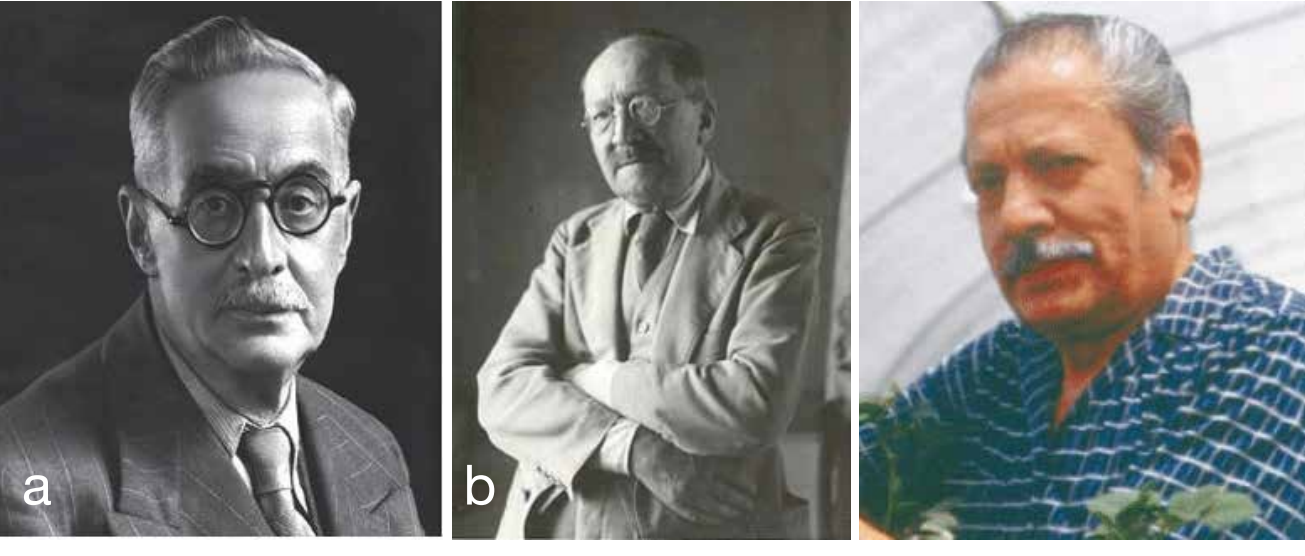

Figura 4.2. Botánicos y agrónomos que contribuyeron al conocimiento sobre los recursos genéticos en el Perú:

a) Fortunato Herrera b) Augusto Weberbauer y c) Carlos Ochoa

De alguna manera, sus años de estudio dieron continuidad y permitieron desarrollar la visión científica y experiencia iniciada por el Profesor Nicolai Ivanovitch Vavilov, uno de los investigadores más destacados de la historia de los recursos genéticos vegetales en el mundo. Vavilov tuvo una activa vida académica hasta 1942, año en el que el régimen estalinista de la Unión Soviética lo condenó a trabajos forzados en Siberia y murió en prisión en 1943. Vavilov organizó expediciones a Mesoamérica y a la región Andina a finales de 1920 y principios de 1930, cuando Ochoa era un joven adolescente. Sin embargo, Ochoa siguió de cerca el trabajo de Vavilov y de sus colaboradores, y lo conoció a detalle para erigir su importante obra. En relación con el trabajo de Vavilov, Carlos Ochoa relata que:

"En 1925, siendo director del Instituto de Botánica Aplicada, el ilustre profesor Nicolai Ivanovitch Vavilov, mundialmente conocido por sus grandes contribuciones sobre el centro de origen de las plantas cultivadas, envió a América una expedición científica encomendada preferentemente a la recolección y estudio de las papas cultivadas nativas y sus ancestros silvestres. Así, Sergei M. Bukasov exploró y recolectó en México, Guatemala y Colombia (Bukasov, 1930), mientras que Juzepczuk lo hizo en Perú, Bolivia y Chile (Juzepczuk y Bukasov, 1929). Aunque no se conoce un itinerario detallado de sus viajes de recolección, Juzepczuk llegó a Lima a principios de 1927. Se sabe que concentró sus trabajos de campo en los departamentos de Junín y Pasco, en la sierra central y en el departamento de Cusco, al sur del Perú." [En 1933 Juzepczuk y Bukasov publicaron el libro The potatoes of South America and their breeding possibilities].

Asimismo, relata que:

"A fines de 1932, el célebre biólogo N. I. Vavilov, después de hacer extensas recolecciones en América Central y Ecuador, pasó al Perú, donde estuvo muy pocos días. En esa oportunidad y en compañía de A. Weberbauer, visitó Lima y sus vecindades; entre las formaciones lomales cerca de Chorrillos recolectaron tubérculos de una papa silvestre que poco tiempo después fueron reproducidos en Leningrado, dando origen a una nueva especie silvestre que Juzepczuk y Bukasov describieron bajo el nombre de S. vavilovii." (Ibid)

Para Carlos Ochoa, el trabajo de Vavilov y sus colaboradores fue una fuente primaria de inspiración y de aportes teóricos y metodológicos. Por ejemplo, Vavilov (1992) utilizaba los conceptos de "plantas cultivadas primarias", "especies y variedades salvajes", diversidad varietal, diversidad racial, variedades y razas en su sistema de clasificación de plantas cultivadas y parientes silvestres. Vavilov (1992) incluye dentro de un solo grupo ecológico a las plantas cultivadas primarias y a las especies y variedades salvajes más cercanas con estas, justamente por sus afinidades ecológicas, y resalta cómo en el caso de las montañas existirían condiciones óptimas que promueven la diversidad varietal y la diferenciación de razas y variedades, así como la conservación de una amplia gama de tipos fisiológicos (Vavilov, 1951). Algunas de esas categorías fueron utilizadas por Ochoa y aún en la actualidad son utilizadas por especialistas en estudios de plantas domesticadas (Figuras 4.3a y 4.3b).
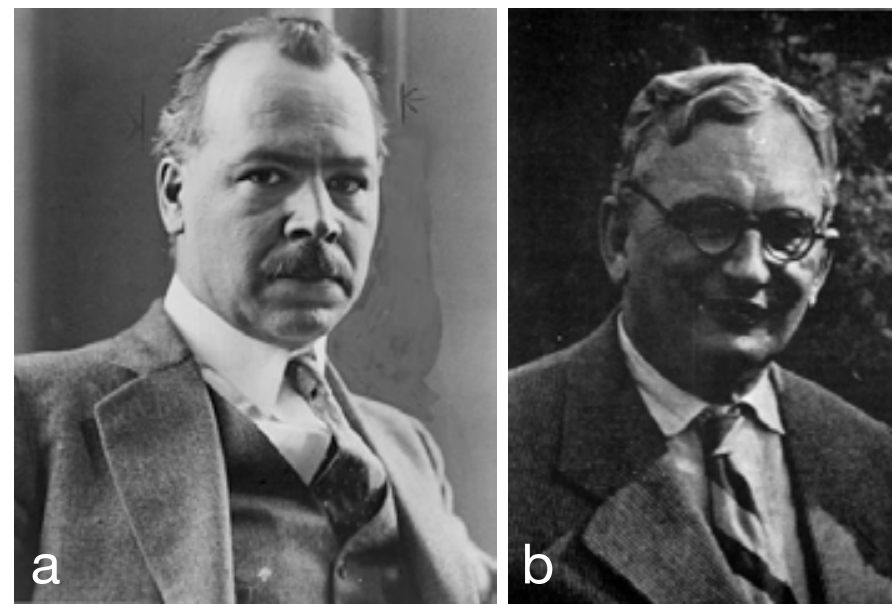

Figura 4.3. Agrónomos rusos que contribuyeron al conocimiento sobre los recurso genéticos en el Perú: a) Nikolai Vavilov y b) Sergei V. Juzepczuk

En la década de 1960, un destacado aporte fue el trabajo publicado por Grobman et al.(1961), Races of Maize in Peru. Their origins, evolution and classification. Esta publicación centra su atención en la documentación de la diversidad genética de maíz en la región andina del Perú. En los años setenta, los cultivos nativos comenzaron a ser un tema de importancia para las ciencias agrarias, los trabajos de Vavilov, Grobman et al. (1961), Weberbauer (1945), Raimondi, Fortunato Herrera (1930) y los del propio Carlos Ochoa constituyen los cimientos de esta etapa de gran productividad científica. Es la época en la que adquirió mayor ímpetu la importancia de reconocer las variedades de cultivos productores de granos y tubérculos, y las de los frutales, el reconocimiento y el valor de las variedades locales de cultivos exóticos. Es la época en que adquiere auge la conservación ex situ de recursos genéticos, el mejoramiento genético de los 
principales cultivos comerciales, la búsqueda de estrategias para maximizar la productividad de alimentos y materias primas para la industria. Es la época del proceso de inserción de la Revolución Verde en el Perú y en otras partes del mundo, y es la época en la que despertó la crítica al modelo (Freire, 2009).

En Las papas de Sudamérica: el Perú, el Dr. Carlos Ochoa (1999) señala que en reuniones realizadas en el Centro Internacional de la Papa en los años 1973 y 1974 ya se trataba el tema de la erosión genética, aunque aún eran poco claras las investigaciones y políticas públicas para abordarla. Es la época en la que Frankel (1974) plantea su análisis sobre el proceso y comienzan a adoptarse medidas institucionales desde la FAO al respecto (Casas y Velásquez-Mila, 2016). Ya para entonces, Ochoa había realizado varios diagnósticos en distintas áreas del Perú y de Sudamérica, incluyendo su estudio clásico sobre la disminución temporal de las variedades de papa de Chiloé (Ochoa, 1999; Velásquez Milla et al., 2011).

De acuerdo con Mario Tapia (Tapia, comunicación personal 2016) y Enrique Moya (Moya comunicación personal 2016), ambos especialistas en el estudio y manejo de recursos genéticos, el concepto "recursos genéticos" se comenzó a utilizar, explícitamente, en el medio académico del Perú a partir de mediados de los años sesenta. De acuerdo con Tapia (comunicación personal, 2016), es en el año 1978 cuando, a nivel andino, se construyeron los bancos de germoplasma de granos y tubérculos: en Bolivia se construyeron dos y en Perú se impulsaron tres. Este proyecto fue posible gracias al financiamiento del International $\mathrm{Bu}$ reau of Plant Genetic Resources (IBPGR, ahora Biodiversity) y la coordinación institucional del Instituto Interamericano de Cooperación para la Agricultura (IICA). La marcha de estos proyectos y las políticas de colectas y documentación de los materiales permitió transitar del concepto de almacenar y conservar semillas a coleccionar accesiones representativas de as variedades de especies portadoras de tales semillas; es decir, la política de conservación dio un importante viraje hacia la valoración de los genes y su conservación a partir de esas muestras o accesiones.

De todos los investigadores de la década de los sesenta pueden destacarse los trabajos de Alexander Grobman (Grobman et al., 1961), Miguel Paulette, Wilfredo Salhuana, Alfonso Cerrate, Manuel Arca (Molestina, 2002), entre otros (Figura 4.4). En los años setenta sobresalen los de Carlos Ochoa (Ochoa, 1999), Oscar Blanco de la Facultad de Agronomía y Zootecnia de la Universidad de San Antonio Abad de Cusco, quien fundó el Centro de Investigación en Cultivos Andinos (CICA) en 1976 y fue asesor de la FAO en temas de recursos genéticos, Julio Valladolid, fundador e impulsor del Proyecto Andino de Tecnologías Campesinas (PRATEC) con énfasis particular en la investigación sobre saberes locales (Valladolid, 1993, 1998, 2002), Miguel Holle (Molestina, 2002), Mario Tapia (Tapia, 2016), Ricardo Sevilla y Rolando Egúsquiza, experto en el género Solanum, uno de los mayores conocedores de papa domesticada y silvestre en el Perú (Egúsquiza, 2000; 2015). Es de destacarse que los investigadores de esta última generación comenzaron a subrayar y a incorporar al lenguaje de la literatura mundial el término de "recursos genéticos andinos". Un término que, sobre todo a partir de la reunión de la Cumbre de la Tierra en Río de Janeiro en 1992, comenzará a tener un significado de particular relevancia en el contexto de la protección de los derechos de propiedad y propiedad intelectual.

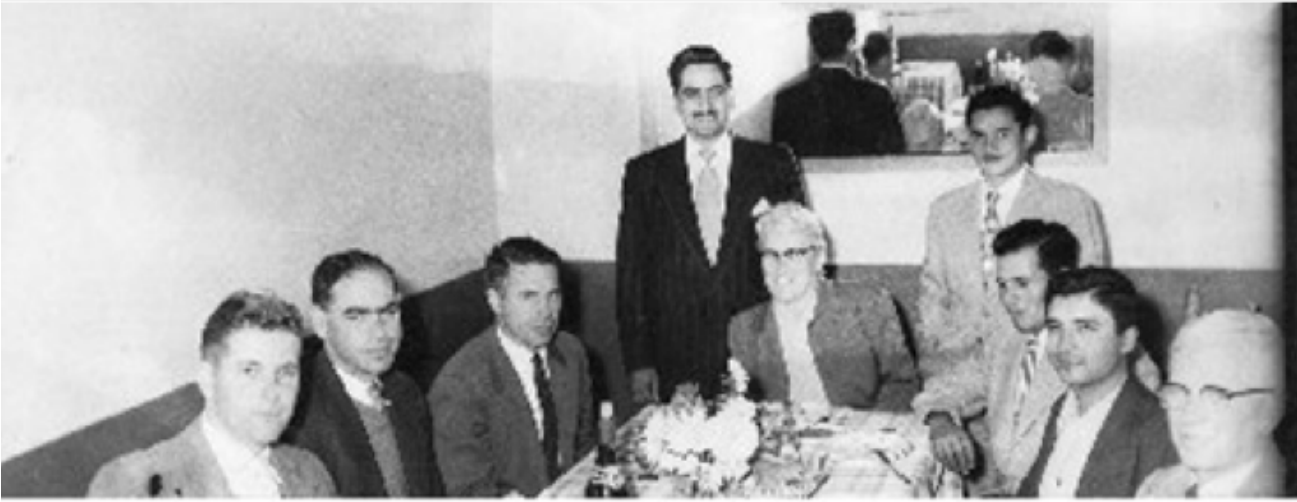

Figura 4.4. De izquierda a derecha: Federico Scheuch, Alexander Grobman, Earl E. Smith, Miguel Paulette, Helen P. Mangelsdorf, Wilfredo Salhuana, Alfonso Cerrate, Manuel Arca y Paul C. Mangelsdorf (Foto: Wilfredo Salhuana).

\section{La biotecnología y los recursos genéticos en el Perú}

Los biotecnólogos son otro grupo de investigadores que se inscriben en este proceso, Marce Gutiérrez Correa en su artículo El camino de la biotecnología en la Universidad Nacional Agraria La Molina, Perú (2012) señala que ya en 1973 surge la ingeniería genética, y con ella el advenimiento de la "biotecnología" término que había sido acuñado en 1917 por el húngaro Kar Ereky (Fári y Kralovánszky, 2006). En los últimos doce años, los avances de ambas disciplinas son espectaculares, afirma Gutiérrez-Correa (2012), con avances que van desde la ingeniería biológica hasta la genómica funcional transcriptómica, proteómica, metabolómica y flujómica) (Klamt y Stelling, 2003; Villena y Gutiérrez-Correa, 2008; Weld et al., 2006)

Pero aun antes que la ingeniería genética, la biotecnología tuvo una historia de gran trascendencia a nivel mundial. La biotecnología consiste en el manejo de seres vivos en procesos tecnológicos. Su historia es, por lo tanto, muy antigua, tanto como lo es el manejo de los organismos mediante selección artificial; es decir, tan antigua como la domesticación (Casas et al., 2016b). Las técnicas modernas del mejoramiento a partir de la manipulación de los sistemas reproductivos, el fomento de variabilidad genética a partir del manejo de agentes mutagénicos, las cruzas de linajes favorables, el manejo de protoplastos, la fecundación in vitro, el trasplante de embriones, son todas técnicas que ilustran el legado de la comprensión de los mecanismos reproductivos y el desarrollo de técnicas que continúan estableciendo pautas en las escuelas de biotecnología peruanas y del mundo. La ingeniería genética en el Perú ha tenido desarrollo regulado a partir de la moratoria al uso y liberación de organismos genéticamente modificados, y han sido instituciones como el CIP o el INIA los principales centros desde donde se han desarrollado y mantenido los incipientes esfuerzos de investigación en ingeniería genética.

En efecto, a nivel nacional existen diversos niveles de implementación del uso de la biotecnología, como lo ha representado Pastor (2016). El uso de la biotecnología en el Perú se 
implementa de manera más amplia, por su difusión y demanda, a nivel de los agricultores organizados, quienes son los principales usuarios de los productos resultantes del cultivo de tejidos, micropropagación, entre otros. En contraparte, el uso de la ingeniería genética es menos difundido y es aplicado por instituciones nacionales en casos concretos, siempre con apoyo de la cooperación internacional, debido a los avances en conocimientos y en herramientas biotecnológicas que se hallan más difundidas fuera del país. Sin embargo, el mayor apoyo suele ser para este último nivel de implementación (véase Figura 4.5) y como dice Pastor (2016):

"[...] la finalidad de la biotecnología sería la de valorar y promover la agregación de valor a los recursos genéticos, coadyuvando a la distribución justa y equitativa de los beneficios que se deriven de su utilización. La implementación de estas biotecnologías requiere fundamentalmente de beneficiarios (agricultores) organizados y capacitados, pero también de apoyo político y económico desde el Estado y del apoyo de la cooperación internaciona"

\section{NIVEL DE}

\section{IMPLEMENTACIÓN}

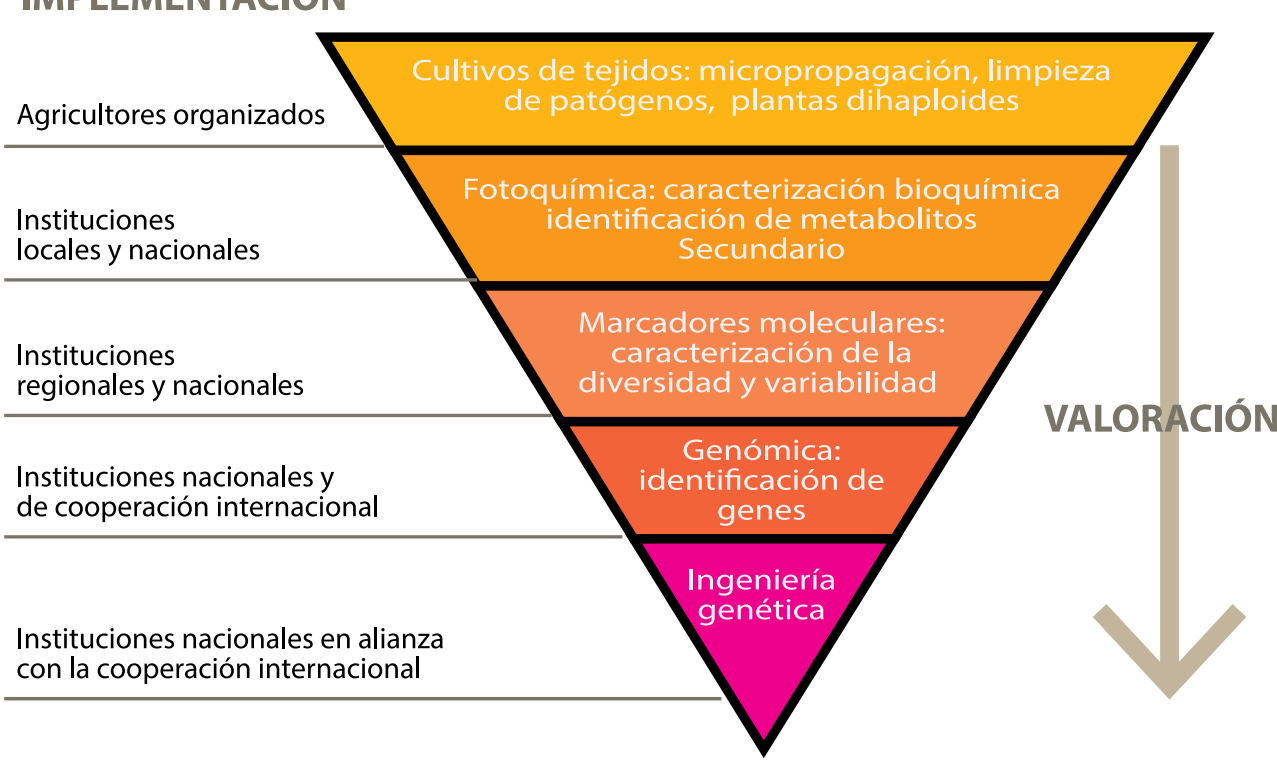

BENEFICIO JUSTO Y EQUITATIVO

Figura 4.5. Pirámide del uso de la biotecnología en el Perú. Tomado de Pastor (2016).

\section{El concepto de recursos genéticos en los organismos oficiales ambientales nacionales}

En el impulso del concepto de "recursos genéticos" la FAO (creada en 1945) tiene un pape muy importante. A partir del documento 70 Años de la FAO (1945-2015) de la FAO (2015) se presenta la siguiente cronología de los conceptos asociados a los recursos genéticos. Entre 1957-1961, es la FAO la institución que impulsa la Campaña Mundial de la Semilla, y con ello se habla también de variedades mejoradas. Durante la década de 1960, los investigadores

observaron que las enfermedades, la contaminación ambiental y las prácticas agrícolas estaban causando una alarmante disminución de la biodiversidad en todo el mundo. La protección de la biodiversidad era crucial para impulsar la productividad de los ecosistemas y una investigación bien planificada y ejecutada dirigida a su conservación podría ser enormemente beneficiosa... (FAO, 2015).

En 1965 se empieza a hablar de recursos fitogenéticos y la contaminación ambiental (Conferencia de las Naciones Unidas sobre el Medio Humano celebrada en Estocolmo en 1972). Se pidió a la FAO que actuara para conservar la agricultura, la silvicultura, la pesca y otros recursos naturales, y que fortaleciera la labor que ya estaba realizando). Además, en 1965 FAO nombra un grupo de expertos para estudiar los posibles métodos de protección de los recursos Fitogenéticos.

Finalmente, la Conferencia de la FAO de 2001 adoptó el Tratado internacional sobre los recursos fitogenéticos para la alimentación y la agricultura, jurídicamente vinculante, para de esta manera apoyar el trabajo de los ganaderos y agricultores de todo el mundo (pág. 41). E Tratado se considera de mucha importancia en el logro del objetivo de posibilitar la continuidad de la disponibilidad de los recursos fitogenéticos que los países necesitan para alimentar a su población y a las generaciones futuras. El Tratado entró en vigor en 2004.

El Convenio sobre la Diversidad Biológica CDB (1993) ha jugado un papel importante en el desarrollo de los conceptos consensuados referidos a los recursos genéticos, definiéndolos de la siguiente manera: por recursos genéticos "se entiende el material genético de valor real o potencial", por material genético se entiende "todo material de origen vegetal, animal, microbiano o de otro tipo que contenga unidades funcionales de la herencia". (Secretaría de Convenio sobre la Diversidad Biológica. 2001. Convenio sobre Diversidad Biológica. Textos y anexos. Finalmente, y más reciente aún, el MINAM, "punto focal" nacional de la CDB, en su Quinto Informe (2014) se refiere a los recursos genéticos como uno de los servicios de aprovisionamiento de los ecosistemas, que es una nueva forma de ver a los recursos genéticos.

A nivel nacional, entre los primeros registros bibliográficos en los que se usa el término "recursos genéticos" en el Perú se encuentran dos publicaciones de 1976 registradas en la Biblioteca Agrícola Nacional (BAN) de la Universidad Nacional Agraria La Molina (UNALM): Vincent et al. (1976) y Tonsmann et al. (1976). El libro Recursos Genéticos Vegetales de Sevilla y Holle (1995) es un gran aporte al tema de los recursos genéticos. 


\section{Reseña histórica institucional relacionada con los recursos genéticos}

\section{Instituciones a nivel internacional}

Ya se ha mencionado el papel tan importante que ha jugado desde 1945 la FAO en el proceso de formación del concepto de "recursos genéticos". Sin embargo, existe otra institución importante en este proceso: el Instituto Internacional de Recursos Fitogenéticos (IPGRI, por sus siglas en inglés). Un instituto de investigación internacional con el mandato de avanzar en la conservación y el uso de la diversidad genética para el bienestar de las generaciones actuales y futuras. Es un Centro del Grupo Consultivo sobre Investigación Agrícola Internaciona (CGIAR, por sus siglas en inglés). A partir de diciembre del 2006, IPGRI opera bajo el nombre Biodiversity International.

También es importante la instancia denominada Grupo Consultivo para la Investigación Agrícola Internacional (CGIAR). El CGIAR fue establecido en 1971, patrocinado por el Banco Mundial, la FAO y el PNUD, desempeñando un papel muy importante en el cambio de discurso relacionado con los recursos vegetales. La misión del CGIAR es contribuir a la seguridad alimentaria y a la erradicación de la pobreza en los países en desarrollo a través de la investigación, el patrocinio, la creación de capacidad y el apoyo político mediante la promoción del desarrollo agrícola sostenible basado en una ordenación ambientalmente racional de los recursos naturales. Hay cinco temas principales de investigación: (1) el aumento de la productividad; (2) la protección del medio ambiente; (3) el salvamento de la biodiversidad; (4) políticas de mejora y (5) fortalecimiento de la investigación nacional. Dieciséis centros internacionales de investigación agrícola (IARCs), también conocidos como "Centros de Aprovechamiento Futuro", forman la red mundial de CGIAR, realizando programas de investigación en colaboración con una serie de instituciones patrocinadoras. (Portal web FAO: http://www.fao.org). El convenio Internacional de los RRGG por la FAO es un hito muy importante para la valoración de los RRG y su propiedad intelectual en el país.

Finalmente, a nivel internacional es destacable el papel del Convenio sobre la Diversidad Biológica (CDB), tratado internacional jurídicamente vinculante con tres objetivos principales: la conservación de la diversidad biológica, la utilización sostenible de sus componentes y la participación justa y equitativa en los beneficios que se deriven de la utilización de los recursos genéticos. Su objetivo general es promover medidas que conduzcan a un futuro sostenible. Propuesto en junio (5) de 1992 y entró en vigor en diciembre (29) de 1993. http://www.un.org/ es/events/biodiversityday/convention.shtml (http://bit.ly/1fG1RRU). El punto focal nacional es el Ministerio del Ambiente (MINAM)

\section{Instituciones a nivel nacional}

A nivel nacional, entre las instituciones que son parte de la historia del tema de estudio de recursos genéticos, destacan la Universidad Nacional Agraria La Molina (UNALM), la Universidad
Nacional San Antonio de Abad (Cusco), la Universidad Nacional San Cristóbal de Huamanga (Ayacucho), la Universidad Nacional de Puno (Puno) y la Universidad Nacional de Cajamarca (Cajamarca), por citar a cuatro de las más destacadas.

Una institución de carácter internacional, pero asentada en el Perú y que jugó un papel importante es el Centro Internacional de la Papa, que inicia sus actividades en 1971. Fue fundado en e año 1971 y es uno es uno de los mayores centros dedicados a la investigación científica en el mundo en papa, camote, yuca y otros tubérculos y raíces, con el objetivo de obtener el pleno alcance de sus capacidades alimenticias para beneficiar a los países en vías de desarrollo (CIP, 2016).

En cuanto a programas de investigación relacionados a los recursos genéticos llevados adelante en la UNALM, uno de los más importantes es el Programa de Investigación en Maíz (1953), cuyos primeros trabajos fueron realizados en 1950 por la Sección de Fisiología Vegeta del Instituto de Botánica de la Escuela Nacional de Agricultura (ENA) La Molina, hoy Universidad Nacional Agraria. En 1953, en el mes de mayo, se crea el Programa Cooperativo de In vestigaciones en Maíz bajo la Resolución № 4264 Escuela Nacional de Agricultura -Fundación Rockefeller. Se oficializó con el Decreto Supremo 7-1 en 1975. Con sede en la Universidad Nacional Agraria - La Molina. Apartado 456. Lima, Perú. (UNALM, 2016)

El Programa de Investigación y Proyección Social en Raíces y Tuberosa Andinas, es también precursor del tema y es un programa que participa permanentemente en la búsqueda de soluciones tecnológicas para el mejoramiento de la producción y de las raíces y tuberosas. Este programa inició sus actividades en noviembre de 1965, bajo el liderazgo del profesor ingeniero Carlos Ochoa. Es una unidad de estudio, investigación, enseñanza y proyección social en raíces y tuberosas y en otras especies afines de la Facultad de Agronomía de la Universidad.

A los esfuerzos anteriores, a nivel andino se suman otros como el de 1978, año en el que se construyeron los llamados "Bancos de Germoplasma de granos y tubérculos"; en Bolivia se hicieron dos y en Perú tres, en Camacani (Puno), Kayra (Cusco), y en Alpachaca (Ayacucho) con las respectivas universidades regionales. Participaron en la gestión José Esquinas Alcázar y Mario Tapia, y por las Universidades Óscar Blanco, Luis Lescano, Julio Valladolid y Fernando Barrantes. Como ya se ha mencionado anteriormente, este proyecto aportó a crear las condiciones para agregar al concepto de semillas el concepto de accesiones como recursos genéticos.

A inicios del siglo XXI tiene un gran aporte el Proyecto in situ, un proyecto de carácter nacional, interinstitucional e interdisciplinario, en el que participa el IIAP, INIA, PRATEC, CCTA, y ONG del Cusco (Arariwa y CESA); y se inicia con fuerza el estudio del tema de parientes silvestres, la conservación in situ, el reconocimiento explícito de los conocimientos tradicionales y el papel de los campesinos en la conservación in situ en sus chacras.

\section{El papel de los herbarios}

Los herbarios tienen un papel muy importante de los antecedentes relacionados con los recursos genéticos sobre todo por su continuidad. Los herbarios más importantes del país están relacionados con las universidades que albergaron escuelas botánicas muy significativas, entre las cuales se destacan las siguientes: 
En Lima se cuenta con el Herbario San Marcos (HSM). Desde 1918, Universidad Nacional Mayor de San Marcos. Lima. ( http://museohn.unmsm.edu.pe/index.php/div/bot)

Al sur destaca el herbario del Cusco, Herbario Vargas (HV). Desde 1920, Universidad Nacional San Antonio Abad del Cusco (http://bi.unsaac.edu.pe/herbario.php)

En el norte es muy reconocido el herbario de Trujillo: Herbarium Truxillense (HUT).Desde 1941. Universidad Nacional de La Libertad-Trujillo (http://bit.ly/1S1qx7r)

\section{Organismos oficiales ambientales nacionales}

Los organismos relacionados también jugaron un papel en el desarrollo del tema, y aunque han soportado la inestabilidad política del país, han sobrevivido cambiando de razón social en las última décadas. Así, tiene que destacarse el Instituto Nacional de Investigación y Promoción Agraria (INIPA) de fines de los ochenta (1987); el INIA, Instituto Nacional de Investigación Agraria, de abril de 1988 a diciembre de 1990, que se ocupaba de hacer investigación de cultivos agrícolas; luego el INIAA Instituto Nacional de Investigación Agraria Agroindustrial, de 1991 a 1993, que realizaba labores de investigación en cultivos agrícolas e industriales; y finalmente el año 2008 que, por medio del Decreto Legislativo $N^{\circ}$ 1060, el Instituto Nacional de Innovación Agraria (INIA) es designado como Ente Rector del Sistema Nacional de Innovación Agraria (http://www.inia.gob.pe).

Además, está la entidad pública encargada de los temas ambientales como lo fue el Consejo Nacional de Ambiente (CONAM) en un inicio (2004-2008) y actualmente lo es el Ministerio de Ambiente (MINAM) a partir del 2008 siendo el "punto ocal nacional" del Convenio de Diversidad Biológica (CDB), llevando adelante las políticas relacionadas con el tema de los recursos genéticos, entre otras responsabilidades.

\section{La línea de tiempo del concepto recursos genéticos: una propuesta}

Si tuviéramos que graficar temporalmente cómo se fueron perfilando los conceptos en torno al de los recursos genéticos en los últimos aproximadamente 65 años, comenzaríamos con la "época" de los tubérculos, los "granos", los bulbos, los rizomas, en los años cincuenta. luego en los sesenta las llamadas "variedades mejoradas", si bien es cierto que ya se hablaba de la diversidad genética, la velocidad de transmisión de los conocimientos científicos a la producción toma varios años. $Y$ en este proceso los agrónomos han tenido un papel muy importante, especialmente los investigadores en maíz y papa. Los ochenta son años de las semillas $y$ de los bancos de germoplasma, y los noventa la década en la que se adopta con fuerza el tema de los "recursos genéticos", aunque se refería a ellos desde los años setenta. Pero ya en el siglo XXI se comienza a hablar con más fuerza de los genes, del mejoramiento genético de una manera explícita, con su máximo producto biotecnológico: los transgénicos, como resultado de la ingeniería genética. Pero por otro lado también inicia el reconocimiento de los procesos vigentes de domesticación, la evolución del concepto de recursos genéticos, ahora incorporando a los parientes silvestres, a las arvenses y a los silvestres en general. Además, se empiezan a incluir otras aristas como son los derechos de propiedad, no solo de las semillas, sino de los conocimientos alrededor de ellas por parte de las culturas locales, debido a que e término ADN se vuelve término de la vida diaria y se reconoce que existen otras epistemologías relacionadas como son los conocimientos tradicionales (Figura 4.6).

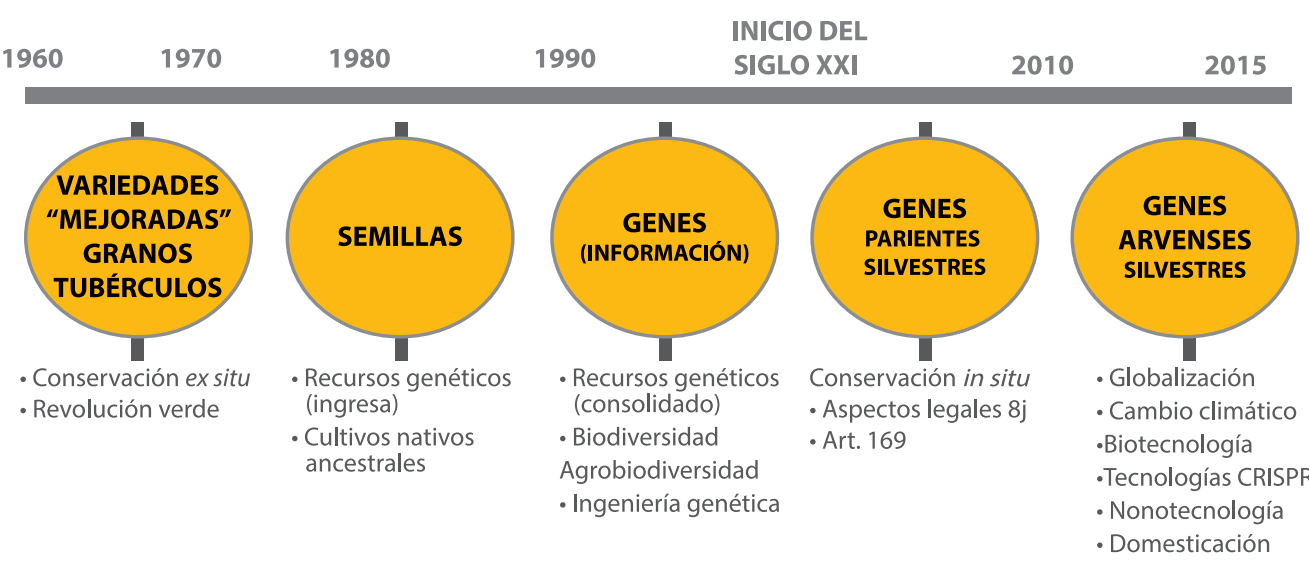

Figura 4.6. Línea de tiempo. Tendencia de la actividad científica sobre los recursos genéticos en el Perú relacionados con la alimentación (55 años, 1960-2015)

\section{Lo avanzado en el conocimiento sobre los recursos genéticos vegetales: las plantas útiles del Perú}

Uno de los esfuerzos más grandes de sistematización de información sobre especies de plantas útiles a nivel nacional es el realizado, por cerca de treinta años, por Antonio Brack, naturalista y primer Ministro del Ambiente del Perú, quien hizo una exhaustiva revisión de trabajos relacionados con especies de plantas con usos conocidos en diversas partes del país (Brack, 1999, 2003 2005; Brack y Bravo, 2005). Es como resultado de esta sistematización que Brack determina que existen cerca de 5000 especies de plantas, la cuarta parte de las plantas del Perú (20 000 según Brako y Zarucchi, 1993 y León et al., 2006) tienen algún uso para diferentes grupos culturales de Perú.

De las plantas útiles, cerca de 4400 son especies vegetales nativas y 600 son introducidas, y son utilizadas para 49 fines distintos (Brack, 1999), entre las cuales destacan: 782 especies comestibles, 1400 medicinales, más de 1600 ornamentales, más de 480 son especies forrajeras, 134 especies tintóreas y colorantes, 179 especies usadas como veneno y conocidas por ser tóxicas, 618 especies para madera y construcción, 132 como combustible, y cerca de 120 utilizadas para agroforestería. 
Se determinó que 1700 especies son cultivadas o manejadas y 182 especies de plantas son cultivadas intensivamente y presentan signos avanzados de domesticación (Brack, 2003a; Brack y Bravo, 2006) (Figura 4.7).

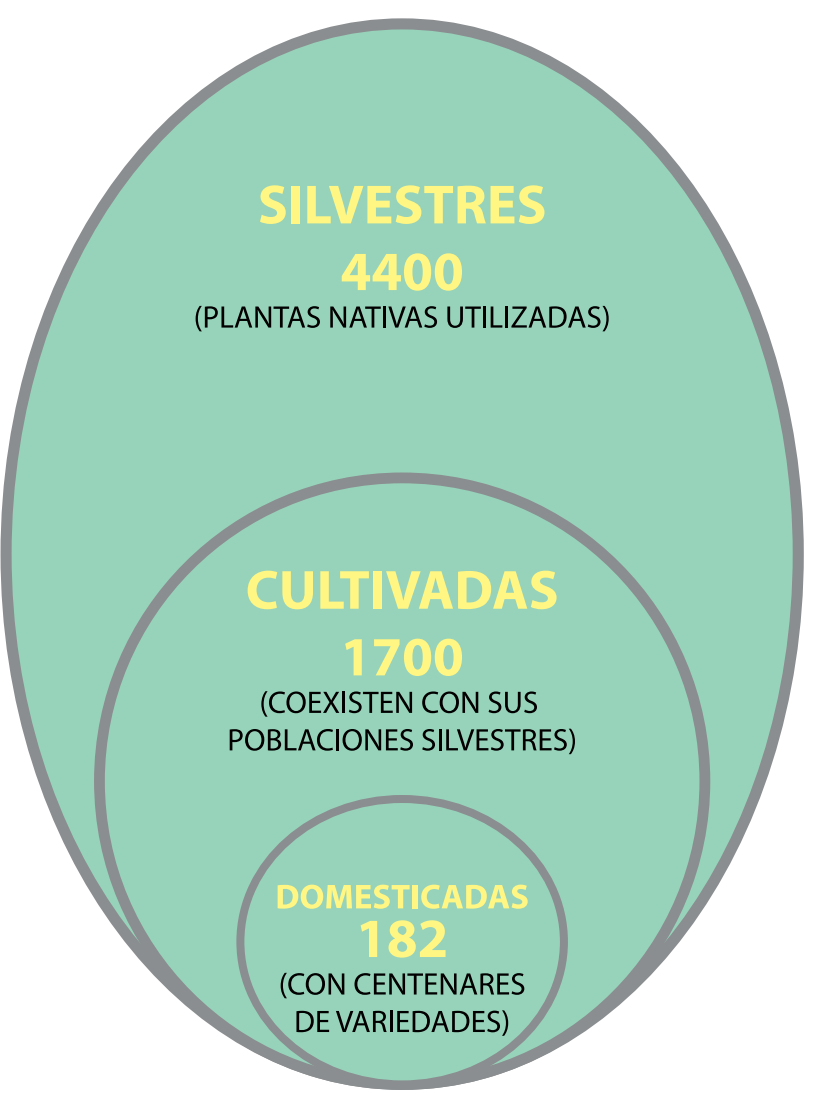

Figura 4.7. Plantas útiles, cultivadas y domesticadas del Perú, según Fuente: Brack 2003 y Brack et al., 2006.

De las 182 especies de plantas domesticadas nativas, 85 son de origen amazónico, 81 de origen andino y solo 8 especies de origen costeño. Adicionalmente a las especies de origen nativo, existen 7 especies que fueron domesticadas en el continente americano para ser luego introducidas en muchos casos en épocas preincaicas y que son de gran importancia económica en la actualidad, como es el caso del maíz y el maní.

Existen otras dos especies que son consideradas por el National Research Council (1989) como especies domesticadas de la región andina, y que son el Juglans neotropica (Familia Juglandaceae) y Rubus glauca (Familia Rosaceae), de las cuales habría que profundizar en mayores estudios para determinar si efectivamente son especies domesticadas en esta región.
Las especies domesticadas representan a 62 familias botánicas, 52 pertenecientes al grupo de las dicotiledóneas y 12 a las monocotiledóneas (incluyendo las del NRC). En el Tabla $4.1 \mathrm{se}$ presenta una síntesis del registro de plantas domesticadas. Se observa el número de géneros por familia y especies por género, siendo el grupo de las dicotiledóneas el que posee el mayor número de especies domesticadas. La familia con mayor número de especies domesticadas es la Solanaceae, con 32 especies, siendo en el género más abundante Solanum, seguido del género Capsicum con 6 especies. Le sigue la familia Amaryllidaceae con 11, Fabaceae con 10 especies y Passifloraceae, que posee 9 especies de plantas domesticadas

Tabla 4.1. Plantas domesticadas del Perú. Resumen por familia y género botánico. (Fuente: MINAM, 2014b)

\begin{tabular}{|c|c|c|c|c|c|}
\hline Familia botánica & Género & $\begin{array}{l}N^{\circ} \\
\text { especies }\end{array}$ & Familia botánica & Género & $\begin{array}{l}N^{\circ} \\
\text { especies }\end{array}$ \\
\hline \multicolumn{3}{|c|}{ Dicotiledóneas } & \multicolumn{3}{|c|}{ Dicotiledóneas } \\
\hline Acanthaceae & Fittonia & 2 & \multirow[t]{3}{*}{ Malphigiaceae } & Bunchosia & 1 \\
\hline Amaranthacea & Amaranthus & 1 & & Malpighia & 1 \\
\hline \multirow[t]{3}{*}{ Anacardiaceae } & Anacardium & 1 & & Byrsonima & 1 \\
\hline & Spondias & 2 & Malvaceae & Gossypium & 1 \\
\hline & Schinus & 1 & Mimosaceae & Inga & 3 \\
\hline \multirow[t]{2}{*}{ Annonaceae } & Annona & 5 & Moraceae & Pouroma & 1 \\
\hline & Rollinia & 1 & \multirow[t]{3}{*}{ Myrtaceae } & Eugenia & 2 \\
\hline \multirow[t]{2}{*}{ Apiaceae } & Arracacia & 1 & & Myrciaria & 1 \\
\hline & Eryngium & 1 & & Psidium & 1 \\
\hline \multirow[t]{2}{*}{ Apocynaceae } & Thevetia & 1 & \multirow[t]{2}{*}{ Nyctaginaceae } & Mirabilis & 2 \\
\hline & Couma & 1 & & Bougainvillea & 2 \\
\hline \multirow[t]{3}{*}{ Asteraceae } & Smallanthus & 1 & Onagraceae & Fuchsia & 3 \\
\hline & Tagetes & 2 & Oxalidaceae & Oxalis & 1 \\
\hline & Zinnia & 2 & Passifloraceae & Passiflora & 9 \\
\hline Basellaceae & Ullucus & 1 & Polemoniaceae & Cantua & 1 \\
\hline \multirow[t]{3}{*}{ Bignoneaceae } & Tecoma & 2 & Pontederiaceae & Eichornia & 1 \\
\hline & Crescentia & 1 & Portulacaceae & Portulaca & 1 \\
\hline & Jacaranda & 2 & \multirow[t]{2}{*}{ Rosaceae } & Prunus & 1 \\
\hline Bixaceae & Bixa & 1 & & Rubus & 1 \\
\hline Bombacaceae & Quararibea & 1 & Rubiaceae & Genipa & 1 \\
\hline Boraginaceae & Heliotropium & 1 & Sapindaceae & Sapindus & 1 \\
\hline Brassicaceae & Lepidium & 1 & Sapotaceae & Pouteria & 4 \\
\hline
\end{tabular}

Continúa en la siguiente página 


\begin{tabular}{|c|c|c|c|c|c|}
\hline Familia botánica & Género & $\begin{array}{l}\mathbf{N}^{\circ} \\
\text { especies }\end{array}$ & Familia botánica & Género & $\begin{array}{l}\mathbf{N}^{\circ} \\
\text { especies }\end{array}$ \\
\hline Cactaceae & Opuntia & 1 & \multirow[t]{10}{*}{ Solanaceae } & Capsicum & 6 \\
\hline Caprifoliaceae & Sambucus & 1 & & Cyphomandra & 1 \\
\hline Caricaceae & Carica & 3 & & Lycopersicon & 2 \\
\hline Chenopodiaceae & Chenopodium & 3 & & Nicotiana & 1 \\
\hline Chrysobalanaceae & Couepia & 2 & & Physalis & 2 \\
\hline \multirow[t]{2}{*}{ Clusiaceae } & Rheedia & 1 & & Solanum & 12 \\
\hline & Platonia & 1 & & Brugmansia & 5 \\
\hline Convolvulaceae & Ipomoea & 1 & & Brunfelsia & 1 \\
\hline \multirow[t]{5}{*}{ Cucurbitaceae } & Cucurbita & 3 & & Streptosolen & 1 \\
\hline & Sechium & 1 & & Solanum & 1 \\
\hline & Cyclanthera & 1 & Sterculiaceae & Theobroma & 4 \\
\hline & Sicana & 1 & Tropaeolaceae & Tropaeolum & 3 \\
\hline & Lagenaria & 1 & \multirow[t]{3}{*}{ Verbenaceae } & Aloysia & 1 \\
\hline Erytroxilaceae & Erythroxylon & 2 & & Lantana & 2 \\
\hline \multirow[t]{4}{*}{ Euphorbiaceae } & Manihot & 1 & & Lippia & 1 \\
\hline & Caryodendron & 1 & Monocotiledoneas & & \\
\hline & Plukenetia & 1 & \multirow[t]{3}{*}{ Amaryllidaceae } & Hippeatrum & 5 \\
\hline & Hevea & 1 & & Eucharis & 4 \\
\hline \multirow[t]{7}{*}{ Fabaceae } & Phaseolus & 2 & & Ismene & 2 \\
\hline & Lonchocarpus & 1 & Araceae & Xanthosoma & 2 \\
\hline & Pachyrrizus & 2 & Arecaceae & Bactris & 1 \\
\hline & Arachis & 2 & \multirow[t]{2}{*}{ Asparagaceae } & Agave & 1 \\
\hline & Canavalia & 1 & & Furcraea & 1 \\
\hline & Erythrina & 1 & Bromeliaceae & Annanas & 1 \\
\hline & Lupinus & 1 & Cannaceae & Canna & 2 \\
\hline Gesneriaceae & Gloxinia & 1 & Commelinaceae & Dichorisandra & 1 \\
\hline Icacinaceae & Poraqueiba & 1 & Dioscoreacea & Dioscorea & 1 \\
\hline Juglandaceae & Juglans & 1 & Heliconiaceae & Heliconia & 1 \\
\hline Lauraceae & Persea & 1 & Liliaceae & Alstroemeria & 2 \\
\hline \multirow[t]{3}{*}{ Lecythidaceae } & Grias & 2 & \multirow[t]{2}{*}{ Marantaceae } & Calathea & 1 \\
\hline & & & & Marantha & 1 \\
\hline & & & Poaceae & Zea & 1 \\
\hline
\end{tabular}

Existen algunos estudios que brindan ciertas evidencias de que existirían por lo menos ocho especies más de plantas que se encontrarían bajo proceso de domesticación, de las cuales por lo menos dos serían resultado de procesos actuales de uso y manejo intensivo como la Caesalpinea spinosa, con trabajos de varios años que estarían representando procesos de selección artificial y domesticación, como el realizado por la UNSCH. También existe el caso de la Oenocarpus bataua (Gonzáles y Torres, 2011), especie sobre la cual existe un fuerte interés económico por las frutas que produce y por lo cual el Instituto de Investigación de la Amazonia Peruana ha realizado desde hace algunos años diversos trabajos de investigación en cuanto a su propagación para la intensificación del cultivo (MINAM, 2014b).

En los casos de la Guazuma crinita y Calycophyllum spruceanum (Weber et al., 2001), estas son especies cuyo proceso de domesticación se ha iniciado de manera participativa desde hace unos -relativamente pocos- años atrás, por el interés en la madera. Mientras que el caso de las palmeras Mauritia flexuosa (Manzi y Coomes, 2009) y Astrocaryum chambira (Coomes, 2004; Guel y Penn, 2009) son parte de procesos locales de domesticación de plantas por un interés de las comunidades locales en los productos de dichas palmeras, principalmente los frutos. En el caso de la especie aromática Minthostachys mollis o "muña" existe un grupo de investigación de la Universidad Hermilio Valdizán (Tello, 2012), que estudia el manejo de esta especie en la región Huánuco (MINAM, 2014).

Hay cerca de 26 especies de plantas frutales (Tabla 4.2) que se indican como cultivadas en el trabajo de Brack (2003b) sobre frutales del Perú y de la corta lista que proporciona e IIAP mediante el trabajo de Mejía (1995) sobre algunas especies de frutales bajo proceso de domesticación, en cuyos casos se cuenta con información sobre su forma de cultivo (mayor intensidad de manejo con base en múltiples prácticas de tipo agronómico). Sin embargo, es necesaria más información de la mayoría de las especies aquí presentadas para poder determinar si efectivamente se encuentran bajo domesticación incipiente

Tabla 4.2. Lista de especies de plantas cultivadas sugeridas a investigar para evalua intensidad de manejo y posible domesticación incipiente (Fuente: MINAM, 2014b).

\begin{tabular}{ccccc} 
Familia botánica & Nombre científico & Nombre común & Hábito & Distribución \\
\hline Annonaceae & Duguetia caspi & tortuga caspi & árbol & Amazonía \\
\hline Apocynaceae & Couma macrocarpa & leche caspi & árbol & Amazonía \\
\hline Apocynaceae & Hancornia speciosa & manga & árbol o arbusto & Amazonía \\
\hline Apocynaceae & Macoubea guianensis & coto huayo & árbol & Amazonía \\
\hline Bombacaceae & Pachira aquatica & huimba & árbol & Amazonía \\
\hline Bombacaceae & Ceiba pentandra & ceibo & árbol & Amazonía \\
\hline Burseraceae & Dracoydes peruviana & copal comestible & árbol & $\begin{array}{c}\text { Amazonia, San } \\
\text { Martin y Huánuco }\end{array}$ \\
\hline Cactaceae & Hylocereus undatus & pitaya & cactus & $\begin{array}{c}\text { Costa y zonas } \\
\text { áridas }\end{array}$
\end{tabular}




\begin{tabular}{|c|c|c|c|c|}
\hline Familia botánica & Nombre cientifico & Nombre común & Hábito & Distribución \\
\hline Cactaceae & Opuntia soehrensii & ayrampo & cactus & $\begin{array}{c}\text { Cusco y Apurimac, } \\
\text { Costa }\end{array}$ \\
\hline Cactaceae & Pereskia aculeata & guamacho & cactus & Amazonía \\
\hline Caryocaraceae & Caryocar glabrum & almendro colorado & árbol & Amazonía \\
\hline Caryocaraceae & Caryocar villosum & almendro pequi & árbol & Amazonía \\
\hline Clusiaceae & Garcinia brasiliensis & charicuelo liso & árbol & Amazonía \\
\hline Muntingiaceae & Muntingia calabura & yumanasa & árbol & Amazonía \\
\hline Moraceae & Brosimum alicastrum & machinga & árbol & Amazonía \\
\hline Rubiaceae & Borojoa sorbilis & Borojó & árbol & Amazonía \\
\hline Sapindaceae & Talisia esculenta & pitomba & árbol & Amazonía \\
\hline Solanaceae & Solanum caripense & mamoncillo & árbol & Amazonía \\
\hline Sterculiaceae & Guazuma ulmifolia & atadijo & árbol & Amazonía \\
\hline Zingiberaceae & Renealmia alpinia & Misqui panga & arbusto & Amazonía \\
\hline Araceae & Monstera deliciosa & costilla de adan & trepadora & Amazonía \\
\hline Arecacea & Elaeis oleifera & puma yarina & palmera & Amazonía \\
\hline Arecacea & Euterpe oleraceae & huasai & palmera & Amazonía \\
\hline Arecacea & Euterpe precatoria & huasai chonta & palmera & Amazonía \\
\hline Arecacea & Phytelephas macrocarpa & yarina & palmera & Amazonía \\
\hline Arecacea & Maximiliana maripa & shapajilla & palmera & Amazonía \\
\hline
\end{tabular}

\section{Nuevos componentes y enfoques de los recursos genéticos en el siglo XXI}

En los últimos quince años el concepto de recursos genéticos se ha ido relacionando con otros que no existían, al menos explícitamente, en sus inicios en la década de los cincuenta. Entre los nuevos componentes asociados hoy al de los recursos genéticos se tienen, entre los más importantes, los siguientes:

1. Las culturas indígenas que hasta hace tres décadas no tenían espacio en el tema, hoy están en la agenda de los recursos genéticos, sus conocimientos sobre las plantas, materia prima de la rama de la ciencia más "prometedora" de este siglo: la biotecnología, los pone en un papel muy importante para el futuro. En el país se han identificado 76 etnias que pertenecen a 16 familias etnolingüísticas (INDEPA, 2010).

2. Los recursos genéticos, la diversidad y la agrobiodiversidad son parte de la cultura y, finalmente, del tema del desarrollo.

3. Los recursos genéticos son parte de los estudios históricos incorporando el concepto de domesticación, como la fuente de la agrobiodiversidad, para reforzar el de conservación in situ.

4. La conservación in situ de los recursos genéticos es tan importante como la ex situ, la primera está asociada a las culturas locales, a sus campos de cultivos, así como a las áreas naturales de conservación.
Los recursos genéticos tienen un fuerte componente legal relacionado con los derechos de propiedad, están involucrados en el Convenio 169 de la OIT relacionado con el respeto de las culturas, formas de vida e instituciones tradicionales de los pueblos indígenas y la consulta y participación efectiva de estos pueblos en las decisiones que les afectan (http://intranet.oit. org.pe). De igual forma están relacionados con el artículo 8j del Convenio sobre Diversidad Biológica que señala que “...con arreglo a su legislación nacional; respetará, preservará y mantendrá, los conocimientos, las innovaciones y prácticas de las comunidades indígenas y locales que entrañen estilos tradicionales de vida pertinentes para la conservación y la utilización sostenible de la diversidad biológica y promoverá su aplicación más amplia, con la aprobación y la participación de quienes posean esos conocimientos, innovaciones y prácticas, y fomentará que los beneficios derivados de la utilización de esos conocimientos, innovaciones y prácticas se compartan equitativamente" (Convenio sobre Diversidad Biológica).

También está relacionado con el Reglamento de la Ley 26839 referida a la Conservación y Aprovechamiento Sostenible de la Diversidad Biológica, el cual precisa que las zonas de agrobiodiversidad “.... están orientadas a la conservación y uso sostenible de especies nativas cultivadas por parte de los pueblos indígenas, no se pueden destinar para fines distintos a los de conservación de dichas especies y el mantenimiento de las culturas indígenas". De hecho, este sería el mecanismo más importante de conservación in situ de la agrobiodiversidad. En este marco, el Ministerio de Agricultura (MINAG) ha coordinado la formulación de una propuesta de reglamento para el reconocimiento y creación de las zonas de agrobiodiversidad, con un enfoque promotor y de consolidación de estas zonas (MINAM, 2011)

5. Finalmente, los recursos genéticos surgen como una estrategia fundamental para hacer frente al ya aceptado cambio climático, y en esa línea se ha ampliado la visión de lo que pueden ser los recursos genéticos potenciales para ampliar la oferta alimentaria incluyendo a: los parientes silvestres de las plantas domesticadas, las especies arvenses acompañantes de las cultivadas y cualquier especie silvestre que tenga un potencial alimentario (Figura 4.8).

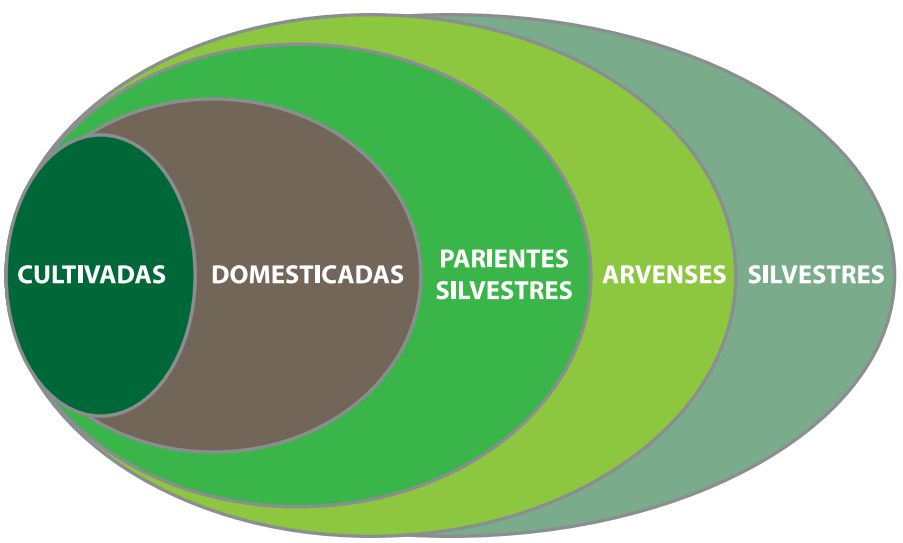

Figura 4.8. Recursos fitogenéticos relacionados con la alimentación en el Perú Tendencias de cómo se fue ampliando el tema en los últimos sesenta años. (Fuente: Elaboración propia) 
Los recursos genéticos se encuentran envueltos en el polémico tema de los organismos vivos modificados (OVM) considerados como una amenaza, sobre todo en las áreas que centros de origen y diversificación de planta cultivadas. A nivel nacional existe una ley de Moratoria frente a los OVM, la Ley N 29811 que establece la Moratoria al Ingreso y Producción de Organismos Vivos Modificados al Territorio Nacional por un período de diez años, relacionada con los impactos potenciales sobre la biodiversidad nativa. Esta Moratoria consiste en la prohibición del ingreso o producción nacional de OVM para fines de crianza o cultivo (liberación al ambiente), promueve: a) la construcción de capacidades para una correcta evaluación de riesgos y b) establecimiento de líneas de base de la diversidad biológica potencialmente afectada.(MINAM, 2016)

Los nuevos enfoques en relación con los recursos genéticos los consideran parte de los servicios de un ecosistema y, además, se le incluye como parte de los Bienes y Servicios Públicos Globales, la pregunta entonces es: ¿Se pueden considerar los recursos genéticos un "Bien Público Global"? ¿Es el gen un "Bien Público Global"? es parte de los nuevos enfoques que tienen estos recursos que quizá se conviertan en servicios en las próximas décadas.

\section{Bibliografía}

Alban, J. A., 1994. La mujer y las plantas útiles silvestres en Marañon. Informe. Proyecto WWW 7560, Loreto.

Alban, J. A., 1998. Etnobotánica y conservación en la comunidad andina de Pamparomas, Huaylas, Ancash Perú. Tesis MSc, Facultad de Ciencias Biológicas
Universidad Nacional Mayor de San Marcos, Lima.

Albán, J. B., Millán y F. Kahn, 2008. Situación actual de la investigación etnobotánica sobre palmeras de Perú. Revista peruana de biologia, 15(1): 133-142.

Aste-Tonsmann, J., W. Salhuana-Mackee, A. Remy-Pflucker, R. Sevilla-Panizo, 1976. El uso del lenguaje común en I formación y recuperación de información de un banco Nacional Agraria La Molina, Perú, 2: 58-65.

Benfer, Jr., R. A., B. Ojeda, N. A Duncan, L. R. Adkins, H. Ludeña, M. Vallejos, y G. Villarreal, 2010. La Tradición Religioso-Astronomica en
Arqueologia PUCP, 11: 53-102.

Blácido, M. 2012 Recopilación y análisis de documentación en investigación ambiental priorizada (informe final). Lima, Perú.

Blanco O. y Blanco M. 1995. Cultivos andinos y la Investigación Universitaria. Colección: Recopilación

Bonavia, D., 1991. Perú hombre e historia: de los orígenes al siglo XV. Edubanco Ed., Lima, Perú.

Bonavia, D., 1993. La papa: apuntes sobre sus origenes y su domestic

Brack, A.. 1999. Diccionario enciclopédico de plantas útiles del Perú. Centro Bartolomé de las Casas, Cusco. Perú

Brack, A., 2003a. Perú - Diez mil años de domesticación. Lima.

Brack, A. 2003b. Frutas del Perú. Universidad San Martín de Porres. Lima, Perú.

Brack A., F. Bravo, 2006. Perú: legado milenario / Peru: millenary /egacy. Universidad San Martín de Porres, Lima.

Brack A., C. Aranda, M. Bernales, R. Bustamante, L. Campos, F. Capurro, M. Castro, J. Delgado, E. Galarza y L. Gomero, 2008. Diagnóstico Ambiental del Perú. Ministerio del Ambiente, Lima.

Brako, L. y J. Zarucchi, 1996. Catálogo de las Angiospermas y Gimnosperm

Brush, S. B., 1992. Reconsidering the green revolution: Diversity and stability in cradle areas of crop domestication. Human Ecology, 20(2), 145-167.

Brush, S. B., 2005. Cultural research on the origin and maintenance of agricultural diversity. Nature Knowledge: Ethnoscience, Cognition, and Utility, 379-385. h, S. B., 2008. Farmers Bounty: Locating Crop Diversity in the Contemporary World. Yale University Press.

arey, M., 2010. Commodities, Colonial Science, and Environmental Change in Latin American
History Review, 2010(107): 185-194

Carstensen, F., 1986. Yucatan's gilded age: Haciendas, henequen, and international harvester, 1860-1915. By Allen Wells. Albuquerque: University of New Mexico Press.

Casas, A. y F. Parra, 2016. Capítulo 5. La domesticación como proceso evolutivo. En: Casas, A.,J. Torres-Guevara y Parra (Eds.). Domesticación en el continente americano. Volumen 1. Manejo de biodiveridad y evolución dirigida Autónoma de México /Universidad Nacional Agraria La Molina, pp. 133-158.

Casas A., R. Lira, I. Torres, A. Delgado-Lemus, A. I. MorenoCalles, S. Rangel-Landa J Bado-Lemus, A. I. MorenoPérez-Negrón, M. Vallejo, F. Parra, B. Farfán-Heredia y Y. Arellanes. 2016a. Ethnobotany for sustainable ecosystem management: A regional perspective in the Tehuacán Valley. En: Lira, R., A. Casas y J. Blancas (Eds.). Ethnobotany of Mexico. Interactions of peoples and plants in Mesoamerica. Capithio 8Springer, Utrech

asas, A., A. I. Moreno-Calles, M. Vallejo y F. Parra. 2016b. Capitulo 2. Importancia actual y potencial de los recursos (Eds.). Domesticación en el continente americano. Volumen 1. Manejo de biodiveridad y evolución dirigida por las culturas del Nuevo Mundo. Universidad Nacional Autónoma de México /Universidad Nacional Agraria La Molina, pp. 51-74.

Casas, Fray Bartolome de, 1875 . Historia de las Indias. Imprenta de Miguel Ginosta, Madrid.

Casas, Fray Bartolomé de, 1964. Apologética historia de las Indias. En: Gill y Gaya, Samuel. Historiadores de los siglos XVI y XVII, Consejo Superior de Investigaciones

Ccana-Ccapatinta, G. V., C. Serrano-Flores, E. J. UrrunagaSoria, J. C. Pari, W. Galiano Sánchez, S. L. Crockett, G. L. von Poser y C. del Carpio Jiménez. 2014. Assessing the four Peruvian Hypericum species using the mine forced four Peruvian Hypericum species using the murine forced dele de Ferreyra, E. 1979. Plantas que curan las heridas Chez (Cactaceae) and Dactys y A. Tecante, 2009. The Opuntia in Mexico: A historical perspective of use, interaction and distribution. Biodiversity and Conservation, 18:33373355.

Cieza de León P., 1913. The war of Quito. The Hakluyt Society, Londres, Reino Unido. 
Cieza de León P., 1922. La crónica del Perú. Calpe, Madrid, Earls, J., 1996. Rotative rank hierarchy and recursive España.

Cieza de León P., 2002. Descubrimiento y conquista del Perú. S. L. Dástin, España.

1996. Rotative rank hierarchy and recursive viable system. Society, 24(1, 2): 297-320.

CIP, 2016. http://cipotato.org/es/acerca-del-cip/visitado en Earls, J., 2009. Organización social y tecnológica de la noviembre 2016.

Clement C. R., 2017. Capítulo 1. Panorama de los recursos genéticos de Brasil, con énfasis en la Amazónia. En: Casas, A., J. Torres-Guevara y F. Parra (Eds.)
Domesticación en el continente americano: Tomo Perspectivas de investigación y manejo sustentable de recursos genéticos en el Nuevo Mundo. Universidad Nacional Autónoma de México /Universidad Nacional
Agraria La Molina, pp. 25-54.

Clement, C. R., M. de Cristo-Araújo, G. Coppens deckenbrugge, A. Alves-Pereira y D. Picanço domestication: the origins of agrobiodiversity in indigenous Amazonia. En: Casas, A., J. Torres-Guevara y F. Parra (Eds.). Domesticación en el continente americano. Volumen 1. Manejo de biodiveridad evolución dirigida por las culturas del Nuevo Mundo. Universidad Nacional Autónoma de México/Universidad

Cobo, B., 2017. Historia del Nuevo Mundo. Fondo Antiguo. Fondos Digitalizados, Universidad de Sevilla, España.

Colón, C., 1998. Diario de navegación y otros escritos. Bundateción de Clásicos Dominicanos, Ediciones

Conway, G., 1998. The doubly green revolution: food for all in .

Coomes, O. T., 2004. Rain forest 'conservation-through-use'? Chambira palm fibre extraction and handicraft production in a land-constrained community, Peruvian
Biodiversity and Conservation, 13(2): $351-360$.

Dean, W., 1987. Brazil and the struggle for rubber: a study in environmental

De la Vega, G. Comentarios reales de los incas. Biblioteca

Delgado, J. V. and M. Zwarteveen, 2008. Modernity, exclusion and resistance: Water and indigenous struggles in Peru.

Díaz del Castillo, B., 1982. Historia verdadera de la conquista de la Nueva España. Instituto Gonzalo Fernández de Oviedo y UNAM, Madrid, 2 vols.

Dourojeanni, M., 1986. Recursos Naturales, Desarrollo y Conservación en el Perú. En: Enciclopedia Gran Geografía der
Barcelona.

Earls, J., 1971. The structure of modern Andean social categories. Journal

Earls, J., 1986. Andenes y Camellones en el Perú Andino. CONCYTEC. Lima

Earls, J., 1989. Planificación Agrícola andina. Ediciones agricultura andina para la adaptación al cambio climático en cuencas hidrográficas. Tecnología y sociedad, 1

Eguren, F. E., 2006. Reforma Agraria y Desarrollo Rural en el Perú. En C. P. - CEPES. Reforma Agraria y Desarrollo Sociales CEPES, Lima, Perú, pp. 20-35

Egúsquiza, R., 2000. La papa. Producción, transformación y comercializacón. Prisma, Programa de Desarrollo Perú.

squiza, R. 2005. La papa en el Perú. Universidad Nacional Agraria La Molina, Lima, Perú.

Engel, F. A., 1987. De las begonias al maíz: vida y producción en el Perú antiguo. Ediagraria, Universidad Naciona Agraria La Molina.Lima, Perú

Engel, F., 1963. A preceramic settlement on the central coast of Peru: Asia, Unit 1. Transactions of the American

Fári, M.G. and U. P. Kralovánszky, 2006. The founding father of (Korl) Ereky. International Journ biotechnology: Karoly (Karl) Ereky. Int.
of Horticultural Science, 12 (1): 9-12.

Food and Agriculture Organization, FAO (2015). 70 Años de la FAO(1945-2015). FAO: Roma

e, P. 2009. ¿Extensión o comunicación? Siglo XXI Editores, México.

Gonzáles, A. y G. M. Torres, 2011. Manual de producción de plantones Oenocarpus bataua C. Martius "Ungurahui". Instituto de Investigad
IIAP, Iquitos, Perú

Grobman, A., W. Salhuana and R. Sevilla with P. C. Mangelsdorf, 1961. Races of Maize in Perú. Their origins, evolution and classification. Pub. 915. National Academy of Sciences-NRC, Washington, D.C.

Grobman, A., D. Bonavia, T. D. Dillehay, D. R. Piperno, J. Iriarte and I. Holst, 2012. Preceramic maize from Paredones and Huaca Prieta, Peru. Proceedings of the National

Guel, A. and J. Penn, 2009. Use of the chambira palm (Astrocaryum chambira) in rainforest communities of the Peruvian Amazon. Student Summer
http://scholarworks.gvsu.edu/sss/20

Gutiérrez, M., 2012. El camino de la biotecnología en la

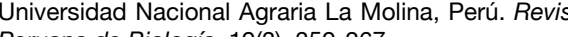

Harlan, J., 2005. Crops and man. American Society of Agronomi Inc. Madison, Wisconsin.

errera, F., 1930. Estudios sobre la flora del departamento de Cuzco. San Martin,Lima,Peñ.

Herrera-Estrella, L., A. Depicker, M. Van Montagu y J. Schell, phant cels using a Ti-plismid-deried vector. Nature,
303(5914): 209-213.

Herrera-Estrella, L., M. De Block, E. H. J. P Messens, J. P. Hernalsteens, M. Van Montagu, y J. Schell, 1983b. Chimeric genes as dominant selectar
cells. The EMBO journal, 2(6): 987 .

Humboldt, A., 1991: Viaje a las regiones equinocciales del nuevo continente. (2. ${ }^{a}$ ed.). Monte Ávila Editores. Caracas, Venezuela. 5 Vols.

Humboldt, A., 1995. Personal narrative of a journey to the equinoctial regions of the newcontinent. Penguin Books.

Ibáñez, V., 1989. Nuevas aportaciones a la investigación haenkeana. La botánica en la Expedición Malaspina. 1789-1794. Madrid, Lunwerg

Instituto Nacional de Desarrollo de Pueblos Andinos, Amazónicos y Afroperuano (INDEPA). 2010. Mapa etnolingüistico del Perú. Ministerio de Cultra del Perú,

Instituto Nacional de Innovación Agraria INIA.2016.http:// www.inia.gob.pe Ministerio de Agricultura del Perú,

Klamt, S. and J. Stelling, 2003. Two approaches for metabolic pathway analysis? Trends in Blotechnology, 21: 64-69.

La Torre-Cuadros, M.A y J. A. Albán, 2006. Etnobotánica en los Andes del Peru. En: M. Moraes R., B. Øllgaarid, Económica de los Andes Centrales Universidad Mayor de San Andrés, La Paz, 2006: 239-245.

León, B., N. Pitman y J. Roque, 2006. Introducción a las plantas endémicas del Perú. Revista peruana de. biologia. Número especial 13(2).

MacNeish, R. S. 1992. The origins of agriculture and settled

Manzi, M. and O.T Coomes, 2009. Managing Amazonian palms for community use: A case of aguaje palm (Mauritia 257: 510-517.

Mayer, E., 2002. The articulated peasant: Household Westview Press.

Mayer, E. 2004. Casa Chacra y Dinero. Economías Domésticas y Ecología en los Andes. Instituto de Estudios Peruanos (IEP). Lima.

Ministerio del Ambiente (MINAM), 2011. Plan Nacional de Acción Ambiental PLANAA Perú 2011-2021. MINAM Lima.

Ministerio del Ambiente (MINAM), 2011. Reglamento de Ley $\mathrm{N}^{\circ} 29811$, Ley que establece la Moratoria al Ingreso y Producción de Organismos Vivos Modificados al Territorio Nacior

Ministerio del Ambiente MINAM, 2014a. V Informe Naciona ante el Convenio sobre la Diversidad Biológica. Ministerio

Ministerio del Ambiente MINAM, 2014b. Servicio de elaboración de un documento ténico sobre especies gestión del acceso a los recursos genéticos. MINAM, Lima, Perú

sterio del Ambiente MINAM, 2016. Moratoria al ingreso de transgénicos -ovm- En el Perú (2011-2015). Protegiendo nuestra diversidad biologicay cullural Reporte del estado de la implementación de la Ley $n^{\circ}$. 29811. Informes

Mejía, K., 1995. Diagnóstico de recursos vegetales de la amazonía peruana. Documento técnico 16. IIAP. Iquitos,

Mujica, A., y S. E. Jacobsen, 2006. La quinua (Chenopodium quinoa Willd.) y sus parientes silvestres. Botán
Económica de los Andes Centrales, 32: 449-457.

Murra, J. V., 1984. Andean societies. Annual Review of Anthropology, 13(1), 119-141.

urra, J. V., 1985. The limits and limitations of the "vertical archipelago" in the Andes. Andean ecology and ecological complementarity. University of Tokyo Press, Tokyo, Japón.

urra, J. V., 2002. El mundo andino: población, medio oz-Garmendía, F., 2004. La botánica al servicio de la Corona. La Expedición de Ruiz, Pavón y Dombey a Molestina, C. J., 2002. IICA: 60 años de historia institucional. Editorial Agromeriica, San José, Costa Rica.

National Research Council. 1989. Lost Crops of the Incas National Academy Press. USA.

Ochoa, C. M., 1999. Las Papas de Sudamérica: Perú (Parte I). Lin. C. Lilips, O. L., R. Vásquez Martí, P. Núñn-Vargas, A. L.Monteagudo, M. E. Chuspe-Zans, W. GalianoRose, 2003a. Efficient plot based floristic assessment of tropical forests. Journal of Tropical Ecology, 19:629-645 Phillips, O. L., P. Nuñez-Vargas, A. L. Monteagudo, A. Peña-
Cruz, M. E. Chuspe-Zans, W. Galiano-Sánchez, M. Cruz, M. E. Chuspe-Zans, W. Galiano-Sanchez, M
Y. Halla y S. Rose, 2003b. Habitat association among Amazonian tree species: a landscape-scalo
Blackwell Publishing Ltd. Reino Unido.

a de Ayala, F. G., 1991. Nueva coronica y buen gobierno. Biblioteca Ayacucho, Caracas, Venezuela.

ras, Barrenechea, R. 1962. Los cronistas del Perú (15281650). Sanmartí Impresores, Lima, Perú.

Programa de Naciones Unidas para el Medio Ambiente (PNUMA). Convenio de Diversidad Biológica. Organización de las Naciones Unidas, Nueva York. Quilter, J., E. Bernardino Ojeda, M. P. Deborah, H. S Daniel, G. J. John, G. J., y S. Elizabeth, S. Wing, 1991. The
subsistence economy of El Paraíso, Peru. Science, 251, 277-283.

Raimondi, A., 2005. Mirada intima del Perú. Epistolario, 1849 1890. Fondo Editorial del Congreso del Perú y Banco 
Rostorowski, M., 2009. Pachacamac y el Señor de los Milagros. El señorío de Pachacamac. Señoríos indígenas Lima, Perú.

Rostorowski, M., 2011. Pachacutec. Inca Yupanqui. Instituto de estdios Peruanos (IEP). Lima, Perú.

Rostorowski, M., 2014. Historia del Tahuantinsuyu. Instituto de estdios Peruanos (IEP). Lima, Perú.

Rostorowski, M., 2016. Aproximación antropológica a los mitos andinos y otros ensayos. Instituto de estudios Peruanos (IEP). Lima, Peru.

Sahagún, Fr. B. de 1992. Historia general de las cosas de la Nueva España. Editorial Porrúa, México.

Sandweiss, D. H., H. McInnis, R. L. Burger, A. Cano, B. Ojeda, R. Paredes y M. D. Glascock. (1998). Quebrada jaguay: early South American maritime adaptations. Science,

Schischkin, B., 1960. Sergei Vassiliyevich Juzepczuk (1893 1959). Revista Taxon Vol. 9 No5 (junio 1960) pp. 142-145.

Secretaría del Convenio sobre la Diversidad biológica, 2001.
Convenio sobre Diversidad Biológica. Textos y anexos. Convenio sobre Diversidad Biológica. Textos y anexos. UNEP,Canadá.

Sevilla, R. y M. Holle, 1995. Recursos Genéticos Vegetales. Producción Personal. Centro Internacional de la Papa, Universidad Nacional Agraria La Molina. Lima, Peru. Soukup, J., 1970. Vocabulario de los nombres vulgares
de la flora peruana y catálogo de géneros. Ediciones

Tapia, M. E., 1999. Agrobiodiversidad en los Andes. Fundación Friedrich Ebert, Lima, Perú.

Tello, M., 2012. Avances en la domesticación de la "muña Minthostachys mollis (Kunth) Griseb. con fines de explotación comercial en Huánuco, Penu. Simposio de Torres-Guevara, J., A. Cruz-Soriano y F. Parra Rondinel, 2016. La conseracio "Conservación in situ de cultives nativos y sus parientes silvestres en el Perú" Capítulo 13. En: Casas, A., J. Torres-Guevara y F. Parra (Eds.). Domesticación en el continente americano. Volumen 1. Manejo de biodiveridad y evolución dirigida por las culturas del Nuevo Mundo. Universidad Nacional Autónoma de México /Universidad Nacional Agraria La Mollna, UNALM, 2016. pp. 361-386. htp:// z introduccion.tm\#1 (visitado en noviembre de 2016).

Universidad Nacional San Cristóbal de Huamanga UNSCH. (S.f) Generación de tecnología para el mejoramiento de la Ayacucho. Presentación del Instituto de Desarrollo de Sector Informal.

Valladolid, J., 1993. Las plantas en las culturas andinas y en occidente moderno. ¿Desarrollo o d

( of life in the chakra. En: Apfel-Marglen, The spirit of regeneration: Andean culture confronting
Western notions of development. Zed Books, Londres, pp. 51-88.

alladolid, J., 2002. Crianza de la agrobiodiversidad en los Andes del Perú. PRATEC, Proyecto Andino de Techologlas Campesinas. Lima, Peru.

Cilov, N. I., 1992. Origin and geography of cultivated plants. Cambridge University Press, Cambridge, U.K.

elásquez-Milla, D., A. Casas, J. Torres-Guevara y A.
Cruz-Sorian, 2016. Capítulo 4. Erosión Genética en comunidades andinas tradicionales. Factores ecológicos y socioculturales que influyen en la pérdida y conservación de agrobiodiversidad. En: Casas, A. J. Torres-Guevara y F. Parra (Eds.). Domesticación biodiveridad y evolución dirigida por las culturas del Nuevo Mundo. Universidad Nacional Autónoma de . 97-132.

y M. Gutierrez-Correa, 2008 . Genomica funcional de hongos filamentosos. Bios 1: 28 - 31 .

cent, L., K. Rawal, G. Hersh, J. April, 1976. El banco datos Ue germoplasma de maíz del Exir. Informativo del maiz-

Watson, J. D. y F. H. C. Crick, 1953. Molecular structure of nucleic acids. A structure of deoxyribose nucleic acid. Nature 171, 737-738.

A. J. Sin. Sotelo, H. Vidaurre, H. K. Dawson y A. J. Simons, 2001. Participatory domestication of agroforestry trees: an example from the Peruvian

Weberbauer, A. 1945. El mundo vegetal de los Andes Peruanos. Estudio Fitogeográfico. Estación experimenta Agraria. Dirección de Agricultura del Ministerio de

Weld, R. J., K. M. Plummer, M. A. Carpenter y H. J. Ridgway, 2006. Approaches to functional genomics in filamentous

Yacovleff, E. y F. L. Herrera, 1941. El Mundo Vegetal de los Antiguos Peruanos. Perú. Fundación EI Libro Total http://www.ellibrotota.

Zeder, M. A., 2006a. Central questions in the domestication of plants and animals. Evolutionary Anthropology: Issues,

eder. M. A 2006b. Documenting domestication: new Dogical paradigms. University of Gealifornia Press

Zimmerer K. S. 1991. Wetland production and smallolder persistence: Agricultural change in a highland Peruvian region. Annals of the Association of American Geographers, 81(3), 443-463. 


\section{Domesticaciones americanas:}

cuando la recursividad humana con ayuda de algunas plantas

hace maravillas contra el peso de la geografía y de la migración original

\section{Resumen}

Nuestra especie entró en grupos pequeños al continente americano a través de Beringia hace 20-15 000 años. Compartió con Siberia Oriental el chamanismo y con él la búsqueda de plantas y hongos alucinógenos y, como consecuencia, el conocimiento detallado de la flora y el continuo interés por experimentar. Al entrar en el interior del continente americano, nuestra especie contribuyó -por la caza continua- a la extinción de su megafauna. Una alteración climática hace 12 000-10 000 años ('Dryas Joven') obligó a cambiar un patrón de aprovechamiento de recursos naturales, de la cacería a la siembra consciente de las especies de plantas silvestres más buscadas cerca de los asentamientos. El contexto americano es singular por no contar con animales de tiro y pocas herramientas metálicas, llevando a los humanos a convertirse en la principal fuerza laboral. El fuego fue bastante usado para abrir espacios para los cultivos. Más que el cultivo del ager predominó el cultivo de una huerta, en donde continuamente se experimentó y se introdujeron plantas de varias partes hasta construir un sistema de policultivo. La necesidad de producir todo en una superficie reducida, contribuyó a su éxito agronómico y nutricional, y a su difusión a través del trópico precolombino. El manejo individual (en la siembra y cosecha) de las plantas tuvo como consecuencia el gigantismo y una variación extraordinaria de formas y colores de frutos y semillas. La propia geografía física propició la diversidad dentro y entre los sistemas. Por lo tanto, en contraste con otras partes del mundo, no se ve un centro de origen de los cultivos neotropicales. Varios de los sistemas agrícolas prehispánicos permitieron el auge demográfico y la especialización social, y desde allí las civilizaciones precolombinas conocidas. Algunos sistemas no pudieron mantener la fertilidad de los suelos o manejar las oscilaciones climáticas del Niño y sus civilizaciones terminaron. El entendimiento de la domesticación de las plantas americanas jamás ha sido tan importante como lo es ahora para seguir garantizando la seguridad alimentaria. 


\section{Abstract}

Humans entered as small groups into the Americas through Beringia approximately 20-15,000 years ago. Shamanism was shared with eastern Siberia, and with it came the search for hallucinogenic fungi and plants, and thus an in-depth knowledge of the flora and a continuing interest in testing plants. Going southwards, our species contributed to the extinction of the American megafauna. A climate change 12000 to 10000 years ago ('Younger Dryas') forced people to change the way natural resources were used from hunting towards the conscious planting of preferred wild species close to the settlements. The American context is a special one given the absence of draft animals and the reduced number of metallic implements, with people being the main work force. Fire has been frequently used to clear the land for planting. Rather than raising plants in a clean open field ager, a kitchen-garden was frequently used with continuous trials and introductions from many parts up to building a polycrop system. The need to produce all food and goods from a reduced size land contributed to its agronomical and nutritiona success, and therefore its diffusion through the pre-Columbian tropics. The individual handling of plants (namely at planting and harvest) resulted into gigantism and an uncommon diversity of shapes and colors in fruits and seeds. Physical geography lead to diversity among and within systems. Consequently and in contrast with other regions of the world, no center of origin of American crops can be seen. Several of the pre-Columbian agricultural systems resulted in demographic growth and social stratification, and from there the very famous civilizations. A few systems could not keep up with soil fertility or manage the climatic variations of El Niño, and their civilizations came to an end. Understanding the domestication of American crops has never been as important as it is now, if it is to continue to ensure food security.

Palabras clave: domesticación, origen de la agricultura,

poblamiento y difusión humana en el continente americano

\section{La entrada por Beringia}

Abordar el estudio de la domesticación de las plantas americanas implica primero conocer la gente, ciertamente desde la época precolombina. Es obvio que la domesticación no ha parado; un ejemplo es Zizania palustris de los Grandes Lagos de Norteamérica. Su aprovechamiento ha sido por siglos, su domesticación o entrada en el domus -como lo entendía Jack Harlan (1975, p. 63)o dominio humano arranca en la segunda mitad del siglo XX (Hayes et al., 1989). Sin embargo, los plazos de tiempo, como se verá, son tales que debemos considerar épocas miles de años antes del presente (A.P.) (Tabla 5.1). Pese a una efímera colonización de parte del pueblo vikingo en el extremo oriental de Canadá (L'Anse aux Meadows, Newfoundland) (Diamond, 2005), alrededor del undécimo siglo de nuestra era, el poblamiento original de las Américas antes de 1492 se hizo a través de Alaska, en tres migraciones humanas desde Beringia (Wells, 2002). Las evidencias son genéticas y lingüísticas, aplicándose a todos los pueblos americanos estudiados en los últimos cien años. Las evidencias genéticas han sido relacionadas a haplotipos de inmunoglobulinas (Crawford, 1998), microsatélites de ADN no codificante (Crawford, 1998) y polimorfismos de ADN en el cromosoma Y (Wells, 2002, 2007). Las evidencias lingüísticas se han enfocado en: 1) la relación entre los idiomas nativos americanos (hablados desde antes de 1492) con aquellos de la parte oriental de Siberia, y 2) la relación entre los mismos idiomas nativos americanos (Greenberg, 1987). Cabe mencionar la coherencia y la sincronía en la divergencia entre varios aspectos físicos genéticos y un logro inmaterial como lo es el idioma. La primera migración amerindia que llegó hasta América del Sur es la más antigua y la que más se diversificó, llegando a 583 idiomas (Cavalli-Sforza et al., 1994). La segunda migración Na-Dene entró en América del Norte hace 8000 años A.P. y dejó huella en los pueblos Atabascanos (oeste de Canadá y Alaska oriental), Apache y Navajo, que no llegaron a América del Sur. No se ha descartado que esta segunda migración se haya realizado por las costas del Pacífico (Wells, 2007). La tercera y más reciente migración Eskimo-Aleut concierne únicamente al norte de Canadá y Alaska; por quedarse en estas latitudes extremas, esta gente intervendrá poco en la domesticación de plantas americanas.

Tabla 5.1. Algunos cultivos americanos y fechas de hallazgos arqueológicos, y lugares.

\begin{tabular}{llll}
\multicolumn{1}{c}{ Cultivos } & \multicolumn{1}{c}{$\begin{array}{c}\text { Fechas años } \\
\text { A.P. }\end{array}$} & \multicolumn{1}{c}{ Lugares } & \multicolumn{1}{c}{ Fuentes } \\
Calathea allouia & 9300 & Prov. Guayas, Ecuador & Piperno y Stothert, 2003 \\
\hline Capsicum baccatum? & 6100 & Prov. Guayas, Ecuador & Perry et al., 2007 \\
\hline Cucurbita moschata? & 9300 & Prov. Guayas, Ecuador & Piperno y Stothert, 2003 \\
\hline Cucurbita pepo & 9900 & Edo. Oaxaca, México & Smith, 1997 \\
\hline Gossypium barbadense & 5490 & Dep. Lambayeque, Perú & Dillehay et al., 2007 \\
\hline Lagenaria siceraria & 9300 & Prov. Guayas, Ecuador & Piperno y Stothert, 2003 \\
\hline Manihot esculenta & 7000 & Prov. Coclé, Panamá & Piperno, 2006 \\
\hline Phaseolus lunatus & 5600 & Dep. Lima, Perú & Kaplan y Lynch, 1999 \\
\hline Phaseolus vulgaris & 4300 & Dep. Ancash, Perú & Kaplan y Lynch, 1999 \\
\hline Zea mays & 8700 & Edo. Guerrero, México & Piperno et al., 2009 \\
\hline
\end{tabular}

¿Por qué el sistema agricola precolombino se parece más a una pequeña huerta de policultivo cuando su contraparte en el Viejo Mundo es un campo grande?, ¿Por qué solo se veía gente con picos de madera mientras que en la Creciente Fértil y en el Egipto Antiguo se veían arados jalados por bueyes?, ¿Por qué se usaron metates por acá y grandes ruedas para la molienda de granos por allá?, ¿Por qué las papas andinas y los frijoles precolombinos son multicolores en contraste con el trigo o la arveja?, ¿Por qué varios cultivos de grano del Viejo Mundo fueron sustituidos por los del Nuevo Mundo desde 1493 en adelante? Estas son algunas preguntas de geografía histórica que se tratará de contestar a continuación. 
Si bien hay consenso en que el poblamiento del continente americano antes de 1492 se hizo a través de Beringia (Dillehay, 2000; Wells, 2007; Fagan, 2011; Watson, 2011), la fecha de este poblamiento sigue siendo objeto de discusiones. Un punto de intenso debate es la fecha de la primera migración. A favor de una migración reciente ( 14 000 años A.P.) están las evidencias genéticas usando ADN mitocondrial (Sykes, 2001), o polimorfismo en el cromosoma $Y$ (Ruiz-Linares, 1999; Wells, 2007), incluyendo una reconsideración de la diversidad de idiomas americanos (Nettle, 1999) que apunta a una rápida diferenciación de estos. Algunos hallazgos arqueológicos en Alaska central no muestran la presencia de humanos antes de 14.5-13 000 años a.P. (Dale Guthrie, 2006; Fagan, 2011). A favor de una migración temprana ( 30 000 años a.P.) están algunas evidencias genéticas usando ADN mitocondrial (Torroni et al., 1994), y también de modo indirecto los hallazgos de Monte Verde cerca de Puerto Montt en Chile (Dillehay et al., 2008) y los de Pedra Pintada cerca de Taperinha en Brasil (Roosevelt et al., 1996). Pero la migración - a pie - se hizo en un período glaciar: el mar de Bering había retrocedido porque una enorme cantidad de agua estaba fijada como hielo sobre el norte de Canadá y las Montañas Rocosas, además de todo el ártico (Fairbanks, 1989). El último período glaciar fue hace 18000 años a.P. (Fairbanks, 1989; Petit et al., 1999; Yokoyama et al., 2000; Graham, 2011), o hace 26-20 000 años a.P. (Clark et al., 2009). Sigue el debate pendiente de nuevos hallazgos arqueológicos, considerando que se necesitaría un paso libre en Beringia y unos 3000 años para cubrir la distancia de Alaska hasta Chile (Stringer y Andrews, 2012).

\section{La crónica escasez de gente en las Américas}

Una consecuencia del patrón de colonización humana en esta parte del mundo es una población original muy pequeña y de composición genética bastante uniforme (Fagan, 2011). En genética de poblaciones, esta situación de migración de unos individuos seguida por una expansión geográfica y demográfica se conoce como "efecto fundador" (Nei, 1987; Avise, 1994). Los pueblos americanos precolombinos pagarán un alto precio por este efecto fundador a momento de la introducción de las enfermedades del Viejo Mundo, con alta mortandad (Crosby, 1991; McNeill, 1998). La duración del contacto con el ganado hizo que en el Viejo Continente la población humana tuviera la oportunidad de desarrollar resistencia a enfermedades tales como la viruela o el sarampión (Crosby, 2004; Mann, 2011). Esta situación no existió en el Nuevo Mundo hasta 1493 cuando llegaron el caballo, el ganado vacuno, caprino y porcino (Bennett y Hoffman, 1991; Crosby, 2003). La caída demográfica fue catastrófica (Borah, 1992), y explica en buena parte la facilidad con la cual desaparecieron los imperios azteca e incaico (McNeill, 1998). La amplitud de esta catástrofe demográfica conforta la hipótesis de la entrada original de poca gente al continente americano y en pocas migraciones. Cabe recordar que en el momento de las migraciones a través de Beringia estos mismos animales domésticos del Viejo Mundo aún no habían llegado al oriente de Siberia, donde por igual provocaron después severas caídas demográficas (Mann, 2011). Cabe decir que el oriente de Siberia fue poblado hace 20000 años A.P. (Wells, 2007), mientras que estos mismos animales domésticos fueron domesticados en Asia suroccidental hace 10000 años A.P. (Larson et al., 2014). Entonces la población humana que entró en las Américas jamás estuvo en contacto con los animales domésticos del Viejo Mundo una vez que el mar volvió a ocupar Beringia 14000 - 12000 años a.P. (Crawford, 1998)

\section{La extinción de animales que podrían haber cambiado el transporte y la agricultura}

La entrada por Alaska hace $\sim 15,000$ años A.P. debido a los limitantes climáticos hace que el patrón económico y cultural haya sido predominantemente la cacería. De hecho, las condiciones climáticas de la zona hasta hoy solo permiten la caza como tipo de subsistencia, y recientemente unas pocas industrias extractivas. La gente migrando hacia el sur seguirá en este patrón, empujando hacia la extinción gran parte de la megafauna americana con la ayuda de alteraciones climáticas (Leakey y Lewin, 1995; Guthrie, 2006). Al igual como pasó con la fauna de muchas islas al momento de su descubrimiento en los siglos XVI y XIX de nuestra era; por ejemplo la extinción del dodo en Mauritius en 1598-1662 (Gill y West, 2001), la fauna, por no haber visto jamás al hombre cazador, no había desarrollado el miedo y el instinto de fuga. Asi desaparecieron el mamut, el mastodonte, el bisón de estepa, el oso de cara corta, el perezoso gigante de suelo, el caballo, varios camélidos, solo para mencionar algunos (Gill y West, 2001; Janis, 2001; Guthrie, 2006). Esta cacería fácil empujó a la gente hacia el oriente y hacia el sur (cabe hacer notar que es el mismo patrón de cacería que aún se encontró en Monte Verde en Chile: Dillehay et al., 2008), llevando a la extinción al caballo y otros animales susceptibles de jalar una carga. En efecto, no todos los animales se prestan para ser domesticados, esto es debido a siete características específicas de su morfofisiología (por ejemplo, tamaño, velocidad de crecimiento, alimento de fácil consecución) y de su comportamiento (e.g. carácter dócil, jerarquía grupal, ausencia de pánico y reproducción en cautiverio) (Diamond, 2012); y no todos tienen la fuerza para las labores agrícolas. El perro acompañó a la gente en la entrada al continente americano, pero solo se presta a jalar un trineo (Schwartz, 1997), y no hay nieve en todas partes. Cabe señalar que la fauna americana - que sobrevivió la extinción pleistocénica - solo contribuyó con animales domésticos como la llama, la alpaca, el cuy y el pavo (Harlan, 1995), aunque en tiempos precolombinos hubo selección de razas de perros para comer en México y Perú (Schwartz, 1997). La falta real de animales de tiro en tiempos precolombinos dejó pocos incentivos para el uso de la rueda. La rueda existió, como lo muestran unas pequeñas figuras de terracota de México -en Veracruz, 1400 años A.P.- (Burland, 1976), hace 5000 años A.P. pues en Asia suroccidental los bueyes ya jalaban carretas con ruedas y arados (Diamond 1997), una diferencia profunda con la América precolombina.

\section{Una geografía no facilitadora de la comunicación}

La entrada de los primeros americanos fue por Alaska, no por el oriente, y el destino de continente podría haber sido distinto con una entrada por el Saint-Laurent o por el Río Amazonas o por el Río de la Plata. ¡Entraron por la parte más montañosa, y, además, volcánica En términos de geografía física, el continente americano en el lado Pacífico tiene una comunicación norte-sur frecuentemente interrumpida por el relieve o el clima (e.g. desiertos de Altar, Sechura, Atacama). La comunicación del oeste hacia el este tampoco es fácil, con excepción de los grandes llanos de Norteamérica y de la pampa sudamericana. Sin embar- 
go, los grandes llanos de Norteamérica son cada año expuestos a tornados impredecibles y devastadores. El bosque boreal y la selva amazónica completan esta dificultad de comunicación longitudinal (Cabrera y Willink, 1980). Muchos de los ríos también comunican en e sentido latitudinal -Mississippi, Cauca, Magdalena, Orinoco, Paraná-, con la excepción de río Amazonas. Cabe notar en el lado Pacífico el número reducido de grandes ríos -Columbia, Sacramento, Colorado, Santiago, Balsas, Patía, Santa- y sus valles atravesando empinadas cordilleras. América Central solo podría verse como corredor en sus tres depresiones $-\mathrm{Te}-$ huantepec, Nicaragua, Panamá-; por el resto tiene relieve quebrado con muchos volcanes muy activos. La geografía americana no es, entonces, muy propicia a la comunicación. No es casual que el Tahuantisuyu de los Incas que se extendió desde el río Ancasmayo (Nariño, Colombia) hasta el río Maule (Región del Maule, Chile) logró esta extensión territorial solo en 1527, por ser el primero en implementar una red de caminos (Lumbreras, 1987). Como lo recordó Diamond (2002), el eje del continente americano es norte-sur o latitudinal, y el movimiento de cultivos se hace en contra de un gradiente fotoperiódico. Un cultivo de arracacha presente en Nariño (Patiño, 1964) podrá adaptarse a las condiciones de la Sierra Nevada de Santa Marta (Reichel-Dolmatoff, 1988) a la misma altitud, pero luego de un trabajo de selección por los diez grados de diferencia en latitud. La papa oriunda de los Andes centrales (Spooner et al., 2005) será seleccionada para adaptarse a las condiciones de Chiloé (Gavrilenko et al., 2013), con una diferencia de treinta grados en latitud. El maíz oriundo de la cuenca mediana del río Balsas (Matsuoka et al., 2002) (18 ${ }^{\circ} 30^{\prime}$ latitud Norte) será seleccionado en la Quebrada de Humahuaca (Cámara-Hernández y Arancibia de Cabezas, 2007) $\left(23^{\circ}\right.$ latitud Sur), una vez atravesado el Istmo de Panamá tropical.

Otro factor que complica tales condiciones es que la zona del Pacífico desde México hasta Perú puede ser afectada por las oscilaciones climáticas de El Niño, responsables de graves sequías en América Central (las cuales tuvieron impacto en el colapso de la civilización Maya: Gil, 2001) o de inundaciones catastróficas en la costa Pacífica de América del Sur (que contribuyeron en el fin de la civilización Moche: Fagan, 1999).

\section{Cuando los ríos traían polvo del sol}

Entre las industrias más significativas del progreso humano está el trabajo de los metales. Otras especies animales usan herramientas, como los chimpancés (Hernández-Aguilar et al., 2007) o el pinzón carpintero (Wilson, 1992), pero la metalurgia es marca de nuestra especie; además, deja huellas en el tiempo, pues los metales trabajados pueden mantenerse por unos años, a veces muchos siglos. El trabajo de los metales es un evento tardío en la historia de los pueblos americanos, aproximadamente hace 4000 años A.P. para el cobre y el oro (Root 1963; Fagan, 2004). Su papel en la agricultura ha sido, por lo tanto, limitado, desde allí la escasez de hachas o palas con partes metálicas cortantes. El oro, relativamente abundante en las aluviones de ríos de América Central, Colombia y Perú (Root, 1963; Burland, 1976), no dio lugar a herramientas duras (en escala de dureza 2.5 contra 5 para el hierro: Hodgman et al. 1959), pero sí a piezas de adorno de excepcional belleza. El estaño y el plomo, de temperaturas de fusión más asequibles $\left(232{ }^{\circ} \mathrm{C}\right.$ y $326^{\circ} \mathrm{C}$, respectivamente, contra $1063^{\circ} \mathrm{C}$ para el oro:
Hodgman et al., 1959), son metales blandos (dureza: 1.5 para ambos: Hodgman et al., 1959) no aptos para herramientas agrícolas. El hierro o sus aleaciones necesitan temperaturas más altas $\left(1515^{\circ} \mathrm{C}\right.$ para el primero: Hodgman et al., 1959), conseguidas en pequeños hornos con carbón vegetal y sopletes; estos hornos aparecieron más tarde en la historia precolombina (Root, 1963). La gente tuvo entonces que usar el fuego para dejar libre un terreno para la siembra. Además de algunos árboles útiles salvados a propósito (Hernández-Xolocotzi, 1959) y preservados más o menos, la tumba y la quema eran usualmente totales, tratando que el fuego no se salga de control. El uso repetido del fuego contra una flora poco adaptada ha causado la erosión de muchos suelos del trópico americano, desde tiempos precolombinos hasta hoy. Este uso ayudó a controlar las malezas y a impedir el regreso inmediato de la vegetación original, y contribuyó al éxito de los sistemas agrícolas. Sin embargo, trae un elemento intrínseco de inestabilidad: si el sistema agrícola es exitoso, entonces alimentará a más personas, y para esto necesitará más área bajo cultivo o menor tiempo de rotación y descanso del suelo, y más quemas.

\section{La insaciable curiosidad precolombina}

Por último, debemos notar un rasgo sociocultural compartido entre Siberia oriental y Alaska: el chamanismo. El chamanismo existe en ambos lados de Beringia en el momento del cruce hace 26-14 000 años a.P. (Clark et al., 2009; Graham, 2011), pues entonces este rasgo era común entre la misma gente (Watson, 2011). Al migrar hacia el sur, el chamán descubre una flora nueva jamás vista en Beringia en la cual busca, mediante pruebas y errores, las plantas que curan o que permiten sus ritos. Cabe mencionar que el chamanismo existe mucho antes que la domesticación de plantas con fines alimenticios en el Nuevo Mundo. El chamanismo ha perdurado hasta hoy en muchos pueblos amerindios, por ejemplo, el huichol en Nayarit, México (Lumholtz, 1902); el desana en el Vaupés, Colombia (Reichel-Dolmatoff, 1997); el shuar en Morona-Santiago, Ecuador (Bennett et al., 2002); el toba-pilagá en Formosa, Argentina (Arenas, 1992). Este rasgo tendrá importancia en la búsqueda de plantas y hongos alucinógenos, donde el Nuevo Mundo se revelará particularmente rico (Schultes y Hofmann, 1992) (Tabla 5.2). Es importante destacar que es el uso, durante milenios y hasta el presente, lo que ha revelado las propiedades de estas plantas, y, desde luego, es la demostración del detenido conocimiento de la flora neotropical. Es posible que por su extensión territorial Eurasia y la Creciente Fértil en particular cuenten con un número igualmente alto de plantas y hongos alucinógenos, pero estos cayeron en desuso (La Barre, 1970), mientras que miles de años después de los primeros usos, América del Sur cuenta con diez veces más plantas y hongos con uso psicotrópico y mágico conocido.

Tabla 5.2. Número de plantas y hongos alucinógenos por zonas geográficas.

\begin{tabular}{ccccccc} 
Europa & África & Oeste asiático & $\begin{array}{c}\text { Sureste } \\
\text { asiático }\end{array}$ & $\begin{array}{c}\text { Norte y } \\
\text { Centroamérica }\end{array}$ & $\begin{array}{c}\text { América } \\
\text { del Sur }\end{array}$ & $\begin{array}{c}\text { Total } \\
12\end{array}$ \\
14 & 4 & 23 & 38 & 41 & 132 \\
\hline
\end{tabular}

Fuentes: Dobkin de Ríos, 1977; Plowman, 1984; Schultes y Hofmann, 1992; Wink y van Wyk, 2008 


\section{Un cambio climático no esperado}

Alrededor del duodécimo milenio antes de nuestra era, un cambio climático afectó la disponibilidad de alimentos (Wells, 2010). El interglaciar con temperaturas en aumento progresivo es súbitamente interrumpido por un período caliente de 1500 años, seguido por un período frío de 900 años (13 500-12 600 A.P) (Fairbanks, 1989; Fagan, 2005). Este cambio es conocido como "Dryas Más Reciente", por una planta rosácea, la Dryas octopetala, característica de la vegetación del Ártico (Ronning, 1996), debido a una nueva expansión de esta vegetación en la zona boreal. En paralelo, en los Andes vuelve a bajar el páramo y los bosques andinos (Heusser y Shackleton, 1994). El patrón de consumo extractivista (colecta, cacería) permitió una expansión demográfica sostenida primero y luego acelerada. El brutal regreso de temperaturas frías empujó este patrón al extremo y lo hizo tambalear. En lugar de caminar lejos hasta las poblaciones de plantas preferidas cada vez más escasas, alguien pensó que era más fácil sembrarlas cerca de los campamentos. Fue la entrada de algunas plantas en el domus, es decir, la domesticación, y significó la discontinuidad espacial, temporal y biológica con las plantas de la población madre. La idea de sembrar -reconocida con razón como un acto fundamental en el inicio de la agricultura (Harlan 1975)- puede haber ocurrido más de una vez y puede haber sido copiada, y explica en buena parte el gran número de plantas domesticadas en las Américas en tiempos precolombinos (ver las compilaciones de Clement, 1989; Harlan, 1992; León, 1992; Smith, 2006). Puede haber sido la idea de una persona con poca movilidad, como un anciano o una mujer con niño pequeño, y de paso el inicio de la vida sedentaria para ver el resultado del "experimento".

\section{El cultivo de los silvestres afuera de los lugares donde crecen}

Los datos arqueológicos (Tabla 5.1) y genéticos (p. ej. para frijol común, hace 8200 y 8500 años A.P. en Mesoamérica y en los Andes, respectivamente: Mamidi et al., 2011) y otros estudios (Tehuacán, Puebla, México: MacNeish, 1967; Aguadulce, Coclé, Panamá: Piperno y Pearsall, 1998; Santa Helena, Guayas, Ecuador: Piperno y Pearsall, 1998) permiten la hipótesis de este inicio de la domesticación hace $\sim 9000$ años A.P. Las fechas parecen iguales en muchos sitios, en un principio no conectados, y las fechas implican a varios cultivos, dejando entender que el problema de abastecimiento era común a través de varias comunidades humanas, y que la respuesta tuvo la misma lógica sencilla: sembrar para colectar cerca en lugar de ir a colectar lejos, porque la gente por su sentido de observación ya había entendido la conexión entre la semilla germinada dando una planta adulta y luego una futura cosecha. Cabe notar que muy probablemente se sembraron las mismas formas silvestres que más adelante darán lugar a los cultivos. Es lo que se pudo ver con el teocintle (Benz, 2001), el frijol (Berglund-Brücher y Brücher, 1976; Kaplan et al., 2015), y la calabaza (Smith, 1997). La siembra de los silvestres explica la larga duración de la eliminación de la dispersión natural en el proceso de domesticación, 11000 a 8000 años a.P. (Fuller et al., 2014). Llama la atención que no se tienen documentados muchos abandonos de este nuevo patrón de siembra-cosecha, dejando suponer que había una ventaja definitiva en seguir el proceso de domesticación, quizás la seguridad de cosechar algo. Igualmente, debía haber un medio para reconocer las plantas en el proceso de sus parientes silvestres ancestrales. Como no se seleccionaba sobre el sistema reproductivo de las plantas, entonces gracias al flujo de genes los caracteres silvestres dominantes tenían altas posibilidades de regresar y arruinar el esfuerzo de domesticación. Pero el acto de sembrar afuera (en el espacio y/o en el tiempo) del contacto con la(s) población(es) madre(s) del pariente silvestre ayudó a avanzar en la domesticación y así lograr la diferenciación.

Los marcadores moleculares que fueron tan frecuentemente usados para ubicar el lugar de domesticación apuntan más bien a la población silvestre de la última cosecha (Debouck 2016), asumiendo que las formas silvestres aún tienen hoy la misma posición geográfica que en esta época, mientras que la domesticación real tuvo lugar en otra parte. Así como lo hemos visto, el maíz altoandino (Grobman et al., 1961) tiene su origen en la cuenca mediana del Balsas (Matsuoka et al., 2002), el frijol de la raza nueva granada (Singh et al., 1991) viene de los Andes centrales (Chacón-Sánchez et al., 2005), el ib maya (Martínez-Castillo et al., 2004) viene de occidente de México (Andueza-Noh et al., 2013), el cacahuate mexicano (Smith, 1967) viene del Gran Cháco (Kochert et al., 1996) y la yuca centroamericana (Dickau et al., 2007) proviene del suroccidente de la cuenca amazónica (Olsen y Schaal, 2001).

\section{Unas plantas dando una mano a gente recursiva}

La imposibilidad de poder arar por falta de animales de tiro y de rejón metálico, obligó a otro manejo de las plantas cultivadas, es decir, un manejo individual debido a la siembra por sitio. La atención del agricultor se concentró entonces sobre pequeños grupos de plantas individuales, no sobre comunidades vegetales grandes. Las consecuencias en varios cultivos americanos son el gigantismo de las partes cosechadas - se trata de minimizar el esfuerzo y de maximizar el beneficio- (Smartt, 1988), la variación estética -se seleccionan los variantes de partes cosechadas como frutos, semillas, tubérculos, con colores muy llamativos- (Hawkes, 1983), y posiblemente de manera indirecta el valor nutricional. Cabe notar que varias plantas americanas tienen un aporte calórico superior por superficie sembrada en comparación a sus pares en el Viejo Mundo (Crosby, 2003). El color muy llamativo de varias papas andinas ayudó en el momento de la cosecha (iselección indirecta!), pero se puede pensar que era una búsqueda sistemática para variar una dieta proclive a la monotonía. El gigantismo puede explicar el éxito del maíz en África occidental contra los cereales locales (sorgo, mijos) (National Research Council, 1996). Lo mismo puede haber pasado en Chile donde los Mapuches adoptaron el maíz al lado de su Bromus mango (Wilhelm de Mösbach, 1992). Llama la atención que es en las Américas donde se encuentra el mayor número de domesticaciones por género vegetal, con Capsicum (5), Cucurbita (5), Phaseolus (7) y Solanum sección Petota (7) (Hawkes, 1990; Debouck y Smartt, 1995; Heiser, 1995; Pickersgill, 2007). No se sabe si estos casos son fortuitos, pero se nota que la gente precolombina no dejó perder estos recursos alimenticios.

Por otra parte, la única fuerza laboral, siendo la gente misma, no permitió que se modificaran grandes superficies por ciclo; desde allí viene la necesidad de producir todo lo necesario hasta la próxima cosecha en el mínimo perímetro (Anderson, 1997). Aquí puede estar la razón 
de las mezclas de cultivos. Nuevamente, el agudo sentido de observación ayudó: en efecto, no es raro observar en el occidente del Eje Neovolcánico de México el frijol común silvestre creciendo sobre el tallo del teocintle (Miranda-Colín, 1967). Pero la mezcla de cultivos (maíz-friol-calabaza-chile como cuadrilogía de base en Mesoamérica, o papa-oca-quinua-tarwi en la zona altoandina) contribuyó a sistemas agronómicamente más estables y nutricionalmente más balanceados. Esta verdadera innovación de añadir plantas puede haber sido la iniciativa de una persona, pero el contexto hizo que el sistema policultivo fuera adoptado en casi todo el mundo agrícola precolombino.

Otra consecuencia importante: el rendimiento del trabajo individual puede multiplicarse con la ayuda de varias personas. En varias partes de la América precolombina, algunas operaciones agrícolas exigentes en mano de obra (como la siembra o la cosecha) son operaciones colectivas con activa participación de la familia o de la comunidad. También se requiere mano de obra importante para la elaboración de las terrazas; estas son principalmente distribuidas del lado Pacífico del continente desde 2800 años a.P. (Donkin, 1979), por donde entraron los primeros americanos y donde aparentemente ocurrieron muchas de las primeras domesticaciones.

\section{Epílogo}

La especie humana entró al Nuevo Mundo con conceptos del Viejo Mundo sin haber entendido

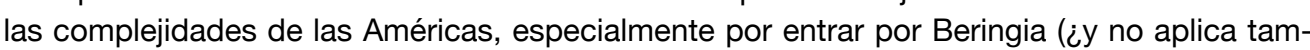
bién cuando entró por las Bahamas en 1492?). Así, la cacería puede haber eliminado varios animales domésticos potenciales que hubieran facilitado diversas operaciones agrícolas o de transporte. No obstante, la entrada por Beringia trajo el chamanismo y con él la búsqueda de plantas y hongos alucinógenos, y desde allí la curiosidad insaciable de conocer la flora y las ganas de experimentar con las plantas. Este conocimiento y este sentido de experimentación fueron -quizá- la salvación cuando arribó el "Dryas más Joven", cambio climático que marcó el arranque de la agricultura en unos pocos focos del mundo. La geografía física del continente complicó la migración del lado Pać́fico, dejando frecuentemente las comunidades humanas poco comunicadas. La geografía física del continente, por la ubicación de los yacimientos de metales y carbón, también frenó el desarrollo de una metalurgia aplicable en la agricultura.

En contraste con la Creciente Fértil de Asia occidental, en el caso de las Américas, no hay un centro de origen de las plantas cultivadas. Es verosímil que en los años treinta los botánicos rusos (Bukasov, 1930; Vavilov, 1939) pudieron aún observar una gran concentración geográfica de variedades de unos cultivos, pues el mejoramiento científico aún no había conducido a la extinción de un gran número de variedades tradicionales. Pero tal concentración era el resultado final de movimientos de plantas oriundas de muchas partes del continente americano gracias a eficaces -aunque de corto rango- circuitos de semilla. Fue también el resultado de la construcción de sistemas donde, como lo permitan las condiciones ecológicas (clima y suelo), se asocian varias plantas, cuya finalidad es la producción de alimentos y otros productos para el abastecimiento de la comunidad por todo el año (Anderson, 1997). De esto son testigos los movimientos precolombinos del maíz (Thompson, 2006), frijol (Chacón-Sánchez et al., 2005), maní (Dillehay et al., 2007), y yuca (Piperno, 2006).
Pese a estas dificultades geográficas y climáticas, la gente precolombina hizo una demostración de un talento sin igual como domesticador y fitomejorador de plantas. Su legado ha sido un aporte del $40 \%$ a la mesa del mundo de hoy, un impacto tremendo en la revolución texti y del transporte en el siglo XIX a.D. ¡Sí, nos dejaron semillas de maíz, de frijol y muchos más cultivos gigantes y bellos, pero también semillas de esperanza y de humanidad!

\section{Agradecimientos}

El autor extiende un especial agradecimiento a los organizadores del Simposio, Fabiola Parra Rondinel, Alejandro Casas y Juan Torres Guevara, por la amable invitación a compartir en La Molina las informaciones aquí reunidas. El autor agradece calurosamente a Josefina Martínez Realpe por su cuidado en la edición del manuscrito. 


\section{Bibliografía}

Anderson, E., 1997. Plants, man and life. Missouri Botanical Clark, P. U., A. S. Dyke, J. D. Shakun, A. E. Carlson, J. Clark, Garden, St. Louis, Missouri, USA.

Andueza-Noh, R., M. L. Serrano-Serrano, M. I. ChacónSánchez, I. Sánchez del Pino, L. Camacho-Pérez, J. Coello-Coello, J. Mijangos-Cortes, D. G. Debouck y J. Martínez-Castillo, 2013. Multiple domestications of the Mesoamerican gene pool of Lima bean (Phaseolus
lunatus L.): evidence from chloroplast DNA sequences. Genetic Resources and Crop Evolution, 60 (3): 10691086 B. Wolhlfarth, J. X. Mitrovica, S. W. Hostetler y A. M. McCabe, 2009. The Last Glacial Maximum. Science

lement, C. R., 1989. A center of crop genetic diversity in western Amazonia. BioScience, 39 (9): 624-631.

Crawford, M. H., 1998. The origins of Native Americans: evidence from anthropological genetics. Cambridge Universty Press, Cambidge, Unted Kingdom.

Arenas, P., 1992. El Chaco, su gente y las plantas. Universidad de Córdoba, Córdoba, España. inlit. Margo

Avise, J. C., 1994. Molecular markers, natural history and Crosby, A. W., 2003. The Columbian exchange: biological and

Bennett, D. y R. S. Hoffman, 1991. Ranching in the New World. En: H.J. Viola y C. Margolis (Eds.). Seeds of
change. Smithsonian Institution Press, Washington, DC, USA, pp. 90-111.

Bennett, B. C., M. A. Baker y P. Gómez-Andrade, 2002. Ethnobotany of the Shuar of eas
in Economic Botany, 14: 1-299.

Benz, B. F., 2001. Archaeological evidence of teosinte domestication from Guilá Naquitz, Oaxaca. Proceedings 2104-2106.

Berglund-Brücher, O. y H. Brücher, 1976. The South American wild bean (Phaseolus aborigineus Burk.) as ancestor of the common bean. Economic Botany, 30 (3): 257-272.

Borah, W., 1992. The historical demography of aboriginal an colonial America: an attempt at perspective. En: W. M. Denevan (ed.). The native population of the Americas in 1492. $2^{\mathrm{a}}$ ed., The University of Wisconsin Press, Madison,

Bukasov, S. M., 1930. The cultivated plants of Mexico, Guatemala and Colombia. Bulletin of Applied Botany

Burland, C. A., 1976. Peoples of the sun: the civilizations of pre-Columbian America. Praeger Publishers Inc., New

Cabrera, A. L. y A. Willink, 1980. Biogeografía de América Latina. $2^{\mathrm{a}}$ ed., Organización de

Cámara-Hernández, J. y D. Arancibia de Cabezas, 2007. Maíces andinos y sus usos en la quebrada de Humahuaca y regiones vecinas. Facultad de Agronomia, Universidad

Cavalli-Sforza, L. L., P. Menozzi y A. Piazza, 1994. The history and geography of human genes. Princeton
Press, Princeton, New Jersey, USA, $1059 \mathrm{p}$. cultural consequences of 1492. Edición 30 aniversario,

Crosby, A. W., 2004. Ecological imperialism: the biological expansion of Europe, 900-1900. $2^{\mathrm{a}}$ edición,
University Press, New York, New York, USA.

Debouck, D. G., 2016. Your beans of the last harvest and the possible adoption of bright ideas. En: R. Lira, A. Casas people and plants in Mesoamerica Springer, New York, New York, USA, pp. 367-387.

Debouck, D. G y J. Smartt, 1995. Beans, Phaseolus spp. (Leguminosae-Papilionoideae). En: J. Smartt y N. W.
Simmonds (Eds.). Evolution of crop plants. $2^{\mathrm{a}}$ edición, Longman Scientific \& Technical, Harlow, United Kingdom.

De Feo, V., Della Porta, G., Urrunaga Soria, E., Urrunaga Soria R., \& Senatore, F. (1998). Composition of the essential oil
of Tagetes filifolia Lag. Flavour and Fragrance Journal,
13(3): 145-147. 13(3): $145-147$

lamond J., 1997. Guns, germs and steel - The fates of human societies. W.W. Norton \& Co., New York, New York, USA.

amond, J., 2002. Evolution, consequences and future of plant and animal domestication. Nature, 418 (6898) $700-707$

Diamond, J., 2005. Collapse: how societies choose to fall or succeed. Viking Penguin, New York, New York, USA. Diamond, J., 2012. The local origins of domestication. En P. Gepts, T. R. Famula, R. L. Bettinger, S. B. Brush, A. B. Damania, P. E. McGuire y C. O. Qualset (Eds.) Blodiversity in agriculture. Domestication, evolution, and sustainability. Cambridge University Press, New York,

Dickau, R., A. J. Ranere y R. G. Cooke, 2007. Starch grain crops into tropial dry and humid forests of anam Proceedings of the National Academy of Sciences USA, 104 (9): 3651-3656.

Chacón-Sánchez, M. I B. Pickersgill y D.G. Debouck, 2005. Dillehay, T. D., 2000. The settlement of the Americas: a new

Domestication patterns in common bean (Phaseolus prehistory. Basic Books, New York, New York, USA. vulgaris $L$.) and the origin of the Mesoamerican and Andean cultivated races. Theoretical and Applied
Dillehay, T. D., J. Rossen, T. C. Andres y D. E. Williams, 2007. Preceramic adoption of peanut, squash, and co
northern Peru. Science, 316 (5833): 1890-1893.
Dillehay, T. D., C. Ramírez, M. Pino, M. B. Collins, J. Rossen y Harlan, J. R., 1992. Crops and Man. $2^{\mathrm{a}}$ edic., American Society J. D. Pino-Navarro, 2008. Monte Verde: seaweed, food, 320 (5877): $784-786$.

Dobkin de Ríos, M., 1977. Plant hallucinogens and the religion of the Mochica - an ancient Peruvian people. Economic
Botany, 31 (2): 189-203.

Donkin, R.A., 1979. Agricultural terracing in the aboriginal New World. Viking Fund Publ. Anthropol. 56, Wenner Gren Foundation Anthropol. Res., The University of Arizon

Euren, F., 2006. Reforma agraria y desarrollo rural en Perú. Reforma agraria y desarrollo rural en la región

Fagan, B., 1999. Floods, famines, and emperors - El Niño and the fate of

Fagan, B.M., 2004. The seventy great inventions of the ancient world. Thames \& Hudson Ltd, London, United Kingdom.

Fagan, B., 2005. The long summer: how climate changed

Fagan, B., 2011. The first North Americans. Thames \&

Fairbanks, R. G., 1989. A 17,000-year glacio-eustatic sea level record: influence of glacial melting rates on the Younge Dryas event and

Fuller, D. Q., T. Denham, M. Arroyo-Kalin, L. Lucas, C. J. Stevens, L. Qin, R. G. Allaby y M. D. Purugganan, domestication revealed by an expanding archaeologica Proceedings of the National Academy of Sciences USA, 111 (17): 6147-6152

Gavrilenko, T., O. Antonova, A. Shuvalova, E. Krylova, N. Alpatyeva, D. M. Spooner y L. Novikova, 2013. Genetic diversity and origin of cultivated potatoes based on plastid microsatellite polymorphism. Ge
and Crop Evolution, 60 (7): 1997-2015.

Gil, R. B., 2001. The great Maya droughts - Water, life and death. Univ. New Mexico Press, Albuquerque, New

Gill, A. y A. West, 2001. Extinct. Channel 4 Books, London, United Kingdom, $256 \mathrm{p}$

Graham, A., 2011. A natural history of the New World. The University of Chicago Press, Chicago, USA.

Greenberg, J. H., 1987. Language in the Americas. Stanford

Grobman, A., W. Salhuana, R. Sevilla y P. C. Mangelsdorf, 1961. Races of maize in Peru: their origins, evolution an classification. National Academy of Sciences, National

Guthrie, R. D. 2006. New carbon dates link climatic change with human colonization and
Nature, 441 (7090): 207-209.

Harlan, J. R., 1975. Crops and Man. American Society of Agronomy and Crop Science Society of America, of Agronomy and Crop S

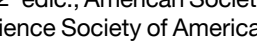
Inc., Madison, Wisconsin, USA.

Harlan, J. R., 1995. The living fields: our agricultural heritage Cambridge University Press, Cambridge, United Kingdom. Kawkes, J.G., 1983. The diversity of crop plants. Harvard
University Press. Cambridge, Massachusetts, USA.

wkes, J. G., 1990. The potato: evolution, biodiversity and genetic resources.
Kingdom, $259 \mathrm{p}$.

ayes, P. M., R. E. Stucker y G. G. Wandrey, 1989. The domestication of American wildrice (Zizania palustris, Poaceae). Economic Botany, 43 (2): 203-214.

heiser, C. B., 1995. Peppers, Capsicum (Solanaceae). En: Smartt, J. y N. W. Simmonds (Eds.). Evolution of crop plants. $2^{a}$ edición, Longman Scientific \& Technica,

ernández-Aguilar, R. A., J. Moore y T. R. Pickering, 2007. Savanna chimpanzees use tools to harvest the of the National Academy of Sciences USA, 104 (49): 19210-19213. de Yucatán. En: E Beltrán (ed). Los recursos naturales del Sureste y su aprovechamiento. Inst. Mex. Rec. Nat. Renov., Mexico 2 (3): 3-57.

usser, L. E. y N. J. Shackleton, 1994. Tropical climatic variation on the Pacific slopes of the Ecuadorian Andes based on a 25,000-year pollen record from deep-sea sedil

odgman, C. D., R. C. Weast y S. M. Selby, 1959. Handbook of chemistry and physics. Chemical Rubber Publishing Co., Cleveland, Ohio, USA.

uamantupa, I., M. Cuba, R. Urrunaga, E. Paz, N. Ananya, M. Callalli, y H. Coasaca, 2011. Riqueza, uso y origen de plantas medicinales expendidas en los mercados de la ciudad del Cusco. Revista Peruana de Biología,

is, C., 2001. Victors by default: the mammalian succession. En: S. J. Gould (Ed.). The book of life. W. W. Kaplan, L. y T. F. Lynch, 1999. Phaseolus (Fabaceae) in archaeology: AMS radiocarbon dates and the Bignificance for pre-Colany, 53 (2): $261-272$.

Kaplan, L., D. L. Lentz, V. Slotten, P. Sheets y A. N. Hood, 2015. Phaseolus from Cerén - A late Classic Maya site. Economic Botany, 69 (2): 150-160.

Kochert, G., H. T. Stalker, M. Gimenes, L. Galgaro, C. RomeroLopes y K. Moore, 1996. RFLP and cytogenetic evidence on the origin and evolution of allotetraploid domesticated peanut, Arachis hypogaea (Leguminose
Journal of Botany, 83 (10): 1282-1291.

a Barre, W., 1970. Old and New World narcotics: a statistica question and an ethnological reply. Economic Botany, 24 (1): 73-80.
19210-19213. 
Larson, G., D. R. Piperno, R. G. Allaby, M. D. Purugganan, L. Andersson, M. Arroyo-Kalin, L.Barton, C. C. Vigueira, T. Denham, K. Dobney, A. N. Doust, P. Gepts, M. T. P. Gilbert, K. J. Gremillion, L. Lucas, L. Lukens, F. B. Marshall, K. M. Olsen, J. C. Pires, P. J. Richerson, R. Rubio de Casas, O. I. Sanjur, M. G. Thomas y D. Q.
Fuller, 2014. Current perspectives and the future of domestication studies. Proceedings of the future of Academy of Sciences USA, 111 (17): 6139-6146.

Leakey, R. y R. Lewin, 1995. The sixth extinction: patterns of life and the future or

León, J., 1992, Los recursos fitogenéticos del Nuevo Mundo. En: E. Hernández Bermejo y J. León (Eds.). Cultivos Marginados: Otra Perspectiva de 1492. Food and Agriculture Organization of the United Nations, Rome, Italy, pp. 3-22.

Lumbreras, L.G., 1987. The peoples and cultures of ancient Peru. Smithsonian Institution Press, Washington, D.C

Lumholtz, C. 1902, Unknown Mexico: explorations in the Sierra Madre and other regions, 1890-1898. Vol. Charles Scribner's Sons, New York, New York, USA.

MacNeish, R. S., 1967. A summary of the subsistence. En:
D. S. Byers (ed.). The prehistory of the Tehuacan Valley. D. S. Byers (ed.). The prehistory of the Tehuacan Valley.
Vol. 1. Environment and subsistence. Univ. Texas Press, Vol. 1. Environment and subsisten
Austin, texas, USA, pp. 290-309.

Mamidi, S., M. Rossi, D. Annam, S. Moghaddam, R. Lee, R. Papa y P. McClean, 2011. Investigation of the using multilocus sequence data. Functional Plant Biology, 38 (12): 953-967.

Mann, C. C., 2011. 1491: new revelations of the Americas before Columbus. 2a edición, Vintage Books, New York, New York, USA.

Martínez-Castillo, J., D. Zizumbo-Villareal, H. Perales-Riveray P. Colunga-GarcíaMarín, 2004. Intraspecific diversity and from the Yucatan peninsula, Mexico. Economic Botany 58 (3): 354-380.

Matsuoka, Y., Y. Vigouroux, M. M. Goodman, J. Sánchez G, E. Buckler y J. Doebley, 2002. A single domestication for maize shown by multilocus microsatellite genotyping. Proceedings of the National Academy of Sciences USA,
$99(9)$ : 6080-6084.

McNeill, W. H., 1998. Plagues and peoples. Anchor Books, Miranda-Colín, S., 1967. Origen de Phaseolus vulgaris L.
(Frijol común). Agrociencia, 1 (2): 99-109.

Nei, M., 1987. Molecular evolutionary genetics. Columbia University Press, New York, New York, USA.

Nettle, D., 1999. Linguistic diversity of the Americas can be reconciled with a recent colonization. Proceedings of the Nation National Research Council, 1996. Lost crops of Africa. Vol. 1 Grains. National Academy Press, Washington, D.C., USA.
sen, K. M. y B. A. Schaal, 2001. Microsatellite variation in cassava (Manihot esculenta, Euphorbiaceae) and its wild relatives. further evidence, Er a southern Amazonian origin of domestication. American Journal of Botany, 88

Pino, V. M., 1964. Plantas cultivadas y animales domésticos en América equinoccial. $1^{12}$ edic, Imprenta Departamental Cali, Valle, Colombia.

Perry, L., R. Dickau, S. Zarrillo, I. Holst, D. M. Pearsall, D. R. Piperno, M. J. Berman, R. G. Cooke, K. Rademaker, A. J. Ranere, J. S. Raymond, D. H. Sandweiss, F. Scaramelli, K. Tarble y J. A. Zeider, 2007. Starch fossils and the spp. L.) in the Americas. Science, 315 (5814): 986-988. It, J. R., J. Jouzel, D. Raynaud, N. I. Barkov, J-M. Barnola, I. Basile, M. Bender, J. Chapellaz, M. Davis, G. Delaygue, M. Delmotte, V. M. Kotlyakov, M. Legrand, V. Y. Lipenko C. Lorius, L. Pepin, C. Ritz, E. Saltzman y M. Stievenard, (20.000 Nature, 399 (6735): 429-436.

Pickersgill, B., 2007, Domestication of plants in the Americas: insights from Mendelian and molecular genetics. Annals insights from Mendelian and
of Botany, 100 (5): 925-940.

Piperno, D. R., 2006. Identifying manioc (Manihot esculenta Crantz) and other crops in pre-Columbian tropica America through starch grain analysis: a case study E. Emshwiller y B. D. Smith (Eds.). Documenting domestication: new genetic and archaeological paradigms. University of California Press, Berkeley,

Piperno, D. R. y D. M. Pearsall, 1998. The origins of agriculture in the lowland Neotropics. Academic Press, San Diego

Piperno, D. R. y K. E. Stothert, 2003. Phytolith evidence for early Holocene Cucurbita domestication in southwe

iperno, D. R., A. J. Ranere, I. Holst, J. Iriarte y R. Dickau, 20ilentarch grain and phytolith evidence for early nint valley, Mexico Proceedings of the National Academy of Sciences USA, 106 (13): 5019-5024.

Plowman, T. 1984, The origin, evolution, and diffusion of coca, Erythroxylum spp., in South and Central America. En: S. Stone (ed.). Pre-Columbian plant migration. Parvard University Press, Cambridge, Massachusetts, USA, pp. 124-157.

Reichel-Dolmatoff, G., 1988. Cultural change and environmental awareness: a case study of the Sierra Nevada de Santa Marta, Colombia. Proceedings of the chel-Dolmatoff, G., 1997. Rainforest shamans: essays on thel-Dolmatoff, G., 1997. Rainforest shamans: essays on
the Tukano Indians of the northwest Amazon. Themis the Tukano Indians of the northwest Amazon.

Ronning, O. I., 1996. Svalbards flora. Norsk Polarinstitut, Oslo, Norway.
Ona
Roosevelt, A. C., M. Lima da Costa, C. Lopes Machado, M. Michab, N. Mercier, H. Valladas, J. Feathers, W. Barnett, M. Imazio da Silveira, A. Henderson, J. Sliva, B. Chernoff,
D. S. Reese, J. A. Holman, N. Toth y K. Schick, 1996. Paleoindian cave dwellers in the Amazon: the peopling

Root, W. C., 1963. Metallurgy. En: J.H. Steward (Ed.) Handbook of South American Indians. Bureau of Cooper Square Publishers Inc. New York, New York, USA, pp. 205-228.

Ruiz-Linares, A. 1999. Microsatellites and the reconstruction of the history of human populations. En: D. B. Goldstein y C. Schlötterer (eds.). Microsatellites: evolution and Kingdom, pp. 183-197.

Schultes, R. E. y A. Hofmann, 1992. Plants of the gods: their sacred, healing and hallucinogenic powers. Healing Art Press, Rochester, Vermont, USA

Schwartz, M., 1997, A history of dogs in the early Americas. Yale University Press, New Haven, Connecticut, USA.

Senatore, F., Urrunaga Soria, E., Urrunaga Soria, R., Della Porta, G., y De Feo, V. (1998). Essential oils from two
Peruvian Satureja species. Flavourand fragrance journal, 13(1): 1-4.

Singh, S. P., P. Gepts y D. G. Debouck, 1991. Races of common bean (Phaseolus vulgaris, Fabaceae). Econom Botany, 45 (3): 379-396.

Smartt, J., 1988. Morphological, physiological and biochemical changes in Phaseolus beans under domestication. En: P. Gepts (ed.). Genetic resources Dordrecht The Netherlands, pp. 143-161.

Smith, B. D., 1997. The initial domestication of Cucurbita (5314): 932-934. h, B. D., 2006. Eastern NorhAmerica as an independent National Academy of Sciences USA, USA 103 (33): 12223-12228.

Smith, C. E., 1967. Plant remains. En: D.S. Byers, (ed.). The prehistory of the Tehuacán valley.
Austin, Texas, USA, pp. 220-255.

Spooner, D., K. McClean, G. Ramsay, R. Waugh y G. J. Bryan, 2005. A single domestication for potato based on multilocus amplified fragment length polymorphism genotyping. Proceedings of the National Academy of Sciences USA, 102 (41): 14694-14699. tringer, C. y P. Andrews, 2012. The complete world of human New York, USA.

(y)es, B., 2001. The seven daughters of Eve. W.W. Norton \& Co., Inc. New York, New York, USA.

Thompson, R. G., 2006. Documenting the presence of maize in Central and South America through phytolith analysis of food residues. En. M. A. Zeder, D.G. Bradley, E. Emshwiller y B.D. Smith (eds.). Documenting domestication. new genetic and archaeologica California, USA, pp. 82-95.

Torroni, A., J. V. Neel, R. Barrantes, T. G. Schurr y D. C. Amerinds and its implications for timing their entry into North America. Proceedings of the National Academy of Sciences USA, 91 (3): 1158-1162.

avilov, N. l., 1939. The important agricultural crops of preColumbian America and their mutual relationships. Izd. Gos. Geog.
(10): $1-25$.

Watson, P., 2011. The great divide: nature and human nature in the Old World and the New. Harper Collins, New York, New York, USA.

ells, S., 2002. The journey of man: a genetic odyssey. Random House, New York, New York, USA.

ls, S., 2007. Deep ancestry: inside the genographic 作,

s, S., 2010. Pandora's seed: the unforeseen cost of USA.

gena de Chile. Editorial Andres Bello, Santiago, Chile.

W. W. Norton \& Co. Inc., New York, New York, USA.

, M. y B. E. van Wyk, 2008. Mind-altering and poisonous plants of the world. Timber Press, Portland, Oregon, USA. Fyama, Y., K. Lambeck, P. De Deckker, P. Johnston y L. K. observed sea-level minima. Nature, 406 (6797): 713-716. 


\section{Al toro ¿por las astas?}

Reflexiones sobre aproximaciones teóricas

y metodológicas a la temática de la domesticación en el área andina meridional

Verónica S. Lema

\section{Resumen}

En este trabajo presento, en primer lugar, una reflexión sobre las distintas vías que usualmente se emplean para llevar adelante el estudio de la domesticación vegetal, enfatizando los abordajes arqueológicos y arqueobotánicos sobre el tema, considerando la medida en la cual los mismos constituyen y delimitan la problemática, o bien, se derivan de una definición previa de la misma. En segundo lugar, me aboco a presentar sucintamente qué sabemos sobre este tema en la historia prehispánica del Noroeste de Argentina (en el marco de los Andes Meridionales) y cómo nos hemos aproximado al entendimiento y definición de las trayectorias de domesticación en el área. Me interesa particularmente volver "a foja cero" la reflexión sobre los modos de estudiar la domesticación al considerar epistemes y ontologías nativas que subvierten significativamente los términos que constituyen la alteridad y la relacionalidad, lo humano y lo no humano, y nos fuerzan a mirar y reflexionar desde otros lugares que tapizan y constituyen otros mundos.

Palabras clave: domesticación, ontología, crianza, cultivo, Andes.

\section{Introducción}

Los estudios que he realizado en los últimos años sobre las trayectorias del proceso de domesticación vegetal en el Noroeste de Argentina (NOA) se han montado sobre dos vías analíticas que, lejos de ser paralelas, se han cruzado constantemente: una vía etnobotánica/etnográfica y una vía arqueobotánica/arqueológica. La primera ha sido principalmente fuente de reflexiones teóricas, generadora de marcos interpretativos y de nuevas preguntas. La segunda, ha sido mi principal fuente de datos sobre las trayectorias de cambio en las prácticas de manejo sobre e entorno vegetal en el pasado prehispánico de la región. Cuando inicié mi doctorado, tenía una problemática que me inquietaba: el cambio de modo de vida de grupos cazadores recolectores a agricultores en el NOA, siendo las astas por donde tomar a este toro la domesticación y su detección a nivel arqueológico. Como suele ocurrir con las investigaciones, a medida que uno las desarrolla se da cuenta que el toro no es del todo el animal que uno pensaba y las 
astas no son el mejor punto por donde sujetarlo; así, desligué una idea de causalidad lineal y unívoca entre domesticación y orígenes de la agricultura y reubiqué el foco de mi investigación en el cultivo, antes que en la domesticación, como un punto clave de inflexión en la historia de las prácticas de manejo, una historia que se hacía cada vez más dendrítica y múltiple. Años después, trabajos en profundidad a nivel etnográfico junto a colegas, me llevaron a un descentramiento, esta vez epistémico, considerando el modelo relacional andino de uywaña o crianza mutua como una teoría válida -al igual que cualquier otra generada en el ámbito académico- a ser empleada y evaluada frente al registro arqueológico. Hoy estoy profundizando mis investigaciones sobre dicho modelo, considerando las implicancias del mismo no solo desde un punto de vista epistémico, sino también ontológico.

El nuevo toro que se me presenta actualmente es la historicidad de las prácticas de cultivo en el NOA (fundamentalmente en la provincia de Jujuy), desde una perspectiva que emplee modelos locales de relación con el entorno como referentes de indagación, principalmente a(s) lógica(s) de la crianza mutua. Este nuevo animal analítico que estoy definiendo no sé si tiene astas, o si de tenerlas es de allí de donde conviene asirlo. Como la historia de los seis sabios ciegos y el elefante, uno no está solo en esta tarea, habiendo diversos investigadores que procuran definir y abordar a este animal/problema, intentando asirlo desde la mayor cantidad de puntos de vista -teóricos y metodológicos- posibles. Sin considerar a ninguno absoluto, sino a todos complementarios entre sí, es que en las páginas siguientes presento los avances que los investigadores que trabajan en el NOA -incluyéndome- han aportado a este tema. Aún resta la paradoja de saber si estamos abordando a un animal definido desde distintos flancos, o bien, si estamos definiendo a un animal en función de los flancos desde donde procuramos asirlo.

\section{Astas y paleoastas}

¿Cuáles son las astas desde las cuales se suele asir al toro de la domesticación? ¿Cómo se hace esto cuando se le intenta asir desde el registro arqueológico? Tanto en uno como en otro caso los abordajes para el entendimiento de este fenómeno relacional pueden agruparse en:

1. Taxonómicos: cuando se aborda la trayectoria de cambio en la relación entre un cierto taxón y las sociedades humanas con las que se encuentra, o ha encontrado a lo largo de tiempo, interactuando. En realidad, el abordaje taxonómico no estudia uno, sino un complejo de taxa que son los que han ido definiéndose o redefiniéndose a lo largo del tiempo y de la relación (forma antecesora silvestre, cultivada, malezoide, domesticada, tolerada fomentada; cuyo estatus taxonómico es muchas veces difícil de establecer de acuerdo con Harlan, 1992; Casas, 2001). A esta aproximación se vincula la idea de planta cultivada como artefacto (Ford, 1979, 1985), como unidad biocultural (Balée, 1998), plantas con diversos "grados de domesticación" (Guillén et al., 2015 y bibliografía allí citada) o "sem domesticadas" (Clement, 1999). Los estudios genéticos (sea en poblaciones actuales o en restos arqueológicos), morfológicos, fisiológicos o sobre el "síndrome adaptativo de la do-

\footnotetext{
1 Las citas a lo largo del texto procuran ser más representativas de líneas de abordaje del tema de domesticación, que un racconto exhaustivo de antecedentes bibliográficos.
}

mesticación" (Epimaki et al., 1996; Smith, 2006, puede consultarse también el No. 100, vol. 5 de la revista Annals of Botany de 2007) entrarían dentro de este apartado, al igual que la definición sensu stricto de domesticación como plantas que han perdido su capacidad de reproducción si no cuentan con asistencia humana (De Wet y Harlan, 1975; Ford, 1979, 1985; Hillman y Davies, 1990; Harlan, 1992; Gepts, 2005; Smith, 2006; Fuller, 2007). A nive morfológico -y con aplicación arqueobotánica- esta definición encuentra su correlato al establecer como plantas domesticadas aquellas que evidencian esta incapacidad en sus estructuras reproductivas y/o de dispersión. Este puede pensarse como el abordaje que se asocia a una de las dos astas principales del toro.

2. Ecológicos: el abordaje en este caso es desde una escala más amplia que abarca el medio ambiente y el medio social en sus uniones e interdigitaciones más estrechas, las cuales se reflejan a nivel de paisaje, sea tanto su evolución como su estructuración. En este caso, los estudios se pueden centrar también en un taxón y la conformación, cambios e interacciones de sus poblaciones en un espacio dado y con un grupo humano determinado. Es por ello que los estudios poblacionales entran dentro de este apartado, al igual que los estudios sobre paisaje y fenómenos como selvas o bosques antropogénicos y "tierras negras" (Casas, 2001; Hather y Mason, 2002; Gnecco y Aceituno, 2004; Balée, 2010; Clement et al., 2015). También los estudios sobre manejo de malezas en relación a formas domesticadas, los complejos silvestre-cultivado-domesticado, perfiles polínicos y estudios paleoambientales, entre otros. Desde este abordaje se encuentran definiciones de domesticación como un proceso evolutivo que lleva a que poblaciones vegetales puedan prosperar en ambientes creados por humanos, divergiendo sus rasgos morfológicos, reproductivos, fisiológicos y genéticos de las poblaciones silvestres emparentadas (Hawkes, 1969; Harlan, 1992; Guillén et al., 2015). Este puede pensarse como el abordaje que se asocia a la otra asta, de las dos principales que tiene nuestro toro o animal/problema.

3. Sociales: este abordaje ha sido característico de los estudios mayormente orientados a la temática de "los orígenes de la agricultura" donde el desarrollo o incorporación de esta como modo de vida fue una problemática estudiada durante mucho tiempo de forma cas exclusiva por arqueólogos. A diferencia de lo que ocurre en abordajes etnobotánicos o con sociedades actuales, ha sido recién en los últimos tiempos que se han desarrollado algunos estudios arqueológicos que evalúan los derroteros de la domesticación a parti de un "paquete" teórico distinto que ha incluido, por ejemplo, teoría de la práctica, decision making y género, entre otros (véase el volumen 50 , número 5 , de la revista Current Anthropology de 2009, dedicado al tema y una reflexión sobre el mismo en Lema, 2012). Parecería existir en los abordajes al tema una tensión entre lo individual y lo social con respecto a procesos de cambio en las relaciones con el medio, la cual se traduce en la caracterización de los inicios de la domesticación versus los inicios de la agricultura (véase el volumen 52, número 4, también de la revista Current Anthropology de 2011). A este aspecto vinculado a la escala se sumaría otro que refiere al impacto, ya que la presencia de restos de plantas domesticadas puede ir aparejada, o no, a la detección de un cambio más general o global en los grupos cazadores recolectores (por ejemplo, en el tamaño de la población, circuitos de movilidad y tecnología); lo cual, si es el caso, suele caracterizarse como un momento de grupos humanos "transicionales" (Aschero y Hocsman, 2011). Ge- 
neralmente, y a diferencia de la agricultura, se ha considerado que la domesticación por sí sola no marca un cambio notable en los modos de vida de las poblaciones humanas; es por ello que, desde un punto de vista instrumental, es vista como una técnica más que se suma al repertorio de herramientas (por ejemplo, las prácticas de intensificación o ampliación de dieta) aplicadas a la resolución de problemas vinculados principalmente al modo social de vinculación con el ambiente (por ejemplo, fenómenos de circunscripción territorial, demografía, dieta). En el caso de ciertos taxa, o de preparaciones culinarias vinculadas a los mismos (por ejemplo, plantas con propiedades psicoactivas o materia prima de bebidas embriagantes), se ha considerado que la presencia de una especie domesticada en un contexto general cazador-recolector puede generar cambios sociales de relevancia, vinculados especialmente al prestigio social y/o a prácticas religiosas y culticas (Harlan 1992). Sin embargo, la presencia de restos de plantas domesticadas en estos casos suele estar asociada más a redes de intercambio entre colectivos sociales que a cambios en los modos productivos, lo cual suele desafectar a estos casos de la problemática general de la domesticación de especies vegetales.

Estos abordajes no suelen tener un lugar destacado en las síntesis generales que sobre domesticación se hacen (por ejemplo, Larson et al., 2014), en parte por eso de que: "el cultivo tiene relación con actividades humanas, mientras que la domesticación se relaciona con la respuesta genética de la planta o animal que está siendo atendido o cultivado" (Harlan, 1992 $64)$, y en parte porque su comprensión reviste un carácter fuertemente local que difícilmente logra ser aunado en grandes modelos o síntesis globales. Estos abordajes son entonces difíciles de ubicar en nuestro animal-problema, es, como si nuestro toro tuviese un pequeño cuerno en la frente cuya sujeción no implica la sujeción del problema como un todo.

4. Relacionales: en este abordaje no se pone tanto el énfasis en uno de los dos grandes polos o términos de la relación (plantas/gente), sino en la relación misma. En tanto este abordaje puede entenderse como la cadena que se coloca entre las fosas nasales del toro para sujetarlo mejor, implica a las tres astas antes mencionadas: lo taxonómico, lo ecológico, lo social. Este abordaje tiene, además, una perspectiva diacrónica, ya que se entiende que los distintos tipos de relación, o sus "intensidades", generaron distintas trayectorias evolutivas e históricas de un taxón, de un paisaje, de un grupo humano, dependiendo el caso y el énfasis que la investigación pone en los encadenamientos relacionales. Aquí se sitúan los estudios sobre prácticas de manejo sobre el entorno (Casas, 2001; Lema, 2009a 2010a), los "grados de dependencia" (Harris, 1989), la idea de cultivo sin domesticación y cultivo predomesticación (Hillman y Davies, 1990). Aquí se sitúan también las aproximaciones que ven a la domesticación en el marco de procesos evolutivos (naturales, sociales) la domesticación en el marco de las prácticas de intensificación u otros entendimientos de la relación humano-entorno, su cambio, motores y engranajes.

5. Teóricos: la perspectiva teórica desde la cual se estudia la domesticación podría pensarse como el esqueleto del toro, la estructura que lo sostiene y articula sus partes constitutivas. Tanto la problemática de la domesticación como la de los inicios de la agricultura se han abordado con mayor frecuencia desde marcos teóricos ecológico-culturales y ecológico-evolutivos. Recientemente, la búsqueda de la escala de análisis en motivaciones indivi- duales o grupales se satisface mayormente desde la ecología del comportamiento humano, usando como herramientas heurísticas el modelo de ampliación de dieta, manejo del riesgo, teoría de construcción de nicho y la coevolución humano-planta (Gremillion y Piperno, 2009; Hayden, 2009; Kuijt, 2009; Pearsall, 2009). En menor medida se emplean la teoría de la práctica y la ecología histórica (Balée, 1998; Bruno, 2009; Denham, 2009). En un trabajo previo (Lema, 2012) mencioné también que se deben considerar y evaluar aproximaciones no darwinianas a los procesos evolutivos, incluyendo la biología dialéctica (Levins y Lewontin, 1985) y la teoría de los sistemas de desarrollo (Oyama, 2002; García, 2005), pudiendo sumarse también las corrientes Evo-devo a la reflexión. Si bien cada vez son más escasos los investigadores que se inscriben en una única línea teórica y lo explicitan, se pueden ver en las distintas investigaciones desarrolladas, los supuestos teóricos que están detrás o sustentando la mirada, las preguntas y las líneas de indagación del investigador.

6. Ontológicos: este punto es quizá el más esencial y menos tratado; y conduce no solo a definir la domesticación y otros términos, o a entender hasta dónde llega una definición u otra o qué teoría aplicar para entender la relación entre humanos y ambiente, sino a considerar la existencia de otros mundos, donde la alteridad y la relacionalidad -entre diversos aspectosse constituyen desde lugares muy distintos a los que estamos acostumbrados a frecuentar. Otro mundo, otra ontología, implica una nueva epistemología -es decir, cómo conocemos ese mundo-y a una nueva heurística -es decir, qué herramientas usamos para conocer- que son esenciales para definir a nuestro animal/problema, ese al cual insistentemente queremos asir. En los últimos años se ha reivindicado un giro ontológico en Antropología (Viveiros de Castro, 2010; Holbraad et al., 2014) donde "se llevan a serio" las perspectivas nativas, en un proceso en el que los investigadores se han expuesto a una expropiación simbólica radical: no se trata de considerar distintos modos de ver el mundo -lo cual, en definitiva sería seguir insistiendo en nuestra ontología que considera que existe un mundo y distintas formas de verlo- sino de la existencia de mundos múltiples parcialmente conectados (Strathern, 2004). Podemos pensar entonces, ya que vamos a hablar de los Andes, qué pasaría si el animal nunca fue un toro sino una llama... y quienes trabajamos en la zona sabemos que la forma de sujetar a uno es muy distinta a la forma en que se sujeta la otra..

\section{El Noroeste argentino, estado de situación}

Ahora bien, ¿hasta dónde se encuentran configuradas estas astas para el caso del estudio de la domesticación prehispánica en el NOA?

1. Esta línea de estudios se ha centrado en abordajes morfológicos, anatómicos y biométricos en macrorrestos botánicos arqueológicos (Lema, 2009a, 2011b) y en microrrestos (Oliszewski y Babot, 2015), procurando dilucidar la presencia de formas domesticadas y silvestres. Los estudios en macrorrestos han permitido detectar la presencia de ambas formas junto a morfotipos intermedios: ejemplares con rasgos novedosos con respecto a los registrados en la colección de referencia, con caracteres métricos en rangos de valores intermedios -o en área de traslape- entre los registrados para las formas silvestre y las domesticadas actuales; o bien, que combinan rasgos que se encuentran por separado en 
estas dos y que podrían corresponderse con formas híbridas/malezoides/ cultivadas no domesticadas (Lema, 2009a). Esta asociación se constató para Cucurbita maxima subsp. andreana/subsp. maxima (semillas, pericarpios y pedúnculos) y Phaseolus vulgaris var. vulgaris/ var. aborigineus (semillas y vainas) (Lema, 2009a, 2010a, 2015; Martínez et al. 2015, ms), junto a la presencia de formas posiblemente intermedias de Capsicum baccatum/chacoense (frutos y semillas) (Lema, 2012). Situaciones similares han sido registradas para Chenopodium quinoa (granos y tallo) (Calo, 2010, Lema, 2010b, Aguirre, 2012, Arreguez et al., 2015, Babot y Hocsman, 2015). En el último año, estudios genéticos han dado resultados interesantes para este último taxón (Andrade et al., 2014); a la vez que se encuentran en desarrollo nuevos proyectos de estudio para los otro taxa mencionados. Tanto desde las aproximaciones morfológicas, como desde las recientes moleculares, los complejos silvestre-cultivado-domesticado (Altieri y Merrick 1987, Beebe et al., 1997; Zizumbo-Villareal et al., 2005) parecen ser preponderantes y corrientes en la mayoría de los taxa para momentos cronológicos tempranos, e incluso tardíos, en el NOA (Ratto et al. 2014; Martínez et al., 2015, (Lema, 2014c).

En estos estudios de domesticación centrados en lo morfológico se han analizado también, mediante experimentación, los factores tafonómicos (desecamiento, carbonización) que pueden alterar tamaño y forma de los distintos órganos vegetales estudiados, al igual que factores ligados al procesamiento de los mismos en el pasado (hervido, tostado, etc.) (Babot, 2009; Lema, 2011a, Capparelli et al., 2015). En este sentido podemos decir que la morfometría en restos arqueobotánicos se ha de considerar como el reflejo de: 1) La variabilidad biocultural: variabilidad resultante de las presiones selectivas (naturales, culturales) que actuaron en un momento dado sobre cierta población vegetal; 2) La variabilidad pos-colecta: transformaciones sufridas por la planta $u$ órgano desde que es colectado hasta su recuperación por el arqueólogo, incluyendo procesos posdeposicionales (tafonómicos en sentido estricto, como desecamiento, fractura, plegamiento, entre otros) y efectos de los procesamientos (hervido, molienda, tostado, carbonización);3) La variabilidad analítica: generada por la metodología y técnicas aplicadas por el investigador (análisis de tamaño, análisis de forma, estadística uni, bi, o multivariada, pruebas paramétricas, pruebas no paramétricas).

Además de atender estos aspectos al momento de reconstruir morfotipos pasados, un estudio acerca de la evolución de la forma necesita buenos controles cronológicos, los cuales requieren de excavaciones que no solo atiendan a la recuperación de restos vegetales (empleo de zarandas de malla menor a un milímetro, flotación, embolsado en campo y análisis en laboratorio, precauciones en la colecta de artefactos para análisis de microrrestos, toma adecuada de muestras de sedimento, ver Belmar y Lema, 2015), sino que también posean una reconstrucción de eventos cronológicos de "grano fino", en los cuales ubicar el hallazgo de restos arqueobotánicos. Los fechados radiocarbónicos po AMS sobre macrorrestos han permitido controles más rigurosos a este respecto, pero lamentablemente aún son escasos en nuestro país debido a los costos que representan. Otro aspecto que resulta crucial en los estudios arqueobotánicos es la colección de referencia; sabemos que ella no posee los mismos elementos que podemos recuperar en el registro arqueológico, ya que los taxa son resultado de relaciones historicamente situadas y por ende, irreplicables. En el caso de los estudios de evolución de la forma, la ausencia de ejemplares de referencia de carácter híbrido cuya historia de cruzamientos sea conocida representa un gran obstáculo. Para sortear esta dificultad se han llevado a cabo cruzamientos experimentales entre formas silvestres, espontáneas y domesticadas de $C$. maxima junto a estudios fisiológicos tendientes a caracterizar la dormancia en los híbridos y su biometría, de modo tal que pueda rastrearse la presencia de formas híbridas y de conjuntos funcionales con dormancia diferencial en el registro arqueológico de la región (Martínez et al., 2015).

En cuanto a la información con la que contamos sobre los taxa cultivados en el NOA, la microrregión de Antofagasta de la Sierra (ANS, puna de Catamarca) posee uno de los registros más completos. A partir de evidencia de microrrestos, se sabe que en torno los 7000-6100 años A.P., las sociedades cazadoras recolectoras consumían tubérculos o raíces (quizá Adesmia horrida o Hoffmanseggia eremophila, considerando su explotación contemporánea como combustible en los sitios del área) (Babot, 2011) y granos de la especie silvestre Amaranthus hybridus L. var. hybridus (Arreguez et al., 2015). Entre ca. 5000-4500 años A.P. se procesaron frutos y semillas silvestres no locales como Opuntia sp. y "domesticadas" como Chenopodium quinoa y/o Ch. pallidicaule ${ }^{2}$ y Zea mays de endospermo córneo, según se desprende del análisis de microrrestos en artefactos de molienda (Babot, 2011). Posteriormente, ca. 4500-3200 años A.P., se incorporan taxones de ambientes mesotérmicos (microrrestos afines a $A$. caudatus/A. mantegazzianus, rizomas de Canna edulis, vainas de Prosopis sp./algarrobo y frutos de Juglans australis) y partes subterráneas obtenidas de especies microtérmicas domesticadas o tal vez "transicionales" (granos de almidón afines a Oxalis tuberosa y Solanum tuberosum, con señales de deshidratación previa al molido) (Babot, 2011). En cuanto a la producción en el área, la presencia de tallos de Chenopodium aff. quinoa es interpretada como evidencia de la siega de panojas y el cultivo local de esta planta ca. 3670-3490 años A.P. (Aguirre, 2012). A diferencia de lo que ocurre en Catamarca, los sitios arqueológicos puneños de las provincias vecinas de Jujuy y Salta carecen de restos de especies vegetales para el Holoceno temprano y medio (Lema, 2014c). En el Holoceno tardío, en cambio, se cuenta hacia el 3500-3000 años A.P. con evidencias de Capsicum aff. chacoense en un contexto funerario de la pre puna de Jujuy (Lema, 2012). Se sugiere además la presencia de "grupos agropastoriles" ca. 3000-2500 años A.P. con consumo de quenopodiáceas, tubérculos y maíz a través del análisis de microrrestos e isótopos en tiestos y manos de moler (Fernández et al., 1992, Babot et al., 2012).

Por lo tanto, se puede considerar que el lapso en torno a los 4000-3000 años A.P. resultó crucial en el inicio del cultivo y manejo de especies vegetales, al menos en algunos sectores de puna del NOA; siendo el inicio del milenio (2000 años A.P.) el momento de aparición masiva a nivel regional de macrorrestos de especies -a primera vista- domesticadas. Los estudios anatómicos en macrorrestos (Lema, 2011b) permitieron apreciar mayor diversidad de la previamente asumida y la detección de morfotipos/formas intermedias. A nivel

2 Se transcriben las identificaciones botánicas tal como figuran en la bibliografía citada al igual que los términos entrecomillados (para una discusión más desarrollada sobre las implicancias de los niveles de resolución taxon 
conceptual, en los últimos años, la domesticación dejó de acaparar el entendimiento de las formas de relación entre humanos y su entorno, o estableciendo un destino inexorable hacia el cual se dirigían formas pre/semi domesticadas; poco a poco, la domesticación pasó a formar parte del panteón de las prácticas de manejo (Lema, 2010a).

2. Esta perspectiva resulta difícil de desarrollar puesto que en el NOA se tiene la particularidad de recuperar escasos restos arqueobotánicos (lo cual, si bien tiene relación con la cantidad de litros de sedimento flotados en un sitio o con el tamaño de la red de malla de las zarandas empleadas para tamizar los sedimentos excavados, no parecería explicar del todo el fenómeno, véase Belmar y Lema, 2015). Esto determina que no se puedan realizar por ejemplo, estudios de tendencias en los cambios de las formas de ciertos órganos útiles a lo largo del tiempo, o evaluar la fijación de un carácter a nivel poblacional en un taxón dado, o bien estudiar la representación diferencial de ejemplares silvestres, malezoides y domesticados a lo largo de una secuencia, tal como se suele hacer en estudios del Viejo Mundo. Asimismo, a diferencia de lo que ocurre en este último espacio, los estudios palinológicos en el NOA son escasos, a pesar de que los estudios paleoambientales a partir de otros proxy están en crecimiento y han sido de utilidad para la detección de disturbios antrópicos en sitios ubicados en la provincia fitogeográfica de Yungas (piedemonte oriental de las sierras subandinas), ca. 2000 años A.P. (Echenique y Kulemeyer, 2003; Lupo y Echenique, 2001, Lema, 2010b).

Asociaciones entre antecesores silvestres, formas híbridas o intermedias, formas domesticadas y formas cultivadas no domesticadas (entre las cuales puede incluirse a las formas híbridas) se han detectado hasta el momento en sitios formativos ubicados en el área pedemontana del NOA para los casos de C. maxima subsp. maxima-subsp. andreana Phaseolus vulgaris var. vulgaris-var. aborigineus. El piedemonte oriental del NOA evidencia la presencia de antecesores silvestres (C. maxima subsp. andreana y $P$. vulgaris var. aborigineus) ausentes en otros sitios arqueológicos de esta ecoregión en los Andes Meridionales. Cuando los mismos aparecen en los sitios por fuera de esta área, lo hacen solo en su forma domesticada o con caracteres intermedios. Exceptuando el caso de Chenopodium, los sitios con macrorrestos arqueobotánicos de formas antecesoras (como C. maxima subsp. andreana en Pampa Grande y Cueva de los Corrales $1, P$. vulgaris var. aborigineus en Pampa Grande y sitios del Aconquija, y Capsicum aff. chacoense en Huachichoana III Pampa Grande) se ubican en los límites altitudinales de su dispersión actual. Esto puede interpretarse como intentos por adecuar dichas formas a otras ecorregiones -algo muy característico de la domesticación temprana en el área andina- en el marco de procesos de domesticación que tuvieron lugar entre el 3000 y 2000 años A.P. aproximadamente. Esta generación de morfotipos adaptados a nuevos pisos altitudinales, generaría nuevos ecotipos cultivados aislados geográficamente de sus antecesores silvestres, pero sin concretar barreras reproductivas con los mismos (procesos de domesticación alopátricos).

En lo que se refiere a malezas de cultivo, pueden mencionarse restos de Solanum eleagnifolium en el sitio formativo Campo del Pucará (Lema, 2009a), al igual que las malváceas reportadas para Cardonal (Calo, 2010) podrían representar este tipo de plantas, ya que varios miembros de esta familia son reconocidas malezas -mucha con usos medicina- les- en los campos actuales de cultivo del NOA (Lema, 2014a). También se registró polen de Malvaceae en el sitio Moralito ya mencionado, así como de Plantago sp. en heces de camélidos en Pampa Grande, junto a proporciones elevadas de polen de Amaranthaceae y Chenopodiaceae en ambos casos (Lema, 2014c). Además del registro palinológico de malezas para reconocer disturbio antrópico, o como vía para identificar la presencia de sistemas agrícolas (Jones, 2009), resulta interesante y enriquecedor considerar también el consumo de malezas, habiendo algunos avances que indican procesamiento en granos de Chenopodium, tanto para sitios formativos (Calo, 2010) como tardíos (Ch. quinoa var. melanospermum, Chenopodium aff. carnosulum Ratto et al. 2014; Petrucci et al. ms). Asimismo, explorar otro tipo de usos potenciales ( $\mathrm{rg}$. medicinales, forrajeros), e incluso considerar su rol como antecesores de formas domesticadas, puede llevar a reconsidera la categoría de "maleza" y las implicancias que las plantas que se colocan en esta categoría pudieron tener para las sociedades del pasado. En este sentido, en comunidades actuales del NOA muchas de las plantas que nosotros consideramos malezas, al igual que otras formas silvestres, suelen ser toleradas en espacios de cultivo o sembradas en los mismos; correspondiendo muchas de estas malezas a Chenopodiaceae, Amaranthaceae, Solanaceae, Plantaginaceae y Malvaceae (Lema, 2006, 2014a, 2014b).

3. Si bien hay evidencias de formas domesticadas (incluyendo al maíz, cuya "llegada" a NOA es aún un tema sin resolver) desde ca. 4000 años A.P.; es en el lapso cercano al 2000 años A.P. cuando se da una "explosión" de restos de especies domesticadas en el NOA. A partir de los 4500/ 4000 años A.P. se registra un marcado aumento de humedad y un incremento en las evidencias de ocupaciones de "cazadores recolectores transicionales", con más sitios ocupados al mismo momento en ANS (Oliszewski y Olivera, 2009; Aschero y Hocsman, 2011). En ese período se incorpora la producción a pequeña escala de quenopodiáceas y posiblemente razas de maíces de endosperma duro y tubérculos microtérmicos (Aschero y Hocsman, 2011). Para el período ca. 4500- 3000 años A.P., se establece un escenario de circunscripción social, con reducción de la movilidad residencial-sin reducción de la macromovilidad hacia ambas vertientes de los Andes-y la activación de dispositivos de demarcación espacial, junto a la presencia de camélidos domesticados y ausencia de pastoralismo pleno tanto en la puna de Catamarca, como en la de Jujuy Salta (Yacobaccio, 2001; López, 2009, Aschero y Hocsman, 2011). En el lapso 4000-3500 años A.P., tanto camélidos como especies vegetales domesticadas se incorporan a la economía, consolidándose el pastoreo hacia ca. 3000 años A.P., incorporándose luego a esta (ca. 2500-2000 años A.P.) -como principal sustento- la agricultura, la cual se incrementó a la par con el crecimiento demográfico a partir de ca. 2000 años A.P. (Oliszewski y Olivera, 2009). En este inicio de la era, el paisaje del NOA cambia drásticamente y se reconocen estructuras agrícolas y sitios residenciales en sectores de puna, prepuna y valles. Solo en ANS la instalación de grupos plenamente agropastoriles en el primer milenio es interpretado como resultado del paulatino incremento en las prácticas agrícolas intensivas y extensivas que dieron lugar a sitios residenciales de planta subcircular asociados a campos de cultivo (Oliszewski y Olivera, 2009; Pérez, 2010). Los estudios desarrollados sobre restos de Chenopodium para el Holoceno medio e inicios del Holoceno tardío en la microregión, poseen continuidad en las evidencias de microrrestos recuperados en los cuchillos/ rae- 
deras de módulo grandísimo empleadas en la siega y procesamiento postcosecha de ejemplares afines a Ch. quinoa/Ch. pallidicaule -y quizá tubérculos microtérmicos- en el período ca. 1500-1100 años A.P. (Escola et al., 2013). Estos taxa podrían haber prosperado en espacios con rasgos materiales poco contundentes, semejantes a los actuales huertos puneños, contrastando con los paisajes agrarios con extensos campos de cultivo que están presentes en ANS en momentos posteriores al 1000 años A.P. (Escola et al., 2013).

Podría pensarse que el cambio hacia asentamientos agropastoriles del primer milenio traería aparejados cambios en el manejo de plantas domesticadas y que un cambio en la espacialidad con parcelas de cultivo claramente instaladas podría correlacionarse con un manejo distinto. Sin embargo, este no parece ser el caso, ya que los análisis antes mencionados que indican complejos silvestre-cultivado-domesticado para porotos y zapallo, al igual que para las quínoas de sitios del Aconquija, son de este período. Asimismo, la ausencia de formas domesticadas de manera exclusiva se ve acompañada de un conjunto nuevo de plantas: las malezas. Las primeras instalaciones agropastoriles de este milenio en puna, valles y quebradas son caracterizadas como "aldeas", siendo frecuente la asociación espacial entre unidades residenciales y campos de cultivo, mas ocasional la separación de ambos y escasas las situaciones donde se combinan los dos patrones (Korstanje et al., 2015). Estas aldeas no se consideran unidades autocontenidas y autosuficientes, manteniendo nexos con diversos espacios de explotación y residencia a lo largo del paisaje en el marco de un calendario agrícola móvil en el tiempo y el espacio (Lema, 2014c). En cuanto a la escala espacial, la infraestructura aldeana y agrícola del $1^{\mathrm{e}}$ milenio ronda las 200-500 ha, llegando excepcionalmente a 800 ha (Korstanje et al., 2015). Esta escala, sin embargo, al cargarse de historicidad demostró que no es resultado de un único proceso constructivo planificado y coordinado centralmente en sitios de Antofalla (puna de Catamarca), sino el resultado de un espacio agrario que se amplió a lo largo de tiempo mediante el crecimiento y agregación de redes de riego que delimitaron módulos funcionales mínimos disponibles para el cultivo (Quesada, 2010; Quesada y Maloberti, 2015). A pesar de que pudieron haber existido formas de trabajo corporativo a nivel supradoméstico para explicar esta infraestructura agraria en sitios puneños -sobre todo en lo que hace a la gestión del riego (Delfino et al., 2015)- no es necesario postular su existencia para explicar el paisaje agrícola temprano (Quesada, 2010). La autonomía de las familias, como unidades de producción, en la gestión de los espacios de cultivo se explicaría en la estructuración espacio temporal de los cultivos y su cuidado, ya que habría existido un régimen agrícola intensivo y extensivo, con huertas próximas a las casas y cultivo en lugares más alejados bajo un sistema de barbecho sectorial, dentro o no de las mismas redes de riego, activándose a lo largo del ciclo anual pequeñas secciones de los complejos hidráulicos y permaneciendo inactiva, a la vez, gran parte de los mismos (Quesada 2010). Caso distinto es el del Valle de Ambato (Catamarca) donde el sector productivo habría estado separado de las áreas residenciales y donde el primero refleja un sistema integral único agropastoril de tipo intensivo (Figueroa et al., 2010, Figueroa, 2013). En la zona de valles se han detectado también eventos rituales asociados a la construcción de infraestructura agrícola gestionada a nivel familiar y comunal (Franco y Berberián, 2011). El análisis de suelos de estructuras arqueológicas productivas (empleando indicadores sedimentológicos, químicos y de microrrestos), ha permitido considerar las actividades agrícolas junto a las ganaderas en espacios compartidos, la rotación de cultivos (maíz y probablemente Solanum tuberosum, Chenopodium quinoa y Ullucus tuberosus), la quema de rastrojos y la fertilización mediante abono con guano (Korstanje, 2010, Korstanje et al. 2015). La agricultura del primer milenio se interconectaba con las actividades pastoriles y poseía un control técnico sobre la producción de especies vegetales, el agua, el suelo y su fertilidad, con una sofisticada interdigitación de sus requerimientos, por lo que no se la puede considerar "simple" o de "bajo desarrollo" (Lema, 2014c, Korstanje et al., 2015).

4. A pesar de que en gran medida desconocemos cómo era la relación exclusiva entre sociedades humanas y formas silvestres antecesoras en el NOA, hemos visto que los complejos silvestre-cultivado-domesticado caracterizan la relación entre las sociedades del área y las comunidades vegetales en el caso de varios taxa (lo cual ha sido constatado por distintos medios y por distintos investigadores) tanto durante el Formativo como durante el Tardío. Aún queda la incógnita acerca de si este modo de relacionamiento es el reflejo de la escala de gestión de ciertos espacios de cultivo ( $\mathrm{vg}$. escala doméstica/huertos) o bien de una ecosofía propia del área. Asimismo, cabe destacar que el aprovechamiento de frutos de especies silvestres ha tenido una gran relevancia a lo largo de la historia de la región, sobre todo los frutos de especies arbóreas del género Prosopis, (algarrobos) con una historia de uso continuo desde las ocupaciones más tempranas del área hasta la actualidad, diversificándose con el tiempo las preparaciones realizadas a partir de las vainas (Capparell y Lema, 2011). En lo que refiere a los modos de relación, ciertamente el lenguaje se ha matizado en los últimos tiempos, considerándose cada vez más la presencia de prácticas de protección, manejo, fomento y cultivo de taxones no domesticados; de producción sin domesticación, de especies transicionales, intermedias, semidomesticadas, en proceso de domesticación y malezoides, todo ello tanto en contextos cazadores recolectores como agropastoriles tempranos entre el 3500-1500 años A.P. (Lema, 2009a; 2010a; Calo, 2010; Babot, 2011; Aschero y Hocsman, 2011). También el empleo de los términos huerto, huerto doméstico, producción hortícola/agrícola y horticultura (Muscio, 2001; Haber, 2006; Lema, 2009a; Calo, 2010; Quesada, 2010; Babot, 2011, Aschero y Hocsman, 2011; Ortiz y Heit, 2012; Aguirre, 2012, Escola et al., 2013) comenzaron a ser de uso más frecuente en la literatura arqueológica. Su indagación es aun hipotética ya que sus indicadores arqueológicos no son fáciles de precisar. Hasta el presente, la agricultura y el cultivo sin domesticación son posibilidades mayormente sugeridas a partir del estudio de los conjuntos arqueobotánicos y artefactuales que a partir de elementos constructivos, cuya carencia, justamente, es muchas veces pensada como indicador de estos modos de producción de pequeña o baja escala

Un aspecto a destacar, es la temprana relación que las sociedades que habitaron el NOA establecieron con las plantas psicoactivas. Los registros más tempranos de restos de pipas y macrorrestos vegetales de cebil (Anadenanthera colubrina var. cebil) proceden de sitios de ca. 4000-3500 años A.P. en la puna de Jujuy, posteriormente las pipas pasan a formar parte de casi todos los conjuntos de objetos propios y distintivos de los múltiples agregados sociales o "culturas" del Formativo regional (Lema, 2016). Si bien la relación con y el consumo de estas plantas siguió hasta momentos tardíos, su presencia y mayor 
difusión se dio en concordancia con los inicios de la domesticación de especies animales y vegetales y el establecimiento de sociedades agropastoriles. Aunque escasos, los estudios que han procurado determinar dichas plantas han detectado la presencia de restos afines a tabacos silvestres (Nicotiana. aff. longiflora), (Lema et al., 2015) o bien diagnósticos a nivel de género solamente (Nicotiana spp) (Capparelli et al., 2006, Silva et al., 2016). El sector oriental del NOA se encuentra entre las áreas propuestas como factible de haberse visto involucrada en la domesticación del tabaco (Goodspeed, 1954), por lo tanto, la indagación pormenorizada de su presencia (lo cual no es una tarea fácil debido a la escasa posibilidad de conservación de sus hojas, lo pequeño de sus semillas y el valo diagnóstico parcial de sus microrrestos) resulta de interés, particularmente en un potencial contexto hortícola como el antes mencionado.

5. Desde fines de los ochenta y, con mayor fuerza, a partir de la década de los noventa predominan en la arqueología del NOA las corrientes procesuales o posturas ecológico-culturales -sumándose luego posiciones ecológico-evolutivas- en las que se aplican modelos de optimización de recursos y dieta, ecuaciones de costo-beneficio y estrategias de manejo del riesgo para entender la domesticación (principalmente de camélidos) y la adopción de los primeros "cultígenos" desde una visión racionalista, utilitarista y economista de los ecosistemas, e instrumental de las tecnologías (Yacobaccio y Korstanje, 2007; Lema, 2008). A pesar de que hoy en día resulta difícil encontrar explícitamente la adscripción de un investigador a un marco teórico, los supuestos subyacentes, o "de base", de estas líneas de pensamiento son los que siguen preponderando en el estudio y caracterización de los grupos cazadores recolectores transicionales. Una única excepción a esta corriente dominante fueron los aportes de A. Haber acerca del tema. El autor propone que la domesticación ya no debe buscarse en la modificación de los esqueletos de los animales -donde puede no estar reflejada- sino en cambios al interior de la estructura social, sobre todo en las reglas de acceso a los recursos ya que, desde una perspectiva dialéctica, la domesticación, en tanto que representación y prácticas de dominación de la naturaleza externa, reproduce a y es reproducida por las representaciones y prácticas de dominación entre humanos, por lo tanto en la práctica domesticación y dominación serían inseparables: la domesticación es entendida como metapatrón en tanto que es una nueva relación entre relaciones (Haber, 2006). Esta aproximación -que podríamos encuadrar dentro de las corrientes posprocesuales en arqueología- la retomaremos en la sección siguiente.

En los últimos años una tendencia creciente ha sido generar modelos o propuestas a nive exclusivamente local, sin procurar explicar el fenómeno de la domesticación a nivel supra regional (NOA). Asimismo, la evidencia con la que hoy contamos nos lleva a replantear la idea de transición y qué comprendería la misma: ¿evidencias del consumo de la primera planta domesticada o del cultivo de la misma?, ¿el manejo desde su forma silvestre hacia su forma cultivada y luego domesticada?, ¿el tránsito hacia la primera parcela de cultivo, hacia las primeras modificaciones del ecosistema o el rastro más temprano de una planta domesticada?, ¿el establecimiento de un calendario agrícola anual, las manifestaciones más tempranas de diversas modalidades de manejo del agua, la presencia de mecanis mos supradomésticos para gestionar espacios productivos?, ¿el momento en que las die- tas -de humanos y/o animales- comienzan a estar basadas en plantas cultivadas (aspecto en crecimiento gracias al número cada vez mayor de análisis de isótopos estables)?. Estamos, por lo tanto, ante un panorama teórico un tanto más abierto y menos rígido, pero donde la idea de recurso, dieta y movilidad siguen siendo pilares de la argumentación.

6. Para muchos, la palabra domesticación hace referencia a 'dominio' o 'control', para otros, domesticado es 'uniforme', 'predecible', 'único'. Estas acepciones del término domesticación son comunes al mundo occidental moderno, pero en gran parte del mundo andino, existe una ecosofía de relación con el medio que proyecta prácticas muy lejanas a las que se asocian con el término domesticación y que me interesa poner en consideración a través de la siguiente interrogante: ¿hasta qué punto es válido pensar conceptualmente desde la domesticación en los Andes? ¿qué posibilidades hay de "llevar a serio" la(s) lógi$\mathrm{ca}(\mathrm{s})$ de uywaña -crianza mutua- en nuestras investigaciones?

Una de las implicancias del término domesticación ha sido la de su derivación bajo la idea de dominio, algo que si bien no está en su origen etimológico (Harlan, 1992), sí se asoció a mismo, incluso para referir al dominio de los hombres sobre otros hombres. Domesticación deriva del latín domus, en el sentido de 'hogar' -más que de casa- en tanto que refiere a lo conocido, al refugio, a un lugar donde se siente que se conoce lo que ocurre y se posee cierta capacidad de control sobre ello, se oponía originalmente a agrios en el sentido de agreste, indómito (indomable), extraño, salvaje (silvestre) y ajeno, un lugar donde los humanos se veían disminuidos en su capacidad de controlar los procesos y eventos que allí sucedían (Harlan, 1992; Hodder, 1992; Hodder y Cessfor, 2004). De estas categorías y oposiciones deriva la idea de la "conquista" de la naturaleza -la cual eclipsó gran parte de la historia de Occidente y cuyo sostenimiento, hasta el día de hoy, ocasionó y ocasiona escenarios amenazantes y devastadores-, de su sujeción, su dominio, su rendición a la mano del hombre. Hodder en Europa-Asia y Haber en el NOA ven que la domesticación de los animales se asocia temporalmente a una domesticación de los propios hombres, una sujeción de los mismos a relaciones sociales más estructuradas y duraderas, siendo la casa, unidad o compuesto doméstico de la materialización de dicho proceso de "domesticidad". En Hodder sigue indeleble la asociación domesticación-dominio al proponer que, en un momento dado, las personas se disciplinan bajo estructuras sociales a largo plazo, volviéndose cuerpos dóciles, sujetados, domados, atrapados. Haber (2006) también sostiene esta idea, al hacer un desplazamiento semántico entre la sujeción de la naturaleza externa (domesticación) a la sujeción de la naturaleza "interna" o social (dominación): "En este marco, domesticación y dominación son inseparables en las prácticas y sus representaciones se reproducen mutuamente" (Haber, 2006:27), de allí que la domesticidad sea entendida como un metapatron, una relación entre relaciones (de humanos entre sí y de humanos y componentes naturales), articulada por una dialéctica entre dominación y naturalización. Esto parecería contrastar con el empleo de uywaña como marco de significación en tanto incluye relaciones recí procas entre seres de múltiple carácter donde se ve implicada "la protección, el amor y la obediencia" (Haber, 1997:380; en relación a Martínez, 1976). Tanto Hodder como Harlan confluirán en la idea de domesticación como "traer al domus", la asunción, en un momento dado de la historia humana, de una división entre doméstico (de la casa, del hogar) versus salvaje o silvestre y luego la transformación práctica y simbólica de traer lo silvestre al hogar 
y transformarlo. La domesticidad se enfoca en las relaciones y prácticas de transformación de la naturaleza y la definición de las unidades sociales de apropiación de la misma (Haber, 2006). Analizando estos procesos desde "el giro animista" y de uywaña como episteme local, Haber (2009) se aproxima a las formas locales de relacionalidad y crianza desde un lugar que nos ofrece una perspectiva diferente, donde las redes de vinculaciones predominan sobre esencias y apropiaciones, aproximándose así, de manera más honda y comprometida, a un mundo otro que abordaremos a continuación.

Podemos considerar que en el ámbito andino se han tomado generalmente los conceptos de uywa y sallqa a modo de análogos entre domesticado y silvestre respectivamente, siendo los animales de este último dominio criados por entes no humanos (Achachilas, Lawllas, etc.) (Arnold et al., 1992; Grillo-Fernández, 1994). En realidad estos conceptos implican más aspectos que se entienden al analizar los desplazamientos semánticos existentes entre la tríada runa-sallqa-huaca, hilvanados por el hilo de la crianza. La crianza implica conversación, diálogo, entendimiento, pactos, negociaciones, reciprocidades, intercambios y acuerdos entre personas humanas y no humanas. Puede verse como este concepto vuelve activas a plantas, suelo, clima, animales, cerros y al espacio mismo, a diferencia de la idea de "manejo" que les otorga un carácter más pasivo (y más funcional a la idea de dominio). En este sentido la propuesta de Ingold (2000) de que las acciones humanas en el ambiente son de incorporación, antes que de inscripción resulta operativa. Al no ser de inscripción, las acciones no corresponden a una manufactura, no se hace un artefacto a partir de un material preexistente, sino que la agencialidad propia de las plantas ${ }^{3}$ establece condiciones para su cultivo, cuidado o crianza. El autor sugiere fundir las categorías semánticas de "hacer/ fabricar" (making) propia del mundo inerte, con la de "criar" (growing) propia del mundo vivo, resultante del compromiso mutuo de agentes activos en el "hacer".

La "crianza mutua" es una relación de protección y cuidado que permite la continuidad de la vida, involucrando prácticas que habilitan un intercambio propicio de flujos vitales entre criadores y criados a fin de que éstos se reproduzcan y "florezcan" (Grillo-Fernández, 1994: Valladolid-Rivera, 1994: Rengifo-Vásquez, 1999; Lema, 2013). Existe una multiplicidad de seres que pueden ser criadores y criados (humanos, cerros, plantas, animales, agua), pero con diferencias en cuanto al dispendio de potencia y sus capacidades productivas y destructivas; las relaciones de crianza son por lo tanto relaciones reciprocas, forzosas y asimétricas (Lema, 2014b). Estas relaciones se sustentan en una socialidad ampliada, basada en el intercambio de esfuerzos, sustancias y/o flujos de energías, mediado por pagos, acuerdos y reciprocidades en relación a las particularidades de cada sujeto (humano o no humano) (Bugallo y Tomasi, 2010; Lema, 2013).

Las reflexiones e investigaciones orientadas a la caracterización y comprensión de las lógicas de la crianza, encuentran en el multinaturalismo y su mirada en y desde los cuerpos (Viveiros de Castro, 2004, 2010) un punto de anclaje argumentativo relevante (Lema, 2013). El multinaturalismo es el nombre dado al abordaje antropológico de una concepción propia de gran parte de los pueblos indígenas de América -elaborado mayormente a partir

3 Agencialidad que es dada por la ontología local donde las plantas encuentran su lógica, adscripción y definición; no referimos a una agencialidad en un sentido naturalista refiriendo a aspectos "activos" de las plantas desde una ontología occidental de
(ciclo de crecimiento, principios activos, propiedades físicas o nutricionales, entre otros, como en VanderVeen 2014) de la experiencia amazónica- donde se propone que existe una continuidad de las interioridades entre los distintos seres (capacidad social del dispendio de potencia; que en e caso andino podría verse en los llamados flujos vitales, fuerza vital, animu, almita, coraje, qallpa; Cavalcanti-Schiel, 2007; Bugallo y Vilca, 2011), junto a una discontinuidad de los cuerpos o exterioridades (forma material visible y actitudinal: aspecto físico, cualidades, propiedades, comportamiento, patologías) que los especifica (Viveiros de Castro, 2004 2010; Descola, 2012). Es por ello que se entiende que la cultura es una y común a muchos seres y que la diferencia está dada por los cuerpos o naturalezas, el multinaturalismo es una oposición lógica al multiculturalismo; y es lógica por ser onto-lógica.

Desde esta perspectiva, la crianza entonces intercepta la manipulación, transformación, crecimiento y consumo de cuerpos y fuerzas vitales (Pazzarelli, 2013, 2014); operar sobre los primeros permite regular a los segundos, sea a través del correcto sacrificio de los animales y el tratamiento de sus partes, los modos de cocción de los alimentos, por medio del desecamiento, en el tratamiento de las semillas desde la cosecha a la siembra, etc. (Bugallo y Vilca, 2011, Pazzarelli, 2013, 2014; Lema, 2014b; Pazzarelli y Lema, 2015). Dado que se crían y devoran las fuerzas vitales (interioridad) de todos los seres que forman parte de la red, encausar correctamente estos flujos requiere de aspectos técnicos precisos que operan sobre los cuerpos (exterioridad). En el ámbito de la crianza volver algo "productivo", "fértil", conlleva aplicar de manera correcta una serie compleja de dispositivos y operadores lógicos en un paisaje que se constituye como interlocutor y comensal (relaciones de interfagocitosis) (Vilca, 2009) y se encuentra habitado por, a la vez que encarna a, diferentes alteridades no humanas, con la que los humanos negocian la productividad y fertilidad de lo que crían, incluyendo su propia vida, a través de series constantes de "esfuerzos" (Lema y Pazzarelli, 2015, Pazzarelli y Lema, 2015) donde la productividad, fertilidad y fecundidad, no están exentas de peligrosidad.

Estas negociaciones, pactos y diálogos que constituyen la crianza, se entrelazan con e parentesco, por lo tanto, vemos aquí que domesticar no sería tanto traer al domus, a hogar, domesticar -criar, en el mundo andino- es incorporar al ayllu (ayllu en el sentido de Sendón, 2009), es ligar a los seres humanos y no humanos a esa dimensión parental de la vida social que trasciende el universo social de los humanos vivos y que trasciende también lo que nosotros entendemos por ámbito doméstico. El ayllu incluye la chacra, animales de pastoreo, cerros, ríos, entre otros, con quienes se establecen relaciones de parentesco ${ }^{4}$ y compadrazgo, ayllu y pacha se crían mutuamente (conformando un paisaje-persona), al igual que la casa se cría mutuamente con la familia (Grillo-Fernández, 1994; Valladolid-Rivera, 1994). Todos crían chacra (el cerro, los seres humanos, el zorro) y son criados por la chacra que crían, todos crían chacra y son, a la vez, la chacra de alguien (las personas son un componente de la chacra del Cerro-Apu), al mismo tiempo cada chacra es una persona con sus singularidades (Grillo Fernández, 1994). La chacra es, a su vez, modelo y referente para el uywa ${ }^{5}$, el rebaño, la "chacra con patas", donde la semilla son

4 Alpacas y llamas son hijas (no "como" hijas) del pastor y también son su madre (Quiso Choque, 1994). El modelo de crianza mutua genera y reproduce las relaciones de parentesco del ayll

5 Si bien uywa es la denominación para el rebaño de camélidos, su nombre ritual es panqara (flores), ya que, cual una flor, en un momento puede procrearse bien y en otro desaparecer, por eso también puede tener el nombre ritual de neblin 
los padrillos y sembrar es empadrar, la hacienda, por ende se siembra (Quiso-Choque, 1994). Asimismo, la chacra y su género puede ser el modelo que determine la forma en que las personas generan vínculos de filiación y alianza (Rösing, 2003). Conceptualmente chacra es todo aquello que se cría (Valladolid-Rivera, 1994).

En este marco general, las plantas requieren ser criadas, ya sea por humanos, el cerro, el monte, los $A p u$, o animales (como por ejemplo el zorro) y a la vez crían a humanos, a sus hijos y a otras plantas (Valladolid-Rivera, 1994; Rengifo-Vásquez, 1999; Lema, 2013 2014b). Las plantas son también sensibles a la desatención: abandonan a un criador y pasan al ámbito de crianza de otro, lo cual se marca en una discontinuidad de sus cuerpos (morfología, sabor, propiedades: de alimenticia a medicinal, por ejemplo) y amerita que las personas las distingan anteponiendo el prefijo sacha, kita o yuta y se diga que se han vuelto aparu o aparoma (Valladolid-Rivera, 1994; Lema, 2006; Torres-Guevara y Parra-Rondinel, 2008; Lema, 2013, Lema, 2014a, 2014b). Este cambio en el plano exterio o exterioridad se da junto a una continuidad en la interioridad que define a toda planta: requieren ser criadas, son sensibles a la desatención o suerte del criador, pueden negar la socialidad. Esto último tiene implicancias fuertemente negativas tanto para humanos como para no humanos manifestándose en la apariencia física y en el comportamiento: la negación de la socialidad marca una discontinuidad en cuerpos enviciados que no dan producto, sino que se van en vicio (Lema, 2013, 2014a, 2014b). Las discontinuidades empíricamente observables entre los cuerpos son marcas de la socialidad de la crianza, la interioridad de las plantas que requieren ser criadas y que crían a sus hijos o a otros seres, su capacidad de pasar de un criador a otro, o bien, de enviciarse.

La crianza de plantas puede hacerse mediante riego, tanto en unidades del paisaje creadas por las personas, como en el caso de los rastrojos de alfa (Medicago sativa), como en otras que no lo son, tal como la crianza mediante riego de vegas (que en el algunos casos cambian, significativamente, su nombre al de potrerillos) y poblaciones de espuru (Pennisetum chilense) o la quema controlada de pastizales para la alimentación del ganado (Quiso-Choque, 1994: Haber, 2006: Quesada, 2007; Lema, 2014b). Puede verse como esto desdibuja una asumida frontera entre espacios "naturales" (en el sentido de no intervenidos) y "construidos" (en el sentido de manufacturados, productivos). Plantas del cerro presentes en los sembraderos, rastrojos y quintas son toleradas, eventualmente erradicadas si se necesita el espacio, a la vez que se siembran plantas del cerro o del monte en los sembraderos, chacras y quintas, principalmente medicinales (Lema, 2006, 2014a, 2014b). También en algunos casos se siembran plantas de las chacras humanas en el monte (frutos) (Quinteros, 1999). Antes que formas silvestres, domesticadas o antecesores silvestres los distintos tipos de plantas se caracterizan por una fluidez entre criadores humanos y no humanos, siendo la señal de ello una discontinuidad y transformación en los cuerpos y/o sus propiedades. Es la red de crianza y socialidad en que se ven insertas estas plantas lo que marca un cambio, que no se refleja necesariamente en la espacialidad que ocupan las mismas (Lema, 2014a). Así como la casa es el espacio físico que alberga y reproduce a los miembros humanos de una unidad doméstica, los espacios productivos de crianza gestionados por estos (chacra, rastrojo, quinta, sembradero, corral, potrero), son los ámbitos que albergan y reproducen a los miembros no humanos de dicha unidad (Bugallo y Tomasi,
2010). En estos espacios también están presentes las plantas de criadores no humanos, las cuales son amparadas e incorporadas, en ciertos casos, a la crianza humana: los espacios domésticos no son ámbitos exclusivos para los criadores humanos.

La crianza implica fluidez entre ámbitos, porosidad de espacios. Lo doméstico es un ámbito de crianza humana que no puede entenderse en términos fijos o estrictos, las prácticas son dinámicas y los ámbitos de crianza de humanos y no humanos se superponen entre sí, diluyéndose mutuamente los límites. La crianza mutua constituye una gramática de socialidad ampliada que habilita lo doméstico -como habitar la crianza-, pero no necesariamente lo domesticado (Lema, 2013, 2014a).

Plantas cultivadas (antes que domesticadas) son lo que abunda, plantas que se deslizan entre cultivadores y cambian su cuerpo por estar inmersas en los flujos de crianza, aunque el cambio morfoanatómico (lo detectable hasta ahora en el registro arqueobotánico) no siempre sea el caso como cuando estamos ante plantas fomentadas, como las que integran las vegas criadas, o toleradas como ciertas malezas y formas híbridas en los huertos actuales del NOA. No hay un quiebre, un punto sin retorno, no se gana la batalla del dominio sobre la naturaleza porque tal cosa no existe conceptualmente (Weismantel, 2015). La crianza -antes que el dominio- como lógica de interacción y de transformación (en distinto grado) de la "naturaleza" que otro cría, el ayllu -antes que el domus- como urdimbre sobre la cual la trama relacional se desplaza, una lógica pendular antes que de incrustación, nos lleva a pensar en términos relativos antes que absolutos, nos lleva a replantear desde cuándo las sociedades andinas han criado su entorno y en qué medida seremos capaces de verlo en el registro arqueológico.

\section{Recapitulando}

Desde el Arcaico (ca. 4000-2500 años A.P.) y el Formativo (ca. 2500-1500 años A.P.) parece iniciarse en el Noroeste argentino un modo de cultivar que no apunta a, o se cierra en, formas domesticadas de manera exclusiva. En dichos períodos se daría inicio a un proceso de crecimiento continuo, vegetal, de un modo de relación con el entorno que no resulta ser propio de un momento o una "etapa" ¿será el inicio de ese modo andino de relacionarse con el medio siguiendo la(s) lógica(s) de la crianza? Las plantas comienzan a ser cultivadas posiblemente en espacios productivos gestionados por unidades domésticas, lo cual quizá sea el motivo de una explosión de diversidad y la ausencia de una única corriente homogénea de presiones selectivas que den como resultado un morfotipo único cultivado y/o domesticado con baja diversidad. Los complejos silvestre-cultivado-domesticado indicarían que los límites de esos espacios no constituían barreras, sino que eran porosos, permitiendo que lo que estaba más allá de sus límites se cruzara con lo que estaba contenido dentro de los mismos, algo propio de las estrategias hortícolas (Vogl et al., 2002). La presencia temprana -ca. 2000-1500 años A.P.- de formas silvestres antecesoras junto a formas domesticadas e intermedias (por ejemplo, sitio Pampa Grande), o bien junto a otras especies domesticadas (caso de C. maxima subsp. andreana en Cueva de los Corrales; sugiriendo esta última situación que podría tratarse del desplazamiento del taxón como maleza de cultivo) y en momentos posteriores la presencia 
de formas domesticadas junto a intermedias (caso de sitos del Tardío -ca. 800 años A.P.- de Catamarca), con presencia siempre de malezas de tipo agrícolas o no, hablaría a favor de una persistencia de tal modo de criar la naturaleza, de domesticarla. Lo que vemos es quizá el inicio de una ecosofía, una bio-tecno-lógica propia del NOA, de los Andes, de una región cuyos límites son difusos aún; en el Arcaico y Formativo comienza el cultivo y este, fundado en estrategias diversificadoras, parece haberse perpetuado en el tiempo, incluso, hasta el presente.

Durante el Formativo, por ejemplo, se desarrollaron morfotipos de Cucurbita que corresponden a frutos consumibles (pericarpio delgado) y otros empleados como recipientes (pericarpio engrosado), habiéndose desarrollado probablemente estrategias de conservación de los primeros, a fin de diferir su consumo (Lema, 2009a, 2011a, 2012). Considerando la diversidad de empleos y morfotipos que muestran estas poblaciones bajo cultivo, donde el modo de cultivo habría permitido la introgresión y generación de híbridos, puede pensarse que, entre estos últimos, algunos habrían sido alentados, cuidados y sembrados (cultivados) al responder a los fines antes mencionados; otros habrían sido erradicados al poseer rasgos considerados nocivos (quizá los que manifestaran la presencia de principios tóxicos, aunque podrían haber sido detoxificados mediante su exposición al fuego, considerando el tizne en algunos restos; Lema, 2011b) y aquellos híbridos que carecieran de uno u otro tipo de carácter (deseado o nocivo) habrían sido tolerados, convirtiéndose eventualmente en malezas. Por lo tanto, la especialización morfológica y los bajos índices de variación en valores biométricos no parecen ser señal de domesticación o selección cultural en el NOA -a diferencia de lo que se suele sustentar como evidencia de domesticación plena en otros casos de estudios arqueobotánicos- y no parece serlo tampoco en os conjuntos cultivados actualmente por campesinos de diversas partes de Sudamérica. Incluso los análisis que he efectuado en ejemplares actuales de cultivares de $C$. maxima subsp. maxima del NOA muestran índices elevados de variación, inusuales de acuerdo a lo que se espera para un cultivar o variedad (Lema, 2009 b; Lema, 2010 c). Hasta el momento, las formas de crianza apuntaron y apuntan a la diversificación, al cruzamiento y al flujo génico.

Por lo general se asume que las poblaciones de plantas "semidomesticadas" o "incipientemente domesticadas", es decir, aquellas cultivadas no domesticadas con diferencias de distinto tipo o grado respecto a sus parientes silvestres, se caracterizan por ser heterogéneas, con gran diversidad y altos coeficientes de variación por la presencia de más de un tipo y los efectos iniciales de la hibridación, cultivo y cría selectiva (Newsom et al., 1993; Clement, 1999). Si esta variabilidad persiste a lo largo del tiempo en el registro arqueológico de una región, estará indicando la ausencia o baja incidencia de acciones como el asilamiento reproductivo y la cría selectiva (Gremillion, 1993), que es lo que se está comenzando a interpretar para momentos tardíos en el NOA (difiriendo de lo que se interpreta en otras regiones de los Andes, Bruno, 2008). En este punto, se debe atender a las frecuencias relativas de los tipos de plantas detectadas arqueológicamente: si el conjunto arqueobotánico se encuentra constituido por unos cuantos ejemplares del cultivo con caracteres híbridos o intermedios junto con la forma domesticada y silvestre, es probable que estemos ante las primeras etapas de prácticas de cultivo generadas localmente (casos del Formativo del NOA). Si, en cambio, el conjunto arqueobotánico se encuentra constituido por unos pocos ejemplares del cultivo con caracteres híbridos o intermedios junto con la forma domesticada solamente, es probable que estemos, no ante poblaciones transicionales como en el caso anterior, sino ante poblaciones cultivadas en las que persisten caracteres ancestrales, o existe aún una alta tasa de cruzamiento con poblaciones silvestres o con malezas (casos del Tardío del NOA). Puede verse que las diferencias son de grado, lo cual hace altamente probable que los cambios ocasionados por las primeras etapas de cultivo y presión selectiva no sean evidentes en el registro arqueobotánico (Smith, 2006), y quizá por ello sea tan difícil detectarlo a nivel arqueológico.

Si bien no sabemos aún hasta qué punto las formas hibridas del Formativo y del Tardío pueden estar involucradas en estrategias de cultivo distintas o no, podemos asumir preliminarmente que ambas están apuntando a generar y/o mantener diversidad de formas con distinto grado de asociación con el hombre, las cuales pueden ser vistas como retardadoras de una domesticación plena (Hillman y Davies, 1990), o bien como evidencia de que la estrategia de manejo responde a otra visión de la interacción humano-planta donde no se pretende homogeneizar los cultivos, sino diversificarlos y permitir la introgresión en distintas medidas, grados y direcciones, estrategia que se halla en vigencia hoy día en muchas comunidades campesinas e indígenas (Altieri y Merrick, 1987). Junto con esto debe atenderse al hecho de que las formas antecesoras silvestres o parientes silvestres de muchas plantas son consideradas en diversas regiones de los Andes, no solo como propias de otros criadores no humanos (Lema, 2014a) y como su alimento (Villagrán y Castro, 2003), sino también como propias de otras eras o épocas, momentos generalmente correspondientes a otras formas de humanidad (Arnold et al., 1992, Rivera-Cusicanqui, 2015). Atender a nociones locales del tiempo, donde el pasado debe estar presente para cuajar y posibilitar un futuro (Rivera-Cusicanqui, 2015), quizá sea una vía para entender en términos locales el porqué de su presencia en los campos de cultivo. Esta tendencia sostenida en el tiempo, ligada al mantenimiento e incremento de la diversidad biocultural, se nos presenta como parte del patrimonio material e inmaterial de muchas comunidades locales de la región; su estudio, reconocimiento y valoración resultan fundamentales para dar argumentos sólidos a la hora de hacer frente a situaciones actuales que están borrando esta diversidad genética, las lógicas que la sustentan y el mundo del cual forman parte. Los aportes de estudios arqueológicos, arqueobotánicos, etnobotánicos y paleoetnóbotanicos son fundamentales a la hora de plantear una mirada políticamente comprometida que se hace fuerte en los aportes transdisciplinares, en la valoración de ontologías locales y en "tornar serio" e discurso indígena. Seamos conscientes de ello o no, las astas que elijamos para definir/asir a toro de la domesticación tendrán consecuencias políticas a futuro.

\section{Coda}

"Llevar a serio" las concepciones nativas (Viveiros de Castro, 2010) no es "adoptar el punto de vista del otro", considerar lo emic, ni -para el caso arqueológico particularmente- aplicar distintos tipos o niveles de analogías entre el presente y el pasado (Lema, 2012); tampoco es el eufemismo de usar términos atractivos o de moda en la academia para seguir diciendo lo mismo, sino dejarse permear -en tanto investigadores occidentales y modernos- por sus lógicas y su episteme. En palabras de Viveiros de Castro (2002), consiste en tornar las ideas nativas en conceptos y de allí el mundo posible que esos conceptos proyectan; poniendo la lógica indígena a la misma altura que la lógica antropológica. Como dice este autor "no se 
trataría solo, o apenas, de la descripción antropológica del kula (en cuanto forma melanésica de socialidad), sino del kula en cuanto descripción melanésica de la socialidad (como fórmula antropológica) [...] es preciso saber transformar las concepciones en conceptos, extraerlos de ellas y devolverlos a ellas" (Viveiros de Castro, 2002: 128, mi traducción). Parafraseando entonces a este investigador, podría decirse que no se trataría solo, o apenas, de la interpretación antropológica de la crianza (en cuanto forma andina de domesticación), sino de la crianza en cuanto interpretación andina de la domesticación (como fórmula antropológica). Una vez dicho esto, ¿qué consecuencias se desprenderían de esta interpretación andina de la domesticación?, pues hacia allí se orientan hoy mis reflexiones. En principio, considerando estas lógicas distintas, la mirada se amplía para abarcar aspectos que, desde nuestra lógica, no tendrían relación con la domesticación y el cultivo -como los textiles, los techos de las casas, los muertos o la música, entre muchos otros aspectos (Stobart, 1994; Arnold y Yapita, 1996; Gose, 2001)pero que resultan esenciales al dar lugar a otras ontologías.

Para finalizar, si reconocemos en los cultivadores del pasado y del presente la generación y mantención de gran parte de la diversidad biocultural bajo cultivo en los Andes y decimos que nos proponemos tornar serias sus concepciones "desfolclorizándolas", debemos dejar que su episteme tiña e interpele los proyectos de investigación, de aplicación y las políticas vinculadas al manejo del entorno ambiental... porque convengamos que si el toro termina siendo un minotauro es otra idea acerca de la historia, del pasado y de la evolución la que explicaría las características que nuestro animal-problema tiene hoy.

\section{Bibliografía}

Altieri, M. A y L. Merrick, 1987. In situ conservation of crop Balée, W., 1998. Historical ecology: premises and postulates. genetic resources through maintenance of tradition farming systems. Economic. Botany, 41(1): 86-96. En: W. Balée (Ed.). Advances in historical ecology. Columbia University Press. Nueva York, pp 13-29.

Aguirre, M. G., 2012. Recursos vegetales: uso, consumo y Balée, W., 2010 Amazonian Dark Earths. Tipitt: Journal of producción en la Puna meridional argentina (5000-1500 the Society for the Anthropology of Lowland South
AP). Tesis para optar al grado de Doctor en Ciencias
America, 8(1) Articulo 3. (en línea, disponible en: http://

Andrade, A., P. Babot, D. Bertero, S. Costa Tártara, R. Ceruti, M. Manifiesto, 2014. Argentina En: Bazile D. e 2013 Capitulo 5.5. FAO (Santiago de Chile) y CIRAD, Montpellier, Francia, pp. 504-518.

Arreguez G J. Martínez N Oliszewski y G. Ponessa, 2015. Prón. J. de macrorrestos vegetales en sitios arqueológicicos de Holoceno medio y tardío en el Noroeste argentino: el caso del amaranto y la quínoa. En: C. Belmar y V Lema (Eds.). Avances y desafíos metodológicos en arqueobotánica: miradas consensuadas y diálogos compartidos desde Sudamérica. Monografías Arqueológicas, Facultad de Newgraphic y Cuald Eduction, Unilo

mold D. D. Jiménez y J. Yapita, 1992. Hacia un orden Amold, D., D. Jimenez y J. Yapita, 1992. Hacia un
andino de las cosas. Hisbol/llca, La Paz, Bolivia.

Arnold, D. y J. Yapita, 1996. Madre Melliza y sus crías. Ispall Mama wawampi. Antología de la papa. Hisbol/lica, La Maza Bolivia.

Aschero, C. y S. Hocsman, 2011. Arqueología de las ocupaciones cazadoras-recolectoras de fines de Chilena 43 Número Especial, 1: 393-411.

Babot, M. P., 2009 Procesamiento de tubérculos y raíces por grupos agropastoriles del noroeste argentino prehispánico: análisis de indicadores en residuos
molienda. Treballs $D$ Étnoarqueologia, 7: 67-82.

Babot, M. P., 2011. Cazadores-recolectores de los Andes centro-sur y procesamiento vegetal. Una discusión desde la puna meridional argentina (ca. 7,000-3,200 AÑOS a.p.) Chungara, Revista de Antropología Chilena,

Babot, M. P., S. Hocsman, R. Piccón Figueroa y C. Haros, 2012. Recetarios prehispánicos y tradiciones Marschoff y F. Pazzarelli (Eds.). Las manos en la masa. Arqueologías, antropologís e historias de la alimentación en Suramérica. Universidad Nacional de Córdoba, Facultad de Filosofía y Humanidades, Museo de Antropologia - Instituto Superior de Estudios SocialesUniversidad Nacional de Tucumán, pp: 235-270.

Babot, M.P. y S. Hocsman, 2015. Quinoa. A Millenary Grain in Northern Argentina. Encyclopaedia of the History of Science, Technology, and Medicine in Non-Western Cultures. Springer Science+Business Media Dordrec America, 8(1) Articulo 3. (en línea, disponible en: http:

eebe, S., Ch. O., Toro, A. González, M. Chacón y D. Debouck, 1997. Wild-weedy-crop complexes conservation and breeding. Genetic resources and crop evolution, 44: 73- 91

Imar, C. y V. Lema, 2015 Avances y desafíos metodológicos en arqueobotánica: miradas consensuadas y diálogos compartidos desde Sudamérica. Monografías Arqueológicas, Facultad de Patrimonio Cultural Educación, Universidad SEK. Newgraphic y Cia Ltda. Santiago de Chile.

Bruno, M. C. 2008. Etnobotánica y las investigaciones sobre la agricultura prehistórica en la cuenca del Lago Titicaca En. Rivera-Casanova, C. (Ed.). Arqueologia de las tierras altas, valles interandinos y tierras bajas de Bolivia. Instituto de Investigaciones Antropológicas Arqueológicas- Universidad Mayor de San Andrés. Programa de Investigación Estratégica en Bolivia. La Paz, Bolivia, pp. 27-34.

o, M. C. 2009 Practice and history in the transition to food production. Current Anthropology, 50(5): 703-706.

Buallo, L. y Tomasi J., 2010. Crianzas mutuas. El trato a los animales desde las concepciones de los pastores puneños (Jujuy, Argentina) Revista Española de Antropologia Americana, 42 (1): 205-224.

Bugallo, L. y M. Vilca, 2011. Cuidando el ánimu: salud enfermedad en el mundo andino (puna y quebrada de Jujuy, Argentina). Nuevo Mundo Mundos Nuevos, Debates (en linea, dispovible en: hitp://nuevomundo.

Casas, A., 2001. Silvicultura y domesticación de plantas en Mesoamérica En: Aguilar, B., S. Domínguez, J. Caballerosociedad. Estudio sobre la relación entre seres humanos y plantas en los albores del siglo XXI UAM-S.M.A.R.N.YP. México: pp.123-158.

Calo, C., 2010. Plantas útiles y prácticas cotidianas entre los aldeanos al sur de los Valles Calchaquies (600 aC - 900 Ciencias Naturales FCNYM- UNLP. Inédita.

Capparelli, A. y V. Lema, 2011. Recognition of post-harvest processing of algarrobo (Prosopis spp.) as food from two sites of Northwestern Argentina: an ethnobotanical an Journal of An tir Andes of Peru and Colombia, and their implications for experimental approach for desiccated macroremains. 
Capparelli, A., M. Pochettino, D. Andreoni y D. Iturriza, Fernández, J., H. Panarello y A. Ramos, 1992. El análisis 2006. Difference between written and archaeologica record: The case of plant micro remains recovered
at a Norhwestern Argentinean pipe. En: Ertug, $F$ at a Norhwestern Argentinean pipe. En: Ertug, $F$.
(Ed.). Proceedings of the IV International Congress (Ed.). Proceedings of the IV International Congress
of Ethnobotany. Estambul: Yeditepe University: pp. of Ethno
$397-406$.

Capparelli, A, M.L. Pochettino, V. Lema, M. L. López, D. Andreoni, M. L. Ciampagna y C. Llano, 2015. interpretation: a qualitative step in the history of archaeobotany in Argentina. Vegetation History and archaeobotany 24: 151-163.

Cavalcanti-Schiel, R., 2007. Las muchas naturalezas en los Andes. Perifèria, 7: 1-11.

Clement, C., 1999. 1492 and the loss of Amazonian crop genetic resources. I. The relation between domestication 53:188-202.

Clement, C., W. Denevan, M. Heckenberger, A. Junqueira, E. Neves, W. Teixeira y W. Woods, 2015. The domestication of Amazonia before European conquest. Proceedings of the Royal Society Biological Sciences
282: $32-40$.

De Wet, J. y J. Harlan, 1975. Weeds and domesticates: evolution in the man-made habitat. Economic Botany,

Denham, T., 2009. A Practice-Centered Method for Charting the Emergence and transformation of Agriculture.

Delfino, D., V. Espiro y A. Díaz, 2015. Prácticas sociales en el pasado y presente de Laguna Blanca (Dpto. Belén comunitario agrocéntrico En: Korstanje, A.. M. Lazzari, M. Basile, F. Bugliani, V. Lema, L. Pereyra Domingoren y M. Quesada (Eds.) Crónicas materiales precolombinas. Arqueología de los primeros poblados del Noroeste
Argentino. Sociedad Argentina de Antropología, Buenos Aires: pp. 385-426.

Descola, P., 2012. Más allá de naturaleza y cultura. Amorrortu editores, Buenos Aires.

Echenique, M. y J. Kulemeyer, 2003. La excavación arqueológica de una "mancha blanca", el Sector M43C en el sitio Moralito, Departamento San Pedro, Provincia de Jujuy (República Argentina). En: Ortiz, G. y B. Ventura arqueológicas en la vertiente oriental de los Andes $y$ las tierras bajas de Bolivia y Argentina EdiUnju, San Salvador de Jujuy, Argentina: pp. 99-130.

Epimaki, M. K., S. Singh y P. Gepts, 1996. Genetic control of the domestication sindron

Escola, P., S. Hocsman y P. Babot, 2013. Entre las residencias y los campos de cultivo. Aportes de los cuchillos/ raederas de módulo grandisimo a la cuestión del laboreo agrícola en Antofagasta de la Sierra (Puna de Catamarca) elaciones de la Sociedad Argentina de Antropologí, 38(1): 83-110. de elementos traza y de las relaciones entre isótopos años AP) de la puna jujeña, como indicadores de su manufactura autóctona y funcionalidad probable. Cuadernos Facultad de Humanidades y Cien

ueroa, G., 2013. Estrategias productivas en Aguada de Ambato (Catamarca, Argentina). Relaciones de la agrop., M. Dantas y A. Laguens, 2010. Prácticas agropastoriles e innovaciones en la producción de
plantas y animales en los Andes del Sur. EI Valle de Ambato, Argentina,Primer Milenio d.C. Internation Journal of South American Archaeology, 7: 6-13.

anco, V. y E. Berberián, 2011. Prácticas agrícolas de sociedades campesinas en el valle de Tafí (100 a.C.

Ford, Richard, 1979. Paleoethnobotany in American Archaeology. En: M. Schiffer (Ed.) Advances in Nueva York: pp. 285-336.

ord, Richard, 1985. The processes of plant food production in prehistoric North America. Anthropological papers

er, D. 2007. Contrasting patterns in crop domestication and domestication rates: recent archaeobotanical
insights from the Old World. Annals of Botany, 100: insights

García, V., 2005 .Explicar sin techos, sin pisos, el desarrollo sin muros. Revista colombiana de Filosofía de la Ciencia

Gepts, P., 2005. Introduction of transgenic crops in centers of origin and domestication. En: D. L. Kleinman, A. science and technology. From maize to menopause. The University of Wisconsin Press, Wisconsin: pp. 119-134.

Gnecco, C. y J. Aceituno, 2004. Poblamiento temprano y espacios antropogénicos en el norte de Sudamérica. Complutum, 15: 151-164.

, P., 2010. Aguas mortifferas y cerros hambrientos. Rito agrario y formación de clases

dspeed, T., 1954. The genus Nicotiana. Chronica Botanica Company, Massachusetts.

million, K., 1993. The evolution of seed morphology in domesticated Chenopodium: an archaeological
study Journal of Ethnobiology, 13(21): 149-169.

Guillen, S., T. Terrazas y A. Casas, 2015. Effects of natural and the role of adaptation to xeric and mesic environments Ecology and Evolution doi. 10.1002/ece3.1478

Gremillion, K. y D. Piperno, 2009 Human Behavioral Ecology Phenotypic (Developmental) Plasticity, and Agricultura Origins Insights from the Emerging Evolution
Synthesis, Current Anthropology, 50(5): 615-619 artificial selection on survival of columnar cacti seedlings:
Grillo Fernández, E., 1994 El paisaje en las culturas andina y occidental moderna. En: E. Grillo Fernández, V. Quiso (Eds.). Crianza andina de la chacra. PRATEC, Lima: 9-46.

Haber, A., 1997. La casa, el sendero y el mundo. Significados culturales de la arqueología, la cultura material y el paisaje en la

Haber, A. 2006. Una arqueología de los oasis puneños. Domesticidad, interacción e identidad en Antofalla, primer y segundo milenios d.C. Jorge

Haber, A., 2009. Animism, relatedness, life: post-Western perspectives Cambridge Archaeological Journal 19 (3): $418-430$

Harlan, J., 1992. Crops and man. American Society of nomy. Wisconsin.

Harris, D., 1989. An evolutionary continuum of people-plan 政. UnwinHyman, Londres: pp. 11-26.

Hather, J. y S. Mason, 2002. Introduction: some issues in the archaeobotany of hunter- gatherers. En: S. Mason Perspectives from the northern temperate zone. Institute of archaeology, University College: pp. 1-14.

Hawkes, J. G., 1969. The ecological background of plant domestication. En: Ucko y Dimbleby (Eds.). The domestication and exploitation of plant
Duckworth \& Co. Londres: pp. 17-29.

Hayden, B., 2009. The proof is in the pudding. Feasting an the o rigins of domestication. Current Anthropology, 50(5): 597-

Hillman, G. y M. S. Davies, 1990. Measured domestication rates in wild wheats and barley under primitive cultivation, and their archaeological
of World Prehistory, 4(2): 157-222.

Hoder, I., 1992. Theory and practice in archaeology.

Hodder, I y C. Cessford 2004. Daily Practice and Social

Holbraad,M., M. Pedersen y E. Viveiros de Castro, 2014. The Politics of Ontology: Anthropological Positions. Fieldsights - Theorizing the Contemporary, Cultura fieldsights/462-the-politics-of-ontology-anthropologicalpositions

Ingold, T., 2000. The perception of the environment. Essays on livelihood, dwelling and skill. Routledge, Londres On livelihood,
Nueva York.

Jones, M., 2009. Dormancy and the Plough: weed seed biology as an indicador of agrarian change in the first millennium AD En: A. Fairbairn y E. Weiss (Eds.). From Valle del Bolsón (1991-2005) En: Korstanje, A. y M.
Quesada (Eds.). Arqueología de la agricultura. Casos de estudio en la región andina argentina. Ed. Magna, Tucumán, Argentina: pp. 48-75.

Kanje, A., P. A. Cuenya y M. Maloberti, 2015. Usos de suclo, actividades domesticas y paisajes campesinos: problemas a (con enfasis en microfósiles). En: C. Belmar y V Lema (eds) Avances y desalfos metodológicosen arqueobotánica: Sudamérica. Monografias Arqueológicas, Facultad de Patrimonio Cultural y Educación, Universidad SEK. Newgraphic y Cia Ltda. Santiago de Chile: pp.254-277.

Korstanje, A., M. Quesada V. Franco Salvi, V. Lema y M. Maloverti, 2015. Gente, tierra, agua y cultivos: los primeros paisajes agrarios del hoy noroeste argentino. Lema, L. Pereyra Domingorena y M. Quesada (Eds.). Crónicas materiales precolombinas. Arqueología de los primeros poblados del Noroeste Argentino. Sociedad

Kuijt, I., 2009. What Do We Really Know about Food Storage Surplus, and Feasting in Preagricultura
Current Anthropology, 50(5): 641-644

arson, G., D. Piperno, R. Allaby, M. Purugganan, L. Vigueira, T. Denham, K. Dobney, A. Doust, P. Gepts, M. Gilbert, K. Gremillion, L. Lucas, L Lukens, F. Marshal K. Olsen, J. Pires, P. Richerson, R. Rubio de Casas, O. Sanjur, M. Thomas y D. Fuller, 2014. Current perspectives and the future of domestication studies PNAS 111 (17)

ema, V., 2006. Huertos de altura: el manejo humano de especies vegetales en la puna argentina. Revista de .

ema, V., 2008. ¿De qué hablamos cuando hablamos de domesticación vegetal en el NOA? Revisión de antiguas propuestas bajo nuevos abordajes teoricos. En: $\mathrm{S}$. UNIANDES-CESO, Bogotá, Colombia: pp. 97-126.

ema, V., 2009a. Domesticación vegetal y grados de dependencia ser humano-planta en el desarrollo cultura prehispánico del Noroeste argentino. Tesis para optar al
grado de Doctor en Cs Naturales FCNYM - UNLP Inédita.

Lema, V., 2009b. Criterios de selección en los procesos de manipulación vegetal: el potencial de la información etnobotánicaen la interpretación de restos arcinf

Lema, V., 2010a. Procesos de domesticación vegetal en pasado prehispánico del Noroeste argentino: estudio de las práclicas más allá de los origenes. Relaciones ema V., 2010b. Confluencia y emergencia: domesticación y prácticas de manejo del entorno vegetal en la frontera. En: Bárcena R., Chiavazza H (Eds.). Actas - Arqueología Argentina en el Centenario de la Revolución de Mayo. T. III FFyL Universidad Nacional de Cuyo, Mendoza, Argentina: pp. 1043-1048. 
Lema, V., 2010c. Cultivation, production and domestication: evaluating the archaeological visibility of interactions between human societies and plant populations in the
past En: Pochettino, M.L., A. Ladio y P. Arenas (Eds.) Tradiciones y transformaciones en Etnobotánica. Cyted,

Lema, V., 2011a. The possible influence of post-harvest objectives on Cucurbita maxima ssp.maxima and ssp. Northwest: an archaeological example. Journal of Anthropological and Archaeological Sciences, 3(1):113- 139 .

Lema, V., 2011b. Lo micro en lo macro: el tratamiento microscópico de macrorestos vegetales para la
identificación de prácticas y modos de relación con el entorno vegetal en el estudio arqueológico de domesticación vegetal. Arqueología, 17: 57-79.

Lema, V., 2012. Nuevas ideas sobre la domesticación ¿nuevas ideas sobre el Formativo? Aportes para una relectura crítica. Precirculados del Taller Arqueología del periodo Formativo en Argentina: un encuentro para integra areas y sub-disciplinas, revisar significados y potenciar
el impacto de las investigaciones en curso, Tafí del
Valle,Tucumán. Inédito.

Lema, V., 2013. Crianza mutua: una gramática de la sociabilidad andina. Actas de la X Reunión de Nacional de Córdoba (Formato CD).

Lema, V., 2014a. Criar y ser criados por las plantas y sus espacios en los Andes Septentrionales de Argentina.
En: Benedetti A. y Tomasi J. (comp.). Espacialidades altoandinas. Nuevos aportes desde la Argentina. Tomo I: Miradas hacia lo local, lo comunitario y lo doméstico.
Editorial de la Facultad de Filosofía y Letras, Universidad Editorial de la Facultad de Filoso

Lema, V., 2014b. Hacia una cartografía de la crianza: domesticido

Lema, V., 2014c. Boceto para un esquema: domesticación y agricultura temprana en el Noroeste argentino. Revis

Lema, V., 2015. Non domestication cultivation in the Andes: plant management and nurturing in the Argentinean 24:143-150

Lema, V., 2016. Historicidad de las prácticas y representaciones vinculadas al consumo de psicoactivos en el Noroeste
de Argentina. Actas de la XI Reunión de Antropología del Mercosur. Diálogos, prácticas y visiones desde Sur. Compiladores: Guigou, Lelio Nicolás y otros http: $/ /$ xiram.com.uy/actas-del-congreso/grupos-de-trabajo
ponencias-grupo-de-trabajo-75

Lema, V. En prensa. Geografías y prácticas: plantas que circulan, que se quedan y que se van para no volver. En: Ventura, B. y G. Ortiz (Eds.) Actas del III Taller Sur Arqueología y tohoria de la a y Andes Centro los Andes de Argentina, Bolivia y Perú. ema, V. y F. Pazzarelli, 2015. Memoria fértil. La crianza de la historia en Huachichocana. Nuevo Mundo. Mundos Nuevos. URL: http://nuevomund
DOI: $10.4000 /$ nuevomundo.67976

ema, V., D. Andreoni, A. Capparelli, G. Ortiz, R. Spano, M. Quesada y F. Zorzi, 2015. Protocolos y avances en e estudio de residuos de pipas arqueológicas de Argentina. y précticas elocias actuales ns, R. y R. Lewontin, 1985. The dialectical biologist. sity Press, Cambridge.

ópez, G. 2009. Diversidad arqueológica y cambio cultural en astos Grandes, puna de Salta, a lo largo del Holoceno 34:149-176.

upo, L. y M. Echenique, 2001. Reconstrucción arqueopalinológica de los distintos momentos de Noroeste argentino. Asociación Paleontológica Noroeste argentino. Asociación Paleontológica
Argentina. Publicación especial 8. XI Simposio Argentino de Paleobotánica y Palinología: 125-130.

Isluga. Anales de la Universidad del Norte, 10: 255-327.

tínez, A., S. Pérez, V. Lema y F. López Anido, 2015 Modificación de caracteres ligados a la domesticación en Cucurbita maxima. Utilización de la morfometría como herramienta para
malacitana 40: 95-106.

Martínez, A., V. Lema, S. Pérez y F. López Anido Pedúnculos y pericarpios de Cucurbita maxima: un aporte para la reconstrucción del proceso de domesticación del
zapallo criollo en el Noroeste argentino. Etnobiología. En evaluación.

Muscio, H., 2001. Una revisión crítica del Arcaico surandino. Fichas de cátedras. Oficina de publicaciones de de Buenos Aires https:/ecaths1.s3 amazonaws com/ argentina1/Arcaico\%20Surandino\%20(Muscio).pdf

Newsom, L.A., S. D. Webb y J. S. Dunbar, 1993. History and geographic distribution of Cucurbita pepo go
Florida. Journal of Ethnobiology, 13(1): $75-98$.

Oliszewski, N. y D. Olivera, 2009. Variabilidad racial de macrorrestos arqueológicos de Zea mays (Poaceae) y sus relaciones con el proceso agropastoril en puna meridional argentina (Antofagasta de la sierra,

Oliszewski, N. y M. P. Babot, 2015. Procesos de selección del poroto común en los valles altos del noroeste argentino en tiempos prehispánicos. Análisis micro y Belmary V Lema (eds) Avances y desafíos metododológicos en arqueobotánica: miradas consensuadas y diálogós compartidos desde Sudamérica. Monografía Arqueológicas, Facultad de Patrimonio Cultural Elucación, Universidad SEK. Newgraphic y Cia Ltd Santiago de Chile: pp. 301-324.

Ortiz, G. y C. A Heit, 2012. Consumos pedemontanos tempranos de la cuenca d
San Francisco (Jujuy, Argentina) En: Babot, P., M. Quiso Choque, V., 1994. Kayuni yapu (chacra con patas) Marschoff y F. Pazzarelli (Eds.). Las manos en la masa. Arqueologias, antropologias e historias de la alimentación en Suramérica. Universidad Nacional de Córdoba, Facultad de Filosofía y Humanidades, Museo de Antropologia - Instituto Superior de Estudios Sociversidad Nacional de Tucumán: pp. 621-638.

Oyama, S., 2002. The nurturing of natures. En: Grunwald, A, M. Gutmann y. M. Neumann-Held (Eds.). On Huma Foundations. Springer Verlag, Nueva York, pp. 163-170.

Pazzarelli, F., 2013. 'Sin lo de adentro, el chivo no se forma' Notas sobre interioridades y exterioridades desde los Andes jujeños. Actas de la X Reunión Antropología del (Formato CD).

Pazzarelli, F., 2014. "O rastro do pastor. Criação de animais técnicas para fazer carne em Jujuy", Anais do Seminário de Antropologia da UFSCAR, 1: 430-443.

Pazzarelli, F. y V. Lema, 2015. Masticar-digerir-deshidratar: lógicas de la transformación en challas de arrieros.
Primeras Jornadas sobre el Altiplano Sur: Miradas Primeras Jornadas sobre el Altipl
Disciplinares. Tilcara, Argentina.

Pearsall, D., 2009. Investigating the Transition to Agriculture. Current Anthropology, 50(5): 609-613.

Pérez, S., 2010. Variabilidad en la producción de palas y/o azadas líticas de la Puna argentina. Estudios

Petrucci, N., V. Lema, M. L. Pochettino, V. Palamarczuk, R. Spano y M. Tarragó From weed to wheat: a diachronic approximation to ancient biocultural diversity in the Santa Vegetation history and archaeobotany.
Valluacion en:

Quesada, M., 2007. Paisajes agrarios del área de Antofalla. Procesos de trabajo y escalas sociales de la producción optar al grado de Doctor en Ciencias Naturales. FCNYMUNLP. Inédita-

Quesada, M., 2010. Agricultura campesina en el área de Antofalla (1997-2007) En: A. Korstanje y M. Quesada (Eds.) Arqueología de la agricultura. Casos de estudía en la región andina argach
Argentina: pp.76-103.

Quesada, M. y M. Maloberti, 2015. Continuidades en la construcción del paisaje agrario entre los Períodos Formativo y de Desarrollos Regionales en el oeste de Winkel (eds.). Racionalidad campesina en los Andes del Sur. Reflexiones sobre el cultivo de la Quinoa y otros vegetales andinos EdiUnju, Jujuy, Argentina: pp. 140-165.

Quinteros, A., 1999. El monte es nuestro padre, cuando el monte muere, sus hijos mueren también. En: $M$.
Arévalo, R. Panduro, A Quinteros y G. Rengifo Vásquez (Eds.) Hacer brillar la chacra. Agricultura campesina alto amazónica. San Martin. PRATEC, Lima: pp. 95-111.

Quinteros y G. Rengifo Vásquez (Eds). Hacer brillarla chacra. Agricultura campesina alto amazónica. San Martin. PRATEC, Lima: pp. 113-140. Crianza de alpacas y llamas en la comunidad de Ajanan Choque, G. Rengifo Vásquez y J. Valladolid Rivera (Eds.) Crianza andina de la chacra. PRATEC, Lima: pp. 233-314. Ratto, N., V. Lema, M. L. López 2014 Entierros y ofrendas: prácticas mortuorias, agrícolas y culinarias en los siglos XIII y XIV en Tinogasta (Catamarca, Argentina)

Rengifo Vásquez, G., 1999. Vivencia alto amazónica. En: M Sociologí de la imagen Miradas chíxi desde la historia andina, Ed. Tinta Limón. Buenos Aires.

Rösing, I., 2003. Religión, ritual y vida cotidiana en los Andes: los diez géneros de Amarete. Iberoamerican Andes: Ios diez

endón, P., 2009 Los ayllus de la porción oriental del departamento del Cusco. Aproximación comparativa d'Etudes Andines, 38(1): 107-130.
d'ter

Silva, V., G. Miguez y A. Korstanje, 2016. Análisis de microvestigios en pipas procedentes de ocupaciones prehispánicas de las selvas meridionales del Noroeste 53: 33-52

h, B., 2006. Documenting domestication in plants in the archaeological record. En: $M$.

eder, E. Emshwiller, D. Bradley, B. Smith (Eds.). Documenting domestication: new genetic and archaeologica paradigms. University of California Press, Berkeley,

trathern, M., 2004. Partial Connections. New York: AltaMira tobart, H., 1994 Flourishing horns and enchanted tubers: music and potatoes in highland
of Ethnomusicology 3: 35-48

Torres-Guevara, J. y F. Parra-Rondinel, 2008. Parientes silvestres de plantas nativas cultivadas andinas (Perü) los sachas. CCTA, Lima.

alladolid Rivera, J., 1994. Agricultura campesina andina: crianza de la diversidad de la vida en la chacra. En: $E$. y J. Valladolid Rivera (Eds.). Crianza andina de la chacra. PRATEC, Lima: pp. 315-378.

a, M., 2009. "Más allá del 'paisaje'. El espacio de la pun y quebrada de Jujuy: ¿comensal, anfitrión,
Cuadernos FHyCS-UNCJu, 36: 247-261.

Villagrán, C. y V. Castro, 2003. Ciencia indígena de los Andes del Norte de Chile Santiago, Chile. Editorial Universitaria S.A.

veiros de Castro, E., 2002. "O nativo relativo" Mana, 8(1): 113-148.

viros de Castro, E., 2004. Perspectivismo y multinaturalismo en la América indígena En: García Hierro, P. y Surrallés (Eds.). Tierra adentro. Territorio indígena y percepción
del entorno. Tarea Gráfica Educativa, Lima, pp. 37-82

viveiros de Castro, E 2010. Metafísicas canibales. Lineas de antropología postestructural. Katz Editores, Buenos Aires. 
Vogl, C. R., B. N. Vogl-L ukasser y J. Caballero, 2002. Yacobaccio, H y A. Korstanje, 2007. Los procesos de Homegardens of Maya Migrants in the District of Palenque, Chiapas, Mexico. En: J. R. Stepp, F. S. Sociedad Argentina de Antropología, 32: 191-216. biocultural diversity. The International Society of Zizumbo-Villarreal, D., P. Colunga-García Marín, E. Payro de la Cruz, P. Delgado-Valerio y P. Gepts., 2005. Weismantel, M., 2015. Seeing like an archaeologist: Viveiros Population structure and evolutionary dynamics of de Castro at Chavin de Huantar Journal of Social

\section{Ajíes or chile peppers (Capsicum spp.): history and biology}

Barbara Pickersgill

\section{Abstract}

The genus Capsicum belongs to the family Solanaceae, originated in South America, where the majority of species occur, but spread north to Mesoamerica and the southern United States by natural means, probably dispersal by birds. After the European Conquest, Capsicum spread rapidly, reaching Italy by 1526 , Germany by 1543 and the Balkans before 1569 . Initially the plants were grown in greenhouses, but then outside in suitable climates in Portugal. Chile peppers could thus be produced more cheaply than the imported and expensive black pepper (Piper nigrum L.), so their popularity increased rapidly. Faced with losing a valuable monopoly in the trade of pepper, Portuguese spice merchants organised prohibition of the cultivation of Capsicum and destruction of the plants. Nevertheless, Capsicum spread along European sea trading routes. By the $17^{\text {th }}$ century, sailors customarily carried dried chiles on long voyages. The date at which Capsicum reached Africa is not known, but by 1542 it was established in India. Today, many Indians find it hard to believe that before the $16^{\text {th }}$ century their curries and other hot dishes owed their pungency to spices other than Capsicum, notably ginger and black pepper. The pungency of Capsicum is due to compounds called capsaicinoids, synthesised in the epidermis of the placenta. The pungency of Capsicum originated through duplication of genes that already existed, together with changes in the time and tissue in which these genes are expressed. The principal capsaicinoids, capsaicin and dihydrocapsaicin, are among the most pungent compounds known. Pungency has traditionally been measured in Scoville heat units and a taste threshold of one part in 16 million corresponds to $160 \times 10^{5}$ Scoville units. Compounds responsible for the pungency of ginger possess the vanillyl group. Burning and pain result from very specific effects on nerve cells, but repeated exposure leads to desensitization. The desensitization associated with habitual consumption of hot peppers is well-known to lovers of Indian or Mexican food. Hot peppers increase perspiration, stimulate the flow of saliva and may help to overcome loss of appetite. They also stimulate secretion of gastric juices, so may aggravate stomach ulcers. They increase peristalsis, having laxative action. Capsicum seeds that had passed through the digestive tracts of rodents (cactus mice and pack rats) all failed to germinate, whereas seeds that had passed through the digestive tracts of birds known to be dispersers of Capsicum germinated. Field studies in Arizona and Bolivia showed that all fruits removed during the day were taken by birds and no fruits were removed during the night, when rodents are active. These data support the view that capsaicinoids provide chemical protection for fruits of pungent peppers. Wild peppers show adaptations for bird 
dispersal. Their fruits are small, an abscission zone at the base of the fruit enables ripe fruits to be removed readily from the plants, fruits are borne in an erect position, exposed above the leaves, and turn red when ripe, a colour attractive to birds. Domestication in chile peppers resulted in loss of most adaptations of the fruits to bird dispersal. Ripe fruits are retained on the plant until harvested, fruits are often borne hidden among the foliage, increased considerably in size, so entire fruits can no longer be readily carried away by birds. Changes after domestication are often distinguished as diversification. Fruits of domesticated peppers vary in size shape, colour, position, pungency and flavour, while there is much less intraspecific variation in vegetative or floral characters. Variation in the fruits may have been selected for aesthetic reasons, since the different colours found in ripe peppers are attractive in themselves, as well as in the colour that they contribute to salsas and other dishes. The most distinct and least variable of the domesticated species is $C$. pubescens, easily recognised by its purple flowers and dark seeds. The fruits have thick walls, so are used fresh, not dried. The aji named "rocot uchu", the most cold-tolerant of the cultivated species. White flowers with yellow markings at the base of each corolla lobe and straw-coloured seeds make $C$. baccatum easy to distinguish. It was domesticated from wild peppers treated taxonomically as a separate variety within $C$. baccatum and distributed from southern Peru to southern Brazil The taxonomic treatment of the remaining domesticated peppers is controversial. They are often regarded as three closely related species; $C$. annuum, $C$. frutescens and $C$. chinense. Each seems to have been domesticated independently in different parts of the range of a widespread and variable complex of wild peppers, within which it is impossible to draw boundaries delimiting distinct taxa. The morphological and molecular differences provide the justification for recognising them as distinct. Fertility of the hybrids varies considerably, the three taxa are treated as distinct species. In Mexico, domestication of local wild peppers, occurred possibly several times, and subsequent diversification has produced the various types of chiles included in C. annuum. In northern Amazonia, local wild peppers are the presumed progenitor of domesticated $C$. chinense. In Mesoamerica, the oldest specimens of Capsicum so far recovered come from caves in the Tehuacán valley, about 7000 years old. The earliest seeds of Capsicum from Tehuacán are within the size range of modern wild $C$. annuum; there is no increase in size throughout the various preceramic phases; and the one preceramic fruit that I have seen is very similar to fruits of modern wild $C$ annuum. Alternatively, the Tehuacán chiles could have been cultivated but not yet subjected to sufficiently strong human selection to have developed features of the domestication syndrome. Seeds of a size corresponding to those of modern domesticated $C$. annuum appeared about 6000-5200 B.P. Some pottery vessels of shapes associated with preparation or consumption of chocolate to try to determine whether the practice of adding chile to chocolate existed 2400 years ago. Recent excavations at Huaca Prieta Peru, have produced remains of Capsicum as early as or earlier than the age claimed for the oldest chiles from the Tehuacán caves in Mexico. One seed from Paredones was directly dated to $10,650-10,430$ cal. B.P., identified as C. pubescens, C. baccatum. C. chinense and C. frutescens in levels dated about 7600-6500 cal. B.P.

Keywords: Ají, archaeological signs of domestication, Capsicum, chile peppers, domestication, origins of agriculture.

\section{Introduction}

During his return from his successful first voyage, Columbus wrote an account of his discoveries that ended with an appeal for "a little assistance" from King Ferdinand and Queen Isabella of Spain to enable him to undertake further explorations. In return, he offered "as much gold as they need, as great a quantity of spices, of cotton, and of mastic ... I promise also rhubarb and other sorts of drugs ..." (traducción de Major, 1847). Some of these promises could not be honoured, but Columbus already knew that he could guarantee spices. In his Journal entry for 15 January 1493 he reported that, on the island of Hispaniola, "... there is much axi, which is their pepper, and it is stronger than pepper, and the people will not eat without it, for they find it very wholesome" (translation by Morison, 1963, cited by Purseglove et al., 1981).

The Arawak name axí, now usually spelled ají, is today used for various species of Capsicum $\mathrm{L}$. in Spanish-speaking South America, partially replacing the Quechuan name uchu. Chile, used in Mexico and other countries of Mesoamerica, is derived from the Náhuatl word chichiltic meaning red (Andrews, 1984) and is now employed throughout much of the world to distinguish Capsicum peppers with pungent fruits from other sorts of peppers.

Capsicum is a member of the family Solanaceae. The genus appears to have originated in South America, where the majority of species occur, but spread north to Mesoamerica and the southern United States by natural means, probably dispersal by birds. Capsicum was confined to the Americas before some of the domesticated species spread to Europe, Africa and Asia after the Conquest.

The Spanish conquistadors were soon followed by priests, who introduced to the Americas crops grown in Spain, such as citrus, melons and grapes, and also sent seeds of American crops, including chile peppers, back to Europe (Andrews, 1984). Chile peppers, like tomato and potato, were initially regarded by Europeans with suspicion, perhaps because they were recognised as related to some very poisonous members of the Solanaceae, such as deadly nightshade (Atropa belladonna L.), mandrake (Mandragora officinarum L.) and henbane ( $\mathrm{Hy}$ oscyamus niger L.), all of which were used in witchcraft and black magic. Thus, the Italian physician Matthioli, writing around 1570, claimed that Capsicum caused disease of the kidneys and liver, while in 1595 the Belgian physician Dodoens cautioned that it was dangerous to eat Capsicum if one was bled often and "it killeth dogs, if it be given to them to eat" (Andrews, 1984; Somos, 1984). Nevertheless, Capsicum spread rapidly, reaching Italy by 1526 , Germany by 1543 and the Balkans before 1569 (Andrews, 1984). Initially the plants were grown in greenhouses, but it was soon discovered that they could be grown outside in suitable climates, such as that of Portugal. Chile peppers could thus be produced more cheaply than the imported and therefore expensive, black pepper (Piper nigrum L.), so their popularity increased rapidly. Faced with losing a valuable monopoly in the trade of pepper, Portuguese spice merchants organised prohibition of the cultivation of Capsicum and destruction of the plants.

Nevertheless, Capsicum peppers continued to spread along European sea trading routes, probably aided by the fact that Capsicum seeds remain viable for many months. Dried fruits retain their pungency, so added flavour to the very limited shipboard diet. By the $17^{\text {th }}$ century, 
sailors customarily carried dried chiles on long voyages. The date at which Capsicum reached Africa is not known, but by 1542 it was established in India (Andrews, 1984). Today, many Indians find it hard to believe that before the $16^{\text {th }}$ century their curries and other hot dishes owed their pungency to spices other than Capsicum, notably ginger and black pepper.

\section{Pungency and its physiological effects}

The pungency of Capsicum fruits is due to a group of compounds called capsaicinoids that are unique to Capsicum. They are synthesised in the epidermis of the placenta (seed-bearing portion of the fruit). The fruit wall and seeds are therefore not in themselves pungent, though the cells producing capsaicinoids may burst, causing capsaicinoids to leak over the surface of the seeds and the inner wall of the fruit, so that these appear pungent (Zamski et al., 1987). Kim et al. (2014) reported that all the genes involved in synthesis of capsaicinoids are present also in tomato, but that at least three of these genes have undergone rounds of duplication in Capsicum compared to tomato. In Capsicum, they are expressed in the developing placenta whereas in tomato they are not. Kim et al. (2014) therefore concluded that the pungency of Capsicum originated through duplication of genes that already existed, together with changes in the time and tissue in which these genes are expressed.

The principal capsaicinoids, capsaicin and dihydrocapsaicin, are among the most pungent compounds known. Humans can detect them by taste at dilutions of one part in 15-17 million parts of water. Pungency has traditionally been measured in Scoville heat units and a taste threshold of one part in 16 million corresponds to $160 \times 10^{5}$ Scoville units. The pungency of capsaicinoids is due to three features of the molecule: presence of a vanillyl group, presence of an acid - amide bond, and length of the side chain (Figure 1). Pungency appears first when there are six carbon atoms in the side chain, peaks with a side chain of nine carbon atoms, and then declines as the length of the side chain increases (Maga and Todd, 1975). Compounds responsible for the pungency of ginger possess the vanillyl group and a long side chain, but lack the acid - amide bond, so are much less pungent than the capsaicinoids (Figure 1). The pungent principle from black pepper lacks both the vanillyl group and the acid - amide bond and has a short side chain with an aromatic derivative substituted for one of the terminal hydrogen atoms (Figure 1). Therefore, black pepper also is much less pungent than chile pepper, as Columbus accurately observed.

Capsaicinoids are responsible for many of the physiological effects of hot peppers. Burning and pain result from very specific effects on nerve cells, but repeated exposure leads to de sensitization. Experimenters who applied a 1\% solution of capsaicin ten times to their tongues found that they could no longer sense pungency at dilutions greater than about one in 3000 parts of water. Taste thresholds for other pungent spices such as ginger were also affected, but not ability to perceive basic tastes such as sweet, salt, sour or bitter. The desensitization associated with habitual consumption of hot peppers is well-known to lovers of Indian or Mexican food.

Hot peppers increase perspiration, which may partially explain their popularity in hot climates. They stimulate the flow of saliva and may help to overcome loss of appetite. They also stimulate secretion of gastric juices, so may aggravate stomach ulcers. They increase peristalsis, so have a laxative action. Capsaicinoids inflame the skin, induce coughing and sneezing and have an extremely irritating effect on mucous membranes of the eyes, nose and other parts of the body. Fruits of pungent peppers are used in manufacture of some gargles and lozenges for sore throats and ointments for rheumatism, lumbago or neuralgia. Some of their properties were known to and exploited by indigenous people of the Americas. Thus, use of chile peppers to treat coughs is recorded for Mexico (Long-Solis, 1986), while various tribes of northern Amazonia use hot peppers to treat fevers, including malaria (Nascimento Filho et al., 2007). Long-Solis (1986) also reported use of hot chile and salt to alleviate pain associated with tooth decay. She quoted a cure for colic given by Fray Bernardino de Sahagún, who arrived in Mexico in 1529. This involved treatment with a suppository consisting of lime, saltpetre, drops of liquidambar sap and chile. Long-Solis (1986) commented dryly that such a remedy would almost certainly cause a pain more intense than that of the original colic.

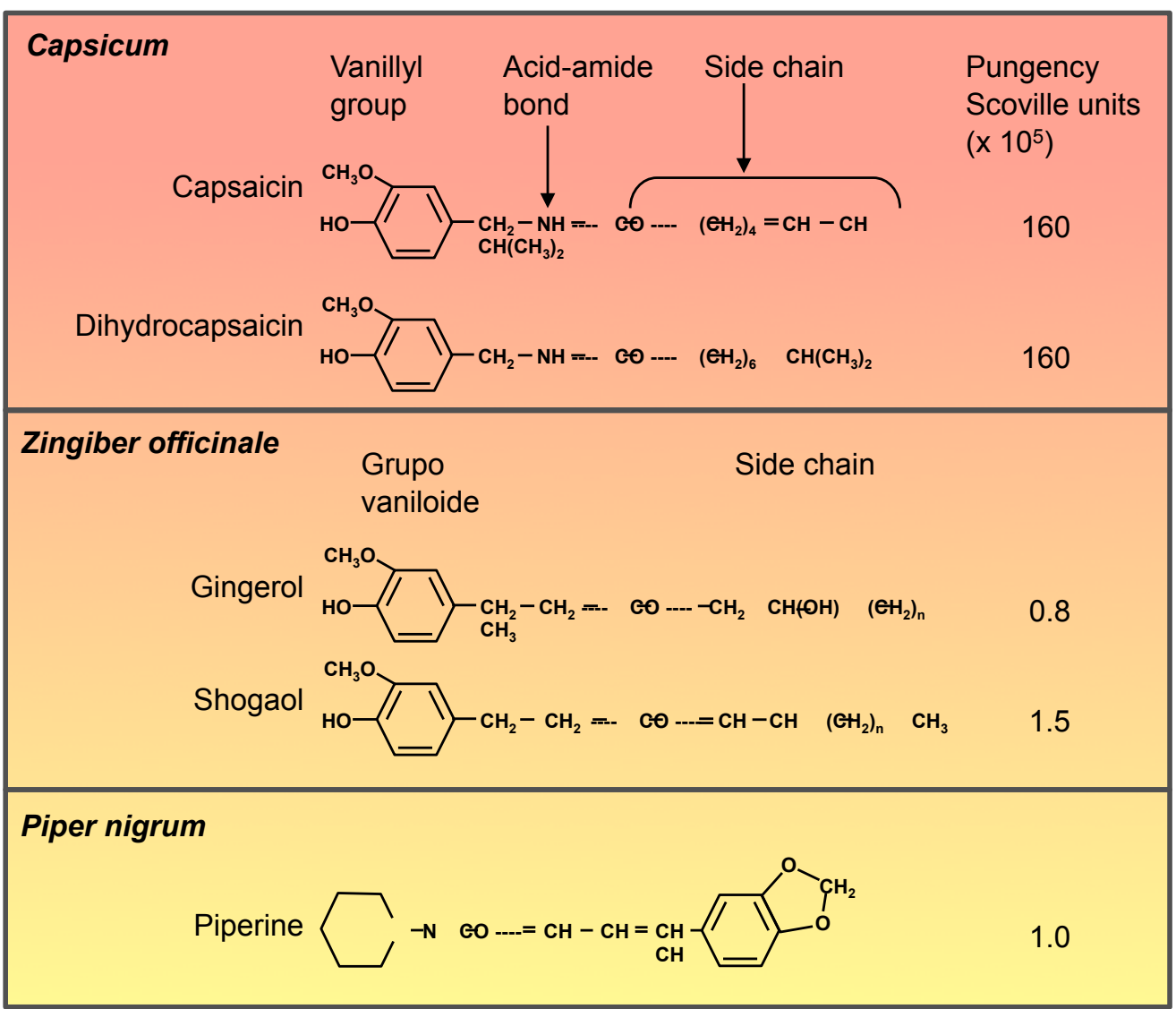

Figure 1. Chemical structure of compounds responsible for the pungency of Capsicum ginger Zingiber officinale and black pepper Piper nigrum and their pungencies measu-

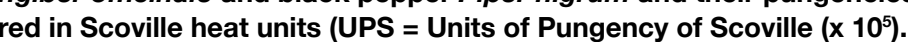


The burning and irritant effects of capsaicinoids were used in punishments for children in various parts of the Americas. The Codex Mendoza, produced soon after the conquest of Mexico, contains a drawing depicting a father holding his eleven-year-old son over the smoke of a fire on which chile peppers had been thrown, while a mother threatens her six-year-old daughter with the same punishment (image reproduced in Long-Solis, 1986). Among the Macuxi of northern Amazonia, parents of disobedient children might discipline them by inserting into the child's anus a fruit of malagueta (Capsicum frutescens L.), with the apex broken off so that the pungen juice could escape. Hot peppers, inserted into the anus or rubbed into purposely-made cuts on the body, also figured in rites to ensure that adolescent boys became brave warriors and hunters (Nascimento Filho et al., 2007). Hot peppers were used in chemical warfare by the natives of Santo Domingo. They attacked the fort built by Columbus by lobbing calabashes full of wood ashes and ground chiles into the fort (Castellanos cited in Patiño, 1964). This is a forerunner of modern use of capsaicin in sprays sold for personal protection against muggers.

Many wild peppers have very pungent fruits, in which capsaicinoids seem to have a dual function: preventing fungal infection of the fruit, and deterring mammalian seed predators while not affecting the legitimate agents of seed dispersal, namely birds. Tewksbury et al. (2008) found that, in a population of a wild species of Capsicum that was polymorphic for pungency, over $90 \%$ of the ripe fruits were infected with a species of Fusarium Link, introduced by hemipteran bugs that pierced the fruit wall while foraging on the fruits. Fruits were infected regardless of their pungency, but infection of the seeds was almost twice as high in non-pungent compared to pungent fruits. Laboratory experiments showed that both capsaicin and dihydrocapsaicin inhibited growth of Fusarium in direct proportion to their concentration in the growth medium. In other experiments, Tewksbury and Nabhan (2001) and Levey et al. (2006) found that Capsicum seeds that had passed through the digestive tracts of rodents (cactus mice and pack rats) all failed to germinate, whereas seeds that had passed through the digestive tracts of birds known to be dispersers of Capsicum germinated as well as seeds in a control sample. They concluded that rodents are seed predators, whereas birds are seed dispersers. Levey et al. (2006) further found that birds, unlike mammals, do not perceive capsaicin as an irritant, because birds and mammals differ in the vanilloid receptors that interact with the vanillyl group of capsaicinoids to produce pain. Field studies of wild chiles in Arizona and Bolivia showed that all fruits removed during the day were taken by birds and that virtually no fruits were removed during the night, when rodents are active. Taken together, these data support the view that capsaicinoids provide chemical protection for fruits of pungent peppers.

\section{Adaptations to bird dispersal}

Wild peppers show many adaptations for bird dispersal. Their fruits are small, so can be swallowed easily by their dispersers. An abscission zone at the base of the fruit enables ripe fruits to be removed readily from the plants. Fruits are borne in an erect position, exposed above the leaves, so that, when ripe, they are easily seen. In the wild relatives of the domesticated peppers, the fruits turn red when ripe. This is well-known to be a colour attractive to birds. The red pigments of Capsicum fruits are carotenoids, chemically related to the carotene of carrot, long recognised as a precursor of vitamin A. Capsicum fruits are thus good sources of vitamin $\mathrm{A}$, and also of vitamin $\mathrm{C}$ (they contain more vitamin $\mathrm{C}$ per unit weight than citrus fruits). Today red peppers are often fed to intensively raised hens, because carotenoids in the fruits are not broken down in the birds' bodies but enhance the colour of the yolks of their eggs.

\section{Effects of human selection}

Domestication in chile peppers has resulted in loss of most of the adaptations of the fruits to bird dispersal. The abscission layer at the base of the fruit is no longer present, so ripe fruits are retained on the plant until harvested. Fruits are often borne in a pendent position, hidden among the foliage, so no longer easily visible. Fruits have also increased considerably in size, so entire fruits can no longer be readily carried away by birds that feed on them. This increase in size affects also other parts of the plant (leaves, flowers and seeds). The suite of characters affected by human selection during domestication is known as the domestication syndrome. In Capsicum, this therefore includes loss of fruit dispersal, increased size, especially of the fruit, and change in fruit position. One change that cannot be seen, but may have been the first trait of the domestication syndrome to evolve, is loss of seed dormancy (Pickersgill, 2016).

Changes resulting from human selection after domestication are often distinguished as diversification. Charles Darwin (1875) observed that in domesticated plants, variation is usually greatest in that part of the plant used by humans. In Capsicum, the part used is the fruit. Fruits of domesticated peppers vary in size, shape, colour, position, pungency and flavour, while there is much less intraspecific variation in vegetative or floral characters. Variation in the fruits may have been selected for aesthetic reasons, since the different colours found in ripe peppers are attractive in themselves, as well as in the colour that they contribute to salsas and other dishes. Alternatively, variation in the fruits may serve to distinguish different local types. Standley (1946) reported that indigenous people in Guatemala believed that it was best to plant seeds grown locally, otherwise the plants would never be happy; they would become homesick, pine away and the crop would fail. This is an early description of what would now be called ecological adaptation. Another possibility is that differences in fruit colour and shape act as markers for invisible characters such as flavour or pungency. This is what Boster (1985) called selection for perceptual distinctiveness.

We know from the writings of Europeans who settled in the New World soon after the Conquest that peppers with fruits of different qualities, and hence uses, existed in various parts of the Americas before the arrival of Europeans. Perhaps the most detailed account is that for Mexico. The Franciscan friar Bernardino de Sahagún described the chiles sold in the Aztec capital Tenochtitlán: “... mild red chiles, broad chiles, yellow chiles, cuitlachilli, tempilchilli, chichioachilli. [The chile seller] sells water chiles, conchilli; he sells smoked chiles, small chiles, tree chiles, thin chiles, those like beetles. He sells hot chiles, the early variety, the hollow-based kind. He sells green chiles, sharp-pointed red chiles, a late variety... Separately he sells strings of chiles, chiles cooked in an olla, fish chiles, white fish chiles..." (translation by Coe, 1994). Sahagún also described the dishes eaten by the Aztec nobility: "cazuela de gallina con chile bermejo, tomates y pepitas de calabaza molidas; cazuela de gallina hecha 
con chile amarillo ... muchos potajes de chile; una manera de chilmolli, hecho con chiltécpitl y tomates, otra manera de chilmolli hecho de chiles amarillos y tomates ... usaban también comer peces blancos, en cazuela, con chile amarillo y tomates y con pepitas de calabaza molida; axolotl con chile amarillo; comían, también, una manera de pececillos colorados con chiltécpitl; y otra cazuela de unas hormigas aludas con chiltécpitl ... Los manjares más apreciados se consideraban el pescado blanco iztimichi, preparado con chile y tomate y ajolote sazonado con chile amarillo. También comían ranas con salsa de chile..." (cited by Long-Solis, 1986). Sahagún's description of the salsas served with these dishes is particularly vivid: "picante; muy picante; muy, muy picante; brillantemente picante; extremadamente picante; picantísima" (cited por Long-Solis, 1986).

For Peru, Garcilaso de la Vega, son of a Spanish conquistador and an Inca noblewoman, wrote an account of the customs of his mother's people many years after he had left Peru and was living in Spain. He stated that the people were so fond of aji that they would not eat without it, which recalls Columbus's report from the West Indies, and went on to describe the different types of ají known to the Incas: "El común es gruesso, algo prolongado y sin punto: llámanle 'rócot uchu'; quiere dezir pimiento gruesso, a diferencia del que se sigue; cómenlo sazonado o verde, antes que acabe de tomar su color perfecto, que es colorado. Otras hay amarillos y otros morados, aunque en España no he visto más de los colorados. Hay otros pimientos largos, de un geme, poco más, poco menos, delgados como el dedo menique o marguerite ... otro pimiento hay menudo y redondo, ni más ni menos que una guinda, con su pezón o palillo; llámanle 'chinchi uchu'; quema mucho más que los otros, sin comparación; críase en poco cantidad y por ende es más estimado' (cited by Patiño, 1964). The Jesuit Padre Bernabé Cobo, who travelled throughout much of Spanish South America early in the $17^{\text {th }}$ century, gave a more complete description of the variation that he encountered: "el fruto... uno es grande como limas y ciruelas grandes; otro, tan pequeño como piñones y aun como granos de trigo, y entre estos dos extremas hay muchas diferencias en su tamaño. En el color se halla no menor variedad, aunque todo ají conviene en ser verde antes de madurar. La misma dicrepancia se halla en la forma y hechura; porque uno es redondo; otro, prolongado, y otros, de otras muchas formas. ... El mayor de todos se llama rocoto ... el ají desta planta es muy grande, del tamaño de una lima, y aun como una mediana naranja, redondo, y alguno prolongado; uno, de color verdinegro, y otro, muy colorado; no quema su cascara como la de los otros ajíes, sino que se deja comer cruda, como si fuera otra fruta. Otro ají hay largo y grueso, mayor que el más largo dedo de la mano, y éste se halla de muchos colores; uno es colorado muy encendido; otro, verde oscuro; otro, morado, negro, amarillo, y otro, verde claro... Otro... del tamaño y hechura de un dátil; otro ají hay como aceitunas, y todos ellos son de varios colores. El más hermoso a la vista es uno tan parecido en el color, tamaño y hechura a las guindas ... Hállase otro aji muy picante y tan pequeño como piñones, Finalmente, son tantas las diferencias que se hallan de ají en estas Indias, que pasan de cuarenta" (Cobo, 1964).

Domesticated Capsicum peppers today are treated as belonging to either three or five different species, depending on taxonomic opinion. However, it is generally accepted that there were at least five, probably more, independent domestications of Capsicum in different parts of the Americas and that traits of the domestication and diversification syndromes arose independently in each domesticate.

\section{Taxonomic treatment of the domesticated peppers}

The most distinct and least variable of the domesticated species is C. pubescens R. \& P., easily recognised by its purple flowers and dark seeds. The fruits have thick walls, so are used fresh, not dried. The aji named by Garcilaso as "rocot uchu" and by Cobo as "rocoto" is almost certainly C. pubescens, still known as rocoto in Andean countries. This is the most cold-tolerant of the cultivated species. It is found throughout the Andean region, though Patiño (1964) considered that it did not reach Colombia before the Spanish Conquest. It appears to have been introduced to Mexico between 1930 and 1940 and is known there as manzana (Laborde y Pozo, 1982). It has not so far been found in the wild. Its closest relatives are two Bolivian wild species, C. eximium Hunz. and C. cardenasii Heiser \& P.G. Smith, both of which have purple flowers, though neither has dark seeds. Although both produce fertile hybrids with $C$. pubescens, neither seems likely, on morphological or molecular grounds, to be its immediate wild progenitor. Nee, Bohs and Knapp (2006) noted that the eastern flank of the Andes in Bolivia is a rich region for Solanaceae, in which several new and narrowly endemic taxa have recently been discovered. This region is still botanically under-explored, so a wild progenitor of $C$. pubescens may yet be found there.

Although $C$. pubescens offers some characters, such as cold tolerance, of potential interest to Capsicum breeders, it has not been exploited as a genetic resource because it is reproductively isolated from the other domesticated species and their close wild relatives. Unilatera incompatibilities cause styles of $C$. pubescens, $C$. eximium and $C$. cardenasii to inhibit pollen tubes of the other domesticated species. In the reciprocal crosses, pollen tubes may reach and fertilise the ovules but, at least when $C$. pubescens is the pollen parent, hybrid seeds are inviable because embryo and endosperm break down early in seed development (Pickersgill, 1997). $F_{1}$ hybrids between $C$. pubescens and both $C$. frutescens and $C$. annuum $L$. have been produced by using techniques such as embryo rescue or doubling the chromosome number of one parent, but these hybrids are extremely sterile and have not been used any further in breeding programmes (Pickersgill, 1997)

White flowers with yellow markings at the base of each corolla lobe and straw-coloured seeds make $C$. baccatum easy to distinguish from the other domesticated species. It includes some of the most popular ajíes of the Andean countries, such as escabeche of coastal Peru, but is little known outside South America. It was domesticated from wild peppers treated taxonomically as a separate variety within $C$. baccatum and distributed from southern Peru to southern Brazil. Analysis of genome-wide DNA polymorphisms distinguished two majo groups within domesticated C. baccatum, suggesting to Albrecht et al. (2012) that $C$. baccatum was domesticated more than once. However, both domesticated groups seem to be most closely related to wild C. baccatum from the highlands of Peru and Bolivia. Wild C. baccatum from Brazil apparently played no part in the origin of domesticated $C$. baccatum and therefore constitutes an unexploited genetic resource for future improvement of $C$. baccatum.

Both wild and domesticated $C$. baccatum can be crossed with the remaining three taxa of domesticated Capsicum without the use of any special techniques. However, when all domes- 
ticated and some wild accessions of $C$. baccatum are used as pollen parent, $F_{1}$ hybrids show a virus-like syndrome of morphological abnormalities and are completely sterile. This virus-like syndrome results from an interaction between an allele of a nuclear gene from $C$. baccatum with the cytoplasm of the female parent. Reciprocal $F_{1}$ hybrids are morphologically normal but their fertility is greatly reduced because they are heterozygous for various structural rearrangements of the chromosomes. This has so far precluded use of $C$. baccatum as a genetic resource for improvement of other domesticated species of Capsicum.

The taxonomic treatment of the remaining domesticated peppers is controversial. They are often regarded as three closely related species; $C$. annuum, $C$. frutescens and $C$. chinense Jacq. Each seems to have been domesticated independently in different parts of the range of a widespread and variable complex of wild peppers, within which it is impossible to draw boundaries delimiting distinct taxa (Pickersgill et al., 1979). Each of the domesticated taxa incorporates a different segment of the genetic variation of the wild complex and all three have diverged further from one another during their independent evolution in cultivation, although they display much parallel variation in fruit colour, shape, position and pungency. A given domesticated pepper can usually be assigned, reasonably confidently, to one of these three taxa. However, in Amazonia there are some poorly understood peppers that are intermediate between domesticated C. frutescens and domesticated $C$. chinense. These could be either products of hybridisation in cultivation or relicts of an early stage in differentiation of $C$. frutescens and $C$. chinense (Carvalho et al., 2014). Genome-wide polymorphisms, namely AFLPs (Toquica et al., 2003; Ibiza et al., 2012) and ISSRs (Carvalho et al., 2014), support the view that the three domesticated taxa now represent distinct evolutionary lineages. Sequencing of the gene Pun1, which controls pungency, indicates that diversification for this trait has occurred independently in each lineage. Non-pungent cultivars of $C$. annuum are homozygous for a large deletion that spans the promoter and part of the coding region of Pun1, while non-pungent $C$. chinense carries a smaller deletion near the beginning of the coding sequence of Pun1 and non-pungent $C$. frutescens is homozygous for a deletion near the end of the coding region (Stellari et al., 2010). It would be interesting to examine sequences of alleles involved in other single gene traits, such as yellow or brown fruits, that are assumed to have developed independently in each of the three domesticated taxa, to determine whether each of these traits likewise involves different changes in the same gene.

The morphological and molecular differences between the three taxa, together with their presumed incorporation of different segments of the gene pool of the ancestral wild complex, so that they provide somewhat different genetic resources for the plant breeder, provide the justification for recognising them as distinct. Those who favour treating them as a single species emphasise the impossibility of dividing the wild complex satisfactorily and the fact that all elements of the complex, both wild and domesticated, hybridise readily in all combinations. Fertility of the hybrids varies considerably, but this applies also to within-taxon hybrids, because there have been many structural changes in chromosomes within and between taxa in this complex (Pickersgill, 1991). In the remainder of this chapter, the three taxa are treated as distinct species.

In Mexico, domestication of local wild peppers, possibly several times (Pickersgill, 2016), and subsequent diversification has produced the various types of chiles included in $C$. annuum. In northern Amazonia, local wild peppers are the presumed progenitor of domesticated C. chin- ense (Carvalho et al., 2014). This species includes pungent peppers such as murupi, popular throughout Amazonia, small-fruited peppers known as charapita in Peru and as olho de peixe or pimento de cheiro in Brazil, and the Scotch Bonnet or habanero peppers, originally from the West Indies and Mesoamerica but now grown worldwide and, like several of the other variants of $C$. chinense, valued for aroma as well as pungency. Other landraces of $C$. chinense have more restricted distributions, for example miscuchu and the brown-fruited aji panca of Peru. Chinchi uchu, described by Garcilaso as more pungent than other peppers, was probably $C$. chinense (Garcilaso, 1609 by Markham, 1871). The progenitor of $C$. frutescens was probably the pepper known as malagueta and widespread as a weed or cultivated in house gardens throughout tropical Latin America. Like C. annuum, C. frutescens may therefore have been domesticated more than once, with lowland Central America and Amazonia both suggested as possible regions of domestication. A cultivar of $C$. frutescens is used in the manufacture of Tabasco sauce.

Wild versus domesticated are not discrete states in C. baccatum or in the $C$. annuum complex, but opposite ends of a continuum connected by various intermediates: plants with small fruits which no longer separate readily from the plant; plants with fruits larger than those of typical wild peppers but which do separate readily from the plant; plants with small fruits that are pendent, not erect; plants with small erect fruits of colours other than red. These intermediates are described as semi-domesticated. Their existence contrasts with the situation in crops such as maize, in which no intermediates between domesticated maize and its presumed wild progenitor survive today. This has probably occurred because human selection is less intense in Capsicum than in crops such as maize. In Capsicum, fruits may be used while they are still green and unattractive to birds, so there is less concern about loss of the crop and hence less strong selection for loss of dispersal than in cereals or grain legumes, where it is importan to farmers that mature seeds or fruits be retained on the plant until harvested. Furthermore Capsicum is not a staple crop. Latin Americans may not be able to live without Capsicum, but they do not rely on Capsicum for much of their dietary calories. Yield is thus less important in Capsicum than in a staple food crop like maize. Selection for increased yield, i.e. larger fruits was therefore probably less strong in Capsicum than in maize or beans.

\section{Archaeological record of Capsicum}

In Mesoamerica, the oldest specimens of Capsicum so far recovered come from caves in the Tehuacán valley, in the state of Puebla, Mexico. These are said to be about 7000 years old. However, cave sites present problems for archaeologists, since deposits may be disturbed by falls of rock from the roof or the activities of rodents and other burrowing animals. Occurrence of a specimen in a particular layer of a deposit is therefore no guarantee that the specimen is the same age as other materials with which it is apparently associated. Accelerator mass spectrometry (AMS) dating can be carried out on very small samples, so it is now possible to date biological material directly, though the sample is destroyed in the process. The Tehuacán caves were excavated before the development of AMS dating and none of the Capsicum specimens has been directly dated, but direct dates on putatively early maize and 
beans from these caves have shown that both crops appeared significantly later than previously thought (Smith, 2005). The earliest seeds of Capsicum from Tehuacán are within the size range of modern wild $C$. annuum; there is no increase in size throughout the various preceramic phases; and the one preceramic fruit that I have seen is very similar to fruits of modern wild C. annuum (Pickersgill, 2016). Capsicum does occur wild in the Tehuacán valley today (Casas et al., 2001), but the specimens in the caves could also represent a trade item. Dried fruits of Capsicum are light, so easily transported; retain their pungency; and do not deteriorate if kept in dry conditions. Alternatively, the Tehuacán chiles could have been cultivated but not yet subjected to sufficiently strong human selection to have developed features of the domestication syndrome. Seeds of a size corresponding to those of modern domesticated $C$ annuum appeared only after a gap of about 1500 years in the Tehuacán archaeological record. In caves in Tamaulipas, north-east Mexico, coprolites (prehistoric faeces) containing seeds identified as those of Capsicum and intermediate in size between those of modern wild and domesticated C. annuum were recovered from levels dated about 6000-5200 B.P. (Pickersgill, 2016). The archaeobotanical record of Capsicum in Mesoamerica is too limited to show where, when or how many times $C$. annuum was domesticated. However, the Tamaulipas coprolites and those from various levels of the Tehuacán caves do show that chile peppers have been eaten by Mesoamericans for at least 6000 years.

Bernal Díaz, who accompanied Cortes on the conquest of Mexico, recorded that the Aztec emperor Moctezuma drank chocolate flavoured with chile pepper and various other ingredients. Chile pepper seems to have been a standard addition to chocolate over much of Mesoamerica, including among the Maya, from whom the Aztecs obtained their cacao (Coe, 1994). Archaeologists have found that it may be possible to determine what plants or plant products were cooked or stored in pottery vessels by analysis of the residues within the vessels. Powis et al. (2013) therefore studied some 2400-year-old pottery vessels of shapes associated with preparation or consumption of chocolate to try to determine whether the practice of adding chile to chocolate existed 2400 years ago. Unexpectedly, no traces of chocolate were found but residue from one pot tested positively for dihydrocapsaicin and four other pots showed traces of putative breakdown products of dihydrocapsaicin. All were serving vessels from elite burial or cache offerings and none contained seeds or other macroremains of Capsicum. Powis et al. (2013) therefore concluded that the vessels had contained a sauce or paste of chile. They noted that Capsicum is included in a number of Mayan herbal remedies, so the contents of the pots could have been intended for medicinal use in the next world. They also noted that interior surfaces of pots are sometimes covered with a mixture of chile and ash to repel insects, so capsaicinoids extracted from clay of the 2400 -year-old pots could, alternatively, have been residues of attempts to preserve other contents that failed to survive.

Recent excavations at Huaca Prieta and neighbouring Paredones, at the mouth of the Chicama river on the north-central coast of Peru, have produced remains of Capsicum as early as or earlier than the age claimed for the oldest chiles from the Tehuacán caves in Mexico. One seed from Paredones was directly dated to $10,650-10,430$ cal. B.P. (Chiou et al., 2014). Chiou et al. (2014) identified seeds of $C$. pubescens, C. baccatum. C. chinense and C. frutescens in levels dated about $7600-6500$ cal. B.P. but claimed that by about $5300-4100$ cal. B.P. C. pubescens had disappeared and $C$. baccatum had begun to dominate the assemblage, while after 4500 cal. B.P. C. baccatum was the only species of Capsicum present. None of these species occurs outside cultivation in coastal Peru today, so they were presumably either traded in to Huaca Prieta and Paredones or cultivated locally, following earlier cultivation and possible domestication elsewhere. The thick-walled fruits of $C$. pubescens are unsuitable for drying, so this species is perhaps an unlikely trade item. Chiou et al. (2014) therefore concluded that Capsicum has been cultivated in coastal Peru for at least 8000 years.

Seeds, fruit stalks, fruits and fruit fragments of Capsicum are reported from many other sites in the dry coastal region of Peru from preceramic times onwards (revision by León, 2013). Some intact fruits from preceramic levels are indistinguishable from fruits of modern wild $C$ baccatum, while other specimens are clearly domesticated on the basis of seed size or loss of dispersal, shown by retention of fruits on their fruit stalks (Pickersgill, 1969). Contrary to the findings of Chiou et al. (2014) that $C$. baccatum was the only species on the north-central coast after 4500 cal. B.P., C. chinense and probably C. frutescens were present in the post-pottery sites of Pachacámac and Estaquería on the central and south coasts (Pickersgill, 1969), and León (2013) cites a report of $C$. pubescens in both macroscopic remains and human coprolites from Huaca de la Luna, in the lower Moche valley, with a date of about 2000 B.P.

The importance of aji to some pre-Inca cultures is shown by inclusion of Capsicum fruits among grave offerings in mummy bundles from coastal cemeteries and by depictions of aj fruits on pots and textiles (Yacovleff y Herrera 1934; Towle, 1961). Among the Inca, fruits of aji may even have become a form of currency, analogous to cacao beans in Mesoamerica. According to Valcarcel (1925), “... bajo el Inka no se conoció moneda i que ciertos productos preferidos como el ají eran quizá el rudimento de un sistema monetario. Hasta hace pocos años se compraba en la plaza del Cusco con el llamado "Rantii", o sea un manojo de ají." Yacovleff y Herrera (1934) stated that a rantii was a handful of six fruits.

The religious significance of aji is shown by the fact that, among the Inca, as in several other parts of the Americas, the strictest forms of fasting involved abstaining from ail, while the form of the Inca creation myth prevalent north and east of Cuzco names the four brothers who emerged at the beginning of the world as Manco Capac, who became the first Inca, Ayar Cachi (cachi means salt), Ayar Uchu (uchu means Capsicum pepper) and Ayar Sauca (sauca means pleasure). The allegorical interpretation given by Garcilaso de la Vega is that "by the salt they say that the instruction that the Ynca gave in the rational life is to be understood. The pepper represents the delight they received from this teaching; and the word for pleasure is to show the joy and satisfaction in which they afterwards lived." (Garcilaso, 1609 translated by Markham, 1871).

Since Garcilaso's time, Capsicum peppers, both ajies and chiles, have added interest to bland carbohydrate-rich diets, have provided a source of vitamins accessible to poor people throughout the tropics and subtropics, since Capsicum can be grown easily on a backyard scale, and have revolutionized cooking in parts of the world far removed from their native Americas. 


\section{Bibliography}

Albrecht, E., D. Zhang, R. A. Saftner y J. R. Stommel, 2012. Laborde Cancino, J.A. and O. Pozo Campodónico, 1982. Genetic diversity and population structure of Capsicum baccatum genetic resources. Genetic Resources and Agricultura y Recursos Hidráulicos Instituto Nacional de Investigaciones Agrícolas, D.F., México.

Andrews, J., 1984. Peppers: The Domesticated Capsicums. León, E., 2013. 14,000 Años de Alimentación en el Perü University of Texas Press, Austin, Texas.

Boster, J. S., 1985. Selection for perceptual distinctiveness: evidence from Aguaruna cultivars of Manihot esculenta. Economic Botany, 30. 310-325.

Carvalho, S. I. C., C. F. Ragassi, L. B. Bianchetti, F. J. B. Reifschneider, G. S. C. Buso y F. G. Faleiro, 2014 Morphological and genetic relationships between frutescens $L$. and C. chinense Jacquin). Genetics and Molecular Research, 13: 7447-7464.

Universidad San Martín de Porres Fondo Editorial,

evey, D. J., J. J. Tewksbury, M. L. Cipollini and T. A. Carlo, 2006. A field test of the directed deterrence hypoth

Long-Solis, J., 1986. Capsicum y Cultura: La Historia del Chill. Fondo de Culura Econónica, D.F., México.

Maga, J. A. and P. H. Todd, 1975. Capsicum. CRC Critica Reviews in Food Sclence and Nuthion, 6: 177-199.

Casas, A. A Valiente-Banuet, J. L Viveros, J Caballero L. Major, R. H., (Translator andeditor) 1847. Letters of Cortés, P. Dávila, R. Lira and I. Rodriguez, 2001. Plant resources of the Tehuacán-Cuicatlán valley, México. Economic Botany, 55: 129-166.

Chiou, K. L., C. A. Hastorf, D. Bonavia and T. D. Dillehay, 2014 Documenting cultural selection pressure changes chile pepper (Capsicum baccatum L.) seed size through
time in coastal Peru (7,600 BP-Present). Economic Botany, 68: 190-202.

Cobo, B., [1653] 1964. Obras del P. Bernabé Cobo. Biblioteca de Autores Españoles Tomo XCl. Ediciones Atlas,

Coe, S. D., 1994. America's First Cuisines. University of Texas Press, Austin, Texas.

Darwin, C., 1875. The Variation of Animals and Plants under Domestication. 2a edition. John Murray, London.

Garcilaso de la Vega, [1609] 1871. Royal Commentaries of the Incas. Markham, C.R. (Translator). Hakluyt Society

Ibiza, V. P., J. Blanca, J. Cañizares and F. Nuez, 2012. Taxonomy and genetic diversity of domesticate Capsicum species in the Andean region. Gen
resources and crop evolution, 59: 1077-1088.

Kim, S., M. Park, S. I. Yeom, Y. M. Kim, J. M. Lee, H. A. Lee, E. Seo, J. Choi, K. Cheong, K. T. Kim, K. Jung, G. W. M.S. Kim, B. C. Kang, Y. D. Jo, H. B. Yang. H. J. Jeong, W. H. Kang, J. K. Kwon, C. Shin, J. Y. Lim, J. H. Park J. H. Huh, J. S. Kim, B. D. Kim, O. Cohen, I. Paran, M. C. Suh, S. B. Lee, Y. K. Kim, Y. Shin, S. J. Noh, J. Park, Y. S. Seo, S. Y. Kwon, H. A Kim, J. M. Park, H. J. Kim S. B. Choi, P. W. Bosland, G. Reeves, S.-H. Jo, B. W. Lee, H. T. Cho, H. S. Choi, M. S. Lee, Y. Yu, Y. D. Choi, H. S. Pai, H. K Ahn I Yeam, J J Giovannoni, J K C Rose, I. Sørensen, S. J. Lee, R. W. Kim, I. Y. Choi, B.-S. Choi, J. S. Lim, Y. H. Lee and D. Choi, 2014. Genome sequence of the hot pepper provides insights into the evolution of pungency in Capsicum species. Nature Genetics, 46: 270-278. Society, London.

Nascimento Filho, H. R. do, R. I Barbosa and F. J. de Freitas Luz, 2007. Pimentas do gênero Capsicum cultivada de uso. Acta Amazonica, 37: 559-565.

Nee, M., L. Bohs and S. Knapp, 2006. New species of Solanum and Capsicum (Solanacea) from Bolivia, with clarification of nomenclature in some Bolivian Solanum. Brittonia, 58: 322-356.

Patiño, V.M., 1964. Plantas Cultivadas y Animales Domesticos en América Equinoccial. Tomo Il. Plantas
Imprenta Departamental, Cali, Colombia.

Pickersgill, B. 1969. The archaeological record of chill peppers (Capsicum spp.) and the sequence of domestication in Peru. American Antiquity, 34: 54-61.

Pickersgill, B., 1991. Cytogenetics and evolution of Capsicum L. En: T. Tsuchiya y P. K. Gupta (Eds.). Chromosome Engineering in Plants: Genetics, Breeding, Evolution. sterdam, pp.139-160.

Pickersgill, B., 1997. Genetic resources and breeding of Capsicum spp. Euphytica, 96: 129-133.

Pickersgill, B., 2016. Chile peppers (Capsicum spp.). En: R. Lira, A. Casas y J. Blancas (Eds.). Mexican Ethnobotany:

Pickersgill, B., C. B. Heiser and J. McNeill, 1979. Numerical some species of Capsicum. En: J. G. Hawkes, R. N of the Solanaceae. Linnean Society Symposium Series No. 7. Academic Press, London, pp. 679-700.

Powis, T. G., E. Gallaga Murrieta, R. Lesure, R. Lopez Bravo, L. Grivetti, H. Kucera and N. W. Gaikwad, 2013. Prehispanic use of chili peppers in Chiapas, Mexico. PLoS ONE, 8(11):
e79013. doi:10.1371/journal.pone.0079013: e79013.

Purseglove, J. W. E. G. Brown, C. L. Green and S. R. L
Smith, B. D., 2005. Reassessing Coxcatlan Cave and the Toquica, S. P., F. Rodríguez, E. Martínez, M. C. Duque and early history of domesticated plants in Mesoamerica. 9438-9445.

Somos, A., 1984. The Paprika. Akadémiai Kiadó, Budapest. Standley, P. C., 1946. Food plants of Indians of the Guatemalan highlands. Journal of the Arnold Arboretum, 27: $395-400$.

Stellari, G. M., M. Mazourek and M. M. Jahn, 2010. Contrasting modes for loss of pungency between cultivated and wild species of Capsicum. Heredity, 104:

Tewksbury, J. J. and G.P. Nabhan, 2001. Directed deterrence by capsaicin in chillies. Nature, 412: 403-404.

Tewksbury, J. J., K. M. Reagan, N. J. Machnicki, T. A. Carlo, D. C. Haak, A. L. C. Peñaloza and D. J. Levey 2008. Evolutionary ecology of pungency in wild chilies. 11808-11811. Interactions of People and Plants in Mesoamerica. Cap. taxonomic studies on variation and domestication in Robbins, 1981. Spices. Vol. 1, Longman, Londres.
J. Tohme, 2003. Molecular characterization by AFLP
(T) of Capsicum germplasm from the Amazon departmen 50: 639-647.

M. A., 1961. The Ethnobolanbian Peru. Aldine Publishing Company, Chicago, Illinois.

Valcarcel, L. E., 1925. Del Ayllu al Imperio. Editorial Garcilaso,

Yacovleff, F. and F. L. Herrera, 1934. El mundo vegetal de los

mski, E., O. Shoham, D. Palevitch and A. Levy, 1987 Ultrastructure of capsaicinoid-secreting cells in pungen and nonpungent red pepper (Capsicum antiguos Peruanos. Revista de Museo Nacional, Lima, 


\section{Evolución y domesticación de los camélidos sudamericanos}

Jane C. Wheeler

\section{Resumen}

Los camélidos son artiodáctilos; se reconoce la existencia de dos géneros, Lama y Vicugna en el Nuevo Mundo, y uno, Camelus, en el Viejo Mundo. Actualmente, cuatro especies de camélidos sobreviven en el Nuevo Mundo, dos de ellas domésticas: la llama, L. glama y la alpaca $V$. pacos y sus respectivos ancestros silvestres el guanaco $L$. guanicoe y la vicuña $V i-$ cugna vicugna. Se reconocen tres especies en el Viejo Mundo, dos domésticas, el dromedario Camelus dromedarius y el bactriano $C$. bactrianus, así como una especie silvestre $C$. ferus que no es ancestro de los domésticos. El género Alforjas, y su descendiente Camelops nunca salieron de Norteamérica, mientras que especies de Hemiauchenia migraron hacia América del Sur hace aproximadamente 3.3 millones de años (M.A.), donde a su vez dieron origen a la Lama y Vicugna hace aproximadamente 2 M.A. El guanaco es el artiodáctilo silvestre más grande del continente americano y la forma ancestral de la llama doméstica. Se han reportado restos fósiles de $L$. guanicoe en depósitos del pleistoceno en Argentina con una antigüedad de aproximadamente 2 M.A. Antes del contacto Europeo, la distribución del guanaco se extendió de la costa del Pacífico hasta los glaciares de los Andes, hasta la Tierra del Fuego, al este se extendió por el Chaco Paraguayo, las Pampas y la Patagonia hasta la costa Atlántica. Se ha estimado una población de 30 a 50 millones de guanacos, número que declinó rápidamente bajo el dominio europeo, llegando a 7 millones en el siglo XIX debido a la cacería indiscriminada y a la crianza de ovejas. En 1969 el guanaco peruano se encontraba al borde de la extinción y en 1971 el gobierno peruano lo declaró especie amenazada, con una población de 589750 Los guanacos exhiben un coloración semejante, variando de un marrón-rojizo oscuro en las poblaciones sureñas (Lama guaunicoe guanicoe) a un marrón más claro con amarillo ocre en la subespecie norteña (L.g. cacsilensis). L. g. guanicoe se localiza en Patagonia, Tierra del Fuego y Argentina, $L$.g. huanacus en la vertiente oeste de los Andes chilenos, y L. g. cacsilensis desde la costa hasta grandes alturas en la vertiente oeste de los Andes del Perú. Estudios de ADN mitocondrial muestran solamente dos subespecies, la norteña $L$. $g$. cacsilensis y la sureña L. g. guanicoe, la cual incluye a L. g. guanicoe, L. g. huanacus y L. g. voglii. Actualmente, la vicuña habita elevaciones por encima de 3800 metros en los Andes; pero restos paleontológicos de las pampas argentinas apoyan el origen del género Vicugna en esa región de tierras bajas hace 2 M.A. El análisis de ADN mitocondrial apoya una divergencia de al menos 2 M.A. entre la vicuña y el guanaco. Fósiles de Tarija, Bolivia incluyen restos de 97000 años A.P. Los restos más antiguos de vicuñas procedentes de la zona altoandina han sido fechados en 22 
$220 \pm 130$ años A.P. en la Cueva Rosselló, Perú, pero análisis de ADN mitocondrial indican que la distribución actual es resultado de una expansión demográfica asociada al último evento glacial del pleistoceno hace 14 000-12 000 años A.P. No se han encontrado restos de vicuña en depósitos paleontológicos de Ecuador ni de Colombia. Se encontraron restos de un fósi de vicuña, Vicugna gracilis en depósitos del Pleistoceno tardío en Argentina y Uruguay y en la Patagonia, pero desapareció durante la transición del Pleistoceno al Holoceno. En el Perú, la población precolombina de vicuñas fue de 2 millones y mayormente en zonas Andinas. Antes de la conquista se prohibía la cacería de la vicuña, y se realizaban chakus para capturar esquilar las vicuñas para luego liberarlas. Después de la conquista solamente sobrevivían 400 000 vicuñas a nivel andino, 250000 de estas en el Perú. En 1971 se estimó que solo había entre 5000 y 10000 vicuñas en el Perú y 2000 más en Bolivia, Argentina y Chile. La lista roja del UICN en 2015 la población Andina se estimó en 347273.

La llama es el más grande de los camélidos sudamericanos domésticos, se asemeja a su ancestro Lama guanicoe cacsilensis y se ha adaptado a un amplio rango de ambientes. Juega un rol fundamental en la economía de los pobladores altoandinos, proporcionando carne, fibra estiércol y como animal de carga. Estudios arqueozoológicos y genéticos indican que la domesticación de la llama ocurrió en varias localidades en los Andes. En el noroeste de Argentina y el norte de Chile, entre los 5000 y 3000 años A.P. Un segundo centro de domesticación en los Andes centrales del Perú alrededor de 4000 años A.P. Hay evidencia de la crianza de llamas en la costa norte de hace 1400 años y en Ecuador. Más tarde, durante la Cultura Chiribaya (1250 años A.P.), se han encontrado restos de llamas y alpacas naturalmente momificadas, que evidencian una crianza sofisticada entre cero a mil metros de elevación en la costa sur de Perú. Es imposible estimar el número de llamas existentes antes de la conquista, sin embargo, debería haber excedido por mucho a la población actual dado que los registros administrativos de la época documentan la virtual desaparición de los rebaños en menos de cien años de contacto. La apariencia física de las llamas de El Yaral ha documentado la existencia de la variedad suri y revela la existencia de llamas productoras de fibra fina y fibra gruesa. Mediante selección, los criadores lograron reducir el grosor de la fibra y la variación de esta, hasta producir un animal caracterizado por vellón de una sola capa donde el grosor de las fibras primarias acercaba al grosor de las secundarias, creando una llama productora de fibra fina ideal para la producción textil. Adicionalmente, seleccionaron por vellones de un solo color, sin manchas. Las llamas de fibra gruesa, en contraste, tenían vellones mayormente manchados. La crianza de ganado autóctono en los Andes casi desapareció con la llegada de los españoles en poco más de un siglo. Después de la conquista en 1532, los documentos administrativos registran la merma de aproximadamente $90 \%$ de los camélidos domésticos y el $80 \%$ de la población humana. Actualmente, la mayoría de llamas son propiedad de criadores tradicionales, quechua y aymara-hablantes, quienes utilizan minuciosos sistemas de clasificación de sus animales basados en el color, características de la fibra y conformación, lo cual aparenta indicar la previa existencia de sistemas de manejo selectivo para producción de fibra. La domesticación de la alpaca fue independiente y posiblemente más temprano que la domesticación de la llama. Excavaciones en Telarmachay, ubicado a los 4440 msnm, en los Andes centrales del Perú, revelaron una secuencia ocupacional entre 9000 y 1800 años A.P. y un registro del proceso de la domesticación de la alpaca. Documentos coloniales registran una rápida disminución de las poblaciones y su desplazamiento a zonas de gran altura. En 1967 se registraron 3290 000 alpacas en el Perú. Sin embargo, el censo agropecuario de 2012 ha reportado 3685516 alpacas. La hibridación entre especies y variedades de camélidos es un hecho. En el caso de la llama y la alpaca, el análisis de ADN mitocondrial y nuclear ha documentado amplia hibridación bidireccional que alcanza por lo menos $80 \%$ de las alpacas y $40 \%$ de las llamas. Aunque puede haber ocurrido hibridación prehistórica, no se debe subestimar el impacto negativo de la conquista en la crianza autóctona andina. También, durante los últimos treinta años o más, ha sido práctica común cruzar alpacas con llamas para aumentar la cantidad de fibra obtenida de cada animal y así aumentar los ingresos obtenidos bajo un sistema de pago por peso de la fibra. No hay duda del impacto negativo de esta hibridación entre la alpaca y la llama. Actualmente existen pruebas genéticas para identificar los híbridos, y sería prudente aplicarlas con el objetivo de preservar los genomas originales de la alpaca y la llama.

Palabras clave: alpacas, camélidos, domesticación, guanacos,

llamas, recursos genéticos animales, vicuñas.

\section{Introducción}

\section{Origen y evolución}

Los camélidos sudamericanos se clasifican, junto con los camellos del Viejo Mundo, en el orden Artiodactyla (Owen, 1848) o Cetartiodactyla (Montegelard et al., 1997) suborden Tylopoda (Illiger, 1811) familia Camelidae (Gray, 1821) y subfamilia Camelinae (Gray, 1821); pero a nive de Tribu están subdivididos en Lamini (Webb, 1965) y Camelini (Webb, 1965). Se reconoce la existencia de dos géneros, Lama y Vicugna en el Nuevo Mundo, y un género, Camelus, en el Viejo Mundo. El proceso de rumiar evolucionó por separado en Tylopoda y en el suborden Pecora (Bohlken, 1960). Los camélidos se caracterizan por la ausencia de cuernos o astas, la presencia de verdaderos caninos superiores e inferiores separados de los premolares por una diastema, la posición de la arteria vertebral confluyente con el canal neural en las vértebras cervicales, el estómago dividido en tres secciones, anatomía de las piernas posteriores que permite descansar sobre el vientre con las rodillas dobladas y los garrones hacia atrás, y la presencia de una almohadilla digital en lugar de cascos o pezuñas.

En 1758, Linnaeus describió a los dos camélidos sudamericanos domésticos como Camelus ama "Camelus peruvianus Glama dictus" (llama) y Camelus pacos "Camelus peruvianus laniger Pacos dictus" (alpaca), juntándolos en un solo género con los dromedarios "Camelus dromedarius" y bactrianos "Camelus bactrianus" del Viejo Mundo. Más tarde, los dos camélidos sudamericanos silvestres fueron descritos como Camelus guanicoe por Müller en 1776, y Camelus vicuña por Molina en 1782. En 1775, Frisch propuso la creación del género Lama para las cuatro especies del Nuevo Mundo, pero su trabajo no fue aceptado por la Comisión Internacional de Nomenclatura Zoológica (Hemming, 1958a) que asigna la autoría de Lama a Cuvier, 1800 (Hemming, 1958b). La primera referencia válida que separa a la vicuña en otro género (el género Vicugna) es la de Miller (1924), quien se basó en la morfología hipselodonte de los incisivos. 
El análisis de ADN mitocondrial y nuclear de los cuatro camélidos sudamericanos (Stanley et al., 1994; Kadwell et al., 2001) confirma la clasificación en dos géneros. Actualmente, cuatro especies de camélidos sobreviven en el Nuevo Mundo, dos de ellas domésticas: la llama, $L$. glama (Linnaeus, 1758) y la alpaca $V$. pacos (Linnaeus, 1758), y sus respectivos ancestros silvestres el guanaco L. guanicoe (Müller, 1776) y la vicuña Vicugna vicugna (Molina, 1782) (Tabla 8.1). Se reconocen además tres especies en el Viejo Mundo, dos domésticas, el dromedario Camelus dromedarius Linnaeus, 1758 y el bactriano C. bactrianus (Linnaeus, 1758), así como una especie silvestre $C$. ferus que no es ancestro de los domésticos (Silbermayr et al., 2009).

La tribu Lamini, representada por fósiles del género Pleiolama (Webb y Meachan, 2004) -previamente llamada Pliauchenia (Cope, 1875)-, se originó en las grandes llanuras de América de Norte hace 13.6 M.A. (Harrison, 1985; Webb and Meachan, 2004) (Tabla 8.2) donde dio origen a los géneros Alforjas, hace 10-4.5 M.A. (véase Harrison, 1979) y Hemiauchenia hece 10-0.1 M.A. (véase Webb, 1965, 1974). El primero, Alforjas, y su descendiente Camelops (4.5-0. M.A.) nunca salieron de América del Norte (Harrison, 1979; Webb, 1965, 1974), mientras que algunas especies de Hemiauchenia migraron hacia América del Sur durante la transición del Plioceno y Pleistoceno hace aproximadamente 3.3 M.A. (Woodburne, 2010), donde, a su vez, dieron origen a la Lama y la Vicugna hace aproximadamente 2 M.A. (López-Aranguren, 1930; Cabrera, 1932; Webb, 1972; Harrison, 1985). También se han encontrado restos de un segundo género, Palaeolama, (2.0-0.1 M.A.) en ambos continentes (Webb, 1974, Woodburne, 2010). Solamente la Lama y la Vicugna sobrevivieron la transición al Holoceno hace unos 10000 años.

\section{Tabla 8.1. Clasificación sistemática de los Camélidos Sudamericanos Actuales}

\begin{tabular}{|c|c|}
\hline Orden & Artiodactyla Owen, 1848 \\
\hline Suborden & Tylopoda Illiger, 1811 \\
\hline Familia & Camelidae Gray, 1821 \\
\hline Subfamilia & Camelinae Gray, 1821 \\
\hline \multirow[t]{9}{*}{ Género } & Lama Cuvier, 1800 \\
\hline & Lama glama (Linnaeus, 1758) - Ilama domestica \\
\hline & Lama guanicoe (Müller, 1776) - guanaco silvestre \\
\hline & Nombres Inválidos \\
\hline & Camelus Linnaeus, 1758 \\
\hline & Lama Frisch, 1775 (rechazado, ICZN Opinión 258) \\
\hline & Auchenia Illiger, 1811 (anteriormente utilizado por Thunberg, 1789) \\
\hline & Lama Lesson, 1827 \\
\hline & Llama Gray, 1872 \\
\hline \multirow[t]{8}{*}{ Género } & Vicugna Miller, 1924 \\
\hline & Vicugna vicugna (Molina, 1782) -vicuña silvestre \\
\hline & Vicugna pacos (Linneaus, 1758) - alpaca domestica \\
\hline & Nombres Inválidos \\
\hline & Camelus Molina, 1782 \\
\hline & Auchenia Illiger, 1811 (anteriormente utilizado por Thunberg, 1789) \\
\hline & Lama Lesson, 1827 \\
\hline & Llama Gray, 1872 \\
\hline
\end{tabular}

Tabla 8.2. Clasificación sistemática de los Camélidos Sudamericanos fósiles, según Harrison $(1979,1985)$

\begin{tabular}{|c|c|}
\hline Orden & Artiodactyla Owen, 1848 \\
\hline Suborden & Tylopoda Illiger, 1811 \\
\hline Familia & Camelidae Gray, 1821 \\
\hline Subfamilia & Camelinae Gray, 1821 \\
\hline Tribu & Lamini Webb, 1965 - camélidos sudamericanos \\
\hline \multirow[t]{5}{*}{ Subtribu } & Lamina Harrison, 1979 \\
\hline & $\begin{array}{l}\text { Pleiolama Webb y Meachen } 2004 \text { (13.6-9 M.A.) } \\
\text { (previamente Pliauchenia Cope 1875) }\end{array}$ \\
\hline & $\begin{array}{l}\text { Hemiauchenia H. Gervais y Ameghino, } 1880 \text { (10-0.1 M.A.) (clasificado como } \\
\text { un subgénero de Palaeolama por Guérin y Faure 1999) }\end{array}$ \\
\hline & $\begin{array}{l}\text { Palaeolama P. Gervais, } 1867 \text { (3/2-0.1 M.A.) } \\
\text { Lama Cuvier, } 1800 \text { (origino hace } 2 \text { M.A., sobrevive hoy) [Puede incluir } \\
\text { Lama (Vicugna) gracilis H. Gervais y Ameghino, 1880, descrito como } \\
\text { intermediario entre vicuña y guanaco por Menegaz y Ortiz-Jaureguizar } \\
\text { (1995) y Guérin y Faure (1999); asignado a Vicugna en un estudio de } \\
\text { aADN por Weinstock y colaboradores (2010) y reconocido como un } \\
\text { genero separado por Cartajena y colaboradores (2010) y Cajal et al. } \\
\text { (2010)]. }\end{array}$ \\
\hline & Vicugna Miller, 1924 (Origino hace 2 M.A. y sobrevive hoy) \\
\hline \multirow[t]{3}{*}{ Subtribu } & Camelopina Harrison, 1979 \\
\hline & Alforjas Harrison, 1979 (10-4.5 M.Y.) \\
\hline & Camelops Leidy, 1854 (4.5-0.1 M.Y.) \\
\hline
\end{tabular}

\section{Los camélidos sudamericanos silvestres}

\section{El guanaco, Lama guanicoe (Müller, 1776)}

El guanaco es el artiodáctilo silvestre más grande del continente sudamericano y la forma ancestral de la llama doméstica. López-Aranguren (1930), Cabrera (1932) y Menegaz et al. (1989) han reportado restos fósiles de L. guanicoe en depósitos de la época pleistocena en Argentina que tendrían una antigüedad de aproximadamente 2 millones de años (Webb, 1974). En Tarija, Bolivia, Hoffstetter (1986) también reporta su presencia en estratos que han sido fechados entre 73000 y 97000 M.A. por MacFadden et al. (1983), utilizando polaridad magnética, y también entre 44 000-21 000 años A.P. por Coltori et al. (2007) con base en radiocarbono. No se ha reportado la presencia de guanacos a grandes elevaciones en el ecosistema Puna de los Andes antes del fin del Pleistoceno hace 12000 a 9000 años A.P. (Hoffstetter, 1986).

Antes del contacto europeo, la distribución del guanaco se extendió de la costa del Pacífico hasta los glaciares de los Andes, desde aproximadamente $S 8^{\circ}$ hasta las islas de Tierra del Fuego y Navarino (S $55^{\circ}$ ); al este se extendió por el Chaco Paraguayo, las Pampas y la Patagonia hasta la costa Atlántica (Torres, 1985; Tonni y Politis, 1980). Raedeke (1979) ha estimado una población de 30 a 50 millones de guanacos, con base en el cálculo de la capacidad de carga de esta área. 
El número de guanacos declinó rápidamente bajo el dominio europeo, llegando a 7 millones en el siglo XIX debido al impacto de la cacería indiscriminada y la crianza de ovejas. En 1954, Dennler de la Tour alertó al público sobre la urgente necesidad de eliminar la caza de chulengos y establecer reservas para proteger el guanaco patagónico antes de que desapareciera. En 1969, Grimwood reportó que el guanaco peruano se encontraba al borde de la extinción, y en 1971 e gobierno peruano lo declaró especie amenazada. Según la lista roja de especies amenazadas de UICN (IUCN - www.iucnredlist.org), en 2015 la población del guanaco fue estimada entre 535750 y 589750 guanacos. La mayoría de los guanacos se ubican al sur, con una población estimada de aproximadamente 3000 individuos en el Perú (Wheeler et al., 2006b).

Todos los guanacos exhiben un coloración semejante, variando de un marrón-rojizo oscuro en las poblaciones sureñas (L. g. guanicoe) (Figura 8.1b) a un marrón más claro con amarillo ocre en la subespecie norteña (L.g. cacsilensis) (Figura 8.1a). El pecho, vientre y porción interna de las piernas son blancos, la cabeza es gris con delineación blanca alrededor de los labios, ojos y orejas. La fibra tiene un diámetro de 16.5 a $24 \mathrm{~mm}$ y contiene $5-20 \%$ pelo (Verscheure y García, 1980). No existe dimorfismo sexual con excepción de caninos grandes en los machos adultos. El alto a la cruz en animales adultos es $110-120 \mathrm{~cm}$ en $L$. g. guanicoe de Patagonia y Tierra del Fuego (Cabrera and Yepes, 1960; Franklin, 1982; Herre, 1952; Raedeke, 1979; Mac Donagh, 1949), y solamente $100 \mathrm{~cm}$ en el guanaco norteño L. g. cacsilensis (Herre, 1952). E largo del cuerpo (punta de la nariz a la base de la cola) reportado varía de $167 \mathrm{~cm}$ (MacDonagh 1949), $185 \mathrm{~cm}$ (Cabrera and Yepes, 1960), $191 \mathrm{~cm}$ (Raedeke, 1979) y $210 \mathrm{~cm}$ (Dennler de la Tour, 1954) para L. g. guanicoe, y $90-100 \mathrm{~cm}$ para L. g. cacsilensis de Calipuy, Perú (Kostritsky Vilchez, 1974). El peso de animales vivos para L. g. guanicoe adultos ha sido reportado entre 120 y 130 kg (Raedeke, 1979; Miller et al., 1973), en contraste con los 96 kg de L. g. cacsilensis (Kostritsky y Vilchez, 1974).
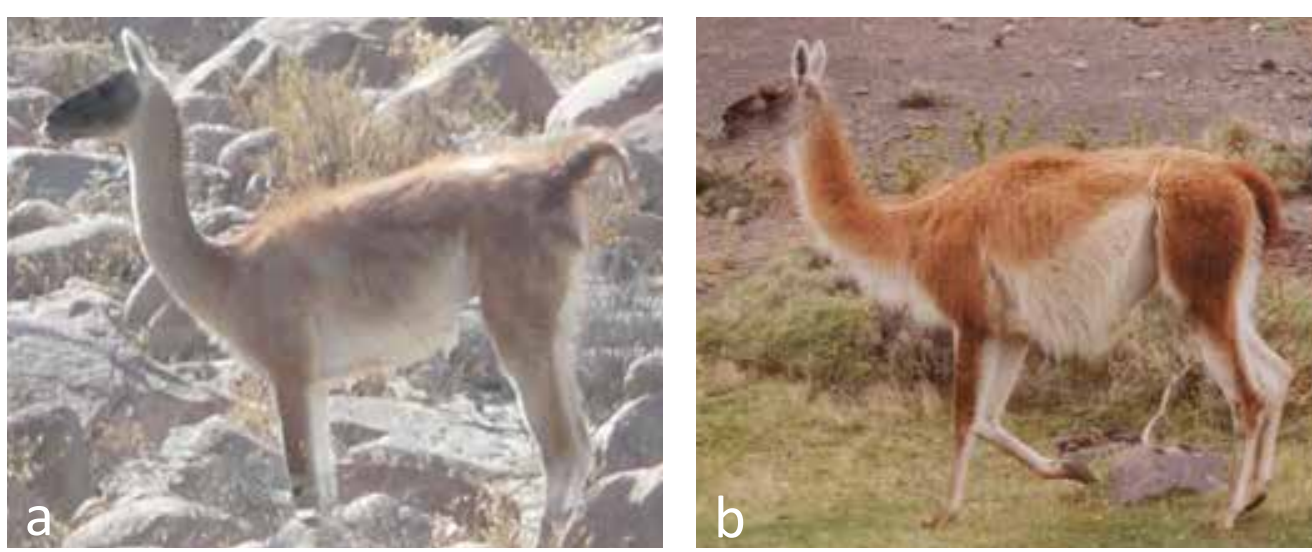

Figura 8.1. Subespecies de guanaco. a) Lama guanicoe cacsilensis $\left(8^{\circ}-18^{\circ} 30^{\prime} \mathrm{S}\right)$ y b) Lamaguanicoe guanicoe $\left(22^{\circ}-55^{\circ} 50^{\prime} \mathrm{S}\right)$.

De acuerdo a la distribución, tamaño y coloración de los guanacos, González et al., (2006) propusieron cuatro subespecies de estos camélidos: la primera, Lama guaunicoe guanicoe
(Müller, 1776), se localiza en Patagonia, Tierra del Fuego y Argentina, al sur de los S $35^{\circ}$; la segunda, $L$.g. huanacus (Molina, 1782), ocupa la vertiente oeste de los Andes Chilenos entre los $S 22^{\circ}$ y S $38^{\circ}$ (Cunazza ,1992); la tercera, L. g. cacsilensis (Lönnberg, 1913), se encuentra desde la costa hasta grandes alturas en la vertiente oeste de los Andes entre los $S 8^{\circ}$ y $S 18^{\circ} 30^{\prime}$ en el Perú (Hoces, 1992) y el norte de Chile (Torres, 1992); y la cuarta, L. g. voglii (Krumbiegel, 1944), vive en la vertiente este de los Andes Argentinos, el sureste de Bolivia y el noroeste de Paraguay (Torres, 1992), aproximadamente entre los $S 21^{\circ}$ y S $32^{\circ}$. Las características físicas y la distribución de estas subespecies no están del todo claras y hay poca información sobre la variación geográfica en la morfología de los guanacos. Las poblaciones más estudiadas son las del extremo sur, las cuales muestran una gran diferencia en la morfología (más grandes y oscuras) (L. g. guanicoe) de los animales del extremo norte de su distribución (más pequeñas y claras) (L. g. cacsilensis)

Recientemente, Marín et al. (2008) han analizado la secuencia completa del citocromo-b y parte del región control. Las poblaciones sureñas se caracterizan por una reducida variabilidad genética, lo que sugiere la posibilidad de haber sufrido un severo cuello de botella genético o un evento de extinción con recolonización en el pasado. Esta situación contrasta con los altos niveles de diversidad genética encontrados en la norteña $L$. g. cacsilensis, esto indica que sus poblaciones han sido relativamente estables durante largos períodos, lo cual les ha permitido la acumulación de niveles relativamente altos de diversidad genética.

\section{La vicuña, Vicugna vicugna (Molina, 1782)}

Actualmente, la vicuña habita elevaciones por encima de 3800 metros sobre el nivel del ma -msnm, entre los S $9^{\circ} 30^{\prime}$ y $S 29^{\circ}$ en los Andes. Sin embargo, restos paleontológicos procedentes de las pampas de Argentina documentan el origen del género Vicugna en esta región hace dos millones de años (López-Aranguren, 1930; Cabrera, 1932; Webb, 1974; Harrison, 1985), aunque Menegaz et al. (1989) concluyen que la vicuña evolucionó del guanaco en las pampas al inicio del Holoceno. El análisis de ADN mitocondrial apoya una divergencia de por lo menos dos millones de años entre la vicuña y el guanaco (Stanley et al., 1994). Fósiles de Tarija, Bolivia -en la vertiente oriental de los Andes- incluyen restos de vicuña (Hoffstetter 1986) fechados entre 97000 y 73000 años A.P. (MacFadden et al., 1983) o 44 000-21 000 años A.P. (Coltori et al., 2007) documentando la expansión de la vicuña hacia el oeste. Los restos más antiguos de vicuñas procedentes de la zona alto Andina han sido fechados en 22220 130 años A.P. en la Cueva Rosselló, Perú (a 3875 msnm) (Shockey et al., 2009), pero el análisis de ADN mitocondrial realizado por Marín et al. (2007a) indica que la distribución actual de la vicuña es aparentemente el resultado de una expansión demográfica asociada al último evento glacial del pleistoceno hace 14 000-12 000 años A.P. No se han encontrado restos de vicuña en depósitos paleontológicos (Hoffstetter, 1986) ni en sitios arqueológicos (Miller y Gill, 1990) de Ecuador ni de Colombia.

Se han encontrado restos de un pequeño fósil semejante a la vicuña, Lama (Vicugna) gracilis (Gervais y Ameghino, 1880), en depósitos del Pleistoceno tardío y del Holoceno temprano en las Pampas del este de Argentina (Provincia de Buenos Aires) y Uruguay; en la Patagonia de Uruguay, Argentina y Chile, así como en Calama, costa norte de Chile (Cartagena et al., 2010). 
Estos fósiles aparentemente pertenecen a un género separado que desapareció durante la transición del Pleistoceno al Holoceno (Cajal et al., 2010).

Se ha estimado que en el Perú la población precolombina de vicuñas fue de dos millones (Brack, 1980), y ciertamente esta cifra habría sido mayor al nivel Andino. Antes de la conquista se creía que tanto las vicuñas, como los guanacos, conformaban los rebaños de los apus o dioses de las montañas. Se prohibía la cacería de la vicuña, y solamente la realeza incaica podría utilizar atuendos de su fibra. Se realizaban chakus para capturar y esquilar las vicuñas para luego soltarlas. Después de la conquista, estas prácticas de utilización sostenible desaparecieron, y en 1957 Koford calculó que solamente sobrevivían 400000 vicuñas a nivel andino, con 250000 en el Perú. Doce años más tarde Grimwood (1969) reportó la existencia de solamente 10000 vicuñas en el Perú, y dos años después Jungius (1971) estimó que solo había entre 5000 y 10000 vicuñas en el Perú y 2000 más entre Bolivia, Argentina y Chile. Según la lista roja de especies amenazadas del UICN (IUCN - www.iucnredlist.org ), en 2015 la población Andina se estimó en 347273.

Dos subespecies de vicuña han sido descritas principalmente con base en las diferencias de tamaño. La primera y más grande, Vicugna vicugna vicugna (Molina, 1782) (Figura 8.2b) se ubica entre $S 18^{\circ}$ y $S 29^{\circ}$, mientras que la segunda y más pequeña, $V$. v. mensalis (Thomas, 1917 ) (Figura 8.2a) se encuentra entre $S 9^{\circ} 30^{\prime}$ y $S 18^{\circ}$. Una supuesta tercera subespecie, $V$. $v$. elfridae (Krumbiegel, 1944) ha sido descrita con base en vicuñas en jardines zoológicos de Alemania.
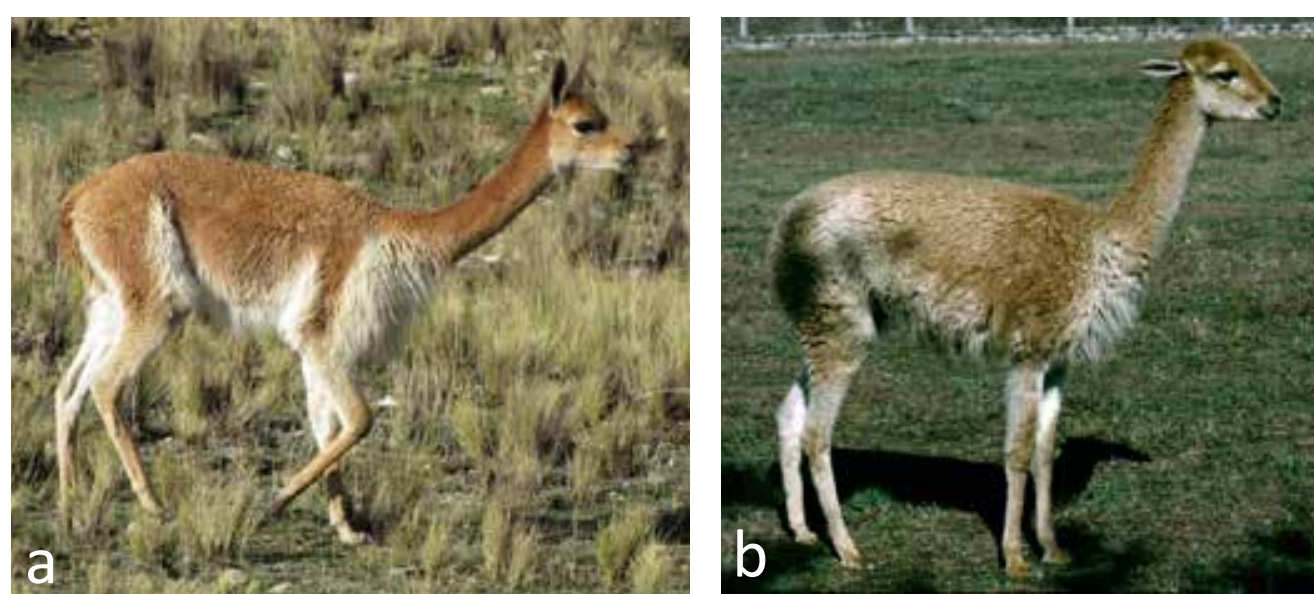

Figura 8.2. Subespecies de vicuña. a) Vicugna vicugna subsp.mensalis $\left(9^{\circ} 30^{\prime}-18^{\circ} \mathrm{S}\right) \mathrm{y}$ b) Vicugna vicugna subsp.vicugna $\left(18^{\circ}-29^{\circ} \mathrm{S}\right)$.

La vicuña norteña, $V$. v. mensalis, es la más estudiada. Se distingue principalmente por el largo mechón de fibra que crece en su pecho. La cabeza, el cuello, la espalda, los costados y la superficie de la cola tienen coloración de canela oscura, mientras que las partes inferiores de la cara, el vientre y la cola, así como la superficie interior de las piernas son blancos, los ojos y orejas están delineados en blanco. En animales adultos el largo promedio del vellón es 3.28 $\mathrm{cm}$, en el pecho los pelos alcanzan 18 a $20 \mathrm{~cm}$ (Hofmann et al., 1983). El diámetro de la fibra es $12.52 \pm 1.52 \mu \mathrm{m}$ (Carpio and Solari, 1982) y el promedio del largo del vellón en machos adultos es $3.2 \mathrm{~cm}$ según Carpio y Santana (1982). En contraste, $V$. v. vicugna no posee mechón en e pecho y su coloración es beige claro, con una mayor distribución del color blanco cubriendo no solo el vientre, sino también la mitad inferior del costado hasta la cresta del íleo y gran parte de las extremidades.

Los estudios de ADN nuclear (Wheeler et al., 2001, 2003; Dodd et al., 2006; Wheeler y Laker, 2008) y mitocondrial (Marín et al., 2007a) han validado las dos subespecies, aunque Sarno y colaboradores (2004) opinan lo opuesto. Con base en el análisis de 261 individuos procedentes de 29 poblaciones ubicadas en Perú, Chile y Argentina, Marín et al. (2007a) encontraron evidencia que $V$. v. mensalis y $V . v$. vicugna son linajes mitocondriales separados, cuya actual distribución aparentemente es el resultado de una expansión demográfica durante la última glaciación del Pleistoceno hace 14000 a 12000 años, cuando se estableció una zona de aridez extrema, conocida como la diagonal seca, entre los $\mathrm{S} 22^{\circ} \mathrm{S} 29^{\circ}$ (Wheeler y Laker, 2008). En estas condiciones la $V$. $v$. vicugna logró sobrevivir, y hoy demuestra evidencia genética de un aislamiento demográfico. Mientras que al norte, entre los $S 18^{\circ}$ y $S 22^{\circ}$, en condiciones de mayor humedad, la $V$. v. mensalis pasó por una rápida expansión demográfica antes de registrar evidencia de los más recientes impactos antropogénicos en su genoma.

\section{Los Camélidos Sudamericanos Domésticos}

\section{La llama, Lama glama (Linnaeus, 1758)}

La llama es el más grande de los camélidos sudamericanos domésticos y se asemeja a su ancestro, Lama guanicoe cacsilensis, en casi todos los aspectos de morfología y comportamiento (Kadwell et al., 2001). Igual que el guanaco, la llama se ha adaptado a un amplio rango de ambientes. Juega un rol fundamental en la economía de los pobladores alto Andinos, proporcionando carne, fibra, estiércol y servicio como animal de carga para transporte de comestibles en zonas donde la producción agrícola es nula o casi nula debido a la elevación, y es muy importante en la vida ritual (Bolton, 2006).

Tanto los resultados de los estudios arqueozoológicos, como los de ADN (Wheeler et al., 2006a; Kadwell et al., 2001; Bruford et al., 2003) indican que la domesticación de la llama ocurrió en varias localidades en los Andes. En el noroeste de Argentina y el norte de Chile, los esfuerzos de arqueólogos y arqueozoólogos han recabado evidencia de la domesticación de la llama (aumento en tamaño relativo al guanaco y cambio en los patrones de los asentamientos humanos) en la puna seca a elevaciones superiores a $3200 \mathrm{msnm}$ y entre los 5000 y 3000 años A.P. (Mengoni-Goñalons y Yacobaccio, 2006; Cartajena, 2009; Cartajena et al., 2007, Benavente, 1985; Olivera y Grant, 2009; Yacobaccio, 2004). También hay evidencias de un segundo centro de domesticación -igualmente con aumento en tamaño relativo al guanaco- en los Andes centrales del Perú a los 4000 msnm y alrededor de 4000 años A.P. (Mengoni-Goñalons y Yacobaccio, 2006; Moore, 1988, 2012; Kent, 1982). 

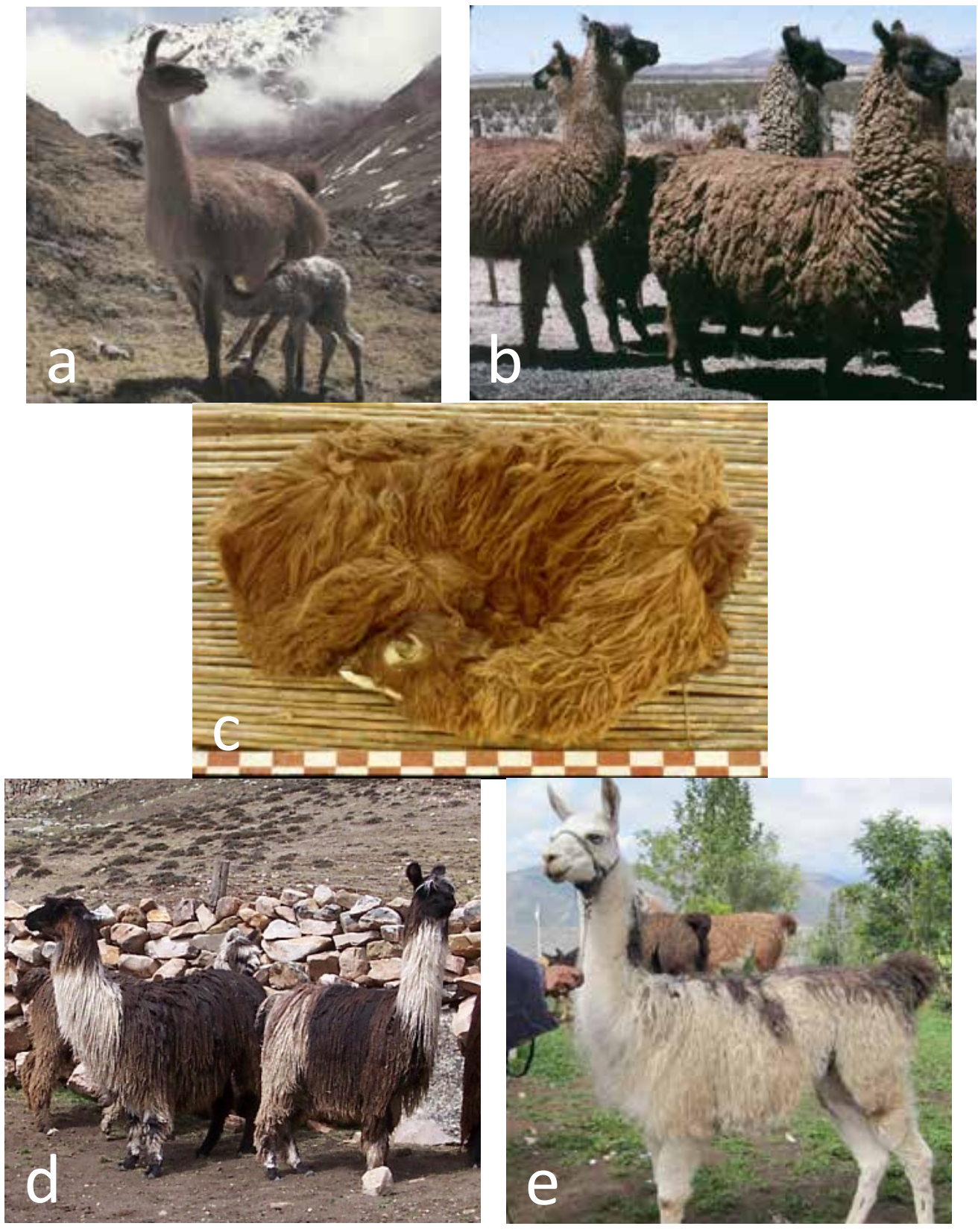

Figura 8.3. Variedades de llama. a) Lama glama, variedad k'ara o ccara; b) Lama glama, variedad chacu; c) Lama glama, variedad suri, momia de El Yaral, 900-1000 años A.P.; d) Lama glama, variedad suri y e) Lama glama, variedad Ilamingo.
Después de su domesticación en la puna, restos de llama aparecen en sitios arqueológicos de los valles interandinos del Perú (Wing, 1986), y hay evidencia de la crianza de llamas en la costa norte de hace 1400 años (Shimada y Shimada, 1985) y en Ecuador (Wing, 1986; Stahl, 1988; Miller y Gill, 1990). Más tarde, durante la Cultura Chiribaya (1250 años A.P.), se han encontrado restos de llamas y alpacas naturalmente momificadas, que evidencian una crianza sofisticada entre cero a mil metros de elevación en la costa sur del Perú (Wheeler, 1995; Lozada et al., 2009), y entre 900 y 1000 años A.P. se criaban llamas en el bosque de neblina en la vertiente este de los Andes (Wheeler, 1995). Durante el apogeo incaico (1470-1532), caravanas de llamas acompañaron al ejército durante sus campañas de conquista, alcanzando una distribución desde el sur de Colombia hasta el centro de Chile. No existe información exacta sobre la distribución de este animal al este de los Andes, aunque se presume que había una población grande en Argentina. Es imposible estimar el número de llamas existentes antes de la conquista, sin embargo, debería haber excedido por mucho a la población actual dado que los registros administrativos de la época documentan la virtual desaparición de los rebaños en menos de cien años de contacto (Flores Ochoa, 1977).

Debido a la ausencia de escritura en los Andes prehispánicos y debido a la pérdida de información sobre las prácticas de crianza de los pueblos precolombinos, ocasionada por la mortalidad masiva de los rebaños y sus criadores, el estudio de los restos arqueológicos y arqueozoológicos puede facilitar la reconstrucción de tales prácticas. La excelente preservación de llamas y alpacas naturalmente momificadas en el sitio de El Yaral (Valle de Moquegua, al sur del Perú) (Rice, 1993) ha proporcionado una primera vista a la apariencia física de llamas y alpacas hace 900 a 1000 años (cultura Chiribaya). Estos animales fueron sacrificados mediante un golpe entre las orejas e inmediatamente enterrados debajo de los pisos de las casas, donde la extrema sequedad del medioambiente llevó a su conservación.

La investigación sobre la apariencia física de las llamas de El Yaral ha documentado la existencia de la variedad suri (Figura 8.3c) y revela la existencia de llamas productoras de fibra fina y fibra gruesa (Wheeler et al., 1995; Lozada et al., 2009). El diámetro promedio del vellón de las llamas de fibra fina era $22.2 \pm 1.8 \mathrm{~mm}$, mientras que el promedio de los animales de fibra gruesa era $32.7 \pm 4.2 \mathrm{~mm}$. Mediante una selección intencional, los criadores lograron reducir tanto el grosor de la fibra como la variación de esta hasta producir un animal caracterizado por vellón de una sola capa donde el grosor de las fibras primarias acercaba al grosor de las secundarias, creando una llama productora de fibra fina ideal para la producción textil. Adicionalmente, seleccionaron por vellones de un solo color, sin manchas. Las llamas de fibra gruesa, en contraste, tenían vellones, en su mayoría, manchados.

Antes del descubrimiento de las momias de El Yaral, la información más detallada sobre la crianza de llamas y alpacas prehispánicas provenía de informes escritos durante la época colonial. Estos documentos describen la utilización de llamas como animales de carga, pero no mencionan la existencia de llamas productoras de fibra fina. Esta omisión posiblemente se deba a la confusión de los españoles en diferenciar llamas de alpacas (en su percepción eran ovejas, Gade, 2013) y sus diferentes fines utilitarios, o simplemente se deba a su interés en llamas cargueras para la explotación minera. A pesar de su perspectiva europea, estos documentos proporcionan detalles sobre la crianza inca de camélidos domésticos. Existían enormes rebaños de propiedad del estado y otros dedicados a distintas deidades, todos bajo el control de los llama 
camayoc, miembros de una casta hereditaria de especialistas dedicados al cuidado y crianza de estos animales. Existían rebaños de llamas de color entero -sin manchas- marrón, negro y blanco, para sacrificio a distintas deidades, y para la producción de fibra de alta calidad para la industria textil estatal (Murra, 1965, 1975, 1978; Brotherston, 1989). Se utilizó el quipu, que es un dispositivo de registro hecho de cuerdas anudadas de fibra de camélido o algodón, en el que registraron detalles de la producción (cuántos animales, de qué color, mortalidad, entre otros) utilizando un sistema de cálculo de base 10 para administrar todos los detalles de la crianza y producción. Adicionalmente existían rebaños comunales y de propiedad privada.

La crianza de ganado autóctono en los Andes casi desapareció con la llegada de los españoles. En poco más de un siglo después de la conquista en 1532, los documentos administrativos registran la merma de aproximadamente $90 \%$ de los camélidos domésticos (Flores Ochoa 1982) así como el $80 \%$ de la población humana (Wachtel, 1977; Mann, 2005). Los rebaños de la costa y los valles interandinos fueron los primeros en desaparecer, desplazados para la producción de ovejas, cabras, vacas y cerdos traídos por los conquistadores. En la puna este proceso fue más lento debido al impacto negativo de la altura y el clima inhóspito sobre los invasores y sus animales; esta región marginal se convirtió hasta el día de hoy en un refugio para las llamas y alpacas y sus criadores. Las prolongadas guerras civiles y la imposición de tributos pesados, pagados en llamas o con efectivo obtenido de su venta, llevó a una rápida reducción de los rebaños. Para 1615, las llamas y alpacas habían casi desaparecido incluso en la cuenca del Titicaca (Flores-Ochoa, 1982), su antiguo centro de mayor producción (Murra 1975). El impacto de esta mortalidad catastrófica en la diversidad genética de los camélidos y las prácticas de crianza ha sido poco estudiado. Se estima que la población andina de llamas en la década de los noventa era de 3776793 (Wheeler, 1995). Existen pequeños grupos cerca de Pasto, Colombia ( $\left(1^{\circ}\right)$ y Riobamba, Ecuador (S $\left.2^{\circ}\right)$. Al sur se extienden hasta los $27^{\circ}$ en e centro de Chile, y al este en las provincias de Jujuy, Catamarca y Salta del noroeste Argentina (aproximadamente $\mathrm{OE} 65^{\circ}$ ). Sin embargo, la zona de mayor producción se ubica entre los $\mathrm{S} 11^{\circ}$ y $S 21^{\circ}$ a elevaciones entre 3800 y $5000 \mathrm{msnm}$.

El nombre 'llama' proviene del quechua (Flores-Ochoa, 1988) y se conoce como qawra en aymara (Dransart, 1991). Aunque no existen razas específicas de llamas, se pueden identificar por lo menos cuatro variedades: k'ara (Figura 8.3a), chaku (Figura 8.3b), suri (Figura 8.3c, d) y llamingo (Figura 8.3e). La mayoría de las llamas en Perú, Bolivia y el norte de Chile pertenecen a la variedad k'ara (palabra quechua y aymara), caracterizada por escaso crecimiento de fibra en el cuerpo y de pelo muy corto en la cara y las piernas. Al este en Argentina la variedad lanuda o chaku es común, y según Frank y Wehbe (1974) existen siete tipos distintos de fibra. En estos animales la fibra es densa y se extiende a la cara donde crece entre y dentro las orejas, pero no en la parte inferior de las piernas. La palabra chaku es palabra quechua (Flores-Ochoa, 1988) los criadores aymara la llaman t'awrani (Dransart, 1991). Llamas con características intermedias entre k'ara y chaku existen en toda la zona de su distribución. La variedad suri se caracteriza por su fibra larga, organizada en ondas, que cae a ambos lados del cuerpo de manera semejante a la oveja Lincoln. Igual que la alpaca suri, representan un pequeño porcentaje de llamas, pero han existido desde la época preincaica (Wheeler et al., 1995, 2012). En Ecuador, el llamingo, una variedad genéticamente distinta, pequeña y no lanuda, ha existido por lo menos durante los últimos 2000 años (Miller y Gill, 1990).
Actualmente, la mayoría de llamas son propiedad de criadores tradicionales, quechua y aymara-hablantes, quienes utilizan minuciosos sistemas de clasificación de sus animales basados en el color, características de la fibra y conformación, lo cual parece indicar la previa existencia de sistemas de manejo selectivo para producción de fibra. Sin embargo, no es nada claro hasta qué punto los criadores actuales practican este tipo de selección dirigida. Flores-Ochoa (1988) indica que los criadores quechua hablantes dividen sus llamas en dos grupos: allin millmayuq y mana allin millmayuq que corresponde a animales con fibra fina animales con fibra gruesa. Los colores van del blanco al negro y marrón, pasando por todas las tonalidades intermedias, con manchas y patrones irregulares de color, y llamas con el patrón de coloración silvestre del guanaco todavía existen. La calidad de la fibra es dispareja, con una amplia variación en el diámetro y tendencia a la dominancia de pelo (fibra primaria) sobre el vellón (fibra secundaria). El promedio del grosor de la fibra en hembras k'aras es de $32.5 \pm 17.9 \mathrm{~mm}$ y $35.5 \pm 17.8 \mathrm{~mm}$ en los machos, mientras para los chakus es de 27.0 $\pm 15.6 \mathrm{~mm}$ para las hembras y $29.1 \pm 12.7 \mathrm{~mm}$ para los machos (Vidal, 1967). Cuando se compara esta fibra con las llamas prehispánicas de El Yaral, registraron $22.2 \pm 1.8 \mathrm{~mm}$ para los animales de fibra fina y $32.7 \pm 4.2 \mathrm{~mm}$ para los de fibra gruesa, queda claro que la fibra no solamente ha engrosado, pero también se ha perdido uniformidad del vellón (Wheeler et al., 1995). Este resultado es producto de la falta de selección y buen manejo en la reproducción, que probablemente comenzó durante la conquista. El cruce entre las llamas finas y llamas gruesas de El Yaral abarcaría el rango de variación en el vellón de las llamas actuales. Adicionalmente, el análisis de ADN mitocondrial y nuclear de una muestra grande de llamas andinas ha revelado que aproximadamente $40 \%$ de la población son híbridos, producto de cruce con alpacas (Kadwell et al., 2001).

\section{La alpaca, Vicugna pacos (Linnaeus, 1758)}

La alpaca es más pequeña que la llama y se asemeja a su ancestro, la vicuña Vicugna vicugna mensalis, en muchos aspectos morfológicos y de organización social (Kadwell et al., 2001). Juega un rol importante tanto en la economía, como productor de fibra para uso personal y venta, carne, estiércol para fertilizante y combustible, cuero, ligamentos y huesos para vestimentas y utensilios, y en la cultura y ceremonias de la población andina.

La domesticación de la alpaca fue independiente y posiblemente más temprano que la domesticación de la llama. Excavaciones en el abrigo rocoso de Telarmachay, ubicado a los $4440 \mathrm{msnm}$, en los Andes centrales del Perú, revelaron una secuencia ocupacional entre 9000 y 1800 años A.P. y un registro del proceso de la domesticación de la alpaca (Lavallee et al., 1986; Wheeler, 1984, 1986, 1999). En este sitio se documentó un cambio de la caza generalizada de guanaco, vicuña y la taruca (9000-7200 años A.P.), a la caza especializada de guanaco y vicuña (7200-6000 años A.P.), al control de formas tempranas de alpacas llamas domesticas (6000-5500 años A.P.), y, finalmente, al establecimiento de una economía predominantemente pastoril a partir del 5500 años A.P. (Wheeler 1986, 1999). Más tarde, hace 3800 años, aparece evidencia de la crianza de alpacas a menor elevación en los valles interandinos (Wing, 1972; Shimada, 1985), e igualmente en sitios de la costa sur del Perú hace 1000 años (Wheeler et al., 1995; Lozada et al., 2009). 

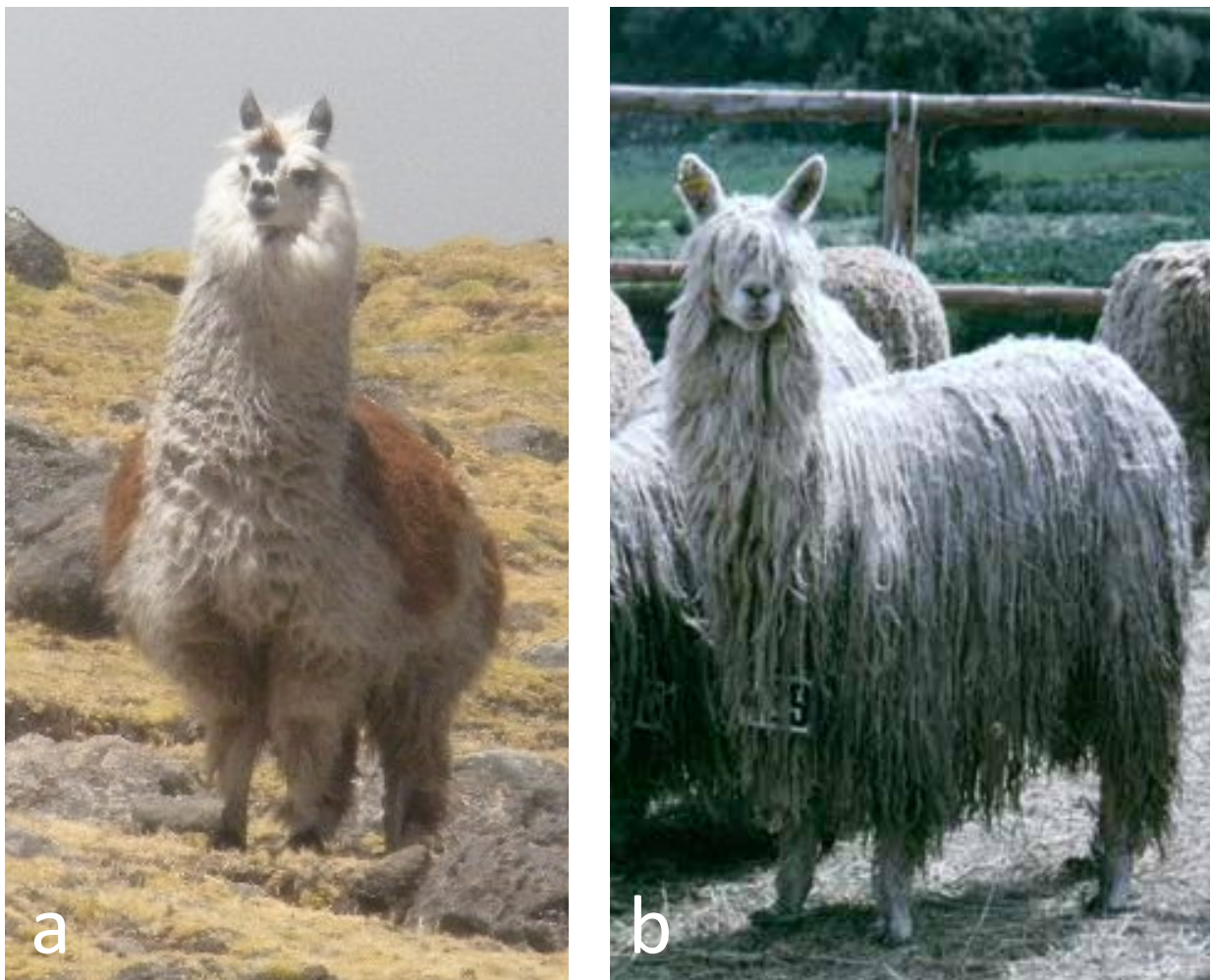

Figura 8.4. Variedades de alpaca. a) Vicugna pacos, variedad huacaya y

b) Vicugna pacos, variedad suri

Aunque han sido introducidas en estos países recientemente, no se han encontrado restos de alpaca en los sitios arqueológicos precolombinos en Argentina (Olivera y Grant, 2009) Chile (Cartajena et al., 2007; Cartajena, 2009) o Ecuador (Miller y Gill, 1990). No es posible estimar el número de alpacas que existieron antes de la conquista. Documentos coloniales registran una rápida disminución de las poblaciones y su desplazamiento a zonas de gran altura (Flores-Ochoa, 1977). En 1967 se registraron 3290000 alpacas en el Perú, mientras que en 1986 se reportaron 2510912 y en 1991 el estimado de la población total a nivel andino fue de 2811612 (Wheeler, 1995). Sin embargo, el censo agropecuario de 2012 ha reportado 3685516 alpacas (Instituto Nacional de Estadística e Informática, INEI, 2013).

No se puede aplicar el concepto europeo de raza a los camélidos sudamericanos domésticos porque no existen ni sociedades de razas ni registros genealógicos sistemáticos y escritos que documenten su desarrollo histórico. Mientras que la existencia de razas depende de la reproducción controlada y dirigida, la situación actual de la alpaca (y de la llama) es de una crianza mayormente al azar, sin selección por características deseables en los padres ni registros de parentesco de las crías. Aunque los antiguos criadores no tenían escritura, se puede afirmar, sin embargo, que llegaron a practicar la selección controlada. La evidencia proporcionada por alpacas sacrificadas y naturalmente momificadas en el sitio de El Yaral, costa sur del Perú, hace 1000 años, demuestra la existencia de alpacas con fibra extra fina $(17.9 \pm 1.0 \mathrm{~mm}$ promedio del vellón) y fina (23.6 $\pm 1.8 \mathrm{~mm}$ promedio del vellón) (Wheeler et al., 1995). El resultado de la selección queda claro cuando se compara el grosor de la fibra y la uniformidad del vellón de las alpacas momificadas con los mismos valores en alpacas actuales que tienen promedios del vellón entre $26.8 \pm 6.0 \mathrm{~mm}$ y $32.1 \pm 2.4 \mathrm{~mm}$ (Wheeler et al., 1995)

La llegada de los españoles fue desastrosa (Gade, 2013). Los rebaños de alpacas y llamas sufrieron altas mortalidades, fueron desplazados de la costa, los valles interandinos y la mayo parte de la puna por el ganado de origen europeo. Actualmente sobreviven en áreas marginales de gran altura donde la producción agrícola es muy limitada o imposible de practicar (Flores-Ochoa, 1982). La distribución actual de la alpaca se extiende desde aproximadamente los $\mathrm{S} 8^{\circ}$, donde ha sido recientemente reintroducida en Cajamarca, hasta los $\mathrm{S} 20^{\circ}$ cerca al lago Poopo en Bolivia, con pequeñas poblaciones recientemente introducidas en el norte de Chile el noroeste de Argentina y en el sur de Ecuador.

La alpaca se llama paqocha en quechua (Flores-Ochoa, 1988) y allpachu en aymara (Dransart, 1991)- En el Perú se estima que 120000 familias dependen de la crianza de alpacas y $80 \%$ de sus rebaños contienen entre 50 y 100 animales (Quicaño, 2009). A pesar de la falta general de control sobre la reproducción, existen dos fenotipos o variedades de alpaca reconocidas por sus nombres quechuas como huacaya o wakaya (Figura 8.4a) y suri (Figura 8.4b). La huacaya se caracteriza por su abundante fibra, rizada y de apariencia esponjosa semejante a la oveja merina, mientras que el suri tiene fibra larga que cae a los lados del cuerpo en ondas y parece una oveja lincoln. Existen animales con características intermedias de fibra, y estos han sido denominados chili por Cardozo (1954). Cruces entre huacaya y huacaya producen una pequeña proporción de suri, y cruces entre suri con suri producen una pequeña proporción de huacaya. Aunque no se practica selección sistemática, aproximadamente el $90 \%$ de las alpacas son huacayas (Novoa, 1989). Ponzoni et al. (1997) sugirieron que el fenotipo suri podría ser producto de un solo gen dominante, y Renierei et al. (2009) han concluido que la fibra del suri es un rasgo cualitativo determinado por uno o dos loci. Recientemente, utilizando microsatélites para examinar la diferencia entre suri y huacaya en dos poblaciones altamente seleccionadas, La Manna et al. (2010) han reportado la no existencia de diferenciación genética entre los dos. Los criadores aymara del norte de Chile no tienen suris y simplemente llaman a sus animales allpachu (Dransart, 1991). Los vellones de ambas variedades varían desde blanco a negro y marrón, pasando por todas las tonalidades intermedias, pero tienden a mayor uniformidad y menor cantidad de manchas que las Ilamas.

En comparación con las alpacas prehispánicas, el grosor de la fibra actual es mayor, 31.2 $\pm 3.8 \mathrm{~mm}$ para huacayas (Carpio, 1991) y $26.8 \pm 6.0 \mathrm{~mm}$ para suris (Von Bergen, 1963), y los vellones son notoriamente disparejos, con concentraciones de hasta $40 \%$ pelo en ambas variedades. Ciertamente, el impacto negativo de la conquista es un factor importante en el deterioro de la producción alpaquera. Estudios de ADN mitocondrial y nuclear (Kadwell et al., 2001; Wheeler et al., 2006a; Marín et al., 2007a , Barreta-Pinto, 2012) han documentado la existencia de un alto porcentaje de hibridación entre llamas y alpacas que afecta entre 80 y $90 \%$ de las alpacas actuales (Kadwell et al., 2001) 


\section{Hibridación}

En 2001, Kadwell y colaboradores utilizaron secuenciación de ADN mitocondrial y cebadores de microsatélites de ADN nuclear para estudiar los orígenes de los camélidos sudamericanos domésticos. Analizaron más de ochocientas muestras de los cuatro camélidos procedentes de un amplio rango de distribución andino. Los resultados de este estudio confirmaron la separación genética de Lama y Vicugna hace aproximadamente 2 a 3 M.A. Determinaron que el guanaco y la vicuña son los ancestros de la llama y la alpaca respectivamente, y dieron evidencia de una hibridación a gran escala entre llama y alpaca afectando el $40 \%$ de las llamas y $80 \%$ de las alpacas. Estudios posteriores (Wheeler et al., 2006a) han encontrado que la tasa de hibridación puede alcanzar hasta $90 \%$ de las alpacas y que la práctica de cruzar llamas con alpacas amenaza la preservación del genoma original de la alpaca.

Los criadores tradicionales reconocen la existencia de híbridos llama $\mathrm{x}$ alpaca. En quechua lo denominan wari (Flores-Ochoa, 1988) y en aymara wik'uña (Dransart, 1991). En quechua se dividen en llamawari o híbrido que parece llama, y paqowari o híbrido semejante a la alpaca (Flores-Ochoa, 1977). Los aymara hablantes utilizan waritu y wayki para identificar os híbridos que parecen a llama y alpaca respectivamente, así como el término genérico wakayu para las crías producto del cruce entre llama y alpaca (Dransart, 1991). Aunque es fácil reconocer cruces de primera generación, no es fácil identificar los demás. Debido a la magnitud del problema, es necesario utilizar pruebas de ADN para identificar con precisión los animales híbridos.

Las cruzas entre los camélidos sudamericanos silvestres y domésticos producen crías fértiles, pero raramente ocurren en la naturaleza. La pacovicuña, híbrido del cruce alpaca con vicuña, ha recibido mucha atención debido a su potencial como productor de fibra fina (Calle- Escobar, 1982). Con base en una muestra muy pequeña $(n=5)$, Carpio y colaboradores (1990) reportaron diámetros de fibra entre 13.3 y $17.3 \mathrm{~mm}$ en cruces $\mathrm{F} 1$, pero esta finura, en apariencia, aumenta rápidamente en las generaciones siguientes. El fenotipo de la pacovicuña puede o no parecerse a la vicuña dependiendo de las características físicas de la mitad alpaca, generalmente es un poco más grande y menos grácil que su progenitor silvestre. No hay información científica sobre la fijación de rasgos fenotípicos de generación a generación en os híbridos de alpaca x vicuña, y falta mucha investigación para evaluar su potencial como productor de fibra fina.

Lamentablemente, durante el segundo mandato de Alan García como presidente del Perú (1985-1990), el gobierno promovió el cruce masivo entre alpaca y vicuña como solución a la pobreza de los criadores de alpacas, sin ningún estudio previo y, sobre todo, sin considerar que esta actividad representa una amenaza al genoma de ambas especies. Adicionalmente, en EE.UU. la pacovicuña (Paco-Vicuna Association and Registry) o pacuna (Pacuna Registry, The Vicuna Alpaca Registry) es criada y promocionada como si fuera un nuevo tipo de ganado. La UICN (2015, www.iucnredlist.org) considera que la crianza de la pacovicuña para fines comerciales, tanto en los Andes como al nivel global, puede representar una nueva amenaza para la vicuña.
La posibilidad de que existan, o puedan existir, llamas y alpacas cerriles que puedan haberse cruzado con los camélidos silvestres ha sido poco investigada. Según Murra (1978), en 1543 Xerez observó que en ocasiones el número de llamas era tan grande que algunos escaparon del control humano, y en 1555 el mismo autor escribió que una vez al año soltaban un número de llamas como ofrenda a los dioses para que vivieran como silvestres. Se desconoce si estas llamas se asilvestraron o si se juntaron con los silvestres, pero el consenso de opinión es que hoy en día no existen grupos de animales cerriles en los Andes centrales. Sin embargo, en 1940 MacDonagh reportó la existencia de un grupo de híbridos de guanaco con llama viviendo en estado silvestre en la provincia de Córdoba, Argentina. Estos animales eran producto de cruces naturales (sin interferencia humana) y generalmente exhibían el fenotipo guanaco, aunque algunos de ellos tenían manchas blancas en la cabeza y la parte superior del cuello, mientras que otros eran casi completamente blancos. No hay información sobre cambios en el tamaño del cuerpo o la calidad de la fibra. El comportamiento de los híbridos era virtualmente idéntico al comportamiento de los guanacos ya que vivían y se reproducían sin problema.

En el caso de los camellos, se ha reportado alta incidencia de hibridación entre el dromedario y el bactriano, sobre todo a lo largo de las antiguas rutas de caravanas donde hubo contacto entre ambos (Silbermayer et al., 2009). A diferencia de los camélidos sudamericanos, los ancestros silvestres del dromedario y el bactriano están extintos, y la única especie de camello silvestre sobreviviente, Camelus ferus, no es ancestro directo de los domésticos (Silbermayer et al., 2009).

Otro híbrido dentro de la Subfamilia Camelinae, es producto de la inseminación artificial de una hembra guanaco con semen de un dromedario macho (Skidmore et al., 1999). Este cruce no ocurre en la naturaleza, y no ha producido animales fértiles. Ha sido denominado Cama.

No hay duda de que la hibridación ha jugado un rol fundamental en la formación de las alpacas y llamas actuales (Stanley et al., 1994; Kadwell et al., 2001; Wheeler et al., 2006a; Marín et al., 2007b; Barreta Pinto, 2012; Marshall et al., 2014). Queda abierta, sin embargo, la discusión sobre cuándo ocurrió. Aunque Marshall et al. (2014) piensan que la hibridación ocurrió en el momento de su domesticación y fue entre los animales bajo el control humano y los silvestres, otros autores opinan que es más reciente, posiblemente iniciando con la conquista, y entre animales ya domesticados (Stanley et al., 1994; Kadwell et al., 2001; Wheeler et al., 2006a; Marín et al., 2007b; Renieri et al., 2009). Sería un error pensar que desde el inicio del control humano hubo control sobre el empadre y selección intencional para ciertos fenotipos. La información de Telarmachay indica que era muy difícil lograr la sobrevivencia de los animales bajo el control humano. Hubo mortalidad masiva de las crías, ciertamente debido a las condiciones de los corrales y el brote de enfermedades que no afectaban a los silvestres. También, es en este momento que comenzaron a cazar a los depredadores. En tales circunstancias hablar de selección dirigida y manejo genético no tiene sentido, y existe la posibilidad de que cruces entre los cuatro camélidos sudamericanos pueden haber ocurrido con resultante introgresión genética. Sin embargo, el gran entrecruzamiento en el ADN que hoy se ha documentado, es con toda seguridad resultado del cruce entre alpacas y llamas una vez domesticadas. 


\section{ADN y conservación}

Desde que el descubrimiento de la estructura del ADN por Watson y Crick en 1953 dio origen a la ciencia de la genética molecular, la rapidez del avance tecnológico nos ha llevado hoy a la rutinaria secuenciación de genomas completos. La información así obtenida permite la reconstrucción de la historia evolutiva de las especies, de otro modo inaccesible en la mayoría de los casos, y en el caso de los camélidos sudamericanos esta información es esencial para planificar su conservación, dada la drástica historia de reducción en tamaño de las poblaciones en las cuatro especies.

En el caso de la vicuña, los análisis de las poblaciones andinas actuales (Dodd et al., 2006; Marín et al., 2007a; Wheeler y Laker, 2008; Wheeler et al., 2001, 2003) han documentado la existencia de cinco grupos genética y geográficamente distintos, cada uno con variabilidad genética reducida. Aunque el número de animales ha aumentado al punto que la vicuña se encuentra clasificada en la categoría de menos preocupación por el IUCN (IUCN, 2015) y la venta de fibra obtenida de la esquila de animales vivos proporciona un importante ingreso para las comunidades vicuñeras (Wheeler y Hoces, 1997; Lichtenstein y Vilá, 2003), la cacería ilegal es todavía un gran problema. Es necesario iniciar medidas distintas de conservación para cada uno de los cinco grupos con la finalidad de prevenir una mayor pérdida de diversidad genética (Wheeler et al., 2001; Marín et al., 2007a; Wheeler y Laker, 2008).

En el caso del guanaco, el análisis de las poblaciones andinas actuales (Marín et al., 2008) ha encontrado que, contrario a la vicuña, existe considerable variabilidad genética en ambas subespecies. Esta situación valida la estrategia de traslado de individuos para repoblar áreas adyacentes y, por lo tanto, junto con investigación adicional sobre la genética, puede facilitar medidas de conservación, sobre todo para la subespecie norteña, L. g. cacsilensis, la cual se encuentra en situación de peligro crítico en el Perú (Decreto Supremo 004-2014-MINAGRI; Wheeler et al., 2006b).

En el caso de la llama y la alpaca, el análisis de ADN mitocondrial y nuclear ha documentado amplia hibridación bidireccional que alcanza por lo menos $80 \%$ de las alpacas y $40 \%$ de las llamas (Kadwell et al., 2001; Wheeler et al., 2006a). Aunque puede haber ocurrido hibridación prehistórica, no se debe subestimar el impacto negativo de la conquista en la crianza autóctona andina. También, durante los últimos treinta años o más, ha sido práctica común cruzar alpacas con llamas para aumentar la cantidad de fibra obtenida de cada animal y así aumentar los ingresos obtenidos bajo un sistema de pago por peso de la fibra. No hay duda del impacto negativo de esta hibridación sobre la alpaca y la llama. Actualmente existen pruebas genéticas para identificar los híbridos, y sería prudente aplicarlas con el objetivo de preservar los genomas originales de la alpaca y la llama.

\section{Bibliografía}

Baretta, Pinto, J., 2012. Estudio de la Variabilidad Genética en Camélidos Bolivianos. Tesis de Doctorado, Universidad de León, España.

Benavente, M. A., 1985. Reflexiones en torno al proceso de domesticación de los camélidos en los valles del centro y sur de Chile. Boletín del Museo Regional Araucanía,

Bolton, M., 2006. Genetic defects or generative prototypes? Competing models for livestock improvement in souther Bolivia. Journal of the Royal Anthropological Institute

Bohlken, H., 1960. Remarks on the stomach and the systematic position of the Tylopoda. Proceedings
Zoological Society of London, 134:207-215. Brack, A., 1980. Conservación de la vicuña en el Perú.
Ministerio de Agricultura y Alimentación, Lima.

Brotherston, G., 1989. Andean Pastoralism and Inca ideology. En: Clutton-Brock, J. (Ed.). The walking larder patterns of Ltd., Londres, pp. 240-255.

Bruford, M.W., D.G. Bradley y G. Luikart, 2003. DNA markers Reviews Genetics, 4(11): 900-910.

Cabrera, A., 1932. Sobre los camélidos fósiles y actuales América austral. Revista del Museo de la 33: 89-117.

Cabrera, A. y J. Yepes, 1960. Mamiferos Sudamericanos. Ediar, Buenos Aires.

Cajal, J., E. P. Tonni y V. Tartarini, 2010. The extinction of some south american camelids: the case of Lama Vicugn
Gracilis. Mastozooogia Neotropical, 17(1): 129-134.

Calle Escobar, R., 1982. Producción y Mejoramiento de la . La Paz.

Carpio, M., 1991. Aspectos tecnológicos de la fibra de los camélidos Andinos. En: Novoa, C. y A. Florez, (Eds.)
Producción de rumiantes menores: Alpacas. RERUMEN, Lima, pp. 279-359.

Carpio, M. y P. Santana, 1982. Estudio preliminar de longitud y análisis cuticular en la fibra de vicuña. Informes de Trabajos de Investigación en Vicuñas, 1
2-53. Universidad Nacional Agraria La Molina. Lima.

2-53. Universidad Nacional Agraria La Molina. Lima.

Carpio, M. y Z. Solari, 1982. Diámetro de la fibra en el vellón de la vicuña. Informes de Trabajos de Investigación en Molina. Lima.

Carpio, M., C. Leyva, Z. Solari y J. Sumar, 1990. Diameter and Length Variations in Different Types of Alpaca Schriftenreine des Deutschen Wollforschungsinstituts. 106: 76-90. Cartagena, I., 2009. Explorando la variabilidad morfométrica
Tardío y el Formativo Temprano en Quebrada Tulán, norte de Chile. Revista del Museo de Antropologia, 2: 199-212. Universidad Nacional de Cordoba, Argentina.

artagena, I., L. Núñez y M. Grosjean, 2007. Camelid domestication on the western slope of the Puna de Atacama, northern Chile. Anthropozoologica, 42: 155-173. Cartagena, I., P. López, I. Martínez, 2010. New camelid (Artiodactyla: Camelidae) record from the late Pleistocene of Calama (Second Region, Chile): a morphological and Geológicas, 27(2): 197-212.

oltorti, M., L. Abbazzi, P. Ferretti, P. lacumin, F. Paredes Ríos, M. Pellegrini, P. Pieruccini, M . Rustioni, G. Tito
y L. Rook, 2007. Last Glacial mammals in South America: a new scenario from the Tarija Basin (Bolivia). Naturwissenschaften, 94:288-299.

Cope, E. D., 1875. On some new fossil Ungulata. Proceedings 261.

Cunazza, C., 1992. Chile: the guanaco. En: Torres, H. (Ed) South American Camelids: an action plan for their protection. IUCN, Gland (Suiza), pp. 16-18.

Cuvier, G., 1800. Leçons d'Anatomie Comparée. Baudouin, Imprimeur de I'Institut National. Paris (Francia).

ecreto Supremo 004-2014-MINAGRI. 2014. Lista de Especies Amenazadas de Fauna Silvestre Legalmente
Protegidas. El Peruano 8 de abril 2014:520497-52054. Dennler de la Tour, G., 1954. The Guanaco. Oryx, 2: 273-279. Dodd C. S., J. Rodríguez, D. Hoces, R. Rosadio, J. C. Wheeler y M. W. Bruford, 2006. Genetic Diversity and En: Gerkin, M., C. Renieri (Eds.). South American Camelid Research, Vol. I. Wageningen Academic Publishers, Wageningen, pp. 87-96.

Dransart, P.Z., 1991. Fibre to fabric: the role of fibre in camelid economies in prehispanic and contemporary Chile. Tesis D. Phi., Linacre Collage, Oxford University, Reino Unido. En: Flores Ochoa, J.A. (Ed.). Pastores de Puna. Instituto
En Pas En: Flores Ochoa, J.A. (Ed.). Pastores de
de Estudios Peruanos, Lima, pp. 15-52.

Flores Ochoa, J.A., 1982. Causas que originaron la actua distribución espacial de las alpacas y llamas. En en los Andes Centrales. Senri Ethnological Studies 10. Osaka, pp. 63-92.

Flores Ochoa, J.A. 1988. Clasificación y nominación de sudamericanos. En: Flores Ochoa, J.A. UNSAAC, Cusco, pp. 121-137.

Frank, E. N. y V. E. Wehbe, 1974. Primer informe de avance de/ componente camélidosdomésticos. Acuerdo República Argentina-Unión Europea para el Programa de Apoyo para la Mejora en la Producción de
Camélidos Argentinos. Buenos Aires. 
Franklin, W.L., 1982. Biology, Ecology, and Relationship to Man of the South American Camelids. En: Mares, M. A., H. H. Genoways (Eds.). Mammalian Biology in
South America. Pymatuning Laboratory of Ecology Special Publication 6, University of Pittsburgh Linesville,

Frisch, J. L, 1775. Das Natur-System der vierfüssigen Thiere in Tabellen, darinnen alle Ordnungen, Geschlechte und sondern beygesetzten unterscheidenden Kennungen, angezeight werden zum Nutzen der erwachsenen Schuljugend. Günther, Glogau.

Gade, D.W., 2013. Llamas and Alpacas as Sheep in the Colonial Andes Zoogeographty Meets Eurocentrism.
Journal of Latin American Geography, 12(2): 221-243.

Gervais, H., F. Ameghino 1880. Los mamiferos Fósiles de la América Meridional/Les mammifères

González, B. A., R. E. Palma, B. Zapata y J. C. Marín, 2006. Taxonomic and biogeographical status of guanaco Lama 36: 157-178.

Gray, J. E., 1821. On the natural arrangement of vertebrose animals. London Medical Repository, 15: 296-310.

Grimwood, I. R., 1969. Notes on the distribution and status of some Peruvian mammals, 1968. American Committee
for International Wildlife Protection. New York Zoologica Society Special Publication No. 21, 87 pp.

Harrison, J. A., 1979. Revision of the Camelinae (Artiodactyla Tylopoda) and Description of the New Genus Alforjas. Paleontological Contil
95: 1-20.

Harrison, J. A., 1985. Giant Camels from the Cenozoic Paleobiology, 57: 1-29.

Hemming, F. 1958a. Official Index of Rejected and Invalid International Trust for Zoological Nomenclature. Londres.

Hemming, F., 1958b. Official List of Works Approved as for Zoole

Herre, W., 1952. Studien über die wilden und domestizierten Leipzig, Neue Folge, 19(2/4): 70-98.

Hoces, D. 1992. Perú. En: Torres, H. (Ed.). South American Camelids: an action plan for their protection. IUCN Gland (Suiza), pp. 19-22.

Hofmann, R. K., K. C. Otte, C. F. Ponce y M. A. Ríos, 1983. El manejo de la vicuña silvestre. Sociedad Alemana de El manejo de la vicuña silvestre. Sociedad

Hoffstetter, R., 1986. High Andean Mammalian Faunas During the Plio-Pleistocene. En: Vulleumier, F. y M. Monasterio University Press, Oxford (Reino Unido), pp. 218-245.

Illiger, C., 1811. Prodromus systematis mammalium et avium, additus terminus zoographicus utriusque classis eorumque versione germanica. Sumptibus C. Salfeld,
Berolini [Berlin]: [1]-301, Errata et Omissa. Alemania. N, 2015. The IUCN Red List of Threatened Species. 2015.2. (en línea, disponible en y www.iucnredlist.org/ details/11186/0 para guanaco.

stituto Nacional de Estadística e Informática, INE (2013). Resultados Difinitivos: IV Censo Nacional Agropecuario 2012. (en línea, disponible en: http://sinia.minam.gob.pe/index. ungius, H., 1971. The vicuña in Bolivia: the status of an endangered species and recommendations for its 146.

adwell M., M. Fernández, H. F Stanley, R. Baldi, J. C. Wheeler, R. Rosadio y M. W. Bruford, 2001. Genetic Woyal Society London $B$. Biol Sci. 268(1485): 2575-2584.

Kent, J. D. 1982. The domestication and exploitation of the South American camelids: Methods of analysis and their application to circum-lacustrine archaeological sites in Bolivia

Koford, C. B., 1957. The vicuña and the puna. Ecologica Monographs, 27(2): 153-219.

Kostritsky, B. y A. Vilchez, 1974. Informe en extenso, proyecto Santuario Nacional del Guanaco, Calipuy. Dirección Forestal y Caza, Ministerio de Agricultura,

Krumbiegel, I., 1944. Die neuveltlichen tylopoden Zoologischer Anzeiger, 145: 45-70.

a Manna, V., A. La Terza, S. Ghezzi, S. Saravanaperumal, N. Apaza, T. Huanca, R. Bozzi y C. Renieri. 2010. Analysis of genetic distance between Peruvian Alpaca (Vicugna
Pacos) showing two distinct fleece phenotypes, Sur Pacos) showing two distinct fleece phenotypes, Su and Huacaya, by means of microsatellite mark

avallee, D., M. Julien, J.C. Wheeler y C. Karlin, 1986 Telarmachay Chasseurs et Pasteurs Prènistoriques des Andes.

ichtenstein, G. y B. M. Vilá, 2003. Vicuña use by Andean Communities: An Overview. Mountain Research and Development, 23(2): 198-202.

Linnaeus, C., 1758. Sistema Naturae per Regna Tria Naturae Secundum Classes, Ordines,Genera, Specoes, cum Characteribus, Differentiis, Synonymis, Locis. Editio decima,reformata. Impensis Direct Laurentii Salvi.

nberg, E., 1913. Notes on guanacos. Arkiv für Zoolog (Stockholm), 8(19): 1-8.

ópez Aranguren, D.J., 1930. Camélidos fósiles argentinos. Anales de la Sociedad Cientifica Argentina 109 (15-35)

ozada, M.C., J.E. Buikstra, G. Rakita y J.C. Wheele,
2009. Camelid Herders: The ForgottenSpecialists in the Coastal Señorio of Chiribaya, Southern Peru. En: Tribute to Michael E. Moseley. UCLA Cotsen Institute of Archaeology Press, Los Angeles, pp. 351-364.

MacDonagh, E.J., 1940. Observaciones sobre guanacos cruzados con llamas. Revista del Museo de la Plata

MacDonagh, E. J., 1949. Los guanacos de Curámalal. Notas de Museo de la Plata, Zoología, 14: 505-537.

MacFadden, B. J., O. Siles, P. Zeider, N. M. Johnson y K. E. Campbell, 1983. Magnetic polarity stratigraphy of of Southern Bolivia. Quaternary Research (Orlando), 19: $172-187$.

Mann, C. C., 2005. 1491: New Revelations of the Americas before Columbus. Knopf, NewYork (New York, U.S.A.) pp. 465

Marín, J. C., C. S.Casey, M. Kadwell, K. Yaya, D. Hoces, J. Olazabal, R. Rosadio, J. Rodriguez, A. Sportono, Phylogeograr y J. C. Wheeler, 2007a. Mitochondria Implications for Conservation. Heredity, 99: 70-80.

Marin, J. C., B. Zapata, B. A. Gonzalez, C. Bonacic, J. C. Wheeler, C. Casey, M. Bruford, R. E. Palma, E. Poulin, taxonomía y domesticación de alpacas y llamas: nueva evidencia cromosómica y molecular. Revista Chilena de
Historia Natural, 80: 121-140.

Marín, J.C., A. E. Spotorno, B. Gonzalez, C. Bonacic, J. C. Wheeler, C. S. Casey, M. W. Bruford, R. E. phylogeography and systematics of guana guanicoe, ARTIODACTYLA: CAMELIDAE). Journal of Mammalogy. 89(2): 269-281.

Marshall, F. B. K. Dobney, T. Denham y J. M. Capriles, 2014 Evaluating the roles of directed breeding and gene flow in Animal Domestication. Proceedings of the National Academy of Sciences

Menegaz, A., F. Goin, E. Ortiz Jaureguizar, 1989. Análisis morfológico y morfométrico multivariado de los representantes fósiles y vivientes del genero Lam (Artiodactyla, Camelidae). Sus implicancias sistemáticas biogeograftcas, ecologicas y biocronológicas.

Mengoni Goñalons, G. L. y H. D. Yacobaccio, 2006. The Domestication of South American Camelids. A View Bradley, E. Emshwiller, B. G. Smith (Eds). Documenting Domestication: New Genetic and Archaeological Paradigms. University of California Press, Berkeley, California, pp. 228-244.

Miller, G. R. y A.R. Gill, 1990. Zooarchaeology at Pirincay, a formative period site in highland Ecuador. Journal of Field Archaeology, 17: 49-68.

Miller, G.S. Jr., 1924. A second instance of the developmen of rodent-like incisors in an artiodactyl. Proceedings of the United States National Museum, 66(8) no. 2545: 1-4. iler, S., J. Rottman, R.D. Taber, 1973. Dwindling and endangered ungulates of Chile: Vicugna, Lama,
Hippocamelus and Pudu. North American Wildlife Conference, 38: 55-68.

ina, J. I., 1782. Saggio sulla Storia Naturale del Chil. Stamperia di S. Tommaso d'Aquino, Boloña, pp. 367.

ontgelard, C., F.M. Catzeflis y E. Douzery, 1997. Phylogenetic relationships of artiodactyls and cetaceans as deduced from the comparison of cytochrome $b$ and 12S rRNA mitochondrial sequences. Molecular Biology

ore, K. M., 1988. Hunting and herding economies on the Junin Puna. En: Wing, E. S., J. C. Wheeler (Eds.). Economic prehistory of the Central Andes. BAR Internation

Moore, K. M., 2012. Grace Under Pressure: Responses to Changing Environments by Herders and Fishers in the Formative Lake Titicaca Basin, Bolivia. En: Miller, N.
F., K. M. Moore, K. Ryan (Eds.). Sustainable Lifeways Cultural Persistence in an Ever-Changing Environment. University of Pennsylvania Press. (Philadelphia, U.S.A.) pp. 244-272

Miller, P. L. S., 1776. Erste Classe, Säugende Thiere. In Des Ritters Carl von Linné vollständiges Naturalsystem nachder zwölften Lateinischen Ausgabe, 1773-1776.pp 1-62 + 3 pls. Suppl, pp.384, Register 36, unnumbered

urra, J. V., 1965. Herds and herders in the Inca state. En: Leeds, A. y S. P. Vayda (Eds.). Culture and Animals. Publication 78, Washington, D.C., pp. 185-216.

Murra, J.V., 1975. Formaciones económicas y políticas de mundo andin
pp. 339 . México, Siglo Veintiuno, México, D.F., pp. 263.

Novoa, C., 1989. Genetic improvement of South American camelids. Revista Brasiliera de Genética, 12(3):123-135.

Olivera, D. E., J. L. Grant, 2009. Puestos de altura de Puna argentina: zooarqueología de Real Grande 1 y 6 Alero Tomayoc. Revista del Museo de Antropologí, $151-168$ n, R., 1848. The Archetype and Homologies of the
Vertebrate Skeleton. John Van Voorst, Londres, pp. 201.

Paco-Vicuna Association and Registry. (en línea, disponible en: www.pacovicunaassociation.com).

Pegistry, The Vicuna Alpaca Registry (en línea, disponible en: www.pacuna.com)

Ponzoni, R.W., D. J. Hubbard, R. V. Kenyon, C. D. Tuckwell, B. A. McGregor, A. Howse, I. Carmichael, G. J. Judson,
1997. Phenotypes resulting from Huacaya by Huacaya, Suri by Huacaya and Suri by Suri crossings. Proceeding of the 12th National Conference of the Association for the Advancement of Animal Breeding and Genetics, Armidale, Australia, pp. 136-139. 
Quicaño, l., 2009. Al margen del poder. Los alpaqueros Tonni, E. P., G. G. Politis, 1980. La distribución del guanaco huancavelicanos. En: Desco (Ed.), Peru Hoy. Luces sombras del poder. Desco, Lima, pp. 283-320. (Mammalia, Camelidae) en la provincia de Buenos Aires durante el Pleistoceno Tardíi y Holoceno. Los factores
climáticos como causas de su retracción. Ameghiniana 17(1): 53-66.

Raedeke, K.J., 1979. Population dynamics and socioecology,
of the guanaco (Lama guanicoe) of Magallanes, Chile. University Microfilms International, Ann Arbor, Michigan pp. 404.

Renieri, C., A. Valbonesi, V. LaManna, M. Antonini y M. Asparrin 2009. Inheritance of Suri and Huacaya type of fleece in

Alpaca. Italian Journal of Animal Science, 8:83-91.

Rice, D. S., 1993. Late intermediate period domestic architecture and residential organization at La Yaral. En: Rice, D.S., C. Stanish, P. Scarr (Eds). Domestic South Central Andes. University of lowa Press, Ames, lowa, pp. 66-82.

Sarno, R. J., L Villalba, C. Bonacic, B. Gonzalez, B. Zapata, D. W. MacDonald, S. J. OBrien y W.E. Jonson, 2004 in Chile and Bolivia utilizing mtDNA and microsatellite markers: implications for vicuña conservation
management. Conservation Genetics, 5: 89-102.

Shimada, M., 1985. Continuities and changes in pattern of faunal resource utilization: Formative through Cajamarca periods. En: Terada, K., K. Onuki (Eds). Excavation at Huacaloma in the Cajamarca Valley, Peru, 1979

Shimada, M., I. Shimada, 1985. Prehistoric llama breeding an 50(1):3-26.

Shockey, B. J., R. Salas-Gismondi, P. Baby, J. L. Guyot, M. C. Baltazar, L. Huamán, A. Clack, M. Stucchi, F. Pujos Cave Faunas of the Andes of Central Perú: Radiocarbo Ages and the Survival of Low Latitude Pleistocene DNA. Palaeontologia Electronica 12.3.15.

Silbermayer, K., P. K. Orozco-terWengel, P. Charruau, D. Enkhbileg, C. Walzer, C. Vogl, F. Schwarzenberger, P. Kaczensky y P. A. Burger, 2009. High mitochondria differentiation levels between wild and domestic Bactrian camels: a basis for rapad detection of materna

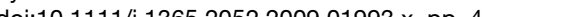

Skidmore, J. A., M. Billah, M. Binns, R. V. Short yW. R. Allen, dromedarus $x$ Lama guanco Proceamelings Camelus Society London B Biol. Sci., 266:649-656.

Stahl, P. W. 1988. Prehistoric camelids in the lowlands of w. W. 15:355-365.

Stanley, H. F., M. Kadwell y J. C. Wheeler, 1994. Molecular Evolution of the Family Camelidae - A Mitochondrial DNA Study. Proceedings of the Royal Society London B, Biol. Sci., 256: 1-6.

Thomas, O., 1917. Preliminary diagnosis of new mammals obtained by the Yale National Society Peruvian 68(4), pp. 1-3.

, H., 1985. Guanaco: distribución y conservación del guanaco. UICN/CSE Grupo Especialista en Camélidos Sudamericanos, Informe Especial No. 2. Cambridge
University Press, Cambridge, pp. 37. Torres, H., 1992. South American Camelids: an action plan for (U) Gland, Suiza.

erscheure, H., C. García, 1980. El Guanaco (Lama guanicoe Muller) como recurso natural renovable. 1. Alguna Producción Animal, 1:15-22.

Vidal, O., 1967. La crianza de la llama y algunas características de su fibra. Tesis, Universidad Nacional Agraria La Molina, Lima, 78 pp.

on Bergen, W., 1963. Wool Handbook. Interscience, Nueva

Wachtel, N., 1977. The vision of the vanquished: the Spanish conquest of Peru through Indian eyes, 1530-1570. Nucleic Acids. Nature 171:737-738.

ha. S. D. 1965. The Osteology of Camelops. Bulletin of the Los Angeles City Museum of Science: 1 . Bulletin

ebb, S. D., 1972. Locomotor Evolution in Camels. Forma et Functio, 5: 99-112.

Webb, S. D., 1974. Pleistocene Llamas of Florida, with a Brief Review of the Lamini. En: Webb, S.D. (Ed.). Pleistocen Gainesville, Florida, pp. 170-213.

Webb, S. D. y J. Meachen, 2004. On the Origin of Lamine Camelidae Including a new Genus from the Late Miocene of the High Plains. Bulletin of
Natural History, 36:349-362.

Wheeler, J. C., 1984. On the Origin and Early Development of Camelid Pastoralism in the Andes. En: Clutton-Brock, J. y C. Grigson (Eds.). Animals and Archaeology, Vol. 3 , Early Herders and Their Flocks. British Archaeological
Reports, BAR Series International 202, Oxford (Reino Unido), pp. 395-410

Wheeler, J. C., 1986. De la chasse a l'elevage. En: Lavallée, D, M. Julien, J.C. Wheeler, C. Karlin. Telarmachay chasseurs et pasteurs préhistoriques des Andes pp. 21-59.

Wheeler J. C., 1995. Evolution and Present Situation of the South American Camelidae. Biological Journal of the Linnean Society, 54: 271-295.

Wheeler J. C., 1999. Patrones prehistóricos de utilización de los camélidos sudamericanos. Boletin de Arqueologia

heeler, J. C., A. J. F. Russel y H. Redden, 1995. Llama Hybrids. Journal of Archaeological Science, 22: 833-840. Kadwell y M. W. Bruford, 2001. Diversidad Genética Revista de Investigaccciones Veterinarias del Peru Peru. En: Lemons, J, R Victor y D. Schaffer (Eds).
Wheeler, J. C. y D. Hoces, 1997. Community Participation, Sustainable Use and Vicuña Conservation in Peru.

Wheeler, J. C., M. Fernández, R. Rosadio, D. Hoces, M. manejo de poblaciones de vicuñas en el Perú. RIVEP

estocástica de poblaciones del guanaco peruano. In: $\mathrm{M}$. Divera and S. Puig (Eds). Actas IV Congreso Biodiversidad. Catamarca (Argentina), 76 . alr, J. C., J. Laker, 2008. The vicuna in the Andean altiplano. En: Gordon, I. (Ed.). The vicuña: the theory
and practice of community-based wildlife management. Springer, New York, pp. 21-34.

Wheeler, J. C., M. Fernández, R. Rosadio, D. Hoces, M. Kadwell, M. W. Bruford, 2003. Genetic Diversity and Conserving Biodiversity in Arid Regions. J. Kluwer Academic Publishers, Boston, pp. 327-344.

Wheeler, J. C., D. Hoces y M.W. Bruford, 2006 a. Proyección estocastica de poblaciones del guanaco peruano. estocastica de poblaciones del guanaco peruano
En: Miragaya, M., D. Olivera y S. Puig (Eds). Actas IV CongresoMundial sobre Camélidos. FIDA, CFI,
Fundación Biodiversidad. Catamarca, Argentina, p. 76. Fundación Biodiversidad. Catamarca, Argentina, p. 76.

Wheeler, J. C., L. Chikhi, M.W. Bruford. 2006a. Case study in genetics of animal domestication:South American
Camelids. En: Zeder, M.A., D.G. Bradley, E. Emshwiller, B.G. Smith (Eds). Documenting Domestication: New Gelific and Ars. Docume

Wheeler J., D. Hoces y M. Bruford, 2006b. Proyección

heeler, J. C., L. Maturrano, J. M. Aguilar y S. White, 2012. Evaluación genética de las variedades de llama k'ara, VI Congreso Mundial de Camélidos Sudamericanos. Arica, Chile, pp. 228.

Wing E S, 1972. Utilization of animal resources in the Peruvian Andes. En: Seiichi, I. K. Terada (Eds). Andes 4 : Excavations at Kotosh, Peru, 1963 and 1964. University of Tokyo Press, Tokio, pp. 327-352.

g, E. S., 1986. Domestication of Andean Mammals. En: Vulleumier, F. y M. Monasterio (Eds.). High Altitude Woodburne, M. O., 2010. The Great American Biotic Pens. Journal of Mammalian Evolution, 17:245-264. 39(1): 237-247. 


\title{
La quimera de la domesticación de la vicuña y la falacia de la crianza en semicautiverios
}

Julio B. Sumar

\begin{abstract}
Resumen
La domesticación de la vicuña ha estado en la agenda de criadores y científicos, desde la mitad de siglo XVI hasta el presente, motivados por la gran finura del pelo de este animal y el alto valor comercial de las prendas hechas con este. En 1931, el doctor Luis Maccagno, profesor de la Escuela Nacional de Agricultura y Veterinaria de Lima, propuso el establecimiento de "criaderos de vicuñas del Estado", para promover su domesticación. Hizo referencia al Criadero de Vicuñas de Cala-Cala, iniciado en 1919, preparando un gigantesco cerco de piedra de un $1.5 \mathrm{~m}$ de ancho por $2 \mathrm{~m}$ de alto, en un espacio físico de aproximadamente 1000 ha de pastizales en la puna. En 1944 el ingeniero Jorge Gallegos, director de la Granja Modelo de Puno, y después en 1954 Nicolás R. Santolalla, en 1956 el ingeniero Calderón Lynch, y en 1982 el ingeniero Rigoberto Calle-Escobar hicieron intentos por domesticar la vicuña y/o cruzarla con la alpaca para obtener fibras de alta calidad en animales domesticables. En 1972, el Ministerio de Agricultura recibió informaciones de la Sociedad Zoológica de Frankfurt, Alemania, de que el rebaño de Cala-Cala era un peligro para las vicuñas silvestres, ya que algunos ejemplares de vicuñas no puras podrían escapar y formar harenes y diseminar características de alpaca y llamas en hatos de vicuñas silvestres. En la década de los sesenta, la Universidad de San Marcos impulsó el desarrollo de infraestructura de investigación con áreas de sanidad, pastos y forrajes, reproducción y mejoramiento genético en alpacas. Investigadores de esta universidad hicieron cruzas de machos de vicuñas con hembras de alpacas, obteniendo la primera generación F1 llamada pacovicuña y retrocruzas con vicuñas puras y pacovicuñas, obteniendo ejemplares más parecidos a la vicuña (F2), así como retrocruzas con alpacas; es decir, ejemplares de 7/8, 1/2, y 1/4 de alpaca. En este último caso se obtuvieron ejemplares blancos con algunas características de vicuña Las retrocruzas arribaron a una F3 sin obtener la combinación ideal (un animal con 2-3 libras de fibra del color y finura de la vicuña, y de fácil manejo). No existe forma de fijar en la F1 o F2 las características de finura de fibra de la vicuña y la cantidad que produce la alpaca. También se cruzaron vicuñas puras macho con hembras de alpaca de la raza suri; los animales resultantes presentaron un patrón de distribución del color de vicuña y fibra característica de la raza suri sin el uncusani o pelo blanco largo del pecho de las vicuñas. El tipo de vellón suri es dominante sobre el tipo huacayo. Cuando se cruzaron dos pacovicuñas entre sí se obtuvieron ejemplares con manchas en el cuerpo y en los miembros, o blancos, sin la finura de fibra esperada.
\end{abstract}


La rápida recuperación de las poblaciones de vicuñas en el Perú inició en los años sesenta. La Cooperación Alemana desarrolló un sistema basado en la protección del hábitat natural de la vicuña y contra los cazadores furtivos, así como el estudio integral de los hábitos de esta especie. Se pasó de 2000 ejemplares a los 60000 al término del Convenio. De ahí en adelante se trató de seguir esta misma metodología, hasta que el Estado abandonó el sistema de protección por "un novedoso enfoque" basado en la "crianza en semicautiverio" promovido por falsos expertos. El semicautiverio consiste en cerrar a grupos de vicuñas libres en ciertas extensiones de pastizales de altura, valiéndose de alambradas, a fin de que sean capturadas y esquiladas fácilmente, los falsos expertos sostenían que el manejo continuo domesticaría la especie. Este manejo es inconveniente por las siguientes razones: 1) el término "semicautiverio" es inadecuado, ya que califica un sistema de sometimiento forzado; 2) los defensores de este sistema lo hacen sin un conocimiento básico del comportamiento de la vicuña; 3) no se toma en cuenta la capacidad de carga de las pasturas de las altiplanicies del centro y sur del Perú; 4) los depredadores de la vicuña encuentran más fácil su tarea en animales encerrados que en animales libres; 5 ) los abrevaderos naturales deben estar al alcance de todas las familias de vicuñas; 6) los rebaños de machos errantes carecen de manejo, y 7) no hay un seguimiento minucioso de la conducta, tasa de crecimiento y datos sobre el ritmo de crecimiento de la fibra y rendimiento. Los mal llamados "criadores de vicuñas" usan corrales sin tener en cuenta la conducta de este animal ni sus movimientos migratorios con el cambio de estaciones. El sistema de semicautiverio es aberrante, para luego mediante los chakus atrapar a las vicuñas, trasladarlas a superficies cercadas con escasos recursos hídricos. Estando encerradas, también están sujetas a un "pequeño chaku", mediante el cual las dirigen a corrales de encierro y así, al esquilarlas, las someten a un gran estrés y a la desorganización social y territorial. El arreo de las vicuñas requiere de mucha gente vociferante, tremendamente ruidosa, tratando de dirigirlas a los embudos. Esto aumenta el nerviosismo de los animales, y en ocasiones provoca la muerte de algunos ejemplares que se rompen el cuello al embestir las instalaciones fijas. Se propone: 1) dejar a las vicuñas en su estado de libertad total de desplazamiento y reproducción, y un sistema de control de caza furtiva, con ocasionales chakus de acorralamiento, captura, esquila y liberación; 2) usar la transferencia de embriones de vicuñas a vientres alpaca, con el fin de facilitar el manejo de crías dentro de un rebaño de animales domésticos; 3) usar biotecnologías nuevas poco invasivas como el monitoreo de hormonas reproductivas en heces, orina y saliva, inseminación artificial, transferencia de embriones y fertilización in vitro, criopreservación de espermatozoides, embriones y oocitos, tejidos gonadales, sexaje de espermatozoides, transferencia nuclear, y clonación de células somáticas, y 4) ensayar en vicuñas en cautiverio suplementos de forrajes. Hay observaciones en zoológicos que indican que la sobreoferta de alimentos evita confrontaciones de machos y mejora los índices de natalidad.

Palabras clave: camélidos, domesticación, manejo de recursos genéticos, manejo de fauna silvestre, semicautiverio, vicuñas.

\section{Introducción}

La vicuña (Vicugna vicugna) es una de las dos especies de camélidos silvestres íntimamente ligadas a la historia del Perú, habiendo desempeñado un importante rol en las culturas regionales desde la época preinca hasta el presente. La domesticación de esta especie ha estado en la agenda de criadores y científicos desde la mitad de siglo XVI hasta hoy, motivados por la gran finura de su pelo (13 $\mu$ en promedio) y, desde luego, por el elevado valor comercial de las prendas que se elaboran con este. De acuerdo con fuentes históricas, como la "Reducción de Indios" de Juli, Puno (Pimentel, 1954) a mediados del siglo XVI los Jesuitas ya tenían un rebaño de 600 vicuñas. Siglos más tarde, en 1847, el cura Juan Pablo Cabrera del Distrito de Ayaviri, Provincia de Macusani, Puno, dirigió el acoplamiento de un macho vicuña y hembras alpaca, logrando, de acuerdo con reportes de la época, veinte pacovicuñas que pastaban mansamente bajo el cuidado de un pastor, acción por la cual el Congreso de la Republica le otorgó la Medalla del Congreso y otros honores.

El doctor Luis Maccagno (Macagno, 1931) propuso el establecimiento de "criaderos de vicuñas del Estado" para promover la domesticación de estos animales. En 1944, Jorge Gallegos, director de la Granja Modelo de Puno, en Chuquibambilla, informó de la crianza de pacovicuñas, dando cifras entre 3-6 libras de vellón finísimo y poniendo énfasis en su_domesticación completa. Más tarde, Calderón Lynch (1956) afirmó que existe gran interés en conservar la vicuña y en organizar su crianza y domesticación. Refierió que existen dos criaderos oficiales de vicuñas, uno en la Provincia de Azángaro, en la Hacienda Cala-cala (Kala-Kala), "con más de 25 años de trabajo, contando en la actualidad con más de 350 ejemplares, y el otro criadero entre los departamentos de Puno y Cusco, ubicados en los fundos de San Martin de La Raya y Vilcanota". Santolalla (1954) propuso cruzar la vicuña con alpaca, mediante "cruces absorbentes" de vicuñas machos sobre hembras alpacas y pacovicuñas hembras, hasta llegar a una pureza racial que produciría una cantidad mucho mayor de fibra fina que la vicuña pura que solo produce unas cuantas onzas. Dice también Santolalla (1954) que las hembras alpaca podrían dedicarse a estos cruzamientos sin el riesgo de que mermara la población de alpacas, lo que permitiría continuar los planes de mejoramiento. Termina diciendo que en cinco o diez generaciones de este cruzamiento absorbente se tendrían vicuñas domesticadas. En un sentido similar, Calle-Escobar (1982), especialista en ovinos, abogó por la domesticación de la vicuña mediante cruzamientos de macho vicuña con la alpaca. Sugirió haber producido una pacovicuña que producía 3 libras de fibra anualmente, y que la F1 era totalmente doméstica. Dedicó diez páginas de su libro a ponderar las virtudes de la pacovicuña. Los documentos citados son solamente los más relevantes sobre la vicuña; sin embargo, es abundante la literatura en este tipo de propuestas.

\section{Centro Nacional de Conservación de Camélidos Sudamericanos de Kala-kala, Puno}

Según la versión de Maccagno, el Criadero de Vicuñas de Cala-Cala, se habría iniciado en 1919, preparando un gigantesco cerco de piedra de $1.5 \mathrm{~m}$ de ancho por $2 \mathrm{~m}$ de alto. Abarcaba un espacio físico de aproximadamente 1000 ha de pastizales en la puna. Atrapó vicuñas sil- 
vestres de los alrededores (se desconoce cuántas), oficializó este encierro como "Criadero de Vicuñas", y consiguió el permiso del Estado peruano para comercializar la fibra en Inglaterra. En 1971, Jungius (1971) de la Sociedad Zoológica de Frankfurt, Alemania, viajando a Bolivia para asesorar a ese país en la conservación de las vicuñas, hizo un viaje al Perú para visita Pampa Galeras y el llamado Criadero de Vicuñas de Cala-Cala, Puno. Salió encantado de Pampa Galeras donde vio el trabajo de sus paisanos Hoffman y Otte. Luego visitó Cala-Cala, haciendo un llamado de "alarma" de lo que sucedía en este criadero, manifestando que:

“...quiero enfatizar que la vicuña no ha sido domesticada nunca, a pesar de los múltiples intentos llevados a cabo hace más de cien años. En Cala-cala, las vicuñas han sido cruzadas con alpacas para producir los pacovicuñas que combinan la alta finura de la vicuña con la cantidad de fibra de la alpaca. Desafortunadamente, los animales híbridos no estaban separados de las alpacas, por lo que los cruzamientos entre ellos ocurrieron al azar, de manera que hibridos de diferentes generaciones se mezclaban con animales vicuñas y alpacas puras. Para hacer la situación peor, se añadieron llamas a este rebaño multiespecifico".

Jungius (1971) enfatizó que ninguno de los animales que vio debía salir de este encierro, y el Estado debe hacerse responsable de ello. Dejaba en manos del Ministerio de Agricultura de Perú, el futuro de Cala-Cala. Esta "advertencia" llegó tarde, ya que Cala-Cala suplió de vicuñas a otras zonas del país, especialmente a la sierra central del Perú. En estas circunstancias, el Ministerio de Agricultura recurrió al IVITA de la Universidad Nacional Mayor de San Marcos (UNMSM), para que se involucrara en un proyecto que procurara mejorar las metas y métodos del proyecto Cala-Cala.

En primer término, la UNMSM creó El Centro de Preservación de Camélidos Sudamericanos para proteger a la vicuña y conservar las alpacas de colores grises, roanos y negros que están en riesgo de desaparecer, las cuales pastarían en las otras 5000 ha de Cala-Cala. En este mismo fundo, en un área de aproximadamente $1000 \mathrm{ha}$, se encontraba una alta variedad de fenotipos, que iba de las vicuñas puras (sin tener la certeza de ello), hasta alpacas cas puras. Se encontraban también pacollamas (un entero, un capón y dos hembras). No existían registros ni información sistemática, solo relatos verbales del personal que trabajó en el fundo. Estas personas afirman que habiendo comprobado que la pacovicuña producía mayor cantidad de fibra fina que la vicuña pura, introdujo alpacas al criadero, así como también algunos ejemplares de llamas hembras. En 1972, el Ministerio de Agricultura recibió informaciones de la Sociedad Zoológica de Frankfurt, Alemania, de que el rebaño de Cala-Cala era un peligro para las vicuñas silvestres, ya que algunos ejemplares de vicuñas no puras podrían escapar y formar harenes y diseminar características de alpacas y llamas en hatos de vicuñas silvestres. Lo que Jungius no supo es que antes de su visita en 1972, el Ministerio de Agricultura, permitió que se escogieran a "ojo de buen cubero" vicuñas de Cala-Cala, para ser trasladadas a otras zonas de repoblamiento, especialmente a las zonas central y norte del país. De ahí que las vicuñas muestren genes de alpaca e incluso de llamas (Kadwell et al., 2001)

El plan desarrollado por el Convenio Ministerio de Agricultura-IVITA-UNMSM, debía hacer una selección rigurosa por fenotipo para separar lo que podrían ser vicuñas puras del resto de híbridos. El primer año debían sacrificarse todos los machos que no fueran vicuñas puras pacos. El segundo año deberían separarse las hembras híbridas para retirar durante el tercer año las pacovicuñas machos y el cuarto año a las hembras pacovicuñas. El quinto año debían introducirse machos de Pampa Galeras y continuar por varios años con este trabajo. Mientras tanto, se harían estudios de enfermedades infecciosas y parasitarias, y aspectos técnicos de producción de fibra. El Proyecto de Cala-Cala no prosiguió debido a cambios de política y se entregaron los animales a los extrabajadores del fundo. Se carece de información actualizada sobre ese rebaño (Sumar, 1975). Sin embargo, se sabe que el trasiego de vicuñas continuó posteriormente y el CONACS permitió la venta de doscientas vicuñas de Cala-Cala para un fundo en las alturas de La Libertad, un caso escandaloso en el que el presidente de esa institución se vio involucrado.

\section{El rebaño de vicuñas y pacos} de la granja modelo de Auquénidos de La Raya

El IVITA, de la UNMSM tuvo presencia en la exgranja de Auquénidos de La Raya del Ministerio de Agricultura, incrementando a partir de la década de los sesenta sus actividades con el fin de desarrollar una infraestructura de investigación con áreas definidas de sanidad, pastos y forrajes, reproducción y mejoramiento genético de alpacas. Así también, el Criadero de Vicuñas le fue entregado a la UNMSM para su manejo, que no era sino un potrero alambrado de no más de 30 ha, en las que se apiñaban más de 150 ejemplares de vicuñas puras y pacovicuñas en diferentes grados de cruzamiento; algunos con un arete numerado, pero sin ninguna información ni registros que indicaran su manejo y grado de cruzamiento. Se tuvo que empezar nuevamente desde cero. Se cruzaron machos vicuñas con hembras alpacas, obteniendo la primera generación F1 llamada pacovicuña (aunque algunos genetistas dicen que debía llamarse vicuñapacos). Luego se hicieron retrocruzas con vicuñas puras y pacovicuñas, obteniendo ejemplares más parecidos a la vicuña (F2), así como retrocruzas con alpacas (macho alpaca x pacovicuña hembra). Es decir, se contaba con ejemplares de $7 / 8,1 / 2$, y $1 / 4$ de alpaca; en este último caso, se obtuvieron ejemplares blancos, con algunas características de vicuña En ambos casos de retrocruza se obtuvo una F3 sin obtener la combinación ideal, que serí un animal con 2-3 libras de fibra del color y finura de la vicuña, así como de fácil manejo. No existe la forma de fijar las características en F1 o F2 con la finura de la vicuña y la cantidad de fibra de alpaca. Así también se cruzaron vicuñas puras machos con hembras alpaca de la raza suri. El resultado fueron animales con el patrón de distribución del color de la vicuña y la fibra con las características de la raza suri de alpaca, sin el uncusani o pelo blanco largo del pecho de las vicuñas. El tipo de vellón suri es dominante sobre el tipo huacayo. Cuando se cruzaron dos pacovicuñas entre sí se obtuvieron, por lo general, ejemplares con manchas en el cuerpo y en los miembros, o blancos, sin la finura esperada. La heterocigosis en estos cruces resultó negativa. Cabe mencionar que un grupo de investigadores ingleses y peruanos recomienda la cruza de las alpacas del Perú con vicuñas puras (Kadwell et al., 2001). Lo que sorprende es el hecho de que no hubo ningún comentario en el Perú de tomar la pluma y decir que tal recomendación era el camino a la catástrofe. Para más datos acerca de Cala-Cala pueden leerse e artículo de Jungius (1971), con información confiable sobre la composición y situación de los animales de Cala-Cala. 
Y así llegamos al siglo XXI con la idea de "domesticar la vicuña" con el "manejo en semicautiverio". La arqueozoólaga Jane Wheeler (1995) afirma que "existen fuertes evidencias que la vicuña ha sido domesticada, dando como resultado a la alpaca". Según este estudio, la domesticación de los camélidos se originó en la puna a elevaciones entre 4000 y 4900 msnm, alrededor de 6000 años A.P. en lugares donde la vicuña, el guanaco y la taruca fueron las presas principales de los primeros cazadores humanos. Estos cazadores lograron un control sobre grupos de vicuñas que posteriormente fueron las primeras alpacas y que sentaron las bases de una economía de subsistencia. La pregunta pertinente al respecto es ¿de qué vicuña habla la Dra. Wheeler, de la que existió en el Pleistoceno o de la actual vicuña?

\section{Características fenotípicas y comportamiento de la pacovicuña (F1)}

El llamado híbrido pacovicuña ( $F 1$ ) adquiere algunas características de su padre vicuña y otras de su madre alpaca. Así, el color canela y blanco del pelaje, como el patrón de distribución del color y calidad de fibra, es muy similar a los de la vicuña, incluyendo, -aunque no muy prominentemente- el pelo largo y blanco del pecho, llamado delantal o uncusani. Por ello puede ser confundido fácilmente con la vicuña. Lo que hereda de la alpaca es el cuello más grueso y aparentemente más corto, así como los miembros delanteros y posteriores más gruesos y fuertes que los de la vicuña. El temperamento de los animales de la F1 es también similar al de la vicuña; es decir, un animal indócil, nervioso, escurridizo y de dif́́cil manejo, aun habiendo nacido en cautiverio y con la presencia diaria del hombre. Por ser la pacovicuña más robusta que la vicuña, es más difícil mantenerla en cautiverio, y sujetarla con fines de someterla a algún tratamiento.

En el Proyecto Vicuña del IVITA se formaron familias compuestas de un macho vicuña y siete alpacas hembras blancas, entre tres y seis años de edad. Se separó a las familias con alambradas para evitar las peleas entre los machos. En sus hábitos diarios de pastoreo, e macho vicuña obtuvo la subordinación de las hembras alpaca, a base de mordiscones en los corvejones, actuando como el jefe de familia. El macho vicuña sirvió a la vez de vigía, guía y dueño absoluto de las hembras con las cuales compartía un territorio. Después de un período de empadre de noventa días, se retiró a las hembras a un rebaño especial y los machos permanecieron en sus encierros hasta la nueva temporada de empadre. La preñez obtenida era del $90 \%$. El aislamiento de las familias por alambradas evita las peleas y mejora la fertilidad de las familias (Sumar, 1992). Así también se formaron familias de vicuñas hembras con un macho alpaca sexualmente muy activo, llamado jhayñacho, pero no exhibió el comportamiento de los machos vicuñas y no hubo reproducción.

\section{La cebra y el principio de Ana Karenina}

Jared Diamond $(1981,1999)$ científico que ha investigado biología evolutiva, sostiene que Tolstói, el autor ruso de la obra Ana Karenina, nos puede enseñar algo sobre domesticación de animales, cuando al inicio de su famosa obra, dice "que las parejas felices son todas iguales, y que cada pareja infeliz, lo es a su manera". Nos dice también que "el ser humano busca simples explicaciones a ciertos sucesos, pero evita pronunciarse sobre las posibles razones de las fallas". Diamond escogió a las cebras, como un ejemplo de las equivocaciones de muchos naturalistas de mediados del siglo XVIII. Como ejemplo, el naturalista inglés Walter Rotschild mandó traer cebras de África y someterlas al cuidado de expertos en amansar y manejar caballos, a fin de ponerlas a jalar carrozas. $Y$ así fue que logró poner a cuatro cebras a jalar su carroza. Un día en que paseaba por las calles londinenses, las cebras entraron en pánico, se desbocaron causando destrozos en las calles; hubo varios muertos y heridos, y ahí terminó el intento de domesticar a un animal peligroso y con tendencia al pánico.

De acuerdo con el principio de Ana Karenina, un candidato silvestre (salvaje), debe poseer ciertas características biológicas y de comportamiento que los haga candidatos a la domesticación. Diamond describe por lo menos siete razones o características, que nosotros debemos reconocer cuando pensamos en domesticar alguna especie para evitar equivocaciones. Entre estas meciona: 1) tamaño corporal y peso, debiendo el animal adulto pesar más de $42.5 \mathrm{~kg}$ y de preferencia herbívoro; 2) tasa de crecimiento con rápida ganancia de peso, para que sea rentable; 3) problemas generados de tener animales silvestres en confinamiento; 4) predisposición desagradable y peligrosa, adquiriendo vicios y los machos territoriales desafiando al hombre para sacarlo de su territorio; 5) complicada conducta sexual (véase Bosch y Svendsen, 1987); 6) predisposición al pánico, de temperamento nervioso, rápidos y programados para salir volando cuando perciben algún peligro, y 7) casi todas las especies de animales domésticos tienen en común la estructura social de sus ancestros: viven en rebaños, mantienen una bien desarrollada jerarquía de dominio entre sus miembros y los rebaños ocupan territorios que se traslapan. Después de explicar cada una de ellas, Diamond $(1981,1999)$ tiene una referencia explícita a la vicuña y dice textualmente que:

las vicuñas se agrupan en familias, mantienen territorios exclusivos, no permitiendo el ingreso de otros machos adultos, que viven en familias de más o menos diez animales, que consisten en un macho líder, su harem y sus crías; cada familia tiene un territorio de pastoreo exclusivo, así como dormideros exclusivos. Este comportamiento, y su tendencia al pánico, así como su compleja conducta sexual, impiden la domesticación de las vicuñas.

La rápida recuperación de las poblaciones de vicuñas en el país se inició en los años sesenta del siglo pasado. La Cooperación Alemana, bajo la batuta de los doctores Hoffman y Otte, desarrolló un sistema basado en la protección del hábitat natural de la vicuña así como medidas de protección contra los cazadores furtivos, y un estudio integral sobre los hábitos de esta especie. Se pasó de 2000 ejemplares a 60000 al término del Convenio. De ahí en adelante se trató de seguir la misma metodología, hasta que el Estado abandonó el sistema de protección por "un novedoso enfoque" basado en la "crianza en semicautiverio". Este enfoque fue promovido por falsos expertos, quienes sostenían que la vicuña esquilada no es objeto de caza, ya que está privada de su vellón, y que el sistema de semicautiverio era una propuesta sustentable y la definitiva solución al "problema de la vicuña". El semicautiverio consiste en encerrar grupos de vicuñas libres en ciertas extensiones de pastizales de altura, valiéndose de alambradas, a fin de facilitar su captura, y esquilada. Los falsos expertos plantearon que el manejo continuo de esta manera domesticaría a la especie. Este manejo resulta inconveniente por las siguientes razones: 1) el término semicautiverio no es el más adecuado, ya que es un sistema de sometimiento forzado; 2) los defensores de este sistema 
realizan este manejo sin un conocimiento básico del comportamiento de la vicuña; 3) no se toma en cuenta la capacidad de carga de las pasturas ya depredadas de las altiplanicies de centro y sur del Perú; 4) los depredadores no humanos de la vicuña encuentran más fáci su tarea en animales encerrados que en animales libres; 5) los abrevaderos naturales deben estar en sitios al alcance de todas las familias de vicuñas; 6) los rebaños de machos errantes carecen de un manejo, y 7) no hay un seguimiento minucioso de la conducta, ni de la tasa de crecimiento ni de datos sobre el ritmo de crecimiento de la fibra y su rendimiento. Salinas (1999) menciona que los mal llamados "criadores de vicuñas" "están usando corrales y/o cercos fijos sin tener en cuenta las situaciones espaciales y conductuales de este animal ni sus movimientos migratorios espontáneos que ocurren con el cambio de estaciones". Cabe mencionar que hay numerosos tratados que detalladamente instruyen a los futuros criadores de vicuñas sobre cómo construir estos establecimientos de semicautiverio, a los que este autor denomina "cárceles de la vicuña" (Zúñiga, 2007).

\section{Carta abierta del Dr. William Vivanco a quien salve la vicuña}

En enero de 2012, el doctor William Vivanco elaboró una propuesta sobre el espinoso problema de la vicuña, cuyo título era: "Carta abierta a quien salve a la vicuña". Dicha carta fue enviada a numerosos profesionales, que, de una u otra manera, trabajaban con la vicuña, algunos de los cuales contestaron dando sus puntos de vista. Aprovecho la oportunidad del Simposio y de este libro para comentar dicha carta, así como las opiniones de los otros consultores.

El doctor Vivanco inventa un nuevo sistema de cría de vicuñas, a la que él llama "explotación zootécnica,y/o manejo zootécnico de la vicuña". Él fue testigo y actor de la producción de carne de venado y sangre del velvet de las cornamentas del venado rojo (Cervus elaphus), un anima silvestre, que se mejoró mediante zootecnias, según el autor de la carta. El término "zootecnia", según el diccionario de Oterza-Fernández y Carmona-Medero (1993), es la ciencia dedicada a la cría, mejoramiento y explotación de los animales domésticos útiles al hombre, a fin de obtener de ellos la máxima producción y productividad. Para redundar en el término zootecnia, Lincoln et al. (1998), dicen que "Zootechnics is the science of breeding and rearing domestic animals", y su sinónimo de zootecnia es "animal husbandry". Vivanco menciona que los chakus de Pachacutec (palabras peyorativas) no son lo más adecuado para salvar a la vicuña. Más aun, a los que defienden el sistema de chakus los llama "absolutamente ignorantes, sean estos ecologistas, antropólogos, sociólogos y diversos profesionistas". Continúa Vivanco diciendo que "la explotación en silvestría es un sistema perverso, que a la larga pondrá nuevamente a la especie en extinción que los vicuñeros de explotación en silvestría, o pseudovicuñeros deben desaparecer". Para no cansar a los lectores de este libro, terminaré diciendo de la conversación que tuvo Vivanco con un especialista argentino en vicuñas, el ingeniero Francisco Rigalt, sobre que en Argentina habían logrado un kilo de fibra por vicuña adulta esquilada cada dos años. Esta información es definitivamente falsa, tratándose de la subespecie Vicugna vicugna vicugna, cuyo manto de color canela hace una curvatura a nivel de los costillares, dejando un vellón blanco de poca finura (comparando a la producción de fibra fina de la vicuña peruana Vicugna vicugna mensalis), cuyo cobertura de color es más grande. Rigalt (2011), contrario a lo que afirma Vivanco, menciona en la parte correspondiente a productividad y rentabilidad de los sistemas lo siguiente:

Los mayores rendimientos promedios se logran en las poblaciones manejadas en silvestría en el 2010, en el que fueron esquiladas 1565 vicuñas con un promedio de producción individual de $416 \mathrm{~g}$ de vellón, duplicando a lo producido individualmente en semicautiverio en el mismo año, que tuvo un promedio de $221 \mathrm{~g}$ de vellón por animal.

¿Quién tiene la información correcta, Rigalt o Vivanco? En cuanto a las opiniones de los otros profesionales consultados, de todas las respuestas, la más sensata e inteligente, correspondía al ingeniero Juan Chávez Cossío, quien dijo sin ambages que: "a la vicuña hay que aprovecharla de una manera global y en su contexto natural". No comento las otras opiniones, ya que las considero, en algunos casos interesadas, y en otros inconsistentes, lo que nos indica la falta de ideas y de conocimiento.

En mi opinión, el sistema de semicautiverio es el más aberrante, ya que consiste en construir alambradas abarcando, por lo general, una extensión de tierras limitada para luego mediante los chakus atrapar a las vicuñas en silvestría, trasladarlas a esas superficies cercadas, depredadas y con escasos recursos hídricos. Sin embargo, estando ya encerradas en estas pasturas, también están sujetas a un "pequeño chaku" para dirigirlos a los corrales de encierro y así, cada vez que quieren esquilar, someterán a un gran estrés y a la desorganización social y territorial de las vicuñas presas. El arreo de las vicuñas no debería manejarse como el arreo de ovejas o cabras, ya que requiere de mucha gente vociferante, tremendamente ruidosa, tratando de dirigirlos a los embudos. Esto aumenta el nerviosismo de los animales al verse cercados, también la muerte de algunos ejemplares cuando se rompen el cuello al embestir las instalaciones fijas (muertes que se ocultan a la vista de los asistentes al chaku). El largo encierro por la esquila y las ceremonias que se hacen para los turistas -sangrando a algunas vicuñas para luego pintarles las cara con su sangre a los gringos sorprendidos para que, según ellos, tengan la fortaleza y la velocidad de las vicuñas- cuando, por el contrario, el encierro debió ser lo más breve para disminuir el estrés.

Existía en el pasado la costumbre de que en los cuarteles del ejército en las serranías hubiera una vicuña de mascota, la cual andaba libre en los cuarteles con actitud muy agresiva hacia los adultos civiles y en especial a los niños. Estos animales eran simplemente amansados (domados), mas no domesticados. La tendencia moderna, ecológica para la vicuña es dotar a estos animales de las Ilamadas "cinco libertades" (Bonacic y Gimpel, 2008):

1. Libres de hambre, de sed y de malnutrición

2. Libres de turbaciones e incomodidades

3. Libres de dolor, lesiones y enfermedades

4, Libres para expresar su comportamiento normal, y

5. Libres de temor y peligro

En cuanto a la domesticación del venado rojo al que se refiere Vivanco, este junto al gamo común o europeo (fallow deer en inglés) (Dama dama), han constituido desde el medioevo en 
Inglaterra y en otros países europeos, fuente de sabrosa carne (venison en inglés) a las poblaciones. Desde esa época hasta el presente, el venado rojo se encuentra en corrales amplios de manejo, como en el caso de Argentina (Pordomingo, 1994) y también, en los llamados parques o cotos de caza en una suerte de clausura, con gente (guardaparques) que se ocupaba de su cuidado y caza. Sin embargo, no ha habido cambios en la morfología ni el color de los venados para considerar que estaban domesticados. Más aun, el venado rojo ha sido cruzado con el wapiti (Cervus canadensis) o alce de las Montañas Rocallosas. Este venado también es sometido a encierros, dobla en peso al venado rojo, y además producen el velvet (terciopelo, piel agamuzada que recubre los cuernos en crecimiento), muy requerido por la gente de Asia, por sus cualidades vigorizantes sexuales. Los híbridos entre estos dos cérvidos son de mayor productividad, que los padres. Más aun, Jaczewski (1976) descubrió que se podía inducir el crecimiento de cuernos en las hembras y así aumentar la productividad del velvet. El venado de cola blanca (white-tailed deer en inglés) es también una especie silvestre que está siendo manejada adecuadamente en EUA y en Canadá (Barber y Dobbs, 1997).

El biólogo evolutivo Reed (1981) de la Universidad de Illinois en Chicago, EUA, nos dice que los animales con mayores características para ser domesticados son los cérvidos. Una importante lectura para entender mejor los pros y contras del manejo (farming deer) de estos animales es el artículo de Fletcher (2001)

\section{Perspectivas y recomendaciones}

Queda claro entonces que las vicuñas (Vicugna vicugna mensalis o Vicugna vicugna vicugna) no pueden ser domesticadas. En Suecia, existe un animal silvestre de muy buena carne que es el moose o alce nórdico (Alces alces) que hay que cazarlo en las temporadas y en el número que ha sido estudiado por sus especialistas en ecología y forestería, y que representa el $30 \%$ del consumo anual de carnes, en ese país de diez millones de habitantes. Las poblaciones de estos animales se mantienen estables, y se los alimenta en invierno con vehículos trineo que van colocando heno de mezclas de leguminosas y gramíneas, sobre la nieve. Los animales no bien ven a los vehículos de reparto, se acercan a pocos metros de los vehículos; de esta manera evitan la pérdida de peso de las madres en invierno, y mejoran la natalidad de crías, manteniendo una población saludable y estable. Una experiencia del IVITA de la UNMSM en la Estación de La Raya era distribuir, a lo largo de las alambradas donde se apiñaban las vicuñas y las pacovicuñas, ensilaje de avena, que a juicio y experiencia de los profesionales del IVITA y de los cuidantes de estos animales, era el forraje por excelencia para ellos. Muy temprano en la mañana todos estos animales encarcelados ya estaban esperando su ración junto a las alambradas. ¿Hay alguien en el Perú que haya recogido esta experiencia y la aplique a gran escala?

\section{Crianza en semicautiverio en otros países}

Esta crianza en semicautiverio se aplica también en Argentina (Estación Experimental de Abrapampa, Jujuy) así como en otras áreas de las punas jujeñas (Rigalt, 2011). Existe un informe de Canedi (1995), cuyo contenido se refiere al crecimiento de las vicuñas en cautivi- dad, producción, nivel técnico y recursos humanos, así como mercados para la fibra de vicuñas. En Chile hay una tendencia en mantener a las vicuñas en silvestría, aunque ensayaron algunos "chakus modernos" con fines de estudio de los efectos del acorralamiento, captura esquila y liberación (Sarno et al., 2009). Chile tiene varias reservas de vicuñas, entre las que sobresale la Reserva Nacional de Vicuñas de la provincia de Parinacota (Parque Lauca). Ecuador ha reintroducido la vicuña ya extinguida en ese país en los páramos del Chimborazo con ayuda del Perú y Chile; y Bolivia tiene establecidas dos Reservas Nacionales de Vicuñas, la de Ulla-ulla y la de Nazacara (INFOL, 1980). Ojalá que estos dos últimos países mencionados aprendan de nuestros errores.

\section{Algunas propuestas para el uso sustentable de la vicuña}

Para no pecar de escribir solo críticas, propongo algunas alternativas a la "solución del problema vicuña":

1. Dejar a las vicuñas en su estado de libertad total de desplazamiento y reproducción, y crear un sistema de control de caza furtiva con ocasionales chakus con fines de estudio de los efectos del acorralamiento, captura, esquila y liberación según la topografía de la zona, y eliminar a los grupos de machos y animales enfermos o viejos. Esto último, previo a una amplia difusión y convencimiento a la población del país, para evitar el mayúsculo escándalo a Proyecto Especial del Dr. Brack, cuando la prensa publicó las carcasas de vicuñas colgadas en el matadero de La Molina. Se puede monitorear el grado de estrés con muestras pequeñas de las heces frescas o tomadas del recto de algunos animales (Arias, et al., 2013).

2. Usar la transferencia de embriones interespecífica para transferir embriones de vicuñas a vientres alpaca, de manera que nacerían junto a las alpacas y así podría manejarse mejo dentro de un rebaño de animales domésticos mansos. Esto hay que experimentar para evitar que, factores epigenéticos, cambien ,para mal, la finura de la vicuña. En Temuco, Chile, en la Hda. de la Dra. Alejandra von Baer, vi un chulengo o guanaquito, nacido por transferencia de un embrión de guanaco, en vientre llama, y se le veía tan manso como las crías de llama. Claro que éste es el caso de un solo chulenguito, por lo que hay que experimentar en mayor número; no tengo información del comportamiento del guanaquito en estado adulto. Sumar $\mathrm{J}$ (2013) describe la transferencia interespecifica en los camélidos domésticos, y se puede ensayar embriones de vicuña en vientre alpaca y/o llama. Bunch et al. (1977), describen la exitosa propagación de ovinos salvajes, mediante la trasferencia interespecifica.

3. Existen hoy en biotecnología nuevas y avanzadas técnicas no-invasivas o poco invasivas. Como el monitoreo de hormonas reproductivas en las heces, orina y saliva, la inseminación artificial, transferencia de embriones y fertilización in vitro, criopreservación de los espermatozoides, de embriones y oocitos, de tejidos gonadales, sexage de espermatozoides, transferencia nuclear, y la clonación de células somáticas, etc. (Pukazenthi et al., 2004; Ptak et al., 2002). Hay también información para producir blastocistos in vitro y transferirlos a otros recipientes (Takagishi et al., 2003). 
4. Ensayar en alguna comunidad que tenga vicuñas en cautiverio, con suplementación de forrajes de buena calidad. Hay observaciones en animales mantenidos en zoológicos, y de costumbres territoriales, que la sobreoferta de alimentos evita las confrontaciones de machos, y mejora notablemente los índices de natalidad.

Emulando a la juventud francesa de Mayo de 1968, que pintó en los muros de Paris, La imaginación al poder, en protesta por mejores condiciones de vida, quisiera pintar en las mentes de los futuros especialistas en vicuñas la imaginación para la vicuña.

\section{Bibliografía}

Arias, N. M. Requena y R. S. Palme, 2013. Measuring faecal Diamond, J., 1981. Zebras and the Anna Karenina Principle. glucocorticoid metabolites as non-invasive tool for What can Tolstoy teach us about our failure to montoring adernocortical activity in South American

Barber, D y S. Dobbs, 1997. White-Tailed Deer, Financial Diamond, J., 1999. Zebras, unhappy marriages, and the Anna Sroduction Sustainable Production. Branch,

steel. Chapter 9. Northon \& Company (Eds.). NY. London.

Bonacic C. y J.Gimpel 2008. Five Freedoms. Alpaca World Fletcher, T. J., 2001. Farmed deer: new domestic animals

Bosch, P.C. y Svendsen, G.E., 1987. Behaviour of male and female vicuña (Vicugna vicugna Molina 1782) as relation to reproduch
$68(2): 425-429$.

defined by controlled breeding. Reproduction. Fertil.
definestic defined by contro

ray, A. R., 1974. Deer Farming: Red Deer. Farm Production Hofmann, R. K. et al., 1983. El manejo de vicuña silvestre. and Practice. Ministry of Agriculture and Fisheries,

Buncch, T. D., W. C. Foote y B. Witaker, 1997. Interspecies Ovum Transfer to Propagate Wild Sheep. Journal of Wild I Management, 41(4): 726-730.

Calderón-Lynch, A., 1956. La vicuña. En: Informaciones 1 Dirección de Ganadería. Crianza y Explotación de los Auquénidos Peruanos. Ministerio de Agricultura. Lima, perú, pp. 6-8.

Tomos 1 y 2. Publicado por Deutsch Gesellsshartt fur Technische Zuzammenarbeit (GTZ) GMBH. (Sociedad Alemana de Cooperación Técnica, Eschbom).

INFOL, 1980. Comunicaciones de la vicuña. Centro de Documentación del Convenio Multinacional

Jaczewski, Z., 1976. The Induction of Antler Growth in Female Red Deer. Boletín de la Academia Polaca de
Ciencias, XXIV(1). Kadwell, M. et al., 2001. Genetic analysis reveals the wild En: Canedi, A. A. (Ed). Bioeco situación de la Vicuña. de las poblaciones de Vicuñas en la Provincia de Jujuy, Argentina. Informe Estado de Avance año 1995. Universidad Nacional de Jujuy, Argentina. ancestors of the llama and alpaca. Proceedings
Royal Society of London B., 268: 2575-2584.

incoln, R., Y. Boxshall y P. Clark, 1998. Dictionary of Ecology, Evolution, and Systematics. Cambridge University Press.
Maccagno, L. 1931. Domesticación, Producción y Explotación de la Vicuña. Boletín de la Dirección de Agricultura y Ganade.

Moore, G.H., 1979. Deer: Wapiti hybrids, mating, calving and growth rate. Farm Production \& Practice. Ministry and growth rate. Farm Production \& Practice. Ministry
of Agriculture and Practice. Wellington, New Zealand.

Oteiza-Fernández, J. y J. R. Carmona Medero, 1993. Diccionario de Zootecnia. Editorial Trillas, México.

Pordomingo, A., 1994. Aspectos reproductivos del Ciervo Colorado: Para ir conociendo las nuevas alternativa

Ptak, Q, M, et al., 2002. Preservation of the Wild Europea Mouflon: The First Example of Genetic Management Using
a Complete Program of Reproductive Biotechnologies. Biology of Reproduction, 66: 796-801.

Pucazhenthi, B. D. y D. E.Wildt, 2004. Which reproductives tecnologies are most relevant to studying, managin and conserving wildlife? Reproduction, Fertility and Development, 16: 33-46.

Reed, C.A., 1981. The beginning of animal domestication In: Mason, J.J (Ed.) Evolution of Domesticated Animals. Longman Publishing Company.

Rigalt, F., 2011. Manejo de la Vicuña en la República de Argentina. En: VII Congreso de la Asociación Latinoamericana de Especialistas en Pequeños

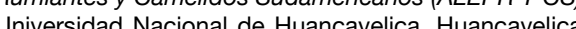
Perú, pp. 27-32. vicuñas domesticas formadas a base de cruces de vicunas domesticas formadas a base de cruces de alpaca de desecho. Lanas $y$ Lanares, 17 M: 8

Salinas, F. V. Residencia y Comportamiento de la Vicuña. Congreso Mundial sobre Camelidos Sudamericanos.

rno, R. J. et al., 2009. Molecular genetic evidence for social group disruption of wild vicuñas (Vicugna vicugna) Research, 84: 28-34.

Sumar, J., 1972. El Criadero de Vicuñas de Cala-Cala, Puno. Anales de la ll Convención Inter.Sobre Camélidos Altiplano, Puno, Perú.

Sumar, J. et al., 1972-1977. Centro Regional de Preservación de Camélidos Sudamericanos de Cala-Caltura, Zona Agraria XII, Puno.

Sumar, J., 1992. Módulo de Producción de Pieles de PacoPerú.

Takagishi, K., K. Momozawa y Y. Fukuda, 2003. In Vitro Production of Blastocyst and Embryo Transfer in Mammals. Journal of Mammalogy: Ova Res., 20: 2-6.

Vivanco, W., 2010. Carta abierta a quien salva a la Vicuña. Wheeler, J.C., 1996. Domestication de la Vicuña. En: XIII 3, pp. 105-106.

Wheeler, J.C., 1955. Evaluation and present situation of the South American Camelidae Biological Journal of the Linnean Society,54: 271-295.

Zúñiga-Velando, M. A., 2007. La vicuña y su manejo técnico. Universidad Alas Peruanas, Comunidad Campesina de Distrito de Lucanas. 
Factores e indicios

de conservación in situ

\section{y evolución bajo domesticación de maíz en México en el último siglo}

Rafael Ortega Paczka, Baruch Xocoyotzin Chamorro Cobaxin

\section{Resumen}

Donde persiste la agricultura tradicional se sigue presentando evolución bajo domesticación de las especies cultivadas. En México, actualmente dos millones de familias de agricultores seleccionan su semilla de la cosecha anterior, aun cuando el gobierno mexicano y empresas desde hace setenta años han impulsado la adquisición de semillas comerciales. En tal contexto, el principal objetivo de este ensayo es llamar la atención sobre la urgencia por establecer firmes políticas públicas que estimulen la continuidad de la evolución bajo domesticación de maíz en las mejores condiciones. Ello requiere a cciones para asegurar semilla de buena calidad, con buenas características de adaptación al ambiente natural y agrícola, con características ligadas a buenos rendimiento y alta calidad del grano, así como mejores precios para la parte de la cosecha que comercializan. En cien años: a) se ha ampliado la superficie y el rango de condiciones en donde se cultiva maíz; b) ha aumentado el número de quienes seleccionan semilla como consecuencia de los repartos agrarios y colonización de tierras, o disminuido debido a la migración, principalmente de los jóvenes; c) han aumentado los desastres agrícolas (sequías y huracanes); d) se han llevado a cabo políticas públicas y de mercado que incentivan la siembra de algunas variantes de maíz; e)se han puesto en práctica políticas favorables a la adopción de maíces mejorados, maquinaria agrícola, fertilizantes y herbicidas, y f) han aumentado las consecuencias negativas asociadas aldesarrollo de mercados para ciertos tipos de maíz. Al inicio de la década de los cuarenta surgió interés en la conservación y uso de la diversidad de maíz de México, cuando se evidenció que los maíces mejorados norteamericanos no eran útiles para el mejoramiento de maíz de México. Durante la segunda mitad del siglo pasado se iniciaron campañas para adoptar semillas mejoradas, fertilizantes químicos, agroquímicos y maquinaria agrícola (la llamada Revolución Verde), y un desprecio hacia las técnicas y prácticas campesinas tradicionales.

En la actualidad existe consenso acerca de que el ancestro del maíz fue el teocintle; sin embargo, poco se investiga sobre el papel actual de las poblaciones de teocintle en la evolución reciente de los maíces nativos de México. Existen múltiples evidencias de que con frecuencia ocurren cruzas de poblaciones nativas de maíz con teocintles compatibles con maíz, pero los agricultores consideran al teocintle una maleza que hay que eliminar y en la selección de se- 
milla eliminan mazorcas con rasgos de teocintle. Uno de los aspectos más destacados de la diversidad de maíz en México es que cada población nativa tiene escasa adaptabilidad a ambientes diferentes de donde se cultiva, pero la enorme diversidad de poblaciones nativas en su conjunto está adaptada a una gran diversidad de ambientes. Es muy importante estudiar si en ese desplazamiento y adaptación a condiciones más limitantes ha jugado un papel importante la acumulación de numerosas mutaciones.

La categoría taxonómica "raza" para maíz fue primeramente propuesta y definida por Anderson y Cutler en los años cuarenta, y posteriormente precisada por Hernández-Xolocotzi, quien planteó que una raza de maíz es una población con un conjunto sustancial de características en común que la distinguen como grupo y la diferencian de otras poblaciones, con capacidad de transmitir con fidelidad dichas características a las generaciones posteriores en un área ecológica específica. En este trabajo consideramos que una raza no es una "población", sino un conjunto de poblaciones distribuidas en un área, generalmente grande, que, por lo regular, no permite cruzamientos. Una raza incluye poblaciones nativas que difieren en caracteres que visualmente se detectan con facilidad, como textura y color de grano, y caracteres como adaptación a un ambiente particular o en su rendimiento. No es una categoría satisfactoria para describir la diversidad que mantiene una familia o una comunidad rural o que se encuentra en un área geográfica: Es necesario definir categorías de clasificación inferiores, tales como subrazas, tipos y poblaciones locales específicas. Hay consenso en que en México y en Guatemala se encuentra el centro de origen de domesticación y principal centro de diversidad de maíz. Los datos más aceptados son la existencia de 59 o 64 razas de maíz en México. Si bien en regiones tropicales y de alturas intermedias se reportan pérdidas considerables de maíces nativos, en el país -en su conjunto- recientemente se colectaron todas las razas de maíz reportadas por trabajos anteriores, lo que sugiere que una parte considerable de la diversidad de maíz con que contábamos hace setenta años aún se mantiene.

Dada la enorme diversidad dentro y entre poblaciones nativas de maíz en México, así como el frecuente entrecruzamiento espontáneo y dirigido entre dichas poblaciones, la selección de semilla para mantener la identidad de las poblaciones de maíz y mejorar sus características juega un papel fundamental en la conservación in situ y su evolución. Aunque el cruzamiento entre poblaciones nativas locales y con introducciones exóticas son también muy relevantes. En cambio, aunque no está bien estudiado, no parece que el flujo génico de los teocintles, parientes cercanos hacia el maíz haya sido un factor de evolución sobresaliente en el último siglo. En algunas áreas cálidas bajas, así como en algunas de alturas intermedias los maíces mejorados han sustituido en parte a la diversidad nativa, especialmente por maíces de grano blanco usados para tortillas, sin igualarlos en calidad de los alimentos. En cambio, casi no han sustituido a los maíces nativos para usos especiales tradicionales, ni a los que se cultivan en amplias regiones con limitantes de suelo o bajas temperaturas. Por otro lado, en amplias regiones las generaciones avanzadas de maíces mejorados combinados con maíces nativos forman parte del patrimonio biocultural de las comunidades de agricultores, campesinos e indígenas que manejan esas poblaciones como lo hacen con los maíces nativos.

Se encontraron evidencias de que los agricultores recuperan la diversidad de maíz que tenían antes de sequías o tormentas tropicales devastadoras, pero también casos en los que se pierden maíces valiosos. Se encontraron procesos de deterioro de la diversidad como consecuencia de destrucción de unidades de producción de vanguardia por repartos agrarios. Son reducidos los esfuerzos gubernamentales para conservar in situ los maíces nativos y en general la cultura tradicional, en cambio se ha favorecido con abundantes recursos la adopción de maíces híbridos. La conservación in situ y la evolución bajo domesticación del maíz en manos de agricultores debe ser protegida e impulsada por el Estado Mexicano y la comunidad internacional porque esos procesos son fundamentales para la subsistencia de cerca de dos millones de familias indígenas, campesinas y agricultores mestizos del país, así como porque esos procesos constituyen gran parte de la evolución del maíz en el mundo.

Palabras clave: conservación in situ, domesticación, maíz,

México, recursos genéticos prioritarios, teocintles, Zea spp.

\section{Introducción}

Se ha supuesto que bajo conservación in situ las especies vegetales domesticadas en parte se conservan pero a la vez siguen evolucionando, lo que es de gran trascendencia para la humanidad. En ocasiones parte de la evolución bajo domesticación de las especies vegetales y animales se puede observar sin mucha dificultad, de hecho la teoría de evolución que formuló Darwin en parte se construyó observando los considerables avances obtenidos en la selección y formación de razas de animales domésticos en el siglo XIX. Pocos trabajos han intentado ilustrar que en el presente, donde persiste la agricultura tradicional, se sigue presentando evolución bajo domesticación de las especies cultivadas, así como las causas que favorecen o son contrarias a dicha evolución.

Aquí se presenta un ensayo, basado en datos históricos, cuantitativos experimentales, anecdóticos, y de los censos correspondientes al último siglo, que sugieren una gran trascendencia de la labor de selección de semilla, introducción y experimentación de nuevas variantes, as como de otras prácticas de manejo de los maíces locales nativos (llamados en México "maíces criollos"). Esta práctica se realiza por alrededor de dos millones de familias de agricultores medios, campesinos mestizos e indígenas que en México seleccionan su semilla cada año a partir de su cosecha del año previo. Su importancia radica no solo en que así se autoabastecen de semilla, sino también a que contribuyen significativamente a la conservación de la diversidad de maíz y a su evolución bajo domesticación; lo que es muy importante siendo México el centro de origen y diversificación primario del maíz y siendo esta especie cultivada la más importante en ese país desde muchos puntos de vista. Desafortunadamente el gobierno mexicano en general y las instituciones públicas y empresas en particular, desde hace al menos hace 70 años han estado impulsando la adquisición cada ciclo de cultivo de semillas comerciales, generalmente híbridas aún para condiciones en que son superadas por poblaciones nativas; no obstante, como diría el Maestro Efraím Hernández-Xolocotzi, (comunicación personal), "esos campesinos necios han seguido con su labor cada ciclo agrícola".

Los estudios de diversidad de maíces de México son muy abundantes pero ha habido períodos en que se ha prestado poco interés al tema. En comparación a los estudios de diversidad, 
los trabajos que han tratado de registrar los procesos de mejoramiento de maíces nativos por agricultores e incluso por científicos son relativamente menos abundantes. El principal objetivo de este ensayo es hacer una revisión de estos dos tipos de trabajos y llamar la atención de la urgencia e importancia de que se establezcan firmes políticas públicas que estimulen dichas labores, tanto por su valor para el mejoramiento genético futuro como por la importancia que tiene para los propios agricultores que la realizan, ya que les asegura: semilla de buena calidad; buenas características de adaptación al ambiente natural y agrícola; característica ligadas con rendimiento y calidad del grano per se, y de los alimentos que se elaboran con ellos, así como mejores precios para la parte de la cosecha que comercializan.

La profundidad de tiempo a lo largo de la cual se intenta explorar la evolución bajo domesticación del maíz en manos de agricultores en México abarca aproximadamente cien años (1915-2015) y entre los factores que más han influido en esa evolución parecen ser especialmente relevantes: a) la ampliación de la superficie y principalmente del rango de condiciones en donde se cultiva maíz; b) el aumento o disminución del número de quienes seleccionan semilla cada año como consecuencia de los repartos agrarios y procesos de colonización de tierras que tuvieron lugar en diferentes ritmos entre 1915 y 2010; la disminución relativa de miembros de las familias en actividades agrícolas debido a asistencia a escuelas de niños y adolescentes, la migración a ciudades del país y hacia el extranjero principalmente de los jóvenes; c) el incremento de desastres agrícolas, especialmente fuertes sequias y huracanes y la labor de los agricultores para recuperar sus semillas perdidas; d) los efectos de políticas públicas y de los mercados al incentivar algunas variedades y desincentivar la siembra de otras variantes de maíz; d) los efectos de políticas publicas que favorecen la adopción de maíces mejorados así como de uso de maquinaria agrícola, fertilizantes y herbicidas; e) consecuencia de desarrollo de mercados para los diferentes tipos de maíz.

Además de lo anterior, para ejemplificar algunas de las condiciones en que evolucionan los maíces nativos, en este ensayo se recurre a mencionar lo reportado en la literatura sobre e proceso de evolución bajo domesticación a que estaban sometidos algunos de los maíces criollos que fueron seleccionados como material de partida para el mejoramiento genético en la década de los cuarenta del siglo pasado. Esta fue una elección que en buena medida realizaron los técnicos mexicanos del Antiguo Instituto de Investigaciones Agrícolas, quienes fueron obligados por el gobierno mexicano a proporcionar dichos materiales a sus competidores: Ios fitomejoradores de la Oficina de Estudios Especiales, financiada en parte por la Fundación Rockefeller.

\section{Períodos de interés y abandono en la diversidad de maíces nativos}

En el último siglo, que es el período que intenta cubrir este ensayo, ha habido épocas de mayor interés que otras en la diversidad de maíz de México tanto por parte de los medios intelectuales, como del gobierno y la sociedad mexicana. Entre 1910 y 1943 hay obras que señalan interés en el estudio de la diversidad de maíz de México. Por ejemplo, los trabajos de Chávez (1913), Khankhoe (1930) y los de N. I. Vavilov (Kuleshov, 1930; Vavilov, 1931). Pero, indudable- mente, comparado este tema con otros como la demanda y repartición de tierras, el interés público en la diversidad de maíz en México y su conservación fue muy reducido en esos años.

Hubo considerable interés en la diversidad de maíz de México a principio de la década de los cuarenta del siglo pasado, cuando quedó en evidencia de que los maíces mejorados norteamericanos no eran útiles como base para el mejoramiento genético de maíz de México (Limón-García, 1945). Y sobre todo el interés creció de 1944 a 1951 cuando se iniciaron los trabajos de la Oficina de Estudios Especiales, institución producto de la colaboración de la Fundación Rockefeller y la Secretaría de Agricultura de México, uno de cuyos primeros frutos fueron la colección de "alrededor de 2,000 muestras de maíces nativos" y la obra "Razas de maíz en México" (Wellhausen et al., 1951).

A principios de la segunda mitad del siglo pasado se iniciaron en México las campañas para adopción de semillas mejoradas, fertilizantes químicos, otros agroquímicos y maquinaria agrícola. Y con base en los primeros éxitos obtenidos en el país con esas innovaciones, pero sobre todo con base en los éxitos que se estaban obteniendo en Estados Unidos con los nuevos paquetes tecnológicos, afloró una prepotencia de los técnicos relacionados a esos programas y un desprecio en relación a la técnicas y prácticas campesinas tradicionales, entre ellas la selección de semilla. Una manifestación de ello es el siguiente párrafo escrito por el doctor Oscar Brauer, entonces Director del Colegio de Postgraduados

el aumento de la producción solo podrá alcanzarse cuando se apliquen a la agricultura todos los conocimientos científicos máximos. "...Si se estudia y se trabaja y los resultados se aplican al desarrollo económico de la agricultura, la agricultura será progresista y los rendimientos de la tierra serán más altos. Si la agricultura se sigue manejando con la idea que es un arte, o cualquier otra cosa, y que su producción depende de la voluntad de Ceres o de Xipe, la producción seguirá donde estaba cuando

se adoraba a esas diosas. (Brauer-Herrera, 1968)

Este período de confianza desmedida en la ciencia agrícola formó parte de lo que después se denominó "Revolución Verde", proceso que incluyó muy diversas medidas de apoyo al desarrollo de la agricultura, entre las que estuvo el acopio gubernamental de las cosecha con precio de garantía. En esta actividad se castigó en el precio de compra a los maíces de color, lo que indujo a muchos agricultores a dejar de cultivar esos maíces o cultivarlos solo para autoconsumo.

Otros apoyos fundamentales a la producción agrícola en general y de maíz en lo particular fue el desarrollo de la industria de los fertilizantes químicos y su venta subsidiada a los agricultores y campesinos, así como el otorgamiento de créditos con bajos intereses.Es de hacerse notar que entre 1954 y fines de la década de los sesenta del siglo pasado hubo poco interés en colectar y estudiar la diversidad nativa de maíz de México, los trabajos se concentraron en obtener híbridos para las regiones de riego y buen temporal, híbridos basados en líneas derivados de unas pocas colectas élite de maíces nativos, así como de introducciones de Estados Unidos y otros países que revolucionaran el tipo de planta y grano (genes de enanismo, androesterilidad, alta calidad o cantidad de proteína, contenido elevado de carotenoides, genes que alteraran considerablemnte la morfología de la planta como de androesterilidad, "braquítico 2" o "tallo cuadrado") (Ortega-Paczka, 1985). 
A fines de los años sesenta del siglo pasado hubo de nuevo interés en los maíces nativos debido a que: a) a pesar de los apoyos en mejoramiento y otros aspectos a las zonas de riego y buen temporal, empezó a ser insuficiente la producción de maíz del país; en 1965 por primera vez se tuvo que importar 40,000 toneladas de este grano, cuando años antes era exportador (CONASUPO, 1988; Villa-Issa, 2011); b) hubo evidencias de que los programas de mejoramiento genético centralizados en cuatro macroregiones no eran suficientes (Muñoz-Orozco et al., 1976) y que se establecieron programas de mejoramiento genético en numerosas regiones de agricultura campesina de temporal, programas que iniciaron con la colecta de maíces nativos; c) el insigne catedrático mexicano Efraím Hernández Xolocotzi y varios de sus colaboradores se dedicaron por varios años a colectar y estudiar los maíces nativos de varias regiones del país (Hernández-Xolocotzi y Alanís-Flores, 1970; Ortega-Paczka, 1973).

A partir de mediados de la década de los ochenta se fue dejando de apoyar a la agricultura en general y a la campesina en lo particular, llegándose a modificar considerablemente e marco legal agrario con las reformas del artículo 27 constitucional en 1992. La adopción de las lamadas "políticas neoliberales" incluyó que se disminuyeran mucho los apoyos a la investigación agrícola, en particular al estudio y mejoramiento de los maíces nativos.

Después de setenta años de considerable impulso del gobierno de las empresas semilleras al uso de semilla híbrida certificada de maíz, en el país solo se siembra con dicha semilla, si acasoen el $22 \%$ de la superficie en el país (Aquino et al., 2001), otro 10-15\% se siembra con generaciones avanzadas de mejorados. La producción campesina y un segmento importante de la producción comercial siguen dependiendo de la semilla obtenida de la cosecha anterior de maíces nativos.

Casi todo el mejoramiento genético "moderno" de maíz en México se ha circunscrito a mejoramiento de maíces blancos para tortillas para condiciones favorables, es decir maíces cultivados en suelos profundos y riego o temporal bueno y eso solo en cuatro macro regiones de país (cálido-húmeda o tropical, cálido seca o subtropical, Valles Altos Centrales y Bajío-Llanos de Jalisco), quedando fuera la mayor parte del territorio nacional que se caracteriza por suelos delgados y/o escasa precipitación, así como todos los tipos especiales de granos de maíz (maíces de color, pozoleros, para forraje, para elotes, para palomitas, para totopos del Istmo de Tehuantepec y para muchos otros usos).

No obstante que en muchas comunidades de México hay evidencias de pérdida de maíces criollos, a nivel nacional el "Proyecto Global de Maíces Mexicanos", coordinado por la CONABIO de 2008 a 2011 (CONABIO, 2011), colectó muestras de todas las razas registradas hace 20, 50 o 70 años atrás, excepto una (palomero de Chihuahua).

En cuanto a conservación de diversidad de maíz se ha apostado a la conservación ex situ en bancos de germoplasma, pero se han registrado problemas y deficiencias frecuentes en bancos de semillas, como en el caso del Banco de Germoplasma del INIA-INIFAP, este ha padecido: períodos de escasez de apoyos (1954-1960, 1979-1989), cambios en estructura y objetivos (1983, 2012, 2014), deficiencias conceptuales y de formación de su personal (1954-1960, 19801983), desdén por la conservación in situ, escasa integración con fitomejoramiento y centros de enseñanza (casi todo el tiempo excepto de 1967 a 1980) (Ortega-Paczka, 1999, 2000).
El movimiento en pro de la conservación in situ de la diversidad de maíces nativos en México ha adquirido recientemente considerable fuerza a raíz de los motivos anteriores, así como por la creciente conciencia ambiental de su población, por la resistencia a la autorización de la siembra de maíces transgénicos y por los trabajos que ha tenido que emprender el gobierno mexicano en relación a la problemática de dicha autorización.

\section{Procesos biológicos y sociales en la conservación in situ y domesticación actual de maíces nativos en México}

Este apartado trata de centrarse en los procesos biológicos que más influyen en la conservación in situ y la evolución reciente de los maíces nativos en México. No obstante, para ubicarlos es necesario también abordar los contextos sociales en que actúan esos procesos biológicos.

\section{Maíces que cultiva una familia campesina cada ciclo}

Un tema de partida sobre conservación in situ y evolución bajo domesticación de maíz es la decisión que hace cada ciclo el agricultor y su familia sobre ¿Qué poblaciones locales nativas o qué maíces mejorados sembrar cada ciclo? (Figura 10.1). Poco se ha estudiado las razones por las que conservan o cambian sus maíces a sembrar los agricultores tradicionales de México. Al respecto, Perales (1998) señala que hay que distinguir entre "variedades mayores"- las

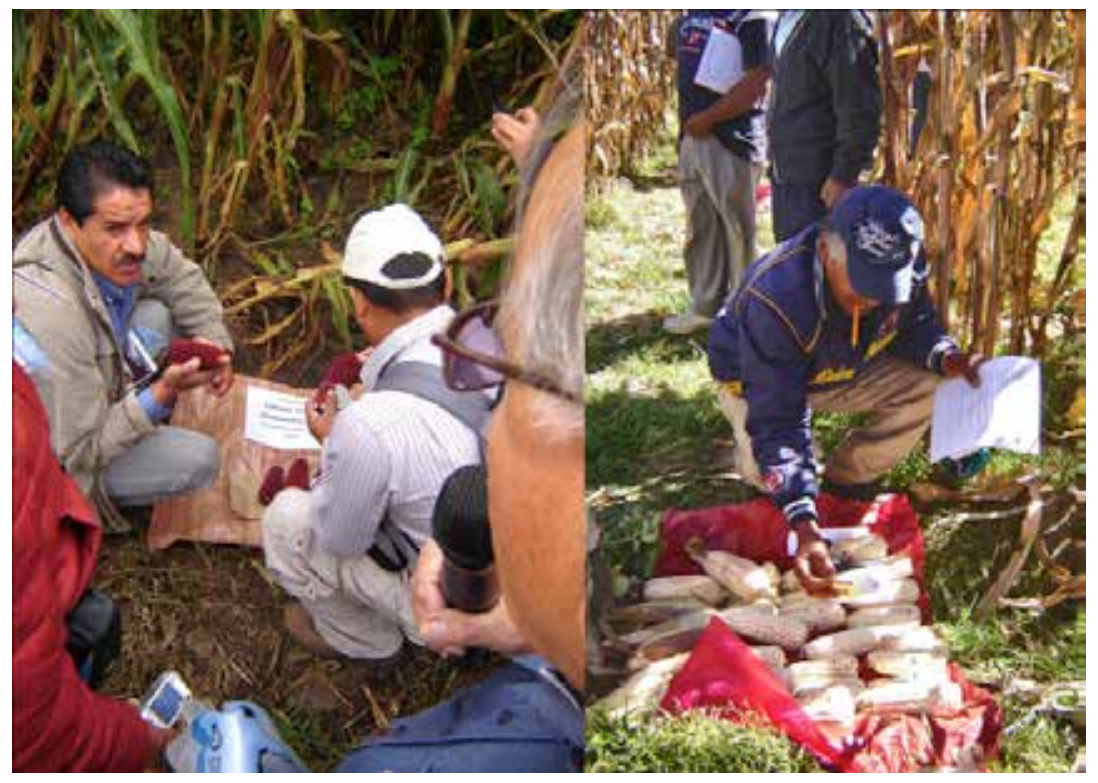

Figura 10.1. Investigación de campo explorando los criterios campesinos para definir las variedades de maíces a cultivar en cada ciclo agrícola. 
que se siembran en mayor cantidad y que con frecuencia al menos en parte se destinan al mercado, cuyo cultivo en lo fundamental está regido por dicho mercado y que por lo tanto con cierta frecuencia cambian- $y$ las variedades "menores" que se cultivan fundamentalmente para autoconsumo, las cuales dependen de la cultura local y por lo tanto generalmente cambian menos. El primer autor de este capítulo considera que por lo menos se debe reconocer un tercer tipo que sería "variedades en experimentación", ya que muy numerosos agricultores cada año cultivan generalmente en pequeñas superficies nuevas variantes ya sea de procedencia local o introducidas de otras regiones.

Es interesante observar que la decisión sobre la "variedad mayor" a cultivar cada año recae generalmente sobre el varón jefe de familia, que generalmente es el más interesado en la producción para la venta, aunque en algunas culturas indígenas las mujeres juegan también un importante rol en la comercialización de maíz. Por lo que toca a la decisión de cuales "variedades menores" cultivar, que son fundamentalmente para autoconsumo en la familia, con frecuencia la esposa y/o madre del jefe de familia influyen mucho.

En cuanto a las variedades en experimentación, se siembran a iniciativa de cualquier miembro adulto de la familia, aunque los que son más propensos a introducir innovaciones en la agricultura son los jóvenes (Rist, 2000)

Muñoz-Orozco (2003) resume de la siguiente manera algunas de las causas de la enorme diversidad de maíz en México:

Se distinguen dos grandes dominios en el patrimonio genético nativo: el de los caracteres relativos a los usos alimentarios esenciales para la supervivencia humana, en donde la muje ha sido determinante, y el de los caracteres adaptativos, esenciales para la supervivencia de la planta y en donde la acción del hombre ha sido decisiva

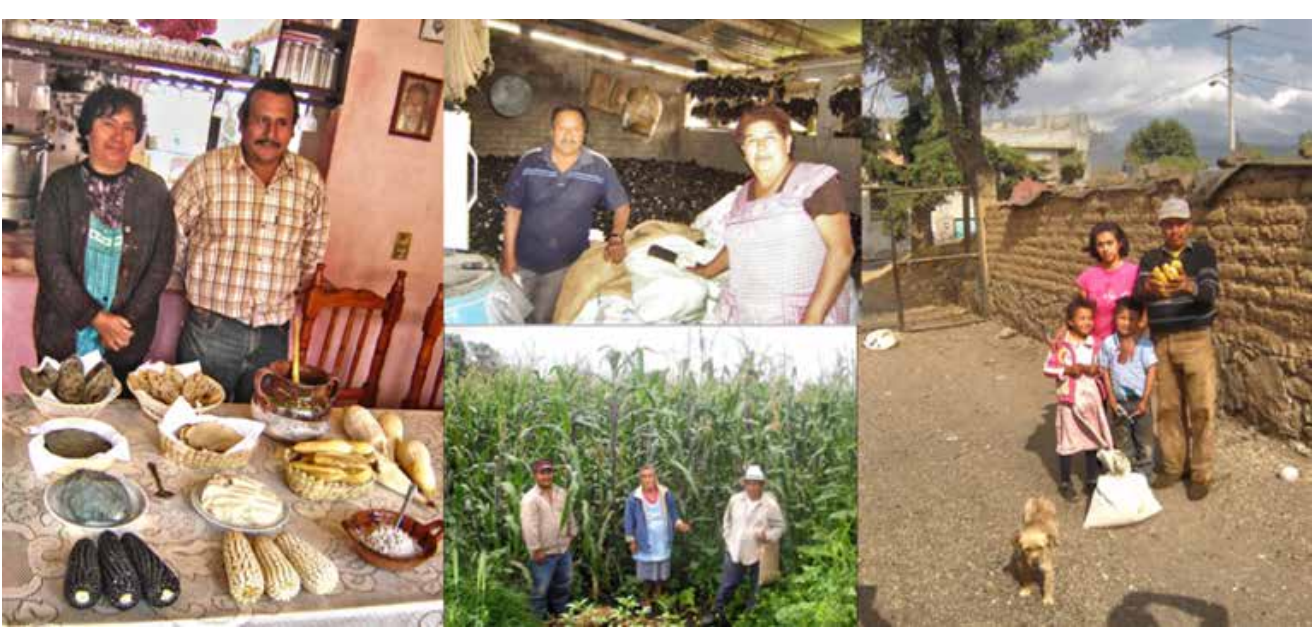

Figura 10.2. La conservación in situ y el estudio de la evolución bajo domesticación de los maíces nativos entre las familias campesinas debe involucrar principalmente a sus miembros adultos, no solo a los jefes de las familias.
Con base en lo anterior propone que los sujetos que conducen la conservación in situ y la evolución bajo domesticación de los maíces nativos son las familias campesinas, principalmente sus miembros adultos, que viven en las comunidades y no solo los campesinos jefes de las familias (Figura 10.2)

Otra conclusión de este apartado es que las poblaciones locales nativas, incluida su diversidad genética interna, son la unidad básica de conservación y evolución bajo domesticación del maíz; no en vano casi todos los bancos de germoplasma ex situ de maíz intentan conservar lo más que pueden muestras de esas poblaciones locales nativas.

Diversidad genética entre y dentro de poblaciones nativas y dentro de cada planta

Cada grano y, por lo tanto, cada planta de maíz de una población nativa generalmente es e resultado de unión de un óvulo de una planta con un grano de polen de otra planta que difieren genéticamente. Así, por lo general, cada planta de maíz es un híbrido diferente, es decir, existe un alto grado de diversidad incluso entre y dentro de semillas o plantas de una población nativa de esta especie cultivada. A su vez, una población nativa local es un conjunto de plantas que se cruzan libremente en un campo de cultivo y que se expresa en la cosecha con cierta diversidad en planta, mazorca y grano (Figura 10.3).

En la mayor parte de México, una familia campesina o de agricultores cultiva cada año más de una población nativa de maíz (Figura 10.4) y en el territorio de las comunidades se cultiva una considerable diversidad de poblaciones nativas (Figura 10.5). Entonces, en el territorio de esa co-

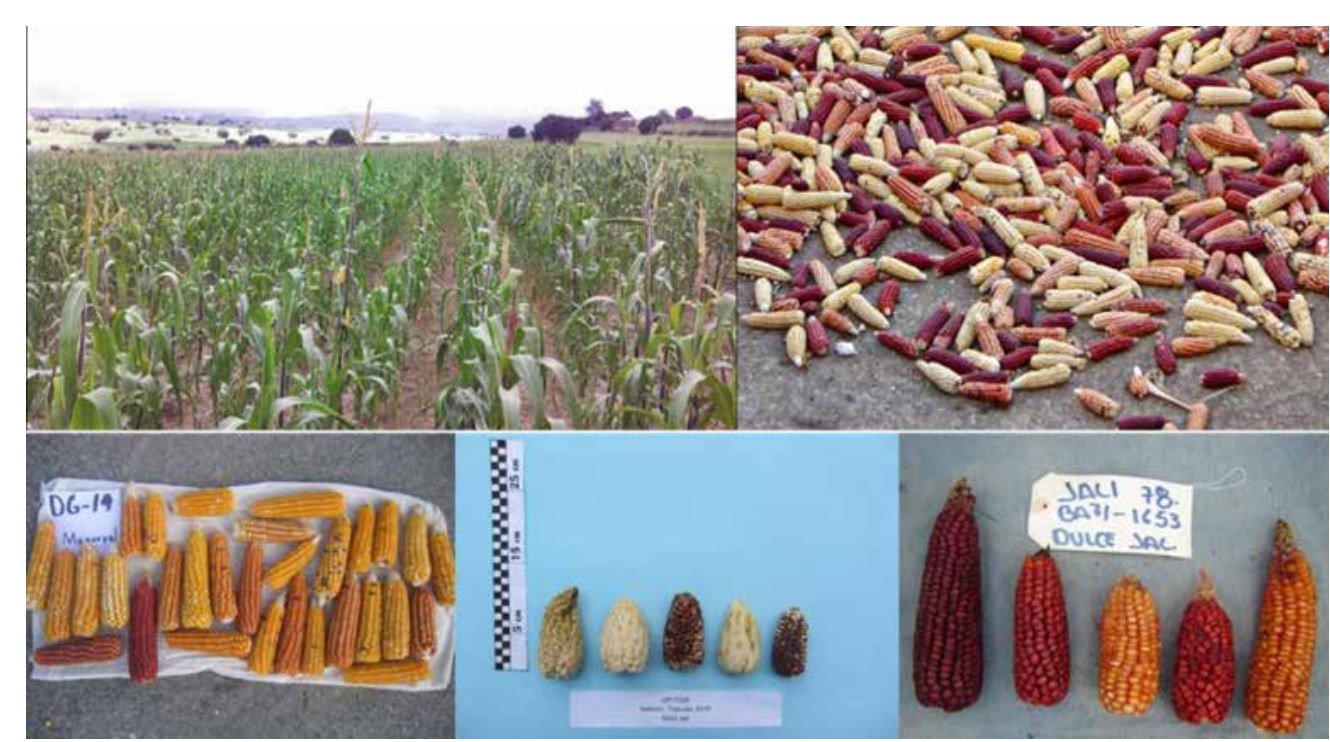

Figura 10.3. Una población nativa local (landrace) es un conjunto de plantas que se cruzan libremente en un campo de cultivo y que se expresa en la cosecha con cierta diversidad en planta, mazorca y grano. 


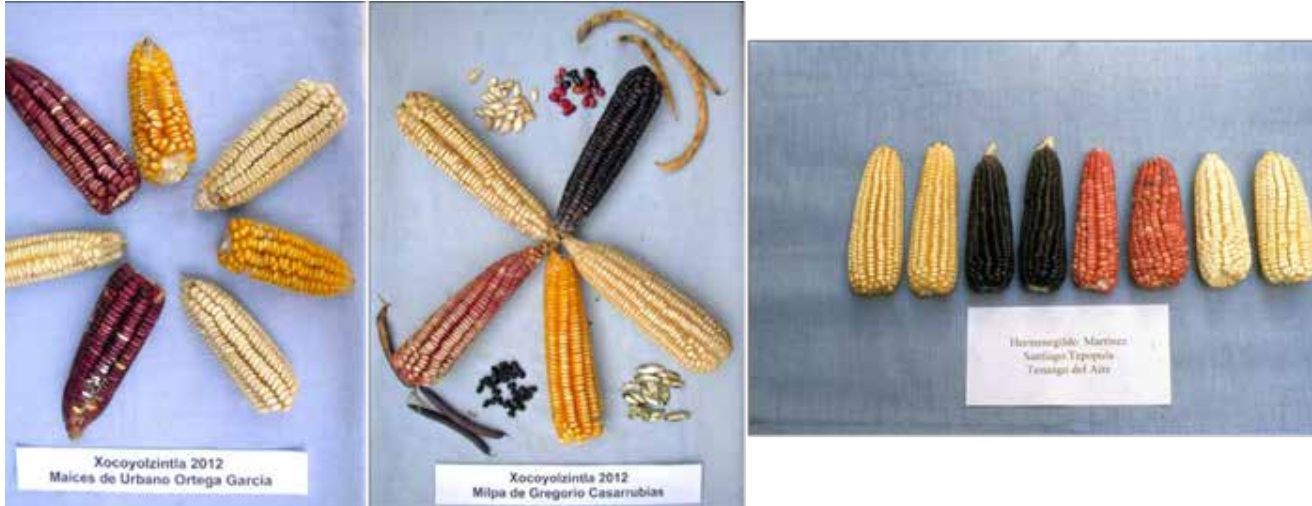

Figura 10.4. Un patrón de manejo de maíz común en la mayor parte de México es que una familia campesina o de agricultores cultiva cada año más de una población nativa de maíz.

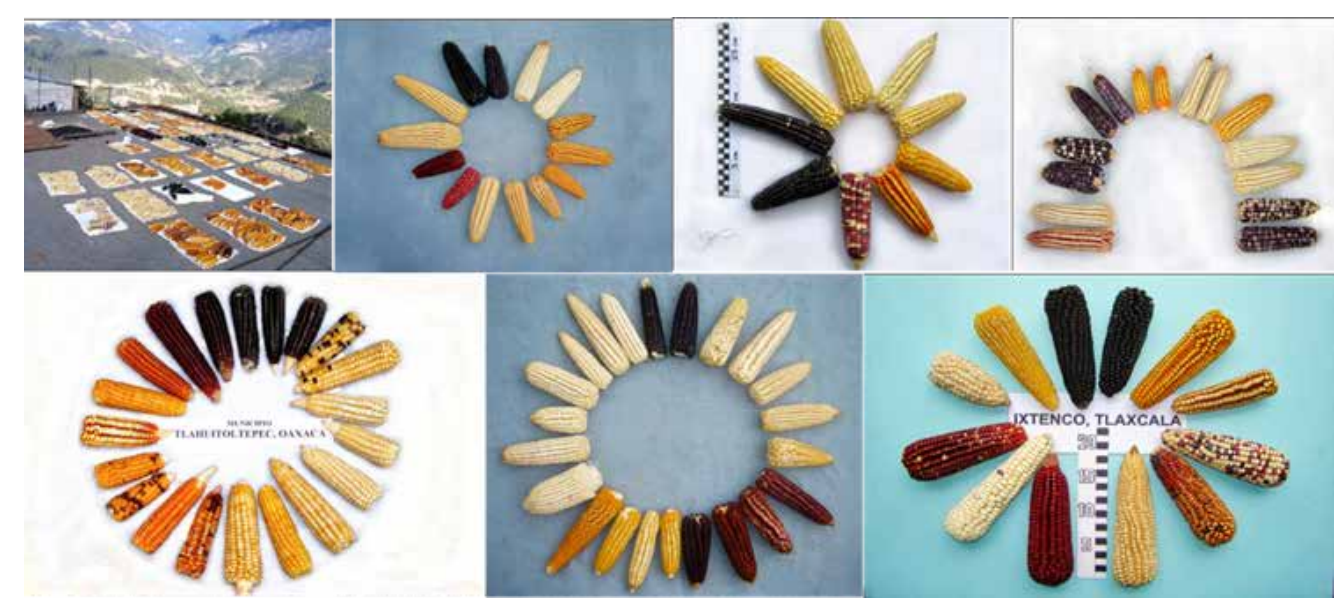

Figura 10.5. En los territorios de las comunidades se cultiva una considerable diversidad de poblaciones nativas de maíz destinadas a cubrir diferentes requerimientos culturales, técnicos y ecológicos.

munidad coexisten diferentes poblaciones de maíz que con alta frecuencia se mezclan por causas como que la población sembrada un ciclo es diferente a la que se cultivó el ciclo anterior y quedaron semillas en el campo. De igual modo, se cruzan con recurrencia por ser vecinas y coincidir en la floración.

Por otro lado, como se verá más adelante, es usual que los agricultores mezclen o siembren en hileras alternas dos poblaciones de maíz para facilitar su cruzamiento y así obtener una nueva población que se siembra varios ciclos y en la cual seleccionan mazorcas segregantes que reúnan los caracteres favorables de las dos poblaciones originales y se eliminen los caracteres desfavorables.
Como producto de estos procesos, las poblaciones locales nativas son bastante diversas, para conservarlas y mejorarlas es necesaria la selección de semilla cada ciclo agrícola.

\section{Esfuerzos campesinos}

\section{por aislar sus poblaciones nativas de maíz}

Frecuentemente los agricultores y campesinos cuentan con diferentes parcelas, por lo que para reducir los cruzamientos y la pérdida de calidad en la cosecha por mazorcas y granos fuera de tipo, siembran a cada población nativa de maíz en un terreno diferente. Desafortunadamente, en muchas regiones de México los campesinos tienen una o dos parcelas muy pequeñas, no obstante, cuentan con numerosas y diferentes poblaciones de maíz -generalmente de distinto color de grano, pero con un ciclo biológico bastante parecido-, razón por la cual se cruzan mucho entre sí. Las mantienen separadas por rigurosa selección de semilla, como la que reportó Anderson (1947) en los Altos de Guatemala.

Resulta menos difícil mantener aisladas poblaciones de diferente ciclo vegetativo, ya que por lo regular, estas no coinciden en la floración porque generalmente se cultivan en diferentes agroecosistemas (riego y temporal, por ejemplo) en terrenos bastante separados, y las ocasionales cruzas no se adaptan a ninguno de los dos agroecosistemas por ser intermedias, asi pues, se eliminan. Cuando, por ejemplo, en el mismo agroecosistema se siembran surcos de un maíz de ciclo corto, para que produzca elotes pronto, dentro de una parcela de un maíz más tardío, no coinciden en floración y no hay cruzamientos.

\section{La selección tradicional de semilla de maíz}

Poco se ha valorado en el país la enorme y crucial labor de cerca de dos millones de agricultores y, con frecuencia, de sus esposas e hijos que al principio de cada ciclo seleccionan la semilla de maíz a sembrar a partir de su cosecha anterior. En general, las poblaciones nativas son bastante diversas a simple vista, dentro de las cuales se seleccionan los mejores individuos. Desafortunadamente casi todos los agricultores hacen la selección de semilla sobre las mazorcas ya cosechadas y almacenadas en su casa o troje, esto trae como consecuencia que la selección humana sea más efectiva para caracteres de mazorca y grano y no de planta, y esto se hace en función del uso que se le vaya a dar a la siguiente cosecha (Figura 10.6). Las características de planta, como los agricultores no las seleccionan, dependen fundamentalmente de la selección que ejerza el medio natural.

Como resultado de un origen cercano o remoto de un grupo de poblaciones nativas de maíz que se manejan en un mismo tipo de agroecosistema en una comunidad (que se siembran en fechas similares, coinciden en la floración) resulta con frecuencia un grupo de poblaciones con características de planta similares (que dependen de la selección ambiental natural y de agroecosisterma particular) pero diferenciadas y separadas en características de mazorca y grano por la selección humana, las cuales generalmente tienen usos diferentes (por ejemplo de grano blanco para tortillas comunes, de color morado para elotes y antojitos de color, de color amarillo para dar a sus animales; Figura 10.7) 


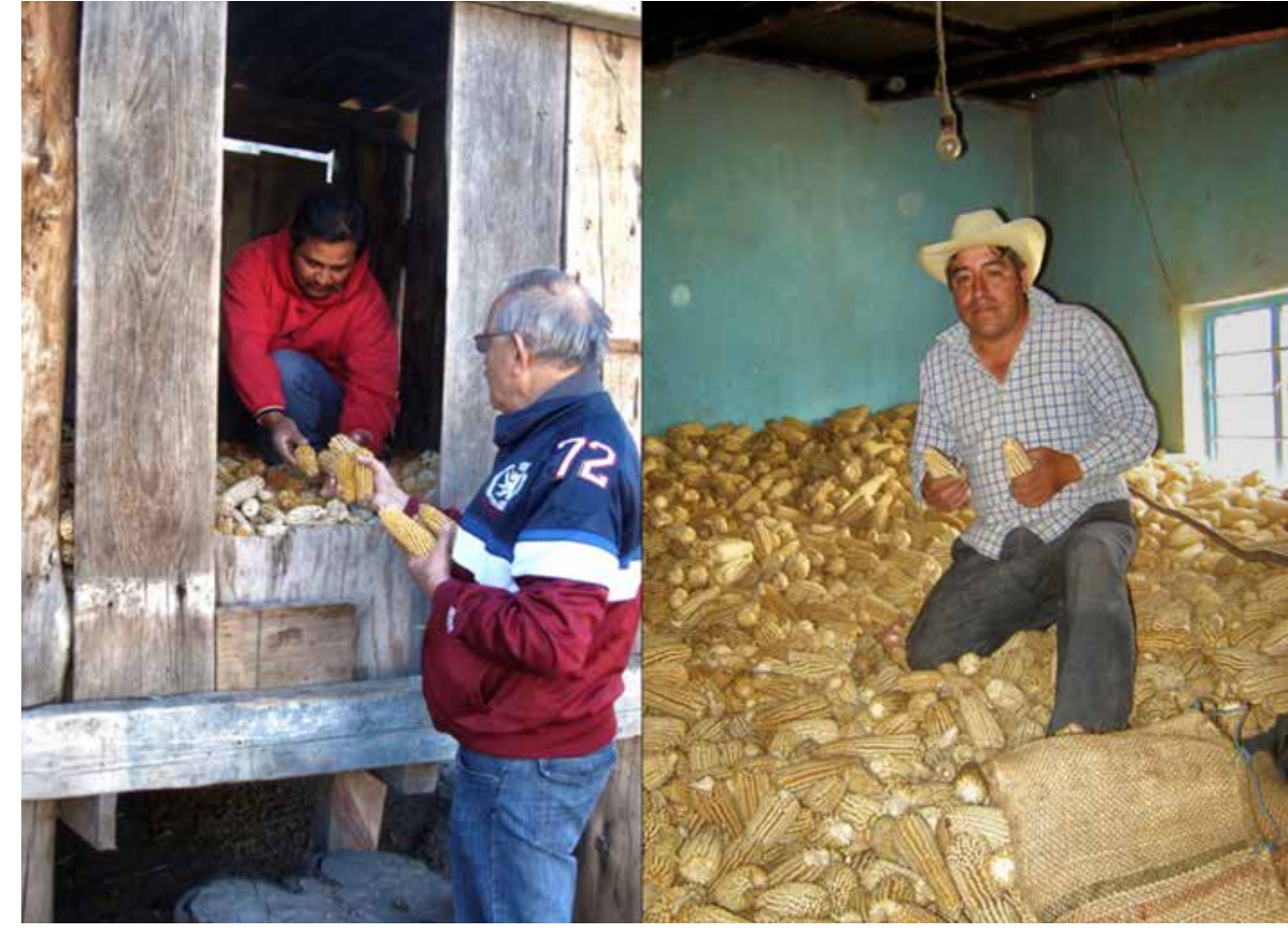

Figura 10.6. Los agricultores hacen la selección de semilla con base en las mazorcas ya cosechadas y almacenadas en su troje, lo que trae como consecuencia que la selección humana se concentre en caracteres de la mazorca y grano y no de la planta.

Uno de los problemas que enfrentan los agricultores y campesinos que seleccionan semilla de maíz de su cosecha anterior es el eliminar las mazorcas y granos fuera de tipo y color, producto de polinización con polen de otras poblaciones vecinas. Esto lo necesitan hacer principalmente para mantener las características de sus poblaciones nativas y que sean útiles para la forma de consumo por la cual se cultivan.

\section{La introducción de poblaciones de maíz "exóticas"} y su influencia en la evolución bajo domesticación

Como previamente se ha mencionado, los agricultores a menudo siembran poblaciones nativas de otras comunidades o regiones o híbridos comerciales en superficies que, por lo general, son pequeñas. Hasta cierto punto estos materiales son considerados "exóticos" para el lugar donde se realiza su cultivo. Estas introducciones son de suma importancia para la evolución bajo domesticación del maíz debido a las siguientes causas:

Como esas poblaciones han sido introducidas a un medio natural y agrícola al que no están adaptadas - pero por otro lado son diversas en su morfología, fenología, repuesta a factores de

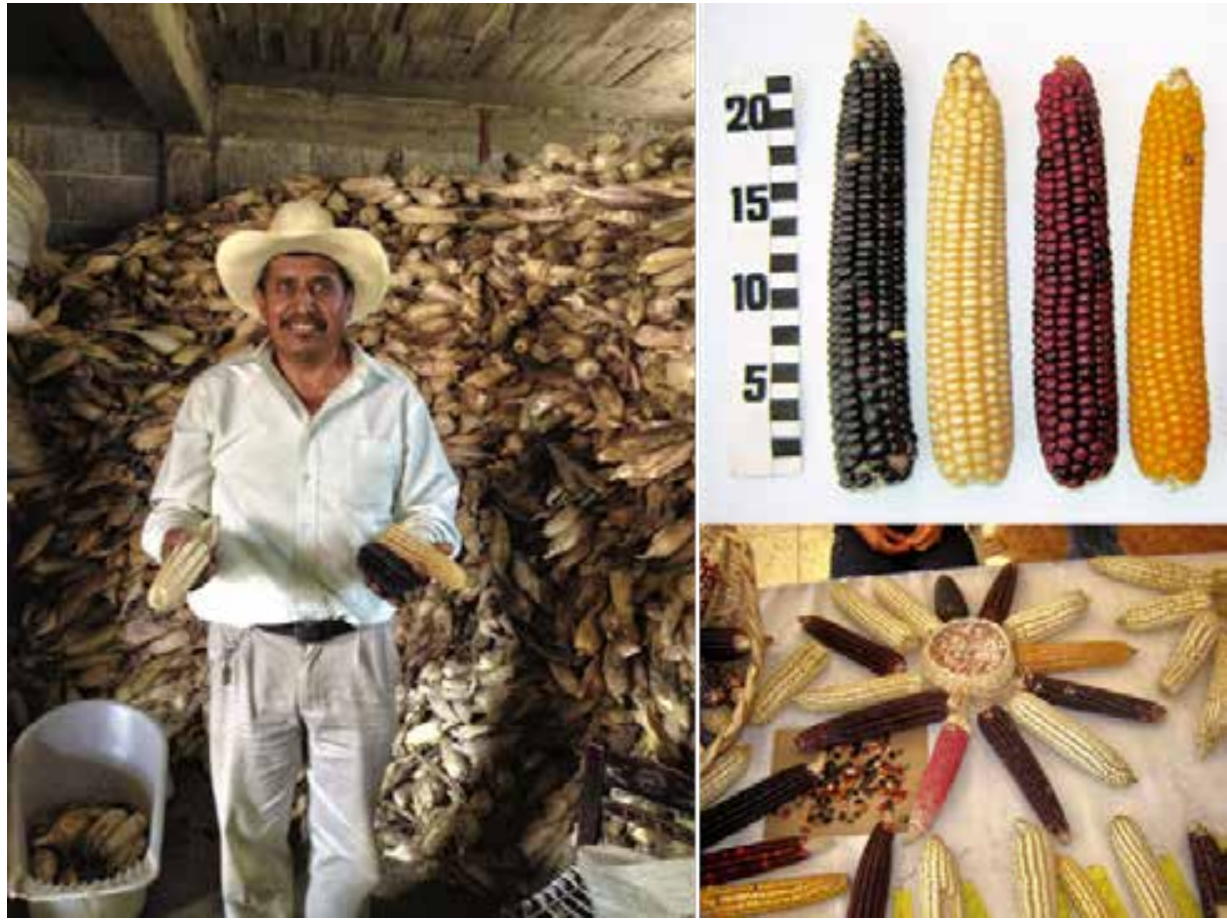

Figura 10.7. Frecuentemente se encuentran grupos de poblaciones con características de planta similares, pero diferenciadas y separadas en características de mazorca y grano por la selección humana, con usos diferentes (grano blanco para tortillas, morado para elotes y antojitos de color, o amarillo para los animales).

estrés, en general son diversas genéticamente y en su interacción con el ambiente-, aparecen plantas que están mejor adaptadas y/o que son más productivas en polen o grano. Es relativamente fácil hacer la selección, y la población evoluciona muy rápidamente en unas cuantas generaciones en especial adaptándose a su nuevo ambiente.

Las poblaciones, introducidas en forma natural o por las prácticas agrícolas conscientes de los agricultores, con frecuencia coinciden en floración con poblaciones nativas vecinas, resultando plantas o de plano poblaciones híbridas que en las siguientes generaciones segregan plantas que combinan características deseables de ambos progenitores y que están mejor adaptadas que las plantas de las poblaciones exóticas originales. Además, con regularidad, la población segregante se retrocruza hacia material local. Si el material exótico original fue sembrado por el campesino por tener características de grano peculiares y hace selección hacia ese tipo de material, como resultado de la cruza, retrocruzas, selección del ambiente y selección humana resulta en una nueva población nativa que, en gran parte, la planta se parece mucho a las poblaciones nativas, pero que conserva características de grano del material introducido, presentándose el fenómeno que llamó Anderson (1949) "hibridación introgresiva". 
El papel del teocintle en la evolución reciente de los maíces nativos de México

Si bien en la actualidad existe casi consenso entre los estudiosos del origen y evolución original del maíz en que su ancestro fueron teocintles (Kato-Yamakake, 2009; Matsuoka et al., 2002), una pregunta que poco se investiga desde hace muchos años es el papel actual de las poblaciones de los teocintles en la evolución reciente de los maíces nativos de México. Desde luego que existen múltiples evidencias de que muy seguido ocurren cruzas de poblaciones nativas de maíz con teocintles compatibles con maíz (Khankhoe, 1930; Kato-Yamakake, 2009) pero también es cierto que -en especial en las partes altas del Estado de México- los agricultores consideran al teocintle raza chalco como una maleza que hay que tratar de eliminar, y en la selección de semilla eliminan mazorcas que parecen tener germoplasma recientemente introducido de teocintle.

Por lo anterior, se considera que en la actualidad los teocintles no juegan un rol importante en la evolución bajo domesticación de los maíces nativos. Parece que tampoco han aportado gran cosa a los maíces mejorados, aunque sí se han hecho varios intentos por aprovecharlos como fuente de germoplasma para diferentes caracteres.

\section{El papel de la mutación en la evolución \\ de poblaciones locales nativas}

Poco se ha estudiado el rol que han jugado las mutaciones naturales en la evolución reciente (100 años) de los maíces nativos. Para que una mutación se fije tiene que tener una ventaja adaptativa para el maíz o crear una variante que sea útil a quien selecciona la semilla. Los usos tradicionales del maíz están, por lo general, definidos desde hace bastante tiempo y parece difícil que en cuanto aparezca una mutación cualitativa el agricultor que la observa le encuentre una utilidad.

Como se verá más adelante, al parecer uno de los aspectos más destacados de la diversidad de maíz en México es que cada población nativa tiene escasa adaptabilidad a ambientes diferentes de donde se cultiva, pero la enorme diversidad de poblaciones nativas en su conjunto está adaptada a una gran multiplicidad de ambientes. Además, como también se verá, probablemente uno de los renglones en que pueden haber evolucionado los maíces nativos, en los cien años que se analizan, es en adaptación a nuevos ambientes, sobre todo por su cultivo en nuevas áreas muy limitantes en humedad y suelos pobres. Por lo anterior, parece muy importante ver si en ese desplazamiento y adaptación a condiciones más limitantes ha jugado un papel importante la acumulación de numerosas mutaciones.

A diferencia de los maíces nativos en el mejoramiento genético de maíz, han tenido un enorme papel algunos mutantes cualitativos, por ejemplo, genes de enanismo, braquítico 2, opaco 2 y otros relacionados con androesterilidad.

\section{Las razas de maíz en México}

La categoría taxonómica "raza" fue propuesta y primeramente definida para maíz por Anderson y Cutler (1942). Esta categoría ha sido analizada y precisada por varios autores, entre ellos Hernández-Xolocotzi y Alanís-Flores (1970), quienes llegaron a precisar lo siguiente:

La categoría taxonómica de raza es una población con un conjunto sustancial de características en común que la distinguen como grupo y la diferencian de otras poblaciones, con capacidad de transmitir con fidelidad dichas características a las generaciones posteriores que ocupa un área ecológica específica.

A la definición anterior, el primer autor de este ensayo solo considera que la raza no es una "población" en el sentido que la considera Dobzhansky (1966), sino un conjunto de poblaciones, ya que las diferentes poblaciones de una raza están distribuidas en un área generalmente grande que no permite cruzamientos con regularidad.

Una raza incluye con frecuencia poblaciones locales nativas que difieren en caracteres que visualmente se detectan con facilidad, como textura y color de grano, y en caracteres fundamentales como adaptación a un ambiente particular o en su capacidad de rendimiento (Silva, 1992; González-González, 2007; Aguilar-Juárez, 2016; Figura 10.8). En ese sentido, no es una

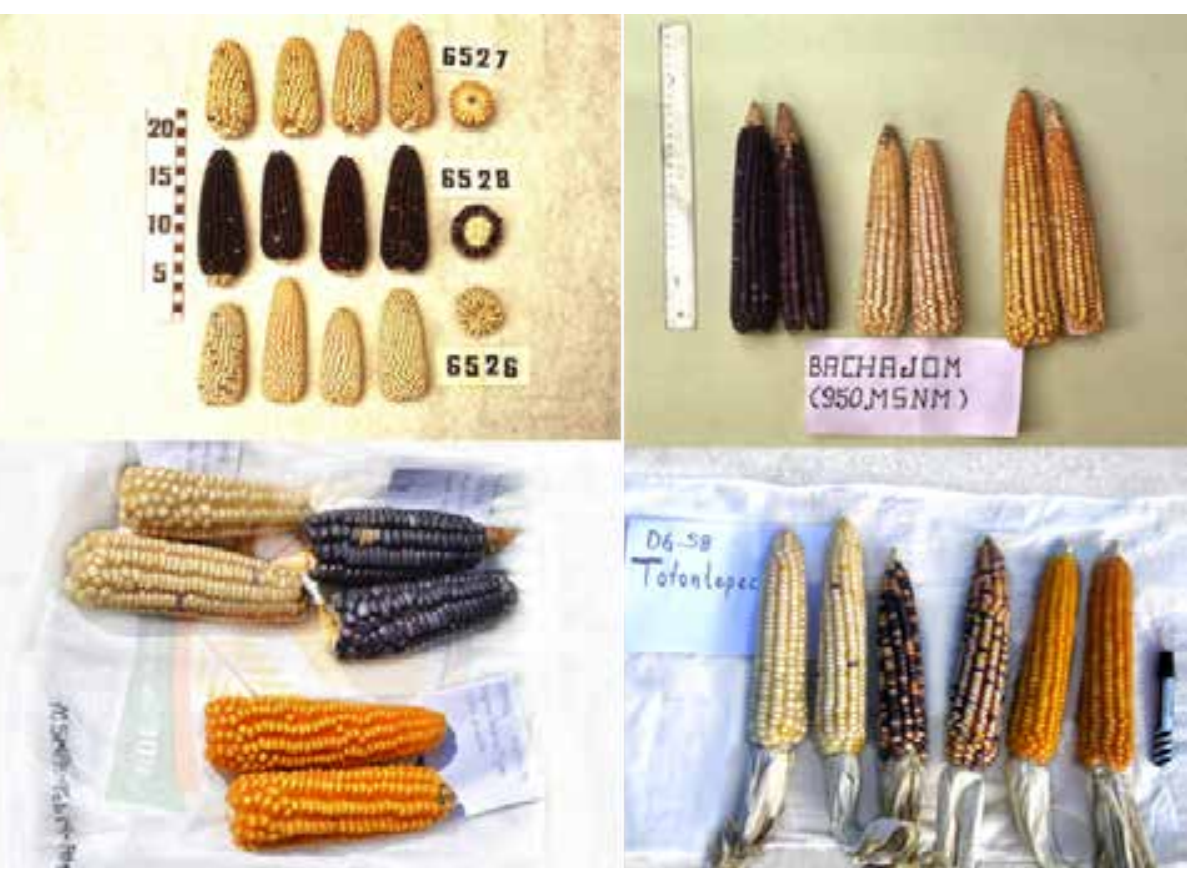

Figura 10.8. Una raza incluye con frecuencia poblaciones locales nativas que difieren en caracteres que visualmente se detectan con facilidad, como textura y color de grano, $y$ en caracteres fundamentales como adaptación a un ambiente particular o en su capacidad de rendimiento. 
categoría satisfactoria para describir la diversidad que mantiene una familia o una comunidad rural o que se encuentra en un área geográfica, hay que definir categorías taxonómicas inferiores, tales como subrazas, tipos y poblaciones locales específicas.

Prácticamente todos los investigadores de la diversidad nativa de maíz de México y el mundo han utilizado, con considerable éxito, sin embargo, también hay que tomar en cuenta que:

a. Ramos Rodríguez (1972) y Herrera Cabrera (1999) encontraron variación continua con relación a caracteres vegetativos y de mazorcas entre las colectas de razas y grupos de la parte central del país. La mayoría de las poblaciones nativas que cultivan los agricultores mexicanos corresponden a diversidad intermedia entre dos o más razas; es decir, que por lo menos en la actualidad no hay claras separaciones entre la mayoría de las razas, generalmente es posible encontrar poblaciones intermedias entre dos de ellas.

b. Sánchez et al. (2000), mediante isoenzimas, encontraron más variación dentro de las razas que entre ellas mismas.

c. Las razas más bien representan segmentos de esa diversidad que sirven de referencia para su entendimiento. El estudio de las razas se basa en muestras típicas de las mismas.

A medida que se han colectado muestras de poblaciones nativas de maíz de nuevas regiones y que se ha profundizado en el estudio de la diversidad de maíz en México, ha habido necesidad de reconocer más razas, así: Wellhausen et al. (1951) describieron 25 razas y dejaron pendientes siete unidades como "razas no bien definidas"; Ortega Paczka et al. (1991) consideraron 41 razas, Sánchez et al. (2000) describen 59 razas, Benz (1986), con base en nuevas muestras y otros postulados teórico-conceptuales, detalla cinco nuevas razas, si bien las muestras críticas no han podido ser conseguidas por otros; Aragón-Cuevas et al. (2006) al describir la diversidad de maíz en el estado de Oaxaca menciona 9 posibles nuevas razas adicionales no descritas; Carrera-Valtierra et al. (2012) proponen cinco razas adicionales; Ortega-Corona et al. (2013), reportan que en la exploración nacional de 2007 2010 colectaron muestras de 53 razas. Como resultado del Proyecto Global de Maíces Mexicanos, coordinado por la CONABIO del año 2006 al 2012, se establece que hay 64 razas de maíz en México ampliamente reconocidas por los especialistas (CONABIO, 2011). En la Figura 10.9 se presentan fotografías de algunas de las razas de maíz de México. Sobre su distribución se puede ver en el Servicio Nacional de Inspección y Certificación de Semillas (SNICS, 2016)

Es muy importante y urgente llevar a cabo estudios que incluyan las muestras críticas con las que se han basado los diferentes autores para mencionar o describir razas de maíz en México. Parte de esos estudios se están llevando a cabo por un grupo de investigadores del Sistema Nacional de Recursos Fitogenéticos, grupo encabezado por los doctores Amalio Santa Cruz Varela y Leobigildo Córdova Téllez, profesores investigadores del Colegio de Postgraduados campus Montecillo. Por ahora, las cifras más aceptadas de razas de maíz en México son de 59 (Sánchez et al., 2000) o 64 (CONABIO, 2011).
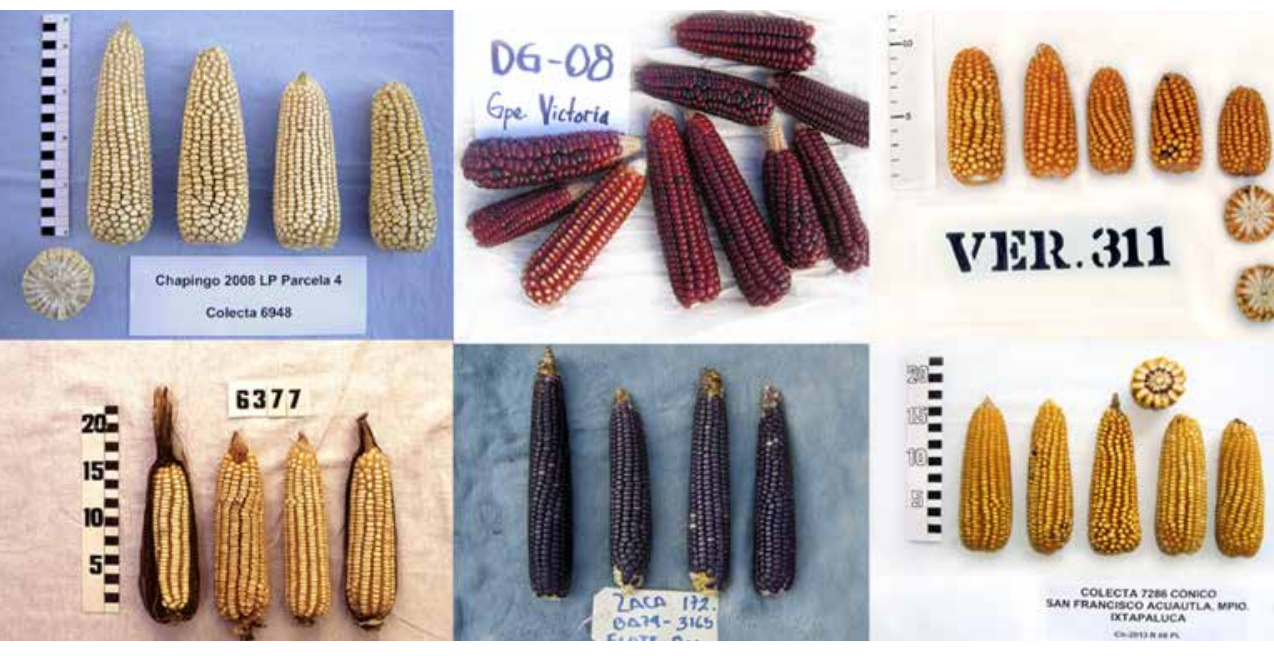

Figura 10.9. Ejemplos de algunas de las razas de maíz descritas en México.

Evolución de la superficie de maíz cultivada en el país, de los grandes cambios en número y naturaleza

de las unidades de producción

y los destinos de la producción, y su influencia en la diversidad de maíz y ambientes de selección

La enorme diversidad de maíz que existe en la actualidad en el territorio mexicano no solo está relacionada a que es el centro de origen de esa planta, sino también a que en el país subsisten las comunidades campesinas y su agricultura tradicional, y a que estas se fortalecieron considerablemente a raíz de que recibieron tierras o, por lo menos, las aseguraron a través de la Reforma Agraria.

Repasemos brevemente la enorme diversidad ambiental en que se cultiva esa planta en la actualidad en el país. El maíz se cultiva desde el nivel del mar hasta alrededor de los 3400 metros de altitud; predomina el cultivo bajo condiciones de temporal con precipitaciones pluviales que varían de los 300 a 3000 milímetros anuales, en climas de semidesierto cálido y templado, templado húmedo y cálido húmedo. Vavilov (1931) sobre la diversidad de maíces nativos de México destacó: "lo más importante y poco destacado a la fecha, es la asombrosa diferenciación ecológica de esta planta".

Un aspecto que parece muy importante para vislumbrar los aspectos en que ha evolucionado el maíz in situ en México son las nuevas regiones y condiciones en que se ha ido cultivando, desafortunadamente es un tema que no se había ni siquiera mencionado antes de este ensayo. 
La superficie en que se cultiva maíz en México ha aumentado de manera considerable de hace un siglo a la fecha. Como se puede ver en la Figura 10.10 y Tabla 10.1, se estima que la superficie cultivada de maíz en México ha subido aproximadamente de 5000000 hectáreas en 1910 a alrededor de 7200000 hectáreas en los últimos 40 años, si bien se observa un sensible descenso entre 1910 y 1920 a consecuencia de la fase armada de la Revolución Mexicana. Parte importante del ascenso de 1920 a 1970 es producto de la Reforma Agraria y colonización de nuevas tierras -también influyó el aumento en la demanda de granos por aumento de la población en general y sobre todo de la población urbana- que fueron acompañadas por políticas públicas para abastecer a las ciudades y comunidades rurales con producción nacional. Otro factor para el aumento de la superficie cultivada con maíz fue el crecimiento de la ganadería bovina, porcina y de producción de carne de pollo y de huevo.

El relativo estancamiento de la superficie sembrada con maíz de 1970 a la fecha es producto de la crisis agrícola general del país y las políticas neoliberales a partir de la firma del Tratado de Libre Comercio con Estados Unidos y Canadá en 1993, en particular los compromisos para importar maíz sin aranceles.

Conforme indica Villa-Issa (2011):

A principios del siglo pasado, México era un país cuya economía dependía casi exclusivamente del campo; más del 72\% de la población estaba involucrada en ese sector. Sin embargo, la propiedad sobre la tierra estaba concentrada en muy pocas personas, alrededor del 97

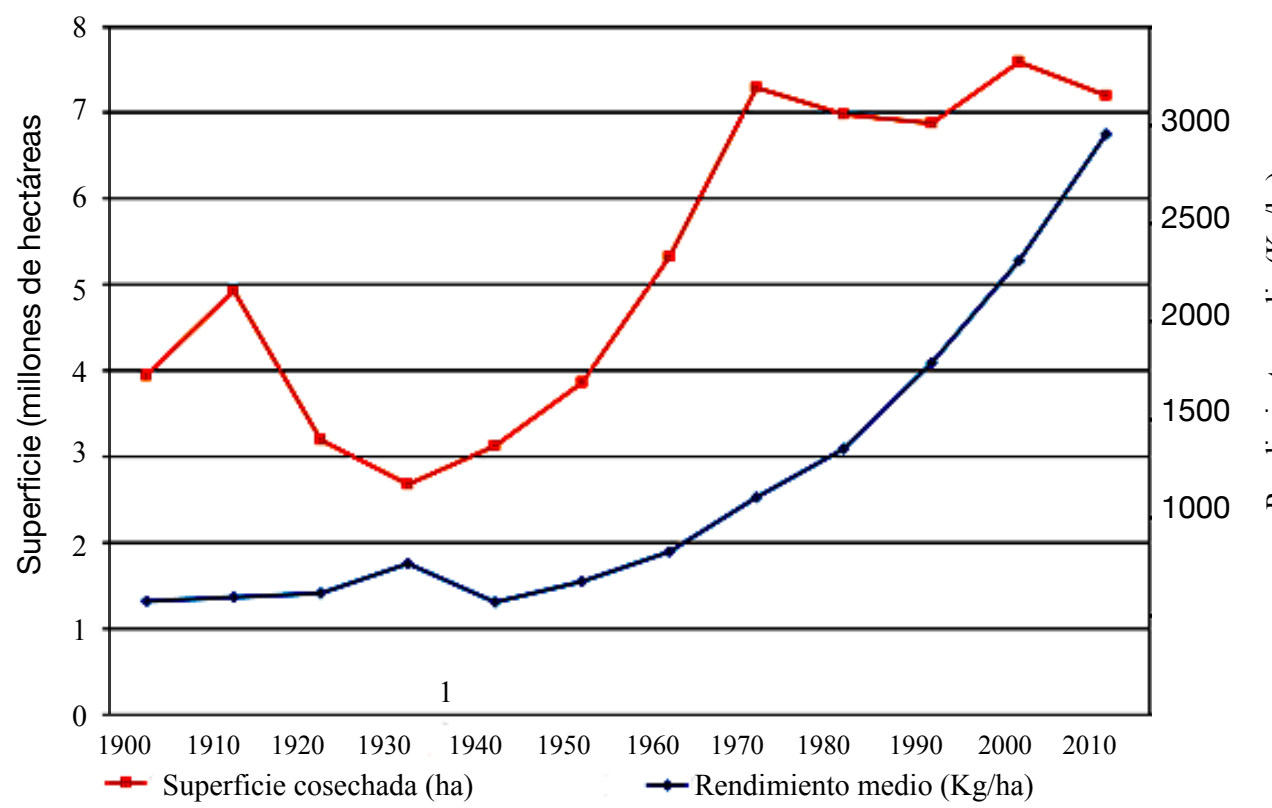

Figura 10.10. Superficie cosechada y rendimiento medio del maíz en México. 1900 a 2010. Fuente: elaboración propia a partir de INEGI, 2015.
Tabla 10.1. Características de la producción agrícola de maíz en México 1900 a 2010

\begin{tabular}{cccc} 
Año & $\begin{array}{c}\text { Superficie cosechada } \\
\text { (ha) }\end{array}$ & $\begin{array}{c}\text { Rendimiento medio } \\
\text { (kg/ha) }\end{array}$ & $\begin{array}{c}\text { Producción } \\
\text { (t) }\end{array}$ \\
\hline 1900 & 3947863 & 576 & 2271698 \\
\hline 1910 & 4927880 & 599 & 2917504 \\
\hline 1920 & 3193051 & 619 & 1959774 \\
\hline 1930 & 2680263 & 769 & 1845615 \\
\hline 1940 & 3130878 & 574 & 1797507 \\
\hline 1950 & 3862391 & 679 & 2442399 \\
\hline 1960 & 5324961 & 831 & 4446712 \\
\hline 1970 & 7291843 & 1107 & 8107096 \\
\hline 1980 & 6979328 & 1351 & 9383176 \\
\hline 1990 & 6878780 & 1791 & 12388523 \\
\hline 2000 & 7589510 & 2310 & 17526454 \\
\hline 2010 & 7202496 & 2953 & 21088716 \\
\hline
\end{tabular}

Fuente: Elaboración propia a partir de INEGI 2015.

$\%$ era propiedad de unas 830 personas o corporaciones. En contraparte, aproximadamente 3.5 millones de campesinos no tenían tierra.

Con respecto a la Reforma Agraria, se calcula que entre 1915 y 2002 se dotó con un total de 101523669 hectáreas a 3453239 agricultores y campesinos (Tabla 10.2) (Morett-Sánchez, 2003), parte importante de las cuales se han dedicado al cultivo de maíz principalmente dedicado al autoconsumo, ya sea en cultivos únicamente de maíz o asociado con frijoles, calabazas y otras plantas en el sistema "milpa".

El considerable aumento en la superficie cultivada de maíz registrado de 1920 a 1970 indudablemente, implica con frecuencia el cultivo de maíz en nuevas áreas, sobre todo marginales de temporal, en tierras entregadas a campesinos e indígenas, o tomadas por ellos. Esta situación se considera que llevó a numerosos maíces nativos a nuevos ambientes más estresantes que de donde provenían, lo que los ha obligado a evolucionar y a adaptarse en pocos años a las nuevas tierras agrícolas. Esto, entre muchas otras cosas, es muy importante en la actualidad, ya que muchos de esos maíces nativos forman un excepcional acervo genético de reserva para hacer frente al cambio climático que se vislumbra. Este proceso de translocación de maíces nativos a ambientes cada vez más estresantes y de obligarlos a adaptarse a ellos en gran parte sigue teniendo lugar debido a la alta tasa de crecimiento de la población en muchas comunidades rurales, que obliga a muchos hijos sin tierras a amplia la frontera agrícola, ocupando nuevas áreas marginales de su propia comunidad, o a desplazarse y colonizar nuevas regiones.

También hay que tomar en cuenta que el enorme proceso de urbanización y la sustitución del cultivo del maíz por otros cultivos en la mayoría de las mejores tierras del país ha despla- 
zado el cultivo de maíz a tierras marginales en las cuales parece que ha tenido que evolucionar para adaptarse a esas condiciones limitantes en cuanto a profundidad de suelos, acidez o alcalinidad, suelos de laderas, etcétera. En cuanto a la urbanización, basta mencionar que la mayoría de las mejores tierras de la cuenca del valle de México, valles de Puebla y Tlaxcala, valles centrales de Oaxaca, llano de Guadalajara, región de Jala hoy están ocupadas por áreas urbanas. En la mayoría de las zonas de riego, el maíz ha sido sustituido por sorgo y hortalizas.

Tabla 10.2. Resoluciones presidenciales dotatorias de tierras (1915-2002).

\begin{tabular}{|c|c|c|c|c|}
\hline Períodos & Años & Superficie (ha) & Beneficiados & $\begin{array}{l}\text { Superficie pro- } \\
\text { medio (superfi- } \\
\text { cie/persona) }\end{array}$ \\
\hline Venustiano Carranza & $1915-1920$ & 381926 & 77203 & 4.9 \\
\hline Álvaro Obregón & $1921-1924$ & 1730686 & 164128 & 10.5 \\
\hline Plutarco Elías Calles & $1925-1928$ & 3186294 & 302539 & 10.5 \\
\hline Emilio Portes Gil & 1929-1930 & 2438511 & 187269 & 13.0 \\
\hline Pascual Ortíz Rubio & 1931-1932 & 1225752 & 57994 & 21.1 \\
\hline Abelardo L. Rodríguez & $1932-1934$ & 2060228 & 158393 & 13.0 \\
\hline Lázaro Cárdenas & 1934-1940 & 17906424 & 811157 & 22.1 \\
\hline Manuel Ávila Camacho & 1940-1946 & 5944450 & 157836 & 37.7 \\
\hline Miguel Alemán Valdés & 1946-1952 & 4844123 & 97391 & 49.7 \\
\hline Adolfo Ruíz Cortínez & 1952-1958 & 4894390 & 231888 & 21.1 \\
\hline Adolfo López Mateos & 19581964 & 11361370 & 304498 & 37.3 \\
\hline Gustavo Díaz Ordaz & $1964-1970$ & 14139574 & 216695 & 65.3 \\
\hline Luis Echeverría Álvarez & $1970-1976$ & 12773888 & 205999 & 62.0 \\
\hline José López Portillo & $1976-1982$ & 5938939 & 92912 & 63.9 \\
\hline Miguel de la Madrid & $1982-1988$ & 8446614 & 223804 & 37.7 \\
\hline Carlos Salinas de Gortari & $1988-1994$ & 3641500 & 159502 & 22.8 \\
\hline Ernesto Zedillo & 1994-1997 & 552000 & 100000 & 5.5 \\
\hline Vicente Fox & 2001-2002 & 57000 & 4031 & 14.1 \\
\hline
\end{tabular}

Total período $\quad 1915-2002 \quad 101523669 \quad 3453239$ Fuente: Morett (2003) con datos de la Secretaria de la Reforma Agraria e Informes Presidenciales.

\section{La persistencia \\ de las culturas indígenas y la conservación in situ de la diversidad de maíz}

Otro aspecto fundamental que cabe destacar es que, no obstante el alto grado de trans culturación que ha tenido lugar en las comunidades indígenas, el número de hablantes de lenguas indígenas ha aumentado como consecuencia del crecimiento de la población, no así su proporción con la población humana del país; esto se puede observar en la Tabla 10.3 . Esto es muy importante porque como Hernández-Xolocotzi (1998) destacó como conclusión en uno de sus últimos trabajos: La persistencia de grupos étnicos con antecedentes prehistóricos y tecnología tradicional ha mantenido el proceso de selección empírica en la domesticación de plantas y animales, lo que constituye un importante modo de conservar in situ la diversidad de germoplasma existente en el país.

Por su parte, Boege (2008) destaca a) que gran parte de las razas de maíz de México está en territorios indígenas; b) que "la gran mayoría de los indígenas y campesinos pobres -que es el $80 \%$ de todos los productores- mantiene el germoplasma nativo en condiciones tanto ambientales como sociales muy difíciles". En otra parte, el mismo autor indica que:

El inventario de los maíces en territorios indígenas permite documentar las adaptaciones que hicieron los productores en condiciones agroecológicas extremas, como la sequía o la abundancia de lluvias, las altas o bajas temperaturas durante el ciclo agrícola, la altitud, vientos, suelos someros, ácidos, alcalinos, etcétera. (Figura 10.11)

Los indígenas están entre los sectores de población que más se han desplazado a tierras nuevas, llevando sus maíces a nuevas condiciones y/o adoptando maíces de otras comunidades, lo que favorece a la evolución bajo domesticación de esa planta cultivada.

La diversidad de maíz cultivada por las comunidades campesinas e indígenas se ha conservado considerablemente alta; sin embargo, la creciente población urbana por lo genera consume maíz blanco o crema, y cuando estos no se encuentran disponibles entonces consumen amarillo de importación, sobre todo en tortillas. Asimismo, resulta importante destacar el considerable y constante consumo de maíz blanco en forma de elotes y tamales. Se debe reconocer que algunos tipos de maíz que antes eran consumidos casi exclusivamente por las poblaciones rurales -como los morados-, ahora son muy apreciados y demandados por importantes sectores urbanos, así como por los migrantes en Estados Unidos, lo que ha implicado el aumento de su cultivo y probablemente ha influido en que evolucionen al prestárseles mayor atención. Más adelante en este capítulo se aborda la recientemente rápida difusión del cultivo de maíz de la raza ancho de Guerrero y Morelos, sobre todo hacia el occidente del país, así como algunos indicios de su evolución para adaptarse a nuevos ambientes de cultivo. 


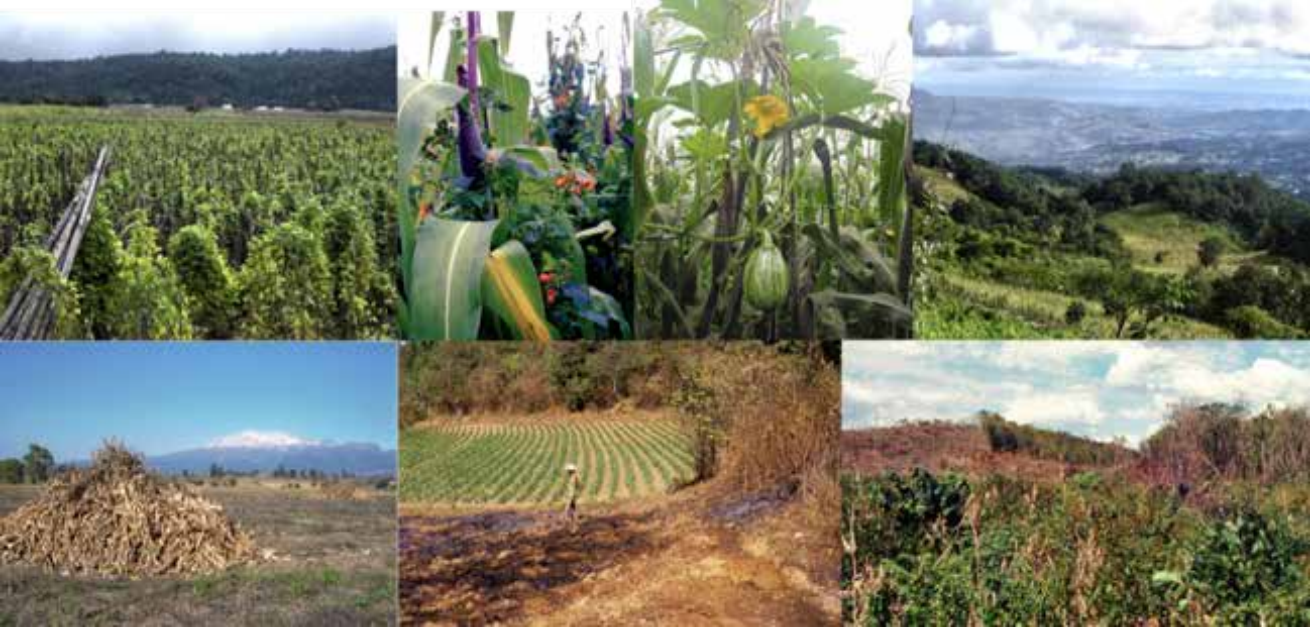

Figura 10.11. La diversidad de maíces en territorios indígenas se encuentra relacionada con las adaptaciones que resultan de la selección artificial que hicieron los productores en distintas condiciones agroecológicas extremas, como la sequía o la abundancia de lluvias, las altas o bajas temperaturas durante el ciclo agrícola, la altitud, la fuerza de los vientos, las condiciones de los suelos (someros, ácidos, alcalinos, entre otros).

\section{Cambios en el manejo agrícola del maíz y en la procedencia del maíz que se consume}

La mayor parte de las siembras de maíz ahora se manejan bastante diferente que hace, po lo menos, setenta años, cuando se empezaron a popularizar los agroquímicos y cuando empezó a escasear la mano de obra agrícola al generalizarse la asistencia de niños y adolescentes a las escuelas, y la migración de los jóvenes en forma estacional o para siempre a las ciudades del país y/o a los Estados Unidos. Tal vez en la mayor parte de la superficie ahora se aplican ertilizantes químicos y herbicidas, asi mismo, se ha reducido considerablemente la superficie de maíz asociado con frijol, calabaza y otras plantas en el sistema milpa. Como los maíces nativos evolucionaron bajo la fertilidad natural de los suelos, con las aplicaciones de fertilizantes químicos sus plantas crecen más y con frecuencia se caen por debilidad del tallo, el peso de las mazorcas más grandes y los vientos (Figura 10.12). En las tierras que no se puede roturar, y que antaño se preparaban por roza-tumba-quema y después de uno o dos ciclos de milpa se dejaba que se recuperara la vegetación por diez o más años, ahora generalmente casi no se dejan descansar y está prohibido quemar.

El cambio climático también requiere maíces con características diferentes. Uno de los as pectos más importantes es que se ha retrasado la fecha de inicio del temporal de lluvia, por lo que se acorta el ciclo de cultivo del maíz y se requieren maíces de menor ciclo de vida. También por el cambio climático, y porque esos sistemas requieren mucho trabajo humano, han disminuido mucho las superficies que se sembraban; por ejemplo, los maíces "de humedad

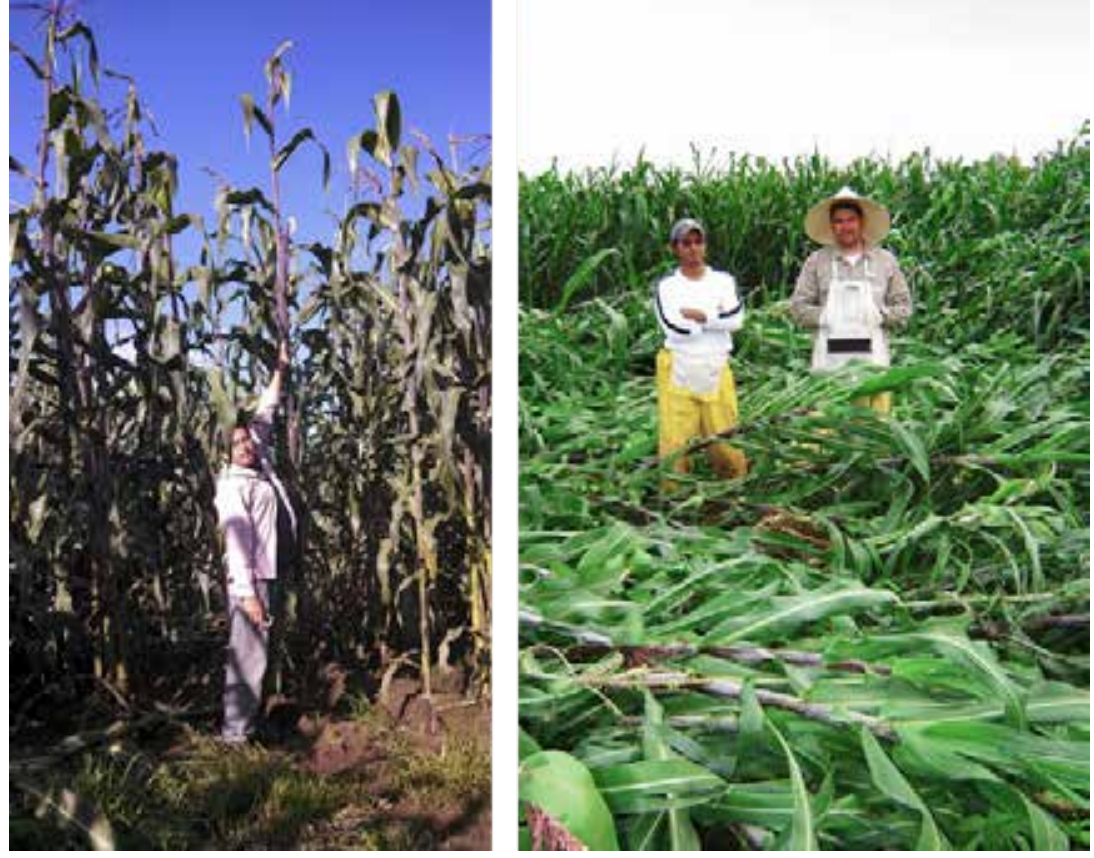

Figura 10.12. Los maíces nativos evolucionaron bajo la fertilidad natural de los suelos; sin embargo, las aplicaciones de fertilizantes químicos determinan que sus plantas crezcan más y con frecuencia se caen debido a la debilidad del tallo, al peso de las mazorcas -generalmente de mayor tamaño- o debido a los vientos.

Tabla 10.3. Población de tres años y más que habla lengua indígena en México (1910-2010).

\begin{tabular}{cccc} 
Año & Población total & Hablantes de lengua indígena & Porcentaje \\
\hline 1910 & 15200000 & 4900000 & 32.24 \\
\hline 1921 & 14334800 & 4177449 & 29.14 \\
\hline 1930 & 14834780 & 2251086 & 15.17 \\
\hline 1940 & 16552722 & 2490909 & 15.05 \\
\hline 1950 & 19653552 & 2447408 & 12.45 \\
\hline 1960 & 35923129 & 3030254 & 8.44 \\
\hline 1970 & 48225238 & 3111415 & 6.45 \\
\hline 1980 & 66846833 & 5181038 & 7.75 \\
\hline 1990 & 81249645 & 5282347 & 6.5 \\
\hline 1995 & 80219337 & 5483555 & 6.84 \\
\hline 2000 & 84794454 & 6044547 & 7.13 \\
\hline 2010 & 112336538 & 6913362 & 6.15 \\
\hline
\end{tabular}

Fuentes: Cifuentes (1988). INEGI (2010) e INAU (2014). 
residual" cultivados en partes altas del país, es decir, en marzo o abril cuando generalmente no hay lluvias, pero que aprovechaban la humedad residual conservada en los suelos por precipitaciones de fines del año anterior y de las escasas lluvias de principio de año conocidas como "cabañuelas".

Como se verá más adelante, ahora existe la tendencia en que disminuya la diversidad de maíz cultivada en muchas comunidades, debido a la escasez de mano de obra y porque ahora muchos campesinos cuentan con mayores recursos monetarios provenientes de las remesas de sus parientes en Estados Unidos y de subsidios gubernamentales -con los que cubren muchas necesidades adquiriendo productos en las tiendas minoristas y grandes almacenesmientras que antes tenían que obtener sus satisfactores casi exclusivamente de sus milpas, huertos y por recolección; por ejemplo, antes necesitaban más que ahora maíces que dieran elotes y parte del grano pronto, que dieran maíces de distintos colores y para diferentes usos.

Factores negativos a la conservación in situ y evolución bajo domesticación en maíz es que se ha ido facilitando el abasto comercial de grano de maíz o tortillas a las comunidades provenientes de otras partes del país o de los Estados Unidos, con frecuencia en forma de harinas industrializadas en parte gracias al desarrollo de las comunicaciones y de la comercialización también recientemente se están desarrollando mucho pequeñas empresas elaboradoras de tortillas con máquinas y que abastecen a los hogares de tortillas por medio de camionetas, motocicletas y bicicletas o bien a través de tiendas (véase la Figura 10.13).
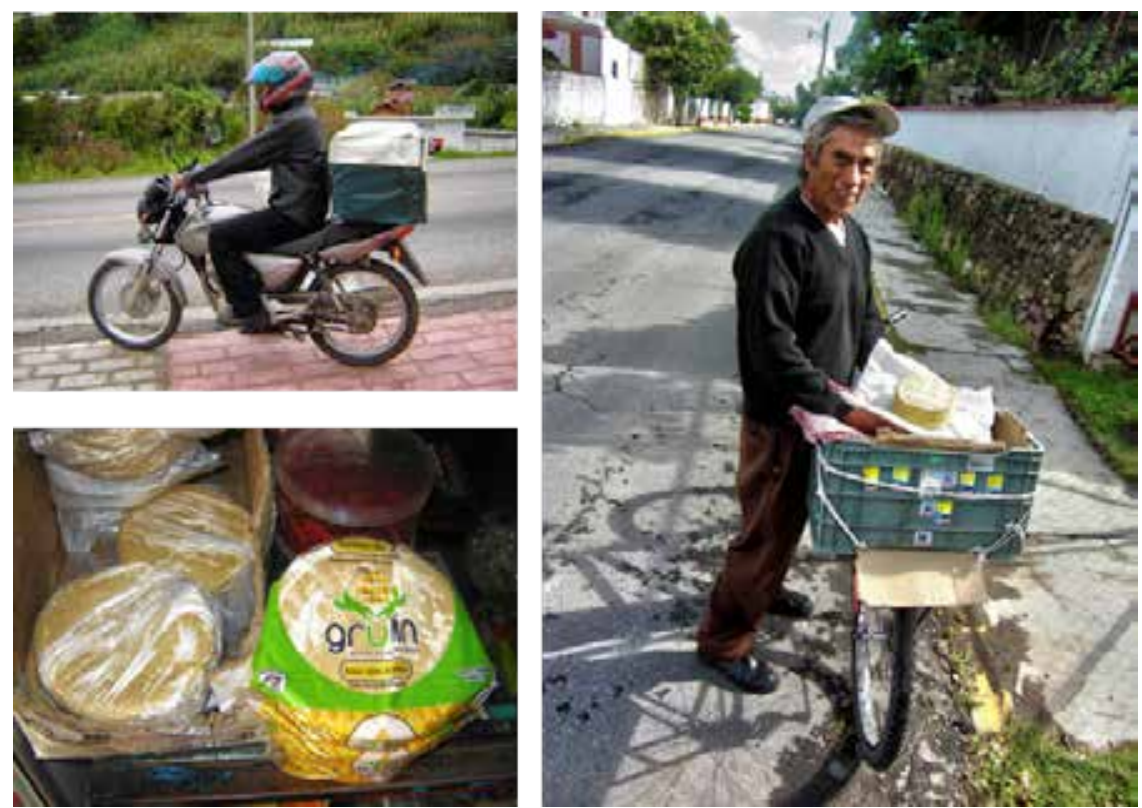

Figura 10.13. Factores negativos a la conservación in situ. Las harinas industrializadas y pequeñas empresas elaboradoras de tortillas con máquinas que abastecen a los hogares de tortillas por medio de camionetas, motocicletas, bicicletas o tiendas.

\section{Programas de impulso a maíces mejorados}

Desde -por lo menos- 1947, con la Fundación de la Comisión del Maíz, se han llevado a cabo considerables esfuerzos gubernamentales por impulsar la siembra de maíces mejorados y el uso de fertilizantes químicos; en un principio solo se contaba con variedades de polinización abierta, pero ya para 1958 dominaba la producción de semilla híbrida. Los trabajos de difusión desde un principio estuvieron apoyados con subsidios para la venta de semilla y fertilizantes de cerca del $50 \%$ de su costo, pronto contaron con el apoyo de los gubernamentales Banco Ejidal y Banco Agrícola para su venta a crédito (Anónimo, 1958). Otra estrategia para inducir el cambio de los cultivares tradicionales de maíz por mejorados ha sido el programa "Kilo x kilo" que consiste en que agentes del gobierno intercambien semillas tradicionales de los campesinos por semillas mejoradas.

En 2002, como parte de las reformas neoliberales, se terminó con la Productora Nacional de Semillas (PRONASE), dejando al mercado de semillas de maíz y demás cultivos casi exclusivamente en manos de las compañías trasnacionales.

No obstante los grandes esfuerzos y apoyos gubernamentales a la siembra de maíces híbridos de semilla certificada, estos materiales genéticos nunca han cubierto más del $36 \%$ de la superficie nacional de maíz, y la mayor parte del tiempo no ha superado el $22 \%$. Además, estos esfuerzos casi de forma exclusiva, se han dirigido al caso de híbridos de grano blanco supuestamente para tortillas y algunos híbridos de grano amarillo de germoplasma extranjero con destino a alimentación de ganado. La población tanto rural como urbana reconoce que la calidad tortillera de los híbridos es inferior que la de los maíces nativos.

Un fenómeno que no se esperaba cuando se inició la venta de semilla híbrida fue que muchos agricultores la manejarían como sus cultivares nativos, seleccionando mazorcas con buenas características como semilla para la siguiente siembra, a veces revolviendo semilla o sembrándola en surcos alternados con maíces nativos. A esas poblaciones generalmente los agricultores las llamaban en el estado de Chiapas "Rocamex", derivado del nombre de la Fundación Rockefeller, o "híbrido" en 1971 o "híbrido criollo" en 1991 (Ortega Paczka, 1973; véase Figura 10.14)

Los "híbridos acriollados" tienen considerable importancia en la evolución reciente de maíz en México porque reúnen muchos de los avances logrados por los fitomejoradores con la adaptación a los nichos específicos de los agricultores. Además, en el caso de los maíces amarillos regularmente se trata de germoplasma extranjero, por lo que se puede considerar que enriquecieron la diversidad de maíz. Parte importante de los maíces que han sobresalido en rendimiento y características agronómicas en evaluaciones de colectas de maíces provenientes de agricultores en los últimos decenios, en particular en ambientes tropicales, no son propiamente maíces nativos sino "híbridos acriollados" (Ortega-Paczka et al., 1991) Ron-Parra et al. (2006) reportan para el occidente de México que "las generaciones avazadas de híbridos amarillos parecen provenir de materiales comerciales de las décadas de los sesenta y los setenta y las generaciones avanzadas de los híbridos blancos derivadas de las razas celaya y tuxpeño". 


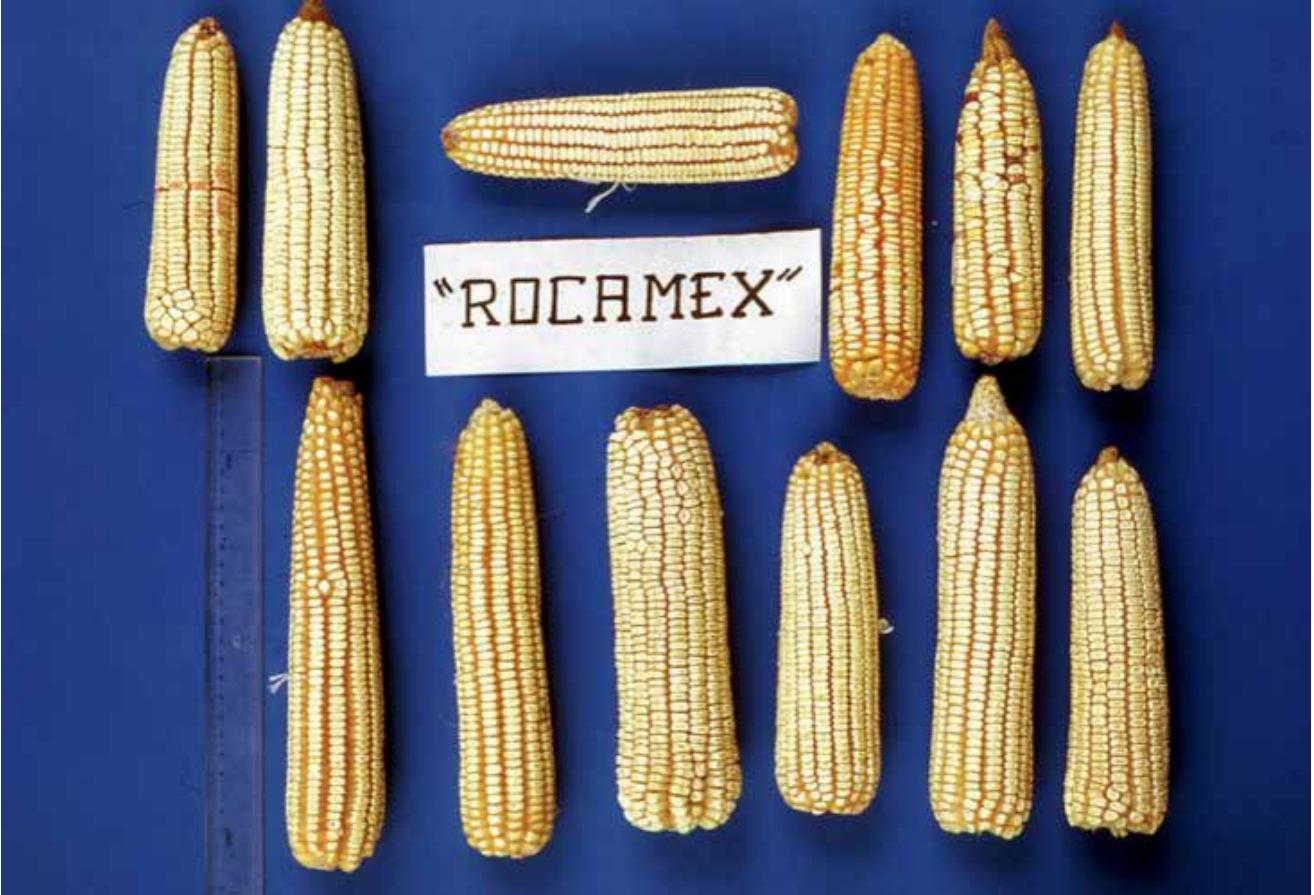

Figura 10.14. Las semillas híbridas frecuentemente son utilizadas por los agricultores como sus cultivares nativos, seleccionando mazorcas con buenas características como semilla para la siguiente siembra, a veces revolviendo semilla o sembrándola en surcos alternados con maíces nativos. Estos procesos determinan el acriollamiento de los máices mejorados. En la fotografía se ilustra la variedad conocida como "Rocamex" por los agricultores de Chiapas. El nombre deriva del nombre otorgado por la Fundación Rockefeller.

Los maíces mejorados tanto de semilla certificada, así como sus generaciones avanzadas, han desplazado principalmente a maíces nativos de las productivas razas Tuxpeño, Tuxpeño Norteño y Celaya que están adaptadas a buenos suelos y adecuada disponibilidad de agua, mientras que el resto de razas han sido poco afectadas porque no hay híbridos para las condiciones agroecológicas en que se cultivan o porque son maíces de especialidad, es decir, con características de textura o color de grano particulares que se destinan a usos distintos al de tortillas comunes.

\section{Diversidad de maíces nativos en estados, regiones y comunidades y del país}

En la actualidad hay consenso de que en México y Guatemala se encuentra el centro de origen, domesticación y principal centro de diversidad de maíz (Matsuoka et al., 2002; Kato-Yamakake, 2009). Como ya se indicó antes, el dato más aceptado en cuanto a razas de maíz en México es de 59 razas (Sánchez et al., 2000) o 64 (CONABIO, 2011).
Si bien en muchas regiones principalmente tropicales y de alturas intermedias del país se reportan pérdidas considerables de maíces nativos (centro y sur de Tamaulipas por Ortega-Paczka 1999; Tierra Caliente de Guerrero por Romero-Peñaloza y Ortega-Paczka, 1996; partes tropicales de Chiapas, por Ortega-Paczka, 1973, 1999, así como por Perales-Rivera y Hernández-Casillas, 2005; occidente del país por Ron-Parra et al., 2006), en el país en su conjunto recientemente se acaba de lograr colectar todas las razas de maíz reportadas por trabajos anteriores, excepto la raza Palomero de Chihuahua, aunque hay otros reportes de que algunas otras razas están en peligro, como la Jala, que es la de mazorca más grande, los problemas con esta raza son que su área típica de distribución se ha reducido mucho por urbanismo y construcción de carreteras y deficiencias de humedad en las fechas que se acostumbraba sembrar por cambio climático (Aguilar-Castillo y Carballo-Carballo, 2007). En algunas regiones incluso recientemente se reportan razas antes no registradas ahí (Oaxaca por Aragón-Cuevas et al., 2006; Península de Yucatán, por Dzib-Aguilar, 2008), parte de ello se explica por no haberse colectado antes en muchas regiones que estaban aisladas o por recientes introducciones con fines de experimentación campesina. Lo anterior sugiere que una parte considerable de la diversidad de maíz con que contábamos hace 70 años aún la mantiene el conjunto de agricultores y campesinos del país.

En las partes tropicales de Chiapas, según Ortega-Paczka (1999) y Perales-Rivera y Hernández-Casillas (2005), hoy es difícil encontrar maíces nativos de ciclo corto que aún hace 40 años eran comunes; en esta región y otras casi han desaparecido los maíces de escaso peso hectolítrico que eran muy comunes cuando en la comercialización predominaba la venta por volumen, debido a que ahora predomina la venta por peso (Ortega-Paczka, 1973).

En varias partes del país casi han desaparecido los maíces nativos de grano amarillo porque, como se indicó antes, la CONASUPO; empresa acopiadora gubernamental, la adquiría a menor precio que los maíces de color blanco. En cambio, por lo menos en los alrededores de la Ciudad de México ha cobrado mayor importancia comercial los maíces nativos de grano morado, por ser ahora apreciados para elaborar tortillas y antojitos de color azul (Figura 10.15). En un apartado especial de este ensayo se analiza la gran expansión que ha registrado en los últimos años la raza Ancho que se usa principalmente para el pozole (Figura 10.16).

\section{Resiliencia de la diversidad de maíz en manos campesinas}

No obstante la enorme importancia del tema, existen pocos estudios de campo sobre lo que sucede con la diversidad nativa de maíz en México a raíz de la ocurrencia de sequías o tormentas tropicales desastrosas ocasionales, así como lo que está pasando con el cambio climático.

Amplias regiones del país son afectadas con frecuencia por la ocurrencia de sequías o de tormentas tropicales desastrosas. Entre las sequías graves que se han presentado destaca la general de país en 1882; la de 1957 particularmente en la región templado semiárida que se extiende en los Ilanos del norte de Guanajuato al sur de Chihuahua; la sequía de 2007 a 2013 en el norte del país y la de 2015 en la parte sur del país, esta última atribuida al fenómeno del "Niño" (Tabla 10.4). Entre las tormentas tropicales desastrosas destacan "Gilberto" en 1988, "Isidoro" en 2002 y "Patricia" en 2015 (Tabla 10.5). 

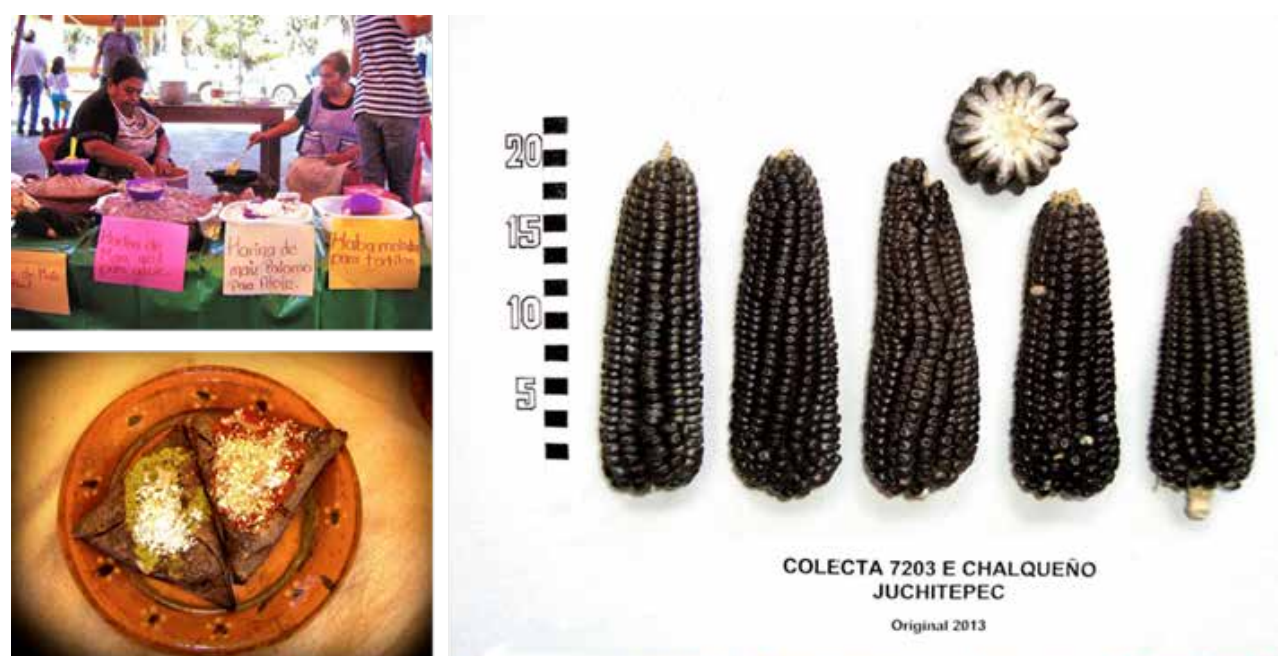

COLECTA 7203 E CHALQUEÑO JUCHITEPEC
Originat 2013

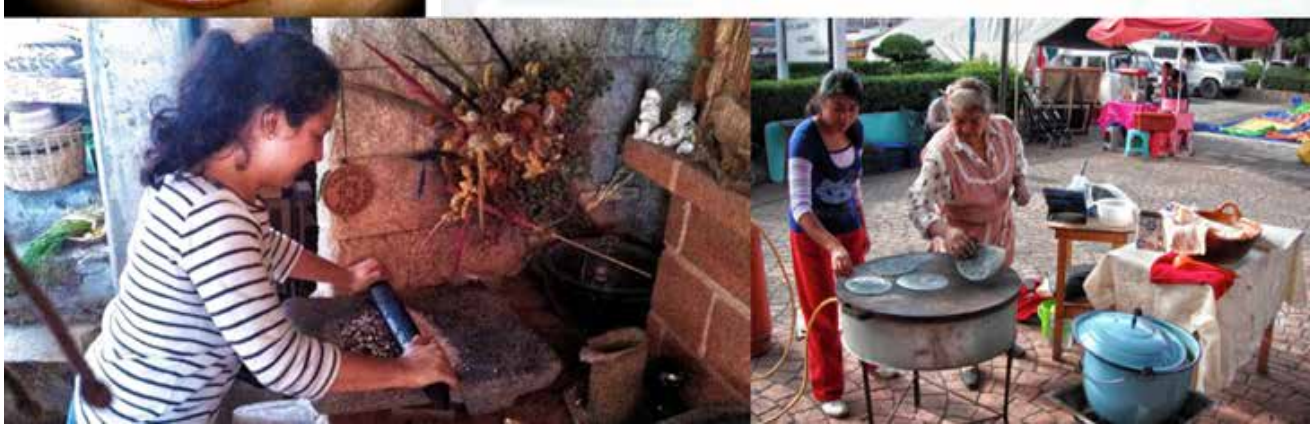

Figura 10.15. En los alrededores de la Ciudad de México han adquirido importancia comercial los maíces nativos de grano morado, para elaborar tortillas y antojitos de color azul.

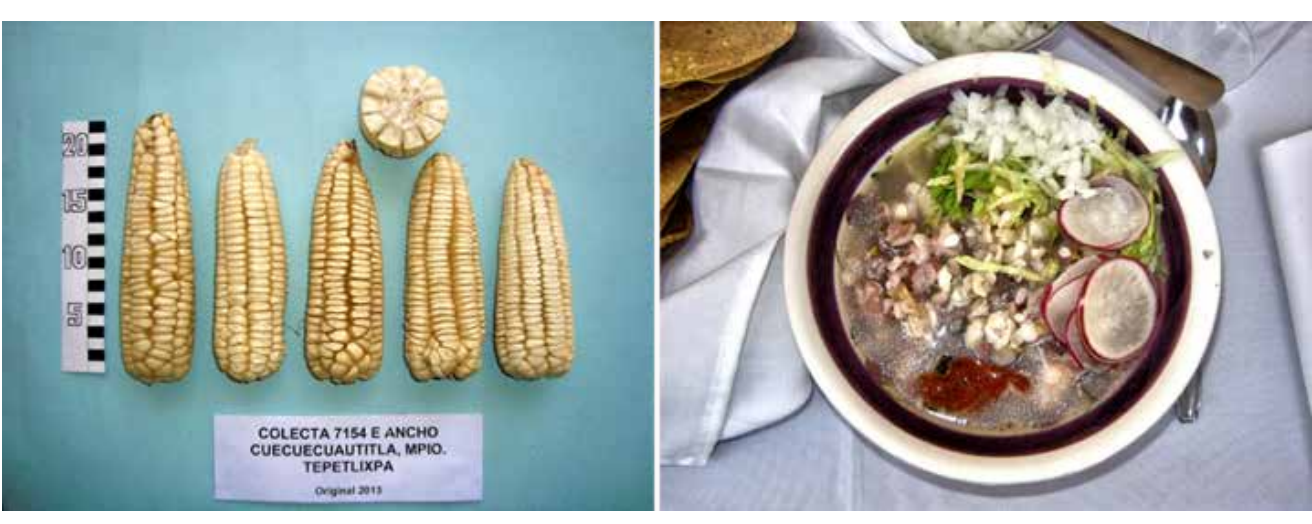

Figura 10.16. En los últimos años se ha registrado una gran expansión de la raza Ancho, la cual se usa principalmente para la elaboración del platillo denominado pozole, un plato típico de fiestas en todo México.
Con respecto a la sequía de 1957 en la región templado semiárida, el primer autor de este ensayo tuvo la oportunidad de colectar los maíces nativos en 1974. Por lo menos en ese año ya no oyó quejas de los agricultores por cultivares de maíces nativos perdidos y no recuperados. En ese trabajo se logró colectar considerable diversidad de la raza cónico norteño -que es la dominante- y algunas muestras de maíces nativos tardíos de siembras de humedad residual posiblemente de las razas chalqueño y celaya. Observó que en algunos lugares conservaban cosecha de años atrás, lo que tal vez explique la recuperación de la semilla a partir de los que tienen esa práctica.

Dzib-Aguilar (2008) en la colecta de maíces nativos en la Península de Yucatán en 1999, once años después de los enormes destrozos que causó el huracán "Gilberto" reunió una amplia diversidad de maíces, que se puede decir incluía la diversidad encontrada en 1947 por Efraím Hernández Xolocotzi, pero además colectó algunas poblaciones que claramente eran generaciones avanzadas de maíces mejorados y seis muestras ( $2.5 \%$ de lo colectado) pertenecientes a razas no reportadas antes en la península, las cuales fueron introducidas presumiblemente de otros estados.

La resiliencia de la agricultura campesina e indígena mexicana en lo que se refiere a la recuperación aproximada de la diversidad de maíz anterior a catástrofes meteorológicas no se debe sin embargo sobreestimar, existen al menos dos observaciones de que poblaciones de maíces nativos sobresalientes en experimentos colectados en años anteriores a catástrofes las perdie-

Tabla 10.4 . Las peores sequías que afectaron al sector agrícola de México de 1917 a 2015

\begin{tabular}{lll} 
Año & Lugar & Daños \\
1917 & Casi todo el país & Pérdida de las cosechas \\
\hline 1921 & Norte y noroeste & Muerte del ganado, pérdida de las cosechas . \\
\hline 1923 & Norte y centro & Pérdida de las cosechas. \\
\hline 1925 & Norte & Muerte de ganado, pérdidas de cosechas, incendios forestales. \\
\hline 1932 & Todo el país & Pérdida de cosechas, muerte del ganado. . \\
\hline 1935 & Casi todo el país & Pérdida de cosechas, muerte del ganado. . \\
\hline 1941 & Centro del país & Pérdida de las cosechas, se secaron manantiales. \\
\hline 1943 & Casi todo el país & Pérdida de las cosechas, muerte de ganado. \\
\hline 1957 & Casi todo el país & Grandes pérdidas en la agricultura. \\
\hline 1962 & Casi todo el país & Pérdidas en la agricultura y la ganadería, se secaron pozos y presas. \\
\hline 1969 & Casi todo el país & Pérdidas en la agricultura y ganadería. \\
\hline 1977 & Casi todo el país & $\begin{array}{l}\text { Pérdidas graves en la agricultura y la ganadería, incendios forestales, fuer- } \\
\text { te calor. }\end{array}$ \\
\hline 1993 & Norte y Centro & $\begin{array}{l}\text { Coahuila, la sequía más grave en los últimos } 40 \text { años: pérdidas totales de } \\
\text { 11 } 500 \text { cabezas de ganado. }\end{array}$ \\
\hline 1994 & Sur & La peor sequía en Chiapas. \\
\hline 1995 & Norte & Sinaloa: más de 5000 reses muertas y el $40 \%$ de siembras siniestradas. \\
\hline & &
\end{tabular}


Chihuahua: murió 1000000 de cabezas de ganado y se pierden 40 mil hectáreas de cultivo.

Campeche, Tabasco y Yucatán: la peor sequía desde hace 20 años.

Coahuila: 100000 cabezas de ganado murieron y se perdió el 50\% de los cultivos.

Nuevo León: 300000 cabezas de ganado murieron, no se sembraron más de 80000 hectáreas de cultivos básicos.

Durango: 20000 cabezas de ganado murieron, no se sembraron 640000 hectáreas de cultivos básicos.

Norte, Veracruz: 10000 cabezas de ganado murieron, se afectaron 200000 hectáreas de cultivos de temporal.

Estado de México: se dejaron de sembrar 300000 hectáreas de cultivos de temporal.

Zacatecas: 10000 cabezas de ganado murieron, se siniestraron 700000 hectáreas de cultivos básicos y pastizales.

San Luis Potosí: el $25 \%$ de la población del estado estuvo en riesgo de padecer hambruna. Se perdieron 200000 hectáreas de cultivos de temporal.

Sonora: la peor sequía en 30 años; las presas del sur del estado al 20\% de su capacidad.

Sinaloa: dejaron de sembrarse 120 mil hectáreas, las presas se encontraron al $10 \%$ de su capacidad.

Coahuila: murieron 4500 cabezas de ganado.

Zacatecas: 182000 hectáreas de frijol y maíz destruidas, 80000 campesinos en la mayor pobreza.

1999 Norte

Sonora. 800000 reses en peligro de morir, 25000 hectáreas de cultivos de temporales siniestradas. Se dejaron de sembrar 70000 hectáreas de cultivo en los valles del Yaqui y Mayo.

Tamaulipas: daño en 7400 hectáreas de cultivos básicos.

\begin{tabular}{lll}
2009 & Norte & $\begin{array}{l}\text { Sinaloa, Zacatecas y Guanajuato: } 2.7 \text { millones de hectáreas siniestradas } \\
\text { en siete de los principales cultivos }\end{array}$ \\
2011 & $\begin{array}{l}\text { Norte } \\
\text { y Centro }\end{array}$ & $\begin{array}{l}\text { Municipios de quince estados del país sufrieron por la sequía (Baja Cali- } \\
\text { fornia, Oaxaca, Yucatán, Chiapas y Guerrero). En Yucatán se dio la peor } \\
\text { sequía de las últimas dos décadas. }\end{array}$ \\
\hline
\end{tabular}

2015 Sur del país

Partes intermedias y cálidas de Michoacán, Guerrero, Oaxaca y Chiapas, pérdida de cosechas de temporal.

Fuentes: +

Florescano-Mayet, E.; J. Sancho y Cervera y D. P. Gavilán-Arias. 1980. Las sequías en México: historia, características y efectos. Comercio Exterior 30 (7): $747-757$.

García-Jiménez, F., O. Fuentes-Mariles y L. G. Matias-Ramirez. 2007. Sequías. Serie Fascículos. 1a reimpresión. Secretaria de Gobernación Centro Nacional de Prevención de Desastres. México, D. F. 36 p.

2015. (en linea, disponible en htrp://www vertigopolitico com/

articulo/35103/Sufren-sequia-15-entidades-del-pais.
Tabla 10.5. Huracanes en México considerados como los más devastadores de 1955 a 2015.

\begin{tabular}{|c|c|c|c|}
\hline Huracán & Año & Zona de impacto & Daños \\
\hline Janet & 1955 & Quintana Roo & $\begin{array}{l}\text { Provocó la muerte de más de } 600 \text { personas y pérdi- } \\
\text { das por } 1.5 \text { mil millones de dólares actuales. }\end{array}$ \\
\hline México & 1959 & Costa del Pacífico & $\begin{array}{l}\text { Considerado el más poderoso del Pacífico, categoría } \\
\text { 5. Dejó más de } 1000 \text { muertos a su paso. }\end{array}$ \\
\hline Beulah & 1967 & $\begin{array}{l}\text { Quintana Roo y noreste } \\
\text { de México }\end{array}$ & $\begin{array}{l}\text { Las peores inundaciones de la historia en Tamauli- } \\
\text { pas. Causó daños por } 700 \text { MDD actuales) }\end{array}$ \\
\hline Gilberto & 1988 & Yucatán & $\begin{array}{l}\text { Uno de los más intensos y devastadores en el Océa- } \\
\text { no Atlántico durante el siglo XX. }\end{array}$ \\
\hline Paulina & 1993 & $\begin{array}{l}\text { Chiapas, Oaxaca y Gue- } \\
\text { rrero }\end{array}$ & $\begin{array}{l}\text { Causó la muerte de entre } 230 \text { a } 400 \text { personas. Se } \\
\text { registraron daños por } 7500 \text { millones de pesos. }\end{array}$ \\
\hline $\begin{array}{l}\text { Opal y } \\
\text { Roxane }\end{array}$ & 1995 & $\begin{array}{l}\text { Península de Yucatán a } \\
\text { Veracruz }\end{array}$ & $\begin{array}{l}\text { Las peores inundaciones que Campeche había pa- } \\
\text { decido desde } 1927 \text {. }\end{array}$ \\
\hline Kenna & 2002 & Pacífico mexicano & $\begin{array}{l}\text { El segundo más poderoso sobre México, entre } 1980 \\
\text { y 2002, solo superado por Gillberto. }\end{array}$ \\
\hline Isidoro & 2002 & Yucatán & $\begin{array}{l}\text { Más de } 100000 \text { hectáreas de cultivos de maíz, hor- } \\
\text { talizas, henequén y frutas. }\end{array}$ \\
\hline Wilma & 2005 & Península de Yucatán & $\begin{array}{l}\text { Considerado el huracán más destructivo en la histo- } \\
\text { ria de México. Casi } 10000 \text { MDD en pérdidas. }\end{array}$ \\
\hline Stan & 2005 & $\begin{array}{l}\text { Chiapas, Oaxaca } \\
\text { y Veracruz }\end{array}$ & $\begin{array}{l}\text { Tan solo en Chiapas devastó } 400000 \text { hectáreas de } \\
\text { maíz y café. }\end{array}$ \\
\hline $\begin{array}{l}\text { Manuel e } \\
\text { Ingrid }\end{array}$ & 2014 & $\begin{array}{l}\text { Costa del Pacífico } \\
\text { y Golfo de México }\end{array}$ & $\begin{array}{l}\text { Fue un fenómeno inédito en la historia reciente, de- } \\
\text { bido al ingreso simultáneo de ambos por el Pacífico } \\
\text { y el Golfo. }\end{array}$ \\
\hline Patricia & 2015 & $\begin{array}{l}\text { Jalisco, Nayarit, } \\
\text { Michoacán y Colima }\end{array}$ & $\begin{array}{l}\text { Afectadas } 40000 \text { hectáreas de cultivos de plátano, } \\
\text { papaya, maíz y arroz. }\end{array}$ \\
\hline
\end{tabular}

ron sus campesinos. Una de esas observaciones la reporta Dzib-Aguilar (2008) quien a fines de 2002, después del paso del huracán "Isidoro", intentó recolectar muestras mayores de trece maíces sobresalientes que se habían colectado en 1999 y solo se pudo obtener semilla de dos. El primer autor de este ensayo colectó alrededor de 100 muestras de los maíces nativos en el sureste del Estado de México en 1995 a 1997, las cuales se evaluaron en experimentos de campo y como resultado se detectaron algunas muestras como prometedoras en rendimiento, caracteres agronómicos y diferentes tipos de color y textura de grano; en 2001 se buscó semilla adicional de esas poblaciones sobresalientes con los agricultores donantes cinco años atrás y la mayoría de ellos ya no las sembraban, algunos porque los habían perdido en sequías, otros porque los habían sustituido por otros cultivares y, en un caso porque el agricultor había envejecido y dejado de sembrar y sus descendientes se dedicaban a otras actividades. Lo anterior indica que para la conservación de la diversidad de maíz se deben combinar las estrategias in situ y ex situ. 


\section{Problemas tradicionales y nuevos en la agricultura}

La crisis general que vive México, por lo menos desde 1982, con frecuencia es más aguda en el medio rural y repercute en la conservación de la diversidad de maíz y su evolución bajo domesticación. Entre los problemas están: a) el aumento de la población de las comunidades que ocasiona, con frecuencia, mayores fragmentaciones de la tenencia de la tierra y a su uso más intensivo; b) como consecuencia del uso intensivo de la tierra, del cambio climático, del uso inadecuado de agroquímicos y maquinaria, y otros fenómenos ha disminuido en general la fertilidad de los suelos; c) por la necesidad de asistir a las escuelas y otros procesos, la población infantil y de adolescentes ya poco participan en las actividades agrícolas y la cultura rural sufre una considerable erosión; d) gran parte de la juventud emigra a las ciudades del país o a los Estados Unidos en busca de mejores ingresos y nivel de vida, en muchas comunidades rurales quedan pocos adultos, predominando viejos y niños, lo que entre muchas otras cosas provoca escasez de mano de obra agrícola, y e) en la vida rural hay cambios sustanciales como la ahora existencia de recursos monetarios producto de remesas de trabajadores, así como de subsidios, lo que aunado a que ahora han proliferado de tiendas de abasto en casi todas las comunidades rurales, provoca que ya muchos productos se compren y no haya necesidad de producirlos, entre ellos muchos productos derivados del maíz. En los últimos años por ejemplo, también en las áreas rurales se está desarrollando la producción semiindustrial de tortillas y su distribución a los hogares por repartidores en camionetas, motocicletas y bicicletas, esto provoca una disminución considerable en el consumo de la propia cosecha de maíz en la alimentación humana.

Todo lo anterior está amenazando seriamente la cultura tradicional de la milpa, incluida la diversidad de maíz y su evolución bajo domesticación.

\section{Experimentos de campo con colecciones de maíces nativos}

Vega-Zaragoza (1973), al comparar en experimentos de campo a colecciones de maíz efectuadas en la región de los Valles Altos Centrales de los estados de México, Puebla, Tlaxcala e Hidalgo a principios de los años cincuenta con otra de principio de los setenta del siglo pasado, registró que los rendimientos promedio de los maíces nativos se incrementaron en $44 \%$ y atribuyó ese aumento a la "influencia de las variedades mejoradas y la selección del hombre". En la "influencia de las variedades mejoradas" destacó la infiltración genética en los nativos originada por la llegada de polen de campos vecinos cultivados con mejorados.

Herrera-Cabrera (1999) en el distrito de Chalco, Estado de México, que forma parte de los Valles Altos Centrales, comparó las muestras de maíces nativos acopiadas de 1968-1972 con las reunida en 1995-96 y encontró que: a) el rendimiento de grano de la segunda colección fue mayor en 400 kg/ha, pero esa diferencia no resultó estadísticamente significativa; b) la longitud de mazorca fue ligeramente mayor en las segunda colección, pero tampoco resultó significativa; c) en cuanto a incidencia de Puccinia sp. en el follaje, tampoco se detectaron diferencias significativas.
Ortega-Paczka (1973) indica que: "Los maíces criollos de las partes tropicales de Chiapas colectados en 1971, en comparación con los colectados en 1946, en experimento en Cotaxtla, Veracruz, fueron superiores estadísticamente en grado altamente significativo $(0.01 \%)$ en los caracteres: longitud y peso de mazorca, así como en peso, volumen y densidad de grano."

Con respecto a los resultados en investigaciones citadas sobre comparación de colecciones de maíces nativos acopiadas en las mismas áreas geográficas de diferentes años, se anotan las siguientes limitaciones:

1. Las diferencias observadas entre colecciones acopiadas en diferente tiempo, por lo menos en parte, pueden deberse a diferentes frecuencias de tipos contrastantes en período vegetativo en diferentes etapas, así como a la desaparición e introducción de variantes.

2. Diferencias en las áreas colectadas en diferentes períodos, así como de los criterios para elegir las poblaciones de maíz a colectar y las técnicas de colecta.

3, Edad diferente de la semilla de las diferentes colecciones en las evaluaciones. En particular, las viejas colecciones se evaluaron con semilla original que tiene muchos años o con aumentos de semilla que tenían varios años de edad, mientras que las colecciones recientes se evaluaron con semilla nueva. Esto provoca diferencias en germinación de las semillas y en vigor de las plántulas que repercuten en disminución del rendimiento por factores fisiológicos de las semillas pero no genéticos.

4. Posibles cambios en las características del las accesiones guardadas en los bancos de germoplasma por número reducido de plantas que participaron en las polinizaciones controladas y por efecto de la renovación de semilla en campos experimentales bajo diferentes condiciones a las de los agricultores donantes.

No obstante lo anterior, por lo menos parte de las diferencias encontradas en el rendimiento y sus componentes en colecciones de maíces nativos realizadas recientemente en relación con colecciones antiguas de las mismas regiones pueden deberse a efecto de la evolución bajo domesticación de los maíces nativos en manos de los agricultores y campesinos. Es muy importante que se realicen más investigaciones de este tipo que son cruciales para estimar el efecto de la evolución bajo domesticación del maíz en cuanto a magnitud de la diversidad registrada, rendimiento y sus componentes, longitud de ciclo de vida, susceptibilidad a diferentes tipos de estrés y muchos caracteres más.

\section{Antecedentes de maíces nativos que fueron material para el mejoramiento}

Un tema muy interesante en mejoramiento genético en México son los antecedentes que se han logrado recuperar de los maíces que han servido como material de partida en mejoramiento genético. Como refiere Limón-García (1945), en un principio los fitomejoradores del Instituto de Investigaciones Agrícolas de la Secretaría de Agricultura y Fomento intentaron usar germoplasma sobresaliente de la Faja Maicera de los Estados Unidos como base para el mejoramiento genético del maíz en México, pero debido a que esos materiales no mostraron adecuada 
adaptación a los ambientes de México, se decidió buscar poblaciones nativas sobresalientes en rendimiento y caracteres agronómicos, habiendo logrado ubicar magníficos maíces nativos para varios de los programas regionales de mejoramiento. Un hecho que es poco conocido es que por lo menos una parte importante de los materiales sobresalientes que se han usado como material de partida en mejoramiento genético procedieron de explotaciones agrícolas de vanguardia, tales son los casos de Haciendas "Carmen de Benítez" y "San Juan de la Generala" en Tamaulipas; un agricultor de apellido Capitaine en el norte de Veracruz, otro en Celaya Guanajuato (Limón-García 1945), la variedad "Urquiza" de la Hacienda Obrejuelos, cerca de Querétaro" (Wellhausen et al., 1951); agricultores menonitas en Zacatecas. En algunos casos, como en la Hacienda San Juan de la Generala, hay indicios de que en la hacienda se practicó selección con técnicas de Genética Moderna antes de ser colectada y pasar a formar parte de programa de mejoramiento del Antiguo Instituto de Investigaciones Agrícolas.

Hace algunos años el autor de este ensayo se enteró que un agricultor del área de Amecameca, Estado de México, tenía una población nativa con mazorca muy larga; por ello, se buscó a esa persona y se ha estado en contacto con él. Al preguntarle si sabía de dónde y cómo habían logrado un maíz de esas características, dicha persona indicó que su padre durante muchos años seleccionó su semilla, al parecer, por selección masal moderna. Este maíz nativo se ha estado evaluando contra criollos élite de la región, así como en comparación con híbridos comerciales y con frecuencia los ha superado en rendimiento; pero tiene planta muy alta y susceptible a que caiga al suelo por efecto de los vientos y su mazorca pesada. En vista de sus virtudes y deficiencias esta población nativa se ha incluido en el programa de mejoramiento para el sureste del Estado de México de la Universidad Autónoma Chapingo (Figura 10.17).

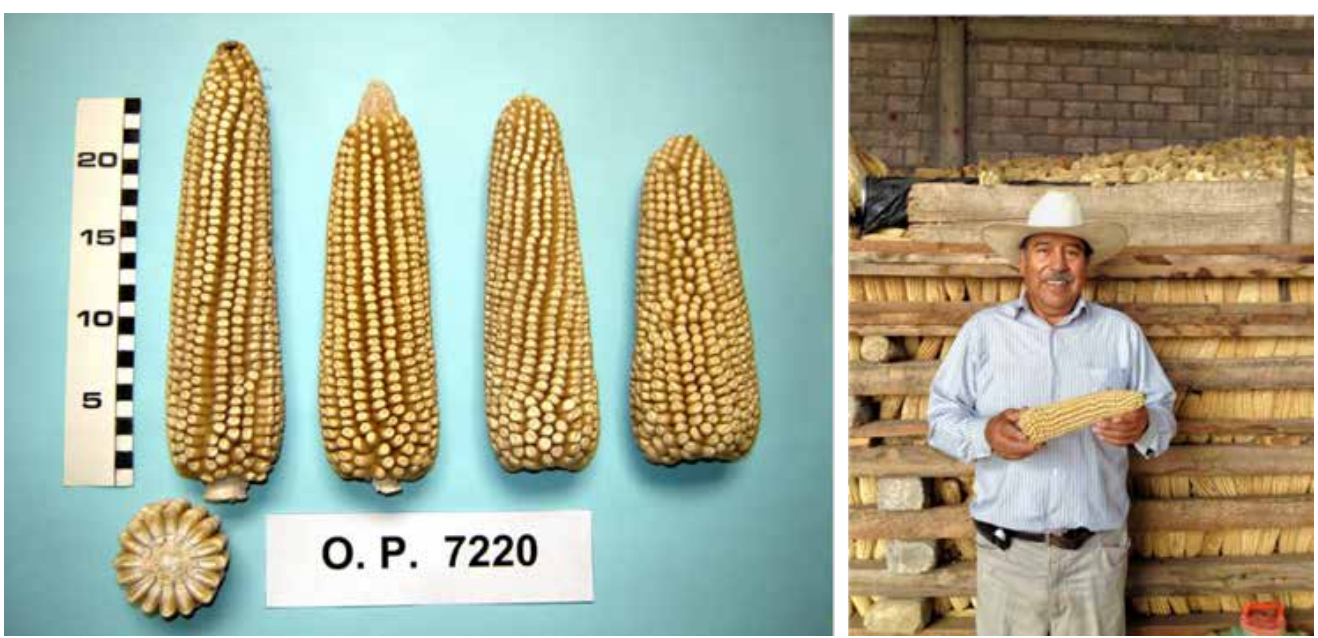

Figura 10.17. Variedad nativa con mazorca excepcionalmente grande. Este maíz nativo con frecuencia supera el rendimiento de maíces mejorados, pero su planta es muy alta y susceptible a caer por efecto del viento y el peso de la mazorca. Esta población nativa se ha incluido en el programa de mejoramiento para el sureste del Estado de México de la Universidad Autónoma Chapingo.
A principio de la década de los noventa del siglo pasado el primer autor de este ensayo realizó una exploración etnobotánica para ver el estado de conservación de diversidad de maíz en el centro de Tamaulipas. Esta región es especialmente interesante porque si bien no destaca por ser un centro de gran diversidad morfológica, en varias haciendas que existieron en la primera mitad de dicho siglo se colectaron muy importantes maíces nativos de donde se obtuvieron las líneas de maíz para las regiones subtropicales por parte de las instituciones de fitomejoramiento del gobierno mexicano. Desafortunadamente, en la exploración de fines de siglo se observó que los descendientes de los agricultores que habían sido beneficiados con tierras de dichas haciendas, ya no prestaban gran atención a la conservación de aquellos cultivares élite sino que, de forma general, sembraban generaciones avanzadas de maíces mejorados.

\section{Raza de maíz ancho que recientemente se ha dispersado y consecuencias en su diversidad}

Desde hace algunos años se ha investigado con cierto detalle la evolución de la distribución de la raza de maíz ancho (Perales et al, 2003; Ron-Parra et al. 2006; Carrera-Valtierra et al., 2012; Aguilar-Juárez, 2016), la diversidad dentro de la raza (Aguilar-Juárez, 2016), así como algunos cambios en las características de las plántulas en poblaciones que se han introducido a una nueva área (González-Regalado, 2016). La distribución geográfica de esta raza se ha expandido de gran manera en los últimos años (véase la Figura 10.18), lo que ha traído como

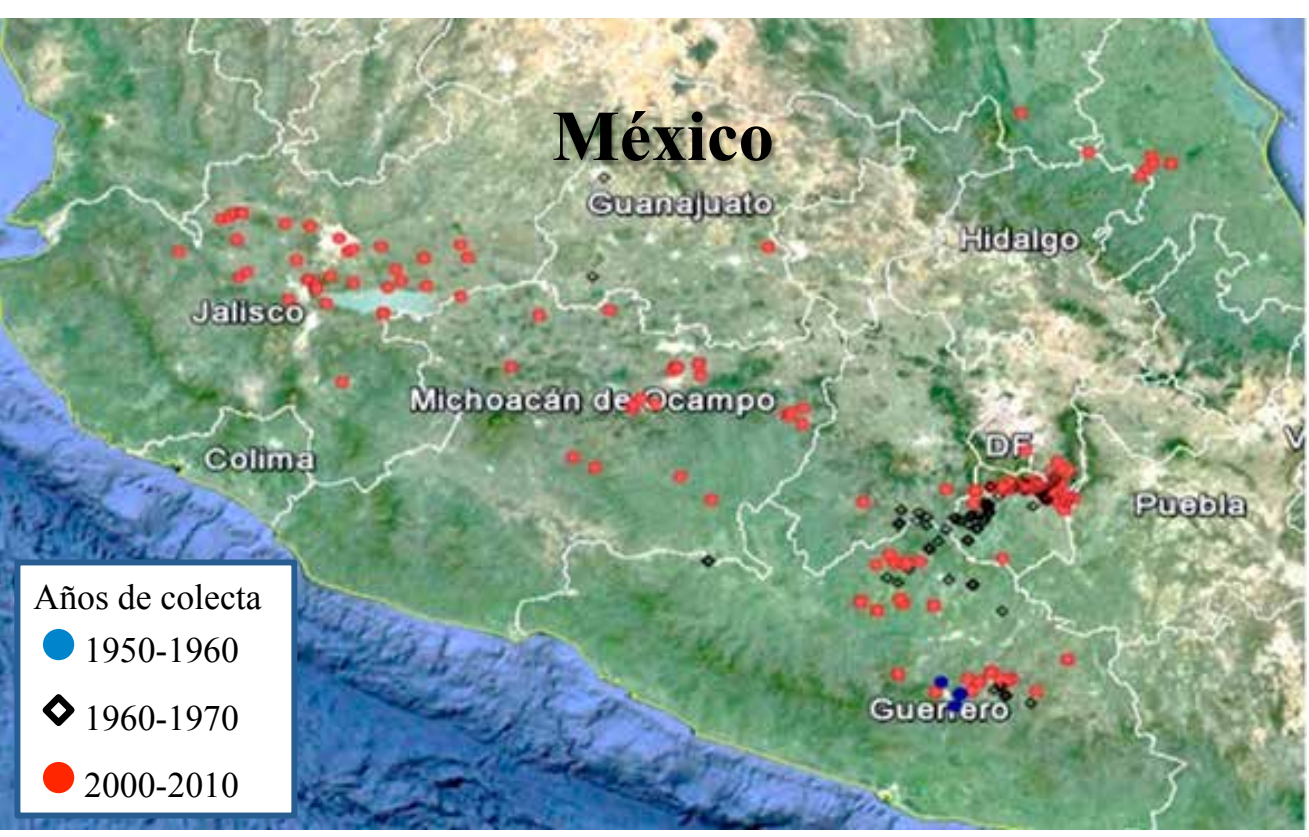

Figura 10.18. Distribución geográfica de la raza Ancho, las cual se ha expandido en los últimos años, ocasionando cambios en su morfología debido a selección natural y 
consecuencia importantes cambios en su morfología por selección ambiental y humana, así como por cruzamientos con maíces locales de las nuevas áreas de distribución (Aguilar-Juárez, 2016; González-Regalado, 2016). En algunas poblaciones de esta raza han sido tan importantes los cambios que se ha propuesto la posibilidad de que se hayan generado nuevas razas (Aguilar-Juárez y González-Regalado, 2012; Carrera-Valtierra et al., 2012); sin embargo, se ha comprobado que se trata de una sola raza, si bien una serie de poblaciones han evolucionado a nivel de proponerlas como subraza y otra se propone como grupo intermedio entre Ancho y Chalqueño por ser producto de su cruzamiento y ulterior selección (Aguilar-Juárez, 2016).

\section{Procedimientos de agricultores para mejorar las características de sus maíces}

Los agricultores al efectuar selección de semilla dentro de sus poblaciones locales, no solo pretenden conservar las características de las mismas, eliminando mazorcas fuera del tipo, 0 granos con evidencias de que son cruzas con maíces diferentes de los vecinos, sino que buscan y en gran parte consiguen mejorarlas conforme a modelos que tienen. Entre los esfuerzos de los agricultores por contar con maíces con mejores características también se registra con mucha frecuencia la introducción de cultivares de otras regiones y su adaptación a nuevos ambientes. Un aspecto muy importante es que, entre los materiales genéticos que utilizan como material de partida, así como en las técnicas de hibridación y selección que practican los agricultores y campesinos, es frecuente encontrar materiales y técnicas copiadas o inspiradas en los trabajos que hacen los fitomejoradores.

Ortega-Paczka (1973) relata varios ejemplos de cómo agricultores de áreas tropicales de Chiapas han comparado y combinado maíces nativos y mejorados. Un agricultor de maíz ancho en el sureste del Estado de México notó que su cultivar era de grano algo cremoso, y para blanquearlo mezcló semilla de ese cultivar con un maíz nativo de grano blanco, sembró la mezcla por varias generaciones y fue seleccionando los granos tipo ancho, pero más blancos.

Muchos de los campesinos de México que en las décadas de los cincuenta a los setenta de siglo pasado dejaron de sembrar maíces criollos amarillos, por su menor precio en el mercado, ahora se interesan en recuperarlos. Tal es el caso de Don Pedro Cruz de Juchitepec, Estado de México, quien no esperó a que obtuviéramos los fitomejoradores una variedad mejorada amarilla, sino que él seleccionó un lote de doscientas mazorcas de entre las remanentes de un experimento de maíces criollos y mejorados amarillos establecidos por nosotros, formó un compuesto, lo sembró y se puso a seleccionar semilla de la cosecha, desafortunadamente después de un par de años desistió de seguir esa selección y adoptó un criollo amarillo de otro agricultor de la región.

Quizás el caso más conocido en México de generación por un agricultor de un material sobresaliente con base en materiales y conocimientos de fitomejoradores con formación universitaria, es la generación de la variedad Nal-Xoy por el Sr. Rufino Chi Canul en la península de Yucatán, población que se siembra bastante en dicha región. Esta persona fue ayudante por unos años de un fitomejorador y luego continuó solo la labor de mejoramiento, alternó surcos de la población PR-7822 mejorada del CIMMYT de grano blanco con surcos de una población de grano amarillo de la raza Nal-Tel y luego seleccionó por adaptación y grano amarillo. Además de haber obtenido el Nal-Xoy original de grano amarillo, posteriormente dentro de ese material seleccionó los granos blancos que aún segregaba y así formó el Nal-Xoy Blanco (Dzib-Aguilar, 2008).

\section{A manera de conclusiones}

En la revisión de literatura efectuada y exposición de observaciones propias de los autores se encontraron causas y datos favorables a la conservación in situ y la evolución bajo domes ticación de los maíces nativos en diferentes partes y en México en su conjunto en el último siglo, pero también se identificaron procesos y ejemplos de reducción de la diversidad de esa planta cultivada.

México forma parte del centro de origen y diversidad del maíz y hay persistencia del uso de maíces nativos con diferentes características para usos específicos; los productores tienen sus parcelas de 0 a 3,400 metros sobre el nivel del mar y en lugares con precipitaciones de 300 a $3000 \mathrm{~mm}$ de precipitación pluvial. La diversidad que conservan de esa planta y que evoluciona en sus manos es enorme y tiene vital importancia para las propias comunidades que la conservan, para el país y para el mundo.

La categoría de raza ha sido muy útil para entender hasta cierto grado la diversidad de maíz en México pero si se quiere profundizar esa categoría no es suficiente, se tienen que usa otros conceptos como subraza, tipo y población local nativa. A medida que se han hecho más exploraciones y estudios más detallados, se han descrito nuevas razas. Las cifras de número de razas de maíz en México más aceptadas por ahora son 59 (Sánchez et al., 2000) ó 64 (CONABIO, 2011).

Entre 1915 y 1980 en México tuvo lugar un considerable reparto agrario y procesos de apertura de nuevas tierras a la agricultura por lo que aumentó el número de agricultores principalmente maiceros y se amplió el rango de ambientes en que se cultiva el maíz. A partir de mediados del siglo pasado gran parte delos agricultores han adoptado el uso de fertilizantes, herbicidas y maquinaria agrícola, lo que ha provocado importantes cambios en el manejo agrícola del maíz. Estos factores parece que han influido en la evolución de maíz ya que ha tenido que adaptarse a nuevos ambientes.

Los datos estadísticos muestran que el 80 \% de los productores de maíz en México, que son alrededor de dos millones de familias, siguen obteniendo su semilla de su cosecha anterior $y$ que en la mayoría de los casos sus cultivares son nativos, si bien es considerable el uso de generaciones avanzadas de híbridos con frecuencia combinados con maíces nativos.

Se encontraron indicios de que poblaciones nativas de maíz han seguido evolucionando in situ en el último siglo en México en adaptación a nuevos ambientes, aumento en el rendimiento de grano y caracteres agronómicos, y esto podría no solo haber ocurrido por procedimientos tradicionales sino incluso por la aplicación consciente de principios y técnicas de la Genética Moderna por agricultores. 
Dada la enorme diversidad dentro y entre poblaciones nativas de maíz en México y el frecuente entrecruzamiento espontáneo y dirigido entre dichas poblaciones, la selección de semilla para mantener la identidad de las poblaciones de maíz y mejorar sus características juega un papel fundamental en la conservación in situ y evolución, aunque el cruzamiento entre poblaciones nativas locales y con introducciones exóticas son también muy importantes; en cambio, aunque no está bien estudiado, no parece que el flujo génico de los teocintles, parientes cercanos hacia el maíz haya sido un factor de evolución sobresaliente en el último siglo; por lo que se refiere a las mutaciones cualitativas no parecen haber contribuido mucho a la evolución de los maíces nativos pero desde luego que se han aprovechado considerablemente en mejoramiento genético; en un aspecto en que la acumulación de mutaciones cada una de efectos pequeños pudiera tener efecto reciente es en la adaptación a nuevos ambientes cada vez más limitantes en cuanto a humedad del suelo, altas temperaturas ambientes y baja fertilidad.

En algunas áreas cálidas bajas, así como en algunas de alturas intermedias los maíces mejorados han sustituido en parte a la diversidad nativa, especialmente a maíces de grano blanco usados para tortillas, sin igualarlos en calidad de los alimentos; en cambio casi no han sustituido a los maíces nativos para usos especiales tradicionales, ni a los que se cultivan en amplias regiones con limitantes de suelo o bajas temperaturas. Por otro lado en amplias regiones, las generaciones avanzadas de maíces mejorados combinados con maíces nativos forman parte del patrimonio biocultural de las comunidades de agricultores, campesinos e indígenas que manejan esas poblaciones como lo hacen con los maíces nativos.

En cuanto a sequías o tormentas tropicales devastadoras, se encontraron algunas evidencias de que los agricultores recuperan la diversidad de maíz que tenían antes de esos fenómenos meteorológicos, pero también se encontraron casos en que se pierden maíces valiosos.

encontraron también algunos procesos de deterioro de la diversidad como consecuencia de destrucción de unidades de producción de vanguardia por repartos agrarios.

Son reducidos los esfuerzos gubernamentales para conservar in situ los maíces nativos y en general la cultura tradicional, en cambio se ha favorecido con abundantes recursos la adopción de maíces híbridos. La conservación in situ y la evolución bajo domesticación del maíz en manos de agricultores debe ser protegida e impulsada por el Estado Mexicano y la comunidad internacional porque esos procesos son fundamentales para la subsistencia de cerca de dos millones de familias indígenas, campesinas y agricultores mestizos del país, así como porque esos procesos constituyen gran parte de la evolución del maíz en el mundo.

\section{Recomendaciones}

Continuar la compilación de información y la realización de investigaciones sobre la evolución reciente de los maíces en poder de los agricultores en México.

Establecer como política pública que se estimule decididamente la labor de selección de semilla campesina y otros factores de evolución bajo domesticación del maíz en México.

\section{Agradecimientos}

A los agricultores y campesinos mestizos de México que aportaron gentilmente saberes y muestras de maíz, así como que permitieron que se les tomaran las fotografías que aparecen en este trabajo.

Al Sr. Marcos Moreno Moreno, Auxiliar de Técnico de Investigación de la Universidad Autónoma Chapingo, quien ha procesado y conservado muchas de las muestras de mazorcas fotografiadas e incluidas en el trabajo.

A los colaboradores del proyecto "Conservación y mejoramiento participativo de maíces criollos para el sureste del Estado de México", quienes tomaron las fotografías en las que se indica el autor específico, el resto son fotografías tomadas directamente por el Dr. Rafael Ortega Paczka. El proyecto citado ha sido sostenido por la Universidad Autónoma Chapingo y recibió financiamiento complementario del Sistema Nacional de Recursos Fitogenéticos de 2002 a 2011.

Al M. C. Cecilio Mota Cruz que revisó un borrador de este trabajo e hizo importantes sugerencias al mismo.

A los Diseñadores Gráficos Álvaro Luna Castillejos y Jorge Enrique Ibarra Sánchez, empleados administrativos de la Universidad Autónoma Chapingo, quienes editaron las fotografías que se incluyen en el trabajo. 


\section{Bibliografía}

Aguilar-Castillo J. A y A. Carballo-Carballo A., 2007. Comisión Nacional para el Conocimiento y Uso de Recuperación conservación y aprovechamiento de la raza Jala de maizz: una alternativa para las razas en peligro de extinción. Colegio de Postgraduados-Sistema Nacion

Aguilar-Juárez, J. A., 2016. Diversidad genética de maíz ancho en México.

Aguilar-Juárez., J. A. y J. J. González-Regalado, 2012. Diversidad de maíces criollos y determinación de sus custodios en el sureste del Estado de Mexico. Tesis Universidad Autónoma Chapingo, México.

Anderson, E., 1947. Field studies of Guatemalan Maize.
Annals of the Missouri Botanical Gardens, 34: 433-467.

Anderson, E., 1949. Introgressive hybridization. John Wiley

Anderson, E. y H. C. Cutler, 1942. Races of Zea mays: I. Their recognition and classification. Annals of the Missour Botanical Gardens, 29: 69-86.

Anónimo, 1958. Modesta colaboración del personal técnico de la comisión (Comisión Nacional de Maíz) a la Oficina de Estudios Económicos y Sociales de la Campaña Político Electoral, que realiza el Partido Revolucionario Institucional, en favor del Señor Licenciado Don Adolfo López Mateos, para ocupar la Presidencia de la
República durante el perído de gobierno 1958-1964.

República durante el período de gobierno 1958-1964.

Aquino P, F. Carrion, R. Calvo y D. Flores, 2001. Selected
Maize Statistics. En: P. L. Pingali (Ed.). World Maize Facts and Trends, Meeting World Maize Needs: Technological Opportunities and

Aragón-Cuevas C., F., S. Taba, J. M. Hernández- Casillas. J de D. Figueroa-Cárdenas., V. Serrano-Altamirano. y F.
H. Castro- García, 2006. Catálogo de maíces criollos de Oaxaca. INIFAP-SAGARPA, Libro Técnico No. 6, Etla, México, $346 \mathrm{p}$.

Benz, B. F., 1986. Taxonomy and evolution of Mexican maize. Tesis de doctorado.Universidad de Wisconsin-Madison

Boege, E., 2008. El patrimonio biocultural de los pueblos indigenas. Hacia la conservación in situ de la biodiversidad y la agrodiversidad en los territorios indígenas. Instituto Nacional de Antropología e Historia-Comisión Naciona
para el Desarrollo de los Pueblos Indígenas, México.

para el Desarrollo de los Pueblos Indígenas, México.

Brauer-Herrera., O., 1968. La tecnologia y la ciencia en
el desarrollo de la agricultura. En: O. Brauer-Herrera. el desarrollo de la agricultura. En: O. Brauer-Herrera.
Diagnóstico de las ciencias agrícolas en México. Centro Dacionostil de Productividad, México, pp. 4-5.

Carrera-Valtierra, J. A., J. Ron-Parra y M. M. Morales-Rivera, 2012. Cinco nuevas razas de maíz (Zea mays L. spp. mays).

Chávez, E., 1913. Cultivo del maíz. Boletín No. 74 de la Dirección Genera Ag proyecto global "Recopilación, generación, actualización y análisis de información acerca de la diversidad genética de maíces y sus parientes silvestres en México". (En línea proyectoMaices.html).

CONASUPO. 1988. El mercado de las subsistencias populares. Cincuenta años de regulación. Tomo II, EUDEBA. Buenos Aires.

Dzib-Aguilar L A 2008 Estudios etnobotánico y de germoplasn participativo de maiz en Yucatán. Tesis de Doctorado. Universidad Autónoma de Yucatán, Mérida, México.

González-González, M., 2007. Diversidad del maiz: Potencial agronómico y perspectivas para su conservación y Tesis de Doctorado. Colegio de Postgraduados, Texcoco, México.

onzález-Regalado, J. J., 2016. Adaptación de maíces anchos traslocados al agroecosistema de humedad residual en el sureste del Estado de México. Tesis de de las plantas en México: una apreciación personal En: T. P. Ramamoorthy, R. Bye, A. Lot y J. Fa (Eds.). Instituto de Biología Universidad Nacional Autónoma de México, pp. 715-735.

Hernández-Xolocotzi, E. y G. Alanís-Flores, 1970. Estudio morfológico de cinco razas de maíz de la Sierra Madre Occidental de México: Implicaciones fil

Herrera-Cabrera, B. E., 1999. Diversidad genética y valor agronómico entre poblaciones de Maíz de la raza Chalqueño. Tesis de Doctorado. Colegio de
Posgraduados en Ciencias Agrí́colas. Texcoco, México. Poza Chalqueno. Tesis de Doctarado. Colegio de Es Nacional de Estadística y Geografía (INEGI), 2015. Estadsticas historicas de Mexico 2014. (En linea, disponible en: http://www.inegi.org.mx/prod_serv/contenidos/
espanol/bvinegi/productos/nueva_estruc/HyM2014/9.\%20 Agropecuario,\%20aprovechamiento.pdf.

ato-Yamakake, T. A., 2009. Teorías sobre el origen del maíz En: T.A. Kato-Yamakake, C. Mapes-Sánchez, L. M. Mera(eds.). Origen y diversificación del maiz: una revisión analítica. Universidad Nacional Autónoma de México y Comisión Nacional para el Conocimiento y Uso de la Biodiversidad, México, pp. 43-68.

Khankhoe, P., 1930. Nuevas variedades d emaíz. Boletín de Investigación Número 1. Reproducido en Revista de

Kuleshov, N.N., 1930. Maices de México, Guatemala, Cuba, Comper. nández-Xolocotzi, E., 1998. Aspectos de la domesticación Geografía Agrícola. Núm. 54 (2015), pp. 49-59.
Panamá y Colombia (Según las colecciones de N. S. Bukasov). En: N. S. Bukasov. Las Plantas Cultivadas de México, Guatemala y Colombia. Boletín de Botánica 150 (en ruso). Traducción al Español por Jorge León. 1981. CATIE, Turrialba, Costa Rica, pp. $40-53$

Limón-García, E., 1945. Informe de trabajos realizados en e Campo Agrícola Experimental de León, Gto. de marzo

Co 1941 a dicie Expe dim 1945. Mecanoescito. Mexico.

Matsuoka, Y., Y. Vigouroux, M. M. Goodman, J. Sánchez G., E. for maize shown by multilocus microsatellite genotyping. PNAS, 99: 6080-6084.

Morett-Sánchez, J. C., 2003. Reforma agraria: Del latifundismo al neoliberalismo. Universidad Autónoma Chapingo/

Muñoz-Orozco, A., 2003. Decifrando la diversidad del maíz de los nichos ecológicos de México. En: A. Muñoz-Orozco (Ed.). Centli-Maiz: Prehistoria e Historia, Diversidad, Nacional de Recursos Fitogenéticos SNICS-SAGARPA, México, pp. 133-142.

Muñoz-Orozco, A., A. Carballo-Carballo y V. GonzálezHernández, 1976. Mejoramiento del maíz en el CIAMEC. Análisis crítico y reenfoque del programa. En: Sociedad Mexicana de Fitogenética (compiladores). Memoria del VI Congreso Nacion

Ortega-Corona, A., M. de J. Guerrero-Herrera y R. E. del maiz nativo y sus parientes silvestres distribución del maiz nativo y sus parientes silvestres en México. INIFAP, México.

Ortega-Paczka, R., 1973. Variación en maíz y cambios socieconómicos en Chiapas, México, 1946-1971. Tesis de

Ortega-Paczka, R., 1985. Recursos genéticos para el mejoramiento de maíz en México. Primera Parte: Análisis cientifíco de la Sociedad Mexicana de Fitogenética $A$. C., No. 3, pp. 19-36.

Ortega-Paczka, R., 1999. Genetic erosion in Mexico. En: FAO. Proccedings of Technical Meeting on the Methodology of the FAO World Information and Early Warning System

Ortega-Paczka, R., 2000. Colecciones de semilla y sus relaciones con conservación in situ. Revista de Geograft

Ortega-Paczka, R., J. Sánchez-González, F. Castillo-González J.M. Hernández-Casillas, 1991. Estado actual de los Paczka, G. Palomino-Hasbach, F. Castillo-González, V. A. González-Hernández y M. Livera-Muñoz (Eds.). Avances en el estudio de los recursos fitogenéticos. SOMEFI, Chapingo, México, pp. 161-185.

Perales Rivera, H. R., 1998. Conservation and evolution of . de Doctorado. University of California-Davis. des, R. H, S. B. Brush y C. O. Qualset, 2003. Landraces of maize in central Mexico: An altitudinal transect. conomic Botany, 57:7-20.

Perales-Rivera, H. R. y J. M. Hernández-Casillas, 2005. Diversidad del maíz en Chiapas. En: M. GonzálezEspinosa., N. Ramírez-Marcial y L. Ruiz-Montoya (coord.). Diversidad biológica en Chiapas. ECOSURRamos-Rodríguez, A., 1972. Descripción de la variación morfológica de los maíces de las partes oriental del Estado de Mexico y de la central del Estado de Puebla. Tesis de Licenciatura. UNAM, Facultad de Ciencias.

Rist, S., 2000. De la investigación a la acción: Aspectos conceptuales, metodológicos e institucionales para la campesinas de los Andes Bolivianos. Revista de

mero-Peñaloza, J. y R. Ortega-Paczka, 1996. Sistemas de cultivo, variedades y erosión genética en maíz en Geografía Agrícola, 22-23: 113-129.

Ron-Parra., J., J. J. Sánchez-Gonzalez, A. A. JiménezCordero, J. A. Carrera-Valtierra, J. G. Martín-López, M. M. Morales-Rivera., L. de la Cruz-Larios, S. A. Hurtado de la Peña, S. Mena-Munguia y J. G. Rodríguez-Flores, Scientia-CUCBA, 8(1): 1-139.

Sanchez G., J., M. M. Goodman y C. W. Stuber, 2000 Isozimatic and morphological diversity in the races of maize of Mexico. Economic Botany, 54(1): 43-59.

Servicio Nacional de Inspección y Certificación de Semillas (SNICS), 2016. Mapa de Distribución de Colectas, distribución de colectas d ela Red Maiz. mx/rfaa/Paginas/Basicos_e Industriales/Maiz/Mapa Distribucion.aspx.

Silva C., E. G., 1992. Estudio agronómico y taxonómico de colecciones de la raza de maíz Cónico, su colección central y perspectivas de uso en mejoramiento Monetico. Tesis de

avilov, N. I., 1931 (1994). México y Centroamérica como centro básico de origen de las plantas cultivadas del Nuevo ta de Geografa Agrícola, No. 20: 15-34.

a-Zaragoza, G., 1973. Estudio de la infiltración genética de los maices mejorados sobre los criollos de temporal 政 -Issa, M. R., 2011. ¿Qué hacemos con el campo mexicano?. 2a edic. Colección Biblioteca Básica d Agricultura. Colegio de Postgraduados, Montecillos,

hausen, E. J., L.M. Roberts y E. Hernández-Xolocotzi, en colaboración con P.C. Mangelsdorf, 1951. Razas de Folleto Técnico No. 5, Oficina de Estudios Especiales Secretaría de Agricultura y Ganadería, México, D.F. 


\section{Los agaves \\ y las prácticas mesoamericanas de aprovechamiento, manejo y domesticación ${ }^{1}$}

Patricia Colunga-GarcíaMarín; Ignacio Torres-García; Alejandro Casas, Carmen J. Figueredo Urbina; Selene Rangel-Landa; América Delgado-Lemus;

Ofelia Vargas; Dánae Cabrera-Toledo; Daniel Zizumbo-Villarreal; Aguirre-Dugua Xitlali; Luis E. Eguiarte; Guadalupe Carrillo-Galván

\section{Resumen}

Las prácticas de aprovechamiento y manejo humano de plantas, como la domesticación, pueden tener efectos evolutivos sobre las mismas. Para Darwin, las plantas y animales domesticados fueron fundamentales en la construcción de su teoría y en la actualidad siguen siendo objeto de estudio sobre biología evolutiva. La domesticación es un proceso evolutivo continuo de selección artificial por humanos que puede determinar divergencias entre poblaciones silvestres y cultivadas. Al conjunto de rasgos, o características, que diferencia a las plantas domesticadas de sus ancestros silvestres se le conoce como síndrome de domesticación, y estos rasgos, al estar sometidos a fuerzas selectivas similares, constituyen una expresión de convergencia evolutiva. Estas tendencias han sido documentadas en decenas de especies domesticadas, así como en sus parientes silvestres; entre ellas se encuentra el caso del árbo de las maravillas: los agaves.

Los agaves han sido de mucha importancia para las culturas indígenas americanas debido a los diversos usos que se le han dado desde hace, aproximadamente, 10000 años; razón por la cual decenas de ellos han llegado a domesticarse, y aún en la actualidad encontramos vigentes muchas prácticas de manejo, uso y domesticación. Presentamos una revisión de distintos casos de estudios con agaves, con el propósito de documentar las consecuencias y evidencias etnobotánicas, morfológicas, ecológicas y genéticas que ha tenido la interacción humano-agaves en el continente americano. Documentamos las distintas características de los síndromes de domesticación, así como los usos del agave destacando los más actuales y la problemática asociada a ella. Identificamos cuatro principales usos: 1) alimento, 2) fibra, 3) bebidas sin fermentar y fermentadas, y 4) bebidas destiladas, siendo esta última la de mayor importancia actual. Además, se documentaron las características del síndrome de domesticación en cada caso. Existen 
22 categorías de usos con más de 100 especies empleadas actualmente. Los agaves son manejados in situ y ex situ en distintos agroecosistemas como monocultivo y cultivos tradicionales en sistemas agroforestales. Las evidencias revisadas aquí nos llevan a plantear que, dependiendo de los propósitos o móviles de selección, las características del síndrome de domesticación pueden variar. Los sistemas agroforestales tradicionales exhibieron importantes características que los ubican como sistemas que permiten salvaguardar estos recursos genéticos. La extracción de poblaciones silvestres sin planes de manejo sustentable parece tener consecuencias demográficas y genéticas que amenazan la permanencia de las especies. Las huellas fenotípicas y genéticas de selección humana relacionadas con un conjunto de usos particulares no han sido estudiadas, por lo que es necesario contribuir al conocimiento de estos usos y continuar la documentación de la relación humano-agave.

Palabras clave: agaves, domesticación, magueyes, manejo forestal, Mesoamérica, mezcal, recursos forestales no maderables.

\section{Introducción}

Las plantas del género Agave L. son emblemáticas de Mesoamérica, región cultural conformada durante el período prehispánico (Kirchhoff, 1943), y que ha sido reconocida como un centro primario de origen de agricultura y domesticación de plantas (Harlan, 1975; Hawkes, 1983; Vavilov, 1992). En esta área, los pobladores han desarrollado y mantenido un núcleo de alta diversidad de cultivos de los cuales actualmente depende parte importante de la humanidad. Siendo una de las principales cunas mundiales de agricultura, Mesoamérica cuenta con una profunda tradición de domesticación de plantas de por lo menos 10000 años (Flannery, 1986; MacNeish, 1992).

Colunga-GarcíaMarín y Zizumbo-Villarreal (1993) y Casas et al. $(2007,2014)$ coinciden en plantear que, debido a la resistencia cultural de sus pueblos nativos, sus sistemas agroalimentarios conservan dos características clave por las que Mesoamérica sigue siendo un centro dinámico de diversificación de recursos bióticos, principalmente plantas, a través de domesticación: 1) el mantenimiento de complejos poblacionales de plantas bajo diferentes intensidades de manejo, los cuales pueden corresponder a distintos grados de domesticación, y 2) la conservación de altos niveles de diversidad a todos estos niveles de manejo y domesticación. Ejemplos de diversificación y domesticación bajo manejo y selección tradicional, en los que pueden observarse estas dos características clave, han sido descritos por Colunga-GarcíaMarín et al (1986) para e caso de los nopales (Opuntia L. spp.), por Zizumbo-Villarreal et al. (2005) para el frijol (Phaseolus vulgaris L.) y por Casas y colaboradores para distintas especies de cactáceas columnares, leguminosas (Leucaena Benth. spp.), diferentes especies de quelites y de árboles domesticados (Casas et al., 1997, 1999a, 1999b, 2007, 2015a, 2015b; Blancas et al., 2010, 2013; Otero-Arnaiz et al., 2005; Parra et al., 2010).

En este capítulo presentamos una revisión de evidencias etnobotánicas, morfológicas genéticas de tres casos que ilustran, para siete especies del género Agave (Asparagaceae: Agavaoideae, APGIII, 2009), las dos características claves de las prácticas tradicionales mesoamericanas de domesticación mencionadas arriba.
Primeramente, revisamos la antigüedad y características históricas de lo que Gentry (1982) denominó la simbiosis entre humanos y agaves, presentando una síntesis de los cuatro grandes síndromes de domesticación que pueden reconocerse en este grupo de plantas como resultado de tan larga historia de interacción, así como de los móviles de selección relacionados con sus cuatro usos más importantes: alimento, fibra, bebidas sin fermentación (aguamiel) y fermentadas (pulque), y bebidas destiladas (mezcales). Después abordamos específicamente el caso de los agaves con los que se realiza la producción de los mezcales debido a que la producción de estas bebidas es actualmente el móvil más importante de uso, selección y cultivo de un gran número de especies en México. En segundo lugar, revisamos las evidencias etnobotánicas, morfológicas y genéticas de los tres casos abordados en torno a una pregunta central: ¿Cuál ha sido el efecto de la interacción entre humanos y agaves en la diferenciación y diversificación morfológica y genética de las especies estudiadas? Finalmente, presentamos un panorama general de la problemática de los agaves mezcaleros en México, discutimos las implicaciones de nuestros hallazgos y las de los proyectos de interacción entre la sociedad, las instituciones científicas y las organizaciones gubernamentales y no gubernamentales para poner en marcha estrategias de manejo sustentable de estos recursos bioculturales. Ponemos énfasis en el hecho de que el mantenimiento de la cultura de los pueblos mesoamericanos, de alto aprecio y fomento de la diversidad de sus plantas domesticadas, es central para enfrentar los grandes cambios ambientales y culturales que se viven actualmente a escala mundial, y que se han denominado "cambio global" (Vitousek 1994) en sus dimensiones ecológicas y sociales.

\section{Interacción humano-agaves en Mesoamérica y síndromes de domesticación}

Agave es un género que, de manera natural, solo se distribuye en el área comprendida entre el sur de los Estados Unidos de América y el norte de Sudamérica, abarcando Colombia, Venezuela y las islas del Caribe; siendo México su centro geográfico de origen y diversidad (Gentry, 1982). El $75 \%$ de las especies de este género crecen en México y $57 \%$ de ellas son endémicas. Crecen prácticamente en todo su territorio, pero son especies clave y especialmente representativas de sus ecosistemas áridos y semiáridos (García-Mendoza, 2011).

Además de ser su centro geográfico de origen y diversidad, México es también su centro de diversificación bajo aprovechamiento, manejo y selección humana, y como Gentry (1982) sostuvo: "fue aquí, en donde la gran diversidad genética de un género rico en usos potenciales cayó en manos de los pueblos que desarrollaron el principal centro de agricultura de las Américas".

Las investigaciones arqueológicas indican que la interacción entre humanos y agaves en Mesoamérica se inició desde la prehistoria, hace por lo menos 11000 años (Smith Jr., 1967; McNeish, 1967; Flannery, 1986; Smith Jr., 1986). Los seres humanos que poblaron el actual territorio de México asaban y horneaban tallos, bases foliares y pedúnculos de la inflorescencia de agave para consumirlos como alimento. A lo largo de estos milenios los agaves han sido usados de múltiples formas por los pueblos mesoamericanos, de modo que a la 
fecha hemos registrado más de 22 categorías de uso (Tabla 1) y alrededor de 40 usos específicos, los cuales abarcan prácticamente todas las partes estructurales de los agaves (Colunga-GarcíaMarín y May-Pat, 1993).

Los principales usos de los agaves han estado relacionados con sus características biológicas más distintivas: 1) Almacenamiento de carbohidratos en los tallos, bases de las hoja y savia de la inflorescencia al final de su ciclo reproductivo. Los agaves son plantas rosetófilas, perennes y monocárpicas, es decir, se reproducen sexualmente, solo una vez, al final de su existencia. Esto ocurre, usualmente, después de un período de crecimiento entre cinco y veinticinco años o más, dependiendo de la especie y del ambiente en el que vive. Excepto en unas pocas formas caulescentes, el tallo es grueso y abreviado. Este, junto con las bases de las hojas imbricadas en espiral, forma una masa fibrosa que actúa como estructura de reserva rica en carbohidratos, los cuales son utilizados de forma natural por la planta para el desarrollo de la inflorescencia. La translocación de recursos de esta masa fibrosa a la inflorescencia ocurre acompañada, en muchas especies, del flujo abundante de una savia también rica en carbohidratos. 2) Hojas fibrosas, con saponinas y armadas. Sus hojas poseen dientes laterales y una espina terminal, pero además contienen una alta concentración de saponinas, que son metabolitos secundarios tóxicos e irritantes para los humanos y otros animales. 3) Estructura de roseta y sistema amplio de raíces superficiales. Tienen un sistema de raíces superficiales muy extendido que, junto con su forma de rosetas, les permite captar agua de forma eficiente en ambientes de poca precipitación y retener suelo en pendientes elevadas. Muchas especies son capaces de propagarse vegetativamente a través de estolones, hijuelos axilares, hijuelos basales o bulbilos: característica que les permite formar manchones clonales y que ha sido aprovechada por los seres humanos para propagar fenotipos deseables (Gentry, 1982; Colunga-GarcíaMarín et al., 2007; Torres et al., 2015b).

Las prácticas de aprovechamiento y manejo humano de plantas, como la domesticación, pueden tener efectos evolutivos sobre las mismas. La domesticación es un proceso por el cual las poblaciones de plantas experimentan una serie de cambios fenotípicos y genotípicos, que suelen ser graduales y continuos, como consecuencia de la reproducción diferencial de los individuos favorecidos por los seres humanos, elección humana o selección artificial segun Darwin (1859). Este favorecimiento puede ser consciente o inconsciente, y ocurre en relación con la adecuación fenotípica de estos genotipos a las necesidades, preferencias y prácticas de uso y manejo de los grupos humanos que los utilizan (Darwin, 1859; Colunga-GarcíaMarín y Zizumbo-Villarreal, 1993 Gepts, 2004; Pickersgill, 2007; Casas et al., 2007; Casas et al., 2014, 2015a, 2015b). Al conjunto de rasgos, o características, que diferencia a las plantas domesticadas de sus ancestros silvestres, se le conoce como síndrome de domesticación. Estos rasgos, al estar sometidos a fuerzas selectivas similares, constituyen una expresión de convergencia evolutiva.

La larga interacción entre los grupos humanos y los agaves en Mesoamérica ha dejado huellas morfológicas, fisiológicas y genéticas relacionadas con los propósitos o móviles que han tenido los humanos para usarlos, manejarlos y seleccionarlos. Estas huellas o características conforman diferentes síndromes de domesticación. Proponemos que para los agaves son cuatro síndromes que están ligados a sus usos más importantes: alimento, fibra, bebidas con o sin fermentación (aguamiel y pulque) y bebidas destiladas (mezcales).
Debido a que los agaves son usados de forma muy variada entre los pueblos mesoamericanos, y que muchas especies tienen una distribución geográfica amplia, al estudiar los síndromes o tendencias de domesticación de cada especie o variedad podemos encontrar que: 1) su síndrome de domesticación refleja la interacción que sus diferentes usos han tenido en las presiones de selección que los humanos han ejercido históricamente sobre ella, 2) en una misma región geográfico-cultural coexisten variedades de una misma especie con síndromes de domesticación diferentes, ya que han sido seleccionadas para usos distintos, y 3) a lo largo de la distribución geográfica de una especie existen síndromes diferentes de domesticación según el contexto ecológico y cultural en el que han sido usadas, manejadas y seleccionadas. Este aspecto se puede ejemplificar especialmente con el caso de Agave angustifolia Haw., la especie de Agave con la distribución más amplia, objeto de una gama extensa de usos y probablemente el ancestro silvestre de varias especies cultivadas (Gentry, 1982; García-Mendoza et al., 1993).

Revisaremos ahora tres de los síndromes o tendencias de domesticación que proponemos, discutiéndolos en relación con tres de sus usos principales e ilustrándolos en la Figura 11.1. El síndrome que ha resultado de su uso para mezcales lo analizaremos en una sección aparte.

1. Alimento. En este caso las características seleccionadas han sido el tamaño, la concentración de carbohidratos, y el sabor del tallo y del pedúnculo de la inflorescencia. Estas estructuras morfológicas se aprovechan cuando las plantas, hacia el final de su ciclo de vida, concentran en ellas una gran cantidad de energía (carbohidratos) para el desarrollo de las estructuras reproductivas. La gente corta el pedúnculo de la inflorescencia antes del desarrollo de las flores -es decir, castra a la planta-, lo utiliza, y deja el resto de la planta in situ durante meses o años, hasta que los carbohidratos, que de otra forma se hubieran usado para la producción de flores y néctar, alcanzan su máxima concentración en el tallo. Es entonces cuando les cortan las hojas (la base foliar queda prendida al tallo) y lo cosechan. A esta estructura le llaman "piña" o "cabeza" por su similitud a la infrutescencia de Ananas comosus (L.) Merr. Tanto los pedúnculos como las cabezas, asados u horneados bajo tierra, han sido ampliamente utilizados como alimento desde hace al menos 11,000 años tanto en Mesoamérica (Smith, 1967) como en la región cultural denominada Aridoamérica, ya que con el uso del fuego son fácilmente convertidos en un alimento muy dulce, con palatabilidad y digerible. Las características de los carbohidratos complejos (fructanos) que contienen han sido caracterizados y bautizados como agavinas por López et al. (2003). Se conocen alrededor de 60 especies empleadas para este uso y cerca de 12 presentan claros signos de domesticación. (v. gr. Agave tequilana F. A. C. Weber, A. americana var. oaxacensis Gentry, A. angustifolia; Gentry, 1982; Colunga-GarcíaMarín et al., 2007; Torres et al., 2015a). Este síndrome de domesticación está compuesto por: a) gigantismo en las partes usadas (cabezas y pedúnculos), y b) mayor concentración de carbohidratos (azúcares) en ellas.

2. Fibra. Para este uso, las características seleccionadas han sido la longitud y ancho de las hojas, la cantidad y resistencia de las fibras que contienen, y su calidad en relación a uso para el que se seleccionen. La utilización de las hojas de agaves por su fibra es tan antiguo e importante como el alimenticio. Hay evidencias arqueológicas de este apro- 
vechamiento de al menos hace 9000 años antes del presente (A.P.) (King, 1986). Este uso probablemente se desarrolló, inicialmente, con la misma técnica arcaica: el asado al fuego. Existen alrededor de 48 especies que se emplean para este uso y alrededor de 12 presentan claros signos de domesticación ( $v$. gr. Agave fourcroydes Lem., A. sisalana Pe-

rrine, A. angustifolia) (Gentry, 1982; Colunga-GarcíaMarín, 2003; Colunga-GarcíaMarín et al. 2007). Con las fibras se elaboran costales, sogas y cordeles, herramientas de trabajo que fueron muy importantes en México hasta los años cincuenta cuando empezaron a sustituirse con plásticos. En la época prehispánica, las fibras de agave se usaban incluso para elaborar vestimentas, ya fuera solas o combinadas con algodón (Kelly, 1944 Coggins y Shane III, 1989; García-Martínez, 1987; Benz et al., 2006). Este síndrome de domesticación está compuesto por: a) gigantismo en la parte usada (hojas), y b) mayor proporción de fibra en ellas.

3. Savia comestible, para elaborar bebidas sin fermentar (aguamiel) o fermentadas (pulque). Para este apartado, las características seleccionadas han sido la cantidad y calidad de la savia, lo cual se logra seleccionando un mayor tamaño de la roseta y savia con mayor contenido de azúcares y propiedades organolépticas deseables. El aprovechamiento de la savia que fluye del tronco al pedúnculo floral es también un uso muy antiguo, pero las evidencias materiales de su utilización son relativamente más recientes, de hace unos 3500 años A.P. (Parsons et al., 1990). A esta savia se le llama "aguamiel" por su dulzor, y una vez fermentada se le conoce como pulque. Existen alrededor de 18 especies en el país que se emplean para este uso y cerca de 10 especies cultivadas presentan evidentes signos de domesticación, (Agave salmiana var. salmiana Otto ex Salm-Dyck, A. atrovirens var mirabilis (Trel.) Gentry, A. mapisaga Trel.) (Gentry, 1982; Colunga-GarcíaMarín et al, 2007; Alfaro-Rojas et al., 2007; Mora-López et al., 2011). El pulque llegó a ser muy apreciado en todos los círculos sociales de México, pero su abasto comenzó a disminuir dramáticamente en el período posterior a la Revolución Mexicana cuando las grandes haciendas pulqueras fueron sujetas al reparto agrario (Álvarez, 2015). Posteriormente, con la expansión de la industria cervecera, después de la década de los cincuenta, su comercio decayó aún más (Álvarez, 2015). Este síndrome está compuesto por: a) mayor cantidad de savia, y b) gigantismo en toda la planta.

Aunado a las características que conforman los tres aspectos del síndrome de domesticación referidos anteriormente, las culturas que han aprovechado los agaves también han dirigido la selección hacia: 1) variantes con dientes más pequeños y espaciados, característica que los hace menos peligrosos para su manipulación durante sus diversas formas de aprovechamiento y cosecha, 2) variantes con concentraciones bajas de saponinas, y, en el caso de especies de reproducción vegetativa, hacia 3) variantes con mayor producción de propágulos (Colunga-GarcíaMarín, 1998; Colunga-García Marín et al., 2007; Vargas-Ponce et al., 2007; Figueredo et al., 2014; Torres et al., 2015b).

Una de las prácticas de importancia agroecológica fundamental en el sistema agrícola mesoamericano ha sido el empleo de los agaves para conformar cercos vivos y para reforzar bordos de terrazas en terrenos con alta pendiente, plantándolos en hileras en sentido perpendicular a ella. Estas prácticas también ayudan a evitar la depredación de los cultivos
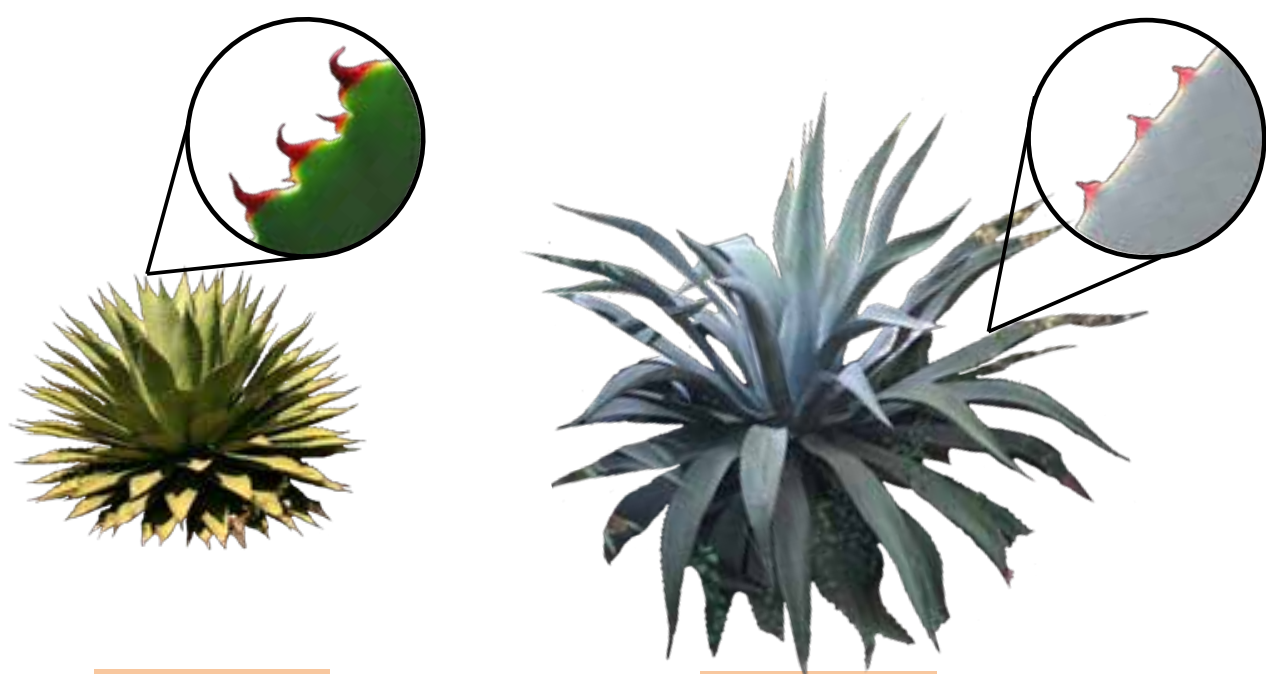

Silvestre $t \quad$ Domesticado

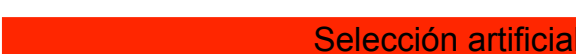

Usos ancestrales

\section{Alimento}

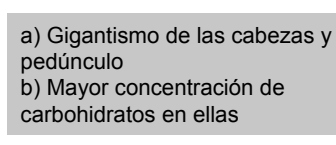

Fibra

a) Gigantismo de la hojas
b) Mayor proporción de fibra en b) Mayor
las hojas.

Figura 11.1. Esquema de los síndromes de domesticación en especies de agaves, distinguiendo entre los usos ancestrales y actuales, y las características distintivas para cada caso. Se tomó como referencia las especies $A$. inaequidens silvestre y $A$. hookeri domesticado (Diseño: I. Torres y C. J. Figueredo, Fotos: Ignacio Torres-García)

por parte de venados y pecaríes, así como para retener el suelo y la humedad. Los registros arqueológicos de este uso son de al menos 1000 años de antigüedad (García-Payón, 1979). La importancia de este aprovechamiento se acrecentó con la introducción del ganado por parte de los colonizadores europeos hace cerca de 500 años. En este tiempo, los cercos vivos se convirtieron en una estrategia fundamental de los pueblos nativos para proteger 
sus cultivos y compaginar la actividad agrícola con la ganadera (Colunga-GarcíaMarín y Zizumbo-Villarreal, 2007; Zizumbo-Villarreal et al., 2013). Para este uso las variedades más apreciadas son aquellas que tienen mayor dentición, lo cual es contradictorio con una de las características en la que coinciden los cuatro síndromes de domesticación que aquí se proponen. Por lo tanto, es posible encontrar variedades para las que la mayor dentición es parte de su síndrome de domesticación (Carillo-Galván, 2011) como lo discutiremos más adelante en uno de los casos analizados.

Otras categorías de uso han sido también de gran importancia para los pueblos originarios (Tabla 11.1). Las huellas fenotípicas de selección humana relacionada con estos usos no han sido estudiadas, pero podría ser muy interesante. Tal es el caso de la posible selección de variedades con escapos florales robustos para la construcción de viviendas en áreas como los valles de Tehuacán y del Mezquital en México, en donde las viviendas de los pueblos tradicionales tienen como componentes principales las hojas y los escapos de varias especies A. salmiana, A. marmorata Roezl., A. potatorum Zucc., entre otras). En amplias áreas andinas, Agave americana $\mathrm{L}$. es de los pocos recursos que brindan material para la construcción y, por lo tanto, una de las especies más utilizadas con este propósito.

Hoy en día, cerca de 107 taxa del género Agave son ampliamente usados en México, en donde reciben 570 nombres diferentes en 26 idiomas nativos, además del español (Colunga-GarcíaMarín et al., 2007).

Existen varias aplicaciones modernas de los agaves, como son la extracción de saponinas precursoras de esteroides como el cortisol (Gentry, 1982; Debnath et al., 2010). También el uso de los carbohidratos de sus tallos y la lignocelulosa de sus hojas para producir biocombustibles como el etanol (Borland et al., 2009; Somerville et al., 2010). Así como el potencial uso farmacéutico de las agavinas para la prevención o manejo de enfermedades o padecimientos como el sobrepeso, el síndrome metabólico, la obesidad, la diabetes y la osteoporosis (López y Urías-Silva, 2007)

Entre las especies más usadas destacan Agave americana, $A$. angustifolia, $A$. fourcroydes, A. salmiana, $A$. sisalana y otras que han sido menos documentadas como $A$. mapisaga y $A$. hookeri Jacobi. Estas especies fueron y aún siguen siendo altamente valoradas en México. Después de la llegada de los conquistadores europeos a América, su uso y cultivo se extendió hacia África, Asia y Europa (Gentry, 1982). Especies como A. sisalana han sido muy importantes económicamente en países como Tanzania, India, Brasil y China para la extracción y comercio de sus fibras (Gentry, 1982).

En el presente, el móvil más importante de uso, cultivo y selección de especies de Agave en México es el de la producción de las bebidas destiladas genérica y tradicionalmente llamadas "mezcales", pero con otros nombres regionales como "tuxca", "raicilla", "bacanora" o "tequila", siendo este último el más famoso. El tequila es un mezcal con Denominación de Origen desde 1975. Según la Norma Oficial Mexicana que lo rige (NOM-006; Secretaría de Economía 2012b), solo puede producirse a partir de la variedad azul de la especie $A$. tequilana, pero puede producirse en cinco estados de la República Mexicana, y no solo en el Valle de Tequila, Jalisco, de donde obtuvo su fama y su nombre.
Tabla 11.1. Categorías de uso generales de las especies de agaves en México, especificando la parte de la planta que es empleada para cada propósito (Revisión I. Torres y S. Rangel-Landa).

Categorías de uso Parte utilizada

1. Alimenticio

2. Bebida destilada Tallo, bases foliares, escapo, savia, botones florales

2. Bebida destilada

4. Medicina humana

5. Medicina veterinaria

6. Aislante y condimento (barbacoa)

7. Material de construcción

8. Cerca viva

9. Retención del suelo

10. Obtención de utensilios Tollo, bases foliares, savia fermentada

11. Ornato

12. Forraje

13. Combustible

14. Elaboración de papel

15. Obtención de fibras

16. Jabón (Saponinas)

17. Carnada para cacería

18. Delimitación de terrenos

19. Obtención de insectos comestibles

20. Elaboración de artesanías

21. Ceremonial

22. Juguetes Savia extraída del tallo Hojas, savia, destilado

Hojas, savia, destilado Hojas, cutícula

Hojas, escapo, fibras Planta completa

Planta completa

Espinas, escapo, hojas Planta completa, escapos y flores

Hojas, escapo y botones florales Hojas, tallos y escapo seco Hojas

Hojas

Hojas

Escapo, flores

Plantas completas

Plantas completas, hojas

Hojas, escapos

Individuos completos, escapos, destilado

Hoja, escapos, espinas

\section{El mezcal: origen y evolución}

La palabra "mezcal" proviene del náhuatl, la lengua hablada por los aztecas, y significa "agave cocido" (Gran Diccionario Náhuatl, 2016). En México, esta palabra tiene tres acepciones: 1) las plantas de Agave usadas para cocer sus cabezas como alimento; 2) el alimento obtenido de la cocción bajo tierra de sus cabezas, y 3 ) la bebida que se obtiene de destilar los jugos y fibras fermentadas (mostos) obtenidos de las cabezas cocidas de los agaves. La acepción más conocida es la de las bebidas destiladas de Agave, y es en ese sentido en el que usamos aquí el término. En este caso el término hace una referencia clara a la materia prima usada y a su uso más antiguo, el alimenticio, a partir del cual se desarrolló su aprovechamiento para bebidas fermentadas y destiladas. 
El área en la que al arribo de los españoles se horneaban tradicionalmente cabezas de agave para alimento humano fue llamada por Henry Bruman $(1940,2000)$ "La gran región cultural del mezcal” (Fig. 11.2). En esta área, Bruman señaló que los agaves como alimento probablemente fueron: 1) el elemento más difundido de la dieta nativa antes del desarrollo de la agricultura, 2) fundamentales en todas las regiones de Mesoamérica y sur de Aridoamérica, excepto en las tierras bajas tropicales, y 3 ) la base primordial sobre la cual se superpusieron, más tarde, los recursos alimenticios cultivados en Mesoamérica.

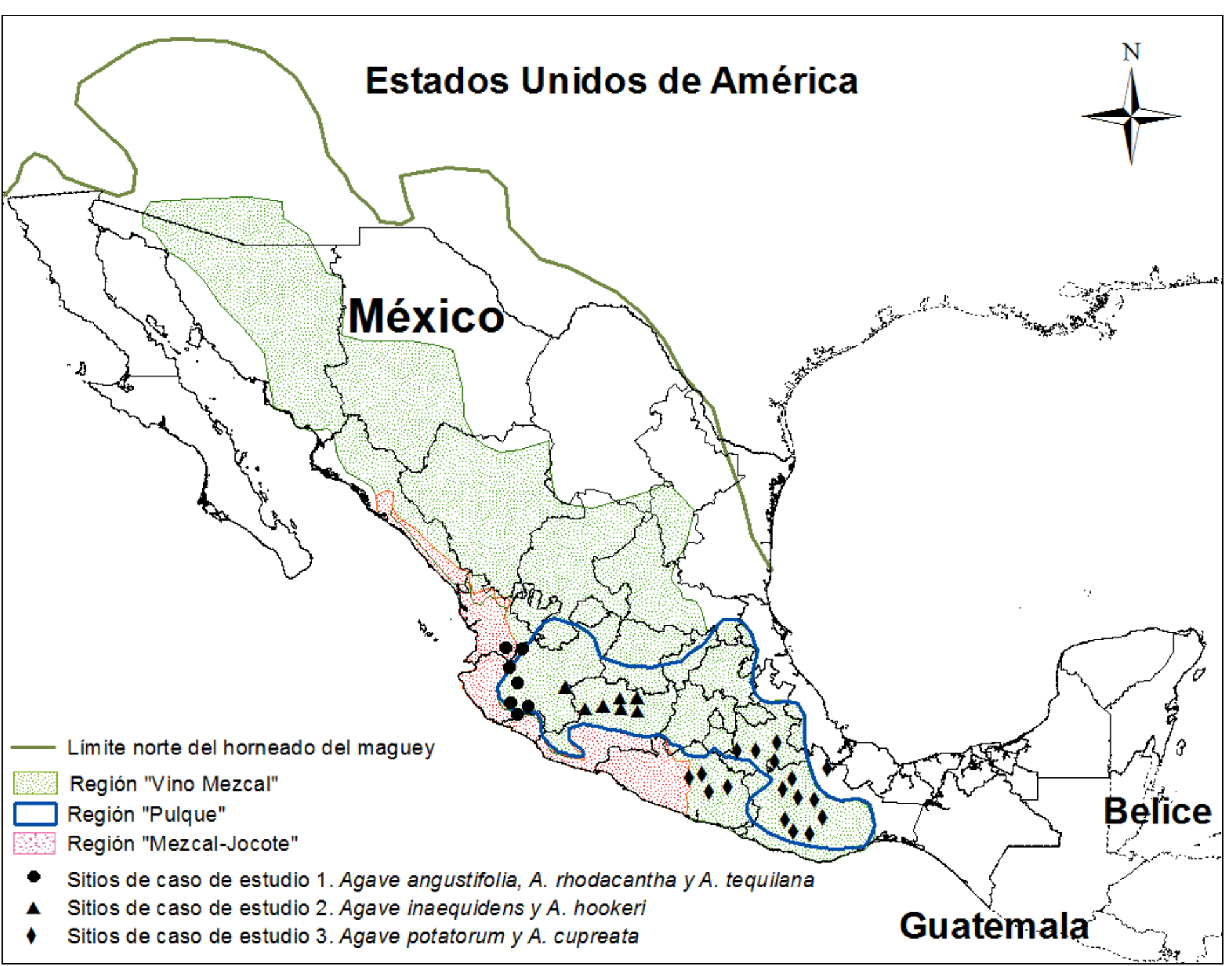

A partir de este uso, el horneado de cabezas de agaves para bebidas fermentadas y destiladas pudo haberse iniciado. El área con una cultura de horneado de agaves para bebidas fermentadas se denominó por el mismo autor como la región cultural del "Vino-Mezcal". Dentro de esta área describió cinco sub-áreas según la importancia relativa de otras bebidas alcohólicas. En una de ellas las bebidas predominantes eran, justamente, las de agave y las de jocote o ciruela nativa (Spondias L. spp.). El valle de Tequila, en honor del cual la bebida recibe su nombre, se encuentra en las cercanías de esta área (Figura 11.2). Colindando con esta, hacia el centro de México, se encuentra el área de predominio del pulque, bebida fermentada de agave que podría haber sido descubierta junto a su uso alimenticio, ya que es posible que los humanos, al cortar e pedúnculo floral para usarlo como alimento, hayan observado y probado la savia que fluía de la planta.

Pero ¿cómo y cuándo pudo iniciarse la destilación de los fermentos (mostos) de agave? La fermentación es un proceso natural descubierto y empleado por todas las culturas humanas, pero la destilación no lo es, y no ha sido descubierta o inventada por todos los pueblos. En el caso de los agaves, el destilado más común ha sido el del mosto, también llamado tepache o tuba, obtenido de los jugos extraídos de las cabezas horneadas, pero también puede destilarse la savia fermentada de la inflorescencia: el pulque.

Para la región del "Vino-Mezcal", existe una descripción inequívoca de que la población indígena de la Costa y de la Sierra de Nayarit preparaba esta bebida hace ya más de 400 años a partir de los mostos obtenidos de las cabezas de agave horneadas (de Arregui, 1612, en Zizumbo-Villarreal y Colunga-GarcíaMarín, 2007). Para la región que en la actualidad es el sur del estado de Jalisco hay una descripción de 1579 acerca de sus usos prehispánicos, entre los que se incluye la elaboración de "vino" (Relación de Zapotitlán, 1579 en Zizumbo-Villarreal y Colunga-GarcíaMarín, 2007), palabra que los españoles usaban de forma ambigua para diferentes bebidas alcohólicas, tanto fermentadas como destiladas.

Aunque la invención prehispánica de los destilados de Agave permanece controversial, Zizumbo-Villarreal et al. (2009a) han presentado evidencias que fortalecen la hipótesis de su elaboración en la región del "Vino-Mezcal" desde hace 3500 años, probablemente con fines ceremoniales y usándose un tipo de vasija que se habria desarrollado

Figura 11.2. Regiones culturales de producción de bebidas alcohólicas en México, modificado a partir del mapa propuesto por Bruman
(1940). Se indica la gran área cultural en la que los agaves han sido (1940). Se indica la gran área cultural en la que los agaves han sido usados como alimentos y bebidas fermentadas. Se indican las localiño S. Rangel-Landa). 
a partir de las ollas de cerámica usadas para cocinar frijoles. Por su parte, Serra-Puche y Lazcano-Arce (2016), también han encontrado evidencia que indica que en Tlaxcala pudo haberse producido mezcal en el 300 a. C, también con fines ceremoniales.

Habiéndose originado los mezcales a partir del uso alimenticio de los agaves, y evolucionado con la selección de características similares, su síndrome de domesticación incluye muchas de as características de los tres síndromes principales en agaves (Figura 11.1). Está compuesto por: a) gigantismo de la parte usada (cabezas) y b) mayor concentración de carbohidratos en ellas, así como c) menor dentición de las hojas y d) menor cantidad de saponinas para favorecer la cosecha. Por otra parte, es posible que del uso de los agaves para la producción de bebidas fermentadas y destiladas haya surgido una presión selectiva hacia asociaciones exitosas de microrganismos con los mostos (las huellas que dejaron estas presiones selectivas no ha sido estudiadas hasta ahora).

La revisión de la literatura indica que en México son usados actualmente 56 taxones del género Agave para la producción de mezcal en 26 de las entidades federativas, hay que tener en cuenta que el empleo de algunos taxones es muy reciente para este uso, como es el caso de $A$. fourcroydes, mientras que la mayoría han sido aprovechados de manera tradicional (Colunga-GarcíaMarín et al., 2007; Torres et al., 2015a). Esto representa un tercio de todas las especies que crecen en el país y abarcan prácticamente todo su territorio. Estas especies, además, según Colunga-GarcíaMarín et al. (2007), podrían contar con al menos 250 variedades tradicionales; producto de su aprovechamiento, manejo y selección bajo distintas condiciones ambientales y culturales a lo largo de los milenios en los que ha ocurrido la interacción humano-agaves. Esta diversidad biológica no tiene par en el mundo de las bebidas alcohólicas.

Sabemos muy poco de la evolución bajo manejo y selección tradicional de los 56 taxones con que se produce mezcal en México. Aparentemente, solo 12 de ellas son cultivadas y presentan claros signos de domesticación, 11 tienen un manejo incipiente y 37 son aprovechadas de poblaciones silvestres (Torres et al., 2015a). De igual forma, aún es necesario revisar la taxonomía de muchas de estas especies, así como caracterizar sus variedades (Apéndice 1).

\section{Consecuencias del manejo y domesticación de los agaves en Mesoamérica: casos de estudio}

Agave angustifolia, $A$. tequilana y A. rhodacantha Trel en Jalisco y Colima

El primer caso que revisaremos son los estudios realizados dentro de la porción central del área cultural del "Mezcal-Jocote", en donde Colunga-GarcíaMarín y Zizumbo-Villarreal (2007) plantearon la hipótesis de que ahí, por su historia y condiciones ecológicas, debía ubicarse un núcleo importante de diversificación de agaves bajo manejo y selección artificial tradicional (Fig. 2).

La aproximación de estudio en este caso, que incluye a $A$. angustifolia, $A$. rhodacantha Trel. y A. tequilana (Figura 11.3 A, F y G), ha sido multidisciplinaria al emplear la arqueología, etno-
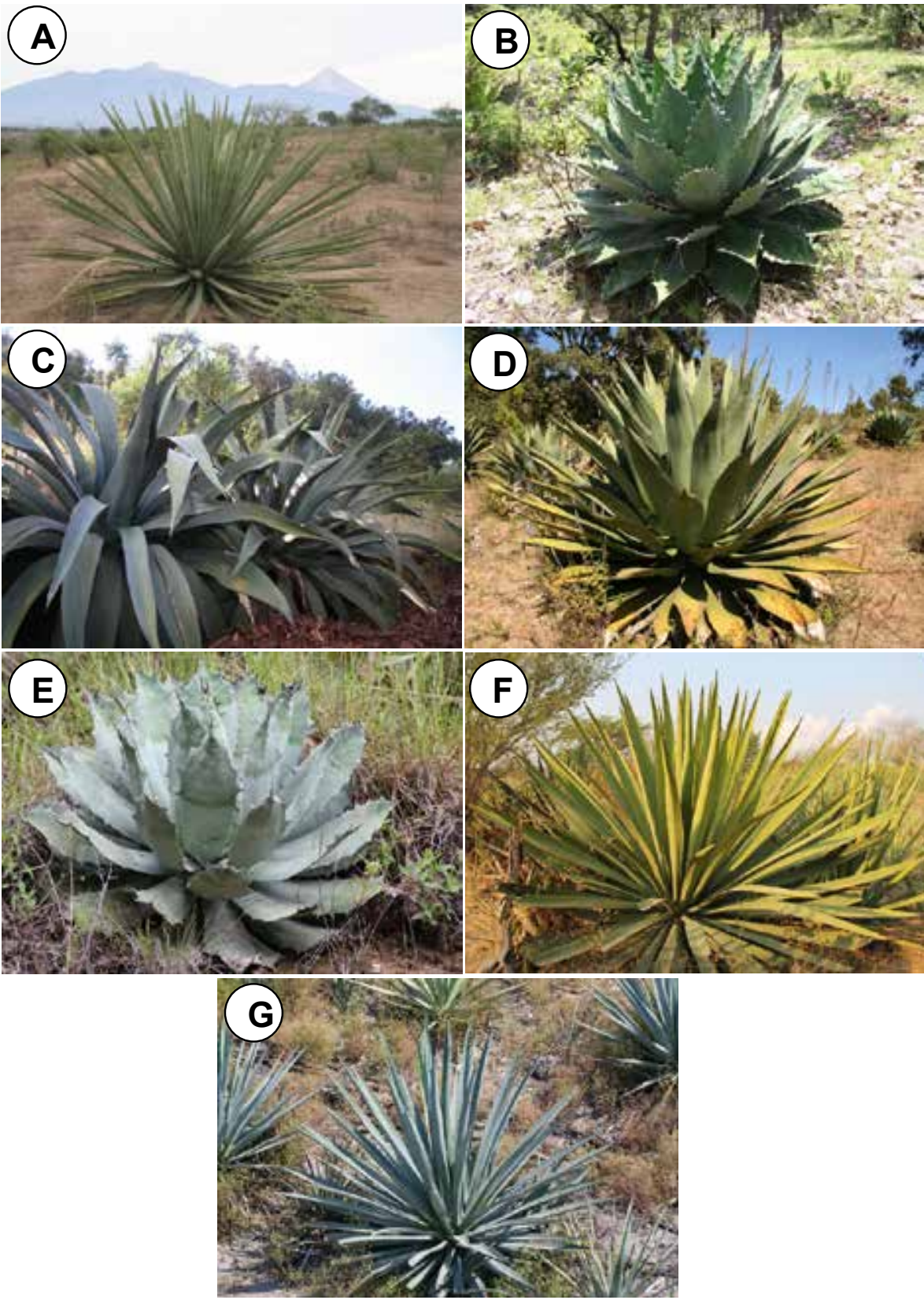

Figura 11.3. Especies de agaves de los tres casos de estudios indicados en este capítulo. A) Agave angustifolia cultivado; B) A. cupreata silvestre; C) A. hookeri en cerca viva; D) A. inaequidens silvestre en bosques de pino encino; E) $A$. potatorum silvestre (Foto A. Delgado-Lemus); F) A. rhodacantha cultivado (Foto C. Lucio); G) A. tequilana (Fotos: I. Torres, excepto $E$ y F). 
historia, etnobotánica, agroecología, morfología y genética, en un área que va de la costa del estado de Colima al Valle de Tequila en el estado de Jalisco. Los pueblos prehispánicos de esta zona dejaron numerosas evidencias arqueológicas de la importancia de los agaves como fuente de alimento y fibra, y algunas evidencias que sugieren su importancia en la obtención de bebidas alcohólicas (Zizumbo-Villarreal et al., 2009b).

Las estribaciones de los volcanes de Colima son algunas de las regiones en donde se refugió la población nativa de la zona estudiada después de la conquista española, y que hasta hace veinte años aún se encontraba relativamente aislada. En esta región, la elaboración actual de mezcal tradicional, llamado localmente "vino-mezcal" o simplemente "vino", se basa en la tecnologia prehispanica de horneado de las cabezas bajo tierra, la fermentación
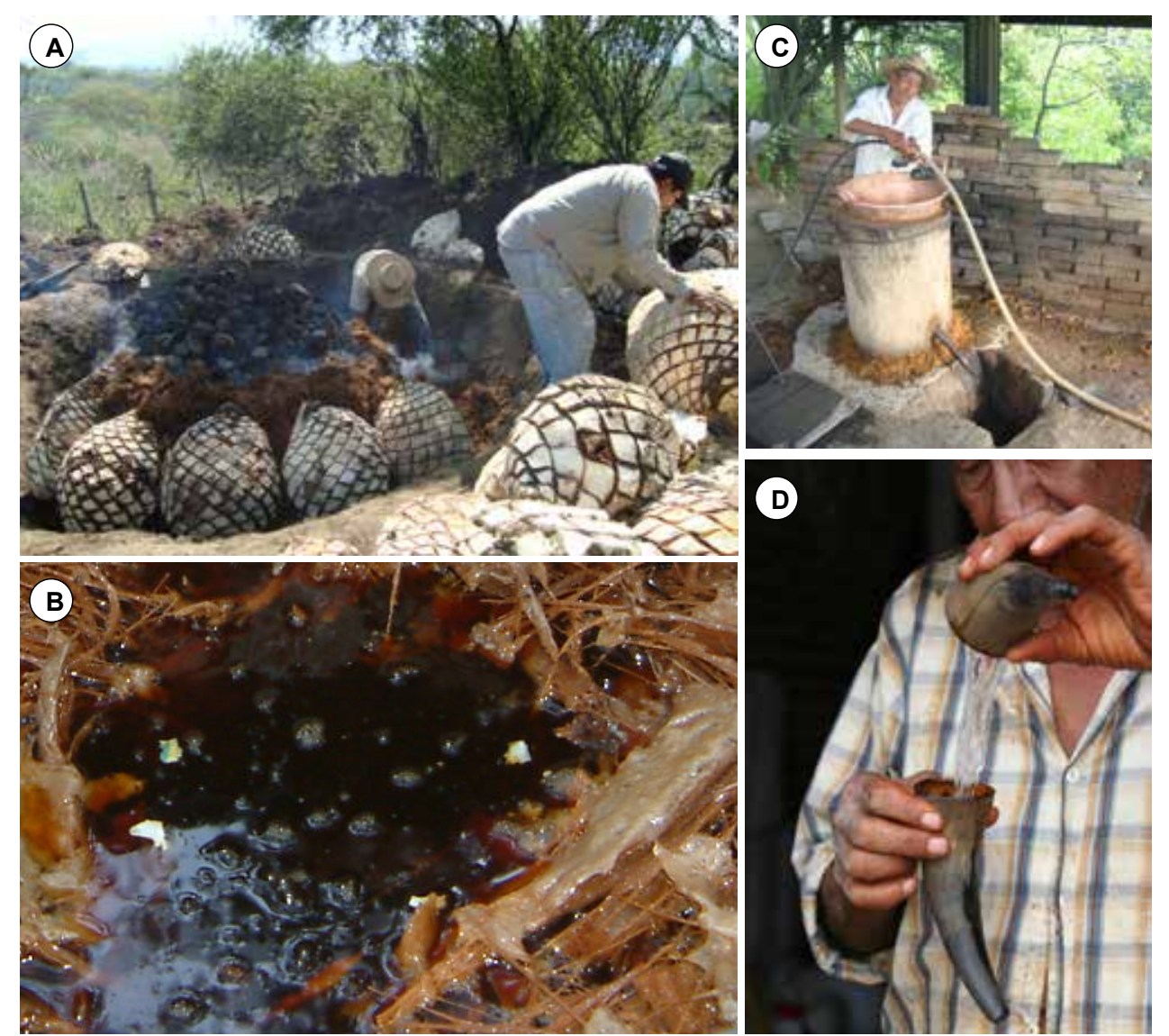

Figura 11.4. Procesos de elaboración del vino-mezcal en Zapotitlán de Vadillo, Jalisco. A) Cocimiento bajo tierra de las cabezas de agave llamadas "mezcal" (Foto: G. CarriIlo), B) Mezcal fermentado conocido como tuba para elaborar vino-mezcal, C) Destilación de la tuba (Foto: P. Colunga-GarcíaMarín), D) Corroboración del grado alcohólico del vino-mezcal (Foto: I. Torres). de sus jugos y bagazo en pozos subterráneos cavados en la roca, "pozos de peña", asi como en la separación del alcohol con el destilador de tipo asiático que fue introducido a la región hace unos cuatrocientos años (Fig. 11.4). Este proceso se basa, a su vez, en una tradición agroalimentaria prehispánica de miles de años de antigüedad, en la que los agaves han estado integrados de manera central y continúa hasta el presente (Zizumbo-Villarreal et al., 2012, 2014). Esto sugiere fuertemente que la diversidad de variedades locales usadas hoy en día, incluyendo al agave azul, es el resultado de miles de años de selección humana (Colunga-GarcíaMarín y Zizumbo-Villarreal, 2007).

Esta región es el área en donde Vargas-Ponce et al. (2007) encontraron la mayor riqueza de variantes reconocidas tradicionalmente por los agricultores: 40 de 44 (Figura 11.5) y agriculto-

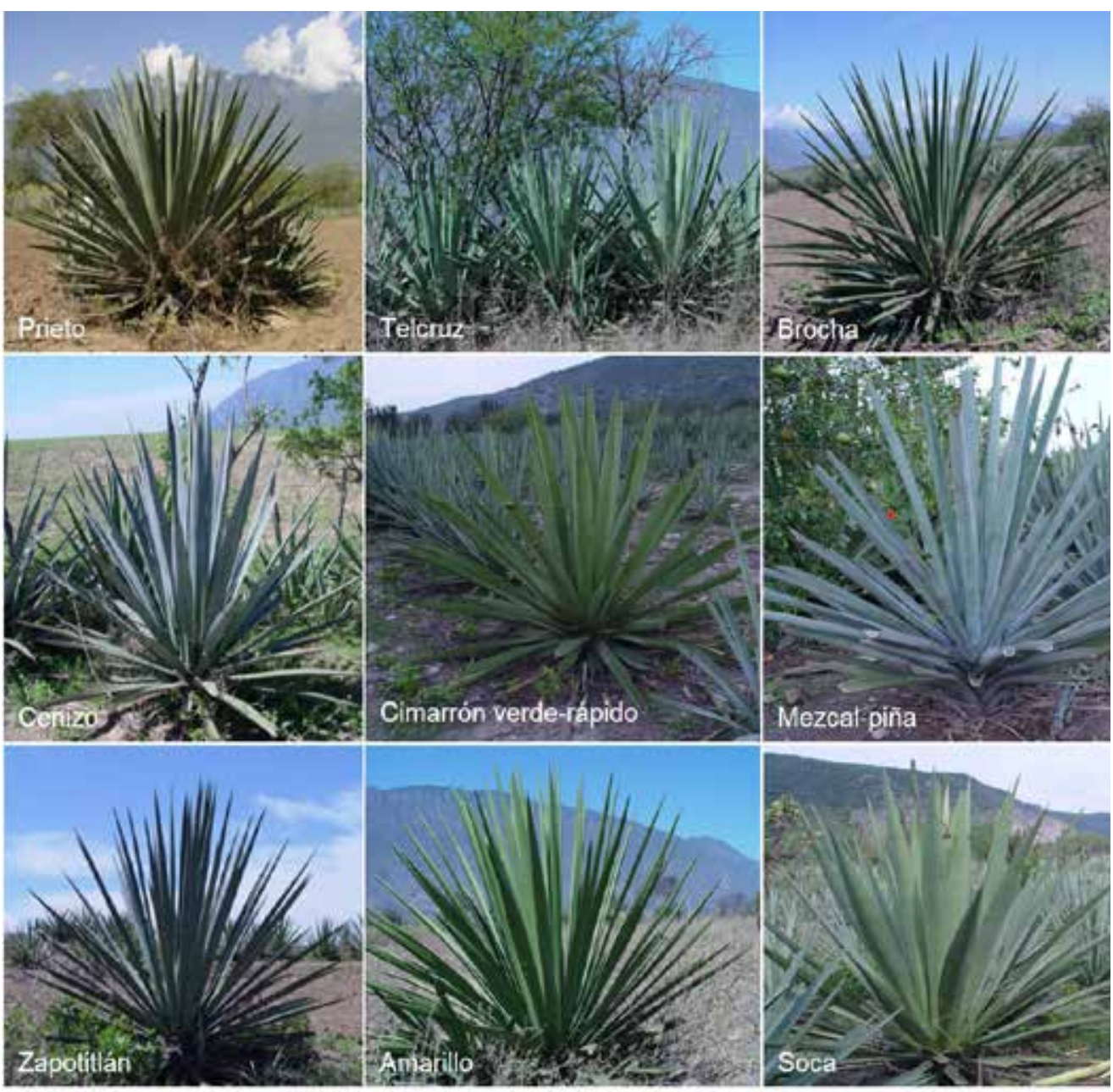

Figura 11.5. Cultivares tradicionales de Agave del sur de Jalisco (Fotos: O. Vargas-Ponce). 
res cultivando 10 y hasta 33 variedades tradicionales de Agave presentes en una sola parcela, cultivadas en el agroecosistema complejo conocido como milpa, basado en maíz, frijol y calabaza, y que incluye también el manejo de ganado o en mezcaleras (Figura 11.6 A y B). El sistema de aprovechamiento y manejo de los agaves en esta zona, además de incluir a la milpa y las mezcaleras, también comprende poblaciones silvestres, toleradas y fomentadas. Las plantas de agave son propagadas generalmente de forma vegetativa, pero ocasionalmente también lo son usando plántulas nacidas de semillas, toleradas o fomentadas in situ, o producidas en viveros para cultivo ex situ en cercos vivos, bordos y terrazas asociados al cultivo de milpa y a la producción de ganado (Zizumbo-Villarreal et al., 2013).

En contraste, en los alrededores del valle de Tequila, solo se encontraron cinco variedades tradicionales: el agave azul, dominando el área, cuya especie solo se conoce bajo cultivo, y cuatro variedades que prácticamente desaparecieron con la expansión agroindustrial del agave azul, considerado un clon debido a la práctica agronómica de propagación exclusivamente asexual de esta variedad y a su baja fertilidad (Escobar-Guzmán et al., 2008).

Vargas-Ponce et al. $(2007,2009)$ encontraron que la riqueza de variantes de Agave cultivadas tradicionalmente en la región es el resultado de las siguientes acciones continuas: 1) mantenimiento y mejoramiento de variedades regionales antiguas, y adaptación de variedades de otras regiones: ambas con huellas morfológicas del proceso de domesticación; 2) introducción y mejoramiento de germoplasma silvestre, seleccionado por el mismo agricultor o por otros, hace uno o muchos ciclos de cultivo; 3) tolerancia y fomento de plantas silvestres que crecen dentro de las parcelas, y 4) cultivo en cercos vivos, bordos y terrazas.

La mayor parte del germoplasma encontrado pertenece al complejo Agave angustifolia, acervo biológico del que posiblemente se domesticó y originó $A$. tequilana var. azul. También se encontraron poblaciones silvestres y cultivadas de $A$. rhodacantha y posibles híbridos de ellas, lo que concuerda con la opinión de Gentry (1982) de que pueden formar complejos genéticos. Dos de las variedades tradicionales, una de cada especie, han sido muy importantes como cercos vivos y fuente de fibra (Vargas-Ponce et al., 2007; Zizumbo-Villarreal et al., 2013). Algunas de las variantes utilizadas, al parecer las más modernas, están siendo seleccionadas por la suavidad de sus fibras, característica deseable al momento de la molienda, facilitando así esta parte fundamental del proceso de elaboración del "vino-mezcal" (Macario Partida, comunicación personal).

La riqueza de variantes en las parcelas es favorecida por los agricultores como una estrategia que les permite: 1) producción continua de plantas maduras, ya que las variedades tienen ciclos de vida de diferente duración; 2) diversidad de sabores, adaptada al gusto tradicional por mezcales elaborados con mezclas de diferentes especies y variedades de Agave; 3) menor ataque de depredadores y enfermedades, lo que evita el uso de herbicidas e insecticidas, y permite su asociación con los cultivos tradicionales alimenticios (Zizumbo-Villarreal et al., 2013).

La diversidad y la estructura genética del sistema tradicional y el de su contraparte, el sistema agroindustrial del tequila, se investigó analizando 37 poblaciones con 69 loci ISSR (Inter Simple Sequence Repeats), un marcador genético dominante, empleando tres estimadores de diversidad (Vargas-Ponce et al., 2009). Este estudio indicó que las variedades tradicionales de $A$. angustifolia tienen una elevada diversidad genética $\left(H_{B T}=0.442\right)$, similar o incluso mayor a la que
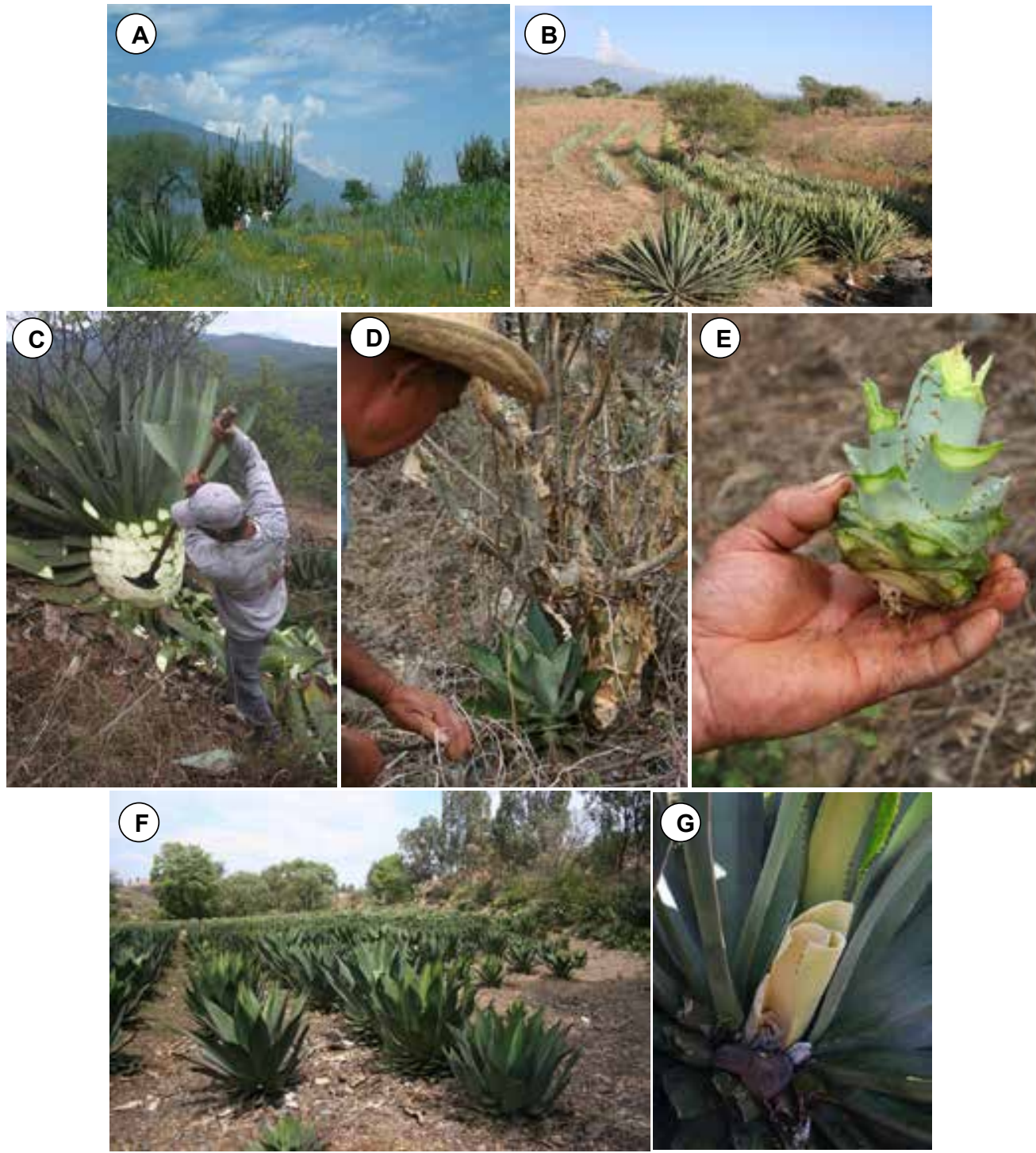

Figura 11.6. A y B) Agroecosistemas tradicionales o mezcaleras del sur de Jalisco (Foto A: P. Colunga.GarcíaMarín y B: I. Torres), C) Agave inaequidens silvestres siendo cortaA: P. Colunga.GarciaMarín y B: 1 . Torres), C) Agave inaequidens silvestres siendo cortado para la producción de mezcal; $D$ y E) Manejo ex situ de $A$. inaequidens, extracción de plántulas sivestres para el cultivo en huertas en la región de Sahuayo, Michoacán, $F)$ Cultivos de $A$. inaequidens, G) $A$. hookeri con perforación en el meristemo central para la extracción de savia; (Fotos: I. Torres).

se encuentra en las poblaciones silvestres de esta especie $\left(H_{B T}=0.428\right)$. El agave tequilero $(A$ tequilana var. azu), en contraste, tiene $73 \%$ menos diversidad $\left(H_{B T}=0.118\right)$. El análisis a nivel de 
parcelas mostró la misma tendencia de contraste entre las parcelas manejadas tradicionalmente y las de producción agroindustrial de tequila con base en el clon agave azul. Un caso aun más drástico de pérdida de diversidad genética, por efecto de las plantaciones agroindustriales, fue encontrado por Colunga-GarcíaMarín et al. (1999) para el caso del henequén (A. fourcroydes).

La evaluación de la diferenciación, o estructura genética, de los tres acervos manejados por los agricultores tradicionales mostró que las poblaciones silvestres no son muy diferentes entre sí $\left(F_{S T}=0.179\right)$, pero esta diferenciación es mucho mayor cuando se comparan con las formas de agave toleradas o fomentadas $\left(F_{S T}=0.333\right)$ y aun mayor en las variedades tradicionales cultivadas $\left(F_{S T}=0.360\right)$. Entonces, existe una mayor diferenciación o estructura genética poblacional conforme aumenta la intensidad del manejo y selección humana. Esto probablemente esté relacionado con una disminución del flujo génico entre poblaciones, asociado a la disminución de la propagación sexual (basada en semillas) y un incremento de la asexual (basada en hijuelos y bulbilos) conforme se intensifica su manejo.

A través del análisis de la variación morfológica de las 22 variedades mezcaleras cultivadas incluidas en este estudio (Vargas-Ponce et al., 2007), se evidenció que el síndrome o tendencia de domesticación preponderante está relacionado con una mayor producción del producto deseado y una mayor facilidad de manejo y procesamiento. Comprende las siguientes características: 1) gigantismo de tallo y hojas, lo cual incluye un mayor tamaño de la cabeza, que es donde se acumulan los azúcares y 2) disminución del índice de dentición. Por su parte, la exploración etnobotánica mostró que son más frecuentes las variantes que la gente considera que tienen: 3) una buena concentración de azúcares, ideal para la producción de mezcal, 4) alta capacidad de producción de hijuelos, 5) un ciclo de vida más corto (entre seis a ocho años), y 6) menor cantidad de saponinas. En los agroecosistemas mezcaleros del sur de Jalisco hay un manifiesto gradiente de variación en las características que incluye su síndrome de domesticación, esto debido a la diversidad de variantes que se mantienen en cultivo y a que históricamente varias de ellas se han usado con tres propósitos: materia prima para la producción de mezcal, fibra y cercas vivas.

Carrillo-Galván (2011) realizó un estudio etnobotánico y morfológico detallado de dos de estas variedades, el ixtero verde ( $A$. angustifolia) y el ixtlero amarillo (A. rhodacantha) (Figura $11.3 \mathrm{~F}$ ), las cuales históricamente han sido las más importantes por su fibra (ixtle en náhuatl), pero también han sido usadas para la elaboración de mezcal y para constituir cercos vivos. El síndrome de domesticación de ambas variedades incluye: 1) gigantismo en hojas y cabezas, 2) mayor fibrosidad en hojas y 3) mayor longevidad. Sin embargo, mientras que el ixtero verde tiene como cuarta característica una menor dentición, en contraste, el ixtlero amarillo presenta una mayor dentición. Lo anterior es explicado por esta autora por el hecho de que e ixtlero verde ha sido la variedad más apreciada en la región para el uso de su fibra, por lo que se ha seleccionado con una menor dentición que permite un manejo más fácil de las hojas a momento de su cosecha. La casi desaparición de la tradición ixtlera, debido a la introducción del plástico, ha traído consigo la disminución del cultivo de esta variedad llevándola casi a su total extinción. El síndrome de esta variedad coincide con el encontrado por Colunga-GarcíaMarín et al. (1996) para el henequén (A. fourcroydes), el cual fue domesticado por los mayas de la Península de Yucatán para la producción de fibra. Por otra parte, la mayor dentición del ixtlero amarillo es explicada por Carrillo-Galván (2011) por el hecho de que ha sido la variedad preferida como cerco vivo, puesto que esta característica es fundamental para evitar el paso de ganado y personas a los cultivos. Aunque el aprovechamiento de la fibra de los agaves ha declinado, actualmente el ixtero amarillo es una variedad muy abundante en la región por su uso con triple propósito. Además de utilizarse como cerco vivo es el preferido para la obtención de mezcal, ya que es la variedad que le da el sabor y olor distintivo a los mezcales de la región (Colunga-GarcíaMarín et al., 2011; Zizumbo-Villarreal et al., 2013).

Es importante señalar que, al inicio de estos estudios, hace trece años la producción de mezcal en las estribaciones de los volcanes de Colima no respondía aún a la moda del mezcal que existe hoy día en México, sino a un mercado regional en el cual tienen prestigio y tradición desde hace cientos de años. En el estado de Colima esta variedad es muy apreciada y llamada popularmente "tuxca" por producirse tradicionalmente en las márgenes del río Tuxcacuesco.

\section{Agave inaequidens y A. hookeri en Michoacán}

Nuestro segundo caso de estudio se encuentra en lo que Bruman (1940) llamó la subárea cultura del "Pulque", contigua a la del "Mezcal-Jocote" (Figura 11.2). Esta área se distingue porque el pulque era la bebida predominante a la llegada de los españoles, aunque también se producían bebidas fermentadas a partir del mezcal cocido y el jocote. Aquí revisaremos los estudios realizados recientemente en Agave inaequidens Koch. (Figura 11.3 D) y A. hookeri (Figura 11.3 C) por Figueredo et al. $(2014,2015 a, 2015 b)$ y Torres et al. $(2015 b, 2016)$ en el estado de Michoacán (Figura 11.2).

Agave inaequidens es una especie multipropósito de importancia cultural de la que se han documentado 16 categorías de uso y alrededor de 34 usos específicos. Sus aprovechamientos ancestrales más importantes, pero que paulatinamente han caído en desuso en gran parte de las comunidades donde tuvieron cierto auge, son la extracción de fibras para la elaboración de cordelería (Valenzuela-Zapata et al., 2011), la savia de la inflorescencia para elaborar pulque y la cocción de su pedúnculo floral como alimento. La especie es comúnmente conocida como maguey alto o bruto, este último nombre se debe al alto contenido de saponinas y cristales de oxalato de calcio en la savia de sus hojas, por lo cual es cáustica y produce dermatitis de contacto a los humanos.

Torres et al. (2015b, 2016) encontraron que actualmente en Michoacán esta especie es usada principalmente para la elaboración de mezcal, y que con este fin su aprovechamiento ocurre en un gradiente de intensidad de manejo que incluye cerca de 13 prácticas distintas. Este gradiente abarca tres formas principales de manejo: 1) la simple extracción de poblaciones silvestres sin ningún tipo de acciones intencionadas dirigidas a su conservación (Figura 11.6 C); 2) el manejo in situ de estas poblaciones que puede incluir: a) la tolerancia de individuos de distintos tamaños -lo cual ha tenido ciertas repercusiones, como se discutirá más adelantecuando se desmonta el bosque con la intención de que produzcan y liberen semillas; b) recolección y dispersión de semillas en sitios propicios para su germinación y establecimiento, y e trasplante de plantas jóvenes de origen vegetativo o sexual a sitios con más posibilidades de éxito (Figura 11.6 D y E); c) reintroducción de plántulas crecidas en viveros y d) la suspensión 
de la cosecha por dos años o más; y 3) su cultivo ex situ, en parcelas, huertos o cercas vivas (Figura 11.6 F). Las cercas vivas se construyen a través del trasplante esporádico de plantas juveniles silvestres. Los cultivos actualmente se establecen con plántulas crecidas en vivero a partir de semillas recolectadas de las poblaciones silvestres, en monocultivo y por lo general usando agroquímicos. El cultivo en parcelas es una práctica relativamente nueva, de no más de veinticinco años, de acuerdo con entrevistas a los productores locales. Desconocemos la posibilidad de un manejo bajo cultivo y selección artificial más antiguo (la revisión de fuentes históricas podría ser reveladoras en este sentido).

La gente reconoce actualmente diez variantes morfológicas silvestres de $A$. inaequidens de acuerdo con la forma y coloración de las hojas, así como por el tamaño y forma de los dientes. Estos caracteres, sin embargo, no son un factor relevante al momento de elegirlas para elaborar mezcal. Por lo general, son las plantas de mayor vigor las que se seleccionan para introducirlas al cultivo ex situ (Figueredo et al., 2014) y la mayoría de los manejadores toleran in situ los individuos reproductivos de menor tamaño. Este hecho ha determinado una selección direccional histórica que ha favorecido la reproducción y establecimiento in situ de fenotipos de menor tamaño, es decir, que el tamaño promedio de los individuos ha sido progresivamente cada vez más pequeño. Estos fenotipos pequeños proveen menor cantidad de materia prima para la elaboración de mezcal, determinando así que los manejadores tengan que extraer in situ una mayor cantidad de individuos que en el pasado. Consecuentemente, los individuos tolerados producen una menor cantidad de semillas. Evidencia de estos hechos es el testimonio de múltiples manejadores, los cuales hacen referencia al gran tamaño de los agaves que cosechaban hace 30 años y que actualmente es sumamente raro encontrarlos.

El análisis de la diversidad genética de $A$. inaequidens llevado a cabo por Figueredo et al. (2015) incluyó 16 poblaciones de las tres categorías de manejo, empleando como marcador molecular diez loci microsatelitales (SSR: Simple Sequence Repeats) que son marcadores co-dominantes. Se encontraron altos niveles de diversidad genética $(\mathrm{He}=0.707)$, sin diferencias significativas entre categorías de manejo (silvestres $\mathrm{He}=0.704$, manejo in situ $\mathrm{He}=0.733$, cultivo ex situ $\mathrm{He}=0.698$ ). No obstante, se encontró una diferenciación o estructura genética moderada entre las poblaciones $\left(F_{S T}=0.112\right)$. Estos resultados se explican debido a los mecanismos naturales de flujo génico mediado por murciélagos nectarívoros y otros organismo que transportan el polen a grandes distancias (León, 2013). Así también por el manejo dinámico de los propágulos por parte de los productores de mezcal, puesto que sus cultivos los conforman con base en propágulos de distintas fuentes silvestres, es decir, el manejo contribuye al flujo génico entre distintas poblaciones regionales. Estos resultados, en conjunto, nos sugieren que esta especie se encuentra en una fase incipiente de domesticación, puesto que existen elevados niveles de diversidad morfológica y genética, pocas divergencias de las poblaciones y un elevado flujo de genes entre ellas, en parte natural y en parte artificial.

Aun cuando se encontraron elevados niveles de diversidad genética poblacional en la especie, los autores consideran que algunas poblaciones están en riesgo por su sobre explotación para producir mezcal y la forma en que se manejan, puesto que algunas poblaciones tienen bajos tamaños poblacionales, baja diversidad genética y baja talla de los adultos (Figueredo $e$ al., 2014, 2015a, 2015b; Torres et al., 2015b, 2016).
Agave hookeri es otra especie conocida solamente bajo cultivo, con la cual se produce pulque en esta región (Figura $11.6 \mathrm{G}$ ), aunque esta práctica ha disminuido notablemente. En la actualidad aún se encuentra cultivada como cerca viva en algunos poblados de la Meseta Purépecha en Michoacán, pero es progresivamente escaso. Debido a su similitud morfológica con A. inaequidens, Gentry (1982) planteó que esta especie es su ancestro silvestre más probable. Actualmente es posible encontrar cercas vivas donde están mezclados individuos de $A$. inaequidens y $A$. hookeri con la posibilidad de entrecruzamiento entre ellos, tal y como lo registró Gentry (1982) hace algunas décadas. Además de su uso para producir aguamiel y pulque, prevalece su uso como cerca viva, ornamental y para producir fibras, aunque existe una pérdida de interés y de conocimiento de esta última práctica. Existe una disminución de sus plantaciones e incluso se le ha sustituido por otras especies pulqueras reconocidas de otras zonas de México, tales como A. salmiana y $A$. mapisaga.

La gente de la región usa el término purépecha akamba para referirse a los magueyes. Distinguen dos tipos: el toro akamba o negro, que se encuentra en el monte, o silvestre, y que corresponde a $A$. inaequidens y vaca akamba o blanco, que se encuentra generalmente como cerca viva y es $A$. hookeri. La distinción de estos dos tipos está asociada a la condición cáustica y a las diferencias en el patrón de dentición. Debido a esto, en otras regiones el $A$. hookeri es denominado maguey manso, justamente como reconocimiento de la menor dentición como de su menor contenido de saponinas que lo hacen menos cáustico. Ambas son características que la gente reconoce en sus prácticas de manejo.

A diferencia de lo registrado en $A$. inaequidens, en el caso de $A$. hookeri se evidenció que las plantas exhiben el síndrome de domesticación, con individuos de gran tamaño y meno dentición (Figura 11.1), además de bajos niveles de diversidad genética $\left(H_{E}=0.496\right)$ y elevada estructura poblacional $(F S T=0.280)$. Las consecuencias del proceso de domesticación en esta especie están asociadas a las prácticas de propagación de los cultivos. Luego de la extracción de aguamiel y pulque, de los remanentes de los individuos sin meristemo principal emergen hijuelos de meristemos axilares y son estos los que se utilizan para conformar los nuevos cultivos. La reproducción sexual es baja debido a la remoción de las inflorescencias o quiote para extraer pulque. En cambio, la propagación vegetativa es alta en los cultivos, lo que determina una mayor uniformidad morfológica entre individuos así como una pérdida de variantes alélicas. Estos hechos determinan asimismo mayor probabilidad de fijación de ciertos genotipos, limitaciones al flujo de genes y, consecuentemente, una diferenciación más pronunciada entre poblaciones.

Lamentablemente $A$. hookeri es una especie pulquera que desde nuestra perspectiva, se encuentra en peligro de desaparecer principalmente por el desinterés de las generaciones actuales por mantener su cultivo. Así también, por el cambio de uso de suelo donde las cultivan, y porque el consumo de pulque también ha disminuido de manera generalizada en estas comunidades.

Para otras especies pulqueras, como es el caso de $A$. mapisaga y $A$. salmiana del nororiente del estado de México, estudios con marcadores ISSR también han reportado diversidad genética baja $(\mathrm{He}=0.28)$, además de muy bajo flujo de genes entre las poblaciones $(\mathrm{Nm}=0.24$ Alfaro-Rojas et al., 2007). 


\section{Agave potatorum en el Valle de Tehuacán-Cuicatlán y A. cupreata en Michoacán y Guerrero}

Nuestro tercer caso de estudio también se encuentra en la subregión del "Pulque", y se trata de las investigaciones realizadas por Torres et al. (2013, 2015a, 2016), Delgado-Lemus et al. (2014a 2014b) y Félix-Valdez et al. (2015) sobre Agave potatorum Zucc. (Figura $11.3 \mathrm{G}$ ) en el valle de Tehuacán-Cuicatlán que se encuentra en los estados de Oaxaca y Puebla (Figura 11.2).

Los resultados de Torres et al. (2013, 2015a, 2016) y Delgado-Lemus et al. (2014a, 2014b) indican que en el área de estudio $A$. potatorum es una especie altamente vulnerable, esto pesar de que $A$. potatorum crece en una zona en la que los estudios arqueológicos han demostrado una interacción entre humanos y agaves desde hace aproximadamente 12000 años. También, a pesar de que este agave ha sido una especie multipropósito de gran importancia económica y cultural para la que existe un amplio conocimiento ecológico tradicional. Los autores de los trabajos referidos consideran que su alta vulnerabilidad se debe a que: 1) no ha sido domesticada y su manejo es apenas incipiente; 2) tiene una distribución restringida; 3) solo se reproduce sexualmente, y 4) en algunas regiones específicas sus poblaciones están siendo sobre explotadas para producir mezcal y no existen acciones importantes para su conservación a futuro. Aunque se han producido mezcales localmente desde hace unos cien años, hace apenas unos diez que los pobladores han iniciado prácticas de manejo incipiente de conservación del recurso (Torres et al., 2013).

Félix-Valdez et al. (2015) realizaron una comparación de la diversidad y estructura genética de poblaciones silvestres sometidas a extracción, poblaciones no sometidas, y plantas crecidas en dos viveros usadas para reforestar áreas en explotación. Estas últimas procedían de semillas obtenidas de poblaciones silvestres circundantes. Sus resultados, con base en el análisis de 12 poblaciones y siete loci de microsatélites, mostraron que la categoría de silvestres sin extracción resulta la más diversa $\left(H_{T}=0.870\right)$, pero no presenta diferencias significativas con las poblaciones de otros estatus de manejo: silvestres bajo extracción $\left(H_{T}=0.720\right)$ y poblaciones cultivadas en viveros $\left(H_{T}=0.690\right)$

Félix-Valdez et al. (2015) consideran que estos resultados deben tomarse con cautela. El hecho de que no haya diferencias significativas en la diversidad genética entre las categorías de manejo, solamente sugiere que el aprovechamiento no ha tenido consecuencias sobre la diversidad genética de las poblaciones. Sin embargo, otros aspectos poblacionales sí se han visto afectados, por ejemplo, la extracción sistemática de plantas ha llevado a una baja densidad de individuos reproductivos, lo cual afecta la probabilidad de visita de los polinizadores. Esta especie, depende casi por completo de la reproducción sexual, ya que no presenta propagación vegetativa. Esto, aunado a la poca distancia observada de dispersión de las semillas, ha llevado a una diferenciación o estructuración genética alta de sus poblaciones $\left(\phi_{P R}=0.36\right)$, mucho más de la que se espera en plantas con características de historia de vida similar, incluyendo a sus congéneres. Los autores consideran, además, que el escaso flujo genético que se observa entre las poblaciones, todas ellas con valores significativos de endogamia en todos los loci $\left(F_{I S}=0.25-0.31\right)$, está comprometiendo la viabilidad de las poblaciones de $A$. potatorum en esta región.
Es importante destacar que, aunque las poblaciones estudiadas están relativamente cercanas unas de otras (entre tres y $20 \mathrm{~km}$ de distancia), la estructura es alta. Este rango de distancias es corto en relación con los polinizadores principales: los murciélagos Leptonycteris yerbabuenae Martínez \& Villa, los cuales pueden viajar hasta $100 \mathrm{~km}$ en una noche. Ello indica que la dispersión de semillas y su establecimiento se encuentran sometidos a presiones selectivas altas (Rangel-Landa et al., 2015).

Estos resultados son consistentes con los obtenidos por Aguirre-Dugua y Eguiarte (2013) y Scheinvar (2008) con ISSRs para A. potatorum, así como para su pariente cercano $A$. cupreata Trel. et Berger (Figura 11.3 D), una especie que cuenta con una distribución más amplia en los estados de Guerrero y Michoacán. Estos autores detectaron altos niveles de diversidad genética en ambas especies ( $\mathrm{He}=0.30-0.31$ y 0.32-0.36, en $A$. potatorum y $A$. cupreata, respectivamente), lo cual consideran que refleja los patrones históricos de retención de diversidad genética dentro de las poblaciones. Lo anterior, asociado a sus largos ciclos de vida y altos niveles de polinización cruzada a corta y larga distancia mediada por murciélagos (lo cual permite un flujo génico elevado). Aunque estos valores también sugieren un manejo apropiado por parte de los productores, los autores consideran, de manera similar a lo encontrado por Félix-Valdez et al. (2015), que la amenaza de extinción de estas especies permanece debido a la sobre-extracción de individuos reproductivos adultos. Esto ha afectado notoriamente la tasa de crecimiento poblacional (lambda) por la disminución en la cantidad de semillas disponibles para la regeneración de las poblaciones (Torres et al., 2013, 2015a). También reduce la probabilidad de visita de los polinizadores debido a la poca oferta de recursos nectaríferos. La reducción de visitas de polinizadores implicaría una disminución en el flujo genético entre poblaciones y mayores tasas de endogamia (Estrella, 2008). Esto afectaría a largo plazo la adecuación de estas poblaciones que dependen enteramente de las semillas para su permanencia (como ya se mencionó, no producen hijuelos ni bulbilos).

Afortunadamente, los niveles de diversidad que existen actualmente en estas poblaciones representan una base firme sobre la cual se pueden establecer programas de manejo basados en la regeneración natural y en la reforestación. Scheinvar (2008) encontró que la diversidad genética de los viveros de $A$. cupreata basados en la recolección de semillas a nivel local $(\mathrm{He}=0.32)$ es representativa de la diversidad de las poblaciones silvestres, lo cual señala el potencial de esta estrategia en la conservación de los recursos genéticos de estas especies en el largo plazo.

\section{El estudio de la domesticación y manejo: su aporte a la construcción de alternativas para el aprovechamiento actual de los magueyes}

A pesar de toda la evidencia histórica y científica relacionada a la amplia distribución en México de las especies de agaves mezcaleras y su uso tradicional desde hace miles de años, la Denominación de Origen Mezcal (DOM) y la Norma Oficial Mexicana asociada a ella (NOM-070) (Secretaría de Comercio y Fomento Industrial 1994) únicamente reconocen algunos municipios de solo nueve de las 26 entidades federativas en donde se ha reportado la elaboración tradicional de mezcal. Irónicamente, también están excluidos los productores de 
os estados de Jalisco y Tlaxcala, en donde se han encontrado evidencias que indican que su elaboración puede datar de hace milenios (Zizumbo-Villarreal et al., 2009a; Serra-Puche y Lazcano-Arce, 2016).

Los productores excluidos no pueden llamar a sus bebidas "mezcal", aunque sean mezcales. Deben llamarlas, hasta hoy, "destilado de agave"; con lo que el Estado Mexicano los priva del uso de una denominación histórica que les pertenece. Pero el despojo ha tratado de ir más lejos, buscando disminuir sus posibilidades de competencia en el mercado nacional internacional, dominados por grandes empresas transnacionales. Han tratado de prohibirles el uso de la palabra Agave en la información comercial al consumidor, para evitar que los pueda identificar como lo que son: destilados de Agave que tradicionalmente se llaman "mezcales" en México. En 2011, la Secretaría de Economía (SE) junto con la Cámara Nacional de la Industria Tequilera (CNIT), el Consejo Regulador del Mezcal (COMERCAM) y el Consejo Regulador del Tequila (CRT) presentaron el proyecto de NOM-186 (Secretaría de Economía, 2012a), que pretendía, entre otras cosas, obligarlos a llamarse "destilados de agavácea" y prohibirles su elaboración usando el 100\% de azúcares de agaves, como es su tradición. De forma simultánea, y para completar las medidas propuestas en la NOM-186, el Instituto Mexicano de la Propiedad Industrial (IMPI) presentó el proyecto de declarar el término Agave como una marca registrada de uso exclusivo de los productores de las DO tequila, mezcal y bacanora (IMPI, 2011), violando la legislación nacional e internacional en materia de propiedad intelectual.

En virtud de que dichas propuestas no fueron aprobadas, los mismos actores están proponiendo actualmente el proyecto de NOM-199 (Secretaría de Economía, 2015a) para llamar komitl (término que significa olla en náhuatl) a los mezcales que se producen fuera de la DOM, un nombre sin ningún reconocimiento ni arraigo cultural. En la detallada búsqueda de especies y nombres comunes asociados a la producción de mezcales en México hecha por Colunga-GarcíaMarín et al. (2007) y Torres et al. (2015a), en la que se encontraron 767 nombres comunes, no se encontró ninguna referencia a este término. Adicionalmente, la NOM-199 pretende prohibirles informar al consumidor las variedades de agaves usadas si estas están consideradas en alguna DO. Esto es contrario a la información científica que indica que la distribución de las especies y variedades de Agave, y la de su uso para elaborar mezcales tradicionales, son más amplias que lo reconocido por la DOM y no son históricamente privativas de ella (CONABIO 2006; Colunga-GarcíaMarín et al., 2007). De forma paralela, el Consejo Regulador del Mezcal ha hecho una nueva propuesta de NOM-070 (Secretaría de Economía, 2015b) en la que se autocensurarán de usar en el etiquetado del término 100\% Agave y lo sustituirán por $100 \%$ maguey, esto claramente para favorecer a los productores tequileros y en detrimento de los consumidores.

¿Qué implicaciones tienen nuestros hallazgos para el futuro de los agaves como recursos genéticos? Pensamos que los casos revisados representan dos situaciones contrastantes con un denominador común.

Por un lado, dentro de la región cultural del Mezcal-Jocote, encontramos un núcleo antiguo y continuo de diversificación de agaves en el que se manejan tanto variedades domesticadas antiguas como variedades en proceso de domesticación y poblaciones toleradas, fomentadas y silvestres. Esto, dentro de una estrategia que a los agricultores les ha permitido mantener alta diversidad y un proceso dinámico de selección y adaptación a un ambiente ecológico y cultural cambiante. No obstante, este núcleo se encuentra amenazado por el éxito de la agroindustria del tequila, que está poniendo en riesgo la existencia tanto de las variedades domesticadas como la de las poblaciones silvestres a través de: 1) la expansión del cultivo del clon agave azul; 2) la extracción desmedida de poblaciones silvestres de agaves en las épocas periódicas de escasez del agave azul cultivado, y 3 ) las estrategias legales ya descritas para desplazarlas del mercado. En el valle de Tequila, el desarrollo de esta agroindustria ya fue la causa de la desaparición de las otras variedades con las que se producía tradicionalmente la bebida (Valenzuela-Zapata y Nabhan, 2003; Colunga-GarcíaMarín y Zizumbo-Villarreal, 2007).

Algo semejante, pero de consecuencias aun mayores, ocurrió a principios del siglo XX en la Península de Yucatán, cuando, con fines agroindustriales, se expandió el monocultivo de una sola de las variedades de henequén ( $A$. fourcroydes) aprovechadas para la obtención de fibras, desapareciendo las otras que fueron seleccionadas por los mayas en la época prehispánica (Colunga-GarcíaMarín, 2003)

La demanda que ha generado la moda de los mezcales artesanales tradicionales en México está ayudando a los productores del sur de Jalisco a mantener sus variedades y su sistema de cultivo. Sin embargo, está pendiente fortalecer esta tendencia y, sobre todo, restaurar las poblaciones silvestres, ya muy mermadas, y de las cuales el sistema depende para mantener diversidad genética a largo plazo.

Para el caso de $A$. inaequidens, $A$. hookeri, $A$. potatorum y $A$. cupreata, tenemos una si tuación contrastante, ya que ha sido justamente la moda del mezcal la que ha ocasionado la sobre-explotación y decremento de las poblaciones silvestres. En cambio, tienen muy pocos años los esfuerzos de conservarlas a través del manejo de las poblaciones silvestres y su cultivo.

Es así como patrones culturales de demanda han determinado el florecimiento y auge de estas bebidas y por ende su manejo, cultivo y extracción, pero también su decaimiento e incluso desaparición. Si no se aplican acciones de manejo inmediatas dirigidas a su conservación, se ponen en peligro tanto el recurso como la actividad misma. Afortunadamente, como han señalado Torres et al. (2015b), estas experiencias incipientes de manejo y cultivo son expresiones del profundo y antiguo conocimiento y uso tradicional de estas especies, y tienen alto potencial para que, con base en ellas, se desarrollen estrategias de manejo sustentable.

Este último aspecto es justamente el denominador común de las situaciones contrastantes analizadas: en ambas regiones y complejos de especies encontramos la amenaza de los sistemas de comercialización masiva, pero en ambas existe la fortaleza de un profundo y antiguo conocimiento y uso tradicional de las especies involucradas como base de su aprovechamiento, así como la motivación para innovar en las tecnologías de manejo.

Es por ello que una alternativa para enfrentar la amenaza de los sistemas de comercialización masiva y sobreexplotación, que llevan a la homogenización genética y cultural, es promover el intercambio de experiencias de uso y manejo de los recursos de agave entre productores tradicionales de diferentes regiones. Con ello se puede lograr un manejo campesino de los recursos genéticos de Agave bajo la tradición mesoamericana de mantener diversidad y núcleos 
dinámicos de domesticación. De esta manera se podrían enfrentar las presiones de las agroindustrias del tequila y del mezcal, que están llevando a la erosión de los recursos silvestres y cultivados, y con ello a la erosión de la cultura que los sustenta y que, a la vez, resulta de ellos.

Esto es precisamente lo que Catarina Illsley Granich, desde el Grupo de Estudios Ambientales (GEA) propuso e inició a partir del proyecto de largo plazo que dirigió con productores de mezcal de Agave cupreata en el estado de Guerrero (Illsley et al., 2007). Su objetivo principal era fortalecer el manejo campesino como una estrategia esencial para la conservación, recuperación y manejo sostenible de estos recursos genéticos. El Laboratorio de Manejo y Evolución de Recursos Genéticos (MARGEN) del Instituto de Investigaciones en Ecosistemas y Sustentabilidad, junto con GEA, están dando continuidad a estas ideas (Casas et al., 2016). A principios del 2015 se llevó a cabo un importante intercambio de experiencias entre distintas regiones mezcaleras del país en el marco de la primera Reunión Nacional de Manejadores de Maguey Forestal (Torres, 2015c).

En dicha reunión confluyeron productores de los Estados de Guerrero, Jalisco, Michoacán San Luis Potosí y Oaxaca con el objetivo principal de dar a conocer a los productores de los distintos estados el proyecto impulsado por Catarina Illsley expresado en el manejo forestal comunitario de $A$. cupreata. Otro objetivo fue conocer las ventajas socio-ambientales del manejo in situ en pro de la conservación de la diversidad biológica y los servicios ambientales que este provee. Finalmente, explorar una manera legítima de poder reconocer u otorgar un distintivo "verde" que ostente la botella de mezcal, el cual pudiera verse redituado en el desarrollo de las comunidades poseedoras de este tipo de manejo. En este espacio, cada región mezcalera compartió las distintas maneras de aprovechar y manejar sus agaves. En dicha reunión se acordó la creación de la Red Nacional de Manejadores de Maguey Forestal (RNMMF), la cual es una iniciativa que tiene como objetivos: 1) propiciar los intercambios de conocimiento campesino, 2) acercar a la academia a la documentación y resolución de problemas desde la visión comunitaria, y 3) seguir visualizando la mejor manera de poder otorgar este distintivo "verde" a las comunidades que decidan adoptar este tipo de manejo. Dicha iniciativa sigue en construcción, los intercambios campesinos se encuentran vigentes (ya se han llevado a cabo cuatro en distintas zonas mezcaleras del país), y en proceso de fortalecer su perspectiva en un movimiento civil que incorpore temáticas de manejo y gestión de mercados, todos los cuales serán fundamentales para el desarrollo de estrategias de manejo sustentable de los recursos analizados.

Otra alternativa muy importante para enfrentar la amenaza que significan tanto la comercialización masiva como la situación legal de los mezcales artesanales tradicionales sobre su existencia y el patrimonio biocultural que representan, será la organización de productores, académicos, consumidores y comercializadores para enfrentar legalmente, a nivel nacional $e$ internacional, a la DOM. Como ya mencionamos, esta DO es discriminatoria para una buena parte de los pueblos nativos y mestizos que han mantenido viva esta tradición, central de la cultura agroalimentaria de Mesoamérica y por tanto Patrimonio Cultural Material e Inmaterial de nuestro país (Colunga-GarcíaMarín et al., 2010). Es necesario conjuntar toda la experiencia disponible para plantear no una DOM como existe ahora, sino diversas DO que representen verdaderas indicaciones geográficas que distingan los mezcales de las diferentes regiones bioculturales por sus variedades distintivas, formas de cultivo y de elaboración.
Una situación legal no excluyente, sino una que reconozca la diversidad biocultural de los mezcales de México, será un incentivo para que siga floreciendo un patrimonio biocultural de una riqueza sin par en el mundo de las bebidas alcohólicas. A partir de su aprovechamiento respetuoso podrán beneficiarse múltiples sectores económicos.

Se trata de una lucha en la que los principales protagonistas que ejercen presiones hostiles son, por un lado, las grandes industrias tequileras y mezcaleras, varias de ellas ya trasnacionales. Por el otro lado, el gobierno federal y los gobiernos regionales que se ajustan a las demandas de los requerimientos comerciales de tales empresas y de los intermediarios irresponsables que buscan abaratar el producto empobreciendo su calidad o adulterándolo En contraparte, en esta lucha los productores y las organizaciones civiles que los acompañan tienen un papel central para lograr objetivos de aprovechamiento sustentable, pues son los principales actores del proceso productivo y la gestión de mercados justos. Los académicos tienen mucho que aportar con sus investigaciones etnobotánicas, ecológicas y sociales que contribuyen a resolver problemas técnicos para el aprovechamiento sustentable y mejores condiciones económicas para los productores. De manera particular y muy importante, los consumidores conscientes resultan clave en la cadena de producción y valor. Reconocer el valor real de los mezcales artesanales, su consumo y el pago justo resulta fundamental, sin ello el sistema carece de un futuro sustentable.

\section{Conclusiones}

Las evidencias discutidas en este capítulo indican que en México aún se conserva una gran diversidad de recursos genéticos de agave bajo aprovechamiento, manejo, y selección tradicional, y que esta diversidad es el producto de una relación milenaria de las culturas mesoamericanas con estas plantas, bajo una racionalidad centrada en el uso múltiple, el mantenimiento de complejos poblacionales bajo diferentes intensidades de manejo y la conservación de altos niveles de diversidad en cada una de ellas.

Como producto de esta racionalidad, podemos encontrar para una misma especie, variedades con diferentes grados de domesticación: desde aquellas en las que se observan huellas morfológicas incipientes de su selección, hasta aquellas que ya han perdido su capacidad de sobrevivir y reproducirse en estado silvestre. Este es el caso de $A$. angustifolia bajo manejo y selección tradicional. De esta especie encontramos el aprovechamiento de poblaciones silvestres, toleradas y fomentadas, de variedades con signos incipientes de domesticación, de variedades con huellas claras de domesticación, como el ixtero verde discutido en este capítulo, e incluso de especies derivadas de ella, como el agave azul (A. tequilana var. azu/). Esta última, a igual que el henequén ( $A$. fourcroydes), también derivado de $A$. angustifolia, solo se encuentran bajo cultivo y tienen una capacidad muy reducida de reproducción sexual. Hasta principios del siglo XX, estas dos especies aún formaban parte de complejos varietales con alta diversidad morfológica, pero su manejo intensivo bajo esquemas agroindustriales hizo de ellas casos extremos de disminución de diversidad genética por sobre explotación de una sola variedad.

Las evidencias etnobotánicas y morfológicas de los estudios de caso mostrados nos llevan a plantear que, dependiendo de los propósitos o móviles de selección, las características del 
síndrome de domesticación pueden variar. No obstante, podemos mencionar cuatro características o rasgos que son comunes a todas las especies bajo el proceso de domesticación: 1) aumento del tamaño de la estructura morfológica usada, 2) mayor producción del producto deseado (carbohidratos en la cabeza y pedúnculo, savia de la inflorescencia, fibra en las hojas), 3) menor dentición y 4) menor cantidad de saponinas.

Las poblaciones estudiadas de $A$. inaequidens, $A$. cupreata y $A$. potatorum tienen pocos años de ser usadas, cultivadas y seleccionadas para la producción de mezcal y aún exhiben elevados niveles de diversidad genética, flujo de genes y baja estructura poblacional. Esto se debe, probablemente, a que aún no transcurre el tiempo evolutivo necesario para la fijación de caracteres a nivel genético y observar consecuencias del proceso de selección humana. D igual forma, pudimos evidenciar que el manejo de estas poblaciones en agroecosistemas tradicionales contribuye al mantenimiento de la diversidad, por lo que este tipo de manejo debe ser incluido en estrategias de aprovechamiento sustentable y conservación de estos recursos genéticos. Sin embargo, hay que tener en cuenta que existen casos de sobre explotación de algunas poblaciones y se empieza a evidenciar consecuencias negativas de este aprovechamiento, como es el hecho de la disminución de la diversidad genética, de los tamaños efectivos de la población y del flujo de genes.

Para la especie pulquera (A. hookeri), mencionada en este capítulo, sí se evidenciaron con secuencias claras de la domesticación, debido a la fijación de fenotipos gigantes, pérdida de diversidad y mayor estructura poblacional. También se ha registrado pérdida de tradición de uso hacia esta práctica, lo cual amenaza la permanencia de estas especies.

México cuenta con una gran diversidad tanto de agaves como de otras tantas especies útiles para la sociedad. Para salvaguardar estos recursos genéticos necesitamos tener un conocimiento detallado de ellos. A pesar de los esfuerzos de investigación ya realizados en esta temática, las huellas fenotípicas y genéticas de selección humana relacionadas con un conjunto de usos particulares no han sido estudiadas, por lo que es necesario contribuir al conocimiento de estos usos y continuar la documentación de la relación humano-agave.

\section{Bibliografia}

Aguirre-Dugua, X. y L. E. Eguiarte, 2013. Genetic diversity, Casas, A., R. Lira, I. Torres, A. Delgado, A. I. Morenoconservation and sustainable use of wild Agave cupreata and Agave potatorum extracted for mezca Environments,

Alfaro-Rojas, G., J. P. Legaria-Solano, J. E. Rodríguez-Pérez 2007. Diversidad genetica en poblaciones de agaves México. Revista Fitotecnia Mexicana, 30(1): 1-12.

Álvarez, G., 2015. Del maguey al vaso: el manejo del pulque en las pulquerías del Distrito Federal y en las localidades en Ciencias Ambientales, ENES, UNAM Morelia, Michoacán.

APG III (The Angiosperm Phylogeny Group), 2009. An update of the Angiosperm Phylogeny Group classification for orders and families of flowering plants: APG IIII. Botanic Journal of the Linnean Society, 161:105-121.

Benz, B. F., L. López-Mestas y J. Ramos-Vega, 2006. Organic offerings, paper, and fibres from the Huitzilap shaft tomb, Jalisco, Mexico. Ancient Mesoamerica, 17: 283-296.

Blancas, J., A. Casas, D. Pérez-Salicrup, J. Caballero y E. Vega, 2013. Ecological and sociocultural factors of and Ethnomedicine, 9: 39.

Blancas, J., A. Casas, S. Rangel-Landa, I. Torres, E. PérezNegrón, L. Solís, A.I. Moreno, A. Delgado, F. Parra, Y
Arellanes, J. Caballero, L. Cortés, R. Lira y P. Dávila, 2010. Plant management in the Tehuacán-Cuicatlán Valley. Economic Botany, 64(4): 287-302.

Borland, A. M. H. Griffiths, J. Hartwell y J. A. C. Smith, 2009. Exploiting the potential of plants with crassulacean acid metabolism for bioenergy production on marginal lands. Journal of Experimental Botany, 60: 2879-2896.

Bruman, H. J., 1940. Aboriginal Drink Areas of New Spain. Ph.D Disertation. Universidad de California, Berkeley.

Bruman, H.J. 2000. Alcohol in Ancient Mexico. The Unirvesity of Utah Press. Utah.

Carrillo-Galván, M. G., 2011. Domesticación de Agaves productores de Fibra en el Centro-Occidente de México: una aproximación etnobotánica y morfológica. Tesis maestría en Ciencias Biológicas Opción Recursos Naturales. Centro de Investigación Científica de Yucatán,

Casas, A., F. Parra, J. Blancas, 2015a. Evolution of humans and by humans. En: Albuquerque, U. P. Medeiros, P. Casas, A. (Eds.). Evolwtionany ethnobiology. Spring

Casas, A., F. Parra, S. Rangel, S. Guillén, J. Blancas y C. J. Figueredo. Evolutionary ecology and ethnobiology.
2015b. Albuquerque, U.P. Medeiros, P. y Casas, A. (Eds.) Evolutionary ethnobiology. Springer. The Netherlands: pp. 37-57. Calles, S. Rangel-Landa, J. Blancas C. Larios, L.
Solís, E. Pérez-Negrón, M. Vallejo, F. Parra, B. FarfánHeredia, Y. Arellanes y N. Campos, 2016 Ethnobotan for Sustainable Ecosystem Management: A Regiona Perspective in the Tehuacán Valley. En Lira, R., a.
Casas, J. Blancas (Eds.). Ethnobotany of Mexico. Interactions of people and plants in Mesoamerica. Springer: pp. 560.

Casas, A., A. Camou, S. Rangel-Landa, L. Solís, I. Torres, A. Delgado-Lemus, A.I. Moreno Calles, M. Vallejo, S. Guillén, J.J. Blancas, F. Parra, X. Aguirre, B. FarfánHeredia y Y. Arellanes, 2014. Manejo tradicional de biodiversidad de y ecosistemas en Mesoamérica: Valle de Tehuacán. Investigación Ambiental. Ciencia

Casas, A., A. Otero-Arnaiz, E. Pérez-Negrón y A. ValienteBant of plants in
$1101-1115$.

Casas, A., A. Valiente-Banuet, A. Rojas-Martínez y P. Dávila, 1999a. Reproductive biology and the process stellatus in Central Mexico. American Journal of Botany, 86: 534-542.

Casas, A., J. Caballero, A. Valiente-Banuet, J. A. Soriano y P. Davila, 1999b. Morphological variation and the process of domestication of Stenocereus stellatus (Cactaceae) Central Mexico. American Journal of Botany, 86:

Casas, A., J. Caballero, C. Mapes y S. Zárate, 1997. Manejo de la vegetación, domesticación de plantas y origen de

Bo

( of plants in Mesoamerica Annals of Botony, 100: 1101-1115.

Coggins, C. C., y Shane III, O. C. ,1989. El Cenote de los sacrificios. Tesoros mayas extraídos del Cenote Sagrado
de Chichén Itzá, México.

colunga-GarcíaMarín, P., 1998. Origen, variación y tendencias evolutivas del henequén (Agave fourcroydes Lem.). Boletín de la Sociedad Bo
Perspectivas), 62: 109-128.

Colunga-GarcíaMarín, P., 2003. The domestication of (n) A. GómezPompa, M. F. Allen, S. L. Fedick y J. J. Jiménez-Osornio (eds.). The Lowland Maya Area. Three Millennia at the Human-Wildland Interface. The Haworth Press Inc. Binghampton, NY, pp. 439 - 446.

Colunga-GarcíaMarín, P. y D. Zizumbo-Villarreal, 2007. Tequila and other Agave spirits from west-central Mexico: current germplasm diversity, conservation and orifo: la agricultura en Mesoamerica. Boletin de la Sociedad 
Colunga-GarcíaMarín, P. y D. Zizumbo-Villarreal, 1993. Delgado-Lemus A., I. Torre, J. Blancas, A. Casas, 2014a La evolución de las plantas bajo selección artificial y manejo agricola. En: Leff, E. y J. Carabias (Eds.)
Cultura y Manejo Sustentable de los Recursos Naturales. Vol. I. CIIH-UNAM. Miguel Ángel Porrúa.

Colunga-GarcíaMarín, P. y F. May-Pat. 1993. Agave studies in Yucatan, Mexicol. Past and present germplasm diversity

Colunga-GarcíaMarín, P., D. Zizumbo-Villarreal A. GarcíaMendoza, C. Mlisley-Granich, C. Perez-Ricardez, Mezcales artesanales tradicionales de México: Patrimonio Cultural Inmaterial de la Humanidad, En: Mezcal, arte tradicional. Revista-Libro Artes de México, Número 98. Julio. México D.F.

Colunga-GarcíaMarín, P., D. Zizumbo-Villarreal y J. MartínezTorres, 2007. Tradiciones en el aprovechamiento de los agaves mexicanos: una aportación a la protección legal y conservación de su diversidad biológica y cultural. En: Colunga-García Marín, P., A. Larqué Saavedra, L. Eguiarte y D. Zizumbo-Vilareal (Eds.), En lo ancestra CICY-CONACYT-CONABIO-INE. pp 229-248 + Anexo xxi-xxxviii.

Colunga-GarcíaMarín, P., E. Estrada-Loera y F. May-Pat, 1996. Patterns of morphological variation, diversity and domestication of wild and cultivated populations of 8gave in Yucatan, $1069-1082$.

Colunga-GarcíaMarín, P., E. Hernández-Xolocotzi y A. Castillo-Morales, 1986. Variación morfológica, manejo . Agrociencia 65: 7-49.

Colunga-GarcíaMarín, P., G. Carrillo-Galván, D. ZizumboVillarreal y O. Vargas-Ponce. 2011. Agaves ixtleros de Sur de Jalisco. Centro de Investigación Científica de
Yucatán. pp. 117.

Colunga-GarcíaMarín, P., J. Coello-Coello, L. Eguiarte y D. relations between henequén Agave fourcroydes and its wild ancestor $A$. angustifolia Haw. American Journal of Botany, 86 (1): 115-123.

CONABIO, 2006. Mezcales y diversidad $2^{a}$ ed. Comisión Nacional para el Conocimiento y Uso de la Biodiversidad México.

Darwin, C., 1859. The origins of species by means in natural selection or the preservation of
struggle for life. Wiley, London.

2010. B., M. Pandey, R. S. Sharma, P. Thakur y P. Lal 2010. Biotechnological intervention of Agave sisalana: A unique fiber yielding plant with medicinal property.
Journal of Medicinal Plants Research, 4(3):177-187.

Delgado-Lemus A., A. Casas y O. Téllez, 2014b. Distribution, abundance and traditional management of Agave potatorum in the Tehuacan Valley, Mexico: bases for sustainable use of non-timber forest products. Jour
of Ethnobiology and Ethnomedicine, 10: 63. Vulnerability and risk management of Agave species in and Ethnomedicine, 10: 53 .

Escobar-Guzmán, R. E., F. Zamudio-Hernández, K. Gil Vega y J. Simpson, 2008. Seed production and gametophyte formation in Agave tequilana and Agave american

Estrella, P., 2008. Efecto de la explotación humana en la biología de la polinización de Agave salmiana y Agav potatorum en el Valle de Tehuacán-Cuicatlán. Tesis de Félix-Valdez, L. I., O. Vargas-Ponce, D. Cabrera-Toledo, A. Casas, A. Cibrian-Jaramillo y L. de la Cruz-Larios, 201 on the diversity and genetic structure of Agave potatorum (Asparagaceae) in central Mexico. Genetic Resource and Crop Evolution, 63 (7): 1255-1271, DOI 10.1007 s10722-015-0315-6.

gueredo, C., 2015b. Domesticación y divergencias morfológicas y genéticas entre poblaciones silvestres cultivadas de Agave inaequidens y A. hookeri. Tesis $d$ M, Morelia

igueredo, C. J., A. Casas, P. Colunga, A. González y J. Nassar, 2014. Morphological variation, management and domestication of 'maguey alto' (Agave inaequidens) Journal of Ethnobiology and Ethnomedicine, 10: 66 .

Figueredo, C., A. Casas, A. González-Rodríguez, J. Nassar, P. Colunga-GarcíaMarín y V. Rocha, 2015a. Genetic structure of coexisting wild and managed agave domestication. AoB Plants doi: 0.1093/aobpla/plv114.

nery, K. (Ed.), 1986. Guilá Naquitz. Academic Press. New York.

García-Martínez, B., 1987. Los pueblos de la sierra. El poder 1700. El Colegio de México, México.

García-Mendoza, A. J., 2011. Agavaceae. Flora del Valle de Tehuacán-Cuicatlann. Instituto de Biología, UNAM. D. F, México. 88: pp. 95.

García-Mendoza, A., P. Colunga-GarcíaMarín y R. Bye, 1993. Los usos del Agave angustifolia Haw., ancestro silvestre del henequén en su área de distribución geográfica. En: Memorias de la Conferencia Nacional sobre el Henequé y la Zona Hencquenera de Yucatán. P. Peniche R. y Santamaria B. (comp.). pp 92-112 Gán.

García-Payón, 1979. La zona arqueológica de TecaxicCalixtlahuaca y los matlatzinca: etnología y arqueología (textos de la segunda parte), edición de Wanda Tommas Biblioteca Enciclopédica del Estado de México, tomo 30 try, S., 1982. Agaves of continental North America. The University of Arizona Press. EUA. Experiment. Plant Breeding, 24: 1-44.
Gepts, P., 2004. Crop Domestication as a Long-term Selection
Harlan, J., 1975. Crops and man. American Society of Agronomy and Crop Science Society of America. Madison, Wisconsin.

Hawkes, J. G., 1983. The diversity of crop plants. Harvard University Press. Cambridge, Massachusetts, USA.

Illsley, C., E. Vega, I. Pisanty, A. Tlacotempa, P. García, P. Morales, G. Rivera, J. García, V. Jiménez, F. Castro y M. Calzada, 2007 Maguey papalote: hacia el manejo
campesino sustentable de un recurso colectivo en campesino sustentable de un recurso colectivo en el tropico seco de Guerrero, Mexico. En: P. ColungaGarciaMarin, L. Eguiarte, A. Larque, and D. Zizumbolos mezcales y otros agaves México: CICY-CONACYTCONABIO-INE: pp. 319-338.

IMPI, 2011 Declaratoria por la que se regula el uso de Ia marca Agave en Tequila, Mezcal y Bacanora. http://www. cofemersimir.gob. mx/mirs $/ 24458$

Kelly, I. 1944. Kelly, I. 1944. Ixtle weaving at Chiquilistlan, Jalisco. Notes in Middle A.
Ethnology, 42: 106-112.

King, Mary Elizabeth, 1986. Preceramic Cordage and Basketry from Guilá Naquitz. En: Flannery K. V. (Ed.) Guilá Naquitz: Archaic Foraging and Early Agriculture in Oaxaca,

Kirchhoff, P. 1943. Mesoamérica: Sus límites geográficos, composición étnica y caracteres culturals. Acta na, 1: 92-107

León, A., 2013. Aspectos de la fenología, visitantes florales y polinización de Agave inaequidens Koch. ss inaequidens (Agavaceae) en el Estado de Michoacán. Michoacana de San Nicolás de Hidalgo.

López, M. G. y J. E. Urías-Silvas, 2007. Agave fructans as prebiotics. Recent Advances in Fructooligosaccharides Norio, Benkeblia Noureddine and Onodera Shuichi. Research Signpost 37/661 (2), Fort P.O., Trivandrum-695 023, Kerala, India.

López, M. G., N. A. Mancilla-Margalli y G. Mendoza-Díaz, 2003. Molecular structures of fructans from Agave tequilana Weber azul. Journal of Agricultural and Food

MacNeish, R. S., 1992. The origins of agriculture and settled life. Oklahoma University Press.

Mora-Lopez, J., L. Reyes-Agüer, J. A. Flores-Flores, J. L. Peña-Valdivia, C. Beatriz y J. R. Aguirre-Rivera, 201 Variación mortológica y humanización de la secciôn Salmianae del género Agave. Agrociencia, 45(4): 465-

Otero-Arnaiz, A., A. Casas, J. L. Hamrick y J. Cruse, 2005 Genetic variation and evolution of Polaskia chichipe Central Mexico analyzed by microsatellite polymorphism. Molecular Ecology, 14(6): 1603-1611.

Parra, F., A. Casas, J. Peñaloza-Ramírez, A. C. Cortés-Palomec Evolution under domestication: Ongoing artificial selection and divergence of wild and managed Stenocereus pruinosus (Cactaceae) populations in the 1990. Maguey utilization in highland central Mexico: an archaeological ethnography (No. 82). Ann Arbor: Museum

ersgill, B., 2007. Domestication of plants in the Americas: Insights from mendelian and molecular genetics. Annals of Botany, 100: 925-940.

Rangel-Landa S., P. Dávila y A. Casas, 2015. Facilitation of Agave potatorum: An ecological approach for assiste population recovery. Forest Ecology and Management,

einvar, E., 2008. Genética de poblaciones silvestres y cultivadas de dos especies mezcaleras Agave cupreata y Agave potatorum. Tesis
Ecología, UNAM, pp. 105.

Secretaría de Comercio y Fomento Industrial, 1994. Norma Oficial Mexicana NOM-070-SCFI-1994. bebidas la Federación. México D.F. 17 de agosto.

Secretaria de Economía, 2012a. Proyecto de Norma Oficial Mexicana PROY-NOM-186-SCFI-2012. Bebidas alcohólicas-Bebidas alcohólicas elaboradas a parti de agave-Especificaciones, métodos de prueba e 5 de julio.

Secretaría de Economía, 2012b. Norma Oficial Mexicana NOM-006-SCFI-2012, Bebidas alcohólicas-TequilaEspecificaciones. Diar
D.F. 13 de diciembre

Secretaría de Economía, 2015a. Proyecto de Norma Oficia Mexicana PROY-NOM-199-SCFI-2015, Bebidas información comercial y métodos de prueba Diario Oficia de la Federación. México D.F. 29 de febrero.

Secretaría de Economía, 2015b. Proyecto de Norma Oficial Mexicana PROY-NOM-070-SCFI-2015, Bebidas alcohólicas-Mezcal-Especificaciones. Dar

Serra-Puche, M. C. y J. C. Lazcano-Arce, 2016. EI Mezca, una bebida prehispánica. Estudios etnoarqueológicos.
Instituto de Investigaciones Antropológicas. UNAM.

Smith Jr. y C. E., 1967. Plant remains. En: Byers D. (Ed.). The prehistory of the Tehuacán Valley, Vol. 1: Environment and
subsistence. University of Texas Pres, Austin. pp. 220-525. ( Na., C. E., 1986. Preceramic plant remains from Guila Naquitz. En: Flannery, K.V. (Ed.) Guilá Naquitz. Archaic Academic Press. New York, pp. 265-301.

Somerville, C, H. Youngs, C. Taylor, S. C. Davis y S. P. Long, 2010. Feedstocks for lignocellulosic biofuels. Science

Torres, I., 2015c. Informe de la Reunión Nacional de Manejadores de Maguey Forestal. México D.F. GEA, 
Torres, I., 2016. Aprovechamiento de Agaves Mezcaleros en el Vitousek, P. M., 1994. Beyond global warming: ecology and centro de México: Una aproximación socio-ecológica para su manejo sustentable. Tesis de Doctorado en Ciención
Biológicas, UNAM, Morelia, Michoacán , pp. 183.

Torres, I., A. Casas, A. Delgado-Lemus y S. Rangel-Landa, 2013. Aprovechamiento, demografía y establecimiento de Agave potatorum en el Valle de Tehuacán, México: Aportes etnobiologicos y ecologicos para su manej

Torres, I., A. Casas, E. Vega, M. Martínez-Ramos, A. DelgadoLemus, 2015a. Population dynamics and sustainable potatorum in the Tehuacán-Cuicatlán Valley. Economic of Botany, 69(1): 26-41.

Torres, I. J. Blancas, A. León y A. Casas, 2015b. TEK local perceptions of risk, and diversity of mana practices of Agave inaequidens in Michoacán, Mexico. Journal of Ethnobiology and Ethnomedicine, 11: 61.

Universidad Nacional Autónoma de México. 2012. Gran Diccionario Nahuatl [en linea]. Disponible en la Web http://www.gdn.unam.mx. [ref del 11 de Mayo de 2016].

Valenzuela-Zapata AG, Lopez-Muraira I, Gaytán MS. 201 Traditional Knowledge, Agave inaequidens (Koch) Conservation, and the Charro Lariat Artisans of San
Miguel Cuyutlan, Mexico. Ethnobiology Letters, 2: 72-80. Miguel Cuyutlán, Mexico. Ethnobiology Letters, 2: 72-80.

Valenzuela-Zapata, A. G. y G. P., Nabham, 2003. Tequila: natural and cultural history. Tucson University Press.

Vargas-Ponce, O., D. Zizumbo-Villarreal y P. ColungaGarcíaMarín, 2007. In situ diversity and maintenance of traditional Agave landraces used in spirits production in

Vargas-Ponce, O., D. Zizumbo-Villarreal, J. Martínez-Castillo, Diversity and structure of landraces of Agave grown for spirits under traditional agriculture: a comparison with wild populations of $A$. angustifolia (Agavacea) and commercial plantations of $A$. tequilana. American. Journal of Botany, 96: 448-457.

Vavilov, N. I., 1992. Origin and geography of cultivated plants. Cambridge: Cambridge University Press. global change. Ecology, 75(7): 1861-1876.

zumbo-Villarreal, D. y P. Colunga-GarcíaMarín, 2007. La inces en el occidente de Mexico. pp. 85-112. En: ColungaGarcia Marin, P., A. Larque Saavedra, L. Eguiarte y D. Zizumbo-Villarreal (Eds.), En lo ancestral hay futuro: de CONABIO-INE ISBN: 078-068-6532-18-0.452 PP

Zizumbo-Villarreal, D., A. Flores-Silva y P. ColungaGarcialMarin, 2012. The Archaic Diet in Mesoamerica: Domestication. Economic Botany, 66 (4): 328-343.

zumbo-Villarreal D. A. Flores-Silva y P.

GarcíMarin 2014. The food system during the foung period in West Mesoamerica. Economic Botany, 68 (1): 67-84.

Zizumbo-Villarreal, D., F. González-Zozaya, A. OlayBarrientos, L. Almendros-López, P. Flores-Pérez y P. Colunga-GarcíaMarín, 2009a. Distillation in Western Mesoamerica Before European Contact. Economic

Zizumbo-Villarreal, D., F. González-Zozaya, A. OlayBarrientos, R. Platas-Ruiz, M. Cuevas-Sagardi, Almendros-Lopez, y P. Colunga-GarcialMarin, 2009b. A Bave sp. in : 288-302

mbo-Villarreal, D., O.Vargas-Ponce, J. J. Rosales-Adame y P. Colunga GarcíaMarín. 2013. Sustainability of th the elaboration of mezcal and tequila spirits in western Mexico. Genetic Resources and Crop Evolution, 60: 33-47.

zumbo-Villarreal, D., P. Colunga-GarcíaMarín, E. Payró de la Cruz, P. Delgado-Valerio, y P. Gepts, 2005. Population Structure and Evolutionary Dynamics of Wild-WeedyDomesticated Complexes of Common Bean in a Botany, 63(4): 413-426.
Apéndice 1. Especies de Agave usadas como alimento, aguamiel y/o bebidas fermentadas, bebidas destiladas y fibra. La última columna señala las especies que presentan claros signos de domesticación.

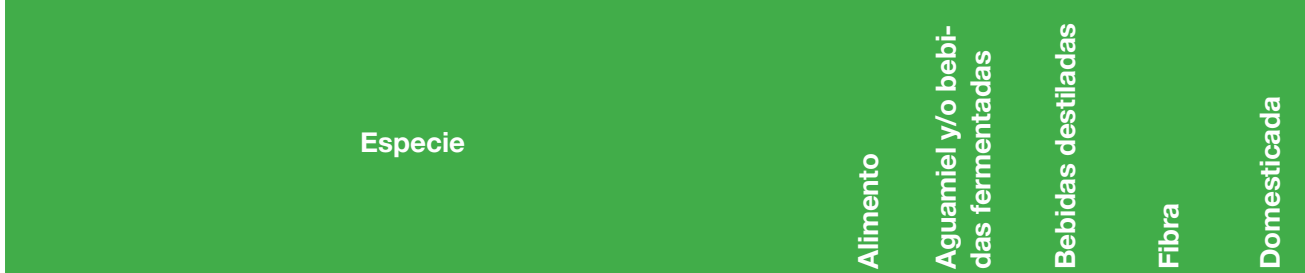

Agave aktites Gentry

\begin{tabular}{lllllllll}
\hline Agave albopilosa I.Cabral, Villarreal \& A.E.Estrada & & & & & X & \\
\hline Agave americana L. & X & X & X & X & X \\
\hline
\end{tabular}

Agave americana var.expansa (Jacobi) Gentry

Agave americana $L$ var marginata

Agave americana L. subsp. protoamericana Gentry

Agave americana L. var. oaxacencis Gentry

Agave angustiarum Trel.

Agave applanata Lem. ex Jacobi

Agave asperrima Jacobi

Agave asperrima subsp. potosiensis (Gentry) B.Ullrich

Agave atrovirens Karw. ex Salm-Dyck

Agave aurea Brandegee

Agave bovicornuta Gentry

Agave bracteosa S. Watson ex Engelm.

Agave capensis Gentry

Agave cantala (Haw.) Roxb. ex Salm-Dyck

Agave cerulata Trel.

Agave cerulata subsp. dentiens (Trel.) Gentry

Agave chiapensis Jacobi

Agave chrysantha Peebles

$x$

$x$

Agave chrysoglossa I.M.Johnst.

Agave colorata Gentry

Agave cupreata Trel. \& A.Berger

Agave deserti Engelm.

$x$

$x$ 


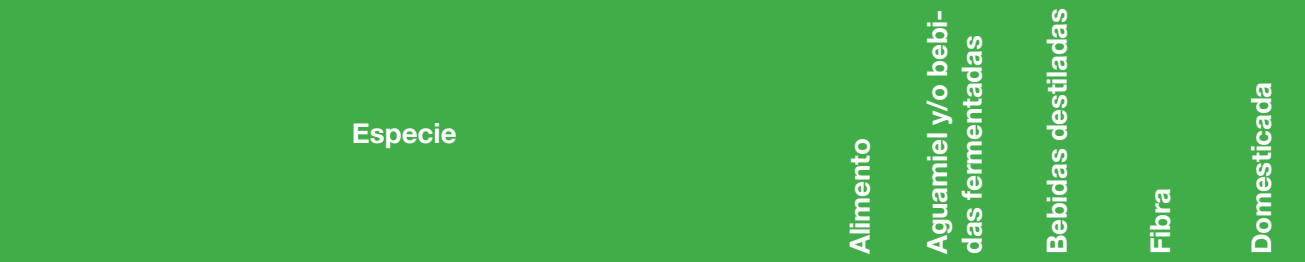

Agave deserti var. pringlei (Engelm. ex Baker) W.C.Hodgs. \& Re-

veal

$x$

Agave deserti var. simplex (Gentry) W.C.Hodgs. \& Reveal $x$

Agave desmettiana Jacobi

Agave durangensis Gentry $x$

Agave felgeri Gentry

\begin{tabular}{lll} 
& $x$ & $x$ \\
$x$ & $x$ & $x$ \\
\hline
\end{tabular}

Agave filifera Salm-Dyck

Agave fortiflora Gentry

Agave fourcroydes Lem.

$x \quad x$

Agave funkiana K.Koch \& C.D.Bouché

$\begin{array}{lllll}x & x & x^{*} & x & x\end{array}$

Agave geminiflora (Tagl.) Ker Gawl

Agave gentry B. Ullrich

Agave gigantensis Gentry

Agave guadalajarana Trel.

Agave hookeri Jacobi

Agave horrida Lem. ex Jacobi

Agave inaequidens Koch subsp. Inaequidens Koch

Agave jaiboli Gentry

Agave karwinskii Zucc.

Agave kerchovei Lem.

Agave kewensis Jacobi

Agave lechuguilla Torr.

Agave macroacantha Zucc.

Agave mapisaga Trel.

Agave margaritae Brandegee

Agave marmorata Roezl

Agave maximiliana Baker

Agave maximiliana var. katharinae (A.Berger) Gentry

Agave mitis Mart.

\begin{tabular}{|c|c|c|}
\hline wl. & & $x$ \\
\hline & $x$ & $x$ \\
\hline
\end{tabular}

$x$

$x$
$x$

\begin{tabular}{lllll}
$x$ & $x$ & $x$ & & $x$ \\
$x$ & & $x$ & $x$ & \\
\hline
\end{tabular}

$\begin{array}{llll}x & x & x & x \\ x & & x & x\end{array}$

$\begin{array}{lllll}x & & x & x & \\ x & x & x & x & x \\ x & x & x & x & \end{array}$

$x$

$\begin{array}{lll}x & x & x\end{array}$

$\begin{array}{llll}x & x & x & \\ x & x & x & \\ x & x & x & x\end{array}$

$\begin{array}{ccccc}x & x & x & x & x \\ & & x & & \\ x & x & x & x & \\ x & x & x & & \\ x & x & & & \\ x & & & x\end{array}$

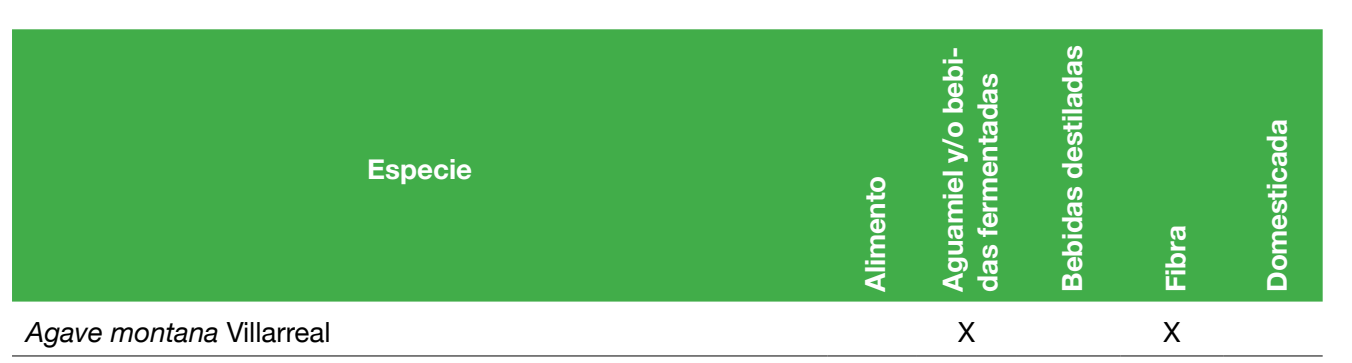

Agave montana Villarreal

Agave montium-sancticaroli Garcia-Mend.

Agave multifilifera Gentry

Agave murpheyi Gibson

Agave nussaviorum García-Mend.

$\begin{array}{llll}x & & x & \\ x & x & x & x \\ x & & x & x \\ x & & x & \end{array}$

Agave ocahui Gentry

Agave ortgiesiana (Baker) Trel.

Agave ovatifolia G.D.Starr \& Villarreal

Agave palmeri Engelm.

Agave parrasana A.Berger

Agave parryi Engelm.

Agave parviflora Torr.

Agave peacockii Croucher

Agave pelona Gentry

Agave polianthiflora Gentry

Agave potatorum Zucc.

Agave rhodacantha Trel.

Agave salmiana Otto ex Salm-Dyck

Agave salmiana subsp. crassispina (Trel.) Gentry

Agave salmiana var. angustifolia A.Berger

Agave salmiana var. ferox (K.Koch) Gentry

Agave schidigera Lem.

Agave schottii Engelm.

Agave seemanniana Jacobi

Agave shawii Engelm.

Agave shrevei Gentry

Agave shrevei subsp. magna Gentry

Agave sisalana Perrine

$x$

$x$

$x$

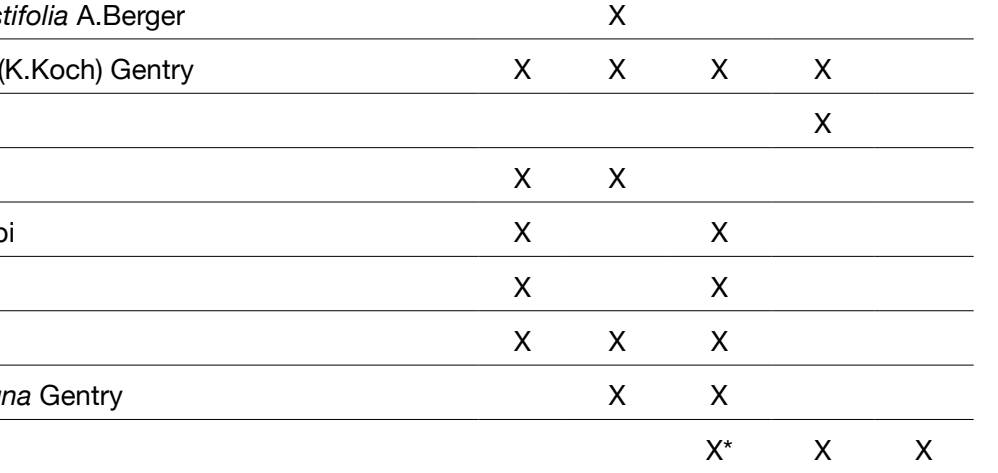




\begin{tabular}{|c|c|c|c|c|c|}
\hline Especie & 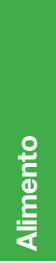 & 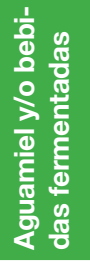 & 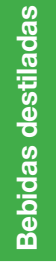 & 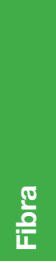 & 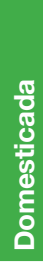 \\
\hline Agave sobria Brandegee & $x$ & & $x$ & & \\
\hline Agave striata Zucc. & & $x$ & & $x$ & \\
\hline Agave striata subsp. falcata (Engelm.) Gentry & & & & $x$ & \\
\hline Agave stricta Salm-Dyck & & & & $x$ & \\
\hline Agave subsimplex Trel. & $\mathrm{x}$ & & & & \\
\hline Agave tequilana F.A.C.Weber & $x$ & $x$ & $x$ & $x$ & $x$ \\
\hline Agave thomasiae Trel. & & & & $x$ & \\
\hline Agave titanota Gentry & & & $x$ & & \\
\hline Agave triangularis Jacobi & $x$ & & & $x$ & \\
\hline Agave univittata Haw. & & & $x$ & $x$ & \\
\hline Agave valenciana Cházaro \& A. Vázquez & & & $x$ & & \\
\hline Agave vera-cruz Mill. & $x$ & & $x$ & & \\
\hline Agave victoriae-reginae T. Moore & & & $x$ & $x$ & \\
\hline Agave vilmoriniana A.Berger & $x$ & $x$ & & $x$ & \\
\hline Agave vivipara $\mathrm{L}$. & $x$ & $x$ & $x$ & $x$ & \\
\hline Agave vivipara var. deweyana(Trel.) P.I.Forst. & & & & $x$ & \\
\hline Agave weberi J.F.Cels ex J.Poiss. & & $x$ & $x$ & $x$ & \\
\hline Agave wocomahi Gentry & $x$ & $x$ & $x$ & $x$ & \\
\hline Agave xylonachanta Salm-Dyck & $x$ & & & $x$ & \\
\hline Agave yuccifolia DC. ex Redouté & & & & $x$ & \\
\hline Agave zebra Gentry & $x$ & & $x$ & & \\
\hline
\end{tabular}

\section{Uso muy reciente}

Fuentes:

Caballero J. y L. Cortes. 1982-2016. Base de Datos Etnobotánicos de Plantas de México (BADEPLAM). Jardín Botánico, IB-UNAM, México. Colunga-Garcíamarin, P., D. Zizumbo-Villarreal y J. Martinez-Torres. 2007. Tradiciones en el aprovechamiento de los agaves mexicanos: una

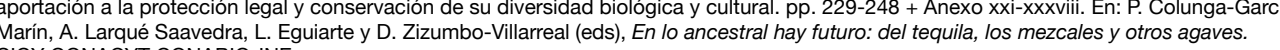
MVY-CONACYT-CONABIO-INE.

Torres I., A. Casas, E. Vega, M. Martinez-Ramos y A. Delgado-Lemus. 2015. Population dynamics and sustainable management of mescal

The Plant List 2013. The Plant List: A working list of all plant species Version 1.1 (en linea, disponible en http://www.theplantist.org). Consul- 


\section{Uso, manejo y domesticación de cactáceas en Brasil}

Reinaldo Farias Paiva de Lucena, Camilla Marques de Lucena, Marcos Vinicius Meiado, Denise Dias da Cruz, Maristela Oliveira de Andrade y Alejandro Casas

\section{Resumen}

La familia Cactaceae se encuentra en todo el territorio brasileño, pero es un ícono de la región semiárida, con una alta diversidad de especies. Este capítulo hace una revisión general de publicaciones sobre los cactos de Brasil, principalmente de la zona semiárida, su conocimiento, uso y estado de conservación; de las principales especies, así como las perspectivas de investigación, considerando el alto nivel de endemismo existente en la región y el país. Brasil alberga una biodiversidad de las más elevadas a escala continental, la flora de Brasil reconoce 46097 especies 4747 de las cuales son especies de algas, 5712 de hongos, 1524 de briofitas, 1253 de licofitas, 30 de gimnospermas y 32831 especies de angiospermas. Los cactos incluyen 260 especies agrupadas en 39 géneros que representan tres subfamilias: Cactoideae, Opuntioideae y Pereskioideae (Taylor y Zappi, 2004). Más del 7096 de los cactos brasileños es endémico. La familia Cactaceae se encuentra en todos los dominios fitogeográficos brasileños, pero la mayor diversidad se encuentra en las regiones nordeste y sureste de Brasil, en áreas de vegetación de Caatinga (92 especies) y Mata Atlántica (95 especies). También destaca la región meridional, específicamente Río Grande do Sul, con 78 especies, destacando las globosas y cilíndricas de los géneros Frailea. Existen especies de amplia distribución como Cereus jamacaru subsp. jamacaru, encontradas en más de diez estados brasileños. En contraparte, muchas especies son endémicas y de distribución restringida, como Melocactus sergipensis y varias especies y taxa intraespecíficos de este género. Su distribución es tan puntual que son buenos indicadores del estado de conservación de las regiones en las que se encuentran y han sido utilizadas como criterio para definir áreas protegidas, como es el caso del Área de Protección Ambiental Grutas de los Brejões, en el Estado da Bahía. Debido a la pérdida significativa de hábitat, muchas especies aún desconocidas para la ciencia pueden estar siendo eliminadas antes de ser descubiertas. Por eso, se ha considerado urgente el desarrollo de programas que promuevan la conservación efectiva y la reducción de riesgo de extinción de especies, como el Plan de Acción Nacional para la Conservación de las Cactáceas implementado en $\mathbf{2 0 1 0}$ por el Ministerio del Medio Ambiente. Como en otras regiones de continente, en Brasil las cactáceas son importantes recursos. Las poblaciones tradicionales las han empleado como recursos no maderables (alimento humano, forraje, mágico-religioso, medicinal, ornamental y veterinario) y como maderable (combustible y construcción). Una de 
las categorías de uso no maderable más citada es como alimento humano, para lo cual son utilizados los frutos y su pulpa; destacando especies de los géneros Cereus, Melocactus, Opuntia y Pilosocereus, también se consume la pulpa de especies de Melocactus para preparar dulces y los cladodios de Opuntia para consumo como jugo. Prácticamente todas las cactáceas se cortan en pedazos para dar de comer a los animales. Se ha analizado el uso y manejo apropiado de la especie exótica $O$. ficus-indica como alternativa para conservar especies nativas como Pilosocereus gounellei subsp. gounellei y P. pachycladus subsp. pernambucoensis. Debido a su uso mágico-religioso, algunas especies son plantadas enfrente de las casas o jardínes para evitar "mal de ojo" y envidia. Los cactos citados para tal fin son: C. jamacaru subsp. jamacaru, Melocactus sp., N. cochenillifera, $P$. gounellei subsp. gounellei y O. ficus indica. Las cactáceas tienen fines terapéuticos, se ha registrado el uso de la cáscara de $C$. jamacaru para tratar problemas renales asma y fiebre, el uso de pulpa de Melocactus zehntneri ingerida con miel o azúcar sirve para tratar la tos, bronquitis y debilidad física. En Bahía una de las especies más utilizadas para fines medicinales es $\mathrm{O}$. ficus-indica, para tratar calentura ("calor o inflamación del intestino"), inflamación vaginal, infección urinaria, gripa, dolor de barriga, reumatismo, resecamiento (presión de vientre), dolor de garganta, inflamación de útero, barriga hinchada y disentería. En Paraiba cinco cactos (C. jamacaru subsp. jamacaru, Melocactus sp., O. ficus-indica, $P$. gounellei subsp. gounellei y $P$. pachycladus subsp. pernambucoensis) se usan para tratar 27 tipos de dolencias, y una de las especies más citadas fue $C$. jamacaru subsp. jamacaru usada para tratar 15 enfermedades: colesterol elevado, heridas, forúnculos, gastritis, gripa, infección del tracto urinario, inflamación, problemas de la columna vertebral, problemas de la uretra, problemas en los riñones, reumatismo, secreción vaginal, sinusitis, tos y úlceras. Tienen uso veterinario: la pulpa de $P$. gounellei subsp. gounellei se usa para desatragantar animales (principalmente caprinos). Melocactus sp., se sumerge en agua que beben las gallinas que padecen gripa ("gogo"), $P$. gounellei subsp. gounellei se usa para tratar inflamaciones, aplicando la pulpa tópicamente. En el desierto baiano las espinas de $C$. jamacaru se usan para coser las heridas de parto de las vacas. $C$. jamacaru y $P$. pachycladus se usan como leña y en los fogones domésticos. C. jamacaru y de Pilosocereus catingicola se usan en tejados, puertas y ventanas. La pintura para las casas se prepara con mucílago de $O$. ficus-indica mezclada con cal. C. jamacaru y $P$. gounellei se usan como cercas vivas. Una de las especies más importantes es $C$. jamacaru, usada como alimento, forraje, medicina y construcción. Es una especie manejada en proceso incipiente de domesticación. Se ha documentado divergencia morfológica entre poblaciones silvestres y manejadas, pero estudios recientes de genética de poblaciones no han encontrado importantes diferencias entre ambos tipos de poblaciones. Los estudios se encuentran aún en proceso y se aspira a que constituya un modelo de estudio de varias especies con una situación similar en el nordeste brasileño.

Palabras clave: Caatinga, cactáceas, domesticación, etnobotánica, Mata Atlántica nordeste brasileño, recursos forestales no maderables.

\section{Introducción}

La familia Cactaceae se encuentra en todo el territorio brasileño, sin embargo, es de sentido común que destaque particularmente como uno de los íconos de la región semiárida. Además de su alta diversidad de especies, los cactos desempeñan un importante papel en el escenario cultural y simbólico para la población de esas regiones, teniendo también relevancia en la economía de las unidades de producción familiares. A pesar de este contexto de relevancia significativa, los estudios y la información científica, y con colectas sistemáticas sobre la familia Cactaceae de Brasil, aún son poco frecuentes.

Considerando la importancia de los cactos en el territorio brasileño, el presente capítulo busca realizar una evaluación de publicaciones sobre esta familia botánica, poniendo énfasis en el conocimento, uso y estado de conservación de tales especies. No obstante, no fue nuestro objetivo realizar una revisión detallada de cada especie, sino transmitir una visión general para Brasil, destacando la región semiárida, para la cual existe la mayor concentración de trabajos realizados. También destacamos la importancia de la necesidad de realizar más estudios etnobotánicos para documentar el conocimiento y uso de las cactáceas por las poblaciones tradicionales, considerando la escasez o carencia de información con esta temática. Otra línea importante que debe ser atendida por los investigadores y etnobotánicos es el manejo y domesticación de especies, en nuestro caso de las cactáceas, pues los datos científicos sobre el tópico son prácticamente ausentes para Brasil, sobre todo en relación con especies nativas y endémicas.

De tal forma, el presente capítulo está estructurado en secciones que abordan específicamente temáticas sobre la diversidad, conservación, usos madereros y no maderables de los cactos, así como un estudio de caso, demostrando detalladamente los usos de una especie común de la región semiárida, Cereus jamacaru subp. jamacaru.

\section{Diversidad de cactos en Brasil}

Con más de 8.5 millones de $\mathrm{km}^{2}$, Brasil es el mayor país de América del Sur y alberga una biodiversidad de las más elevadas a escala continental, representativa de sus dominios fitogeográficos. De acuerdo con la Lista de Especies de Flora de Brasil (2015), se reconocen 46 097 especies para la flora brasileña, siendo 4747 especies de algas, 5712 especies de hongos, 1524 especies de briofitas, 1253 de licofitas, 30 especies de gimnospermas y 32831 especies de angiospermas. Dentro de estas especies de la flora brasileña, la familia Cactaceae destaca por presentar una amplia distribución en el territorio nacional, con representantes en todos los dominios fitogeográficos y estados de Brasil (Taylor y Zappi, 2004; Zappi et al., 2015).

Los cactos están representados en Brasil por la presencia de 260 especies que tienen las más variadas formas de vida (i.e., arbustos, subarbustos, hierbas, árboles, lianas y trepadoras) y se encuentran en sustratos terrícolas, rupícolas, así como en hábitats epífitos y hemiepífitos (Zappi et al. 2015). Todas estas especies se agrupan en 39 géneros que representan tres subfamilias: Cactoideae, Opuntioideae y Pereskioideae (Taylor y Zappi, 2004). Más 
del $70 \%$ de todos los cactos de Brasil es exclusivo de este país, es decir, son endémicos, siendo 14 géneros encontrados exclusivamente en el territorio brasileño (Zappi et al., 2015).

Brasil está geopolíticamente dividido en 27 unidades federativas: 26 estados y un Distrito Federal, los cuales se agrupan formando las regiones centro-oeste (tres estados y el Distrito Federal), nordeste (nueve estados), norte (siete estados), sur (tres estados) y sudeste (cuatro estados). Las especies de cactos se distribuyen por todo el territorio nacional, pero existen dos áreas de Brasil bastante representativas en número de especies de la familia Cactaceae: el Brasil oriental y el Brasil meridional (Taylor y Zappi, 2004; Zappi et al., 2011a). Tal representatividad está directamente relacionada con la gran diversidad de hábitats de esas regiones, ocasionada por la variación edafoclimática que se encuentra en tales áreas, la cual determina la formación de distintoss dominios fitogeográficos con diferentes comunidades de plantas adaptadas a condiciones ambientales específicas.

Actualmente se reconocen seis dominios fitogeográficos en Brasil: Amazonia, Caatinga, Cerrado, Mata Atlántica, Pampa y Pantanal. Independientemente de las condiciones ambientales, las especies de la familia Cactaceae se encuentran en todos los dominios fitogeográficos que se distribuyen en las cinco regiones brasileñas mencionadas. La primera área que merece destacarse por la mayor diversidad de cactos es el Brasil oriental, o sea, la parte este del país, la cual engloba áreas de las regiones nordeste y sudeste de Brasil, siendo representada sobre todo por áreas de Caatinga y Mata Atlántica (Taylor y Zappi, 2004; Zappi et al., 2011a). En esa área se encuentran numerosas especies raras y endémicas, pues la Caatinga y la Mata Atlántica son los dominios fitogeográficos que presentan el mayor número de especies dentro del territorio brasileño (Taylor y Zappi, 2004; Zappi et al., 2015). En la Caatinga, un bosque tropical seco localizado mayormente en la región Nordeste de Brasil, se han descrito 92 especies de cacto agrupadas en 24 géneros, siendo 44 especies y 4 géneros endémicos de ese ecosistema (Zappi et al., 2015). A su vez, es en la Mata Atlántica, un bosque tropical húmedo distribuido de forma marcadamente fragmentada en áreas próximas al litoral brasileño, en donde se observa el mayor número de especies de la familia Cactaceae, habiéndose registrado hasta el momento un total de 95 especies y 21 géneros de cactos, con 56 especies y 4 géneros endémicos (Zappi et al. 2015). Además, es justamente en la Mata Atlântica en donde se encuentra el mayor número de especies de Rhipsalis Gaertn. (34 especies), el género de Cactaceae epífitas que presenta al mayor número de especies en el território nacional (37 especies) (Zappi et al., 2015).

La segunda área de Brasil que también merece destacarse por el número de endemismos de especies de cactos, es el Brasil Meridional, representada por la región del sur del país. En esa región se encuentran 78 especies en los dominios fitogeográficos de la Pampa, una región pastoril de planicies, y de Mata Atlántica, en donde más de la mitad de las especies encontradas en esos dominios fitogeográficos son endémicas (Zappi et al., 2011a; 2015). A diferencia de la Mata Atlántica del Brasil oriental, donde se encuentran muchas especies epífitas de Cactaceae, en la región sur de Brasil, en especial en el estado de Río Grande del Sur, donde destacan las especies rupestres de Cactaceae globosas y cilíndricas de los géneros Frailea Britton \& Rose y Parodia Speg. (Zappi et al., 2011a; 2015). Muchas de las especies de esos géneros son endémicas de la región sur de Brasil donde se encuentran en un número reducido de poblaciones que se distribuyen en las pampas gauchas de Uruguay y Argentina (Zappi et al., 2011a; 2015).

\section{Conservación de cactáceas de Brasil}

Algunas especies como la Cereus jamacaru DC. subsp. jamacaru, conocida popularmente en Brasil como mandacaru o cardeiro, presentan una amplia distribución geográfica y son fácilmente encontradas en más de diez estados brasileños. En contraparte, muchas especies de cactos que se encuentran en Brasil son endémicas y tienen una distribución restringida y puntual, como Melocactus sergipensis N.P. Taylor \& M.V. Meiado, la última especie descrita para la família Cactaceae que posee apenas una sola población en la Caatinga y que se encuentra críticamente amenazada de extinción (Taylor et al., 2014; Meiado, 2015; Meiado et al., 2015a). Varias especies de cactos, sobre todo en la región de la cuenca hidrográfica de Río San Francisco, en el Brasil Central, también presentan distribución restringida y puntual, como el Melocactus azureus Buining \& Brederoo, el Melocactus ferreophilus Buining \& Brederoo, el Melocactus pachyacanthus Buining \& Brederoo subsp. pachyacanthus y el Melocactus pachyacanthus Buining \& Brederoo subsp. viridis N.P. Taylor. Estas especies raras están más amenazadas de extinción, pues cuentan con un menor número de poblaciones que las demás especies de cactos que se encuentran en el Brasil Central (Meiado et al., 2015b). De tal forma la presencia de esas especies debe utilizarse como indicador para el establecimiento de unidades de conservación, como es el caso del Área de Protección Ambiental Grutas de los Brejões, en el Estado de Bahía, en donde se encuentran representantes de Melocactus ferreophilus Buining \& Brederoo (Meiado et al., 2015b). Además de esto, proyectos que tengan como objetivo el conocimiento acerca de la biología de tales especies y que garantizan su éxito reproductivo deben ser ampliamente incentivados para promover la manutención de las poblaciones en sus ambientes naturales.

De acuerdo con Zappi et al. (2011b), el principal argumento para apoyar la conservación de las Cactaceae de Brasil está relacionado con el grado de singularidad que los cactos brasileños presentan, en relación con los géneros y especies endémicas, cuando se les compara con la situación en todo el continente americano. Debido a la pérdida significativa de hábitat en los más diversos dominios fitogeográficos del país, muchas especies aún desconocidas para la ciencia pueden estar siendo eliminadas de sus hábitats naturales antes de ser descubiertas. Así, resulta urgente el desarrollo de programas que promuevan la conservación efectiva y la reducción de riesgo de extinción de esas especies, como el Plano de Acción Nacional para la Conservación de las Cactáceas, implementado en 2010 por el Ministerio del Medio Ambiente (Zappi et al., 2011b). De acuerdo con Meiado et al. (2015b), los esfuerzos de esos programas de conservación deben involucrar tres partes: (1) el poder público que puede patrocinar esos programas; (2) la comunidad científica, que debe intensificar las investigaciones básicas y los inventarios florísticos de las especies de la familia Cactaceae, ya sea como el desarrollo y mejoramiento de técnicas que garanticen el éxito reprodutivo, la conservación ex situ y la conservación de las poblaciones de cactos en sus ambientes naturales, y (3) la sociedad, que debe reconocer el valor socioeconómico y ambiental de los bosques y aprender a utilizar sus recursos naturales de forma sustentable, evitando con ello, la destrucción de nuevas áreas y la extinción de la flora local y de la fauna que utiliza esos cactos como recurso alimentario. 


\section{Conocimento botánico local sobre cactáceas de Brasil}

En Brasil, principalmente en la región semiárida, son varios los usos registrados para la familia Cactaceae. Estudios etnobotánicos han descrito la diversidad de cactáceas y las potencialidades de usos atribuidos a los miembros de esa familia (Lucena et al., 2005; Andrade et al., 2006a, 2006b; Albuquerque et al., 2010; Nascimento, 2010; Lucena et al., 2012a, 2012b, 2012c, 2013, 2014) (Figura 12.1).

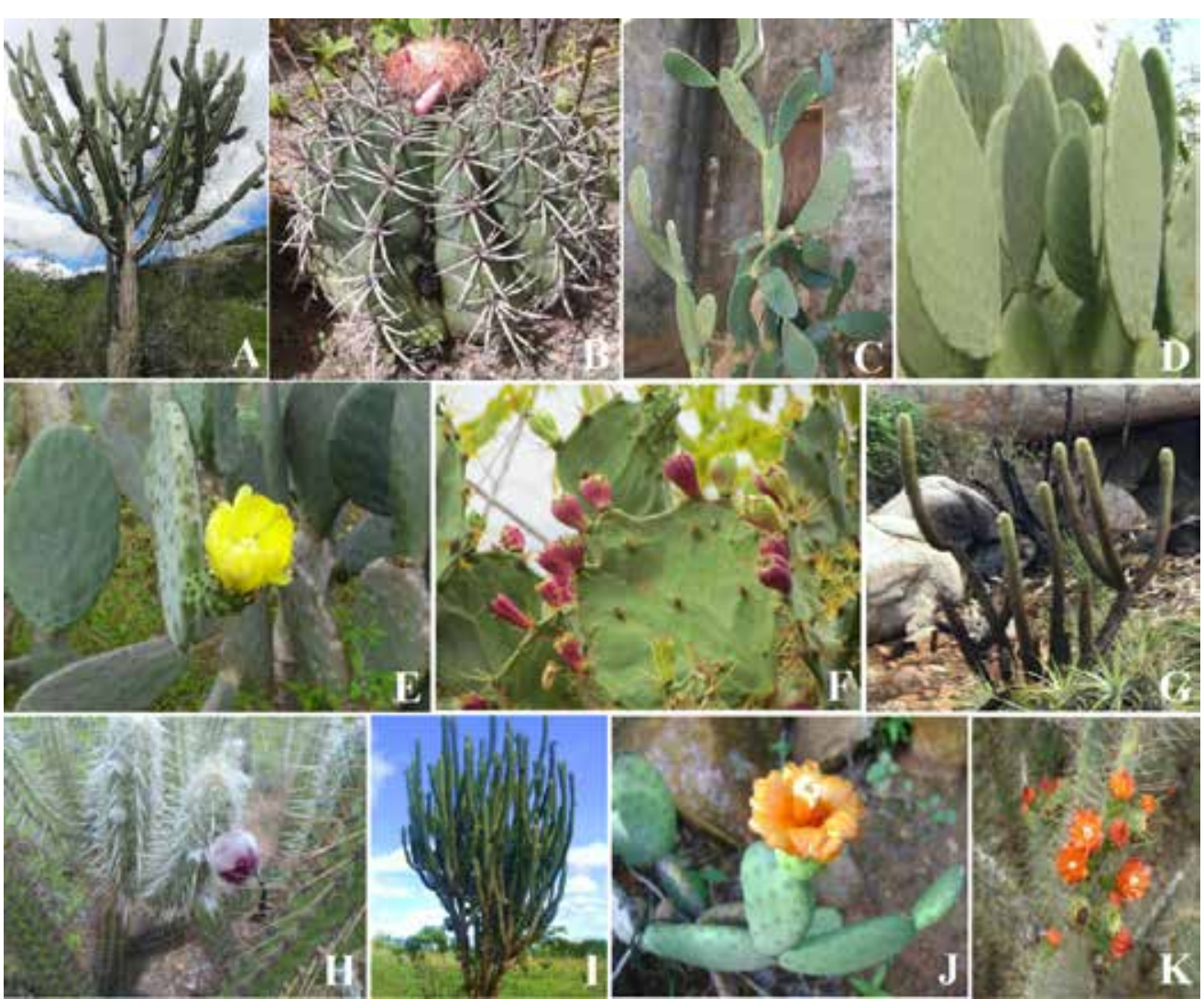

Figura 12.1. Algunas de las especies de cactos encontradas en las zonas semiáridas del estado de Paraíba, Nordeste de Brasil.:A) Cereus jamacaru DC. subsp. jamacaru; B) Melocactus zehntneri (Britton \& Rose) Luetzelb.; C)Nopalea cochenillifera (L.) SalmDyck; D. Opuntia sp.; E) Opuntia ficus-indica (L.) Mill.; F. Opuntia dillenii (Ker Gawl.) Haw.; G) Pilosocereus chrysostele (Vaupel) Byles \& G.D. Rowley; H) Pilosocereus gounellei (F.A.C. Weber) Byles \& G.D. Rowley subsp. gounellei; I) Pilosocereus pachycladus F. Ritter subsp. pernambucoensis (F. Ritter) Zappi; J) Tacinga inamoena (K. Schum) N.P. Taylor \& Stuppy, Y K) Tacinga palmadora (Bitton \& Rose) N.P. Taylor \& Stuppy. Fotos: C. M. Lucena.
Entre las poblaciones tradicionales, las cactáceas han sido fuente de varios recursos, tanto no maderables -alimento humano, forraje, mágico-religioso, medicinal, ornamental y veterinario-, como maderables -combustible, construcción y tecnología- (Andrade-Lima, 1989; Lima 1996; Albuquerque, 2001; Albuquerque y Andrade, 2002; Andrade et al., 2006a, 2006b; Agra et al., 2007; Araújo et al., 2008; Albuquerque et al., 2010; Lucena et al., 2012a, 2012b, 2012c $2013,2014,2015)$ y, además de esto, son consideradas como alimento de emergencia.

\section{Conocimiento botánico local sobre usos no maderables de cactáceas}

Una de las categorías de uso no maderable más citada es como alimento humano, para lo cual son utilizados los frutos y la pulpa (miolo) de varias especies (Andrade et al., 2006a; Lucena et al., 2013, 2015). Lucena et al. (2013) registraron en una comunidad rural semiárida de Paraiba el uso del fruto in natura de ocho especies: Cereus jamacaru DC. subsp. jamacaru, Melocactus sp., Nopalea cochenillifera (L.) Salm-Dyck, Opuntia ficus indica (L.) Mill., Opuntia stricta (Haw.) Haw., Pilosocereus gounellei (F.A.C.Weber) Byles \& Rowley subsp. gounellei, Pilosocereus pachycladus F. Ritter subsp. pernambucoensis (F. Ritter) Zappi y Tacinga palmadora (Britton \& Rose) N.P. Taylor \& Stuppy. En la región semiárida de Bahía, la pulpa (parénquima acuoso) de Melocactus sp. es utilizada para hacer dulce casero, y el cladodio o raqueta de la especie exótica O. ficus indica es utilizada para la alimentación humana, en forma de ensalada o jugo (Andrade et al., 2006a). La tendencia del uso de pulpa del Melocactus sp. también se registró en el desierto de Paraíba, en el municipio de Lagoa (Lucena et al., 2012b). Además, en la comunidad de San Francisco, en Cariri de Paraíba, uno de los cactos más utilizados en la alimentación humana es el $O$. ficus-indica que sirve para recetas de dulces, pastel, mermeladas, sopas o en platillos servidos acompañando con frijoles, carne y arroz (Lucena et al., 2013).

Otra categoría de uso no maderable prominente en Brasil es el uso forrajero (Figuras 12.2 12.3), pues la mayoría de las especies son utilizadas para alimentar ganado caprino, bovino y ovino en la región semiárida (Andrade et al., 2006a; Lucena et al., 2012c, 2013, 2015; Nunes et al., 2015). Las cactáceas pueden ser servidas a los animales cortadas en pedazos (con o sin penso para animales) (Lucena et al., 2012a, 2012b) o los individuos son quemados por completo para eliminar las espinas (Lima, 1996; Lucena et al., 2013, 2015), como se realiza con la mayoría de las especies. Andrade et al. (2006a) citan que algunos residentes de la región semiárida baiana utilizan antorchas para quemar las espinas de los cactos y así facilitar el manejo de las especies que son servidas a los animales. El estudio realizado por Lucena et al. (2013) destaca que el uso y manejo apropiado de la especie exótica $O$. ficus-indica puede ser una alternativa para conservar especies nativas como $P$. gounellei subsp. gounellei y $P$. pachycladus subsp. pernambucoensis.

Debido a su uso mágico-religioso, algunas especies son plantadas enfrente de las casas residenciales o jardines para evitar lo que los agricultores llaman "mal de ojo" y envidia. Los cactos citados para tal finalidad son: $C$. jamacaru subsp. jamacaru, Melocactus sp., N. coche nillifera, P. gounellei subsp. gounellei y O. ficus indica (Lucena et al., 2012a, 2012b, 2013, 2015). 


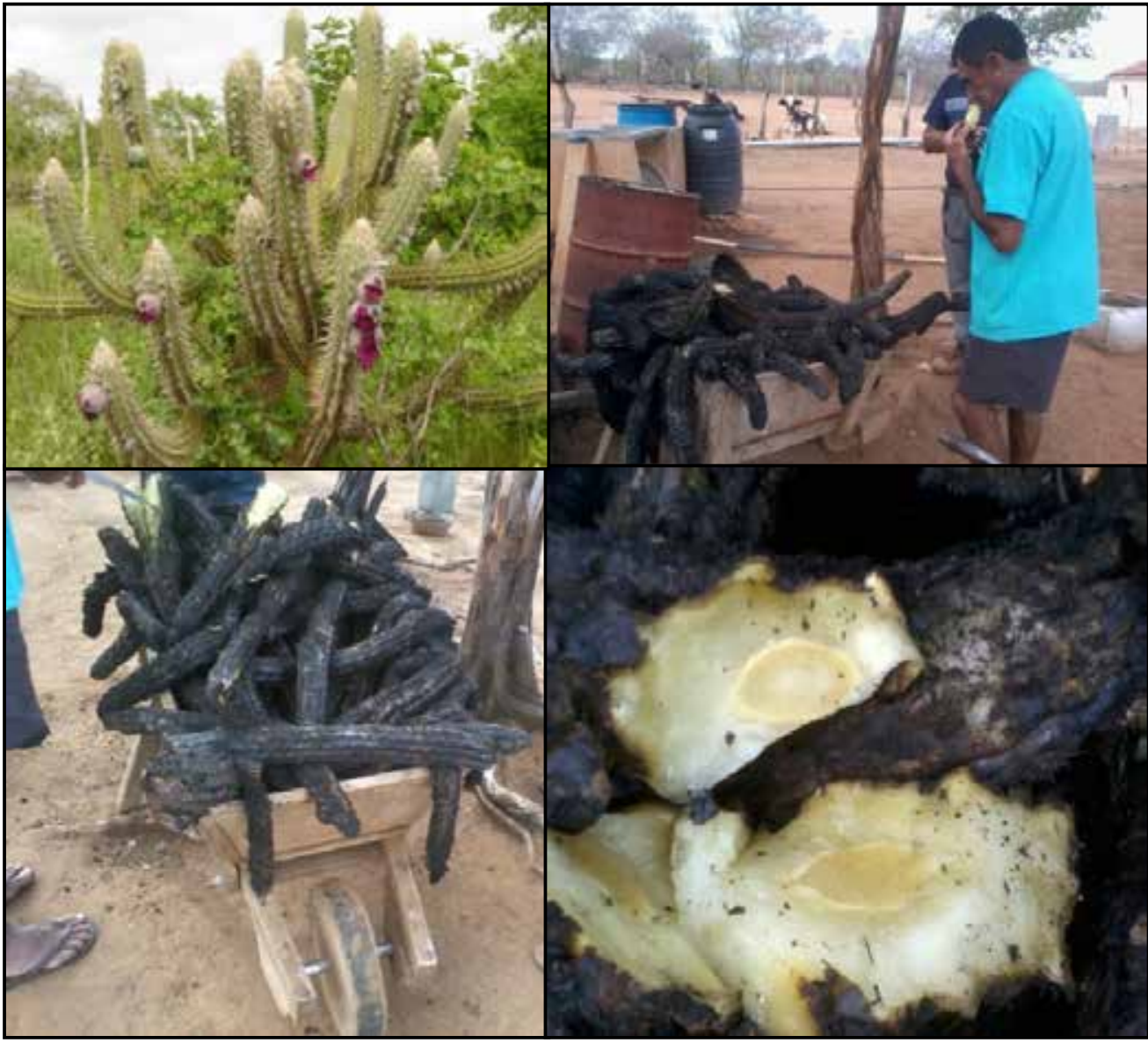

Figura 12.2. Pilosocereus gounellei (F.A.C. Weber) Byles \& G.D. Rowley subsp. gouneIlei siendo utilizado como forraje en la comunidad de Santa Rita, municipio del Congo, Paraíba, Brasil. Fotos: C. M. Lucena.

Varios estudios etnobotanicos han registrado el uso de las cactáceas para fines terapéuticos (Albuquerque, 2001; Albuquerque y Andrade, 2002; Andrade et al., 2006b, Lucena et al., 2013, 2014, 2015). En el municipio de Alagoinha, estado de Pernambuco, Albuquerque y Andrade (2002) registraron el uso de la cáscara de C. jamacaru para tratar problemas renales. Ribeiro et al (2014) relataron el uso de la misma especie en la comunidad Serrado Zabelê, en la Chapada de Araripe en el estado de Ceará, para tratar enfermedades como asma y fiebre. En Paraíba, Agra et al. (2007) registraron que el uso de pulpa de Melocactus zehntneri (Britton \& Rose) Luetzelb ingerida con miel o azúcar sirve para tratar la tos, bronquitis y debilidad física. En el semiárido baiano una de las especies más utilizadas para fines medicinales es la $O$. ficus-indica, siendo descrita para tratar once problemas de salud: calentura ("calor o inflamación del intestino"), inflamación vaginal, infección urinaria, gripa, dolor de barriga, reumatismo, resecamiento (presión de vientre), dolor de garganta, inflamación del útero, barriga hinchada y disentería (Andrade et al., 2006b).

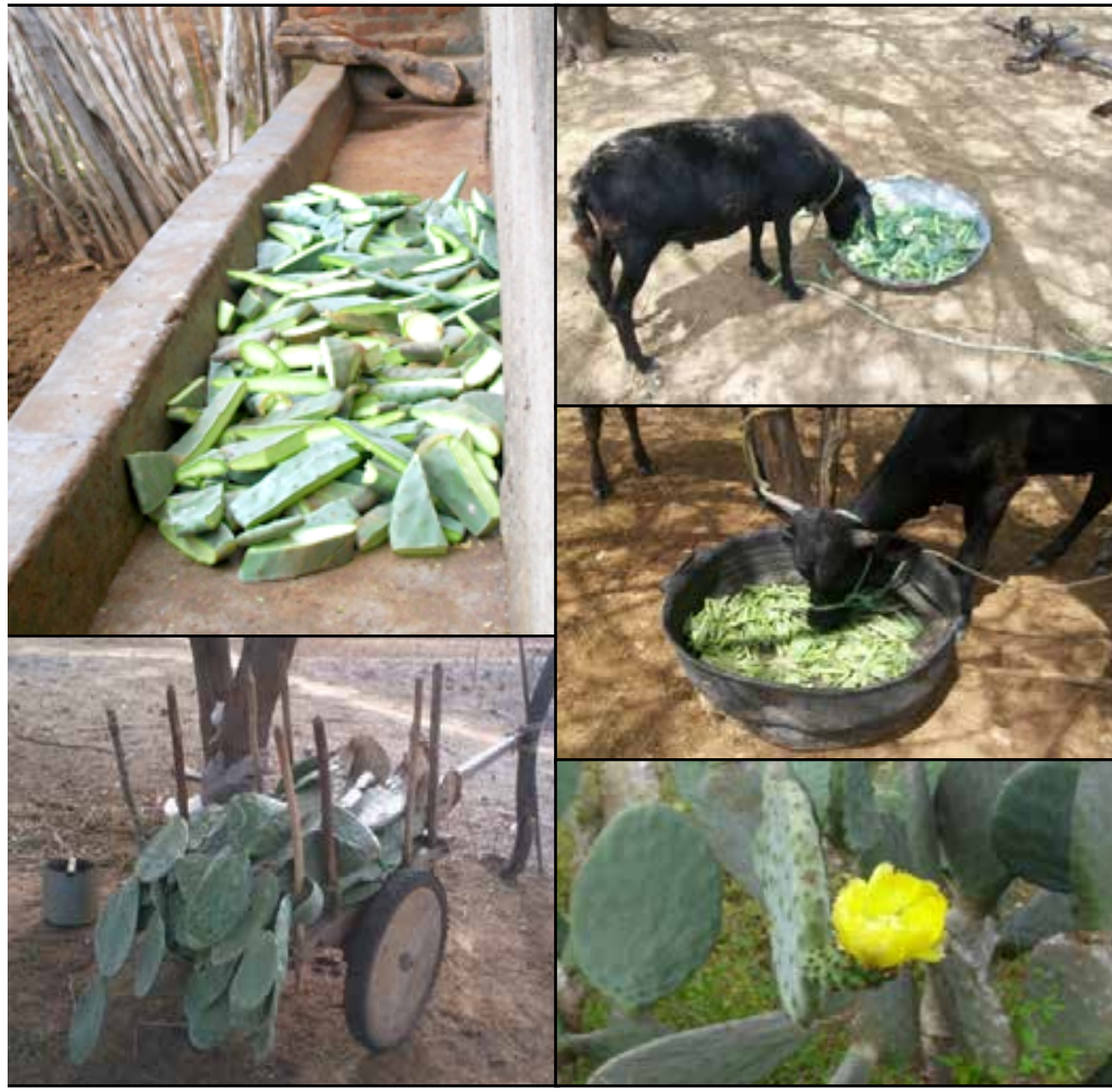

Figura 12.3. Opuntia ficus-indica (L.) Mill.; siendo utilizado como forraje en la comunidad de Santa Rita, municipio del Congo, Paraíba, Brasil. Fotos: C. M. Lucena

En el semiárido paraibano, Lucena et al. (2014), realizaron un estudio en cuatro comunidades rurales, registrando el uso de cinco cactos (C. jamacaru subsp. jamacaru, Melocactus sp., $O$ ficus-indica, $P$. gounellei subsp. gounellei e $P$. pachycladus subsp. pernambucoensis) para tratar 27 tipos de dolencias. Una de las especies más citadas fue $C$. jamacaru subsp. jamacaru, que es usada para tratar 15 enfermedades: colesterol elevado, heridas, forúnculos, gastritis, gripa, infección del tracto urinario, inflamación, problemas de la columna vertebral, problemas de la uretra, problemas en los riñones, reumatismo, secreción vaginal, sinusitis, tos y úlceras. La segunda especie más citada fue Melocactus sp., siendo utilizada para tratar 11 enfermedades: amebiasis, bronquitis, cálculos renales, catarro, coqueluche, fatiga, gripa, problemas la garganta, de los pulmones y tos. 
Para su ornamentación, las mujeres de las comunidades rurales del semiárido afirman plantar los cactos en sus solares y jardines. Dos especies muy citadas son Melocactus sp. y C. jamacaru subsp. jamacaru (Lima, 1996; Lucena et al., 2012a, 2012b, 2013, 2015); sin embargo otras especies también apreciadas por los hombres y mujeres de las familias reales son $P$. gounellei subsp. gounellei (Lucena et al., 2012a, 2012b) y P. pachycladus subsp. pernambucoensis (Lima, 1996; Lucena et al., 2013, 2015).

En la categoría veterinaria, Lucena et al. $(2013,2015)$ registraron en Paraba el uso de la pulpa de la especie $P$. gounellei subsp. gounellei para desatragantar animales (principalmente caprinos). Lucena et al. (2012a) registraron el uso de dos especies para tratar enfermedades de los animales, siendo una de ellas Melocactus sp., cuya pulpa del cladodio se sumerge en e agua que beben las gallinas que padecen gripa ("gogo"). La otra especie es $P$. gounellei subsp. gounellei, la cual se usa para tratar inflamaciones, siendo utilizada para ello la pulpa aplicada tópicamente. En el desierto baiano, Andrade et al. (2006a) registraron el uso de las espinas de C. jamacaru para coser las heridas de parto de las vacas.

\section{Conocimiento botánico local sobre usos madereros de cactáceas}

Al considerar las categorías de usos madereros, el uso como combustible es limitado entre las cactáceas, pues son pocas las especies arbóreas en la región semiárida paraibana. Aun así, Lucena et al. $(2013,2015)$ registraron el uso de madera de dos especies de cacto columnar $(C$. jamacaru subsp. jamacaru y P. pachycladus subsp. subsp. pernambucoensis) como leña y en los fogones domésticos de las comunidades rurales de San Francisco y Santa Rita.

Tanto en las categorías de construcción rural como en las domésticas, los cactos son utilizados por las poblaciones rurales de las zonas semiáridas de Brasil (Andrade et al., 2006a; Lucena et al., 2013, 2015). Andrade et al. (2006a) registraron que en la zona semiárida baiana la médula leñosa de $C$. jamacaru y de Pilosocereus catingicola (Guerke) Byles \& Rowley es transformada en tejados, puertas y ventanas para las residencias. Un uso interesante, y al mismo tiempo positivo, registrado en esa región es el de la preparación de pintura para las casas con el mucílago de $O$. ficus indica mezclada con cal. Según los moradores, el mucílago de $O$. ficus indica, además de ayudar a la fijación de la cal, también contribuye a prevenir insectos como Triatoma sp. (chinche o barbeiro) que causan problemas de salud (mal de Chagas) en el municipio (Andrade et al. 2006a). En relación con el uso en las construcciones rurales, es común en las zonas semiáridas brasileñas el uso de individuos completos de C. jamacaru subsp. jamacaru y P. gounellei subsp. gounellei para la confección de cercas vivas (Lucena et al., 2012a, 2012b, 2013, 2015).

A partir de los estudios etnobotánicos registrados en la región del nordeste de Brasil, es posible observar la importancia social, económica y cultural que poseen las varias especies de Cactaceae para las poblaciones tradicionales de la región. Con todo, es notable la importancia de llevar a cabo nuevos estudios etnobotánicos que investiguen de forma más minuciosa la relación entre seres humanos y cactáceas, y de esta manera registrar no sólo las potenciali- dades de las especies, sino también las formas actuales de interacción y manejo de los cactos nativos de la zona semiárida nordestina. Hoy en día, las investigaciones etnobotánicas y etnobiológicas en general deben ir más allá del registro de usos y poner mayor énfasis en la docume tación de las interacciones que expresan formas de manejo. Estas formas de manejo constituyen experiencias que representan ya camino andado para poner en práctica estrategias de aprovechamiento sustentable, conservación y hasta la recuperación de polaciones y comnidades deterioradas por las acciones humanas.

\section{Cereus jamacaru DC. subsp. jamacaru: Un estudio de caso}

Uno de los géneros que se encuentra en la mayoría de los dominios fitogeográficos brasileños (i.e. Caatinga, Cerrado, Campos Rupestres y Mata Atlántica) es Cereus, que está representado por 15 especies, siendo 8 de estas endémicas (Taylor y Zappi, 2004). Y de entre las especies que representan tal género, una de las de mayor importancia es Cereus jamacaru DC. subsp. jamacaru (subfamilia Cactoideae, grupo Cereoideae), un cacto columnar conocido popularmente como cardeiro, jamacaru, mandacaru, mandacaru-de-boi, mandacaru-facheiro, jamaracurú jumucurú, mandacaru-de-faixo, jumarucú, cumbeba y urumbeba (Zappi y Aona, 2014). Dicha especie está presente en todo el nordeste brasileño, en los estados de Alagoas, Bahía, Ceará Sergipe, Minas Gerais, Paraíba, Pernambuco, Piauí y Rio Grande do Norte (Hunt et al., 2006 Silva y Alves, 2009; Zappi y Aona, 2014). Son cactos de porte arbustivo o arbóreo y se desarrollan en suelos rasos, encima de rocas y suelos pedregosos (Lima, 1996; Rocha y Agra, 2002).

Cavalcanti y Resende (2007) verificaron que las plantas adultas (reproductivas) de esa especie presentan alturas que varían entre 3.75 y $6.54 \mathrm{~m}$. A partir del tronco principal se presentan brotes laterales, el tallo presenta espinas rígidas y en su interior almacena grandes cantidades de agua. Según Rocha y Agra (2002), los frutos son bayas $(10-13$ x 5-9 cm) ovoides, dehiscentes, de color rosado a rojo, pulpa blanca y mucilaginosa, y las semillas son de 1.5 a $2.5 \mathrm{~mm}$ de longitud.

Las flores presentan antésis nocturna, miden de 14 a $18 \mathrm{~cm}$, son blanquecinas verdosas, solitarias, sésiles, poseen numerosos estambres, los filamentos se encuentran insertos en el perianto y presentan anteras globosas. Las flores son visitadas por murciélagos y mariposas y, generalmente, florecen de enero a agosto (Braga, 1960; Rocha y Agra, 2002). Los frutos son frecuentes entre los meses de febrero y septiembre (Rocha y Agra, 2002).

La propagación de los individuos puede ser tanto sexual, a partir de semillas, como asexua o vegetativa, a través del rebrote de plantas de ramas caídas o a partir de estacas (Correia et al., 2012).

En períodos de sequía de la región semiárida nordestina, la $C$. jamacaru subsp. jamacaru es una de las principales fuentes de alimento para los animales (Cavalcanti y Resende, 2007; Lucena et al., 2012a, 2013, 2015; Nunes et al., 2015), ya sean animales silvestres, como los pájaros (Gomes et al., 2014), o domesticados, como los caprinos (Lucena et al., 2013) y bovinos (Lucena et al., 2012a). Además, los frutos son muy apreciados como alimento humano, 
particularmente por los agricultores paraibanos (Lucena et al., 2013). En el desierto baiano, Andrade et al. (2006a) encontraron que además de ser utilizado como alimento humano (e fruto), el mandacaru se usa en la alimentación animal (los cladodios o ramas quemadas), en la ornamentación de jardines y en la construcción doméstica (puertas y ventanas).

En las mesorregiones áridas paraibanas de la denominada seridó (Lucena et al., 2012a), e desierto (Lucena et al., 2012b) y la denominada cariri (Lucena et al., 2013, 2015), el uso de $C$. jamacaru subsp. jamacaru se registró en diversas categorías: alimento humano (fruto in natura), forraje (ramas quemadas), construcción (cercas rurales y/o domésticas), medicinal (tratamiento de inflamaciones), tecnología (la madera se utiliza para fabricar cabos de herramientas) ornamental, sombra y veterinario (se preparan cubetadas de pulpa para atender problemas digestivos de los animales).

A pesar de que se ha registrado el consumo de los frutos in natura en varias comunidades rurales del nordeste de Brasil, muchas personas entrevistadas dijeron no consumirlo frecuentemente, debido a prejuicios o creencias. Algunas personas, por ejemplo, afirman que la pulpa del fruto se parece a los huevos de los sapos o la llamada "espuma de sapo", por su textura y coloración y, además, algunas personas entrevistadas también afirman que su consumo puede ser un riesgo para la salud debido al mito de que cuando se ingiere, las semillas pueden causar apendicitis (Cruz et al., 2013)

Em varios estados del nordeste, la especie es referida para usos medicinales, como por ejemplo, su uso para tratar dolencias renales en el estado de Pernambuco (Albuquerque Andrade, 2002), para tratar padecimientos respiratorios en el estado de Paraíba (Agra, 1996; Albuquerque, 2001; Lucena et al, 2012b, 2015), para tratar inflamaciones en genitales, sífilis y hemorroides en el estado de Bahía (Andrade et al., 2006b), para tratar colesterol alto en los estados de Ceará, Piauí y Paraíba (Lucena et al., 2012b), para tratar úlceras de estómago (Agra et al., 2007; Lucena et al., 2012b) y problemas de exceso de flujo menstrual (Lucena et al., 2015) en el estado de Paraíba. Lucena et al. (2014) realizaron un estudio en cuatro comunidades de la región semiárida nordestina, habiendo registrado que $C$. jamacaru subsp. jamacaru fue una de las especies más citadas en la categoría medicinal para tratar 16 problemas de salud: problemas de la columna vertebral, secreción vaginal, tos, colesterol, heridas, gastritis, forúnculos, infección del tracto urinario, gripa, inflamación, reumatismo, sinusitis, problemas en los riñones, problemas en la uretra y úlceras.

Además de las varias categorías en que $C$. jamacaru subsp. jamacaru se encuadra, en el Seridó paraibano, la especie también es utilizada como bioindicador de fenómenos naturales: en este caso, la floración indica una buena estación lluviosa (Lucena et al., 2012a).

Un estudio realizado en la comunidad rural del municipio de Congo, en Paraíba, registró una mayor frecuencia de individuos de C. jamacaru subsp. jamacaru en áreas antropizadas (por ejemplo, los jardines de residencias, solares, huertas y áreas de cultivo) lo que, consecuentemente, puede estar ocurriendo debido al manejo ex situ de la especie que es cultivada en las proximidades de las residencias para ser utilizada como alimento, forraje y planta ornamenta (Lucena et al., 2015). Dicha prática de manejo ex situ se conoce como plantación, la cual se propaga artificialmente a partir de estructuras reproductivas vegetativas o sexuales que son removidas de individuos de poblaciones silvestres, de manera similar al manejo registrado para Stenocereus stellatus y S. pruinosus en el Valle de Tehacán en México por Casas et al. (1997; Parra et al., 2010)

En una comunidad rural del nordeste de Brasil, en el estado de Pernambuco, más del 50\% de los entrevistados en un estudio afirmó eliminar el mandacaru de las áreas de cultivo, argumentando que los individuos no ofrecen tantos benefícios, que ocupan espacio y presentan espinas, las cuales son consideradas como características negativas (Cruz et al., 2013).

Vale la pena resaltar que a pesar de los varios potenciales de uso que tiene el mandacaru, son aún escasos los estudios sobre manejo y domesticación de la especie. Con base en tal información sería posible apreciar que $C$. jamacaru subsp. jamacaru es una cactácea columna nativa interesante para estudiar el proceso de domesticación, así como los aspectos culturales y económicos que involucran la selección artificial.

Sabemos que el mandacaru es una especie con varios usos, apreciada por las popblaciones tradicionales de las zonas semiáridas nordestinas. Sabemos que se cultiva y que esos individuos cultivados pueden producir frutos de mayor tamaño que los silvestres. Suponemos que el cultivo ha involucrado selección artificial por frutos de mayor tamaño y ramas y tallos más vigorosos. Es posible, entonces, que el manejo diferencial de fenotipos en áreas antropizadas determine diferencias morfológicas comparadas con las poblaciones silvestres. Podemos suponer que tal diferenciación se debe, en parte, al manejo selectivo, aunque es posible que las diferencias en los patrones reproductivos favorezcan la diferenciación, como se ha documentado en otras especies de cactáceas. También hipotetizamos que la selección artificial, por una mayor abundancia de fenotipos deseables en áreas antropizadas, determina cambios en la diversidad y estructura genética de las poblaciones. El propósito de este estudio de caso es, entonces, probar tales hipótesis: a) los diferentes usos y formas de manejo de mandacaru promueven procesos de domesticación, siendo posible registrar diferencias morfológicas y genéticas entre las poblaciones silvestres y cultivadas; b) los individuos de mandacaru que presentan cladodios con mayor diámetro, frutos de mayor tamaño y con colores atractivos serán más frecuentes en poblaciones manejadas, y c) el manejo de individuos de mandacaru afecta la fenología de la especie debido a selección artificial que generalmente favorece los sistemas reproductivos para una mayor productividad durante períodos más prolongados.

\section{Consideraciones finales}

Como se expuso en el presente capítulo, en Brasil existe una gran diversidad de cactáceas, pero al mismo tiempo pocos estudios etnobotánicos que permitan analizar la relación entre las poblaciones humanas y los cactos, principalmente en las regiones semiáridas, las cuales sufren mayor presión ambiental debido a cambios de alta incertidumbre en las estacionalidades diversas aciones antrópicas. Se observó que ya existen registros puntuales que presentan la condición de especies amenazadas de extinción para determinadas cactáceas.

Estudios etnobotánicos ya han evaluado la diversidad de usos no maderables y madereros para las cactáceas, así como la importancia cultural y económica de esas especies para las 
poblaciones rurales. Con todo, se hacen necesarias investigaciones sobre los procesos de manejo y posible domesticación de cactos de Brasil. En particular, se presentó aquí la importancia de estudiar el caso del mandacarú, pero quizá existae diversos casos que requieren atención debido a su importancia cultural y económica, y que han involucrado acciones deliberadas de manejo por los pobladores de las regiones semiáridas del Brasil.

\section{Agradecimento}

Agradecemos a la "Coordenação de Aperfeiçoamento de Pessoal de Nível Superior" (Capes) del Gobierno Federal de Brasil por conceder una beca de doctorado a una de las autoras, Camilla Márques de Lucena, así como una de posdoctorado a otro autor, Reinaldo de Lucena. Al Programa de Pós Graduação em Rede em Desenvolvimento e Meio Ambiente (Prodema UFPB), así como al Instituto de Investigaciones en Ecosistemas y Sustentabilidad (IIES) de la Universidad Nacional Autónoma de México (UNAM), por su apoyo durante las estancias doctoral y posdoctoral referidas.

\section{Bibliografía}

Agra, M. F., 1996. Plantas da medicina popular dos Cariris Araújo, T. A. S., N. L. Alencar, E. L. C. Amorim y U. P. Prasil. Editora União, João Pessoa.

Agra, M. F., G. S. Baracho, I. J. D. Basílio, K. Nurit, V. P. Coelho y D. A. Barbosa, 2007. Sinopse da flora medicinal do

Albuquerque, U. P., 2001. The use of medicinal plants by the cultural descendants of african people in Brazil. Acta

Albuquerque, U. P. y L. H. C. Andrade, 2002. Uso de recursos de Pernambuco (Nordeste do Brasil). Interciencia, 27: 336-346.

Albuquerque, U. P., R. F. P. Lucena y N. L. Alencar, 2010 Métodos e técnicas para a coleta de dad, 2010. Albuquerque, U. P., R. F. P. Lucena e L. V. F. C. Cunha. (Eds). Métodos e técnicas na pesquisa etnobotânica. Recife: Editora NUPEEA, p. 40-64.

Andrade-Lima, D., 1989. Plantas das caatingas. Rio de Janeiro: Academia Brasileira de Ciências.

Andrade, C. T. S., J. G. W. Marques y D. C. Zappi, 2006 Utilização de cactáceas por sertanejos baianos. Tipos conexivos

Andrade, C. T. S., J. G. W. Marques y D. C. Zappi, $2006 \mathrm{~b}$ Utilização medicinal de cactáceas por sertanejos baianos. Revista Brasileira de Plantas Medicinais, 8(3): 36-42. Albuquerque, 2008. A new approach to study medicin knowledge. Journal of Ethnopharmacology, 120: 72-80. Braga, R. 1960. Plantas do Nordeste, especialmente do Ga, R., 1960. Plantas do Nordeste
Ceará. 2. ed. Fortaleza: ESAM.

Casas, A. y J. Caballero, 1996. Traditional managemen and morphological variation in Leucaena esculenta Guerrero, Mexico. Economic Botany, 50(2): 167-181. substratos no desenvolvimento de mandacaru (Cereus RITTER), xiquexique (Pilosocereus gounelli (A, WEBWR (Melocactus bahiensis BRITTON \& ROSE). Revist Caatinga, 20(1): 28-35

Correia, D., I. C. Silva, E. H. S. Nascimento y J. P. S. Morais, 2012. Produção de mudas de Mandacaru. Circul Cruz, M. P., N. Peroni y U.P. Albuquerque, 2013. Knowledge, seasonal dry forest (NE, Brazil).
and Ethnomedicine, 9(79): 1-20.

Gomes, V. G. N., Z. G. M., Quirino y H. F. P. Araujo, 2014 Frugivory and seed dispersal by birds in Cereus jamacar
Cavalcanti, N. B. y G. M. Resende, 2007. Efeito de diferentes jamacaru P. DC.), facheiro (Pilosocereus pachycladus EX K. SCHUM.) BLY. EX ROWL.) e coroa-de-frade Téchica. Embrapa Agroindústila Tropical, Fortaleza. use and management of native wild edible plants from a
$32-40$

Hunt, D. R., N. P., Taylor y G. Charles, 2006. The New Cactus n. Milbourne Port: DH Books.

Lima, J. L., 1996. Plantas forrageiras das caatingas: usos e potencialidades. Petrolina: EMBRAPA.

Jardim Botânico do Rio de Janeiro. Lista de Espécies da Flora do Brasil. Disponible en: <http://florado
gov.br/>. Visitado el 21 de octubre de 2015 .

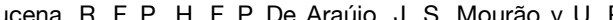
Albuquerque. 2005. A flor chegou, chuva avisou meteorologia popular no semiárido paraibano. En: Alves, Â. C. G., R. F. P. Lucena y U. P. Albuquerque (Orgs.).
Atualidades em Etnobiologia e Etnoecologia. Vol. 2. Atualidades em Etnobiologia e Etnoecor
Editora NUPEEA, Recife: pp. 171-182.

Lucena, C. M., G. G. S. Costa, T. K. N. Carvalho, N. M Guerra, Z. G. M. Quirino y R. F. P. Lucena, 2012a. Uso conhecimento de cactáceas no municipio de Så Biologia e Farmácia (Biofar): 121-134.

Lucena, C. M., G. M. Costa, R. F. Sousa, T. K. N. Carvalho N. A. Marreiros, C. A. B. Alves, D. D. Pereira y R. F. P. Lucena, 2012b. Conhecimento local sobre cactáceas em comunidades rurais na mesorregião do sertão da

Lucena, R. F. P., T. C. Soares, C. F. A. Vasconcelos Neto, T. K. N. Carvalho, C. M. Lucena y R. R. N. Alves, 2012c. Uso de recursos vegetais da Caatinga em uma comunidad rural do curimataú paraibano (Nordeste do Brasil). Polibotánica, 34: 217-238.

Lucena, C. M., R. F. P. Lucena, G. M. Costa, T. K. N. Carvalho, G. G. S. Costa, R. R. N. Alves, D. D. Pereira, J. E. S. Ribeiro, C. A. B. Alves, Z. G. M. Quirino y E. N. Nunes, 2013. Use and knowledge of Cactaceae in Northeaster, 9(62): $1-11$.

Lucena, C. M., T. K. N. Carvalho, E. A. Marín, E. N, Nunes, R. S. Oliveira, J. G. Melo, A. Casas y R. F. P. Lucena, 2014 Potencial medicinal de cactáceas en la región semiárid del Nordeste de Brasil. Gaia Sci
Populações Tradicionais: $36-50$

Lucena, C. M., T. K. N. Carvalho, J. E. S. Ribeiro, Z. G. M. Quirino, A. Casas y R. F. P. Lucena, 2015. Conhecimento botânico tradicional sobre cactáceas no semiárido $d$ Brasil. Gaia Scientia, 9(2): 77-90.

Meiado, M. V., 2015. Seed germination of Melocactus sergipensis N.P. Taylor y M.V. Meiado, the newest Brazilan cactus destined for extinction. Plant Biology, 30 .

Meiado, M. V., L. Y. S. Aona, J. P. B. Nascimento, A. T. Lima y D. C. Zappi, 2015a. Cactaceae. Pp. 115-142. In: A. P. N. Prata, M. C. V. Farias e M. F. Landim (Org.). Flora de
Melado, M. V., M. C. Machado, D. C. Zappi, N. P. Taylor $y$ J. A. Siqueira Filho, 2015b. Ecological attributes, São Francisco Watershed. Gaia Scientia, 9(2): 40-53.

ascimento, V. T., 2010. Estudo comparativo de plantas alimentícias em comunidades rurais da caating pernambucana e paraibana: etnobotânica, potencial perico en Blotecnología. (Programa de Pós graduados en

nes, A.T., R.F.P. Lucena, M.V. Santos y U.P. Albuquerque 2015. Local knowledge about fodder plants in the Ethnobiology and Ethnomedicine, 11 (12): 1-12.

Ribeiro, D. A., L. G. S. Oliveira, D. G. Macêdo, I. R. A. Menezes, J. G. M. Costa, M. A. P. Silva, S. R. Lacerda y M. M. A. Souza, 2014. Promising medicinal plants for bioprospection in a Cerrado area of Chapada do Araripe, Northeastern Brazil. Journal of Ethnopharmacology, 155(3): 1522-1533.

Rocha, E. A. y M. F. Agra. 2002. Flora do Pico do Jabre, Bras Cacteceae Juss. Acta Botanica Brasileira, 16:15-2

Silva, L. R. y R. E. Alves, 2009. Caracterização físico-química de frutos de "mandacaru". Revista Acadêmica: Ciências Agrarias e Ambientais, (2): 199-205.

Taylor, N.P., M. V. Meiado, E. S. Bravo Filho y D. C. Zappi. 2014. A new Melocactus from the Brazllian stat

aylor, N. y D. Zappi, 2004. Cacti of Eastern Brasil. Roya Botanical Gardens, Kew. 511p.

appi, D. C., N. P. Taylor y J. Larocca, 2011a. A riqueza das Cactaceae no Brasil. Pp. 17-29. En: Ribeiro-Silva, S., D. C., Zappi, N. P. Taylor y M. C. Machado (Orgs.). Plano de Açao Nacional para a Conservaçáo das Cactáceas. Mendes de Conservação da Biodiversidade.

Mppi, D. C., N. P. Taylor y M. R. Santos, 2011b. Conservação das Cactaceae do Brasil. Pp. 29-30. In: Ribeiro-Silva, S.,
D. C. Zappi, N. P. Taylor e M. C. Machado (Orgs.). Plano de Ação Nacional para a Conservação das Cactáceas. Mendes de Conservação da Biodiversidade.

appi, D. y L. Aona, 2014. Cactaceae in Flora brasiliens de 2014.

appi, D. C., N. P. Taylor, M. R. Santos y J. Larocca. 2015. Cactaceae. En: Lista de Especies da Flora do Brasil. Rio de Janeiro: Jardim Botânico do Rio de Janeiro. Disponivel em: <hltp://Horadobrasil.jbrj.gov.br/jabo/ 


\section{El manejo de plantas silvestres alimenticias en escenarios de deforestación, ilustrado por una comunidad mestiza de la Amazonía Peruana}

Gisella S. Cruz-García y Lore Vael

\section{Resumen:}

Las plantas silvestres alimenticias son un componente esencial de la dieta de la población rura en distintas partes del mundo, teniendo un rol importante en su seguridad alimentaria y diversidad nutricional. Dada la alarmante disminución de los bosques, la colecta de estas especies ocurre cada vez más en ecosistemas antropogénicos, donde las comunidades activamente las manejan para asegurar su disponibilidad y acceso. Este es ciertamente el caso de Ucayali, que es una de las regiones de la Amazonía Peruana con mayores tasas de deforestación, donde las poblaciones locales están en una constante adaptación frente a la pérdida de biodiversidad. Esta presentación analiza los resultados de un estudio realizado en una comunidad mestiza de Ucayali, cuya área boscosa ha disminuido considerablemente en las últimas décadas. Se desarrollaron grupos focales para documentar las características principales, colecta y formas de manejo de las plantas silvestres alimenticias, así como los roles de género asociados. De un total de treinta especies documentadas, el $70 \%$ se colecta de la chacra (campo agrícola), e $57 \%$ del monte (bosque) y el $43 \%$ de la huerta. Contrario a lo documentado por otros estudios, más del $40 \%$ de las plantas son colectadas exclusivamente por hombres. De un total de veinte especies manejadas, $90 \%$ han sido trasplantadas ex situ, $35 \%$ son desmalezadas, $20 \%$ fertilizadas, mientras que tres especies son regadas, otras tres son podadas y una es protegida. La división de las prácticas de manejo refleja la división de género de los espacios productivos del hogar. El estudio concluye que los procesos de manejo y domesticación de recursos genéticos son muy importantes para la seguridad alimentaria de familias rurales y conservación de recursos clave frente a escenarios de deforestación y pérdida de biodiversidad.

Palabras clave: Amazonía, domesticación incipiente, manejo de plantas, plantas comestibles, proceso de domesticación, seguridad alimentaria 


\section{Introducción}

Los seres humanos han sido cazadores y recolectores por aproximadamente $350000 \mathrm{ge}$ neraciones, agricultores por 600 generaciones, y la agricultura industrializada ha existido por solo dos generaciones (Pretty, 2003). En la actualidad, la colecta y consumo de plantas silvestres alimenticias de ecosistemas agrícolas y no agrícolas han sido documentados en múltiples contextos culturales, ilustrando su uso e importancia para la seguridad alimentaria y diversidad nutricional de familias rurales en todo el mundo (Bharucha y Pretty, 2010; Cruz-Garcia y Ertug, 2014; Scoones, Melnyk y Pretty, 1992). Las familias rurales colectan plantas silvestres alimenticias en ambientes desde los inmensamente intervenidos como los campos agrícolas, pasando por sistemas mayormente de subsistencia como las huertas, hasta en áreas menos intervenidas como bosques primarios y secundarios. Sin embargo, las familias colectan tales especies cada vez más en ambientes antropogénicos en vez de hacerlo en ecosistemas prístinos, debido a la alarmante disminución de los bosques (Ogle y Grivetti, 1985; Price, 1997). Este es ciertamente el caso de Ucayali, que es una de las regiones de la Amazonía Peruana con mayores tasas de deforestación (Oliveira,et al., 2007) donde las poblaciones locales están en una constante adaptación frente a la pérdida de biodiversidad. Bajo este contexto, el manejo de las plantas alimenticias silvestres constituye una práctica esencial para asegurar la disponibilidad y acceso a aquellas especies que son parte de la dieta local, además de ser libres de costo monetario para las familias.

El objetivo de este capítulo es ilustrar los procesos de manejo de recursos fitogenéticos en la interfase bosque-agricultura frente a escenarios de fuerte presión de deforestación, como es el caso en Ucayali. En este capítulo se documentan las características, formas de colecta y manejo de plantas silvestres alimenticias en una comunidad mestiza, cuya área boscosa ha disminuido considerablemente en las últimas décadas. Es una investigación etnobotánica que incorporó una perspectiva de género, ya que las relaciones hombres-mujeres gobiernan el conocimiento, uso, acceso y manejo de los recursos naturales (Howard, 2003; Rocheleau y Edmunds, 1997; Sunderland, Achdiawan, Angelsen et al., 2014). De esta manera, se documentaron los roles de género en la colecta y en el manejo de las plantas estudiadas. Para empezar, el capítulo presenta una explicación de las generalidades e importancia de las plantas silvestres alimenticias, continuando con una descripción de las características principales del sitio de estudio en relación con los procesos actuales de deforestación. Luego, el capítulo detalla cómo la investigación de manejo de plantas silvestres alimenticias fue llevada a cabo, y presenta los resultados correspondientes a las características principales, colecta y manejo de estas plantas desde un enfoque de género. Finalmente, se presenta en este capítulo una reflexión sobre el rol de los procesos de manejo de recursos fitogenéticos en contextos de deforestación y pérdida de biodiversidad. Se pone énfasis en las implicaciones de los recursos y su manejo en la seguridad alimentaria de los hogares rurales.

\section{Generalidades e importancia} de las plantas silvestres alimenticias

Las plantas silvestres y domesticadas han sido dicotomizadas en el pasado. Esta dicotomía fue desafiada en 1868 por Darwin, quien propuso en su libro La variación de los animales y las plantas bajo domesticación (1868) que la domesticación es un proceso dinámico. No obstante esta importante construcción teórica, así como las relevantes contribuciones teóricas de De Candolle y Vavilov para explicar el cuándo y dónde del origen de las plantas cultivadas, los científicos no mostraron tanto interés en el cómo y el porqué de los procesos de domesticación hasta la década de los sesenta con el advenimiento de la teoría de sistemas y otros conceptos clave de la ecología. Fue entonces cuando científicos como Flannery, Binford, Harris, Jarman y Higgs empezaron a desarrollar modelos gradualísticos explicando la transición de la caza y la recolección hacia la agricultura (Harris, 1989, 1996). Esto trajo consigo una gran transformación en el estudio de la agricultura, echando por tierra, o al menos cuestionando seriamente, la distinción dicotómica entre las formas de vida de cazadores-recolectores y agricultores. Igualmente, estudios etnobotánicos han demostrado que las sociedades de cazadores-recolectores pueden desarrollar actividades agrícolas, y que los agricultores también cazan y recolectan en la actualidad (Adaya, Bdliya, Bitrus et al., 1997; Harlan, 1975; Ogle y Grivetti, 1985) Indudablemente, la recolección de plantas silvestres alimenticias por sociedades agrícolas constituye un componente muy variable, pero aún importante de su subsistencia (Bharucha y Pretty, 2010; Heywood, 1999; Scoones, Melnyk y Pretty, 1992).

La palabra "silvestre" no implica la ausencia de manejo, entendiendo por "manejo" el conjunto de acciones o prácticas directamente o indirectamente desarrolladas por los humanos para favorecer la disponibilidad de poblaciones o fenotipos individuales dentro de las poblaciones de especies útiles (González-Insuasti y Caballero, 2007). Ciertamente, las plantas silvestres pueden ser manejadas a distintos niveles por comunidades rurales (Cotton, 1996). Las interacciones de los humanos con las plantas silvestres, semidomesticadas y domesticadas están claramente contextualizadas en gradientes, como el propuesto por Harris (1989) para explicar el surgimiento de sistemas agrícolas, y como el propuesto por Wiersum (1997b) para analizar los sistemas forestales. En este gradiente se llevan a cabo actividades de explotación de plantas, con efectos ecológicos de acuerdo con la intensidad de tales actividades, la naturaleza de los sistemas alimentarios, las características socioeconómicas del contexto en el que ocurren, y su relación con la energía invertida por unidad de área manejada. Este gradiente de condiciones de manejo nos ayuda a conceptualizar las interacciones entre los humanos y las plantas, teniendo en cuenta que el manejo cambia en el tiempo y en el espacio, en un gradiente que puede ser bidireccional y no determinante. Además, en este modelo los niveles de interacción con las plantas no son pasos preestablecidos que siguen un orden en determinada dirección, lo que implica que no se tiene que pasar necesariamente de un nivel de interacción al siguiente. De esta manera, algunas plantas silvestres cultivadas están moviéndose hacia la domesticación, mientras que otras que fueron intensamente manejadas en el pasado son solo toleradas o ligeramente protegidas en el presente (Harris, 1989), considerando que para la mayoría de especies nunca ocurre la transición de planta cultivada a planta domesticada (Harlan, 1975). 
Una especie puede tener simultáneamente distintas formas e intensidades de manejo en distintos lugares y, al mismo tiempo, no ser manejada en otros (González-Insuasti y Caballero, 2007; Ogle, 2001). Las personas locales y los científicos pueden usar distintas clasificaciones de qué es silvestre o domesticado. Por ejemplo, una especie puede ser considerada silvestre por un grupo sociocultural, pero clasificada como domesticada por otro grupo sociocultural, inclusive por algunos científicos, lo que tiene repercusiones en las conclusiones de una investigación (Michon y De Foresta, 1997; Orwa et al., 2009). Por ello, la domesticación es un concepto y proceso localmente diferenciado (Cruz-Garcia y Price, 2014b). Ya que este estudio fue realizado desde una perspectiva etnobotánica, el inventario de plantas silvestres alimenticias fue construido por aquellas especies que son clasificadas como "silvestres" por la población local. De esta manera, el estudio incluye especies que no son consideradas localmente como domesticadas, en un gradiente que parte de un estado de plantas exclusivamente silvestres (lo que denota ausencia de manejo), a silvestres promovidas o protegidas, cultivadas y semidomesticadas localmente.

Las plantas se pueden agrupar en tres categorías principales de acuerdo con el grado de manejo: (1a) especies recolectadas, (1b) especies con manejo incipiente y (1c) especies cultivadas. Además, hay un gradiente dentro del manejo incipiente que incluye: (2a) tolerancia, (2b) protección, (2c) promoción y (2d) cultivo ex situ (Casas et al. . 1997). La colecta de plantas también puede ser considerada como una forma de manejo incipiente al planear las estrategias de recolección, cambiar o rotar las zonas de recolección para amortiguar el impacto y restringir las actividades y técnicas de recolección mediante acuerdos comuntarios (Casas et al., 1997; González-Insuasti y Caballero, 2007). Por otro lado, para poder entender mejor los procesos de manejo y domesticación, es necesario reconocer los aspectos socioculturales relacionados con el uso y valoración de cada especie en particular (Casas et al., 1996). Ciertamente, los valores atribuidos por las personas a las especies de plantas van a afectar sus incentivos para manejarlas (Guijt, 1998) y para continuar usándolas (Ogle, 2001). Adicionalmente, para tener una visión integral del manejo de recursos fitogenéticos es necesario efectuar el análisis desde una perspectiva de género, ya que los hombres y las mujeres pueden tener diferentes conocimientos sobre las propiedades de las plantas, así como distintas estrategias para su manejo, propagación y utilización (Kiptot y Franzel, 2012).

Cada vez hay más evidencia de que las plantas silvestres alimenticias constituyen un componente esencial de la canasta global de alimentos (Bharucha y Pretty, 2010), ofreciendo una gran contribución a la seguridad y soberanía alimentaria, así como a la diversidad nutricional de cientos de millones de personas en el mundo (Heywood, 1999). Por ejemplo, el uso y maneo de estas plantas han sido documentados en Latinoamérica para las comunidades nahuas y mixtecas de México (Casas et al., 1996), en los Andes Bolivianos (Vandebroek y Sanca, 2007) y en Cuba (Volpato y Godinez, 2007). En África se ha documentado ampliamente la importancia de los vegetales silvestres (Chweya y Eyzaguirre, 1999), y el consumo de especies silvestres ha sido analizado para comunidades sambaa en Tanzania (Vainio-Mattila, 2000) y en el Reino de Swaziland (Ogle y Grivetti, 1985). El consumo de plantas silvestres alimenticias es también muy común en Asia, por ejemplo, se ha documentado su uso en el noreste de Tailandia (Cruz-García y Price, 2011), en Vietnam (Ogle et al., 2001) y en Nepal por los rai y sherpas (Daniggelis, 2003). Las plantas silvestres alimenticias mejoran la calidad nutricional y el contenido de mi- cronutrientes de la dieta rural (Grivetti y Ogle, 2000; Heywood, 2011), y proveen de metabolitos secundarios como aceites esenciales, alcaloides y fenoles (Heywood, 1999; Johns, 2007) además de que algunas de ellas son también fuentes importantes de leña, forraje, madera y de múltiples usos medicinales, domésticos y culturales (Cruz-Garcia y Ertug, 2014). Las plantas silvestres alimenticias constituyen un recurso clave para las familias más vulnerables y pobres del mundo (Johns y Eyzaguirre, 2006). Estas especies son, además, importantes para cubrir los requerimientos alimentarios durante los períodos de escasez, siendo parte de central de las estrategias de adaptación de las familias rurales (Daniggelis, 2003; Heywood, 1999; Scoones et al., 1992), y complementando la disponibilidad estacional de los cultivos (Adaya, Bdliya Bitrus et al., 1997).

A pesar de que cada vez existe mayor evidencia de la importancia de las plantas silvestres alimenticias para las sociedades rurales, su conservación ha recibido muy poca atención en los bancos de germoplasma, en las agencias de recursos genéticos (Heywood 2011) y en los programas de seguridad alimentaria. De la misma manera, las plantas silvestres alimenticias son considerablemente ignoradas por programas de agricultura y extensión rural (Ogle et al. 2003; Prasad-Aryal et al., 2009), así como en la planificación territorial (Cunningham, 2000). La importancia de estas plantas para la seguridad alimentaria es generalmente ignorada en la investigación de sistemas y políticas alimentarias. Aunque estos alimentos están ganando cierta atención, esta es aún muy limitada (Aphane, Chadha y Oluoch, 2003; Heywood, 1999; Scoones, Melnyk y Pretty, 1992). Dentro del ámbito científico, las plantas silvestres y semidomesticadas han sido pobremente atendidas en la investigación agrícola (Chweya y Eyzaguirre, 1999). Como consecuencia, estas plantas son equivocadamente denominadas recursos vegetales "menores" o "suplementarios", así como especies "no convencionales" o "subutilizadas" (Ogle, 2001). Peor aún, siendo numerosas de estas especies plantas arvenses, son consideradas por los estudiosos de la agronomía como "malezas" (Casas et al., 1996).

La colecta de plantas silvestres alimenticias ocurre cada vez más en ecosistemas antropogénicos, ya que, debido a las alarmantes tasas de deforestación, las familias rurales cada vez se encuentran más lejos de los bosques y otros ecosistemas poco intervenidos, por lo que prefieren colectar en áreas más cercanas al hogar (Price y Ogle, 2008). Ogle y Grivetti (1985) llamaron a este fenómeno "paradoja botánica-dietética" (botanical dietary paradox) y explicaron que los agricultores dependen cada vez más marcadamente de las "malezas" agrícolas cuando disminuye el área boscosa. De esta manera, estos autores encontraron en una investigación que llevaron a cabo en Swaziland que el área con mayor intensidad de manejo representaba también el área en donde se obtenían mayores cantidades de plantas silvestres alimenticias consumidas. De la misma manera, Kosaka et al. (2006; 2006) encontraron en un estudio realizado en la provincia de Savannakhet, en Laos, que el grado de dependencia en especies forestales alimenticias aumentaba con la cercanía al bosque, mientras que las comunidades más alejadas del bosque dependían más de las plantas silvestres y arvenses presentes en los campos de cultivo para compensar la falta de recursos forestales. De esta manera, el consumo y manejo de plantas silvestres alimenticias de sistemas antropogénicos constituye una estrategia esencial para la seguridad alimentaria de aquellas familias rurales en la frontera de deforestación (Cruz-Garcia y Price, 2014b). Ciertamente, ha sido documentado que los procesos de deforestación han promovido (indirectamente) que las familias rurales propaguen, 
protejan, trasplanten y realicen colecta selectiva de algunas especies con el fin de asegurar la disponibilidad y acceso de aquellas plantas útiles que están siendo amenazadas (Balemie y Kebebew, 2006; Daly, 2014; Price, 1997).

\section{Deforestación y pérdida de biodiversidad en la Amazonía peruana}

La Amazonía posee la mayor extensión de bosques tropicales del mundo, así como una gran biodiversidad (Foley et al., 2007; Lu, 2009; Malhi et al., 2008). Después de Brasil, Perú es e país con la mayor extensión de bosque amazónico (Lu, 2009); sin embargo, tiene un estimado de 64500 hectáreas deforestadas cada año, que están mayormente concentradas en los departamentos de Ucayali y Madre de Dios (Oliveira et al., 2007).

El presente estudio se llevó a cabo en la comunidad de Pueblo Libre, ubicada en el departamento de Ucayali. Ucayali tuvo una población estimada de 490000 habitantes en el año 2012. La mayoría de los pobladores (60\%) se encuentran asentados en la capital Pucallpa, que es la segunda capital del departamento más habitada de la Amazonía Peruana (INEI, 2011a). La deforestación y degradación de bosques en la región se atribuye mayormente a la expansión de tala legal e ilegal, al desbroce de tierras y a la expansión de carreteras (Galarza y La Serna, 2005; Miranda et al., 2014). Ucayali es el principal centro de industria maderera en el país (Ramos-Delgado, 2009), lo que se refleja en que las empresas de procesamiento maderero y agrícola contribuyen al $13 \%$ del producto interno bruto del departamento (INEI, 2011b; MINEM-GOREU, 2007). En el año 2002, la mitad del bosque de Ucayali fue declarada de producción permanente, por lo que ha sido explotada por concesiones cedidas por el entonces Instituto Nacional de Recursos Naturales (INRENA) (INEI, 2011c). Después del 2002, aumentó la proporción de madereros que hacían tala de manera ilegal al perder sus permisos debido a cambios en las regulaciones (Smith et al., 2006). El 80-95\% de la tala de árboles en el Perú es ilegal (Cossío et al., 2014; Sears y Pinedo-Vasquez, 2011). Se calcula que en el año 2010 se llegó a deforestar el 9\% del área forestal original de 8.7 millones de hectáreas en Ucayal (Porro et al., 2015).

Las principales actividades productivas de Ucayali son la agricultura, la ganadería y la producción forestal, contribuyendo en conjunto a cerca del $20 \%$ del producto bruto interno (INEI, 2011b; MINEM-GOREU, 2007). Los principales cultivos que se utilizan para elaborar productos en forma de pan para transportar largas distancias son yuca, maíz, plátano, arroz y frijol. En la última década hubo un incremento en la producción de palma aceitera, así como cacao (Salisbury y Fagan, 2013). Con respecto al clima, los promedios anuales son 1800-3000 mm de precipitación (Fujisaka et al., 2000), una temperatura de $25.7^{\circ} \mathrm{C}$ y una humedad relativa de $80 \%$ (Lojka et al., 2008). El 20\% del territorio de Ucayali está habitado por comunidades indígenas, mientras que la población mestiza, que está principalmente constituida por migrantes de la serranía del país, mayormente vive cerca de la carretera Federico Basadre o cerca de los bancos del río Ucayali y sus tributarios (Porro et al., 2015). La carretera, que conecta la ciudad de Pucallpa con Lima (860 Km), fue construida en 1945 (Pimentel et al., 2004).
Pueblo Libre es una comunidad mestiza ubicada a la altura del km 60 de la carretera Federico Basadre, siguiendo $22 \mathrm{~km}$ por un desvío afirmado, a $174 \mathrm{msnm}$ (Figuras 13.1 y 13.2). Fue oficialmente fundada en el año 1994 por los habitantes que ya llevaban mucho tiempo asentados en ese lugar. La comunidad de Pueblo Libre está habitada por pobladores cuyas familias migraron de la serranía, costa u otras partes de la Amazonía. Tiene una población aproximada de 75 familias, con un total de más de 350 personas. La mayoría de las viviendas cuenta con electricidad y agua potable, también hay señal telefónica y un telecentro donde los pobladores tienen acceso a internet (construido en 2013 por un proyecto financiado por USAID). La principal fuente de ingreso de los pobladores proviene de plantaciones de palma aceitera, cacao y plátano, y, en menor grado, de la ganadería. No hay terrenos de tenencia comunal en Pueblo Libre, y el bosque, que es de propiedad privada, se encuentra fragmentado en los distintos terrenos de los hogares. La mayoría del bosque es secundario (Vael, 2015).

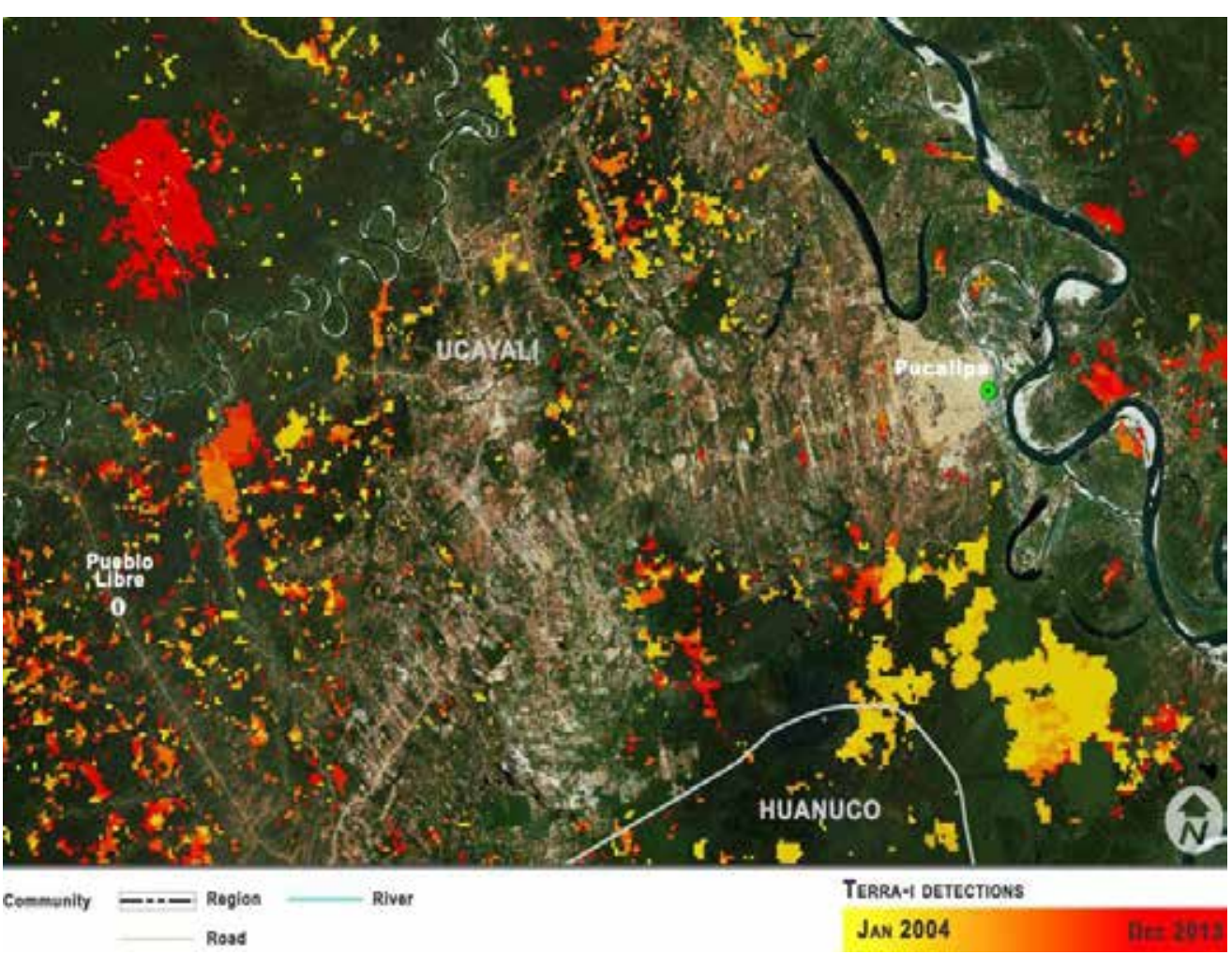

Figura 13.1. Ubicación de la comunidad mestiza de Pueblo Libre, en el departamento de Ucayali, Amazonía Peruana. El mapa indica en un gradiente de color el cambio de uso de suelos ocurridos desde enero del 2004 hasta diciembre del 2013, de acuerdo a las detecciones del programa Terra-i (CIAT, 2015). Asimismo, se puede observar la carretera Federico Basadre, terminando en la ciudad de Pucallpa, y la deforestación ocurrida alrededor de la carretera y caminos aledaños antes del 2004. Fuente: Terra-i; mapa elaborado por: Paula Paz. 


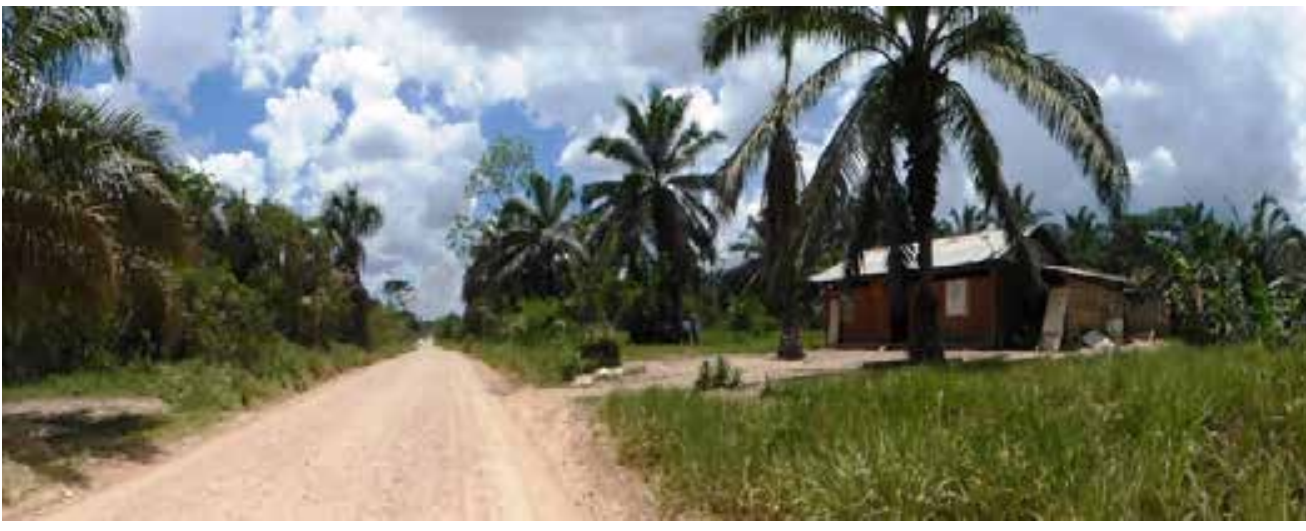

Figura 13.2. Fotografía de la comunidad mestiza de Pueblo Libre, Ucayali, Perú. Foto G.S. Cruz-García.

\section{El estudio de los procesos de manejo a través de las plantas silvestres alimenticias}

Para entender los procesos de manejo de recursos fitogenéticos en la frontera de deforestación de la Amazonía Peruana, se desarrolló un estudio etnobotánico en la comunidad mestiza Pueblo Libre, ubicada en Ucayali. La investigación se llevó a cabo entre agosto y septiembre del 2014 , y constó de grupos focales mixtos (hombres y mujeres) con participantes de 23 a 52 años de edad que fueron identificados por los pobladores de la comunidad como conocedores de plantas silvestres alimenticias de uso contemporáneo. Los grupos focales son particularmente útiles cuando uno está interesado en comprender el uso del lenguaje y la cultura cotidiana de un grupo sociocultural, así como en explorar el grado de consenso sobre un tema específico (Morgan y Kreuger, 1993). Finalmente, se llevó a cabo la colecta de especímenes vegetales con el acompañamiento de expertos locales, además de revisión de literatura para detallar si cada especie es endémica o introducida, así como su forma de crecimiento y ciclo de vida (USDA 2015a, b). Todos los informantes participaron libremente en el estudio y con consentimiento.

La lista de plantas silvestres alimenticias registradas en el área de estudio se construyó usando los nombres locales en español, que es el idioma principal de los pobladores de la comunidad de Pueblo Libre. La identificación botánica de las especies se llevó a cabo por la taxónoma vegetal María Elena Chuspe Zans del Herbario de la Universidad Intercultural de la Amazonía Peruana, ubicado en Pucallpa, donde los especímenes colectados se encuentran en repositorio (no obstante, es preciso aclarar que seis de las especies registradas no pudieron ser colectadas). En los grupos focales primero se discutió la definición local de plantas silvestres alimenticias para entender el 'dominio cultural' que corresponde a la categoría mental o sujeto de interés de la población local. Borgatti (1999) define al dominio cultural' como el conjunto de elementos que son todos del mismo tipo o categoría correspondiente a un grupo sociocultural. Asimismo, este autor enfatiza que la definición del 'dominio cultural' es el primer paso en un estudio etnobotánico. Después se les pidió a los participantes que enlistaran las plantas silves- tres alimenticias de la comunidad, y finalmente se les pidió que detallaran sus características, formas de colecta y manejo, así como los roles de los hombres y mujeres asociados a tales actividades. Con respecto a las características de las especies, se preguntó acerca de las partes comestibles y su forma de preparación. Los tipos de manejo evaluados fueron la recolección simple, el trasplante (o siembra), la implementación de riego, fertilización, desmalezado, poda protección y acolchonado (incorporación de residuos vegetales o 'mulch').

\section{Las plantas silvestres alimenticias en una comunidad mestiza de Ucayali}

Las plantas silvestres alimenticias constituyen un dominio cultural de la población de la comunidad mestiza de Pueblo Libre, quienes las definen como "las plantas del monte y las que traemos del monte y sembramos o trasplantamos cerca de la casa... también las plantas que crecen en la huerta o chacra y no necesitan de mucho cuidado". Un total de 30 especies, pertenecientes a 18 familias botánicas, fueron mencionadas por los participantes de los grupos focales. La familia botánica con mayor número de especies es la Arecaceae, que es la familia de las palmeras, con siete especies, seguida por la Fabaceae con tres especies. De este total, 27 fueron identificadas hasta el nivel de especie y tres fueron identificadas hasta el nivel de género (Tabla 13.1). Solo dos especies son introducidas, Artocarpus altilis (Parkinson) Fosberg (originaria de Asia y el Pacífico) y Colocasia esculenta (L.) Schott (proveniente de Australasia), las demás plantas son nativas. El $63 \%$ de las especies son árboles, $13 \%$ son hierbas, $13 \%$ trepadoras, dos árboles arbustivos y un arbusto. Todas las especies son perennes, con excepción de Physalis angulata L. que es anual.

La fruta es la parte comestible más comúnmente usada por los pobladores de Pueblo Libre, llegando a un $80 \%$ de las especies de plantas silvestres alimenticias. El tubérculo o raíz es la principal parte comestible del $17 \%$ de las especies, mientras que la 'chonta' y la semilla son consumidas en dos especies. La 'chonta' es la parte interna del tallo de una palma. El $90 \%$ de las especies presentan solo una parte comestible. Con respecto a la forma de consumo, todas las frutas son consumidas crudas, con excepción del 'camu camu', la especie Myrciaria dubia (Kunth) Mc Vaugh, la cual se consume principalmente como bebida. 'Camu camu' es una fruta caracterizada por el gran contenido de vitamina C que posee (Rodrigues et al., 2001). El $23 \%$ de las especies son frutas que también son consumidas como bebida ('refresco') ya sean crudas o cocinadas; adicionalmente dos frutas son consumidas como "chupete" (helado en agua). La 'cocona' o Solanum sessiliflorum var. sessiliflorum Dunal es utilizada para preparar una salsa con ají que es típica de la Amazonía peruana, y el 'ungurahui' o Oenocarpus bataua Mart., que se cocina en aceite. El 20\% de las especies (cinco tubérculos o raíces y una 'chonta') son cocinadas y consumidas como 'carbohidrato' junto con pescado, pollo u otros alimentos. La 'chonta' de Euterpe precatoria Mart. y Bactris gasipaes Kunth es consumida como verdura cruda, por ejemplo en las ensaladas, y el 'achiote' o Bixa orellana L. es la única especie usada como condimento y para dar color a la comida. El $23 \%$ de las especies es consumido de dos o más formas distintas. Por ejemplo, el 'pijuayo' o B. gasipaes es consumido de cinco formas distintas: su fruto se come crudo, se consume cocinado como 'refresco' o como 'carbohidrato', mientras que su 'chonta' 
Tabla 13.1. Lista de las plantas silvestres alimenticias indicando familia botánica, nom-

bre cientifico, nombre local, si es endémica o introducida, forma de crecimiento, ciclo de vida, partes comestibles y lugar de colecta.

\begin{tabular}{|c|c|c|c|c|c|c|c|c|}
\hline $\begin{array}{c}\text { Familia } \\
\text { botánica }\end{array}$ & Nombre científico & Nombre local & $\begin{array}{c}\text { Nativa o } \\
\text { introducida }\end{array}$ & $\begin{array}{l}\text { Forma de } \\
\text { crecimiento }\end{array}$ & $\begin{array}{l}\text { Ciclo de } \\
\text { vida }\end{array}$ & $\begin{array}{c}\text { Partes } \\
\text { comestibles }\end{array}$ & Dónde se colecta & Manejo \\
\hline Anacardiaceae & Spondias mombin L./Spondias venosa Mart. ex Colla & uvos & nativa & árbol & perenne & fruta & monte & \\
\hline Araceae & Colocasia esculenta (L.) Schott & pituca & $\begin{array}{l}\text { introducida } \\
\text { (Australasia) }\end{array}$ & hierba & perenne & tubérculo o raíz & monte/chacra & $\mathrm{T}$ \\
\hline \multirow{7}{*}{ Arecaceae } & Attalea phalerata Mart. ex Spreng. & shebon & nativa & árbol & perenne & fruta & monte & \\
\hline & Bactris gasipaes Kunth & pijuayo & nativa & árbol & perenne & fruta, chonta & chacra & $T, R, A, D$ \\
\hline & Mauritia flexuosa L.f. & aguaje & nativa & árbol & perenne & fruta & monte/chacra & Po \\
\hline & Oenocarpus bataua Mart. & ungurahui & nativa & árbol & perenne & fruta & monte & \\
\hline & Phytelephas macrocarpa Ruiz \& Pav. & yarina & nativa & árbol & perenne & fruta & monte & \\
\hline & Astrocaryum sp. G.Mey. & huicungo & nativa & árbol & perenne & semilla & monte & \\
\hline & Euterpe precatoria Mart. & huasai & nativa & árbol & perenne & fruta, chonta & monte & \\
\hline Asteraceae & Smallanthus sonchifolius (Poepp.) H.Rob. & yacón & nativa & hierba & perenne & tubérculo o raíz & chacra/huerta & $\mathrm{T}$ \\
\hline Bixaceae & Bixa orellana L. & achiote & nativa & árbol arbustivo & perenne & semilla & chacra/huerta & $T$ \\
\hline Dioscoreaceae & Dioscorea cf. trifida L.f. & sachapapa & nativa & trepadora & perenne & tubérculo o raíz & chacra & $T$ \\
\hline \multirow{3}{*}{ Fabaceae } & Inga edulis Mart. & guaba & nativa & árbol & perenne & fruta & chacra/huerta & $\mathrm{T}$ \\
\hline & Inga sp. & shimbillo & NA. & árbol & perenne & fruta & monte & \\
\hline & Pachyrhizus tuberosus (Lam.) Spreng. & ashipa & nativa & trepadora & perenne & tubérculo o raíz & chacra/huerta & $\mathrm{T}$ \\
\hline Icacinaceae & Poraqueiba sericea Tul. & umari & nativa & árbol & perenne & fruta & chacra/huerta & $\mathrm{T}$ \\
\hline Malvaceae & Matisia cordata Humb. \&Bonpl. & zapote & nativa & árbol & perenne & fruta & monte/chacra/huerta & $\mathrm{T}, \mathrm{Pr}, \mathrm{R}, \mathrm{A}, \mathrm{D}$ \\
\hline Marantaceae & Calathea allouia (Aubl.) Lind. & dale dale & nativa & hierba & perenne & tubérculo o raíz & monte/chacra & $\mathrm{T}$ \\
\hline Moraceae & Artocarpus altilis (Parkinson) Fosberg & pan de árbol & $\begin{array}{c}\text { introducida } \\
\text { (Asia y el Pacífico) }\end{array}$ & árbol & perenne & fruta & chacra/huerta & T, D \\
\hline Myrtaceae & Myrciaria dubia (Kunth) Mc Vaugh. & camu camu & nativa & árbol arbustivo & perenne & fruta & chacra & $T, R, A, D$ \\
\hline \multirow{2}{*}{ Passifloraceae } & Passiflora acuminata DC. & granadilla & nativa & trepadora & perenne & fruta & monte/chacra/huerta & \\
\hline & Passiflora quadrangularis L. & tumbo & nativa & trepadora & perenne & fruta & chacra/huerta & $\mathrm{T}, \mathrm{D}$ \\
\hline \multirow{2}{*}{ Rubiaceae } & Genipa americana L. & huito & nativa & árbol & perenne & fruta & monte/huerta & \\
\hline & Inga feuillei DC. & pacay & nativa & árbol & perenne & fruta & monte/chacra & $\mathrm{T}$ \\
\hline \multirow{2}{*}{ Sapotaceae } & Manilkara bidentata (A.DC.) A.Chev. & quinilla & nativa & árbol & perenne & fruta & monte & Po \\
\hline & Pouteria caimito (Ruiz \& Pav.) Radlk. & caymito & nativa & árbol & perenne & fruta & chacra/huerta & T \\
\hline \multirow{2}{*}{ Solanaceae } & Physalis angulata $\mathrm{L}$. & muyaca & nativa & hierba & anual & fruta & monte/chacra & \\
\hline & Solanum sessiliflorum var. sessiliflorum Dunal & cocona & nativa & arbusto & perenne & fruta & chacra/huerta & $\mathrm{T}, \mathrm{D}$ \\
\hline Sterculiaceae & Theobroma cacao L. & cacao & nativa & árbol & perenne & fruta & monte/chacra & $T, S, D, P o$ \\
\hline Urticaceae & Pourouma cecropiifolia Mart. & ubilla & nativa & árbol & perenne & fruta & chacra/huerta & $\mathrm{T}$ \\
\hline
\end{tabular}

se consume cruda como verdura o también cocinada como 'refresco'.

De un total de 30 especies documentadas, el $70 \%$ se colecta de la chacra (campo agrícola), el $57 \%$ del monte (bosque) y e $43 \%$ de la huerta. Casi dos tercios de las especies (64\%) es colectado en dos o más lugares. Más del $40 \%$ de las plantas son colectadas exclusivamente por hombres $37 \%$ por hombres y mujeres, $17 \%$ exclusivamente por mujeres y $7 \%$ por niños. Todas las plantas que son colectadas exclusivamente por las mujeres son los tubérculos o raíces que crecen en la 'chacra' y son cocinados como 'carbohidrato', a excepción de la 'cocona' con la que ellas preparan salsa de ají para acompañar los alimentos. Las plantas que son colectadas por los hombres son los árboles frutales -incluyendo todas las palmeras como Mauritia flexuosa L.f. o $E$. precatoria- que requieren ya sea trepa el árbol para colectar los frutos, o tumbarlo para colectar los frutos o extraer la 'chonta'. Igualmente, todas las especies que solo crecen en el monte son colectadas únicamente por los hombres. Los niños gustan mucho de colectar frutos de la 'muyaca' (P. angulata) y del 'zapote' (Matisia cordata Bonpl.), las cuales, de acuerdo a los pobladores, hay en mayor cantidad que antes en la comunidad porque "crecen como mala hierba". Todas las especies que son colectadas tanto por hombres como por mujeres son sembradas en la chacra o huerta, en su mayoría son frutos que no requieren tanto esfuerzo físico para ser colectados (por ejemplo, la mitad son trepadoras y árboles arbustivos), con excepción de la Passiflora acuminata DC., la cual no es sembrada porque crece como "mala hierba". 


\section{Manejo en la interfase bosque-agricultura desde un enfoque de género}

Dos terceras partes de las plantas silvestres alimenticias tienen algún tipo de manejo aparte de la recolección simple (Figura 13.3). De un total de 20 especies manejadas, 90\% han sido trasplantadas ex situ, mientras que dos especies que no han sido trasplantadas son podadas (M. flexuosa y Manilkara bidentata (A.DC.) A.Chev.). El 35\% de las especies manejadas son desmalezadas, $20 \%$ tratadas con fertilizantes, mientras que tres especies reciben riego, otras tres son podadas, una es protegida y ninguna es manejada en términos de acolchonado. Todas las especies que se protegen, riegan, fertilizan y desmalezan son trasplantadas. El $65 \%$ de las especies tiene un solo tipo de manejo, tres especies tienen dos tipos de manejo, tres especies tienen cuatro tipos de manejo y solo una especie, $M$. cordata, tiene cinco tipos de manejo.

Los detalles con respecto a los roles de género para cada tipo de manejo se pueden apreciar en la Figura 13.3. En esta es posible identificar que prácticas como el desmalezado y la poda se lleva a cabo solamente por hombres, al igual que la protección de $M$. cordata, que es la única especie a la que le hacen un pequeño cerco con palitos para protegerla de los pollos, no obstante que consideran que esta planta "crece como mala hierba". Hay cuatro especies exclusivamente sembradas por hombres -Theobroma cacao L., M. dubia, Inga feuillei DC. y $B$. gasipaes-, tres sembradas solo por mujeres -Pouteria caimito (Ruiz \& Pav.) Radlk., Inga edulis Mart. y Passiflora quadrangularis L.--, el resto de las especies son trasplantadas o sembradas por ambos. La fertilización y el riego son realizados ya sea únicamente por hombres o por hombres y mujeres, dependiendo de la especie. De esta manera, $T$ cacao y $M$. dubia, que son especies comercializadas, son abonadas (y manejadas) exclusivamente por los hombres, y $B$. gasipaes junto con $M$. cordata son abonadas y regadas por hombres y mujeres.

En Pueblo Libre, las actividades agrícolas se realizan mayormente por los hombres, quienes son los principales responsables del cuidado de la chacra, y en ciertas ocasiones por las mujeres. Esto se refleja en el hecho de que el $27 \%$ de las especies que son trasplantadas o sembradas en la chacra son manejadas solo por hombres, el resto tanto por hombres como por mujeres, y ninguna especie sembrada en la chacra es manejada exclusivamente por las mujeres. Por otro lado, las mujeres son las responsables del cuidado de la huerta, pero la decisión de qué sembrar en la huerta es tomada por ambos. Esto se manifiesta en el hecho de que el $33 \%$ de las especies que se siembran en la huerta son manejadas exclusivamente por mujeres, las demás tanto por hombres como por mujeres, y ninguna especie sembrada en la huerta es manejada exclusivamente por los hombres.

\section{Manejo de recursos fitogenéticos, deforestación y seguridad alimentaria}

Los resultados de este estudio ilustran la diversidad de plantas silvestres alimenticias consumidas por una comunidad mestiza de Ucayali, Perú, así como la complementariedad espacial de los distintos ecosistemas antropogénicos para la provisión de estos alimentos.

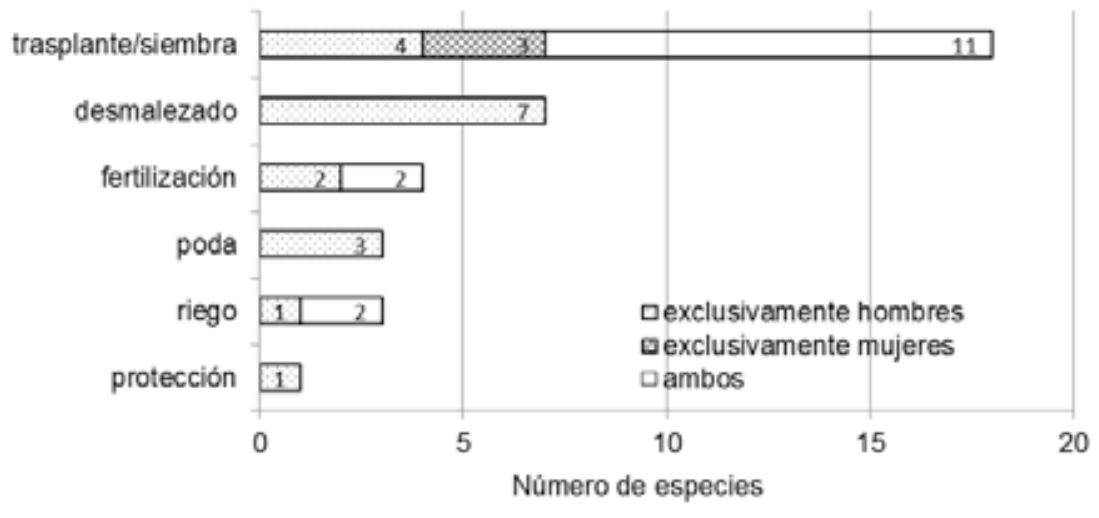

Figura 13.3. Número de especies para cada tipo de manejo y de acuerdo a roles de género.

Esto se refleja claramente en que una mayor parte de las especies se colecta en dos o más lugares, incluyendo la huerta, la chacra y el monte. Ciertamente, el estudio de las plantas silvestres alimenticias nos permite apreciar que los ecosistemas no deben considerarse de manera aislada, ya que son componentes complementarios del sistema agrícola-forestal. La importancia de esta complementariedad ha sido reportada como esencial para la seguridad alimentaria de las familias rurales en otras partes del mundo, por ejemplo, en el noreste de Tailandia (Cruz-Garcia y Price, 2014a) y en el oeste de Java en Indonesia (Abdoellah y Marten, 1986). Sin duda, Frison et al. (2011) enfatizaron que la diversidad dietaria está cimentada en la diversidad de los sistemas agrícolas.

Se ha reportado para el Perú un total de 782 especies de plantas alimenticias (Brack, 1999). En 1994 se reportó, para toda la Amazonía de Sudamérica, un total de 131 especies de plantas silvestres alimenticias, principalmente árboles y palmeras, consumidas por comunidades indígenas (Defour y Wilson, 1994). Adicionalmente, el Jardín Botánico-Arboretum El Huayo (JBAH) de la Universidad Nacional de la Amazonía Peruana (UNAP) ubicado en lquitos, Amazonía Peruana posee 46 especies de frutales comestibles de consumo humano para los cuales se detalló su uso en los caseríos aledaños (Freyre, 2003). Al tomar en cuenta estos números, la cantidad de plantas silvestres alimenticias documentada para la comunidad de Pueblo Libre ( $n=30$ especies) podría parecer baja. Sin embargo, comparando con otros estudios realizados en la Amazonía, e número de especies de plantas silvestres alimenticias de Pueblo Libre es mayor que el encontrado por Reyes-García et al. (2006) para las comunidades Tsimane' de la Amazonía Boliviana $(n=18)$; y muy similar al número de especies de uso alimenticio reportado por Vásque y Peláez para los pobladores del caserío Berlín en Bagua Grande en Amazonas, Perú $(n=29)$.

El uso de los 'dominios culturales' (Borgatti, 1999) es un importante punto de partida para e estudio de los procesos de manejo de especies vegetales, ya que distintos grupos sociales o culturales perciben y conciben el mundo de una manera diferente como resultado de distintas 
condiciones y experiencias sociales, históricas, culturales y ambientales (Brosius, Lovelace y Marten, 1986). En esta investigación se pudo observar que especies como T. cacao, que son categorizadas como domesticadas por los científicos, son clasificadas como silvestres por los pobladores de sus centros de origen. En el caso del cacao, las familias de Pueblo Libre no solo o comercializan, sino que también lo consumen crudo como "fruta silvestre". Estos resultados se alinean con la consideración de Michon y De Foresta (1997) quienes enfatizaron que los pobladores rurales y los científicos pueden tener distintas clasificaciones para lo silvestre y lo domesticado; asimismo, son congruentes con el planteamiento de González-Insuasti y Caballero (2007), quienes explicaron que una especie puede tener distintas formas de manejo en diferentes lugares, y a Cruz-Garcia y Price (2014b) quienes, basadas en un estudio realizado en Tailandia, resaltaron que la domesticación es un proceso localmente diferenciado.

Los resultados de esta investigación muestran que el manejo, particularmente el trasplante o siembra, es común para las plantas silvestres alimenticias, ya que dos terceras partes de estas especies son manejadas. Indudablemente, los seres humanos han intervenido las poblaciones de especies silvestres en todas partes del mundo, por ejemplo, cambiando la diversidad y densidad de plantas alimenticias, trasplantando especies útiles o introduciendo nuevas especies (Daly, 2014; Parrotta et al., 2015; Wiersum, 1997a). El manejo de plantas silvestres ha sido documentado en Latinoamérica, por ejemplo, en Chile (Daly, 2014), Bolivia (Reyes García et al., 2005) y México (Casas et al., 1996; González-Insuasti y Caballero, 2007).

La zona de estudio ha sido, y sigue siendo, muy afectada por la alta tasa de deforestación (Miranda et al., 2014; Porro, Lopez-Feldman y Vela-Alvarado, 2015; Smith, et al., 2006). Se ha reportado que procesos como cambio de uso de suelos, deforestación, expansión agrícola y ganadera, junto con el manejo insostenible y extractivo de recursos naturales, los cuales son comunes en Ucayali, son causa de la disminución de biodiversidad y, consecuentemente, de las plantas silvestres alimenticias (Daly, 2014). La disminución de plantas útiles afecta directamente (disponibilidad y acceso a alimentos) e indirectamente (modificación de factores ecológicos) la seguridad alimentaria de las familias rurales (Bina-Agarwal et al., 2015; Van Noordwijk t al., 2014). Frente a este escenario, el manejo de recursos fitogenéticos es una estrategia que permite a las familias rurales asegurar la disponibilidad y acceso a sus alimentos, siendo estos dos pilares clave de la seguridad alimentaria (FAO, 1996). De esta manera, las distintas prácticas de manejo cumplen un rol crítico en escenarios de deforestación y pérdida de biodiversidad, ya que estas permiten: (1) que los pobladores tengan suficiente diversidad alimentaria y nutricional a través del acceso y disponibilidad a estos recursos, y (2) la conservación de recursos fitogenéticos clave dentro de sistemas antropogénicos que, de otra manera, se podrían perder. Igualmente, tal como lo enfatizaron Ogle y Grivetti (1985) en su 'paradoja botánica-dietética', los resultados de este estudio ilustran que la colecta de plantas silvestres en escenarios de deforestación ocurre mayormente en ecosistemas antropogénicos (teniendo en cuenta que la mayor parte del bosque es secundario), los cuales cumplen un rol esencial para la conservación de biodiversidad a través de las prácticas de manejo.

Los resultados de esta investigación evidenciaron que ambos, hombres y mujeres, contribuyen al manejo de las plantas silvestres alimenticias. Por ejemplo, los hombres están más responsabilizados de los frutales que crecen en la chacra y las plantas útiles del bosque, mientras

que las mujeres están más responsabilizadas de aquellas plantas que crecen en las huertas así como de las raíces y tubérculos de la chacra. Estas divisiones de género en las prácticas de cosecha y manejo están relacionadas con la división de género de los espacios productivos del hogar. Por ejemplo, Mulyoutami et al. (2015) encontraron en un estudio realizado en el sur de Sulawesi que la responsabilidad de trabajo de la mujer es mayormente en áreas cercanas a la casa (por ejemplo, en las huertas), mientras que el hombre se dedica más a la siembra del cacao y sistemas agroforestales. De manera similar, Chambers y Momsen (2007) concluyeron de un estudio conducido en la región Bajío de México que las mujeres trabajan las áreas más cercanas al hogar para poder cuidar con mayor facilidad de los niños y realizar las labores domésticas. Sin embargo, el conocimiento etnobotánico diferenciado por género no solo se debe a las divisiones de trabajo ("la mujer trabaja la huerta y el hombre la "chacra'"). Por ejemplo, los resultados de este estudio indicaron que la cosecha de frutos de las palmeras es realizada solo por los hombres ya que, de acuerdo con los pobladores, requiere de un mayor esfuerzo físico. Esta división de actividades también se ha reportado en otros lugares, por ejemplo, Roshetko y Dinarto (2008) indicaron que los hombres de Wonogiri y Ponorogo en Java central son los encargados de trepar ciertos árboles para colectar semillas, mientras que las mujeres colectan las semillas de otras especies de árboles que se pueden obtener sin necesidad de treparlos.

Concluyendo, el estudio sobre las plantas silvestres alimenticias consumidas por una comunidad mestiza de Ucayali, Perú, ilustra que los procesos de manejo de recursos fito-genéticos, particularmente de las plantas silvestres alimenticias, son muy importantes para la seguridad alimentaria de familias rurales y la conservación de recursos clave en la interfase bosque-agricultura frente a escenarios de deforestación y pérdida de biodiversidad.

\section{Agradecimientos}

Agradecemos a María Elena Chuspe Zans del Herbario de la Universidad Intercultural de la Amazonía Peruana que amablemente realizó las determinaciones botánicas de las especies, a Madeleine Hancco que colaboró con la realización de los grupos focales, a José Sanchez-Choy por todo su apoyo en Pucallpa, y a Paula Paz del equipo Terra-i del CIAT por la elaboración de mapa. También extendemos nuestros agradecimientos a los pobladores de Pueblo Libre en Ucayali, por compartir con nosotros sus valiosos conocimientos.

\section{Bibliografía}

Abdoellah, O. S.y G. G. Marten, 1986. The complementany roles of homegardens, upland fields, and rice fields for meeting
nutritional needs in West Java. En: Marten, G. E. (Ed.). Traditional agriculture in Southeast Asia. A human ecology perspective. Westview Press, London: pp. 293-325. ya, A. L., H. Bdliya, H. Bitrus, M. Danjaji, D. Eaton, M Omoluabi, G. Polet, M. Salisu, S. S. Sanusi, M. T. Sarch, y M. Shuaibu, 1997. The Hidden Harvest: the role of wild foods in agricultural systems. Local level assessment 
of the economic importance of wild resources in the Cotton, C. M., 1996. Ethnobotany. John Wiley \& Sons, Hadejia-Nguru wetlands, Nigeria. Hidden Harvest Project Research Series. Instopment (IIED), Nigeria.

Aphane, J., M. L. Chadha y M. O. Oluoch, 2003. Increasing the consumption of micronutrient-rich foods throug production and promotion of indigenous foods. FAOAVRDC International Workshop. The World Vegetable
Center (AVRDC), Taiwan.

Balemie, K. y F. Kebebew, 2006. Ethnobotanical study of Ethiopia Journal of Ethnobiology and Ethnomedicine.

Bharucha, Z. y J. Pretty, 2010. The roles and values of wild foods in agricultural systems. Philosophice

Bina, A., R. Jamnadass, D. Kleinschmit, S. McMullin, S. Mansourian, H. Neufeldt, J. A. Parrotta, T. Sunderland
y C. Wildburger, 2015. Introduction. Forests, trees an landscapes for food security and nutrition. En: Vira, B C. Wildburger y S. Mansourian (Eds.). Forests, trees and landscapes for food security and nutrition. A global
assessment report. CPF and IUFRO, Vienna: pp. 13-24. assessment report. CPF and IUFRO, Vienna: pp. 13-24.

Borgatti, S., 1999. Elicitation techniques for cultural domain
analysis. En: Schensul, J. J., M. D. L. Compte, B. K. analysis. En: Schensul, J. J., M. D. L. Compte, B. K.
Nastasi, y S. P. Borgatti (Eds.). Enhanced ethnographic methods: audiovisual techniques, focussed group interviews and elicitation techniques.

Brack Egg, A., 1999. Diccionario enciclopédico de las plantas útiles del Perú. Centro de Estudios Regionales Andino Naciones Unidas para el Desarrollo (PNUD), Cusco.

Brosius, J. P., G. W. Lovelace y G. G. Marten, 1986. Ethnoecology: an approach to understanding traditional agricultural knowledge. En Marten, G. E. (Ed.).) Traditional agriculture in Southeast Asia. A human ecology
perspective. Westview Press, London: pp. 187-198. perspective. Westview Press, London: pp. 187-198.

Casas, A., J. Caballero, C. Mapes y S. Zárate, 1997. Manejo de la vegetación, domesticación de plantas y origen de Botánica de México, 61: 31-47.

Casas, A., M. Del Carmen Vázquez, J. L. Viveros y J. Caballero, 1996. Plant management among the Nahua and the Mixtec in the Balsas River Basin, Mexico: an ethnobotanical approach to the study of
domestication. Human Ecology, 24 (4): 455-478.

Chambers, K. J. y J. H. Momsen, 2007. From the kitchen and the field: gender and maize diversity in the Bajio regio 28 (1): $39-56$

Chweya, J. A. y P. B. Eyzaguirre, 1999. The biodiversity of Resources Institute (IPGRI), Rome.

CIAT, 2015. Terra-i. An eye on habitat change (en linea, disponible en: www.terra-i.org/terra-i.html).

Cossío, R., M. Menton, P. Cronkleton y A. Larson, 2014. A literature review. CIFOR.
London.
Lon.

uz-Garcia, G. S. y F. Ertug, 2014. Introduction: wild food plants in the present and past. En: Chevalier, A., E. Marinova y L. Peña-Chocarro (Eds.). Plants and Choices and diversity through time. Oxbow Books,

Cruz-Garcia, G. S. y L. L. Price, 2011. Ethnobotanical investigation of wild food plants used by rice farmers in Northeast Thailand. Journal of Ethnobiology and

ruz-Garcia, G. S. y L. L. Price, 2014a. Gathering of wild food plants in anthropogenic environments across th households. Ecology of Food and Nutrition, 53: 1-24.

ruz-Garcia, G. S. y L. L. Price, 2014b. Human-induced movement of wild food plant biodiversity across farming
systems is essential to ensure their availability. Journa of Ethnobiology, 34 (1): 68-83.

Cunningham, A. B. 2000 . Applied ethnobotany: people, wild plant use and conservation. Earthscan, London.

Daly, B. A., 2014. Narrating changing foodways: wild edible plant knowledge and traditional food systems in Mapuche

Daniggelis, E. E., 2003. Women and 'wild' foods: nutrition and household security among Rai and Sherpa foragerfarmers in Eastern Nepal. En: Howard, P. (Ed.). Women and plants. Gender relations in biodiversity management and conservation. Zed Press and

Defour, D. L. y W. M. Wilson, 1994. Characteristics of "wild" plant foods used by indigenous populations in Amazonia En: Ekkin, N. (Ed.). Eating on the wild side

AO, 1996. Rome declaration on world food security and World Food Summit plan
Rome: 13-17.

oley, J. A., G. P. Asner, M. H. Costa, M. T. Coe, R. DeFries, H. K. Gibbs, E. A. Howard, S. Olson, J. Patz
y N. Ramankutty, 2007 . Amazonia revealed: forest degradation and loss of ecosystem goods and services in the Amazon Basin. Frontiers in Ecology and the Environment, 5 (1): 25-32.

reyre, H. V., 2003. Plantas de importancia económica ecológica en el jardín botánico-Arboretum el Huayo, Iquitos, Perú. Folia amazónica, 14 (1): 2003

Fison, E. A., J. Cherfas y T. Hodgkin, 2011. Agricultura biodiversity is essential for a sustainable improvement
in food and nutrition security. Sustainability, 3: 238-253 Fujsaka, S., G. Escobar y E. J. Veneklaas, 2000. Weed fields and forests: interactions between land use an the composition of plant communities in the Peruvian Amazon. Agriculture, Ecosystems \& Environment, 78
(2): 175-186. Galarza, E. y K. La Serna, 2005. Las concesiones forestales en en of British Columbia, Vancouver.
Ecuador y Perú.

PDR. Agroforestry Systems, 67 (1): 1-17.

González-Insuasti, M. S. y J. Caballero, 2007. Managing plant resources: h4,
(3): $303-314$.

Grivetti, L. E. y B. M. Ogle, 2000. Value of traditional foods in meeting macro- and micronutrient needs: the wild
plant connection. Nutrition Research Reviews, 13 (1): $31-46$.

Guijt, I., 1998. Valuing wild plants with economics and participatory methods: an overview of the Hidde Harvest methodology. En: Prendergast, H. D. V., N. L.
Etkin, D. R. Harris y P. J. Houghton (Eds.). Plants for Etkin, D. R. Harris y P. J. Houghton (Eds.). Plants for food and medicin $223-235$.

Harlan, J., 1975. Crops and man. American Society of Agronomy and Crop Science Society of America

Harris, D. R., 1989. The evolutionary continuum of peopleplant interactions. En: Harris, D. R. y G. C. Hillman (Eds.) Foraging and farming: the evolution

Harris, D. R., 1996. Domesticatory relationships of people, plants and animals. En: Ellen, R. y K. Fukui (Eds.). Berg, Oxford, Washington DC: pp. 437-463.

Heywood, V., 1999. Use and potential of wild plants in farm households. FAO, Rome.

Heywood, V., 2011. Ethnopharmacology, food production, nutrition and biodiversity conservation: towards a sustainable future for indigenous
Ethnopharmacology, 137: 1-15.

Howard, P., 2003. Women and the plant world: an exploration. En: Howard, P. (Ed.). Women and plants. Gender relations in biodiversity management and conservation. Zed Press
and Palgrave Macmillan, London and New York: pp. 1-48.

NEI, 2011 Perí: Perfil de lo pobiza por York. pp. 1-48. El, 2011a. Perú: Perfil de la pobreza por departamentos,
2001-2010. Instituto Nacional de Estadística e Informática (INEI), Lima.

INEI, 2011b. Producto Bruto Interno por departamentos, 2001-2010. Instituto Nacional de Estadística e

INEI. 2011c. Ucayali: Compendio estadistico departamental, 2010. Instituto Nacional de Estadística e Informática

Johns, T., 2007. Agrobiodiversity, diet and human health. En: Jarvis, D. I., C. Padoch, y D. Cooper (Eds.). Managing biodiversity in agricultur

Johns, T. y P. B. Eyzaguirre, 2006. Linking biodiversity, diet and health in policy and practice. Proceedings of the and health in policy and practice.
Nutrition Society, 65: 182-189.

Kiptot, E. y S. Franzel, 2012. Gender and agroforestry in Africa: a review of women's participation. Agroforestry Aystems, 84 (1): $35-58$

Kosaka, Y., S. Takeda, S. Prixar, S. Sithirajvongsa y K. saka, Y. S. Takeda, S. Sithirajvongsa y K. Xaydala, 2006 Plant diversity in paddy fields in relation to agricultura practices in Savann
Botany, 60 (1): 49-61.

Lojka, B., J. Lojkova, J. Banout, Z. Polesny y D. Preininge, 2008. Performance of an improved fallow system in the Systems, 72 (1): 27-39.
Syinan Pobilization in response tor case: Indigenous Peruvian Amazon. University of Oregon.

Malhi, Y., J. T. Roberts, R. A. Betts, T. J. Killeen, W. Li y C. A. Nobre. 2008. Climate change, deforestation, and the fate of the Amazon. Science, 319 (5860): 169-172.

Michon, G. y H. De Foresta, 1997. Agroforests: pre-domestication of forest trees or true domestication of forest ecosystems?

MINEM-GOREU, 2007. Caracterización del departamento de Ucayali, con fines de ordenamiento territorial. Ministerio Ucayali (GOREU), Pucallpa.

Miranda, J. J., L. Corral, A. Blackman, G. Asner y E. Lima. 2014. Effects of protected areas on forest cover change Amazon. No. Inter-American Development Bank.

Morgan, D. L. y R. A. Kreuger, 1993. When to use focus groups and why. En: Morgan,
focus groups. Sage, London.

Mulyoutami, E., J. Roshetko, E. Martini y D. Awalina, 2015 Gender roles and knowledge in plant species selection and domestication: a case study in South and Southeast. Sulawesi. International Forestry Review, 17 (4): 99-111.

ggle, B. M., 2001. Wild vegetables and micronutrient nutrition. Studies on the significance of wild vegetables in women's Uppsala.

ggle, B. M., H. T. A. Dao, G. Mulokozi y L. Hambraeus, 2001 Micronutrient composition and nutritional importance of gathered vegetables in Vietnam. International Journal of

Ogle, B. M. y L. E. Grivetti, 1985. Legacy of the chameleon: Edible wild plants in the kingdom of Swaziland, Souther Cultural and ecological analysis. Ecology of Food and Nutrition, 17 (1): $31-40$.

Ogle, B. M., H. T. Tuyet, H. N. Duyet y N. N. X. Dung, 2003 Food, feed or medicine: the multiple functions of edible
wild plants in Vietnam. Economic Botany, 57 (1): 103-117.

Oliveira, P. J., G. P. Asner, D. E. Knapp, A. Almeyda, R. GalvánGildemeister, S. Keene, R. F. Raybin y R. C. Smith, 2007. Land-use allocation protects th
Science, 317 (5842): 1233-1236.

Orwa, C., A. Mutua, R. Kindt, R. Jamnadass y A. Simons. 2009. Psidium guajava. Agroforestry Data.
reference and selection guide version 4.0.

Parrotta, J. A., J. D. d. Pryck, B. D. Obiri, Christine Padoch, B. 
Powell, C. Sandbrook, B. Agarwal, A. Ickowitz, K. Jeary, Anca Serban, T. Sunderland, y T. N. Tu. 2015. The historical, environmental and socio-economic context of forests and
tree-based systems for food security and nutrition. En: Vira, B., C. Wildburger y S. Mansourian (Eds.), Forests trees and landscapes for food security and nutrition. $A$

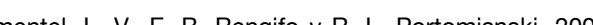
The L. V., E. B. Rengifo y R. L. Portomisnski, 2004. The great encyclopedia of the Ucayali Region: Peruvia

Porro, R., A. Lopez-Feldman y J. W. Vela-Alvarado, 2015 Forest use and agriculture in Ucayali, Peru: Livelihood strategies, poverty and wealth in an Ant
Forest Policy and Economics, 51: 47-56

Prasad Aryal, K., A. Berg y B. M. Ogle, 2009. Uncultivated plants and livelihood support - a case study from the Applications, 7: 409-422.

Pretty, J., 2003. Agri-culture, reconnecting people, land and nature. Earthscan, London.

Price, L. y B. M. Ogle, 2008. Gathered indigenous vegetables in Mainland Southeast Asia: a gender asset. En Resurreccion, B. P. y R. Elmhirst (Eds.). Gender and natural resource management: livelihoods, mobility and interventions. Earhscan, London: pp. 213-242.

Price, L. L., 1997. Wild plant food in agricultural environments: a study of occurrence, management, and gathering rights in Northeast Thalland. Human Organization, 56 (2): 209-22

Ramos Delgado, N., 2009. Impacto de la producción forestal maderable en la economía de la región Ucayali, Perú. No. Universidad Nacional Agraria La Molina, Lima (Perú). Escuela de Postgrado. Especia

Reves-Garcí, V, T. Huanca, V Vadez, W. Leonard, y D. Wilkie, 2006. Cultural practical and economic value of wild plants: a quantitative study in the Bolivian Amazon. Economic Botany, 60 (1): 62-74.

Reyes García, V., V. Vadez T. Huanca, W. Leonard y D. Wilkie 2005. Knowledge and consumption of wild plants: comparative study in two Tsimane' villages in the Bolivian Amazon. Ethnobotany Research and Applications, 3 (3): 201-207.

Rocheleau, D. y D. Edmunds, 1997. Women, Men and Trees: Gender, Power and Property in Forest and Agraria Landscapes. World Development, 25 (8): 1351-1371.

Rodrigues, R. B., H. C. De Menezes, L. Cabral, M. Dornier y M.
Reynes. 2001. An Amazonian fruit with a high potential as Reynes. 2001. An Amazonian fruit with a high potential as
a natural source of vitamin C: the camu-camu (Myrciaria a natural source of vitamin C: the

Roshetko, J. M. y A. Dianarto, 2008. Tree Seed ProcurementDiffusion Pathways in Wonogiri and Ponorogo, Java. Small-scale Forsty, 7 (3-4): 333-352.

Salisbury, D. S. y C. Fagan, 2013. Coca and conservation: borderlands GeoJournal, 78 (1): 41-60.
Scoones, I., M. Melnyk y J. N. Pretty, 1992. The hidden harvest: wild foods and agricultural systems: a literature for Environment and Development, London.

ears, R. R. y M. Pinedo-Vasquez, 2011. Forest policy reform and the organization of logging in Peruvian Amazonia.

mith, J., V. Colan, C. Sabogal y L. Snook, 2006. Why policy reforms fail to improve logging practices: The rol of governance and norms in Peru. Forest Policy and

Sunderland, T., R. Achdiawan, A. Angelsen, R. Babigumira A. Ickowitz, F. Paumgarten, V. Reyes-García y G. Shively, forest product use: a global comparative study. World Development.

SDA, 2015a. Germplasm Resources Information Network (GRIN) (en línea, disponible en: www ars-grin gov/cgibin/npgs/html/taxgenform.pl?language=es)

SDA. 2015b. Natural Resources Conservation Service (en linea, disponible en: http://plants.usda.gov/java/

Vael, L., 2015. Ethnobotanical study of the plant use in the natural landscape of two mestizo communities in the ingenieurswetenschappen. Universiteit Ghent, Ghent Belgium.

ainio-Mattila, K., 2000. Wild vegetables used by the Sambaa in the Usambara Mountains, NE Tanzania. Annales Botanici Fennici, 37 (1): 57-67.

an Noordwijk, M., J. Bayala, K. Hairiah, B. Lusiana, C. Muthuri, N. Khasanah y R. Mulia. 2014. Agroforestry solutions for buffering climate variability and adapting to change. En: Fuhrer, J. y P. Gregory (Eds.). Climate change impact and adaptation in agricultural systems.

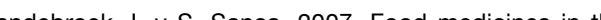
Bolivian Andes (An anca, 2007. Food medicines in the En: Pieroni, A y L. LPrice (Eds). Eating and healing: traditional food as medicine. Food Products Press, an imprint of The Haworth Press, Inc., NY: pp. 273-295.

olpato, G. y D. Godinez, 2007. Medicinal foods in Cuba: Promoting health in the household. En: Pieroni, A. L.L.Price (Eds.). Eating and healing: traditional food as medicine. Food Products Press, an imprint of The Haworth Press, Inc., NY: pp. 213-236.

Wiersum, K. F., 1997a. From natural forest to tree crops, codomestication of forests and tree species, an overview. Netherlands Journalor Agricultural Science, 45: 425-438. Wiersum, K. F., 1997b. Indigenous exploitation and management of tropical forest resources: an evolutionary continuum in forest-people interactions. Agriculture,
Capítulo 14

\section{Las plantas aromáticas en los Andes peruanos}

Milka Tello Villavicencio

\section{Resumen}

a alimentación de la humanidad en sus inicios fue principalmente herbívora. Por lo tanto, las plantas fueron de los primeros organismos que se incorporaron a la cultura humana, eventualmente en procesos de selección artificial de acuerdo a las necesidades de las sociedades que formó el Homo sapiens. Las interacciones entre los seres humanos y las plantas aromáticas han llamado la atención, pues fueron y continúan siendo importantes elementos en diversas prácticas culturales que influyen en la vida cotidiana de las personas. El presente texto desarrolla algunas líneas con base en experiencias de investigación realizadas en las plantas aromáticas que se usan en la zona andina del departamento de Huánuco, Perú. Se pone particular énfasis en una de las especies más significativas en esa región, "la muña" Minthostachys mollis. Se denominan aromáticas todas aquellas especies de plantas que desprenden un aroma y/o sabor intenso a los sentidos del gusto y el olfato humano. Tales propiedades se deben al elevado contenido en sustancias con propiedades químicas, bioquímicas u organolépticas muy específicas. Las sustancias o principios activos, pueden encontrarse en las hojas, tallos, bulbos, rizomas, raíces, flores, semillas y frutos; ya sea en árboles, arbustos o plantas herbáceas. La región andina es uno de los principales centros de origen y diversificación de cultivos a nivel mundial, y ello se ha identificado desde los primeros trabajos clásicos sobre el origen de las plantas cultivadas y de la agricultura, y ha sido considerada como tal, de forma consistente, por los diversos autores que han desarrollado teorías sobre este tópico durante el siglo XX y hasta el presente. Sin embargo, existe escasa información sobre la domesticación de plantas aromáticas, medicinales o rituales. No obstante, los datos más antiguos sobre el uso de este grupo de plantas se encontraron en momias, piezas de cerámica preinca e inca, collcas (almacenes) y registros de los cronistas sobre las plantas alimenticias que comían en el incanato. Se sabe también que la coca fue domesticada y hoy en día existe una extraordinaria percepción de variación intraespecífica de plantas aromáticas y medicinales, uso diferencial de estas, valor cultural y económico, asi como manejo y procesos selectivos que sugieren la ocurrencia de procesos de domesticación en algunas especies. Reconocer dichos procesos de manejo y domesticación resulta de gran importancia en el desarrollo del potencial de recursos que proveen compuestos secundarios para la medicina, el arte culinario, la ornamentación y la cosmética, así como usos antiguos para el control orgánico de la proliferación de insectos y hongos que constituyen plagas. La muña es una de las plantas aromáticas más extendidas en la región andina de 
Perú. De ella se reconocen especies y variedades con propiedades diferenciales. La variación intraespecífica de esta y otras especies aromáticas puede hacer referencia genérica (macho y hembra, sin que nada tenga relación con la sexualidad de las planta sino con atributos morfológicos y organolépticos), así como otros criterios como la altitud en la que viven, los colores de sus tallos y follaje, la forma de sus hojas, la intensidad de su olor y sabor, entre otros atributos. Estos atributos reconocidos por la gente andina en algunos casos se expresan en procesos de selección artificial, los cuales han sido aún poco analizados, pero son similares a algunos procesos documentados en Mesoamérica. En este capítulo se muestran resultados de intentos por manejar y cultivar de manera intensiva la muña, con el fin de elevar su potencial de aprovechamiento y prevenir la afectación de poblaciones naturales. El proceso parte de reconocer la fenología, en particular la época de producción de flores y frutos, su siembra, germinación y establecimiento. Asimismo, los procesos de propagación sexual $y$ asexual que permiten incrementar su disponibilidad en parcelas, los cuidados que deben tenerse, los períodos de cosecha y el mantenimiento de plantaciones. Existen conocimientos y técnicas tradicionales que permiten resolver problemas ligados al proceso descrito, cuya documentación permite acortar pasos en el proceso de innovación tecnológica. El proceso de innovación se ilustra con una especie, pero puede involucrar prácticas en otras especies, no solo aromáticas.

Palabras clave: Andes, cultivo, domesticación, Huánuco, manejo de recursos vegetales, plantas aromáticas.

\section{Introducción}

Las plantas son componentes particularmente importantes de la biodiversidad; estas fueron de los elementos de la naturaleza que de forma más temprana llamaron la atención de los seres humanos, y de los cuales se generaron conocimientos de primordial importancia. En buena parte, debido a que estos recursos han proporcionado satisfactores básicos de la subsistencia tales como alimentos, medicinas, vestido, materiales para construcción de viviendas y leña; pero también elementos culturales fundamentales como ornamentos, elementos rituales y esencias aromáticas, y muchos otros productos que satisfacen necesidades espirituales de las personas. Yauri (2009) sostiene que la alimentación de la humanidad en sus inicios fue principalmente herbívora. Por lo tanto, las plantas fueron de los primeros organismos que se incorporaron a la cultura humana, y eventualmente en procesos de selección artificial de acuerdo a las necesidades de las sociedades que formó el Homo sapiens y sus predecesores del género Homo (Casas et al., 2015a; Casas y Parra, 2016). Posteriormente, pasaron por el proceso de selección artificial y otras fuerzas evolutivas que moldean la domesticación de miles de especies de organismos, entre ellas plantas, animales y microorganismos, muchas de las cuales conocemos hoy en día, y otras miles de especies de todo el mundo, de las cuales se desconoce el estatus de manejo y domesticación en el que se encuentran (Blancas et al., 2013; Casas et al., 2015b, 2016). La población de diversas áreas del mundo, entre ellas la de la región andina, que ha sido una de las áreas de origen de la domesticación en el Nuevo Mundo, mantiene vivo su interés por incorporar nuevas espe- cies en su dieta, en su salud y otros importantes aspectos de la cultura. Tal interés permite continuar hasta el presente con actividades de domesticación, no solo continuando con la domesticación de las especies ya domesticadas y que continúan bajo tal proceso evolutivo, sino también incorporando continuamente nuevas especies silvestres, arvenses o ruderales a estos procesos. Estos pueden apreciarse en numerosos sitios de los Andes peruanos y de otros países (Casas et al., 2007, 2015b, 2016), como si la historia de la humanidad mantuviera la continuidad de procesos muy antiguos.

El conocimiento andino de la flora regional involucra un conjunto de información que permite a las poblaciones de la región hacer, analizar, aprender, calcular, interpretar y enseña los elementos del mundo que las rodean, el mundo andino, biofísico y cultural. Los pobladores de la región constantemente están poniendo a prueba sus suposiciones sobre fenómenos naturales y artificiales, experimentos para contestar sus preguntas, y prácticas que les permiten manejar sus recursos en el tiempo y en el espacio de acuerdo con sus requerimientos básicos, sus costumbres, sus deseos, sus anhelos y su curiosidad (Mujica, 2014).

Las interacciones entre los seres humanos andinos y las plantas aromáticas han llamado la atención de la autora de este capítulo, pues fueron y continúan siendo importantes elementos en diversas prácticas culturales que influyen en la vida cotidiana de las personas, en el caso estudiado, las de la región andina del Perú. El presente texto desarrolla algunas líneas sobre el tema referido, con base en experiencias de investigación realizadas en las plantas aromáticas que se usan en la zona andina del departamento de Huánuco, Perú. Se pone particular énfasis en una de las especies más significativas en esa región, "la muña" [Minthostachys mollis (Benth.) Griseb.], la cual, a su vez, representa una condición que es similar a la de numerosas especies nativas de esta región milenaria. Se iniciará este capítulo definiendo un par de términos que se consideran fundamentales al abordar el tópico del presente capítulo: (1) plantas aromáticas, se denominan aromáticas todas aquellas especies de plantas que desprenden un aroma y/o sabor intenso a los sentidos del gusto y olfato humano. Tales propiedades se deben al elevado contenido en sustancias con propiedades químicas, bioquímicas u organolépticas muy específicas, y (2) las sustancias o principios activos pueden encontrarse en las hojas, tallos, bulbos, rizomas, raíces, flores, semillas y frutos; ya sea en árboles, arbustos o plantas herbáceas.

En el presente estudio se utilizará el concepto de planta aromática, en un sentido amplio, para denominar al extenso y variado conjunto de especies botánicas que forman las plantas medicinales, aromáticas y condimentos.

\section{Antecedentes}

\section{Características de la Región Andina del Perú}

os Andes peruanos conforman la parte central de la cadena montañosa de la Cordillera de los Andes, al sur del continente americano, incluye porciones de Perú, así como de_Argentina, Chile, Bolivia, Ecuador, Colombia y Venezuela. Este macizo de montañas atraviesa 
territorio peruano de norte a sur, dando lugar a cumbres nevadas, lagos, quebradas, ríos y valles que se mezclan con la selva por el lado oriental, con los desiertos por el lado occidental, abriéndose en la parte central de la cordillera, con numerosos valles interandinos. Esta fisiografía brinda variados y frágiles hábitats, cual si fueran pisos altitudinales de diferentes tamaños, combinándose con factores abióticos climáticos, creando microclimas, algunos de ellos únicos en el planeta, los cuales favorecen la existencia de diversas especies vegetales y animales. Junto a estos paisajes, se asientan diferentes poblaciones humanas con sus culturas y costumbres, las cuales influyen desde hace miles de años, y hasta el presente, la gobernanza y el manejo de los ecosistemas andinos (Kawsaypacha, 2014). Los habitantes de esta región constantemente enfrentan diferentes condiciones ambientales muy dinámicas, continuamente cambiantes; y bajo tal escenario, los pobladores andinos no solo cultivan las plantas domesticadas, herencia de sus antepasados, sino también evalúan e incorporan a su órbita cultural nuevas especies, nativas e introducidas, con atributos favorables, principalmente desde el punto de vista alimenticio, medicinal y otros usos, con propiedades de resistencia a los factores bióticos y abióticos extremos que caracterizan los ambientes andinos. El resultado de los conocimientos, las técnicas de manejo y otras experiencias que derivan de la interacción entre las sociedades andinas y los recursos regionales se transmiten mayormente de forma oral y práctica entre los miembros de las comunidades y sus descendientes, así como con miembros de otras comunidades, tal comunicación resulta crucial en la construcción de elementos culturales y diversos rasgos que influyen en la seguridad alimentaria y el bienestar de los pueblos de la región.

El Perú cuenta con ocho regiones naturales, según la clasificación de Javier Pulgar Vidal (1981). Once ecoregiones, según Brack (1988), y posee 84 zonas de vida, de acuerdo con el Sistema de clasificación de unidades ambientales de Holdridge (ONERN, 1976). Según e Sistema Thornthwaite que maneja el Senamhi, el Perú registra 28 climas. Posee tres cuencas hidrográficas: la del Pacífico, la del Atlántico Marañón y la del Lago Titicaca. Estas zonas también cuentan con numerosos ríos, riachuelos, lagos y lagunas. La región andina es uno de los principales centros de origen y diversificación de cultivos a nivel mundial, y ello se ha identificado desde los primeros trabajos clásicos sobre el origen de las plantas cultivadas $y$ de la agricultura, y ha sido considerada como tal, de forma consistente, por los diversos autores que han desarrollado teorías sobre este tópico durante el siglo XX y hasta el presente (Vavilov, 1926, 1951).

\section{Los hábitats y las plantas aromáticas}

Las montañas andinas del Perú conforman un extraordinario mosaico de variados y numerosos hábitats, en los cuales se encuentran diversas especies de plantas aromáticas, silvestres y cultivadas. Entre los ambientes contrastantes se pueden destacar los microclimas de las quebradas, los de las cercanías de lagos, las áreas rocas y acantilados, los bosques y pastizales; asimismo, los mesoclimas causados por las montañas como barreras captadoras de la humedad que proviene del Océano Atlántico, y cuya sombra orográfica determina en buena medida la existencia de los hábitats áridos y secos de la vertiente occidental y la costa peruana, hasta los muy húmedos de la vertiente oriental que desembocan en la cuenca amazónica. En cada una de las zonas de vida mencionadas es posible encontrar diversidad de especies que conviven con sus criadores, los pobladores campesinos, principalmente quechuas y aymaras de los Andes peruanos (Torres y Parra, 2009).

El clima está relacionado con la altitud, la latitud y la cercanía a la costa desértica o a la selva húmeda. La vertiente occidental es más seca no solo por la sombra orográfica mencionada, sino porque la evaporación en los mares del Océano Pacífico es limitada debido a la presencia de la Corriente de Humboldt, la cual por provenir de la Antártida es muy fría. En la vertiente oriental la mayor humedad se asocia a la captura de los vientos húmedos del Atlántico y la cercanía a la Amazonía que nace a partir de este fenómeno (Tapia y Frías, 2000). En general, se considera que el clima andino va de subtropical a frío, con aire muy seco y tiene dos fases estacionales: una lluviosa entre noviembre y marzo, y una seca de abril a octubre. En la temporada lluviosa se pueden apreciar numerosas especies de plantas silvestres con diferentes tonalidades de verdor y algunas con llamativas flores, sobre un tapiz de pastos naturales, e rocío de la mañana, el frío de la puna, la brisa de las lagunas y la humedad de las neblinas, que cubren las cumbres. Pero cuando se visita los Andes en la época seca, nos recibe un hermoso cielo azul, con un sol radiante que contrasta con la gran diversidad de flores silvestres con una amplia riqueza de formas, colores y aromas. En todo este diverso paisaje andino, sus numerosos y únicos hábitats, se desarrollan especies de plantas aromáticas y medicinales, también diversas y únicas con marcados niveles de endemismo (véase la Figura 14.1)

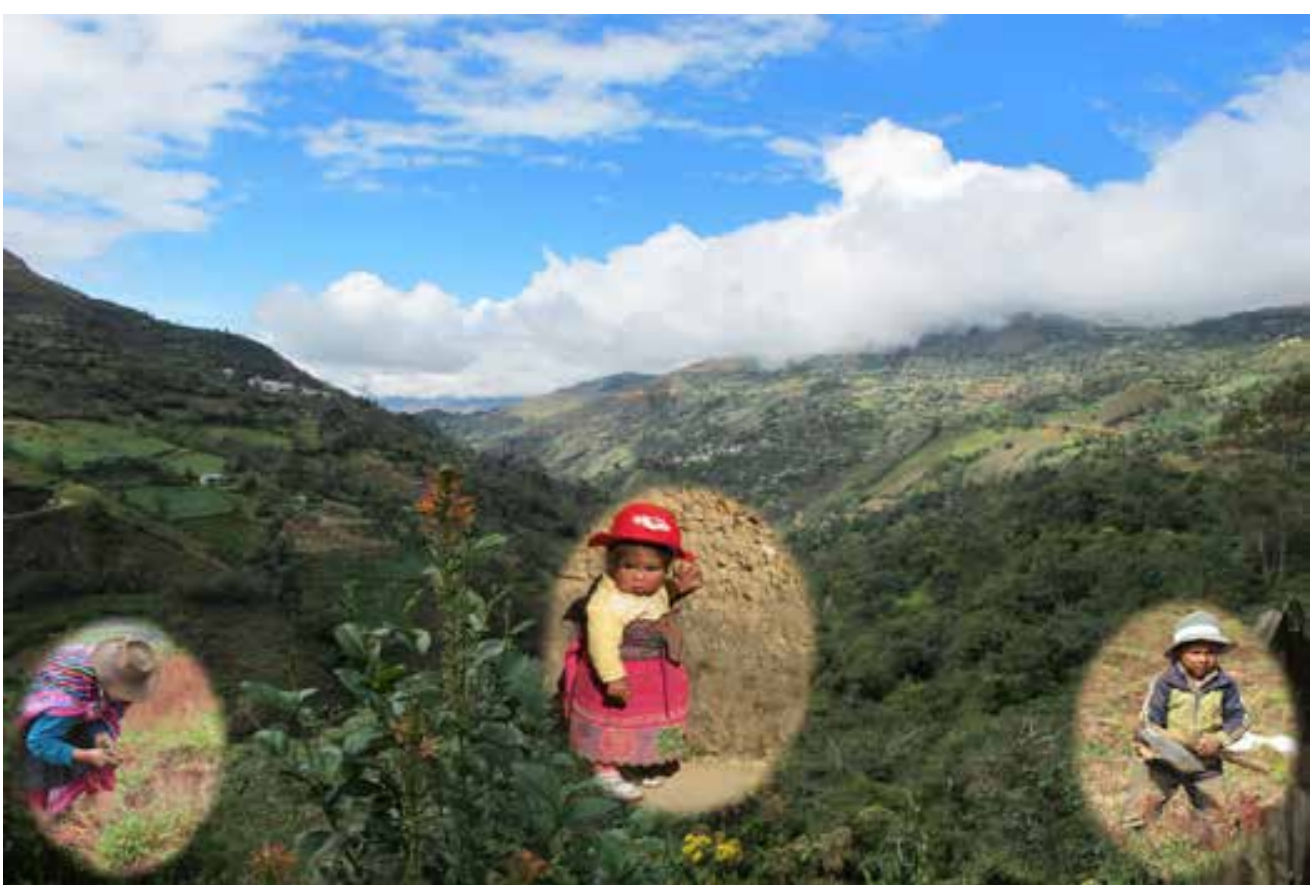

Figura 14.1.Vista panorámica del distrito de Churubamba-Huánuco y sus habitantes. 


\section{Plantas aromáticas a través de la historia del Perú}

Los datos más antiguos sobre el uso de este grupo de plantas se encontraron en momias, piezas de cerámica preinca e inca, collcas (almacenes) y registros de los cronistas sobre las plantas alimenticias que comían en el incanato. Veamos a continuación cada uno de estos contextos.

\section{Momias}

Se hallaron restos de muña (Minthostachys mollis) en una momia de 6000 años de antigüedad que se encontraba en perfecto estado de conservación en el Perú. La muña fue identificada por Cornejo Bouroncle, de acuerdo con el especialista en paleopatología, José Manuel Reverte Coma (Reverte-Coma, 2016), quien sostiene que por la calidad de conservación de sus momias, solo el método empleado por los incas tiene comparación con las técnicas de embalsamamiento practicadas para preservar las momias en Egipto.

\section{Cerámica}

Como muestra de la importancia de una planta sagrada del imperio incaico, la coca (Erythroxylum coca Lam.) es una especie que se distribuyó geográficamente no solo en el Perú, donde se ubicaba la capital del Tahuantinsuyo en la ciudad del Cuzco, sino también en otras áreas de los actuales países de Ecuador, Colombia, Bolivia, Chile y Argentina. En Ecuador se han encontrado muestras de cerámica con representaciones de personas que se encuentran sentadas sobre taburetes masticando coca. Esta planta era consumida tal como lo hacen hoy los indígenas en amplias zonas de los Andes. Claramente, la coca fue un recurso muy importante en la vida ritual y espiritual de la sociedad del incanato. En la actualidad, cuando uno visita la región Andina de Perú, es notorio el consumo de la coca en el momento del descanso (a media mañana), que es la hora de masticar coca (chacchar), para mitigar el hambre y el cansancio, al mismo tiempo de tener fuerzas para continuar el trabajo del campo (véase la Figura 14.2). Pero es muy significativo que en los rituales de pago a la tierra, los campesinos incluyen de forma prácticamente insustituible las hojas de coca. Es también revelador de su importancia ritual la "lectura de la coca" que practican en los pueblos los sabios locales para predecir el futuro, sobre todo las características del temporal, lo que les ayuda a tomar decisiones en sus prácticas agrícolas.

Una planta que se emplea como hortaliza comestible y también como planta medicinal es la caigua (Cyclanthera pedata (L). Schrad.), que fue representada en un jarrón de cerámica de la cultura mochica, en el Perú. Tal representación revela la importancia del uso y los beneficios en la alimentación y medicina de esa cultura (Figura 14.3)

\section{Collcas}

Las collcas fueron construcciones incas empleadas como almacenes, ubicadas en las laderas de los cerros, cerca de las ciudadelas incas; estas construcciones tenían un sistema adecuado de ventilación y drenaje. Allí se almacenaban los granos de maíz y también los tubérculos, pero

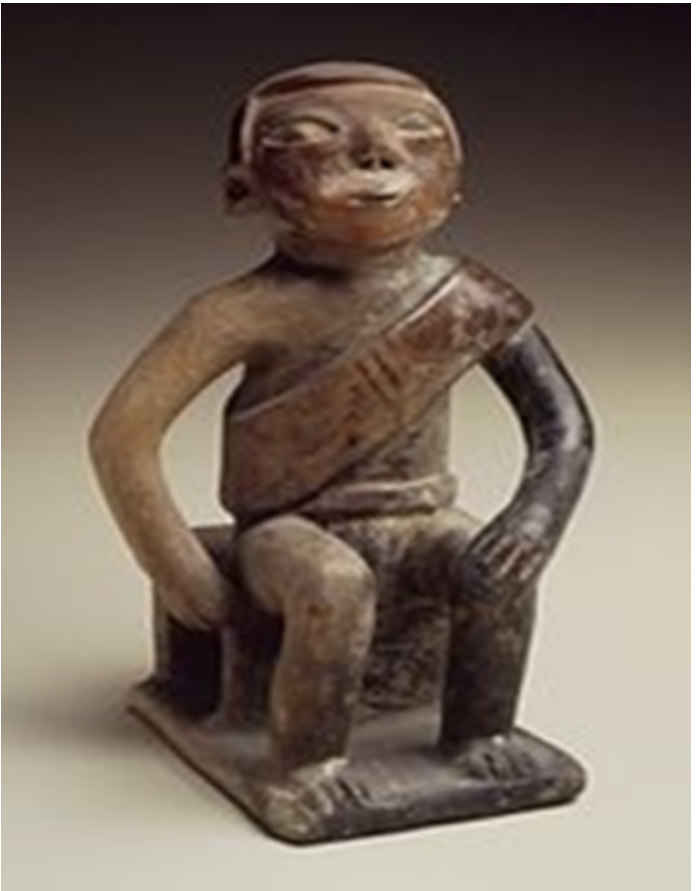

Figura 14.2. Coquero sentado en su banquillo.

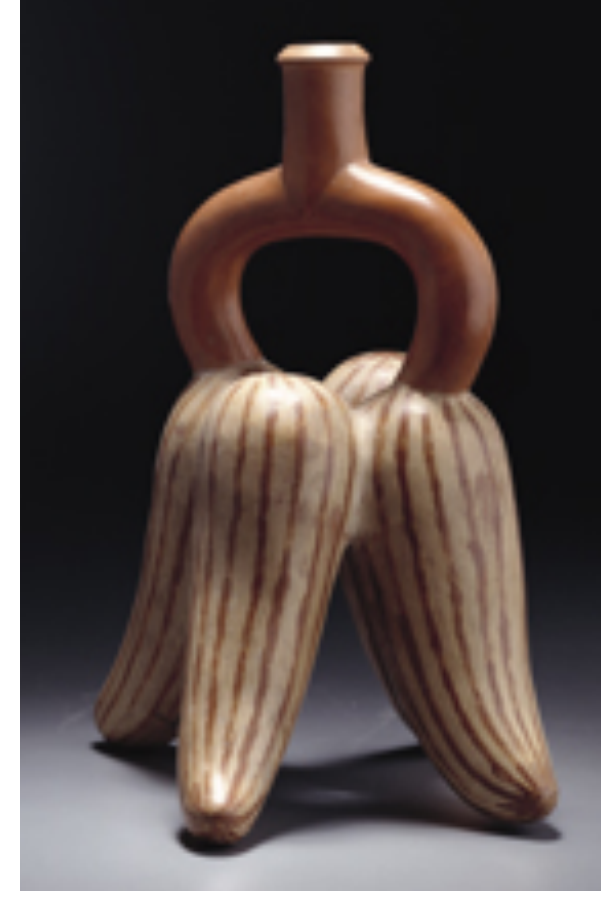

Figura 14.3. Caiguas de la Cultura Mochica. cada uno de los productos agrícolas tenía almacenes diferentes con características propias, de tal forma que los alimentos de las cosechas eran aseguradas para todo el estado del incanato. Es probable que también emplearan plantas aromáticas nativas como elementos insecticidas o fungicidas que contribuyeran a la preservación de los productos. Esta hipótesis se sustenta con base en el actual uso de la muña, como medida de control de las plagas de almacén de la papa. Esta es una práctica ampliamente extendida en las comunidades de los Andes peruanos. Del mismo modo, se ha encontrado en las collcas de Huánuco pampa (provincia de 2 de mayo, Huánuco) particular abundancia de muñas creciendo en los alrededores de las zonas donde se ubican las collcas, y según refieren los pobladores y guardianes de esta ciudadela inca, hasta la fecha la población va cada año a recoger muña de ese lugar - para guardar sus papas de consumo familiar- porque tiene una fragancia que protege de las plagas de almacén (véase la Figura 14.4).

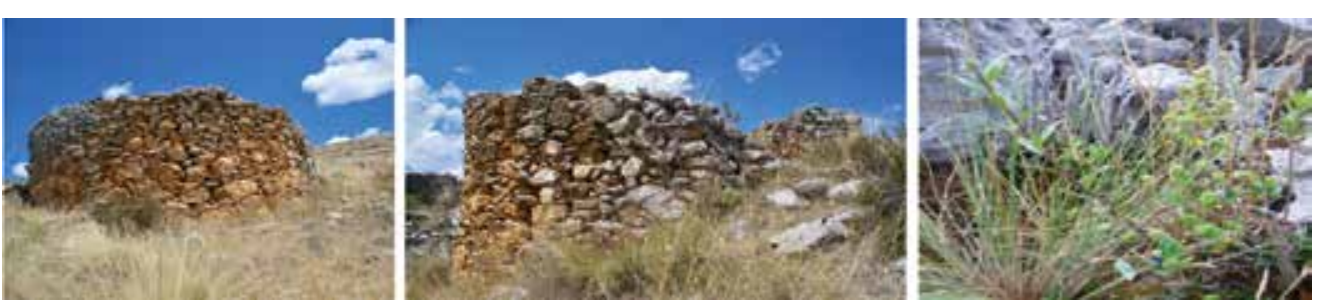

Figura 14.4. Almacenes incas de Huánuco pampa, donde se encuentran plantas de muña. 


\section{Formas de uso ritual y religioso}

En toda la zona andina del Perú se continúan realizando algunas ceremonias religiosas, como el pago a la tierra antes de la siembra, con ofrendas a la pachamama, donde no pueden faltar las hojas de coca (véase la Figura 14.5).
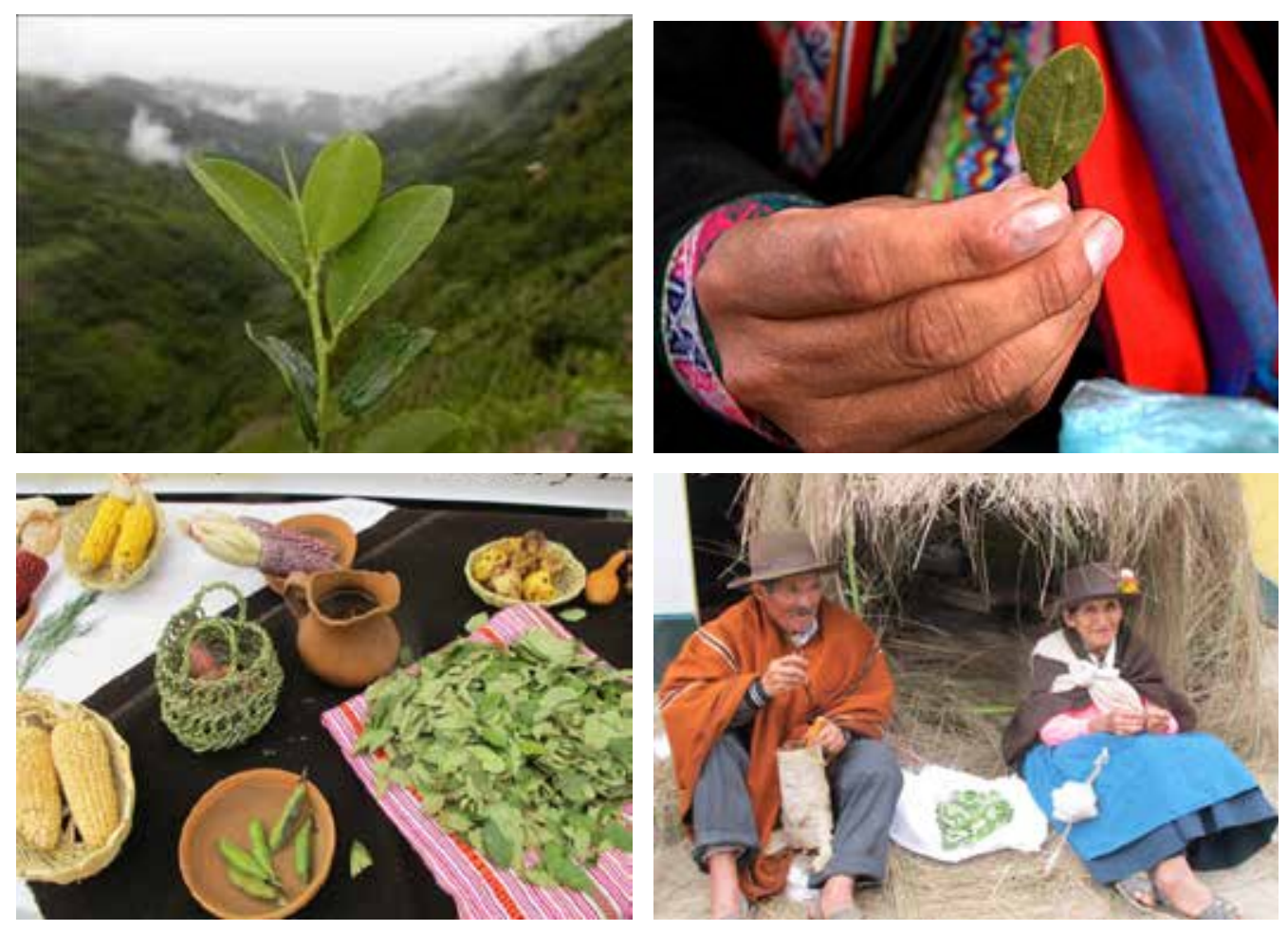

Figura 14.5. La coca (Erythroxylum coca) y usos.

Pago a la tierra con hojas de coca, antes de la siembra.

\section{Uso comestible}

Los cronistas registran que las numerosas y variadas plantas con que se alimentaban los indios del incanato recibían el nombre de «yuyos». Las comían crudas y cocidas. Antúnez de Mayolo (2011) señala que las plantas condimentarias cumplían dos funciones: dar sabor a los alimentos y mejorar las propiedades digestivas del consumidor. Las plantas que registran para este rubro son: chincho, challcallta, chijchipa, huacatay, mangacaqui, muña, masasera, paico, pichuquita, rocoto, uchu, entre las más importantes.

Las hierbas aromáticas estuvieron presentes en la preparación de las comidas antiguas andinas. Pulgar Vidal (1989), por ejemplo, registra que los pueblos andinos usaban piedras calentadas al fuego y se introducían en mates que contenían agua dulce, sal, ají y hierbas, lo que se denominaba yacu-chupe, el antepasado del "caldo verde". En la Provincia de Ambo del departamento de Huánuco se registró el siguiente testimonio sobre la preparación de un caldo muy antiguo, denominado illay. El procedimiento consiste en recoger hojas de muña, romperlas y ponerlas en un recipiente con agua fría que sacan del riachuelo o puquial, a la cual adicionan sal y ají tostado, lo acompañan con maíz tostado o cancha, así como con papas asadas.

Al analizar el nombre de esta sopa, y conociendo que todo illa tiene un procedimiento de preparación básico en común como refiere Yauri (2009), esta forma antigua de preparación del caldo verde de papas illay conduce a la hipótesis de que se trata de la forma original antigua de preparación del famoso caldo verde, uno de los platillos más típicos que en la actualidad se consume en los departamentos de la Sierra Central del Perú, especialmente en Huanuco.

\section{Importancia de las plantas aromáticas en la población de los Andes peruanos}

Las plantas aromáticas tienen importancia alimenticia, medicinal y cultural para el poblador peruano. El Perú ha aportado al mundo más de 1400 especies de plantas aromáticas y medicinales, de las cuales se conocen las propiedades curativas y usos tradicionales, según lo refiere Brack (2005). Cuando se presenta una dolencia simple, un resfrío u otra emergencia como fiebre, dolor de estómago, entre otras, las familias campesinas o pobladores andinos que viven en la ciudad recurren al botiquín verde que tienen en sus casas (huertas, hierbas secas almacenadas en algún sitio especial), en la comunidad, en el campo o con algún vecino, o en última instancia las adquieren en los mercados y herboristerías rurales y urbanas, para seleccionar una o más hierbas, según sea el caso, y aplicar los conocimientos y prácticas adquiridas para tratar tales malestares.

También, las plantas aromáticas se consideran valiosos presentes o regalos, o muestras de afecto y cariño entre amigos y parientes. Si alguien va a visitar a alguna amistad, por lo menos debe coger algunas ramas de plantas aromáticas, como la muña, pero estas no pueden ser cualquier morfotipo, debe ser uno que tiene aroma singular o diferente de los que abundan. Es este, por ejemplo, el caso de la muña con olor a toronjil, la cual se entrega a los amigos que se visitan. En otros casos se ha observado que se llevan ramas o algunas plántulas o plantas juveniles de alguna especie aromática cuyo cultivo y domesticación se está ensayando en su huerta del visitante. Esta actitud está presente en el diario vivir del poblador andino, favorecen el intercambio de experiencias de manejo, seguramente el flujo génico de los materiales que se transportan, y revelan, en otras palabras, que las plantas aromáticas mantienen una importancia cultural particular entre los pueblos andinos.

La interrelación permanente con su medio ambiente y las necesidades básicas que tien por satisfacer una familia andina, las mueven continuamente a explorar, estudiar e investiga sus recursos naturales, especialmente los fitogenéticos, de su comunidad. Los conocimientos propios y únicos, que constituyen la base de prácticas agrícolas, son compartidos, como se ilustra en los párrafos anteriores, involucrando un amplio rango de actividades que perduran y mantienen a la sociedad (Pochettino, 2007). Los productos de este proceso milenario son: 
- El conocimiento de las propiedades curativas de las plantas.

- El uso de plantas aromáticas en la alimentación como saborizantes.

- La selección y forma de empleo de plantas aromáticas como repelente de insectos.

- La selección y forma de empleo de plantas aromáticas como conservantes y/o refrigerantes.

- Selección de plantas aromáticas de uso religioso y místico.

- El manejo (in situ y ex situ), la propagación, cuidado y la eventual domesticación de numerosas especies.

\section{Uso de las plantas aromáticas}

El consumo de las plantas aromáticas gira alrededor de las principales necesidades de la familia andina y la cosmovisión campesina (Valera, 2000). En el caso de las plantas aromáticas silvestres, estas se encuentran disponibles en ciertos períodos del año, por lo tanto, su uso se relaciona con la estacionalidad de la disponibilidad espacial y temporal de la flora existente (Arias, 2009). Los principales usos de las plantas aromáticas son: alimentación, medicina, preservante y aromática, como se muestra en la Figura 14.6.

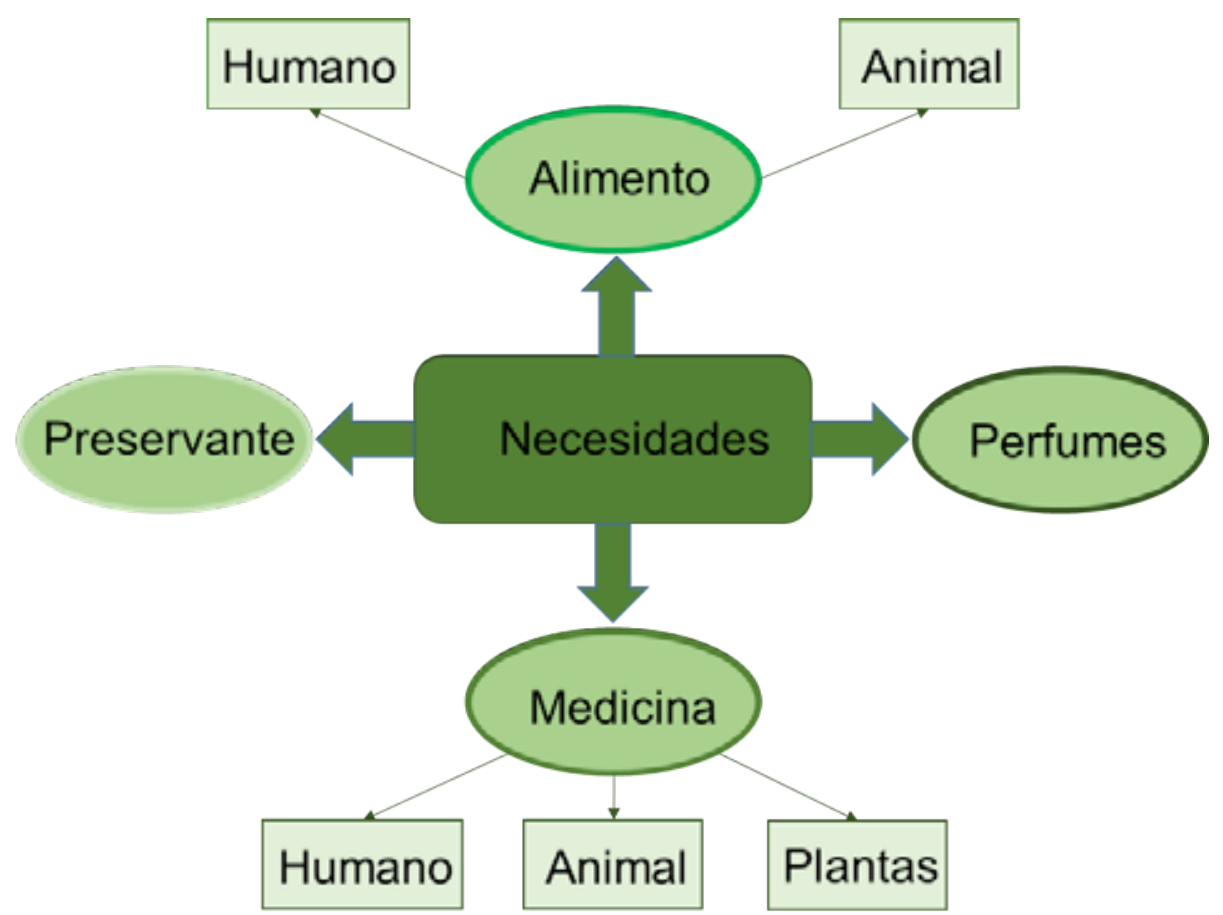

Figura 14.6. Diferentes usos de las plantas aromáticas. Fuente: Elaboración propia.
En relación con el uso, las diferentes plantas aromáticas se pueden agrupar en:

- Plantas religiosas, mágicas y rituales (asociadas a pagos y ritos andinos), el ejemplo más claro de este grupo de plantas es la coca.

- Plantas alimenticias preventivas de enfermedades.

- Plantas condimentarias o saborizantes.

- Plantas aromáticas que perfuman los espacios o las personas.

- Plantas medicinales.

- Plantas conservadoras de los productos de las cosechas.

- Plantas repelentes de insectos.

- Plantas cosméticas o usadas con el fin de embellecer los espacios y las personas.

- Un panorama de estos usos se puede apreciar en las Figuras 14.7 y 14.8.
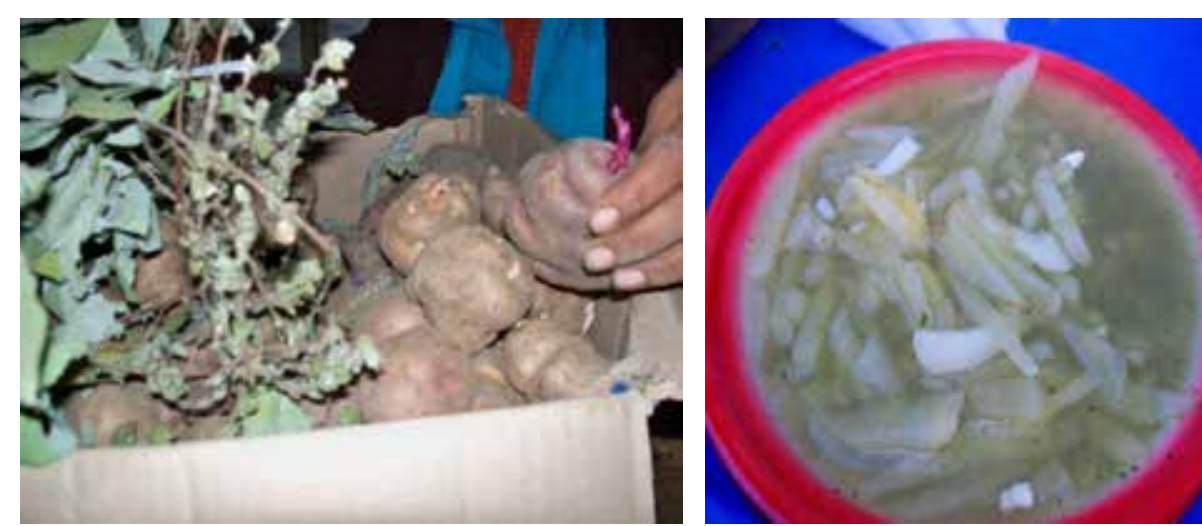

Figura 14.7. Usos de la muña en Huanuco Perú: a) hojas de muña y eucalipto para ahuyentar a las plagas de almacén, y b) muña como saborizante en la comida.

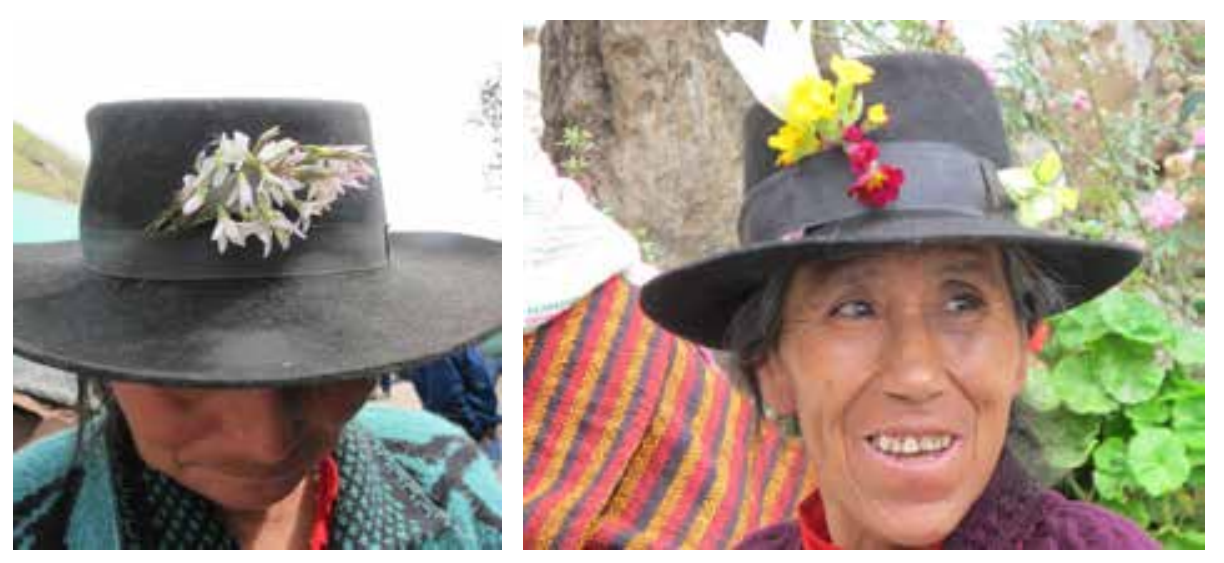

Figura 14.8. Adorno de sombreros con flores aromáticas silvestres y cultivadas. 


\section{Formas de uso que se mantienen en la región andina}

A continuación se enlistan las formas de consumo de las plantas aromáticas en la Región Andina.

En la alimentación

- Mates o infusiones

- Hojas y/o follaje fresco, picado y/o molido

- Hojas y/o follaje deshidratado

- Raíces y/o tubérculos hervidos

- Sopas

- Guisos

\section{- Mazamorras}

En la salud

- Infusiones o mates

- Macerados

- Asados

- Emplastos

- Masticados

\section{En los cultivos}

- Macerados

- Siembra junto con los cultivos principales

\section{En el almacén}

- Ramas de plantas como cama y también para cubrir los productos (tubérculos)

- Hojas en granos almacenados

\section{Diversidad de especies aromáticas nativas e introducidas en la zona andina}

Las plantas aromáticas que crecen y se cultivan en la región andina se agrupan, según su origen, en dos categorías: la primera de ellas comprende a las especies nativas de la región y la segunda a aquellas que, en su gran mayoría, fueron introducidas por los conquistadores del Perú durante los primeros años de la Colonia, o incluso plantas de más reciente introducción. Estas se han adaptado a las condiciones socioecológicas regionales y han sido adoptadas e incorporadas en la cultura, la dieta y la medicina tradicional de los pobladores andinos.

\section{Plantas nativas}

Son numerosas las plantas nativas aromáticas que crecen y se aprovechan en la región andina. La familia Asteraceae es la que presenta mayor número de especies, seguida de las de la familia Lamiaceae, como se puede apreciar en la Tabla 14.1, donde se muestran algunas de las especies más importantes.

\section{Tabla 14.1. Diversidad de especies nativas aromáticas en la zona andina}

\begin{tabular}{|c|c|c|}
\hline & Nombre cientifico & Nombre común \\
\hline Familia Asteraceae & $\begin{array}{l}\text { Tagetes elliptica Sm. } \\
\text { Tagetes foeniculacea Desf. } \\
\text { Artemisia absinthium L. } \\
\text { Senecio outberkiaeifolius } \\
\text { Senecio tephrosioides Turcz. } \\
\text { Barnadesia dombeyana Less. } \\
\text { Ambrosia arborescens Mill. } \\
\text { Ambrosia peruviana All. } \\
\text { Anthemis cotula L. } \\
\text { Baccharis lanceolata Khunt } \\
\text { Schkuhria pinnata (Lam.) Kuntze ex Thell }\end{array}$ & $\begin{array}{l}\text { chincho } \\
\text { jaccha anis } \\
\text { ajenjo. } \\
\text { wiro wiro. } \\
\text { huamanripa } \\
\text { huamanpita. } \\
\text { marco grande. } \\
\text { marco chico. } \\
\text { mariamata } \\
\text { chilca negra } \\
\text { canchalagua }\end{array}$ \\
\hline Fam. Lamiaceae & $\begin{array}{l}\text { Minthostachys mollis Griseb. } \\
\text { Stachys arvensis } L \text {. } \\
\text { Salvia formosa L' Herr. } \\
\text { Clinopodium insulare (Candargy) Govaerts } \\
\text { Clinopodium weberbaueri (Mansf.) Govaerts }\end{array}$ & $\begin{array}{l}\text { muña } \\
\text { papagora } \\
\text { salvia } \\
\text { pichiuquita } \\
\text { orégano del inca }\end{array}$ \\
\hline Fam. Verbenaceae & $\begin{array}{l}\text { Aloysia triphylla Royle } \\
\text { Verbena litoralis Kunth }\end{array}$ & $\begin{array}{l}\text { cedrón de palo } \\
\text { verbena }\end{array}$ \\
\hline Fam. Gentianaceae & $\begin{array}{l}\text { Gentianella alborosea (Gilg) Fabris } \\
\text { Gentianella thyrsoidea (Hook.) Fabris }\end{array}$ & $\begin{array}{l}\text { jicampuri. } \\
\text { japalanshaco }\end{array}$ \\
\hline Fam. Solanaceae & Cestrum auriculatum L'Hér & hierba santa \\
\hline Fam. Chenopodiaceae & Dysphania ambrosioides (L.) Mosyakin \& Clemants & cashua o paico \\
\hline Fam. Geraniaceae & $\begin{array}{l}\text { Erodium cicutarium L' Herr. } \\
\text { Pelargonium odoratissimun Ait }\end{array}$ & $\begin{array}{l}\text { aguja aguja } \\
\text { malvita de olor }\end{array}$ \\
\hline Fam. Urticaceae & Urtica urens $\mathrm{L}$. & ishanca \\
\hline Fam. Equisetaceae & Equisetum arvense $\mathrm{L}$. & cola de caballo \\
\hline Fam. Malvaceae & $\begin{array}{l}\text { Althaea officinalis L. } \\
\text { Muehlenbeckia volcanica (Benth.) Endl }\end{array}$ & $\begin{array}{l}\text { raíz altea } \\
\text { pasamullaca }\end{array}$ \\
\hline Fam. Piperaceae & Piper elongatum Vahl & matico cordoncillo \\
\hline Fam. Cucunibitaceae & Cyclanthera pedata (L.) Schrad. & caigua \\
\hline
\end{tabular}




\section{Plantas introducidas}

Las plantas aromáticas introducidas en la región andina están ampliamente distribuidas en todo el país, forman parte de sus cultivos juntamente con otras plantas aromáticas y hortalizas. La gente las cultiva no solo para el uso diario, sino para comercializarlas, por lo tanto, las parcelas de estas especies son grandes en comparación con aquellas en las que se propagan especies nativas. Las plantas introducidas más utilizadas son las que se muestran en la Tabla 14.2.

Tabla 14.2. Especies aromáticas introducidas

\begin{aligned} & Nombre cientifico Nombre común \\ & Origanum vulgare $\mathrm{L}$. orégano \\ & Melissa officinalis $\mathrm{L}$. toronjil \\ & Mentha viridis $(\mathrm{L}$.) $\mathrm{L}$. hierbabuena \\ & \hline Chamomilla recutita $(\mathrm{L}$.$) Rauschert$ manzanilla \\ & Foeniculum vulgare Mill. hinojo \\ & \hline Pimpinella anisum $\mathrm{L}$ anís \\ & \hline\end{aligned}

\section{Distribución altitudinal en los Andes peruanos}

En la Región Andina las microcuencas son áreas naturales de delimitación de unidades geográficas, las cuales se prestan para estudiar las regiones como unidades ecosistémicas. Estas unidades son irrigadas por las fuentes de agua (lagunas) que se ubican en la cabecera (la parte alta de la cuenca) de la zona; considerando las gradientes altitudinales que existen y los paisajes que generan. Es usual que los pobladores locales, los académicos, los miembros de ONG e incluso los tomadores de decisiones gubernamentales dividan las cuencas transversalmente en tres grandes franjas denominadas: parte alta, media y baja (Díaz, 2000). Cada una de ellas, tiene paisajes y ambientes similares; por tanto, la flora que habita en ellas también lo es. A continuación se muestra un ejemplo de la distribución altitudinal de plantas aromáticas en la microcuenca de Mito, Huánuco, en la tabla 14.3

La parte alta de la microcuenca (de 3200 a más de $4000 \mathrm{~m}$ de altitud) presenta relieves empinados a un tanto suaves en los límites con el páramo. Se encuentra en ese piso la presencia de pastizales naturales (frecuentemente predominando especies de los géneros Stipa, Festuca y Muhlenbergia), así como pequeños relictos de bosques de queñuales (Polylepis spp.). La zona media (entre 3200 y $2500 \mathrm{~m}$ de altitud) muestra un relieve suave y plano a inclinado, la vegetación primaria ha sido sustituida por cultivos. En la zona baja (2500 a 2000m de altitud) el relieve es predominantemente empinado, hay presencia de especies arbustivas xerofíticas y vegetación estacional.
Tabla 14.3. Distribución altitudinal de las plantas aromáticas en la microcuenca de Mito. Parte de la microcuenca donde se les encuentra: A: Alta, B: baja, M:Media

$\begin{array}{cc}\text { Nombre científico Nombre vulgar } & \begin{array}{c}\text { Parte de } \\ \text { la microcuenca }\end{array}\end{array}$

FAM. LAMIACEAE

Origanum vulgare L.

orégano

$\mathrm{A}, \mathrm{M}, \mathrm{B}$

Melissa officinalis L.

toronjil.

$A, M, B$

Mentha viridis $(\mathrm{L}.) \mathrm{L}$

Minthostachys mollis Griseb.

hierbabuena.

$A, M, B$

Mentha piperita L.

muña.

$A, M$

Stachys arvensis $\mathrm{L}$.

Salvia formosa L' Herr.

Clinopodium insulare (Candargy) Govaerts

menta

A,M,B

papagora

$A, M$

salvia

$M$

Clinopodium weberbaueri (Mansf.) Govaerts

pichiuquita.

A,M

\section{FAM. ASTERACEAE}

Tagetes elliptica Sm.

orégano del inca

Tagetes foeniculacea Poepp.

Chamomilla recutita (L.) Rauschert

chincho

$\mathrm{A}, \mathrm{M}, \mathrm{B}$

jaccha anis

$\mathrm{A}, \mathrm{M}, \mathrm{B}$

Artemisia absinthium L.

manzanilla.

$A, M, B$

Senecio outberkiaeifolius

Senecio tephrosioides Turcz.

ajenjo.

$\mathrm{A}, \mathrm{M}$

wiro wiro.

$A, M$

Perezia multiflora (Bonpl.) Less

huamanripa

$A, M$

Barnadesia dombeyana Less.

Ambrosia arborescens Mill.

escorzonera.

A,M

huamanpita.

A,M

Ambrosia peruviana Will

marco grande.

$\mathrm{A}, \mathrm{M}$

Anthemis cotula L.

marco chico.

$M$

Baccharis lanceolata Khunt

mariamata

A,M

chilca negra

A,M

FAM. APIACEAE

Foeniculum vulgare Mill.

hinojo

$A, M, B$

Pimpinella anisum L

anís

$M, B$ 


\section{Criterios de clasificación campesina de las plantas aromáticas}

El campesino toma criterios simples, comúnmente duales y antagónicos, para clasificar a las plantas, ya sea dentro de una misma especie, como dentro de variedades de plantas aromáticas, aunque también entre algunos de los yuyos comestibles (Pestalozzi, 1998; Yauri, 2009). Estas dualidades pueden ser: 1) genérico: hembra y macho, 2) color del tallo o follaje: negro y blanco; 3) altitud o ubicación en la cuenca: bajera, que se encuentra en el valle interandino y de altura o puna; 4) olor: fuerte y suave; 5) grosor de las hojas: gruesas y delgadas, y 6) tamaño de hojas: grande y pequeño.

Es pertinente aclarar que el criterio para clasificar a las plantas con un criterio genérico (macho y hembra) no tiene ninguna relación con la sexualidad de la planta, sino más bien con características morfológicas que permiten diferenciar variedades intraespecíficas y que involucran otros elementos de la visión andina del mundo "todo en la naturaleza tiene su pareja", es decir, una hembra y un macho. Por lo general, las plantas hembras deben tener las siguientes características: 1) color de follaje: verde claro; 2) forma de hojas: redondeadas o formas similares; 3) color de tallo: tonos claros, y 4) olor y textura: suave. Es pertinente señalar que formas de clasificación varietal y criterios similares fueron reportados también entre pueblos nahuas y mixtecos de región mesoamericana por Casas et al. $(1996,2007)$, así como por Blancas et al. (2013).

Puede apreciarse, quizá, que estas características de belleza y delicadeza permiten a los pobladores andinos establecer una relación con lo femenino, y por ello las plantas se designan como "hembras", estas plantas pueden compartir el mismo hábitat con los "machos" en algunos casos, pero en otros se ubican en altitudes ligeramente distintas.

Por otra parte, las plantas denominadas "machos" se caracterizan por tener las siguientes características: 1) color de follaje: verde oscuro o purpureo: 2) forma de hojas: alargadas; 3) color de tallo: con tonos oscuros, y 4 ) olor: fuerte. De manera similar al grupo de plantas descritas en el párrafo anterior, estos atributos se relacionan con la rudeza, la fortaleza, la aspereza de los hombres. Tanto las variedades hembras como machos pueden tener usos diferenciales $y$ específicos. Por ejemplo, en el tratamiento de algunas enfermedades, los campesinos refieren que se necesita una planta macho de una determinada especie, debido al aroma que emite. En algunos casos se emplean los dos morfotipos y en otros uno solo, pero si por alguna razón es difícil conseguir el indicado, se puede utilizar el alternativo si es que este se encuentra a la mano. Los curanderos y médicos naturistas de los Andes son exigentes en seleccionar sus diferentes morfotipos para el tratamiento de las enfermedades y malestares, lo mismo que para ahuyentar plagas y enfermedades de sus animales y plantas. En Mesoamérica, Casas et al. $(1996,2007)$ y Blancas et al. (2013) muestran que en algunas especies de plantas comestibles estas diferencias morfotípicas de variedades intraespecíficas involucran procesos de selección artificial y eventualmente procesos de domesticación

Hay especies cuyo valor comercial es diferenciado en el mercado, de acuerdo con las bondades que representa su condición varietal. Por ejemplo, en el caso de la "flor de arena"(Clinopodium revolutum (Ruiz \& Pav.) Govaerts), la gente paga dos veces más por las plantas

hembras, las cuales crecen a mayor altitud, que por las plantas machos; pues la variedad hembra es más efectiva en la aromatización del ambiente, en la fijación del aroma, de los aceites esenciales propios de la variedad.

A continuación se mostrarán algunos ejemplos de especies aromáticas con sus respectivos morfotipos, características morfológicas y usos.

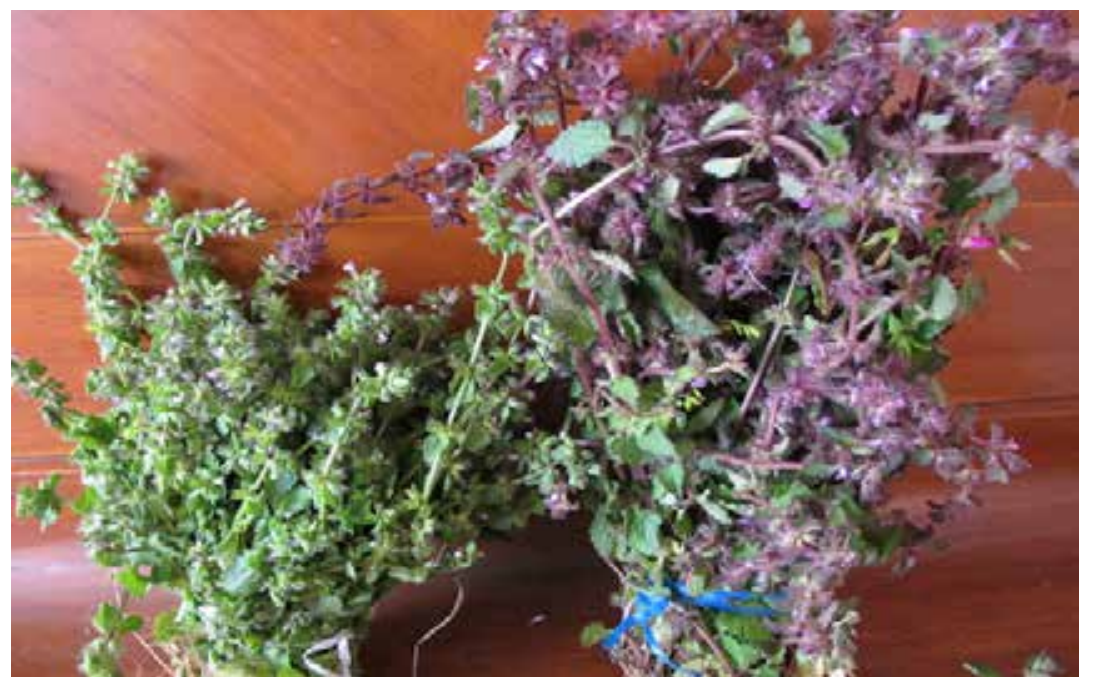

Figura 14.9. Papagora (Stachys arvensis L.) hembra color verde, y macho color púrpura.

Tabla 14.4. Diferencias entre individuos o morfotipos de Minthostachys mollis

Características de muñas blancas y negras, diferenciadas por mujeres campesinas

Muña blanca o yuraj muña Muña negra o yana muña

•Muña hembra

- Crece mayormente en la orilla de los ríos -Crece en la parte baja

- Hojas más anchas

- Hojas y tallos blancos

-Hojas lisas, brillosas y florean poco

-Hojas y tallos verdes

-Hojas sencillas, suaves

-Tallos delgados, verdes

- Tallos y guías blancas

- Al secarse la muña el tallo es verde

-No tiene mucho olor
•Muña macho

- Crece en la parte alta

- Hojas largas

-Hojas y tallos negros

- Hojas toscas.

- Hojas ásperas de color verde oscuro

Tienen hojas dobles o gruesas

-Venas pronunciadas en las hojas

- Tallo negro

-Tallo grueso

- Tallos y guías negras

-Tienen mucha flor

- Al secarse sus hojas son negras

-Tiene olor fuerte 

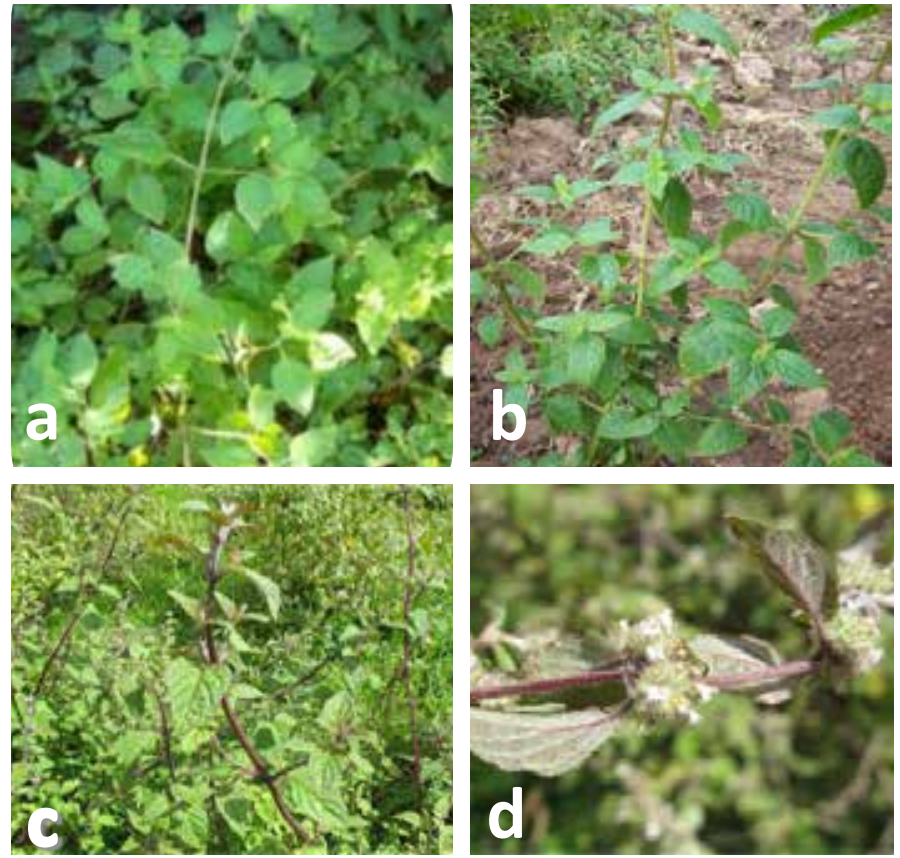

Figura 14.10. Características de muñas blancas y negras: a y b) yuraj muña o muña blanca (Minthostachys mollis); c y d) yana muña o muña negra (Minthostachys mollis).

\section{Tabla 5. Diferencias en el uso de individuos o morfotipos de Minthostachys mollis.}

Usos de las muñas blanca y negra, según mujeres campesinas

Muña blanca o hembra

Muña negra o macho

·Caldo verde (papas, sal y hierbas surtidas, agua) • Bronconeumonía

-Caldo de papas

-Comida

- Para almacenar papas

- Para caldo de cordero

- Para crema de habas

- Jacha caldo(caldo de hierbas)

•"yacu caldo" (papa, agua, sal y muña)
Bronconeumon

- Para el aire

- Para guardar papas

- Para la tos

- Para la gripe

- Para guardar papa, oca, mashua

-Se usa para remedio.

- Para la próstata y gastritis.

-Para la fiebre con meados en frotación

-Frotación

Frío

-Para desparasitar los ganados

- Para hacer baños

-Para almacenar maíz
Tabla 6. Diferencias entre individuos o morfotipos de Tagetes elliptica

\begin{tabular}{rcc} 
Características & Chincho huacatay & Chincho chincho \\
Género & hembra & macho \\
\hline Color de follaje & blanco o verde claro & negro o verde oscuro \\
\hline Olor & suave & fuerte a pachamanca \\
\hline Tamaño de hojas & pequeñas & grandes \\
\hline Color de flor & amarillo claro & amarillo intenso \\
\hline Uso & ají, condimento & pachamanca \\
\hline
\end{tabular}
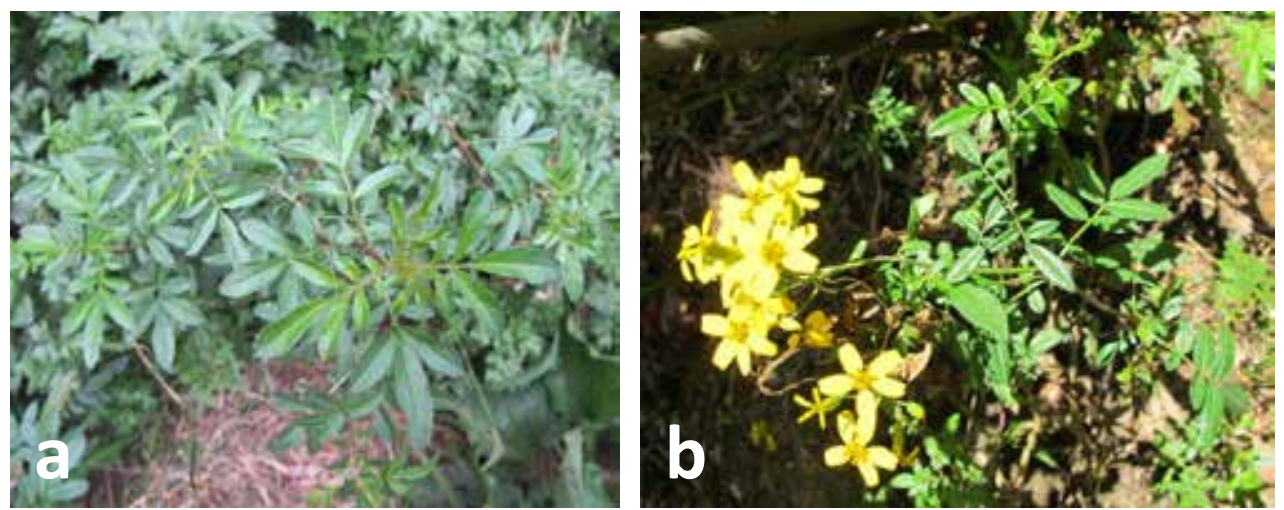

Figura 14.11. Características morfológicas de los chinchos hembra y macho: a) chincho hembra y b) chincho macho.

La pacha muña presenta dos clases, las dos son lamiaceas, pero diferentes especies, como se puede apreciar en la Figura 14.12
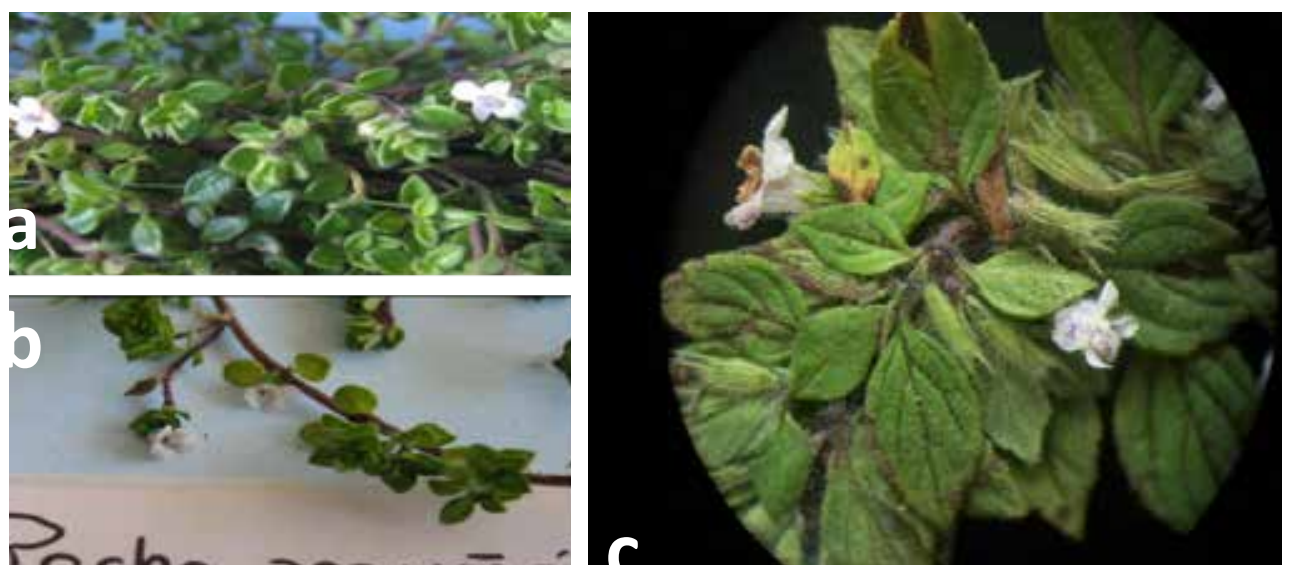

Figura 14.12. Diferentes especies de pacha muña: a y b) pacha muña hembra (Clinopodium nubigenum (Kunth) Kuntze, y c) pacha muña macho (Minthostachys sp.). 
Analizando estos ejemplos en la región de Huánuco, se puede comprender cómo en un ambiente local de nuestro país, y por ende de la región andina, las plantas tienen origen divino ligado a lo femenino, como señala Yauri (2009).

\section{Domesticación y manejo tradicional de especies aromáticas}

La domesticación de plantas cultivadas en la Región Andina se remonta a miles de años atrás, cuando los primeros habitantes de ésta área geográfica seleccionaban las plantas silvestres en los pisos ecológicos de los valles interandinos y vertientes orientales de los Andes, escalando posteriormente hacia los lugares más altos de las montañas (Brack, 2003; Tapia y Frías, 2007). Todo el proceso acumulativo de especies y variedades de estas como producto de la domesticación de plantas y animales en la región andina estuvo vinculado a una organización cultural basada en el respeto a los ecosistemas del entorno y a los cambios que podrían causar sus actividades. Ello permitió el desarrollo de una relación de mutualismo entre las poblaciones humanas, vegetales y animales (Brush, 2004; Tapia y Frías, 2007; Medina, 2011).

No se han encontrado ancestros silvestres bien definidos de las especies de plantas medicinales andinas, incluyendo el caso de la coca. Ello ha conducido a algunos autores a sostener que no hubo domesticación de plantas medicinales. Sin embargo, esta aseveración no puede sostenerse fácilmente, pues es un hecho que la coca fue domesticada y que en la actualidad la percepción de variedades intraespecíficas que se han descrito en párrafos anteriores involucran mecanismos de selección artificial y de domesticación que no han sido suficientemente investigados. En un alto porcentaje, las plantas medicinales de la región son endémicas. Las plantas que son llevadas a la huerta del agricultor han recibido una selección desde la recolección de semillas o plántulas o plantas juveniles en función de las características del follaje, efectividad medicinal, aromas y otras propiedades. No han sido seleccionadas necesariamente en función de sus componentes aromáticos, aunque debe investigarse con mayor detalle la naturaleza de la diferenciación aromática de plantas hembra y macho en función de sus compuestos químicos y/o la concentración de estos en sus tejidos.

La parte que se consume es la que representa mayor valor en los procesos de manejo, selección artificial, y domesticación. El interés por una especie silvestre generalmente lleva al campesino a las siguientes interrogantes: 1) ¿Dónde crece la planta? (su hábitat); 2) ¿Cómo crece? (hábito de crecimiento y forma de propagación); 3) ¿Cuáles son las características y atributos de sus flores y frutos? (características morfológicas), y 4) ¿En qué fechas del año producen mayormente hojas, flores, fruto y "comida" o medicina? (aspectos fenológicos)

Las observaciones detalladas, por períodos de tiempo largo y continuo permiten responde las interrogantes, y tales respuestas resultan clave para entender las particularidades del manejo y los mecanismos que involucra el proceso de domesticación. Las plantas seleccionadas para su consumo, y por ende para su manejo y eventual domesticación, pasan generalmente por los siguientes lugares del territorio campesino:
Monte $\longrightarrow$ Huerta $\longrightarrow$ Chacra

Los factores que se consideran o evalúan para el cultivo de una especie aromática son:

- La accesibilidad (incluyendo la lejanía o cercanía de los sitios donde se obtienen, lo abrupto del terreno o de los árboles, cuando se trata de plantas epífitas, para llegar a ellas, entre otros aspectos).

- La frecuencia de uso

- El tamaño de las poblaciones silvestres, su distribución y abundancia

- La demanda en el mercado

\section{Manejo tradicional de especies aromáticas (manejo de poblaciones silvestres)}

Las especies silvestres son manejadas tradicionalmente de dos formas: (1) "sujetas a crianza" en la huerta familiar, y (2) recolectadas en el campo.

\section{Las plantas silvestres}

"sometidas a crianza" en la huerta familiar

Las plantas de mayor uso y valor cultural son sometidas a "crianza" en lugares adjuntos o cercanos a la casa, con el propósito de que sean de fácil accesibilidad a la familia; estos lugares tienen diferentes denominaciones: huerta, corralón y/o canchón. Las huertas familiares en las diferentes casas, son las farmacias naturales o despensas hortícolas y frutícolas; en ellas se encuentran plantas aromáticas y/o medicinales, algunas hortalizas o hierbas que se emplean para las ensaladas, sopas o aderezo, también algunos árboles frutales nativos. En los huertos se desarrollan conocimientos para obtener medios de vida, empleando la diversidad vegetal a través de las especies silvestres y domesticadas (Valera, 2000).

os ensayos de manejo y las primeras etapas de selección artificial y del proceso de domesticación de las especies aromáticas y medicinales tienen lugar en la huerta familiar, luego pasan al campo adyacente a la casa. Por lo tanto, la huerta también funciona como un laboratorio de investigación, y las prácticas que se llevan a cabo en él involucran secuencias de actividades frecuentemente con el siguiente orden: adaptación de las especies de los ambientes silvestres a los hábitats antropogénicos, identificación de la o las formas de propagación (sexual y vegetativa), cultivo (propagación deliberada para incrementar la abundancia de individuos), cuidados y manejo fitosanitario y cultivo a mayor escala, capaz de satisfacer demanda comercial; como se aprecia en la Figura 14.13

El proceso de adaptación es el paso básico y crucial en el proceso de manejo y eventual domesticación. Cuando la gente trae una planta silvestre a la huerta generalmente no la colocan en cualquier lugar, ellos observan si el suelo donde crece es rico o no en materia orgánica, si requiere de alta humedad, si crece en la sombra o en áreas abiertas, en fin, todas las necesidades básicas de la planta son considerada, antes de plantarlas en la huerta o en las cercanías de la casa. Ade- 
más, las protegen de los animales domésticos. Luego que ven que tienen éxito en la sobrevivencia en el nuevo hábitat, pasan a la siguiente etapa del manejo que consiste en determinar las formas de propagación y cuidados para incrementar su supervivencia. Esta fase involucra la observación de numerosas plantas silvestres en el campo y también comparando la planta manejada con otras plantas similares o que pertenecen a la misma familia taxonómica (no siempre es factible este hecho en el contexto tradicional, pero los científicos logran establecer tal asociación).
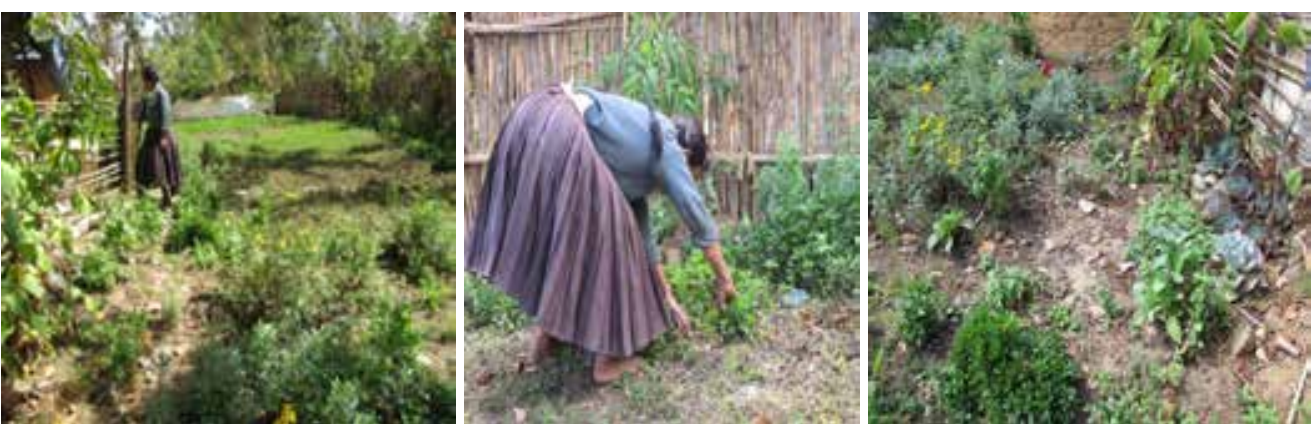

Figura 14.13. Huerta familiar en la localidad de Malconga, Huánuco.

Los campesinos "curiosos", como denominan a aquellos que gustan o tienen interés por la investigación y experimentación tradicional, realizan una serie de ensayos de formas de propagación de las plantas en las especies de su interés hasta lograr su objetivo; por lo tanto, os huertos constituyen centros de experimentación en el proceso de manejo de plantas que eventualmente pueden desembocar en procesos de domesticación y adaptación de las plantas aromáticas (Valera, 2000)

En el proceso de domesticación participan todos los miembros de la familia, y también familiares y vecinos, intercambiando sus experiencias. La domesticación se convierte entonces en una experiencia de aprendizaje y práctica colectiva más que una creación individual. Algunas plantas domesticadas son herencia de sus antepasados y las crían con cariño y cuidado. Del huerto salen en forma progresiva a parcelas más grandes. Las especies que tienen acogida en el mercado, por tanto, ya cuentan con un buen manejo agronómico para su propagación comercial (Valera, 2000).

\section{Plantas recolectadas en el campo}

as poblaciones silvestres que se encuentran en áreas extensas, ya sean perennes o estacionarias, son recolectadas. Estas plantas aromáticas se distribuyen en diferentes hábitats o microclimas de los Andes, los campesinos conocen y ubican a cada una de ellas, además, saben de su fenología. La recolecta de estas especies se hace siguiendo las recomendaciones de las personas "expertas" o "las que saben cómo recoger para ser usadas y comercializadas". La recolección para uso de la familia la hacen con cuidado y tomando en cuenta las características de los morfotipos y los usos específicos que tiene cada una de ellas; mientras que la recolecta para vender en los mercados no respeta estas diferencias, todo es mezclado y comercializado como un solo morfotipo. En los lugares cercanos a la ciudad se recolectan as plantas aromáticas silvestres y se venden en fresco, por manojos o atados; mientras que, en lugares muy distantes, las plantas aromáticas se recolectan y se secan, para ser comercializados deshidratados y por kilos, como se observa en la Figura 14.14
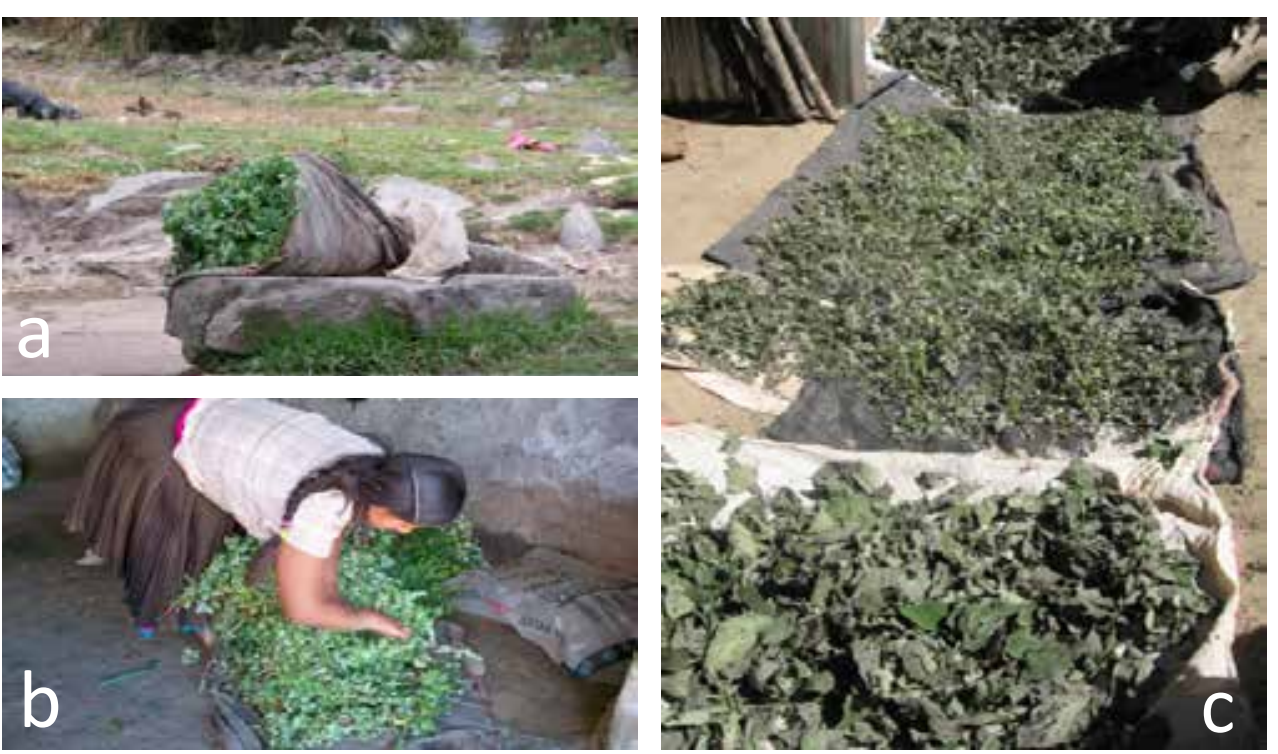

Figura 14.14. a y b) recolecta de muña para ser comercializada, y c) hojas de muña secadas al sol.

En la acción recíproca entre los productos de la chacra y la cocina nacen los diferentes platos de comida, buscando solucionar la dieta de su familia, como se puede apreciar en la Figura 14.15 que se muestra a continuación.

Sobre la base del conocimiento adquirido, los pobladores andinos desarrollan otras aplicaciones o experimentos para la salud y también para la alimentación. En este proceso es común que la gente trate de contestar interrogantes como las que siguen:

- ¿Qué parte de la planta tiene más aroma o dónde se encuentra su "remedio"?

- ¿Cuál es la forma más adecuada de usar esta planta?

- ¿Si su aroma se parece a una planta conocida, entonces esta, también curará enfermedades o dolencias similares?

- ¿Si junto varias plantas de aroma similar sería más fuerte su poder curativo?

- ¿Cómo se clasifica esta planta, como caliente o fresca?

- ¿Esta planta puede bajar la fiebre?

- ¿Es probable que el aroma de esta planta ahuyente o mate a la plaga y/o enfermedad?

- ¿Si mi ganado come esta planta, y le hace bien a su barriga, entonces a mí también me puede hacer bien?

- ¿Si esta planta cura tal enfermedad a mi hijo, también puede curar a mi animal? 


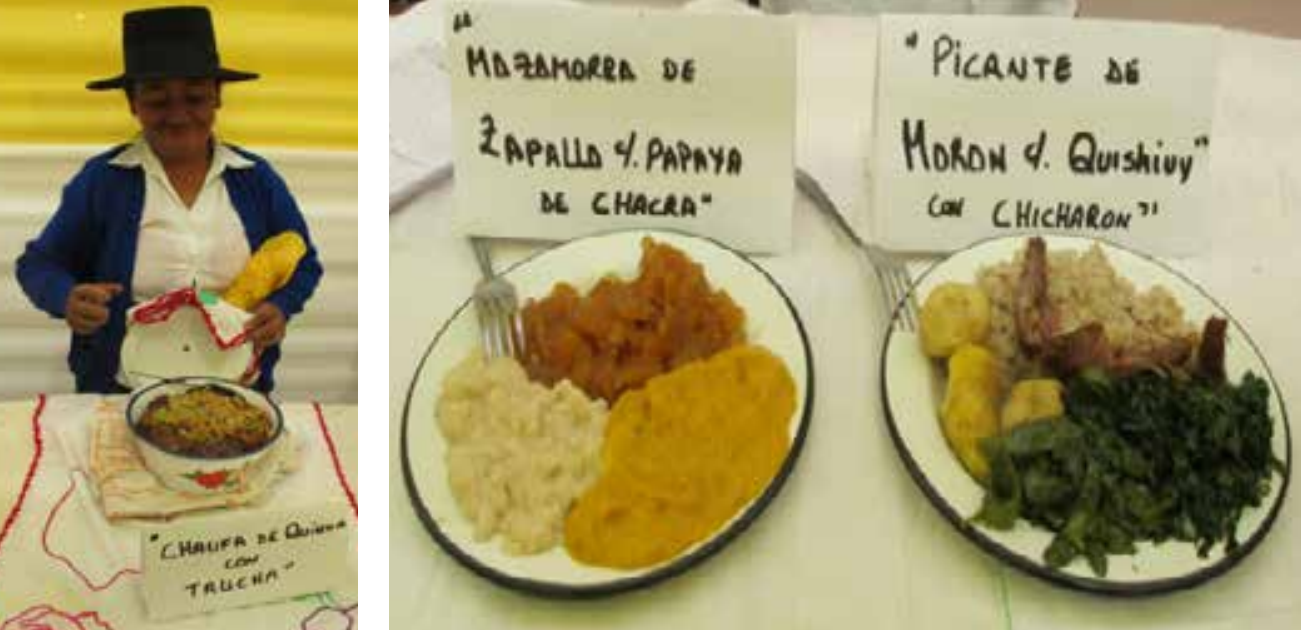

Figura 14.15. Presentación de potajes preparados con productos nativos de la zona y sazonados con hierbas del lugar, presentados en ferias locales.

Las respuestas a estas preguntas son el resultado de muchos años de experimentos de pruebas y errores, éxitos y fracasos, que realizan los campesinos; luego son transmitidos a su descendencia de forma oral y práctica, los mismos que hoy conocemos. Estas actividades son continuas en el tiempo y espacio de la región andina, ya que cada día se presentan nuevos escenarios climáticos, enfermedades, personas conocedoras que mueren y son pocos los que desean continuar con estos conocimientos. Existe una influencia muy fuerte de la cultura occidental, al igual que el fenómeno de la migración a las ciudades por parte de los jóvenes, que hacen peligrar todo este conocimiento y trabajo de domesticación y manejo de las especies y ambientes.

Las formas de manejo de las plantas aromáticas silvestres, en las tres zonas altitudinales de las microcuencas de los Andes, siguen los patrones que se muestran en la Tabla 14.7.

\section{Domesticación de algunas especies nativas}

Se han observado en pocos campos de agricultores de la región de Huánuco algunos procesos de manejo y cultivo bajo distintos niveles de intensidad. Algunos se encuentran en las fases iniciales, otros en etapas avanzadas, más simples o más complejos, respectivamente; como es el caso de las especies Tagetes elliptica (chincho), Tagetes minuta (huacatay), Tagetes foeniculacea (jacha anís), Stachys arvensis (papagora) y Anthemis cotula (mariamata). Estas especies ya están instaladas en campos de cultivo comercial a pequeña escala, con buenas características de follaje y respuesta al corte o poda.

Un caso especial de domesticación que involucra el cultivo y selección artificial de los fenotipos con características más apreciables es el de Minthostachys mollis (muña), trabajado por docentes de la Escuela Académico Profesional de Agronomía de la Universidad Naciona Hermilio Valdizán. El proceso desarrollado se detalla en el siguiente apartado.
Tabla 14.7. Formas de manejo de las plantas aromáticas en el ande peruano.

\begin{tabular}{cccc} 
Zonas altitudinales & \multicolumn{2}{c}{ Formas de manejo de las plantas aromáticas } \\
\hline $\begin{array}{c}\text { Baja } \\
(1500 \text { a } 2500 \mathrm{~m})\end{array}$ & $\begin{array}{c}\text { Recolección en lugares cono- } \\
\text { cidos (fuentes de agua, bordes } \\
\text { de chacra y dentro de ellos) }\end{array}$ & Cultivo en la huerta & $\begin{array}{c}\text { Cultivo en la chacra } \\
\text { con fines comerciales }\end{array}$ \\
\hline $\begin{array}{c}\text { Media } \\
(2500-3500 \mathrm{~m})\end{array}$ & $\begin{array}{c}\text { Recolección en diferentes } \\
\text { lugares(monte o bosque } \\
\text { y campos de cultivo) }\end{array}$ & Cultivo en la huerta. & $\begin{array}{c}\text { Cultivo en pequeñas } \\
\text { parcelas o en asocia- } \\
\text { ción con otros cultivos }\end{array}$ \\
\hline $\begin{array}{c}\text { Alta } \\
\text { (más de } 3500 \mathrm{~m})\end{array}$ & $\begin{array}{c}\text { Recolección en mayor grado. } \\
\text { Manejo incipiente (protección) }\end{array}$ & Cultivo en la huerta y/o cerca de la vivienda \\
\hline
\end{tabular}

\section{entre poblaciones de Lamiaceae en Huánuco}

Una de las especies aromáticas ampliamente difundida y distribuida en la región de Huá nuco es la muña y otras especies del género Minthostachys. Las especies aromáticas de Minthostachys y algunas otras lamiáceas emparentadas son todas conocidas en la región como muñas.

Las muñas se encuentran tanto en la vegetación natural como en sitios perturbados del paisaje cultivado. Schmidt-Lebuhn consideró que el aislamiento reproductivo es muy débil en el grupo, un hecho que se confirmó con datos moleculares (Schmidt-Lebuhn, 2008). El autor referido considera que existe un alto flujo genético entre las poblaciones regionales y que un número considerable de poblaciones probablemente son híbridos, no solo entre taxa de Minthostachys, sino también con algunos géneros de Lamiaceae emparentados, como es el caso del género Clinopodium

En la región de Huánuco se encontraron tres especies del género Minthostachys y un posible híbrido: M. mollis, con tres variedades: mollis, mandoniana e hybrida, así como las especies $M$. latifolia, $M$. spicata y $M$. sp. El mayor número de especies (tres) se encontró en la provincia de Pachitea, en altitudes entre 1832 hasta $3644 \mathrm{~m}$ de altitud. El taxón más ampliamente distribuido en el plano altitudinal es $M$. mollis var. mollis, ya conocida de la región. Las demás variedades de $M$. mollis y las especies $M$. latifolia, $M$. spicata y $M$. sp. presentaron distribuciones altitudinales más restringidas.

La distribución de las variedades de $M$. mollis se traslapa casi por completo; en el campo se encontraron a menudo lado a lado. M. mollis var. hybrida se limitó al valle del río Huallaga (Tello, 2011). 


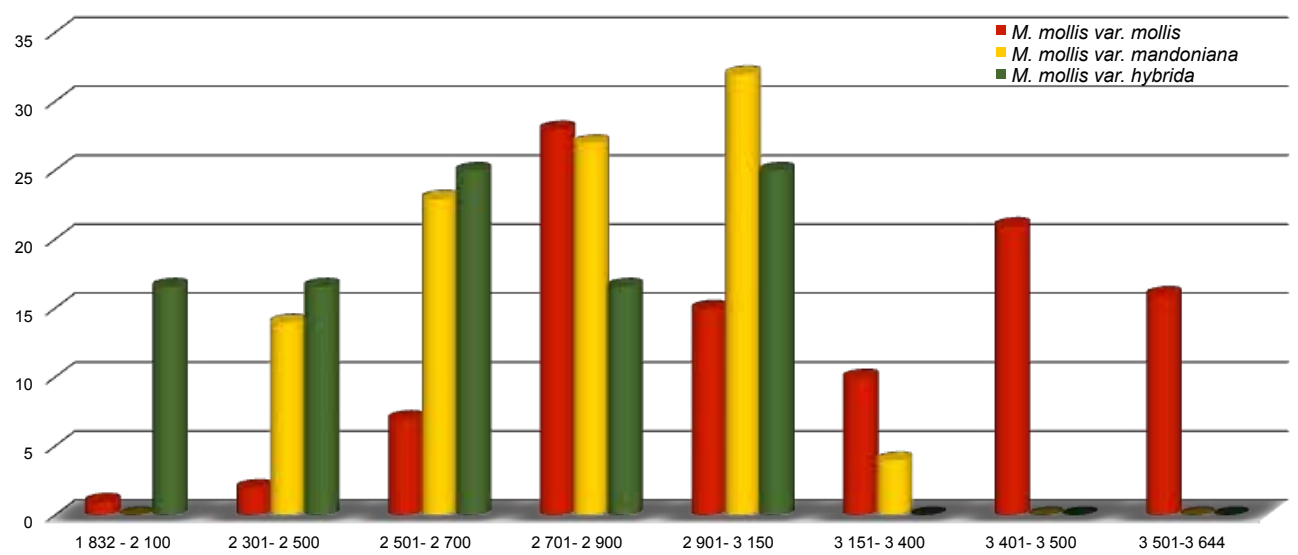

Figura 14.16. Distribución altitudinal de las variedades de Minthostachys mollis.

Se muestra en forma proporcional: Minthostachys mollis var. mollis $(n=97)$;

M. mollis var. mandoniana $(n=22)$ y M. mollis var. hybrida $(n=12)$.

Aún se desconoce si de la variación intra e interespecífica se trata de una diferenciación incipiente o más bien de una hibridación y homogeneización entre poblaciones previamente separadas. Cerca del punto altitudinal más alto para Minthostachys, a los $3553 \mathrm{~m}$, dentro del clima frío y cerca de dos individuos de $M$. mollis var. mollis, se encontró el taxón denominado por ahora Minthostachys sp., un posible híbrido intergenérico entre Minthostachys mollis y Clinopodium nubigenum, como sugiere el Dr. Schmidt-Lebuhn. La propuesta de este autor se basa en la presencia en dicho taxón de características morfológicas de las dos especies emparentadas. La especie de Clinopodium referida se observó en cercanía con Minthostachys sp. Una hibridación con Clinopodium reflejaría la cercanía filogenética de este género y Minthostachys (Tello, 2011). Sin embargo, hace falta profundizar en estudios morfológicos y genéticos que aclaren la naturaleza de ese Minthostachys sp., determinar si se trata de este género o no. Asimismo, es importante identificar los polinizadores de ambas especies y determinar si existen traslapes tanto en fenología como en visitantes florales, la cercanía de los individuos de ambos taxa es un argumento insuficiente para concluir sobre la posible hibridación entre individuos de ambos géneros.

\section{Introducción al cultivo ex situ de muña con fines comerciales}

Esta planta aromática y medicinal es bien conocida y difundida en los Andes peruanos desde tiempos incaicos; el uso está vigente en la zona rural y urbana, pero todo el material vegetal proviene de poblaciones silvestres. La demanda en el mercado es cada vez es mayor y las poblaciones silvestres sobreexplotadas sufren las inclemencias no solo del clima, sino también de la presión de la recolección bajo intensidad creciente.
Por esas razones, y por considerar grandes potencialidades de aumentar la disponibilidad del recurso sin afectar las poblaciones naturales, varios grupos de investigación se han planteado desarrollar su cultivo. Los autores de este capítulo, ante los cada vez más inestables precios del mercado, hemos impulsado estudios de esta especie con el fin de desarrollar estrategias productivas sustentables. En un trabajo previo (Tello, 2014) expusimos las fases de nuestros estudios para desarrollar el cultivo de la muña, siguiendo las etapas que se mencionan a continuación:

- Determinación de las formas de propagación

- Ensayos de siembra

- Establecer el protocolo de propagación masiva de plántulas

- Identificación del tamaño y número de días al trasplante definitivo

- Determinación del distanciamiento en campo definitivo

- Determinar el número de cortes o cosecha por año con y sin riego

- Fenología de la muña

- Extracción de aceites esenciales

En relación con la forma de propagación, se determinó que se pueden realizar dos formas, mediante estacas y mediante la propagación de semillas sexuales, esto último realizado en almácigos para su posterior trasplante. Para efectuar la colecta de semillas consideramos pertinente llevar a cabo estudios fenológicos de la muña, los cuales permitieron determinar que esta tiene una duración de dos meses. Después de la colecta de semillas, estas se germinaron durando el proceso de 10 a 15 días en almácigo. Posteriormente, las plantas se trasplantaron a campo definitivo a los 30 o 45 después de la germinación. Las plantas crecieron y la floración se presentó de 5 a 6 meses después del trasplante.

Los principales estudios realizados en manejo agronómico fueron el establecimiento de plantas a una distancia de $1 \mathrm{~m}$ entre plantas y $1.20 \mathrm{~m}$ entre surcos; el riego, que es un factor importante para la producción de follaje previo a la floración y en la etapa de trasplante; la incorporación de materia orgánica en el terreno de cultivo que revirtió efectos negativos significativos en la producción de follaje (véase Figura 14.17). La extracción de los aceites esenciales se realizó mediante la técnica de arrastre de vapor a nivel experimental.

\section{Conservación}

La conservación de las plantas aromáticas está estrechamente relacionada con la intensidad de uso y la disponibilidad del recurso, también con la manera de enfrentar cada día nuevos escenarios, nuevas necesidades y nuevas prácticas de extracción.

Las parcelas agrícolas son una de las formas de conservación in situ, al igual que la colección de plantas vivas en los huertos familiares; práctica tan antigua, que no solo desempeña papeles importantes para la familia andina, sino también para la ciencia. Se ha estimado un ahorro de $400 \%$ de inversión en la investigación de principios activos, en la industria de semillas, agroquímicos y farmacéuticos, al utilizar los conocimientos tradicionales ligados a 

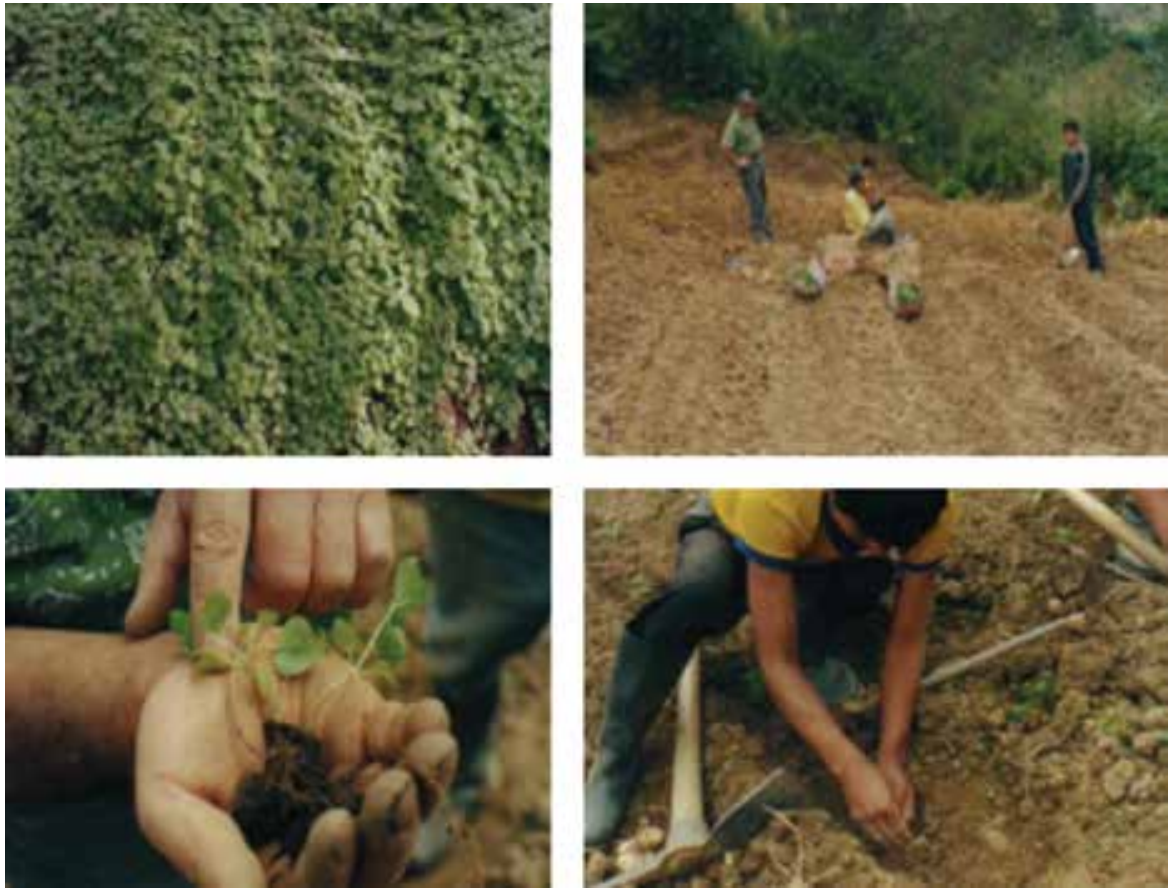

Figura 14.17. Cultivo de la muña.

los recursos genéticos, específicamente la etnobioprospección, gracias a la conservación y práctica continua de la conservación y consumo de las plantas aromáticas (Valera, 2000; Pochettino, 2007).

Las formas de conservación ex situ se desarrollan en pisos ecológicos diferentes al de sus hábitats u otras regiones andinas. Las semillas de las plantas "caminan", se dice así porque los pobladores andinos trasladan semillas de las plantas aromáticas que son interesantes o tienen prospección comercial; es por eso que se pueden encontrar especies en proceso de adaptación en nuevos escenarios al que crecen normalmente. Esta experiencia de mover altitudinalmente el germoplasma de acuerdo con las condiciones del temporal parece una estrategia de enorme importancia en el logro de la adaptabilidad de los cultivos. En este caso se aprecia en ensayos de cultivo de plantas en proceso incipiente de domesticación, pero revela estrategias que podrían ser vigentes en otras especies de cultivos y que merecen investigación específica. De esta manera, las familias campesinas cumplen un rol protagónico en la conservación de recursos como los analizados y muy probablemente aquellos con mayor historia de manejo y domesticación, perdurando en el tiempo y en el espacio, en forma dinámica y en concordancia con las variaciones del clima y el entorno (Valera, 2000; Pochettino, 2007).

Es importante mencionar que junto a estas estrategias de manejo y producción de plantas aromáticas, los pueblo regionales de los Andes practican formas de preservación en forma deshidratada para ser usadas en cualquier momento, las mismas que también son llevadas con facilidad a diferentes regiones de los Andes peruanos, especialmente a la zona urbana. De tal forma, junto a las estrategias de propagación y cultivo, las estrategias de preservación complementan el objetivo de mantener disponibles los recursos vegetales que resultan de interés para un pueblo y su cultura.

\section{Bibliografía}

Antúnez-deMayolo, R. S., 2011. La nutrición en el antiguo

Arias-Toledo, B., 2009. Diversidad de usos, prácticas de de plantas medicinales en Córdoba, Argentina el uso Latinoamericano y del Caribe de Plantas Medicinales Aromáticas, 8 (5), 389 - 401 .

Blancas, J., A. Casas, D. Pérez-Salicrup, J. Caballero y E. Vega, 2013. Ecological and sociocultural factors influencing plant management in Náhuatl communities of the Tehuacán Valley, Mexico. Journal of Ethnobiology and Ethnomedicine, 9: 39

Brack, A., 1988. Ecología de un País complejo. En Gran Geografía del Perú-Naturaleza y Hombre. Editorial Juan Mejia Baca-Manfer.

Brack, A., 2005. Biodiversidad: Firmeza necesaria. Boletín electrónico- Asociación de Egresados y Graduados de la Pontificia Universidad Católica del Perú. http://www.

coll

Brack, A., 2003. Perú: Diez mil años de domesticación. Programa de las Naciones Unidas para el Desarrollo Lima, Perú.

Brack, A. y C. Mendiola, 2010. Ecología del Perú. Asociación Editorial Bruño.

Brush, S. B., 2004. Farmers' Bounty. Locating crop diversity the contemporary World. Yale University Press. New Haven and London.

Casas, A., M. C. Vázquez, J. L. Viveros y J. Caballero, 1996. Plant management among the

Nahua and the Mixtec of the Balsas river basin: an ethnobotanical approach to the study of

Casas, A., A. Otero-Arnaiz, E. Pérez-Negrón, y A. Valiente-

of plants in Mesoamerica. Annals of Botany, 100(5):
$1101-1115$

Casas A., F. Parra, J. Blancas. 2015. Evolution of humans and by humans. En: Albuquerque, U.P., P. Medeiros Utrecht, Holanda, pp. 21-36.

Casas, A., F. Parra, S. Rangel, S. Guillén, J. Blancas y C. J. Figueredo. Evolutionary ecology and ethnobiology Evolutionary ethnobiology. Springer. Utrecht, Holanda, pp. 37-57.

Casas A., J. Blancas, A. Otero-Arnaiz, J. Cruse-Sanders, R. Lira, A. Avendaño, F. Parra, S. Guillén, C. J. Figueredo, I. Torres-García, S. Rangel-Landa. 2016. Evolutionary ethnobotanical studies of incipient domestication of plants in Mesoamerica. En: Lira, R., A. Casas y J. Blancas (Eds.). Ethnobotany of Mexico. Interactions of peoples Utrecht, Holanda, 257-285.

Casas, A y F Parra. 2 . Parra (Eds.). Domesticación en el continente americano. Volumen 1. Manejo de biodiversidad y evolución dirigida por las culturas del Nuevo Mundo. Universidad Nacional Autónoma de México /Universidad Nacional Agraria La Molina, Perú, pp. 133-158.

Díaz Vargas, C., 2000. Empleo de técnicas tradicionales de producción y conservación in situ de plantas nativas cultivadas en la micro- cuenca Huarmiragra- Huánuco. En: Felipe-Morales, C. B. y A. Manrique (Eds.). Agrobiodiversidad en la región Andina y amazónica. Investigación en Agricultura (NGO-CGIAR). Lima, Perú. Mapa Ecológico del Perú Gúa Explicativa Ministerio Mapa Ecológico del Perú,
de Agricultura. Lima, Perú.

waysaypacha 2014. Diálogos de la tierra Declaración de los académicos del Perú frente a los desafíos del cambio 
climático y a propósito de lavic
partes. PUCP. Lima, Perú. Tesis Doctoral en Ciencias, especialidad en Genética. epistemología en el mundo andino. En: Ansión, J. y A. M. Villacorta (Eds.). Qawastin ruastin viendo y haciendo. Encuentros entre sujetos del conocimiento en la universidad. PUCP. Lima, Per

Pestalozzi, H. U. A., 1998. Flora ilustrada altoandina. La relación entre hombre, planta y medio ambiente en Ayllu Majasaya Mulli. Herbario Nacional de Bolivia.

Pochettino, M. L., 2007. Conocimiento botánico tradicional. Boletín Latinoamericano y del Caribe de Plan
Medicinales y Aromáticas (BLACPMA), 6: (1): 3 .

Medicinales y Aromalicas (BLACPMA), 6. (1): 3.

Pulgar-Vidal, J., 1981. Geografía del Perú: las ocho regiones naturales del Perú. Lima, Perú. Editorial Universo.

Reverte-Coma, J. M., 2016. Momificación en Perú. Museo de Antropologia y Criminalistica de la Escuela Medicina Legal de la Universidad Complutense de Madrid. http://

Schmidt-Lebuhn, A. 2008. Monophyly and phylogenetic relationship of . 2008 . Montachys (Labiatec.Nepetoideac) Systematics and Evolution, 270: 25 -38 (2008).

Tapia, M., 2000. Agrobiodiversidad en la Región Andina. En: Felipe-Morales B. y A. Manrique (Eds.). Agrobiodiversidad Grupo Consultivo Internacional de Investigación en Agricultura (NGO CGIAR). Lima, Perú. Codos, Mexico.

Tello, M. 2011. La experiencia de investigación sobre la "muña" o "muña" y el diálogo de conocimientos en Huánuco. En: Ansión, J., y A. M. Villacorta (Eds.) Jorres, J. y F. Parra., 2009. Parientes silvestres de plantas

vera-Silva, J. L., 2000. Utilidad de las diversas especies vegetales en los huertos familiares. Experiencias de campesinos en el Distrito de Magdalena, Cajamarca. nacional de Investigación en Agricultura (NGO-CGIAR). Lima, Perú.

avilov, N. I., 1926. Studies on the origin of cultivated plants Leningrad Institut Botanique Appliqui. Et d'Amlioration des Plantes, 127.

vilov, N. I., 1951. The origin, variation, immunity and breeding of cultivated plants (traducido del ruso por $\mathrm{K}$. Starr Chester). Chronica Botanica, 13: i-xviii \& 1-364.

Yauri Montero, M., 2009. Simbolismo de las plantas alimenticias nativas en el imaginario andino. Universidad Ricardo Palma. Editorial Universitaria. Lima, Perú. Qawastin ruastin viendo y haciendo. Encuentros entre Agrobiodiversidad en la región Andina y amazónica.
Capítulo 15

\section{El sistema agroalimentario mesoamericano precolombino: origen, diversificación y difusión de sus recursos fitogenéticos}

Daniel Zizumbo-Villarreal y Patricia Colunga-GarcíaMarín

\section{Resumen.}

En Mesoamérica se originó y desarrolló un sistema agroalimentario complejo cuyo eje fundamental lo constituían el maíz, los frijoles, las calabazas y los chiles. Además, se integraron cientos de especies de plantas con diferente grado de manejo agrícola (cultivo) y domesticación. Este sistema fue la base económica y cultural de grandes culturas precolombinas. Aún es tema de debate dónde, cuándo, cómo y quiénes generaron este sistema, así como las rutas de su difusión hacia el sur. Intentamos contestar estas preguntas, integrando evidencias paleoecológicas arqueológicas, etnobotánicas y genético-moleculares. El sistema alimentario inicial se pudo estructurar con especies de la selva baja caducifolia que resultaron favorecidas por el fuego y que respondieron positivamente a la selección y al manejo humano. Es posible que haya sido establecido po grupos humanos que arribaron a Mesoamérica hace 11500 a 10500 años y que presentaban una adaptación cultural basada en la recolección de granos y semillas. Se pudo integrar a partir del uso de las poblaciones silvestres utilizando piedras moledoras, fuego, cenizas y hornos bajo tierra. El sistema inicial pudo favorecer los asentamientos de los seres humanos para dar inicio a la domesticación y agricultura tan temprano como hace 9000 años. Las plantas mesoamericanas domesticadas se difundieron hacia el sur a través de la vertiente del Pacífico donde se distribuían selvas secas, arribando a Panamá y a la costa norte de Suramérica tan tempano como hace 7900 - 7400 años, y a la costa sur de Ecuador y norte del Perú entre 6700-6500 AP. La domesticación significó para las plantas dependencia con respecto a los seres humanos para sobrevivi y reproducirse, y para los humanos la domesticación tuvo un alto costo social histórico que aún no valoramos. El estudio de su dinámica actual es fundamental para establecer estrategias de conservación y restauración, así como para evaluar el riego de escape de genes domésticos, incluyendo transgenes. La alta diversidad de recursos fitogenéticos generados durante miles de años, en multitud de ambientes y contextos culturales, presenta grandes amenazas a raíz de los cambios sociales y económicos que está provocando la globalización de los mercados.

Palabras clave: domesticación de plantas, Mesoamérica, milpa, Zea, Phaseolus, Cucurbita. 


\section{Introducción}

Aún es tema de debate en dónde se presentaron las condiciones ecológicas y culturales que dieron origen al sistema agroalimentario mesoamericano caracterizado por el cultivo y el consumo del maíz, los frijoles, las calabazas y los chiles. Asimismo, es tema de debate cuándo, cómo y quiénes pudieron conformar este sistema, el cual posibilitó, en primera instancia, la sedentarización de los grupos humanos de recolectores-cazadores y, posteriormente, el desarrollo de culturas más complejas en organización social. Las respuestas son relevantes porque el sistema alimentario, el cuidado y selección de los recursos biológicos asociados, llevaron a la domesticación del paisaje natural y la de sus componentes biológicos.

Mesoamérica es uno de los centros primarios de domesticación de plantas y origen de agricultura en el mundo, de acuerdo con las conclusiones de Vavilov en 1940 (Smith, 1995). Es una región cultural considerada una cuna de civilización en el Nuevo Mundo en donde una serie de sociedades florecieron en diferentes regiones y ambientes, desde la olmeca y las culturas de occidente, hasta la mexica (azteca) y la maya. Todas estas sociedades comparten su sistema agroalimentario como principal rasgo cultural. Este sistema está basado en el sistema agrícola denominado milpa, al cual se integran otros sistemas productivos como los huertos o solares familiares, con más de 150 especies de plantas cultivadas, domesticadas o en proceso de domesticación (Perales y Aguirre, 2008), además de áreas de vegetación natural con diferente grado de humanización.

En este capítulo se revisará, analizará y discutirá la literatura disponible para buscar respuesta a algunas preguntas relevantes acerca del origen, la difusión y la diversificación del sistema agroalimentario mesoamericano en la época precolombina, como son: a) ¿En dónde y cuándo se domesticaron el maíz, los frijoles y las calabazas, y en dónde se pudo establecer el sistema agrícola de la milpa?; b) ¿Qué grupos humanos pudieron conformar el sistema agroalimentario inicial?; c) ¿Cómo se pudo estructurar?; d) ¿Fue posible la domesticación simultánea de algunas especies de plantas en varios sitios de América tropical?; e) ¿A través de qué rutas y cuándo se pudieron difundir las especies vegetales domesticas entre Mesoamérica y Sudamérica? A partir de este análisis se discutirá el significado de la domesticación para las plantas y para los humanos en Mesoamérica, así como la importancia de estudiar la dinámica evolutiva actual de estas plantas. Finalmente, se concluirá y se puntualizarán algunas de las amenazas y los retos que se presentan para la conservación de los recursos fitogenéticos mesoamericanos.

¿En dónde y cuándo se domesticaron el maíz, los frijoles y las calabazas, y se pudo establecer el sistema agrícola de la milpa?

Se han propuesto dos regiones ecológicamente diferentes como áreas de origen de la domesticación y la agricultura en Mesoamérica: (a) la provincia biogeográfica oaxaquense - Vales de Tehuacán y Oaxaca- (MacNeish, 1964; MacNeish y Eubanks, 2000) y (b) la Provincia Balsas-Jalisco, en la cuenca del río Balsas (Matsuoka et al., 2002; Piperno et al., 2009; Zizumbo-Villarreal y Colunga-GarcíaMarín, 2010). Las evidencias paleoecológicas señalan que a finales del Pleistoceno, a consecuencia del cambio climático, en la provincia oaxaqueña se establecieron, predominantemente, los matorrales xerófilos, mientras que en la provincia Balsas-Jalisco, las selvas secas caducifolias (Piperno, 2006; Piperno et al., 2007). En ambas provincias se presenta aún en la actualidad una alta riqueza de especies, tanto de gramíneas, como de leguminosas y agaves. Estas comunidades vegetales presentan un alto porcentaje de plantas preadaptadas al fuego (Zizumbo-Villarreal y Colunga-GarcíaMarín, 2010).

as evidencias arqueológicas sugieren que las poblaciones humanas arcaicas que habitaron la provincia oaxaqueña se alimentaban principalmente con los granos del pasto Setaria parviflora (Poir.) Kerguélen, con los tallos de varias especies de agaves, con las semillas de la calabaza Cucurbita pepo L, y con los frutos de la ceiba (Ceiba parvifolia Rose). La carne de animales pequeños como venados, pecaríes y roedores era también un componente muy importante en su dieta (Callen, 1967; MacNeish, 1967; Flannery, 1986; Smith, 2005). Las evidencias arqueobotánicas sugieren, además, que en esta provincia se pudo domesticar el pasto (Setaria parviflora), la calabaza (Cucurbita) pepo, y el chile (Capsicum annuum L.) (Austin, 2006; Smith, 2006; Kraft et al., 2015). Sin embargo, no hay registros paleoecológicos ni arqueológicos que sugieran la presencia de poblaciones silvestres de maíz, y en el registro arqueobotánico, e maíz doméstico aparece tardíamente, hace uno 6200 años (Benz, 2001; Piperno y Flannery, 2001). Estos dos hechos ponen en duda que el sistema agroalimentario basado en la milpa se haya originado en esta provincia.

La distribución geográfica de las poblaciones silvestres progenitoras del maíz doméstico (Zea mays L.), de los frijoles (Phaseolus lunatus L. y P. vulgaris L.) y de la calabaza (Cucurbita argyrosperma Huber), así como los registros arqueobotánicos de maíz y calabaza domésticos, con una antigüedad histórica de 8000-9000 años antes del presente (A.P.), sugieren que en la provincia Balsas-Jalisco se pudo establecer de manera inicial el sistema agrícola de milpa (Piperno et al., 2009; Ranere et al., 2009; Zizumbo y Colunga, 2010; Zizumbo et al., 2012).

\section{¿Qué grupos humanos pudieron estructurar el sistema agroalimentario inicial?}

Los registros arqueológicos, lingüísticos y genéticos indican que a finales del Pleistoceno $e$ inicios del Holocen, arribaron y poblaron América varios grupos humanos con diferentes rasgos culturales. Los primeros grupos que ingresaron lo hicieron por la costa norte del océano Pacífico, utilizando pequeñas embarcaciones, y se difundieron hasta el sur del continente hace aproximadamente 15000 años. Estos grupos se fueron internando, paulatinamente, de la costa al continente, a través de la desembocadura de los ríos, siguiendo su lecho hasta sistemas lagunares intermontanos, ricos en megafauna gregaria. Poseían rasgos tecnológicos de las tradiciones Nenana y El Jobo, caracterizados por sus herramientas líticas de lascas simples, arpones elaborados con huesos y lanzaderas de arpones de madera. Estos grupos humanos presentaban una adaptación cultural al ambiente centrada en la recolección de productos de mar, la pesca y la caza de mamíferos marinos (Dixon, 2001).

Posteriormente, otros grupos humanos pudieron haber ingresado desde Beringia hace cerca de 13000 A.P. Estos se caracterizaban por su tradición tecnológica de proyectiles 
acanalados conocidos como Clovis (Raff y Bolnick, 2014; Rasmussen et al., 2014). Sus actividades productivas alrededor de los lagos interiores del continente pudieron estar centradas en la recolección y la pesca de fauna de agua dulce, así como en la caza de megafauna gregaria del Pleistoceno tardío.

Poblaciones de ambos grupos humanos llegaron y se distribuyeron en Mesoamérica tanto en as costas como en los lechos de los ríos Santiago-Lerma, ocupando refugios rocosos y campamentos alrededor de lagos intermontanos ricos en megafauna, como el sistema lagunar de Chapala-Sayula-Zacualo, el Valle de México y el Valle de Puebla (Niederberger, 1979, Lorenzo y Mirabel, 1986; MacNeish y Nelken-Terner, 1983a; Dixon, 2001. Hacia el sur, ocuparon sitios cercanos a ríos y lagos intermontanos de Chiapas y Guatemala (MacNeish y Peterson, 1962; Gruhn et al., 1977; Acosta-Ochoa, 2010). La distribución de sus campamentos sugiere su difusión hacia la costa del Caribe, a través del lecho de los ríos Grijalva, Motozintla y Motagua. Ocuparon campamentos y refugios rocosos en Belice, Quintana Roo y la costa norte de Yucatán (MacNeish y Nelken-Terner, 1983b; Lohse et al., 2006, Acosta-Ochoa, 2011; González et al., 2014).

Hacia el sur, ocuparon refugios en la costa occidental de El Salvador, Honduras, Nicaragua Costa Rica y sur de Panamá (Cooke, 2005; Cooke et al., 2007; Ranere y López, 2007). En el norte de Sudamérica, ocuparon refugios cerca de los lagos intermontanos de Colombia, así como en la costa sur de Ecuador y en la costa norte de Perú (Rossen y Dillehay, 1999; Stothert et al., 2003; Aceituno y Castillo, 2005; Aceituno y Rojas, 2012). Se dispersaron por la costa del Pacífico hasta el sur de Chile, Argentina y Uruguay antes del 12000 A.P.

Posteriormente, entre 12000 y 11000 A.P., otros grupos humanos ingresaron a América, estos tenían alta movilidad y posiblemente utilizaban al perro y al fuego para la defensa y la caza, respectivamente (Dixon, 2001; Wayne et al., 2006). Presentaban una adaptación cultural centrada en la recolección de granos, semillas, nueces, raíces y tubérculos, y la caza de animales era también una actividad importante. Los registros arqueológicos indican que estos grupos utilizaban campamentos portátiles, fibras para tejidos y herramientas, y poseían una organización social que pudo incluir a un líder o chamán, quien trataba con las potencias sobrenaturales. Tenían un cuerpo de creencias ligadas a sus ancestros, a quienes ofrendaban, en sus sepulturas, artefactos exóticos durables y arte rupestre. Pudieron hacer recorridos largos a lugares sagrados, a áreas de recolecta de plantas "mágicas" y a sitios de intercambio de objetos perecederos. Para la cosecha y la transformación de los alimentos utilizaban piedras cortadoras y raspadoras unifaciales, piedras quebradoras y moledoras, fogones, piedras y cenizas calientes para el cocimiento en hornos bajo tierra (MacNeish, 1964, 1967b: MacNeish y Nelken-Terner, 1983a; Amick, 1997; Black y Thoms, 2014).

En el suroeste de Norteamérica, estos grupos humanos pudieron lograr una adaptación cultural a condiciones semidesérticas basada en la recolección y consumo de granos de pastos como Oryzopsis, Sporobolus y Pannicum, así como de tallos de agaves (Agave spp.), nopales (Opuntia spp.), y sotoles (Dasylirion spp.). Complementaban su dieta con bellotas y nueces de Quercus spp., Pinus spp. y Prosopis spp., así como frutos de saguaros (Carnegiea gigantea) y tunas (Opuntia spp.). La fauna pequeña, entre la que se incluían venados, pecaríes, conejos, ratones, serpientes, patos y palomas, formó parte importante de su dieta (MacNeish, 1967a Doebley, 1984; Black y Thoms, 2014).
Estos grupos humanos posiblemente ingresaron a Mesoamérica, entre 11500 y 10500 A.P., integrándose culturalmente con los grupos preexistentes, ocupando áreas semidesérticas o semihúmedas, con elevaciones bajas a intermedias de pie de monte, entre la costa occidenta y los valles intermontanos a lo largo de los ríos. Ocuparon la cuenca del río Balsas, los valles de Tehuacán-Cuicatlán, los valles centrales de Oaxaca y Chiapas, así como Guatemala, E Salvador, Honduras y Costa Rica. En estos ambientes pudieron recolectar una amplia riqueza de pastos de las especies Zea, Tripsacum y Setaria, semillas de las especies de Phaseolus, Hyptis y Salvia, bellotas, nueces y vainas de Quercus; Pinus, Prosopis y Leucaena, frutos de Solanum, Physalis, Capsicum, Psidium, Pachycereus y Opuntia, así como los tallos y raíces de Agave y Pachyrhizus (MacNeish, 1967a; Flannery, 1986; Smith, 1986; Zizumbo-Villarreal y Colunga-GarcíaMarín, 2010).

Con el uso de piedras cortadoras, raspadoras, quebradoras y moledoras, así como de fogones y hornos bajo tierra, estos grupos humanos pudieron iniciar la estructuración del sistema agroalimentario básico mesoamericano y los procesos de domesticación de las especies (MacNeish 1964; Zizumbo-Villarreal y Colunga-GarcíaMarín, 2010; Zizumbo-Villarreal et al., 2012).

\section{¿Cómo se pudo estructurar}

\section{el sistema agroalimentario inicial?}

Las evidencias paleoecológicas indican que el paisaje de la provincia Balsas-Jalisco hasta Panamá fue transformado con el uso del fuego hace entre 10000 y 7000 años, posiblemente utilizado por los humanos para facilitar la caza de animales y la recolección de ciertos productos vegetales (Piperno, 2006; Piperno et al., 2007). El aclareo de la vegetación con fuego, en este ecosistema, favorece a ciertas especies, rompiendo el letargo de sus semillas o favoreciendo su rebrote a nivel del suelo. El paisaje se pudo transformar en un mosaico de fases sucesionales de la selva seca decidua, tendiendo a conformar pastizales y bosquetes con especies favorecidas por el fuego, las cuales fueron aprovechadas por los grupos humanos. Este proceso, a su vez, pudo estimular el aprovechamiento recurrente de los sitios quemados, el acortamiento de los trayectos de cosecha, y el incremento del período de permanencia en los campamentos (Zizumbo-Villarreal y Colunga-GarcíaMarín, 2010; Piperno, 2011; Zizumbo-Villarreal et al., 2012).

El sistema alimentario, por lo tanto, se pudo conformar a partir del consumo de granos y semillas de las especies anuales pioneras que resultaron favorecidas por el fuego, las cuales podían ser conservadas y almacenadas todo el año, así como de tallos y raíces comestibles que están disponibles a lo largo de las temporadas. Las proporciones de su ingesta seguramente se adecuaron a las necesidades nutricionales humanas. Los requerimientos de carbohidratos, pudieron ser obtenidos de los granos de los pastos Setaria, Tripsacum y Zea, así como de los tallos y las raíces de los agaves, de jícamas (Pachyrhizus erosus (L.) Urb) y de las papas (Solanum spp.). Los requerimientos de proteínas pudieron ser obtenidos de las semillas de Phaseolus, Enterolobium, Prosopis y Leucaena. Los requerimientos de lípidos de las semillas de Cucurbita; Hyptis y Salvia. Los requerimientos de vitaminas y minerales de los frutos de los chiles (Capsicum spp.), tomates (Physalis spp.), jitomates (Solanum lycopersicum) y ciruelos (Spondias spp.), véase Zizumbo-Villarreal y Colunga-GarcíaMarín, 2010; Zizumbo-Villarreal et al., 2012. 
La protección y posterior dispersión y cuidado de los propágulos de estas especies en los sitios quemados pudo dar origen al sistema agrícola de roza-quema. Estudios etnobotánicos recientes sugieren que en la provincia Balsas-Jalisco se pudo establecer un sistema alimentario utilizando poblaciones silvestres de estas especies, con la tecnología precerámica de la que disponían las poblaciones humanas arcaicas distribuidas en esta provincia, antes de que fueran cultivadas y domesticadas (Zizumbo-Villarreal et al., 2012).

Algunos pobladores de la provincia Balsas-Jalisco saben elaborar, aun hoy en día, una amplia gama de alimentos con granos, semillas y frutos de poblaciones silvestres de maíz, frijol, y calabaza, utilizando tecnología precerámica, incluyendo al menos seis grupos de alimentos básicos: (a) las palomitas, elaboradas al exponer a ceniza caliente los granos y semillas de maíces, frijoles, calabazas, mezquites (Prosopis ssp.) y guanacaxtles o parotas (Enterolobium cyclocarpus (Jacq.) Griseb.); (b) los pinoles, elaborados al tostar y moler los granos y las semillas de maíces, frijoles, calabazas, chía gorda (Hyptis suaveolens (L). Poit.), mezquites y guanacaxtles; (c) los atoles, elaborados al diluir en agua los pinoles de maíz, frijol, calabaza, chía y guanacaxtle; (d) los tamales, elaborados con los pinoles de maíces, frijoles y calabazas, aglutinados con jugos de agave y envueltos en hojas de varios árboles y cocidos en hornos bajo tierra; (e) los tepaches, elaborados con los jugos diluidos en agua y fermentados de ciruelas, mezquites, tunas y piñuelas (Bromelia spp.), y (f) las salsas, elaboradas con los frutos frescos, secos o asados de chiles combinados con jitomates, tomates, guajes (Leucaena leucocephala (Lam.) de Wit.) y ciruelas. Las evidencias etnobotánicas señalan que más de 25 platillos pudieron conformar el sistema alimentario inicial (Zizumbo-Villarreal et al., 2012).

Con el consumo combinado de cinco o seis grupos de especies (maíz, frijoles, calabazas, chiles, jitomates y tomates) se pudo lograr la complementariedad nutricional en el sistema alimentario, lo cual pudo, a su vez, favorecer el asentamiento de los grupos humanos y su desarrollo cultural, en donde el maíz llegó a constituirse como la principal fuente de carbohidratos para las poblaciones humanas; los frijoles la principal fuente de proteínas y micronutrientes: las calabazas la principal fuente de ácidos grasos; los chiles, los tomates y los jitomates las principales fuentes de vitaminas y antioxidantes. Así, se pudo constituir un sistema alimentario básicamente vegetariano, complementado con la carne de animales de caza e insectos ( $\mathrm{Zi}$ zumbo-Villarreal et al., 2012).

\section{¿Fue posible la domesticación simultánea de plantas, en varios sitios de América tropical?}

Los registros arqueológicos para el Pleistoceno final y el Holoceno temprano ( 14 200-9600 A.P.) indican varias tradiciones culturales líticas con un nivel tecnológico y de organización social similares, las cuales coinciden parcialmente en tiempo y en ambientes ecológicos, tanto en Mesoamérica -México, Guatemala, El Salvador, Honduras, Nicaragua y Costa Rica-, como en el sur de Panamá, el noreste de Sudamérica, la cuenca del río Cauca en Colombia, la costa sur de Ecuador, y la costa norte del Perú. Estas tradiciones líticas están caracterizadas por conjuntos de piedras raspadoras, moledoras, morteros, piedras unifaciales, lascas poco retocadas, así como fogones y en algunos casos hornos bajo tierra (MacNeish, 1967b; Dillehay et al., 1997; Rossen y Dillehay, 1999; Stothert et al., 2003; Aceituno y Castillo, 2005; Ranare y
López, 2007; Ranere et al., 2009; Maggard, 2011; Maggard y Dillehay, 2011; Aceituno y Loaiza, 2014; Pagan-Jiménez et al., 2015).

os restos botánicos asociados a diversos tipos de piedras moledoras indican que fueron utilizadas por grupos humanos para la molienda y transformación de su alimento, mientras que los análisis micromorfológicos y genéticos de los restos botánicos de las plantas asociadas a ellas señalan que algunas habrían sido domesticadas tempranamente. Estas plantas pertenecen a géneros o especies que están distribuidos naturalmente tanto en Mesoamérica como en Sudamérica, como son: Cucurbita, Phaseolus, Capsicum, Solanum, Amarantathus y Chenopodium (Piperno et al., 2000; Sanjur et al., 2002; Piperno y Stothert, 2003; Chacon et al., 2005; Piperno y Dillehay, 2008; Piperno et al., 2009; Kraft et al., 2015). Otros estudios indican a domesticación de plantas de géneros y especies con distribución restringida a Mesoamérica o a Sudamérica, como Agave; Zea, Setaria; y Spondias para la primera y Manihot esculenta Crantz, Maranta arundinacea L., y Dioscorea trífida L. para la segunda (Perry, 2002; Chandler-Ezell et al., 2006).

Así, tanto las evidencias arqueológicas, como botánicas, ecológicas y genéticas, refuerzan la hipótesis de un inicio temprano y relativamente simultáneo del proceso de domesticación y de agricultura en varios sitios de América tropical, bajo condiciones ecológicas de tierras bajas, de pie de monte, y valles intermontanos semihúmedos y semisecos, donde se distribuyen las selvas deciduas, los matorrales espinosos semiáridos y xerófilos (Piperno y Pearsall, 1998; Piperno, 2011).

El proceso de domesticación temprano y simultáneo en diferentes regiones preparó el camino para la integración de los sistemas agroalimentarios y la intensificación de la agricultura en toda América tropical. Hacia el 6000 A.P. el maíz ya era parte importante en la dieta en Panamá, en la costa sur de Ecuador y en el norte de Perú, mientras que la yuca, domesticada en el suroeste de Brasil, ya se cultivaba en la Cordillera Central de Colombia, en Panamá, en Centroamérica y en la costa del Golfo de México (Pope et al., 2001; Dickau, 2005; 2010; Dickau et al., 2007; Perry et al., 2007; Pohl et al., 2007; Zarrillo et al., 2008)

\section{¿A través de qué rutas y cuándo se pudieron difundir las plantas domesticas entre Mesoamérica y Sudamérica?}

a ruta de difusión de plantas domesticas de Mesoamérica hacia Sudamérica ha sido propuesta con base en varias evidencias como: (a) la distribución geográfica de las poblaciones humanas en el Pleistoceno final y el Holoceno temprano; (b) la presencia de restos arqueobotánicos asociados a las piedras moledoras utilizadas para elaborar los alimentos por estas poblaciones humanas, y (c) las relaciones genético-moleculares de las plantas domésticas. En Mesoamérica, la ruta hacia el sur se ha trazado a partir de la provincia Balsas-Jalisco, hacia e puente panameño (Cooke et al., 2005; Dicauk, 2005) y a la costa Caribe de Colombia y Venezuela. De ahí, al noreste de Sudamérica (Payán-Jiménez et al., 2015) y a la cuenca media de Cauca en Colombia (Aceituno y Rojas, 2002; Aceituno y Loaiza, 2014). Más hacia el sur, la ruta pudo haber sido por la costa sur de Ecuador y el norte de Perú (Dillehay et al., 2003; Pearsall et 
al., 2004; Stothert et al., 2003; Grobman et al., 2012). La difusión hacia Brasil se ha planteado a través de dos rutas: una por el sur, cruzando los Andes hacia el suroeste de Brasil y noroeste de Bolivia, y otra por el norte, siguiendo el río Orinoco y el río Amazonas (Freitas et al., 2003).

Los registros arqueobotánicos de granos de almidón y fitolitos de maíz, asociados a las piedras moledoras, sugieren esta ruta e indican el arribo del maíz a Panamá tan temprano como hace 7400 años, a la costa norte de Sudamérica entre $7900-7670$ años A.P., al valle medio del río Cauca en Colombia entre 8000-7700 años A.P. y a la costa sur de Ecuador y norte del Perú entre 6700-6500 años A.P. (Dickau, 2005; Dickau et al., 2007; Zarrillo et al., 2008; Grobman et al., 2012; Aceituno y Loaiza, 2014).

En cuanto a la difusión de las plantas sudamericanas hacia Mesoamérica, los registros arqueobotánicos de los granos de almidón de la yuca, asociados a las piedras moledoras, han señalado también la ruta por el puente panameño, registrándose la yuca en Mesoamérica hace 5800 años. Los cultivados sudamericanos sagú, ñame y malanga también pudieron seguir la ruta del puente panameño (Dickau, 2005; 2010; Dickau et al., 2007)

Para el caso del archipiélago antillano, los registros paleoecológicos señalan que el paisaje de las islas fue modificado con el fuego entre el 5500 al 3800 A.P. (Burney et al., 1994). Los registros arqueobotánicos, por su parte, señalan la presencia del maíz hace 4000 años y de la yuca hace 3600 años, sugiriendo que la difusión del maíz y de la yuca pudieron realizarse antes de la expansión Arawak por el Caribe con dirección de sur a norte (Pagán-Jiménez et al., 2005 2015). El chile habanero (Capsicum chinense Jacq.) es posible que siguiera la ruta de las islas del Caribe siguiendo al maíz y la yuca, mientras que el cacao (Theobroma cacao L.), el cacahuate (Arachis hypogaea L.), y el achiote (Bixa orellana L.), se habrían difundido tardíamente, siguiendo, posiblemente, la ruta del puente panameño. La mayoría de estos cultivos llegaron a Mesoamérica antes de la Conquista europea (Colunga-GarcíaMarín y Zizumbo-Villarreal, 2004 Zizumbo-Villarreal et al., 2014).

La difusión temprana del maíz en sitios en donde no se presentaban los parientes silvestres pudo acelerar la fijación de los caracteres domésticos. Por su parte, las condiciones culturales y ambientales en cada región promovieron la diversificación y la diferenciación genética. El cultivo del maíz y sus asociados se pudieron convertir en la herramienta biotecnológica que posibilitó estructurar sistemas agrícolas en un amplio rango de condiciones ecológicas limitativas, como en el caso del área Olmeca, el área Maya y el archipiélago Antillano, en donde la milpa se complementó con cultivares Suramericanos como Manihot, Dioscorea y Maranta (Pohl et al., 1996, 2007; Pope et al., 2001; Colunga-GarcíaMarín y Zizumbo-Villarreal, 2004 Payán-Jiménez et al., 2015).

\section{¿Qué significó la domesticación para las plantas y para los humanos?}

Es importante puntualizar que la domesticación es un proceso evolutivo modulado por la selección y manejo humano sobre las plantas. Es decir, sin la presencia y la acción humana no existirían las plantas domesticadas. También es importante remarcar que este proceso evolutivo aún continúa, y que su resultante principal ha sido el que en las poblaciones de plantas seleccio- nadas y manejadas por los humanos se han fijado alelos que les confieren fenotipos favorables al consumo y al cultivo, y que durante este proceso también se han fijado alelos que las han limitado o hecho perder su capacidad de sobrevivencia en condiciones naturales, pasando a depender total o parcialmente de los humanos (Colunga-GarcíaMarín y Zizumbo-Villarreal, 1993).

Para el maíz ha significado la pérdida de su capacidad de dispersión y adecuación al ambiente natural, como consecuencia de la fijación de mutaciones en los genes que determinan esta capacidad, como lo es la desarticulación de los granos en la mazorca, la reducción de la cubierta dura del grano, la reducción a solo un eje de crecimiento, la reducción en el número de mazorcas, y el incremento en el número de hileras y de granos en la mazorca (Dorweiler et al., 1993; Doebley, 2004, 2006).

Para los frijoles ha significado la pérdida de su capacidad de dispersión y adecuación natural como consecuencia de la fijación de mutaciones en los genes que determinan la dehiscencia de sus vainas, la latencia en sus semillas, la insensibilidad al fotoperíodo, el hábito de crecimiento determinado y el incremento de tamaño y peso de la semilla (Koinange et al., 1996).

Para la calabaza ha significado el decremento en su capacidad de dispersión y adecuación al ambiente natural, a través de la fijación de mutaciones ligadas a la pérdida del anillo de abscisión del fruto, al engrosamiento y dureza del pericarpio, al cambio de la forma del fruto y el incremento en tamaño y peso del fruto y la semilla (Piperno et al., 2002; Smith, 2006).

Para el chile, significó la reducción en su capacidad de dispersión natural, a través de la fijación de alelos ligados a la pérdida del anillo de abscisión del fruto, al doblamiento del pedúnculo que lo soporta, al incremento en su tamaño y al cambio en su coloración (Pickersgill, 1971; 2011).

Para los humanos ha significado un alto costo social, al hacer una gran inversión de trabajo año tras año en: (1) la selección de variantes con mutaciones favorables a la cosecha, el consumo y el manejo, (2) el cotejo del comportamiento productivo de las variantes selectas, (3) los cuidados durante el almacenamiento del acervo genético novedoso, y (4) la multiplicación de la semilla. En consecuencia, puede decirse que tenemos una deuda histórica no reconocida con los campesinos que han generado, conservado y mejorado a los cultivares año tras año, desde que estos perdieron su capacidad adaptativa a las condiciones naturales.

\section{¿Cuál es la importancia de estudiar}

\section{la dinámica evolutiva actual de estas plantas?}

Un aspecto relevante de su importancia radica en que el proceso de evolución bajo manejo y selección humana sigue siendo actual y dinámico. En regiones y sitios donde crecen juntas poblaciones silvestres y domésticas de maíces, frijoles, calabazas, chiles, tomates y otras especies, se generan enjambres genéticos silvestre-arvense-domésticos, como producto de entrecruzamiento natural, y cuya dinámica también está influenciada fuertemente por la selección y el manejo agrícola de los campesinos (Pickersghill, 1971; Wilson et al., 1994; Doebley, 2004; Papa y Gepts, 2004; Zizumbo-Villarreal et al., 2005).

En el maíz, los estudios genético-moleculares y de la estructura demográfica de poblaciones 
silvestres y domesticas de las tierras bajas y altas de las provincias Balsas-Jalisco y Neovolcanense nos indican flujo genético activo entre las subespecies silvestres Zea mays subespecie parviglumis y Zea mays subespecie mexicana. Así como flujo genético entre estas dos subespecies con los maíces domésticos. En las tierras bajas de la provincia Balsas-Jalisco, donde se distribuye principalmente la subespecie parviglumis, el flujo genético es mayor entre esta subespecie con los maíces criollos domésticos, pero en las tierras altas el flujo es mayor con la subespecie mexicana, en donde esta subespecie predomina. El desplazamiento de los alelos domésticos por alelos silvestres en esta provincia ha provocado que los maíces criollos muestren mayor identidad genética con la subespecie mexicana que con su progenitor silvestre, la subespecie parviglumis (Heerwaarden et al., 2011; Hufford et al., 2013).

En el caso del frijol común ( $P$. vugaris) y el frijol lima (P. lunatus), los análisis genético-moleculares y de estructura genético-demográfica señalan flujo genético significativo entre las poblaciones silvestres y las domésticas de las dos especies, a pesar de que se consideran especies predominantemente autógamas. Este flujo genético es, además, asimétrico, casi cuatro veces más grande del acervo doméstico al silvestre, con la consecuente pérdida de diversidad en las poblaciones silvestres, por el desplazamiento de alelos silvestres por domésticos en sus poblaciones (Papa y Gepts, 2004; Payro et al., 2005; Zizumbo-Villarreal et al., 2005; Martínez-Castillo et al., 2006, 2007).

En el caso de las calabazas, los estudios genético-moleculares y de estructura genética indican flujo genético significativo (Wilson et al., 1994; Montes y Eguiarte, 2002). Sin embargo, los análisis genético-demográficos señalan que la asimetría del flujo puede ser hasta trece veces más grande del acervo doméstico hacia el silvestre, lo cual ha provocado abatimiento de la diversidad genética en las poblaciones silvestres, así como un alto desplazamiento alélico de alelos silvestres por domésticos y una baja diferenciación genética entre las poblaciones arvenses y las domésticas (Priori, 2015).

Un alto número de poblaciones seleccionadas y cultivadas por los humanos no han podido ser domesticadas debido a su biología reproductiva o a la baja intensidad de selección artificial y manejo humano. Estas poblaciones también presentan alta frecuencia o incluso fijación de alelos que les confieren fenotipos favorables al consumo y al cultivo, pero no han perdido su capacidad de sobrevivencia en condiciones naturales, por lo que son consideradas semidomesticadas o en proceso de domesticación. Las poblaciones cultivadas, tanto semidomesticadas como silvestres, se pueden escapar del cultivo y convertirse en invasoras tanto de hábitats naturales como transformados, y entrecruzarse con las poblaciones silvestres de su especie, como es el caso de muchas especies de pastos como Andropogon y Cynodon, u otras especies cultivadas como Opuntia y Cylindropuntia.

Por lo tanto, el estudio de la dinámica evolutiva de los acervos silvestre-arvense-doméstico nos permite estimar el papel del campesino en la generación o pérdida de diversidad genética. Así mismo, nos ayuda a establecer las medidas de conservación, restauración y evaluación del riesgo de migración de alelos y propágulos de plantas domésticas y de genotipos semi-domesticados (Martínez-Castillo et al., 2008).

\section{Conclusiones y perspectivas}

El sistema alimentario inicial mesoamericano se pudo estructurar con especies de la selva baja caducifolia que resultaron favorecidas por el fuego y que respondieron positivamente a la selección y al manejo humano. El sistema pudo ser establecido por grupos humanos que arribaron a Mesoamérica hace 11500 a 10500 años y que presentaban una adaptación cultural basada en la recolección de granos y semillas. Este sistema inicial, basado en el maíz, la calabaza, el frijol y e chile, se pudo integrar a partir del uso de las poblaciones silvestres de estas especies, utilizando piedras moledoras, fuego, cenizas y hornos bajo tierra. Este sistema pudo favorecer el asentamiento humano para dar inicio a la domesticación y agricultura tan temprano como hace 9000 años.

Las plantas mesoamericanas domesticadas se difundieron hacia el sur, a través de la vertiente del Pacífico, en donde se distribuyen las selvas secas, arribando a Panamá y la costa norte de Suramérica tan temprano como 7900-7400 años, y a la costa sur de Ecuador y norte del Perú entre 6700-6500 A.P.

La domesticación significó para las plantas dependencia a los humanos para sobrevivir, y para los humanos un histórico alto costo social que no valoramos. El estudio de la dinámica actual de la evolución bajo manejo y selección humana es fundamental para establecer estrategias de conservación y restauración, así como para evaluar el riesgo de escape de genes domésticos incluyendo transgenes hacia las poblaciones silvestres.

La alta diversidad de recursos fitogenéticos generados en multitud de ambientes presenta en la actualidad grandes amenazas a raíz de los cambios sociales y económicos que está provocando la globalización de los mercados, tales como: (a) la destrucción acelerada del hábitat, a reducción de las selvas bajas y los bosques de encino-pino, debido a su desplazamiento por la ganadería y el desarrollo urbano; (b) la perturbación de los sitios de anidación y destrucción de polinizadores, particularmente murciélagos para los agaves, así como las abejas y los colibríes para los frijoles y las calabazas; (c) la introducción de plantas invasoras, como los pastos africanos utilizados en la ganadería extensiva; (d) el uso excesivo de agroquímicos, particularmente los herbicidas; (e) el abandono de los cultivos tradicionales nativos; (f) el desplazamiento de los cultivares nativos con cultivares mejorados y transgénicos promovidos por los programas gubernamentales y privados; (g) la intensificación de la agricultura con alta inversión; (h) el abandono del campo por migración y por el desplazamiento humano, e (i) el cambio demográfico en la agricultura mexicana, quedando en las áreas rurales solo los campesinos viejos realizando las actividades agrícolas.

Entre los principales retos que enfrentamos para la conservación de los recursos genéticos mesoamericanos está: (a) la necesidad de monitorear el proceso evolutivo en los enjambres genéticos silvestre-arvense-doméstico en cada una de las especies, a fin de establecer las estrategias adecuadas de conservación, restauración y aprovechamiento; (b) la necesidad de establecer programas de conservación participativa in situ que incluyan la diversidad de la milpa; (c) la necesidad de establecer programas adicionales a los de conservación ex situ, y (d) la urgente necesidad de apoyar económicamente a las unidades productivas tradicionales, para que conserven su germoplasma y lo mejoren. 


\section{Bibliografía}

Aceituno, F. y N. Castillo, 2005. Mobility strategies in Cooke, R., 2005. Prehistory of Native Americans on the Colombia's midlle montain range between the early an middle holocene. Before farming, 2:1-17.

Aceituno, F. y S. Rojas, 2012. Del Paleoindio al Formativo: 10.000 años para la historia de la tecnología lítica en
Colombia. Boletín de Antropología, 26 (43): 124-156.

Aceituno, J. y N. Loaiza, 2014. Early and Middle Holocen evidence for plant use and cultivation in the Middle Cauca River Basin, Cordillera Central (Colombia).

Acosta-Ochoa, G., 2010. Late-Pleistocene/Early-Holocen Tropical Foragers of Chiapas, Mexico:Recen

Acosta-Ochoa, G., 2011. El poblamiento de las regiones

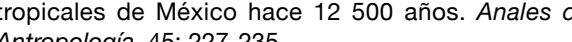

Amick, D., 1996. Regional patterns of Folsom mobility and land use in the American Southwest. World Archaeology,

Austin, D., 2006. Fox-tail millets (Setaria:Poaceae) Abandoned food in two hemispheres. Economic Botany,

Benz, B., 2001. Archaeological evidence of teocintle of the National Academy of Sciences of the USA, 98 2104-2106.

Black, S. y A. Thoms, 2014. Hunter-gatherer earth ovens in the antiquity, 79(2): 203-206.

Burney, D., L. Burney y R. MacPhee, 1994. Holocene charcoa stratigraphy from Laguna Tortuguero, Puerto Rico, and the timing of human arrival on the island. Journal of Archaeological Science, 21(2): 273-28

Callen, E., 1967. Food habits of some Pre-Columbian Mexican Indians. Economic Botany, 19(4): 335-343.

Chacon, S., B. Pickersgill y D. Debouck, 2005 Domestication patterns in common bean (Phaseolus vulgaris $\mathrm{L}$.) and the origin of the Mesoamerican an Andean cultivated races. Theoretical and Applied

Chandler-Ezell, K., D. Pearsall y J. Zeidler, 2006. Root and tuber phytoliths and starch grains document manioc (Manihot esculenta), arrowroot (Maranta arundinacea),
and lerén (Calathea sp.) at the Real Alto site Ecuador. Economic Botany, 60 (2): 103-120.

Colunga-GarcíMarí, P. y D. Zizumbo-Villarreal, 1903 Evolución bajo agricultura tradicional y desarrollo sustentable. En: E. Leff y J. Carabias (Coord.) Cultura y manejo sustentable de los Recursos Naturales. Volumen I. CIIH-UNAM-Miguel Ángel Porrúa. México. pp. 123-164.

Colunga-GarcíaMarín, P. y D. Zizumbo-Villarreal, 2004 Domestication of plants in Maya Lowlands. Economi
Botany, 58 (supplement): S101-S110. and divergence. Journal of Archaeological Research, 13: $129-187$

Cooke, R., M. Jiménez y A.J. Ranere, 2007. Influencias humanas sobre la vegetación y fauna de vertebrados y punana. actualización de datos arqueozoológicos precolombina. En: Jackson, JBC y F Santos-Granero (Eds.) . Ecología y Evolución en los Trópicos. Smithsonian Tropical Research Institute, Panamá: 562-593. transition to agriculture in prehistoric Panama: evidence from starch grains and macro
Temple University, Philadelphia.

ckau, R., A. Ranere y R. Cooke, 2007. Starch grain evidence for the preceramic dispersals of maize and root crops into tropical dry and humid forests of Panama. Proceedings of the National Academy of Sciences of the USA, 104:

Dickau, R., 2010. Microbotanical and macrobotanical evidence of plant use and the transition to agriculture in Panama. En: VanDerwarker A. y T. Peres (Eds.), consideration of issues, methods, and cases. New York: Springer, pp. 99-134.

Dillehay, T., J. Rossen y P. Netherly, 1997. The $\mathrm{N}$ anchoc tradition: The beginnings of

Dillehay, T., J. Rossen, G. Maggard, K. Stackelbeck aggregation in the Late Pleistocene and Early Holocen on the north coast of Peru. Quaternary International, 109-110: 3-11

Dillehay, T., C. Ramirez, M. Pino, M.B. Collins, J. Rossen y J.D. Pino-Navarro, 2008. Monte Verde: Seaweed, food,
medicine and peopling of South America. Science, medicine and
320: 784-786

Dixon, E., 2001. Human colonization of the Americas: timing

Doebley, J., 1984. "Seeds" of wild grasses: A major food for Southwestern Indians. Economic Botany, 38: 52-64. Review Genetics, 38: 37-59.

Doebley, J., 2006. Unfallen grains: how ancient farmers turned weeds into crops. Science, 312: 1318-1319. Teocintle glume architecture 1: a genetic locus controlling a key step in maize evolution. Science,

lannery, K., 1986. Guila Naquitz, archaic foraging and early agricu.
York. ickau, R., 2005. Resource use, crop dispersals, and the P. Netherly, 2003. Localization and possible socia technology and process. Quarternary Science Reviews

Dorweiler, J., A. Stec A, J. Kermicle y J. Doebley, 1993
Freitas, F., G. Bendel, R. Allaby y T. Brown, 2003. DNA from primitive maize races and archaeological remains: implications for the domestication of maize and its
expansion into South America. Journal Archaeological Science, 30: 901-908.

González, A., A Terrazas, W. Stinnesbeck, M. Benavente, J. Avilés, C. Rojas, J. Padilla, A. Velásquez, E. Acevez y E. Fre, 2014. The first human settlers on the Yucatan Peninsula: Evidence from drowned caves in the State
of Quintana Roo (South Mexico). En: Kelly E. Graf (Ed). Paleoamerican Odyssey, Texas A\&M University Press: 19. College Station, Texas: pp. 323-337.

Grobman, A., D. Donavia, T. Dillehay, D. Piperno, J. Iriarte e I. Hols, 2012. Preceramic maize from Paredones and Huaca Prieta, Peru. Proceedings of the National
Academy of Sciences of the USA, 109 (5): 1755-1759.

Gruhn, R., A. Bryan y J. Nance, 1977. Los Tapiales: Paleo-indian camp site in the Guatemala Highlands. Proceedings of the American Philosophical Society, 121: 235-273

Heerwaarden, J., J. Doebley, W. Briggs, J. Glaubitz, M. Goodman, J. Sanchez-Gonzalez y J. Ross-lbarra, 2011. Genetic signals of origin, spread, and introgression in a large Acte of maze landraces. P ASA, 108(3): 1088-1002.

Hufford, M., P. Lubinksy, T. Pyhájárvi, M. Devengenzo, N. flic 9:1003477.

Koinange, E., S. Singh y P. Gepts, 1996. Genetic control of the domestication syndrome in common bean. Crop
Science, 36:1037-1045.

Kraft, K., C. Brown, G. Nabhan, E. Luedeling, J. Luna Ruiz, Geo Coppens d'Eeckenbrugge, R. Hijmans y P. domesticated chili pepper (Capsicum annuum) in Mexico. Proceedings of the National Academy of Sciences of the USA, 111(17): 6165-6170.

Kwak, M., J. Kami y P. Gepts, 2009. The putative Mesoamerican center of domestication of Phaseolus vulgaris $\mathrm{L}$. is located in the Rio Lerma-Santiago basin

Lohse, J., J. Awe, C. Griffith, R. Rosenwing y F. Valdez, 2006. Preceramic occupations in Belize: Updating th paleoindian and archaic record. Latin American Antiquity,

Lorenzo, J. y L. Mirabell, 1986. Tlapacoya: 35, 000 años de historia en el Lago de Chalco. Colección Cientifica, Historia, México.

MacNeish R. y F. Peterson, 1962. The Santa Marta Rock Shelter, Ocozocoautla, Chiapas, México. New World Archaeological

MacNeish, R, 1964. Ancient Mesoamerica civilization. Science, 143: 531-537.

MacNeish, R., 1967a. A summary of the subsistence. En:
Environment and subsistence. Volumen 1: University Texas Press, Austin, pp. 290-309.

can archaeology. Biennial Review of Anthropology, 5: 306-331.

Neish, R. y A. Nelken-Terner, 1983a. The Preceramic of Mesoamerica. Journal of Field Archaeology, 10 (1): 71-84.

acNeish, R. y A. Nelken-Terner, 1983b. Final Annual Report of the Belize Archaic Archaeological Reconnaissance, Boston.

acNeish, R. y M. Eubanks, 2000. Comparative analysis of the Rio Balsas and Tehuacan models for the origin of maize. Latin American Antiquity, 11(1): 3-20.

Magard, G y T. Dillahay, 2011. El Palto Phase (13800-9800 BP). En: T. D. Dillehay (Ed.). New perspectives on food production and social organization. Cambridge University

aggard G., 2011. A Las ocupaciones humanas de Peistoceno Final y el Holoceno Temprano en la costa norte del Perú. Boletín de arqueología PUCP (Perú)

atsuoka, Y., Y. Vigouroux, M. Goodman, G.J. Sánchez, E. Buckler y J. Doebley, 2002. A single domestication for Proceedings of the National Academy of Sciences of the USA, 99: 6080-6084.

artínez-Castillo, J., D. Zizumbo-Villarreal, P. Gepts, P. Delgado-Valerio y P. Colunga GarcíaMarín, 2006 Structure and Genetic Diversity of Wild Populations of Lima Bean.(Phaseolus lunatus L.) from the Yucatan Peninsula, Mexico. Crop Science, 46: 10711080.

artínez-Castillo, J., D. Zizumbo-Villarreal, P. Gepts y P. Colunga-Garciamarín, 2007. Gene flow and genetic structure in the wild-weedy-domesticated complex of domestication and diverity Mesoamerican center of artínez-Castillo, J., D. Zizumbo-Villarreal y P. ColungaGarcíaMarín, 2008. Genetic erosion and in situ landraces in its Mesoamerican diversity center Genetic Resources and Crop Evolution, 55(7): 1065-1077.

Montes-Hernández, S. y L. Eguiarte, L. E., 2002. Genetic structure and indirect estimates of gene flow in three taxa of Cucurbita (Cucurbitaceae) in western Mexico. American Journal of Botany, 89: 1156-1163.

derberger C 1979. Early sedentary economy in the basin of Mexico. Science, 203: 131-142.

gán-Jiménez, J., M. Rodríguez, L. Chanlatte e Y. Narganes, 2005. La temprana introducción y uso de algunas plantas domésticas, silvestres y cultivos en Las Antillas precolombinas:una primera revaloración desde la perspectiva del "arcaico" de Viequé
Diálogo Antropológico, 3(10):7-33.

agan-Jimenez, J., R Rodríguez-Ramos, B. Reid, Van den Bel Corinne y M. Hofman, 2015. Early dispersals of maize and other food plants into the Southern Caribbean and Northeastern South $A$ 
Papa, R. y P. Gepts, 2003. Asymmetry of gene flow and differential geographical structure of molecular diversity in wild and domesticated common bean (Phaseolus vulgaris L.) from Mesoamerica. Theoretical Applied

Payró de la Cruz, E., P. Gepts, P. Colunga-GarciaMarín y D Zizumbo-Villarreal, 2005. Spatial distribution of genetic diversity in wild populations of Phaseo/us vulgaris L. from
Guanajuato and Michoacan, Mexico. Genetic Resources and Crop Evolution, 52(5): 589-599.

Perales, H. y J. Aguirre, 2008. Biodiversidad humanizada. En: Capital Natural de Mexico. Volumen I. Conocimiento act

Pearsall D. K. Chander-Ezell y A. Chandler-Ezell, 2004. Maize in ancient Ecuador: results of residue analysis of stone tools from the Real Alto site. Journal Archaeology Science, 31: 423-442.

Perry, L., 2002. Starch granule size and the domestication of manioc (Manihot esculenta) and sweet po
batatas). Economic Botany, 56: 335-349.

Perry, L., R. Dickau, S. Zarrillo, I. Holst, D.M. Persall, D. Piperno, J.M. Berman, G.R. Cooke, K.Rademaker et al 2007. Starch fossils and the domestication and dispersa of chili peppers (Capsicum spp. L.) in the Americas.

Pickersgill, B., 1971. Relationships between weedy and cultivated forms in some species of chili peppers (genus

Pickersgill, B., 2007. Domestication of plants in the Americas: insights from Mendelian and molecular genetics. Annals

Piperno, D. y M. Pearsall, 1998. The origins of agriculture in the lowland neotropics. Academic Press, San Diego.

Piperno D., T. Andres y K. Stothert, 2000. Phytoliths in Cucurbita and other neotropical Cucurbitaceae and
their occurrence in early archaeological sites from the their occurrence in early archaeological sites from the lowland American tropics. Journal of Archaeological
Science, 27(3)193-208.

Piperno D. y K. Klannery, 2001. The earliest archaeological aize (Zea mays L.) from highland Mexico: New implications. Proceedings of the National Academy of Sciences of the USA, 98: 2101-2103.

Piperno, D., I. Holst, L. Wessel-Beaver y T. Andres, 2002. Evidence for the control of phytolith formation in Cucurbita fruits by the hard ring $(\mathrm{Hr} r)$ genetic locus: archaeological and ecological implications. Proceedings of the National Academy of Sciences of the USA, 99(16:

Piperno, D. y E. Stothert, 2003. Phytolith for early Holocen Cucurbita domesticaction in Southwest Ecuador.

Piperno, D., 2006. Quaternary environmental history and agricultural impact on vegetation in Central Ame

Piperno, D., J. Moreno, J. Iriarte, I. Holst, M. Lachniet, G. Jones, A.J. Ranere y R. Castazo, 2007. Late Pleistocen central balsas watershed of Mexico. Proceedings of the National

Piperno, D. y T. Dillehay, 2008. Starch grains on human teeth reveal early broad crop diet in northern Peru. Proceedings of the National Academy of Sciences of the USA, 105(50) 19622-19627.

Piperno, D., A. Ranere, I. Holst, J. Iriarte y R. Dickau, 2009. Starch grain and phytolith evidence for early nint millennium BP maize from the Central Balsas River of Sciences of the USA, 106: 5019-5024.

Piperno, D., 2011. The origins of plant cultivation and domestication in the new wo process, and new developments. Current Anthropology.

Jones, J Jacob Piperno D, S. France, D. Lentz, J. Gifford, M. Danford y J.Josserand, 1996 Early agriculture in the

Pohl, M., D. Piperno, K. Pope y J. Jones, 2007. Microfossi evidence for pre-columbian maize dispersal in the neotropics from San Andres, Tabasco, Mexico. Proceedings of the National Academy of Sciences of the USA, 104: 6870-6875.

ope, K., M. Pohl, J. Jones, D. Lentz, C. Nagy, C. von Vega el. Quitmyer, 2001. Origin and environmental setting of ancient agriculture in the lowlands of Mesoameric

Priori D., 2015. Recursos genéticos de abóboras: usos, caracterização e avaliação do fluxo gênico. Agronomia Ciências (Fitomelhoramento). Pelotas, Rio Grand del Sur. Brazil.

Raff, J. y D. Bolnick, 2014. Palaeogenomics: Genetic roots of the first Americans, Nature, 506: 162-163.

Ranere, A. y C. E. López, 2007. Cultural Diversity in Late Pleistocene/Early Holocene Populations in Northwest South America and Lower Central America. Internation
Journal of South American Archaeology 1: 25-31.

Ranere, A., D. Piperno, I. Holst, R. Dickau y J. Iriarte, 2009 Preceramic human occupation of the Central Balsas Valley, Mexico: cultural context of early domesticated maize and squash. Proceedings of the Nation
of Sciences of the USA, 106: 5014-5018.

Rasmussen, M., S. Anzcik, M. Waters et al., 2014. The genome of a Late Pleistocene human from a Clovis site in western Montana. Nature, 506: 225-229.

Rossen, J. y T. Dillehay, 1999. La colonización y el asentamiento del norte de Peru: Innovación, tecnologí y adaptación en el valle Dezana. Boletin de Arqueologí

anjur, O., D. Piperno, T. Andres y L.Wessel-Beaver, 2002. Phylogenetic relationships among domesticated and mitochondrial gene: Implications for crop plant evolution and areas of origin. Proceedings of the National Academ of Sciences of the USA, 99 (1):535-540.
Smith, B., 1995. The emergence of agriculture. Scientific Zarrillo S., D. Pearsall, J.Raymond, M. Tisdale y D. Quon American Library, New York, New York, USA.

Smith, B., 2005. Reassessing Coxcatlan cave and the early history of domestication plants in Mesoamerica.
Proceedings of the National Academy of Sciences o the USA, 102: 9438-9445.

Smith, B., 2006. Seed size increase as marker of domestication. En: Zeder et al. (Eds.). Documenting domestication. University of California Press. Berkley,

Smith, C., 1986. Preceramic plant remains from Guila Naquitz. En: Flannery KV (Ed.). Guila Naquitz. Academic

Stothert, K., D. Piperno y T. Andres, 2003.Terminal Pleistocene/Early Holocene Human Adaptation in
Coastal Ecuador: The Las Vegas Evidence. Quaternary International, 109-110: 23-43.

Wayne R, J Leon, domestication: Zeder MA et al. (Eds). Documenting paradigms. University of California Press, Berkley, California: pp. 279-293.

Wilson, H., R. Lira e I. Rodriguez, 1994. Crop-weed gene Bailey (Cucurbitaceae). Economic Botany, 48: 293-300. formative maiz (Zea mays $L$ ) in tropical Ecuador. Proceedings of the National Academy of Sciences

Zizumbo-Villarreal, D., P. Colunga-GarcíaMarín, E. Payró de la Cruz, P. Delgado-Valerio and P.Gepts, 2005. Population structure and evolutionary dynamics of wild-weedy Mesoamerican region. Crop Science, 45 (3): 1073-1083. Origin of agriculture and plant domestication in Wes
Mesoamerica. Genetic Resources Crop Evolution, 57 813-825.

Zizumbo-VillarrealD., A. Flores-Silva y P. Colunga-GarcíaMarín 2012. The archaic diet in Mesoamerica: Incentive for milpa development and specic

Zizumbo-Villarreal D., A. Flores-Silva y P. ColungaGarciaMarin, 2014. The impact of the ceramics on the archaic food system in the West Mesoamerica. Economic Botany, 68(1): 67-84. 


\section{Etnoconservacionismo y prácticas locales en Patagonia: avances y perspectivas}

Ana Haydeé Ladio y Soledad Molares

\section{Resumen}

El paisaje patagónico debe ser pensado como una construcción cultural: causa y efecto de distintas intensidades de manejo que dependen de la visión de las sociedades que lo habitan. La Patagonia Norte se caracteriza por poseer una amplia población rural, criolla y mapuche-tehuelche con economías de subsistencia ligadas a la ganadería, horticultura y la recolección. Nuestra premisa es que en dichas poblaciones existieron -o existen- concepciones, conocimientos y prácticas de uso del ambiente que brindan riqueza de soluciones que permiten la coexistencia de los habitantes y las especies de interés. Nuestro grupo ha estudiado los conocimientos y prácticas albergados por 35 comunidades humanas, con el propósito de distinguir y reactivar aquellas prácticas in situ y ex situ que contienen componentes y mecanismos que generan redundancia, diversidad y autosuficiencia; lo anterior partir de una aproximación etnobiológica y cuali-cuantitativa basada en el trabajo de campo con entrevistas $(>1200)$, talleres comunitarios (20), relevamientos de vegetación y bibliográficos, encontramos que el conocimiento local es redundante y versátil (500 especies de plantas medicinales, 300 comestibles silvestres y 150 especies de plantas cultivadas). La redundancia utilitaria parece depender de prácticas con distintas intensidades de manejo in situ y ex situ que humanizan los ambientes de recolección y que, por ejemplo, en el caso de los bosques de Araucaria araucana, podría representar un proceso de domesticación insipiente. Diferentes normas sociales aseguran el aprovisionamiento de las plantas útiles y un uso eficiente y solidario que evita su sobreexplotación. La visibilización de estos procesos es crucial para arribar a propuestas de acciones que promuevan la conservación biocultural de la región.

Palabras clave: domesticación, etnobotánica, mapuche, paisaje Patagonia. 


\section{Introducción}

La noción de paisaje como una construcción cultural, causa y efecto de un manejo o uso por parte de las sociedades humanas, es un concepto vertebral en etnobiología (Maffi, 2005; Lema, 2013; Molares y Ladio, 2014). Implica que, en su construcción a lo largo del tiempo, hay una manipulación de sus componentes biológicos que depende directamente de la visión de las sociedades que lo habitan (Toledo y Barrera-Bassols, 2008). En los últimos años, numerosos estudios han tratado de identificar aquellas prácticas locales que ayuden a mantener o incluso aumentar la sustentabilidad ambiental. Dicho interés surge como contraposición a los fracasos en términos de conservación de propuestas que no incluían la dimensión cultural (CostaNeto et al., 2009). De este modo, el conocimiento local empieza a ser visibilizado como un sistema de conocimientos con características propias, además de que puede dar respuestas contextuadas y ajustadas in situ ante la variabilidad socio-ambiental. Varios estudios en América y en la Patagonia dan cuenta que en las poblaciones tradicionales se ejecutan prácticas de uso del ambiente que mantienen viva la historia y la experiencia acumulada de la cultura local, y que brindan riqueza de respuestas y soluciones que están en sintonía con el mantenimiento de los recursos naturales (Blancas et al., 2010; Richeri et al., 2013; Lins Neto et al., 2014).

Se trata de dilucidar aquellos conocimientos y prácticas de uso del ambiente que están vinculados con el mantenimiento a largo plazo de ciclos ecológicos, y que, por ende, aseguran su sustentabilidad, es decir, que posibilitan la coexistencia; posibilitan incluso la co-evolución de los habitantes y los recursos naturales (Berkes et al., 2000). En este sentido, el conjunto de saberes ambientales, que forman parte del acervo cultural y acumulativo de las comunidades locales, es de suma importancia; en términos teóricos, corresponde al concepto de conocimiento ecológico tradicional (CET o en inglés TEK, traditional ecological knowledge) descrito como el cuerpo de conocimientos adquiridos a lo largo de la historia, a través de la experiencia directa y el contacto con el medio ambiente (Berkes et al., 2000; Berkes y Davidson-Hunt, 2006). Este conocimiento abarca amplios aspectos de la vida de los pobladores, tanto materiales como espirituales, que actúan de manera acoplada. Es un cuerpo de conocimientos que involucra prácticas y creencias que evolucionan por procesos adaptativos, y que se mantienen por transmisión cultural (Lozada et al., 2006 Ladio, 2011a).

Las poblaciones rurales originarias de la Patagonia han sufrido sucesivos cambios socio-ambientales, así como transformaciones culturales y ecológicas, debidas principalmente a la influencia hegemónica de la sociedad occidental y del mercado, con lógicas del uso del ambiente que en la mayoría de los casos implicaron su sobreexplotación o transformación completa. Este nuevo orden económico-productivo impuesto desde finales del siglo XIX se encuentra ligado a la producción extensiva de ganado ovino (Paruelo et al., 2006; Golluscio et al., 2010), así como a la forestación con especies exóticas (Orellana y
Raffaele, 2010). Paralelamente, las poblaciones locales fueron diezmadas y sus territorios usurpados (Navarro Floria y Delrío, 2011), de manera que sus actividades productivas se restringen a la mera subsistencia. Adicionalmente, el mayor acceso a la sociedad global y la mayor presencia de las instituciones en estos sitios aislados (Eyssartier et al., 2011a,b), los procesos de des-agrarización (Eyssartier et al., 2013), migración (Gundermann y Ruit, 2009), cambio de uso de la tierra (Valverde et al., 2011), el creciente desarrollo de la megaminería de oro y plata (Gutiérrez, 2006) y la actividad petrolera en tierras ancestrales (Galafassi, 2012), son algunos de los otros procesos que vienen suscitando ajustes y cambios en la vida de dichos pobladores.

El conocimiento ecológico tradicional albergado por las comunidades rurales depende directamente de las concepciones o sistema de creencias ("cosmos"), del cuerpo de conocimientos o "corpus" y de su puesta en práctica efectiva o "praxis" (Toledo y Barrera-Bassols, 2008; Ochoa y Ladio, 2014). Esta relación cosmos-corpus-praxis no es estática, y es sensible a cambios socio-ambientales y culturales. Estos cambios pueden disminuir o incrementar la vulnerabilidad de los sistemas humano-ambiente, de modo que tal transformación representa, según corresponda, una pérdida o un aumento de resiliencia (Folke et al., 2002).

El concepto de resiliencia aplicado a la etnobiología ha sido ligado a la habilidad que tiene el sistema de conocimientos y prácticas tradicionales de ajustarse a los disturbios y a los cambios, y al grado en el cual el sistema humano-ambiente es capaz de reorganizarse, aprender y adaptarse (Ladio, 2013). En este contexto, cuando los cambios son inevitables en una sociedad y/o en el ambiente, los sistemas resilientes contienen los componentes y los mecanismos para revitalizar y/o reorganizar los saberes ambientales para una mayor autosuficiencia (Richeri et al., 2013). Más profundamente, se trata entonces de dilucidar el cosmos, el corpus y la praxis que fundamentan las formas de vida que sostienen la coexistencia de los recursos y los pobladores.

En este capítulo, analizaremos algunos de los aspectos arriba señalados, tomando como base las investigaciones etnobotánicas realizadas en los últimos 13 años por el Grupo de Etnobiología del INIBIOMA, focalizando en las siguientes preguntas: 1) ¿cuál es la concepción tradicional (cosmos) que sustentan los pobladores rurales patagónicos acerca de su ambiente y su conservación?; 2) ¿cuáles son los principales conocimientos (corpus) sobre plantas que albergan dichas poblaciones y sus principales características?; 3) ¿qué prácticas de manejo (praxis) se han desarrollado en las comunidades que propician la coexistencia humano-ambiente?

Muchos de estos temas están siendo todavía estudiados y se encuentran en proceso de revisión permanente, es por ello que nos centraremos en el tópico más indagado en la región: las plantas comestibles y medicinales. Esto ya que es una temática que está siendo profusamente revisada en la actualidad, tanto a nivel local como mundial, debido a la crisis alimentaria que se prevé para los próximos años (Viatte et al., 2009; Bharucha y Pretty, 2010 Ladio, 2011b). Por ende, creemos que estos hallazgos pueden orientar a una mayor visibilización de la importancia del conocimiento tradicional en la Patagonia para el desarrollo de políticas vinculadas a la soberanía alimentaria y la sustentabilidad socio-ambiental. 


\section{Materiales y Métodos}

\section{Sitios de estudio}

Este trabajo incluye a trabajos etnobotánicos realizados por el grupo de etnobiología del INIBIOMA en poblaciones rurales y urbanas, situados en un área que abarca una amplia faja de aproximadamente $800 \mathrm{~km}$ de oeste a este de la Patagonia Norte, que incluye a las provincias de Neuquén, Río Negro y Chubut, Argentina. También incluye una gran variación ambiental involucrando a las provincias fitogeográficas Sub-antártica, Patagónica y Monte (Cabrera, 1976). Por ende, representa a un gran repertorio de plantas pertenecientes a distintas unidades fitogeográficas como bosques, estepas, montes y ambientes antrópicos, así como también distintas sociedades en interacción. Se detalla por provincia cada una de las comunidades, las cuales son 35 en total (Figura 16.1):

\section{Provincia de Río Negro}

La ciudad de S.C. de Bariloche con 133500 habitantes (INDEC 2010, www.censo2010.indec. gov.ar// y poblaciones de su zona de influencia (más de $100 \mathrm{~km}$ a la redonda) que comprende áreas sub-urbanas y rurales como: El Manso, Río Villegas, Colonia Suiza, Nirihuau, Dina Huapi, Frutillar, Pilar I, Mascardi y la comunidad mapuche Millalonco-Ranquehue, asentada dentro de la ciudad. La actividad económica principal es la turística junto con el comercio, el empleo público y, en las zonas alejadas, la actividad ganadera y la horticultura. La comunidad semi-rural de Pilkaniyeu, a $70 \mathrm{~km}$ de Bariloche $(800$ habitantes, algunos con ascendencia criolla y mapuche), dedicada a la actividad pecuaria y al empleo público. La comunidad semi-rural de Comallo y áreas aledañas (Laguna Blanca, Pilquiniyeu del Limay, y Cañadón Chileno), (aproximadamente 1000 habitantes en total, que están distantes aproximadamente a $120 \mathrm{~km}$ de San Carlos de Bariloche, y cuya población posee ascendencia mapuche pero también de filiación criolla). En su mayoría están dedicados a la actividad ganadera de subsistencia y el empleo público.

\section{Provincia de Neuquén}

Las comunidades mapuches del Departamento de Catan-lil en la región extra-andina, en el SO de la provincia, que corresponden a las poblaciones mapuche Rams (23 familias), Cayulef (40 familias) y Paineo ( 51 familias), están distantes entre sí en no menos de $50 \mathrm{~km}$. Las poblaciones urbanas más cercanas son Zapala (20 000 habitantes) y Junín de los Andes (9000 habitantes). La actividad económica está basada en la cría y venta de chivas y ovejas, y en la comercialización de lana y tejidos tradicionales, con nula actividad en el turismo. Las comunidades mapuches del Departamento de los Lagos: Curruhuinca, compuesta por aproximadamente 150 familias distribuidas en las localidades de Quila-Quila, Pil-Pil, a $30 \mathrm{~km}$ de la ciudad de San Martín de los Andes, y la comunidad mapuche Pailefilú en el paraje de Malleo, a 30 km de Junín de los Andes. Dichas familias viven de la cría de ganado y actividades ligadas al turismo. La comunidad de Cuyín Manzano (aproximadamente 200 habitantes), Villa Traful (400 habitantes), poblaciones rurales distantes a $70 \mathrm{~km}$ de Bariloche. La mayoría basa su economía en el uso de la tierra, la cría de ganado vacuno y ovino, la venta de artesanía y de actividades relacionadas con el turismo y la caza deportiva de ciervos.

\section{Provincia de Chubut}

Las ciudades cordilleranas de Esquel (33 000 habitantes) y Trevelin (8000 habitantes.), y las ciudades al este, próximas a la costa atlántica, como Dolavon (3300 habitantes), Gaiman (6700 habitantes), Trelew (99 000 habitantes), Rawson (32 000 habitantes) y Puerto Madryn (87 400 habitantes), distantes las dos primeras del resto por aproximadamente $600 \mathrm{~km}$. Dichas comunidades poseen una población heterogénea, principalmente oriunda de las grandes ciudades, descendientes de galeses, chilenos y otros inmigrantes europeos, además de habitantes originarios mapuches y tehuelches. Las principales actividades económicas son las relacionadas a la industria del petróleo, pesca y turismo, para las ciudades del extremo oriental; y las vinculadas a la ganadería, turismo y forestal, para las de la zona cordillerana. También se incluyeron

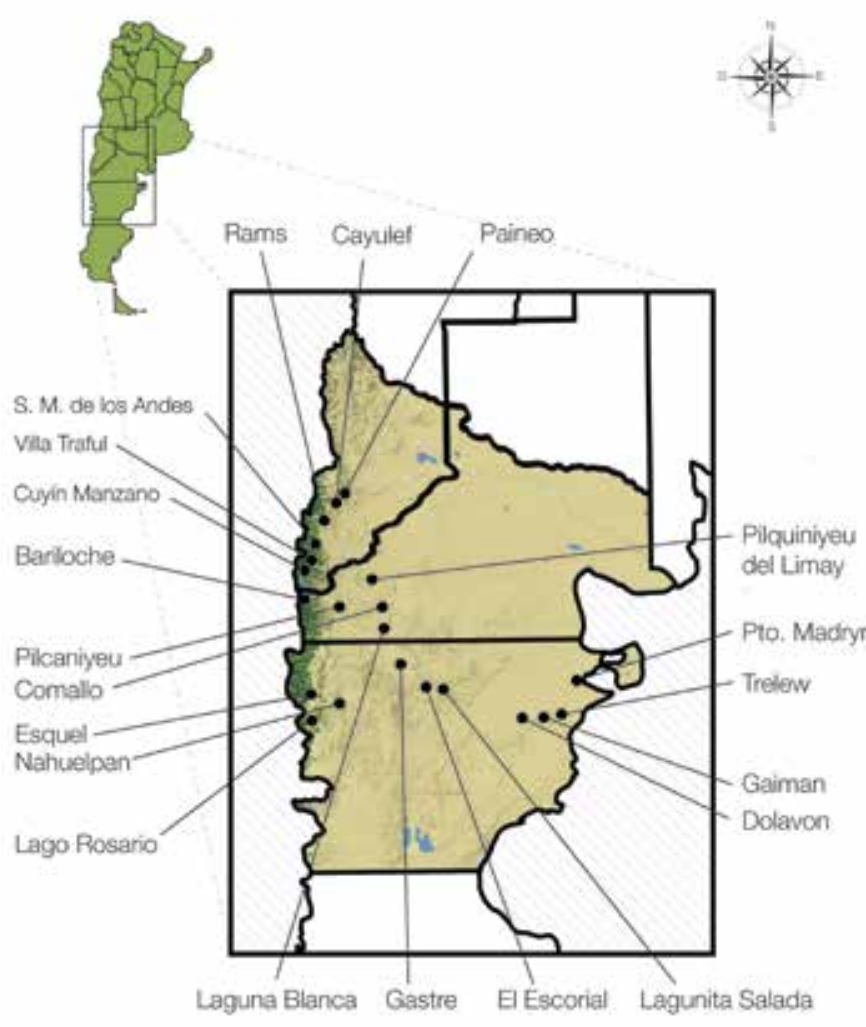

a las poblaciones rurales de la Meseta Chubutense de ascendencia mapuche-tehuelche y/o criollos que habitan la región centro-norte de la provincia del Chubut, principalmente en los asentamientos rurales de los alrededores de Gastre, Lagunita y Gan Gan, en donde cada lugar cuenta entre 20 y 40 familias. Son poblaciones pequeñas cuya actividad económica de subsistencia es la cría de ganado ovino y caprino. Por último, as comunidades mapuche de Lago Rosario y Nahue Pan al oeste de la provincia en la región cordillerana: su población es de 500 y 60 habitantes respectivamente, $y$ sus actividades económicas típicas son la ganadería y la venta de artesanías en madera, cuero y lana.

Figura 16.1. Mapa de las 35 comunidades rurales, semirurales y urbanas que participaron de estudios del grupo de etnobiología del INIBIOMA (Patagonia, Argentina). 


\section{Metodología}

El trabajo de campo comenzó en 1997 y sigue en curso hasta el día de hoy en varias comunidades, en todos los casos sigue la metodología etnobotánica:

\section{Métodos etnográficos}

Primeramente, se procede a la obtención del consentimiento de las comunidades involucradas y sus líderes locales para poder trabajar en el área, además de cada una de las personas intervinientes, siguiendo los lineamientos del Código de Ética de la Sociedad de Etnobiología (2006), los de la Convención sobre la Diversidad Biológica (1992) y los de la Conferencia de las Naciones Unidas sobre Desarrollo Sostenible Río+20 (2012). Siempre se instrumenta junto con cada una de las comunidades las formas de devolución, experiencias participativas y evaluación de los resultados desde el comienzo de la investigación. Mediante entrevistas generales, en todas las comunidades se registraron datos vinculados a las condiciones poblacionales, culturales y socioeconómicas de los informantes (ej. sexo, edad, nivel educativo, bilingüismo, nivel de ingresos, métodos de calefacción, nivel de producción en la actividad ganadera, práctica de trashumancia, recolección, pesca, caza, entre otros.). Luego se prosiguió con el relevamiento del número de especies conocidas y utilizadas como alimento y/o medicina (Ladio y Lozada, 2004a). Esto se efectuó principalmente mediante la triangulación de enlistados libres entrevistas con material de referencia y paseos junto a informantes (Albuquerque et al., 2010).

Asimismo, mediante entrevistas abiertas y a profundidad, se trató de documentar en detalle as concepciones y percepciones asociadas a la utilización de los diferentes recursos biológicos, así como las dificultades con las que se enfrentan los pobladores para recrear y transmitir sus prácticas tradicionales de uso y manejo.

Métodos sociales participativos: Se utilizaron distintas técnicas de actuación social, con distintas dinámicas y materiales, que facilitan el diálogo, la reflexión, la formulación de propuestas y las acciones en una comunidad en forma horizontal, siendo aportes metodológicos que ayudan a visualizar la diversidad al interior y exterior de la comunidad; por ejemplo, recorridos comunitarios de interpretación y talleres de evaluación rápida participativa (PRA) (Albuquerque et al., 2010). Además, participamos en la organización de ferias locales de venta y/o intercambio de productos regionales, semillas y conocimientos, y en la confección de material didáctico en talleres escolares; esto como una oportunidad más de visualizar, rescatar e intercambiar los saberes comunitarios.

Diseño de muestreo: Se incluyen en este trabajo los resultados de 1200 entrevistas de distintos trabajos etnobotánicos realizados. Esto corresponde a aproximadamente 30 informantes (uno por unidad familiar) por comunidad rural, en general, representando del $80 \%$ al $100 \%$ de la población (más detalles en: Ladio y Lozada, 2004a,b; Lozada et al., 2006; Molares y Ladio, 2012; Molares y Ladio, 2014). En el caso de las poblaciones urbanas el diseño incluyó a más personas, se trabajó con entre 100 y 200 personas por estudio de caso, principalmente habitantes y también maestros (véanse mayores detalles en: Ladio y Lozada, 2001; Ladio y Molares, 2013). Las entrevistas fueron de distinta naturaleza y duración, y en general involu- craron varias visitas por informante a sus domicilios particulares o establecimientos rurales, por ende, se destinó un amplio espacio temporal para cada una de ellas. Se realizaron talleres participativos de evaluación (4 en total) y transferencia y/o devolución de resultados (16 en total) con una asistencia promedio de 10 a 30 personas, dependiendo del lugar.

Colecciones biológicas: Se realizaron relevamientos sistemáticos de campo en cada localidad, recolección de material vegetal y confección de ejemplares de herbario. Los ejemplares están depositados en el Herbario del Jardín Botánico de la Patagonia Extra-andina-Centro Nacional Patagónico-CONICET, en el Herbario de la Universidad Nacional del Comahue (BCRU- Index Herbariorum) y en el Herbario del Grupo de Etnobiología, Laboratorio Ecotono La nomenclatura utilizada en la determinación botánica sigue a la base de datos del Instituto Darwinion (Zuloaga y Morrone, 2009, http://www.darwin.edu.ar/Proyectos/FloraArgentina/ fa.htm) y del International Plant Names Index (www.ipni.org). Las listas completas de las especies no se encuentran en este capítulo, pero pueden encontrarse en los trabajos originales. La información relativa a la riqueza de especies totales también fue enriquecida con bibliografía del trabajo de revisión de Rapoport y Ladio (1999) y Molares y Ladio (2009b).

\section{Resultados y discusión}

Nuestros estudios hasta el momento revelan que la utilización de recursos vegetales comestibles y medicinales por parte de las comunidades tradicionales estudiadas reflejan concepciones, conocimientos y prácticas de manejo, que fuera de establecer si son óptimas o no, representan formas propias de ajuste a las condiciones actuales, que les aportan a los pobladores una mayor autosuficiencia en su vida cotidiana. Detallamos a continuación un breve panorama de las mismas:

\section{Concepciones locales sobre el ambiente y su utilización}

En los distintos contextos y comunidades rurales donde hemos trabajado, principalmente descendientes de poblaciones originarias, hemos percibido que para las personas de estos lugares la Naturaleza (abstracción o distinción propia de la biología convencional y el pensamiento occidental) es parte de un concepto más amplio, y que significa su universo rural. Este universo rural es complejo y multifacético, social, natural y supranatural a la vez, pero primeramente implica el concepto de un territorio, una geografía que se convierte en hogar, un espacio cargado de materialidad, simbología y significado que enmarca una forma particular de interpretar la vida, un lugar que es un hogar para la persona y que representa su identidad, historia familiar y sus modos de vida (Molares y Ladio, 2012). Por otra parte, cabe aclarar que cada persona entrevistada nos ha mostrado su propia creatividad con respecto a su construcción del mundo, incluyendo diversas alternativas en la organización simbólica de su entorno -casos que no profundizaremos aquí-

Sin embargo, en su conjunto, todos los casos han sido interpretados por nosotros como propios de una concepción y/o cosmovisión de tipo relacional con el ambiente (sensu CostaNeto 
et al., 2009), mostrando una profunda conexión y complementariedad ser humano-Naturaleza, que determina una utilización pautada por reglas consuetudinarias que implican un uso diversificado, racional y cuidado de las especies de interés alimentario y/o medicinal. Una expresión clara de numerosos informantes lo representa: "solo recolectamos lo que necesitamos, así la Mapu (Madre Tierra en mapudungum) no se enoja". De igual manera se le solicita el permiso para la recolección a la misma planta y luego se le agradece. También, la ruptura de estas reglas implica graves sanciones a nivel personal, familiar e incluso comunitario, que requerirán la actuación de especialistas para la restauración de la armonía perdida.

Otros resultados empíricos de nuestro trabajo de campo muestran que el $100 \%$ de los pobladores entrevistados de la Meseta de Chubut recolecta solo aquellas plantas silvestres de uso medicinal que necesita para uso familiar, evitando así sobre-explotación (Richeri et al., 2013). Otro hallazgo en este sentido se encontró en las poblaciones mapuches del Catan-lil, en donde se explicitó que el acto de alimentarse con recursos silvestres, según la visión mapuche, se refiere a tomar energía o "afutun" (en mapudungum) en total balance con el resto de las manifestaciones de la Naturaleza. De manera que cumple un rol sanador y un rol cósmico para la persona si las plantas son recolectadas con respeto, y sólo en las cantidades que se necesiten (Ladio 2011b). Desde esta perspectiva, todos los integrantes del mundo natural (por ejemplo, la gente y plantas) constituyen elementos igualitarios donde uno no tiene más derechos sobre otro. En donde, por ejemplo, para la recolección de plantas medicinales y comestibles silvestres el espacio es vivenciado de uso común, y a donde todos los vecinos pueden acceder y utilizar, en tanto que se sigan las pautas consensuadas de cuidado (Molares y Ladio, 2012). En este mundo rural, la vigencia de la vida del criancero y sus reglas, de la medicina tradicional, de los Nguillatunes (rogativas de agradecimiento y pedido a la Mapu), del We Tripantu (ceremonia de la renovación de la vida del Solsticio de invierno) y de la solidaridad entre vecinos, son las principales prácticas que sustentan la vida en la tierra (Mapu), y que deben estar en equilibrio con las almas de los antiguos y de los dioses que habitan en el cielo. Según la visión local, este equilibrio es el que genera la renovación de los ciclos ecológicos a través de los cuidados mutuos que brindan todos sus integrantes. Un miembro de la comunidad de Cuyín Manzano lo expresa sintéticamente: "Acá las plantas lo protegen a uno, para mí todas las plantas nos protegen" (Igon et al., 2007) Aunque también, según la visión mapuche, hay plantas de otro tipo, las "brujas" y peligrosas, con un efecto negativo potencial sobre las personas (Molares y Ladio, 2009a). De este modo, las plantas medicinales tienen espíritu (ngenlawen) y, como tales, además de proteger, pueden gobernar y variar sus efectos sobre las personas, castigando severamente acciones incorrectas.

\section{Conocimientos sobre plantas alimenticias y medicinales}

Los pobladores rurales patagónicos albergan un amplio conjunto de conocimientos acerca de las especies, nativas y/o exóticas de la región, las cuales les permiten suplir sus necesidades autónomamente. Por ende, el corpus de conocimientos constituye un elemento fundamenta para encontrar soluciones locales, de ahí la importancia de su conservación, difusión y transferencia (Richeri et al., 2013).

\section{Plantas comestibles silvestres}

Plantas nativas silvestres: Según nuestros relevamientos etnobotánicos e información bibliográfica, tanto en poblaciones rurales como urbanas de la Patagonia, las plantas comestibles silvestres ascienden a cerca de 150 especies nativas totales, encontradas entre 15-35 spp. por comunidad (Rapoport y Ladio, 1999; Ladio, 2001; Ladio y Lozada, 2001; Ladio y Lozada, 2009; Ladio, 2011b; Ochoa y Ladio, 2011; Molares y Ladio, 2015). Las especies comestibles nativas con altos consensos de uso en las poblaciones mapuches estudiadas son diversas, como los frutos silvestres del michay (Berberis microphylla, Berberidaceae), hojas como del culle colorado (Oxalis adenophylla, Oxalidaceae), tubérculos como el yocón (Diposis patagónica, Apiaceae), entre tantas otras. También se encontraron 200 especies exóticas totales (Díaz-Betancourt et al., 1995; Ladio, 2005), hecho que denota el amplio espectro de recursos alimenticios presente en la región. Sin embargo, estas plantas exóticas se conocen y utilizan mucho menos, por ser menor el tiempo de contacto con ellas que con las nativas. Algunas son malezas de reciente llegada a la región traídas por los habitantes intencional o involuntariamente. Otras, tienen una interacción de larga data con los pobladores, quienes las conocen y utilizan asiduamente; como el diente de león (Taraxacum officinale, Asteraceae) y e siete venas (Plantago lanceolata, Plantaginaceae). En general, solo se utilizan entre 5-10 especies exóticas por comunidad (Ladio y Lozada, 2001).

Según las entrevistas, la importancia principal y valor cultural de las plantas silvestres está dado porque diversifican la dieta, y son recursos de amortiguamiento y/o emergencia; especialmente usados cuando la huerta no ofrece todavía cultivos, cuando las tareas del campo demandan muchas horas lejos del hogar, cuando los niños cabalgan hacia las escuelas rurales, entre otros (Ladio y Lozada, 2000; Ladio y Lozada, 2001: Ladio y Lozada, 2003; Ochoa y Ladio, 2014). Sin embargo, para muchas poblaciones, su uso es cada vez más esporádico debido a numerosos factores tanto sociales como ecológicos (Ochoa y Ladio, 2011a,b; Ochoa y Ladio 2014; Molares y Ladio, 2015).

En líneas generales, la riqueza de plantas silvestres comestibles es conocida por igual entre mujeres y hombres de áreas rurales, tendencia que refleja también una asociación con la edad. Las personas mayores saben y usan más plantas que las más jóvenes, siendo interpretado por los pobladores locales como consecuencia del descrédito y valoración negativa ("es cosa de pobres") del uso de plantas silvestres por influencia de la sociedad moderna (Ladio, 2001; Ochoa y Ladio, 2011). En las áreas rurales, los principales recolectores de plantas silvestres parecen ser los niños y las mujeres, y en menor medida hombres mayores y jóvenes que recolectan plantas mientras cuidan a los animales (Ladio y Lozada, 2004b; Ochoa y Ladio, 2014). De los diversos relevamientos sobre el uso actual de plantas comestibles silvestres, encontramos que los pobladores rurales conocen mucho más sobre plantas silvestres, más del doble, que las personas que viven en las ciudades (Ladio y Rapoport, 1999; Ladio, 2001; Ladio y Lozada, 2001). Por otra parte, estudios realizados junto a maestros patagónicos en esta temática, también mostraron que los docentes (urbanos y rurales) tienen conocimientos muy limitados sobre la flora silvestre comestible nativa. Se relevó una riqueza total de 108 especies conocidas por ellos, incluyendo nativas del bosque sub-antártico (11 spp.), estepa 
y monte patagónico (14 spp.), exóticas silvestres (42 spp.) y exóticas cultivadas (36 spp.). Las especies exóticas silvestres y cultivadas fueron las que tuvieron el mayor consenso entre los maestros (Ladio et al., 2007).

Nuestros trabajos en comunidades rurales también revelaron que la adquisición del saber sobre plantas ocurre a edades tempranas entre los niños, y que cuando dejan de acompañar a sus padres en las actividades del campo; por ejemplo, por ir a la escuela ellos pierden el contacto con este escenario de aprendizaje (Ladio y Lozada, 2004; Lozada et al., 2006). Es por ello que el papel de los conocimientos de los maestros sobre el ambiente local se vuelve clave para una educación multicultural, dado que para los niños es importante en su proceso escolar que sus conocimientos puedan ser discutidos, valorados y utilizados, constituyéndose en una herramienta didáctica de movilización cognitiva y afectiva en la construcción de una nueva síntesis curricular, acorde a sus realidades y a la necesidad de la conservación biocultural (Ladio y Molares, 2013).

El pehuén (Araucaria araucana, Araucariaceae, Figura 16.2a), merece un tratamiento diferenciado debido a su significancia cultural y económica en la región. Su utilización en las comunidades mapuches es sustancial y está muy lejos del uso esporádico del resto de las plantas silvestres patagónicas. Las semillas de la Araucaria araucana (piñones del pehuén) son utilizadas profusamente en las provincias de Neuquén y Río Negro, siendo la especie silvestre arbórea nativa de mayor consenso de uso entre las poblaciones mapuches (Ladio y Lozada, 2000; Ladio, 2013 Reis et al., 2014). En Patagonia, distintos documentos históricos avalan que, desde la llegada de os primeros exploradores y viajeros en el siglo XVI, $A$ araucana era la base de la alimentación de las sociedades mapuche-pehuenche, y por intercambio también de otros grupos étnicos de la región. Tal es la importancia cultural, que las sociedades que los utilizaban se autodenominaban en su lengua (mapunzungun) pehuenches (gente del Pehuén). Esta especie es clave de su identidad hasta el día de hoy tanto en Chile como Argentina denominándosela genéricamente el "pan de los mapuche". Esta fuerte significación se renueva, y reafirma anualmente en festividades dedicadas exclusivamente hacia $A$. araucana denominadas Ngillatunes. En estas conmemoraciones se agradece y festeja los ngulliw (piñones) con ofrendas, rezos y cantos.

La práctica de recolección de piñones ocurre generalmente entre febrero y abril, período en que caen los piñones maduros de los conos de los árboles. El "piñoneo" no sólo es realizado por pobladores que habitan los bosques de $A$. araucana, sino también por aquellas comunidades mapuche que viven alejadas de los mismos. De esta manera, las familias suelen trasladarse hacia el bosque en verano para el aprovechamiento de pasturas de la cordillera y establecerse en sitios de residencia semipermanentes en esta zona; tradición que se denomina "veranada". Las familias se quedan en los bosques hasta el otoño cuando, luego de recolectar los piñones y otros recursos silvestres, regresan a la invernada por el resto del año (Ladio y Lozada, 2004b).

Nuestros relevamientos etnobotánicos indican que, en el pasado, la práctica trashumante asociada al piñoneo era realizada por toda la familia: hombres, mujeres y niños la llevaban a cabo Sin embargo, en la actualidad, muchas veces solo la realizan los adultos varones (Ladio y Lozada 2004b; Ladio y Lozada, 2009). En el pasado, el proceso incluía el derribo de las piñas (conos con piñones), generalmente realizada por los hombres con lazos, y la recolección de los piñones en el suelo, esta se efectuaba generalmente por las mujeres y niños. Antiguamente, el uso de los bosques tenía carácter territorial y los árboles eran usados por distintos linajes familiares de forma exclusiva; en la actualidad, el patrón de uso es más complejo e intervienen distintos factores de accesibilidad, debido al hecho, principalmente, de que los bosques fueron usurpados del territorio mapuche. En el presente, la mayoría de los recolectores mapuches deben pedir autorización a las autoridades de las áreas de conservación o a privados para extraer los piñones (Ladio, 2001; Reis et al., 2014). Parte de los piñones son consumidos tostados o cocidos directamente en el lugar durante la veranada, pero se destina una gran cantidad (más de 100 $\mathrm{kg}$ por viaje) para ser trasladados a la invernada (Ladio, 2001; Ladio, 2011b). Del mismo modo esta especie está siendo comercializada informalmente en áreas urbanas y han empezado en a región a desarrollarse pequeñas industrias artesanales que elaboran harinas, alfajores, salsas, escabeches y golosinas con las semillas.

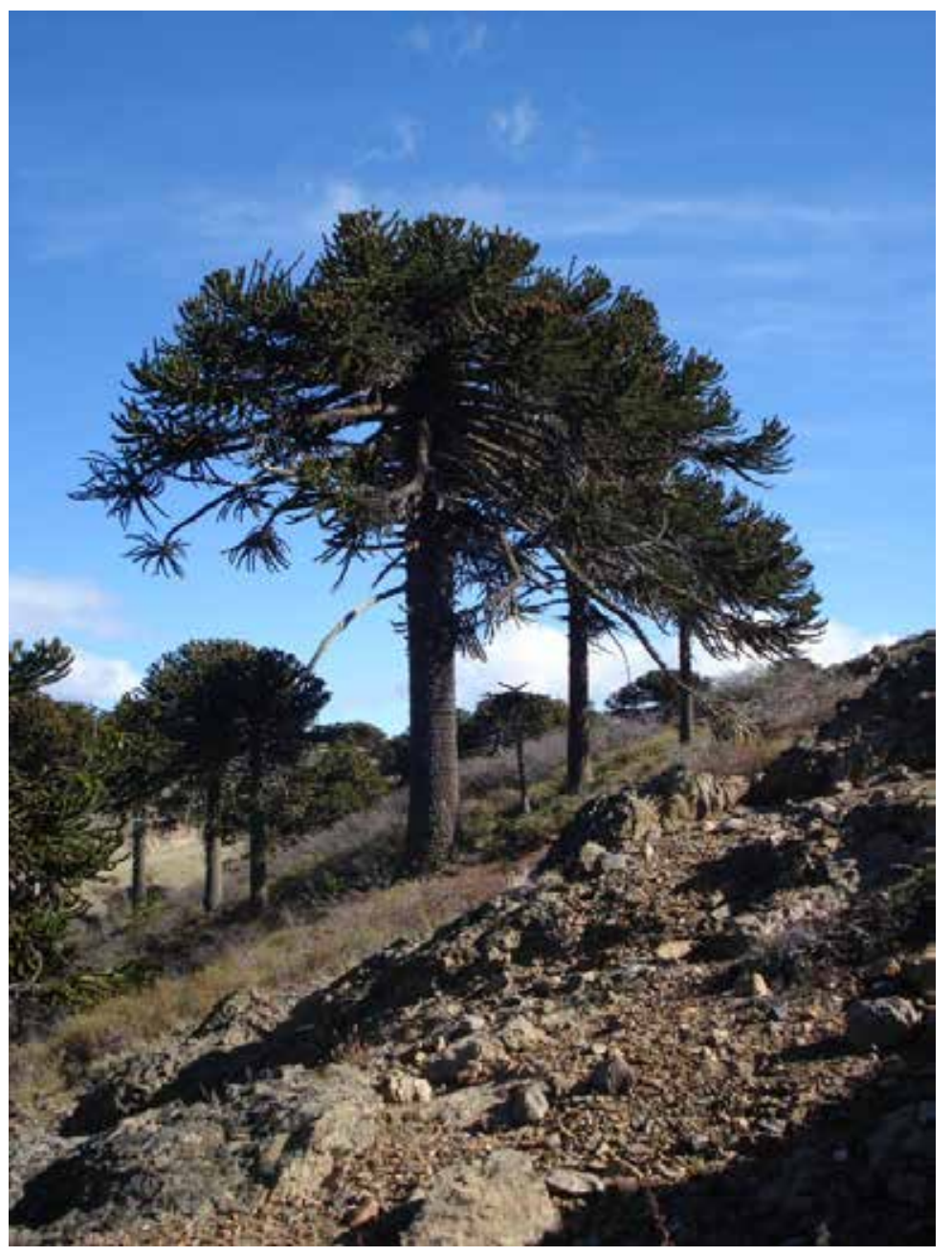

Figura 16.2. Araucaria araucana (pewén), el pan de los mapuche. B. Manejo y protección: torniquete realizado por los habitantes mapuches de Neuquén (Argentina). 


\section{Plantas hortícolas}

La práctica de la horticultura familiar es una costumbre de importancia cultural y social en la región, que involucra, en la actualidad, a más de 150 especies distintas (entre 100-150 por comunidad), principalmente de origen exótico y cosmopolitas (coincidiendo con las que se comercializan preponderantemente a nivel mundial). Las especies más consensuadas son: Lactuca sativa L. (lechuga), Origanum vulgare L. (orégano), Beta vulgaris var. cicla L. (acelga), Solanum tuberosum L. (papa), Pisum sativum L.(arveja), Vicia faba L. (haba), entre otras. En el pasado, era una tradición relevante en la región, pero en el presente la práctica hortícola parece experimentar un notable retroceso (Eyssartier et al., 2008; Eyssartier et al., 2011b).

La horticultura familiar patagónica se destaca por superar condiciones muy exigentes de cultivo debido a las condiciones climáticas locales. Constituye un sistema de subsistencia ligado íntimamente al uso de la tierra y al trabajo familiar, pero que depende directamente del acceso al agua (que es un recurso escaso en las áreas estudiadas). Las plantas hortícolas de la región poseen usos comestibles, medicinales y ornamentales. En las comunidades estudiadas en Pilcaniyeu se cultivan 124 especies totales, y en Comallo unas 129 especies totales, siendo entre el $80-90 \%$ especies exóticas (Eyssartier et al., 2013). En Pilkiniyeu del Limay se cultivan 139 especies, en donde se evidenció que la riqueza de especies en general se incrementa con el área de cultivo (Eyssartier et al., 2011b). Por otra parte, nuestros estudios de campo han mostrado que las comunidades rurales más aisladas, y con menor influencia de la sociedad de mercado, cultivan y recolectan una mayor riqueza de plantas y presentan las huertas más extensas (Eyssartier et al., 2013). En contraste, los habitantes de poblaciones semi-rurales (por ejemplo, Pilkaniyeu), cultivan en invernaderos en una mayor proporción y en huertas más pequeñas (Eyssartier et al., 2011b; Eyssartier et al., 2013). Observamos también que las poblaciones más alejadas de áreas urbanas conservan la tradición de cosechar sus propias semillas; mientras que la población más cercana ha abandonado esta costumbre, donde tampoco hay intercambio de germoplasma (Eyssartier et al., 2013). Los resultados arriba expuestos, en especial los relacionados con el retroceso de la horticultura, la disminución de la riqueza de especies en cultivo y de la pérdida de la tradición del guardado de semillas, son ejes de acción que son actualmente trabajados por el grupo junto con otros organismos gubernamentales y no gubernamentales de la región.

\section{Plantas medicinales silvestres y cultivadas}

La recolección de plantas medicinales en áreas rurales cumple un rol fundamental en el sistema tradicional de salud, además de responder a la escasa presencia de la medicina oficial en estos sitios alejados (Estomba et al., 2005; Estomba et al., 2006; Molares y Ladio, 2009b; Ochoa et al., 2010; Ladio et al., 2013). Según nuestros estudios, actualmente sabemos que cerca de 500 especies totales, nativas y exóticas, se utilizan en la Patagonia con fines medicinales (Molares y Ladio, 2009b), pero por comunidad varía entre 45 y 150 spp. Por ejemplo, en el estudio de caso de Lagunita Salada y El Escorial se encontró que se utiliza una riqueza total de 45 especies medicinales, tanto nativas como exóticas (Richeri et al., 2013). Otros estudios, por ejemplo, en la comunidad Curruhuinca, totalizan 89 spp. (Estomba et al., 2006), mientras que en la comunidad mapuche de Lago Rosario se han referido 131 especies (Molares y Ladio, 2008).

La distinción entre un recurso medicinal o alimentario es difusa para los habitantes rurales. Las plantas se usan para estar mejor y brindar salud, y los vehículos para lograrlo pueden ser a través del consumo como alimento o como medicina, dependiendo del contexto (Ladio et al., 2006). Al igual que en el caso de las plantas comestibles, para seleccionar las plantas medicinales los habitantes aplican los conocimientos trasmitidos en el ámbito familiar, principalmente de manera vertical (de padres a hijos), pero a lo largo de la vida de las personas se van agregando otras vías culturales de aprendizaje (Richeri et al., 2012).

Las principales categorías de uso medicinal son las de atención de enfermedades digestivas, respiratorias, inflamatorias y diuréticas, acorde con una medicina ligada a la prevención y atención primaria de la salud en el ámbito doméstico (Molares y Ladio, 2009a, 2009b; Ladio et al., 2013). En las comunidades rurales, los habitantes interpretan a las plantas de manera holística, considerando tanto sus propiedades utilitarias, físico-químicas y ecológicas para su identificación, junto con apreciaciones de carácter simbólico. El aroma, el sabor y el ambiente de crecimiento de los vegetales son muy importantes en su selección y uso como recursos medicinales (Molares y Ladio, 2012; Molares y Ladio, 2014). Por ejemplo, encontramos que de las 150 especies medicinales usadas actualmente por las comunidades mapuche de Lago Rosario y Nahuelpan (Chubut), cerca del $70 \%$ tienen aroma y/o sabor. Son percibidas como suaves (kochü, en lengua mapuche) o fuertes (füre), y se clasifican en distintos grupos en función de distintas particularidades sensoriales. También notamos que el aroma y el sabor brindan información sobre los tipos específicos de usos medicinales. Así, entre las especies con mayor consenso de uso se destacaron algunas plantas fuertes y amargas empleadas para combatir os trastornos digestivos, por ejemplo: el ajenjo (Artemisia absinthium, Asteraceae), el paico (Dysphania ambrosioides, Chenopodiaceae), la carqueja (Baccharis sagittalis, Asteraceae) y el ñamkulawen (Valeriana carnosa, Valerianaceae). En cambio, se usan plantas de aroma dulce y gusto amargo para combatir los resfríos, por ejemplo: la paramela (Adesmia boronioides, Fabaceae). Plantas intensamente aromáticas, usadas para fines espirituales y religiosos, son empleadas generalmente en forma de sahumerio como vehículo conector del mundo natural con el sobrenatural, como "contra" para repeler "malos aires" o colgadas en el cuerpo o en las casas como amuletos y protectores, por ejemplo: el romerillo patagónico (Chiliotrichum diffusum, Asteraceae) y el charcao (Senecio patagonicus, Asteraceae). La intensidad del aroma y/o el sabor de los vegetales brindan información sobre la mejor forma de prepararlos y utilizarlos. Por ejemplo, aquellos remedios considerados muy fuertes solo pueden ser usados por los adultos, se los prefiere usar en infusión y en bajas cantidades, mientras que los suaves pueden usarse en mayores cantidades y hervirse por algunos minutos (Molares y Ladio, 2009a; Molares y Ladio, 2012). También, encontramos que el aroma y el sabor ayudan a recordar la identidad de las especies en el campo, y hasta a reconocerlas cuando se encuentran en estado deteriorado ya sea porque han sido ramoneadas, taladas o incendiadas (Molares y Ladio, 2012).

Paralelamente, detectamos que la ubicación de las plantas en el ambiente es otro carácter valioso para recordar su identidad y eficacia como recurso: de esta forma las características del suelo, la asociación con otras plantas y la altitud en el gradiente ambiental en el que crecen 
son también aspectos que brindan información útil para su reconocimiento, recolección y uso. Por ejemplo, las plantas que crecen a mayor altitud suelen considerarse más fuertes, aromáticas y efectivas que sus sucedáneas del valle, por lo que son preferidas (Molares y Ladio, 2012) Notamos que las prácticas de oler y degustar están más asociadas a los ancianos que a los jóvenes, de modo que está en riesgo tanto su continuidad en el tiempo como el conocimiento relacionado a las mismas. A esto se suma la inaccesibilidad a muchos de los sitios boscosos que antaño podían visitarse, en general, por problemas político-territoriales, y la imposibilidad de recolectar las especies necesitadas porque ya se encuentran lejos o son poco abundantes.

Lamentablemente, se ha documentado que estas prácticas y conocimientos, tanto de plantas comestibles como medicinales, se están olvidando. En algunos casos sus usos se han suspendido en las comunidades locales, en especial en las generaciones más jóvenes que han perdido el interés por aprender sobre las plantas patagónicas, sus valores y creencias asociadas (Richeri et al., 2013; Ladio y Lozada, 2004a).

\section{Prácticas de manejo}

Los conocimientos arriba mencionados se han desarrollado en las comunidades locales mediante un contacto mayormente prolongado con el ambiente, ya que implican una experiencia directa y/o indirecta (por vía oral) con los recursos del entorno. También implican acciones sobre el ambiente que han favorecido la continuidad y/o la riqueza de especies de interés local medicinal y/o comestible. Denominamos prácticas tradicionales de manejo (TREM, traditional environmental management por sus siglas en inglés) a aquellas actividades que propician el mantenimiento o mejoran la abundancia, diversidad y /o disponibilidad de recursos naturales de un ecosistema (Berkes y Davidson-Hunt, 2006). Dichas prácticas favorecen el mantenimiento del recurso a largo plazo y, normalmente, están asociadas a reglas, valores y normas sociales que propician la sustentabilidad del uso y el mantenimiento de la biodiversidad-como ha sido señalado en este capítulo y ha sido registrado por otros autores en otras regiones del Nuevo Mundo (Turner et al., 2009; Blancas et al., 2010; Moreno-Calles et al., 2011)-. Varios estudios han establecido que existe un contínuum de prácticas que conllevan distintos grados de manipulación sobre el ambiente, desde la recolección en ambientes silvestres hasta el cultivo en espacios totalmente transformados por el ser humano (Blancas et al., 2010; Parra et al., 2012; Lema, 2013). En este gradiente complejo, podemos individualizar prácticas ex situ e in situ, es decir, considerando la distribución de las especies, fuera o dentro del área "natural" descrita según los criterios de la ciencia moderna de la conservación. Dentro de las ex situ, la más distinguible son las prácticas de cultivo, mientras que las in situ involucran prácticas como la tolerancia, el favorecimiento y la protección (Blancas et al., 2010; Lins-Neto et al., 2014). Hasta el momento, pudimos identificar en la región varios ejemplos de prácticas de manejo sobre especies nativas (15-20 especies) en distintos contextos y la existencia de una humanización del ambiente mucho más clara -aunque este tema sigue siendo foco de nuestras investigaciones-:

Cultivo ex situ: Las plantas nativas (semillas, propágulos, plántulas o plantas juveniles) son llevadas a ámbitos domésticos, como huertos y jardines, y de esta manera los pobladores se aseguran del cuidado y la provisión de las especies útiles cerca de sus domicilios. El caso principal es el de la siembra intencional de semillas o renovales de $A$. araucana, por ejemplo, en comunidades mapuches de Catan-lil (Ladio, 2001). Esto se complementa con las prácticas de transporte y almacenamiento de piñones de las familias trashumantes descritas anteriormente, que implican el enterramiento de los piñones en mallines o huertas durante el invierno para que se mantengan frescos. Muchas veces esos piñones germinan y son trasladados y cuidados en las huertas. La costumbre de cultivo esporádico que se encuentra en la actualidad, y que está asociada a las largas distancias de trasporte de piñones, que se describe desde tiempos pre-hispánicos, podría ser un elemento clave para comprender la influencia humana en la distribución espacial de la especie hacia el este de la cordillera de los Andes, y objeto de futuros estudios (Ladio y Lozada, 2000; Reis y Ladio, 2012). Otras especies nativas son cultivadas en estos ámbitos, como la siembra de bulbos de Oxalis adenophylla (culle colorado) en la comunidad criolla de Villa Llanquín, usada como especie medicinal y ornamental (Ochoa y Ladio, 2014), la siembra de esquejes de Baccharis sagittalis (carqueja) y/o Buddleja araucana (pañil) en Pilkaniyeu y Pilkiniyeu del Limay, siendo éstos elementos sustanciales de la herbolaria local (Eyssartier et al., 2010).

Tolerancia: La más contundente en la región es la tolerancia de plantas nativas: cuando se dejan en pie a las plantas comestibles y medicinales nativas, en el momento que los pobladores planifican la transformación del paisaje para la horticultura, la construcción de caminos, de viviendas rurales, corrales, entre otros. Esto ha sido cuantificado escasamente, pero se han encontrado ejemplos en el caso de arbustos medicinales como: la paramela (Adesmia boronioides) y el pañil (Buddleja araucana) en las huertas de Pilkaniyeu (Eyssartier et al., 2010); palo piche (Fabiana imbricata) y pañil (Buddleja globosa) en jardines domésticos de Lago Rosario (Molares y Ladio, 2008); como para árboles nativos como Araucaria araucana y/o Maytenus boaria que son tolerados en las cercanías de las viviendas por su valor utilitario y simbólico (Reis et al., 2014).

Favorecimiento: Esta práctica es también muy significativa mediante el raleo, poda, desmalezamiento y diversos cuidados culturales. Los pobladores favorecen el crecimiento de determinadas especies de interés, tanto medicinales como comestibles, en sus propios ambientes naturales (Richeri et al. 2013). La fertilización del suelo es una práctica común en el área rural. Por ejemplo, a diario, los desechos de alimentos se entierran en áreas circundantes a las viviendas y las cenizas del fogón se esparcen sobre determinados cultivos para mitigar el efecto de plagas y nutrir la tierra. El primer mate (infusión tradicional de llex paraguariensis) de cada cebada se escupe al suelo como ofrenda a la Mapu. Estas acciones de devolución y agradecimiento simbólico implican la aireación y nutrición del suelo, lo que los pobladores reconocen como factores que redundan en un mayor rendimiento de sus cultivos y en la germinación ocasional de semillas de plantas comestibles.

Protección: El ejemplo más paradigmático es nuevamente el caso del Pehuén. Los relatos demuestran que han existido, desde tiempos pre-hispánicos y hasta el día de hoy, prácticas de protección y cuidado de los árboles en sus áreas de ocurrencia natural, además del cultivo in situ y ex situ de semillas señalado previamente (Reis et al., 2014). La Figura 16.2 b, por ejemplo, muestra como un renoval (renuevo) de esta especie, que ha sufrido un daño en su eje apical, ha sido "curado" (se observa un torniquete que sujeta el tallo cortado parcialmente) por algún habitante de los bosques de $A$. araucana de la comunidad Mapuche Puel de Villa Pehuenia 
(Neuquén). Otro ejemplo es el cercamiento de especies útiles muy palatables para el ganado, para lo cual las plantas son ingeniosamente protegidas con palos entretejidos, alambres o cualquier otro material que impida su ramoneo: las drupas carnosas del calafate $(B$. heterophylla), las ramitas medicinales del apio de campo (Apium australe) y el cilantro nativo (Sanicula graveolens) son ejemplos de especies protegidas de esta forma.

A nivel del paisaje, los mallines en las comunidades de estepa, humedales de origen glaciar, son la principal reserva de agua. En estos se encuentra la mayor diversidad vegetal, incluyendo los mejores pastos para el ganado. Los pobladores han manejado estas unidades espaciales a lo largo del tiempo para su aprovechamiento racional, aprovechándolos para el engorde de animales seleccionados (madres y destetados), canalizándolos para el riego de cultivos, y favoreciendo la conservación de plantas medicinales nativas como la pata de williñ (Gamocarpha selliana) y la comestible frutilla silvestre (Potentilla chiloensis) (Molares y Ladio, 2014).

\section{Redundancia, versatilidad y prácticas de manejo complementarias}

Nuestros estudios han revelado que el cuerpo de conocimientos de las poblaciones rurales se basa en una alta presencia de plantas versátiles, es decir, que se utilizan para distintos fines como los medicinales y comestibles, pero también los combustibles, tintóreos, forrajeros, ornamentales, mágicos, entre otros. Esta multifuncionalidad, particularmente evidente en las especies favoritas, parece ser un atributo selectivo de los habitantes sobre su ambiente. Por ejemplo, en el caso de las comunidades de Lagunita Salada y el Escorial (Richeri et al., 2013), la herbolaria se compone de pocas especies ( $45 \mathrm{spp}$.), pero las plantas con mayor importancia cultural son las más versátiles, como es el caso de "ñamkulawen" (V. carnosa) y el "tomillo silvestre" (Acantholippia seriphioides) que son usadas para más de cinco dolencias diferentes, ambas apreciadas como verdaderas panaceas vegetales.

Esto podría mostrar que, por medio del amplio rango de prácticas tradicionales como la recolección, el cultivo y/o la tolerancia de las especies, los pobladores aseguran la provisión de especies necesarias para combatir sus principales enfermedades domésticas. También, este proceso de manipulación del paisaje podría implicar un aumento de la redundancia, es decir, la presencia en una mayor cantidad de especies que pueden cumplir una misma función. Esta propiedad es clave porque no solo ofrece mayores alternativas que disminuyen la presión sobre las distintas especies de plantas (especialmente las nativas), sino también porque permite la absorción de disturbios propiciando una reorganización en el cuerpo de conocimientos cuando, por ejemplo, en caso de que alguna especie se extinga localmente, pueda ser remplazada; u otras situaciones de cambio socio-cultural (Berkes y Davidson-Hunt, 2010 Júnior et al., 2011; Ladio, 2011a). Un ejemplo puede ser el caso de las afecciones hepáticas (una de las más prevalentes en la medicina local), que pueden ser tratadas por Valeriana carnosa, el "ñamkulawen", por Dysphania ambrosioides y/o D. multifida "paico", y por Artemisia absinthium "ajenco", obtenidas tanto por recolección como cultivo (Richeri et al., 2013),toleradas y protegidas en ambientes silvestres y antrópicos (Eyssartier et al., 2013). Como puede observarse a lo largo del texto, numerosas especies exóticas son valiosos recursos para la farmacopea y flora alimenticia mapuche. Distintos factores quimio-taxonómicos y socioeconómicos, así como la particular trayectoria histórica de las comunidades rurales patagónicas, favorecieron la incorporación de estos recursos foráneos a la región, los cuales, debido a su alta disponibilidad y a sus características funcionales y organolépticas, se convirtieron en opciones alternativas viables al conjunto de plantas utilizadas, compatibles con prácticas y preferencias culturales (Molares y Ladio, 2015).

En este sentido cabe señalar que, durante la práctica pastoril de las distintas comunidades, se desarrollan otras actividades mientras se cuidan los animales, como la recolección de plantas comestibles (Ladio y Lozada, 2004b; Ochoa y Ladio, 2014), de leña (Cardoso et al., 2010) y de plantas medicinales (Richeri et al., 2013). Los recursos silvestres recolectados se complementan con los que se obtienen en las huertas para lograr una mejor alimentación y una farmacia casera más completa (Eyssartier et al., 2011a). Por ejemplo, en las poblaciones de la meseta de Chubut, el $70 \%$ de las plantas citadas por la gente del área se obtiene mediante la recolección, mientras que un $30 \%$ de ellas se cultiva, lo cual sería fruto de un conocimiento ambiental extenso que muestra, por un lado, una gran dependencia del acceso a los ambientes de recolección y por el otro la articulación con la horticultura doméstica familiar (Richeri et al., 2013). Por otra parte, nuestros estudios realizados en comunidades mapuche trashumantes del Neuquén también indicaron que la "veranada", en complementación con el "piñoneo", es una estrategia adaptativa y eficaz, que brinda oportunidades de una dieta más rica y nutritiva y un uso diversificado del ambiente de pastoreo, a pesar de que esta práctica conlleve un desplazamiento que implique distancias superiores a los $100 \mathrm{~km}$ (Ladio y Lozada 2004b, 2004b).

\section{Conclusiones}

El paisaje patagónico debe ser pensado en un proceso de humanización creciente, debido a las diferentes intensidades de manejo a las que son objeto las distintas especies de interés. El complejo cosmos-corpus-praxis evidenciado en Patagonia incluye un amplio abanico de recursos útiles aprovechables como alimento y medicina (tanto de plantas nativas y exóticas), muchas veces en sintonía con los cambios ambientales que suceden en cada comunidad.

Sin embargo, los relatos de muchos pobladores locales que viven en condiciones de subsistencia muestran que este complejo, cosmos-corpus-praxis, se está perdiendo o desarticulando en dichas sociedades, y/o no alcanzan a paliar los problemas que los aquejan y representan en la mayoría de los casos ejemplos de sobrevivencia a condiciones muy duras. Entonces, es necesario una mayor atención en los procesos actuales, de modo que se puedan encontrar soluciones superadoras. Nuestra perspectiva es que esto solo es posible si los actores, las sociedades, las instituciones y las organizaciones comienzan a ponerse de acuerdo en considerar a la conservación desde una mirada no centrada solo en los recursos biológicos, sino centrada en un sistema acoplado e indivisible ecológico-social que construye día a día su paisaje en función de sus necesidades. En este sentido, creemos que el trabajo de transferencia de nuestro grupo con las poblaciones locales, maestros, técnicos, agentes de salud y público en general, difundiendo todos estos saberes y lógicas de uso del ambiente que han sido 
resguardados por pobladores tradicionales, es un camino que aporta a la profundización de estos procesos de cambio. Cuantas más plantas sean de interés humano, más de ellas serán cuidadas, toleradas, cultivadas y protegidas, es decir, que estamos planteado la conservación a través del uso, revitalizando las prácticas tradicionales de renovación de ciclos ecológicos, en donde la biodiversidad pertenece tanto al dominio de lo natural como de lo cultural. Esta postura, denominada académicamente etnoconservacionismo (Santos-Fita et al., 2009; Monteles, 2008), brinda una alternativa para reflexionar sobre lo que queremos conservar y cómo, pero sin duda necesita todavía de mayores evidencias cuali-cuantitativas en nuestra región, tarea que esperamos lograr en el futuro.

\section{Agradecimientos}

Agradecemos a los hombres y mujeres de todas las comunidades rurales y urbanas por su amistosa disposición y generosa colaboración para este trabajo. A Erik Müller por su ayuda con la Fig. 1. Además agradecemos a CONICET y a ANPCyT. Este estudio ha sido financiado por los proyectos PICT 2012-1073 y PIP 2013- 11220120100466CO01 cuyo titular es la Dra. A.H. Ladio.

\section{Bibliografía}

Albuquerque, U. P., R. F. P. Lucena y L. V. C. Cunha, 2010. Métodos e Técnicas na Pesquisa Etnobiológica e

Berkes, F., J. Colding y C. Folke, 2000. Rediscovery of traditional ecological knowledge as adaptive management. Ecological Applications, 10(5): 1251

Berkes, F. e I. J. Davidson-Hunt, 2006. Biodiversity, traditiona management systems, and cultural landscapes: Social Science Journal: 35-47.

Berkes, F. e I. J. Davidson-Hunt, 2010. Innovating through commons use: community-based enterprises.

Bharucha, Z. y J. Pretty, 2010. The roles and values of wild foods in agricultural systems. Philosophical transactions sciences, 365(1554): 2913-2926.

Blancas, J., A. Casas, S. Rangel-Landa, A. I. Moreno Calles, I. Torres y E. Perez Negrón, 2010. Plant Management
in the Tehuacán-Cuicatlán Valley, Mexico. Economic Botany, 64: 287-302.

Cabrera, A. L., 1976. Regiones Fitogeográficas Argentinas. Acme S.A.C.I., Buenos Aires, Argentina.

Cardoso, B., A. H. Ladio y M. Lozada, 2010. Utilización de especies combustibles en una comunidad rural de la estepa patagónica. En:. Pochettino, M. L, A. H. Ladio y P. M. Arenas (Eds.). Tradiciones y Transformaciones en Etnobotanica. CYTED, San Salvador de Jujuy: pp.

CostaNeto, E.M., D. Santos Fita y M. Vargas-clavijo, 2009 Manual de Etnozoología. Tundra Edicones, Valencia.

Díz-Betancourt, M. E., L. Ghermandi, A. H. Ladio, I. R. López Moreno, E. Raffaele y E. H. Rapoport, 1995. Weeds as a source for human consumption. A comparison between Tropical, 47(3): 1-7.

Estomba, D., A. Ladio y M. Lozada, 2006. Medicinal wild plant knowledge and gathering patterns in a Mapuche Ethnopharmacology, 103: 109-119.

Estomba, D. A. H. Ladio y M. Lozada, 2005. Plantas medicinales utilizadas por una comunidad Mapuche as cercanías de Junín de los Andes, Neuquén. Boletin Latinoamericano y del Caribe de Plantas Medicinales y Aromáticas, 6: 107-112.

Eyssartier, C., A. Ladio y M. Lozada, 2013. Tradition horticultural and gathering practices in two semi-rura populations of Northwestern

Eyssartier, C., A. H. Ladio y M. Lozada, 2008. Cultura transmission of traditional knowledge in two populations omedicine, 4: 25 .
Essartier, C., A. H. Ladio y M. Lozada, 2010. Conocimiento tradicional sobre plantas en huertas, invernaderos y jardines en dos poblaciones rurales de la estep patagónica. En. Pochettino, M. L., A. H. Ladio y Ethnobotany CYTED, San Salyodor de Juiuy: pp. 485-495.

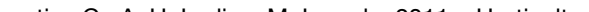

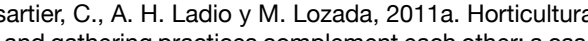
study in a rural population of Northwestern Patagonia. Ecology of Food and Nutrition, 50(5): 429-51.

Eyssartier, C., A. H. Ladio y M. Lozada, 2011b. Traditional horticultura knowledge change in a rural population of 75(1): 78-86.

Folke,C., S.Carpenter, T. Elmqvist, L. Gunderson, C. S. Holling y B. Walker, 2002. Resilience and sustainable transformations. AMBIO, 31(5): 437-40.

Galafassi, G., 2012. Recuperación ancestral mapuche. Divergencias ideológicas y conflictos entre Mapuches y
el Estado. Cuadernos de Antropologia Social, 35: 71-98.

Golluscio, R.A., M.E. Román, A. Cesa, D. Rodan y H. Bottaro, 2010. Aboriginal settlementes of arid Patagonia: Preserving-or sociodiversity? The case of the Mapuche pastoral Cushamen Reserve. Journal of
Arid Environments, 74:1329-1339.

Gundermann, H. H. G. y L. Ruyt, 2009. Migración y movilidad mapuch

Gutiérrez, G., 2006. La Minería del Oro. Explotación a cielo y riesgos. Depactam de de Pastoral Social. Ediciones ICEPH, Bariloche.

Igon, P., A. Ladio y M. Lozada, 2007. Plantas medicinales utilizadas en las Comunidades de Villa Traful y Cuy

INDEC, 2010. Censo Nacional de Población, Hogares y Viviendas 2010. Instituto Nacional de Estadísticas y Censos, Ministerio de Economía, Buenos Aires (en línea, disponible en: www.censo2010.indec.gov.ar).

International Society of Ethnobiology, 2006. Code of Ethics (with 2008 additions) (en linea, disponible en: http:// ethnobiology.net/code-of-ethics/.

I, 2015. International Plant Names Index (en línea, disponible en: www.ipni.org).

Júnior, W. S. F., A. H. Ladio y U. P. Albuquerque, 2011 Resilience and adaptation in the use of medicinal plants with suspected anti-inlammatory activity in the Brazilian Northeast. Journal of Ethnopharmacology, 138(1): 238-52.

adio, A. H., 2005. Malezas exóticas comestibles y medicinales utilizadas en poblaciones del Noroeste patagónico: aspectos etnobotánicos y ecológicos. Medicinales y Aromáticas, 4(4): 11-17. 
Ladio, A. H. y M. Lozada, 2009. Human ecology, ethnobotany Ladio, A. H. y E. H. Rapoport, 1999. El uso de plantas and traditional practices in rural populations inhabiting the Monte region: Resilience and ecological knowledge. Journal of Arid Environments, 73(2): 222-227.

Ladio, A. H. y S. Molares, 2013. Evaluating traditional wild edible plant knowledge among teachers of Patagonia: Patterns and prospects. Learning and Individual

Ladio, A. H., S. Molares, J. Ochoa y B. Cardoso, 2013. Etnobotánica aplicada en Patagonia: la comercialización de malezas de uso comestible y medicinal en una fer' Boletín Latinoamericano y del Caribe de Plantas Medicinales y Aromáticas, 12 (1): 24-37.

Ladio, A. H., 2011. Traditional knowledge of edible wild native and exotic plants in the context of cultural change in human populations of arid Patagonia. Bioremediation, Biodiversity and Bioavailability, 5(1): 60-64.

Ladio, A. H., 2011. Underexploited wild plant foods of NorthWestern Patagonia. En: Filip, R. (Ed.). Multidisciplinary Approaches on Food Science and Nutrition for the XX Century.

Ladio, A. H., S. Molares y E. Rapoport, 2007. Conocimiento etnobotánico de plantas comestibles entre los maestro patagónicos: patrones de variación ambiental oeste-

Ladio, A.H. y M. Lozada, 2000. Edible wild plant use in a Mapuche Community, $28(1)$ : 53-71.

Ladio, A.H. y M. Lozada, 2001. Nontimber Forest Product Use Quantitative Apprat Hum

adio, A. H. y M. Lozada. 2003. Comparison of wild edible plant diversity and foraging strategies in two aborigin and Conservation, 12(5): 937-951.

Ladio, A. H. y M. Lozada, 2004a Patterns of use and knowledge of wild edible plants in distinct ecologica environments: a case study of a Mapuche communily from northwestern Patagonia. Biodiversity and Conservation, 13: 1153-1173.

Ladio, A. H. y M. Lozada, 2004b. Summer cattle transhumance and wild edible plant gathering in a Mapuche Community of
northwestern Patagonia. Human Ecology, 32(2): 225-240. northwestern Patagonia. Human Ecology, 32(2): 225-240.

Ladio, A. H., 2006. Gathering of wild Plant Foods with medicinal use in a Mapuche Community of NW Patagonia. En: Pieroni, A. y L. Price (Eds.). Eating and healing: explorations of traditional food as medicines.

Ladio, A. H., 2001. The maintenance of wild edible plan gathering in a Mapuche Community of Patagonia.

Ladio, A. H., 2013. Mapuche resilience and human adaptation to arid Uplands in NW Patagonia, Argentina. En: Lozny, L. Mountain Environments. Studies in Human Ecology and Adaptation 7. Springer New York, New York: pp. 259-273. del noroeste de la Patagonia. Parodiana, 11(1): 49-62. ema, V. S., 2013. Criar y ser criados por las plantas y sus espacios en los Andes Septentrionales de Argentina. En: Benedetti, A. y J. Tomasi (Eds.). Espacialidades Altoandinas. Avances de Investigación Desde el Noroes

ins Neto, E. M. D. F., N. Peroni, A. Casas, F. Parra, X. Aguirre, S. Guillén y U. P. Albuquerque, 2014 incipient domestication. Journal of Ethnobiology and Ethnomedicine, 10: 33.

ozada, M., A. Ladio y M. Weigandt, 2006. Cultura transmission of ethnobotanical knowledge in a rural community of northwestern Patagonia, Argentina.

Maffi, L., 2005. Linguistic, Cultural, and Biological Diversity. Annual Review of Anthropology, 34(1): 599-617.

Molares, S. y A. Ladio, 2008. Plantas medicinales en una comunidad Mapuche del NO de la Patagonia Argentina. clasificación y percepciones organolépticas relacionadas con su valoración. Boletin Latinoamericano 149-155.

Molares, S. y A. Ladio, 2009a. Chemosensory perception and medicinal plants for digestive ailments in a Mapuch community in NW Patagonia, Argentina. Journal of

Molares, S. y A. Ladio, 2009b. Ethnobotanical review of the Mapuche medicinal flora: use patterns on a region ares, S. y A. Ladio. 2012. Mapuche perceptions an conservation of Andean Nothofagus forests and their in Patagonia, Argentina Biodiversity and Conservation 21(4): 1079-1093.

olares, S. y A. Ladio, 2014. Medicinal plants in the cultural landscape of a Mapuche-Tehuelche community in arid Argentine Patagonia: an eco-sensorial approach.
of Ethnobiology and Ethnomedicine, 10: 61.

Molares, S. y A. Ladio, 2015. Complejos vegetales comestibles y medicinales en la Patagonia Argentina: sus componentes y posibles procesos asociados. Boletin Aromáticas, 14(3): $237-250$. crise ambiental : algumas notas transversais. Time

Moreno-Calles, A. I., E. G. Frapolli, A. Casas e I. Torres, 2011 Traditional agroforestry systems of multi-crop "milpa and "chichipera" cactus forest in the arid Tehuacan subsistence. Agroforestry Systems, 84(2): 207-226.

Navarro Floria, P. y W. Del Río, 2011. Cultura y Espacio: Araucania-Norpatagonia. Universidad Nacional de Río
Negro, Instituto de Investigaciones en Diversidad Cultura y Procesos de Cambio, San Carlos de Bariloche. Economic Botany, 60: 374-385.

onteles, R, 2008. Ecologias e políticas em tempo de
Ochoa, J. y A. Ladio, 2011. Pasado y presente del uso de Richeri, M., M .B. Cardoso y A. H. Ladio, 2013. Soluciones plantas silvestres con órganos de almacenamiento 20(2): 265-284.

Ochoa, J. J. y A. H. Ladio, 2014. Ethnoecology of Oxalis adenophylla Gillies ex Hook. \& Arn. Journal of Ethnopharmacology, 155: 533-543.

Ochoa, J. J., A. H. Ladio y M. Lozada, 2010. Uso de recursos herbolarios entre mapuches y criollos de la comunidad campesina de Arroyo Las Minas (Río Negro, Patagonia Argentina). Boletin Latinoamericano y del Carn.
Plantas Medicinales y Aromáticas, 9(4): 269-276.

Orellana, I. A. y E. Raffaele, 2010. The spread of the exotic conifer Pseudotsuga menziesii in Austrocedrus chilensis Argentina. New Zealand. Journal of Forestry Science, 40:199-209.

Parra, F., J. J. Blancas y A. Casas, 2012. Landscape management and domestication of Stenocereus pruinosus (Cactaceae) in the Tehuacán Valley: human guided selection and gene

Paruelo, J. M., R. A. Golluscio, E. G. Jobbagy, M. Canevari y M. R. Aguiar, 2006. Situación ambiental en la Ecorregión Estepa Patagónica. En: Brown, A., U. Martinez Ortiz M. Acerbi y. Corcuna (Eds.). La Situación Ambienta Argentina. Fundación Vida Silvestre Argentina, Buenos

Rapoport, E. H. y A. H. Ladio, 1999. Los bosques andinopatagonicos como fuentes de alimento The Andean $55-64$.

Reis, M., A. Ladio y N. Peroni, 2014. Landscapes with Araucaria in South America: evidence
dimension. Ecology and Society, 19(2): 43 .

Reis, M. S. y A. H. Ladio, 2012. Paisajes con Araucarias en Sudamérica: construcciones culturales pre-colombinas y del presente para producción de alimento. En: Gallegos, R. Memorias de las Jornadas de reflexión acerca de los
paisajes culturales de Argentina y Chile: pp. 225-244. locales y flexibilidad en el conoc estudios de caso en Patagonia. Ecología Austral, 23 $184-193$.

cheri, M., A. H. Ladio y A. M. Beeskow, 2012. Conocimiento tradicional y autosuficiencia: la herbolaria rural en Aromáticas, 12: 44 - 58.

Santos Fita, D., E. J. Naranjo Pineda y R. Mariaca Méndez 2009. Hacia un etnoconservacionismo de la fauna

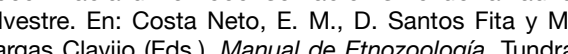
Ediciones, Madrid, España: pp. 97-117.

Toledo, V. M. y N. Barreras-Bassols, 2008. La memoria biocultural. La importancia agroecológica de
sabidurías tradicionales. Icaria editorial, Barcelona.

Turner, N. J., A. Yilmaz, F. Berkes, I. Davidson-Hunt, Z Fusun Ertug y A. Miller, 2009. Cultural Management of Living Trees: An International
Ethnobiology, 29(2): 237-270.

Valverde, S., G. Maragliano, M. Impemba y F. Trentini, 2011. Procesos Históricos, Transformacines Sociales y Construcciones de Frontera. Aproximaciones a las Argentina y Labrador. Canod́ 1 ra edn. Edpatagonia, Fecultad ye Filosofía y Letras Universidad de Buenos Aires. Buenos Aires.

Viatte, G., J. De Graaf, M. Demeke, T. Takahatake y M. R. Arce, 2009. Responding to the food crisis: synthesis of medium-term measures
assessments. FAO, Rome.

Zuloaga, F. O. y O. Morrone, 1999. Catálogo de las plantas vasculares de la República Argentina. II. Monographs in Systematic Botany, Missouri Botanical Garden (en línea, Fisponible en: http://sin (atinoseta Central del Chubut (Argentina). Boletin 


\section{Huertos comerciales del periurbano de la Plata (Buenos Aires, Argentina): reservorio de diversidad biocultural}

María Lelia Pochettino, María Margarita Bonicatto y Julio A. Hurrell

\section{Resumen}

En las proximidades de la ciudad de la Plata se encuentra un área productiva de relevancia llamada Cinturón Hortícola Platense, ubicada en el sector periurbano del área metropolitana, zona de transición entre los sectores netamente urbanos y rurales, con límites móviles según los ritmos de la urbanización. Este cinturón hortícola abastece de hortalizas y verduras a la población del área metropolitana. Si bien se registran algunas grandes unidades productivas, la mayoría de estos huertos comerciales son de agricultura familiar. Este es el tipo de producción en el cual la actividad agropecuaria es la principal fuente de ingresos del núcleo doméstico, aunque puede ser complementada con otras actividades no agrícolas que se realizan dentro o fuera este. Se trata de una actividad con uso preponderante de la fuerza de trabajo familiar, siendo el jefe(a) de ella quien participa de manera directa del proceso productivo. El estudio etnobotánico de 40 huertos comerciales en la zona descrita ha permitido identificar prácticas y características similares a las registradas en los huertos destinados al consumo familiar: 1) Se observaron criterios de selección y prácticas de manejo propias de la unidades domésticas, a pesar de la incidencia del mercado en la decisión de qué y cuándo cultivar. Para ello se presentan y discuten los distintos criterios de selección de semillas (morfológico, productivo, culinario, innovador, independencia, económico); 2) Los huertos familiares son ámbitos de innovación y experimentación. Se presentan y discuten cuatro cultivares típicos correspondientes a Cucurbita maxima var. zapallito, Foeniculum vulgare, Beta vulgaris var. cycla y Dianthus barbatus, valorados por los horticultores locales como "identitarios"; 3) Se registra el interés en apoyar la economía familiar con la producción de alimentos para su comercialización. Por esto se han conformado diversos grupos de agroindustria artesanal con el fin de darle un valor agregado a la producción, aumentar la mano de obra, aprovechar los excedentes de producción y obtener ingresos extra. En este proceso se obtienen productos diferenciados que provienen de hortalizas y frutas sin agrotóxicos, conservantes ni colorantes, además se elaboran mediante técnicas artesanales, rescatando, en su mayoría, recetas tradicionales. De este 
modo se concluye que, al igual que los huertos familiares, los huertos comerciales estudiados constituyen reservorios de variedades vegetales con distinto grado de asociación con el ser humano, y también reservorios de prácticas culturales de manejo. Destacar este carácter es relevante en un momento en el que la agricultura familiar es objeto de legislación y regulación en la Argentina.

Palabras clave: agricultura familiar, agricultura urbana, horticultura, horticultura periurbana, huertos familiares, huertos comerciales, La Plata.

\section{Introducción}

\section{Área de estudio}

La conurbación Buenos Aires-la Plata, de unos $5000 \mathrm{~km}^{2}$ y con casi 14000000 de habitantes, según el Censo Nacional del año 2010, es el área metropolitana de mayor extensión y población de la Argentina. Incluye dos aglomeraciones urbanas contiguas, conformadas a partir de la Ciudad Autónoma de Buenos Aires, la capital del país, y de la ciudad de la Plata, capital de la provincia de Buenos Aires. La conurbación comprende áreas netamente urbanas, unos pocos sectores en la ribera del Río de la Plata con vegetación espontánea remanente, que incluye áreas naturales protegidas, y un sector periurbano o de transición con las áreas rurales circundantes, con límites móviles según los ritmos de la urbanización (Barsky, 2010; Hurrell e al., 2011; Hurrell y Pochettino, 2014; Pochettino et al., 2014) (Figura 17.1).

En las proximidades de la ciudad de la Plata se encuentra el llamado Cinturón Hortícola Platense, un área productiva de relevancia ubicada en el sector periurbano, que abastece de hortalizas y verduras a la población del área metropolitana Buenos Aires-La Plata, y de otras partes del país (Benencia, 1997; Feito, 2005). Si bien en este cinturón hortícola se registran algunas unidades productivas extensas, la mayoría de estos "huertos comerciales" corresponden al ámbito de la agricultura familiar que constituye el objeto de esta presentación.

\section{La horticultura familiar local}

os huertos familiares se definen como espacios de cultivo, por lo general de extensión reducida, localizados en las proximidades de las casas. La producción se destina mayormente al autoconsumo, y en ocasiones para su venta a escala local restringida, como suplemento para la economía doméstica (Wagner, 2002; Pochettino, 2010; Hurrell et al., 2011; Pochettino et al. 2012, 2014). El estudio de estos huertos constituye un tema de creciente interés en Etnobotánica, que aporta tanto a la conservación de la agrobiodiversidad (en particular a la infraespecífica) como a la preservación de la diversidad cultural. Las estrategias de manejo y la selección de especies y variedades no se orientan por las reglas del mercado, sino por preferencias y usos culinarios ligados a tradiciones familiares. Así, los huertos familiares pueden considerarse como verdaderas respuestas adaptativas del grupo humano local, que surgen a partir de su propia experiencia

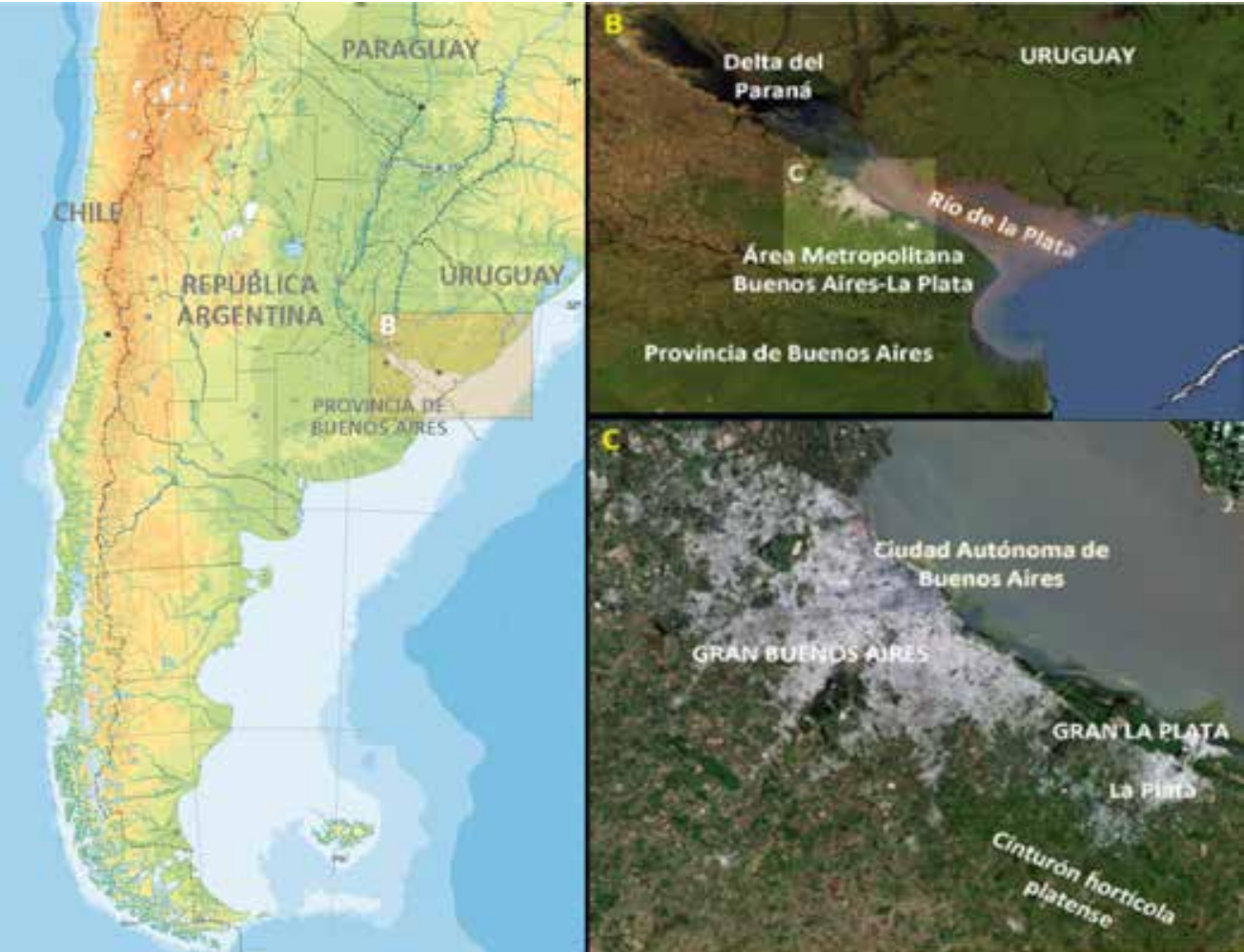

Figura 17.1. a) Argentina y ubicación de la región del Río de la Plata.

b) La región rioplatense y localización del Área Metropolitana Buenos Aires-la Plata. c) Ubicación del Cinturón Hortícola Platense.

en el entorno. Esta temática ha motivado diversas contribuciones en distintas partes del mundo (Nazarea, 1998; Vogl et al., 2002; Wagner, 2002; Watson y Eyzaguirre, 2002; Albuquerque et al., 2005; Vogl-Lukasser y Vogl, 2004; Das y Das, 2005; Huai y Hamilton, 2009; Reyes-García et al. 2012; Pamungkas et al., 2013; Seta et al., 2013; Calvet Mir et al., 2014; entre otros) y también en la Argentina, muchos de estos desarrollados por una línea de investigación del Laboratorio de Etnobotánica y Botánica Aplicada (LEBA), en la Facultad de Ciencias Naturales y el Museo de la Universidad Nacional de La Plata, Argentina (Martínez et al., 2003; Maidana et al., 2005; Lema, 2006; Turco et al., 2006; Del Río et al., 2007; Buet-Costantino et al., 2010; Hurrell et al., 2011 Pérez et al., 2008; Pochettino, 2010; Pochettino et al., 2012, 2014).

La horticultura periurbana local se inició con la fundación de la ciudad de La Plata y la construcción de su puerto hacia fines del siglo XIX, ligada al arribo de inmigrantes de diferentes países europeos que aportaron tanto sus conocimientos como sus prácticas hortícolas tradicionales (García, 2010; Hurrell et al., 2011). Buena parte de esta horticultura incipiente se vinculó al cultivo de la "uva americana" (Vitis labrusca L.) mediante el sistema de parral adaptado a las condiciones locales para la elaboración del denominado "vino de la costa" (por la proximidad 
de los huertos a la ribera del río de la Plata), un producto típico del área. Luego de un período de expansión inicial, el cultivo declinó hasta llegar al borde de la extinción; no obstante, hoy presenta cierta recuperación gracias al esfuerzo de los propios productores locales (Marasas y Velarde, 2000; Velarde et al., 2008; Hurrell et al., 2014).

En la actualidad, la franja productiva platense presenta una elevada heterogeneidad en cuanto al origen de los horticultores y los tipos de huertos (familiares y comerciales), a la organización social del trabajo, los estilos locales de producción, los niveles de incorporación tecnológica y la conservación del material reproductivo. Esta heterogeneidad se refleja asimismo en las prácticas hortícolas que, a menudo, implican la conservación de algunas variedades hortícolas características de la zona (Pochettino et al., 2014).

En el caso que aquí nos ocupa, los propietarios de los huertos periurbanos vinculados a la agricultura familiar (denominados en el área "quinteros" y "quintas", respectivamente) son pequeños productores que destinan los cultivos obtenidos a la comercialización; no obstante por las características del área productiva (tamaño de las parcelas, diversidad de cultivos, manejo y control de malezas y plagas) pueden incluirse en la categoría de huertos familiares, y constituyen una instancia de diversificación en la horticultura de la región.

El sector en estudio responde al tipo social agricultor familiar, caracterizado como aquél donde las unidades doméstica y productiva se hallan físicamente integradas (Prividera y López Castro, 2010). Es decir, la fuerza de trabajo utilizada en la explotación es aportada en su mayor parte por la familia, la producción se dirige tanto al autoconsumo como al mercado, existe diversificación en la producción y, en general, se visualiza el fenómeno de la "pluriactividad"; las familias optan por alternativas productivas y laborales dentro o fuera de su predio. En la $\mathrm{Ar}$ gentina, los agricultores familiares representan el $66 \%$ de las unidades productivas, ocupando el $13,5 \%$ de la superficie (más de 23 millones de hectáreas) (Fornari, 2008) y en el Cinturón Hortícola Platense abarcan el $65,7 \%$ de los 738 establecimientos que producen hortalizas, según el Censo Hortiflorícola de la Provincia de Buenos Aires de 2005.

\section{Metodología}

a información relacionada con el relevamiento de las plantas cultivadas en las "quintas", as como la vinculada a los actores, prácticas y conocimientos asociados, es el resultado de campañas semanales realizadas desde 2001 hasta la fecha.

En una primera instancia, el relevamiento se realizó fundamentalmente por medio de la implementación de la metodología etnobotánica, privilegiando las técnicas cualitativas (Martin 1995; Albuquerque y Lucena, 2004; Quinlan, 2005; Stepp, 2005). Se realizaron entrevistas semiestructuradas y abiertas a 60 individuos adultos de ambos sexos involucrados en la actividad hortícola en 40 unidades domésticas de distintos puntos del cinturón hortícola. Además se realizaron listados libres y observaciones sistemáticas en diferentes espacios en los que transcurre a vida del grupo familiar, en particular, aquellos destinados a la horticultura. En la medida en que resultó posible, se efectuaron caminatas acompañando los desplazamientos de las personas durante el desarrollo de esta actividad (Martínez y Pochettino, 1999; King, 2000).
La información obtenida se refiere a los usos de las variedades hortícolas, la obtención y conservación del material reproductivo, las características reconocidas localmente, las técnicas de producción y manejo, los actores involucrados, los valores asignados y saberes actualizados. Además, se coleccionaron muestras de las especies vegetales involucradas en las prácticas hortícolas, que se identificaron y depositaron en el Laboratorio de Etnobotánica y Botánica Aplicada (LEBA) de la Facultad de Ciencias Naturales y Museo, en la Universidad Nacional de La Plata.

\section{Resultados}

\section{Especies y variedades hortícolas cultivadas}

Como ya se señaló, el Cinturón Hortícola Platense provee la mayoría de vegetales frescos que produce a los sectores netamente urbanos de la conurbación Buenos Aires-La Plata. Dado que la producción es continua, se desarrolla tanto al aire libre como en invernadero. Entre los cultivos al aire libre se destacan: lechuga (Lactuca sativa L.), acelga (Beta vulgaris L. var. cicla L.), tomate (Solanum lycopersicum L.), apio (Apium graveolens L.), "zapallito de tronco" (Cucurbita maxima Duchesne var. zapallito (Carrière) Millán), alcaucil (Cynara scolymus L.), espinaca (Spinacea oleracea L.), repollo (Brassica oleracea L. var. capitata L.), remolacha (Beta vulgaris L. var. vulgaris) e hinojo (Foemiculum vulgare Mill.) (Figura 17.2). Entre los de invernadero: tomate,

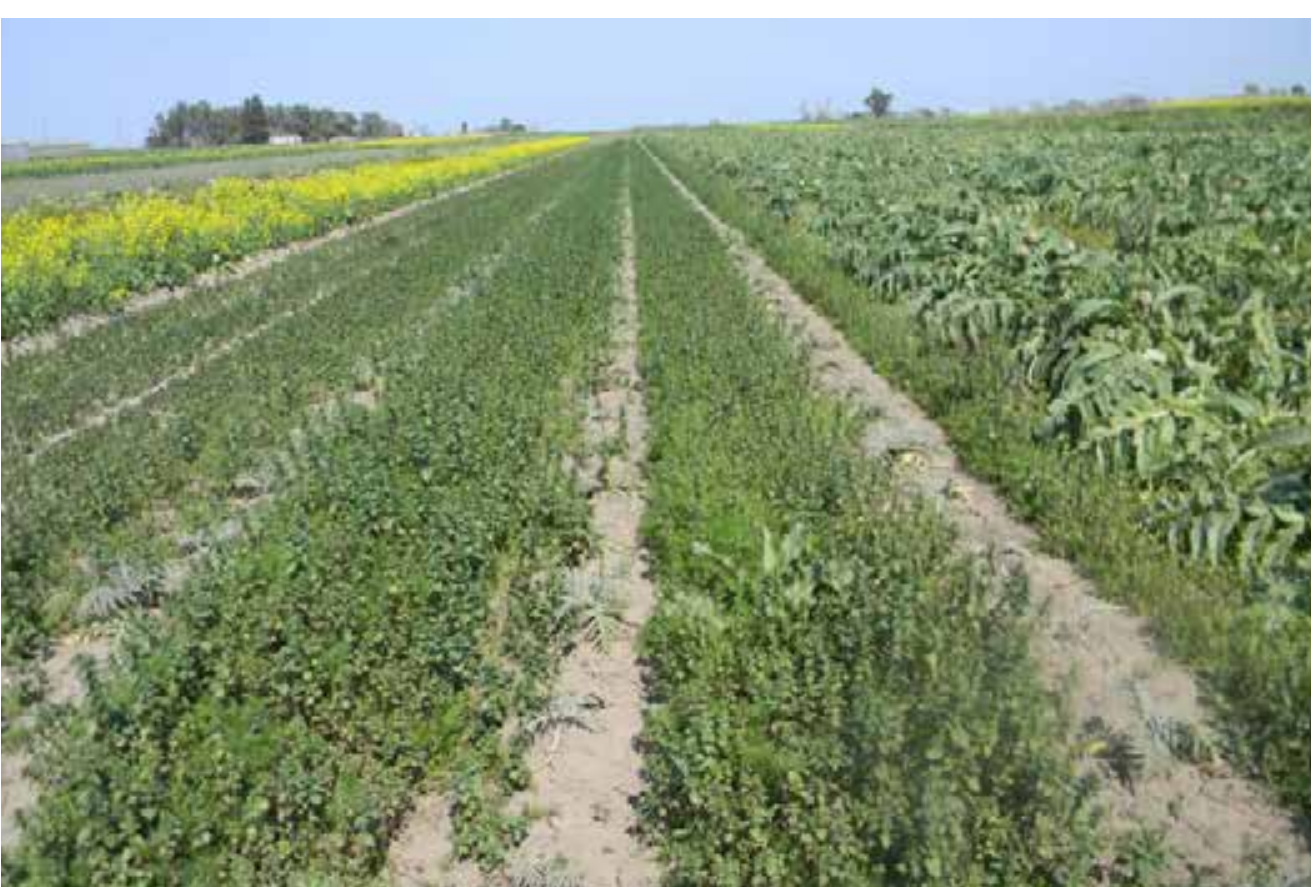

Figura 17.2. Aspecto de una "quinta" del Cinturón Hortícola Platens (producción a campo, a la izquierda grilo, a la derecha alcaucin. 
apio, lechuga, espinaca, pimiento (especies de Capsicum) y otras de volumen de producción escaso, como pepino (Cucumis sativus L.), chaucha (Phaseolus vulgaris L.), frutilla (Fragaria $\mathrm{x}$ ananasa (Weston) Duchesne) y albahaca (Ocimum basilicum L.) (Figura 17.3).

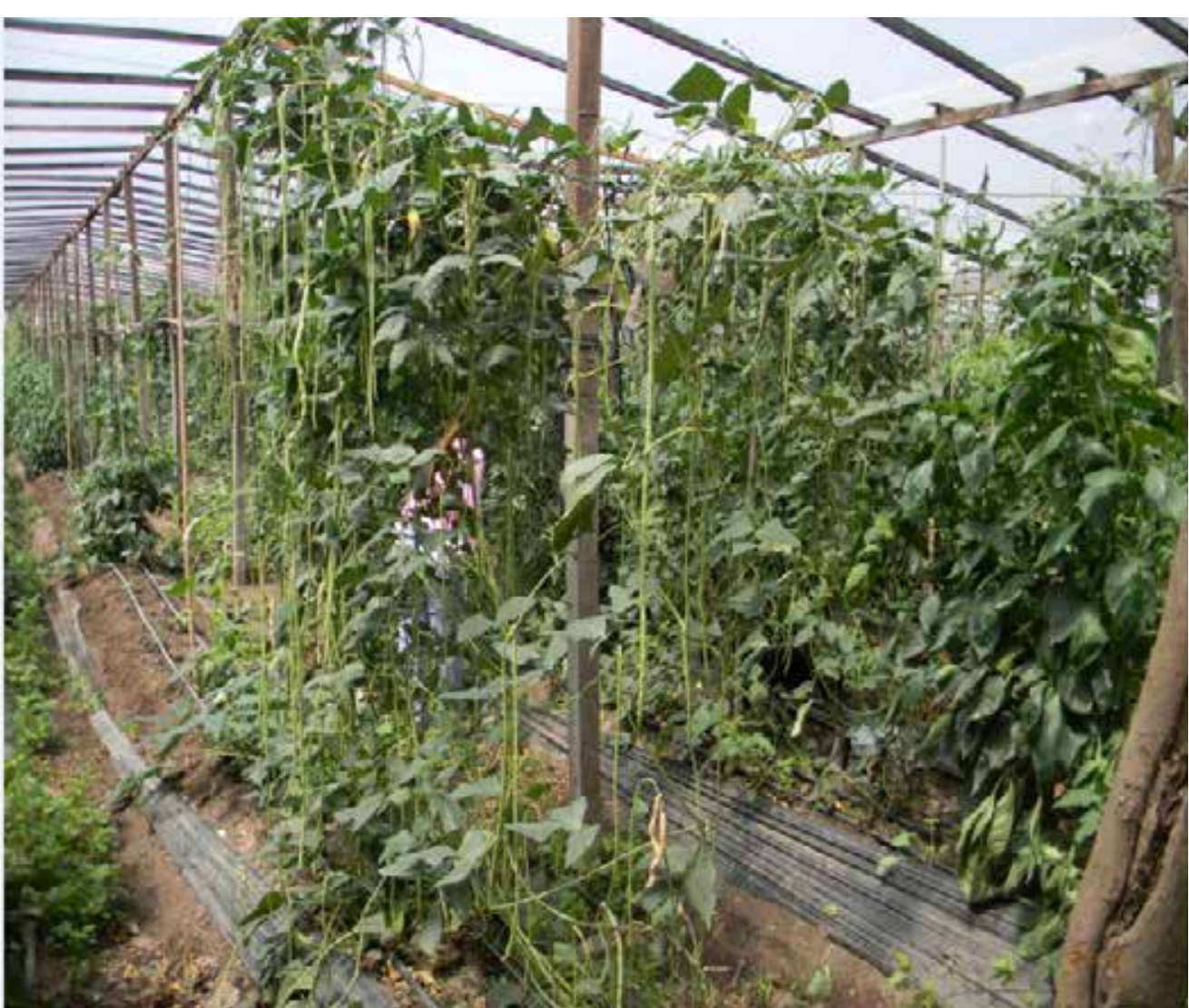

Fig. 17.3. Producción de chaucha metro en invernadero.

Sin embargo, en estos huertos comerciales con agricultura familiar merecen señalarse dos tipos de cultivos que incrementan la agrobiodiversidad: "típicos" y "ocasionales".

\section{Cultivos típicos}

Según la valoración de los propios "quinteros", se trata de variedades de cultivo seleccionadas en el área de estudio, por lo que se consideran patrimoniales y características de la zona. El cultivo típico por excelencia es el llamado "tomate platense", que se desarrolla en la zona desde la década de 1940, caracterizado por un sabor intenso con abundantes semillas y jugo, forma irregular, achatada, costillada o fuertemente lobulada y una gran cantidad de lóculos. Asimismo, se considera un cultivo rústico, adaptado a las condiciones climáticas de la zona y tolerante a distintas plagas locales, según el Grupo de Productores de Tomate Platense (Ahumada et al., 2010). Además de este cultivo, reconocido ampliamente como típico desde su nombre, se registraron también otros cuatro que presentan las características mencionadas. Tres de estos son hortalizas y uno corresponde a un cultivar ornamental.

- Z Zapallito lustroso: El "zapallito de tronco" (Cucurbita maxima var. zapallito) es una variedad botánica conocida solo en cultivo (Millán, 1947), que se restringe a nuestro país. El fruto se consume inmaduro, cuando la "cáscara" está tierna y el mesocarpo aún es jugoso. Su uso está limitado a Sudamérica austral, donde se ha desarrollado como alternativa al "zucchini” (Cucurbita pepo L. Grupo 'Zucchini'), un grupo de cultivares difundido a nivel mundial. El "zapallito lustroso" es una variedad hortícola generada en el área de estudio, con forma esférica y epicarpo muy suave. Se valora localmente debido a que sus características particulares lo hacen un cultivar apto para la preparación de diversas comidas; puede comerse sin pelar y es óptimo para rellenar por su forma regular y tamaño poco variable. En cuanto a su disponibilidad, se han registrado dos poblaciones, una "temprana", que puede consumirse a fines de la primavera y principios del verano, y otra "tardía", disponible a fines del verano y principios del otoño. Este rango de fructificación permite contar durante gran parte del año con material fresco de un producto que es difícil de conservar.

- Hinojo de cabeza gigante (Foeniculum vulgare): es una especie originaria del Mediterráneo y su difusión en todo el mundo está estrechamente asociada a la migración italiana (Hurrell et al., 2009). Es una hortaliza menos consumida que otras, razón por la cual su cultivo se realiza solo en ciertas zonas. La variedad hortícola originada en el área de estudio se denomina "hinojo de cabeza gigante" porque su principal característica morfológica es el gran tamaño de sus partes comestibles: los cogollos tiernos. Tanto el cultivo de esta variedad hortícola como su consumo parecen haberse transmitido desde los descendientes de inmigrantes italianos hacia los "quinteros" de otras procedencias y, en la actualidad, su cultivo es una práctica corriente en el Cinturón Hortícola Platense.

- Acelga de penca verde: La acelga (Beta vulgaris var. cicla) es una variedad botánica originaria del Mediterráneo difundida en muchas partes del mundo. En la Argentina, a diferencia de otros países, se utiliza ampliamente como sustituto de la espinaca debido a su mayor rendimiento, disponibilidad durante casi todo el año y menor precio. Existen distintas variedades hortícolas de acelga, según las características del pecíolo ("penca") y la lámina. Las variedades de cultivo más modernas, divergentes de las formas silvestres, son aquellas en las que el pecíolo alcanza gran desarrollo y es de color blanco, algo fibroso; no obstante, resultan insípidos por su alto contenido en agua y deben cocinarse aparte de las láminas, de consistencia diferente. La variedad hortícola originaria de la zona en estudio presenta pecíolos reducidos, poco fibrosos y de color verde, al igual que la lámina. Por esta razón, pueden cocinarse juntos y tienen el mismo sabor. Es valorada por sus características morfológicas y, además, porque puede consumirse cruda, o bien, una vez hervida, se obtiene $30 \%$ más de producto que en los otros cultivares más difundidos. Asimismo, se aprecia su disponibilidad, de prácticamente todo el año con excepción de la primavera. Por las razones expuestas, además del consumo doméstico, los "quinteros" suelen venderla a distintos establecimientos que elaboran productos alimentarios frescos. 
- Macetilla (Dianthus barbatus L.): es una especie del Mediterráneo, donde aún crece espontánea en algunos países. Su cultivo como ornamental perenne es muy frecuente en el área de estudio, asociado a la actividad hortícola, y practicado en los mismos espacios. El nombre vernáculo "macetilla" es una denominación para la variedad de cultivo local; en otras zonas hay cultivares de la especie que se conocen como "clavel del poeta". Se comercializa por sus flores de colores diversos (blanco, rosado, fucsia, rojo), de larga duración una vez cortadas. Además de ser apreciada por su valor ornamental para la unidad doméstica, también representa una buena oportunidad de venta por vía directa, in situ o en puestos vecinos, en los caminos. Así, el cultivar local se produce como suplemento para la economía familiar. Este fue seleccionado con la intención de obtener un período de floración prologado. Por este motivo, se siembra en tres fechas claves: el 24 de diciembre, a fines de enero y a fines de febrero, para cosecharlas respectivamente el "día de la primavera" (21 de septiembre), el "día de la madre" (tercer domingo de octubre) y el "día de los muertos" (2 de noviembre, Día de los Fieles Difuntos según el Santoral Católico). Estas fechas son los momentos de máxima venta de flores, y cuando alcanzan el mayor precio del año.

\section{Cultivos ocasionales}

Se han relevado numerosos casos de cultivos ocasionales, presentes en unas pocas unidades productivas. Si bien estos se destinan al consumo doméstico, resultan promisorios para la diversificación hortícola local, dado que incluyen también el cultivo de especies silvestres de amplia distribución, como la cardella (Sonchus oleraceus L), por su presencia en diversas recetas familiares, o el "burrito" (Aloysia polystachya (Griseb.) Moldenke), por sus propiedades medicinales.

- Tomate verde vestido (Physalis ixocarpa Brot. ex Hornem): se ha registrado en una unidad productiva, que fue obtenida mediante intercambio en una feria de semillas. A pesar de su importante uso como comestible en Mesoamérica, en nuestra zona se cultiva más bien como una rareza por su cáliz acrescente, y se mantiene debido al criterio innovador de los productores.

- Papa del aire (Sechium edule (Jacq.) Sw.): es una enredadera de amplia difusión entre los productores, aunque sus frutos no salen al mercado y se consumen en forma doméstica. Por su alta productividad fue objeto de interés y difusión en distintos proyectos de extensión y desarrollo, donde se promovía su consumo elaborado de distintas maneras. Sin embargo, no es muy apreciada y se conserva por costumbre.

- Cayote: A veces el cultivo para autoconsumo responde a aplicaciones específicas; por ejemplo, una familia procedente de la Provincia de Salta cultiva Cucurbita ficifolia Bouché con el fin de elaborar "dulce de cayote". Sin embargo, dada la popularidad creciente de esta confitura, en los últimos años han comenzado a distribuir semillas entre productores conocidos y proveen de "cayotes" a las verdulerías locales.

- Cucuza: Vinculado a la cocina italiana, se cultiva una variedad hortícola de Lagenaria siceraria (Mol.) Standl., conservada por "quinteros" inmigrantes de Italia que desde all trajeron las semillas. Se cultiva con fines alimentarios, consumiéndose el fruto cuando está en sus primeros estadios y, una vez maduro, cuando se seca y ahueca, es utilizado para confeccionar artesanías. En el total de entrevistas, esta planta se registró una sola vez, pero la familia que la conserva sostiene que practica su cultivo desde "mucho tiempo atrás".

- Chaucha metro (Vigna unguiculata (L) Walp): es una especie de Leguminosae de origen africano, de relativa popularidad en América tropical entre los afrodescendientes; sobre todo, $V$. unguiculata subsp. unguiculata, de la que se obtienen variedades de semillas comestibles a modo de porotos, llamadas "poroto tape" o "caupí" (Hurrell et al., 2009). En el Cinturón Hortícola Platense, hace unos 4 años se introdujo $V$. unguiculata subsp. sesquipedalis (L.) Verdc., llamada "chaucha metro" por sus legumbres tan largas, hasta de $90 \mathrm{~cm}$ de longitud. A pesar de su introducción reciente, son altamente valoradas y se expenden en ferias locales.

- Grilo (Brassica rapa L. var. rapa): es una Brassicaceae de gran difusión, que provee distintos órganos comestibles, en especial las raíces carnosas conocidas como "nabos". Las hojas tiernas, llamadas "grilo", "grelo" o "rapini", se consideran un producto típico del Cinturón Hortícola Platense, vinculado a la cocina italiana. Durante mucho tiempo se mantuvo como cultivo relictual, pero ha retomado su popularidad en los últimos años, principalmente en relación al desarrollo de proyectos de rescate y valorización de hortalizas locales. Según el testimonio de un agricultor local descendiente de italianos: "(...) le das un hervor, suavecito nomás, un hervor; después lo escurrís, a la sartén, con un dientito de ajo, y le das un salteada (...). Es jriquísimo!".

- Maizón, maizón amarillo: Esta variedad hortícola de maíz (Zea mays L.) es cultivada por agricultores inmigrantes provenientes de Bolivia. Su principal uso es para hacer "humita", plato típico de la cocina boliviana, en el que se emplean tanto los granos como las "chalas" (hojas modificadas que protegen la inflorescencia). Según los agricultores bolivianos locales, no pueden hacer la "humita" con las variedades comerciales que cultivan para el mercado. Una agricultora familiar boliviana comenta: "Maizón hacemos (...), pero sólo para consumo de nosotros. El maizón es el maíz grande, choclo grande, que es más carnoso. Los granos son más grandes y no son tan aguados, y con eso hacemos humita (...)".

\section{Criterios de selección y prácticas de manejo}

Para la reproducción de las especies hortícolas, los productores recurren a la adquisición de semillas u otro tipo de material reproductivo (renovales u órganos de reproducción vegetativa), pero también a la conservación de las propias semillas. Entre las conservadas se encontraron tanto las de variedades hortícolas típicas como las ocasionales y, también, de variedades comerciales obtenidas en comercios (semillerías) y conservadas por lapsos variables (desde un año hasta más de 10). Por último, se encontraron híbridos comerciales como Solanum lycopersicum, "Tomate 110" o Foeniculum vulgare: Hinojo híbrido, que son conservados tantas veces como las características deseadas por los productores persistan, no superando en la mayoría de los casos la generación F3. 
Del total de semillas conservadas (128), el $80 \%$ fue obtenido a través de intercambios, herencias, regalos o distribución por programas estatales; están relacionadas a 9 criterios de conservación (Tabla 17.1, Figura 17.4). El 20\% restante corresponde a variedades o híbridos comerciales relacionados a 6 criterios de conservación (Figura 17.5).

\section{El destino de la producción: agroindustrias artesanales}

Los productos vegetales obtenidos de los huertos se comercializan a través de distintos canales: el más común es la venta en el Mercado Central de La Plata, organismo acopiador a que acuden los comerciantes minoristas. Sin embargo, la variabilidad en los precios hace que muchas veces los productores no obtengan ventajas económicas de la venta de las hortalizas. Hace unos diez años surgió entre los "quinteros" el interés por comenzar a elabora productos artesanales a partir de las frutas y hortalizas que sus familias producían. Por esto, se conformaron varios grupos de agroindustria artesanal con el fin de darle un valor agregado a la producción, aprovechar los excedentes y lograr obtener un ingreso extra para la familia.

Tabla 17.1: Criterios que sustentan la conservación de semillas hortícolas por agricultores familiares del Cinturón hortícola platense.

Criterio Descripción

Afectivo Semillas vinculadas a la historia familiar, a personas por las cuales se siente afecto, a semillas que perdieron o, simplemente, al lapso que se las guarda.

Culinario Semillas de plantas con tradición culinaria en la zona de origen de los agricultores locales o provenientes de recetas familiares. Muchas veces, las plantas conservadas por este criterio se cultivan solo para autoconsumo.

Innovador Semillas conservadas por una actitud innovadora de los horticultores, en cuanto a la predisposición a incorporar semillas "raras" o desconocidas por ellos, o bien semillas que conocen pero que no sembraban; o simplemente por experimentar en la conservación. Muchas de estas semillas son obtenidas en espacios de intercambio locales o en ferias de semillas.

Independencia Semillas conservadas con el fin de independizarse del hecho de tener que comprarlas.

Curativo/medicinal Plantas conservadas por sus propiedades medicinales.

Diversificación Semillas conservadas para incrementar la diversidad en la "quinta".

Morfológico Semillas conservadas por los caracteres morfológicos u organolépticos (color, sabor, olor, textura) de los productos hortícolas. Estas características pueden ser buscadas tanto por criterios personales como impuestos por el mercado.

Productivo Semillas conservadas por los servicios ecológicos que aportan las plantas dentro de los sistemas productivos.

Económico Semillas conservadas con el sentido de ahorrar el dinero que implica su compra. La decisión de conservar por este criterio está mediada por el precio de las semillas en los comercios (semillerías).

Comercial: Subyace a los anteriores, dado que la venta del producto de la "quinta" es parte de la lógica de mercado de los horticultores familiares.

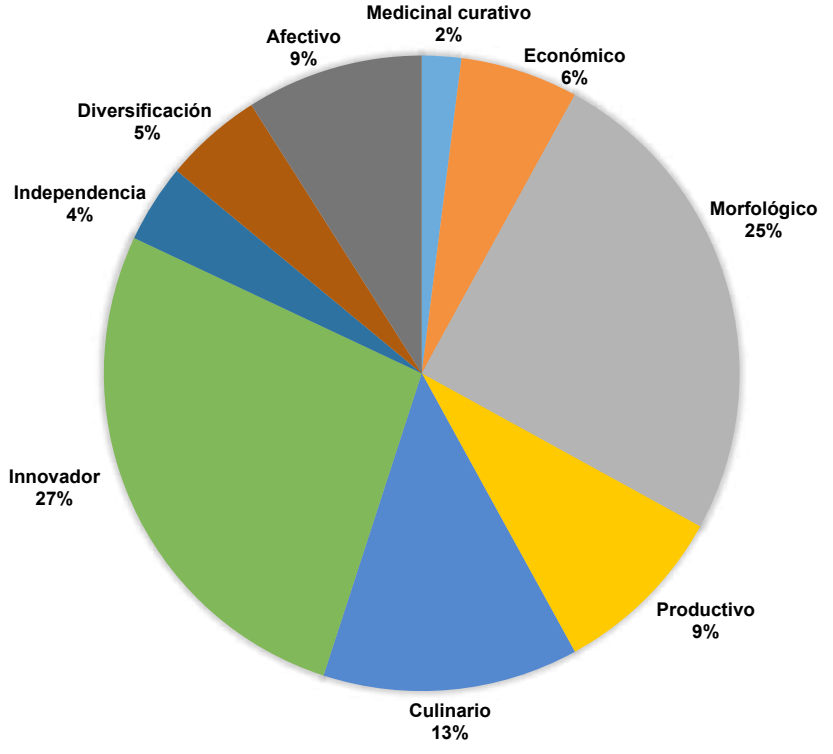

Fig. 17.4. Porcentaje de citas de los criterios que sustentan la conservación de semillas obtenidas por intercambios, regalos, herencias o programas estatales, según los agricultores familiares del Cinturón hortícola platense. (Total de citas 128, total de variedades conservadas 102) Medicinal curativo $0 \%$

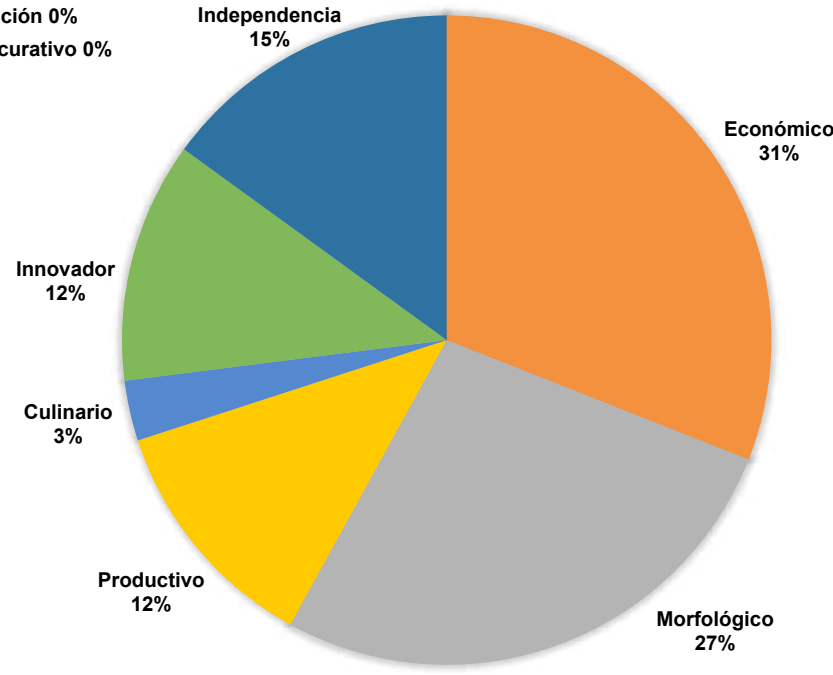

Fig. 17.5. Porcentaje de citas de los criterios que sustentan la conservación de variedades, incluidas las híbridas, de origen comercial, según los agricultores familiares del Cinturón Hortícola Platense. (Total de citas: 33, Total de variedades conservadas: 26) 
Estos grupos desarrollan las siguientes acciones:

- Elaboración de conservas a partir de hortalizas y frutas procedentes de la propia "quinta",

sin utilización de conservantes ni saborizantes químicos sintéticos.

- Comercialización a través de canales directos al consumidor.

- Utilización de técnicas artesanales para llevar a cabo las elaboraciones.

- Participación en ferias, fiestas regionales, talleres y capacitaciones referidos a la temática.

- Interacciones con los productores que están desarrollando dicha actividad.

En este caso, al igual que en la producción de hortalizas, la participación de las mujeres es activa y se caracteriza por su aporte de conocimientos ligados a tradiciones familiares. De este modo, se elaboran distintos productos a partir de recetas familiares, como el "dulce de zapallito lustroso maduro" y el "dulce de tomate platense". Al mismo tiempo, se adoptan las nuevas técnicas promocionadas para la correcta manipulación y comercialización de los productos, como

Tabla 17.2. Destino de los productos hortícolas:

Dulces elaborados con productos de primavera-verano

\begin{tabular}{|c|c|c|c|}
\hline Productos elaborados & $\begin{array}{l}\text { Origen de la } \\
\text { materia prima }\end{array}$ & $\begin{array}{l}\text { Origen de } \\
\text { la receta }\end{array}$ & $\begin{array}{l}\text { Modificación } \\
\text { de la receta }\end{array}$ \\
\hline $\begin{array}{l}\text { Dulce de moras } \\
\text { Morus alba L. }\end{array}$ & $\begin{array}{l}\text { Recolección de plantas } \\
\text { ancianas cultivadas } \\
\text { como ornamentales } \\
\text { presentes en el área }\end{array}$ & $\begin{array}{l}\text { Aportada por la } \\
\text { técnica/Relación pul- } \\
\text { pa-azúcar. Bibliografía }\end{array}$ & $\begin{array}{l}\text { En la cocción, las moras } \\
\text { son trituradas o permane- } \\
\text { cen enteras }\end{array}$ \\
\hline $\begin{array}{l}\text { Dulce de tomate } \\
\text { Solanum lycopersicum } \mathrm{L} \text {. }\end{array}$ & Cultivos propios & $\begin{array}{l}\text { Aportada por la pro- } \\
\text { ductora, receta familiar } \\
\text { tradicional }\end{array}$ & $\begin{array}{l}\text { Relación azúcar/pulpa. } \\
\text { Agregado de esencias de } \\
\text { vainilla, clavo de olor o } \\
\text { pimienta negra. Se tritura el } \\
\text { tomate durante la cocción }\end{array}$ \\
\hline $\begin{array}{l}\text { Dulce de ciruelas } \\
\text { Prunus persica (L.) Batsch }\end{array}$ & $\begin{array}{l}\text { Compra a los viñateros } \\
\text { de la zona }\end{array}$ & $\begin{array}{l}\text { Aportada por la } \\
\text { técnica/Relación pul- } \\
\text { pa-azúcar. Bibliografía }\end{array}$ & $\begin{array}{l}\text { Se trituran las ciruelas du- } \\
\text { rante la cocción, o se dejan } \\
\text { en trozos }\end{array}$ \\
\hline $\begin{array}{l}\text { Higos en almíbar } \\
\text { Ficus carica L. }\end{array}$ & $\begin{array}{l}\text { Recolección de viejos } \\
\text { árboles remanentes en } \\
\text { espacios de cultivo. }\end{array}$ & $\begin{array}{l}\text { Aportada por la } \\
\text { técnica/Relación pul- } \\
\text { pa-azúcar Bibliografía }\end{array}$ & $\begin{array}{l}\text { Variación en el tiempo de } \\
\text { cocción }\end{array}$ \\
\hline $\begin{array}{l}\text { Dulce de higos } \\
\text { Ficus carica L. }\end{array}$ & $\begin{array}{l}\text { Recolección de viejos } \\
\text { árboles remanentes en } \\
\text { espacios de cultivos }\end{array}$ & $\begin{array}{l}\text { Aportada por la } \\
\text { técnica/Relación pul- } \\
\text { pa-azúcar. Bibliografía }\end{array}$ & $\begin{array}{l}\text { Se trituran los higos durante } \\
\text { la cocción, o se dejan en } \\
\text { trozos }\end{array}$ \\
\hline $\begin{array}{r}\text { Dulce de zarzamora } \\
\text { Rubus sp. }\end{array}$ & $\begin{array}{l}\text { Recolección de plantas } \\
\text { antiguas utilizadas } \\
\text { como cerco vivo orna- } \\
\text { mental }\end{array}$ & $\begin{array}{l}\text { Aportada por la } \\
\text { técnica/Relación pul- } \\
\text { pa-azúcar. Bibliografía }\end{array}$ & Ninguna \\
\hline $\begin{array}{r}\text { Zarzamora en almíbar } \\
\text { Rubus sp. }\end{array}$ & $\begin{array}{l}\text { Recolección de plantas } \\
\text { antiguas utilizadas } \\
\text { como cerco vivo orna- } \\
\text { mental }\end{array}$ & $\begin{array}{l}\text { Aportada por la } \\
\text { técnica/Relación pul- } \\
\text { pa-azúcar. Bibliografía }\end{array}$ & Ninguna \\
\hline $\begin{array}{l}\text { Dulce de uvas } \\
\text { Vitis vinifera L., } \\
\text { V. labrusca L. }\end{array}$ & $\begin{array}{l}\text { Recolección de anti- } \\
\text { guas plantas cultivadas }\end{array}$ & $\begin{array}{l}\text { Aportada por la } \\
\text { técnica/Relación pul- } \\
\text { pa-azúcar. Bibliografía }\end{array}$ & $\begin{array}{l}\text { Se pasan las uvas por un } \\
\text { tamiz para sacarles las } \\
\text { cáscaras }\end{array}$ \\
\hline
\end{tabular}

temperatura de cocción de dulces y conservas, esterilización de los frascos, incluso la incorporación de nuevas materias primas para la elaboración de distintos productos, por ejemplo, "licor amaretto", hecho con "carozos" de "níspero" (Eriobotrya japonica (Thunb.) Lindl.). Estas prácticas redundan en un incremento de la agrodiversidad al incorporar los frutos de árboles plantados hace tiempo, muchas veces en el arbolado urbano, o incluso en las propias unidades domésticas pero con fines ornamentales o para sombra, como es el caso de la "morera" (Morus albus L.). En las Tablas 17.2, 17.3 y 17.4 se incluyen los productos elaborados en distintas épocas del año y el modo de obtención de la materia prima, así como el origen de los saberes culinarios y las modificaciones generadas a partir del trabajo grupal. En este proceso se obtiene un producto diferenciado, dado que proviene de hortalizas y frutas sin agrotóxicos, conservantes $n$ colorantes; además, es elaborado a través de técnicas artesanales y, en su mayoría, rescatando recetas familiares.

Tabla 17.3. Destino de los productos hortícolas:

Dulces elaborados con productos de otoño-invierno

$\begin{array}{cccc}\text { Productos elaborados } & \begin{array}{c}\text { Origen de la } \\ \text { materia prima }\end{array} & \begin{array}{l}\text { Origen de } \\ \text { la receta }\end{array} & \begin{array}{c}\text { Modificación } \\ \text { de la receta }\end{array}\end{array}$

Dulce de nísperos Recolección de anti- Aportada por la técnica/ En la cocción, los nísEriobotrya japonica (Thunb.) guas plantas cultivadas Relación pulpa-azúcar. peros son triturados

\begin{tabular}{ccc} 
Lindl. & Bibliografía & permanecen enteros \\
\hline Dulce de quinotos Recolección de anti- Aportada por la produc- Variación en la relación
\end{tabular} Citrus japonica Thunb. guas plantas cultivadas tora. Bibliografía pulpa/azúcar/agua Dulce de limón Recolección de anti- Aportada por la técnica/ Ninguna

Citrus x limon (L.) Osbeck guas plantas cultivadas Relación pulpa-azúcar. Bibliografía

Quinotos en almíbar Recolección de anti- Aportada por la técnica/ En el momento de quitar-

Citrus japonica Thunb. guas plantas cultivadas Relación pulpa-azúcar. le el ácido al quinoto Bibliografía

Dulce de zapallito de tronco Cultivos propios Aportado por la produc- Relación pulpa/azúcar, Cucurbita maxima Duchesne $\quad$ tora, receta familiar tra- agregado de cáscaras de Cucurbita maxima Duchesne Mermelada inglesa Recolección de anti- Aportada por la produc- Ninguna

Diversas especies de Citrus guas plantas cultivadas tora.Bibliografía

Dulce de mandarinas Recolección de anti- Aportada por la técnica/ Ninguna

Citrus reticulata Blanco guas plantas cultivadas Relación pulpa-azúcar. Bibliografía

Mandarinas en almíbar Recolección de anti- Aportada por la produc- Ninguna

Citrus reticulata Blanco guas plantas cultivadas tora. Bibliografía

Naranjas en almíbar Recolección de anti- Aportada por la técnica. Ninguna Citrus $\mathrm{x}$ aurantium $\mathrm{L}$. Grupo guas plantas cultivadas 'Naranja dulce'

Dulce de naranjas Recolección de anti- Aportada por la técnica/ Ninguna Citrus $\mathrm{x}$ aurantium $\mathrm{L}$. Grupo guas plantas cultivadas Relación pulpa-azúcar. 'Naranja dulce' 
Tabla 17.4. Destino de los productos hortícolas: dulces que se pueden elaborar todo el año.

\begin{tabular}{|c|c|c|c|}
\hline Productos elaborados & $\begin{array}{c}\text { Origen de la } \\
\text { materia prima }\end{array}$ & $\begin{array}{l}\text { Origen de } \\
\text { la receta }\end{array}$ & $\begin{array}{l}\text { Modificación } \\
\text { de la receta }\end{array}$ \\
\hline $\begin{array}{r}\text { Dulce de anco } \\
\text { a la naranja o al limón } \\
\text { Cucurbita moschata Du- } \\
\text { chesne, Citrus x aurantium } \\
\text { L. Grupo 'Naranja dulce', } \\
\text { Citrus } \times \text { limon (L.) Osbeck }\end{array}$ & $\begin{array}{l}\text { Cultivos propios de } \\
\text { zapallos } \\
\text { Recolección de cítricos } \\
\text { de antiguas plantas } \\
\text { cultivadas }\end{array}$ & $\begin{array}{l}\text { Aportada por la pro- } \\
\text { ductora, receta familiar } \\
\text { tradicional }\end{array}$ & $\begin{array}{l}\text { Relación pulpa/ } \\
\text { azúcar y agregado } \\
\text { de cítricos }\end{array}$ \\
\hline $\begin{array}{r}\text { Anco en almibar } \\
\text { Cucurbita moschata Du- } \\
\text { chesne }\end{array}$ & Cultivos propios & Aportada por la técnica & $\begin{array}{l}\text { Relación pulpa/ } \\
\text { azúcar/agua. } \\
\text { Agregado esencia } \\
\text { de vainilla, clavo } \\
\text { de olor }\end{array}$ \\
\hline $\begin{array}{l}\text { Dulce de Zanahoria a la } \\
\text { naranja o al limón } \\
\text { Daucus carota L. subsp. sa- } \\
\text { tivus (Hoffm.) Schübl. \& G. } \\
\text { Martens, Citrus } x \text { aurantium } \\
\text { L. Grupo 'Naranja dulce } \\
\text { Citrus } x \text { limon (L.) Osbeck }\end{array}$ & $\begin{array}{l}\text { Cultivos propios de } \\
\text { zanahoria } \\
\text { Recolección de cítricos } \\
\text { de antiguas plantas } \\
\text { cultivadas }\end{array}$ & $\begin{array}{l}\text { Aportada por la técnica/ } \\
\text { Relación pulpa-azúcar. } \\
\text { Bibliografía }\end{array}$ & Ninguna \\
\hline $\begin{array}{r}\text { Dulce de remolacha al } \\
\text { limón } \\
\text { Beta vulgaris L. var. vul- } \\
\text { garis, Citrus } \times \text { limon (L.) } \\
\text { Osbeck }\end{array}$ & $\begin{array}{l}\text { Cultivos propios de } \\
\text { remolacha } \\
\text { Recolección de cítricos } \\
\text { de antiguas plantas } \\
\text { cultivadas }\end{array}$ & $\begin{array}{l}\text { Aportada por la técnica/ } \\
\text { Relación pulpa-azúcar. } \\
\text { Bibliografía }\end{array}$ & Ninguna \\
\hline
\end{tabular}

\section{Discusión y Conclusiones}

Los estudios realizados han permitido identificar prácticas y características similares a las registradas en los huertos familiares, destinados casi exclusivamente al autoconsumo (Pochettino et al., 2012, 2014):

1. Se observaron criterios de selección y prácticas de manejo propias de la unidad doméstica, a pesar de la incidencia del mercado en la decisión de qué y cuándo cultivar.

2. Los huertos familiares son ámbitos de innovación y experimentación, tal como queda demostrado por la presencia de variedades hortícolas típicas, valoradas por los horticultores como símbolo de identidad local, al mismo tiempo que se mantienen cultivos de importancia familiar y se introducen innovaciones para su establecimiento en el repertorio hortícola local.

3. Se registra el interés en apoyar a la economía familiar con la producción de alimentos para su comercialización; por esto, se han conformado diversos grupos de agroindustria artesanal a base hortalizas y frutas sin agrotóxicos, conservantes ni colorantes artificiales, que rescatan recetas tradicionales, con el fin de darle un valor agregado a la producción, aumentar la mano de obra, aprovechar los excedentes de la producción y obtener ingresos suplementarios.

Las prácticas hortícolas relevadas (y los conocimientos que las orientan) en el periurbano platense, si bien son el resultado de un tiempo relativamente corto de experiencia de los pobladores en su entorno local, pueden considerarse conocimientos y prácticas ligados a tradiciones. Estas han resultado en nuevos cultivares localmente establecidos y en acciones sobre el entorno que refleja la adaptación a las condiciones propias de los asentamientos, sean ambientales, culturales, las tradiciones familiares o de origen de ciertos grupos de inmigrantes, las preferencias personales (por ejemplo, culinarias), e incluso la respuesta propia a las demandas del mercado, a través de criterios de selección complejos que trascienden los estrictamente económico-productivos.

Las recetas presentadas contribuyen a demostrar que la permanencia de los saberes de los pequeños productores dentro del sistema productivo local contribuyen a diversificar la producción mediante el cultivo de variedades hortícolas a veces poco apreciadas en el mercado, pero también a partir del aprovechamiento de plantas cultivadas en época remota (incluso con fines ornamentales), de poco valor en la actualidad y que posiblemente hubieran sido eliminadas para otro tipo de uso del terreno (nísperos, moras). Por otra parte, en el caso de los productos elaborados de forma artesanal y destinados a la comercialización, se realizan procesos educativos y de extensión con el fin de promover nuevas tecnologías, que serían también factores de cambio de esos saberes ligados a tradiciones. De este modo, se alcanzaría la "conservación a través de la comercialización”, según propone Evans (1993), quien considera que si los emprendimientos comerciales a pequeña escala (para beneficio de los productores locales y no de intermediarios, basados en el empleo de una gran diversidad de cultivos) pueden garantizar mayores ingresos para los pobladores de distintos hábitats (en nuestro caso, agroecosistemas) que la destrucción de los mismos, se habría dado un importante paso hacia la sustentabilidad de tales sistemas.

De este modo, el conocimiento botánico local orienta las prácticas hortícolas según diversos criterios de selección, y estas mismas prácticas (no solo las conservadoras de la biodiversidad, sino también las que la incrementan) ajustan el conocimiento que las originó a las nuevas circunstancias (en esto reside su valor adaptativo). Así, la recursividad entre conocimientos y prácticas hace posible la evolución del sistema hortícola local en su compleja dimensión biocultural.Se concluye que, al igual que los huertos familiares, los huertos comerciales estudiados constituyen reservorios de variedades vegetales con distinto grado de asociación con las personas, y también reservorios de prácticas culturales de manejo. Destacar este carácter es relevante en un momento en el que la agricultura familiar es objeto de legislación y regulación en la Argentina.

\section{Agradecimientos}

Deseamos expresar nuestro reconocimiento a los "quinteros" del Cinturón Hortícola Platense por su inestimable colaboración durante el desarrollo de esta investigación, por el trabajo de selección que han hecho, así como por su autorización para difundir los resultados e imágenes. 


\section{Bibliografía}

Ahumada, A., M. L. Ciampagna, J. Vera Bahima, J. J. Garat y J. Otero, 2010. Prácticas culturales en la selección y conservación de hortalizas locales en el Cinturón Horticola Platense. En: Pochettino, M. L., A. H. Ladio
y P. M. Arenas (Eds). Tradiciones y Transform. y P. M. Arenas (Eds.). Tradiciones y Transformaciones Salvador de Jujuy: pp. 472-478.

Albuquerque, U. P. y R. F. Lucena, 2004. Métodos e técnicas na pesquisa etnobotânica Livro Rápido/NUPEEA, Recife.

Albuquerque, U. P., L. Andrade y J. Caballero, 2005. Structure and floristics of homegardens in Northeas
Journal of Arid Environments, 62: 491-506.

Barsky, A., 2010. La agricultura de "cercanías" a la cuda los ciclos del territorio periurbano. Reflexiones sobre caso de la Región Metropolitana de Buenos Aires. En: Svetlitza de Nemirovsky, A. (Ed.). Agricultura periurbana en Argentina y globalización. Escenarios, recorridos problemas. FLACSO, Buenos Aires: pp. 15-29.

Benencia, R., 1997. Área hortícola Bonaerense. Cambios en la producción y su incidencia en los sectores sociales.

Buet Costantino, F., E. A. Ulibarri y J. A. Hurrell, 2010. Las huertas familiares en la Isla Paulino (Buenos Aires, Argentina). En: Pochettino, M. L., A. H. Ladio y P. M. Arenas (Eds.). Tradiciones y Transformaciones en
Etnobotánica (ICEB 2009). CYTED-RISAPRET, San Salvador de Jujuy: pp. 479-484.

Calvet Mir, L., T. Garnatje, M. Parada, J. Vallès y V. ReyesGarcía, 2014. Más allá de la producción de alimentos: biocultural. Ambienta (España), 107: 40-53.

Das, T. y A. K. Das, 2005. Inventorying plant biodiversity in North East India. Current Science, 89 (1): 155-163.

Del Río, J. P., J. A. Maidana, A. Molteni, M. Pérez, M. L. Pochettino, L. Souilla, G. Tito y E. Turco, 2007. El rol de las "quintas" familiares del Parque Pereyra Iraola (Buenos Aires, Argentina) en la conservación
agrobiodiversidad. Kurtziana, 33 (1): 217-226.

agrobiodiversidad. Kurtziana, 33 (1): 217-226.

Evans M. I., 1993. Conservation by commercialization. En Hladik C. M., A. Hladik, O. F. Linares, H.Pagezy, A.
Semple y M. Hadley (Eds.). Tropical forests, peop and food: biocultural interactions and application to development. MAB Series, UNES

Feito, M. C., 2005. Antropología y desarrollo. Contribuciones del abordaje etnográfico a las políticas sociales rurales. caso de la producción hortícola bonaerense. La Colmena, Buenos Aires.

Fornari R., 2008. El rol de la Agricultura Familiar (en línea, disponible en: http:///www.or

García, M., 2010. Inicios, consolidación y diferenciación de la horticultura platense. En: Svetlitza de Nemirovsky, A.
(Ed). Agricultura periurbana en Argentina ylobalización.
Escenarios, recorridos y problemas. FLACSO, Buenos Aires: pp. 69-85.

uai, H. y A. Hamilton., 2009. Characteristics and functions of traditional homegardens: a review. Frontiers of Biology

Hurrell, J. A. \& M. L. Pochettino, 2014. Urban Ethnobotany: theoretical and methodological contributions. En: Albuquerque, U. P., L. V. F. Cruz da Cunha, R. F. Lucen y R. R. N. Alves (Eds.). Methods and Techniques in Ethnobiology and Ethnoecology. Springer-Humana
Press, New York: pp. 293-310.

Hurrell, J. A., G. Delucchi, E. A. Ulibarri y M. L. Pochettino 2009. Biota Rioplatense XIV. Hortalizas. Verduras Legumbres. Ed. Lola, Buenos Aires.

Hurrell, J. A., F. Buet Costantino, J. P. Puentes, E. A. Ulibarri y M. L. Pochettino, 2011. Huertos familiares periurbanos de las costas de Ensenada-Berisso y de (Corrientes), 20 (2): 213-229.

urrell, J. A., P. Cabanillas, E. L. Guerrero y G. Delucchi 2014. Naturalización y etnobotánica de Vitis labrusca L. (Vitaceae) en la región rioplatense, Argentina. Revist del Museo Argentino de Ciencias Naturales, n. s. 16

King, A., 2000. A brief review of participatory tools and techniques for the conservation and use of plant genetic resources. En: Friis-Hansen, E. y B. Sthapit (Eds.) Parlicipatory approaches to the conservation and us Resources Institute, Rome: Inp. 27-43.

ema, V. S. 2006 . Hues de altura: el manejo humano de Especies vegetales en la puna argentina. Revista
Escuela de Antropología (Rosario) 12: 173-186.

Maidana J A M. Pérez G. Tito \& E Turco, 2005 Ecohorticultura en el Parque Pereyra La PlataBerazategui, Buenos Aires, Argentina. LEISA (Revista de Agroecología), 20 (4): 42-44.

arasas, M. e I. Velarde, 2000. Rescate del saber tradiciona como estrategia de desarro
Boletin ILEIA 16 (2): 23-24.

tin, G. 1995. Ethnobotany. A methods manual. Chapman \& Hall, London.

Martínez, M. R. y M. L. Pochettino, 1999. El valor de conocimiento etnobotánico local: aporte a la currícula educativa en el área de biología en las escuelas de Molinos. Valles Calchaquies, Provincia de Salta, Argentina. Cuadernos del Instituto Nacional de noamericano, 18

hoztín. M., M. L. Pochettino y P. M. Arenas, 2003. La pluricultura. estrategia de subsistencia en contextos Delpinoa, 45: 89-98.

Millán, R. 1947. Los zapallitos de tronco de Sudamérica extratropical. Darwiniana, 7 (3): 333-345.
Nazarea,V., 1998. Cultural Memory and Biodiversity. University of Arizona Press, Tucson.

Pamungkas, R. N., S. Indriyani y L. Hakim, 2013. The elthnobotany of homegardens along rural corridors as a basis for ecotourism planning: a case study of Rajegwesi
village, Banyuwangi, Indonesia. Journal of Biodiversity and Environmental Sciences, 3(8): 60-69.

Pérez, M., G. Tito \& E. Turco, 2008. La producción sin agrotóxicos del Parque Pereyra Iraola: ¿un sistem agroalimentario localizado en el periurbano? En Velarde, l., A. Maggio y J. Otero (Comps.). Sistemas Nacional de Tecnología Agropecuaria, Buenos Aires: pp. 102-121.

Pochettino M. L, 2010. Huertos periurbanos como aporte a la diversidad agricola, Provincia de Buenos Aires, Argentina. En: Pochettino, M. L., A. H. Ladio y P. M. Arenas (Eds.). Tradiciones y Transformaciones en Etnobotanica (ICEB 2009). CYTED-RISAPRET, Sa Salvador de Jujuy: pp. 186-192.

Pochettino, M. L., J. A. Hurrell y V. S. Lema, 2012. Local Botanical Knowledge and Agrobiodiversity: Homegardens at Rural and Periurban Contexts in Argentina. En. Luna Maldond

Pochettino, M. L., J. A. Hurrell y M. M. Bonicatto, 2014 Horticultura periurbana. estudios etnobotanicos en Ambienta (España), 107: 86-99.

Prividera, G. y N. López Castro (Comps) 2010. Repenser la agricultura familiar. Aportes para desentrañar complejidad pampeana. Editorial CICCUS, Buenos Aires.

Quinlan, M. 2005. Considerations for collecting freelists in the field: 17 (3): $1-16$.
(1)

Seta, T., S. Demissew, y Z. Asfaw, 2013. Home gardens of Wolayta, Southern Ethiopia. An ethnobotanical profile. Academia Journal of Medicinal Plants, 1: 14-30.

Reyes-García, V., L. Aceituno, S. Vila, L. Calvet-Mir, T
Vallès y M. Pardo de Santayana, 2012. Home gardens in three mountain regions of the Iberian Peninsula: Description, motivation for gardening, and gross

Fi, J. R., 2005. Advances in ethnobiological field methods. Feld Methods, 17 (3): 211-218.

urco, E., L. Souilla y M. L. Pochettino, 2006. Relación entre saberes y prácticas culinarios con la conservación de la agrobiodiversidad. Estudio etnobotánico en el Parque Pereyra Iraola (Buenos Aires, Argentina). VII Congres

Velarde, I., C. Voget, G. Avila, C. Loviso, E. Orosco, C Sepúlveda y S. Artaza, 2008. Influencia de la calidad del sistema agroalimentario del vino de la costa de Berisso. En: Velarde, I., A. Maggio y J. Otero (Eds.). Sistemas agroalimentarios localizados en Argentina. Altituto Nacional de Tecnología Agropecuaria, Buenos Aires: pp. 31-66.

Vogl, C. R., B. Vogl-Lukasser y J. Caballero, 2002 Homegardens of Maya Migrants in the District of Palenque (Chiapas/Mexico): Implications for Sustainable K. Zarger (Eds). Ethnobiology and Biocultural Diversity. K. Zarger (Eds.). Ehiversity of Georgia Press, Athens: pp. 631-647.

Vogl-Lukasser, B. \& C. R. Vogl, 2004. Ethnobotanical research in homegardens of small farmers in the Alpine region of Osttirol (Austria). An example for bridge Applications, 2: 111-137.

Wagner, G., 2002. Why plants have meanings. In Ethnobiology and biocultural diversity. En: Stepp, J. R., F. S. Wyndham y R. K. Zarger (Eds.). Ethnobiology and Biocultural 659-667.

Watson, J. W. y P. B. Eyzaguirre (Eds.), 2002. Home garden and in situ conservation of plant genetic resources in farming systems. In 


\section{Domesticación de plantas medicinales aromáticas}

Carrillo-Galván, Guadalupe; Bye, Robert A.; Eguiarte, Luis E.

\section{Resumen}

La domesticación es un proceso evolutivo que implica la selección de ciertas variantes alélicas, principalmente, mediante selección artificial llevada a cabo por los seres humanos. Este proceso conlleva a la diferenciación morfológica, fisiológica y genética en diversos aspectos de la historia de vida de los organismos sujetos a selección artificial; por su parte,,en los parientes silvestres ese conjunto de características ha sido moldeado por la selección natural y otras fuerzas evolutivas. A las características que comparten los organismos domesticados se les ha definido como síndrome de domesticación. Son diversos los casos de plantas domesticadas en los que se ilustra claramente cómo ha ocurrido el proceso de domesticación y cuáles han sido sus consecuencias. Son ejemplos bien conocidos los del maíz, el trigo, el frijol, entre otras especies que han sido ampliamente documentadas. Pero también son numerosos los casos de plantas medicinales aromáticas, las cuales, sin embargo, han sido menos estudiadas.

Una gran parte de los estudios de plantas aromáticas están enfocados a encontrar compuestos activos que puedan ser utilizados en la industria farmacéutica para el tratamiento de alguna enfermedad. Las plantas aromáticas cuentan con una serie de características que hacen difícil su estudio, como por ejemplo, el hecho de que presentan una gran variación morfológica y expresiones en la concentración de metabolitos secundarios. Sin embargo, diversas disciplinas han aportado evidencias para documentar el proceso de domesticación. En consecuencia, el propósito principal de este capítulo es hacer una revisión de las principales plantas aromáticas que han sido domesticadas en el Viejo y en el Nuevo Mundo y discutir acerca de las consecuencias de su domesticación. Para el caso del Viejo Mundo se han documentado nueve centros de diversidad, siendo el principal el Mediterráneo y para el cual se analizan dos casos de estudio: la menta y la manzanilla, de las que existen evidencias de su domesticación en diversas disciplinas. En el Nuevo Mundo, particularmente en Mesoamérica, los estudios son aun más escasos; sin embargo, las que han sido ampliamente estudiadas son el toronjil blanco y el epazote. 
Las plantas medicinales aromáticas constituyen un grupo que ofrece un gran potencial de líneas de investigación novedosas para documentar procesos de domesticación y generar información para el desarrollo de estrategias de fitomejoramiento y de manejo sustentable de estos recursos terapéuticos útiles para los seres humanos. El estudio de la domesticación de estas plantas permite ampliar el horizonte de criterios de selección que, en la literatura, se encuentra marcadamente dirigido a las plantas comestibles.

Palabras clave: domesticación, plantas aromáticas, Lamiaceae, Nuevo Mundo, Viejo Mundo.

\section{Domesticación}

Desde los tiempos de Darwin, la domesticación de plantas ha sido un tema que ha llamado la atención de los biólogos evolutivos (Gerbault et al., 2014; Diamond, 2002; Harlan, 1992). La domesticación se ha definido como un proceso evolutivo en el que la fuerza evolutiva más importante es la selección humana, y cuyo resultado en las poblaciones involucradas ha sido la fijación de un grupo de alelos que les confieren fenotipos favorables al consumo y al cultivo (Gepts, 2004). Debido a que es un proceso, se puede encontrar todo un gradiente de domesticación y de fenotipos, desde aquellas poblaciones cultivadas pero que son morfológica y funcionalmente muy similares a las poblaciones silvestres, hasta poblaciones manejadas cuyo fenotipo es totalmente diferente al de las poblaciones silvestres. Un alto grado de diferenciación puede llevar a las poblaciones de plantas bajo selección y manejo a tener una menor adecuación y nula dispersión en condiciones naturales, y por lo tanto su persistencia depende de las actividades que realicen al respecto los seres humanos (Harlan, 1992; Colunga-García Marín y Zizumbo-Villarreal, 1993; Zohary y Hopf, 1993). A este grado de diferenciación se le conoce como domesticación completa, y a las diferencias morfológicas, fisiológicas y genéticas entre las poblaciones silvestres y domesticadas se le conoce como síndrome de domesticación (Colunga-GarcíaMarín y Zizumbo-Villarreal, 2008; Gepts, 2004; Hammer, 1984).

Es importante mencionar que aunque algunas plantas estén completamente domesticadas, como el maíz (Zea mays L.), el trigo (Triticum monococcum L.), el arroz (Oryza sativa L.), el frijo (Phaseolus vulgaris L.), entre otras especies, el proceso evolutivo bajo selección humana aún continúa, ya que su diversificación evolutiva depende de las preferencias culturales en cada región, las cuales son dinámicas en el tiempo (Da Fonseca et al., 2015).

La domesticación de plantas se ha practicado de manera independiente en varias regiones del mundo: Mesoamérica, Sudamérica (parte andina), suroeste de Asia (Creciente Fértil), el sur de China, el sureste asiático, entre las más importantes, como producto de la búsqueda de las sociedades humanas por satisfacer sus necesidades como alimento, vestido, medicina, etc. (Harlan, 1992). En este sentido, dos principales vías de domesticación han sido documentadas y con ello se han observado ciertos modelos:

1. Domesticación de cultivos por semilla, en particular los cereales. En este grupo, el blanco de la selección humana es la semilla. Algunas características importantes de su síndrome de domesticación son: gigantismo en la semilla, pérdida de la dehiscencia en frutos $u$ otros mecanismos de dispersión natural, así como la pérdida de la dormancia. Ejemplos de estos mecanismos se pueden encontrar en el maíz, el trigo y el arroz, entre otros (Meyer y Purugganan, 2013).

2. Cultivos propagados de manera vegetativa mediante estructuras como los tubérculos, bulbos y raíces ( $p$. ej. Manihot esculenta Crantz). Dado que el blanco de la selección humana puede incluir estructuras vegetativas (tubérculos, rizomas, plantas completas), estas plantas invierten más energía en su propagación vegetativa y suelen destinar menos recursos a su reproducción sexual, por lo tanto, esta selección puede ocasionar una disminución en la fertilidad. Esta característica es un componente importante del síndrome de domesticación de este grupo; además, dependiendo de la finalidad de selección de la planta, puede estar compuesto por cambios en el sabor, cambios en el contenido de almidón, reducción de compuestos tóxicos, etcétera. (Meyer y Purugganan, 2013; McKey et al., 2010).

Los modelos arriba descritos se refieren a plantas cuya finalidad es alimenticia, pero existen otros modelos de domesticación (dentro de la vía de propagación vegetativa) para plantas con otros fines. Por ejemplo, Colunga-GarcíaMarín (1996) documentó el síndrome de domesticación de los agaves productores de fibra (Agave fourcroydes Lem.); los componentes que lo conforman son: gigantismo en hoja, alta cantidad relativa de fibra y menor espinosidad.

Sin embargo, hasta el momento existen pocos estudios que documenten el síndrome de domesticación de plantas medicinales aromáticas (Blanckaert et al., 2012). La mayoría de los trabajos concernientes a estas plantas están enfocados a encontrar compuestos activos que puedan ser utilizados en la industria farmacéutica para el tratamiento de alguna enfermedad (Lewis, 2003; Duke et al., 2002).

Documentar un proceso evolutivo en plantas medicinales aromáticas no es trivial por tres cuestiones principales:

1. Encontrar un buen caso de estudio. Investigar si la gente está ejerciendo selección en alguna planta aromática en particular, indagar cómo, por qué y para qué la está seleccionando (Colunga-GarcíaMarín y Zizumbo-Villarreal, 1993). Aunque las familias Amaranthaceae, Asteraceae, Lamiaceae, Rutaceae y Verbenaceae, entre otras, cuentan con un gran número de especies aromáticas medicinales, solo algunas responden positivamente a cultivo (Fig. 2). En muy pocas se ha documentado que existe evolución bajo selección y manejo humano (Blanckaert et al., 2012; Vogel et al., 2011; Rendón y Núñez-Farfán, 2000; Rivera y Obón, 1992a).

2. Amplia variabilidad morfológica. Estas plantas cuentan con una gran variabilidad morfológica (Melito et al., 2016; Kokkini, 1992; Lawrence, 2007). Esto las hace un blanco para la domesticación ya que esta variabilidad es la materia prima en la cual opera este proceso. Para saber si una planta se encuentra en proceso de domesticación, se requiere probar que la variación morfológica observada se debe a que el humano ha estado ejerciendo selección y manejo sobre sus poblaciones y no es producto o respuesta exclusiva a la variabilidad ambiental (Bajalan y Pirbalouti, 2015). Para comprobarlo se requiere de estudios detallados y se han realizado pocos en plantas medicinales (Blanckaert et al., 2012 Rendón y Núñez-Farfán, 2000; Rendón et al., 2001). 
3. Gran variabilidad en la concentración de metabolitos secundarios. Los principales grupos de metabolitos secundarios son compuestos fenólicos, nitrogenados y terpenos; estos últimos son los principales compuestos de las plantas aromáticas, ya que les confieren e aroma y algunos de ellos son volátiles (p. ej. monoterpenos) (Máthé, 2015). Se ha reportado que las funciones de estos compuestos pueden estar involucradas en la defensa contra el ataque de herbívoros y/o patógenos, en la atracción de polinizadores, en la protección contra el ambiente (formando resina en la superficie de la hoja), entre otros (Cole, 1992) Algunos estudios muestran que la variabilidad de estos metabolitos puede estar determinada por varios factores ya sean genéticos, fisiológicos o ambientales (Melito et al., 2016; Lee y Ding, 2016). Al igual que en el caso anterior, se requiere probar que los cambios en la concentración de los compuestos químicos que sufren las plantas cultivadas frente a las silvestres sean fundamentalmente producto de la selección y el manejo humano (Usa et al., 2015; Bagchi et al., 2009).

Documentar si una planta está en proceso de domesticación no es tarea fácil y menos aún en plantas medicinales aromáticas, ya que, como se discute arriba, cuentan con una gran variación morfológica y de concentración de metabolitos secundarios. Estudios muestran que esta variación está dada en gran medida por las condiciones ambientales (Abad et al., 2012 Goodner et al., 2006; Telci et al., 2006). Diversas disciplinas como la arqueología, botánica, etnobotánica, genética, historia, química, entre otras, pueden ayudar, cada una por su parte, a aportar evidencias, que al integrarlas nos ayudan a documentar el proceso de domesticación de una planta en particular (Gerbault et al., 2014; Zeder, 2015; Zeder et al., 2006; Zohary y Hopf, 1993; Harlan, 1992).

A continuación se presentan ejemplos de estudios de domesticación en plantas aromáticas medicinales del Viejo Mundo y otros de plantas del Nuevo Mundo. En cada sección se incluye una breve introducción para ilustrar algunas evidencias que pueden dar indicio de un proceso de domesticación en plantas medicinales aromáticas.

\section{Plantas aromáticas del Viejo Mundo}

Rivera y Obón (1992a) realizaron una revisión de las evidencias arqueobotánicas de plantas aromáticas en el Viejo Mundo, en particular de la familia Lamiaceae. Estas evidencias ilustran a antigüedad de la interacción de tales plantas con los seres humanos. Se supone que su uso posiblemente fue alimenticio y/o medicinal. En este mismo trabajo, los autores citan el estudio de Zeven y Zhukovsky (1975), quienes encuentran nueve centros de diversidad de plantas cultivadas en el Viejo Mundo (Apéndice 1). Entre estas plantas se registran varias especies de lamiáceas. Rivera y Obón (1992b) mencionan el uso actual de muchas plantas de dicha familia. A continuación se muestra un breve resumen de estos tres aspectos:

\section{Evidencias arqueobotánicas en el Viejo Mundo}

Creciente Fértil: Se han encontrado registros que datan del período Neolítico (6000 a. C.3000 a. C.) en la región comprendida por Turquía, Siria, Iraq, Irán y el Cáucaso. Estruc- turas como núculas (fruto seco indehiscente) carbonizadas de Ajuga chamaepitys (L.) Schred. subsp., chia Arcang, Ziziphora sp. y Teucrium botrys L. se han encontrado en yacimientos que datan del año 5200 a. C., aproximadamente (Helbaek, 1970; Van Zeist y Buitenhuis, 1983)

Centro Mediterráneo: En países como España y Portugal se han encontrado restos pertenecientes a Salvia verbenacea L., Satureja obovata Lag., Teucrium sp. y Thymus vulgaris que también datan del Neolítico. En estos países, además de Italia, Grecia, Israel y Egipto, se han encontrado restos de plantas silvestres de Lavandula dentata L., Rosmarinus officinalis L., Teucrium sp. y Thymus sp. que datan de la Edad de Bronce (1700 a. C.- 800 a. C.) (Hopf, 1979; Rivera et al., 1988).

Centro europeo siberiano: Se han encontrado registros que datan del Neolítico en Gran Bretaña, Francia, Bélgica, Holanda, Suiza, Austria, Alemania, República Checa y Eslovaquia Polonia, Dinamarca y Hungría, principalmente de Mentha arvensis-aquatica Timb.-Lagr, Origanum vulgare L., Ajuga reptans L., Satureja vulgaris (L.) Fritsch, Lycopus europaeus L. Se infiere que varias de estas especies fueron cultivadas en terrazas localizadas en los bordes de los lagos (tomado de Rivera y Obón, 1992a).

\section{Cultivo de plantas aromáticas en el Viejo Mundo}

Entre las plantas cultivadas en el Viejo Mundo se han registrado varias especies aromáticas (Zeven y Zhukovsky, 1975). El principal centro de diversidad de las plantas aromáticas cultivadas es el Mediterráneo. En esta región existen plantas cultivadas de especies como Lavandula angustifolia Mill., Melissa officinalis L., Mentha pulegium L., Origanum majorana, O. syriacum L., Rosmarinus officinalis, Salvia officinalis L., S. sclarea L., S. viridis L., Satureja montana L., Teucrium chamaedrys L., Te. marum L., Thymus serpyllum L., Th. vulgaris y Th. zygis Sm. Se ha propuesto que los cultivos de estas especies son derivados de poblaciones silvestres que se encuentran en la misma área. En algunas de ellas (por ejemplo $R$. officinalis y Th. vulgaris) existen reportes de su cultivo desde el período romano (27 a. C.-476 d. C.) (Zeven y Zhukovsky, 1975).

Es difícil distinguir a las plantas silvestres de $R$. officinalis y Th. vulgaris de las ferales (escapadas de cultivo), ya que estas plantas inician el proceso de colonización en campos de cultivo abandonados (5-30 años) de olivo (Olea europaea L.) o cebada (Hordeum vulgare L.) Por lo tanto, las poblaciones silvestres actuales probablemente son poblaciones ferales que provienen de pobbaciones cultivadas en épocas tempranas en algunas áreas del Mediterráneo (Rivera y Obón, 1992a; Figura 18.1).

Las plantas que se mencionan arriba no están completamente domesticadas, a pesar de la historia de selección y manejo humano que han tenido, ya que aún conservan su capacidad de dispersión natural. En contraste, un buen ejemplo de domesticación completa de plantas aromáticas medicinales es un híbrido de Mentha, el cual es estéril y se propaga de manera vegetativa con ayuda de los seres humanos (Harley y Brighton, 1977). El centro siberiano europeo probablemente sea el lugar de origen del cultivo de varios híbridos de Mentha. Cada uno de estos cuenta con un gran número de formas, las cuales se propagan de manera vegetativa y son comunes a escala local (Lawrence, 2007). 
Colonización de Labiatae en campos de cereal abandonados

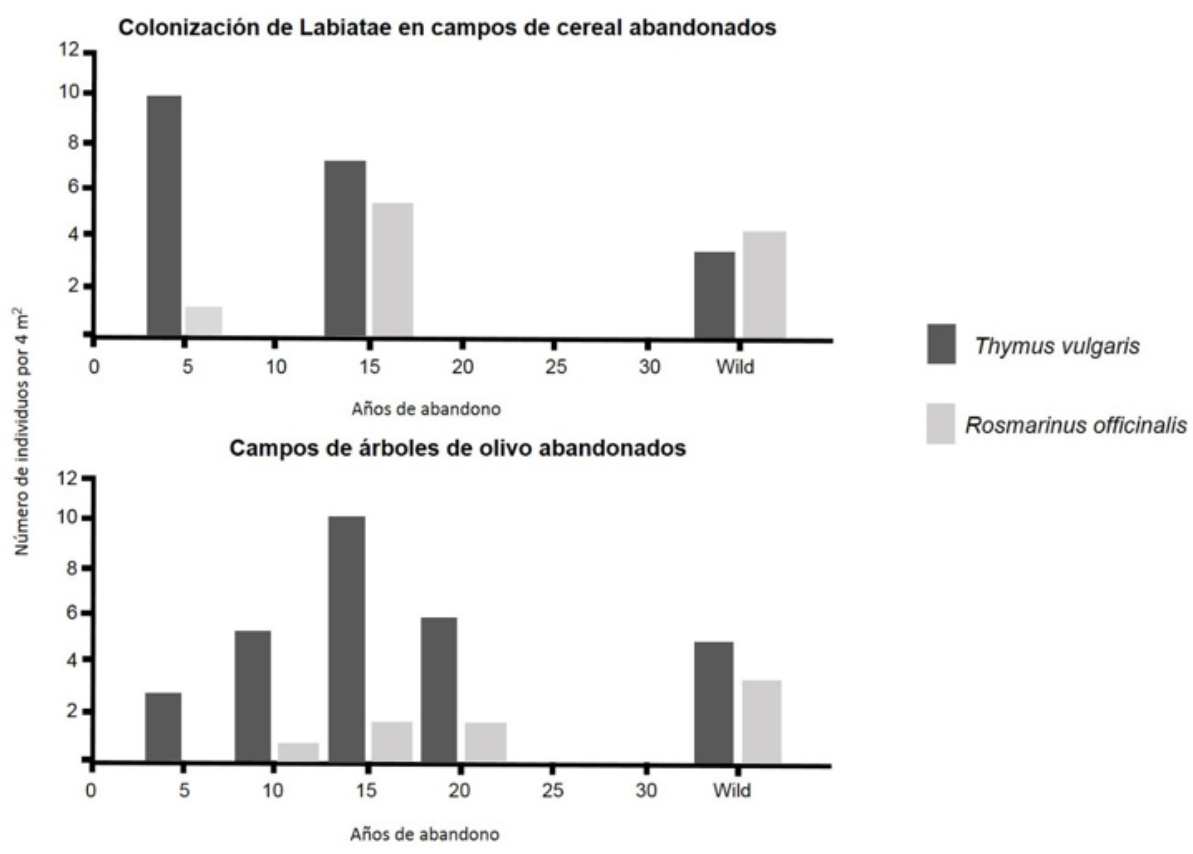

Figura 18.1. Proceso de colonización de dos especies de Lamiaceae en campos abandonados de cereales y olivos. Los datos fueron tomados de una localidad semiárida en una región al oeste del Mediterráneo. La colonización se representa como número de individuos por área. Los espacios vacíos indican que no hay datos disponibles (Modificado de Rivera y Obón, 1992a).

\section{Uso de plantas aromáticas en el Viejo Mundo}

Varías especies de la familia Lamiaceae se utilizan como hierbas culinarias y/o como medicinales. $R$. officinalis se utiliza para aliviar irritación de la piel y/o dermatitis alérgica en Turquía Varías especies de Thymus, igualmente, se utilizan para tratar irritación en la piel o dermatitis en esa misma región. En España ha sido descrita, además, como vermicida. Algunas especies del género Teucrium son usadas para tratar diarrea. Algunas especies del género Mentha tienen propiedades analgésicas, como por ejemplo M. x piperita L., M. arvensis las cuales son utilizadas para aliviar dolores gastrointestinales, otras son altamente tóxicas, como M. australis R. Br. y M. saturejoides F. Muell. (Ribera y Obón, 1992b).

A continuación se abordan dos casos específicos, menta y manzanilla, de los cuales existen evidencias históricas, taxonómicas, químicas y genéticas que dan evidencia de su domesticación.

\section{Menta}

El nombre genérico Mentha es derivado del griego Minthi. En la mitología griega, el dios de inframundo, Hades se enamora de una ninfa llamada Minthi y para protegerla de su esposa
Perséfone, la transforma en una planta de menta (Kokkini, 1992). El hecho de que las mentas se encuentren inmersas en la mitología griega constituye una evidencia de la gran importancia de estas plantas desde períodos muy antiguos.

El género Mentha pertenece a la tribu Menthea, la cual incluye a géneros muy importantes económicamente, como Agastache, Calamintha, Cedronella, Hedeoma, Hysssopus, Monarda, Nepeta, Origanum, Rosmarinus, Salvia, Satureja y Thymus. El género está conformado por dieciocho especies y once híbridos. La hibridación interespecífica ocurre con mucha frecuencia en las poblaciones silvestres o cultivadas, por lo que la especiación híbrida es común en el género (Tucker y Naczi, 2007; Lawrence, 2007; Harley y Brighton, 1977).

Como se menciona anteriormente, los híbridos de Mentha son muy importantes en el proceso de domesticación ya que, al ser parcial o completamente estériles, la propagación vegetativa es su principal mecanismo reproductivo. Esta característica confiere una ventaja para su rápida domesticación debido a que permite fijar genotipos a una mayor velocidad en comparación con la reproducción sexual (Mckey et al., 2010; Vargas-Ponce et al., 2007; Elías et al., 2007; Colunga-GarcíaMarín, 1996). Estos híbridos se cultivan de manera vegetativa mediante rizomas, y se ha reportado que estas estructuras suelen ser muy vigorosas (Harley y Brighton, 1977).

La identificación de estos híbridos es difícil, ya que el género Mentha cuenta con una gran variabilidad morfológica (Tucker, 2012; Tucker y Naczy, 2007). En primera instancia, los taxónomos consideraban la esterilidad como una condición de origen híbrido (Tucker y Naczy, 2007), sin embargo, este aspecto no es una regla. Malinvaud (1901) menciona que se deben inclui otras características que pueden aportar evidencia de hibridación cuando se comparan los posibles híbridos con los parentales; es, por ejemplo, el caso de las inflorescencias con formas mixtas, con ausencia o presencia de tricomas en las estructuras florales, la modificación en el tamaño de las hojas, entre otros rasgos. Aunque la información anterior es obtenida de una cita antigua, las características mencionadas se siguen considerando como criterios taxonómicos para determinar el origen híbrido en muchas mentas.

Aunado a lo anterior, actualmente, los análisis filogenéticos basados en regiones del cloroplasto (rp/16; trnL-trnF) y nucleares (ITS) ayudan a confirmar y a detectar los posibles parentales de los híbridos (Bunsawatt, 2002; Bunsawat et al., 2004). Por ejemplo, análisis filogenéticos mediante marcadores de cloroplasto sugieren que los parentales maternos de M. canadensis L. y M. spicata son M. arvensis y M. Iongifolia (L.) Huds., respectivamente (Bunsawat et al., 2004).

Cuando se tienen evidencias a priori del origen híbrido de algún taxón de Mentha (rasgos morfológicos, citogenéticos, entre otros) los marcadores moleculares como RAPD (Random Amplified Polymorphic DNA) o AFLP (Amplified Fragment Length Polymorphism) han ayudado a corroborar las hipótesis sobre el origen híbrido de muchas especies de Mentha (Shasany et al., 2005; Gobert et al., 2002; Khanuja et al., 2000).

Otra característica muy importante de los híbridos de Mentha es que poseen en su aceite esencial compuestos aditivos; es decir, compuestos tanto maternos como paternos en mayor concentración y, además, pueden encontrase compuestos nuevos, ausentes en las especies parentales (Tucker, 2012; Gavalas et al.., 1998; Murray y Lincoln, 1972). Diversas 
investigaciones sugieren que la producción cualitativa de aceites esenciales está claramente determinada por control genético (Croteau y Gershenzon, 1994; Murray y Hefendehl, 1972). El uso de técnicas de experimentos de hibridación para estudiar el control genético de la biosíntesis de los terpenos (compuestos aromáticos) ha sido ampliamente estudiado en este género (Tucker, 2012; Patra et al., 2001; Gavalas et al., 1998; Murray y Hefendehl, 1972; Murray y Lincoln, 1972; Lincoln et al., 1971).

Un ejemplo de un hibrido estéril ampliamente cultivado por medio de propagación vegetativa es $M$. x piperita (hierbabuena), el cual contiene tres variedades: piperita, crispa y officinalis ( $2 n=72,84$ y 108, respectivamente). Mediante cruzas experimentales y análisis moleculares (AFLP) se ha reportado que los parentales de este híbrido son M. aquatica $L$. $(2 n=96)$ y M. spicata $(2 n=48)$ (Gobert et al., 2002; Murray et al., 1972). Los compuestos más abundantes del aceite esencial del primer parental son: mentofurano (entre 7.6-89.0\%), eucaliptol (23.5\%) y $\beta$-cariofileno (6.1-20.2\%); mientras que en el segundo son carvona (54.6-68.4\%) y oxido de piperitenona (27.7-68.0\%). En comparación, la composición química del aceite esencial en el híbrido $M . \times$ piperita var. piperita se caracteriza por tener altas concentraciones de mentofurano (23.5\%), carvona (61.0-68.0\%), mentol (18.3-35.6\%), mentona (12.1-42.3\%) y pulegona (30.5-51.0\%). Los primeros dos compuestos podrían ser considerados como aditivos, los restantes se encuentran en mayor concentración respecto a los parentales. Las hojas de esta planta han sido usadas tradicionalmente como infusión para aliviar dolores gastrointestinales, así como para eliminar parásitos intestinales por sus propiedades antiespasmódicas, antihelmínticas y antiamibianas que le confieren los compuestos arriba descritos. Lo anterior ilustra los cambios en el aceite esencial que puede sufrir una planta producto de la hibridación interespecífica, y que pueden ser útiles para el humano con fines medicinales.

Actualmente hay un gran interés en la industria por los híbridos de $M$. x piperita por sus compuestos químicos presentes en su aceite esencial, principalmente por mentofurano, el cual es uno de los principales compuestos que le confiere el aroma a esta planta. Este es altamente tóxico y se encuentra en mayor cantidad cuando las plantas están en etapa floral, momento en el que son cosechadas para fines industriales (Kumar et al., 2014). Debido a la gran demanda de este taxón a nivel mundial y a su propagación exclusivamente vegetativa, se ha reportado que este híbrido cuenta con una baja diversidad genética, lo que puede estar relacionado con su defensa limitada ante el ataque de patógenos (Fenwick y Ward, 2001). Dado el alto interés industrial en el aceite esencial de este taxón, se han realizado esfuerzos para obtener genotipos con alto contenido de mentofurano a través de programas de fitomejoramiento por medio de cruzas interespecíficas (Kumar et al., 2014).

\section{Manzanilla}

La manzanilla (Matricaria recutita) es una planta herbácea anual, diploide $(2 n=18)$, nativa de sur y este de Europa, que ha sido utilizada de manera milenaria como remedio medicinal en Egipto, Grecia y Roma (Singh et al., 2011; WHO, 1999; Das et al.., 1998). Es cultivada en países como Hungría, Rumania, Alemania, España, Italia, etc. Sin embargo, Hungría es el principal productor; en este país, la manzanilla crece en suelos pobres y es un recurso que genera ingresos muy importantes para las familia de escasos recursos (Svab, 1979).
Se ha identificado que el aceite esencial obtenido de las inflorescencias (capítulos) contiene 120 compuestos, ya que estas estructuras poseen un gran número de glándulas excretoras de aceite (Pino et al., 2002). Los principales compuestos son: a-bisabolol y sesquiterpenos relacionados (> 50\%), apigenina y glucósidos flavonoides relacionados $(>8 \%)$ y camazuleno (1-15\%), los cuales son conocidos por su actividad antiinflamatoria, antiséptica y antiespasmódica (WHO, 1999).

Raal et al. (2003) realizaron un estudio donde muestran que existen variaciones en cuanto a la concentración de los compuestos de aceites esenciales mencionados arriba en diferentes cultivos de $M$. recutita provenientes de distintas partes de Europa. Estos autores encuentran que la manzanilla cultivada en Gran Bretaña contiene mayor concentración de $\beta$-bisabolo óxido (25\%), en Hungría de a-bisabolol (24\%), en Bélgica y Francia de a-farneseno (5-7\%). En este sentido, estudios han demostrado que la temperatura tiene un mayor efecto sobre la variación en la concentración de los componentes del aceite esencial que el tipo de suelo en el que se encuentran cultivadas las plantas (Karami et al., 2009).

Además de las variaciones ambientales, el manejo humano también tiene un impacto en la concentración de estos componentes en las poblaciones cultivadas de manzanilla. Por ejemplo, las plantas de manzanilla cuentan con raíces superficiales, por lo que no pueden obtener agua de horizontes muy bajos del suelo. Al aplicar riego durante la etapa de floración, se incrementa la producción de capítulos, y al cosecharlos se produce una segunda etapa de floración y se genera un retraso en la formación de semillas (Singh et al., 2011).

El número de capítulos también varía en relación con el espacio que se deja entre una planta y otra en el campo de cultivo. En general, entre más espacio $(10,20,30 \mathrm{~cm})$ mayor el número de capítulos producidos por planta (Pirzada et al., 2011).

Se ha documentado que la mayor concentración de compuestos en los aceites esenciales se encuentra cuando los capítulos están totalmente abiertos, es decir, cuando las flores de la periferia con lígula blanca se encuentran en posición totalmente horizontal. La cosecha manual ayuda a la obtención de una mayor cantidad de capítulos con estas características y a dejar los brotes que aún no están listos, para cosecharlos posteriormente (Singh et al., 2011).

Actualmente, debido a la gran demanda mundial de aceites esenciales de manzanilla para la industria alimenticia, cosmética, de la perfumería y la aromaterapia, la cosecha se realiza de forma mecanizada, la cual permite tener mayor producción de aceite esencial, pero de menor calidad (Singh et al., 2011). La adición de fertilizantes en los campos de cultivo también provoca variación en la concentración de los compuestos en los cultivos de manzanilla (Ghaedi et al., 2015; Emongor et al., 1990).

Solouki et al. (2008) realizaron un estudio sobre la diversidad genética basada en caracteres morfológicos y marcadores moleculares (RAPD) de veinte variedades de manzanilla colectadas en diferentes partes de Irán y cinco obtenidas de Europa. Ellos encontraron que los caracteres con mayor variabilidad (determinada por el coeficiente de variación) son el número de capítulos producidos por planta y el porcentaje de aceite esencial, mientras que los caracteres con menor variación son la altura y el diámetro del capítulo. Dado que la morfología la evaluaron bajo condiciones homogéneas, colocando todas las variedades (diseño de bloques al azar) 
en las mismas condiciones ambientales (en un campo experimental), los autores sugieren que la variación de estas características probablemente está determinada bajo control genético. Además, proponen que los caracteres que presentaron menor variación posiblemente están determinados por un gen. En cuanto a la variación genética de las variedades, fue más alta que la encontrada en estudios realizados por Wagner et al. (2005). El hallazgo de estos autores se discute en el siguiente párrafo.

Dada la importancia industrial que tiene la manzanilla a nivel mundial, se han realizado programas de fitomejoramiento para obtener cultivares homogéneos que cuenten con una mayor producción y mayores concentraciones en los compuestos activos. Mediante estos programas se han obtenido plantas tetraploides para su cultivo, las cuales producen una mayor cantidad de capítulos, aceite esencial y flavonoides por hectárea y son más estables en la composición química comparadas con las diploides (Repcak et al., 1993). Seidler-Lozykowska (2003) muestra que las diferencias morfológicas entre las plantas de manzanilla tetraploides y diploides consisten en que las primeras tienen un mayor diámetro en os capítulos, peso de los capítulos, diámetro del polen, peso de las semillas y longitud de los estomas. Wagner et al. (2005) encontraron que la diversidad genética en las plantas tetraploides es menor que en las diploides y sugieren que, probablemente, es debido a las fuertes presiones de selección sobre estas plantas por la demanda industrial y a su aislamiento reproductivo; estas plantas no se entrecruzan con las plantas de manzanilla diploides (cultivadas o silvestres)

\section{Plantas aromáticas del Nuevo Mundo}

En Mesoamérica existen pocos estudios enfocados a documentar el proceso de domesticación de plantas aromáticas medicinales, a pesar de la gran importancia que tienen y han tenido en la salud y en la cultura de muchos de los pueblos del área (Heinrich et al., 2014; Blanckaert et al., 2012; Blancas et al., 2010; Ankli et al., 1999a; Heinrich, 1998; Argueta et al., 1994; Bye et al., 1995).

No se han encontrado en la literatura trabajos que documenten registros arqueobotánicos de plantas aromáticas medicinales en Mesoamérica. En cuanto a referencias históricas, el Códice De la Cruz-Badiano (1964) muestra muchas plantas con un uso medicinal en la época prehispánica.

En cuanto a estudios etnobotánicos referentes a la selección de plantas aromáticas con fines medicinales, Heinrich (1998) muestra que los pobladores mixes de San Juan Guichicovi, Oaxaca, clasifican a las plantas medicinales de acuerdo a ciertas características organolépticas. El estudio muestra que el criterio de selección está enfocado en el olor [p. ej. aromática fresca, Siparuna andina (Tul.) A. DC.] y en el sabor [p. ej. astringente, Guazuma ulmifolia Lam.; agrio, Citrus limon (L.) Burm.; picante, Capsicum frutescens L.; dulce, Phyta scaberrima (A.L. Juss.) Moldenke]. Además, el efecto fisiológico de ciertas plantas también es un aspecto importante a considerar para los mixes. Algunas plantas producen irritación en la piel y, consecuentemente, son usadas para tratar infecciones en la misma, siendo inapropiadas para uso interno (ya que causan serios efectos tóxicos). Estas características son el criterio más importante para decidir contra qué enfermedad puede ser usada una planta; por ejemplo, las plantas astringentes son valoradas para el tratamiento de diarrea y disentería. Adicionalmente, aunque en menor importancia, la sensación térmica que una planta produce sobre la piel (caliente, tibio, fresco, frío, etc.) también puede ser un criterio de selección. Algo muy importante y que es necesario tener en cuenta es que estas interpretaciones están inmersas en el seno cultural de cada región.

Ankli et al. (1999a) realizaron un estudio para entender el criterio de selección de las plantas medicinales en la región maya de Yucatán. En este estudio hacen una comparación de características organolépticas de plantas medicinales frente a las plantas no medicinales. Encuentran que el criterio de selección es similar al estudio citado en el párrafo anterior, es decir, se basa en el olor y en el sabor de las plantas.

Algo interesante que mencionan estos últimos autores es que las plantas frecuentemente usadas como medicinales son consideradas dulces (p. ej. Pachyrrhizus erosus Urb. var palma), astringentes, de buen olor o aromáticas (Psidium guajava L.). Sin embargo, existe un porcentaje similar en plantas usadas como medicinales y también como no medicinales que son consideradas como amargas [Crossopetalum gaumeri (Loes) Standl.], agrias (Critus aurantifolia Swingle), picantes (Piper amalago L.), malolientes (Zanthoxylum caribaeum Lam.) o de olor fuerte (Dysphania ambrosoides). La inclusión o no de plantas para fines medicinales con estas características, probablemente está asociada a que estas particularidades también son indicadoras de toxicidad.

De manera colateral, Ankli et al. (1999a) en su estudio reportan que la ausencia de olor y sabor es un indicativo de que la planta no tiene un potencial de uso medicinal. Aquí las plantas dulces y de olor fuerte son preferidas para tratar enfermedades respiratorias; plantas astringentes, amargas y aromáticas son usadas para enfermedades dermatológicas; para enfermedades gastrointestinales (por ejemplo, vómito y diarrea) son preferidas plantas aromáticas y amargas; para disentería, plantas con poco aroma o sabor amargo; para dolor y fiebre, plantas aromáticas o malolientes.

Los estudios mencionados anteriormente se basan en el criterio de selección de los especialistas médicos de un grupo étnico particular (mixes, mayas) para utilizar ciertas plantas con fines medicinales, ya que en cada región los recursos y la cultura difieren. Ankli et al. (1999b) también se basan en el criterio de los especialistas médicos locales para documentar la importancia cultural, médica y socioeconómica que tiene esta categoría de plantas para los mayas yucatecos. Estos autores reportan que 320 especies tienen 1549 usos indígenas, los cuales se agrupan para tratar nueve clases de enfermedades. El mayor número de especies se concentran en las clases de enfermedades gastrointestinales (147 spp.), dermatológicas (150 spp.), asociadas con dolor/fiebre (112 spp.) y respiratorias (87 spp.), donde algunas de las especies más importantes son: Mentha aff. piperita, Samolus ebracteatus Kunth, Satureja brownei (Sw.) Brinq. y Croton lundellii Standley, respectivamente para cada clase de enfermedad. Este estudio realza la importancia de ciertas especies en el sistema médico maya.

Los estudios anteriores proporcionan evidencia acerca de los criterios de selección que pueden influir en el proceso de domesticación de las plantas medicinales aromáticas. Sin embar- 
go, cuando se habla de domesticación, como se menciona al inicio de este capítulo, se hace referencia a un proceso evolutivo que involucra procesos de divergencias, por lo que se deben evaluar los cambios genéticos, morfológicos, fisiológicos y reproductivos que han presentado las plantas domesticadas comparadas con sus ancestros. El toronjil blanco (Agastache mexicana subsp. xolocotziana R. Bye, E. Linares y Ramamoorthy) y el epazote (Dysphania ambrosoides) son buenos ejemplos de domesticación de plantas medicinales aromáticas en Mesoamérica, y a continuación se analizan algunos de sus rasgos.

\section{Toronjil blanco}

El proceso evolutivo mediante el cual se pudo originar, aún se desconoce, ya que solo existen poblaciones cultivadas (Figura 18.2). Como una hipótesis, Bye et al. (1987) sugieren que probablemente, es producto de la hibridación entre Agastache palmeri (B. L. Rob.) Standl. (toronjil rosa distribuido en la Sierra Madre Oriental), y A. mexicana subsp. mexicana (toronji morado distribuido en el Eje Volcánico Transversal), aunado a la selección y manejo humano de este híbrido putativo por los pobladores del centro de México. La hipótesis anterior se desprende de las siguientes evidencias: el toronjil blanco cuenta con tres veces más compuestos en su aceite esencial que el toronjil morado (Estrada-Reyes et al. 2004), presenta baja viabilidad en el polen y su cultivo es exclusivamente vegetativo (Bye et al., 1987). Actualmente, el grupo de trabajo del doctor Robert Bye está realizando diversos estudios genéticos, morfológicos, etnobotánicos y químicos para probar esta hipótesis.

El toronjil blanco y el toronjil morado se preparan en infusión y se utilizan de manera conjunta para tratar dolencias gastrointestinales, cardiovasculares y problemas nerviosos. Además, se utilizan para enfermedades culturalmente definidas como "susto" y "espanto" en el centro de México (Linares et al., 1988).

\section{Epazote}

El estudio realizado por Blanckaert et al. (2012) en el municipio y ciudad de Santa María Tecomavaca, Oaxaca (parte de la Reserva de la Biósfera Tehuacán-Cuicatlán) documenta el proceso de domesticación incipiente del epazote, considerando cuatro tipos de evidencias: etnobotánicas, morfológicas, fitoquímicas y genéticas.

Para recabar evidencia etnobotánica, Blanckaert et al. (2012) evaluaron los criterios de selección del epazote blanco y el epazote rojo en distintos grados de manejo mediante entrevistas semiestructuradas. De estas dos variantes existen poblaciones silvestres, de manejo incipiente y además, la primera también se encuentra bajo manejo intensivo. Encontraron que aunque el epazote es considerado como un cultivo menor, estas variedades son ampliamente conocidas como condimento por los pobladores entrevistados en la comunidad $(\mathrm{N}=90)$, además de ser reconocidas y usadas como plantas medicinales (por el $78 \%$ de los entrevistados) contra parásitos intestinales, picaduras de animales, entre otras. La mayoría de los informantes tienen en sus jardines o campos de cultivo la variedad blanca y los criterios de selección están dirigidos hacia las características organolépticas y morfológicas de las plantas (olor, sabor y color de la planta).

Blanckaert et al. (2012) también documentan la variabilidad morfológica bajo condiciones homogéneas mediante un experimento de jardín común. A través de la evaluación de una serie
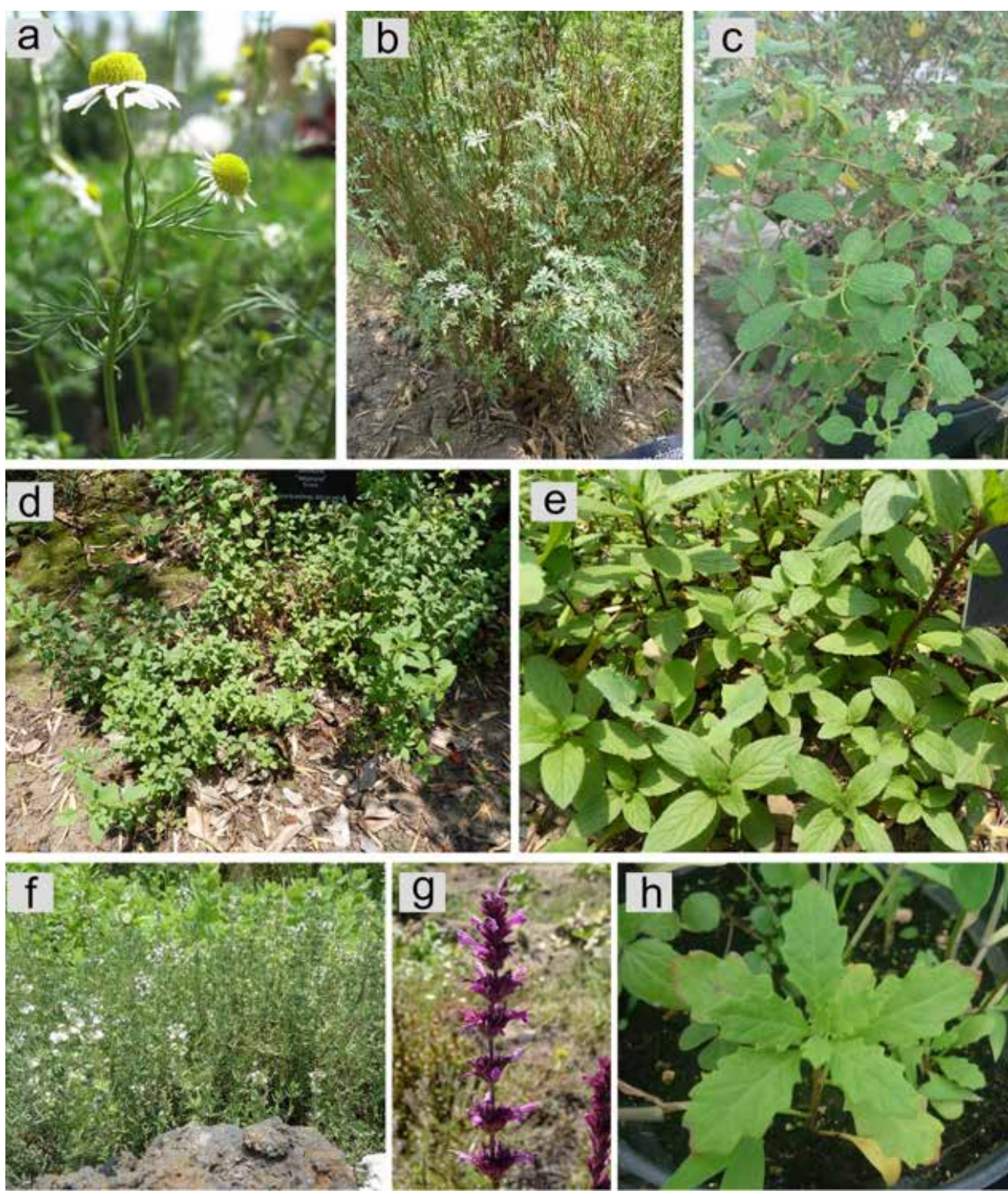

Figura 18.2. Ejemplo de algunas plantas medicinales aromáticas cultivadas: a) manzanilla (Matricaria recutita L., Asteraceae. Foto: Sol Cristians); b) ruda (Ruta chalepensis L., Rutaceae); c) Orégano (Lippia graveolens Kunth, Verbenaceae); d) mejorana (Origanum mejorana L., Lamiaceae); e) menta (Mentha x piperita L., Lamiaceae); f) tomillo (Thymus vulgare L., Lamiaceae); g) Toronjil morado (Agastache mexicana (Kunth) Lint y Epling subsp. mexicana R. Bye, E. Linares y Ramamoorthy, Lamiaceae), y h) epazote (Dysphania ambrosoides (L.) Mosyakin y Clemants, Amaranthaceae). 
de caracteres vegetativos (diez y siete continuos y tres categóricos) en plantas de epazote rojo y epazote blanco provenientes de diferentes grados de manejo (no manejadas, silvestres; manejo incipiente, toleradas o protegidas; manejo intensivo, fomentadas y cultivadas) y diversos análisis multivariados (PCA y UPGMA), determinaron tres grupos: 1) La variante roja silvestre y roja y blanca bajo manejo incipiente, 2) la variante silvestre blanca, y 3) la variante blanca con manejo intensivo. Las variables que determinan el agrupamiento y que presentaron diferencias significativas son el color del parénquima, altura de la planta, número de tricomas, número de dientes, largo de la hoja, ancho de la hoja, ancho y largo de los dientes. Las primeras seis separan al primer grupo de los otros dos, mientras que las últimas tres variables separan al segundo grupo del tercero. En cuanto al análisis genético, un marcador microsatélite QCA076 arroja la misma agrupación que las otras evidencias. La cercana relación y la conservación de la variación de este marcador con la progenie de las plantas estudiadas probablemente es indicativo de características ligadas que han sido seleccionadas en las poblaciones de epazote en el área de estudio.

En cuanto a la evidencia fitoquímica, determinaron que los compuestos responsables de sabor y olor en el aceite esencial fueron: $p$-cimeno, a-trepinoleno, 2-careno, $\delta$-3-careno, D-limoneno, timol, ascaridol, pulegona y farnesil acetona. Asimismo, reportaron que estos compuestos fueron significativamente más bajos en "epazote blanco" cultivado, comparado con los silvestres. Algo muy interesante que encontraron es que ascaridol, un compuesto tóxico para los seres humanos, no fue detectado en el "epazote blanco" cultivado ni en la variante blanco bajo manejo incipiente. Probablemente la selección humana ha provocado que este compuesto se encuentre en muy baja concentración, tanto que al analizar el aceite esencial no pudo ser detectado.

Todo lo anterior indica que las variantes morfológicas en el epazote están asociadas a un gradiente de intensidad de manejo y parecen estar asociadas a la intención de mejorar la palatabilidad, lo cual está correlacionado con una baja defensa química de la planta al disminuir los compuestos tóxicos para los humanos. Al mismo tiempo, la toxicidad presente en estas plantas ayuda a combatir los parásitos intestinales, motivo por el cual se utiliza como medicamento. Los autores discuten el número de tricomas en las plantas del "epazote rojo" silvestre, que es menos preferido que el "epazote blanco" cultivado; este no difiere, por lo que no se ajusta a un modelo de domesticación general (pérdida de defensas físicas). Sin embargo, probablemente, la persistencia de los tricomas es un mecanismo de defensa necesario ante la pérdida de defensas químicas, ya que la variante roja no cuenta con ellos, pero sí con una mayor abundancia en los compuestos que le dan olor y sabor a la planta.

Por último, Blanckaert et al. (2012) concluyen que la evolución del epazote se ajusta a un modelo simple de colonización dentro de un agroecosistema, el cual no induce a la modificación notable de métodos de dispersión de semillas. Sin embargo, el síndrome de domesticación está conformado por gigantismo de las partes útiles y la reducción de defensas químicas para el consumo humano. Este modelo es uno de los pocos que cuenta con diferentes evidencias para documentar el proceso de domesticación de una planta aromática medicinal.

\section{Conclusiones y perspectivas}

Documentar el proceso de domesticación de una planta aromática medicinal resulta ser complejo e interesante. En sentido amplio, el síndrome de domesticación de estas plantas podría estar compuesto por:

1. Cambio en el perfil químico de metabolitos secundarios. Lo cual podría implicar la pérdida o disminución de ciertos compuestos altamente tóxicos para los seres humanos. Sería interesante saber si, al hacer la comparación de los metabolitos secundarios entre plantas domesticadas y sus parientes, existe un cambio en los metabolitos producidos en las partes usadas con respecto a las no usadas, y si estos cambios tienen un efecto en la defensa contra depredadores.

2. Gigantismo en las partes usadas con fines medicinales. Probablemente la energía reservada al dejar de producir ciertos metabolitos secundarios podría ser invertida para incrementar la biomasa en las estructuras usadas por el humano con fines medicinales (cambio en la asignación de recursos). El gigantismo podría ser analizado también como el aumento en la concentración de los compuestos de interés para los humanos.

3. Para lograr domesticación completa en estas plantas, parece ser que la hibridación in ter-específica es muy importante y en este sentido, identificar el carácter híbrido del taxón estudiado y los posibles parientes cuya cruza originó el híbrido se torna un problema relevante de investigación.

4. Mayor inversión de recursos en las estrategias de reproducción vegetativa que en las de reproducción sexual.

Se requieren estudios más detallados para comprender el proceso evolutivo de la domesticación de plantas medicinales aromáticas y los propósitos y mecanismos de selección artificial involucrados. La etnobotánica, genética, química y morfología son buenas herramientas para documentar el proceso evolutivo en estas plantas, como lo muestra el estudio integral realizado por Blanckaert et al. (2012).

Para documentar procesos de domesticación en estas plantas es fundamental realizar experimentos bajo condiciones homogéneas para así detectar la heredabilidad de las características analizadas, ya que estas en particular son altamente sensibles a la variación ambiental.

Como se ha mostrado en el presente capítulo, en las plantas medicinales aromáticas, existe toda una línea de investigación para documentar procesos de domesticación y generar información para el desarrollo de estrategias de fitomejoramiento y de manejo sustentable de estos recursos terapéuticos útiles para el humano. 


\section{Bibliografía}

Abad, M. J., L. M. Bedoya, L. Apaza y P. Bermejo, 2012. The Colunga-GarcíaMarín, P. y D. Zizumbo-Villarreal, 2008. Artemisia L. Genus: A review of bioactive essential oils. (17): 2542-256

Ankli, A., O. Sticher y M. Heinrich, 1999a. Yucatec Maya Medicinal Plants versus Nonmedicinal Plants: Indigenous Characterization and Selection. Human Ecology, 27(4):

Ankli, A., O. Sticher y M. Heinrich, 1999b. Medical Ethnobotany of the Yucatec Maya: Healers' Consensus as a Quant

Argueta, A., L. M. Cano y M. E. Rodarte (Eds.), 1994. Atlas de las plantas de la Medicina Tradicion

Bagchi, G. D., F. Haider, N. Kumar, S. C. Singh y A. A Naqvi, 2009. Essentia Oil Profie of Naturat-Tempera. and Domesticated-Subtropical Artemisia myriantha Wall. ex Bess. var. pleiocephala (Pamp.) Ling rianth Journal of Essential Oil Research, 21(1): 43-45. http://doi.org/10.1080/10412905.2009.9700104.

Bajalan, I. y A. G. Pirbalouti, 2015. Variation in chemical composition of essential oil of populations of Lavandula $x$ intermedia collected from Western
Iran. Industrial Crops and Products 69: 344-347. Iran. I//ustriral Crops and Products 69:

Bunsawat, J., N. E. Elliott, K. L. Hertweck, E. Sproles y L A. Alice, 2004. Phylogenetics of Mentha (Lamiaceae) Evidence from Chloroplast DNA Sequences. Systematic

Bunsawat, J., 2002. Mentha (Lamiaceae) phylogenetic analysis using chloroplast TrnL-trnF and nuclear ribosomalADN

Blancas, J., A. Casas, S. Rangel-Landa, A. Moreno-Calles, I. Torres, E. Pérez-Negrón, L. Solís, A. Delgado-Lemus, F. 2010. Plant Management in the Tehuacan-Cuicatlan Valley, Mexico. Economic Botany, 64(4): 287-302.

Blanckaert, I., M. Paredes-Flores, F. J. Espinosa-García, D. Piñero y R. Lira, 2012. Ethnobotanical, morphological, phytochemical and molecular evidence for the incipient domestication of Epazote (Chenopodium ambrosioides L.: Chenopodiaceae) in a semi-arid region of Mexico.

Bye, R., E. Linares, y E. Estrada, 1995. Biological diversity medicinal plants in Mexico. En: Arnason, J. R. Mata y Romero (Eds.). Phytochemistry of

Bye, R., E. Linares, T. P. Ramamoorthy, F. García, O. Collera, G. Palomino y V. Corona, 1987. Agastache mexicana subsp. medicinal plants. Phytology, 62: 157-163. Cole, M. D., 1992. The significance of the terpenoids in the in Labiate Science. The Royal Botanic Gardens Key, UK. Pp. 315-324. esticación de plantas el establecimiento de corredores biológico-cu pules

Colunga-GarcíaMarín, P., 1996. Origen variación y tendencias evolutivas de henequén (Agave fourcroydes Lem.). Tesis

olunga-GarcíaMarín, P. y D. Zizumbo-Villarreal, 1993. La evolución de las plantas bajo selección artificial y manejo Manejo Sustentable de los Recursos Nds.). Cultura CIIIH-UNAM. Miguel Ángel Porrúa. México. p. 123-163. Croteau, R., Gershenzon, J., 1994. Genetic control of monoterpene biosynthesis in mints (Mentha: Lamiaceae

M., G. Mallavarapu y S. Kumar, 1998. Chamomile
(Chamomilla recutita): Economic botany biology chemistry Medicinal Aromatic Plant Science, 20: 1074-109.

Diamond, J., 2002. Evolution, Consequences and Future of Plant and Animal Domestication. Nature, 418: 700-707.

De la Cruz, M., 1964. Libellus de Medicinalibus Indorum Herbis. Manuscrito Azteca de 1552. Traducción latina de Juan Badiano. Edición Fondo de Cultura Econ

Duke, J. A., M. Bogenschutz-Godwin, J. duCellier y P. A. Duke, 2002. Handbook of medicinal spices. 2da. Ed. CRC Press LLC. Boca Raton, FL.

Elías, M., H. Lenoir y D. McKey, 2007. Propagule quantity and quality in traditional Makushi farming of cassava (Maniho

mongor, V. E., J. A. Chweya, S. O. Keya y R. M. Munavu, 1990. Effect of Nitrogen and Phosphorus on the chamomilla L.) Flowers. East Aft

Estrada-Reyes, R., E. Aguirre Hernández, A. García-Argáez M. Soto Hernández, R. Bye E Linares, G. Heinze y M. Martinez-Vázquez, 2004. Comparative chemical composition of Agastache mexicana subsp. mexican and A. mexicana subsp. xolocotziana.
Systematics and Ecology, 32: 685-694. Polymorphic DNA Markers for cultivar identification in mint. Horticultural Science, 36(4): 761-764. Skoglund, M. Fumagalli, A. J. Samaniego, C. Christian, M. Avila-Arcos, D. Hufnagel, T. S. Korneliussen, F. G. Vieira, M. Jakopsson, B. Arriaza, E. Willerslev, R. Nielsen,
M. B. Hufford, A. Albrechtsen, F. Ross-lbarra y M. T. P. Gilbert, 2015. The origin and evolution of maize in the Southwestern United States. Nature Plants, 1(1): 1-5. http://doi.org/10.1038/nplants.2014.3. érica. Geografía Agrícola, $41: 8$ esculenta): A case study for understanding domestication and evolution of vegetatively propagated crops. Genetic chamomilla L) Flowers. East African Agricultural and

enwick, A. L. y S. M. Ward, 2001. Use of Random Amplifie

seca, R. R., B. D. Smith, N. Wales, E. Cappellini, P.
Gavalas, N., A. M. Bosabalidis y S. Kokkini, 1998. Comparative study of leaf anatomy and essential oils of the hybrid Mentha $\times$ villoso-nervata and its parental species $M$. 46(1): $27-33$

Gepts, P., 2004. Crop domestication as a long-term selection experiment Plant Breeding, 24: 1-44.

Gerbault, P., R. G. Allaby, N. Boivin, A. Rudzinski, I. M. Grimaldi, J. C. Pires, C. C Vigueira, K. Dobney, K. J. Gremillion, L. Barton, M. Arroyo-Kalin, M. D. Purugganan, R. R. Casas, R. Ballongino, J. Birger, D. Q. Fuller, D. G.
Bradley, D. J. Balding, P. J. Richerson, M. Thomas, P. Gilbert, G. Larson y M. G. Thomas, 2014. Storytelling and story testing in domestication. Proceedings of the America, 111(17): 6159-64.

Gobert, V., S. Moja, M. Colson y P. Taberlet, 2002. Hybridization in the section Mentha (Lamiaceae) inferred from AFLP markers. American Journal of Botany, 89(12): 2017-2023.

Goodner, K. L., K. Mahattanatawee, A. Plotto, J. A. Sotomayor y M. J. Jordán, 2006. Aromatic profiles of Thymus hyemalis and Spanish T. vulgaris essential oils by GC-MS/

Ghaedi, J. M., M. Mousavinik, I. Khammari y M. Rahimi, 2015. The changes of yield and essential oil components of German Chamomile (Matricaria reculita L.) under drought stress conditions. Journal of the Saudi Society of Agricultural Science: En prensa.

Hammer, K. 1984. Das domestikationssyndrom. Kulturpflanze 32: $11-34$

Harlan, J. R., 1992. Crops and man. 2da. Ed. Am. Soc. Agronomy, Madison, WI. 284p.

Harley, R. M. y C. A. Brighton, 1977. Chromosome numbers in the genus Mentha L-. Botanical Journal of the Linnean

Heinrich, M. 1998. Indigenous concepts of medicinal plants in Oaxaca, Mexico: lowland mixe plant cassification based on orgalep
Botanik, $72: 75-81$.

Heinrich, M., F. B. Haller y M. Leonti, 2014. A perspective on natural products research and ethnopharmacology in Mexico: The eagle and the serpent on the prickly pea cactus. Journal of

Helbaek, H., 1970. The plant husbandy of hacilar. A study of cultivation and domestication. Excavations at hacilar,

Hopf, M., 1979. Pflanzliche Reste aus Zambujal, Madrider Beitr, 5: 315-341.

Karami, A., M. Khush-khui, M. J. Saharkhiz y F. Sefidkon 2009. Essential Oil Content and Compositions of Germa Chamomile (Chamomillarecultia L. Rauschert) Cultivated in Temperate and Subtropical Zones of liran. Journal of

Khanuja, S. P., A. K. Shanasy, A. Srivastava y S. Kumar, 2000 Assessement of genetic relationship in Mentha species. Euphytica, 111: 121-125.
Kokkini, S., 1992. Essential oils as taxonomic markers in Mentha. En: Advances in Labiate Science. Harley, H. R. UK. Pp. 325-334.

Kumar, B., A. K. Shukla y A. Samad, 2014. Development and characterization of the menthofuran-rich inter-specific hybrid peppermint variety CIMAP-Patra. Molecular

wrence, M. B., 2007. Oil Composition of other Menth species and hybrids. En: M. B. Lawrence (Ed,)

Lee, Y. L. y P. Ding, 2016. Production of essential oil in plants: Ontogeny, secretory structures and seasona
variations. Pertanika Journal of Scholarly Research Reviews, 2(1): 1-10.

wis, W. H., 2003. Medical botany: plants affecting human health. 2da. Ed. New Jersey.

nares, E., B. Flores y R. Bye, 1988. Selección de Plantas Medicinales de México. Ed. Limusa. México.

coln, D. E., P. M. Marble, F. J. Cramer y M. J. Murray, 1971 Genetic Basis for High Limonene - Cineole Content of Exceptional Mentha citrata Hybrids. Theoretical and Applied Genetics, 41: 365-370.

alinvaud, E., 1901. Classification des espèces et hybrides du genre Mentha, Compt. Rend. Co
Paris Dèp. Sec. Sci., 1900: 174-176.

Máthé, I., 2015. Chemical Diversity of Medicinal Plants. En: Medicinal and Aromatic Plants of the Word. Medicinal and Aromatic

elito, S., S. La Bella, F. Martinelli, I. Cammalleri, T. Tuttolomondo, C. Leto, A. Fadda, M. G. Molinu y M. Mulas, 2016. Morphological, chemical, and genetic diversity of wild myrtle (Myrtus communis L.) populations
in Sicily. Turkish Journal of Agriculture and Forestry, 40(2) in Sicily. Turkish Journal of Agriculture and Forestry,

Meyer, R. S., y M. D. Purugganan, 2013. Evolution of crop Species: genetics of domestication and dive
Nature Reviews. Genetics, 14 (12): 840-852.

Murray, M. J. y F. W. Hefendehl, 1972. Changes in by gene 11(8): $2469-2474$

urray, M. J. y D. E. Lincoln, 1972. Oil composition of Mentha aquatica - M. Iongifolia F1 hybrids and $M$. dumentorum Euphytica, 21: 337-343.

Murray, M., D. E. Lincoln y P. M. Marble, 1972. Oil composition of Mentha aquatica $\times M$. spicata $F$, hibrids in relation to the origin of $\times M$. pip
Cytology, 14: 13-29.

Key, D., M. Elias, M. E. Pujol y A. Duputié, 2010. The evolutionary ecology of clonally propagated plants. New Phytologist, 186: 318-332. Patra, N. K., H. Tanveer, S. P. S. Khanuja, A. K. Shasany, H. P. Singh, V. R. Singh y S. Kumar, 2001. A unique
interspecific hybrid spearmint clone with growth 
properties of Mentha arvensis $L$. and oil qualities of Mentha spicata L. Theoretical and Applied Genetics, 102(4): 471-476.

Pino, J. A., F. Bayat, R. Marbot y J. Agüero, 2002. Essentia oil of Chamomilla recutita (L.) Rausch. From Iran. Journal Essential Oil Research, 14, 407-8.

Pirzada, A., M. S Re.za, Z. Saeed, M. S. Abolghasem, H. Hashem y R. Darvishzadeh, 2011. Effects of irrigatio regime and plant density on harvest index of German chamomile (Matricaria chamomilla L.). Australian Journal
of Agricultural Engineering, 2(5), 120-126.

Raal, A., E. Arak, A. Orav y K. Ivask, 2003. Comparación de aceites esenciales de Matricaria recutita $L$. de orige

Repcak, M., P. Cernaj y V. Oravec, 1993). The stability of a high

Rendón, B. y J. Núñez-Farfán, 2000. Population differentiation f the annual Anodic cristata (Mand agrestal populations contrasting habitats. Plant Ecology, 00, 1-9. http://doi. org/10.1023/A.

Rendón, B., R. Bye y J. Núñez-Farfán, 2001. Ethnobotany of Anoda Cristata (L.) schl. (Malvaceae) in central Mexico: Uses, management and population differentiation in the community of Santiago Mamalhuazuca, Ozumba, state
of Mexico. Economic Botany, 55(4), 545-554. http://doi. of Mexico. Economic Botany,

Rivera, D. C Obón y A. Ascencio, 1988. Arqueobotánica y Paleoetnobotánica en el Sureste de España, datos
y Pato y Paleoetnobotánica en el Sureste de España,
preliminares. Trabajos de prehistoria, 45, 317-334.

Rivera, N. D. y C. C. Obón, 1992a. Palaeoethnobotany and archaeobotany of the Labiatae in Europe and the Near East. En: Advances in Labiate Science. Harley, H. R. y pp. 437-454.

Rivera, N. D. y C. C. Obón, 1992b. The ethnobotany of old world babiat En $A d$ H. R. y Reynols. T. (Eds.). The Royal Botanic Gardens Key, UK, pp. 455-474.

Seidler-Lozykowska, K 2003. Determination of the ploidy level in chamomile (Chamomilla recutita (L.) Rausch.) strains rich in alpha-bisabolol. Journal of Applied Genetics, 44(2), 151-155.

Singh, O., Z. Khanam, M. Misra y K. S. Srivastava, 2011 Chamomile (Matricaria chamomilla L.): An overview. Pharmacognosy Reviews, 5(9), 82-95.

Solouki, M., H. Mehdikhani, H. Zeinali y A. Emamjomen, 2008. Study of genetic diversity in Chamomile (Matricaria chamomilla) based on morphological traits and molecular Shasany, A. K., M. P. Darokar, S. Dhawan, A. K. Gupta,
S. Gupta, A. K. Shukla. y S. P. S. Khanuja, 2005. Use of RAPD and AFLP markers to identify inter- and 542-549. http://doi.org/10.1093/jhered/esi091. Polonica, 25:35-9.

Teli, I., E. Bayram, G. Yilma y B. Avci, 2006. Variability in essential oil composition of Turkish basils (Ocimum 34(6), 489-497.

(a., A. O., 2012. Genetics and breeding of the genus Mentha: a model for other polyploid species with secondary constituents. Journal of Medicinally Active Plants, 1(1): cgi/viewcontent cgi? article=10008

ucker, A. O. y R. F. C. Naczi, 2007. Mentha: An overview of (Ed) Mint the genus Mentha. CRC Pr. Laws NYPp 3-35. five cultivars of myrttle (Myrtus communis L). Journal of Essential Oil Research 27(6), 465-476. http:///doi.org/10 $.1080 / 10412905.2015 .1065773$.

Zeist, W. Y. y H. Buitenhuis, 1983. A paleobotanical study of Neolithic Erbaba. Turkey. Anatolica, 10: 47-89.

Vargas-Ponce, O., D. Zizumbo-Villarreal y P. ColungaGarcíamarin, 2007. In situ diversity and maintenance of traditional Agave landraces used in spirits production in
West-Central Mexico. Economic Botany, 61: 362-375.

Gel, H., B. González, y I. Razmilic, 2011. Boldo (Peumus boldus) cultivated under different light conditions, sol humidity and plantation density. Industrial Crops and Products, 34(2): 1310-1312. http://doi.org/10.1016/.

Wagner, C., W. Friedt, R. A. Marquard y F. Ordon, 2005 Molecular analyses on the genetic diversity and (L) tetraploid chamomile (Chamomilla recutita (L.) Rausch.).
Plant Science, 169(5): 917-927.

World Health Organization, 1999. WHO monoghaps on selected medicinal plants. Vol. 1. Malta. Pp. 86-94

Zeder, M. A., 2015. Core questions in domestication research. Proceedings of the National Academy of Sciences,

Zeder, M., E. Emshwiller, B. Smith y D. Bradley, 2006. Documenting domestication: The intersection of genetics Trends in Genetics, 22(3): 139-155.

Zeven, A. C y Zhukovsky, P. M., 1975. Dictionary of cultivated plants and their centres of diversity, PUDOC geningen.

Whary, D. y M. Hopf, 1993. Domestication of Plants in the OId World. 2da. Ed. Oxford University Press, NY.

\section{Apéndice 1}

\section{Centros de Origen de cultivos \\ de algunas plantas aromáticas (Lamiaceae) según Zeven y Zhukovsky (1975)}

1. Chino-Japonés

Elsholtzia Willd., Mentha L., Perilla L. y Stachys L.

2. Indo-Chino-Indonesio

Ocimum L., Orthosiphon Benth. y Pogostemon Desf.

3. Australiano

No hay reportes

4. Indostán

No hay reportes

5. Asia Central

Lallemantia royleana (Wall. y Benth.)

6. Cercano Oriente

Lallemantia iberica Fisch. y Mey.

7. Mediterráneo

Melissa officinalis L., Mentha aquatica L., M. Iongifolia (L.) Huds., M. pulegium L.,

Origanum majorana, O. syriacum L., Rosmarinus officinalis, Salvia officinalis L., S. sclarea L., S. viridis L., Satureja montana L., Teucrium chamaedrys L., Te. marum L.

Thymus serpyllum L. y Th. vulgaris, Th. zygis.

8. Siberiano Europeo

Mentha x gracilis Sole, M. x piperita L., M. x rotundifolia (L.) Huds., M. spicata L., M. suaveolens Ehrh., M. x villosa Huds., Nepeta cataria L. y Origanum vulgare.

9. Africano

Aeollanthus suaveolens Mart. ex Spreng., Hyptis Jacq., Ocimun L. y Orthosiphon 


\section{Impactos evolutivos \\ de las actividades humanas \\ sobre las plantas: \\ manejo, domesticación \\ y conservación in situ y ex situ}

Jennifer M. Cruse-Sanders y Alejandro Casas

\section{Resumen}

El entendimiento de cómo las actividades humanas impactan el patrón de distribución de la diversidad genética de las poblaciones biológicas es importante no solo para documentar el proceso de su manejo y domesticación, sino que resulta esencial para planear la conservación. Las consecuencias intencionales y no intencionales del manejo de recursos genéticos son sumamente dinámicas a través del tiempo, e incluyen procesos tanto naturales como artificiales que pueden impactar los patrones microevolutivos en las poblaciones de organismos y, a su vez, afectar patrones a mayor escala (macroevolutivos). En este capítulo analizaremos el impacto del manejo humano sobre la distribución de la diversidad genética de plantas y su importancia para comprender el manejo, su impacto y su posible contribución a la conservación de organismos silvestres y domesticados. La intensidad de manejo es variable y puede determinar patrones microevolutivos cambiantes y acumulación de diferencias entre poblaciones o, alternativamente, favorecer el flujo génico y la hibridación de linajes que han divergido naturalmente. Para entender esta idea con mayor profundidad, analizamos tres estudios de caso que ilustran diferentes ejemplos de intensidad de manejo y cómo este ha impactado patrones microevolutivos dentro de especies: 1) extracción de una planta medicinal de poblaciones naturales, 2) domesticación in situ de una planta perenne, principalmente comestible y, 3) restauración de una especie rara en un ambiente natural. En el primer caso se analiza el ginseng americano, explotado para un intenso comercio para la medicina china. La recolección en poblaciones silvestres ocasiona impactos altamente significativos en la reducción del tamaño poblacional, diversidad genética y limitaciones a flujo génico, que eventualmente se espera que favorezcan las condiciones para la extinción de poblaciones y la propia especie Panax quinquefolius, nativa de los montes Apalaches naturalmente distribuida desde Quebec hasta Georgia. El estudio muestra que la magnitud del impacto sobre la diversidad genética depende del régimen de cosecha. Hay un régimen generalista mediante el cual se cosechan al azar organismos de la población sin importa sus edades, y que ocasiona mayor impacto genético y demográfico. En contraste, el método 
tradicional efectúa colectas selectivamente, extrayendo individuos después que han producido semillas para asegurar las siguientes generaciones de la población. La protección de las poblaciones regulando métodos de cosecha ha sido parcialmente respetada y por ello han sido ineficaces. Sin embargo, los estudios efectuados permiten identificar técnicas de colecta nocivas y métodos de recuperación de las poblaciones, procurando asimilar la mayor diversidad genética.

El segundo ejemplo muestra el caso de Stenocereus stellatus, una cactácea columnar del centro de México, la cual produce frutos comestibles que se extraen de poblaciones silvestres, de poblaciones bajo manejo silvícola y se cultiva, además, practicando niveles intensivos de selección artificial que han permitido su domesticación. Los tres tipos de poblaciones coexisten en el espacio en dos regiones vecinas de México, pero con diferencias fitogeográficas: el valle de Tehuacán y la Mixteca Baja. La primer región es más seca que la segunda y el reclutamiento de plántulas a partir de semillas ocurre de manera episódica, siendo más dinámica la propagación vegetativa. En la Mixteca Baja hay mayor humedad y e reclutamiento sexual es más frecuente. Los estudios de genética de poblaciones muestran que, a pesar de las diferencias ambientales tan marcadas, los niveles de diversidad y estructura genética son similares, incluso entre regiones. No obstante los procesos selectivos y las posibles barreras al flujo génico natural, dentro y entre regiones se encuentran operando. El movimiento humano de propágulos sexuales (frutos a través del comercio) y asexuales (ramas de fenotipos interesantes intercambiados por relaciones de amistad y parentesco) permite explicar en buena medida los procesos microevolutivos registrados en las poblaciones. Uno de los aspectos más destacados es que las poblaciones silvestres, manejadas bajo técnicas silvícolas, y las cultivadas presentan conectividad y flujo génico. Las poblaciones manejadas y cultivadas llegan a tener mayor diversidad genética que las poblaciones silvestres cercanas, lo que las convierte en verdaderos reservorios de gran trascendencia en el mantenimiento regional e interregional de la diversidad genética. El caso de $S$. stellatus es similar al documentado con otras ocho especies de cactáceas columnares y especies de agaves de México.

El tercer caso es el del zumaque enano, cuyas poblaciones han sido severamente afectadas por grupos humanos en los Estados Unidos. En este caso, la planta dioica puede llegar constituir poblaciones enteramente de plantas macho y otras enteramente de plantas hembra. Acciones preliminares de introducción recíproca de machos y hembras sugiere la viabilidad de recuperación de poblaciones y de efectuar intervenciones para que las poblaciones resultantes puedan asemejar los niveles de diversidad genética que se encuentran en las poblaciones silvestres naturales.

Los estudios analizados muestran que la prospección de poblaciones que pueden ser fuentes de semillas para la restauración es crucial, la meta de lograr maximizar la diversidad genética es un importante criterio, anticipándose al cambio climático y otros cambios globales ambientales. Las colectas en condiciones extremas son tan importantes como las de diversidad genética general. Una predicción de cambio climático estima que el perfil del clima para as especies de plantas se puede mover $500 \mathrm{~km}$ hacia los polos o $500 \mathrm{~m}$ en elevación durante el próximo siglo. Los bancos de semillas pueden ser una importante fuente de material para la restauración ecológica y complementan la conservación in situ de plantas silvestres y cultivadas. Se requiere urgentemente más investigación sobre la variación genética en especies prioritarias a recuperar para delinear zonas de semillas y guías de transferencia de semillas, para los bancos de semillas y para los planes de restauración.

Palabras clave: conservación in situ y ex situ de recursos genéticos, domesticación incipiente, genética de la conservación, ginseng americano, manejo, recursos forestales no maderables, xoconochtli, zumaque enano.

\section{Introducción}

Todas las especies de plantas, así como los ambientes naturales, son afectadas directa o indirectamente por las actividades humanas. Los paisajes naturales reflejan las innovaciones tecnológicas, las limitaciones económicas y las aspiraciones culturales de sus habitantes humanos (Whitney, 1994). Factores independientes a la biología de las especies de un ecosistema incluyendo a las plantas, los animales, hongos y microorganismos, pueden tener enormes implicaciones evolutivas. Entre tales factores podemos identificar algunos a escala global (cambio climático), hasta procesos que ocurren a escala poblacional, incluyendo la fragmentación, la extinción de una especie debido a su extracción por los humanos, entre otros.

El entendimiento de cómo las actividades humanas impactan el patrón de distribución de la diversidad genética de las poblaciones de plantas, animales, hongos y microorganismos es importante no solo para documentar el proceso de domesticación o el manejo de productos forestales, sino que resulta esencial para planear la conservación. Las consecuencias intencionales, así como las no intencionales del manejo humano de recursos genéticos son vigentes y sumamente dinámicas a través del tiempo; esto puede involucrar diferentes tipos de procesos que pueden ser naturales $\mathrm{o}$ artificiales. Tales procesos pueden impactar los patrones microevolutivos en las poblaciones de organismos, los cuales, a su vez, afectarán patrones a mayo escala: los patrones macroevolutivos de las especies. En este capítulo analizaremos el impacto del manejo humano sobre la distribución de la diversidad genética de organismos, particularmente de plantas, y su importancia en términos de la comprensión del manejo, su impacto y su posible contribución a redireccionar sus efectos; la domesticación como una expresión de máxima intensidad en tal manejo y la conservación de organismos silvestres y domesticados. La motivación del manejo humano de especies de plantas resulta en un continuum de intensidad de manejo con consecuencias de distinta magnitud en la distribución de diversidad genética y su conservación. Se trata de un continuum de manejo con una larga historia, cuya huella puede apreciarse en los paisajes y cuyos principios pueden ser de gran relevancia para establecer criterios de acciones para una conservación eficaz y adecuada.

Los patrones de distribución de la diversidad genética neutral a gran escala dentro y entre poblaciones se han usado para inferir historias tales como los centros de domesticación, e uso e intercambio de recursos, así como para generar recomendaciones para la conservación (Doulati-Banehe et al., 2015; Hardigan et al., 2015; Forsberg et al., 2015; Gaut et al., 2015; Parra et al., 2015; Santos et al., 2015). Si la motivación por manejar una especie de planta 
impacta la intensidad de manejo, entonces ¿cómo la intensidad de manejo puede impactar el potencial evolutivo y la distribución de la diversidad genética de una especie? La intensidad de manejo, resultante del valor variable que los humanos otorgan a las plantas, potencialmente puede determinar patrones microevolutivos cambiantes, la acumulación de diferencias entre poblaciones o, alternativamente, favorecer el flujo génico y la hibridación de linajes que han divergido naturalmente. Para entender esta idea con mayor profundidad, analizamos tres estudios de caso que ilustran diferentes ejemplos de intensidad de manejo y cómo estos han impactado patrones microevolutivos dentro de especies:

- Extracción de una planta medicinal de poblaciones naturales

- Domesticación in situ de una planta perenne, principalmente comestible

- Restauración de una especie rara en un ambiente natural

\section{Motivación para el manejo: extracción de plantas medicinales}

Se ha reconocido ampliamente que los productos forestales no maderables (PFNM), incluyendo las plantas medicinales, frecuentemente influencian estrategias para manejar los bosques con el fin de asegurar diversidad y sustentabilidad de los productos aprovechables (Ticktin y Johns, 2001; Teel y Buck, 2002). Más del $80 \%$ de las poblaciones humanas dependen de la extracción de plantas silvestres como una importante fuente de medicinas, las cuales proveen materias primas a la industria farmacéutica mundial y siguen constituyendo una pieza clave en el cuidado de la salud en los contextos rurales (Sheldon et al., 1997). Además, mucha gente en países o contextos urbanos en donde las plantas silvestres colectadas no son la principal fuente de medicinas usa remedios herbales, y la fuente de muchos de tales remedios herbales continúan siendo las poblaciones de plantas silvestres. La sustentabilidad de la cosecha de plantas silvestres requiere que las tasas de extracción no excedan la capacidad de las poblaciones para recuperarse desde el punto de vista demográfico y genético. Pero el logro de esta premisa generalmente significa importantes desafíos para la investigación, para el logro de acuerdos sociales y comerciales y, en pocas palabras, constituye un problema socioecológico de primordial importancia.

Desde una perspectiva de la conservación, la extracción directa de plantas de poblaciones silvestres determina efectos negativos sobre las poblaciones, especialmente las de tamaño pequeño. Las poblaciones pueden ser pequeñas como resultado de la historia natural de la especie en cuestión, de catástrofes naturales y cambios ambientales, así como de un efecto indirecto de actividades humanas tales como la fragmentación de su hábitat o la introducción de especies invasoras. Conforme las poblaciones de plantas decrecen, estas pueden caer en una espiral que las conduce a la extinción, así como la variabilidad demográfica, la endogamia, el aislamiento genético, y la deriva génica conducen a tamaños efectivos poblacionales paulatinamente más pequeños (Ellstrand y Elam, 1993; Primack, 1993; Newman y Pilson, 1997; Briggs y Walters, 1997). Las técnicas de genética de poblaciones son herramientas poderosas para medir los procesos que ocurren en las poblaciones pequeñas, pero el entendimiento de los factores que causan la disminución de las mismas es tan importante como la medición de los procesos.

Los sistemas de extracción de PFNM son sostenibles, solamente, si los recursos como frutos y hojas pueden cosecharse indefinidamente de un área limitada con bajo impacto sobre la estructura y función de las poblaciones de plantas explotadas (Sheldon et al., 1997; Vance, 2002). El impacto de la cosecha sobre las poblaciones silvestres depende, en parte, de la distribución y abundancia, así como de otros aspectos de la biología de las especies, del valor de los recursos y de la parte de la planta que se cosecha (Sheldon et al., 1997). La cosecha sustentable requiere información sobre la tasa de crecimiento, la estructura de la población, fenología reproductiva, sistemas de cruzamiento y dispersión de semillas, así como las prácticas de cosecha de los colectores y de los incentivos socioeconómicos y culturales que influyen la intensidad con la que la llevan a cabo y cómo la llevan a cabo.

La intensidad con la cual los productos silvestres se cosechan depende de las necesidades económicas de los colectores, de las oportunidades de empleo o de la diversidad de fuentes de ingresos, del tiempo disponible para la cosecha y del valor comercial de los productos (Bailey, 1999; Crook y Clapp, 2002). El contexto social y cultural asociado a los productos silvestres, entonces, también influye sobre la frecuencia y la magnitud (en términos de biomasa utilizada) con la cual los recursos silvestres son aprovechados (Bailey, 1999; Crook y Clapp 2002; Pilz y Molina, 2002).

En los bosques deciduos del este de los Estados Unidos de América, varias especies son vulnerables como resultado de su valor medicinal. Plantas como el ginseng americano (Panax quinquefolius), la planta conocida popularmente como raíz amarilla (Xanthoriza simplicissima) la sanguinaria (Sanguinaria canadense), la sello dorado (Hydrastis canadense) y el puerro silvestre (Allium tricoccum) sufren una reducción progresiva de sus poblaciones debido a la sobreexplotación (Nantel et al., 1996; Sheldon et al., 1997; Robbins, 1998; Hackney y McGraw, 2001). Estas especies representan un grupo de plantas herbáceas de lento crecimiento y ciclo de vida largo. Son componentes de los bosques primarios y sus poblaciones son frecuentemente extraídas, afectando drásticamente el número de individuos que las componen y, eventualmente, determinando la extinción de tales poblaciones. Los bosques maduros, donde la mayor parte de las poblaciones de estas especies se encuentran, están también amenazados por la alteración del hábitat como resultado de la suburbanización y la explotación maderera. No obstante que este proceso ha ocurrido por más de 250 años, y aun cuando las poblaciones humanas en el pasado eran mucho mayores que en la actualidad (por ejemplo en las áreas que ahora se encuentran bajo manejo federal a través del sistema de bosques o parques nacionales), la extracción no ha determinado la extinción total de estas especies económicamente importantes. Este hecho conduce a varias preguntas: ¿Cuál es el impacto evolutivo de la extracción de RFNM? Considerando las interacciones a largo plazo entre humanos recolectores y plantas económicamente importantes, otra pregunta pertinente es ¿qué es silvestre? El ginseng americano es una de las plantas medicinales más altamente comercializada en los Estados Unidos, y para analizar preguntas como las anteriores resulta conveniente ver de cerca cómo es el efecto del manejo humano sobre esta planta y qué factores sociales y ecológicos influyen sobre la ruta del impacto. 


\section{El ginseng americano silvestre, Panax quinquefolius}

Panax quinquefolius L. (Araliaceae), el ginseng americano es una planta herbácea de ciclo de vida relativamente corto (de 50 a 100 años), nativa de Norteamérica. Se encuentra en los bosques deciduos a lo largo de los montes Apalaches desde Quebec, Canadá, hasta el sur de Georgia y el oeste de Illinois en Estados Unidos. Aunque la especie tiene una amplia distribución, se le encuentra formando pequeños parches dentro de los bosques latifoliados maduros, junto con otros RFNM valiosos.

El ginseng americano produce una raíz no clonal con un solo rizoma. La raíz, que es frecuentemente ramificada, algunas veces puede adquirir la apariencia de figura humana, lo que le confiere un valor excepcional en la medicina tradicional china. Debido a que la raíz no es clonal, cuando una planta se remueve de una población, significa que un individuo completo, en otras palabras un genet, se pierde de la población. Al inicio de cada estación de crecimiento, en abril, un tallo con un verticilo en espiral de una a cuatro (raramente cinco) hojas palmadas emerge desde el rizoma. Al final de la estación de crecimiento, en septiembre, el tallo y las hojas se tornan de color dorado y se desprenden del rizoma, dejando una cicatriz de la cual emergerán nuevas hojas el siguiente año de crecimiento.

Es posible estimar la edad de una planta de ginseng americano contando el número de cicatrices que dejan las hojas en los tallos a lo largo del rizoma. Estudios demográficos para esta especie indican que las poblaciones naturales de ginseng tienen una estructura de tamaños que reflejan claramente las clases de edad de las poblaciones (Anderson et al., 1993). Las plantas más jóvenes, de uno a dos años de edad, producen una sola hoja (también llamada diente). Las plantas que son de tres a seis años de edad producen dos hojas. Las plantas que son de siete a nueve años producen tres hojas, y las plantas de 10 años o más producen cuatro dientes. Usualmente, las plantas deben tener tres o más hojas antes de producir una umbela, una inflorescencia con pequeñas flores blancas que emerge del centro del tallo. En otras palabras, son las plantas más viejas de la población, de siete años o más, con tres o más hojas, las que tienen la mayor contribución para determinar la siguiente generación. Si las flores son polinizadas, usualmente por insectos generalistas, las plantas producirán una o muchas bayas con una a tres semillas por baya. Algunas investigaciones muestran que las semillas que son dispersadas y enterradas a aproximadamente $2.5 \mathrm{~cm}$ de profundidad tienen el más alto porcentaje de emergencia (McGraw et al., 2005).

El género Panax, uno de los géneros de plantas medicinales más importantes en la medicina tradicional china, consta de doce especies. Dos especies se encuentran en el este de Estados Unidos y diez en Asia. Se ha hipotetizado que las dos especies de Estados Unidos, P. quinque folius y P. trifolium, llegaron de Asia a través de dos eventos de dispersión (Wen y Zimmer, 1996). Panax quinqueifolius, el ginseng americano $(2 \mathrm{~N}=48)$, es un tetraploide, mientras que $P$. trifolium, ginseng enano, una diminuta especie efímera, es diploide (2N=24) (Wen y Zimmer, 1996). Panax ginseng, el ginseng oriental ha sido usado como tónico y curativo en Asia por al menos 2000 años. Esta especie ha desaparecido drásticamente de su condición silvestre, pero su distribución original comprendía desde el norte de China hasta Corea, Manchuria, el norte de Japón y Siberia.
A principios del siglo,xvIII, un misionero jesuita que vivía con una tribu iroqués pensó que la vegetación del este de Canadá era suficientemente similar al hábitat del ginseng oriental y que por lo tanto, el ginseng podría encontrarse en Norteamérica (Goldstein, 1975). Poco después $P$. quinquefolius fue descubierto en los bosques deciduos cerca de Montreal y se estableció entonces un negocio de exportación de ginseng a China, sumamente lucrativo, por comerciantes franceses. Hacia 1752, el precio del ginseng se había elevado a tal magnitud que los buscadores o cazadores de ginseng comenzaron a exportar raíces en grandes cantidades sin importar el tamaño de tales raíces (Goldstein, 1975). Hacia finales del siglo xIX, los colectores de ginseng reportaban que la planta escaseaba aceleradamente.

El mercado para el ginseng americano fluctuó durante el siglo xx, incrementando continuamente desde la década de los sesenta. La mayor parte de la exportación era hacia Hong Kong (alrededor del 90\% o más), pero los Estados Unidos solamente exportaban ginseng a Australia, Malasia, Chile y Canadá (Robbins, 1998). El precio de las raíces silvestres cosechadas era significativamente más elevado que el de las raíces cultivadas, variando de $\$ 60$ dólares de Estados Unidos por kg a \$480 dólares por kg o más, y raramente más de $\$ 10$ dólares por raíces cultivadas. En 1977, la organización U.S. Fish and Wildlife Service impulsó el Convenio para el Comercio Internacional de Especies Amenazadas (CITES, por sus siglas en inglés), en el cual particularmente el Apéndice II planteó reglamentos para proteger el ginseng silvestre y permitir que continuara su existencia en su hábitat natural. Las regulaciones del CITES se aplican tanto a raíces silvestres como cultivadas. Hacia principios del siglo xxl, los Estados Unidos abastecían aproximadamente 60 toneladas de raíces silvestres al año, lo que equivalía de 26.4 a 39.6 millones de plantas colectadas anualmente (Robbins, 2000). Estudios morfológicos de especímenes de herbario de ginseng colectados por más de 150 años proporcionaron evidencia de una reducción en el tamaño del ginseng americano para ese período, aparentemente como resultado de la recolección humana de las plantas de mayor tamaño (McGraw, 2001).

Los patrones culturales de uso del ginseng americano siguieron ciertas tendencias entre los estados en donde era cosechado. Era generalmente "cazado" por hombres que eran también cazadores de animales y comerciantes de pieles. Bajo las regulaciones del estado, había una estación para colectar y vender ginseng. La estación, que variaba entre los diferentes estados de agosto a diciembre, tenía el fin de permitir a las plantas producir semillas para la siguiente generación antes de ser removidas de la población. En la práctica, lo que esto significaba era que un colector pudiera cosechar plantas en casi cualquier lugar, pero solamente venderlos durante las estaciones en las que el comercio era legal. Había competencia por las plantas y la localización de un parche de ginseng silvestre se guardaba celosamente como un secreto. Los cazadores de ginseng exhibían sus raíces más preciadas frecuentemente en frascos de licor (Figura 19.1). De manera muy similar a otras formas de caza, se esperaba que los colectores de ginseng obtuvieran su permiso de colecta mediante una cuota de cosecha en áreas públicas. El mercado de raíces de ginseng variaba a lo largo de la estación y el precio dependía de si las raíces estaban frescas o secas. En algún momento de la temporada, el precio de las raíces alcanzaría su pico, pero una vez que los distribuidores de ginseng obtenían una cosecha suficiente para exportar, e precio de las raíces caería. 


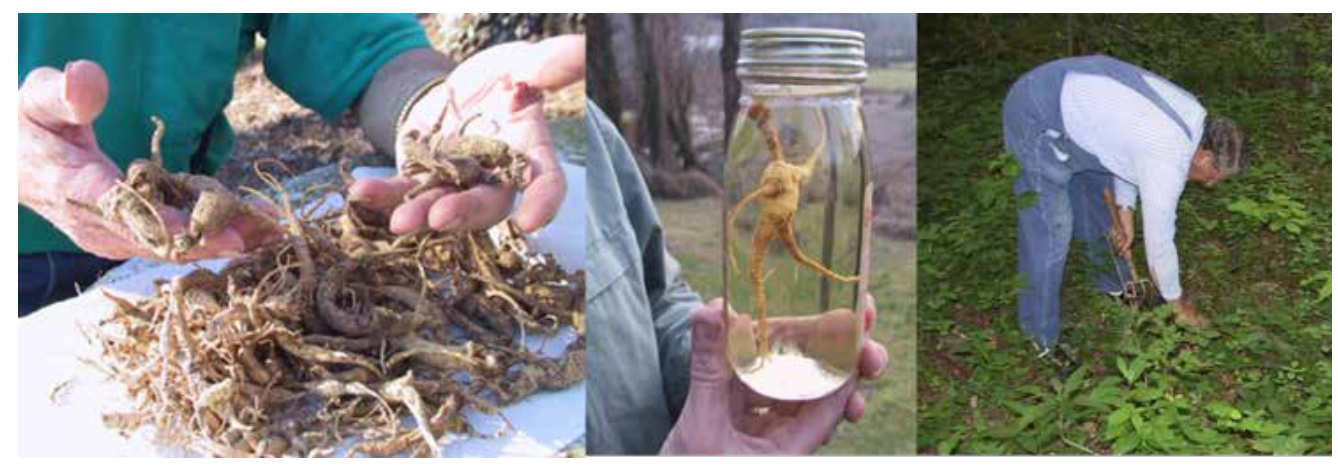

Figura 19.1. De izquierda a derecha: raíces de ginseng americano silvestre, Panax quinquefolius; una colección de raíces que muestra la morfología de las raíces silvestres quefolius; una colección de raíces que muestra la morfología de las raíces silvestres retorcidas y arrugadas que son valoradas en la medicina tradicional china y una raíz de ginseng altamente valorada con la figura de un cuerpo humano, conservado en alcohol. En general, el ginseng es "cazado" por hombres como parte de una economía reservada de pieles y ginseng. Hay una estación para colectar y las raices se exponen. Cuando se colecta, la planta entera se remueve y los guardianes de ginseng plantan las
semillas en la población.

A comienzos del siglo xxl, el USFWS (siglas en inglés de Servicio de los Estados Unidos para la Pesca y la Vida Silvestre) emitió un mandato en el que se especificaba que solamente las plantas más grandes de ginseng, aquellas con tres o más hojas o dientes, podrían ser colectadas en poblaciones silvestres para su comercialización y exportación. La intención era dejar plantas en las poblaciones naturales hasta que tuvieran el tamaño o edad suficiente para producir flores y frutos. La recolección fue también restringida en algunos bosques, incluyendo los parques nacionales y áreas silvestres donde colectar ginseng era ilegal y las leyes estaban dirigidas a proteger las poblaciones silvestres. En algunos casos, como el Parque Nacional de la Gran Montaña (Great Smokey Mountain National Park), las poblaciones se protegieron desde la década de los cuarenta.

Un estudio de genética de poblaciones con base en una muestra de 21 poblaciones de ginseng americano del sur de los montes Apalaches, de Virginia a Georgia, permitió estimar el impacto de más de 250 años de recolección de esta especie sobre la distribución de su diversidad genética (Cruse-Sanders y Hamrick, 2004). Ocho de las poblaciones estudiadas eran protegidas desde la década de los cuarenta, y trece poblaciones eran desprotegidas, es decir, sujetas a recolección legal. El promedio de diversidad genética dentro de las poblaciones fue similar a lo esperado para una especie de planta perenne de ciclo de vida relativamente corto y con un sistema de apareamiento mixto ( $\mathrm{He}=0.072$ ). Sin embargo, la diversidad genética de poblaciones protegidas fue significativamente más alta $(\mathrm{He}=0.076 ; \mathrm{p}<0.005)$ que la de las poblaciones en las cuales la cosecha era permitida $(\mathrm{He}=0.070$; Cruse-Sanders y Hamrick, 2004). En otras palabras, para el ginseng americano, limitar la interacción humana con las poblaciones naturales permitió proteger una cantidad significativa de diversidad genética, mientras que la recolección de ginseng parece reducir la diversidad genética dentro de las poblaciones.
Las comparaciones de diversidad genética entre plantas adultas (aquellas con tres o cuatro hojas) y plantas juveniles (con una o dos hojas) indicó que las plantas de mayor edad mantuvieron significativamente más alta diversidad genética que las plantas más jóvenes. Este resultado sugiere que en la medida en que las plantas de mayor edad se remueven de las poblaciones, hay un acervo genético más pequeño y menos diverso disponible para contribuir a la siguiente generación. Otros estudios detectaron un efecto Allee en poblaciones silvestres de ginseng americano como resultado de una baja adecuación reproductiva en aquellas poblaciones más pequeñas y menos densas (Hackney y McGraw, 2001). Por lo tanto, aun cuando las plantas adultas se mantengan en las poblaciones, conforme el número de individuos disminuye habrá una menor contribución de una generación al acervo genético de las siguientes generaciones.

El resultado más relevante fue cómo la diversidad genética estaba distribuida entre poblaciones como consecuencia de la recolección. Aproximadamente, $50 \%$ del total de la diversidad genética de la especie se debe a diferencias entre poblaciones (Gst=0.479; Cruse-Sanders y Hamrick 2004). Esta estimación es mucho mayor que la registrada para otras especies de plantas con historias de vida similares (Gst=0.15-0.25; Hamrick y Godt, 1996). No obstante, las diferencias entre poblaciones no protegidas representaron una alta estructura genética (Gst=0.491) comparada con la estructura entre poblaciones protegidas (Gst $=0.167$; Cruse-Sanders y Hamrick 2004). Este hecho es consistente con la comparación entre estados en el rango de distribución de la especie. En este caso, se registró $12 \%$ y $8 \%$ del total de la diversidad, respectivamente.

El impacto general de la recolección de ginseng americano silvestre fue una reducción en el potencial evolutivo de la especie a lo largo de su rango de distribución y para las futuras generaciones. Ya que hay muchos tipos diferentes de colectores de ginseng cosechando estas plantas para el mercado medicinal, ¿cómo impactan los diferentes escenarios de recolección el potencial evolutivo de la especie? Por ejemplo, se espera que los recolectores tradicionales de ginseng resguarden mayormente las poblaciones que aprovechan. Su práctica está dirigida a proteger el sitio en el que se encuentran las plantas silvestres, cosechar un porcentaje de las plantas más viejas, y resembrar las semillas en la población para asegurar su disponibilidad en las generaciones futuras. Sin embargo, conforme los precios de ginseng aumentaron, un mayor número de recolectores no tradicionales fueron atraídos a recolectar raíces, priorizando la obtención de ganancias. ¿Puede entonces el tipo de cosecha de ginseng silvestre impactar el potencial evolutivo de la especie?

Con el fin de contestar estas preguntas, se llevó a cabo la simulación de una generación de extracción para así evaluar el impacto de diferentes regímenes de cosecha (Cruse-Sanders et al., 2005). Los escenarios de cosecha que se probaron incluyeron cosecha aleatoria a varios niveles de intensidad, simulando los límites legales al azar y el límite legal cosechando solamente individuos adultos. El límite legal, el porcentaje de plantas a remover para recalcular la diversidad, se determinó como la proporción de plantas adultas en cada población. Se predijo que los colectores "no exigentes", es decir, aquellos que cosecharían aleatoriamente en la población sin importar la edad de la planta, reducirían significativamente la diversidad genética en las poblaciones. La variación entre las estimaciones de la diversidad genética dentro de las poblaciones fue mayor en las poblaciones bajo régimen de cosecha aleatoria, lo que significa que llegaría a ser crecientemente difícil predecir los impactos de la cosecha sobre la diversidad genética. Sin 
embargo, en general, la tendencia fue hacia una reducción en la diversidad genética aun cuando los niveles de cosecha se mantuvieran por debajo del porcentaje de cosecha legal de individuos (Cruse-Sanders et al., 2005).

En el caso del ginseng americano, todos los regímenes de cosecha de plantas fuera de las poblaciones silvestres redujeron significativamente el potencial evolutivo; de acuerdo con las evaluaciones con marcadores genéticos neutrales, se incrementaron las diferencias en diversidad genética entre poblaciones. Lo más probable es que el incremento en las diferencias entre poblaciones donde ocurrió la cosecha resultó de los impactos por deriva génica con diferentes alelos dejados al azar en diferentes poblaciones, ya que tales poblaciones redujeron su tamaño. Si la tendencia en la colecta de ginseng americano conduce cada vez a un menor número de colectores tradicionales y un mayor número de colectores no selectivos o aleatorios, fuera de las tradiciones de largo plazo en la recolección de ginseng, se espera que los impactos evolutivos negativos aumenten

\section{Motivación para el manejo: domesticación de especies de plantas perennes}

En contraste con la extracción de RFNM, el proceso de domesticación de plantas resulta en cambios genéticos en las especies vegetales, conduciendo a plantas cultivadas con características que benefician a los seres humanos (Doebley, 1992). Ejemplos bien conocidos de cultivos anuales que se autopolinizan, tales como el trigo, el maíz y el arroz (los cuales proveen más de la cuarta parte de las calorías que consume la gente en el mundo), muestran una tendencia hacia una reducción de la diversidad genética comparados con sus parientes silvestres, y un cuello de botella genético (Doebley, 1992; Tanksley y McCouch, 1997; Buckler et al., 2001). Sin embargo, modelos emergentes del proceso de domesticación sugieren que, aun en los cultivos más importantes, se ha involucrado un período prolongado de flujo génico y conectividad entre plantas bajo domesticación y sus progenitores silvestres por generaciones (Allaby et al., 2008; Fuller et al., 2009; Tanno y Willcox, 2006). Para especies de plantas perennes los modelos son diferentes (Casas et al., 1997, 1999a).

Mesoamérica y Sudamérica son importantes centros de domesticación de cultivos tradicionales y no tradicionales usados alrededor del mundo. Estos cultivos incluyen plantas cuya domesticación se explica satisfactoriamente con los modelos bien entendidos y aceptados de domesticación: el maíz, la calabaza, el frijol y el chile o ají (Pickersgill y Heiser, 1976; Escalente et al., 1994; Harris, 1967; MacNeish, 1967; Harlan, 1975; Whitmore y Turner, 1992), así como otros cultivos que no lo son, como el frijol (Phaseolus), la oca (Oxalis tuberosa), la papa (Solanum spp.), el amaranto (Amaranthus spp.) y diversas especies de cactos y agaves. Algunas especies, incluyendo plantas semidomesticadas, requieren nuevos modelos para analizar el proceso de su domesticación (Casas et al., 1997, 1999a, 2007; Blancas et al., 2010; Parra et al., 2015). Muchas de estas especies son perennes y frecuentemente con sistema de cruzamiento exogámico obligado, plantas que requieren selección sobre rasgos existentes aunque en el proceso pueden surgir rasgos nuevos asociados a la domesticación y al manejo de la reproducción. El manejo in situ y la propagación vegetativa se han documentado como importantes para las historias de manejo de estas plantas (Casas et al., 1997, 1999b). En particular, estudiamos este proceso más cercanamente con diversas especies de cactos columnares y agaves, y en este capítulo abordaremos el caso del cactus columnar Stenocereus stellatus para ilustrar todo este amplio espectro de especies culturalmente muy importantes $y$, sin embargo, relativamente poco estudiadas.

\section{El xoconochtli, Stenocereus stellatus}

Stenocereus stellatus Riccob. (Cactaceae), el xoconochtli es un cactus columnar relativamente pequeño (hasta $6 \mathrm{~m}$ de alto), endémico del centro de México en parte de la cuenca del río Balsas, en los estados de Morelos y Guerrero, y en la cuenca del río Papaloapan, en los estados de Puebla y Oaxaca. La evidencia arqueológica del valle de Tehuacán indica que diferentes especies de cactus, incluyendo Stenocereus stellatus, han sido usados por los seres humanos por más de 5,500 años en esta importante área de domesticación temprana de plantas (MacNeish, 1967) Debido a que las plantas de ciclo de vida largo alcanzan lentamente la madurez reproductiva, la historia del uso de especies de cactus y otras plantas arbóreas representan un diferente tipo de proceso de domesticación, el cual ocurre a través de manejo in situ. La gente de la región extrae los frutos de poblaciones silvestres de cactus que se encuentran naturalmente formando parte de matorrales xerófitos y bosques tropicales secos. Cuando los bosques naturales se desmontan para establecer áreas de cultivo o pastizales para forrajeo del ganado, algunos individuos de cactus se dejan en pie (manejo in situ) y sus densidades frecuentemente se aumentan artificialmente a través de la propagación vegetativa de ramas de plantas, las cuales se seleccionan de plantas madre, debido a que presentan características deseables tales como sabor dulce, mayo tamaño, color de la pulpa, cantidad de espinas, entre otras. Este modelo de domesticación también sugiere que las ramas de las poblaciones cultivadas que se encuentran en los huertos en los poblados se derivan de semillas propagadas intencional o inintencionalmente, así como de ramas de individuos, generalmente de aquellos que han pasado por un proceso selectivo en las poblaciones manejadas in situ o a través del intercambio de materiales vegetativos entre la gente que los cultiva en sus huertos de un poblado, o aun entre poblados distantes entre sí. Al ser una especie polinizada por murciélagos y exogámica obligada (que requiere cruzarse forzosamente con un individuo genéticamente distinto), las poblaciones de S. stellatus silvestres manejadas in situ y cultivadas en huertas se encuentran potencialmente conectadas a través del movimiento de polen y semillas, así como de propágulos vegetativos, esto último determinado principalmente por actividades humanas (Casas et al., 1999b; Horner et al., 1998; Arias-Coyotl et al., 2006).

Estudios ecológicos de la dos regiones en las cuales se distribuye $S$. stellatus en el centro de México indican que hay diferencias en suelos, altitudes y precipitación pluvial que influencia el crecimiento, la sobrevivencia y la distribución de la diversidad genética de esta especie (Casas et al., 2007; Cruse-Sanders et al., 2015). El valle de Tehuacan y la Mixteca Baja, donde se distribuye S. stellatus, son parte de las cuencas de los ríos Papaloapan y Balsas, respectivamente en el sur y centro de México. El valle de Tehuacán, que tiene menor altitud, promedios de precipitación entre sitios de 300-500 mm por año y suelos predominantemente calizos con parches derivados 
de rocas volcánicas y aluviales derivados de areniscas y lutitas, presenta matorrales xerófitos y bosque tropical seco. La Mixteca Baja presenta un complejo de áreas montañosas con matorrales xerófitos en las partes bajas y más secas, hasta bosques de pino en las partes altas; en esta región la precipitación va de los 600-800 mm anuales. Las diferencias físicas entre las regiones determinan diferencias en reclutamiento de plántulas de cactus, con más altas tasas de reclutamiento en la Mixteca Baja (Casas et al., 1999b). La germinación de semillas y el éxito de las plántulas en el establecimiento dependen, significativamente, de la humedad (Rojas-Aréchiga et al., 2001; Guillén et al., 2015; Rodríguez et al., 2015). Hay, además, importantes diferencias culturales y etnolingüísticas que influyen la clasificación de las prácticas de manejo y los rasgos de los frutos de S. stellatus entre las dos regiones (Casas et al., 1997).

Existe evidencia que sostiene la ocurrencia de fuertes presiones selectivas sobre $S$. stellatus que han conducido a cambios significativos en rasgos morfológicos. Los frutos de las plantas cultivadas son más grandes, con menor densidad de espinas y más pulpa y con más amplia variedad de colores; los frutos de las poblaciones manejadas in situ tuvieron rasgos intermedios (Casas et al., 1999a). Casas et al., (2006) analizaron 23 caracteres vegetativos y reproductivos, incluyendo la forma del fruto, el color de la pulpa, el número de espinas, el número y tamaño de semillas, de ovarios y de óvulos, entre otros, de 20 a 50 individuos de 19 poblaciones y encontraron evidencia de que el manejo humano ha favorecido la diversidad fenotípica. Los índices de diversidad morfológica por población se basaron en promedios de valores de diversidad de Simpson (D) para rasgos cuantitativos y cualitativos. Estas medidas fueron significativamente más altas en poblaciones manejadas y cultivadas comparadas con poblaciones silvestres en ambas regiones (Casas et al., 2006). El promedio de la diversidad morfológica fue mayor en las poblaciones silvestres de la Mixteca Baja comparado con el del valle de Tehuacán; sin embargo, no se identificaron diferencias significativas en los promedios de los índices de diversidad morfológica entre regiones. Siendo una especie considerada como en proceso de domesticación incipiente en Mesoamérica, S. stellatus presentó rasgos de domesticación más marcados dentro de un contínuum de intensidad de manejo humano.

Estudios de genética de poblaciones con base en marcadores neutrales en S. stellatus indican que el manejo humano ha promovido también la diversidad genética en poblaciones manejadas y cultivadas (Casas et al., 2006, Cruse-Sanders et al., 2015). Cruse-Sanders et al. (2015) encontraron mayor diversidad en las poblaciones manejadas, intermedia en las poblaciones cultivadas y la menor diversidad en las poblaciones silvestres, con diferencias significativas en el número de alelos observados y estimaciones de heterocigosidad dentro de poblaciones. Las poblaciones manejadas en la Mixteca Baja tuvieron significativamente mayor diversidad genética que las poblaciones manejadas del valle de Tehuacán, reflejando un manejo más activo a la par de mayor actividad de intercambio y comercio de S. stellatus en la Mixteca. Las poblaciones no mostraron evidencia de cuellos de botella, lo que es contrario a la expectativa basada en los modelos clásicos de domesticación para la mayor parte de los cultivos, pero este patrón es consistente con los modelos para plantas de ciclo de vida largo en sistemas agrícolas tradicionales.

A escala regional no se encontraron diferencias significativas en el promedio de diversidad genética por población, pero sí diferencias significativas en cómo la diversidad genética está estructurada (Cruse-Sanders et al., 2015). La diversidad genética entre poblaciones en el valle de Tehuacán fue dos veces más alta que la encontrada entre poblaciones en la Mixteca Baja (Cruse-Sanders et al., 2015). Existe evidencia de plantas propagadas clonalmente en dos de tres poblaciones cultivadas en la Mixteca Baja. En el valle de Tehuacán se encontró evidencia de plantas propagadas clonalmente en dos poblaciones manejadas in situ y en dos de tres poblaciones silvestres que fueron estudiadas, pero no en las poblaciones cultivadas. Dos poblaciones manejadas in situ cercanas a los poblados se identificaron como las principales fuentes de movimiento de genes en cada región, y una población manejada in situ en la Mixteca Baja fue la única fuente de movimiento de genes entre regiones. A través de entrevistas etnobotánicas, se documentó que los campesinos de la Mixteca Baja plantan tanto tallos como semillas de frutos que se obtienen en los mercados regionales. Algunos campesinos reportaron viajar largas distancias para obtener material para sus huertas (Cruse-Sanders et al., 2015). Este patrón de manejo es, posiblemente, la razón por la cual se identificó menor estructura genética en esta última región y mayores índices de conectividad genética para algunas poblaciones manejadas de la Mixteca Baja. La otra posible causa es que en la Mixteca Baja el reclutamiento de plántulas derivadas de semillas es más dinámico que en Tehuacán, donde este proceso es episódico. Por lo tanto, el flujo génico entre las poblaciones de la Mixteca Baja es más alto que en el valle de Tehuacán

Estudios de diversidad genética en otras especies de cactus manejados in situ en Mesoamérica, tales como Polaskia chichipe, P. chende y Escontria chiotilla, encontraron una ligera reducción en la variación genética entre la poblaciones manejadas y cultivadas comparadas con las poblaciones silvestres (Otero-Arnaiz et al., 2005; Tinoco et al., 2005; Contreras-Negrete et al., 2015). Estudios de genética de poblaciones en otra planta perenne, Agave parryi, usada en la prehistoria por la gente, indicaron que las poblaciones silvestres tenían significativamente más alta diversidad genética, y los patrones de diversidad condujeron a los autores a inferir flujo génico a largas distancias, potencialmente asociado a redes de comercio durante el tiempo de su cultivo (Parker et al., 2010). Adicionalmente, las poblaciones cultivadas de $A$. parryi tuvieron mayor variación entre poblaciones así como patrones de heterocigosidad fijada, características ausentes en las poblaciones silvestres presumiblemente debido a la propagación vegetativa de esta especie (Parker et al., 2010). Colectivamente, este conjunto de investigaciones, así como las que se muestran en los capítulos 3 y 11 de este volumen (Casas et al., 2017; Colunga-GarcíaMarín et al., 2017), documenta la gradación del impacto evolutivo que el manejo humano ha tenido sobre las especies de plantas. Como grupo, las especies de plantas perennes manejadas o promovidas por la gente como parte del proceso de domesticación en Mesoamérica muestra un contínuum de diversidad morfológica y genética paralelo al gradiente de intensidad de manejo.

\section{Motivaciones para el manejo: \\ los impactos evolutivos de restaurar plantas en sus hábitats naturales}

Al considerar los impactos humanos sobre el potencial evolutivo de las especies de plantas surgen algunas preguntas en relación con los impactos que resultan de restaurar poblaciones de plantas más que de extraerlas. Si la extracción de plantas de la naturaleza determina una reducción en el tamaño de la población y un aumento en el riesgo de su extinción, como en el 
caso del ginseng Panax quinquifolius, analizado anteriormente, o resulta en cambios demográficos y en la distribución de la diversidad genética, como en el caso de Stenocereus stellatus, las acciones de conservación necesariamente deben incluir el mantenimiento de colecciones ex situ diversas para poder restaurar poblaciones variadas en los ambientes naturales apropiados.

La Estrategia Global para la Conservación de Plantas (Global Strategy for Plant Conservation, surgida de la Convención de la Diversidad Biológica, 2012) delinea algunos enfoques recomendados para la conservación in situ y ex situ, los cuales incluyen tres metas clave:

- Al menos $75 \%$ de las especies de plantas amenazadas conocidas deben ser conservadas in situ (Meta 7)

- Al menos $75 \%$ de las especies de plantas amenazadas en colecciones ex situ, preferentemente en el país de origen, y al menos $20 \%$ deben estar disponibles para programas de recuperación y restauración (Meta 8 )

- $70 \%$ de la diversidad genética de cultivos, incluyendo sus parientes silvestres y otras especies de plantas económicamente valiosas, deben ser conservadas al mismo tiempo que se respetan, preservan y mantienen asociadas al conocimiento indígena local (Meta 9).

En tanto que líderes de programas de conservación trabajaron conjuntamente para evaluar avances hacia la Estrategia Global para la Conservación de Plantas, se desarrolló una importante herramienta metodológica: la Estrategia Norteamericana de Jardines Botánicos para la Estrategia de Conservación de Plantas, 2016-2020 (BGCl, 2016). Esta estrategia estableció actividades específicas que los jardines botánicos pueden llevar a cabo para apoyar las metas globales de conservación de plantas, incluyendo: la documentación de floras, la evaluación de amenazas, el manejo apropiado de la tierra, el mantenimiento de colecciones ex situ, así como la conservación de diversidad de cultivos y prácticas culturales.

No obstante, el logro de estas acciones recomendadas puede tener impactos evolutivos no intencionales sobre la especie a conservar a través de procesos de selección artificial y natural así como a través de procesos de deriva génica y efecto fundador. Es, por lo tanto, necesario considerar las fuerzas microevolutivas en el trabajo para conservar especies de plantas. Contando con jardines botánicos en todo el mundo, es posible coordinar esfuerzos para trabajar en la conservación de especies de plantas nativas (Lughadha et al., 2004; BGCl, 2016); hay ejemplos de esfuerzos de restauración que proveen ideas sobre tales impactos. Las consideraciones genéticas por conservar y restaurar plantas son bien entendidas (Brown y Briggs, 1991; Hufford y Mazer, 2003; Falk et al., 2006; Neale, 2012). Sin embargo, pocos estudios han evaluado la diversidad genética de especies reintroducidas (Neale, 2012).

Las estrategias de conservación cuidadosamente planeadas deben tomar en cuenta la diversidad genética existente en las poblaciones con el fin de analizar qué tan buenas son las fuentes de material para la restauración. Cuando el objetivo es restaurar especies de plantas en niveles existentes de diversidad genética, el monitoreo genético de poblaciones naturales y restauradas es necesario (Ramp, 2006). Las estrategias de conservación que seleccionan artificialmente o mezclan genotipos pueden, potencialmente, ser los mejores para el éxito general de las especies restauradas, pero impactan la trayectoria evolutiva de la población (Smulders et al., 2000). Por ejemplo, la endogamia es valorada como un importante factor a considerar que influye sobre el potencial de las poblaciones a corto plazo, mientras que e éxito a largo plazo es impactado más por la deriva génica (Booy et al., 2000). En múltiples poblaciones, la deriva génica y la selección pueden conducir a una pérdida de diversidad y contribuir a un incremento de la diferenciación genética a escala de paisajes en la medida en que diferentes alelos pueden llegar a fijarse en diferentes poblaciones (Ellstrand y Elam, 1993; Cruse-Sanders y Hamrick, 2004). Todas las fuerzas microevolutivas mencionadas arriba pueden impactar la adaptabilidad de las poblaciones (Shaffer, 1981; Vander Mijnsbrugge et al., 2010) y, eventualmente, los grandes patrones de diversidad para una especie a escala de paisaje. Consideramos, a continuación, el caso de un arbusto amenazado en Norteamérica, Rhus michauxii, como un ejemplo de las oportunidades que existen para conservar una especie in situ.

\section{El zumaque enano, Rhus michauxii}

Rhus michauxii Sarg (Anacardiaceae), el zumaque enano o zumaque de michaux es un arbusto pequeño que se encuentra en sustratos secos, arenosos a rocoso y submáficos en la región de Piedemonte del sureste de Estados Unidos. Esta especie es una de las plantas más amenazadas en la región y es protegida bajo el Acta de Especies Amenazadas de los Estados Unidos (U.S. Endangered Species Act). Las hojas de esta especie son estacionalmente deciduas y crecen sobre tallos cortos y peludos que forman colonias en hábitats abiertos, ruderales, que son frecuentemente mantenidos con fuego o perturbados por otros medios. $R$. michauxii es una especie dioica y las plantas macho y hembra responden de manera diferencial a la competencia por crecimiento vegetativo en su comunidad (Emrick y Jones, 2008). Es una especie polinizada por abejas generalistas, pero hay evidencia que sugiere que la receptividad de polen por las flores femeninas no siempre corresponde al momento en el que el polen está disponible. Las semillas colectadas en poblaciones naturales o producidas ex situ mediante polinización manual usualmente presentan bajas tasas de germinación.

El rango de distribución natural de $R$. michauxii incluye la planicie costera interior y el Piedemonte de Georgia, Carolina del Norte, Virginia, y Carolina del Sur, donde se cree que se encuentra extinta (USFWS, 1993). Rhus michauxii es rara a lo largo de su rango de distribución y ha sobrevivido significativamente la pérdida de hábitat, en parte, debido a la supresión por fuego y conversión de hábitats. La mayor parte de las poblaciones remanentes de esta especie son de solamente un sexo y a considerable distancia de otras poblaciones y, por lo tanto, son capaces de reproducirse únicamente de forma clonal. Como muchas otras especies dioicas, ha sido significativamente impactada por la fragmentación de hábitat (USFWS, 1993).

A nivel local, se registró históricamente en cinco condados de Georgia. Hacia 2007, R. michauxii se encuentra solamente en dos poblaciones, cada una compuesta por plantas de un solo sexo (una de machos y otra de hembras) separadas por más de 160 km (Chafin, 2007). La población de machos se encontraba en la zona del Broad River Wildlife Management Area (BRWMA) en el condado de Elbert, al este de Georgia, y representaba la única población real- 
mente silvestre que permanecía en el extremo sureño de su distribución. La población de hembras se encontraba en la base de una torre de agua en el condado de Newton, Georgia. La población de hembras se extinguió en algún momento y se recuperó con material cultivado derivado de la población hembra original.

Un estudio en el jardín botánico de Atlanta logró desarrollar métodos para propagar y restaurar plantas en hábitats naturales (Cruse-Sanders et al., en preparación). En colaboración con el Departamento de Recursos Naturales de Georgia (GADNR, por sus siglas en inglés), se impulsaron esfuerzos para restaurar el BRWMA a través de una quema ecológica prescrita en 2009, la cual resultó en una respuesta significativamente positiva en la población de machos de R. michauxii (Figura 19.2). La población respondió rápidamente, incrementando de 2 a 40 tallos en seis meses y cuatro años después, para el 2012, incrementó a más de 150 tallos (un incremento de 75 veces). Concurrentemente al período de la investigación, la población de solamente hembras en Georgia también contenía aproximadamente 150 tallos en un área de $100 \mathrm{~m} \times 50 \mathrm{~m}$. En febrero de 2010, los rizomas de 22 plantas hembras se removieron y trasplantaron a la población de machos y 19 plantas, inicialmente, sobrevivieron.

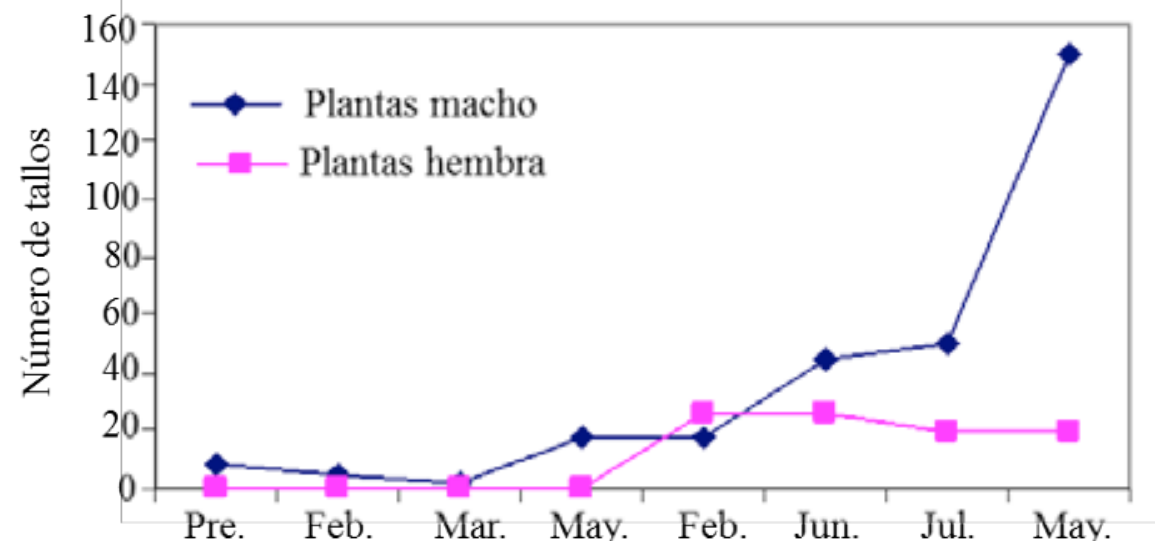

Figura 19.2. Número de tallos de zumaques enanos, Rhus michauxii, en una población natural en Georgia, Estados Unidos, después de acciones de restauración.

Una pregunta natural que siguió fue si al incremento en tallos de $R$. michauxii dentro de la población macho después del fuego representaba la propagación clonal de los dos individuos remanentes (con un máximo de dos genotipos multilocus), o el reclutamiento de plantas que persistieron en la población bajo la tierra hasta que se presentaron las condiciones ecológicas adecuadas (representando más de dos genotipos multilocus). Un estudio genético se llevó a cabo para determinar los impactos evolutivos de las acciones de conservación para esta especie.

Con el fin de establecer la relación entre poblaciones de machos y de hembras y determinar cómo la población de machos se había recuperado del cuello de botella poblacional, comparamos genotipos multilocus de las plantas con base en el análisis de aloenzimas de muestras colectadas de la población de machos en BRWMA en el condado de Elbert ( $\mathrm{N}=51$ plantas), la plantas hembras del condado de Newton ( $\mathrm{N}=52$ plantas), y las hembras de $R$. michauxii que se plantaron en BRWMA ( $\mathrm{N}=19$ plantas sobrevivientes; Cruse-Sanders et al., en preparación). El análisis de aloenzimas se llevó a cabo siguiendo los métodos de Sherman-Broyles et al. (1992). De los 24 loci resueltos, cinco fueron polimorficos; sin embargo, dos de estos se omitieron en el análisis debido a que no resolvieron de forma confiable en todas las muestras. Tres loci se usaron para efectuar comparaciones de genotipos multilocus. En general, las plantas macho muestreadas en BRWMA tuvieron 10 genotipos multilocus (Figura 19.3; Cruse-Sanders et al., en preparación). Las plantas hembra trasplantadas a BRWMA tuvieron la mitad del número de genotipos multilocus encontrados en la población de machos. Los mismos genotipos multilocus que se encontraron más comúnmente en la población de machos fueron también los más comunes en las muestras de plantas hembras de las dos localidades. Los resultados de diagnóstico genético indican que la población de 150 plantas macho de $R$. michauxii que rebrotaron después de que el hábitat se manejó con fuego prescrito tuvieron que rebrotar de un mínimo de 8 diferentes plantas que se encontraban en estado de dormancia bajo tierra.

El número de genotipos multilocus en la población de machos fue mayor que en cualquiera de las nueve poblaciones de $R$. michauxii muestreadas en Carolina del Norte en un estudio previo (el rango fue de 1 a 7 con una media de = 4.1; Sherman-Broyles et al., 1992). Sin embargo

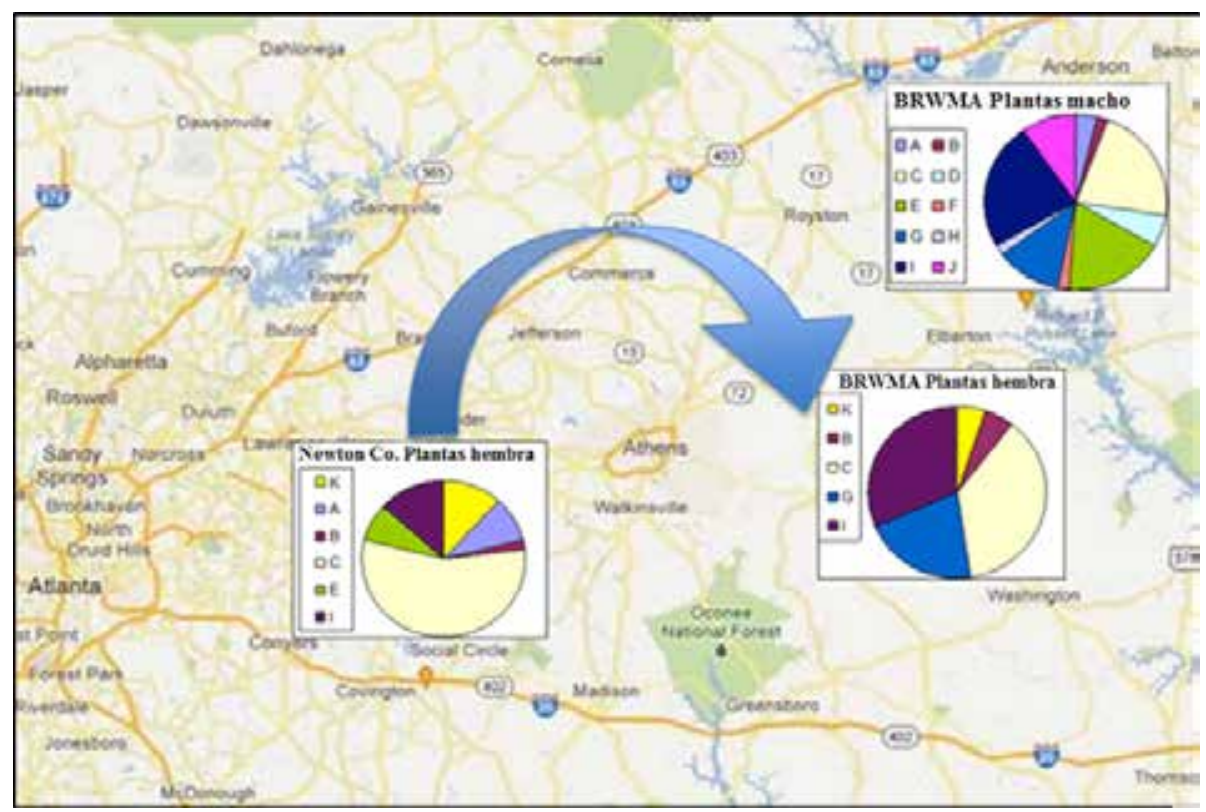

Figura 19.3. Diversidad genética en poblaciones restauradas de zumaque enano, Rhus michauxii, en Georgia Estados Unidos. Diferentes colores representan genotipos multilocus únicos presentes en cada población: hembras del condado de Newton (seis genotipos) de la población de hembras original. Plantas macho de BRWMA (diez genotipos) era la población de machos original, y en BRWMA las hembras (cinco genotipos) fueron las 22 hembras trasplantadas de Newton a BRWMA. 
la diversidad genética a nivel de especie evaluada con base en el porcentaje de loci polimórficos detectado para las poblaciones en Georgia es menor que la mitad del nivel detectado en otras partes del rango de distribución de $R$. michauxii (porcentaje de loci polimorficos $=0.21 \mathrm{y}$ 0.47 , respectivamente; Sherman-Broyles et al., 1992). La diferencia en estas dos medidas se basa, probablemente, en las frecuencias alélicas más estables que se presentan en la población BRWMA antes de que esta se colapsara.

Con base en las similitudes en diversidad genética neutral entre las poblaciones de machos y hembras, hubo buenas razones para mezclar las plantas de las dos localidades. Evidencia genética de este estudio apoya también los métodos usados para el trasplante de material de una población a otra. La submuestra de plantas hembra que se movió de Newton a BRWMA mantuvo la mayor proporción de diversidad genética que existía en la población de hembras. Este estudio provee apoyo para introducir diversidad genética adicional a las poblaciones de Georgia para incrementar el potencial tanto evolutivo como reproductivo de esta especie en el extremo sureño del rango de distribución. Estudios con otras especies de plantas raras en experimentos de restauración de praderas con Cirsium dissectum y Succisa pratensis indicaron que la combinación de plantas de más de una población fuente introdujo significativamente más polimorfismos genéticos, y tuvo ventaja en la diversidad que existe entre poblaciones que constituyen fuentes de propágulos que se encuentran en poblaciones naturales (Smulders et al., 2000).

\section{Intensidad de manejo: conectando esfuerzos in situ y ex situ}

En el reconocimiento que el manejo humano de especies vegetales, incluyendo la domesticación, ocurre a lo largo de un contínuum, se ha notado que las interacciones entre gente y plantas comienza en los ambientes silvestres (Lins Neto et al., 2014). En un extremo del contínuum, las actividades de recolección de plantas silvestres o sus productos también ocurre a lo largo de un gradiente, el cual frecuentemente involucra acuerdos sociales, herramientas y estrategias de recolección (Lins-Neto et al., 2014). Más allá, a lo largo del contínuum referido, el manejo más intenso involucra la promoción o fomento de poblaciones dirigida a aumentar la densidad de los organismos aprovechables. Esta actividad puede involucrar selección artificial, promoviendo la abundancia diferencial de fenotipos de acuerdo con sus atributos. Estas actividades pueden determinar poblaciones semidomesticadas o con domesticación incipiente en áreas donde se encuentran poblaciones silvestres o domesticadas. La mayor intensidad de manejo resulta en niveles crecientes de selección artificial y domesticación, frecuentemente en zonas fuera del área natural de distribución de una especie (Figura 19.4; Blancas et al., 2010; Lins Neto et al., 2014). Por ejemplo, a lo largo del contínuum entre recolección de recursos forestales no maderables y la domesticación y cultivo intensivo, el manejo incipiente puede ser selectivo o no selectivo, con un gradiente de intensidad de selección artificial como indicador de la intensidad de manejo de plantas (González-Insuasti y Caballero, 2007).

De forma creciente, la conectividad entre material genético de plantas mantenido ex situ y el manejo in situ emerge como una estrategia de conservación y de preocupación. Si e

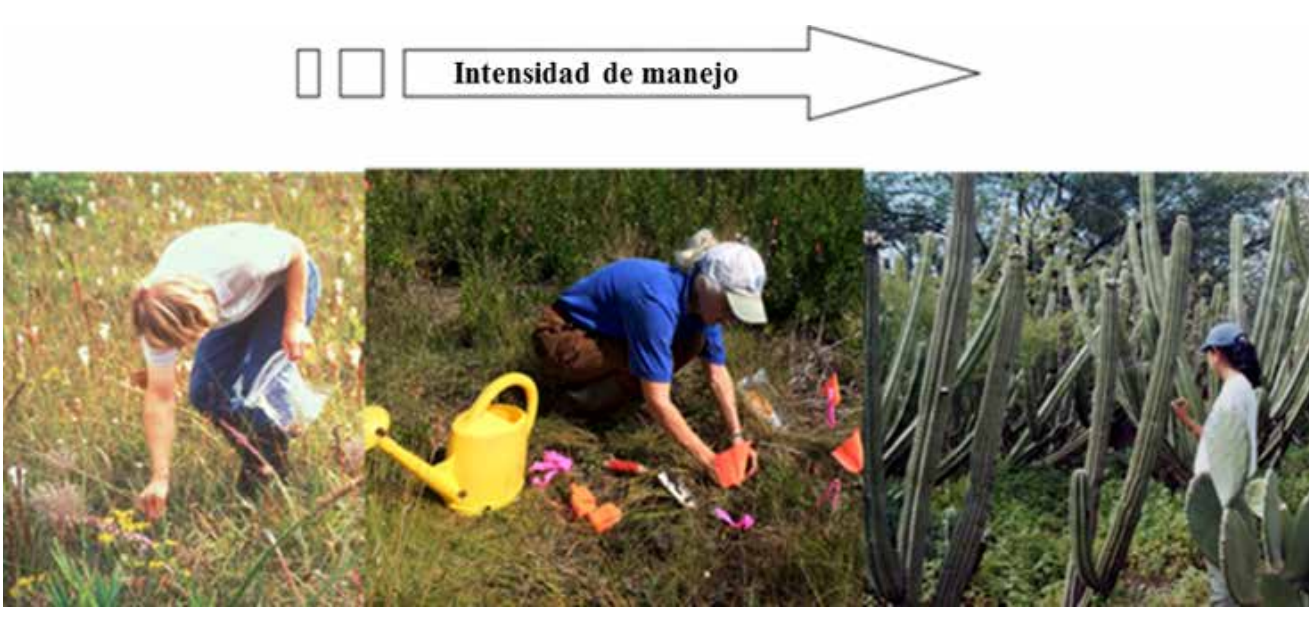

Figura 19.4. Gradiente de intensidad de manejo resultante de un gradiente de manipulación de especies de plantas desde la recolección simple de productos vegetales a la domesticación incipiente, $\mathrm{y}$ a la manipulación selectiva y domesticación ex situ de plantas cultivadas, $\mathbf{y}$ hacia plantas permanentemente cultivadas (con base en Blancas et al., 2010). Las diferentes intensidades de manejo impactan patrones micro-evolutivos dentro de poblaciones, incluyendo selección, fragmentación que favorece la endogamia y la deriva génica, así como el flujo génico que puede ser intencionalmente interrumpido o promovido. Fotos de recolección de productos de plantas silvestres, aumentando plantas propagadas en hábitats restaurados y huertas en donde se cultiva Stenocereus stellatus.

manejo se encuentra directamente conectado con las colecciones ex situ, como en el caso de las plantas que son cultivadas y aquellas que se salvaguardan a través de programas de conservación; o indirectamente, como es el caso de especies medicinales que dependerán de manera creciente del enriquecimiento complementario del material silvestre o de esfuerzos simulando lo silvestre, nuestro entendimiento de cómo el manejo humano impacta los patrones evolutivos en plantas es esencial. Históricamente, algunos esfuerzos han considerado e impacto del cultivo sobre la diversidad genética de las especies (Vander Mijnsbrugge et al., 2010; Dolan et al., 2008; Menges et al., 2004; McKay et al.., 2005; Primack, 1993). Por ejemplo, los esfuerzos de restauración de la especie Ammophila breviligulata en Norteamérica resultaron en reintroducciones que no simularon poblaciones naturales. Material vegetal derivado de viveros carecían de la misma cantidad de diversidad que había en las poblaciones naturales y, presumiblemente, carecían de habilidad para adaptarse a futuros cambios climáticos (Neale, 2012). La fuente de semillas impactó la cantidad de diversidad disponible para la restauración en un stock cultivado de Ariaucaria nemorosa (Kettle et al., 2008). Había evidencia de un cuello de botella genético en plantas crecidas a partir de semillas colectadas de árboles. Plantas cultivadas a partir de semillas colectadas fuera del piso del bosque tenia mayores niveles de diversidad genética, pero eran endogámicas comparadas con las de las poblaciones fuente (Kettle et al., 2008). Sin embargo, la investigación está demandando nuevas líneas capaces de atender no solamente las consideraciones genéticas para la restauración, sino también la planeación para los cambios climáticos futuros (Havens et al., 2015). 
La prospección de fuentes de semillas para la restauración anticipándose al cambio climático significaría que las colectas maximicen las muestras de las condiciones extremas, además de colectar diversidad genética en general (Havens et al., 2015). Una predicción de cambio climático estima que el perfil del clima para las especies de plantas se puede mover $500 \mathrm{~km}$ hacia los polos o $500 \mathrm{~m}$ en elevación durante el próximo siglo (Thuiller, 2007). El almacenamiento de semillas es una de las estrategias delineadas en el GSPC (CBD, 2012). Los bancos de semillas proveen una importante fuente de material para la restauración ecológica y complementa la conservación in situ de plantas silvestres (León-Lobos et al., 2012; PCA, 2015). Sin embargo, de acuerdo con el segundo reporte sobre el Estado de los Recursos Genéticos del Mundo (State of the World's Plant Genetic Resources), la vulnerabilidad genética de las especies cultivadas era una preocupación para 60 países aun cuando el número de colecciones ex situ creció cerca del 20\% entre 1996 y 2008 (FAO, 2010; León-Lobos et al., 2012). Aunque Brown y Briggs (1991) recomendaron colectar semillas de al menos 50 individuos a través de una población con el fin de resguardar un estimado del $95 \%$ de diversidad genética neutral en especies raras, se requiere urgentemente más investigación sobre la variación en especies para delinear zonas de semillas y guías de transferencia de semillas para los bancos de semillas y para los planes de restauración (PCA, 2015).

Conforme se acumula evidencia sobre los cambios en la diversidad genética, la cual resulta del manejo a intensidades variables, podemos buscar hacia delante y hacia atrás. Los planes futuros de conservación pueden desarrollarse incorporando los cambios climáticos futuros y os procesos microevolutivos apropiados para cultivos, plantas raras y especies usadas en a restauración. Las inferencias históricas pueden ser también refinadas en relación con los patrones de uso e impacto del proceso de domesticación. Se necesita más investigación para mapear los cambios genéticos que se pueden predecir que ocurrirán a lo largo de un contínuum de intensidad de manejo.

\section{Bibliografía}

Allaby, R. G., D. Q. Fuller y T. A. Brown, 2008. The genetic Chafin, L. G., 2007. Field guide to the rare plants of Georgia. expectations of a protracted model for the origins

of domesticated crops. Proceedings of the Nationa
Academy of Sciences USA, 105 (37): 13982-13986.

Anderson, R.C., J. S. Fralish, J. E. Armstrong y P. K. Benjamin, 1993. The ecology and biology of Panax quinquefolium 129 (2) $357-372$.

Arias-Coyotl, E., K. E. Stoner y A. Casas, 2008. Effectiveness of bats as pollinators of Stenocereus stellatus (Cactaceae) La Mixteca Baja, central Mexico. American Journal of Botany, 93: 1675-1683. Bailey, B., 1999. Social and economic impacts of wild
harvested products. Tesis de doctorado. West Virginia University, Morgantown.

BGCI, 2016. North American Botanic Garden Strategy for Plant Conservation, 2016-2020. Bo
Conservation International, llinois, USA.

Blancas, J., A. Casas, S. Rangel-Landa, I. Torres, E. PerezNegron, L. Solis, A. I Moreno, A. Delgado, F. Parra, Y. Arellanes, J. Caballero, L. Cortés, R. Liray P. Dávila, 2010. Plant management in the
Botany, 64 (4): 287-302.

Booy, G., R. J. J. Hendricks, M. J. M. Smulders, J. M. Va Groenendael y B. Voseman, 2000. Plant Biology, 2(4)

Briggs, D. y S. M. Walters, 1997. Plant Variation and Evolution $3^{a}$ edición, Cambridge University Press, New York. Brown, A. H. D. y J. D. Briggs, 1991. Sampling strategies for
genetic variation in ex situ collections of endangered plant species. En: D. A, Falk y K. E. Holsinger (eds.). Genetics and conservation of rare $p$ lan

Buckler, E.S., J. M. Thornsberry y S. Kresovich, 2001. Molecular diversity, structure and diversity of Casas, A., B. Pickersgill, J. Caballero y A. ValienteBanuet, 1997. Ethnobotany and domestication in xoconochth,
Stenocereus stellatus (Cactaceae), in the Tehuacan Valley and La Mixteca Baja, Mexico. Economic Botany 51: 279-292.

Casas, A, J. Caballero, A. Valiente-Banuet, J. A. Soriano y P. Davila. 1999a. Morphological variation and the process of domestication of Stenocereus stellatus (Cactaceae) in central Mexico. American Journal of Botany, 86: 522-533.

Casas, A., A. Valiente-Banuet, A. Rojas-Martinez y P. Davila, 1999b. Reproductive Biology and the process of domestication of the columnar cactus Stenocereus
stellatus in central Mexico. American Jounal of Botany stellatus in centrit $534-542$.

Casas, A., A. Otero-Arnaiz, E. Perez-Negron y A. Valiente-
State Botanical Garden of Georgia, Athens, USA.

Contreras-Negrete, G., E. M. Ruiz-Duran, D. Cabrera-Toledo, A. Casas, O. Vargas y F. Parra, 2015. Genetic diversity Polaskia chende (Cactaceae) in the Tehuacan-Cuicatlan merkers. Genetic Resources and Crop Evolution, 62, (1): 85-101.

onvention on Biological Diversity (CBD), 2012. Global Strategy for Plant Conservation: 2011-2020. Botani

Crook C. y R. S. Clapp, 2002. The paradox of market-oriented conservation: Lessons from the Tropical Forests. En: Jones, E. T., R. J. MClain y J. Weigand (Eds.). Nontimber
Firest Products in the United States. University Press o Kansas, K. S. Lawrence, pp. 163-179.

Cruse-Sanders, J. M. y J. L. Hamrick, 2004. Genetic diversity in harvested and protected populations of wild American ginseng, Panax quinquefolius L. (Araliaceae). American Journal of Botany, 91, (4): 540-548.

Cruse-Sanders, J. M. y J. L. Hamric, 2004. Spatial and genetic structure within populations of wild American ginsen (Panax quinquefolius

Cruse-Sanders, J. M., J. L. Hamrick y J. A. Ahumada, 2005. Consequences of harvesting for genetic diversity in study Biodiversity and Consenvation, 14 (2): 493-504. Cruse-Sanders, J. M., K. C. Parker, E. A. Friar, D. I. Huang 2015. Managing diversity: Domestication and gene flow in Stenocereus stellatus Riccob. (Cactaceae) in Mexico. Ecology and Evolution, 3 (5): 1340-1355.

Doebley, J., 1992. Mapping the genes that made Maize. Trends in Genetics, 8 (9): 302-307.

olan, R. W., D. L. Marr y A. Schnabel, 2008. Capturing genetic variation during ecological restorations: An Ecology, 16 (3): 386-396.

Doulati-Baneh, H., S. A. Mohammadi, M. Labra, F. de Mattia, I. Bruni, V. Mezzasalma y R. Abdollahi, 2015. Genetic characterization of some wild grape populations (Vitis vinifera subsp., sylvestris) of Zagros mountains (Iran

Istrand, N. C. y D. R. Elam, 1993. Population genetic consequences of small population size - Implication Systematics 24: 217. Annual Review of Ecology and

mrick, V. y J. Jones, 2008. Influence of competition on the density of the federally endangered michaux's sumac
(Rhus michauxii) at Fort Pickett, Virginia. Southeastern Naturalist, 7 (1): 61-68. and structure of wild and managed populations o to identify a conservation strategy. Plant Genetic 
Escalante, A. M., G. Coello, L. E. Eguiarte y D. Piñero, 1994. Genetic structure and mating systems in wild and cultivated populations of Phaseolus coccineus and $P$, vulgarls
(Fabaceae). American Journal of Botany, 81: 1096-1103.

Falk, D., C. Richards, A. Montalvo y E. Knapp, 2006. Population and ecological genetics in restoration ecology. En: Falk, D. A., M. A. Palmer y J. B. Zedler
(Eds.). Foundations for Restoration Ecology. Island Press, (Eds.). Foundations for R

FAO, 2010. The second report on the state of the world's plant genetic resources. Organización de las Naciones Unidas para la Alimentacion y la Agricultura. (En linea, thematic-sitemap/theme/seeds-pgr/sow/en/, consultado el 8 de junio de 2016).

Forsberg, N. E. G., J. Russell, M. Macaulay, M. W. Leino y structuring in century old barley (Hordeum vulgare). Heredity, 114 (2): 195-206.

Fuller, D. Q., L. Qin, Y. F. Zheng, Z. J. Zhao, X. Chen, L. A. Hosoya y G. P. Sun, 2009. The domestication process
and domestication rate in rice: spikelet bases from the and domestication rate in rice: spikelet
lower Yangtze. Science, 323:1607-1610.

Gaut, B. S., C. M. Diez y P. L. Morrell, 2015. Genomics and the contrasting dynamics of annual and peren domestcation. Thends ingesetas, 31 (12): 709-719.

Goldstein, B., 1975. Ginseng: its history, dispersion and
folk tradition. American journal of Chinese medicine folk tradition.
3: 223-234.

Gonzalez-Insuasti, M. S., J. Caballero, 2007. Managing plan resources: How intensive can it be? Human Ecology,

Hackney, E. E, y J. B. McGraw, 2001. Experimental demonstration of an Allee effect in Am.
Conservation Biology, 15 (1): 129-136.

Hamrick, J. L. y M. J. Godt, 1996. Effects of life history traits on genetic diversity in plant species. Philosophica 351: 1291-1298.

Hardigan, M. A., J. Bamberg, C. R. Buell y D. S. Douches, 2015. Taxonomy and genetic differentiation among wild and cultivated ge

Harlan, J. R., 1975. Crops and man. American Society of Agronomy, Madison, WI.

Harris, D. R., 1967. New light on plant domestication and origins of agriculture Review. Geographical Review. 57 (1): 90-107.

Havens, K., P. Vitt, S. Still, A. T. Kramer, J. B. Fant y K. Schatz, 2015. See sourcing for restoration in an Era of clim
change. Natural Areas Journal, 35 (1):122-133.

Horner, M. A., T. H. Fleming y C. T. Sahley, 1998. Foragin behavior and energetics of a nectar-feeding bat, Leptonycteris curasoae (Chiroptera : Phyllostomidae). Journal of Zoology, 244: $575-58$

Hufford, K. M. y S. J. Mazer, 2012. Local adaptation and the effects of grazing on the performance of Nassella pulchra:
Implications for seed sourcing in restoration. Restoration Ecology, 20 (6): 688-695.

Ele, C. J., R. A. Ennos, T. Jaffre, M. Gardner y P. M. Hollingsworth, 2008. Cryptic genetic bottlenecks during restoration of an endangered tropical conifer. Biological Conservation, 141 (8): 1953-1961.

Leon-Lobos, P., M. Way, P. D. Aranda y M. Lima, 2012. The role of ex situ seed banks in the conservation of plant Ecology and Diversity, 5 (2): 245-25

ins-Neto, E. M. F., A. Casas, F. Parra, X. Aguirre, S. Guillen y U. P. Albuquerque, 2014. Brazilian and Mexica experiences in the study of incipient domestication.

ughadha, E. N., J. Baillie, W. Barthlott, N. A. Brummitt, M. R. Chee, A. Farjon, R. Govaerts, K. A. Hardwick, C. HiltonJ. Pleasants, V. Savolainen, G. E. Schatz, P. Smith, I. Turner, P. Wyse-Jackson y P. R. Crane, 2004. Measuring the fate of $W$ plant diversity: towards a foundation for future monitoring and opportunities for urgent action. Philosophical transactions of the Royal Society Biologica

MacNeish, R. S., 1967. A summary of the subsistence. En Byers, E. D. (Ed.). The prehistory of the Tehuacan Valley.

McKay, J. K., C. E. Christian, S. Harrison y K. J. Rice, 2005 How local is local?" A review of practical and conceptual issues in the $13: 432-40$.

Graw, J. B., 2001. Evidence for decline in stature of American ginseng plants from herbari
Biological Conservation, 98 (1): 25-32.

McGraw, J. B., M. A. Furedi, K. Maiers, C. Carroll, G. Kauffman, A. J. Lubbers Wolf, R. Anderson, R. Anderson, B. Wilcox, D. Drees, M. E. Van der Voort, M. Albrecht, M. and harvest season in wild American $\mathrm{H}$ ginseng. Northeastern Naturalist, 12 (2): 141-152.

Menges, E. S., E. O. Guerrant Jr. y S. Hamzé, 2004. Effects of seed collection on the extinction risk of perennial plants. En: Guerrant J., E. O., K. Havens y M. Maunder (Eds.). Ex situ plant conservation: Supporting species survival

Nantel, P., D. Gagnon y A. Nault, 1996. Population viability analysis of American ginseng and wild leek harvested in stochastic environments. Conservation Biology, 10
(2): 608-621. Neale, J. R., 2012. Genetic considerations in rare plant reintroduction: Practical applications (or How are we doing?). En: Maschinski, J. y K. E. Haskins. Plant
reintroduction in a changing climate, promises and perils. Center for Plant conservation, Island Press, St.Louis, USA, pp. 71-88.

Newman, D. y D. Pilson, 1997. Increased probability of extinction due to decreased genetic effective population size: Experimental popul
Evolution, 51 (2): $354-362$.
Otero-Arnaiz, A., A. Casas, J. L. Hamrick y J. Cruse-Sanders, 2005. Genetic variation and evolution of Polaskia chichipe (Cactaceae) under domestication in the Tehuacan Valley, Central Mexico. Molecular Ecology,

Parker, K. C., D. W. Trapnell, J. L. Hamrick, W. C. Hodgson y A. J. Parker, 2010. Inferring ancient Agave cultivation practices from contemporary genetic patterns. Molecular
Ecology, 19 (8): $1622-1637$.

Parra, F., A. Casas, V. Rocha, A. Gonzalez-Rodriguez, S. Arias-Montes, H. Rodriguez-Corea y J. Tovar, 2015 Spatial distribution of genetic variation of Stenocereus
pruinosus (Otto) Buxb. In Mexico: Analysing evidence on the origins of its domestication. Genetic Resources and crop evolution. 62(6): 893-912.

Pickersgill, B. y C. Heiser, 1976. Cytogenetics and evolutionary change under domestication. Philosophical Transactions of the Royal Soceity of Lo
Biological Sciences, 275 (936): 55-69.

Pilz, D. y R. Molina, 2002. Commercial harvests of edib mushrooms from the forests of the Pacific Northwest United States: Issues, management and monitoring
for sustainability. Forest Ecology and Management for sustain 3 -16.

Primack, R. B., 1993. Essentials of Conservation Biology.

Plant Conservation Alliance (PCA), 2015. National seed strategy for rehabilitation and restoration, 2015-2020. The disponible en: disponible en: http: 8 de junio de 2016).

Ramp, J. M., S. K. Collinge y T. A. Ranker, 2006. Restoration (Asteraceae). Conservation Genetics, 7: 631-649.

Robbins, C. S., 1998. American ginseng: The root of North Americe's medicinal herb trade. TRAFFIC North America report B347.

Robbins, C. S., 2000. Comparative analysis of management regimes and medicinal plant trade monitoring mechanisms for American ginseng and
Conservation Biology, 14: 1422-1434.

Rojas-Aréchiga, M, A. Casas y C. Vazquez-Yanes, 2001. Seed germination of wild and cultivated Stenocereus stellatus Mexico. Journal Arid Environments, 49: 279-287.

Santos, E., C. B. M. Cerqueira-Silva, G. M. Mori, D. Ahnert, D. L. N. Mello, J. L. Pires, R. X. Correa y A. P. de Souza,
2015.Genetic structure and molecular diversity of cacao 2015.Genetic structure and molecular diversity of cacao
plants established as local varieties for two Centuries: The genetic history of cacao plantations in Bahia, Brazil. PLOS One, 10 (12): e0145276.

Shaffer, M. L., 1981. Minimum population sizes for species conservation Bioscience, 31 (2): 131-134.

Sheldon, J. W., M. J. Balick y S. A. Laaird, 1997. Medicina plants: Can utilization and conservation coexist? Garden, New York, USA.

Groyles, S. L., J. P. Gibson, J. L. Hamrick, M. A. Bucher y M. J. Gibson, 1992. Comparisons of allozyme diversity among rare and widespread Rhus species. Systematic Botany, 17 (4): 551-559.

mulders, M. J. M., J. van der Schoot, R. H. E. M. Geerts, A. G. Antonisse-de Jong, H. Korevaar, A. van der Werf y B. Vosman, 2000. Genetic diversity and the reintrod
of meadow species. Plant Biology, 2: 447-454.

K. y G. Wilcox, 2006. How fast was wild whea nno, K. y G. Wilcox, 2006. How fast was
domesticated? Science, 311: 1886-1886.

Tanksley, S. D. y S. R. McCouch, 1997. Seed banks and molecular maps: Unlocking genetic potential from th

Teel, W. S. y L. E. Buck, 2002. Between wildcrafting and monocultures: Agroforestry options. En: Jones, E. T., Products in the United States Lawrence, University Press of Kansas, pp. 199-222.

uiller, W., 2007. Climate change and the ecologist. Nature, 448: 550-552.

Ticktin, T. y T. Johns, 2002. Chinanteco Management of Aechmea magdalenae (Bromeliaceae): Implications for Incorporating TEK and TRM
Economic Botany, 56: 177-191.

inoco, A., A Casas, R. Luna, K. Oyama, 2005. Population genetics of Escontria chotilla in wild and silviultura managed populations in the Tehuacan Valley, Centra Mexico. Genetic Resources and Crop Evolution, 52: 525-538.

SFWS (N. Murdock y J.Moore.), 1993. Michaux's Sumac recovery plan. Fish and Wildlife Service, Atlanta, U.S.

Wen, J. y E. A. Zimmer, 1996. Phylogeny and biogeography of Panax L. (The ginseng genus, Araliaceae): Inferences Molecular Pylogenetics and Evolution, 6 (2): 167-177.

Whitmore, T. M. y B. L. Turner, 1992. Landscapes of cultivation in Mesoamerica on the eve of the conquest. Association

Whitney, G. G., 1994. From Coastal Wilderness to Fruited Plain: A history of environmental change in temperat University Press, Cambridge. ance, N. C., 2002, Ecological considerations in sustainable use of wild plants. En: Jones, E. T., R. J. McLain y J.
Weigand. Non-timber Forest Products in the United States, Lawrence, University Press of Kansas, pp. 151-162.

ander Mijnsbrugge, K., A. Bischoff y B. Smith, 2010. A question of origin: Where and how to collect seed for 11(4): $300-311$ 


\section{Avances en el estudio de la fauna de los traspatios familiares en el sureste de México}

Ramón Mariaca Méndez

\section{Resumen}

El traspatio, solar, huerto o patio -conocido en inglés como kitchen garden o homegarden-, es un sistema biocultural que generalmente, y en múltiples regiones del mundo, presenta tres componentes visibles importantes: el humano, el vegetal y el animal. El de microorganismos también se encuentra presenta y cumple funciones altamente importantes en los suelos y en los componentes aéreos a los que favorece o para los que puede constituir agentes patógenos, pero en general este es un componente que ha sido muy poco analizado. La fauna del solar es una respuesta a la interacción entre el ser humano, su cultura y el ambiente. Este trabajo es producto de recorridos de campo y recopilación bibliográfica a lo largo de la región sureste de México, en donde predominan los climas cálido-húmedos y subhúmedos. Hemos registrado un total de 17 especies de fauna doméstica, la mayoría de ellas exógenas y de razas mestizas; así como una cantidad elevada de especies silvestres -la mayoría de las cuales se lleva a los traspatios en etapas de cachorros o juveniles-, polluelos y huevos desde los montes circunvecinos. Este tipo de interacción ha ocurrido en distintas partes de México desde tiempos prehispánicos. En la región sureste de México, la zona de culturas maya de mayor importancia, se han registrado en total 14 especies de mamíferos silvestres, 53 de aves silvestres y 12 de reptiles. Estas especies pertenecen a las siguientes categorías antropocéntricas de uso: 1) alimentación; 2) de trabajo; 3) de protección; 4) de ornato o recreación; 5) para la comercialización; 6) como mascota, 7) medicinales. Frecuentemente quedan fuera del registro aquellos animales pertenecientes a otras categorías, como, por ejemplo, la que puede denominarse 8) inocua, cuya presencia es propia del huerto, ya sea por asociación a otros componentes o por su presencia efímera, pero que su presencia o ausencia no afectan de manera significativa al sistema, y 9) el de fauna dañina, cuya presencia en el traspatio es indeseable y la gente invierte energía procurando mantenerlos fuera de estos espacios. La mayor parte de los componentes de la fauna de traspatio es atendida por las mujeres y existe un trato diferencial a las especies de acuerdo con sus características biológicas, su uso, valor y significado cultural. Normalmente la fauna del traspatio tiene una función económica incluyendo el autoconsumo, pero también permite satisfacer otras necesidades familiares. La cría y atención de la fauna incluye aspectos relacionados con conocimientos autoecológicos empíricos, etnotaxonomías locales, etnomedicina, y hasta 
con la arquitectura vernácula. También se involucran aspectos de la cosmovisión familiar, la presencia o ausencia de algunos componentes en el huerto dependen marcadamente de este aspecto. Las interacciones con la fauna de traspatio involucran procesos de doma permanente y puede involucrar crianza sistemática. No sería descartable que en la región sureste de México y en otras partes del mundo, en los procesos de domesticación animal, el traspatio haya sido un espacio crucial para llevar a cabo la doma, la crianza con distintos niveles de intensidad y eventualmente las cruzas que determinaron divergencias con respecto a los parientes silvestres de los animales domésticos.

Palabras clave: domesticación animal, etnozoología, huertos,

Mesoamérica, mayas, traspatios.

\section{Introducción}

El traspatio familiar, huerto, huerto familiar, solar, kitchen garden o homegarden, estos últimos términos en inglés, es un espacio físico que rodea a la casa habitación, en donde cohabitan, con cierta armonía, la unidad doméstica campesina (o suburbana), plantas cultivadas y animales criados por ellos, interactuando con el ambiente inmediato (Figura 20.1). Desde luego también existen organismos de otros reinos, tales como hongos de cuyos cuerpos fructíferos en algunas regiones son aprovechados, y microorganismos, que, aunque invisibles, también cumplen funciones altamente importantes en los suelos y en los componentes aéreos a los que favorecen o para los que puede constituir agentes patógenos, pero en general este es un componente que ha sido muy poco analizado. En consecuencia, de acuerdo con Mariaca et al. (2007), es factible definir al traspatio familiar como

el agroecosistema con raíces tradicionales, en el que habita la unidad doméstica y donde los procesos de selección, domesticación, diversificación y conservación están orientados a la producción y reproducción de flora y fauna y, eventualmente de hongos. Tal espacio se encuentra en estrecha relación con la preservación, las condiciones sociales, económicas y culturales de la unidad familiar y contribuye al enriquecimiento, generación y apropiación de tecnología...

El objetivo de considerar a la unidad doméstica formada por una familia nuclear o extensa además de otras personas que sin ser parientes ahí habitan, es porque tal unidad guía la construcción y dirige la función de ese espacio. Delimita la forma, la estructura, la diversidad y la riqueza de especies, así como la historia y perspectiva futura de esta forma de producir satisfactores en relación con la diversidad biológica y la cultura locales (Mariaca et al. 2007).

Lo anterior implica que existen cuatro elementos, en realidad subsistemas, básicos que componen el sistema general: un subsistema vegetal que incluye el conjunto de especies silvestres, arvenses y domesticadas que coexisten en ese espacio; un subsistema animal que incluye fauna domesticada y silvestre llevada deliberadamente al sitio o que eventualmente se establece en el sitio de manera natural; la unidad doméstica constituida por el grupo familiar que mantiene y toma decisiones sobre la estructura y conducción del sistema, as

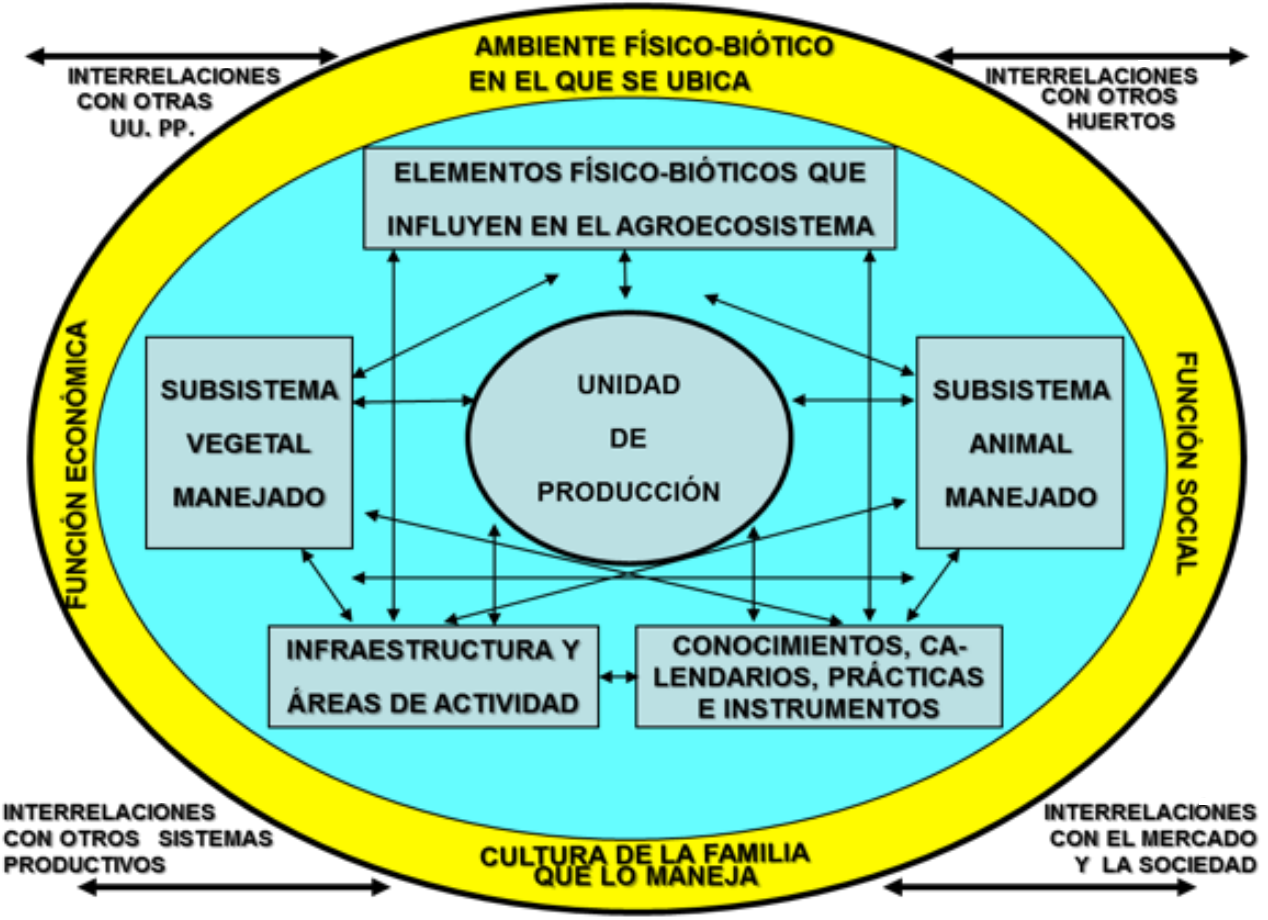

Figura 20.1 Diagrama del traspatio familiar con sus elementos constitutivos y sus interacciones dentro y entre sistemas (Tomado de Lerner et al., 2009).

UU. PP = unidades de producción.

como un entorno físico, biótico (en cuyo contexto se incluyen los organismos de otros reinos referidos arriba), económico, social y cultural (Figura 20.1). El elemento humano, central en cualquier agroecosistema, está compuesto por las personas que lo habitan, quienes influenciados por su cultura y adaptándose a las condiciones del medio, realizan cotidianamente actividades productivas y reproductivas a través de su conocimiento, su visión del mundo y su tecnología.

Asimismo, la familia suele construir todo un conjunto arquitectónico dentro del traspatio conformado normalmente por: (1) la casa-habitación, (2) la cocina, (3) el cerco, (4) el jardín o zona de plantas de ornato, (5) el área o áreas de plantas cultivadas, (6) los corrales, (7) la o las fuentes de agua, (8) el área de fecalismo, (9) el área de lavado de ropa y trastos, (10) el área de aseo personal (baño), (11) el almacén de leña, (12) el almacén de granos, (13) la bodega, (14) el área social, (15) área de esparcimiento de los niños, (16) el área o áreas de trabajo, (17) el área de quemado y/o enterrado de basura, (18) otras estructuras como: temascales, hornos de pan, altares, capillas o cruces protectoras, entre otras (Mariaca, 2012).

El subsistema vegetal está conformado principalmente por las plantas cultivadas por la familia, así como otras que son toleradas, y unas pocas arvenses y plantas silvestres, estas 
últimas, en la parte trasera, cuando el terreno es lo suficientemente grande o no se ha terminado de acondicionar. Martínez-Alfaro (1990) recopiló 39 categorías antropocéntricas de uso de los componentes de este subsistema. Tales categorías se definen como aquellas a las que un grupo humano otorga un valor utilitario o incluso nocivo a las de plantas, también se pueden determinar tales categorías de acuerdo con los productos que se obtienen de esos componentes del subsistema. La mayoría están presentes en los traspatios: 1) abonos verdes, 2) las que causan alergias, 3) alimenticias o comestibles, 4) aromáticas -saborizantes perfumes, etcétera-, 5) aquellas destinadas a elaborar artesanías, 6) las arvenses o malezas entre las cuales se encuentran varas especies alimenticias, medicinales o forrajeras, 7) las usadas para preparar bebidas refrescantes o alcohólicas, 8) aquellas de las que se obtienen ceras, 9) las utilizadas para establecer cercas vivas o muertas, 10) las especies utilizadas con fines ceremoniales (amuletos, plantas mágicas, para ritos o que involucran tabúes), 11) aquellas que aportan colorantes, 12) las que son anticontaminantes, 13) las utilizadas como material de construcción de muebles o casas, 14) aquellas deliberadamente identificadas para control biológico (insecticidas, fungicidas, herbicidas), 15) especies que tienen una función como cortinas rompevientos, 16) las que brindan productos cosméticos, 17) las que proveen artículos para usos domésticos (cocina, envolturas, tendederos, pegamentos, entre otros) 18) las que constituyen drogas con propiedades narcóticas -alucinógenos, enervantes, tranquilizantes-, 19) las edulcorantes o dulcificantes, 20) las que representan emblemas con significado simbólico, 21) las plantas que constituyen biocombustibles que proveen energía -carbón, leña-, 22) las empleadas como agentes para prevenir la erosión; 23) las empleadas como especias o condimentos, 24) las utilizadas para preparar bebidas reconfortantes o estimulantes, 25) las que brindan fibras utilizadas para confeccionar textiles, cordelería cestería, 26) las que se aprovechan como forrajes, 27) aquellas que producen gomas y látex aprovechable, 28) las que brindan productos de uso industrial -por ejemplo, antioxidantes, materiales sustitutos de plásticos, componentes de explosivos, entre otros-, 29) las que brindan productos para fabricar instrumentos musicales, 30) las que proveen de materiales para elaborar herramientas útiles en las prácticas agrícolas, ganaderas, la caza, la pesca y la recolección, 31) las que proveen medicinas, tanto para los seres humanos como para los animales domésticos, 32) las melíferas, 33) las oleaginosas, de las que se extraen aceites comestibles o de uso artesanal o industriales, 34) las ornamentales o estéticas, 35) las que se utilizan para purificar agua, 36) las productoras de resinas, 37) las que producen taninos, frecuentemente usados en la curtiduría de pieles, 38) las plantas tóxicas y venenosas para los humanos y sus animales domésticos, y 39) las plantas urticantes. En el caso del sureste de México, la diversidad florística listada es la siguiente: 524 especies en Yucatán, 500 en Campeche, 449 en Quintana Roo, 811 en Tabasco y 426 en Chiapas.

El subsistema faunístico está integrado por: 1) la fauna de protección, 2) la fauna para la reproducción de la unidad familiar, 3) la fauna de trabajo, 4) la fauna ornamental, 5) la fauna empleada como mascota, 6) la fauna medicinal y simbólica, 7) la fauna dañina, 8) la fauna sin uso directo que es parte de la estructura del agroecosistema. Es justamente a este subsistema al que se dedicará mayor atención en este capítulo.

Tanto la flora como la fauna cuentan con elementos nativos como exógenos introducidos. Estos últimos son descendientes de especies que fueron introducidas al continente americano en el siglo XVI por los colonizadores españoles, otras más que se introdujeron tardíamente, pero que se encuentran en el área hasta la fecha. $Y$ después de casi cinco siglos de crianza y domesticación local de esa fauna exótica, los linajes expresan los criterios de selección propios de las culturas locales, frecuentemente divergiendo de sus ancestros domesticados en el Viejo Mundo. Por ello, siendo la domesticación un proceso continuo, se refleja en los organismos criados localmente, no obstante que estos sean animales introducidos de Europa, Asia o África. Al hacer una revisión bibliográfica sobre el tema, probablemente más del $95 \%$ de los estudios realizados se han enfocado en la vegetación, ignorando al ser humano y a la fauna así como a los factores del microambiente.

\section{El contexto de la fauna del traspatio familiar}

La fauna es un elemento dinámico que da sensación de movimiento permanente en el interior del traspatio; sin embargo, su fragilidad es mayor que el componente vegetal, ya que puede desaparecer en pocos días debido a factores como mal manejo, enfermedades, depredación, robo y, en algunos casos, su venta.

En un traspatio nuevo, normalmente, el primer animal doméstico llegará por obsequio de la familia de la que provienen los recién casados y se incrementará en función de los ingresos familiares, de la reproducción de la población pionera y de la compra de nuevos ejemplares. También llegarán animales silvestres cuando el varón o la familia salen al campo y traen polluelos, cachorros o huevos, o por la captura de algún adulto.

Observaciones de campo nos indican que con excepción de las familias más pobres, hay a menos alguna gallina, de tal manera que la gallina (Gallus gallus domesticus) es el animal más frecuente $(99.5 \%$ ) en los huertos familiares del sureste de México. En parte por ser de bajo precio, su fácil cría, su alta tasa de reproducción y su utilidad. Asimismo, la presencia del pavo o guajolote (Meleagris gallopavo) y del cerdo (Sus scrofa) representa alguna condición de ahorro e incluso bonanza familiar.

En ese sentido, la fauna ha sido considerada como la alcancía familiar y como el reservorio de proteína animal; sin embargo, la poca atención que ha recibido este elemento por parte de la academia ha determinado un sensible vacío en la literatura sobre los huertos familiares o traspatios. Se ha observado que el traspatio es atendido generalmente por la esposa, la mujer principal de la familia, quien hace el trabajo doméstico cotidiano, apoyado por los hijos menores; el esposo hace las labores más pesadas, como poner postes, sembrar o podar árboles, matar y preparar cerdos o bovinos y hacer construcciones interiores, casi siempre apoyado por los hijos mayores.

En consecuencia, el cuidado que una mujer da a los animales y a las plantas del traspatio familiar en mucho denotan una extensión del cariño y amor con que cuidan y atienden a sus hijos, pudiendo considerarse como una extensión de la mujer misma, ya que se pueden observar muchas emociones y motivaciones que incluyen percepciones visuales (la belleza de los componentes) e incluso olores (fragancias agradables) y texturas delicadas desde el punto de vista humano. 


\section{La fauna del traspatio en el pasado}

Si bien el traspatio familiar pudo estar presente entre los primeros sistemas de manejo agrícola del Valle de Tehuacán, Puebla, una de las áreas más tempranas de agricultura en México (McNeish, 1967), se ha podido determinar que entre los olmecas prehispánicos, una de las funciones de los huertos de traspatio eran ser un importante centro de atracción de fauna silvestre que era cazada o capturada para consumo (Vanderwaker, 2006).

Su presencia en la zona maya preclásica y clásica ha sido poco estudiada por la arqueología (p.e. Manzanilla y Barba, 1999 en Cobá Quintana Roo y Goñi, 1995 y Gotz, 2011 en diferentes puntos de la península de Yucatán), quedando aún datos interesantes por develarse en un futuro. Para el momento del contacto europeo con el continente americano se cuentan con importantes fuentes como son las relaciones histórico-geográficas de la gobernación de Yucatán (De la Garza et al., 1983) y la obra de Diego de Landa (1983), escritas respectivamente en 1577 y 1578

Mariaca et al. (2012) analizaron estas obras con el fin de sistematizar y analizar la información que sobre el solar o traspatio maya se encontraba en ambas obras. En los años cuarenta de siglo XVI, y con base en testimonios de Antón de Alaminos (capitán de barcos en numerosas expediciones españolas en las islas y el continente americano), Francisco de Montejo y Alonso Hernández Portocarrero, participantes en la expedición de 1519 encabezada por Hernán Cortés, Pedro Mártir de Anglería menciona que en la orilla del río Grijalva y probablemente en Potonchán, las casas y edificios de piedra estaban separados por huertos (citado por Goñi, 1995).

La fauna domesticada o en proceso de domesticación, en tiempos prehispánicos, de la península de Yucatán es de al menos 17 nombres comunes, que pueden incluir de 17 hasta 30 especies, mencionadas tácitamente, más otras cinco, que pueden ser hasta ocho, que a menos en el siglo XX eran ya criados en los traspatios o solares y que por ser silvestres es bastante probable que ya hayan estado desde el siglo XVI. Esto haría un cálculo de 22 a 38 especies criadas en los traspatios prehispánicos al momento del contacto de los europeos con las culturas mesoamericanas, mismas que incluirían tres a cuatro mamíferos, a dos insectos, uno a dos reptiles y de 16 a 26 aves (Tablas 20.1, 20.2, 20.3 y 20.4)

Tabla 20.1. Mamíferos de origen americano criados en las áreas habitacionales del área maya de Yucatán durante el siglo XVI, según fuentes de ese siglo.

Especie Información

Referencias del siglo xvi

1. Nombre en maya pek, alak pek (perro manso Hay perros naturales de la tierra que no tienen criado en casa), k'iik'bil (perro pelo ninguno, y no ladran, que tienen los dientes de la tierra sin pelo), tsom (pe- ralos y agudos, la orejas pequeñas, tiesas y lerro de esta tierra de pelo muy vantadas, a estos engordan los indios para comer corto)

Nombre perro

en españo

Nombre Canis familiaris y los tienen por gran regalo, estos se juntan con
los perros de España y engendran, y los mestizos que de ellos proceden ladran y tienen pelo, y también los comen los indios como a los demás; y también los indios tienen otra suerte de perros que tienen pelo, pero tampoco ladran y son del mismo tamaño que los demás. (Relación de la ciudad de Mérida: 78 ).

[.. ] y perros que los indios crían que llamamos [...] y perro de la tiera que no tien crin que llamamos perro de la tierra, que no tienen ningún pelo y cómuy princiol comid y dicen que tio tienen por muy prichón muy godo (Redación de Mabor de un lechón muy gordo (Relación de Mama Kantemo: 114)

Asimismo, crian en sus casas, perros naturales de la tierra... también crían perros de Castilla y los comen (Relaciones de Motul: 273).

\begin{tabular}{|c|c|c|}
\hline 2. Nombre en maya & keh, wakna',yuk' & \multirow{3}{*}{$\begin{array}{l}\text { [...] y crían otros animales domésticos de los } \\
\text { cuales dan el pecho a los corzos, con los que los } \\
\text { crían tan mansos que no saben írseles al monte } \\
\text { jamás, aunque los lleven y traigan por los montes } \\
\text { y crien de ellos [...]; (Landa } 1983 \text { [1566]: 66). }\end{array}$} \\
\hline $\begin{array}{r}\text { Nombre } \\
\text { en español }\end{array}$ & $\begin{array}{l}\text { venado cola blanca, } \\
\text { venado temazate }\end{array}$ & \\
\hline $\begin{array}{r}\text { Nombre } \\
\text { científico }\end{array}$ & $\begin{array}{l}\text { Odocoyleus virginianus } \\
\text { Mazama mazama }\end{array}$ & \\
\hline \multirow{2}{*}{$\begin{array}{r}\text { 3. Nombre en maya } \\
\text { Nombre }\end{array}$} & chu & \multirow{3}{*}{$\begin{array}{l}\text { Hay un animal que llaman Chu a maravilla travie- } \\
\text { so, tan grande como un perrillo, de hocico como } \\
\text { lechón. Críanlo las indias, y no les dejan cosa que } \\
\text { no les hozen y trastornen, y es cosa increíble que } \\
\text { son a maravilla amigos de burla con las indias, } \\
\text { y las espulgan, y se llegan siempre a ellas, y no } \\
\text { pueden ver al hombre más que a la muerte. Hay } \\
\text { muchos de éstos y andan siempre a manadas en } \\
\text { hilo, uno tras otro, encajados los hocicos (de) los } \\
\text { unos debajo de la cola de los otros, y destruyen } \\
\text { mucho la heredad de maíz donde entran (Landa } \\
1983 \text { [1566]: 149-150). }\end{array}$} \\
\hline & coatí & \\
\hline $\begin{array}{l}\text { Nombre } \\
\text { científico }\end{array}$ & Nasua nasua & \\
\hline
\end{tabular}


Tabla 20.2. Insectos de origen americano criados en las áreas habitacionales del área maya de Yucatán durante el siglo XVI, según fuentes de ese siglo.

Especie Información

1. Nombre en maya ko'lel kab, yilk'il kab

Nombre abeja sin aguijón

en español

Nombre Mellipona beeckei
científico

Hay dos castas de abejas y ambas son muy más peas son muy más pequ colme las nuestras. Las mayon mu nas prian ch panal como las nuestras, sino ciertas vejigultas como la mies de cera, todas juntas unas a otras, llenas de colme colmena y reventar con un palito estas vejiguitas y así corre la miel y sacan la cera cuando les parece
(Landa 1983 [1566]: 138).

\begin{tabular}{|c|c|c|c|}
\hline \multirow{2}{*}{\multicolumn{2}{|c|}{$\begin{array}{r}\text { 2. Nombre en maya } \\
\text { Nombre } \\
\text { en español }\end{array}$}} & muk'ay & \multirow{3}{*}{$\begin{array}{l}\text { Solíase coger grana, y dicen que era de la mejor de las } \\
\text { Indias, por ser tierra seca, y todavía cogen en algunas } \\
\text { partes alguna, los indios (Landa } 1983 \text { [1566]: 145). } \\
\text { Uno de los más preciosos frutos que se crían en } \\
\text { nuestras Indias Occidentales es la grana cochinilla, } \\
\text { mercadería igual con el oro y la plata, sobre cuya } \\
\text { bondad, beneficio y fidelidad fuimos servidos de [a] } \\
\text { cometer al Marqués de Guadalcázar, virrey de la Nue- } \\
\text { va España [...]; (Leyes de Indias, 1620, Ordenanza } \\
\text { de Felipe III). }\end{array}$} \\
\hline & & cochinilla & \\
\hline & $\begin{array}{r}\text { Nombre } \\
\text { científico }\end{array}$ & Dactylopius coccus & \\
\hline
\end{tabular}

Tabla 20.3. Reptiles de origen americano criados en las áreas habitacionales del área maya de Yucatán durante el siglo XVI, según fuentes de ese siglo.

Especie Información Referencias del siglo xvi

1. Nombre en maya huh Nombre iguana
en español

Nombre Iquana iguana científico en la tierra,... péscanlas los indios con lazos, encara-
[...] muchas iguanas, [...] ponen huevos en mucha cantidad y andan siempre cerca de la mar $y$ de donde hay aguas, indiferentemente se guarecen en el agua y madas en los arboles y en agujeros de ellos, y es cosa increible lo que sufren el hambre, que acaece estar vivas, después de tomadas, veinte y treinta días sin comer bocado y sin enflaquecer; y he oído que hay experiencia hecha, que si les frotan las barrigas con arena engordan mucho. El estiércol de éstas es admirable medicina para curar nubes de los ojos, puesto fresco en ellas (Landa 1983 [1566]: 137).
Tabla 20.4. Aves de origen americano criadas en las áreas habitacionales del área maya de Yucatán, durante el siglo XVI, según fuentes de ese siglo.

Especie Información

1. Nombre en maya kut'sa, kutsil ximbal, kuts ha'

Nombre pato cairina pato de

en español indio, pato perulero

Nombre Cairina moschata

científico

Referencias del siglo xvi

También crían patos naturales de esta tierra que aprovechan de su pluma para tejer en sus vestidos, y también los comen, y es buena comida (Relación de la ciudad de Mérida:81).

Crían para la pluma cierta casta de anadones blancos grandes que creo les vinieron del Perú, y así les pelan muchas veces las barrigas, y quieren aquella pluma para las labores de sus ropas (Landa 1983(1566): 145). .. t también crían patos de dos o tres suertes, naturales de esta tierra y de fuera de ella y se aprovechan de solamente

Hay otros anadoncitos pequeños y de mucha hermosura que se llaman Maxix; son muy mansitos y se crían saben huir (Landa 1983 [1566]: 147). [Nota: mixix significa pato pequeño]

2. Nombre en maya

Hay unas aves en todo semejantes a las perdices de

Nombre pixixeh, pihihi

en español

Nombre pijije colana, salvo que son de muy altas piernas, aunque

científico coloradas y tienen ruin comer; son, empero, a maravi-

Nombre científico Dendrocygna autucmalis

3. Nombre en maya tso', ulum

Nombre pavo doméstico

en español

Nombre Melleagris gallopavo cientifico
[...] crían en sus casas mucha cantidad de gallinas de la tierra, que son como pavas [...]; (Relaciones de Motul: 274)

[...] y a asimismo muchas gallinas de Castilla y de la tierra que los indios llaman ulum, y lo mismo a las de Castilla (Relaciones de Sucopó: TII-119).

kuts [pavo silvestre o pavo de monte] (Agriocharis ocellata),

Hay muchos pavos que aunque no son de tan hermosas plumas como los de acá de España, las tienen muy galanas $y$ son a maravilla hermosos, $y$ tan grandes como los gallos de los indios y de tan buen comer. $A$ todas las grandes matan los indios, en los árboles, con las flechas, $y$ a todas les hurtan los huevos $y$ los (empollan) sus gallin

1983 [1566]: 146).

[...] hay muchas pavas en las montañas que difieren poco a las de España, cosa de muy buen comer, aves muy medrosas; $y$ sale un indio con dos perros, y en ladrando el perro se sube encina de un árboly el indio con una cerbatana la derriba por grande que sea. (Relaciones de Tekit: 288). 
Especie Información

4. Nombre en maya k'ambul

Nombre hocofaisán, faisán

en españo

Nombre Crax rubra

científico

(n)erencias del siglo xui

[...] ave grande y hermosa que suelen criar los indios Diccionario Motul, siglo XVI, en Diccionario Maya-Cordemex (1980: 377).

Hay un pájaro grande como las gallinas de allá que laman Cambul, muy hermoso a maravilla y de gran denuedo y buen comer (Landa 1983 [1566]: 146).

\begin{tabular}{|c|c|c|c|}
\hline \multirow[t]{3}{*}{5.} & Nombre en maya & nom & \multirow{2}{*}{$\begin{array}{l}\text { Crían los indios en sus casas gallinas o gallipavos que } \\
\text { llaman en España, y danse en muy gran cantidad, por- } \\
\text { que se crían sin agua, y si la beben les es dañosa, que } \\
\text { se les hinchan las cabezas y mueren. (Relación de la } \\
\text { ciudad de Mérida: } 80-81 \text { ). }\end{array}$} \\
\hline & $\begin{array}{r}\text { Nombre } \\
\text { en español }\end{array}$ & $\begin{array}{l}\text { perdiz de Yucatán } \\
\text { (según Pearse), gallina } \\
\text { de monte }\end{array}$ & \\
\hline & $\begin{array}{r}\text { Nombre } \\
\text { científico }\end{array}$ & $\begin{array}{l}\text { Tinamus major perca- } \\
\text { tus, Crypturellus cinna- } \\
\text { momeus goldmani, C. } \\
\text { boucard, C.soui) }\end{array}$ & $\begin{array}{l}{[\ldots . .] \text { perdices que se llaman nom [...].Todos estos ani- }} \\
\text { males que he dicho, comen los indios (Relaciones de } \\
\text { Titzal y Tixtual: } 240 \text { ). }\end{array}$ \\
\hline \multirow[t]{3}{*}{6.} & \multirow{3}{*}{$\begin{array}{r}\text { Nombre } \\
\text { en español } \\
\text { Nombre } \\
\text { científico }\end{array}$} & $\begin{array}{l}\text { (ah) ki' tsutsuy, (ix) } \\
\text { kukutkib, ukum, } \\
\text { akpakal, tsutsuy, } \\
\text { k'ankab }\end{array}$ & \multirow[t]{3}{*}{$\begin{array}{l}\text { [...] también crían palomas de España y las hay de } \\
\text { esta tierra, pero son más pequeñas [...]; (Relación de } \\
\text { la ciudad de Mérida: } 81 \text { ). }\end{array}$} \\
\hline & & paloma & \\
\hline & & $\begin{array}{l}\text { Columba flavirostris } \\
\text { Wagler (silvestre de } \\
\text { pico rojo), } \\
\text { Columba speciosa } \\
\text { (paloma real, chukib), } \\
\text { Leptolila verreauxi } \\
\text { fulviventris (paloma } \\
\text { silvestre), } \\
\text { Oreopelia montana } \\
\text { ¿Columba passerina? } \\
\text { ¿Claravis pretiota? }\end{array}$ & \\
\hline \multirow[t]{3}{*}{7.} & Nombre en maya & $\begin{array}{l}\text { mukuy, k'ancab mukuy } \\
\text { y sakpakal }\end{array}$ & \multirow{3}{*}{$\begin{array}{l}\text { [...] hay dos castas de tortolillas muy saladas, y las } \\
\text { unas muy chiquitas y domésticas para criar, mansas } \\
{[\text { [...]; (Landa 1983(1566): 145-146). }}\end{array}$} \\
\hline & $\begin{array}{r}\text { Nombre } \\
\text { en español }\end{array}$ & tortolita & \\
\hline & $\begin{array}{r}\text { Nombre } \\
\text { científico }\end{array}$ & $\begin{array}{l}\text { Columbigallina } \\
\text { passerina pallescens } \\
\text { (tórtola), } \\
\text { Zenaida asiática (tórto- } \\
\text { la de alas blancas) }\end{array}$ & \\
\hline
\end{tabular}

Especie

Información

8. Nombre en maya bech', (ah) sul

Nombre codorniz (de cuello

en español negro y de cola corta)

Nombre Colinus virginianus.

científico C. nigrogularis

Dactylortyx thoracicus

tatus. en unos pueblos hay más cantidad que en otros (Relación de Tiak y Tieb: 321).

\begin{tabular}{|c|c|c|c|}
\hline \multirow[t]{3}{*}{9.} & Nombre en maya & $\begin{array}{l}\text { k'ota', (ix) k'an, moo'l } \\
\text { op/t'ut', x-op' }\end{array}$ & \multirow{3}{*}{$\begin{array}{l}\text { Hay tres o cuatro castas de papagayos pequeños y } \\
\text { grandes y tantas banda(da)s le ellos, que hacen mu- } \\
\text { cho daño a las sementeras (Landa 1983(1566): 146- } \\
\text { 147). }\end{array}$} \\
\hline & $\begin{array}{r}\text { Nombre } \\
\text { en español }\end{array}$ & $\begin{array}{l}\text { papagayos o guaca- } \\
\text { mayo/ loro yucateco/ } \\
\text { loro de cabeza ama- } \\
\text { rilla/ loro de cabeza } \\
\text { blanca }\end{array}$ & \\
\hline & $\begin{array}{r}\text { Nombre } \\
\text { científico }\end{array}$ & $\begin{array}{l}\text { Ara militaris } \\
\text { Amazona xantholora } \\
\text { A. albifrons } \\
\text { A. ochrocephala }\end{array}$ & \\
\hline \multirow[t]{3}{*}{10.} & Nombre en maya & $\operatorname{cox}$ & \multirow{3}{*}{$\begin{array}{l}\text { Hay otro que llaman Cox tan grande como él, de fu- } \\
\text { rioso paso y meneo, y son los machos negros todos } \\
\text { como un azabache, y tienen unas coronas muy lindas } \\
\text { de plumas, crespas, y los párpados de los ojos amari- } \\
\text { llos y muy lindos (Landa } 1983 \text { [1566]: 146). }\end{array}$} \\
\hline & $\begin{array}{r}\text { Nombre } \\
\text { en español }\end{array}$ & cojolita & \\
\hline & $\begin{array}{r}\text { Nombre } \\
\text { científico }\end{array}$ & $\begin{array}{l}\text { Penélope nigra } \\
\text { P. purpurascens }\end{array}$ & \\
\hline \multirow[t]{3}{*}{11.} & Nombre en maya & $\begin{array}{l}\text { bach, (ah) koba', tso } \\
\text { bach' }\end{array}$ & \multirow{3}{*}{$\begin{array}{l}\text { Hay muchos faisanes pardillos y pintados y de razona- } \\
\text { ble tamaño, y no tales para comer como los de Italia } \\
\text { (Landa } 1983 \text { [1566]: 146). }\end{array}$} \\
\hline & $\begin{array}{r}\text { Nombre } \\
\text { en español }\end{array}$ & chachalaca & \\
\hline & $\begin{array}{r}\text { Nombre } \\
\text { científico }\end{array}$ & Ortalis vetula & \\
\hline \multirow[t]{3}{*}{12.} & Nombre en maya & k'uk, (ah) k'uk'um & \multirow{3}{*}{$\begin{array}{l}\text { Hay otro pájaro grande y muy lindo, de color verde } \\
\text { muy oscuro, que no tiene en la cola más de dos plu- } \\
\text { mas largas, y con no más de la mitad, y al cabo, (unos) } \\
\text { pelos en ellas, y su morar es en los edificios, y no anda } \\
\text { sino a las mañanas (Landa } 1983 \text { [1566]: 146). }\end{array}$} \\
\hline & $\begin{array}{r}\text { Nombre } \\
\text { en español }\end{array}$ & quetzal & \\
\hline & $\begin{array}{l}\text { Nombre } \\
\text { científico }\end{array}$ & $\begin{array}{l}\text { Pharomachrus mo- } \\
\text { cinno }\end{array}$ & \\
\hline \multirow[t]{3}{*}{13.} & Nombre en maya & ixyalchamil & \multirow{3}{*}{$\begin{array}{l}\text { Hay un pajarito pequeño, de tan suave canto como el } \\
\text { ruiseñor, que llaman Ixyalchamil; anda en las paredes } \\
\text { de las casas que tienen huertas y en los árboles de } \\
\text { ellas (Landa } 1983 \text { [1566]: 146). }\end{array}$} \\
\hline & $\begin{array}{r}\text { Nombre } \\
\text { en español }\end{array}$ & ¿? & \\
\hline & $\begin{array}{r}\text { Nombre } \\
\text { científico }\end{array}$ & ¿? & \\
\hline
\end{tabular}

Hay muchas codornices a maravilla, y son algo mayores que las nuestras, y de singular comer; vuelan poco y tomanlas los indios con perros, encaramadas Ios árboles, con lazos que les echan al pescuezo, y s muy gustosa caza (Landa 1983(1566): 146). 


\section{Las especies animales introducidas por los españoles en el siglo XVI}

Con la llegada de la población hispana se creó el "solar" o sitio habitacional dentro de un pueblo. A él llegaron las plantas y animales ya criados con anterioridad por la población maya más plantas y animales traídos de ultramar.

[Se ordena a los caciques, principales y maceguales...] que se introdujese entre los indios la granjería y cría de ganados. Que les enseñasen los oficios mecánicos necesarios en las repúblicas, a mancebos solteros, y que sabiéndolos volviesen a sus pueblos, donde los compeliesen a usarlos y a enseñarles a otros. (Ordenanzas de Tomás López -1552-1553- Apéndice Documento número 8. Landa 1983 [1566]: 232).

También se abandonó el consumo del perro y su uso ceremonial.

La fauna introducida por la población española al solar maya del siglo XVI (Tabla 5), fue reducida: gallinas (Gallus gallus), perros distintos a los mesoamericanos (Canis lupus familiaris), gatos (Felis silvestris catus) y palomas (Columba sp.). También llegaron especies que no estaban destinadas al solar indígena, pero que con el paso del tiempo lo hicieron, tales como caballos (Equus caballus), asnos (Equus africanus asinus), vacas (Bos taurus, B. indicus). Hubo también especies que por su naturaleza no se adaptaron a estos climas, como aconteció con los borregos (Ovis aries) y cabras (Capra aegagrus hircus).

En el caso de las ovejas se sabe que, desde su introducción, generaron varios problemas de adaptación al clima y no prosperaron en la península de Yucatán

[...] aunque el ganado ovejuno, por la aspereza de la tierra, no se da tan bien como

los demás, y la falta de agua es la mayor ocasión de no ser mucho el multiplico [...];

(Relación de la ciudad de Mérida: 81).

Si bien se puede saber cuáles fueron las especies domésticas que llegaron a tierra firme, es poco o nada lo que se sabe acerca del proceso de adaptación de ellos y la forma como comenzaron a ser manejados por la población local. Algunas conjeturas sobre ellos son las siguientes:

- El perro: los que traían los españoles eran mayores, eran usados para la defensa y el ataque a seres humanos mediante el "aperreo", eran alimentados de manera distinta y no eran considerados comestibles; sin embargo, terminaron por cruzarse con el perro local denominado malix, la población maya continuó comiéndose a estos y a los nuevos perros mestizos, razón por la que hubo necesidad de prescribir el uso alimenticio de los perros en general.

- El gato: los felinos tenían un papel importante dentro de la cosmovisión mesoamericana no hay evidencia de su intento de domesticación. Sin duda, el gato causó desconcierto al conocerse su docilidad y facilidad de cría y su importante papel como controlador de fauna nociva pequeña.

- La gallina: su fácil cría, y el que haya sido entregada por los hispanos a los mayas para que la criasen y entregaran como tributo, seguramente permitió su rápida propagación
Tabla 20.5. Fauna introducida a los solares del área maya de Yucatán durante el siglo XVI, según fuentes de ese siglo.

\begin{tabular}{|c|c|c|}
\hline Especie & Información & Referencias del siglo xvi \\
\hline \multirow{2}{*}{$\begin{array}{r}\text { 1. Nombre en español } \\
\text { Especie }\end{array}$} & cerdo & \multirow{3}{*}{$\begin{array}{l}\text { También hay cantidad de caballos alanos y muy lige- } \\
\text { ros, vacas, carneros,..., puercos, gatos, perros y todo } \\
\text { - se cría y hay muy bien [...] (Relación de la ciudad de } \\
\text { Mérida: } 81 \text {. }\end{array}$} \\
\hline & Sus scrofa & \\
\hline 2. Nombre en español & $\begin{array}{l}\text { perros distintos a los } \\
\text { mesoamericanos }\end{array}$ & \\
\hline Especie & Canis lupus familiaris & \multirow{5}{*}{$\begin{array}{l}\text { Dase bien en esta tierra y críase el ganado vacuno y y } \\
\text { porcuno, yeguas, cabras...; [...]; (Relaciones de la Villa } \\
\text { de Valladolid: Tll-43). }\end{array}$} \\
\hline \multirow{2}{*}{$\begin{array}{r}\text { 3. Nombre en español } \\
\text { Especie }\end{array}$} & gato & \\
\hline & Felis silvestris catus & \\
\hline \multirow{2}{*}{$\begin{array}{r}\text { 4. Nombre en español } \\
\text { Especie }\end{array}$} & asno & \\
\hline & $\begin{array}{l}\text { Equus africanus asi- } \\
\text { nus }\end{array}$ & \\
\hline \multirow[t]{2}{*}{ 5. Nombre en español } & gallina & \multirow{4}{*}{$\begin{array}{l}\text { Tienen aves domésticas y que, crían en las casas } \\
\text { como son sus gallinas y gallos en mucha cantidad, } \\
\text { aunque son penosos de criar. Hanse dado a criar aves } \\
\text { de España, gallinas, y crían muchas a maravilla, y en } \\
\text { todos los tiempos del año hay pollos de ellas. Crían } \\
\text { algunas palomas mansas, de las nuestras, y (sé) mul- } \\
\text { tiplican mucho [---]; (Landa } 1983 \text { [1566]: 51). }\end{array}$} \\
\hline & Gallus gallus & \\
\hline \multirow[t]{2}{*}{ 6. Nombre en español } & paloma & \\
\hline & Columba sp. & \\
\hline
\end{tabular}

Notas:

(1) Los caballos (Equus caballus) y las vacas (Bos taurus, B. indicus) entrarían al solar indígena entre los siglos XVII y XIX.

(2) Hubo también especies que por su naturaleza no se adaptaron a estos climas, como aconteció con los borregos (Ovis aries) y cabras (Capra aegagrus hircus).

además que dentro de la cultura local existía ya toda una tradición en la cría del pavo o guajolote, conocido por los españoles como "gallina de la tierra" para diferenciarlos de la "gallina de Castilla" que ellos introdujeron, así como de otras especies como el cambul y las gallinas de monte. También tuvo la ventaja de ser menos enfermiza.

- La paloma: el criar palomas autóctonas y tortolitas, sin duda favoreció la adopción de las palomas europeas, mismas que seguramente los frailes facilitaron su difusión por el papel sagrado dentro del catolicismo que simbólicamente tienen como representante del espíritu santo.

- El cerdo: el que Diego de Landa mencione que el sabor del perro cebado con maíz tiene un sabor similar al del lechón o cerdo pequeño, lo convirtió en el animal que sustituyera al perro en la dieta local, teniendo además la cultura de captura, consumo y probable crianza del pecarí de collar y del de labios amarillos, aunque la carne de estos tenga un sabor poco más fuerte. Otro probable hecho es que al estar en libre pastoreo, el cerdo doméstico se cruzara ocasionalmente con el silvestre o con ferales. 
Este mismo patrón de acomodo de especies introducidas, dado el antecedente de cría y consumo de especies autóctonas, sucedió a principios y a lo largo del siglo XX, cuando llegó de Estados Unidos la abeja italiana (Apis melifera) que -aunque más agresiva que las abejas sin aguijón domesticadas en el área maya y con una miel de menor calidad, pero mucho más productivas- terminó por ser adoptada por la población maya, al grado que al finalizar el siglo $\mathrm{XX}$ e iniciar el XXI, la cría de las abejas nativas está en franco riesgo de desaparecer.

Finalmente, al congregar en pueblos, hacia 1550, alas familias mayas que antes vivían en el monte, junto a sus campos de cultivo, hubo necesidad de que los varones siguieran en sus milpas, mientras las mujeres iniciaran el cuidado y cultivo del solar, encontrándose una referencia muy interesante sobre su forma de trabajar.

[Las mujeres]... son grandes trabajadoras... de ellas cuelgan los mayores y más trabajos de la sustentación de sus casas y educación de sus hijos, y paga de sus tributos, y con todo esto, si es menester, llevan algunas veces carga mayor labrando y sembrando sus mantenimientos. Son a maravilla granjeras, velando de noche el rato que de servir sus casas les queda, yendo a los mercados a comprar y vender sus cosillas. Crían aves de las suyas y las de Castilla para vender y para comer. Crían pájaros para su recreación y para las plumas, con la que hacen sus ropas galanas; y crían otros animales domésticos de los cuales dan el pecho a los corzos, con los que los crían tan mansos que no saben írseles al monte jamás, aunque los lleven y traigan por los montes y críen de ellos.... (Landa 1983 [1566]: 66).

\section{La fauna del traspatio en la actualidad}

Con el fin de clasificar los elementos faunísticos se propone la siguiente categorización antropocéntrica de uso:

Fauna de protección: animales cuya función es el cuidado del huerto familiar: perro (Canis lupus familiaris), gato (Felis silvestris catus) y ganso (Anser anser).

Fauna para la reproducción de la unidad familiar: utilizada para consumo, venta e intercambio en pie o procesado, destacándose: vacas (Bos taurus, B. indicus), cerdo (Sus scrofa), gallina (Gallus gallus), pavo (Meleagris gallipavo), conejo (Oryctolagus cuniculus), pato criollo (Cairina moschata), pato pekín (Anas platyrhynchos) y palomas (Columbina $\mathrm{sp}$.). También se incluye la fauna silvestre que es llevada al huerto por un tiempo y finalmente es consumida o vendida: tortugas de agua dulce como el pochitoque (Kinosternon leucostomum), el guao (Staurotypus tryporcatus) y la jicotea (Pseudemys scripta), iguanas (Iguana iguana), garrobos (Ctenosaura sp.), puercos de monte (Dicotyles tajacu), armadiIlos (Dasypus novemcinctus), tepescuintles (Cuniculus paca), codornices (Colinius virginiuanus), mazates (Mazama americana) y venados (Odocoileus virginianus), entre otros.

Fauna de trabajo: animales que auxilian a la familia en el trabajo cotidiano y que solo llegan a traspatio para pernoctar: bueyes (Bos taurus, B. indicus), caballo (Eqqus caballus), burro (Eqqus africanus asinus) y mulas (Equus africanus asinus x Equus caballus)
Fauna ornamental: animales con función estética que muchas veces se encuentran cautivos: cotorros (Amazona albifrons, A. autumnalis, A. farinosa, A. ochrocephala), cenzontles ( $M i$ mus polyglottus), coatíes (Nasua nasua), pijijes (Dendrocygma autumnalis), mono arañas (Ateles geoffroyi), ardillas (Sciurus sp.) entre otros.

Mascotas: son utilizadas como acompañantes de uno o más de los miembros de la unidad doméstica: perro, gato. Además, Herrera-Flores (2016) encontró 33 especies silvestres en el norte de Yucatán. De ellas tres son reptiles, once mamíferos y diecinueve aves.

Fauna medicinal tradicional: son utilizadas para curar algún tipo de dolencia o para prevenirla. El ejemplo mejor conocido es el de la gallina negra (Gallus gallus domestica) utilizada para limpias y sahumerios; en el caso de la región de Los Altos de Chiapas, la población tzotzil y tzeltal las usan para intercambiar el alma o ch'ulel de los enfermos que ha sido atrapada por el señor de la tierra. Normalmente se usan las gallinas negras, pero ante la falta de estas cualquiera puede ser utilizada (Voght, 1979; Barba de Piña Chan, 1987; Holland, 1989; Zollá y Argueta, 2009, Mariaca, 2013). En el área maya peninsular, específicamente en Cobá, Quintana Roo, Figueroa (2017) relata la práctica ceremonial del k'eex, que se trata de un cambio cuando la vida y el alma de una persona se encuentran en riesgo por causa del mal ocasionado por un alux, un mal viento o la xtabay (espíritu femenino mítico), utilizándose, entre otros productos, un pavo y gallinas negras, que tienen plumas y pie negra. La gallina ahí es utilizada, además, para el pasmo de la sangre, para evitar el aborto, mordedura de serpiente, fortificar la sangre y para el mal de ojo. También menciona otras especies provenientes del solar como son la abeja melipona (Melipona beechi) y su miel, el sebo de vaca (Bos indicus) y de chivo (Capra hircus), el pato (Cairina moschata domestica) y la carne de iguana (Ctenosaura similis).

Fauna dañina: son los animales que afectan negativamente la calidad de vida de los integrantes del huerto familiar, ya sea comiéndose los granos y otros alimentos, devorando huevos y a la fauna aviar: ratas (Rattus rattus, Neotoma sp.), ratones (Mus musculus), serpientes, tlacuaches (Didelphys marsupialis) y felinos como gatos silvestres (Felis silvestris catus) y tigrillos (Leopardus wiedii). También podrían entrar algunos insectos y aves frugívoras que dañan parte de la producción al madurar los frutos como los zanates (Quiscalus mexicanus) y los loros.

Fauna sin uso directo que son parte de la estructura del agroecosistema: animales que viven en los árboles y plantas, entre las piedras, bajo tierra, dentro de las estructuras humanas, así como los que migran cotidianamente usando al huerto como sitio de alimentación o de estancia temporal. Esta fauna generalmente no afecta de forma significativa a los miembros productivos del huerto, pero son parte de las redes tróficas y de las interacciones bióticas naturales, como los artrópodos, pequeños mamíferos, reptiles, anfibios aves y murciélagos.

Poco estudiado y, por tanto, mal caracterizado y analizado de este subsistema se ha resaltado su importancia como "alcancía familiar", en el entendido que la mayor parte de las familias rurales invierten sus excedentes económicos en la cría de animales, siendo un reflejo de bonanza económica grandes parvadas de aves o una abundante piara. 
Un estudio realizado en Hocabá, Yucatán (Aké Gómez, 1999), da cuenta que los componentes económicos más productivos del traspatio maya son la producción de frutales y los animales de traspatio, máxime cuando se alternan con alguna otra actividad económica dentro de solar. Además, la cría de animales del solar representa el 9\% de calorías, el 10\% de proteínas, el $47 \%$ de grasas y el $10 \%$ de riboflavina, niacina y vitaminas A dentro de la dieta familiar (Stuar 1993, mencionado por Carrillo Magaña, 1994)

Nuestro recorrido por alrededor de 200 huertos familiares del sureste de México nos ha permitido distinguir 17 especies de animales domésticos (Tabla 6) distribuidos más o menos homogéneamente, exceptuando a los animales de carga que están casi ausentes en Tabasco y a las abejas sin aguijón que casi han desaparecido de Tabasco y Chiapas, aunque ocasionalmente se encuentre un tronco meliponario en alguna vivienda.

Junto a los animales domésticos aparecen en, aproximadamente, un 3 a $5 \%$ de los huertos familiares del sureste de México ejemplares de fauna silvestre, mismos que en su mayoría han sido traídos del monte o capturados en sus primeros estadios de vida. En algunos casos hay reproducción dentro del huerto. Hemos encontrado alrededor de 94 especies entre aves (63 especies), mamíferos (18 especies) y reptiles (13 especies) principalmente (Tablas 20.7, 20.8 y 20.9 ), teniendo estas una cantidad indeterminada de nombres comunes en español como en las distintas lenguas mayenses y zoque de la región.

Llama la atención que los animales silvestres en su mayoría son considerados como fauna de ornato o recreación (un lujo, un adorno, alegran la casa), algunos son considerados como mascotas cuando son juveniles, ya que al convertirse en adultos se vuelven agresivos terminando por ser sacrificados (para alimentación o no), o soltados en el campo. En ocasiones son encerrados de por vida y en pocos casos se les asigna una pareja para reproducirse.

Es importante mencionar que en el huerto familiar existe un proceso permanente, desde tiempos inmemoriales (tenemos evidencias del siglo XVI), de intento de domesticación de especies silvestres, siendo este seguramente el principio de muchas de las especies domesticadas en la actualidad.

En ese sentido, a partir de lo consultado en la literatura sobre el tema (Valadés 1996; Clutton 1999 y 2002 y; Vilá 2012) y de reflexiones propias de lo observado en campo (Mariaca, 1997), sabemos de todo un proceso permanente de cría de animales silvestres en los traspatios, donde el deseo de la gente es que los animales se reproduzcan y que la descendencia seaa mansa; sin embargo están conscientes de que esto no puede ser, basados en la experiencia adquirida con el paso de los años más lo aprendido de sus mayores.

Hoy sabemos que un animal silvestre puede llegar al traspatio familiar llevado por uno de los miembros de la unidad de producción, o bien solo. Cuando ocurre esto último, el individuo comenzará a frecuentar el espacio humanizado y no será ahuyentado ni atrapado, sino tolerado; después, al comenzar a haber mayor aceptación de la gente y confianza del animal, los primeros comenzarán a fomentar su presencia y la gente a través de dejarles comida o darles facilidades para su reproducción o para un mayor tiempo de estancia en algún lugar del traspatio. Entonces la gente puede atraparlo o el animal permitir la cercanía de la gente, incluso podría llegar a haber contacto físico y una mayor convivencia.
Cuando han crecido en el seno de la familia, por haber sido llevados muy pequeños o porque han nacido en el traspatio, es frecuente, por ejemplo, observarlos en corrales o libres en tota estado de amansamiento, en este momento es cuando se dice que el animal ha sido domado (no domesticado). También iniciará un proceso más cuidadoso de selección humana, buscando reproducir determinadas características bajo cuidado de la familia. Si se diera el caso que el animal en cuestión tuviera en su carga genética genes de docilidad con probabilidades de convivir armónicamente y reproducirse en ámbitos humanizados, entonces estaríamos ante un efecto fundador, con animales semidomesticados en un principio a partir de un aislamiento genético. Con el paso del tiempo, y en la medida que las poblaciones semidomesticadas crecen, se fijan cada vez más las características que empiezan a marcar diferencias palpables con las poblaciones silvestres, comenzarán a aparecer razas, variantes intrarraciales, entre otras variaciones, hasta conformar una especie domesticada.

En este proceso de domesticación permanente, los animales silvestres tolerados y fomentados casi siempre seguirán teniendo vida libre, mientras que los amansados y las poblaciones aisladas genéticamente, podrán regresar a su estado silvestre o semisilvestre como animales ferales. Eventualmente, los domesticados pueden escapar, asilvestrarse y reproducirse con sus parientes silvestres (Figura 20.2). Es oportuno aclarar que este modelo se cumple en los solares que crían fauna silvestre generalmente hasta el nivel de amansado, al mismo tiempo que una vez que llegan animales domésticos de distintas razas, también se da un proceso de mestización al cruzarse libre o selectivamente con los animales criollos que la familia posee.

En la actualidad, el tráfico excesivo de fauna silvestre ha obligado a las autoridades a incautar cualquier ejemplar que se detecte, eso ha impactado en la reducción de animales de este

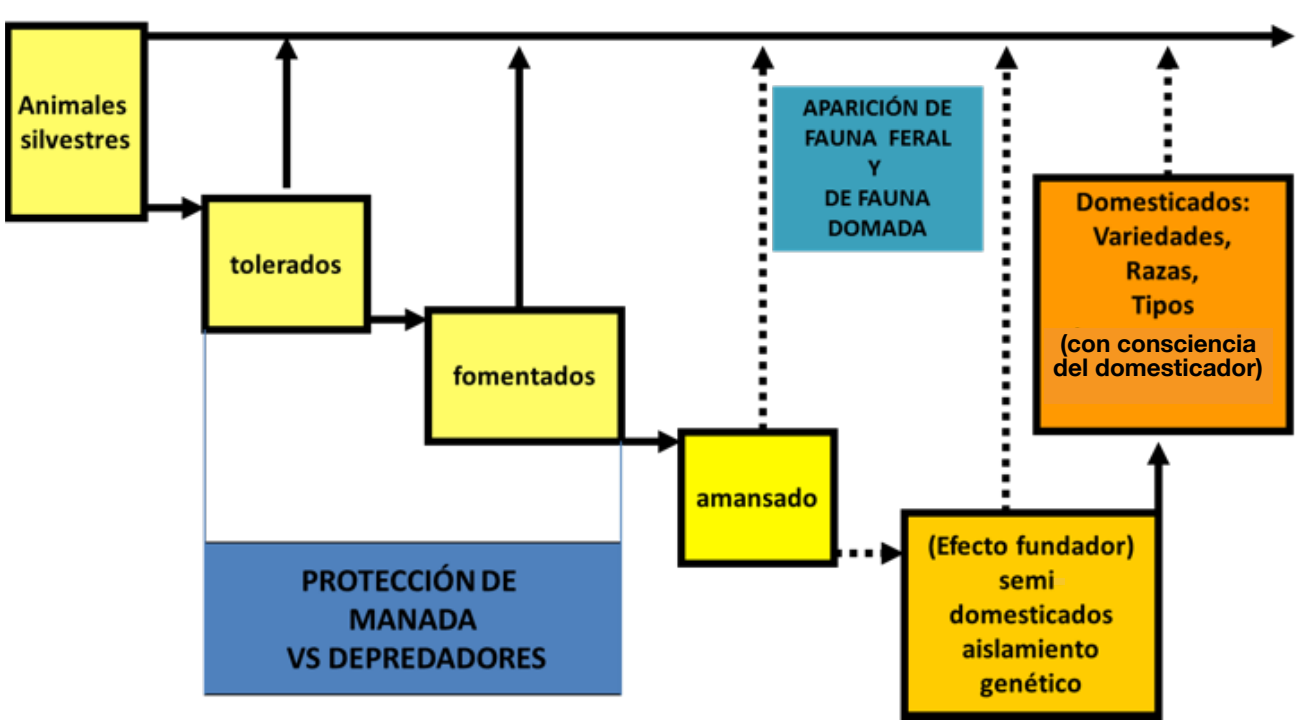

Figura 20.2. Proceso de domesticación animal en traspatios familiares, con base en Valadés (1996), Mariaca (1997), Clutton $(1999,2002)$, Vilá (2012). 
tipo en las casas campesinas; sin embargo, la falta de cobertura de la Procuraduría Federa del Medio Ambiente (PROFEPA) permite aún que en las comunidades rodeadas por montes o bosques, el flujo del bosque o selva al huerto familiar persista. La fauna silvestre representa una parte marginal que enriquece la gastronomía local sumándose a la carne de monte. Acompañando a la fauna criada, están la fauna dañina y la fauna sin uso directo para el ser humano. En el primer caso se trata casi siempre de animales depredadores del espacio antrópico, tales como el tlacuache (Didelphis marsupialis), algunos felinos como el tigrillo y felinos menores (Leopardus wiedii, Felis sp.), ratas caseras (Rattus sp.) e incluso serpientes como la nauyaca (Botrops sp.) o la víbora de cascabel (Crotalus spp.).

\section{Tabla 20.6. El subsistema fauna domesticada presente} en los solares del sureste de México.

\begin{tabular}{llc} 
Nombre común & Cannis lupus familiaris & $\begin{array}{c}\text { Categorías antropo- } \\
\text { céntricas de uso } \\
\text { (este trabajo) }\end{array}$ \\
\hline Gallina & Gallus gallus & $2,3,6$ \\
\hline Cerdo & Sus scrofa & $1,5,7$ \\
\hline Pavo & Melleagris gallopavo & 1,5 \\
\hline Pato & Anas sp. & 1,5 \\
\hline Paloma & Columba sp. & 1,5 \\
\hline Borrego & Ovis aries & 1,4 \\
\hline Gato & Felis silvestris catus & 1,5 \\
\hline Caballo & Equus caballus & 3,6 \\
\hline Vaca & Bos indicus, B.taurus & 2 \\
\hline Burro & Equus africanus asinus & 1,2 \\
\hline Conejo & Sylvilagus sp. Esta especie es silvestre y a la que & 2 \\
& hace referencia más arriba es el conejo europeo & $1,5,6$ \\
\hline Mula & Eue si es domesticado es Oryctolagus cuniculus & 2 \\
\hline Ganso & Anser anser & 3,4 \\
\hline Gallina de Guinea & Numida meleagris & 4 \\
\hline Abejas sin aguijón & Melipona sp. & 1,7 (su miel) \\
\hline Pato peruviano* & Cairina moschata & 1,4 \\
\hline Gatinus & \\
\hline
\end{tabular}

Categorías antropocéntricas de uso: 1) alimentación, 2) de trabajo, 3) de protección, 4) de ornato o recreación, 5) para venta, 6) mascota, 7) medicinal tradicional, 8) inocua, propia del huerto, y 9) dañina.

* Esta especie se encuentra tanto criada con altos niveles de domesticación como silvestre, por ello se encuentra repetida en ambas categorías.
Tabla 20.7. Aves silvestres (63) presentes en algunos traspatios del sureste de México como ornato o mascotas y ocasionalmente como alimento.

\begin{tabular}{llc} 
Nijiji aliblanco & Dendrocigna autumnalis & $\begin{array}{c}\text { Categorías } \\
\text { antropocéntricas } \\
\text { de uso }\end{array}$ \\
\hline Pato real * & Cairina moschata & 1,4 \\
\hline Cercetas, patos & Annas spp. & 1,4 \\
\hline Patos & Aythya spp. & 4 \\
\hline Gallareta americana & Fulica americana & 4 \\
\hline Aguililla rojinegra, halcón Harris & Parabuteo unicinctus & 4 \\
\hline Aguililla cola roja & Buteo jamaicensis & 4 \\
\hline Aguililla caminera & Buteo magnirostris & 4 \\
\hline Halcón guaco & Herpetoheres cachinnans & 4 \\
\hline Halcón selvático & Micrastus semitorquatus & 4 \\
\hline Chachalaca de vientre blanco & Ortalis leucogastra & 4 \\
\hline Chachalaca común & Ortalis vetula & 1,4 \\
\hline Pava, cojolita & Penelope purpurascens & 1,4 \\
\hline Ocofaisan & Crax rubra & 1,4 \\
\hline Pavón & Oreophasis derbianus & 1,4 \\
\hline Codorniz bolonchaco & Odontophorus guttatus & 1,4 \\
\hline Codorniz cotui & Colinus virginianus & 1,4 \\
\hline Codorniz yucateca & Colinus nigrogularis & 1,4 \\
\hline Codorniz ocellada & Cyrtonix ocellatus & 1,4 \\
\hline Cotorra de frente naranja & Aratinga anicularis & 1,4 \\
\hline Cotorra verde & Aratinga orochlora & 4 \\
\hline Perico pecho sucio & Aratinga nana & 4 \\
\hline Cotorra centroamericana & Aratinga strenua & 4,5 \\
\hline Guacamaya roja & Ara macao & 4,5 \\
\hline Periquito barbinaranja & Brotogeris jugularis & 4,5 \\
\hline Loro de corona blanca & Pionus seniles & 4,5 \\
\hline Loro de frente blanca & Amazona albifrons & 4,5 \\
\hline Loro nuca amarilla & Amazona auropalliata & 4,5 \\
\hline Loro de mejilla amarilla & Amazona automnales & 4,5 \\
\hline Loro de cabeza azul & Amazona farinosa & 4,5 \\
\hline Tucaneta verde & Aulacorhynchus prasinus & 4,5 \\
\hline Tucán collarejo & Pteroglossus torquatus & 4,5 \\
\hline Tucán pico de canoa & Ramphastos sulfuratus & 4,5 \\
\hline Quetzal & Pharomacrus mocinno & 4,5 \\
\hline & & 4,5 \\
\hline
\end{tabular}




\begin{tabular}{llc} 
Nombre común & Nombre científico & $\begin{array}{c}\text { Categorías } \\
\text { antropocéntricas } \\
\text { de uso }\end{array}$ \\
\hline Trogón collarejo & Trogon collaris & 4 \\
\hline Trogón violáceo & Trogon violaceus & 4 \\
\hline Momoto coronicafé & Momotus mexicanus & 4 \\
\hline Momoto coroniazul & Momotus momota & 4 \\
\hline Urraca copetona & Calocitta formosa & 4 \\
\hline Papamoscas atigrado & Myiodynastes luteiventris & 4 \\
\hline Mosquero cabezón degollado & Pachyramphus aglaiae & 4 \\
\hline Toledo & Chiroxiphia linearis & 4 \\
\hline Jilguero, clarín & Myadestes occidentalis & 4 \\
\hline Zorzal pardo & Turdus grayi & 4 \\
\hline Zorzal cuellirrufo & Turdus rufitorques & 4 \\
\hline Cenzontle tropical & Mimus gilvus & 4 \\
\hline Chinito & Bombycilla cedrorum & 4 \\
\hline Cardenal & Cardinalys cardinales & 4,5 \\
\hline Cardenal & Cardinalis sp. & 4,5 \\
\hline Chinchinbacal & Euphonia sp. & 4 \\
\hline Azulejo & Thraupis sp. & 4 \\
\hline Mariposo & Passerina ciris & 4 \\
\hline Dominico & Carduelis psaltria & 4 \\
\hline Colorín azul & Passerina cyanea & 4 \\
\hline Semillero de collar & Sporophila torqueola & 4 \\
\hline Bolsero & Icterus sp. & 4 \\
\hline Jilguero dominico & Spinus psaltria & 4 \\
\hline Zacua, oropéndola & Psarocolius montezuma & 4 \\
\hline Tinamú canelo & Crypturellus cinnamomeus & 4 \\
\hline Paloma morada & Patagioenas flavirostris & 4 \\
\hline Paloma ala blanca & Zenaida asiática & 4 \\
\hline Tortola rojiza & Columbina talpacoti & 4 \\
\hline Paloma arroyera & Leptotila verreauxi & 4 \\
\hline Pelícano & Pelecanus sp. & 4 \\
\hline & Narajo (2014) & 4 \\
\hline
\end{tabular}

Tabla 20.8. Mamíferos silvestres (18 spp.) presentes en algunos traspatios del sureste de México como mascotas u ornato.

\begin{tabular}{|c|c|c|}
\hline Nombre común & Nombre cientifico & $\begin{array}{c}\text { Categorías } \\
\text { antropocéntricas } \\
\text { de uso }\end{array}$ \\
\hline Conejo de Castilla & Sylvilagus floridanus & 1,6 \\
\hline Ardilla café & Sciurus deppei & 1,4 \\
\hline Ardilla gris & Sciurus aureogaster & 1,4 \\
\hline Ardilla yucateca & Sciurus yucatanensis & 1,4 \\
\hline Ratón casero & Mus musculus & 6 \\
\hline Tepezcuintle, cereque & Cuniculus paca & 1,6 \\
\hline Sereque & Dasyprocta punctata & 1,6 \\
\hline Zorra gris & Urocyon cinereoargenteus & 6 \\
\hline Coatí, tejón, andasolo & Nasua narica & 6,9 \\
\hline Mapache & Procion lotor & 6,9 \\
\hline Mono araña & Atteles geoffroyi & 6 \\
\hline Pecarí de labios blancos, censo & Tayassu pecari & 1,6 juveniles \\
\hline Pecarí de collar, jabalí & Pecari tajucu & 1,6 juveniles \\
\hline Venado cola blanca & Odocoileus virginianus & 1,6 juveniles \\
\hline Venado temazate, cabrito & Mazama americana & 1,6 juveniles \\
\hline Tapir, danta & Tapirus bairdii & 4,5 \\
\hline Jaguar & Panthera onca & 5,6 juveniles \\
\hline Mico de noche & Potos flavus & 6 \\
\hline
\end{tabular}

Fuentes: Mariaca (2012), Naranjo (2014) y Herrera-Flores (2016)

Categorías antropocéntricas de uso: 1) alimentación; 2) de trabajo; 3) de protección; 4) de ornato o recreación; 5) para venta; 6) mascota; 7) medicinal tradicional; 8) inocua, propia del huerto, y 9) dañina.
Categorías antropocéntricas de uso: 1) alimentación; 2) de trabajo; 3) de protección; 4) de ornato o recreación; 5) para venta; 6) mascota; 7) medicinal tradicional; 8) inocua, propia del huerto, y 9) dañina.

* Esta especie se encuentra tanto criada con altos niveles de domesticación como silvestre, por ello se repite en ambas categorías. 
Tabla 20.9. Reptiles silvestres (13) presentes en algunos los traspatios del sureste de México como mascotas u ornato.

\begin{tabular}{llc} 
Nombre común & \multicolumn{1}{c}{ Nombre científico } & $\begin{array}{c}\text { Categorías antropocén- } \\
\text { tricas de uso }\end{array}$ \\
\hline Caimán & Caiman crocodilus & 1,6 \\
\hline Cocodrilo de río & Crocodylus acutus & 1,6 \\
\hline Cocodrilo de pantano & Crocodylus moreletii & 1,6 \\
\hline Iguana negra & Ctenosaura similis & 1,6 \\
\hline Iguana verde & Iguana iguana & 1,6 \\
\hline Tortuga lagarto & Chelydra serpentina & 1,6 \\
\hline Tortuga casquito & Kinosternon leucostomum & 1,6 \\
\hline Tortuga casquito & Kinosternon scorpioides & 1,6 \\
\hline Tortuga jicotea & Trachemys scripta & 1,6 \\
\hline Tortuga jicotea & Trachemys venusta & 1,6 \\
\hline Tortuga almizclera & Staurotypus salvinii & 1,6 \\
\hline Tortuga almizclera gigante & Staurotypus triporcatus & 1,6 \\
\hline Boa, mazacuata & Boa constrictor & 1,6 \\
\hline
\end{tabular}

Fuentes: Mariaca (2012), Naranjo (2014) y Herrera-Flores (2016)

Categorías antropocéntricas de uso: 1) alimentación; 2) de trabajo; 3) de protección; 4 de ornato o recreación; 5) para venta; 6) mascota; 7) medicinal tradicional; 8) inocua propia del huerto; 9) dañina.

Otro aspecto importante a considerar dentro de la fauna silvestre -casi no abordado a la fecha- es su función ecológica, donde se dan interacciones bióticas entre: fauna-fauna, fauna-ser humano, vegetación-fauna y ser humano-vegetación-fauna. Por otro lado, las instalaciones donde viven los animales o se refugian por las noches o cuando están en proceso reproductivo (nidos, gallineros, corrales, chiqueros, cercos), variarán de región a región debido, entre otras cosas, a los materiales disponibles y a la economía familiar, al clima, al tipo de amenazas que tienen los animales, a los perjuicios que pueden ocasionar estando libres, a las tradiciones locales y a las innovaciones que han demostrado ser adaptativamente exitosas.

Al comparar la fauna usada en tiempos prehispánicos con la actual, salta a la vista un proceso continuo de búsqueda de contar con animales silvestres cada vez más humanizados lográndose esto a través de la cría y doma, sobre todo a partir de cachorros. Esto ha llevado a la población campesina a traer a su casa casi todas las especies de animales que puedan darle alguna utilidad, excepto aquellas que no son atractivas, que son muy agresivas, que no tienen alguna utilidad o a las que se acude con muy poca frecuencia. También se exceptúan algunas especies consideradas tabú o bien tiene que ver con la abundancia de recursos o su escasez. De esta forma, hay especies que en alguna región se consumen y en otras que no. Esto último hace que algunas serpientes o aves sean o no consumidos entre algunos pueblos.
También suele haber un manejo diferenciado entre animales de la misma especie, tal como sucede con los cerdos, ya que hay familias que crían cerdos de raza para venta comercial y cerdos criollos para consumo local o familiar. Tanto en Chiapas como en Yucatán (Terán y Rasmussen, 2010 y Perezgrovas-Garza, 2011), los criollos comen maíz y deshechos y viven prácticamente en libre pastoreo, mientras los "cerdos americanos" necesitan de chiquero, baño diario, alimento especial y medicamentos y vacunas. Claramente, estos últimos tienen mayores tasas de crecimiento y conversión alimenticia y, por tanto, engordan mucho más rápido.

Con los perros sucede algo similar ya que los que tienen habilidad para cazar reciben cuidados y alimentación diferente a los que solo sirven de compañía. De igual manera sucede con las gallinas negras en algunos lugares, ya que se piensa que sirven para proteger a la parvada contra enfermedades naturales y culturales.

Otro aspecto importante y que varía también de pueblo a pueblo, es el manejo que se le da las diferentes especies e incluso el papel que estas puedan tener en la cosmovisión local. Junto con esto, llama la atención al recorrer la geografía regional, la gran diversidad de instalaciones dónde albergan a los animales, tanto por su forma como por sus materiales. A la fecha se ha caracterizado esta diversidad con las casas habitación de acuerdo con su clima y materiales disponibles, así como la cultura que las construye. Así entonces, la arquitectura vernácula da cuenta de casas de techos de dos y cuatro aguas, de paredes ligeras en clima cálido húmedo y de barro y bajareque en climas templados. Sin embargo, a la fecha no se han hecho estudios arquitectónicos a las instalaciones como gallineros, chiqueros, cercos muertos y otras instalaciones, donde en cada región se hace notar la adaptación de la infraestructura a las condiciones ambientales y a la cultura. Con los graneros de maíz, Hernández Xolocotzi caracterizó e hizo notar sus diferencias en 1949.

Con respecto a las estructuras elaboradas para proteger animales, los datos son casi inexistentes; sin embargo, Herrera-Castro (1994) contabilizó en el pueblo de Xuilub, Valladolid, Yucatán, gallineros en el $67 \%$ de los solares, porquerizas en el $44 \%$ y apiarios de abejas meliponas en un $33 \%$ de los traspatios. Sin embargo, en recorridos de campo por prácticamente toda la región maicera maya de Yucatán realizados en 2015 y 2016, encontramos que la cría de abejas sin aguijón se ha desplomado al 2-3\% de los solares, mientras que los gallineros y las porquerizas se han incrementado significativamente a niveles de $95 \%$ y $60 \%$ respectivamente.

Otro tema que comienza a desarrollarse de manera puntual, son los medios por los cuáles las población de cada región se vale para curar a sus animales con los medios de que disponen y sin acudir a medicamentos o remedios de patente (Tablas 20.10 y 20.11). Esta información pasa de generación a generación y se alimenta por la múltiple experimentación empírica realizada a lo largo y ancho del territorio y en ocasiones al transferir experiencias exitosas en una especie a otra, de tal manera que algunas plantas medicinales utilizadas para el ser humano se usan para los animales.

Además de plantas, también se usan metales, tierra, polvos distintos y sustancias industriales que no se relacionan directamente con el mal a tratar, al menos desde la perspectiva médica veterinaria. 
El área del conocimiento que aborda este asunto es la etnoveterinaria y a la fecha ha mostrado que muchos de los remedios utilizados de manera tradicional son efectivos, sobre todo cuando se relacionan con formas de curación de heridas; en otros casos no, sobre todo cuando la causa no puede ser determinada por el campesino, como es el caso de enfermedades parasitarias o virales.

Tabla 20.10. Plantas útiles para el cuidado de las aves de corral en la zona ch'ol de Tapijulapa, Tabasco (Guerrero et al., 2016).

Nombre común Árnica o taniché Tithonia diversifolia

\begin{tabular}{lll} 
& Gliricidia sepium & $\begin{array}{l}\text { contra la viruela aviar (buba), gripe y } \\
\text { enfermedad de newcastle ("peste y mal } \\
\text { de aire"). }\end{array}$ \\
\hline Cocoite & Sysphania ambrosoides & Desparasitante. \\
\hline Epazote & Hyptis verticillata & Control de piojos. \\
\hline Hierba Martín & Citrus limon & Fortalecer las defensas de las aves. \\
\hline Limón & Pimenta dioica & $\begin{array}{l}\text { Suplemento alimenticio; prevención de } \\
\text { la viruela y la gripe aviares. }\end{array}$ \\
\hline Pimienta & Erythrina glauca & $\begin{array}{l}\text { Suplemento alimenticio y prevención de } \\
\text { diversas enfermedades. }\end{array}$ \\
\hline Madre chontal & Nicotiana tabacum & $\begin{array}{l}\text { Prevención de piojos y enfermedades } \\
\text { parasitarias. }\end{array}$ \\
\hline Tabaco & Allium cepa & $\begin{array}{l}\text { Prevención de enfermedades y trata- } \\
\text { mientos de heridas. }\end{array}$ \\
\hline Cebolla & Allium sativum & Tratamiento de viruela aviar (bubas). \\
\hline Ajo & Artemisa ludoviciana & Tratamiento contra la diarrea. \\
\hline Estafiate & Salvia coccinea & $\begin{array}{l}\text { Prevención y tratamiento de enferme- } \\
\text { dades parasitarias. }\end{array}$ \\
\hline Corralillo & Justicia spicigera & Fortalecer las defensas de las aves.
\end{tabular}

Otro aspecto interesante es el de la etnotaxonomía o manera en cómo cada pueblo clasifica a sus animales de acuerdo a criterios propios, principalmente cuando son animales mestizos o de raza indefinida, conocidos localmente como criollos. Tal vez el caso más frecuente en con las aves de corral, presentándose a continuación tres casos de gallinas mencionados por Mariaca (2013):

1. Doña Carmen, experta criadora de gallinas, según la gente de Huimango $2^{a}$ sección, en Cunduacán, Tabasco (Mariaca, 1997): 1) sapo (de patas cortas); 2) morisca (de plumas erizadas); 3) barbona (con la papada con plumada); 4) gringa (de pescuezo desnudo); 5) cambuja (decarne y piel moradas); 6) corunga o corundunga (de rabadilla muy corta o sea, sin tiz o con
Tabla 20.11. Remedios de señoras choles de la región de Oxolotán, Tabasco, México. Fuente talleres comunitarios marzo de 2012.

\begin{tabular}{|c|c|c|}
\hline Enfermedad & Sintomatología & Remedios locales \\
\hline Buba & Granos en la cabeza & $\begin{array}{l}\text { Aplicación en las heridas de cloro } \\
\text { con cal, pasta dental o lodo. }\end{array}$ \\
\hline Ajo & $\begin{array}{l}\text { Membrana como hoja de ajo } \\
\text { debajo de la lengua }\end{array}$ & $\begin{array}{l}\text { Se retira y se aplica una gota de } \\
\text { limón. }\end{array}$ \\
\hline Piojo & Piojos en las plumas & $\begin{array}{l}\text { Baño con detergente, uso de ceniza } \\
\text { de comején. }\end{array}$ \\
\hline Gripe & $\begin{array}{l}\text { Presencia de moco en narinas } \\
\text { y garganta }\end{array}$ & $\begin{array}{l}\text { Frota una pluma impregnada de un } \\
\text { poco de petróleo en la garganta; po- } \\
\text { ner un poco de limón. }\end{array}$ \\
\hline Diarrea blanca & $\begin{array}{l}\text { Diarrea de color blanquecino y } \\
\text { presencia de puntos blancos } \\
\text { en hígado }\end{array}$ & $\begin{array}{l}\text { Ofrece hoja de momo o epazote } \\
\text { diario por una semana. }\end{array}$ \\
\hline Lombrices & $\begin{array}{l}\text { Presencia de lombrices en } \\
\text { intestinos y molleja }\end{array}$ & $\begin{array}{l}\text { Ofrece momo o epazote al menos } \\
\text { una vez por semana. }\end{array}$ \\
\hline
\end{tabular}

la rabadilla "como caída"); 7) copetona (con un mechón de plumas finas sobre la cabeza), y 8) lorigada (de color jabado o blanquinegro).

2. En Suclumpá, comunidad ch'ol del municipio de Salto de Agua, Chiapas, Tina Lerner (Lerner, 2017) encontró veinticuatro tipos distintos de gallinas, veintidós de las cuales se enlistan: 1 ) i'ik'patch (blanca con alas negras); 2) i'ik' bak (carne negra); 3) t'atch (colocha); 4) y'shem (color cenizo ); 5) chu chuk ba (colorado medio amarillo); (6) boch'ol (copete de plumas en cabeza ); 7) t'zelem (jaspeada blanco con negro); 8) p'ilos (jaspeada sin plumas en nuca); 9) tsinbik' muty (marrón con cresta pequeña y pecho y cola gris); 10) l'ik' (negra); 11) (negra y carne blanca); 12) ík bucyal (negra y carne negra); 13) vik, shubitana (nuca pelona); 14) murus (nuca pelona y cabeza negra); 15) xu xu'esh (plumas en las patas); 16) c'nken (roja pequeña); 17) ch'chuc (rojiza); 18) tzilem k'kamb (jaspeada amarilla); 19) tzilem (jaspeada gris); 20) ij'lis (jaspeado blanco); 21) ix biram (pelón); 22) xi'xix muc (rojo).

3. La señora Patricia Pérez Jiménez, ama de casa de ascendencia tzotzil y habitante de San Juan Chamula, identificó trece tipos de gallinas de las cuales se enlistan doce: 1) ik' me (negra); 2) sak' me'(blanca); 3) tsoj' (roja) tsoj me'; 4) k'on me' o k'anal me' kaxlan (amarilla, buena ponedora); 5) p'utum (pinta blanca con negro); 6) sararin (matizados de color gris y gris oscuro); 7) uchul me' (colores de gris y gris oscuro con una textura uniforme, siendo muy escasos); 8) t'ax nuk' (pescuezo pelón); 9) moro (con plumas rizadas); 10) tots jol (copetonas); 11) tson ok (con plumas en las patas) y 12) ex jol (cresta punteada en forma de corona). 
Terán y Rassmusen (2010), encontraron en los solares de Xocén, Yucatán doce gallinas distintas: 1) x'chuukil kaax (color carbón morada); 2) x'tiip kaax (pinta como la melindra); 3) k'an kaax (amarilla); 4) guinda kaax (guinda); 5) x'il kaax (chilmole); 6) sak kaax (blanca); 7) tamkos kaax (de pecho blanco y espalda negra); 8) x'mulix (de pluma erizada); 9) x'p'u kaax (con plumas cerca de los ojos); 10) x'em kaax (de carne, patas y pico negro); 11) $x^{\prime}$ pot kaax (con bucles) y; 12) aak kaax (enana).

A su vez, para las gallinas pelonas o x'pelón kaax, dan trece tipos de ellas: 1) box (negra); 2) k'an (mamarilla); 3) sak (blanca); 4) x'chukil (morada); 5) x'tiip (pinta); 6) guinda (guinda); 7) $x^{\prime} i$ (chilmole); 8) x'mulix (rizada); 9) $x^{\prime} p u$ (con plumas alrededor de los ojos); 10) $x^{\prime} \mathrm{em}$ (carne, patas y pico negros); 11) x'p'ot (con bucles); 12) tankos kaax (de pecho blanco y espalda negra) y; 13) aak kaax (enana)

Estas etnoclasificaciones las hemos encontrado en gallos, patos, pavos y cerdos (Lerner, 2007). Es interesante mencionar que en la comunidad Ch'ol de Suclumpá, Salto de Agua, Chiapas, registramos fotográficamente más de cuarenta biotipos distintos de gallinas.

Sánchez Gutiérrez (2012), en una comunidad relativamente cercana de ahí, Tomás Garrido, Tacotalpa, Tabasco, asoció las características morfológicas de las gallinas ahí encontradas con sus probables razas y subrazas de origen, mencionando: 1) gallina barbusha o barbuda Gallus domesticus L. subespecie barbatus; 2) gallina nuca pelada G. domesticus L. subespecie nudicolis; 3) gallina jolina o $\sin$ cola $G$. domesticus $L$. subespecie ecaudatus; 4) gallina crespa, murusha G. domesticus L. subespecie crispus; 5) gallina zapatuda, con botas -plumas en las patas- $G$. domesticus $L$. subespecie giganteus; 6) gallina copetona o copetuda G. domesticus $L$. subespecie cristatus; 7) gallina enana o chaparra $G$. domesticus L. subespecie dorkingensis; (8) gallina tankax, tankarax o pelona -pocas plumas- G. domesticus L. subespecies crispus y nudicollis; 9) gallina carne negra $G$. domesticus $L$. con característica de la raza de gallina Asiática conocida como Silkie (G. domesticus lanatus, japonicus) tambén llamada gallina cedosa; 10 ) gallina colorada o roja $G$. domesticus $L$. asociada a la raza rhode island red; 11) gallina origada -atigrada negriblanca $G$. domesticus $L$. asociada a la raza Pedresa Española; 12) gallina negra $G$. domesticus L. asociada a la raza penede-senca española; (13) gallina pinta $G$. domesticus $L$. ssociada a la raza pita pinta asturiana que esta relacionada con la Euskal Oiloa y con gallinas centro y nord-europeas, y británicas.; (14) gallina blanca $G$. domesticus L. similares a la plymouth rock blanca norteamericana; (15) gallina café $G$. domesticus L. similar a la raza new hampshire norteamericana; (16) gallina amarilla $G$. domesticus $L$. asociada a la a la raza española Pitiüsa y; (17) gallina gris o ceniza G. domesticus L. con rasgos característicos de las razas andaluza azul y extremeña azul, ambas españolas.

En cuanto a la caracterización del cerdo criollo Lemus-Flores et al. (2005), normalmente se han identificado las siguientes razas mexicanas, producto de más de 500 años de adaptación al medio: el cerdo pelón mexicano, el cerdo pata de mula, el cerdo cuino, el cerdo mamellado y el cerdo casco de mula. Sus características y origen describen en el Tabla 20.12

Tabla 20.12. Cerdos criollos mexicanos. Fuente: Lemus-Flores et al. (2005).

Raza criolla

Cerdo pelón mexicano

\begin{tabular}{|c|c|}
\hline & $\begin{array}{l}\text { cuerpo parcial o totalmente despro- } \\
\text { visto de pelo; color grisáceo o com- } \\
\text { binado con blanco; talla mediana con } \\
\text { alzada de } 57 \text { a } 76 \mathrm{~cm} \text {, longitud de } 83 \\
\text { cm y peso adulto de } 70 \text { a } 83 \mathrm{~kg} \text {. Tiene } \\
\text { semejanza con el Cerdo lbérico. Es el } \\
\text { más abundante y difundido. }\end{array}$ \\
\hline erdo pata de mula & $\begin{array}{l}\text { Poco abundante; presenta sindactilia } \\
\text { dominante sobre pezuña normal; pelo } \\
\text { con coloración variable; tamaño me- } \\
\text { diano y perfil variable más bien cón- } \\
\text { cavo. }\end{array}$ \\
\hline erdo cuino & $\begin{array}{l}\text { Antes abundante, hoy casi extinto; } \\
\text { pelo sumamente erizado pero puede } \\
\text { estar desprovisto de él; principalmente } \\
\text { negro pero también hay rojos y pintos; } \\
\text { es dócil; alcanzan a lo sumo } 49 \mathrm{~kg} ; 53 \\
\text { a } 65 \mathrm{~cm} \text { de alzada; cuerpo pequeño } \\
\text { con tendencia a acumular grasa; cara } \\
\text { cóncava y hocico corto; abundantes } \\
\text { depósitos de grasa en el maceteros; } \\
\text { poco prolíficos. }\end{array}$ \\
\hline & $\begin{array}{l}\text { Se caracteriza por poseer apéndices } \\
\text { pendulosos en la base del cuello lla- } \\
\text { mados mamellas }\end{array}$ \\
\hline
\end{tabular}
mados mamellas

Cerdo casco de mula

Características con couñ estar desprovisto de él; principalmente es dócil; alcanzan a lo sumo $49 \mathrm{~kg} ; 53$ a $65 \mathrm{~cm}$ de alzada; cuerpo pequeño ular grasa; cara depósito y he grasa en el maceteros;
Cabeza y cara rectilínea; orejas media- Probablemente a partir de cerdos Cemirrectas; dorso un tanto rec- ceticos, ibéricos y napolitanos intilíneo, ancas completamente caídas; troducidos por españoles más ani( males de raza asiática introducidos 作 政 y peso adulto de 70 a $83 \mathrm{~kg}$. Tiene

\section{Se originó del cerdo asiático.}

Lam

a mamella se asocia a estirpes de Cerdo Ibérico español y portugués, siendo excepcionco Mediterráneo, tronco Celta.

Su principal característica es la sin- Es una mutación. dactilia o presencia de dedos fusionadactilia o presencia de dedos fusionados, condicion que drobablemente los a Peste Porcina Clásica.

Nota 1: los autores describen también al cerdo criollo de Cuba, al de Uruguay y al Pampa, que no hay en México.

De manera específica Perezgrovas-Garza (2011) encontró cinco grupos o patrones fenotípicos, más uno de animales indefinidos (Tabla 20.13), en la comunidad Tzeltal de Aguacatenango, Chiapas, caracterizada por ser un bolsón de diversidad de esta especie hasta que la Secretaría de Salud en 2012 obligó a confinarlos y propició que la mayoría de la población se deshiciera de sus animales. Estos cerdos coincidían por su morfometría promedia con el cerdo cuino de Nayarit. 
Tabla 20.13. Grupos fenotípicos de cerdos criollos

de Amatenango del Valle, Chiapas, México. Fuente: Pérezgrovas (2011).

Biotipo Frecuencia Característica

De color uniforme, robustos, a veces con manchas blancas en Cerdo de una o más patas, orejas pequeñas y levantadas; existe un tipo veces hasta el abdomen.

\begin{tabular}{lcl}
\hline $\begin{array}{l}\text { Cerdo de } \\
\text { color rubio }\end{array}$ & $26 \%$ & Con subvariedades que varían de color claro a un dorado intenso. \\
\hline Cerdo rojo & $14 \%$ & De color ladrillo, grandes. \\
\hline Cerdo pinto & $14 \%$ & $\begin{array}{l}\text { Blancos o rubios con manchas distribuidas por todo el cuerpo; } \\
\text { subdivididos por el número y tamaño de las manchas (parches } \\
\text { pequeños y escasos y manchas grandes por todo el cuerpo). }\end{array}$ \\
\hline Cerdos cafés & $11 \%$ & $\begin{array}{l}\text { Pueden presentar líneas de color oscuro que recorren todo el } \\
\text { cuerpo de manera horizontal. }\end{array}$ \\
\hline $\begin{array}{l}\text { Cerdos } \\
\text { indefinidos }\end{array}$ & $7 \%$ & $\begin{array}{l}\text { Animales que no se ajustan a los patrones descritos y solo esca- } \\
\text { samente se encontraron cruzas entre cerdos locales y de granja. }\end{array}$ \\
\hline
\end{tabular}

Junto a lo anterior aparece otro aspecto etnobiológico de importancia y que tiene que ver con los conocimientos, mitos y creencias que la gente tiene con respecto a sus ganillas, tal es el caso de la información recopilada por Sánchez (2012) en comunidades de Tacotalpa, Tabasco:

- Al colocar los huevos en el nido, debes hacerlo de dos en dos para que nazcan parejas, es decir, obtengas el mismo número de machos y hembras.

- Para que los pollos salgan gordos debes comer antes de colocar a la gallina en su nido.

- Cuando una gallina está echada (en su nido) y estás preparando las tortillas, no debes dejar que el comal se queme por que los pollitos se pegarán en el cascaron.

- Si se presenta un temblor y tienes gallinas en nidos, debes pasarle la escoba de tu casa por la espalda, iniciando de la cabeza hacia la cola, para que nazcan los pollitos, si no se pierden.

- Cuando un gallo canta por las noches y ningún otro gallo le contesta anuncia mal augurio por lo que hay que matar a ese gallo.

- La gallina de carne negra la utilizan los brujos para realizar sus ritos y hechizos. Se utiliza para ensalmar.

Parecería que, de entrada, algunas de estas ideas no tienen un fundamento real; sin embargo, provienen de la interpretación de la gente y del ambiente cosmológico en el que su cultura se desarrolla. En ese sentido, Mariaca (2012) menciona tres formas de cómo la cosmovisión mesoamericana, en general, y maya, en particular, influye en el manejo de la fauna del traspatio en el sureste de México:

- Cuando se construye una casa se hace un ritual en la siembra del primer horcón y otro al finalizarla. En ambos habrá una ofrenda y sobre todo el segundo será realizado por un sacerdote, por ejemplo el ilol entre los tzotziles y tzeltales y el $h m e n$ entre los yucatecos. Se acostumbra enterrar en el centro una cabeza de gallina, pavo, borrego, vaca o una cabecita de muñeca para "dar de comer a la casa" y así evitar que esta se vaya a comer a alguno de los niños de la familia. También se esparce caldo del animal sacrificado en los cuatro horcones.

- La curación de animales del solar o loh entre los mayas peninsulares se realiza cuando animales del solar enferman y su dueña considera que el problema puede salirse de control. El papel del mhen es fundamental.

- Para protección de las abejas sin aguijón, koole cab o xunan cab (Melipona sp.) se realiza un ceremonial dirigido por el hmen pidiendo protección al dueño de las abejas, donde se ofrecerá saka' al Señor de las abejas.

Asimismo, al abundar sobre la relación entre cosmovisión y cría de determinados animales colores, Mariaca (2013) describe la función del plumaje en las gallinas del área maya a partir de trabajo de campo y revisión bibliográfica, ya que Barba (1987) afirma que la propiciación de la tierra con sacrificio de aves, personas y sahumerio era una práctica mesoamericana previa al siglo XVI:

La gallina blanca, sakil alak o sakil mut, tiene básicamente cuatro usos:

- Curativo: en San Juan Chamula se encontraron dos formas. La primera es en la iglesia donde el i'lol, que es el médico tradicional, cura el mal de ojo y el espanto; la otra manera se refiere al uso del huevo de la gallina blanca que sirve para remediar los corajes o espantos, igualmente en un ritual.

- Para trajes de novia: en San Lorenzo Zinacantán, las plumas se usan en la elaboración del huipil emplumado que es el traje típico de la mujer en su boda.

- Para la construcción de casas: en Bochil utilizan a la gallina blanca cuando van a construir una casa, cortándole el i'lol la cabeza y la enterrándola en medio de la casa para que tengan fuerza los cimientos de esta. En San Juan Chamula se hacen por lo general tres rituales a la casa, el primero al iniciar la construcción, el segundo cuando se pone la primera tijera y el tercero al terminar la casa. En los tres se toma el caldo y se entierran las cabezas y patas en el centro de la casa para asegurar que "los dioses de la tierra no penetren a su interior y causen daño".

Sobre este aspecto, Thompson (1987), Vogt (1979), Incháustegui (1987) y Vázquez Dávila et al. (1987) hacen mención previamente para diferentes áreas del pueblo maya.

La gallina negra, ik'al alak o i'kal mut, se usa en rituales asociados a asuntos donde la maldad está presente, ya sea para evitarla o curar el problema generado, o bien, para generar algún tipo de brujería. En Chamula sirven para hacer limpias tomando al animal por las patas y pasándolo por todo el cuerpo, comenzando en la espalda, de la cabeza a los pies y en pocos minutos el animal debe morir porque si no es así, el trabajo no funciona. Se usan para curar alguna enfermedad echada por la brujería negra, el mal de ojo, la pérdida de alma, el aire, el susto. También para hacer algún mal. Están asociadas con el inframundo, lo diabólico, lo oscuro, lo maligno. 
Cuando es usada para la brujería, la gallina negra se degolla viva en una cueva de la comunidad o lugar retirado donde no sea vista, con la sangre que derrama se hace un círculo y se pone la inicial de la persona a la que se le está haciendo el mal y se le prenden siete velas negras y se hacen oraciones. La pluma sirve para curar el fuego a los niños de pocos meses de nacidos.

En Bochil, la gallina negra sirve para las curaciones que hacen los brujos a una mujer, ya que la persona enferma intercambia su alma ( $k$ 'exoli) con el ave; en cambio, para los hombres se usan gallos negros. En Zinacantán, si la enferma es una mujer se busca una gallina que ha dado por primera vez un huevo; si es una niña se busca a una gallina joven (tsebal me' kaxlan); para un hombre sería un gallo negro ( $(k ' a l k e l e m)$ y para los niños un gallito (k'ox kelem).

Page (2005) hace un análisis teórico y empírico acerca del uso terapéutico-ritual de la gallina negra, mencionando que hay iloletik (plural de i'lol), que prefieren dejarla viva, o sea, no sacrificarla después del ritual "para que confunda al pukuj (diablo) o ch'ulel del brujo"; los que optan por sacrificarla para intercambiar el ch'ulel del ave por el del enfermo, hay quienes la degollan y usan su sangre como parte del intercambio ritual y hay quienes optan por romperles el cuello, descerebrándola. Finalmente, habrá quien dispondrá que la gallina sacrificada sirva de alimento para quienes acudieron a la curación y contundentemente lo evitan ya que la gallina contiene el mal que absorbió del enfermo.

Olavarrieta (1977, citado por Zolla y Argueta, 2009), por su parte, afirma que la vigencia mágica que reviste la gallina negra proviene de la tradición europea en la que prácticamente todas las partes de su cuerpo -incluyendo sus huevos- son utilizadas por la medicina mágica, a la vez que es asociada -junto al gallo del mismo color-con la figura del diablo, en tanto los huevos tienen funciones protectoras contra diablos, brujos y toda clase de desgracias. En cuanto a la sangre, este autor menciona que su uso ritual es prehispánico, simbolizando el líquido vital cuya fuerza se transmite por el solo contacto.

La gallina roja, ts'ajal alak', es usada en Huixtán en el proceso curativo ceremonial para sanar la locura, en tanto que el gallo colorado o tsajal tatmut es utilizado en el ritual de encendido por primera vez de un temazcal ahí y en Ocosingo.

Otras gallinas. Existen al menos cinco rasgos en San Juan Chamula: 1) las patas de gallina (o gallo) o yakan kots /me' alak' no se les debe dar a los niños, ya que entonces no sabrán hacer nudos al ser mayores; 2) para que una persona no sea celosa se le debe dar de comer la cresta o xterex kots de un gallo; 3) cuando nace un pollito de pescuezo pelón, t'ax nuk' o timinuk' se considera como una señal de buena suerte para la familia, ya que traerá abundancia de gallinas a la parvada; 4) al matarse una gallina o un gallo de cuello pelón para consumo o para alguna ceremonia, se le da un masaje en el pescuezo para que no vaya a romperse la piel, ya que si brota sangre se considera como mal augurio; 5) antes y después de la siembra de la milpa, el campesino debe comer patas de pollo en caldo para asegurar que al maíz se ancle bien en el suelo. En Zinacantán, cuando brota en la camada un pollo de seis dedos o uaquim, significa un año de mucha abundancia. Para concluir.

\section{Conclusiones}

Los pobladores del pueblo maya del sureste de México han buscado, y siguen buscando, desde hace más de 2500 años domesticar animales silvestres, llevándolos a sus espacios vitales: los solares.

- El pueblo maya pasado y actual ha buscado domesticar aves principalmente, tal vez debido a su mayor abundancia y facilidad de adaptación al hábitat humano.

- En el caso de los mamíferos, la doma es la fase del proceso de domesticación donde más éxito ha logrado el pueblo maya hasta la actualidad.

- La fauna del traspatio es importante, pero más lo es el ser humano que la cría y la mantiene de acuerdo con sus expectativas.

- Los móviles para mantener fauna dentro del traspatio tiene que ver con la economía y la cultura, en especial la cosmovisión.

- La fauna del traspatio representa una importante fuente de germoplasma adaptado a las condiciones de producción campesina, destacándose la rusticidad y la resistencia a enfermedades.

- La fauna del traspatio representa un campo de estudio bastante amplio en beneficio de la independencia alimentaria de los pueblos y comunidades campesinas. 


\section{Bibliografía}

Aké Gómez, A. E., 1999. Análisis económico-financiero del Herrera-Flores, B. G., 2016. Cacería de subsistencia en comunidades rurales del norte de Yucatán, México. Tesis 1997. Tesis de Licenciatura. Facultad de Econ (an Cristóbal d Las Casas, Chiapas, México.

Barba de Piña Chan, B., 1987. Magia. En Álvarez, R. 1987. Holland R., W., 1989. Medicina Maya en los Altos de Enciclopedia de México. Enciclopedia de México y Chiapas. Colección Presencias № 4. [c. 1963]. Consejo

Carrillo Magaña, F. A., 2004. La parte oculta del solar. Revista de la Universidad Autónoma de Yucatán, 228: 14-21.

Clutton-Brock, J., 1999. A natural history of domesticated
mammals. Cambridge University Press. Cambridge. mammals. Cambridge University Press. Cambridge.

Clutton-Brock, J., 2002. Los animales silvestres y domésticos
en el pasado y en el presente. En: Arroyo-Cabrales, J. y E. Corona M. Relaciones hombre-fauna. Plaza y Valdés,

De la Garza et al., M., 1983. Relaciones Histórico Geográficas Mayas IIFUNAM. 2 tomos.

Figueroa-Fernández, A. L., 2017. Medicina tradicional en la comunidad Maya-hablante de Cobá, Quintana Roo, México y su adaptación a la modernidad. Tesis M. en Casas, Chiapas, México.

Goñi, G., 1995. Solares prehispánicos en la Península de Yucatán. Memorias del II Congreso Internacional de
Mayistas. Centros de Estudios Mayas, Instituto de Investigaciones Filológicas, Universidad Naciona Autónoma de México, pp. 437-457.

Gossen, H. G., 1990. Los chamulas en el mundo de/ sol. Colección Presencias № 17. [c.1980]. Consejo Nacional para la Cultura y las Artes e Instituto Naciona Indigenista. México.

Gotz, Ch.M., 2011. Diferencias socioeconómicas en el uso de animales vertebrados en las tierras bajas mayas del norte. En: Cobos, R. y L. Fernández-Souza. Vida de Yucatán. Ediciones de la Universidad Autónoma de Yucatán. Mérida, Yucatán, México, pp. 45-65.

Guerrero-Sánchez, S., E. J. Cano-Contreras, R. MariacaMéndez y F. Guerrero-Sánchez, 2014. Conocimiento local sobre el manejo sanitario de aves de traspatio en dos grupos mayenses del sureste de México. En: Vásquez Dávila, M. A. (Ed.). Aves, Personas y Culturas. Estudios de Etno-Ornitología 1. Red De Etnoecología Patrimonio Biocultural, Consejo Nacional de Ciencia Tenologia, Instiuto Tecnologico del Valle de Oaxaca, pp. $71-82$.

Hernandez Xolocotzi, E., 1949 Maize granaries in Mexico. Botanical Museum Leaflets. Harvard University, 13(7): 153-192.

Herrera-Castro, N. D., 1994. Los huertos familiares mayas en el oriente de Yucatán. Fasciculo 9. Etnoflora Mérida, Yucatán, México.
Indigenista. México.

háustegui, C., 1987. Los márgenes del Tabasco Chontal. Gobierno del Estado de Tabasco. Villahermosa, Tabasco,

Landa, D., 1983 [original 1566]. Relación de las cosas de Yucatán. Dante. Mérida, Yucatán, México.251 p

aughlin, R. M., 1992. Oficios de tinieblas. Como el zinacanteco adivina sus sueños. En: Vogt, Evon Z. (Ed.). Consejo Nacional para la Cultura y las Artes e Instituto Nacional Indigenista. México, pp. 396-413.

emus Flores, C. M. de L. Alonso Spilbury y J. E Abre Sierra, 2005. Evolución y orígenes del cerdo criollo en Latinoamérica. En: Lemus Flores, C. y M. de L. Alonso Spilbury (Eds.). El Cerdo Pelón Mexicano y otros cerdos criollos. Universidad Autónoma de Nayarit. Nayarit México, pp. 15-28.

Wer, T., R. Mariaca, B. Salvatierra, A. González y E. Wahl., 2009. Aporte de alimentos del huerto familiar a la economía campesina Ch'ol, Suclumpá, Chiapas

acNeish, R. S., 1992. The origins of agriculture and settled

anzanilla, L., y Barba, L., 1990. The study of activities in Classic households: two case studies from Coba an

ariaca Méndez, R., 1997. ¿Qué es la Agricultura? Bajo una Perspectiva Xolocotziana. Colección Coedición Universidad Autónoma Chapingo, México.

Mariaca Méndez, R, 2012. La complefdad familir maya Rel 2012. La cón Méndez (Edss.) El huerto familiar del sureste de México. México, Secretaría de Recursos Naturales y Protección Ambiental del Estado de Tabasco/ ECOSUR, pp. 7-97. Ariaca-Méndez R. 2013. El Conocimiento de la gallina (Gallus gallus domesticus) entre los tseltales y tsotsiles de los altos de Chiapas, México. Etnobiología, 11(1) 29-4

Mariaca Méndez, R., A. González-Jácome y L. M. Arias XV. Ecosur/Einustovip/Uimaroo/Cocytey/Conacyt. ariaca-Méndez, R., A. González-Jácome y T. Lerner Martínez, 2007. El huerto familiar en México; Avances y propuestas. En J. F., López Olguín, A. Aragón García, A. M. Tapia Rojas F. Lo.). Avances An agroecología ambiente. Vol. I, Mexla, pp. 119-138. Reyes, 2010. El huerto familiar maya yucateco en el siglo
Martínez Hernández, J., 1929. Diccionario de Motul: Maya- Thompson, J. S., 1987. Historia y religión de los mayas. $8^{a}$ Español. Mérida, Yucatán, México.

edición. Serie América nuestra. Siglo XXI. México.

Page, J. T., 2005. El mandato de los Dioses. Etnomedicina entre tzotziles de Chamula y Chenalhó, Chiapas. Serie Científica No11, Programa de Investigaciones Universidad Nacional Autónoma de México.

Patishtán Pathistán, P., 2009. Chano Bats'i K'op / Aprenda Tzotzil. Centro Estatal de Literatura, Arte y Lengua Indígenas, Chiapas, México.

Pérezgrovas Garza, R., 2011. El traspatio como elemento del sistema de vida de guacatenango, Chiapas, México. En: Pérezgrovas-Garza, R., G. Rodriguez-Galván y L. Experiencias y reflexiones en Argentina, Bolivia Brasil España, México y Uruguay, Universidad Autónomas Chiapas. Tuxtla, Gutiérrez, México, pp. 99-136.

Sánchez-Gutiérrez M. del R., 2012. Caracterización local de gallinas criollas (Gallus domesticus) encontradas en los traspatios de las familias de Tomás Garrido Rural Sustentable. Universidad Intercultural de Tabasco. Oxolotán Tacotalpa, Tabasco, México.

Tapia Rojas (Eds.). Avances en agroecología y ambiente. Vol. I, México. Universidad Autónoma de Puebla, pp. 119-138

Terán-Contraras, S. y Ch. Rasmussen, 2009. La milpa de los mayas. Universidad Nacional Autónoma de México
y Universidad de Oriente. México.
Valdés Editores. México.

Denwarker. Amber M. 2006 Farming hunting and fishing in the Olmec World. Austin: University of Texas Press. Vázquez Dávila, M. A., M. B. Solis Trejo y E. Hipólito en la cultura chontal de Tabasco. En: SECUR-UNESCO. La vivienda rural en el sureste de México. Seis estudios. Secretaria de Cultura recreación y Cultura del Estado de Tabasco y IV Comité UNESCO Vila comisión Nacional para Mexico de la Vlá, B., 2012. Camélidos Suramericanos. Eudeba, Argentina. ogt, E. Z., 1979. Ofrenda para los Dioses. Análisis simbioticos de rituales

Vogt, E. Z., 1992. Los iloletik: organización y funciones de chamanismo en Zinacantán. En:Vogt, Evon Z. (Ed). Los zinacantecos. [c. 1960]. Colección Presencias $N^{\circ} 56$. Nacional Indigenista. México, pp. 113-12.

Zolla, C. y A. Argueta, 2009. Biblioteca Digital de la Medicina Iradicional Mexicana. Universidad Nacional Autónoma para el Desarrollo de los Pueblos Indios. México. 


\section{Contemporary domestication practices by indigenous peoples and the industry}

Paulina R. Lezama-Núñez \& Dídac Santos-Fita

\section{Abstract}

It is common to think that animal domestication is a done endeavour rather than a never ending process. As such, people imagine that only a certain number of species and breeds constitute the domestic species' portfolio. Still, indigenous peoples around the world perform contemporary breeding management and other practices upon the different livestock species raised in their backyards and beyond, always attempting to improve the survival and characteristics of their animals. They also repeatedly try to reproduce wild species that are useful for different means, or else attractive to have around. In very different settings, guided by scholarly expertise rather than empirical knowledge, professionals of animal and veterinary sciences are also relentlessly trying to advance livestock populations in terms of different criteria established by industry and markets. Whether for rural or urban environments adaptation, neither animals are inert stocks of genes, nor are human norms for management and selection static. When thinking domestication, it would be better to imagine a perpetual conversation among the differen actors, including the environmental conditions, animal species, and people's needs and wants. Under such a picture, the past can be imagined differently, the present seen as it actually is, and the future hold diverse outcomes.

Keywords: biocultural diversity, conservation, anthropocentrism, indigenous ontologies.

\section{Introduction}

Scholars from diverse backgrounds, including anthropology, geography or biology, have approached domestication processes mainly by the study of historical data. Besides, the tendency to recognize a divide between nature and culture has lingered over the attributes and extent of human-animal relations, even though it is recognized that both biological and socio-cultural aspects of such interactions are inextricably intertwined. These and other issues regarding the development of animal domesticates make the concept of 'domestication' not a consensual but a contested one. Among the current debates in domestication studies one can find the questions of what caused it (shortage, abundance or both); what is the balance of the actors' agencies in the processes (symmetrical or asymmetrical); whether it needs intentionality; whether it requires human participation; if there is occurrence of universal conditions 
that characterize all domesticates in any context, among others (summarized by Payne and Evans, 2017; see also references therein).

In general, we can define domestication as 'a process of hereditary reorganisation of organisms into new forms, according to [certain organisms'] interests' (Payne and Evans, 2017). As explained later in this chapter, hundreds of socio-cultural factors, which had been the steering wheel of domestication processes, are now being left out of the human-animal relations equation. Similarly, great alterations of the organisms' biology can result from some of the modern domestication pathways, to the point of removing animals (or plants) completely (van Dooren, 2009; Galusky, 2014; Dilworth and McGregor, 2015).

Considering published and own ethnographic data from recent years, we present a set of case studies as means to reveal how domestication processes are still evolving everywhere in the world, not only among old actors in their original and traditional settings, but also including new species, technologies and scientific approaching. In other words, we show how human-animal relations do not comply, by any means, with categories established during Neolithic revolutions; on the contrary, today we can watch at the shortest time scale ever, how both human and animal populations are mutually leading each other to the materialization of highly dissimilar forms of domestication. Because of this, we need to conceptualize 'domestication' in more dynamic and flexible ways to be able to follow humanity's own pace of change.

\section{World's livestock diversity}

According to the FAO, there exist 38 species and nearly 9000 farm animal breeds that are used for agriculture and food production in the world (along with the ones already gone extinct). About a fifth of them (17\% percent) are currently in risk of extinction, while the status of the majority is unknown (58\%), simply because there is no data about their populations. Among the most common causes of genetic erosion, we find the use of foreign breeds and the consequent abandonment of indigenous or Creole breeds, as well as their cross-breeding with industrial or improved breeds. At the global level, Europe and the Caucasus, as well as North America are the two regions with the highest number of at-risk breeds. Coincidentally, both areas are the most industrialized in terms of livestock production, which implies the use of only a few species and breeds (FAO, 2015). In these areas, it is where more information can be retrieved for all livestock species too, and where institutions and policies for the protection and sustainable use anima genetic resources (AnGRs) are more and better complied (DAD-IS, 2017). In contrast, the livestock diversity of the rest of the world is meagrely known and unprotected. Illustrative of these patterns are the turkey (Meleagris gallopavo) in Mexico. This bird's historical and modern cultural prominence in North American countries has not meant that it is well known locally. In Canada and the USA, the turkey is mostly consumed as products of the bird's improved breeds and rarely seen alive outside poultry production buildings. These countries classify native turkey diversity in terms of phenotypic and ornamental criteria since there, only private owners or so-called poultry fanciers reproduce such flocks and sustain a small demand of 'traditionally' grown turkeys (American Livestock Breed Conservancy, ALBC; Feather site; Rare Breeds Canada). Contrastingly, in Mexico, additional to turkey consumption as processed meat, indigenous turkey populations are still raised in people's backyards across the country, and acquired alive for subsequent use. Mexican turkeys roam in rural and even urban communities, being raised very similarly as in ancient times and almost unnoticed by the country's institutions and policies (Camacho et al., 2011; Lezama-Núñez and Camacho, 2014). Such a discrepancy between the agreements to the FAO's initiatives for AnGRs sustainable use by Mexican institutions, and the reality faced in the field can be observed not only for the native bird, but for all livestock species (i.e. Creole bovines, ovines, caprines, chicken, etc., with five hundred years of evolution since their arrival from the Old World). Their genetic integrity is sometimes even assailed, it can be said, by the authorities supposedly in charge of their protection. In countries such as Spain, Germany, or England, on the other hand, one can find that more attention has been directed to turkey populations' characterization, monitoring and conservation, just as it is done for species belonging to local millennia livelihoods, even though they arrived only five centuries ago to these territories (DAD-IS, 2017). Summarizing, turkey diversity is taken care of, institutionally, by European countries better than by those where it has been used for thousands of years, at least in the case of Mexico. Only here, however, is the turkey still socially reproduced, still being raised by dozens of indigenous cultures as in pre-Hispanic times. This indigenous resource is facing, at the same time, the battering of livestock production industrialization together with the concomitant use and misuse of improved breeds (Camacho et al., 2011. For other American domesticates, the situation has been different because of several reasons. First, the alpaca (Vicugna pacos) and the cuy (Cavia porcellus) have not reached the distribution and importance for meat production and at global scales as the turkey has. Second, and as a related consequence, they have not suffered the level of genetic manipulation and industrialization as the turkey has (although they are on their way, see below: Bolton, 2006; and García, 2010). With the Mesoamerican species, however, both camelids and cuys share a rather lively existence among South American indigenous cultures up until today.

By keeping animal populations exposed to natural selection -and other cultural factors- in Latin America, Africa or Asia, these people, owners of most of livestock diversity (yet unknown and undocumented), are playing a fundamental role in the active conservation not only of biological, but also cultural diversity (biosocial or biocultural diversity). Through the following case studies and academic analyses, we can understand how this kind of dynamic conservation through production of AnGRs, as well as PIGRs (plant genetic resources), establishes the immense difference with the gene banking approach to conservation. Whereas supporting the former approach entails the inclusion of biosocial, more-than-human communities, in their actual environmental conditions and relating animatedly, advocating exclusively or primarily the latter implies an exclusive focus on the genetic components of organisms (FAO, 2009, 2015; van Dooren, 2009; Braverman, 2014). Therefore, human-non human relations change radically, sometimes dying away, in the process of biotechnological conversion. Eventually, conservation management can even be envisioned without 'nature' (see below, van Dooren, 2009; Galusky, 2010; Braverman, 2014).

The disappearance of the 'very skeletal structure' of animals (Galusky, 2010) from our relationships with them, and the preservation of genetic diversity without nature (van Dooren, 2009; Braverman, 2014), as we will see, are consequence of the homogenization practices brought by the dominant system of food production in the world (Jaques and Jacques, 2012). The epistemological, political and economic conditions of such production and commercialization system have also caused the erosion of the world's biocultural diversity, substituting it by 'mo- 
no-cropping cultures' (Jaques and Jacques, 2012). The social process of standardization conceived by the Western civilization can, nevertheless, be resisted by the everyday practices of traditional agricultural societies (Nash, 1993; Steiner, 1994; FAO, 2009; Vadjunec et al., 2016). Actually, this has always been the case, but only recently, are neo-rural communities entering the picture (Cortes-Vázquez, 2014). Also, fresh perspectives of human-non human relating are adding unconventional takes on biocultural diversity conservation (van Dooren 2009, 2016; Kirksey and Shapiro, 2013; Haraway, 2015).

In order to impede the systematic loss of cultures and agricultural varietals, we ought to seriously and urgently, reflect upon the role and extent that such traditional livelihoods, with their bounded genetic resources, will continue having in sustainable food production. As a social process, conservation demands policy and decision making, hopefully inclusive of all remaining biocultural diversity of the world (Alcorn, 1994; Toledo, 2001; van Houtan, 2006; van Dooren, 2009; Barther et al., 2013; Hodges et al., 2014). In any case, lack of knowledge and compliance of the sustainable use policies available today, leave livestock keepers and anima populations themselves unprotected against industrialization and its attritional effects on biocultural diversity (Jacques and Jacques, 2012).

\section{Indigenous or traditional practices versus global or industrial domestication practices}

Throughout this chapter, we will continue using the term indigenous as synonym of traditional when describing the practices that farmers perform as they rear animal populations, still in their original rural environments, and according to inherited or empirically acquired knowledge. On the other hand, we refer as global or industrial to those practices carried out by any cultura group, but attained through (Western) science-based training. Of course, when traditional and industrial ways of animal agriculture find each other in the field, their confrontation can be anything from gentle and handy to harsh and destructive (i.e. for the involved parts, the biological and social elements). In many instances, the outcomes of such interactions can depend more or less upon the farmers' decisions, for they determine whether and how using the introduced technologies is appropriate (e.g. industrial breeds, food and drugs for animals) (Johnson, 1972 Smith, 2011). In countless others, sadly, people cannot have the opportunity of experimenting with the novelties, and their imposition ends partially replacing or completely terminating the indigenous genetic resources (Jacques and Jacques, 2012). Since all grades of cross-breeding between indigenous and industrial breeds of livestock can be found in real situations (i.e. Krausmann, 2004), in the following cases we focus only on the most divergent results of each domestication pathway for three species (cow, pig, chicken). For each case, we first describe some traditional lines of ongoing domestication practices in different geographical regions; next, we present the latest outcomes of the industrial way of domestication intended for global supply. Such ethnographic scheme allows us to show how contrasting, even competing worldviews coexist nowadays in our modes of relating to domestic animals. Finally, we expand on the main lessons we have learned about the conception of domestication processes from conventional (i.e. interventional) and alternative (i.e. relational) approaches.

\section{The Cow, a steak}

Cattle, Bos taurus and Bos indicus, have belonged to our biocultural heritage ever since their domestication in the Neolithic. From genetic data we know that taurine cattle originated in the Fertile Crescent, while indicine or zebu cattle originate from the Indus Valley The reconstruction of their history has been revised elsewhere (Ajmone et al., 2010). Both kinds of phenotypes can cross-breed, so the diversity of the species also encompasses breeds of mixed origin. They travelled to the New World and have adapted to its diverse environmental and cultural conditions for many centuries now, resulting in a high variation in both morphological appearance as well as genetic performance. As a result of their utility to and long coexistence with American cultures, not surprisingly, singular relationships developed between this species and people. For instance, in Venezuela and Colombia,

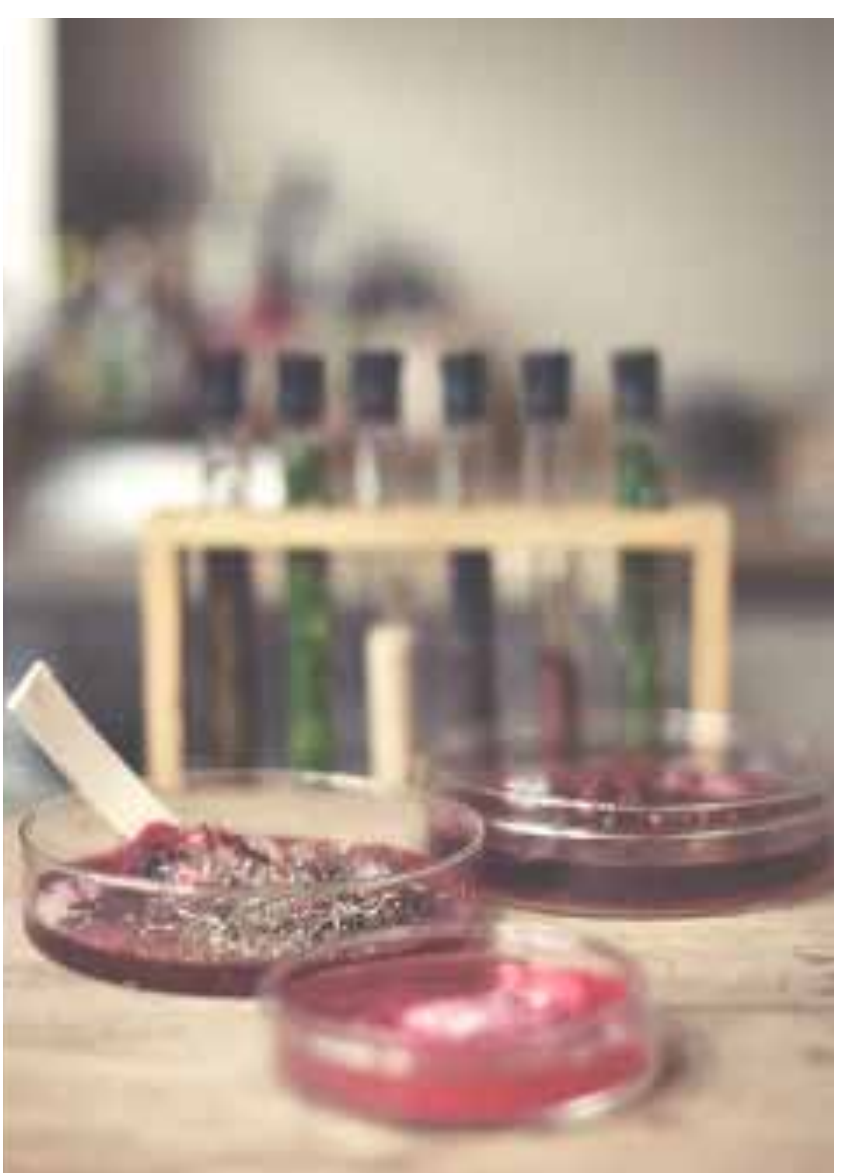

In vitro meat by Design Cultura Lab, Creative Commons BY-NC-ND 3.0 
Guajiro or Wayuu peoples incorporated them in their mythical thought (Perrin, 1987; for a case of plants, see Fowler 2005). Similar processes happened in Mexico, among the Raramuri, Huichol, and Tsotsil peoples, just to mention a few. For the former, we know that cattle became embedded in their conceptions of wealth; for the latter, these animals turned to be very important subsistence resources and/or suitable substitutes for traditionally sacrificed animals, like deer, which were less and less common with colonization expansion. The ritual slaughter and consumption of cattle, sheep or goats among the Raramuris, as can be observed today, serves the purpose of granting rain, avoiding plagues, pleasing God, and so good maize harvests.

Ongoing domestication practices performed by Mexican indigenous peoples include keeping cattle at natural selection's hand, but also specific criteria such as females' maternal ability (reviewed by Lezama-Núñez, 2008). In African countries, the selection criteria of individuals for reproduction include resistance to East Coast, individual fertility, milk performance, phenotypic appearance and dark red coat colour, among others, depending on the cattle owners (Köhler, 2003; Ndumu et al., 2008; Ejlertsen et al., 2012). Industrial practitioners, in contrast, try to convert the existing traditional, multipurpose breeds (that is, simultaneously able to produce meat, milk, and draught power) in specialized populations. In order to achieve so, they retrieve the animals that naturally happen in several environments during their lifetime, and put them in specific environments where their genetic makeup is going to be carefully selected. Their aim is 'to breed them optimally so there is the maximization of input into saleable products" (Willham et al., 1982). These so-called maximization and optimization have resulted, for instance, in the international movements of a handful of sires per breed -or their sperm only-. At industrial production scales, this changes the patterns of cattle genetic diversity globally. Animal life is 'incorporated' (i.e. owned and sold), but not only that: life/ death threshold becomes blurry (see Colombino and Giaccaria, 2016). Furthermore, when there is only some elements from what used to be an animal in all her wholeness (i.e. not only 'life' but also 'livelihood', see Galusky, 2010), and those elements are only used as food by humans (i.e. a steak), then the mere existence of the animal is at doubt, and so the human-animal relations (Galusky, 2010, 2014; Dilworth and McGregor, 2015).

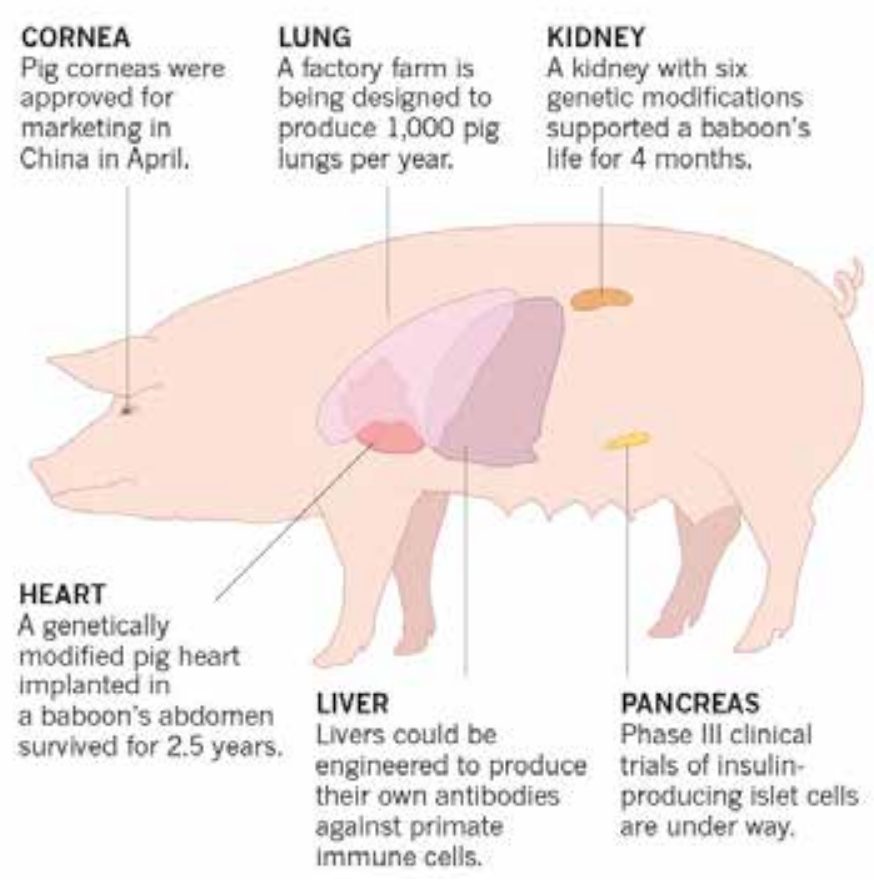

Choice cuts (taken from Reardon, 2015

is too specific as to modify fat content, tissue types or cell lines. Biotechnological advances from such management are making the pig as the most suitable producer of cells, tissues and organs for human therapeutic purposes (Reardon, 2015). Again, the animal and her livelihood is no longer discernible as it becomes isolated, artificially grown 'organs' (Galusky, 2010, 2014 Dilworth and McGregor, 2015).

\section{The pig, organ supplier}

Pigs were first domesticated in Southwest Asia and then spread across the Middle and Near East and westward into Europe by early agriculturalists. European pigs were either domesticated independently or as a result of hybridization between the originally Asian and European wild boar (Ottoni et al., 2013). The millennial tradition of pig husbandry in the Old and its centennia importance in the New World, come with indigenous management practices that still mold their genetic diversity. In Mexico, for instance, the meat flavour of the local pigs is highly valued by Maya peoples and is the reason why they are still raised even at the face of dominant production of industrial breeds. The greater fertility and litter size that females of traditional breeds express are considered among their owners to reproduce their stocks (Boyd, 2001). At the extreme, by food production and biomedicine industries, the criteria of pig diversity management

\section{The chicken, optional}

Gallus gallus is the most widespread domestic species of the world, having had an Asian origin (Zeder, 2010). Mexican Nahua peoples of Central Mexico worry about their hens being able to raise their own progeny, the number of eggs they lay, and their resistance to diseases and harsh climate. The roosters are valued in terms of how protective they are of the flocks against predators (i.e. dogs). Both females and males are also kept for reproduction because of their 'beauty', so people keep diverse phenotypes to make their populations colourful and varied in feather patterns. From one population of chicken, indigenous people throughout Mexican territory, obtain eggs, meat, subjects to be sacrificed to honour God, and company. On the other hand, the poultry industry has developed only-egg, only-meat, and body-less chicken meat by means of its own domestication criteria (Galusky, 2010). 


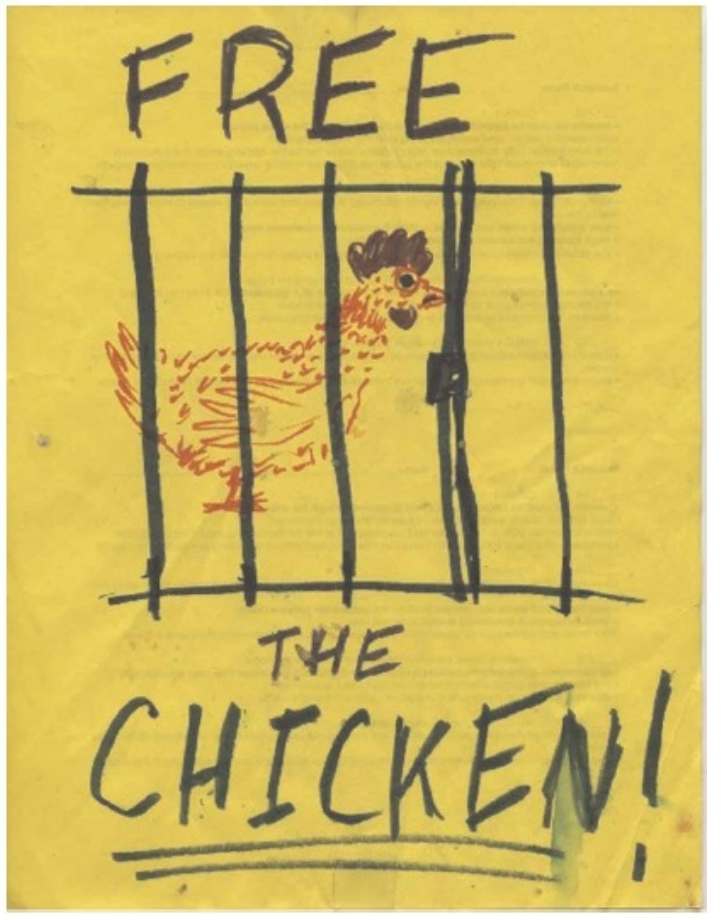

A reminder to let the chicken out, by Wyatt Galusky (taken from Galusky, 2010).

A reminder to let the chiken out, by Wyatt Galusky. (Taken fromn Galusky, 2007)

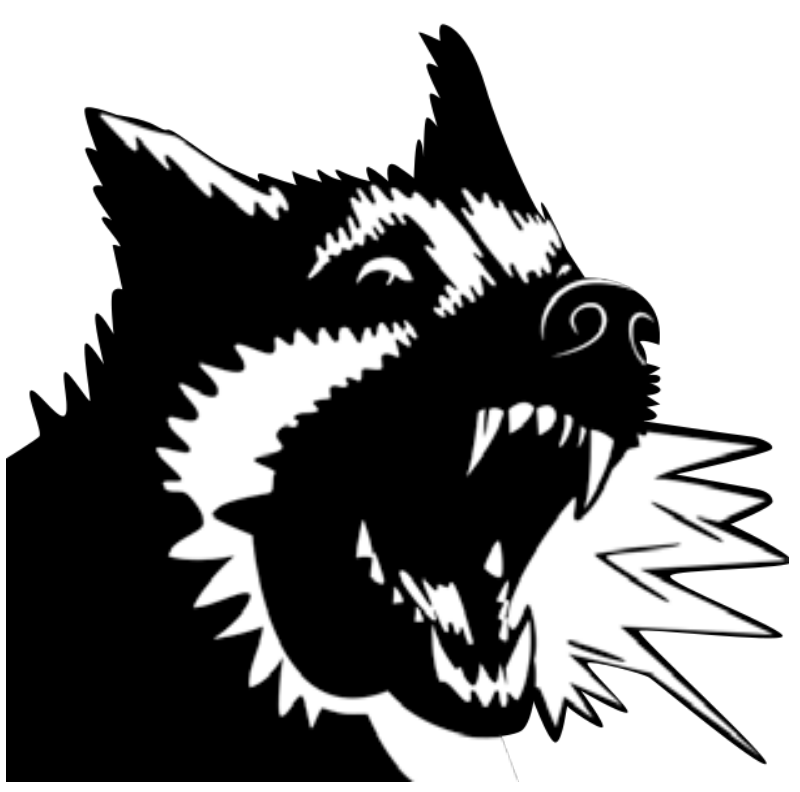

An illustration of a dog done in the style of Eric Drooker, distributed under a CC BY-SA 3 license.

An illustration of a dog done in the style of Eric Drooker, distributed under a CC BY 3 license

\section{Conclusions}

\section{Epilogue}

\section{The dog, furniture}

Canis familiaris is, according to archaeological evidence, the oldest animal domesticate (Zeder, 2012). Hundreds of breeds inhabit the most diverse habitats in the world, from isolated mountainous areas to luxuries homes of the wealthy and famous. The ongoing selection they are subjected to depends upon the jobs they have traditionally done along humans (i.e. shepherding, hunting), their new uses (i.e. blind assisting), or simply their lookings (very small or big, very hairy or hairless, and so on). In addition to serve as biomedical models for research just as pigs or mice, dogs are the ultimate companion species. This however, has not stopped their 'best friend' from devising and performing a surgery that takes away their ability to bark so other humans are not bothered by the noise (AVMA, 2013).
From conventional wisdom we have learned that agricultural revolutions in general, and animal domestication in particular, occurred more or less uniformly around the world, following certain lines of development, and that are past, done events, from which we can still learn why they sometimes did not happen (Zeder, 2012; Larson et al., 2014). Also, that those human-anima relations established during domestication processes were of a more or less homogenous nature (animals as raw material for human use and thought) (Noske, 1993). This way of understanding our coexistence with animals has implied certain modes of approaching their use, abuse and conservation (i.e. interventional approaches, where human domination of nature is the ruling principle) (Kopnina, 2012). Recent advances in both, analytic tools as well as empirica research, however, reveal a different picture. Under such a fresher examination, many different domestication stories unfold, showing how varied and complex our relating with animals (and plants) is and has always been (Bettinger et al., 2010; Scott, 2011). This scholarship, emerging from, and growing in a variety of fields ranging from anthropology and archaeology, to environmental history or social studies of science, are trying to reconstruct and explain the history and 
character of human-animal relations without alluding to the control of nature by humans or, in the end, anthropocentrism. At the heart of this alternative insight lies the interdependency of the human-nature relationship, which is studied under the umbrella of relational approaches. Through these, the concepts of 'person' and 'agency' are being renewed and with it, our understanding of how human and animals interact and affect each other. Where- and when-ever humans and animals have met and are to meet, and whether the relationships they establish have lasted or will last for short or long terms, we can be sure that neither part has remained or will remain unchanged by the other (Noske, 1993; Haraway, 2003, 2015; Ingold, 2008; 2012; Hill, 2011, 2013; Kopnina). Just to mention some of the major consequences of the enduring human interdependence with animals, there are the infectious diseases we have acquired from them, or our adaptation to animal milk consumption (Diamond, 2002). Less tangible evidences of the importance of human-animal interactions are constantly being discovered (i.e., Santos-Fita et al., 2015) or reconsidered (i.e., Hill, 2013).

We will never achieve to know all manners of our relating to animals since they have not left, or we will not find, physical evidence. In other cases, such concrete proof does not exist simply because they are ethereal in nature: encoded in oral traditions and ritual practices we can find the role of certain species in ecological functioning and human survival (i.e. Kuznar, 2001; Santos-Fita et al., 2009; Santos-Fita, 2016). As long as standard ways of conserving and approaching biological diversity do not change, human rights will continue to be violated, and biological and cultural richness disappearing (Alcorn, 2008; Gómez-Pompa and Kaus, 1992; Kopnina, 2012). Human diversity of worldviews is fading from Earth at alarming rates, and with it, better modes of understanding and relating to nature in all its expressions. As Gómez-Pompa and Kaus (1992) put it,

Currently, we are discussing and designing policies for something about which we still know little. And those who do know more have rarely been included in the discussion. The fundamental challenge is not to conserve the wilderness, but to tame the myth with an understanding that humans are not apart from nature. (op cit).

The classical conceptions of 'domestication' are themselves being 'tamed', for they have served only partially to the aspiration of understanding humanity's very nature. A definition of domestication such as the one presented at the beginning of this chapter (Payne and Evans, 2017), for instance, may somewhat facilitate a distinction between domestic and wild species, but overlooks organisms that have provisionally, unconsciously or invisibly accompanied ou species even before being Homo sapiens (Hartigan, n.d.). Let us think, for a moment, how certain tools allow discriminating between populations that have been under more or less human/ anthropogenic environmental selection (i.e. genetic, morphometric, or physiological characters). Now, how can we determine whether and when a 'wild' species has been 'domesticated', or its degree of 'domestication', as they have shared such a deep history with humans, from their association with early hominids to their latest uses by modern humans? Many civilizations, during centuries or millennia, have identified and called themselves as Wolf, Bear, or Jagua people, and without reference to such animals they cannot imagine their place in the world. Do not these kinds of issues lead us to question human self domestication? (Leach et al., 2003; Hare et al., 2012; Hartigan, n.d.). Furthermore, many species are currently managed in such manners that can hardly be called 'wild' anymore, either because they have started to be ex- ploited in new ways or at great scales very recently (i.e. López et al., 2012), or because their habitats are soon to be, or already gone so they can only inhabit reserves, zoos and similar facilities (i.e., van Dooren, 2016). There is even experimentation going on with 'de-domestication' processes of animals and plants (Gamborg et al., 2010).

We consider that not only for the sake of biocultural conservation, but for that of human inquisitiveness per se, we should hasten our efforts to document the remaining diversity of human comprehensions of the world; simultaneously, we should revise the already rich ethnographic recorded information we have in search for alternative, more inclusive and effective, conservation approaches. Post-humanist perspectives of the human's place in the world are contributing to this endless task (reviewed in Kopnina, 2012; Ruiz and Del Cairo, 2016). Ultimately, as many societies have recognized in different places and times throughout human history, and in Haraway's (2015) words, “...all earthlings are kin in the deepest sense...”. Following her, a better care of assemblages, not lone species, not one at a time, is possible should we become aware of the fact that "all critters share a common 'flesh', laterally, semiotically, and genealogically". Eventually, she hypothesizes, "the human people of this planet can again be numbered two or three billion or so, while all along the way being part of increasing well being for diverse human beings and other critters as means and not just ends..." (Haraway, 2015). Perhaps upon whole embracing of this reality does not rest humanity's survival, but closing the eyes to it can put at stake its existence on Earth and, certainly, impoverish the wealth of interactions people enjoy here. Galusky's (2010) questioning of the kind of human -and animals- that the industrial pathway of domestication is giving birth to seems appropriate at this point,

Perhaps a human more accustomed to increasingly controlled environments, increasingly engineered food, increasing intervention on ideal body types via surgery and genetic alteration, increasing reliance on chemical controls of disease and mood, which in turn create a greater dependence on those systems that provide such necessities. Perhaps the domesticated chicken suggests a harbinger of things to come for humans who themselves seek to fully control their diet, their environment, and their stimulation.

To live in a technologically mediated world where surprise is only bad. (op cit).

Whether we change the direction of the sociopolitical processes that are leading us to become such kind of human is to be seen. Speed matters if some of the extant biocultural diversity is to survive. At last, making the decisions to end biocultural diversity loss will speak not only of what modes of relating to the other-than-human living world, the dominant, most powerfu cultures practice, but also about what they consider valuable; that is, their ethical standing (Gómez-Pompa and Kaus, 1992; van Houtan, 2006; Kopnina, 2012). 


\section{Bibliografía}

Ajmone-Marsan, P., J. F. Garcia y J. A. Lenstra, 2010. On Ejlertsen, M., J. Poole y K. Marshall, 2012. Traditiona the origin of cattle: How aurochs became cattle and world. Evolutionary Anthr

Alcorn, J. B., 1994. Noble savage or noble state? Northern myths and southern realities in biodiversity conservation.

Animal Production and Health Paper. No. 167, Rome.
Aiversity. , J. B., 2008. Beauty and the beast - Human rights FAO, 2015. The Second Report on the State of the World's and biocultural diversity. Resurgence Magazine. Animal Genetic Resources for Food and Agriculld century. Issue 250 (September). (Disponible en: 21 . wwwresurgence org/magazine/issue250-indigenousintelligence-diverse-solutions-for-the-21st-centurn.htm!). American Livestock Breed Conservancy, ALBC (https:// livestockconservancy.org).

American Veterinary Medical Association, AMVA, 2013. (Disponible en: https://www.avma.org/KB/Resources/ Canine\%20Devocalization-Final.pdf).

Barthel, S., C. L. Crumley y U. Svedin, 2013. Biocultural refugia: combating the erosion of diversity in landscapes of food production. Ecology and Society, 18(4): 71.

Bettinger, R., L. Barton y C. Morgan, 2010. The origins of food production in north China: A different kind of agricul
revolution. Evolutionary Anthropology, 19: 9-21.

Bolton, M., 2006. Genetic defects or generative prototypes? Competing models for livestock improvement in Souther Bolivia. The Journal of the Royal Anthropological
Institute, 12(3): 531-549.

Boyd, D. J., 2001. Life Without Pigs: Recent Subsistence Changes Among the Irakia Awa, Papua New Guinea.

Braverman, I., 2014. Conservation without nature: the trouble with in situ versus ex situ conservation. Geoforum, 51
$47-57$.

Camacho-Escobar, M. A., P. R. Lezama-Núñez, M. P. Jerez-Salas, et al., 2011. Avicultura indigena mexica
sabiduria milenaria en extinción. AlCA 1: 375-379.

Colombino, A. y P. Giaccaria, 2016. Dead liveness/living deadness: Thresholds of non-human life and death in
biocapitalism. Environment and Planning D: Society and Space, $0(0): 1-19$

Cortés-Vázquez, J. A., 2014. A natural life: neo-rurals and the power of everyday practices in

DAD-IS, 2017. Domestic Animal Diversity Information System of the Food and Agriculture Organization, FAO.
(consulted on April 17 $7^{\mathrm{h}}, 2017$, at: http://dad.fao.org).

Diamond, J., 2002. Evolution, consequences and future of plant and animal domestication. Nature 418(34): 700-707.

Dilworth, T. y A. McGregor, 2015. Moral Steaks? Ethica Discourses of In Vitro Meat in Academia and Australia. J. Agric. Environ. Ethics. 28(1): 85-107.

: Assessments, Rome (Disponible en: http://www fao. org/3/ai4787e/index htmll). Feather site (http:/WW feathersite.com/Poultry/BRKPoultryPage.html).

Fowler, C., 2005. Why is maize a sacred plant? Social history 25(1): $39-57$.

Galusky, W., 2010. Playing Chicken: Technologies of domestication, food, and self. Science as Culture 19(1) 15-35.

Galusky. W., 2014. Technology as responsibility: Failure, food animals, and lab-grown meat. Journal of Agriculture, Environment and Ethics, 27: 931-948.

Gamborg, C., B. Gremmen, S.B. Christiansen y P. Sandoe, 2010. De-Domestication: Ethics at the intersection landscape restoration and animal welfare. Environmental
Values 19: $57-78$. Values 19: $57-78$.

arcia, M. E., 2010. Super guinea pigs. Anthropology Now,
2(2): 22-31. 2(2): 22-31

Gómez-Pompa, A. y A. Kaus, 1992. Taming the Wilderness Myth. BioScience, 42(4): 271-279. Haraway, D. J. 2003. The Companion Species Manifesto: Dogs, People, and Sigific

Haraway, D. J., 2015. Anthropocene, Capitalocene, Environmental Humanities 6: 159-165.

Hare, B., V. Wobberand y R. Wrangham, 2012 . The seffdomestication hy $\mathrm{R}$. Wris: evolution of bestpsychology is due to selection against aggression. Anim Behav 83: 573-85.

Hartigan, J. Domestication (available at: http://www. multispecies-salon.org/domestication/

Hill, E., 2011. Animals as Agents: Hunting ritual and relational ontologies in prehistoric Alaska and Chuko

Hill, E., 2013. Archaeology and animal persons. Toward a prehistory of human-animal relations. Envir
Society: Advances in Research 4: 117-136.

Hodges, J., M. Foggin, R. Long y G. Zhaxi, 2014. Globalisation and the sustainability of farmers, livestock-keepers,
pastoralists and fragile habitats. Biodiversity $15(2-3)$ : 109-118 into ruin: The Loss of food varieties and cultural diversity. to Pastoralists. En: FAO, 2003. Community based relaciones genéticas de los bovinos criollos mexicanos a
Ingold, T., 2008. Bindings against boundaries: entanglements of life in an open

Jaes, P. J. y J. R. Jacques, 2012. Monocropping cultures Sustainability 4: 2970-2997.

Johnson, A.W., 1972. Individuality and experimentation in traditional agriculture. Human Ecology 1(2): 149-159.

Kirksey, S. E. y N. Shapiro, 2013. Hope in blasted
Social Science Information 52(2): 228-256.

Köhler-Rollefson, l., 2003. Community-Based Management of Animal Genetic Resources - with Special Reference management of animal genetic resources. Proceedings
of the workshop held in Mbabane, Swaziland, 7-11 of the worksho
May 2001.

Ottoni, C., L.G. Flink y A. Evin et al., 2013. Pig Domestication and Human-Mediated Dispersal in Western Eurasia Revealed through Ancient DNA and Geometric .

Payne, L. R. y J. D. Evans, 2017. Nested Houses: Domestication dynamics of human-wasp relations in contemporary rural Japan. Journal of Ethnobiology and

Perrin, M., 1987. Creaciones míticas y representación de mundo: el ganado en el pensamiento simbolico Guajiro.

Reardon, S., 2015. New life for pig organs. Nature 527(7577): ontologico en torno al naturalism
Estudios Sociales 55: $193-204$.

ward conservational anthropology: Anthropology 36: 127-146.

Krausmann, 2004. Milk, manure, and muscle power. Livestock and the Transformation of Preindustrial Agriculture

Kuznar, L. A., 2001. Ecological mutualism in Navajo corrals: Implications for Navajo environmentalperceptions and Research, 57(1): 17-39.

Larson, G., D. R. Piperno, R. G. Allaby et al., 2014. Current perspectives and the future of domestication studies. PNAS 111(17): 6139-6146.

Leach, H., 2003. Human domestication reconsidered. Current Anthropology, 44: 349-68.

Lezama-Núnez, P. R. 2008. Estudio de la diversidad y las partir de DNA mitocondrial.
de Ciencias, UNAM, México.

Lezama-Núñez, P. R. y M. A., Camacho-Escobar. 2014 Criterios para la caracterización de las razas del guajolo te doméstico o pavo (Meleagris gallopavo gallopavo). En: Perezgrovas, R., P. Jerez y M.A. Camacho (Eds.). Gallinas criollas y guajolotes nativos de México. Características y sistemas de producción. Réd

López-Ruvalcaba, O. A., J. L. Arcos, G. D. Mendoza, et al. 2012. Reproductive Parameters on female blacklizard Revista Cientifica, FCV-LUZ / Vol. XXII, № 1, 65-71.

Nash, J.C (Ed) 1093 Craftsin the Word Market: The . of Global Exchange
of New York Press.

Noske, B., 1993. The animal question in anthropology. Society \& Animals 1: 185-190.

Ndumu, D. B. R Baumung M. Wurzinger et al. 2008. Performance and fitness traits versus phenotypic appearance in the African Ankole Longhorn cattle: indigenous breeds. Livestock Science, 113: 234-242.
Santos-Fita, D, 2016. La milpa comedero-trampa de los cazadores mayas del centro de Quintana Roo, México: pp. 263-287. En: Moreno-Calles, A., A. Casas, V.M.

antos-Fita, D., E. M. Costa-Neto y E. Cano-Contreras, 2009. El quehacer de la etnozoologia. En: Costa-Neto, E. M. D. Santos-Fita y M. Vargas-Clavijo (Eds.). Manual de Etnozoologia. Una guia teorico-práctica para investigar la interconexión del ser humano con los animales. Tundra

Santos-Fita, D., E. J. Naranjo, E. I. J. Estrada, R. Mariaca y E. Bello, 2015. Symbolism and ritual practices related to Mexico. Journal of Ethnobiology and Ethnomedicine 11(71): 1-13.

Scott, J., 2011. Four Domestications: Fire, Plants, Animals, and ...Us. The Tanner Lectures on Human alues. Entregado a la universidad de Harvard en mayo edu/_documents/a-to-z/s/Scott_11.pdf).

teiner, C. B., 1994. Technologies of resistance: Structura alteration of trade cloth in four societies. Zeitschrift fur Ethnologie, 119: 175-194.

Smith, E. A., 2011. Endless forms: human behavioural diversity and evolved universals. Philosophical Transations of the Royal Society B. 366: 325-332.

Toledo, V. M., 2001. Indigenous peoples and biodiversity En. Levin (Ed.). Encyclopedia of Biodiversity. Academic Press, San Diego.

Vadjunec, J. M., C. Radel y B. L. Turner II, 2016. Introduction: The continued importance of smallholders today Land.
$5(34)$.

an Dooren, T., 2009. Banking seed: Use and value in the conservation of agricultural diversity. Science as Culture

Van Dooren, T., 2016. Authentic Crows: Identity, Captivity and Emergent Forms of Life. Theory, Culture an en México. UNAM, México. 


\section{Bioseguridad en el Perú: \\ Moratoria a los OVM, \\ a mitad de camino de una decisión importante en un centro de origen}

Santiago Pastor Soplín

\section{Resumen}

En el presente capítulo se describen las normas y conceptos que ha desarrollado el Perú para implementar un sistema de bioseguridad para usar de manera responsable los bienes y servicios de la biotecnología moderna, disminuyendo los riesgos y estableciendo las bases del uso sostenible de la diversidad biológica, sobre todo tomando en cuenta su condición de país megadiverso y centro de origen, diversificación y domesticación de agrobiodiversidad, de los más importantes del mundo. Aunque los ensayos iniciales para generar organismo vivos modificados OVM avanzaron con muchos cultivos, animales de granja y peces, en pocos años, la presencia de los OVM en el comercio mundial estuvo dominada por cuatro cultivos: soya, maíz, canola y algodón; y dos caracteres introducidos: tolerancia a herbicidas (RR) y resistencia a insectos (Bt). Pronto se expandieron en países donde fueron autorizados y de ahí al comercio internacional, entrando a muchos países con limitadas capacidades regulatorias. Ante las dudas de estos nuevos alimentos sobre la salud humana, los ecosistemas y la biodiversidad se promovió el Convenio sobre Diversidad Biológica en cuyo texto se invoca a establecer procedimientos, incluido el consentimiento fundamentado previo, en la transferencia, manipulación y uso de OVM. Seis años después se impulsó el Protocolo de Cartagena sobre Seguridad de la Biotecnología, adoptado en el año 2000 y vigente desde el 2003. En el Perú se promulgó la primera ley de bioseguridad en 1999, un año antes de la adopción del Protocolo de Cartagena sobre Bioseguridad. El reglamento de la ley demoró un poco más en el 2002. A pesar del título de la ley sobre "prevención", el contenido de la misma reconoce once actividades posibles con OVM, desarrolla principalmente -y casi de manera única-, la introducción o "importación". Una ley aparentemente limitada, tomando en cuenta la complejidad del tema. Cuando los OVM comenzaron a circular en el mercado internacional, el Perú carecía de regulaciones al respecto; no hubo ninguna política, ley, control, ni barreras para su ingreso en el territorio nacional. Se aprobó y publicó el Decreto № 0108-2002-PCM el 28 de octubre del 2002, el año anterior a la entrada en vigencia del Protocolo de Cartagena. Es decir, desde el punto de vista normativo, el Perú estuvo en la vanguardia de la comunidad internacional en lo que respecta a regulación de los OVM, aunque no necesariamente en su aplicación efectiva. El mayor vacío de la ley No. 
27104 fue la carencia de un capítulo de infracciones y sanciones, lo cual le quita toda fuerza o capacidad de aplicación, desde su promulgación a la fecha. La función del INIA desde su origen, es la de investigar y liderar el Sistema Nacional de Investigación e Innovación Agraria. Es decir, su función es propia de un desarrollador y usuario de bienes y servicios de la biotecnología moderna, lo que genera conflicto con la función encargada de regular en esta materia. Hay indicios de que este conflicto de intereses (ser desarrollador y promotor de biotecnología y ser a su vez, regulador en materia de biotecnología moderna) no ha generado buenas decisiones. La moratoria a los OVM debe servir para construir capacidades para todo lo que implica el análisis de riesgo (evaluación, gestión y comunicación de riesgos) pero también para resolver de la manera más temprana posible, los dilemas institucionales para una adecuada implementación de bioseguridad la medida de un país que es uno de los más importantes centros de origen, diversificación y domesticación de cultivos, del mundo. El actor ambiental pasó de ser un buscador de consensos sin fuerza a ser crucial en la jerarquía de Sector transversal y fundamentalmente normativo, en la gestión pública nacional, en buena medida gracias al fuerte liderazgo ejercido por quien fuera el primer ministro del Ambiente del Perú, Dr. Antonio Brack. Los lineamientos de política ambiental en bioseguridad, sólo se refieren a sus usos e impactos en el ambiente, y no en la salud, alimentación, industria u otros sectores de la sociedad. Las declaraciones se hicieron con escaso sustento técnico y sin evaluaciones previas sobre los riesgos; basados sólo en la oportunidad económica, sin reflexionar en los riegos ambientales en la región donde se estaba proponiendo la liberación. Al escribir este texto han pasado ya 65 meses de los 120 que contempla el plazo de la moratoria a los OVM, y los esfuerzos han tenidos algunos frutos, pero pocos sienten que sean los que correspondan al esfuerzo realizado y mucho menos a las metas establecidas. Un monitoreo reciente, en campos de maíz en la región Piura reportó que de 59 muestras analizadas, 41 dieron un resultado positivo a la presencia de OVM. Esto representa casi el $70 \%$ de los campos inspeccionados. Una situación muy preocupante. El marco normativo y administrativo para que se realice la fiscalización de los OVM, ya existe. La eficacia dependerá del equipo del momento, del equipamiento y de la gestión y responsabilidad de los involucrados. La moratoria tendría que servir para resolver los problemas que limitan la implementación de un sistema de bioseguridad en el Perú. Más allá de los aspectos técnicos, la decisión política más importante pendiente es darle una nueva institucionalidad que corrija los problemas de conflicto de intereses. Al momento que esto se escribe, quedan 55 meses de los 120 de moratoria. Es necesario intensificar el trabajo de diagnóstico, riesgos y regulaciones para prevenir cualquier daño irreversible de consecuencias para la salud humana y los ecosistemas.

Palabras clave: Bioseguridad, organismos vivos modificados, regulación ambiental, riesgos ambientales, riesgos a la salud humana, transgénicos.

\section{Antecedentes}

En este capítulo se describe, sobre la base de normas y conceptos, cómo ha enfrentado el Perú a implementación de un sistema de bioseguridad que busque usar de manera responsable los bienes y servicios de la biotecnología moderna, disminuyendo los riesgos sobre la conservación y uso sostenible de la diversidad biológica; especialmente tomando en cuenta nuestra condición de país megadiverso y centro de origen, diversificación y domesticación, de los más importantes del mundo. El proceso ha sido largo (Pastor, 2012) y continúa en nuestros días con creciente vigencia, este se divide con base en las leyes o hitos normativos más relevantes.

\section{Entrada de los OVM al comercio internacional: sin política pública, sin regulación, sin control y sin barreras}

Los organismos vivos modificados (OVM) inician su presencia experimental en 1986 con la obtención de un tipo de tabaco al cual se logró insertar un gen de resistencia a antibiótico (específicamente kanamicina). En 1994 se autorizó en Estados Unidos de América el primer alimento transgénico: tomate Flavr Savr TM, cuyo carácter agregado por medio de técnicas de biotecnología moderna determinaba el retardo de la maduración, ampliando significativamente su "tiempo de anaquel". Este tipo de tomate fue retirado del mercado dos años más tarde, debido a que presentaba alteraciones en la piel (blanda), sabor y composición, observadas y rechazadas por los consumidores (FAO, 2001).

Los ensayos iniciales avanzaron con muchos cultivos e inclusive también con animales de granja y peces; sin embargo, al cabo de pocos años, la presencia de los OVM en el comercio mundial estuvo dominada principalmente por cuatro cultivos: soya, maíz, canola y algodón y dos caracteres introducidos: tolerancia a herbicidas (RR) y resistencia a insectos (Bt). No demoraron en expandirse en los países donde fueron autorizados y de ahí al comercio internacional, entrando a muchos países con limitadas y/o escasas capacidades regulatorias.

Así, ante las dudas que generaban estos nuevos alimentos respecto a la salud de las personas y especialmente respecto al ambiente y la diversidad biológica, la comunidad internaciona reaccionó en el contexto del Convenio sobre Diversidad Biológica (Naciones Unidas, 1992), en cuyo texto se invoca a que

Las partes estudiarán la necesidad y las modalidades de un protocolo que establezca procedimientos adecuados, incluido en particular el consentimiento fundamentado previo, en la esfera de la transferencia, manipulación y utilización de cualesquiera organismos vivos modificados resultantes de la biotecnología que puedan tener efectos adversos para la

conservación y la utilización sostenible de la diversidad biológica (Art. 19.3).

La implementación de este mandato del CBD después de seis años de negociación tuvo como resultado el Protocolo de Cartagena sobre Seguridad de la Biotecnología del Convenio sobre Diversidad Biológica (Naciones Unidas, 2000) adoptado en el año 2000 y vigente desde el 2003, cuando alcanzó el mínimo de ratificaciones establecidas por el mismo documento.

La normativa nacional también comenzó a gestarse en la segunda mitad de la década de los años noventa, como parte de las acciones nacionales de implementación del CBD. Se avanzó relativamente rápido, lográndose la promulgación de la primera ley de bioseguri- 
dad en 1999, un año antes de la adopción del Protocolo de Cartagena sobre Bioseguridad, Ley N 27104 o Ley de Prevención de Riesgos Derivados del Uso de la Biotecnología (Perú, 1999). El reglamento de la ley demoró un poco más (2002), y, por tanto, hasta ese momento no estuvo completo el marco legal para su funcionamiento. Sin embargo, la existencia de la Ley, con los consensos mínimos que exige entre los actores involucrados, ya marcó una orientación política respecto a la materia regulada. En este caso, a pesar del título de la ley que habla de "prevención", el contenido de la misma, reconociendo once actividades posibles con OVM, desarrolla principalmente -y casi de manera única- la introducción o "importación". Una ley aparentemente limitada respecto de la complejidad del tema y en comparación con legislaciones de otros países donde la implementación es más completa como México, Brasil o Colombia.

Lo cierto es que desde que los OVM comenzaron a circular en el mercado internacional, el país carecía de medios y/o capacidad de regulación en ese período; no hubo ninguna política, ley, control, ni barreras para su ingreso en el territorio nacional.

\section{Entre la Ley $\mathrm{N}^{\circ} 27104$ y la Política Nacional del Ambiente (2009). Sin política publica, con regulación, sin control, sin barreras}

La Ley $\mathrm{N}^{\circ} 27104$ vigente, resultaba inaplicable en tanto no estuviera reglamentada. Este proceso tomó casi tres años, después de muchas negociaciones, acuerdos y desacuerdos entre los actores nacionales, siendo el punto de mayor discrepancia el de la institucionalidad. El sector ambiente estaba recién formándose (no existía Ministerio del Ambiente), y sus capacidades no excedían a las de ser un articulador interinstitucional, relativamente exitoso; po cierto, con ese rol fue integrado a la institucionalidad de la bioseguridad en el reglamento. En el Sector Agricultura hubo un intenso debate para determinar cuál institución sería designada para ejercer como Organismo Sectorial Competente. De facto, las funciones ya estaban siendo ejercidas por el Servicio Nacional de Sanidad Agraria (SENASA). Sin embargo, probablemente la última decisión que cerraría el texto del Reglamento de la Ley №27104 fue la de designar a Instituto Nacional de Investigación Agraria como OSC de Agricultura. Así, se aprueba y publica el DS N0108-2002-PCM el 28 de octubre del 2002, el año anterior a la entrada en vigencia del Protocolo de Cartagena. Es decir, desde el punto de vista normativo, el Perú estuvo en la vanguardia de la comunidad internacional en lo que respecta a regulación de los OVM, aunque no necesariamente en su aplicación efectiva.

Como generalmente sucede, la Ley №27104 se promulgó imperfecta, y, en alguna medida, inaplicable en varios aspectos que se comentarán en los párrafos siguientes.

Contradictoriamente, la Ley №27104 contempla una aplicación rigurosa y cuestionable para algunos del principio precautorio, a través de la cual todo OVM que haya sido rechazado en otro país debe ser rechazado de pleno derecho en el nuestro; del mismo modo, ningún OVM puede ser aprobado en el Perú si antes no ha sido probado en otro país (Ley N²7104, Art. 11).
Cabe resaltar de nueva cuenta que de las once actividades posibles con OVM, solo se incluyeron medidas para la importación, lo cual puede ser una buena señal de la verdadera intención o decisión política de ese momento.

Sin embargo, el mayor vacío de esta ley fue la carencia de un capítulo de infracciones y sanciones, que le quita toda fuerza o capacidad de aplicación, desde su promulgación a la fecha.

Adicionalmente a este grave vacío de carecer de infracciones y sanciones, la medida que probablemente más consecuencias ha traído ha sido la designación del INIA como OSC. La función del INIA, desde su origen y por mandato de creación, es investigar y liderar el Sistema Nacional de Investigación e Innovación Agraria. Es decir, su función es propia de un desarrollador y usuario de bienes y servicios de la biotecnología moderna, lo cual genera conflicto con la nueva función encargada de regulador en esta materia. Ha habido muchas señales de que este conflicto existencial de ser desarrollador y promotor de biotecnología y ser a su vez regulador en materia de biotecnología moderna, no ha generado buenas decisiones, y conforme se vaya acercando el momento de la toma decisiones -con mucha probabilidad- las dudas volverán a viciar el proceso. Como se verá más adelante , la moratoria a los OVM debe servir para construir capacidades para todo lo que implica el análisis de riesgo (evaluación, gestión y comunicación de riesgos), pero también para resolver de la manera más temprana posible los dilemas institucionales que, por los conflictos de interés que generan, claramente enturbian una adecuada implementación de un sistema de bioseguridad eficiente y en la medida de que es un país de los más importantes centros de origen, diversificación y domesticación de cultivos del mundo.

En ninguno de los países en los que el sistema de bioseguridad está relativamente bien implementado, el órgano de investigación e innovación agraria es autoridad en bioseguridad; no lo es el EMBRA en Brasil, ni el INIFAP en México (CIISB, 2017). La razón es que un usuario de un servicio o sistema no debe ser simultáneamente su regulador. La solución a este problema fundamental aún está pendiente.

\section{Entre la Política Nacional del Ambiente y la Ley N²9811 de Moratoria. Con políticas, sin regulación, sin control, sin barreras.}

Después de estos dieciocho años de debate, una de las cosas más claras es la inaplicabilidad de la Ley №27104 y la meritoria, pero aún desenfocada, implementación de la Ley de Moratoria, según como se comentará más adelante.

El capítulo 18 sobre Medio Ambiente del Acuerdo de Promoción Comercial Perú-Estados Unidos (Congreso de la República del Perú, 2006), suscrito el 12 de abril de 2006, obligó al Perú a fortalecer su institucionalidad ambiental, producto probable de lo cual fue la creación del Ministerio del Ambiente en mayo del 2008 (Perú, 2008).

El factor ambiental pasó de ser un buscador de consensos sin fuerza alguna de cumplimiento a la jerarquía de Sector transversal y fundamentalmente normativo, en la gestión pública 
nacional. El fuerte liderazgo ejercido por quien fuera el primer ministro del Ambiente del Perú, el doctor Antonio Brack Egg, hizo pensar, en un inicio, que este cambio institucional pudo haber sido un avance; sin embargo, marchas y contramarchas en varios aspectos de la normativa y gestión ambiental hacen considerar a algunos que la conversión en Sector no habría sido la mejor decisión y que más hubiera valido la pena reforzar el rol de articulador interinstituciona con un estatus de superintendencia o regulador ambiental intersectorial.

A pesar de todo, los primeros años fueron muy fructíferos: pronto se aprobó la primera Política Nacional del Ambiente (Perú, 2009), de carácter multisectorial y de obligatorio cumplimiento, vigente a la fecha. Esa política tiene un componente específicamente dedicado a la seguridad de la biotecnología moderna o bioseguridad.

En estos lineamientos de política, como debe ser, se exige base científica para la toma de decisiones en bioseguridad, pero también criterios ambientales, económicos, sociales y políticos, al momento de la decisión final de autorizar o no el uso de un OVM. Aunque parezca evidente, no está de más remarcar que los lineamientos de política ambiental en bioseguridad solo se refieren a sus usos e impactos en el ambiente, y no en la salud, alimentación, industria 4 otros sectores. Sin embargo, la relación es evidente y las decisiones que se toman en un sector, por ejemplo, el ambiental, tuvieron impacto en otro sector. Así, el Artículo $37^{\circ}$ del Código de Defensa del Consumidor (Perú, 2010) determina que todo alimento que contenga OVM o derivados debe ser informado en la etiqueta. Siete años después de vigente el etiquetado no se aplica sin que medie ninguna explicación formal al respecto.

La Política Nacional del Ambiente, recogiendo el espíritu de los acuerdos ambientales internacionales, determina que se le otorga un valor especial a la evaluación de riesgo y a la necesidad de construcción de capacidades en las instituciones que son Organismos Sectoriales Competentes para optimizar su aplicación. La implementación de la Ley №27104, habiendo sido aprobado su reglamento en el 2002, pasaba por que cada una de los sectores definidos elaborara un reglamento -sectorial- con las especificidades que le son propias a los bienes y servicios que están bajo su ámbito. Así, Agricultura debería elaborar su reglamento para regular cultivos y crianzas; Producción-Pesquería, para regular los OVM de tipo hidrobiológico, y Salud, para alimentos que son OVM o que los contengan. El Sector Agricultura logró concluir y publicar una versión de su reglamento sectorial (Perú, 2011), pero con sesgos y carencias cuya finalidad evidenció, para muchos, el inminente y fácil ingreso de los OVM con fines de cultivo y crianza. De hecho, varios de los ministros del Sector Agricultura, entre los años 2006 y 2011, declararon públicamente la intención de permitir el cultivo de maíz y algodón transgénicos, especialmente en la costa norte. Inclusive, en algún momento tuvo mucha presencia el debate para permitir el salmón transgénico aún no autorizado en su propio país de origen Estados Unidos. Como suele pasar, las declaraciones se hicieron con escaso sustento técnico y, por supuesto, sin ninguna evaluación de riesgo previa; basados únicamente en la oportunidad económica, sin reflexionar en los riesgos ambientales, o frente a la diversidad biológica asociada a los cultivos en cuestión, en la región donde se estaba proponiendo la liberación.

Una medida urgente fue elaborar un mapa de distribución de las razas de maíz (Ministerio del Ambiente, 2010), sobre la base de datos históricos de hace cincuenta años. Es oportuno reconocer la importancia del aporte de datos del Programa de Investigación y Proyección Socia en Maiz de la Facultad de Agronomía de la Universidad Nacional Agraria La Molina. El mapa se elaboró en estrecha coordinación con los especialistas de este programa y rescatando información de sus archivos de varias décadas de antigüedad.

En cualquier caso el mapa resultante echaba por tierra la afirmación de que "en la costa ya no había diversidad de maíz y que, por tanto, podrían permitirse las variedades o híbridos OVM". En el mapa se muestran claramente provincias de la costa norte con cuatro a diez variedades de maíz, con base en data de hace cuarenta a cincuenta años. Es un nivel importante de diversidad para un cultivo, lo cual tendría que generar medidas de bioseguridad sin ninguna duda y, en ningún caso, liberación sin barreras; máxime cuando se trata de un cultivo cuya capacidad de cruzamiento o nivel de alogamia es tan alta. Entonces, lo responsable era actualizar la información de campo y hacer una evaluación de riesgo antes de anunciar liberaciones de OVM de algún tipo.

Como suele suceder, al final de un período presidencial se precipitan hechos en distintas direcciones y las decisiones sucumben a las presiones mayores. El Sector Agricultura logró aprobar y publicar el reglamento sectorial en las postrimerías del gobierno en turno. Sin embargo, la reacción política y social fue inesperadamente alta, en tal medida, que ya en medio del proceso electoral, los dos candidatos presidenciales que quedaron para la segunda vuelta expresaron una posición de reserva y oposición al uso de transgénicos en la agricultura nacional. Las razones técnicas ya llegaron al lenguaje político y era claro para las dos mayores fuerzas políticas de ese momento (2011), entendían que ser país con elevados niveles de biodiversidad y ser centro de origen y domesticación exigía trabajar en sistemas de producción distintos a los de los países "granero", donde si prosperan los OVM.

Por otro lado, en el escenario legislativo hubo una autógrafa (proyecto de ley aprobado po el Congreso de la República, pero no promulgada por el presidente de la República) de ley de moratoria a los OVM, aprobada en la última legislatura del gobierno del 2006 al 2011, que fue observada por el presidente en su momento.

Con el Reglamento Sectorial de Agricultura aprobado muy forzadamente -y una autógrafa de ley de moratoria a los OVM observada por el gobierno saliente- la reacción fue más fuerte y naturalmente en sentido contrario. La nueva legislatura en el Congreso de la República comenzó con media docena de nuevos proyectos de ley sobre moratoria a los OVM, todos los cuales se acumularon en uno que finalmente fue aprobado por el Congreso y promulgado por el nuevo presidente. La Ley №29811, Ley que Establece la Moratoria al Ingreso y Producción de los Organismos Vivos Modificados (OVM) al Territorio Nacional por un período de 10 años (Perú, 2011a).

El nuevo gobierno desarrolla el tema de bioseguridad en un escenario (a fines del 2011) disponiendo de una Política Nacional del Ambiente obtenida con incuestionable consenso, pero con una ley inaplicada e inaplicable ( $\left.{ }^{\circ} 27104\right)$. Y una nueva ley de moratoria, ( ${ }^{\circ} 29811$ ) también con mucho apoyo en las bases de agricultores y ambientalistas, pero con grandes resistencias especialmente desde la industria y comercio semillerista.

En ese momento, el Perú ya disponía de políticas y leyes, pero los OVM siempre presentes, al menos en el comercio de granos, sin control ni barreras implementadas. 


\section{De la Ley №29811 a la actualidad. Con políticas, regulación, control y barreras}

La Ley N ${ }^{\circ} 29811$ resultó retadora al orden establecido en el comercio internacional, de tal manera que las presiones no fueron pocas ni menores. En una práctica, no siempre tan evidente, a pesar de lo minúsculo del comercio exterior peruano, tres gobiernos de países amigos, socios comerciales grandes, se pronunciaron (mediante cartas al más alto nivel de gobierno), en contra de la moratoria establecida y pedían directamente su derogatoria, pronosticando consecuencias catastróficas para nuestro sector agrario y denuncias por obstáculos técnicos al comercio a nuestro país. Al cabo de cinco años de moratoria, nada de esto ha pasado; nuestro agro sigue próspero, pero también con problemas difícilmente atribuibles a la no apertura de los OVM. La agroexportación es básicamente un modelo de crecimiento y desarrollo, y la pequeña agricultura, con todos sus problemas, sigue siendo la productora mayoritaria de alimentos para el mercado nacional y de insumos de alta calidad para la ya poderosa gastronomía nacional.

Tampoco se han producido denuncias por obstáculos técnicos al comercio ante la Organización Mundial de Comercio de parte de los países que advirtieron que lo harían. El mercado de semillas peruano es relativamente pequeño y una denuncia de este tipo probablemente no tendría más mensaje que un "escarmiento" o "reprimenda" a un país que hizo respetar su propia visión de desarrollo -especialmente agrícola-y se tomó el tiempo necesario para construir sus capacidades para una adecuada evaluación de riesgos, tomando en cuenta la característica de país megadiverso. De hecho, la ley de moratoria peruana, una vez promulgada parece haber enfrentado más dificultades de implementación en el frente interno que desde el exterior. Los fundamentos de la norma resultaron muy sólidos tanto desde el punto de vista científico como el legal.

Sobre la base del Protocolo de Cartagena sobre Seguridad de la Biotecnología (Naciones Unidas, 2000) en cuyo preámbulo se considera que:

Reafirmando el enfoque de precaución que figura en el Principio 15 de la Declaración de Río sobre el Medio Ambiente y el Desarrollo, conscientes de la rápida expansión de la biotecnología moderna y de la creciente preocupación pública sobre sus posibles efectos adversos para la diversidad biológica, teniendo también en cuenta los riesgos para la salud humana, reconociendo que la biotecnología moderna tiene grandes posibilidades de contribuir al bienestar humano si se desarrolla y utiliza con medidas de seguridad adecuadas para el medio ambiente y la salud humana, especialmente, reconociendo también la crucial importancia que tienen para la humanidad los centros de origen y los centros de diversidad genética.

Así como en el Artículo XX.g. del Acuerdo General sobre Aranceles Aduaneros y Comercio (GATT, 1947), sobre Excepciones Generales en el que se señala que:

Ninguna disposición del presente Acuerdo será interpretada en el sentido de impedir que toda parte contratante adopte o aplique las medidas: relativas a la conservación de los recursos naturales agotables, a condición de que tales medidas se apliquen conjuntamente con restricciones a la producción o al consumo nacionales.
Cuando de por medio está el daño, pérdida o extinción de variedades de cultivos o crianzas o de otros componentes de la diversidad biológica estamos frente a la condición de "recurso natural agotable" de la diversidad biológica y, por tanto, el país afectado puede tomar las medidas que correspondan evitar o atenuar este impacto negativo.

En el frente interno, la implementación resultó más lenta y complicada. Ya pasamos 65 meses de los 120 que contempla el plazo de la moratoria a los OVM, y los esfuerzos han tenidos algunos frutos, pero pocos sienten que sean los que correspondan al esfuerzo realizado y mucho menos a las metas establecidas. El reglamento de la ley (Perú, 2012) tardó un año, pero se logró con el consenso de todos los sectores públicos involucrados y con la activa resistencia de los regulados, específicamente el sector de la industria y comercio de semillas. Aceptada ya la moratoria, su reclamo técnico más importante era el establecimiento de umbrales o niveles máximos permitidos de mezcla, debidos a presencia involuntaria de cantidades menores de OVM en lotes convencionales (no OVM). Un pedido con cierta lógica técnica pero legalmente inviable, ya que estos umbrales deberían haber sido incluidos en el texto de la ley. La Ley №29811 no hace ninguna mención a umbrales, con lo cual el límite o nivel máximo de OVM no será otro que el Límite Técnico de Detección del equipo o metodología que se use para el diagnóstico. Paradójicamente, se recurría a valores en otros países que sí tienen umbrales, pero cuando se planteaba comenzar por un autocontrol (de los mismos semilleristas) de valores observados de mezcla de OVM, no lo aceptaban. Pedían directamente que se permitiera el $2 \%$ de mezcla transgénica. En cualquier caso, en nuestro marco legal establecido, ningún valor era aceptable.

Para entender la falta o demora en enfocar adecuadamente los esfuerzos de implementación de la Ley N²9811, conviene remitirse a su texto. El primer artículo de la ley define como su objeto: "declárase una moratoria de diez años que impida el ingreso en el territorio nacional de organismos vivos modificados (OVM) con fines de cultivo o crianza, incluidos los organismos acuáticos a ser liberados en el ambiente". Es decir, el objeto de la ley es evitar el ingreso y uso de OVM con fines de producción: que no se siembren ni críen transgénicos libres en el ambiente. Ese debió ser el primer afán en el proceso de implementación; sin embargo, es probablemente e último de todos los actos realizados. Los primeros años de implementación bien podría haberse interpretado la ley de moratoria como hecha para hacer mapas y promover la agrobiodiversidad y no para prohibir los OVM en el ambiente. Por fin se ha logrado, al menos en términos cualitativos o nominales, ya que existe el mecanismo de control construido con mucho esfuerzo, pero resulta inevitable preguntarse al menos dos cosas: ¿qué porcentaje de las mercancías que debieran ser revisadas o ser sujetos de control, están siendo realmente fiscalizadas? En la preparación del sistema y cuando se pensaba que no era el Ministerio del Ambiente el encargado de hacer la fiscalización o muestreo de los embarques en los puntos de entrada del país (zona primaria de puertos y aeropuerto). Siendo una institución cuya función cotidiana es el muestreo de mercancías, estimaba que, como máximo, se podría llegar a tomar muestras de solo el $2 \%$ de las mercancías fiscalizables, específicamente de semillas. Ahora que la función ya ha comenzado a ser ejercida por el Ministerio del Ambiente y la lista de mercancías aprobadas para fiscalización de OVM (Perú, 2016) en el marco de la Ley №29811 es un poco más compleja que sólo semillas de maíz y soya, cabe preguntarse qué parte de esas mercancías fiscalizables están siendo efectivamente fiscalizadas Es importante el acto, pero también el impacto. 
Lo importante, sin duda, es que el marco normativo y administrativo para que se realice la fiscalización de los OVM, ya existe. La eficacia dependerá del equipo del momento, del equipamiento y de la gestión y responsabilidad de los involucrados. En cualquier caso, fue un avance importante que recién fue posible al quinto año.

La segunda pregunta sobre la fiscalización implementada es respecto de las acciones procesos que genera, cuando se identifica una falta; debiera dar lugar a algún tipo de acción, proceso o sanción, comenzando por una remediación para evitar un incremento del problema. Hay al menos dos hallazgos de transgénicos que han trascendido sin acciones posteriores importantes: soya trasngénica en Bagua (Región Amazonas, Perú), producto de un muestreo en julio del 2015 -Bagua es una zona de agricultura familiar, en su mayoría orgánica o al menos ecológica, para cultivos tan importantes con el café o el cacao-.Al preguntar a los funcionarios involucrados por este caso (en un evento público), la respuesta fue aparentemente ligera como en el caso de soya transgénica en el sur de México (Narváez, 2013). La respuesta fue que la soya detectada probablemente procedía de una soya grano comercial que habría sido utilizada como semilla y que no había ningún problema ya que la soya no se cruza con el cacao n con el café; la medida tomada sería un nuevo monitoreo al año siguiente. Pero, ¿es realmente desdeñable tener soya trasngénica en medio de cacao y café orgánico?

De manera similar, cuando se aprobó la siembra de soya transgénica en la península de Yucatán en México, se subestimó el riesgo y no se tomó en cuenta la producción de mie orgánica con fines de exportación al mercado europeo en las inmediaciones de los polígonos aprobados. Esta soya transgénica estaba dentro del alcance del área de forrajeo de las abejas de la zona y la miel resultó contaminada, cuando los compradores europeos de la miel detectaron esta contaminación,se perjudico el acceso de la miel mexicana al mercado europeo: un impacto impensadamente alto. (Narváez, 2013).

Está claro que la soya jamás se va a cruzar de manera natural con el cacao o el café, pero es realmente arriesgado permitir la coexistencia de estos cultivos cuyo mercado es principalmente orgánico, con la soya transgénica, sin ningún tipo de control, más allá de una visita anual de monitoreo.

El otro hallazgo de transgénicos es más preocupante y se ha producido, en un monitoreo reciente, en campos de maíz en la región Piura (Informe de Vigilancia N02-2016-MINAM). "De las 59 muestras analizadas, 41 dieron un resultado positivo a la presencia de OVM, esto representa casi el $70 \%$ de los campos inspeccionados." Lo más curioso ha sido la consecuencia del hallazgo:

Como respuesta inicial a este problema, el Ministerio del Ambiente en coordinación con el Ministerio de Agricultura y Riego y el Instituto Nacional de Innovación Agraria, realizaron una campaña de sensibilización a los agricultores piuranos de tres comisiones de riego en el mes de octubre. La finalidad es explicarles la importancia del uso de semillas de calidad (certificadas) con el fin de mejorar su productividad y evitar incumplir con las normas nacionales.

No hay sanción a ninguno de los actores involucrados y los OVM permanecen en el campo hasta la siguiente campaña y como es fácil prever en maíz, por introgresión, por un número indeterminado de generaciones sin control ni seguimiento

Nuevamente, bien por el acto de fiscalización, pero en este caso, además del acto, cuenta el impacto. Es claramente insuficiente, al menos lo que se puede valorar en función de la información que es pública.

Los esfuerzos iniciales de implementación de la moratoria se concentraron más en la finalidad de la ley (artículo $2^{\circ}$ ) que en su objeto (artículo $1^{\circ}$ ). La finalidad de la ley de moratoria es: " ... fortalecer las capacidades nacionales, desarrollar la infraestructura y generar las líneas de base respecto de la biodiversidad nativa que permita una adecuada evaluación de las actividades de liberación al ambiente de OVM." (artículo $2^{\circ}$ de la Ley N29811). Es más, si se desagrega el mandato de este artículo $2^{\circ}$, tenemos 1) capacidades nacionales, 2) desarrollo de infraestructura, 3) líneas de base y 4) adecuada evaluación de liberación al ambiente de OVM, lo cual quiere decir análisis de riesgo en sus tres componentes (evaluación, gestión y comunicación de riesgos).

El componente abordado con más fuerza, al menos con base en los aspectos públicos de la gestión de la autoridad competente, han sido las líneas de base de la biodiversidad. Es el tema en el que más recursos parecen haberse dedicado, en tal medida que da la impresión que la ley de moratoria estaba siendo interpretada como una ley sobre agrobiodiversidad. Se abordaron trabajos de listados de diversidad por cultivos y de algunas especies animales. La información que se ha acumulado ha sido publicada a nivel de página web (http://bioseguridad.minam.gob. pe/normatividad/implementacion/lineas-de-base/). En ningún caso han pasado mayor revisión que la de los mismos funcionarios del sector responsable o eventos públicos en los que difícilmente se genera un escenario propicio para una adecuada valoración de contenidos. Sería altamente recomendable que la información y documentos generados pasaran por una revisión por pares o se avance en su elaboración hasta llegar a la forma de artículo científico en revistas indexadas. Esa sería una primera medida para estar seguros de la calidad de la información generada a través del esquema de consultorías, y no en convenio con centros e institutos de investigación como lo recomendaba el artículo 28.2 del reglamento de la ley de moratoria:

Para la generación de las Líneas de Base, el MINAM podrá realizar alianzas estra-

tégicas y convenios con entidades académicas o de investigación, públicas y/o

privadas de reconocido prestigio, dentro del ámbito temático de la información

que se pretenda obtener o proceso que se busque implementar (Perú, 2012).

En cualquier caso, el valor o utilidad de una herramienta o información se pone a prueba cuando debe servir para resolver el problema o cuestión para lo que estaba previsto. Las líneas de base deben servir para realizar y tomar medidas de evaluación y gestión de riesgos. Sin embargo, hemos citado al menos dos casos de transgénicos libres en el ambiente ilegalmente (Bagua y Piura), en ninguno de los cuales parecen haberse utilizado las líneas de base o ninguna otra de las herramientas que debemos desarrollar o implementar en el plazo de la moratoria.

Cabe mencionar que ya se cuenta con dos laboratorios (Certificaciones del Perú S. A. y Biotecnología de Alimentos S.A.C.) acreditados para el diagnóstico de OVM, lo cual suma a la institucionalidad necesaria. 
Por otro lado, las mayores carencias observables a partir de la información pública es el escaso avance en el "Proyecto Especial para el Fortalecimiento de Capacidades Científicas y Tecnológicas en Biotecnología Moderna Relativas a la Bioseguridad" (artículo $26^{\circ}$ del reglamento de la ley de moratoria). Sin personal capacitado y laboratorios equipados, poco o nada se podrá hacer al término del plazo de la moratoria. La implementación de este proyecto especial es clave y urgente.

Finalmente, el plazo de la moratoria tendría que servir para resolver los problemas que limitan la implementación de un sistema de bioseguridad en el Perú. No parece que los involucrados estén -todos- enfocados en las mismas prioridades. Más allá de los aspectos técnicos, probablemente la decisión política más importante pendiente es darle una nueva institucionalidad que corrija los problemas de conflicto de intereses y de asignación racional de funciones de regulación a quienes realmente tengan las capacidades y la vocación para desarrollarlas.

Al momento de publicar este artículo, quedan 55 meses de los 120 de moratoria. Es necesario intensificar el trabajo.

\section{Bibliografía}

Centro de Intercambio de Informacion sobre la Seguridad de Pastor, S., 2013. 10 Years: Peru's national biosafety law la Biotecnologia (2017) Perfiles de país de Brasil (http://

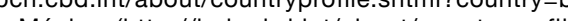
$y$ Mexico (hth://bch. cbd. int/about/countryprofile.

Congreso de la República del Perú, 2006 "ACUERDO DE .

Food and Agriculture Organization FAO (2001) Genetically modified organisms, consumers, food safety and th ISBN 92-5-104560-7. (en línea disponible en: http://www. fao.org/docrep/003/x9602s/x9602s05.htm)

Ministerio del Ambiente, 2010. Mapa de las Razas de Maíz razas-maiz-peru.

Ministerio del Ambiente, 2016. Informe de Vigilancia №022016-MINAM. Disponible en: http://bioseguridad.minam. gob.pe/acciones_vigilancia/vigilancia-n-02-2016minam/ (23/04/2017)

Naciones Unidas, 1947. Acuerdo General sobre Aranceles Aduaneros y Comercio - GATT.

Aciones Unidas, 1992. Convenio sobre la Diversidad Biológica - CBD.

Naciones Unidas, 2000. Protocolo de Cartagena sobre Seguridad de la Biotecnología del Convenio sobre Diversidad Biológica.

10 Tears: Peru's national biosafety law - August, 2013 .

erú,1999. La Ley No27104 o Ley de Prevención de Riesgos Derivados del Uso de la Biotecnología.

Perú, 2002. Reglamento de la Ley №27104 ó Ley de Prevención de Riesgos Derivados del Uso de la Biotecnología. DS N'01004-2002- PCM.

Peru, 2008. Ley de creación, organización y funciones de Ministerio del Ambiente. Decreto Legislativo №1013. Perú, 2009. Política Nacional del Ambiente. Decreto Supremo No012-2009-MINAM

Lê. 2010. Código de Protección y Defensa del Consumidor. Ley No29571.

Perú, 2011. Reglamento Interno Sectorial sobre Seguridad de la Biotecnología en el Desarrollo de Actividades con Organismos Vivos Modificados Agropecuarios o Forestales y sus Productos Derivados. Decreto Suprem

Perú, 2011a. Ley 2981, Ley que Establece la Moratoria al Ingreso y Producción de los Organismos Vivos

erú, 2012. Reglamento de la Ley No29811, Ley que Organism la Moratoria al Ingreso y Producción $c$ un Período de 10 años DS No008-2012-MINAM del 14 de noviembre de 2012.

Narváez Torres, P. R., 2013. Detección de polen convencional Perú, 2016. Listado de mercancías restringidas sujetas a y genéticamente modificado de soya, Glycine max L, en y Yucatán. Tesis de licenciatura, UNAM. 


\section{Estudios y patrones continentales \\ de domesticación y manejo de recursos genéticos: perspectivas}

Alejandro Casas, Fabiola Parra-Rondinel, Ignacio Torres-García, Selene Rangel-Landa, Mariana Zarazúa y Juan Torres-Guevara

\section{Resumen}

Los textos que presentamos en los dos volúmenes de esta obra muestran un marco conceptual que los autores participantes hemos construído, en la última década, acerca de la domesticación como proceso generatriz de recursos genéticos y sobre su importancia en el desarrollo de estrategias para su manejo sustentable. Desde luego, una de las principales conclusiones de este examen cuidadoso es que el mantenimiento de las condiciones del proceso de domesticación constituye la base de cualquier estrategia de manejo sustentable de los recursos genéticos en los contextos rurales. Presentamos también estudios de caso que realizan en distintas regiones del continente americano diferentes grupos de investigación, sus resultados y principales conclusiones, sus problemas tanto en la investigación como en el manejo de los recursos, sus visiones y reflexiones sobre las perspectivas para abordarlos. $Y$ con ambos conjuntos de elementos aspiramos a nutrir teorías que nos ayuden a potenciar el trabajo dentro de nuestros grupos y entre los grupos de investigación con quienes hemos detonado tan valiosa interacción. Buscamos fortalecer estas interacciones, nuestra colaboración en la construcción conceptual y en nuestra praxis, para proteger y aprovechar de manera sustentable los recursos y para contribuir a reivindicar los derechos de propiedad intelectual de los continuos creadores de tan inmenso constructo: los pueblos del continente americano.

Incluimos en esta reflexión que la domesticación es un factor diversificador y que, por lo tanto, genera paulatinamente diversidad. Es esta la idea de domesticación iniciada por Darwin que lo llevó a una de sus principales conclusiones para explicar el origen de la diversidad biológica del planeta. Es tal diversidad biológica el corpus fundamental de los recursos genéticos y en su generación confluyen procesos naturales y artificiales que ameritan comprensión y protección. Pero también, la domesticación incluye el plano de la adecuación de los ecosistemas y los paisajes, el modelaje del universo supra-organísmico que forma parte de la construcción del nicho humano. La domesticación de los ecosistemas, de los paisajes y los territorios es mucho más antigua que los procesos de domesticación de organismos. Hoy están vigentes tanto en los contextos rurales como urbanos. Influyen y son influidos por los procesos que 
involucran la domesticación de organismos. Por eso su análisis no puede excluirse del estudio de los procesos que generan recursos genéticos. Son ambos procesos interescalares mutuamente influyentes, poco atendidos aun cuando se analizan los procesos de domesticación. $Y$ es esta una vertiente teórico-metodológica que amerita un mayor desarrollo por los grupos de investigación que estudiamos la domesticación en un sentido amplio.

La pérdida de diversidad genética es una realidad a escala global y los procesos industriales contemporáneos son claramente los principales responsables de los fenómenos que los determinan: la pérdida de ecosistemas naturales a ritmos inusitados (en los últimos 75 años se han impactado severamente los ecosistemas más que nunca en la historia planetaria); las emisiones de gases de efecto invernadero y el consecuente calentamiento promedio de la superficie terrestre y el cambio climático; la eutroficación; la contaminación de suelos, agua y atmósfera por residuos peligrosos; la destrucción directa de patrimonio biocultural de enorme valor histórico ligado a las guerras, a la extracción de petróleo, a la minería en general, pero sobre todo a su modalidad a cielo abierto, y a la sobreexplotación de recursos maderables y no maderables; el impulso de la agroindustria con niveles altamente ineficientes, y su más reciente expresión ligada al uso de organismos genéticamente modificados. Esta industria, particularmente la de los transgénicos, más que resolver un problema de producción de alimentos y materias primas ha profundizado en la contaminación de ecosistemas, ha generado dependencias tecnológicas y sociales, deformaciones socioculturales que significan la ruptura de procesos constructivos de tecnologías milenarias. Todo ello, en beneficio de grandes corporaciones mundiales que anteponen sus intereses a los del bienestar socioecosistémico.

En el segundo volumen presentamos estudios de caso que abordan desde distintos ángulos los procesos de domesticación, la generación de recursos genéticos y las experiencias regionales de manejo sustentable de estos recursos. Todos ellos se encuentran influenciados por la naturaleza y las culturas locales, abren un abanico de formas de manejo de la diversidad de plantas y animales, de ecosistemas naturales y artificiales en los que habitan. Hay en estos estudios casos de la Amazonía y el nordeste semiárido brasileños, la región Andina del Perú, el nordeste de los Estados Unidos, Mesoamérica, las regiones Andina y Patagónica de la Argentina, las experiencias urbanas de la Plata, los estudios regionales del valle de Tehuacán, la península de Yucatán y la región occidental de Mesoamérica. Pero hay también estudios de caso sobre grupos de plantas en particular: frijoles del género Phaseolus, chiles del género Capsicum, maíz (Zea mays), tuberosas andinas, cactáceas columnares, opuntias y agaves, plantas medicinales y aromáticas, camélidos. Un verdadero caleidoscopio que, no obstante su extensión, aún se queda corto para analizar la enorme riqueza de recursos de este maravilloso continente y la experiencia de los pueblos que lo habitan.

Todos los estudios que componen el segundo volumen son, en conjunto, un extraordinario mosaico de situaciones y contextos bioculturales sobre las cuales se han desarrollado múltiples experiencias de investigación y acciones de aprovechamiento y conservación. Estas investigaciones han obtenido múltiples resultados que forman parte ya de la literatura mundial, en este foro hemos tenido el privilegio de que sus autores las compartan enriquecidas con reflexiones originales de la temática que nos preocupa. Nos serán útiles a todos los que participamos en la obra y a los lectores que la consulten. Aspiramos, ante todo, a acortar dis- tancias para entender los procesos de domesticación y para manejar de manera sustentable los recursos genéticos. Todas las experiencias compiladas aquí tienen en común un conjunto de patrones que analizamos y continuaremos analizando con la meta de utilizar criterios metodológicos similares para hacer comparables los patrones evolutivos observados, sus causas y consecuencias, y coordinar la toma de decisiones en el desarrollo de estrategias similares para su manejo sustentable. Interesa no solo la permanencia de los recursos, sino, sobre todo, la permanencia de los procesos y ello nos conduce y nos compromete a la defensa de la autonomía de las culturas locales y regionales, sus territorios y a compartir con nuestros pueblos e compromiso de defender la soberanía alimentaria. La interculturalidad como base de diálogo de saberes, pero también de respeto a los valores. En el análisis de las perspectivas, esta reflexión ocupa un lugar de excepcional importancia y es la intención de quienes escribimos este texto seguir profundizando en el análisis de qué preguntas son relevantes, qué métodos los apropiados para abordarlas, qué patrones son particulares y cuáles son generales, qué prácticas e intercambios podemos llevar a cabo para potenciar nuestro quehacer, entre otros aspectos. Pero, primordialmente, cómo incluir en la interculturalidad las construcciones transdisciplinarias que permitan nutrir mutuamente los procesos de saberes locales y los sistemas de conocimiento que construyen las ciencias contemporáneas.

Somos conscientes de una de las grandes carencias de esta obra: el abordaje de los procesos de domesticación en microorganismos, particularmente los de los fermentos que han acompañado a los seres humanos en bebidas y alimentos desde la prehistoria. Asimismo, e estudio del manejo y la domesticación de hongos. Es este otro punto de la agenda que hemos identificado en la perspectiva de la investigación científica, en la temática que nos unifica. Estamos entonces frente a la importancia de ligar los estudios de conocimiento ecológico tradicional sobre uso y manejo de fermentos y de hongos con la ciencia de la microbiología y la micología, y con ello completar un panorama aún más integral del estudio de estos procesos. Los reinos vegetal y animal han sido parte central de los estudios de domesticación desde sus orígenes. Los de los reinos que incluyen a las bacterias, a los protozoarios y a los hongos han sido mucho menos estudiados, pero no nulos. Las siguientes versiones o ediciones de estas obras deberán preocuparse por incluirlos.

Las investigaciones que realizamos encuentran un enorme paraguas conceptual en la denominada ciencia para la sustentabilidad. Esta visión paradigmática se ha construído a nive mundial desde hace aproximadamente dos décadas. Se trata de construir virajes importantes en la manera de realizar investigación científica y en la forma de organizar las instituciones de investigación y su vínculo con la sociedad civil y los tomadores de decisiones. Se trata de poner en el primer plano la incorporación de la visión sistémica y el concepto de complejidad en el análisis de procesos socioecológicos. Los recursos genéticos y los procesos de domesticación se encuentran inmersos en sistemas de los que también forman parte los seres humanos, no son elementos o procesos aislados y, como tales, ameritan ser analizados. Se trata también de incluir el concepto de transescalaridad, que indica que los sistemas como los que estudiamos están organizados de manera jerárquica, en los cuales, lo que pasa en un nivel inferior repercute a escala general y viceversa. Resulta imprescindible incluir el concepto de sustentabilidad como eje directriz de las acciones de manejo y la intervención sobre los procesos de resiliencia de los sistemas, como la base para guiar la acción. Se trata de reconocer que las 
visiones fragmentadas de las ciencias son hoy, más que nunca, insuficientes para entender los sistemas complejos cuyos elementos y procesos son mutuamente interdependientes y como tales deben entenderse. Que el abordaje interdisciplinario es, por lo tanto, una necesidad. Y se trata también de comprender que los seres humanos han desarrollado conocimientos desde miles de años antes de que se desarrollara la visión del método científico que hoy prevalece en las ciencias contemporáneas. Este conocimiento heredado y recreado por los campesinos es sumamente valioso y las ciencias deben entender el enorme valor que tienen para enfrentar los problemas socioecológicos actuales. Este punto conduce al desarrollo de teorías sobre interacciones transdisciplinarias entre distintos sistemas de saberes. Particularmente se trata de reconocer el gran valor de los conocimientos tradicionales y los que construyen los ciudadanos día con día. En todos estos enfoques, la etnobiología y su interacción con otras disciplinas y enfoques desempeñan ya un papel de gran trascendencia. Pero es quizá en este último aspecto mencionado en el que su papel es de extraordinaria importancia. Es la etnobiología un puente de enlace entre sectores. Es la base de interacciones interculturales y de la generación de contextos de diálogo. El manejo sustentable de recursos genéticos implica procesos complejos, todos los cuales involucran diálogos de saberes tradicionales y ciencia contemporánea con enfoques interdisciplinarios. Implica, en primer lugar, diagnosticar el estado de la diversidad desde la escala de diversidad genética, de especies, de ecosistemas y paisajes. En segundo lugar, es preciso analizar los procesos que generan tal diversidad y en ello, los moldeadores de la diversidad son seres humanos que guían procesos bioculturales, y con los cuales los investigadores pueden hablar e intercambiar experiencias. Los procesos biológicos y ecológicos incluyen procesos naturales y artificiales de selección, mutaciones, deriva génica, flujo génico y sistemas reproductivos. Entenderlos significa meterse en la intimidad de la naturaleza y la cultura, y analizarlos de manera integrada constituye una metodología no solo apropiada, sino éticamente correcta. En tercer lugar, implica analizar cómo se han mantenido estos procesos por miles de años, cómo los procesos industriales modernos atentan contra su integridad y cómo es posible establecer virajes para lograr su mantenimiento a largo plazo.

Nuevamente, los contextos naturales y culturales del continente americano son diversos, los procesos biológicos de las especies en cuestión también lo son, así como las historias que han moldeado la diversidad de los paisajes. Por ello, el intercambio de experiencias como el que mostramos en esta obra establece pautas de aprendizaje, de mutua influencia y confluencia. Aspiramos a establecer una agenda de investigación y acción que incluya los puntos antes expuestos y a fortalecer la interacción, la colaboración y la experiencia de los grupos que hoy emprendemos la iniciativa y de otros más que, sin duda, se sumarán a la marcha de este proceso para entender y atender los grandes problemas ligados a la comprensión de los procesos generatrices de recursos genéticos y su manejo sustentable.

Palabras clave: continente americano, domesticación interdisciplina, Latinoamérica, recursos genéticos, sustentabilidad, transdisciplina.

\section{Introducción}

La domesticación y las prácticas agrícolas de las principales especies cultivadas del continente americano se originaron en tiempos similares en Mesoamérica y en la región Andina (Vavilov, 1951-2011 MacNeish, 1992; Harlan, 2005), las teorías más recientes proponen un origen neotropical más difuso, incluyendo Mesoamérica y la región tropical sudamericana (Piperno y Pearsal 1998, Piperno 2011). Las teorías clásicas han propuesto que los principales cultivos y animales domésticos tuvieron un sitio claro de origen y a partir de esas áreas se difundieron poco después de Mesoamérica al suroeste y al nordeste de los Estados Unidos de América, en el hemisferio norte y de la región Andina a una vasta región sudamericana, incluyendo zonas áridas y semiáridas al oriente y occidente, así como la región tropical húmeda, principalmente la Amazonía. En estas últimas áreas se adoptaron cultivos mesoamericanos y andinos, y se introdujeron al proceso de domesticación diversas especies locales. En el caso del actual territorio de los Estados Unidos, Bruce Smith (Smith 2006) propuso que la región nordeste pudo haber sido un centro independiente de origen de la agricultura, en donde se domesticaron principalmente cuatro especies de plantas: calabazas locales (Cucurbita pepo subsp. ovifera), Iva annua (una especie de Asteraceae utilizada por sus aquenios comestibles), girasoles (Helianthus annus) y la quenopodiácea Chenopodium berlandieri (Smith, 2006; Piperno, 2011). Se ha sugerido que esta podría ser la zona de domesticación de los arándanos (Vaccinium macrocarpon y $V$. erythrocarpum) que actualmente tienen gran importancia económica; sin embargo, estudios recientes indican que los arándanos se domesticaron a mediados del siglo XX mediante estrategias biotecnológicas intensivas (Jiménez-Bonilla y Abdelnour-Esquivel, 2012). De la región Andina, particularmente de la zona de los alrededores del lago Titicaca (Spooner et al., 2004, 2005; Rodríguez, 2010), la domesticación y la agricultura se difundieron hacia el norte y el sur, siguiendo las montañas de la Cordillera de los Andes, la experiencia técnica migró hacia la costa sudamericana por la vertiente occidental de los Andes, aprovechando las áreas irrigadas por los numerosos ríos y arroyos locales en medio de una de las zonas más áridas del mundo, la continuación septentrional del desierto de Atacama. Encontraron en la región norte de Perú y sur de Ecuador una zona marcadamente más amplia que la del sur, en donde la agricultura tuvo un sitio particularmente propicio desde tiempos tempranos. $\mathrm{De}$ acuerdo con los hallazgos arqueológicos documentados por Piperno (2011), esta zona tuvo una agricultura temprana, relacionada de forma más cercana con la agricultura centroamericana (Mesoamérica) y con la de la región tropical de Panamá y Colombia. De manera que en esa región pudieron confluir, de manera eventual, experiencias de domesticación de dos áreas en principio independientes.

Durante mucho tiempo se consideró que la experiencia andina se difundió a la Amazonía siguiendo la vertiente oriental de las montañas. Sin embargo, estudios recientes (Junqueira et al., 2010; Clement et al., 2015) apuntan a un probable desarrollo temprano e independiente del manejo silvícola, la domesticación y la agricultura en vastas áreas de la Amazonía; aunque esta interpretación ha sido cuestionada por diversos grupos de investigación, sobre 
todo arqueólogos que no encuentran patrones consistentes de asentamientos humanos en el área (véase por ejemplo el estudio de McMichael et al., 2012). Recientemente, los estudios de Levi et al. (2017) han adquirido un importante reconocimiento al documentar en la Amazonía una abundancia anómala de especies arbóreas domesticadas (entre las que destacan Bertholletia excelsa, Inga ynga, Pourouma cecropiifolia, Pouteria caimito y Theobroma cacao) en los alrededores de 85 sitios arqueológicos (las especies mencionadas llegan a ser cinco veces más abundantes que lo esperado) en comparación con su abundancia en áreas sin restos arqueológicos, es decir, sin evidencia de ocupación humana. La abundancia fue particularmente marcada en la zona periférica de suroeste de la cuenca amazónica, el área contigua a la región de los Andes; resultó relativamente baja en la porción central de la cuenca amazónica, nuevamente alta en la porción periférica del nordeste de la cuenca de río Amazonas y finalmente la más baja de todas se encontró en la región de las Guyanas (Levi et al., 2017). La huella de este proceso encuentra un importante sustento en las denominadas terras pretas ( tierras negras en portugués) resultantes de desechos orgánicos antropogénicos, como producto del manejo de ecosistemas locales, acumulados en grandes áreas amazónicas por miles de años. Los autores del último trabajo referido encuentran evidencia de procesos de domesticación de hace más de 8000 años. Este es un tiempo relativamente temprano, considerando que en Mesoamérica y en los Andes el proceso inició hace cerca de 10000 años (véase Smith, 1997 para el caso de la domesticación de Cucurbita pepo en Guilá Naquitz, Oaxaca; Piperno, 2006; Ranere et al., 2009; Piperno 2011, para el caso del maíz, con una antigüedad de más de 8700 años antes del presente en la parte central de la cuenca del río Balsas, México). De tal manera, hoy en día ha ganado un terreno importantísimo la propuesta de un posible origen de la domesticación y de la agricultura en la región amazónica, las cuales pudieron difundir su experiencia hacia las regiones andinas, en la porción suroccidental de la cuenca amazónica, así como a las tierras semiáridas del nordeste brasileño y quizá una región más amplia del oriente de ese país incluyendo las zonas fitogeográficas conocidas como sabana y mata atlántica.

El patrón de modificación de la Amazonía descrito por Levi et al. (2017) es de la mayor importancia en el contexto de analizar la dimensión espacial y temporal de la domesticación del paisaje en tiempos prehistóricos. Ya con anterioridad, Barrera et al. (1977), Gómez-Pompa $(1987,1991)$ y Gómez-Pompa et al. (1987) habían descrito el sistema maya denominado pet-kot que fueron en su momento denominadas selvas artificiales mayas en Mesoamérica, así como el sistema denominado teélom, descrito por Janis Alcorn, quien describió cómo en el presente los teekek de la Huasteca potosina en el oriente de México practican su manejo (Alcorn 1981, 1983, 1984). Asimismo, Casas et al. (1997a), con base en estudios de la silvicultura en la mixteca y en la región nahua de la cuenca del río Balsas (Casas et al. 1996) y en la región del valle de Tehuacán (Casas et al., 1997b, 2007) propusieron que las actividades silvícolas en diferentes regiones de Mesoamérica contribuyeron significativamente a modelar los paisajes a escala regional. Asimismo, diversos grupos de investigación de México han documentado cómo desde tiempos preclásicos (desde hace más de 1000 años y hasta el presente) los grupos campesinos indígenas mesoamericanos moldean la vegetación directa o indirectamente con base en la práctica de silvicultura asociada a la agricultura, a través de una gran diversidad de sistemas agroforestales. De acuerdo con Casas et al. (1997) y Moreno-Calles et al. (2013), las prácticas silvícolas ligadas a la agricultura pudieron haber sido parte de los primeros sistemas agrícolas mesoamericanos desde hace varios miles de años, quizá desde su origen. Levi et al. (2017) interpretan que las terras pretas (Lehmann et al., 2004) son resultado de la silvicultura y de la roza tumba y quema en vastas áreas de la Amazonía. Este proceso sigue vigente, en algunas áreas intensamente, pero en general con relativamente baja intensidad entre los pueblos amazónicos; sin embargo, la silvicultura ligada a las prácticas agrícolas y manejo de paisaje es altamente intensa entre los pueblos mesoamericanos y andinos. Quizá el estudio de estas prácticas en tales áreas pueda servir de modelo para entender y modelar cómo ocurrieron en la antigüedad los procesos que Levi et al. (2017) interpretan que ocurrieron con base en estudios ecológicos y arqueológicos en la Amazonía.

El estudio de las prácticas de silvicultura y la domesticación -y su relación con la agricultura- también ofrece la posibilidad de analizar la domesticación a distintas escalas espaciales y su mutua influencia; es decir, la domesticación vista como un proceso transescalar. En el valle de Tehuacán, Parra et al. $(2010,2012)$ y Cruse-Sanders et al. (2013), por ejemplo, analizaron los casos de la domesticación del Stenocereus pruinosus y S. stellatus, dos cactáceas columnares de importancia cultural y económica en la región. Estos autores encontraron un vínculo entre individuos silvestres transportados a las zonas antropogénicas de manejo, así como la influencia de las plantas que de estas especies son cultivadas en estas áreas, mediante la reproducción sexual con individuos en condiciones silvestres. Así como el transporte de semillas de las áreas cultivadas a las silvestres. La selección de materiales que entran a formar parte del stock cultivado y el flujo de polen y semillas desde poblaciones cultivadas a las silvestres y viceversa, nos ilustra el carácter integral de un sistema en el que uno de los componentes es influido por lo que ocurre en el sistema general. De manera similar, uno puede encontrar hoy en día en distintas regiones de Michoacán y Guerrero, las sabanas naturales en las que se distribuye Zea mays subsp. parviglumis, el pariente silvestre directamente emparentado con el maíz. En estas sabanas se encuentran asociados a las plantas de maíz, frijoles silvestres (Phaseolus vulgaris), así como calabazas silvestres ( $\mathrm{Cu}$ curbita argyrosperma subsp. sororia) y chiles silvestres (Capsicum annuum subsp. glabriusculum). Son estas especies los parientes silvestres de los principales componentes de los policultivos mesoamericanos por excelencia denominados milpas. Se trata no solo de elementos, sino del ensamble funcional de los componentes silvestres en un sistema silvestre. Ello sugiere que los pueblos mesoamericanos domesticaron no solo los componentes por separado, sino que podrían haber domesticado al sistema en su conjunto. Sin embargo, la información arqueológica no apoya esta propuesta, pues los restos arqueológicos de maíz, frijol y calabaza más antiguos tienen fechamientos distintos, y también se han encontrado en sitios diferentes. Los restos más antiguos de calabaza, por ejemplo, tienen entre 8000 y 10000 años, y son del valle de Tehuacán (Smith, 1997); los de maíz tienen más de 8700 años de antigüedad y los más tempranos se encuentran en la región central de la cuenca del río Balsas (Ranere et al., 2009); los de frijol con cerca de 10000 años de antigüedad se han encontrado en la cuenca del río Lerma, al norte de la cuenca del río Balsas (Kwak et al. 2008). Aún estamos, claramente, ante un rompecabezas no resuelto. El sistema de milpa existe en condiciones silvestres, pero la evidencia arqueológica y genética indica que 
los sitios más antiguos de domesticación ocurrieron en sitios distintos; ello no descarta la hipótesis sobre la domesticación del sistema, pues hace falta aún mayor investigación al respecto. Podemos decir que con todos sus avances, las ciencias de la arqueología, la genética y la filogeografía son todavía fragmentarias. El hecho es que la domesticación del Phaseolus vulgaris ocurrió también en la región de la cordillera de los Andes, de acuerdo con diversos trabajos, uno de los más recientes el de Kwak et al. (2012), en el cual identifica la presencia de $P$. vulgaris cultivado en esa región incluso antes de la introducción del maíz. Este hecho indica la domesticación de elementos de forma paralela en diferentes regiones, pero tampoco anula la domesticación de los sistemas silvestres. En el caso del chile, diversos estudios sugieren que su domesticación ocurrió en Tehuacán y en Tamaulipas hace 7000 a 9000 años (Kraft et al., 2014) y de este dato desprendemos una conclusión similar Requerimos, entonces, reconocer que hasta ahora ha predominado la visión de reconstruir la historia de la domesticación de elementos por separado; en parte porque las investigaciones arqueológicas así lo han sugerido. Pero en el presente encontramos evidencia de que la domesticación opera a escalas tanto de elementos particulares como de sistemas en su conjunto. Y quizá los estudios como los de las terras pretas de Levi et al. (2017), los del pet-kot maya (Gómez-Pompa, 1987, 1991; Gómez-Pompa et al., 1987) los del te'elom huasteco (Alcorn, 1981, 1983, 1984), los de la silvicultura mixteca y nahua de la cuenca de río Balsas (Casas et al., 1997a,) y la silvicultura del valle de Tehuacán (Casas et al., 1997b, 2007; Moreno-Calles et al., 2013) son ilustrativas de lo que puede analizarse en el presente para comprender el pasado. Quizá es necesario poner mayor atención en las investigaciones para reconocer las dos escalas de manejo y domesticación.

En el hemisferio sur, de manera similar a lo que ocurrió en el hemisferio norte, en cada zona se incorporaron paulatinamente nuevas especies y subespecies de plantas y animales al nuevo patrón de manejo y domesticación, consolidando progresivamente el sedentarismo y la emergencia de asentamientos cada vez más extensos, densos y duraderos. Pero en esta vasta zona Vavilov (1951-2011) identificó múltiples centros de domesticación y Harlan (2005) la definió como una región "no centro" dada su amplitud y su carácter difuso. Los estudios de Piperno $(1998,2011)$ y los de Levi et al. (2017) sugieren fuertemente que en Sudamérica confluyeron experiencias mesoamericanas, andinas y amazónicas en distintos puntos del área, claramente en el noroeste de Perú, sur de Ecuador (Piperno, 2011) y aparentemente en el suroeste de la cuenca amazónica, en la periferia que colinda con la región andina (Levi et al., 2017). Y es entonces cuando el escenario sudamericano se convierte en la representación más clara de una red difusa de experiencias que pudieron comprender no solo Sudamérica, sino al Neotrópico en general, incluyendo Mesoamérica y la región centroamericana, como lo propone Piperno (2011). Uno de los centros civilizatorios de continente americano más antiguo (4000 años antes del presente) se puede apreciar en el sitio de Caral, en la región del puerto de Supe, Perú (Shady-Solís et al., 2001). Caral se encuentra en la franja hiperárida de Perú, en un valle irrigado por el río Supe que baja de los Andes hacia la costa del Pacífico, determinando un efecto de oasis, como en múltiples áreas de esta franja. Caral es representante de una de las expresiones más antiguas de a complejidad social en el continente americano, con una economía que incluyó la agricultura, a diferencia de múltiples asentamientos precerámicos del área que dependían de una economía eminentemente marina (El Paraíso, Bandurria, Huaca Prieta, Río Seco, Alto Salaverry, Culebras, Huaynuna, y Tortugas). Es Caral una zona de confluencia de elementos culturales de distinto origen. Se han recuperado elementos vegetales regionales, similares a los reportados por Quilter et al. (1991) para El Paraíso, tales como calabaza, frijol, lúcuma (Cucurbita sp., Phaseolus vulgaris, Pouteria lucuma, guayaba (Psidium guajava), pacay (Inga feuillei), camote (Ipomoea batatas) y algodón (Gossypium barbadense), aunque es notoria la ausencia de maíz (Zea mays) (Shady-Solís et al., 2001). También es Caral la expresión de nivel de desarrollo de técnicas de manejo agrícola y de tecnología hidráulica que por miles de años se desarrolló en el Neotrópico, en las zonas alto-andinas y en Mesoamérica. Todo ello permitió uno de los primeros centros civilizatorios del continente americano, más de mil años antes de que se desarrollaran las grandes civilizaciones mesoamericanas (Quilter et al., 1991; Shady-Solís et al., 2001).

Hoy en día es ampliamente aceptado que Mesoamérica y la región andina fueron centros primarios de domesticación y que entre los centros secundarios destacan el nordeste de los Estados Unidos de América y la Amazonía. No obstante, cada vez son más contundentes los elementos que permiten establecer que la Amazonía podría haber sido un centro primario de domesticación que influyó sobre otros centros primarios y secundarios del continente americano (Lehmann et al., 2004; Clement et al., 2015; Levi et al., 2017). De manera similar, otras zonas probablemente también fueron independientes y dinámicas, incorporando plantas y animales a la domesticación desde tiempos tempranos. También es posible que vastas áreas hayan sido influenciadas por los centros primarios que por ahora han sido más claramente identificados, y que hayan alcanzado pronto un mecanismo tanto o más dinámico y propio de manejo y domesticación que los principales centros de domesticación reconocidos. Los estudios arqueológicos están revelando cada vez con mayor claridad la particular abundancia de recursos y la evidencia de procesos locales de domesticación en diversos puntos del continente (Piperno, 2011). En tales centros primarios y secundarios podrán encontrarse patrones de adopción progresiva o de corto plazo de estas técnicas, de acuerdo con las formas de dominio que establecieron las culturas prehistóricas. Y de igual modo es posible prever una amplia gama de condiciones socioecológicas en las cuales la historia civilizatoria se desarrolló. Será una trama compleja de circunstancias la que la arqueología y otras áreas de la ciencia, como la botánica, la zoología, la genética y la filogeografía, tendrán que esclarecer en las próximas décadas. Parece, en otras palabras, que el concepto de centro como lo propusieron Vavilov (1951-2011), Harlan (2005), Smith (2006) y otros autores posteriores, parece diluirse y ganar terreno el de las áreas difusas, como lo propone Piperno (2011), áreas con una alta interacción de experiencias, sumamente dinámicas, en las que la cronología se vuelve un rompecabezas difícil de descifrar y en el que se superponen tiempos, espacios y especies con un difícil acomodo lineal.

El contacto de las culturas del hemisferio norte con las del hemisferio sur aparentemente ocurrió de manera muy temprana, como lo muestra la presencia de plantas como el maíz, originario de Mesoamérica, en la región andina. Igualmente la presencia de los frijoles pallares (Phaseolus lunatus) originarios de forma paralela en las regiones andina y mesoamericana (Piperno, 2011) en estratos de cerca de 7000 años de antigüedad. Ello da cuenta de la extraordinaria movilidad humana durante la prehistoria. En el caso del continente america- 
no, la difusión ocurrió sobre un eje norte-sur a gran velocidad, producto del movimiento de importantes grupos culturales que dieron origen a las grandes civilizaciones en Mesoamérica y la región andina, lo que sustentaría un intercambio temprano y significativo entre las regiones medias de América y los centros de origen en Perú.

Esto, sumado a la aparición de evidencias arqueológicas más recientes, así como las evidencias moleculares, dan nuevas luces al respecto, mostrando un escenario de posible contacto entre las dos grandes regiones y, por lo tanto, apoya la hipótesis de la difusión de la agricultura sobre un eje-norte sur. Por ejemplo, estudios de genética molecular que han propuesto que cultivos como el frijol (Chacón et al., 2005; Bitocchi et al., 2013) o el camot (Roullier et al., 2013) -domesticados por un lado en los Andes, y por otro lado en Centro o Mesoamérica- entraron en contacto cerca del extremo norte de Sudamérica, pudiéndose encontrar una amplia gama de variedades de dichos cultivos que cuentan con una mezcla de los dos acervos genéticos correspondientes a los diferentes centros de origen de tales cultivos; o por estudios más recientes como el de Bedoya et al. (2017) que muestran el movimiento del germoplasma norte-sur de maíz que se ha dado en el continente americano ha sido sumamente importante, con base en el análisis de la distribución de las variedades nativas de este cultivo.

A menudo nos maravilla la evidencia de la presencia de elementos marinos en las zonas montañosas y, con mayor razón, la presencia de elementos propios de un hemisferio en otro. Desde luego, hay muchos más ejemplos que se podrían mencionar y que a lo largo del texto han surgido con mayor detalle (véase por ejemplo el de chile y ajíes por Pickersgill, 2017; el de frijoles por Debouck, 2017; el de diversas especies de frutales tropicales por Clement, 2017 en este volumen). Asimismo, hay aún numerosos sitios por estudiar que permitirán precisar el panorama histórico sobre el origen y difusión de la domesticación, de la agricultura y las prácticas pecuarias (véase Casas et al., 2017; Colunga et al. 2017; Wheeler, 2017). También se irán precisando en las próximas décadas las estimaciones cronológicas de tales eventos, las cuales resultan cruciales para la reconstrucción histórica (véanse los trabajos de Pickersgill, 2017 y Lema, 2017). Las técnicas arqueológicas de fechamiento y de interpretación e identificación precisa de los materiales encontrados en las excavaciones, hoy en día, nos proveen de una literatura con huecos y ambigüedades considerables que para el lector no versado en el tema resultan altamente confusos. Ambos aspectos -la precisión de los relojes para determinar con detalle la dimensión temporal de los eventos, as como la identificación precisa de los restos arqueobotánicos y arqueozoológicos- son quizá de los mayores retos en la investigación arqueológica, para "tomar al toro por las astas" (Lema, 2017), tanto en las zonas previamente estudiadas, así como en nuevas zonas por estudiar. En la historia del estudio de los centros de origen y difusión de la domesticación las hipótesis que se basaron en estudios de diversidad y presencia de parientes silvestres condujeron a los arqueólogos a seleccionar los sitios de mayor interés. Asimismo, en la actualidad los avances en estudios genéticos y filogeográficos plantean hipótesis cada vez más refinadas que ayudarán a corroborarse mediante estudios arqueológicos con técnicas más precisas, capaces de compenetrar en el estudio de la complejidad de los contextos socioecológicos (Piperno, 2011; Kintigh et al., 2014).
El panorama macro y micro del estudio de recursos genéticos

En esta línea de trabajo, resulta pertinente destacar, en primer término, la importancia de abordar el estudio del manejo y domesticación de animales invertebrados -en especial moluscos e insectos (véase por ejemplo Callen, 1967 y Sutton, 1995)- y de microorganismos que fueron utilizados desde tiempos muy antiguos. El estudio del manejo de estos organismos es aún relativamente limitado, y más aún el de su domesticación. Pero, similarmente a como ocurre con plantas y animales vertebrados, los procesos con estos otros organismos también están vivos, son documentables mediante herramientas igualmente similares (etnobiológicas, ecológicas, genéticas, evolutivas) y sería aún mayormente interesante incorpora su estudio desde perspectivas arqueológicas. De hecho, los estudios de coprolitos humanos en el valle de Tehuacán revelan el consumo temprano de insectos por los seres humanos (Callen, 1967). Más aún, estudios recientes muestran que en varias regiones del continente americano y del mundo los insectos no solo se incorporaron a la dieta, sino que los seres humanos practicaron diversas estrategias para adecuar los ambientes de tal manera que les permitiera asegurar la disponibilidad de tan importantes recursos (véase una revisión reciente al respecto en Van Itterbeeck y Huis, 2012). El consumo de moluscos por los hombres prehistóricos, incluso por homínidos previos a Homo sapiens de distintas partes del mundo, ha sido ampliamente documentado debido a la facilidad de su preservación (Colonese et al., 2010), pero es poco sabido acerca de su manejo. El impacto sobre las comunidades de moluscos tanto en mares como en aguas continentales ha tenido una larga historia, $y$ en general, se reconoce que la capacidad de resiliencia de este grupo de organismos a los impactos humanos es alta. Sin embargo, la forma primaria de aprovechamiento de estos recursos desde la prehistoria ha sido la extracción; a lo más, los grupos humanos han emprendido estrategias migratorias en la medida en que los recursos escaseaban. Es hasta recientemente cuando algunos moluscos como el caracol púrpura o el abulón han tenido intervenciones humanas más directas para su protección. Pero el manejo de los moluscos no llega más allá de estrategias de recolección y quizá crianza de algunas especies, pero no existen evidencias de domesticación.

Los microorganismos ofrecen un campo de investigación fascinante y escasamente atendido desde el punto de vista de los procesos de domesticación como los que a lo largo de esta obra hemos revisado sobre grupos de plantas y animales. No obstante, la fermentación y la manipulación de los fermentos y de los procesos de fermentación han estado presentes en prácticamente todas las culturas desde tiempos muy antiguos, desde la prehistoria, de hecho. La fermentación es un proceso que convierte los carbohidratos en distintos productos, entre los cuales destacan el ácido láctico y diversos alcoholes, que pueden influir en el mejoramiento del sabor y en la calidad nutritiva de los alimentos, su textura, así como en la producción de bebidas embriagantes y, sobre todo, en la preservación de alimentos y bebidas (Campbell-Platt, 1994; Van Hylckama Vlieg et al., 2011; Colehour et al., 2014; Gibbons y Rinker, 2015). Diversos autores consideran que el origen de la domesticación de plantas y animales tuvo a la par la domesticación de bacterias y levaduras que contribuyeron a mantener y mejorar los alimentos 
derivados de la domesticación. Desde hace más de 9000 años, por ejemplo, las culturas de medio y lejano oriente produjeron yogurt con la leche, y pronto los fermentos con frutos como la uva y la cebada, el vino, la cerveza, el queso, el kéfir, el shoyu, el pan, el miso y el tempeh en el Viejo Mundo; así como la chicha, el pulque, el mezcal (como fermento de agave cocido), los vinagres, los tepaches, el tesgüino, el chocolate, el téjate, los fermentos de frijol y calabaza en el Nuevo Mundo; y, desde luego, las chichas, los fermentos de mandioca, cacao, piña y otros frutos tropicales y la diversidad de fermentos denominados tocosh que en los Andes se prepara con una gran variedad de papas, mashua y oca, y que constituyen estrategias de conservas de alimentos, adiciones de nutrimentos y probióticos que benefician en muchos sentidos la alimentación. Asimismo, pueden incluirse otros numerosos e importantes fermentos, frecuentemente desdeñados o ignorados en las culturas occidentales. Todos estos son parte de la cultura para mejorar la calidad nutritiva y la preservación de los alimentos. Este campo de investigación es quizá uno de los mayores desafíos de la investigación sobre el manejo y domesticación de los recursos genéticos.

Identificar los progenitores silvestres de los microbios domesticados no es trivial. Es probablemente un reto mucho mayor que el de identificar los parientes silvestres de plantas y animales, sobre todo porque las relaciones fenotípicas entre las especies de microbios y las de parientes silvestres y domesticados no son tan aparentes como en otros organismos, o no siempre lo son. Además, muchas especies de microbios se encuentran distribuidas globalmente y ello dificulta su identificación asociada a un fermento local. Sin embargo, varios estudios ha utilizado la genómica para identificar las fuentes silvestres de microbios domesticados Gibbons y Rinker, 2015). Entre los microorganismos más antiguos se cuentan las bacterias que transforman carbohidratos en ácido láctico. Estos se encuentran naturalmente en numerosas especies de plantas y es posible que la domesticación de plantas y animales haya influido en el cambio de su acción especializada en sustratos de organismos vegetales a sustratos de animales, y es posible que este cambio sea una expresión de la divergencia entre las bacterias silvestres y las domesticadas (Cavanagh, 2015; Gibbons y Rinker, 2015). Otro grupo de organismos importante en la fermentación son las levaduras, particularmente Saccharomyces cerevisiae de las que han divergido un gran número de cepas asociadas a fermentos igualmente diversos. Aunque debe advertirse que existen otras especies de Saccharomyces de gran importancia desde la prehistoria hasta nuestros días. Otros microorganismos importantes son los hongos microscópicos, entre estos Aspergillus, Rhizopus, Penicillium y Monascus, los cuales actúan en las comunidades microbianas que determinan la fermentación de una gran diversidad de alimentos (Gibbons y Rinker, 2015).

El estudio de las comunidades microbianas, las divergencias que han desarrollado a la par de la domesticación de especies de plantas y animales, de los fermentos en los que actúan y las divergencias con respecto a sus progenitores silvestres, son todos temas de investigación de gran trascendencia en los estudios de domesticación. Se trata de organismos que han evolucionado rápidamente, y la identificación de las divergencias y de los procesos mencionados ofrecen retos distintos a los de otros organismos domesticados macroscópicos. Su estudio podría tener grandes contribuciones al entendimiento del origen de las civilizaciones. Diversas especies de organismos invertebrados son parte esencial de la dieta y de la cultura de numerosos pueblos en el mundo, y los fermentos han acompañado la dieta y las ceremo- nias de grupos humanos durante milenios. Por ello, incursionar en estudios etnobiológicos, evolutivos y arqueológicos en aquellas regiones en donde los estudios previos sugieren tener particular relevancia, y regresar a revisar nuevamente los sitios y las colecciones exploradas previamente, nos habla de la gran tarea que tiene por delante la investigación arqueológica de los microorganismos y de animales invertebrados.

\section{El abordaje interdisciplinario en el estudio de los procesos de domesticación}

Las técnicas para extraer $A D N$ de muestras arqueológicas se han refinado desde hace casi tres décadas (Hagelberg y Clegg, 1991; Brown et al., 1994; Leonard et al., 2002; Jaenicke-Després et al., 2003; Herrmann y Hummel, 2012; Wales et al., 2014; Brown et al., 2015). Las oportunidades que estas técnicas brindan son enormes. Más aún cuando la genómica y los estudios de "nueva generación" con SNP (por las siglas en inglés de single nucleotide polymorphysm, o polimorfismo de nucleótidos únicos), de los cuales comienzan a proliferar estudios (Konishi et al, 2006; VonHoldt et al., 2010; Myles et al., 2011; Blackman et al., 2011; Hufford et al., 2012; Schmutz et al., 2014) junto con los estudios del transcriptoma (los productos de la transcripción de genes) (Swanson-Wagner et al., 2012; Koenig et al., 2013; Yoo y Wendel, 2014) están revolucionando la manera de abordar el estudio de características sujetas a selección natural y artificial y que en el pasado reciente los estudios basados en regiones neutrales del genoma no permitían visualizar. Así, la integración de la genética molecular en la comprensión de la selección artificial en rasgos claves durante el proceso de domesticación, junto con la reconstrucción genómica de los restos arqueológicos, que ya se lleva a cabo por algunos grupos de investigación (véanse por ejemplo los estudios de Zeder et al., 2006; Dubcovsky y Dvorak, 2007; Frantz et al., 2016), permitirá en plazos relativamente cortos comprender muchas de las incógnitas y huecos teóricos del rompecabezas que hasta el presente los investigadores hemos contribuido a armar.

Y en tales tareas, la consolidación de aproximaciones interdisciplinarias en la investigación resulta indispensable. Dada la complejidad de patrones y procesos que se involucran en la reconstrucción de procesos de domesticación y de sus consecuencias civilizatorias, así como el abordaje de las escalas en las que tales procesos ocurren, es meritoria la interacción e integración de distintas aproximaciones disciplinarias. Hemos dicho que las aproximaciones etnobiológicas son centrales, pues permiten documentar los procesos vivos, vigentes, y aportan elementos clave para comprender los que pudieron haber ocurrido en el pasado (Bye, 1993; Hernández-Xolocotzi 1993; Casas y Caballero, 1995a, 1996; Casas et al., 1996, 1997, 2007, 2014, 2015, 2016; Caballero et al., 1998; Terrell et al., 2003; Blancas et al., 2013; Albuquerque et al., 2015; Montero-López et al., 2016; Lira et al., 2016). La etnobiología permite compenetrar en los detalles del significado cultural y socioeconómico de los elementos y procesos de los ecosistemas: los blancos u objetivos de la selección artificial y los posibles mecanismos que involucran la selección natural y otros procesos evolutivos naturales y artificiales como la deriva génica y el flujo génico (Casas et al. 2014, 2016, 2017, Colunga et al. 2017). La domesticación, recordemos, es guiada por la cultura y la etnobiología permite documentar con técnicas cuantitativas y cualitativas cómo es que estos procesos operan. Asimismo, a lo largo de los dos volúmenes de esta obra hemos insistido en que 
las herramientas morfométricas, fisiológicas y genéticas contribuyen a documentar los efectos de los procesos culturales que guían la domesticación. En concreto, permiten evaluar en qué y qué tanto divergen las poblaciones domesticadas de las silvestres. En todos estos campos ha habido un crecimiento metodológico de gran relevancia para lograr evaluaciones cada vez más finas. La morfometría desde hace décadas ha ido refinando y ampliando técnicas de análisis univariadas y multivariadas que hoy resultan de gran utilidad para estudiar procesos evolutivos naturales y artificiales. La fisiología de procesos metabólicos fundamentales asociados al crecimiento, la reproducción, la longevidad, entre otros aspectos, se suman al entendimiento de los mecanismos evolutivos y sus consecuencias. No solo los estudios del genoma y del transcriptoma (los genes y los mecanismos y productos moleculares de la transcripción de esos genes, respectivamente) son ya una realidad y herramientas de investigación altamente importantes para la comprensión de procesos evolutivos. La proteómica y la metabolómica son enfoques o áreas de la investigación que contribuyen a complementar la comprensión del panorama con información sumamente fina sobre los elementos que producen los genes que forman parte del genoma, así como los procesos metabólicos en los que estos productos intervienen. Junto con todas estas aproximaciones, la arqueología ha dado saltos vertiginosos en sus técnicas de investigación desde hace varias décadas. Las técnicas de fechamiento mediante carbono 14 son cada vez más precisas, y estas son frecuentemente acompañadas mediante el uso de isótopos estables, los fitolitos, las moléculas de almidones, los restos orgánicos en la dentición (Piperno, 2011; Lema, 2017) y, paulatinamente, el uso de técnicas moleculares como las referidas antes. Junto a todo lo anterior, las aproximaciones biogeográficas y filogeográficas contribuyen también de forma gradual a comprender con mayor profundidad los procesos bioculturales (Casas et al., 2015; Casas y Parra, 2016; Parra y Casas, 2016; Aguirre-Dugua y González-Rodríguez, 2016). Todos estos enfoques hacen evidente la relevancia de un abordaje interdisciplinario en concierto. El desafío metodológico de mayor magnitud es incorporar a la investigación de los procesos socioecológicos de la antigüedad, las aproximaciones complejas que exigen los estudios socioecológicos del presente.

\section{En la búsqueda de la reconstrucción de la historia del origen y difusión de la domesticación en América}

Hasta ahora, todo parece indicar que las áreas de Mesoamérica y los Andes son regiones excepcionalmente importantes en la antigüedad por la forma en que se incorporaron al proceso de domesticación plantas, animales y microorganismos, tal y como lo identificaron De Candolle (1884-2011), Vavilov (1951-2011), Harlan (2005), Hawkes (1986) y Smith (2006) entre otros estudiosos del origen de la agricultura. Pero la trama se vuelve progresivamente más difusa conforme se conoce más de cerca cada una de estas áreas. También se torna difusa la historia conforme avanza en el tiempo el desenvolvimiento de las civilizaciones y conforme avanzó en la historia la experiencia de domesticar plantas, animales y otros organismos menos estudiados. De manera paradójica, los centros de origen inicialmente propuestos son menos claros conforme avanza el conocimiento sobre el origen de las civilizaciones y con- forme se desarrollan métodos de investigación más precisos para el estudio sobre el origen de la domesticación. Hoy en día los escenarios son progresivamente más complejos en la medida en que existe mayor información (Piperno, 2011). Y tal complejidad plantea la necesidad de desarrollar métodos de investigación que permitan conectar la interpretación de los procesos del pasado con aquellos que pueden documentarse en el presente. A la transescalaridad espacial de los procesos, entonces, debe incluirse una aproximación transtemporal, es decir, la transescalaridad en el tiempo. Ambas aproximaciones contribuirán a descifrar de manera más clara cómo ocurrieron los procesos que nos interesan en este análisis. De una fase de esquemas relativamente simples con las primeras hipótesis de De Candolle (18842011) y el desarrollo sustancial obtenido con el uso de técnicas de los fechamientos con carbono 14, deberá transitarse a una fase de mayor precisión -y al mismo tiempo de mayor extensión en escalas espaciales y temporales-y, por lo tanto, de mayor complejidad. Ello posiblemente significará el tránsito de una visión de centros específicos a escenarios más difusos, pero al mismo tiempo más congruentes para explicar la gran movilidad humana, de la cual se sabe que en pocos milenios fue capaz de poblar el planeta y diversificar enormemente sus culturas (Maffi, 2005; Maffi y Dilts, 2014). Comprender dichos estados y procesos es ya hoy el gran reto a esclarecer por las nuevas técnicas de investigación en arqueología, genética y ecología referidas arriba y que han demostrado gran capacidad potencial para abordar tales preguntas de manera holística.

Es aún prematuro establecer patrones específicos para cada región y comunes entre regiones y hemisferios, pues la información cronológica de los estudios arqueológicos ha venido avanzando en precisión y aún es necesario revisar muchos de los materiales y fechamientos publicados previamente para re-armar el rompecabezas. La técnica de fechamiento más popular es la de radiocarbón y ésta se ha complementado con espectrometría de masas y diversas técnicas de calibración. Pero hoy en día los arqueólogos emplean una gran diversidad de técnicas que permiten un aproximación más precisa, involucrando diversas fuentes de información (véase Aitken, 1997; Levy et al., 2008; Williams, 2011; Kintigh et al., 2014). La extraordinaria cultura del maíz, frijol, chile, calabaza y pavo de Mesoamérica puede apreciarse con la misma intensidad en algunas regiones del suroeste y noreste de los Estados Unidos, la costa y los andes sudamericanos, como por ejemplo en la frontera entre Ecuador y Perú. De hecho, la cultura del consumo de maíz, frijoles y calabazas es muy extendida en todo el continente. Sin embargo, la gran cultura del uso, domesticación y diversificación de las tuberosas andinas, la domesticación de los camélidos y de cuys o cuyos son, sin duda rasgos característicos de las culturas sudamericanas de tierras altas que contrastan claramente con las de las tierras bajas del propio hemisferio sur $y$, desde luego, con los del hemisferio norte. Hoy en día se pueden constatar y documentar con detalle estos contrastes a través de estudios etnográficos y etnobiológicos y el porqué de tales contrastes. Esta es sin duda una puerta enorme al entendimiento de las culturas del continente, de los elementos que se difundieron (no solo plantas y animales domesticados sino otros objetos, costumbres y rituales). En parte, este análisis es el que condujo a Kirchoff (1943) y a otros autores (Matos-Moctezuma, 1994) a identificar el área cultural conocida como Mesoamérica; la cual, como mencionamos en otros capítulos de esta obra, requieren una revisión cuidadosa. Existen recursos panamericanos, que pueden identificarse en diferentes regiones del continente 
hoy en día, algunos de los cuales se extendieron desde tiempos precolombinos, otros más que se difundieron bajo la influencia de la colonización europea o aún en tiempos del vertiginoso comercio moderno. Sin embargo, otros permanecen hasta el presente como recursos regionales, altamente apreciados por las culturas locales y frecuentemente desconocidos por las regiones de un mismo país y, más aún, entre hemisferios.

Migraron ampliamente el maíz (Zea mays), los frijoles comunes y pallares (Phaeolus vulgaris y. lunatus, aunque continúan las hipótesis de la doble domesticación en Mesoamérica y Sudamérica, véase Piperno 2011) y otros frijoles (entre éstos el frijol ayocote $P$. coccineus), los chiles y diversos ajíes (Capsicum annuum, Capsicum pubescens, C. chinense, y C. baccatum, véase Pickersgill 2007, 2016, 2017, Kraft et al. 2014), los tomates o jitomates (Solanum lycopersicum; Blanca et al. 2012), los camotes (Jpomoea batatas; Roullier et al. 2011 quienes proponen dos orígenes distintos en Mesoamérica y en el noroeste de Sudamérica y su eventual confluencia) y las yucas (Manihot esculenta; Olsen y Schaal, 2001). Migraron también algunos magueyes o agaves (principalmente Agave americana) y algunos nopales (principalmente Opuntia ficus-indica), asimismo el cacao (Theobroma cacao; Motamayor y Lanaud, 2002 confirman el origen sudamericano de la especie y su domesticación en Mesoamérica), todos estos elementos desde tiempos precolombinos, algunos de ellos varios miles de años atrás. Migraron el perro y el calabazo (Lagenaria ciceraria, Erickson et al. 2005) desde la temprana entrada de los primeros humanos al continente americano, los pavos (Meleagris gallopavo) y los patos (Cairina moschata) del hemisferio norte al hemisferio sur los primeros, de hemisferio sur al hemisferio norte el segundo, también desde hace miles de años.

Pero no migró del hemisferio sur hacia el hemisferio norte la gran diversidad de papas (en Mesoamérica se encuentran tan solo dos o tres variedades de Solanum tuberosum, contrastando con las más de 9000 variedades de ocho especies de Solanum de la sección Petota registradas solamente en el Perú), como tampoco lo hicieron en una magnitud significativa las ocas (en Mesoamérica puede encontrarse en algunos sitios muy restringidos alguna variedad de Oxalis tuberosa, pero se trata en realidad de reminiscencias de lo que pudo haber sido un mayor cultivo), y en absoluto las arracachas, la maca o el aguaymanto (Arracacia xanthorrhiza, Lepidium meyenii y Physalis peruviana, respectivamente, especies que son ausentes en Mesoamérica). Ni tampoco migraron hacia el hemisferio norte plantas tan importantes como la quinoa (Chenopodium quinoa, la cual es ausente en Mesoamérica), de la misma manera que tampoco migraron del hemisferio norte al sur cultivos importantes como los tomates verdes (Physalis philadelphica ausentes en Sudamérica), los huazontles (Chenopodium berlandieri, que migró entre Estados Unidos y México, pero no llegó a Sudamérica), el chile de árbol (Capsicum frutescens) ni el frijol tepari (Phaseolus acutifolius), ni los amarantos mesoamericanos hacia el sur andino, ni los del hemisferio sur hacia la Mesoamérica del norte. De la fauna, recursos tan importantes en Sudamérica como los camélidos y os cuy (Cavia porcellus) son prácticamente ausentes (excepto como eventuales mascotas) en el hemisferio norte del continente americano hasta el presente. ¿Por qué migraron los que migraron y no lo hicieron aquellos que permanecieron con importancia regional o incluso local? Es este un tema de investigación que ayudará a entender la identidad cultural de los pueblos de ambos hemisferios, así como los factores que motivaron los contactos entre las civilizaciones regionales y entre hemisferios desde tiempos remotos y los que aún en el presente carecen de interés. Hoy son estas solamente preguntas generales que en el futuro arrojarán luz acerca de los procesos de difusión en relación con las capacidades adaptativas de los organismos, las cuales fueron y son relevantes, pero también con las motivaciones de las culturas involucradas.

El reconocimiento de procesos de domesticación y la emergencia de procesos civilizatorios coinciden aproximadamente en momentos similares (por lo menos los más antiguos de ellos) en los hemisferios norte y sur, sugieren la ocurrencia de detonadores sincrónicos, al menos en tales procesos originarios. Esta es la pregunta clave del porqué el origen del manejo y de la domesticación que ha motivado a numerosos investigadores (MacNeish, 1967, 1992; Hassan, 1978; Flannery, 1986; Harris, 1996; Casas, 1997, 2007; Blancas et al., 2013; Rangel-Landa et al., 2016). En el contexto de tales preguntas y teorías, adquieren relevancia las explicaciones asociadas a presiones por recursos ligados a cambios climáticos o crecimientos poblacionales simultáneos, de acuerdo con las explicaciones más clásicas planteadas al respecto. Asimismo, son relevantes los avances en el conocimiento del entorno y en el desarrollo de técnicas para manejar los ecosistemas y que no siempre son evidentes en los registros arqueológicos, aunque sí lo son en los estudios etnográficos y etnobiológicos contemporáneos (Casas et al., 1997; Blancas et al., 2013; Rangel-Landa et al., 2016; Zarazúa 2016). A diferencia de regiones del Viejo Mundo como el Medio Oriente y China, en Mesoamérica y en la región Andina el surgimiento de la domesticación tiene momentos más próximos entre sí y, posiblemente, factores causales similares. Sin embargo, las áreas de origen, y quizá los tiempos en los que ocurrieron, parecen más difusas de lo que originalmente propusieron los teóricos sobre el origen de la domesticación y la agricultura en el Nuevo Mundo.

En Mesoamérica, por ejemplo, conforme se amplía la información arqueológica, etnobiológica, genética y filogeográfica, la región aparece más como un entramado de experiencias de domesticación para una misma especie y para diferentes especies. Aunque el maíz parece tener sus principales poblaciones silvestres (Zea mays subsp. parviglumis), en la región sur de la cuenca del río Balsas, son de extraordinaria importancia áreas de diversificación como la península de Yucatán, la porción norteña y media de la cuenca del río Balsas, así como el valle de Tehuacán, y el norte de Méxco, incluyendo Chihuahua y Sonora, o en el centro, como Tlaxcala y Oaxaca (Ortega-Paczka y Chamorro-Cobaxin, 2017). Aparecen en este listado de regiones, áreas que han sido propuestas como importantes sitios de experiencias tempranas de domesticación del maíz, pero otras más con poco reconocimiento histórico. Como mencionamos arriba, en Michoacán y Guerrero es posible observar sabanas naturales en donde coexisten teocintles, frijoles, calabazas y chiles silvestres, pero los datos arqueológicos han registrado que el teocintle comenzó a consumirse en la zona central de la cuenca del río Balsas, los frijoles comunes en la cuenca del río Lerma, las calabazas en el valle de Tehuacán y los chiles en Tehuacán y Tamaulipas. Miller y Schaall (2006) encuentran que Spondias purpurea tiene un centro de domesticación significativo en la península de Yucatán y otro en la región occidental de México. Aguirre-Dugua et al. $(2012,2013)$ encontraron que Crescentia cujete se encuentra en estado avanzado de domesticación en los huertos mayas, pero su relación con las poblaciones silvestres es muy limitada, y, al parecer, sus ancestros silvestres podrían encontrarse más al sur en Centroamérica, posiblemente Honduras y Nicaragua. 
La amplia distribución de los parientes silvestres sería uno de los argumentos más fuertes para sustentar los eventos múltiples de domesticación tanto en la zona mesoamerican como en la sudamericana, por lo que el gran escenario de domesticaciones múltiples es el americano. Como se puede apreciar en los trabajos sobre cultivos americanos, la distribución de sus parientes silvestres es extensa, siendo muy claro en el caso de Phaseolus vulgaris silvestre, cuya distribución es amplia, aunque discontinua, desde las tierras altas de Mesoamérica (México a Panamá) y Sudamérica, hasta la región sur de los Andes, comprendiendo Bolivia y el norte de Argentina. De manera similar, la distribución de la diversidad de especies del género Cucurbita desde el sureste de los Estados Unidos hasta la parte sur de los Andes Centrales, en Sudamérica, casi coincidentemente con la distribución de la especie P.vulgaris. Un patrón similar de distribución lo poseen las especies ancestrales del algodón cultivado y de los granos de amaranto. Más aún, el estudio de Miller y Schaal (2006) sobre Spondias purpurea ha permitido visualizar que al interior de algunos de los centros definidos previamente, como por ejemplo, Mesoamérica, se puede identificar más de un área generatriz pequeña de procesos de domesticación. Por lo tanto, la amplia distribución geográfica y riqueza de las especies silvestres en este rango, y el establecimiento de importantes grupos culturales diferentes en Mesoamérica y la región andina (Harlan, 2005), habría contribuido a la domesticación independiente de estos cultivos, y a la diversificación de los mismos.

El rompecabezas sigue desarticulado, sin duda, y la conjunción de aproximaciones etnobiológicas, ecológicas, genéticas y arqueológicas contribuirán a armarlo con mayor congruencia. Sin embargo, lo más destacado es que el carácter difuso del rompecabezas sugiere que el problema del origen es más complejo que lo planteado originalmente por los teóricos del origen. En el mapa de Vavilov (1951-2011), Mesoamérica aparece como un área pequeña, mientras que Kirchoff (1943) extiende la mancha hasta Costa Rica y Matos-Moctezuma (1994) la propone como un área dinámica en el tiempo. Las interacciones culturales con el sur han sido evidentes desde etapas tempranas. Hay identidad en el área y hay elementos que cuestionan tal identidad porque las interacciones culturales son muy antiguas. El área difusa parece apoyar la hipótesis de Dolores Piperno (Piperno, 2011), de un área sumamente dinámica con conexiones tempranas con Panamá, Colombia, el sur de Ecuador y el norte de Perú, por lo menos.

La región andina es mucho más extensa que el área mesoamericana, y desde la propuesta de Vavilov (1951-2011) aparecía como un mosaico más complicado que Mesoamérica. Harlan (2005) propuso esta amplia región como un "no-centro" por la misma razón. Las nuevas propuestas de la antigüedad de la domesticación y el poblamiento de la Amazonía (Levi et al., 2017: Clement, 2017) hacen aún más difícil hablar de una zona nuclear. La región andina tuvo una intensa interacción con la Amazonía, con el noroeste de Perú, el sur de Ecuador y con Mesoamérica, con todas estas áreas compartió sus experiencias de domesticación. Los grupos humanos de cazadores y recolectores eran sumamente dinámicos y sus movimientos muy probablemente permitían la rápida difusión de innovaciones tecnológicas, sobre todo aquellas que determinaban alguna ventaja en la supervivencia de los pueblos. El rompecabezas es tanto o más complicado que el de Mesoamérica.

\section{Los detonantes de procesos de manejo y domesticación de recursos genéticos}

Continúan, en buena medida, abiertas las preguntas de cómo y por qué se detonaron el maneo y la domesticación de plantas y animales. Y la clave para encontrar respuestas desde luego tendrá un soporte fundamental en la arqueología, pero analizar y entender los procesos actuales -que continúan incorporando nuevas especies al proceso, y continúan innovando rutas de domesticación- resultan clave para entender los procesos originarios. Las presiones por la disponibilidad de recursos son, y muy probablemente lo fueron en el pasado, detonadores primarios. El manejo como una estrategia para lidiar con la incertidumbre y los riesgos de perecer ante la ausencia o escasez de recursos, y la domesticación como una estrategia de dominar el azar y exacerbar los rasgos morfológicos y fisiológicos de los recursos bióticos. Son estas dos reacciones humanas que permitieron en el pasado, y aún permiten en el presente, incrementar tanto la cantidad como la calidad de los recursos y optimizar el esfuerzo de manejo (Casas et al., 1997; 2007, Blancas et al., 2013; Rangel-Landa et al., 2016). Pero los estudios sobre manejo en el presente indican que no solamente funcionan las presiones (actualmente marcadas por la incertidumbre en la producción agrícola o la insuficiencia de productos para atender la demanda en el mercado por ciertos productos forestales). También se involucran: 1) el interés por facilitar el acceso a recursos que naturalmente se encuentran distantes a los sitios de asentamiento, de manera particular, los recursos medicinales y las especias (Carrillo et al., 2017; Tello-Villavicencio, 2017); 2) el aprecio por la belleza y la búsqueda del embellecimiento del entorno; 3) el valor ritual de los elementos bióticos, los cuales también reciben manejo; 4) el control y eliminación de organismos considerados nocivos y, por el contrario; 5) el respeto y la procuración de aquellos elementos vegetales y animales que no causan daño, que son parte de la naturaleza y que tienen derecho a existir (Rangel-Landa et al., 2016), y 6) así como la satisfacción que conlleva el cuidar, el lograr que se reproduzcan y obtener ejemplares con características sobresalientes, esto en plantas como animales. Es decir, se involucran criterios utilitarios, estéticos, éticos, naturalistas y otros considerados de afectación negativa como disparadores de la motivación por el manejo. Pero igualmente se involucra como detonador del manejo la curiosidad humana. Es la curiosidad por experimentar, por apreciar el comportamiento de la germinación, por examinar el éxito en el establecimiento de una planta, qué tan efectiva es la propagación vegetativa, cómo es la sobrevivencia de los cachorros y polluelos, la de las orugas y capullos, cómo es el desarrollo de las cepas de microorganismos, cómo se afecta entre especies que ofrecen su sustrato, cómo entre sitios y materiales utilizados. E manejo no necesariamente resulta de la atención a una necesidad inmediata, sino también es parte de la experiencia de conocer y experimentar lo que en algún momento puede resultar útil. Esta es una experiencia que los etnobiólogos encontramos de manera recurrente en el campo, y no existe razón para considerar que estuvo ausente en las comunidades humanas de la prehistoria.

Actualmente, todos estos procesos se aprecian de igual manera en Mesoamérica (Casas et al., 2017; Colunga et al., 2017; Zizumbo-Villareal y Colunga-GarcíaMarín, 2017) que en la región andina (Torres-Guevara et al., 2017), lo mismo en las experiencias registradas en el nordeste de 
los Estados Unidos (Cruse-Sanders y Casas, 2017), como en la Amazonía (Clement, 2017), e nordeste brasileño (Lucena et al., 2017), en las zonas suburbanas de Perú (Cruz-García y Vael, 2017) de la Plata (Pochettino et al., 2017) y en Los Altos de Chiapas, México (Mariaca-Méndez, 2017) y asimismo en la Patagonia (Molares y Ladio, 2017). Los seres humanos no son sujetos que operan exclusivamente bajo esquemas de estímulo y respuesta. Son organismos con extraordinaria complejidad cultural, curiosidad y creatividad, y el manejo obedece a todos estos factores, no solo a uno. No existe una razón para pensar que los procesos básicos que hoy en día se observan no hayan existido en el pasado. El diseño y refinamiento de herramientas, la diversificación de estrategias de manejo del entorno asociada al uso del fuego son expresiones de estas motivaciones fundamentales que estuvieron presentes en los grupos humanos que antecedieron por millones de años al Homo sapiens. La domesticación del paisaje, así como la de poblaciones de organismos son parte de una historia de innovación tecnológica mucho más antigua que la de nuestra propia especie. Este razonamiento parece simple, pero da cuenta de los procesos que ocurren en la actualidad detonados continuamente como mecanismos de resiliencia y de aquellos que seguramente se detonaron en el pasado.

Los detalles de cómo se detonan estos procesos, cómo se llevan a cabo, cómo determinan modificaciones en los ecosistemas y en los elementos bióticos que los componen, son mu importantes. Son expresiones de la diversidad biocultural, y hoy en día existe un conocimiento con avances significativos en distintas regiones del continente. Pero con todo, son aún limitados ante una realidad tan vasta y compleja. El esfuerzo que hemos hecho en el curso y el simposio que anteceden al presente texto, por diagnosticar los recursos a escalas nacionales nos reveló un conocimiento limitado de lo que se ha logrado documentar. Sabemos mucho de los procesos de domesticación de poco más de 100 especies de plantas y de unos cuantos vertebrados. Pero el universo es de cerca de 7000 especies de plantas domesticadas a nive mundial y posiblemente otras cerca de 10000 especies con formas de manejo incipiente y con grados incipientes, intermedios y avanzados de domesticación, pero en general muy poco conocidos. Hemos documentado muy poco acerca del valor de la crianza de vertebrados invertebrados en la vida de los pueblos. Conocemos algunas técnicas agroecológicas y de manejo forestal que han desarrollado por siglos o milenios los pueblos de América. Pero tenemos claro que la amplitud de estas técnicas y la importancia de su impacto hacia el futuro rebasan nuestra imaginación. Son todas estas, expresiones claras de la pobreza de nuestro conocimiento biocultural actual y de la extraordinaria importancia que tiene reforzar los estudios para documentarla.

El mundo ha apostado a sistemas simplificados, productivistas, altamente ineficientes y altamente destructivos de los ecosistemas. Son estos la causa fundamental de los cambios globales que expresan la crisis ambiental que amenaza al planeta. Es muy claro que en 75 años estos sistemas han tenido una extraordinaria capacidad destructiva, período en el que más de la mitad de los ecosistemas terrestres ha sido severamente afectada y los mares han sido en una extensión desconocida altamente contaminados (Millennium Ecosystem Assessment, 2005; Barnosky et al., 2011). Y resulta urgente detenerlos e impulsar virajes radicalmente distintos. Es preciso reconocer que existe una vasta experiencia humana diseminada en miles de pueblos del continente americano, y que esta puede ser la base de una reconstrucción de os ecosistemas continentales, $y$, desde luego, el razonamiento escala a nivel planetario (Casas et al., 2014, 2017-en prensa). La etnoecología, la agroecología y los procesos participativos transdisciplinarios son más que folklorismo o romanticismo idílico. Son procesos realistas cuyo impulso es de alta prioridad para la seguridad alimentaria y, más aún para la seguridad planetaria, para enfrentar los cambios globales que destruyen el planeta Tierra. No es un discurso ideológico sino un planteamiento que desde las construcciones científicas basadas en el análisis de la complejidad han arribado a conclusiones que en esta dirección ven posibilidades de cambiar el rumbo de derrotero planetario (Casas et al., 2017-en prensa).

Conocer el detalle de las expresiones bioculturales implica grandes esfuerzos internacionales. Es esta -quizá- la principal búsqueda del presente texto. Unificar un cuerpo teórico, pautas metodológicas que nos permitan identificar patrones a escala continental, construir teoría y derivar acciones conjuntas son aspiraciones que rebasan los intereses académicos de los que en este texto participamos. Están dirigidos a una búsqueda común por atender los problemas que han dejado abiertas las venas de América Latina y quizá mucho más allá de la región: las del planeta. Es la búsqueda de conjuntar esfuerzos por investigar bajo programas organizados, de sistematizar la información, analizar datos y obtener conclusiones de manera conjunta. Es la necesidad de explicar e inventariar la experiencia técnica de los pueblos americanos. Se trata de no repetir la historia que enfrentaron hace siglos o milenios los seres humanos que nos antecedieron; de construir sobre lo ya construido. De unificar el esfuerzo del rigor científico que brindan la arqueología, la ecología, la biología, la genética y las matemáticas, con el conocimiento tradicional que surge de experiencias directas, el famoso TEK (Traditiona Ecological Knowledge por sus siglas en inglés), que es más bien un TSKP (Traditional Scientific Knowledge and Praxis). Resulta altamente necesario fusionar los esfuerzos de investigación bajo aproximaciones transdisciplinarias para arribar a soluciones a problemas que surgen más del mundo moderno que del tradicional, pero que afectan igualmente a ambos.

\section{La unificación metodológica y conceptual}

El curso Domesticación y manejo in situ de recursos genéticos y el presente texto abren una puerta en la búsqueda de una unificación conceptual y metodológica para guiar las acciones de investigación disciplinaria, interdisciplinaria y transdisciplinaria sobre los recursos genéticos en los diferentes países del continente americano. Aspiramos a construir una agenda común con problemas y aproximaciones similares que permitan sistematizar adecuadamente y generar lecciones y sugerencias útiles a las políticas públicas dirigidas a la protección y recuperación de recursos genéticos. Al mismo tiempo, esta agenda busca compenetrar en la construcción de teoría que puede vigorizar las teorías evolutivas, la ecología de los recursos, la comprensión de las culturas que los dirigen y construyen y generar contribuciones para su manejo sustentable.

En última instancia, nuestra aspiración científica es contribuir a una ciencia para la sustentabilidad capaz de afrontar los problemas globales con base en la experiencia local. Es nuestra convicción que las culturas locales han enfrentado en repetidas ocasiones problemas similares o análogos a los que hoy se vive a escala planetaria y la forma en la que han enfrentado tales problemas contribuye a atender los problemas y a construir una ciencia para atenderlos: la ciencia para la sustentabilidad. Las culturas americanas constituyen un mosaico de alta 
diversidad, de las más diversas del planeta y los ecosistemas en los que se han asentado y los recursos bióticos que han aprovechado son también de los más variados de la tierra. Por eso, sintonizar la metodología, el marco conceptual y las acciones son metas de primordial importancia que el curso y el texto buscan unificar. Somos hoy resultado de los esfuerzos de nuestros maestros, quienes dieron los primeros pasos en esta dirección. Nos toca establecer esta base que será sin duda una importante guía para los futuros científicos que continuarán la obra. Buscamos establecer premisas que sinteticen la experiencia previa y pongan en perspectiva el trabajo que tenemos por delante. A continuación proponemos algunos temas generales que pueden servir como tesis para establecer líneas de investigación de utilidad a los propósitos de converger en el entendimiento de procesos generatrices de recursos genéticos, su manejo sustentable y su conservación in situ y ex situ.

1. Podemos identificar que en la base de una agenda de investigación como la que se aspira a construir, está la documentación del estado de la diversidad biocultural de la localidad la región o el país que nos preocupa. Qué lenguas, qué culturas existen en las regiones en las que trabajamos, si estas se hablan en la cotidianidad o no, qué proporción de personas las hablan, cómo se autodeterminan, gobiernan y construyen sus acuerdos familiares, comunitarios y a otras escalas, son todos indicadores generales de las culturas locales. Estamos conscientes de que se trata de indicadores reducidos y limitados, pero nos ayudan a tener un diagnóstico. El otro aspecto crucial del diagnóstico es cuál es el estado de los recursos y de los ecosistemas con los que las culturas identificadas interactúan. Existen diversas estrategias para generar indicadores. Por ejemplo, los inventarios de flora y fauna, los diagnósticos de diversidad genética de poblaciones de especies clave, la heterogeneidad de ecosistemas, la diversidad de sistemas productivos donde confluyen actividades agrícolas, pecuarias y el manejo de flora y fauna nativa, los sistemas reconocidos por las personas del área de estudio y los reconocidos por los criterios de clasificación desarrollados por los investigadores. En este diagnóstico es de particular importancia evaluar aquellos recursos y ecosistemas de mayor valor cultural para las personas de la zona de estudio. Por ejemplo, en el caso de los recursos, son indicadores aquellos recursos clasificados de acuerdo con el tipo de utilidad, aquellos que la gente utiliza con mayor frecuencia, aquellos que mayormente prefiere, aquellos reconocidos con mejores atributos, o aquellos que no pueden sustituirse. Los etnobiólogos frecuentemente utilizan técnicas como los listados libres (véase Camou et al., 2008) que parten del principio de que los entrevistados mencionan en orden y en frecuencia aquellos recursos de mayo significado en su vida. De manera similar, las personas de un área suelen mapear e identificar las zonas y tipos de ecosistemas que proveen diferentes recursos y esta herramienta participativa ayuda a discutir aquellas zonas prioritarias que forman parte de sus territorios. Junto a estas evaluaciones de importancia cultural, pueden efectuarse evaluaciones sobre el valor de los recursos en particular, así como del valor de los recursos que proveen los ecosistemas. Para ello, resulta de gran utilidad el diagnóstico de la distribución y abundancia de los recursos en particular, así como la riqueza, diversidad, abundancia de los recursos en los ecosistemas locales (véanse por ejemplo los estudios de Pérez Negrón et al., 2007, 2014). Este análisis permite, asimismo, identificar el balance entre la demanda de recursos por una comunidad humana y su disponibilidad espacial o incluso temporal, si se incluyen estudios fenológicos. En conjunto, estos elementos permiten analizar algunos detonadores básicos de los procesos de manejo, pues la incertidumbre y la búsqueda por asegurar los recursos insustituibles es una motivación primaria de manejo (Casas et al., 2016). Pero hemos discutido en este texto que esta no es la única motivación para manejar recursos. Por ello, documentar el abanico de motivaciones de manejo de recursos, de ecosistemas y de paisajes es hoy por hoy un vasto campo de investigación etnobiológica de gran importancia para analizar por qué las personas deciden manejar recursos y por qué deciden emprender procesos de domesticación.

2. Cómo se atienden las motivaciones del manejo, qué técnicas se utilizan para lograrlo y qué tan eficaces son para hacerlo. Estas estrategias pueden incluir desde acuerdos comunitarios, documentables a través de entrevistas a las autoridades, a los miembros de la comunidad, la revisión de actas y archivos, así como talleres y grupos focales comunitarios. También pueden incluir el diseño de estrategias de aprovechamiento específicos por la gente de la comunidad, la construcción de herramientas o el encuentro en los mercados. Estos elementos generalmente pueden documentarse a través de entrevistas a las personas que llevan a cabo las prácticas de aprovechamiento de recursos o ecosistemas que interesan, y también la observación participante contribuye a complementar el panorama. Otra pregunta de particular relevancia es qué tan efectivas son las prácticas de manejo para lograr el balance entre la energía invertida, la producción obtenida y, sobre todo, qué tan efectivas son para lograr el mantenimiento a largo plazo de recursos y ecosistemas, es decir, qué tan sustentables son las prácticas efectuadas. Una vez más, cuando se analiza un recurso en particular, importa evaluar no solo la sustentabilidad en el aprovechamiento de tal recurso o recursos particulares, sino la permanencia, la resiliencia, la estabilidad de los ecosistemas y paisajes en su conjunto. En una visión sistémica como la que nos interesa promover, resulta muy claro que la sustentabilidad en el aprovechamiento de un recurso puede lograrse en detrimento de otros elementos y/o procesos del sistema. Por ello, la pauta del diagnóstico exige una visión sistémica, cuya complejidad impone interacciones disciplinarias y procesos participativos en los que los principales actores son los usuarios de los recursos y los ecosistemas. En términos prácticos, es factible efectuar diagnósticos sobre cantidades y beneficios obtenidos de los ecosistemas. Es factible también llevar a cabo evaluaciones de la capacidad de recuperación de las poblaciones (en términos de tasa de crecimiento), de las comunidades (en términos de la diversidad e interacciones como la polinización, la dispersión, la facilitación, las interacciones mutualistas, la competencia, entre otras) o, bien, a nivel sistémico, la capacidad de resiliencia funcional, el balance de los ciclos hidrológicos y otros proceso biogeoquímicos que sirven como indicadores de la salud del ecosistema).

3. Documentar cómo operan los procesos de domesticación. Hemos insistido que estos operan a escala de paisaje y a escala de recursos en particular. $Y$ ambas escalas se in fluyen mutuamente. Entender uno y otro nivel escalar requiere aproximaciones distintas. La domesticación del paisaje implica diagnosticar las estrategias de aprovechamiento del territorio y las acciones que se emprenden para optimizar los beneficios de tales ecosistemas. Por ejemplo, si se trata de una cuenca, qué estrategias ponen en práctica los pobladores para mantener suelos y agua; si se trata de bosques, qué estrategias 
para mantenerlos a largo plazo; si se trata de áreas proveedoras de agua, qué se lleva a cabo para garantizar su suministro. Puede tratarse de acuerdos, pero también de obras que moldean el paisaje, y unos y otras son de gran importancia para entender los propósitos y la eficacia de las medidas empleadas. La domesticación de recursos implica otro tipo de estrategias: ante todo, reconocer la variabilidad intraespecífica de los recursos que se domestican, su nomenclatura, sus propiedades y posibles usos y formas de manejo diferencial. Importa saber si existen mecanismos naturales y/o artificiales de selección, deriva génica, flujo génico y sistemas de reproducción. Los mecanismos artificiales pueden analizarse con base en entrevistas y observaciones participantes. Los mecanismos naturales requieren estudios ecológicos tales como evaluaciones de distribución y abundancia, sobrevivencia diferencial de fenotipos, biología floral, mecanismos de polinización y dispersión de semillas en el caso de plantas, migración y movimiento espacial en el caso de animales. El estudio de los tamaños poblacionales, la genética de poblaciones y los tipos de sistemas de cruzamiento son investigaciones ecológicas que ayudan a explicar posibles mecanismos naturales que junto a los artificiales permiten entender los mecanismos que generan divergencias y cómo operan tales mecanismos. a otra fase de los estudios de domesticación es el estudio de los grados de divergencia entre los organismos silvestres y los manejados. Es este, finalmente el resultado de la domesticación y la estrategia que permite evaluar el grado que ha alcanzado. Tener como referente los signos de los síndromes de domesticación (gigantismo de las estructuras y funciones de interés humano, la diversidad morfológica y fisiológica asociada a criterios culturales, el grado de dependencia con respecto a los humanos para sobrevivir y reproducirse), son, entre otros, aspectos que ayudan a entender la naturaleza de la divergencia asociada a intereses humanos. La genética de poblaciones es una herramienta sumamente útil para diagnosticar los efectos evolutivos del manejo. La magnitud de la diversidad genética, su distribución espacial dentro y entre poblaciones, la magnitud del flujo génico, los niveles de endogamia, son todos elementos de gran valor en la interpretación del resultado de procesos evolutivos naturales y artificiales. Hoy en día existen marcadores sumamente informativos acerca de los parámetros de la diversidad genética. Los microsatélites, los SNP, como hemos revisado en párrafos anteriores, permiten evaluar con fineza indicadores neutrales y adaptativos de significado para los seres humanos.

4. Origen y difusión de los procesos de domesticación. Existen herramientas antropológicas lingüísticas y etnobiológicas que permiten reconstruir con base en testimonios orales las áreas de origen de los parientes silvestres, los mecanismos de intervención sobre estos y los procesos de difusión espacial, incluyendo los mecanismos mediante los cuales se llevan a cabo. También existen estudios de carácter ecológico y biogeográfico que permien aproximarse a los patrones naturales de distribución de las especies y su modificación asociada a intervenciones humanas. $Y$, finalmente, tiene un impulso extraordinario el estudio de la distribución de linajes de genes (nucleares, de cloroplasto o mitocondriales), que ayudan a reconstruir áreas de origen y rutas de difusión. Esas herramientas son de gran valor en estudios evolutivos en general y en estudios de domesticación en particular. En este capítulo -y en otros de los dos volúmenes que se presentan- hemos discutido los avances que sobre todo en las dos últimas décadas ha permitido la filogeografía en el estudio del origen y difusión de organismos domesticados. Resultan insuficientes los criterios de presencia de diversidad morfológica y genética para arribar a la conclusión de un centro de origen. Hoy en día es posible rastrear genes, fragmentos de genomas 0 haplotipos, así como marcadores moleculares más sutiles como los SNP que ayudan a identificar regiones del genoma de particular interés desde el punto de vista de los rasgos asociados a los procesos de domesticación. Estas técnicas comienzan a rendir frutos, como se indica en algunas de las lecturas referidas en este capítulo y será, sin duda, una de las herramientas de mayor importancia en los próximos años. Ello no sustituye la importancia de los estudios etnobiológicos y ecológicos como los mencionados en párrafos anteriores. Por el contrario, son elementos que permiten corroborar información y suposiciones que surgen de aproximaciones como las mencionadas.

5. La conservación de recursos genéticos. El manejo sustentable de los recursos genéticos pasa por comprender los mecanismos básicos de los procesos generatrices, los cuales se delinean en los párrafos anteriores. Como hemos insistido en varias partes de este capítulo, la base del manejo sustentable de los recursos genéticos radica en asegurar la permanencia de los mecanismos generatrices de la diversidad de recursos genéticos. A nivel de especies, la conservación de los ecosistemas naturales a través de los sistemas de áreas natrales protegidas es una de las mejores garantías para lograrlo como lo es el manejo agroforestal tradicional o etnoagroforestal que mantiene parte importante de la biodiversidad de los ecosistemas donde están inmersos, pero además son los sistemas en donde han tenido y tienen a lugar los procesos de domesticación en manos de los campesinos (Moreno et al., 2016). Los procesos de crisis global operan sin cesar y la voracidad de las corporaciones industriales que determinan la destrucción planetaria difícilmente cesarán. Ello no significa derrotarse a priori, pero sí buscar mecanismos ya establecidos para fortalecer la conservación de biodiversidad. Confrontar la voracidad de las empresas es una necesidad de la sociedad civil. Son unos cuantos los que destruyen de manera preponderante el planeta y requieren ser confrontados. Existen responsabilidades de la sociedad civil y esas pueden tener caminos más viables para alcanzarse. A nivel de la diversidad intraespecífica asociada a la domesticación, la base de la estrategia es asegurar los mecanismos naturales y artificiales que determinan la generación de tal diversidad. Existen estrategias de conservación ex situ que han demostrado ser sumamente caras e ineficaces para lograr la supervivencia a largo plazo de los materiales que almacenan. Presentan el inconveniente de detener procesos eminentemente dinámicos de evolución influida por las culturas. Sin embargo, existen y deben aprovecharse. La conservación in situ implica mantener vivos los procesos evolutivos naturales y artificiales. Este es un enorme reto dado el proceso de destrucción de ecosistemas que constituyen hábitats de numerosas especies de parientes silvestres con interacción reproductiva con las especies cultivadas, pero resulta de fundamental importancia. Mantener viva la cultura diversificadora, su ímpetu y su razón de ser es el motor fundamental; la existencia de la base de diversidad es la materia prima sobre la que opera tal motor. Estos son los mecanismos básicos de la conservación in situ y la conservación ex situ realmente existente puede contribuir a retroalimentar lo procesos. 
Los aspectos referidos en los párrafos anteriores no pretenden establecer un protocolo esquemático exhaustivo del quehacer en la investigación sobre domesticación y manejo sustentable de recursos genéticos. La flexibilidad que requieren estos enfoques de investigación, su adaptabilidad a las preguntas e hipótesis que se trata de contestar o probar, es parte central de los estudios de la complejidad. Son solo algunas recomendaciones generales que permitirán a los grupos de investigación que iniciamos este camino, y a otros que seguramente se sumarán, una base común de tareas a seguir para unificar criterios en la construcción de teoría y una guía para la praxis dirigida conservar los recursos genéticos que son un legado de los pueblos del continente americano y que serán la base para construir un futuro viable en esta región del mundo.

\section{Bibliografía}

Aguirre-Dugua, X., A. González, L. Eguiarte y A. Casas, Blanca J., J. Cañizares, L. Cordero, L. Pascual, MJ, Diez 2012. Large and round: Morphological and genetic consequences of artificial selection on the gourd Peninsula Mexico Anne the Maya 10077): 1307-1316.

uirre-Dugua X., Casas A., Pérez-Negrón E., 2013. varieties of Cresentiation between wild and domesticated of fruits as bowls in the Yucatan Peninsula, Mexico. Journal of Ethnobiology and Ethnomedicine, 9:76.

Aguirre-Dugua, X. y A. González-Rodríguez, 2016. Chapter domestication with special emphasis on serennial plant En: Lira, R., A. Casas y J. Blancas (Eds.) Ethnobotany of Mexico. Interaction sof people and plants in
Springer, Utrecht, Holanda, pp. 319-367.

Springer, Utrecht,

Aitken M. J., 1997. Sscien based dating in archaeology. Routlefge Taylor and Francis Group. London.

Albuquerque, U., P. Medeiros y A. Casas, 2015. A. Evolutionary ethnobiology. En: Albuquerque, U.P., PMedeiros y A. Casas (Eds.) Evolutiona

(a)

Alcorn J. B., 1981. Huastec noncrop resource management: implications for prehispanic rain forest management.

Alcorn J. B., 1983. El te'lom huasteco: presente, pasado futuro de un sistema de silvicultura indígena. Biótica

Alcorn J. B., 1984. Huastec Mayan ethnobotany. Austin, TX

Barnosky A.D., Hadly E.A., Bascompte J., Berlow E.L. Brown, J.H., Fortelius M., GetzW.M., Harte J., Hasting A., Marquet, P.A., Martinez N.D., Mooers A., Roopnarin Marshall C., Matzke N.,Mindell D.P., Revilla E. y Smith A.B, 2012. Approaching a state shift in Earth's biosphere. Nature, 486: 52-58

Barrera, A., Gómez-Pompa A. y Vázquez-Yanes C. 1977. manejo de las selvas por los mayas sus
silvícolas y agrícolas. Biótica 2: 47-61.

Bedoya C. A., S. Dreisigacker, S. Hearne, J. Franco, C. Mir B. y M. Prasanna, 2017. Genetic diversity and population structure of native maize populations in Latin America and the Caribbean. PLoS ONE 12(4): e0173488.

Bitocchi, E., E. Bellucci, A. Giardini, D. Rau, M. Rodriguez y E. Biagetti, 2013. Molecular analysis of the paralle domestication of the common bean (Phaseolus vulgaris) in Mos-313.

Blackman, B. K., M. Scascitelli, N. C. Kane, H. H. Luton, D. A. Rasmussen, R. A. Bye, y L. H. Rieseberg, domestication center in eastern North America. Proceedings of the National Academy of Sciences, 108(34): 14360-14365.
F. Nuez, 2012. Variation Revealed by SNP Genotyping and Morphology Provides Insight into the Origin of the Tomato. PLOS ONE 7(10): e

lancas, J., A. Casas, D. Pérez-Salicrup, J. Caballero y E. Vega, 2013. Ecological and sociocultural factors of the Tehuacán Valley, Mexico. Journal of Ethnobiology and Ethnomedicine, 9: 39

Brown T. A., R G. Allaby, K. A. Brown, K. O'Donoghue y R. Sallares, 1994. DNA in wheat seeds from Euro
archaeological sites. Experientia 50(6): $571-575$.

Brown, T. A. E. Cappellini, L. Kistler, D. L. Lister, H. R. Oliveira N. Wales y A. research and their implications for archaeobotany.
Vegetation History and Archaeobotany, 24(1): 207-214.

Bye, R. 1993. The role of humans in the diversification of plants in Mexico. En: Ramamoorthy, T. P., R. Bye, A Lot y J. Fa. Biological diversity of Mexico: origins and distribution, Oxford University Press, Oxford, Inglaterra, 707-731.

Caballero, J., A. Casas, L. Cortés y C. Mapes, 1998. Patrones en el conocimiento, uso y manejo de plantas en pueblos indigenas de México. Estudios Atacameños,

Callen, E. O., 1967. Analysis of the Tehuacan coprolites. En Byres, D. S. (Ed.), The Prehistory of the Tehuacan Valley, of Texas Press, Austin, pp. 261-289.

Camou, A., V. Reyes-García, M. Martínez-Ramos y A. in a 200 . Knowedge and use value of plant species HumanEcology, 36: 259-272.

Campbell-Platt, G., 1994. Fermented foods-a world perspective. Food Research

Carrillo, G., R. A. Bye y L. Eguiarte, 2017. Capítulo 18 Domesticación de plantas medicinales aromáticas. En: el continente americano. Volumen 2. Investigación para Mundo. UNAM-UNAM-CONACYT-México. México.

Casas, A. y J. Caballero, 1995. Domesticación de plantas origen de la agricultura en Mesoame

Casas, A. y J. Caballero, 1996. Traditional management and morphological variation in Leucaena esculenta (Moc. et Sessé ex A.DC.) Benth. in the Mixtec region of Guerrero,

Casas, A., M. C. Vázquez, J. L. Viveros y J. Caballero, 1996. Plant management among the Nahua and the approach to the study of phant domestication. Hunca Ecology 24: 455-478.
Schlumbaum, 2015. Recent advances in ancient DNA 
Casas A., J. Caballero, C. Mapes y S. Zárate, 1997a. Manejo Cavanagh D., G. F. Fitzgerald y O. McAuliffe, 2015. From de la vegetación, domesticacion de plantas y origen de

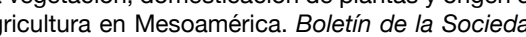
Botánica de Mexico 61:31-47.

Casas, A., B. Pickersgill, J. Caballero, A. Valiente-Banuet, 1997b. Ethnobotany and domestication in xoconochtl, Stenocereus stellatus (Cactaceae), in the Tehuacán Valley and La

Casas, A, A. Otero-Arnaiz, E. Peréz-Negrón y A. ValienteBeflate of plants in

Casas A., A. Camou, S. Rangel-Landa, L. Solís, I. Torres, A. Delgado-Lemus, A. I. Moreno-Calles, M. Vallejo, A. Delgado-Lemus, A. I. Moreno-Calles, M. Vallejo,
S. Guillén, J. J. Blancas, F. Parra, X. Aguirre, B.
Fartán-Heredia YArellanes y E. Pérez-Negrón, 2014. Farfán-Heredia, Y.Arellanes y E. Pérez-Negrón, 2014. Manejo tradicional de biodiversidad y ecosistemas en Mesoamérica: El Valle de Tehuacán. Investigación
Ambiental, Ciencia y Política Pública, 6(2): 23-44.

Casas A., F. Parra, S. Rangel, S. Guillén, J. Blancas y C. J. Figueredo, 2015. Evolutionary ecology and ethnobiology. En: Albuquerque, U.P., P. Medeirosy A. Casas (Eds.) Evolutionary ethnobiology. Springer. The Netherlands,
pp. 37-57.

Casas A., J. Blancas, A. Otero-Arnaiz, J. Cruse-Sanders, R. L. Torres-García y S. Rangel-Landa 2016. Evolutionary ethnobotanical studies of incipient domestication of plants in Mesoamerica. En: Lira, R., A.Casas y J Blancas (Eds.). Ethnobotany of Mexico. Interactions of peoples and plants in Mesoamerica. Capítulo 11. Springer, Utrecht, Holanda, 257-285.

Casas, A. y F. Parra, 2016. Capítulo 5. La domesticación como proceso evolutivo. En: Casas, A.,J. Torres-Guevara y Parra (Eds.). Domesticación en el continente americano. Volumen 1. Manejo de biodiversidad y evolución dirigida Autónoma de México /Universidad Nacional Agraria La Molina, pp. 133-158.

Casas, A., F. Parra, S. Rangel-Landa, J. Blancas, M. Vallejo, A. I. Moreno-Calles, S. Guillén, I. Torres, A. Delgado-Lemus,
C. J. Figueredo, J. M. Cruse-Sanders, B. Farfán-Heredia, L. Solís, X. Aguirre-Dugua, A. Otero-Arnaiz, H. AlvaradoSizzo y A. Camou-Guerrero, 2017. Capítulo 3. Manejo y domesticación de plantas en Mesoamérica. Una estrategia de investigación y estado del conocimiento sobrelos recursos genéticos en México. En: Casas, A., J. Torres-Guevara y F. Parra. Domesticación en manejo sustentable de recursos genéticos en el Nuevo Mundo. UNAM-UNAM-CONACYT-México. México.

Casas A., I. Torres, A. Delgado-Lemus, S. Rangel-Landa, L. Félix-Valdés, D. Cabrera, O. Vargas, C. Ilsley, A. I. A. Castillo, B. Ayala, J. J. Blancas, M. Vallejo, L. Solís, T. Ortíz y A. Bullen, 2017. En prensa. Ciencia para I sustentabilidad: Investigacion, educación y proc field to fermentation: The origins of Lactococcus lactis Microbiology, 47: 45-61.

acón, M., B. Pickersgill y D. Debouck, 2005. Domestication patterns in common bean (Phaseolus vulgaris $\mathrm{L}$.) and de origin of the Mesoamerican an Andean cultivated races.

Clement, C. R., W. M. Denevan, M. J. Heckenberger, A. B. Junqueira, E. G. Neves, W. G. Teixeira y W. I. Woods conquest. Proceedings of the Royal Society, $B$ 282: 20150813.

Clement C. R., 2017. Capítulo 1. Panorama de los recursos genéticos de Brasil, con énfasis en la Amazónia En: Casas, A., J. Torres-Guevara y F. Parra. Domesticación en el manejo sustentable de recursos genéticos en el Nuevo genéticos de Brasil, con enfasis en la Amazónia En en el continente americano. Volumen 2. Investigación l Nuevo Mundo. UNAM-UNAM-CONACYT-México. México.

olehour, A. M., J. F. Meadow, M. A. Liebert, T. J. CeponRobins, T. E. Gildner, Samuel S. Urlacher, B. J.M. Bohannan, J. J. Snodgrass y L. S. Sugiyama, 2014. Local domestication of lactic acid bacteria via cassava
beer fermentation. PeerJ 2:e479; DOI 10.7717/peeri.479

Colonese, A.C. M.A. Mannino, D.E. Bar-Yoset-Mayer, 2010. Marine mollusc exploitation in Mediterranean prehistory: An overview. Quaternary International

olunga-GarcíaMarín, P., I. Torres, A. Casas, C. J. Figueredo, S. Rangel-Landa, A. Delgado, O. Vargas, D. Cabrera-Toledo, X. Aguirre-Dugua, L. Eguiarte, D. A., J. Torres-Guevara yo y domesticación. En: Casas, continente americano. Volumen 2. Investigación para el manejo sustentable de recursos geneticos en el Nuevo Mundo. UNAM-U use-Sanders J. M., E. A. Friar, K. C. Parker, D. I. Huang, S. 2013. Managing diversity: domestication and gene flow in Stenocereus stellatus Riccob

Cruse-Sanders J. M. y A. Casas, 2017. Capítulo 19 Evolutionary impact of human activities on plants: A., J. Torres-Guevara y F. Parra. Domesticación en el continente americano. Volumen 2. Investigación para manejo sustentable de recursos genéticos en el Nuevo Mundo. UNAM-UNAM-CONACYT-México. México. Mundo. UNAM-UNAM-CONACYT-México. México. Casas, A., J. Torres-Guevara y F. Parra. Domesticación D.A. Fad, J.C. Finlayson, D. Lubell y M.C. Stiner, 11. Los agaves y las prácticas mesoamericanas de Mashayekhi, L. M. Prince, A. Otero-Arnaiz y A. Casas,
Cruz-García G. S. y L. Vael, 2017. Capítulo 13. El manejo Hassan F. A., 1978. Demographic archaeology. Advances in de plantas silvestres alimenticias en escenarios de deforestación, ilustrado por una comunidad mestiza de la Amazonía Peruana. En: Casas, A., J. Torres-Guevara y F. Parra. Domesticación en el continente americano. recursos genéticos en el Nuevo Mundo. UNAM-UNAMCONACYT-México. México.

Debouck D., 2017. Capítulo 5. Domesticaciones americanas: la recursividad humana y la ayuda botánica contra el impuesto geográfico y la migración original. En: Casas, continente americano. Volumen 2. Investigación para manejo sustentable de recursos genéticos en el Nuevo
Mundo. UNAM-UNAM-CONACYT-México. México.

Dando A. 1884- 2011. Orgin or culvicted plants. Candolle, A., 1884- 2011. Origin of cultivated plants.
Cambridge University Press, Cambridge, Inglaterra.

Dubcovsky J. y J. Dvorak, 2007. Genome plasticity key factor in the success of polyploid wheat under domestication. Science, 316(5833).

Erickson, D. L., B. D. Smith, A. C. Clarke, D. H. Sandweiss y N. Tuross, 2005. An Asian origin for a 10,000 year-old domesticated plant in the Americas. Proceedings of
the National Academy of Sciences of the USA, 102: the National Acac

Flannery, K. V., 1986. Guilá Naquitz. Archaic foraging and early agriculture in Oaxaca, Mexico. Emerald Group

Frantz, L. A. F., V. E. Mullin, M. Pionnier-Capitan, O. Lebrasseur, M. Oliver, A. Perri, A. Linderholm, V. Matliangell, M. D. F. McCormick, L. Bartousiewicz, E. Gál, É. A. Nyerges, M. V. Sablin, S. Bréhard, M. Mashkour, A. Bălăşescu, B. Gillet, S. Hughes, O. Chassaing, C. Hitte, J. D. Vigne, K. Dobney, C. Hänni, D. G. Bradley y G. Larson, 2016. Genomic and archaeological evidence suggest a dual
origin of domestic dogs. Science 352(6290): $1228-1231$.

Gibbons, J. G. y D. C Rinker, 2015. The genomics of microbial domestication in the fermented food environmen

Gómez-Pompa A., 1987. On Mayan silviculture. Mexica

Gómez-Pompa A., 1991. Learning from traditional ecological knowledge: insights from Mayan silviculture. In: Gómez Pompa A, Whitmore TC, Hadley M, eds. Rain fores Parthenon Publishing Group, 335-341.

Gómez-Pompa A., Flores E y Sosa V., 1987. The 'pet-kot': man-made tropical forest of the Maya. Interciencia 12: 10-15.

Hagelberg, E. y J. B. Clegg, 1991. Isolation and Characterization of DNA from Archaeological Bone. 244(1309): $45-50$.

Harlan J., 2005. Crops and man. American Society of Agronomy Inc. Madison, Wisconsin. Harris, D. R. 1996. Origins and spread of agriculture and pastoralism in
Eurasia. Smithsonian Institution Press. Washington.
Archaeological Method and Theory 1: 49-103.

wkes, J., 1983. The diversity of crop plants. Harvard University Press, Harvard, Mass. E. U. A.

Herrmann, B. y S. Hummel (Eds.), 2012. Ancient DNA: recovery and analysis of genetic material from paleontological, archaeological, museum, medical, and
forensic specimens. Springer Science \& Business Media.

tzi, E., 1993. Aspects of plant domestication in Mexico: a personal view. En: Ramamoorthy, T. P., R. Bye, A. Lot y J. Fa. Biological diversity of Mexico: origins and distribution, Oxford University Press, Oxford

Hufford, M. B., X. Xun, J. van Heerwaarden, T. Pyhäjärvi, J. M. Chia, R. A Cartwright, R. J. Elshire, J. C. Glaubitz, S. E Guill, S. M. Kaeppler, J. Lai, P. L. Morrell, L. M. Wagner, P. Tiffin, J. Wang, G. Zhang, J. Doebley, M. D. McMullen, D. Ware, E. S. Buckler, S. Yang y J. RossIbarra, 2012. Comparative population genomics of maize domestication and improvement. Nature Genetics, 44

enicke-Després, V., E. S. Buckler, B. D. Smith, M. Thomas, P. Gilbert, A. Cooper, J. Doebley y S. Pääbo, 2003. Ear// Allelic Selection in Maize as Revealed by Ancient DNA.

ménez-Bonilla, V. y A. Abdelnour-Esquivel, 2012. Identificación y valor nutricional de algunos materiales
nativos de arándano (Vaccinium spp.). Tecnología en Marcha 26(2): 3-8

unqueira A. Braga, G. H. Shepard y C. R. Clement, 2010 Secondary forests on anthropogenic soils in Brazilia Consenvation, 19:1933-1961.

Kintigh, K. W., J. H. Altschul, M. C. Beaudry, R. D. Drennan, A. P. Kinzig, T. A. Kohler,W. F. Limp, H. D. G. Maschner T. J. Wilkinson, H. T. Wrightg y M. A. Zeder, 2014. Grand challenges for archaeology. Proceedings of the National

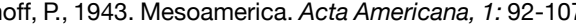
ishi, S., T.lzawa, S. Y.Lin, K. Ebana, Y. Fukuta, T. Sasaki y M. Yano, 2006. An SNP caused loss of seed shattering 1396.

Koenig, D., J. M. Jiménez-Gómez, S. Kimura, D. Fulop D. H. Chitwood, L. R. Headland, R. Kumara, M. Covington, U. K. Devisetty, A. V. Tata, T. Tohge, A. Weigel, Buyd A R. Ferni, Jengm, N. Pauly, D. J. N. Maloo, 2013. Comparative transcriptomics reveals patterns of selection in domesticated and wild tomato. Proceedings of the National Academy of Science. 110(28): E2655-E2662.

ratt, K. H., C. H. Brown, G.P. Nabhan, E. Luedeling, J. J. Bolger, K. Schneeberger, S. Ossowski, C. Lanz, G.
Xiong, M. Taylor-Teeples, S. M. Brady, M. Pauly D. Guna-Ruiz, G. C. d'Eeckenbrugge, R. J. Hijmansg y P.
Gepts, 2014. Multiple lines of evidence for the origin of 
domesticated chili pepper, Capsicum annuum, in Mexico Proceedings of the National Academy of Science 111
(17): 6165-6170.

Kwak, Myounghai, J. A. Kami y Paul Gepts, 2008. The putative Mesoamerican domestication center of Phaseolus vulgaris is located in the Lerma-Santiago Basin of

Kwak, M., O. Toro, D. G. Debouck y P. Gepts, 2012. Multiple origins of the determinate growth habit in domesticate common bean (Phaseolus vulgaris). Annals of Botany

Larson, G., D. R. Piperno, R. G. Allaby, M. D. Purugganan L. Andersson, M. Arroyo Kalinh, L. Barton, C. Climer Vigueira, T. Denham, K. Dobney, A. N. Doust, P. Gepts,
M. T. P. Gilbert, K. J. Gremillion, L. Lucas, L. Lukens, F. B. Marshall, K. M. Olsen, J. C. Pires, P. J. Richerson, R. Rubio de Casas, O. I. Sanjur, M. G. Thomas y D. Q. Fuller, 2014. Current perspectives and the future of domestication studies Proceedings of the National Academy of Science, 111(17): 6139-6146.

Lehmann, J., C. K. Dirse, B. Glaser y W. I. Woods, 2004 Amazonian dark earth. Origins, properties, management

Lema V. S., 2017. Capítulo 6. Al toro ¿por las astas? Reflexiones sobre aproximaciones teóricas y metodológicas a la temática de la domesticación en el área andina meridional. En: Casas, A., J. Torres-Guevara
y F. Parra. Domesticación en el continente americano. ecursos genéticos en el Nuevo Mundo. UNAM-UNAMCONACYT-México. México.

Leonard, J. A., R. K. Wayne, J. Wheeler, R. Valadez, S. Guillén y C. Vilà, 2002. Ancient DNA evidence for Old World origin of New World dogs. Science, 298(5598): 1613-1616.

Levi, C., F. R. C. Costa, F. Bongers, M. Peña-Claros, C. R. Clement, A. B. Junqueira, E. G. Neves, E. K. Tamanaha, F. O. G. Figueiredo, R. P. Salomão, C. V. Castilho, W. E. Magnusson, O. L. Phillips, J. E. Guevara, D. Sabatier, N. C. A. Pitman A. Duque, P. Núñez Vargendoza, Zartman, R. Vasquez, A. Andrade, J. L. Camargo, T. R. Feldpausch, S. G. W. Laurance, W. F. Laurance, T. J. Killeen, H. E. Mendonça Nascimento, J. C. Montero, B. Mostacedo, I. L. Amaral, I. C. Guimarães Vieira, R. Brienen, H. Castellanos, J. Terborgh, M. de Jesus Veiga Carim, J. R. da Silva Guimarães, L. de Souza Coelho, F. D. de Almeida Matos, F. Wittmann, H. F. Mogollón, Coronado, T. Emilio, D. de Andrade Lima Finho, Schietti, P. Souza, N. Targhetta, J. A. Comiskey, B. S. Marimon, B.-H. Marimon Jr., D. Neill, A. Alonso, L. Arroyo, F. A. Carvalho, F. C. de Souza, F. Dallmeier, M. P. Pansonato, J. F. Duivenvoorden, P. V. A. Fine, P. R. Stevenson, A. Araujo-Murakami, G. A. Aymard C., C. Baraloto, D. D. do Amaral, J. Engel, T. W. Henkel, P. D. Daly, R. Gribel, M. Ríos Paredes, M. Silveira, R. Thomas-Caesar. T. R. Baker N. F da Silva, L V. Ferreira, C. A. Peres, M. R. Silman, C. Cerón, F. C. Valverde
A. Di Fiore, E. M. Jimenez, M. C. Peñuela Mora, M. Toledo, E. M. Barbosa, L. C. de Matos Bonates, N. Guillaumet, P. Moller Jorgensen, Y. Malhi, I. P. de Andrade Miranda, J. F. Phillips, A. Prieto, A. Rudas, A R. Ruschel, N. Silva, P. von Hildebrand, V. A. Vos, E. A. Oliveira, H. Ramirez-Angulo, J. F. Ramos, G. Rivas, J. Schöngart, R. Sierra, M. Tirado, G. van der Heijden, E. V. Torre, O. Wang, K. R. Young, C. Baider, A. Cano W. Farfan-Rios, C. Ferreira, B. Hoffman, C. Mendoza, I. Mesones, A. Torres-Lezama, M. N. U. Medina, T. R. van Andel, D. Villarroel, R. Zagt, M. N. Alexiades, H. Balslev, K. Garcia-Cabrera, T. Gonzales, L. Hernandez, W. P. Cuenca, S. Pansini, D. Pauletto, F. R. Arevalo, N. F. Costa Reis, A. F. Sampaio, L. E. Urrego Giraldo, E. H. Valderrama Sandoval, L. Valenzuela Gamarra, C. I. A. Vela y H. ter Steege, 2017. Persistent effects of preColumbian plant domestication on Amazonian forest composition. Science, 355: 925-931.

evy, T. E., T. Higham, C. B. Ramsey, N. G. Smith, E. BenYosef, M. Robinson, S. Münger, K. Knabb, J. P. Schulze, M. Najjar y L. Tauxe, 2008. High-precision radiocarbo dating and historical biblcal archaeology in souther Sciences, 105 (43): 16460-16465.

ira, R., A. Casas y J. Blancas (Eds.), 2016. Ethnobotany of Mexico. Interactions of peoples and plants in , Holanda.

Lucena, R. F. P., C. Marques de Lucena, M. V. Meiado, D. D. da Cruz, M. Oliveira de Andrade y A. Casas, cactáceas no Brasil. En: Casas, A., J. Torres-Guevara y F. Parra. Domesticación en el continente americano. Volumen 2. Investigación para el manejo sustentable de recursos genéticos en el Nuevo Mundo. UNAM-UNAM-

MacNeish, 1967. A summary of the subsistence. En: Byer D. (Ed.) The prehistory of the Tehuacan Valley. Volume 1 Environment and subsistence. University of Texas Press,
Austin, Texas, E. U. A. pp. 290-309. acNeish, R. S., 1992. The origins of agriculture and settled life. Oklahoma University Press, Oklahoma, E.U.A.

Maffi, L., 2005. Linguistic, cultural and biological diversity.

affi, L. y O. Dilts, 2014. Biocultural diversity Toolkit. Volume 1 - Introduction
New York.

Mariaca-Méndez, R., 2017. Capítulo 20. Avances en el estudio de la fauna de los traspatios familiares en y F. Parra. Domesticación en el continente americano. Volumen 2. Investigación para el manejo sustentable de recursos genéticos en el Nuevo Mundo. UNAM-UNAMCONACYT-México. México.

Los-Moctezuma, E., 1994. Mesoamérica. En: Manzanilla, pp. 49-73.
McMichael, C. H., D. R. Piperno, M. B. Bush, M. R. Silman, A. R. Zimmerman, M. F. Raczka, y L. C. Lobato, 2012. Sparse pre-Columbian human habitation
Amazonia. Science, 336(6087): 1429-1431.

Millennium Ecosystem Assessment, 2005. Ecosystems and Human Well-Being: Biodiversity Synthesis. World Resources Instithe, Washinglon, DC.

Miller, A. J. y B. A. Schaal, 2006. Domestication and the distribution of genetic variation in wild and cultivated populations of the Mesoamerican fruit tree Spondias
purpurea L.(Anacardiaceae). Molecular Ecology, 15(6): purpurea L. An $1467-1480$.

Molares S. y A. H. Ladio, 2017. Capítulo 16. Etnoconservacionismo y practicas locales en Patagonia: y F. Parra. Domesticación en el continente americano. Volumen 2. Investigación para el manejo sustentable de recursos geneticos en el Nuevo Mundo. UNAM-UNAMCONACYT-México. México.

Moreno-Calles, A.I., A. Casas, Toledo V.M. y Vallejo, M. (Coord.), 2016. Etnoagroforestería en México.

Montero López, C., F. Trabanino García, C. M. Varela-Scherrer y R. Liendo-Stuardo, 2016. El manejo de un paisaje
construido: Aprovechamiento y explotación de los construido: Aprovechamiento y explotación de los
recursos vegetales y faunísticos en Chinikihá, Chiapas. Revista Etnobiologia, 14(1): 5-22.

Motamayor, J. C. y C. Lnaud, 2002. Molecular analysis of the origin and domestication of Theobroma cacao $L$ En: Engels, J. M. M., V. R. Rao, A. H. D. Brown y M International Plant Genetic Resources Institute IPGRICABI Publishing, Nueva York, pp. 77-88-

Myles, S., A. R.Boyko, C. L. Owens, P. J. Brown, F. Grassi, M. K., Aradhya, y C. D. E and domestication history of the grape. Proceedings of

Olsen, K. M. y B. A. Schaal, 2001. Microsatellite variation in cassava (Manihot esculenta, Euphorbiaceae) and its wild relatives: further evidence for a southern Amazonian
origin of domestication. American Journal of Botany origin of domestic $131-142$.

Ortega-Paczka R. y B. X. Chamorro-Cobaxin, 2017 Capitulo 10. Factores e indicios de conservación in sítu y evolución bajo domesticación de maíz en México F. Parra. Domesticación en el continente americano. Volumen 2. Investigación para el manejo sustentable de recursos genéticos en el Nuevo Mundo. UNAM-UNAMCONACYT-México. México.

Parra, F., A. Casas, J. Peñaloza-Ramírez, A. C. CortésPalomec, V. Rocha-Ramírez y A. González-Rodríguez, 2010. Evolution under domestication: Ongoing artificial
selection and divergence of wild and managed Stenocereus pruinosus (Cactaceae) populations in the

Parra, F., J. Blancas y A. Casas, 2012. Landscape guided selection and gene flow. Journal of Ethnobiology and Ethnomedicine, 8: 32

Parra F. y A. Casas, 2016. Capítulo 6. Origen y difusión de la domesticación y la agricultura en el Nuevo Mundo. En: Casas, A., J. Torres-Guevara y F. Parra (Eds.). Domesticación en el continente americano. Volumen 1. Manejo de biodiveridad y evolución dirigida por

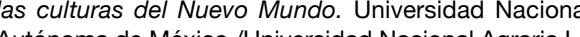
Molina, pp. 159-187.

Pérez-Negrón, E. y A. Casas, 2007. Use, extraction rates and spatial availability of plant resources in icatlán Valley, Mexico: The case o 70(2): 356-379.

Pérez-Negrón, E. P. Dávila y A. Casas, 2014. Use of columnar cacti in the Tehuacán Valley, Mexico: Perspectives for sustainable management of non-timber forest products. insights from Mendelian and molecular genetics. Annals of Botany, 100(5): 925-940.

Pickersgill, B., 2016. Chili peppers. En: Lira R., A. Casas J. Blancas (Eds.). Ethnobotany of Mexico. Interaction of people and plants in Mesoamerica. Springer, Utrecht,

Pickersgill, B., 2017. Capítulo 7. Ajíes o chiles (Capsicum spp.): historia y biología. En: Casas, A., J. Torres-Guevara y. Parra. Domesticación en el continente americano.
Volumen 2. Investigación para el manejo sustentable de recursos genéticos en el Nuevo Mundo. UNAM-UNAMCONACYT-México. México.

iperno, D. R., 2006. Quaternary environmental history and agricultural impact on vegetation in Central America.

Aiperno, D. R. 2011 The Origins of Plant Cultivation and Domestication in the New World Tropics Patterns, Process, and New Developments. Current

Piperno, D. R., y D. M. Pearsall, 1998. The origins agriculture in the lowland Neotropics. Academic Press, San Diego, CA.

Pochettino, M. L., M. M. Bonicatto y Julio A. Hurrell, 2017. Capítulo 17. Huertos comerciales del periurban de la plata (Buenos Aires, Argentina): Reservorio de diversidad Biocultural. En: Casas, A., J. Torres-Guevara y F.Parra. Domesticación en el continente americano. Veursos genéticos en el Nuevo Mundo. UNAM-UNAMCONACYT-México. México.

Quilter, J., B. Ojeda, D. M. Pearsall, D. H. Sandweiss, J. G. Iriarte, 2009 . Preceramic human occupation yf Central Balsas Valley, Mexico: cultural context of early domesticated maize and squash. Proceeding of the National Academy of Sciences of the USA, 106 5014-5018. 
Rangel-Landa S., A. Casas, E. Rivera-Lozoya, I. Torres y Terrell, J. E., J. P. Hart, S. Barut, N. Cellinese, A. Curet, T.
M. Vallejo, 2016. Ixcatec ethnoecology: Biocultural
Denham y M. Pohl, 2003. Domesticated landscapes: The M. Vallejo, 2016. Ixcatec ethnoecology: Biocultural principles of plant management in Oaxaca, Mexico. 2010. Origns and evolulion of culvivated Rodríguez, L. E., 2010. Origins and evolution of cultivated
potato. A review. Agronomia Colombiana, 28(1), 9-17. Roullier, C., G. Rosell, D. Tay, D. McKey y V. Lebot, 2011 Combining chloroplast and nuclear microsatellites to investigate origin and dispersal of New World sweet potato landraces. Molecular Ecology, 20(19): 3963-3977.

Roullier, C., A. Duputié, P. Wennekes, L. Benoit, V. M. Fernandez Bringas, G. Rosse, D. Tay, D. McKey y V.
Lebot, 2013. Disentangling the origins of cultivated Lebot, 2013. Disentangling the origins of cultivated
sweet potato (Ipomoea batatas (L.) Lam.) PLOS ONE, 8(5): e62707.

Schmutz, J., P. E McClean, S. Mamidi, G. A. Wu, S. B. Cannon, J. Grimwood, J. Jenkins, S. Shu, Q. Song, C. Chavarro, B. Abernathy, K. Barry, M. Blair, M. A Brick, M. Chovatia P. Gepts, D. M Goodstein, M. Gonzales, U. Hellsten, D. L. Hyten, G. Jia, J. D. Kelly, D. Kudrna, R. Lee, M. M. S Richard, P. N. Miklas, J. M Osorno, J. Rodrigues, V. Thareau, C. A. Urrea, M. Wang, Y. Yu, M. Zhang, R. A. Wing, P. B. cenome for common bean and genome dual domestications. Nature Genetics, 46(7): 707-713.

Smith, B. D., 1997. The initial domestication of Cucurbita pepo in the Americas 10000 years ago. Science, $276(5314)$ 932-934.

Smith. B. D., 2006. Eastern North America as an independent center of plant domestication. Proceedings of the
National Academy of Science, 103 (33): 12223-12228

Shady-Solís, R. S., J. Haas y W. Creamer, 2001. Dating Caral, Central Coast a preceramic site in the Supe Valley on
of Peru. Science, 292(517): 723-726.

Spooner, D. M. R. G. van der Berg A Rodríguez J. Bamberg R. J. Hijmans y S. Lara Cabrera, 2004. Wild potato (Solanum section Petota; Solanaceae of North and Centra America. Systematic Botany Monographs 68, 1-209.

Spooner, D.M., K. McLean, G. Ramsay, R. Waugh y G. Bryan, 2005. A single domestication for potato based on multilocus amplified fragment length polymorphism genotyping. Proceedings of the National Academy of

Sutton, M. Q., 1995. Archaeological aspects of insect use. Journal of Archaeological Method and Theory, 2(3):

Swanson-Wagner, R., R. Briskine, R. Schaefer, M. B. Hufford, J. Ross-Ibarra, C. L. Myers, y N. M. Springer, 2012. Proceedings of the National Acad by of Sciences, 109(29): 11878-11883.

Tello Villavicencio, M., 2017. Capítulo 14. Las plantas aromáticas en los Andes peruanos. En: Casas, A., J. Torres-Guevara y F. Parra. Domesticación en el continente americano. Volumen 2. Investigación para el Mundo. UNAM-UNAM-CONACYT-México. México. Denham y M. Pohl, 2003. Domesticated landscapes: The Journal of Archaeological Method and Theory, 10(4). 323-368.

Torres-Guevara, J., F. Parra y A. Casas, 2017. Capítulo 4. Panorama de los recursos genéticos en Perú. En: Casas, A., J. Torres-Guevara y F. Parra. Domesticación en manejo sustentable de recursos genéticos en el Nuevo Mundo. UNAM-UNAM-CONACYT-México. México.

nHoldt, B. M. J. P. Pollinger, K. E. Lohmueller, E. Hon H. G. Parker, P. Quignon, J. D. Degenhardt, A. R. Boyko, D. A. Earl, A. Auton, A. Reynolds, K. Bryc, A. Brisbin, J. C. Knowles, D. S. Mosher, T. C. Spady, A. Elkahloun, E. Geffen, M. Pilot, W. Jedrzejewski, C. Greco, E. Randi, D. Bannasch, A. Wilton, J. Shearman, M. Musiani, M. Cargi P. G. Jones, Z. Qian, W. Huang, Z. L. Ding, Y. Zhang, C. D. a rich history underlying dog domestication Nature 464(7290): 898-902.

Vvilov, N. I. 1951-2011. Origin and geography of cultivated plants. Cambridge University Press, Cambridge, Platerr

Van Hylckama Vlieg, J. E. T., P. Veiga, C. Zhang, M. Derrien y L. Zhao, 2011. Impact of microbial transformation of food gastro-intestinal tract. Current Opinion in Biotechnology. 22(2):211-219

an Itterbeeck, J. y A. van Huis, 2012. Environmenta manipulation for edible insect procurement: historical perspective. Journal of Ethnobiology and

Wales, N., K. Andersen, E. Cappellini, M. C. Ávila-Arcos y M. T. P. Gilbert, 2014. Optimization of DNA recovery and remains. PLOS One, 9(1): e86827.

Wheeler J. C., 2017. Capítulo 8. Evolución y domesticación de los camelidos Sudamericanos. En. Casas, A., J. Torresamericano. Volumen 2. Investigación para el manejo UNAM-UNAM-CONACYT-México. México.

illiams, A. N., 2011. The use of distributions in archaeology: a review of methods. Journa of Archaeological Science, 39(3): 578-589.

Yoo, M J. y J. F. Wendel, 2014. Comparative Evolutionary and Developmental Dynamics of the Cotton (Gossypium
hirsutum) Fiber Transcriptome. PLoS Genetics, 10(1):

Zarazúa, M., 2016. Del guajolote a las chicatanas. Uso, manejo y domesticación de recursos geneticos animale en Mesoamerica En: Casas, A.,J. Torres-Guevara y F. Parra (Eds.). Domesticacionen por las culturas del Nuevo Mundo. Universidad Nacion Molina, pp. 283-316. 2010. Genome-wide SNP and Novembre Y R. K. Wayn Autónoma de México / Universidad Nacional Agraria La
Zeder, M. A., E. Emshwiller, B. D.Smith y D. G. Bradley, 2006. Documenting domestication: the intersection of genetics
and archaeology. TRENDS in Genetics, 22(3): 139-155

Zizumbo-Villarreal, D. y P. Colunga-GarcíaMarín, 2017. Capítulo 15. El sistema agroalimentario mesoamericano precolombino: origen, diversificación y difusión de sus recursos fitogenéticos. En: Casas, A., J. Torres-Guevara Y F. Parra. Domesticación en el continente americano. Vre CONACYT-México. México. 


\section{Lista de autores participantes. Tomo 2}

Xitlali Aguirre-Dugua

Departamento de Botánica, Instituto de Biología-UNAM, Circuito Exterior, Ciudad Universitaria, ciudad de México, México 04510.

xitla.aguirre@gmail.com

Hernán Alvarado-Sizzo,

Instituto de Investigaciones en Ecosistemas y Sustentabilidad (IIES), Universidad Nacional Autónoma de México. Antigua Carretera a Pátzcuaro 8701, Col. ExHacienda de San José de la Huerta, Morelia, Michoacan, México 58190.

José Blancas

Centro de Investigación en Biodiversidad y Conservación (CIByC), Universidad Autónoma del Estado de Morelos. Av. Universidad No. 1001, Col. Chamilpa, C.P. 62209, Cuernavaca, Morelos, México.

jblancasv@gmail.com

María Margarita Bonicatto

Laboratorio de Etnobotánica y Botánica Aplicada, Facultad de Ciencias Naturales y Museo, Uni-

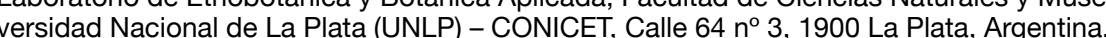
pochett@fcnym.unlp.edu.ar

\section{Robert A. Bye}

Jardin Botanico, Instituto de Biologia-UNAM, Circuito Exterior, Ciudad Universitaria, ciudad de México, México 04510. bye.robert@gmail.com

Dánae Cabrera-Toledo

Laboratorio Nacional de Identificación y Caracterización Vegetal, Depto. Botánica y Zoología, Centro Universitario de Ciencias Biológicas, Universidad de Guadalajara, Zapopan, Jalisco México. danaetoledo@gmail.com

\section{Andrés Camou-Guerrero}

Escuela Nacional de Estudios Superiores (ENES), unidad Morelia, Universidad Nacional Autonoma de México (UNAM), Campus Morelia. Antigua Carretera a Pátzcuaro 8701, Col. ExHacienda de Sa José de la Huerta C.P. 58190, Morelia, Michoacán, México.

Guadalupe Carrillo-Galván Jardín Botánico, Instituto de Biología-UNAM, Circuito Exterior, Ciudad Universitaria, ciudad de México, México 04510 lupita.carrillog@gmail.com

Alejandro Casas

Instituto de Investigaciones en Ecosistemas y Sustentabilidad (IIES), Universidad Nacional Autónoma de México. Antigua Carretera a Pátzcuaro 8701, Col. ExHacienda de San José de la Huerta, Morelia, Michoacán, México 58190.

acasas@iies.unam.mx

An Lolina s/n La Molina, Lima, Perú.

Baruch Xocoyotzin Chamorro Cobaxin

Universidad Autónoma Chapingo, Texcoco, Estado de México, México. baruchxco@gmail.com 


\section{Charles R. Clement}

Instituto Nacional de Pesquisas da Amazônia - INPA; Av. André Araújo, 2936 - Aleixo; 69067-375 Manaus, Amazonas, Brazil.

charlesr.clement@yahoo.com

Laboratório de Evolução Aplicada, Instituto de Ciências Biológicas, Universidade Federal do Amazonas. Av. Gal. Rodrigo Otávio Jordão Ramos, 3000; 69077-000 Manaus, Amazonas, Brazil.

Patricia Colunga-GarcíaMarín

Investigador visitante, El Colegio de la Frontera Sur, México. ECOSUR, San Cristóbal de las Casas, Chiapas, México.

patricia.colunga@gmail.com

Jeniffer M. Cruse-Sanders

Atlanta Botanical Garden, Atlanta Georgia, USA

Aldo Cruz

Coordinadora de Ciencia y Tecnología Andina A.C. Camilo Carrillo 300-A, Lima 11 - Perú. e-mail: aldojcruz@gmail.com

Gisella S. Cruz-García Centro Internacional de Agricultura Tropical (CIAT), Colombia. g.s.cruz@cgiar.org

Denise Dias da Cruz Universidade Estadual de Pernambuco, Pessoa, Brasil

Maristela Oliveira de Andrade

Universidade Estadual de Perambuco, Pessoa, Brasi

Daniel Debouck

Programa de Recursos Genéticos, Centro Internacional de Agricultura Tropical (CIAT) AA 6713

América Delgado-Lemus

Instituto de Investigaciones en Ecosistemas y Sustentabilidad (IIES), Universidad Nacional Autónoma de Mexico. Antigua Carretera a Pátzcuaro 8701, Col. ExHacienda de San José de la Huerta, Morelia, Michoacán, México 58190. america@cieco.unam.mx

Luis Eguiarte

Instituto de Ecología, UNAM. Circuito Exterior, Ciudad Universitaria, México, Ciudad de México

e-mail: luis.eguiarte@gmail.com

Berenice Farfán-Heredia

Instituto de Investigaciones en Ecosistemas y Sustentabilidad (IIES), Universidad Nacional Autónoma de México. Antigua Carretera a Pátzcuaro 8701, Col. ExHacienda de San José de la Huerta, Morelia, Michoacán, Mexico 58190 . e-mail: farfan73@gmail.com

Carmen Julia Figueredo

Instituto de Investigaciones en Ecosistemas y Sustentabilidad (IIES), Universidad Nacional Autónoma de México. Antigua Carretera a Pátzcuaro 8701, Col. ExHacienda de San José de la Huerta, Morelia, Michoacán, México 58190. figueredocj@gmail.com

Susana Guillén

Centro Tlaxcala de Ciencias Biológicas, UNAM-Universidad Autónoma de Tlaxcala-CONACYT. sguillenro@conacyt.mx
Norma Hilgert

Instituto de Biología Subtropical (IBS), Universidad Nacional de Misiones-CONICET y Asociación Civil Centro de Investigaciones del Bosque Atlántico. CONICET

Julio A. Hurrell

Laboratorio de Etnobotanica y Botánica Aplicada, Facultad de Ciencias Naturales y Museo, Un versidad Nacional de La Plata (UNLP) - CONICET, Calle 64 nº 3, 1900 La Plata, Argentina. pochett@fcnym.unlp.edu.ar

Ana H. Ladio Grupo Etnobiología, INIBIOMA-Laboratorio Ecotono, Universidad Nacional del Comahue. CONICET

Verónica Lema Laboratorio de Etnobotánica y Botánica Aplicada, Facultad de Ciencias Naturales y Museo, Universidad Nacional de La Plata. Departamento Científico Arqueología, Facultad de Ciencias Naturales y Museo, Universidad Nacional de La Plata.

Reinaldo Farias Paiva de Lucena

Universidade Estadual de Perambuco, Pessoa, Brasil. reinaldo@cca.ufpb.br

Camilla Marques de Lucena Universidade Estadual de Perambuco, Pessoa, Brasi. camillamlucena@gmail.com

Ramón Mariaca Méndez

El Colegio de la Frontera Sur, Unidad San Cristóbal de las Casas, Chiapas, México. rmariaca@ecosur.mx

Marcos Vinicius Meiado Universidade Estadual de Perambuco, Pessoa, Brasil.

Soledad Molares CIEMEP. CONICET - Universidad Nacional de la Patagonia San Juan Bosco, Esquel, Chubut, Argentina. smolares@gmail.com

Ana Isabel Moreno-Calles Escuela Nacional de Estudios Superiores (ENES), unidad Morelia, Universidad Nacional Autónoma de México (UNAM), Campus Morelia. Antigua Carretera a Pátzcuaro 8701, Col. ExHacienda de Sa José de la Huerta C.P. 58190, Morelia, Michoacán, México. anaisabel_moreno@enesmorelia.unam.mx

Rafael Ortega Paczka Universidad Autónoma Chapingo, Texcoco, Estado de México, México. ropaczka@gmail.com,

Adriana Otero-Arnaiz United States Department of Agriculture. Environment and society capacity building, Ciudad de

Adriana.Otero@fas.usda.gov

Fabiola Parra-Rondinel

Centro de Investigaciones en Zonas Áridas, Universidad Nacional Agraria La Molina, Lima Perú Coordinadora de Ciencia y Tecnología Andina A.C. Camilo Carrillo 300-A, Lima 11, Perú. e-mail: fparra2@gmail.com 


\section{Santiago Pastor Soplín}

Profesor Investigador, Universidad Científica del Sur Km 19, Villa Panamericana Sur, Villa El Salvador, Lima, Perú.

te La Molina s/n La Molina, Lima, Perú.

santiago.pastor.soplin@gmail.com

\section{Edgar Pérez-Negrón}

Instituto de Investigaciones en Ecosistemas y Sustentabilidad (IIES), Universidad Nacional Autónoma de México. Antigua Carretera a Pátzcuaro 8701, Col. ExHacienda de San José de la Huerta,

Barbara Pickersgill

School of Biological Sciences, The University of Reading, United Kingdom (retirada). b.pickersgill888@btinternet.com

\section{María LeliaPochettino}

Laboratorio de Etnobotánica y Botánica Aplicada, Facultad de Ciencias Naturales y Museo, Unipochett@fcnym.unlp.edu.ar

Selene Rangel-Landa

Instituto de Investigaciones en Ecosistemas y Sustentabilidad (IIES), Universidad Nacional Autónoma de México. Antigua Carretera a Pátzcuaro 8701, Col. ExHacienda de San José de la Huerta, Morelia, Michoacan, México 58190.

srangel@cieco.unam.mx

\section{Leonor Solís}

Instituto de Investigaciones en Ecosistemas y Sustentabilidad (IIES), Universidad Nacional Autónoma de México. Antigua Carretera a Pátzcuaro 8701, Col. ExHacienda de San José de la Huerta, Morelia, Michoacán, México 58190.

Isolis@cieco.unam.mx

\section{Julio B. Sumar}

Facultad de Veterinaria, Universidad Nacional Mayor de San Marcos. Estación Principal de Altura de la Raya, Cusco, Peru.

info@reproduccionanimal.org

Milka Tello-Villavicencio

Facultad de Agronomía, Universidad Hermilio Valdizán, Huánuco, Perú.

milka_hco@yahoo.com.pe

Ignacio Torres-García

Instituto de Investigaciones en Ecosistemas y Sustentabilidad (IIES), Universidad Nacional Autónoma de México. Antigua Carretera a Patzcuaro 8701, Col. ExHacienda de San José de la Huerta, Morelia, Michoacán, México, 58190.

itorresg@cieco.unam.mx

Juan Torres-Guevara

Centro de Investigaciones en Zonas Áridas, Universidad Nacional Agraria La Molina, Lima Perú. Camilo Carrillo 300-A, Lima 11 - Perú.

amotape@yahoo.com

\section{Mariana Vallejo}

Instituto de Investigaciones en Ecosistemas y Sustentabilidad (IIES), Universidad Nacional Autónoma de México. Antigua Carretera a Pátzcuaro 8701, Col. ExHacienda de San José de la Huerta, Morelia, Michoacán, Mexico, 58190 .

\section{Ofelia Vargas}

Laboratorio Nacional de Identificación y Caracterización Vegetal, Depto. Botánica y Zoología, Centro Universitario de Ciencias Biológicas, Universidad de Guadalajara, Zapopan, Jalisco México ovargasofelia@gmail.com

Lore Vael

University of Ghent, Bélgica.

Lore.Vael@UGent.be

Jane C. Wheeler

CONOPA - Instituto de Investigación y Desarrollo de Camélidos Sudamericanos, Av. Reusche M-4, Pachacamac, Lima 19, Perú. janecwheeler@conopa.org

\section{Mariana Zarazúa}

Instituto de Investigaciones en Ecosistemas y Sustentabilidad (IIES), Universidad Nacional Autónoma de México. Antigua Carretera a Pátzcuaro 8701, Col. ExHacienda de San José de la Huerta, Morelia, Michoacan, México, 58190

mariana zarazuagmail.com

Daniel Zizumbo-Villarreal

Investigador visitante, El Colegio de la Frontera Sur, México. ECOSUR, San Cristóbal de las Casas, Chiapas, México.

zizumbodaniel@gmail.com

Paulina R. Lezama-Núñez Red Mexicana sobre Conservación y Utilización de los Recursos Zoogenéticos A.C., Oaxaca

paulinazama@hotmail.com

\section{Dídac Santos-Fita}

Centro de Investigación en Ciencias Biológicas Aplicadas, Universidad Autónoma del Estado de México. Avda. Instituto Literario 100, Colonia Centro, Toluca, Estado de México, Mexico. dsantofi@gmail.com 